\title{
POLITYKA OŚWIATOWA \\ Przegląd ekspertyz \\ z wybranych obszarów oświatowych \\ (lata 2008-2018)
}





\section{Dobromir Dziewulak}

\section{POLITYKA \\ OŚWIATOWA \\ Przegląd ekspertyz}

z wybranych obszarów oświatowych

(lata 2008-2018)

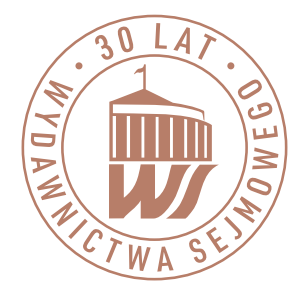

WARSZAWA 2020 
Recenzja wydawnicza

dr hab. Grzegorz Golębiowski

Projekt okładki i stron tytułowych

Edyta Batóg

Redaktor techniczny

Renata Wenclawiak

Redakcja językowa

Tamara Kożuchowska

Korekta

Bożenna Lada

DOI: https://doi.org/10.31268/d.dziewulak.2020.01

(c) Copyright by Kancelaria Sejmu

Warszawa 2020

ISBN 978-83-7666-677-8

KANCELARIA SEJMU

Wydawnictwo Sejmowe

Wydanie pierwsze

Warszawa 2020

http://wydawnictwo.sejm.gov.pl

e-mail: wydawnictwo@sejm.govpl

Druk i oprawa: INTRO-DRUK 
DOI: https://doi.org/10.31268/d.dziewulak.2020.01

Ewie, Marcie i Dobrusi 
DOI: https://doi.org/10.31268/d.dziewulak.2020.01 


\section{Spis treści}

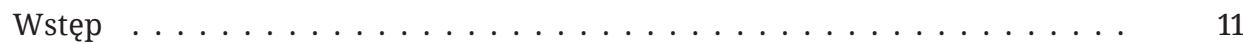

Część 1. Ustrój szkolny

1.1. Obowiązek szkolny w Unii Europejskiej . . . . . . . . . . . . . . . . . . . 17

1.2. Przegląd ustrojów szkolnych w wybranych państwach . . . . . . . . . . . 40

1.3. Szkolnictwo średnie w wybranych państwach Unii Europejskiej . . . . . . 103

1.4. Szkolnictwo wyższe w świetle raportów edukacyjnych . . . . . . . . . . . . 164

1.5. System szkolny Finlandii . . . . . . . . . . . . . . . . . . . . . . . 190

1.6. System szkolny Irlandii . . . . . . . . . . . . . . . . . . . . . . . . 201

Część 2. Program nauczania

2.1. Kształcenie zawodowe w Polsce i wybranych państwach członkowskich Unii Europejskiej . . . . . . . . . . . . . . . . . 227

2.2. Szkolna przedsiębiorczość w systemach oświatowych wybranych państw

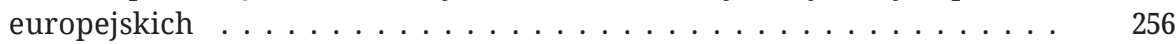

2.3. Edukacja kulturalna w szkolnictwie wybranych państw europejskich . . . 286

2.4. Kształcenie dzieci i młodzieży w zakresie bezpieczeństwa ruchu drogowego w wybranych państwach członkowskich Unii Europejskiej . . 356

2.5. Wychowanie fizyczne w szkołach w wybranych państwach europejskich $\quad 397$

\section{Część 3. Uczniowie}

3.1. Wspieranie uczniów uzdolnionych w szkolnictwie europejskim i USA . .

3.2. Doradztwo edukacyjno-zawodowe w szkolnictwie zawodowym w Polsce i wybranych państwach Unii Europejskiej . . . . . . . . . . . . . . . . . .

3.3. Zwalnianie uczniów z lekcji wychowania fizycznego w szkołach w Polsce i wybranych państwach europejskich . . . . . . . . . . . .

3.4. Dni wolne od zajęć szkolnych dla uczniów działających w sferze publicznej w wybranych państwach Unii Europejskiej . . . . . . . . . . . . 
3.5. Ulgowe przejazdy dla uczniów i studentów w wybranych państwach członkowskich Unii Europejskiej $\ldots \ldots \ldots \ldots \ldots$

\section{Część 4. Organizacja pracy szkoły}

4.1. Kształcenie na odległość w wybranych państwach europejskich . . . . . .

4.2. Wymiar czasu pracy nauczycieli w wybranych państwach Unii Europejskiej .

4.3. Nadzór pedagogiczny w systemach edukacyjnych w Polsce i wybranych państwach członkowskich Unii Europejskiej

4.4. Edukacja dwujęzyczna z językiem migowym dla uczniów głuchych w Polsce i wybranych państwach Unii Europejskiej . . . . . . . . . . . . . .

4.5. Dostęp do podręczników dla dzieci niewidomych i słabowidzących w Polsce, Szwecji i Wielkiej Brytanii . . . . . . . . . . . . . . . . . . . .

4.6. Finansowanie zakupu podręczników szkolnych w wybranych państwach

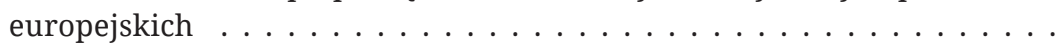

Część 5. Uwarunkowania społeczno-ekonomiczne oświaty

5.1. Wybrane zagadnienia prawa adopcyjnego na Białorusi, Litwie i Ukrainie 637

5.2. Monitorowanie losów dziecka z użyciem baz danych w wybranych państwach członkowskich Unii Europejskiej . . . . . . . . . . . . . . . . .

5.3. Monitorowanie przez polskie wyższe uczelnie karier zawodowych

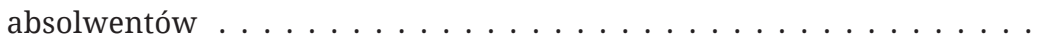

5.4. Instytucja rejestrowanego związku partnerskiego PACS we Francji . . . . 669

5.5. Zasady recenzowania wniosków o granty naukowe finansowane ze środków publicznych we Francji, w Niemczech i Wielkiej Brytanii . . .

Indeks rzeczowy . . . . . . . . . . . . . . . . . . . . . . . . . . . . 691

spis tabel. . . . . . . . . . . . . . . . . . . . . . . . . 693

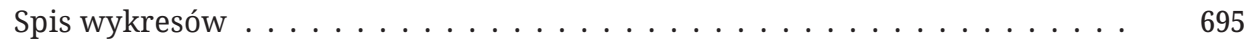

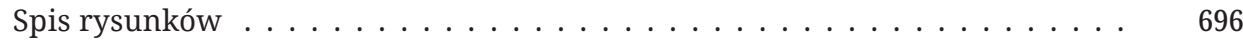




\section{Contents}

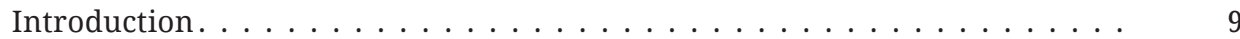

\section{Part 1. School system}

1.1. Compulsory education in European Union . . . . . . . . . . . . . . . . . . 17

1.2. Overview of school systems in selected countries . . . . . . . . . . . . 40

1.3. Secondary education in selected European Union countries . . . . . . . . 103

1.4. Higher education in the light of educational reports . . . . . . . . . . . . . 164

1.5. School system of Finland . . . . . . . . . . . . . . . . . . . . 190

1.6. The school system of Ireland . . . . . . . . . . . . . . . . . . 201

\section{Part 2. School curriculum}

2.1. Vocational education systems in Poland and in selected EU member states 227

2.2. School enterprise in education systems in selected European countries . . 256

2.3. Cultural and artistic education at school in selected European countries . $\quad 286$

2.4. Road safety education for young and older children in the selected European Union members states . . . . . . . . . . . . . . . . . . . 356

2.5. Physical education in schools in selected European countries . . . . . . . . 397

\section{Part 3. Students}

3.1. Supporting the gifted students in the European education and in the United States . . . . . . . . . . . . . . . . . . . .

3.2. Educational and professional counselling services in vocational education in Poland and in selected countries of the European Union . . . . . . . . .

3.3. Exempting students from physical education classes in schools in Poland and selected European countries . . . . . . . . . . . . . .

3.4. Additional days free from school activities for students working in the public sphere in selected European Union countries . . . . . . . . . . . . 
3.5. Reduced travel fares for students in selected European Union members states . . . . . . . . . . . . . . . . . . . . . . . . .

\section{Part 4. Work organisation in school}

4.1. E-learning in selected European countries . . . . . . . . . . . . . . . . 513

4.2. Working time of teachers in selected European Union members states . .

4.3. Pedagogical supervision in the education system of Poland and selected European Union members states . . . . . . . . . . . . . . . . . . . . .

4.4. Bilingual education with sign language in schools for deaf students in Poland and in selected European Union countries

4.5. Access to textbooks for blind and partially sighted children in Poland, Sweden and the United Kingdom . . . . . . . . . . . . . . . . . . . . . 602

4.6. Funding the purchase of school textbooks in selected European countries 622

\section{Part 5. Socio-economic determinants of education}

5.1. Selected issues of adoption law in Belarus, Lithuania and Ukraine . . . . .

5.2. Monitoring the child's fate with the use of databases in selected European Union members states . . . . . . . . . . . . . . . . . . 646

5.3. Graduate career monitoring by Polish institutions of higher education . . 653

5.4. Civil solidarity pact (PACS) in France . . . . . . . . . . . . . . . . . 669

5.5. Rules for reviewing applications for research grants financed from public funds in France, Germany and the United Kingdom . . . . . . . . . . . . . . .



Contents of tables . . . . . . . . . . . . . . . . . . . . . 694

Contents of charts ......................... 696

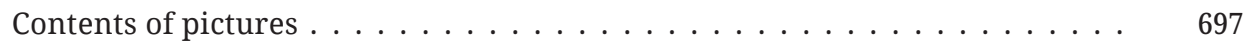




\section{Wstęp}

Polityka oświatowa to dział polityki państwa zajmujący się zagadnieniami oświaty i wychowania, ale także jest to dyscyplina naukowa o teoretycznych podstawach tej działalności. Istotą polityki oświatowej jest dokonywanie wyboru i podejmowanie decyzji w sprawach celu, kierunku i organizacji całokształtu spraw związanych z oświatą, czyli wychowaniem, kształceniem i organizacją systemu szkolnego. Polityka oświatowa nie jest uprawiana w próżni ekonomicznej, społecznej, demograficznej czy politycznej. Stąd też od polityków oświatowych - naukowców i osób bezpośrednio decydujących o modelu oświaty - wymaga się szerokiej wiedzy z różnych dziedzin nauki oraz umiejętności głębokiego rozumienia istoty funkcjonowania państwa w jego wielu obszarach. To, jak zaplanowana, zorganizowana i realizowana jest działalność oświatowa zależy w dużej mierze od prawidłowej diagnozy uwarunkowań ekonomicznych, demograficznych, historyczno-społecznych i ustrojowo-politycznych państwa. Dopiero na jej podstawie dobiera się narzędzia służące budowaniu właściwie działającego systemu oświaty, czyli ustala szczegółowe zasady, którym będzie on podlegać (np. zasada jednolitości, obowiązkowości, bezpłatności, publiczności).

Dodatkowym, immanentnym i niezwykle ważnym elementem dokonywanej diagnozy jest porównawcze spojrzenie na oświatę w kontekście różnych państw i kontynentów. Analiza wprowadzonych reform, zastosowanych rozwiązań, przykłady dobrych praktyk oraz katalog występujących problemów w innych systemach oświatowych mogą zainspirować do zaadaptowania ciekawych rozwiązań na własnym gruncie, ale także mogą ustrzec przed popełnieniem błędów.

Rzetelna diagnoza staje się więc dla polityka oświatowego koniecznością, źródłem niezbędnej wiedzy i nieocenioną informacją o trzech obszarach: o tym, jak jest, jak powinno być oraz - dlaczego nie jest tak, jak być powinno.

Niniejsza książka jest próbą ukazania obszarów krajowej i międzynarodowej polityki oświatowej przez pryzmat wybranych 26 ekspertyz opracowanych w latach 2008-2018 na konkretne zlecenie posłów. W opracowaniu wykorzystano 
polską i obcojęzyczną literaturę przedmiotu, krajowe i międzynarodowe raporty oświatowe oraz dane statystyczne bogato prezentowane na stronach internetowych ministerstw edukacji, władz lokalnych, agencji oświatowych i instytucji wspierających zajmujących się problematyką edukacyjną, organizacji pozarządowych, stowarzyszeń nauczycielskich, uczniowskich i rodzicielskich. Niezastąpionym źródłem informacji stały się międzynarodowe instytucje oświatowe z ich różnorodnymi bazami danych i analizami porównawczymi. Szczególnie użyteczne były: Organizacja Narodów Zjednoczonych ds. Oświaty, Nauki i Kultury (UNESCO) z jej Międzynarodowym Biurem Oświaty (IBE-UNESCO) i Europejskim Centrum Szkolnictwa Wyższego (UNESCO-CEPES), Rada Europy, Sieć Informacji o Edukacji w Europie (Eurydice), Światowa Rada Stowarzyszeń Pedagogiki Porównawczej (WCCES), Europejski Urząd Statystyczny (Eurostat), Europejskie Centrum Rozwoju Kształcenia Zawodowego (Cedefop), Europejska Fundacja Kształcenia (ETF), Międzynarodowa Rada ds. Kształcenia Otwartego i na Odległość (ICDE), Instytut Międzynarodowej Edukacji (IIE), Europejska Agencja ds. Specjalnych Potrzeb Edukacyjnych i Edukacji Włączającej (European Agency for Special Needs and Inclusive Education), Centrum Badań nad uczeniem się przez całe życie (Centre for Research on Lifelong Learning, CRELL), Klub Rzymski (The Club of Rome), Organizacja Współpracy Gospodarczej i Rozwoju (OECD) oraz Bank Światowy.

Celem publikacji jest prezentacja zagadnień mieszczących się w obszarze dyscypliny naukowej, jaką jest polityka oświatowa. Może stanowić źródło wiedzy do oceny mechanizmów i zjawisk społecznych, a także wsparcie przy opracowywaniu szczegółowych analiz z zakresu szeroko rozumianej oświaty. Prezentowane treści pozwalają także na poznanie eksperckiego warsztatu pracy. Mogą stanowić kompendium wiedzy na przykład o procesie budowania podstaw do stawiania prawidłowej diagnozy oświatowej w kontekście uwarunkowań ekonomicznych, ustrojowo-politycznych, historycznych, demograficznych czy geograficzno-klimatycznych.

W konsekwencji tak określony cel został odzwierciedlony w strukturze publikacji, która powinna ułatwić czytelnikowi wyszukiwanie przedstawionych informacji.

Ze względu na obszerny i wielowątkowy materiał ekspercki wybrany do niniejszej publikacji, struktura książki podzielona została na pięć tematycznych części: ustrój szkolny, program nauczania, szkoła a uczniowie, organizacja pracy szkoły, uwarunkowania społeczno-ekonomiczne oświaty.

W części 1 przedstawiono opracowania dotyczące porównawczego aspektu ustrojów szkolnych na przykładzie wybranych państw. Część 2 poświęcona zo- 
stała programom nauczania w szkolnictwie zawodowym i ogólnokształcącym w wybranych krajach. W części 3 zamieszczono materiały dotyczące relacji szkoła-uczeń ze szczególnym uwzględnieniem rozwiązań skierowanych na udzielanie pomocy uczniowi w poszukiwaniu jego talentów i wskazywaniu przyszłej drogi zawodowej. Część 4 poświęcona została aspektom organizacyjnym pracy szkoły, m.in. kształceniu na odległość i wymiarowi czasu pracy nauczycieli. W części 5 przedstawiono materiały z obszaru społeczno-ekonomicznych uwarunkowań oświaty. Znalazły się tu między innymi opracowania na temat wybranych zagadnień prawa adopcyjnego, czy monitorowania losów dziecka z użyciem baz danych w wybranych państwach. Uzupełnieniem publikacji jest indeks rzeczowy, którego zadaniem jest pomóc czytelnikowi odnaleźć szukane przez niego informacje.

Trafiająca na rynek wydawniczy książka skierowana jest do osób zawodowo zajmujących się zagadnieniami polityki oświatowej, a więc problematyką z tak szerokich obszarów tematycznych, jak edukacja, wychowanie, kształcenie, opieka społeczna. Opracowanie powstało z myślą o jego przydatności dla przedstawicieli władz ustawodawczych i wykonawczych w pracach nad zagadnieniami oświatowymi. Stanowi także wygodne źródło informacji przedstawicieli władz samorządowych, dyrektorów szkół, nauczycieli, pedagogów, doradców zawodowych, wykładowców akademickich oraz studentów kierunków pedagogicznych. 



\title{
Część 1
}

\section{Ustrój szkolny}

\author{
Part 1 \\ School system
}





\title{
1.1. Obowiązek szkolny w Unii Europejskiej
}

\author{
Compulsory education in European Union
}

\begin{abstract}
W opracowaniu podjęto próbę porównawczej prezentacji wymiaru długości realizacji obowiązku szkolnego we wszystkich systemach edukacyjnych państw Unii Europejskiej. Przedstawiono krótki rys historyczny kształtowania obowiązku szkolnego. Wyjaśniono znaczenie najważniejszych pojęć związanych z zagadnieniem obowiązku szkolnego, obowiązku nauki, szkoły obowiązkowej i współczynnika skolaryzacji. W podsumowaniu zwrócono uwagę na współczesne tendencje uwidaczniające się w wyniku realizacji obowiązku szkolnego.
\end{abstract}

Słowa kluczowe: oświata, system szkolny, obowiązek szkolny, Unia Europejska

The paper reviews and compares the length of compulsory schooling in all education systems of EU member states. The author outlines the history of compulsory education and gives descriptions of terms related to compulsory schooling, schooling duty and scholarisation. He concludes with recent trends in EU compulsory education.

Keywords: education, school system, compulsory education, European Union

\section{Krótka historia obowiązku szkolnego}

Pierwsze administracyjne próby wprowadzenia obowiązku szkolnego można odnaleźć w Europie w prawodawstwie księstw: Weimarskiego (1619 r.), Gotajskiego (1642 r.) i Brandenburgii (1698 r.)ํ. W Księstwie Oleśnickim w 1683 roku próbę wprowadzenia przymusu szkolnego dla dzieci w wieku od 6 do 9 lat podjęto, publikując Książęcy oleśnicki statut niemieckich szkół miejskich i wiejskich (niem. Fuerstlich Oelsnische deutsche Stadt und Landschulordnung) ${ }^{2}$. W Prusach

1 Opracowanie przygotowano na podstawie ekspertyzy Biura Analiz Sejmowych nr 2368/08 z 14 października 2008 r. D. Dziewulaka zatytułowanej Informacja dotyczaca realizacji obowiązku szkolnego przez uczniów od 6. roku życia w wybranych krajach Unii Europejskiej (Francja, Hiszpania, Niemcy, Wielka Brytania, Włochy) oraz artykułu tegoż autora Obowiazek szkolny w Unii Europejskiej, „Analizy BAS” 2010, nr 9(34).

2 http://www.olesnica.org/Z_przeszlosci_olesnickiego_szkolnictwa.htm. 
w 1717 roku król Fryderyk Wilhelm I Hohenzollern wydał nakaz uczęszczania do szkół elementarnych dla wszystkich dzieci w całym kraju. W Danii w 1739 roku Chrystian VI Oldenburg wprowadził powszechny obowiązek nauki w szkołach podstawowych, jednak nakaz ten nie był respektowany.

Tak więc pierwsze koncepcje wprowadzenia obowiązku szkolnego sięgają XVII wieku. Jednak wszystkie próby wprowadzenia go przed Wielką Rewolucją Francuską 1789 roku udawały się jedynie częściowo lub były zawieszane między innymi z powodu niemożności realizacji (np. brak infrastruktury szkolnej). Sytuacja się zmieniła wraz ze zmianami ustrojowymi i technologicznymi wieku pary. W XIX wieku przymus szkolny został wprowadzony na stałe do większości systemów prawnych (1819 r. - Prusy, 1869 r. - Austria, 1872 r. - Japonia, 1876 r. Wielka Brytania, 1882 r. - Francja, od 1848 r. do 1918 r. - USA, 1900 r. - Holandia, 1930 r. - ZSRR).

W Polsce wprowadzenie obowiązku szkolnego postulował już w 1555 roku Andrzej Frycz Modrzewski w dziele O naprawie Rzeczypospolitej (księga O szkole), jednak odpowiednie ustawodawstwo powstało dopiero pod zaborami. Udało się go wprowadzić zaborcom w 1825 roku w Wielkopolsce i na Pomorzu, a w 1873 roku w Galicji. W niepodległej II Rzeczypospolitej pierwszy siedmioletni obowiązek szkolny wprowadzony został dekretem Naczelnika Państwa w 1919 roku, a następnie ugruntowany na podstawie ustawy z 1922 roku o zakładaniu i utrzymywaniu publicznych szkół powszechnych. Ostatecznie siedmioletni obowiązek szkolny stał się podstawą ustroju szkolnego II Rzeczypospolitej za sprawą reformy szkolnej z 1932 roku (jej zasady obowiązywały do 1948 r.), opracowanej przez Janusza Jędrzejewicza, ówczesnego Ministra Wyznań Religijnych i Oświecenia Publicznego. Reforma usankcjonowana ustawą szkolną z 11 marca 1932 roku ujednolicała w znacznym stopniu cały system szkolny oraz ustanawiała powszechny obowiązek szkolny na szczeblu szkoły powszechnej (odpowiednik dzisiejszej szkoły podstawowej).

\section{Podstawowe pojęcia}

\section{Obowiqzek szkolny}

Obowiązek szkolny to przymus pobierania nauki w szkole od określonego wieku, przez ustaloną liczbę lat (zazwyczaj do ukończenia określonego roku życia, np. do pełnoletności) oraz w ustalonym zakresie i czasie. Są nim obciążeni rodzice lub prawni opiekunowie dziecka. 


\section{Obowiq̨zek nauki}

W niektórych ustrojach szkolnych obok obowiązku szkolnego występuje także pojęcie obowiązku nauki (lub nauczania), który określa przymus pobierania nauki (w szkole lub poza nią) do określonego przez prawo wieku. Obowiązek szkolny, o którym tu mowa, często nazywa się dla potrzeb opisu ustroju szkolnego - kształceniem obowiązkowym w pełnym wymiarze, a obowiązek nauki kształceniem obowiązkowym w niepełnym wymiarze.

\section{Szkoła obowiq̨zkowa}

Innym zagadnieniem łączącym się z tematyką obowiązku szkolnego jest pojęcie szkoły obowiązkowej. Szkoła obowiązkowa to cykl kształcenia, który obowiązkowo należy ukończyć, nawet jeśli uczeń nie podlega już obowiązkowi szkolnemu, gdyż na przykład osiągnął pełnoletność.

\section{Miara powszechności nauczania}

W polityce oświatowej do określania miary powszechności nauczania służą współczynniki skolaryzacji brutto i netto. Współczynnik skolaryzacji brutto jest to miara określająca relację liczby osób uczących się (stan na początku roku szkolnego) na danym szczeblu kształcenia (niezależnie od wieku) do liczby ludności (stan w dniu 31 grudnia) w grupie wieku określonej jako odpowiadająca temu poziomowi nauczania. Na przykład współczynnik skolaryzacji brutto dla poziomu polskiej szkoły podstawowej wylicza się, dzieląc liczbę wszystkich uczniów szkół podstawowych bez względu na wiek na początku danego roku szkolnego przez liczbę ludności w wieku 7-12 lat (wiek przypisany do tego poziomu) według stanu w dniu 31 grudnia tego samego roku (wynik podawany jest w ujęciu procentowym). Współczynnik skolaryzacji netto to miara określająca relację liczby osób (w danej grupie wieku) uczących się (stan na początku roku szkolnego) na danym poziomie kształcenia do liczby ludności (stan w dniu 31 grudnia) w grupie wieku określonej jako odpowiadającą temu poziomowi nauczania. Na przykład współczynnik skolaryzacji netto dla poziomu polskiej szkoły podstawowej wylicza się, dzieląc liczbę uczniów szkół podstawowych na początku danego roku szkolnego w wieku 7-12 lat (wiek przypisany do tego poziomu) przez liczbę ludności w wieku 7-12 lat według stanu w dniu 31 grudnia tego samego roku (wynik podawany jest w ujęciu procentowym). 
Chcąc zatem uzyskać informację na temat realizacji obowiązku szkolnego, czyli pobierania nauki przez uczniów w określonym wieku, należy określić współczynnik skolaryzacji netto dla określonego poziomu nauczania. W przypadku obowiązku szkolnego, który najczęściej obejmuje dwa poziomy nauczania, można wskazać odpowiedni współczynnik skolaryzacji dla szkolnictwa podstawowego i średniego.

W ustrojach edukacyjnych państw Unii Europejskiej (UE) obowiązek szkolny różni się wiekiem rozpoczęcia obowiązkowego cyklu kształcenia oraz długością jego trwania na poszczególnych szczeblach kształcenia, na których obowiązek taki jest obligatoryjny. Współczynnik skolaryzacji netto wskazuje, że w latach 2000-2006 obowiązek szkolny w wybranych krajach UE realizowany był na szczeblu szkolnictwa podstawowego na poziomie od $96 \%$ do prawie $100 \%{ }^{3}$ (w Polsce w roku szkolnym 2006/2007 wynosił 97,6\%" ${ }^{4}$ ), a na szczeblu szkolnictwa średniego oscylował na poziomie od $88 \%$ do prawie $100 \%{ }^{5}$ (w Polsce w roku szkolnym 2006/2007 wynosił 95,6\%6) w zależności od kraju.

\section{Obowiązek szkolny w państwach Unii Europejskiej ${ }^{7}$}

\section{Polska}

Obowiązek nauki i obowiązek szkolny reguluje w Polsce ustawa zasadnicza i ustawa o systemie oświaty. Konstytucja Rzeczypospolitej Polskiej z 2 kwietnia 1997 roku w rozdziale II „Wolności, prawa i obowiązki człowieka i obywatela” w art. 70 stwierdza: 1. Każdy ma prawo do nauki. Nauka do 18 roku życia jest obowiąkowa. Sposób wykonywania obowiazku szkolnego określa ustawa8.

Formy spełniania obowiązku szkolnego reguluje ustawa z 7 września 1991 roku o systemie oświaty (Dz.U. 2004, nr 256, poz. 2572, ze zm.) oraz ustawa z 19 marca 2009 roku o zmianie ustawy o systemie oświaty oraz o zmianie niektórych innych ustaw (Dz.U. nr 56, poz. 458). Czytamy w niej w art. 15 ust. 2: Obowiqzek szkolny dziecka rozpoczyna się z początkiem roku szkolnego $w$ roku kalenda-

3 The State of the World's Children 2008, UNICEF 2008.

4 Oświata i wychowanie w roku szkolnym 2007/2008, Zakład Wydawnictw Statystycznych, Warszawa 2008, s. 33.

5 Tamże.

6 Tamże.

7 Na podstawie materiałów Eurydice, http://www.eurydice.org.pl.

8 http://www.sejm.gov.pl/prawo/konst/polski/kon1.htm. 
rzowym, w którym dziecko kończy 6 lat, oraz trwa do ukończenia gimnazjum, nie dłużej jednak niż do ukończenia 18 roku życia.

Ustawa określiła też możliwość wcześniejszego rozpoczęcia nauki w szkole podstawowej, jeżeli rodzice dziecka wystąpią z takim wnioskiem. Naukę w szkole podstawowej może rozpocząć dziecko, które w danym roku kalendarzowym kończy 5 rok życia, jeżeli wykazuje psychofizyczną dojrzałość do podjęcia nauki szkolnej. Decyzję o wcześniejszym przyjęciu dziecka do szkoły podstawowej podejmuje dyrektor szkoły po zasięgnięciu opinii poradni psychologiczno-pedagogicznej, natomiast decyzję w sprawie odroczenia obowiązku szkolnego podejmuje dyrektor publicznej szkoły podstawowej, w rejonie której dziecko mieszka, po zasięgnięciu opinii poradni psychologiczno-pedagogicznej.

W Polsce mamy zatem do czynienia z ustawową realizacją dwóch obowiązków:

- ustawowym dziesięcioletnim obowiązkiem szkolnym trwającym od 6 do 16 roku życia (obejmującym szkołę podstawową i gimnazjum) oraz

- konstytucyjnym obowiązkiem nauki trwającym do 18 roku życia.

Obowiązek szkolny spełnia się więc przez uczęszczanie do szkoły podstawowej i gimnazjum, publicznych albo niepublicznych, a po ukończeniu gimnazjum podlega się obowiązkowi nauki, który spełnia się przez:

- uczęszczanie do publicznej lub niepublicznej szkoły ponadgimnazjalnej,

- uczęszczanie na zajęcia realizowane w formach pozaszkolnych w placówkach publicznych i niepublicznych posiadających odpowiednią akredytację (szkoły dla dorosłych, placówki kształcenia ustawicznego, placówki kształcenia praktycznego, ośrodki dokształcania i doskonalenia zawodowego),

- uczęszczanie na zajęcia realizowane w ramach działalności oświatowej prowadzonej przez osoby prawne lub fizyczne,

- realizowanie przygotowania zawodowego u pracodawcy.

Uczeń, który ukończył szkołę ponadgimnazjalną przed ukończeniem 18 roku życia, może również spełniać obowiązek nauki przez uczęszczanie do szkoły wyższej.

\section{Austria}

Obowiązek szkolny trwa 9 lat i rozpoczyna się w 6 roku życia. Szczeble kształcenia objęte obowiązkiem szkolnym to:

- Szkoła podstawowa (Volksschule lub Grundschule) - wiek: 6-10 lat,

- Szkoła średnia I stopnia - wiek: 10-14 lat: 
- szkoła podstawowa - poziom wyższy (Volksschule),

- szkoła ogólnokształcąca średnia I stopnia - (Hauptschule),

- szkoła ogólnokształcąca średnia o profilu akademickim - I stopień (Allgemein bildende höhere Schule),

- Klasa IX - wiek: od 14 roku życia:

- szkoła politechniczna prowadząca wstępne roczne kształcenie zawodowe, tzw. rok przedzawodowy (Polytechnische Schule) lub dowolna inna szkoła średnia II stopnia.

Dzieci rozpoczynające naukę w szkole podstawowej muszą ukończyć szósty rok życia do 1 września roku, w którym rozpoczynają I klasę. Dzieci urodzone między 1 września a 31 grudnia mogą rozpocząć naukę wcześniej, jeżeli są dostatecznie dojrzałe umysłowo i fizycznie. Przejście do szkoły średniej I stopnia wymaga ukończenia z pozytywnymi ocenami IV klasy szkoły podstawowej. Do Allgemein bildende höhere Schule przyjmuje się na podstawie wyników w nauce lub wyników sprawdzianu wstępnego. Kształcenie obowiązkowe jest bezpłatne we wszystkich szkołach, z wyjątkiem szkół prywatnych.

\section{Belgia}

Szkolnictwo w Belgii odzwierciedla strukturę narodowo-językową państwa, w której istnieje podział na francuskojęzycznych Walonów, flamandzkojęzycznych Flamandów i mniejszość niemieckojęzyczną. Każda z tych grup ma zapewniony autonomiczny system kształcenia. Wspólnoty: Flamandzka, Francuska i Niemieckojęzyczna posiadają niezależne władze oświatowe - w tym odrębnych ministrów oświaty.

\section{Wspólnota Flamandzka Belgii (język holenderski)}

W obszarze Wspólnoty Flamandzkiej obowiązek szkolny trwa 9 lat i rozpoczyna się w 6 roku życia. Następnie uczniowie objęci są ustawowym obowiązkiem nauczania do ukończenia 18 lat. Szczeble kształcenia objęte obowiązkiem szkolnym to:

- Szkoła podstawowa (Basis onderwijs) - wiek: 6-12 lat,

- Szkoła średnia (Secundair onderwijs) - wiek: 12-16 lub do 18 lat.

Naukę w szkole podstawowej rozpoczyna się na ogół we wrześniu tego roku, w którym przypadają szóste urodziny dziecka. Nie obowiązują specjalne kryteria przyjęć. Do szkoły średniej przyjmuje się przeważnie dzieci w wieku 12 lat, 
a warunkiem przyjęcia jest w większości przypadków posiadanie świadectwa ukończenia szkoły podstawowej (Getuigschrift basisonderwijs). Kształcenie obowiązkowe jest bezpłatne.

\section{Wspólnota Francuska Belgii (język francuski)}

W obszarze Wspólnoty Francuskiej nauka jest obowiązkowa w wieku od 6 do 18 lat. Każda osoba niepełnoletnia kształci się więc obowiązkowo przez 12 lat. Na ten obowiązek składa się obowiązek szkolny, który wynosi 9 lat oraz trzyletni obowiązek nauczania. Obowiązek szkolny, czyli kształcenie obowiązkowe w pełnym wymiarze, odbywa się do wieku 15 lat i obejmuje sześć lat kształcenia w szkole podstawowej (przy czym w wyjątkowych wypadkach może trwać siedem, osiem lub dziewięć lat) oraz co najmniej dwa pierwsze lata kształcenia w pełnym wymiarze w szkole średniej. Obowiązkiem szkolnym nie są w żadnym wypadku objęte osoby w wieku powyżej 16 lat. Po ukończeniu kształcenia obowiązkowego w pełnym wymiarze rozpoczyna się kształcenie obowiązkowe w niepełnym wymiarze. Obowiązek nauki można wypełniać w formie kształcenia w pełnym wymiarze w szkole średniej lub zgodnie z planem zajęć o zmniejszonej liczbie godzin (w niepełnym wymiarze), bądź w ramach programu, który uznaje się za spełniający wymogi obowiązku nauki. Osoba niepełnoletnia może również wypełniać obowiązek nauki, kształcąc się w domu, jeżeli jest to zgodne z warunkami określonymi przez rząd. Szczeble kształcenia objęte obowiązkiem szkolnym to:

- Szkoła podstawowa - wiek: 6-12 lat,

- Szkolnictwo średnie - wiek: 12-15/16 lub do 18 lat.

Sześcioletnie kształcenie w szkole podstawowej jest podzielone na trzy dwuletnie etapy. W ramach kształcenia w szkole średniej wyodrębniono również trzy dwuletnie etapy. Nauka w szkole podstawowej rozpoczyna się we wrześniu roku kalendarzowego, w którym dzieci osiągają wiek 6 lat. Nie obowiązują żadne specjalne warunki przyjęć. Do szkoły średniej dzieci wstępują na ogół w wieku 12 lat. Warunkiem przyjęcia do I klasy szkoły średniej jest posiadanie świadectwa ukończenia szkoły podstawowej (certificat d'études de base, CEB). Rodzice mogą sami wybrać dla swego dziecka zarówno szkołę podstawową, jak i średnią. Kształcenie obowiązkowe jest bezpłatne, a koszty niektórych pomocy szkolnych pokrywają organizatorzy kształcenia. Rodzice ponoszą jednakże pewne wydatki, m.in. koszty wstępu na basen, koszty związane z imprezami kulturalnymi i sportowymi itp. 


\section{Wspólnota Niemieckojęzyczna Belgii (język niemiecki)}

W obszarze Wspólnoty Niemieckojęzycznej kształcenie w pełnym wymiarze jest obowiązkowe w wieku od 6 do 15 lub 16 lat. Następnie nauka jest obowiązkowa do czasu ukończenia 18 lat. Uczniowie, którzy nie ukończyli pierwszych dwóch klas szkoły średniej do czasu ukończenia 15 lat, obowiązkowo kształcą się w pełnym wymiarze co najmniej do czasu ukończenia 16 lat. Szczeble kształcenia objęte obowiązkiem szkolnym to:

- Szkoła podstawowa (Primarschule) - wiek: 6-12 lat,

- Szkoła średnia (Sekundarschule) - wiek: 12-16 lub 18 lat.

Sześcioletnia szkoła podstawowa jest podzielona na dwuletnie etapy, przy czym klasy mogą być pogrupowane w sposób odbiegający od tego podziału. Szkoła średnia jest również podzielona na trzy dwuletnie etapy.

Nauka w szkole podstawowej rozpoczyna się zwykle we wrześniu tego roku, w którym przypadają szóste urodziny dziecka. Nie obowiązują specjalne kryteria przyjęć. Do szkoły średniej przyjmuje się przeważnie dzieci w wieku 12 lat, a warunkiem przyjęcia jest zwykle posiadanie świadectwa ukończenia szkoły podstawowej (Abschlusszeugnis der Grundschule). Kształcenie jest bezpłatne.

\section{Bułgaria}

Kształcenie jest obowiązkowe dla dzieci i młodzieży w wieku od 6 lub 7 lat (zgodnie z decyzją rodziców), trwa do 16 roku życia i kończy się w szkole średniej II stopnia. Szczeble kształcenia objęte obowiązkiem szkolnym to:

- Szkoła podstawowa (начално училище) - wiek: 6/7-9/10 lat,

- Szkoła średnia ogólnokształcąca I stopnia (прогимназия) - wiek: 10/1114/15 lat,

- Szkoły techniczne/zawodowe (професионално технически училища) wiek: 10/11-13/14 lat,

- Szkoły średnie II stopnia - wiek: 14/15-17/18 lat.

Kształcenie obowiązkowe na poziomie obejmującym szkołę podstawową, tj. klasy I-IV, i szkołę średnią I stopnia, tj. klasy V-VIII, jest bezpłatne we wszystkich szkołach z wyjątkiem prywatnych. 


\section{Cypr}

Obowiązek szkolny wynosi 10 lat i obejmuje uczniów od 5 do 15 roku życia. Szczeble kształcenia objęte obowiązkiem szkolnym to:

- Szkoła podstawowa (Dimotiko Scholeio) - wiek: od 5 lat 8 miesięcy do 11 lat 8 miesięcy,

- Szkoła średnia ogólnokształcąca I stopnia (Gymnasio) - wiek: od 11 lat 8 miesięcy do 15 lat.

Jedynym kryterium przyjęć do szkoły obowiązkowej jest wiek ucznia. Kształcenie w szkołach publicznych jest bezpłatne dla wszystkich uczniów. Podstawą przyjęcia do Gymnasia jest świadectwo ukończenia szkoły podstawowej.

\section{Czechy}

Obowiązek szkolny trwa 9 lat i obejmuje uczniów w wieku od 6 do 15 roku życia. Wszyscy uczniowie rozpoczynają naukę w szkole powszechnej (základni škola), a w drugim etapie mogą uczęszczać do gymnázium. Szczeble kształcenia objęte obowiązkiem szkolnym to:

- Szkoła podstawowa i średnia I stopnia (základni škola) - wiek: I etap 6-10 lat, II etap 11-15 lat,

- Szkoła średnia ogólnokształcąca I stopnia (gymnázium) - wiek: 11-13/15 lat.

Szkoły są zrejonizowane, ale rodzice mają prawo wybrać dowolną szkołę. Uczniowie mogą przejść z základni škola po ukończeniu V klasy do ośmioletniego gymnázium lub po ukończeniu VII klasy do sześcioletniego gymnázium, pod warunkiem zdania egzaminu wstępnego, przeprowadzanego przez szkołę. W gymnázium kształci się niecałe 10\% odpowiedniej grupy wiekowej uczniów.

\section{Dania}

Obowiązek szkolny trwa 10 lat. Kształcenie jest obowiązkowe w wieku od 6 do 16 lat. Większość szkół folkeskole prowadzi nieobowiązkową klasę zerową, a wiele również nieobowiązkową klasę X. Szczeble kształcenia objęte obowiązkiem szkolnym to szkoła podstawowa i średnia I stopnia (folkeskole) - wiek: 6-16/17 lat.

Dzieci rozpoczynają kształcenie obowiązkowe w sierpniu tego roku kalendarzowego, w którym przypadają ich szóste urodziny. Rodzice mogą wybrać dowolną szkołę na terenie swojej gminy. Kształcenie w folkeskole jest bezpłatne. 


\section{Estonia}

Obowiązek szkolny trwa 10 lat. Kształcenie jest obowiązkowe od 7 roku życia do czasu ukończenia szkoły podstawowej i średniej I stopnia lub do osiągnięcia wieku 17 lat. Szczeble kształcenia objęte obowiązkiem szkolnym to szkoła podstawowa i średnia I stopnia (Põhiharidus) - wiek: 7-15 lat.

Naukę w szkole rozpoczynają obowiązkowo dzieci, które osiągnęły wiek 7 lat przed 1 października danego roku. Samorządy lokalne są zobowiązane zagwarantować miejsce w szkole każdemu dziecku. Szkoły muszą zapewnić miejsca dla wszystkich dzieci w swoim rejonie. Rodzice mogą zapisać swoje dziecko do dowolnej szkoły, jeśli jest w niej miejsce. Kształcenie obowiązkowe jest bezpłatne.

\section{Finlandia}

Obowiązek szkolny trwa w Finlandii 9 lat. Kształcenie jest obowiązkowe od 7 do 16 roku życia. Szczeble kształcenia objęte obowiązkiem szkolnym to:

- Szkoła podstawowa klasy I-VI (peruskoulu) - wiek: 7-12 lat,

- Szkoła podstawowa klasy VII-IX (grundskola) - wiek: 13-16 lat.

Ustawa o kształceniu obowiązkowym w Finlandii, która weszła w życie 1 stycznia 1999 r., nie wyodrębnia już w szkole powszechnej etapu niższego i wyższego. W ustawie stwierdza się jedynie, że kształcenie obowiązkowe trwa dziewięć lat, oraz że zajęcia dydaktyczne są na ogół prowadzone przez wychowawców klas w klasach I-VI i przez nauczycieli przedmiotu w klasach VII-IX.

Uczniowie muszą rozpocząć kształcenie obowiązkowe w roku, w którym przypadają ich siódme urodziny. Około 1\% rozpoczyna naukę w szkole wcześniej, wymaga to jednak zaświadczenia potwierdzającego dojrzałość szkolną dziecka. Kształcenie obowiązkowe jest w całości bezpłatne. Władze lokalne przydzielają każdemu dziecku miejsce w szkole znajdującej się w pobliżu jego miejsca zamieszkania, ale rodzice mogą wybrać szkołę powszechną zgodnie ze swymi preferencjami.

\section{Francja}

Obowiązek szkolny trwa 10 lat. Kształcenie jest obowiązkowe dla uczniów w wieku od 6 do 16 lat. Szczeble kształcenia objęte obowiązkiem szkolnym to:

- Szkoła elementarna (école élementaire) - wiek: 6-11 lat,

- Szkoła średnia I stopnia (collège) - wiek: 11-15 lat. 
- Szkoła średnia II stopnia (lycée): na ogół w wieku 15 lat uczniowie wstępują do liceum ogólnokształcącego i technicznego (lycée d'enseignement général et technologique) lub liceum zawodowego (lycée professionnel), w którym rozpoczynają piąty rok nauki w szkole średniej (classe de seconde). W momencie ukończenia tej klasy osiągają wiek odpowiadający zakończeniu obowiązku szkolnego. Dalsza edukacja nie jest obowiązkowa.

Rekrutacja uczniów do szkół państwowych odbywa się zgodnie z zasadą rejonizacji. Uczniów zapisuje się na ogół do école élementaire, collège i lycée w rejonie, w którym mieszkają ich rodzice. Kształcenie w szkołach państwowych jest bezpłatne. Rodzice mogą również zapisać swoje dziecko do dowolnej szkoły prywatnej, pod warunkiem że są w niej wolne miejsca. Opłaty w szkołach, które zawarły z państwem umowę na dofinansowanie, nie są zbyt wysokie, ponieważ placówki te otrzymują od państwa znaczne wsparcie finansowe.

\section{Grecja}

Obowiązek szkolny trwa 10 lat. Kształcenie jest obowiązkowe dla uczniów w wieku od 5 do 15 lat. Szczeble kształcenia objęte obowiązkiem szkolnym to:

- Przedszkole (nipiagogeio) - wiek: 3/4-5/6 lat,

- Szkoła podstawowa (dimotiko scholio) - wiek: 5-12 lat,

- Szkoła średnia I stopnia (gymnasio) - wiek: 12-15 lat.

Edukacja przedszkolna trwa dwa lata, od wieku 3 lub 4 do 5 lub 6 lat, i jest prowadzona w przedszkolach, które stanowią samodzielne placówki lub część szkoły podstawowej. Do państwowych szkół podstawowych i średnich przyjmuje się wyłącznie uczniów mieszkających w rejonie szkoły. Do szkół średnich I stopnia uczniów przyjmuje się automatycznie, po ukończeniu przez nich szkoły podstawowej. We wszystkich państwowych szkołach podstawowych i średnich kształcenie jest bezpłatne.

\section{Hiszpania}

Obowiązek szkolny trwa 10 lat. Kształcenie jest obowiązkowe dla uczniów w wieku od 6 do 16 roku życia. Szczeble kształcenia objęte obowiązkiem szkolnym to:

- Szkoła podstawowa - wiek: 6-12 lat,

- Szkoła średnia I stopnia - wiek: 12-16 lat.

Kształcenie obowiązkowe dzieli się na dwa poziomy: kształcenie na poziomie podstawowym, składające się z trzech dwuletnich etapów, oraz kształcenie na poziomie średnim I stopnia, trwające cztery lata. 
Naukę w szkole podstawowej mogą rozpocząć dzieci, które ukończyły 6 lat. W wypadku gdy liczba kandydatów jest większa niż liczba miejsc, stosuje się określone kryteria przyjęć (dochód w rodzinie, rejon szkoły i rodzeństwo w szkole). Przejście ze szkoły podstawowej do szkoły średniej I stopnia odbywa się automatycznie. Kształcenie obowiązkowe jest bezpłatne zarówno w placówkach publicznych, jak i placówkach prywatnych finansowanych ze środków publicznych.

\section{Holandia}

Kształcenie jest obowiązkowe dla uczniów w wieku od 5 do 18 roku życia. Obowiązek szkolny trwa ogółem 13 lat. Każde dziecko obowiązkowo uczęszcza do szkoły w pełnym wymiarze od pierwszego szkolnego dnia miesiąca następującego po jego piątych urodzinach. Dzieci muszą kształcić się w szkole w pełnym wymiarze przez 12 pełnych lat szkolnych i w każdym przypadku do końca roku szkolnego, w którym kończą 16 lat. Następnie powyższy obowiązek jest uzupełniony obowiązkiem w niepełnym wymiarze w placówce prowadzącej kształcenie w ramach obowiązku nauki co najmniej dwa razy w tygodniu przez kolejny rok. Młodzi ludzie, którzy odbywają kształcenie praktyczne na podstawie odpowiedniej umowy w określonym sektorze zatrudnienia, uczęszczają na zajęcia raz w tygodniu w ramach urlopu szkoleniowego i pracują w pozostałe dni tygodnia. Szczeble kształcenia objęte obowiązkiem szkolnym to:

- Szkolnictwo podstawowe (Primair onderwijs) - wiek: 5-12 lat,

- Szkolnictwo średnie (Voortgezet onderwijs):

- szkoły średnie przygotowujące do podjęcia studiów wyższych (Voorbereidend wetenschappelijk onderwijs, VWO) - wiek: 12-18 lat,

- szkoły średnie prowadzące kształcenie ogólne na wyższym etapie (Hoger algemeen voortgezet onderwijs, HAVO) - wiek: 12-17 lat,

- szkoły średnie prowadzące kształcenie przedzawodowe (Voorbereidend middelbaar beroepsonderwijs, VMBO) - wiek: 12-16,

- szkoły średnie prowadzące kształcenie specjalne (Speciaal voortgezet onderwijs) - wiek: 12-18/20 lat.

Do szkoły podstawowej przyjmuje się dzieci w wieku co najmniej 4 lat. Kształcenie w szkole podstawowej jest bezpłatne. Do szkoły średniej przyjmuje się uczniów po ukończeniu szkoły podstawowej lub specjalnej szkoły podstawowej, na ogół w wieku 12 lat. Decyzje w sprawie przyjęcia do szkoły VMBO, HAVO lub VWO podejmuje organ prowadzący (zarząd szkoły), który może powołać komisję rekrutacyjną, aby podejmowała takie decyzje w jego imieniu. Komisja rekruta- 
cyjna składa się z dyrektora i jednego lub kilku nauczycieli z danej szkoły. W jej skład mogą także wchodzić dyrektorzy i nauczyciele ze szkół podstawowych. Dyrektor szkoły podstawowej ucznia ma obowiązek przygotować raport oceniający jego zdolności do nauki i poziom osiągnięć. Rekrutacja do szkół VMBO, HAVO i VWO odbywa się na podstawie oceny predyspozycji uczniów. W tym celu najczęściej w ostatniej klasie szkoły podstawowej przeprowadza się centralnie opracowane sprawdziany, które pozwalają ocenić poziom wiedzy i umiejętności uczniów

\section{Irlandia}

Obowiązek szkolny trwa 10 lat. Kształcenie jest obowiązkowe dla uczniów w wieku od 6 do 16 roku życia. Szczeble kształcenia objęte obowiązkiem szkolnym to:

- Szkoła podstawowa - wiek: 6-12 lat,

- Szkoły ogólnokształcące lub zawodowe o różnym profilu kształcenia (Community school, Comprehensive school, Vocational school, Voluntary secondary school) - wiek: 12-16 lat.

W Irlandii do szkoły przyjmuje się dzieci w wieku od 4 lat (chociaż kształcenie obowiązkowe rozpoczyna się dopiero $\mathrm{w}$ wieku 6 lat). Po ukończeniu szkoły podstawowej (w wieku 12 lat) uczniowie rozpoczynają naukę w pierwszym cyklu (junior cycle) szkoły średniej. Rodzice mogą wybrać szkołę. Kształcenie jest bezpłatne we wszystkich szkołach z wyjątkiem szkół finansowanych ze środków prywatnych.

\section{Litwa}

Obowiązek szkolny trwa 9 lat. Kształcenie jest obowiązkowe dla uczniów w wieku od 7 do 16 roku życia. Szczeble kształcenia objęte obowiązkiem szkolnym to:

- Szkoła podstawowa (pradinè mokykla) - wiek: 7-10 lat,

- Szkolnictwo średnie:

- szkoła ogólnokształcąca średnia I stopnia (pagrindinè mokykla) - wiek: 10-17 lat,

- szkoła ogólnokształcąca średnia I stopnia (gimnazija) - wiek: 15-17 lat,

- szkoła zawodowa średnia I stopnia (profesinè mokykla) - wiek: 15-17 lat,

- szkoła ogólnokształcąca średnia I stopnia - wiek: 11/12-22 lata.

Kształcenie w publicznych szkołach podstawowych i średnich I stopnia jest bezpłatne. Niektóre Gimnazija przeprowadzają selekcję na podstawie ustalonych 
wymogów, określających przedział ocen kwalifikujących z poszczególnych przedmiotów i z uwzględnieniem na przykład specjalnych potrzeb edukacyjnych.

\section{Luksemburg}

Obowiązek szkolny trwa 11 lat. Kształcenie jest obowiązkowe dla uczniów w wieku od 4 do 15 roku życia. Szczeble kształcenia objęte obowiązkiem szkolnym to:

- Przedszkole (Spillschoul) - wiek: 4-6 lat,

- Szkoła podstawowa (Enseignement fondamental cycle 2, 3, 4) - wiek: 6-12 lat,

- Szkoła średnia (Lycee) - wiek: 12-15 lat.

Do placówek przedszkolnych przyjmuje się dzieci, które do 1 września danego roku ukończyły 4 lata. Dzieci przyjmowane do szkoły podstawowej muszą mieć ukończone 6 lat. Przyjęcie do szkoły średniej wymaga pozytywnej opinii wydawanej na zakończenie szkoły podstawowej. Uczniowie placówek przedszkolnych i szkół podstawowych uczęszczają obowiązkowo do placówki w swym rejonie, w pobliżu miejsca zamieszkania. Na poziomie średnim nie istnieją ograniczenia dotyczące wyboru szkoły ani formalnych procedur przyjęć. Kształcenie we wszystkich państwowych placówkach przedszkolnych oraz szkołach podstawowych i średnich jest bezpłatne.

\section{Łotwa}

Obowiązek szkolny trwa 11 lat. Kształcenie jest obowiązkowe dla uczniów w wieku od 5 do 16 roku życia. Szczeble kształcenia objęte obowiązkiem szkolnym to:

- Pirmsskolas (przedszkola, centra konsultacyjne) - wiek: 5-7 lat,

- Sākumskolas (I etap kształcenia obowiązkowego) - wiek: 7-16 lat,

- Pamatskolas (pełny cykl kształcenia obowiązkowego) - wiek: 3-16 lat,

- Vidusskolas (pełny cykl kształcenia obowiązkowego - szkoły te prowadzą nie tylko kształcenie obowiązkowe, ale również kształcenie na poziomie średnim II stopnia) - wiek: 16-19 lat.

Uczniowie, którzy nie odbyli pełnego cyklu kształcenia obowiązkowego, mogą również ukończyć ten cykl w niektórych szkołach zawodowych.

Dzieci są obowiązkowo zapisywane przez rodziców do wybranej placówki po osiągnięciu wieku 5 lat, przy czym każde dziecko ma prawo uczęszczać do szkoły położonej najbliżej swego miejsca zamieszkania. W szkołach publicznych kształcenie jest bezpłatne dla wszystkich uczniów. Publiczne placówki edukacyjne prowadzące kształcenie obowiązkowe nie mogą przeprowadzać sprawdzianów wstępnych. 


\section{Malta}

Obowiązek szkolny trwa 11 lat. Kształcenie jest obowiązkowe dla uczniów w wieku od 5 do 16 roku życia. Szczeble kształcenia objęte obowiązkiem szkolnym to:

- Szkoła podstawowa (primary school) - wiek: 5-11 lat,

- Szkoła średnia (Junior Liceums, secondary schools, Boys'/Girls' Schools) wiek: 11-16 lat.

W sektorze państwowym kształcenie na poziomie średnim prowadzą trzy rodzaje szkól: Junior Lyceums (prowadzące kształcenie ogólne na wyższym poziomie niż w szkołach średnich), secondary schools (szkoły średnie) oraz Boys'/ Girls’ Schools (szkoły dla chłopców/dziewcząt prowadzące kształcenie ogólne dla uczniów, którzy nie uzyskują odpowiednich wyników).

Państwowe szkoły podstawowe istnieją praktycznie w każdym mieście i każdej wsi, natomiast państwowe szkoły średnie funkcjonują na szczeblu regionalnym, a ich uczniowie rekrutują się z wielu szkół podstawowych. Rodzice mieszkający w danej miejscowości wysyłają swoje dzieci do miejscowej szkoły podstawowej. Po jej ukończeniu uczniowie przechodzą do szkoły średniej. Przyjęcie do Junior Lyceum jest uzależnione od dobrego opanowania pięciu przedmiotów. Z pięciu przedmiotów bowiem organizuje się ogólnokrajowe egzaminy wstępne, a warunkiem przyjęcia do Junior Lyceum jest uzyskanie pozytywnych wyników ze wszystkich tych przedmiotów. Uczniowie, którzy nie uzyskali odpowiednich wyników, przechodzą do Boys'/Girls’ Schools. Do szkół średnich przyjmuje się zgodnie z zasadą rejonizacji - rejon szkoły średniej obejmuje grupę położonych w okolicy szkół podstawowych.

\section{Niemcy}

W Niemczech długość trwania obowiązku szkolnego zależna jest od landu i rodzaju kształcenia. Kształcenie w pełnym wymiarze jest obowiązkowe dla uczniów od 6 do 15 lub 16 roku życia, a kształcenie w niepełnym wymiarze obowiązuje od 6 do 18 roku życia. Obowiązek szkolny obejmuje następujące szczeble kształcenia:

- Szkoła podstawowa (Grundschule) - wiek: 6-10 lat (6-12 Berlin i Brandenburgia),

- Szkoły średnie I stopnia (Orientierungsstufe, tzw. faza orientacji w różnych rodzajach szkół lub jako odrębna jednostka organizacyjna) - wiek: 10-12 lat,

- Szkoły średnie I stopnia - Gymnasium, Realschule, Hauptschule, Gesamtschule (rodzaje szkół prowadzące kilka cykli kształcenia) - wiek: 10/12-15/16 lat,

- Szkoły średnie II stopnia - wiek: 15/16-18/19 lat. 
Na ogół dzieci przyjmuje się do Grundschule od 6 lat. Dzieci objęte obowiązkiem nauki szkolnej wstępują do jednakowej dla wszystkich lokalnej szkoły podstawowej. Przejście ze szkoły podstawowej do jednej z kilku rodzajów szkół średnich odbywa się zgodnie z różnymi przepisami, zależnie od ustawodawstwa danego landu. O wyborze szkoły średniej I stopnia decydują rodzice, na podstawie oceny dokonanej przez szkołę podstawową. Przyjęcie do różnych szkół średnich może być uzależnione od wyników w nauce i/lub decyzji władz edukacyjnych. Kształcenie obowiązkowe jest w całości bezpłatne.

\section{Portugalia}

Obowiązek szkolny trwa 9 lat. Kształcenie jest obowiązkowe dla uczniów w wieku od 6 do 15 roku życia. Uczniowie, którzy osiągnęli limit wieku kształcenia obowiązkowego (15 lat), a nie ukończyli z pozytywnymi ocenami ostatniej klasy w III cyklu, mogą kontynuować kształcenie obowiązkowe w ramach kształcenia dorosłych (Educação recorrente). Szczeble kształcenia objęte obowiązkiem szkolnym to dziewięcioletnia szkoła podstawowa (Ensino básico) obejmująca poziom podstawowy i średni I stopnia podzielone na trzy cykle:

- I cykl - wiek: 6-10 lat,

- II cykl - wiek: 10-12 lat,

- III cykl - wiek: 12-15 lat.

Uczniów, którzy osiągają wiek 6 lat, do 15 września obowiązkowo zapisuje się do I klasy w tym samym roku kalendarzowym. Kształcenie w ramach I cyklu mogą również rozpocząć dzieci, które ukończą 6 lat w okresie między 16 września a 31 grudnia, pod warunkiem że w corocznym terminie zapisów ich rodzice lub opiekunowie złożą podanie do szkoły położonej najbliżej ich miejsca zamieszkania (lub miejsca pracy). Nauka w szkołach państwowych jest bezpłatna.

\section{Rumunia}

Obowiązek szkolny trwa 10 lat. Kształcenie jest obowiązkowe dla uczniów w wieku od 6 do 16 roku życia. Szczeble kształcenia objęte obowiązkiem szkolnym to:

- Szkoła podstawowa (școală primară) - wiek: 6-10 lat,

- Szkoła średnia ogólnokształcąca I stopnia - I etap (gimnaziu) - wiek: 10-14 lat,

- Szkoła średnia ogólnokształcąca I stopnia - II etap (Liceu - ciclul interior) wiek: 14-16 lat lub szkoła średnia zawodowa I stopnia (Şcoală de Arte şi Mesenii) - wiek: 14-16 lat. 
Kształcenie obowiązkowe podzielone jest na trzy etapy: szkoła podstawowa (4 lata), I etap szkoły średniej I stopnia - kształcenie ogólne (4 lata) i II etap szkoły średniej I stopnia, w ramach którego prowadzi się kształcenie ogólne, profilowane lub zawodowe (2 lata).

Po ukończeniu şcoală primară i gimnaziu uczniowie mogą kontynuować naukę w ramach niższego cyklu Liceu, w którym prowadzi się kształcenie ogólne, a program obejmuje elementy przygotowujące do wyboru profilu/specjalizacji w szkole średniej II stopnia, lub w Şcoală de Arte şi Meserii (szkole sztuk pięknych i rzemiosła), w której prowadzi się kształcenie zawodowe przygotowujące do podjęcia pracy w różnych zawodach.

\section{Słowacja}

Obowiązek szkolny trwa 10 lat. Kształcenie jest obowiązkowe dla uczniów w wieku od 6 do 16 roku życia. Szczeble kształcenia objęte obowiązkiem szkolnym to:

- Szkoła podstawowa (základná škola):

- I etap (klasy I-IV) - wiek: 6-9 lat,

- II etap (klasy V-IX) - wiek: 10-14/15 lat,

- Szkoła średnia I stopnia (gymnázium) - czas trwania w zależności wyboru toku nauczania; kształcenie ogólne na poziomie średnim I stopnia lub pierwszy i drugi rok kształcenia na poziomie średnim II stopnia - wiek: 10-12 lat lub 14/15/16 lat,

- Szkoła zawodowa średnia I stopnia (stredná odborná škola) (kształcenie zawodowe na poziomie średnim I stopnia i/lub pierwszy i drugi rok kształcenia zawodowego na poziomie średnim II stopnia) - wiek: 10-15/16 lat,

- Szkoła zawodowa średnia II stopnia (strednéodborné učilište) - wiek:15-16 lat,

- Szkoła zawodowa (učilište) - wiek 15-16 lat.

Kształcenie obowiązkowe jest bezpłatne, a jedyne kryterium przyjęć stanowi wiek ucznia. Warunkiem przyjęcia do sześcioletniego lub ośmioletniego gymnázium (w wieku 10, 12 lat) jest ukończenie IV lub VI klasy szkoły podstawowej i zdanie egzaminu wstępnego.

\section{Stowenia}

Obowiązek szkolny trwa 10 lat. Kształcenie jest obowiązkowe dla uczniów w wieku od 6 do 16 roku życia. Obowiązkiem szkolnym objęta jest jednolita dziewię- 
cioletnia struktura obejmująca szkołę podstawową i średnią I stopnia (Osnovna šola), która składa się na:

- I cykl (klasy I-III) - wiek: 6-8 lat,

- II cykl (klasy IV-VI) - wiek: 9-11 lat,

- III cykl (klasy VII-IX) - wiek: 12-14 lat.

Dzieci rozpoczynają kształcenie obowiązkowe w roku kalendarzowym, w którym kończą 6 lat. Zgodnie z przepisami, rodzice mają obowiązek i prawo wybrania szkoły publicznej lub prywatnej, bądź podjęcia decyzji o nauce w domu. Szkoła usytuowana w danym okręgu szkolnym jest zobowiązana przyjąć dzieci zamieszkałe na tym terenie, ale rodzice mogą wybrać inną placówkę, pod warunkiem wyrażenia przez nią zgody.

Ukończenie Osnovna šola umożliwia uczniom przejście do wybranej szkoły średniej II stopnia. Uczniowie, którzy spełnili określony w przepisach wymóg dotyczący kształcenia obowiązkowego i ukończyli co najmniej siedem klas w dziewięcioletniej szkole elementarnej, mogą kontynuować naukę w ramach krótkiego cyklu kształcenia zawodowego.

\section{Szwecja}

Obowiązek szkolny wynosi 9 lat. Kształcenie jest obowiązkowe dla uczniów w wieku od 7 do 16 roku życia. Obowiązkiem szkolnym objęta jest jednolita dziewięcioletnia szkoła podstawowa i średnia I stopnia (Grundskola). Uczęszczają do niej uczniowie od 7 do 16 roku życia. Istnieje możliwość rozpoczęcia nauki w szkole w wieku 6 lub 7 lat.

O wyborze szkoły decydują rodzice, ale w szkołach, w których liczba kandydatów przekracza liczbę miejsc, pierwszeństwo mają uczniowie mieszkający w pobliżu. Kształcenie we wszystkich szkołach jest bezpłatne.

\section{Węgry}

Obowiązek szkolny trwa 13 lat. Kształcenie jest obowiązkowe dla uczniów w wieku od 5 do 18 roku życia. Kształcenie zawodowe można rozpocząć dopiero w wieku 16 lat po zdobyciu wykształcenia ogólnego. Szczeble kształcenia objęte obowiązkiem szkolnym to:

- Przedszkole (tylko klasa zerowa) (óvoda) - wiek: 5-6/7 lat,

- Szkoła podstawowa i średnia I stopnia (általános iskola) - wiek: 6/7-14 lat:

- I cykl - wiek: 6-10 lat, 
- II cykl - wiek: 10-14 lat.

- Szkoła ogólnokształcąca średnia I i II stopnia (gimnázium) - wiek: 10/12/1418/19 lat,

- Szkoła średnia zawodowa (szakközépiskola) - wiek: 14-18/19/20,

- Szkoły zawodowe (szakiskola) - wiek: 14-18/19/20 lat.

Przepisy zobowiązują do prowadzenia bezpłatnego kształcenia obowiązkowego, ale szkoły prywatne mogą pobierać opłaty. Warunkiem przyjęcia do szkoły podstawowej jest posiadanie zaświadczenia o dojrzałości szkolnej dziecka. Szkoły mają obowiązek przyjęcia wszystkich spełniających warunki dzieci, które mieszkają w danym rejonie, ale rodzice mogą starać się o przyjęcie dziecka do dowolnej szkoły. Przyjęcia do szkół średnich odbywają się w drodze postępowania kwalifikacyjnego przeprowadzanego przez szkoły zgodnie z wytycznymi Ministerstwa Edukacji.

\section{Wielka Brytania}

Struktura organizacyjna systemu szkolnego Wielkiej Brytanii nie jest jednolita. Struktury oświatowe Anglii i Walii są relatywnie podobne, natomiast systemy szkolne Szkocji i Irlandii Północnej regulowane są odrębnymi ustawami. Występują w nich inne typy szkół, inne programy i odmienne organizacje pracy szkolnej.

\section{Szkocja}

Obowiązek szkolny w Szkocji wynosi 11 lat i obejmuje dzieci oraz młodzież w wieku od 5 do 16 roku życia. Obowiązek szkolny realizowany jest w ramach następujących szczebli kształcenia:

- Szkoła podstawowa (primary school) - wiek: 5-11 lat,

- Szkoła średnia I stopnia (secondary school) - wiek: 12-16 lat.

\section{Anglia, Walia i Irlandia Północna}

W Anglii i Walii kształcenie jest obowiązkowe dla uczniów w wieku od 5 do 16 lat, ale wiele dzieci rozpoczyna naukę już w klasie zerowej szkoły podstawowej w wieku 4 lat. W Irlandii Północnej obowiązek szkolny rozpoczyna się w wieku 4 lat i trwa do 16 roku życia. Obowiązek szkolny obejmuje następujące szczeble kształcenia: 
- Szkolnictwo podstawowe (primary education) - wiek: 5-11 lat (Anglia i Walia), wiek: 4-11 lat (Irlandia Północna),

- Szkolnictwo średnie I stopnia (secondary education) - wiek: 11-16 lat.

Większość uczniów przechodzi ze szkoły podstawowej (primary school) do szkoły średniej (secondary school) w wieku 11 lat, choć w niektórych regionach Anglii uczniowie uczęszczają do middle school w wieku, odpowiednio - od 8 lub 9 roku życia do 12 lub 13 roku życia. Wiele szkół średnich I stopnia prowadzi również kształcenie na poziomie średnim II stopnia dla uczniów będących w wieku powyżej 16 lat.

\section{Włochy}

Obowiązek szkolny wynosi 10 lat i obejmuje uczniów w wieku od 6 do 16 roku życia. Szczeble kształcenia objęte obowiązkiem szkolnym to:

- Szkoła podstawowa (scuola primaria) - wiek: 6-11 lat,

- Szkoła średnia I stopnia (scuola secondaria di I grado) - wiek: 11-16 lat.

Do obowiązkowej szkoły podstawowej przyjmuje się dzieci, które osiągnęły wiek 6 lat do 31 sierpnia przed rozpoczęciem danego roku szkolnego. Do scuola secondaria di I grado przyjmuje się dzieci, które ukończyły szkołę podstawową. Dzieci uczęszczają na ogół do najbliższej szkoły w swoim rejonie. Kształcenie obowiązkowe jest bezpłatne.

Tabela 1. Długość obowiązku szkolnego w państwach członkowskich Unii Europejskiej

\begin{tabular}{|l|c|c|}
\hline \multirow{2}{*}{ Kraj } & \multicolumn{2}{|c|}{ Obowiązek szkolny } \\
\cline { 2 - 3 } & $\begin{array}{c}\text { Przedział wiekowy } \\
\text { (wiek ucznia) }\end{array}$ & $\begin{array}{c}\text { Czas trwania } \\
\text { (lata) }\end{array}$ \\
\hline Austria & $6(15)$ & 9 \\
\hline Belgia & $6(15)$ & $9+(3)^{9}$ \\
\hline Bułgaria & $7(16)$ & 9 \\
\hline Cypr & $5(15)$ & 10 \\
\hline Czechy & $6(15)$ & 9 \\
\hline Dania & $6(16)$ & 10 \\
\hline Estonia & $7(17)$ & 10 \\
\hline Finlandia & $7(16)$ & 9 \\
\hline
\end{tabular}

9 W nawiasach wskazano długość obowiązkowego kształcenia w niepełnym wymiarze czasu, czyli obowiązek nauki. 


\begin{tabular}{|c|c|c|}
\hline \multirow[b]{2}{*}{ Kraj } & \multicolumn{2}{|c|}{ Obowiązek szkolny } \\
\hline & $\begin{array}{l}\text { Przedział wiekowy } \\
\text { (wiek ucznia) }\end{array}$ & $\begin{array}{c}\text { Czas trwania } \\
\text { (lata) }\end{array}$ \\
\hline Francja & $6(16)$ & 10 \\
\hline Grecja & $5(15)$ & 10 \\
\hline Hiszpania & $6(16)$ & 10 \\
\hline Holandia & $5(18)$ & 13 \\
\hline Irlandia & $6(16)$ & 10 \\
\hline Litwa & $7(16)$ & 9 \\
\hline Luksemburg & $4(15)$ & 11 \\
\hline Łotwa & $5(16)$ & 11 \\
\hline Malta & $5(16)$ & 11 \\
\hline Niemcy & $6(16)$ & $10+(3)$ \\
\hline Polska & $6(16)$ & $10+(2)$ \\
\hline Portugalia & $6(15)$ & 9 \\
\hline Rumunia & $6(16)$ & 10 \\
\hline Słowacja & $6(16)$ & 10 \\
\hline Słowenia & $6(15)$ & 9 \\
\hline Szwecja & $7(16)$ & 9 \\
\hline Węgry & $5(18)$ & 13 \\
\hline Wielka Brytania (Anglia, Walia, Irlandia Płn.) & $4(16)$ & 12 \\
\hline Szkocja & $5-16$ & 11 \\
\hline Włochy & $6-16$ & 10 \\
\hline
\end{tabular}

Źródło: http://www.eurydice.org.pl/files/108_8_pages_B1_PL_A4.pdf.

\section{Tendencje w szkolnictwie obowiązkowym ${ }^{10}$}

W latach 2004-2009 władze oświatowe państw Unii Europejskiej podjęły i zrealizowały ważne reformy związane z wydłużeniem okresu trwania kształcenia obowiązkowego do 10 lat. Wśród państw reformujących czas obowiązku szkolnego znalazły się:

- Polska, gdzie od roku szkolnego 2004/2005 dzieci sześcioletnie odbywają obowiązkowe roczne przygotowanie przedszkolne w przedszkolach lub w oddziałach przedszkolnych w szkołach podstawowych.

10 http://www.eurydice.org.pl/files/KD2009.pdf. 
- Cypr, gdzie obowiązek nauki rozszerzono w roku szkolnym 2004/2005 na dzieci pięcioletnie, które realizują go w formach wychowania przedszkolnego.

- Dania, gdzie w roku szkolnym 2008/2009 obowiązkową nauką objęto dzieci sześcioletnie, które realizują ten obowiązek w formach wychowania przedszkolnego.

W Unii Europejskiej obserwujemy również tendencję wzrostu liczby dzieci czteroletnich uczęszczających do placówek edukacyjnych. Uczęszczanie do placówek wychowania przedszkolnego przeważnie nie jest obowiązkowe (obowiązek kształcenia obejmuje najczęściej dzieci pięcioletnie lub sześcioletnie) można jednak zaobserwować w Europie ogólny trend polegający na wzroście liczby dzieci czteroletnich uczęszczających do przedszkoli lub - rzadziej - szkół podstawowych.

\section{Zakończenie}

Wśród podstawowych zasad polityki oświatowej - jednolitości, obowiązkowości, bezpłatności, publiczności i świeckości - zasada obowiązkowości jest tą, na której szkolnictwo od czterech stuleci buduje powszechność kształcenia młodego pokolenia obywateli. Przymus szkolny - dla jednych zmora młodości, a dla innych idea wykształconego, wykwalifikowanego, mądrego i świadomego społeczeństwa - od wielu lat jest źródłem reform w oświacie, bezpośrednio wpływając na przemiany społeczne, związane choćby z problematyką zatrudnienia. Przywiązywanie znaczenia przez elity polityczne do zagadnień związanych z obowiązkiem szkolnym - a zwłaszcza dotyczących jego długości i sposobu realizacji - stanowi wymierny wskaźnik dalekosiężnej troski o poziom wykształcenia obywateli, co może skutkować w przyszłości na przykład większą mobilnością zawodową społeczeństwa i niskim poziomem bezrobocia. Polityka oświatowa państw Unii Europejskiej od lat charakteryzuje się sukcesywną realizacją idei obejmowania obowiązkiem szkolnym uczniów z jak największej liczby roczników - od najmłodszych aż do pełnoletnich. Najmłodsi realizujący obowiązek szkolny to uczniowie cztero-, pięcioletni (np. Cypr, Luksemburg), a najstarsi to uczniowie siedemnasto-, osiemnastoletni (np. Estonia, Holandia). Długość obowiązku szkolnego w poszczególnych krajach członkowskich Unii Europejskiej w pierwszej dekadzie XXI wieku oscyluje od 9 (np. Austria, Portugalia) do 13 lat (np. Holandia, Węgry) i wszystko wskazuje na to, że ta tendencja utrwali się na stałe w ustrojach szkolnych większości krajów. 


\section{Bibliografia}

Dziewulak D., Polityka oświatowa Wspólnoty Europejskiej, Wydawnictwa Uniwersytetu Warszawskiego, Warszawa 1994.

Dziewulak D., Systemy szkolne państw Unii Europejskiej, Wydawnictwo Akademickie „Żak”, Warszawa 1997.

Dziewulak D., Nauczanie początkowe $w$ wybranych krajach Europy Zachodniej $w$ świetle raportów Rady Europy, „Kwartalnik Pedagogiczny” 1988, nr 3-4.

Dziewulak D., Obowiązek szkolny w Unii Europejskiej, „Analizy BAS” 2010, nr 9(34).

Dziewulak D., Priorytety edukacyjne Wspólnot Europejskich, „Nowa Szkoła” 1993, nr 1.

Dziewulak D., Tendencje oświatowe Wspólnot Europejskich, Biuletyn Centrum Europejskiego Uniwersytetu Warszawskiego / Ośrodka Informacji i Dokumentacji Rady Europy 1993, nr 4.

Dziewulak D., Szkoła średnia II stopnia we Francji, „Kwartalnik Pedagogiczny” 1990, nr 1.

Dziewulak D., System oświatowy Hiszpanii, „Nowa Szkoła” 1994, nr 3.

Dziewulak D., System oświatowy Włoch, „Nowa Szkoła” 1994, nr 5.

Oświata i wychowanie w roku szkolnym 2007/2008, Zakład Wydawnictw Statystycznych, Warszawa 2008.

The State of the World's Children 2008, UNICEF 2008.

\section{Akty prawne}

Konstytucja Rzeczypospolitej Polskiej z 2 kwietnia 1997 r., http://www.sejm.gov.pl/prawo/ konst/polski/kon1.htm.

Ustawa z 7 września 1991 r. o systemie oświaty, Dz.U. 2004, nr 256, poz. 2572, ze zm.

Ustawa z 19 marca 2009 r. o zmianie ustawy o systemie oświaty oraz o zmianie niektórych innych ustaw, Dz.U. nr 56, poz. 458.

\section{Strony internetowe}

http://www.olesnica.org/Z_przeszlosci_olesnickiego_szkolnictwa.htm.

http://www.eurydice.org.pl.

http://www.eurydice.org.pl/files/108_8_pages_B1_PL_A4.pdf. 


\title{
1.2. Przegląd ustrojów szkolnych w wybranych państwach
}

\author{
Overview of school systems in selected countries
}

W opracowaniu podjęto próbę przedstawienia najbardziej charakterystycznych elementów systemów szkolnych w Czechach, Finlandii, Niemczech, Norwegii, Wielkiej Brytanii i we Włoszech. Analizie poddano organizację administracji oświatowej, strukturę publicznego systemu szkolnego oraz kształcenie nauczycieli w wybranych krajach.

Słowa kluczowe: oświata, system szkolny, polityka oświatowa

The paper attempts to present the most characteristic elements of school systems in the Czech Republic, Finland, Germany, Norway, Great Britain and Italy. The organization of the educational administration, the structure of the public school system and the education of teachers in selected countries were analyzed.

Keywords: education, school system, education policy

\section{Wstęp}

W opracowaniu wykorzystano polską i obcojęzyczną literaturę przedmiotu, materiały uzyskane za pośrednictwem Międzynarodowego Biura Edukacji w Genewie, Sieci Informacji o Edukacji w Europie (Eurydice), Europejskiego Centrum Badań i Dokumentacji Parlamentarnej (ECPRD) oraz dostępne w bazach ministerstw oświaty oraz instytucji i organizacji zajmujących się problematyką edukacji i polityki oświatowej w analizowanych państwach.

Ze względu na obszerny i wielowątkowy materiał obejmujący prezentację modeli edukacji w poszczególnych krajach, struktura artykułu oparta została na następującym schemacie:

- nazwa państwa,

- organizacja administracji oświatowej,

- organizacja i struktura edukacji publicznej (od edukacji przedszkolnej do szkolnictwa wyższego),

- nauczyciele. 
Każda analiza ustroju szkolnego została uzupełniona o rysunek przedstawiający schemat systemu szkolnego.

Do opisu i analizy struktur szkolnych wykorzystano Międzynarodową Standardową Klasyfikację Edukacji - ISCED (International Standard Classification of Education). Jest to system służący do gromadzenia, zestawiania i analizowania statystyk dotyczących edukacji (poziomów edukacyjnych, programów, szkoleń, dyplomów itp.), ułatwiających międzynarodową porównywalność1.

Poniżej przedstawiono informacje na temat modelu edukacji w Czechach, Finlandii, Niemczech, Norwegii, Wielkiej Brytanii i we Włoszech².

\section{Czechy}

\section{Organizacja administracji oświatowej}

Podstawą funkcjonowania czeskiego systemu oświatowego jest ustawa o edukacji ${ }^{3}$, która reguluje zagadnienia związane z kształceniem od poziomu przedszkolnego do poziomu szkolnictwa średniego II stopnia i wyższego szkolnictwa zawodowego.

1 Klasyfikacja ISCED została opracowana w połowie lat siedemdziesiątych XX wieku przez UNESCO. Od tego czasu klasyfikację dwukrotnie poddawano rewizji i uaktualnieniu. Ostatnią zmianę przyjętą przez Konferencję Generalną UNESCO przeprowadzono w listopadzie 2011 r., a jej wyniki oznaczono jako ISCED 2011 - i taki zapis stosuje się w krajowych i międzynarodowych opracowaniach dotyczących opisu i analizy funkcjonowania systemów edukacyjnych. Zgodnie z ISCED 2011 poziomy edukacyjne występujące w ustrojach szkolnych poszczególnych państw oznacza się następująco:

- ISCED 0: Wczesna edukacja (opieka żłobkowa - ISCED 010 i/lub edukacja przedszkolna ISCED 020),

- ISCED 1: Szkolnictwo początkowe lub podstawowe,

- ISCED 2: Szkolnictwo średnie I (pierwszego) stopnia,

- ISCED 3: Szkolnictwo średnie II (drugiego ) stopnia,

- ISCED 4: Szkolnictwo policealne,

- ISCED 5: Szkolnictwo wyższe krótkoterminowe,

- ISCED 6: Poziom licencjacki lub równoważny,

- ISCED 7: Poziom magisterski lub równoważny,

- ISCED 8: Poziom doktorancki lub równoważny.

2 Opracowanie przygotowano na podstawie ekspertyzy Biura Analiz Sejmowych nr 2257/16 z 11 stycznia 2017 r. D. Dziewulaka zatytułowanej Informacja na temat modelu edukacji w Czechach, Finlandii, Niemczech, Norwegii, Wielkiej Brytanii i we Włoszech.

3 Zákon ze dne 24. září 2004 o předškolním, základním, stř̌edním, vyšším odborném a jiném vzdělávání (školský zákon), https://www.zakonyprolidi.cz/cs/2004-561. 
Teoretický věk v době

zahájení vzdělávání*
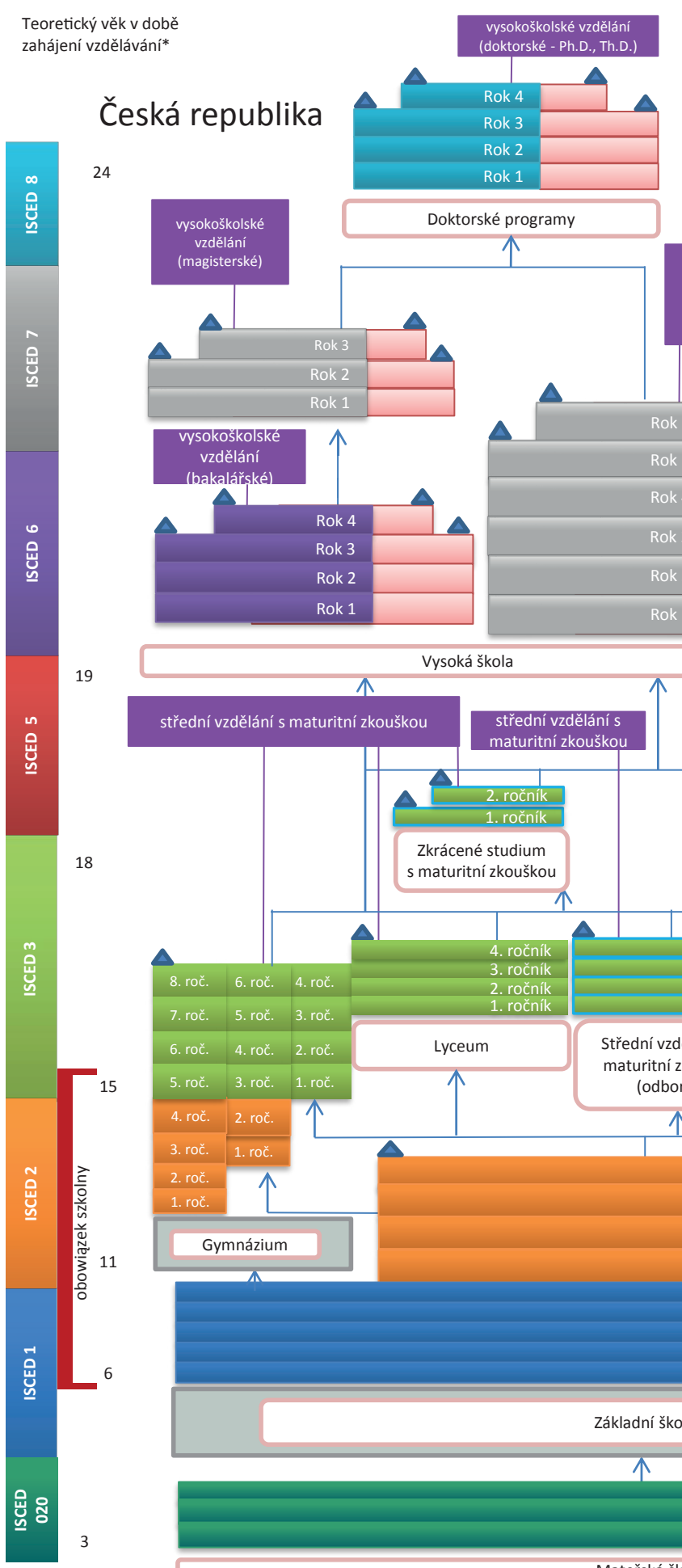

Česká republika
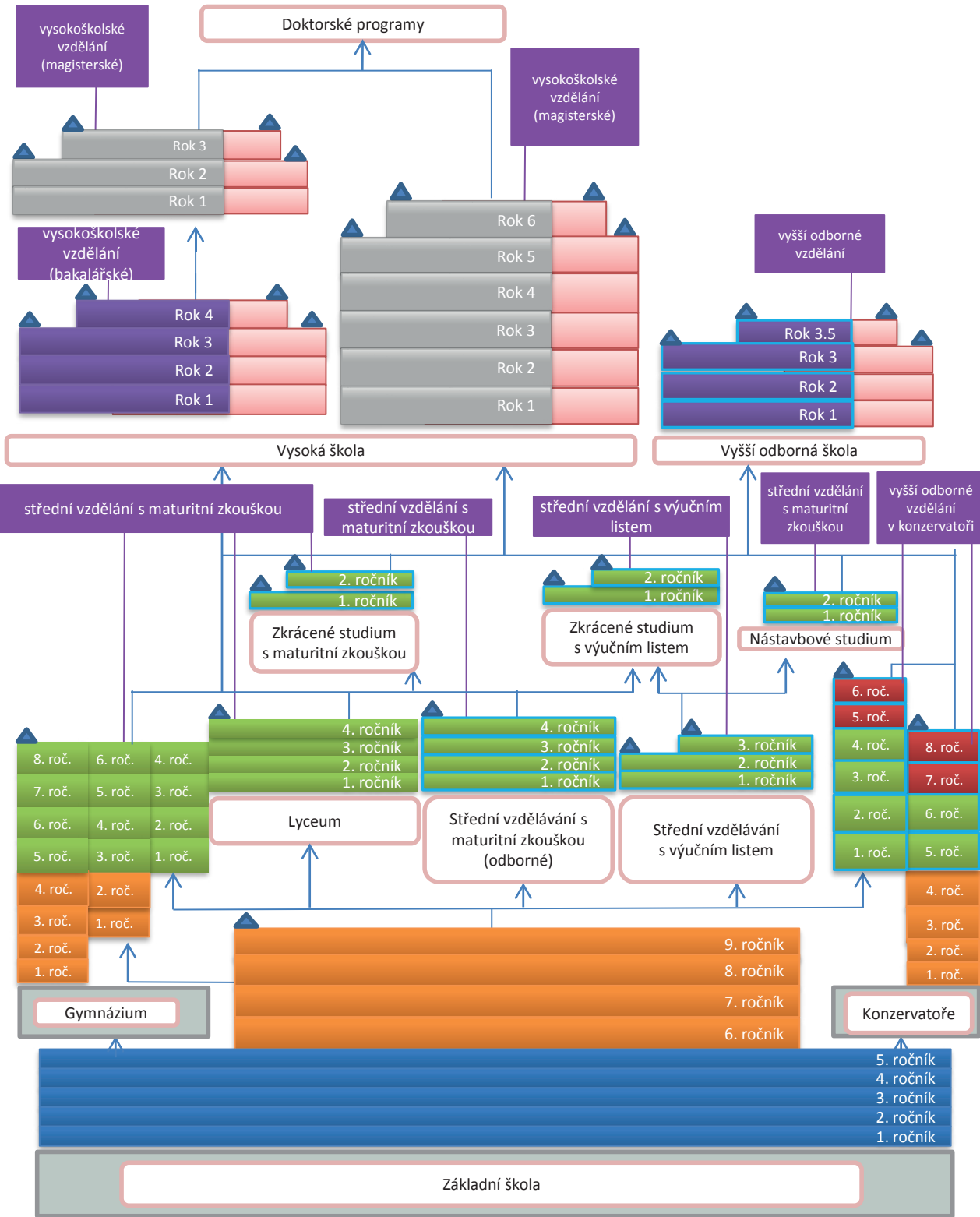

středni vzdělání s maturitní zkouškou

个 


\section{Legenda (wyjaśnienie terminów użytych na rysunku)}

\section{POZIOMY EDUKACYJNE}

Mateřská škola - przedszkole

Základni škola - szkoła podstawowa

Gymnázium - szkoła średnia ogólnokształcąca

Lyceum - liceum (szkoła średnia ogólnokształcąca)

Střední vzdělávánís maturitní zkouškou (odborné) - szkoła średnia z egzaminem końcowym (zawodowym)

Střední vzdělávání s výučním listem - szkoła średnia z certyfikatem przygotowania zawodowego

Konzervatore - konserwatorium (szkoła o profilu artystycznym)

Zkrácené studium s maturitní zkouškou - typ szkoły policealnej umożliwiającej uzyskanie kwalifikacji zawodowych

Zkrácené studium s výučním listem - typ szkoły policealnej umożliwiającej uzyskanie certyfikatu przygotowania zawodowego

Nástavbové studium - szkoła policealna uzupełniająca

Vyšoká škola - szkoła wyższa

Vyšší odborná škola - wyższa szkoła zawodowa

DYPLOMY

Střední vzdělání s maturitní zkouškou - wykształcenie średnie z egzaminem kończącym szkołę Střední vzdělánís výučním listem - wykształcenie średnie z certyfikatem przygotowania zawodowego Vyšší odborné vzdělání v konzervatoři - wykształcenie wyższe zawodowe w konserwatorium Vysokoškolské vzdělání (bakalářské) - wykształcenie wyższe (licencjackie)

vyšší odborné vzdělání - wykształcenie wyższe zawodowe Vysokoškolské vzdělání (magisterské) - wykształcenie wyższe (magisterskie) Vysokoškolské vzdělání (doktorské - Ph.D., Th.D.) - wykształcenie wyższe (doktorat)

OPIS TRANSFERÓW EDUKACYJNYCH (STRZAŁKI) I OZNACZEŃ LAT NAUKI Ročník (roč.) - rok nauki

Rok - rok studiów 
Ministerstwo Edukacji, Młodzieży i Sportu (Ministerstvo školství, mládeže a tělovýchovy) ${ }^{4}$ odpowiada za zintegrowaną politykę edukacyjną państwa, opracowując długoterminowe strategie kształcenia i rozwoju systemu edukacji, które są przedstawiane rządowi co cztery lata. Do zadań ministerstwa należą przede wszystkim:

- sprawy związane z koncepcją, stanem i rozwojem systemu edukacji,

- określanie treści nauczania: zatwierdzanie ramowych programów nauczania, które stanowią podstawę rozwoju szkolnych programów edukacyjnych, akredytacja programów edukacyjnych dla zawodowych szkół wyższych oraz instytucji szkolnictwa wyższego,

- odpowiedzialność za krajową politykę finansowania oświaty - za przygotowanie budżetu i decydowanie o zasadach jego podziału,

- odpowiedzialność za prowadzenie wykazu placówek szkolnych, które mają prawo prowadzić działalność oświatową oraz otrzymywać środki publiczne,

- stanowienie organu prowadzącego instytucje odpowiedzialne za doskonalenie zawodowe nauczycieli.

Władze regionalne, odpowiadające za oświatę na swym terenie, opracowują co cztery lata - zgodnie z celami ogólnokrajowymi - długoterminowe strategie dla swego regionu oraz zakładają i prowadzą szkoły średnie II stopnia i wyższe szkoły zawodowe. Gminy odpowiadają za zapewnienie warunków opieki przedszkolnej oraz kształcenia obowiązkowego. Organami prowadzącymi szkoły i obiekty szkolne mogą być również zarejestrowane kościoły i stowarzyszenia religijne oraz inne podmioty prawne lub osoby fizyczne posiadające pozwolenia na ustawowe zakładanie i prowadzenie szkół. Wszystkie szkoły mają osobowość prawną. Dyrektorom szkół przekazano pełną odpowiedzialność za jakość procesu dydaktycznego, zarządzanie finansami szkół, zatrudnianie i zwalnianie nauczycieli oraz relacje ze społecznością lokalną. Zgodnie z przepisami organ założycielski szkoły jest zobowiązany utworzyć radę szkoły, która umożliwia rodzicom, uczniom, kadrze dydaktycznej oraz przedstawicielom gminy uczestnictwo w zarządzaniu szkołą. Organy założycielskie mianują dyrektorów szkół na podstawie konkursu. Szkoły są finansowane z dwóch źródeł: koszty inwestycyjne i bieżące pokrywają organy założycielskie (regiony i gminy z budżetów regionalnych/gminnych), koszty związane z kształceniem (wynagrodzenia i pomoce dydaktyczne) są przyznawane z budżetu centralnego przez Ministerstwo Edukacji, Młodzieży i Sportu za pośrednictwem administracji regionalnej. Finansowanie odbywa się zgodnie z zasadą wydatków na jedną osobę. Dla szkół kwota na jedną

$4 \quad$ http://www.msmt.cz/. 
osobę jest określana na szczeblu centralnym dla czterech grup wiekowych odpowiadających adekwatnym poziomom edukacji. Środki są przydzielane regionom zgodnie z liczbą uczniów w danej grupie wiekowej. Kwota na jedną osobę dla różnych szkół określana jest przez władze regionalne. Instytucje szkolnictwa wyższego otrzymują fundusze z budżetu państwowego zarówno na koszty bieżące, jak i inwestycyjne. Instytucje szkolnictwa wyższego otrzymują fundusze w zależności od liczby studentów i absolwentów, kosztów związanych z danym kierunkiem studiów oraz określonych wskaźników jakości i wydajności.

\section{Organizacja i struktura edukacji publicznej}

Na strukturę systemu edukacji w Czechach składają się następujące placówki oświatowe:

- przedszkole (mateřská škola),

- szkoła podstawowa i średnia I stopnia (základni škola),

- szkoła średnia ogólnokształcąca I stopnia (gymnázium),

- szkoła średnia ogólnokształcąca I stopnia o profilu artystycznym (konzervatoř),

- szkoła średnia II stopnia (střední vzdělání),

- szkoła policealna (nástavbové studium),

- szkolnictwo wyższe (vyšoká škola).

\section{Przedszkole (mateřská škola)}

Edukacja przedszkolna nie jest w Czechach obowiązkowa, jednakże do przedszkoli uczęszcza około 84\% grupy wiekowej od 3 do 6 lat, z czego 91\% w roku poprzedzającym rozpoczęcie nauki w szkole podstawowej. Od rodziców można pobierać opłaty stanowiące maksymalnie 50\% kosztów bieżących (niezwiązanych z kształceniem) ponoszonych przez gminy. Ostatni rok wychowania przedszkolnego, poprzedzający rozpoczęcie nauki w szkole, jest dla wszystkich dzieci bezpłatny.

\section{Szkoła podstawowa i średnia (základni škola)}

Obowiązek szkolny trwa 9 lat i obejmuje uczniów w wieku od 6 do 15 roku życia. Szkoły są zrejonizowane, ale rodzice mają prawo wybrać dowolną placówkę szkolną. Szczeble kształcenia objęte obowiązkiem szkolnym to:

- Szkoła podstawowa i średnia I stopnia (základni škola) - wiek: I etap 6-10 lat; II etap 11-15 lat, 
- Szkoła średnia ogólnokształcąca I stopnia (gymnázium) - wiek: 11-13/15 lat,

- Szkoła średnia ogólnokształcąca I stopnia o profilu artystycznym (konzervatoŕ) - wiek 11-15 lat.

Wszyscy uczniowie rozpoczynają obowiązkową naukę w jednolitej szkole powszechnej (základni škola), a po jej ukończeniu mają do wyboru dwie drogi kontynuacji nauki. Uczniowie po ukończeniu V klasy základni škola mogą kontynuować naukę w ośmioletnim gymnázium lub w ośmioletnim konserwatorium artystycznym (konzervatoř). Mogą także pozostać w základni škola do ukończenia VII klasy i przejść do sześcioletniego gymnázium, pod warunkiem zdania egzaminu wstępnego, przeprowadzanego przez szkołę. W gymnázium kształci się niecałe $10 \%$ populacji wiekowej uczniów.

Po ukończeniu kształcenia obowiązkowego młodzież może wybrać szkołę średnią II stopnia zakończoną egzaminem maturalnym lub szkołę średnią pozwalająca na zdobycie certyfikatu praktyk zawodowych. Warunkiem przyjęcia do szkoły średniej II stopnia jest ukończenie kształcenia obowiązkowego i spełnienie wymogów wstępnych określonych przez dyrektora střední škola, który również decyduje o przyjęciu kandydata. Jednym z wymogów może być zorganizowany przez szkołę egzamin wstępny (ewentualnie test zdolności). W przypadku rekrutacji w konserwatoriach należy przystąpić do egzaminów sprawdzających konkretne artystyczne umiejętności kandydata. Uczniowie mogą przystępować jednocześnie do trzech wybranych przez siebie szkół. Warunkiem przyjęcia do policealnego cyklu kształcenia jest ukończenie szkoły średniej i spełnienie ewentualnych dodatkowych wymogów określonych dla kandydatów do cyklu policealnego.

\section{Szkoła średnia II stopnia (střední vzdělání)}

Placówki określane jako nieobowiązkowe szkolnictwo średnie II stopnia (střední vzdèlánî) to:

- Szkolnictwo średnie zakończone egzaminem maturalnym (maturitní zkouška):

- gimnazjum ogólnokształcące (gymnázium) - czas trwania 4 lata; wiek: 15-19 lat,

- technikum - czas trwania 4 lata; wiek: 15-19 lat,

- konserwatorium ${ }^{5}$ - czas trwania 4-6 lat; wiek: 15-19/21 lat.

5 Uczniowie w konserwatoriach mogą również ukończyć naukę egzaminem maturitní zkouška, jednak nie przed ukończeniem klasy IV lub klasy VIII w przypadku ośmioletnich konserwatoriów tanecznych. Mimo takiej możliwości, większość uczniów w konserwatoriach kończy naukę uzyskaniem absolutorium. 
- Szkolnictwo średnie prowadzące do zdobycia certyfikatu praktyk zawodowych (střední vzdělání s výučním listem):

- szkoła zawodowa na poziomie średnim II stopnia - czas trwania 2-3 lata; wiek: 15-17/18 lat,

- szkoła średnia ogólnokształcąca i zawodowa II stopnia w szkole średniej ${ }^{6}$ czas trwania 1-2 lata; wiek: 15-16/17 lat.

\section{Szkoła policealna (nástavbové studium)}

- Placówki nieobowiązkowego szkolnictwa policealnego (bez wyższego) ${ }^{7}$ to:

- szkoły policealne, w których nauka kończy się egzaminem (maturitní zko$u s ̌ k a)$,

- techniczny cykl uzupełniający (nástavbové studium) w szkole średniej - czas trwania 2 lata; wiek: 18 lat (i więcej),

- techniczny cykl skrócony w szkole średniej (zkrácené studium) - czas trwania 1-2 lata; wiek: 18 lat (i więcej).

- Szkolnictwo policealne prowadzące do uzyskania certyfikatu praktyk zawodowych:

- zawodowy cykl skrócony (zkrácené studium) w szkole średniej - czas trwania 1-2 lata; wiek: 18 lat (i więcej).

\section{Szkoła wyższa (vyšoká škola)}

W Czechach kształcenie na poziomie wyższym realizowane jest w 28 uniwersytetach (26 publicznych i dwóch państwowych) oraz 45 prywatnych uczelniach wyższych. Nauka w szkołach wyższych, zgodnie z procesem bolońskim, podzielona jest na trzy etapy. Absolwenci studiów I stopnia (trzyletnich lub czteroletnich) otrzymują tytuł zawodowy licencjata (bakalár - Bc). Absolwenci studiów II stopnia (trwających od roku do 3 lat), następujących po ukończeniu studiów licencjac-

6 Uczniowie zdobywają wykształcenie średnie przez ukończenie programu edukacyjnego trwającego rok lub dwa lata. Uczniowie mogą uczestniczyć w tzw. cyklu Praktická škola (rok lub dwa lata) lub w cyklu Odborné učiliště.

7 Absolwenci z wykształceniem średnim II stopnia mogą podwyższyć lub zmienić swoje kwalifikacje w trzech rodzajach cyklów policealnych: w dwuletnim nástavbové studium (cykl uzupełniający) umożliwiającym absolwentom trzyletnich cyklów zawodowych z ogólnymi i teoretycznymi przedmiotami w danym obszarze osiągnięcie poziomu, oraz w dwóch rodzajach zkrácené studium (cyklów skróconych) umożliwiających absolwentom ogólnych i technicznych cyklów nabyć wiedzę z innego obszaru albo umiejętności na wyższym poziomie. 
kich, lub dłuższych studiów jednolitych (trwających 4-6 lat) otrzymują tytuł magistra (magistr - Mgr). Po ukończeniu studiów doktoranckich (3-4 lata) studenci zdają egzamin doktorski i otrzymują stopień naukowy doktora.

W Czechach można podjąć także naukę w płatnych, trzyletnich wyższych szkołach zawodowych (vyšší odborná škola), w których nauka kończy się egzaminem (często praktycznym). Absolwenci otrzymują tytuł dyplomowanego specjalisty (diplomovaný specialista - DiS).

\section{Nauczyciele}

Czteroletni cykl kształcenia nauczycieli przedszkolnych organizowany jest przeważnie na poziomie szkoły średniej II stopnia; istnieją również kursy na poziomie szkolnictwa wyższego. Przyszli nauczyciele przedmiotów teoretycznych na innych poziomach kształcenia muszą uzyskać dyplom uczelni akademickiej na poziomie magisterskim. Różne rodzaje niższych kwalifikacji zawodowych (spoza szkolnictwa wyższego) są wystarczające dla nauczycieli przedmiotów praktycznych. Kształcenie nauczycieli przedmiotów ogólnych jest na ogół równoległe, podczas gdy dla przedmiotów technicznych/zawodowych etapowe. Nauczyciele (z wyjątkiem tych na poziomie szkoły podstawowej) są nauczycielami przedmiotu. Nauczyciele nie mają statusu urzędników państwowych. Ustawa o kadrze pedagogicznej z 2004 roku zawiera uregulowania dotyczące kwalifikacji wymaganych do wykonywania zawodu nauczycielskiego, jak również zapisy dotyczące doskonalenia zawodowego i szczebli awansu zawodowego nauczycieli.

\section{Finlandia}

\section{Organizacja administracji oświatowej}

Podstawowym aktem prawnym dla fińskiej oświaty jest ustawa o kształceniu obowiązkowym ${ }^{8}$. Za kształtowanie polityki oświatowej w Finlandii odpowiada rząd i parlament. Wdrażaniem tej polityki na poziomie centralnym zajmuje się rząd, Ministerstwo Edukacji i Kultury ${ }^{9}$ oraz Fińska Krajowa Agencja ds. Edukacji (Finnish National Board of Education $)^{10}$. Działania ministerstwa wspierają następujące instytucje: Rada ds. Edukacji Dorosłych, Fińska Rada Szkolnictwa Wyż-

$8 \quad$ http://www.finlex.fi/en/laki/kaannokset/1998/en19980628.pdf.

9 http://www.minedu.fi/OPM.

10 https://www.oph.fi/english. 
Rysunek 2. Schemat organizacyjny fińskiego Ministerstwa Edukacji i Kultury

\section{Ministerstwo Edukacji i Kultury}

MINISTER EDUKACJI I NAUKI

Sekretarz Stanu
MINISTER KULTURY I SPORTU

\section{Sekretarz Stanu}

Współpraca międzynarodowa

Audyt wewnętrzny

\section{Stały Sekretarz}

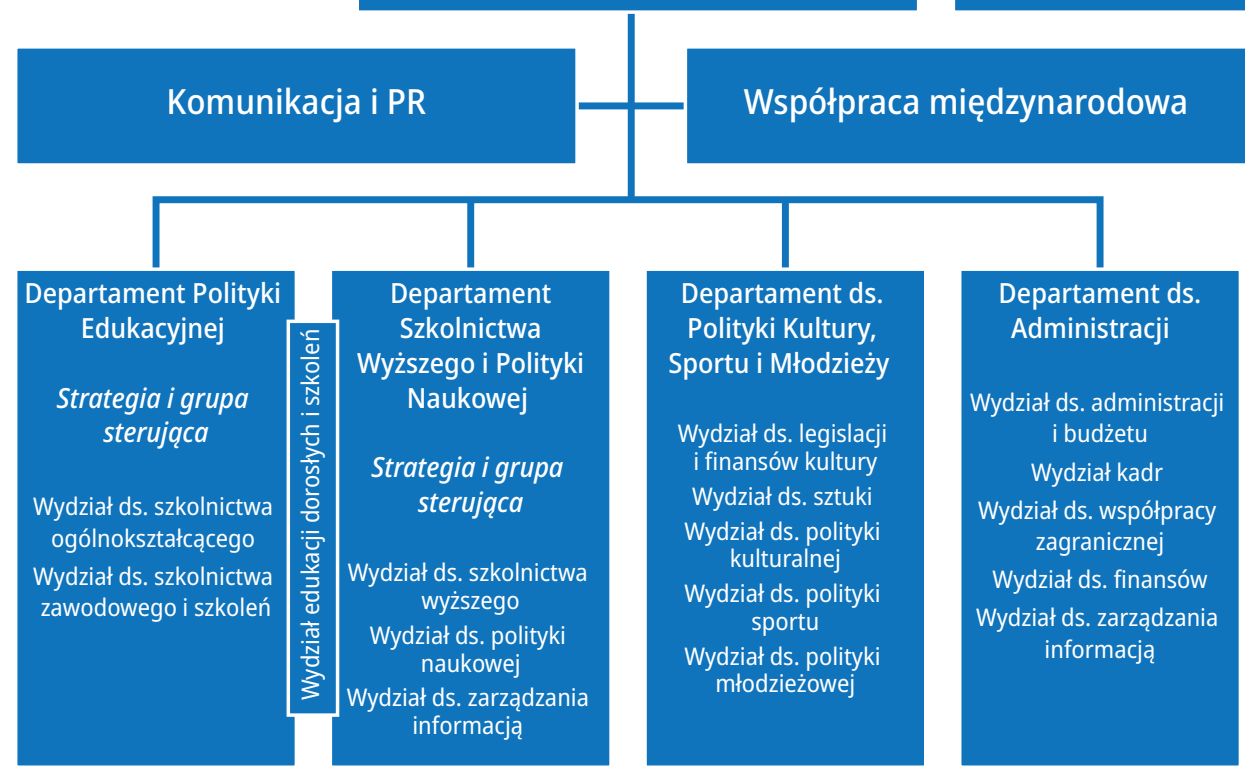

Źródło: Opetus- ja kulttuuriministeriö; http://www.minedu.fi/OPM/Julkaisut/2013/liitteet/Brochure_2013. pdf?lang=fi. 
szego oraz utworzona w 2003 roku Fińska Rada ds. Ewaluacji Edukacji (Finnish Education Evaluation Council) $)^{11}$, której zadaniem jest opracowywanie planu zewnętrznej ewaluacji, zgodnie z wytycznymi Ministerstwa Edukacji i Kultury.

Sprawy oświaty znajdują się w kompetencji jednego Ministerstwa Edukacji i Kultury kierowanego przez dwóch ministrów. Za problematykę oświatową odpowiada Minister Edukacji i Nauki, a za sprawy kultury Minister Kultury i Sportu. Prace obu pionów ministerstwa koordynuje Stały Sekretarz.

System edukacji w Finlandii jest zdecentralizowany. Przepisy dotyczące administrowania i zarządzania szkołami zawarte zostały w ustawie o samorządzie lokalnym ${ }^{12}$. Osobą bezpośrednio odpowiedzialną za funkcjonowanie szkoły jest jej dyrektor. Sposób organizacji kształcenia w placówce określają przepisy przyjęte przez radę szkoły.

\section{Organizacja i struktura edukacji publicznej}

Obowiązek szkolny w Finlandii trwa 9 lat. Kształcenie jest obowiązkowe od 7 do 16 roku życia. Uczniowie muszą rozpocząć kształcenie obowiązkowe w roku, w którym przypadają ich siódme urodziny. Około 1\% dzieci rozpoczyna naukę w szkole wcześniej, lecz wymaga to uzyskania zaświadczenia potwierdzającego dojrzałość szkolną dziecka. W Finlandii rodzice mogą zażądać odroczenia przyjęcia swojego dziecka do szkoły podstawowej na podstawie wyników testów psychologicznych, a jeśli to niezbędne - lekarskich, które wykażą, że dziecko nie jest pod względem umysłowym lub fizycznym gotowe do podjęcia nauki w szkole. Testy może przeprowadzić wybrany przez rodziców lekarz, psycholog lub pracownik szkoły bądź samorządu. Wyniki testów są dla szkoły wiążące.

W Finlandii szkolnictwo obowiązkowe jest w całości bezpłatne. Władze lokalne przydzielają każdemu dziecku miejsce w szkole znajdującej się w pobliżu jego miejsca zamieszkania, ale rodzice mogą wybrać szkołę powszechną zgodnie ze swymi preferencjami.

Na strukturę systemu edukacji w Finlandii składają się następujące placówki oświatowe:

- żłobki i przedszkola (Päiväkoti/daghem),

- klasa zerowa (Esiopetus/Förskoleundervisning),

- szkoła podstawowa (Perusopetus),

11 http://www.edev.fi/portal/english5.

12 http://www.localfinland.fi/en/authorities/local-self-government/Documents/Finnish\%20 Local\%20Government\%20Act.pdf. 
- fakultatywny rok nauki (Lisäopetus),

- szkoła średnia:

- ogólnokształcąca szkoła średnia II stopnia (Lukiokoulutus),

- zawodowa szkoła średnia II stopnia (Ammatillinen koulutus/Yrkesutbildning).

- szkolnictwo wyższe.

\section{Żłobki i przedszkola}

Od urodzenia do wieku 6 lat dzieci mogą uczęszczać do ośrodków opieki dziennej - przedszkoli (päiväkoti/daghem) lub uczestniczyć w zajęciach organizowanych w mniejszych grupach dziennej opieki rodzinnej w domach prywatnych (perhepäivähoitopaikkalfamiljedagvårdsplats), przy czym za wszystkie te formy opieki pobiera się opłaty w umiarkowanej wysokości, uzależnione od dochodów rodziców.

\section{Klasa zerowa}

Przedpoczątkowa edukacja realizowana jest w przedszkolach. Bezpłatną, nieobowiązkową opieką klas zerowych objęte są dzieci w wieku 6-7 lat. Z tej formy edukacji korzysta 96\% sześciolatków.

\section{Szkoła podstawowa}

Jednolita, obowiązkowa, bezpłatna ogólnokształcąca szkoła podstawowa przeznaczona jest dla uczniów od 7 do 16 roku życia. Nauka trwa 9 lat. Po ukończeniu pełnych dziewięciu klas, uczniowie otrzymują świadectwo ukończenia szkoły podstawowej (Perusopetuksen päättötodistus) ${ }^{13}$. Szkoła podstawowa może również obejmować fakultatywny dziesiąty rok nauki (Lisäopetus) przeznaczony dla tych uczniów, którzy nie dostali się do szkół średnich i pomimo ukończenia obowiązkowej nauki pragną uzupełnić wiedzę oraz poprawić wyniki w nauce potrzebne do ubiegania się o przyjęcie do szkół średnich.

W szkolnictwie podstawowym, zwłaszcza w ostatnich trzech latach nauki, uczniowie objęci są intensywną opieką doradczo-edukacyjną. Uczeń może skorzystać z indywidualnych i grupowych spotkań z doradcą, podczas których uczy się poznawać i oceniać własne umiejętności i zainteresowania oraz, jak ukierunkować własne oczekiwania zawodowe na zmieniającym się rynku pracy.

13 https://eperusteet.opintopolku.fi/\#/fi/perusopetus/419550/tekstikappale/430061 


\section{Suomi}

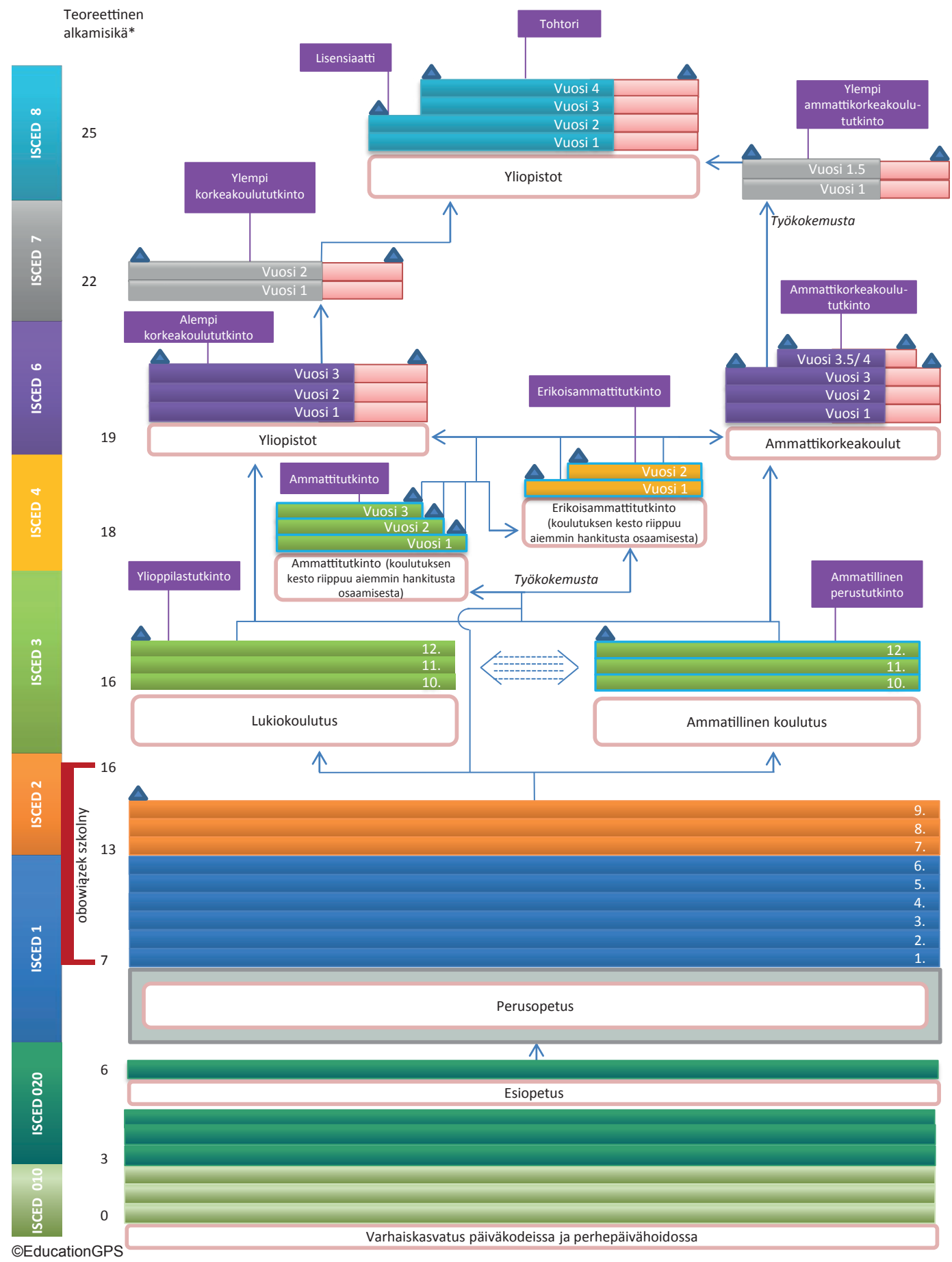




\section{Legenda (wyjaśnienie terminów użytych na rysunku)}

\section{POZIOMY EDUKACYJNE}

Varhaiskasvatus päiväkodeissa ja perhepäivähoidossa - wczesna edukacja i opieka dzienna w rodzinie Esiopetus - edukacja przedszkolna (klasa zerowa)

Perusopetus - szkolnictwo podstawowe

Lukiokoulutus - szkolnictwo średnie ogólnokształcące

Ammatillinen koulutus - szkolnictwo średnie zawodowe

Ammattitutkinto (koulutuksen kesto riippuu aiemmin hankitusta osaamisesta) - dalsze kształcenie zawodowe (czas trwania zależy od dotychczasowej drogi edukacyjnej i doświadczenia)

Erikoisammattitutkinto (koulutuksen kesto riippuu aiemmin hankitusta osaamisesta) - specjalistyczne kształcenie zawodowe (czas trwania zależy od dotychczasowej drogi edukacyjnej i doświadczenia)

Yliopistot - kształcenie uniwersyteckie

Ammattikorkeakoulut - kształcenie w uniwersytetach nauk stosowanych

DYPLOMY

Ylioppilastutkinto - egzamin maturalny

Ammatillinen perustutkinto - wstępne kwalifikacje zawodowe

Ammattitutkinto - dalsze kwalifikacje zawodowe

Erikoisammattitutkinto - specjalistyczne kwalifikacje zawodowe

Alempi korkeakoulututkinto - licencjat uniwersytecki

Ammattikorkeakoulututkinto - licencjat politechniczny

Ylempi korkeakoulututkinto - uniwersytecki dyplom magisterski

Ylempi ammattikorkeakoulututkinto - politechniczny dyplom magisterski

Lisensiaatti - dyplom studiów podyplomowych

Tohtori - doktorat

OPIS TRANSFERÓW EDUKACYJNYCH (STRZAŁKI) I OZNACZEŃ LAT NAUKI

Työkokemusta - doświadczenie zawodowe

Vuosi - rok 


\section{Szkoła średnia}

Nieobowiązkowa szkoła średnia przeznaczona jest dla uczniów od 16 do 19 roku życia. Po uzyskaniu świadectwa ukończenia szkoły podstawowej ponad 90\% absolwentów Perusopetus kontynuuje naukę na szczeblu szkolnictwa średniego z czego ponad 60\% kontynuuje naukę w trzyletnich, ogólnokształcących szkołach średnich (Lukio), a 40\% w trzyletnich lub czteroletnich szkołach zawodowych.

W obu typach szkół uczy się zarówno młodzież, jak i dorośli (powyżej 25 roku życia). Średnie wykształcenie zawodowe można zdobyć zarówno podczas zajęć stacjonarnych w placówkach szkolnych, jak i przez uzyskanie kwalifikacji na podstawie posiadanych kompetencji. Ta druga możliwość sprowadza się głównie do testów kompetencji sprawdzających wymagane umiejętności. Do testów kompetencji przystępują w głównej mierze dorośli mający już pewne doświadczenie zawodowe. Ponadto wszyscy uczniowie, niezależnie od wieku, mają możliwość przyuczenia do zawodu, które odbywa się w ramach programu nauczania lub stanowi przygotowanie do testów kompetencji. Wszystkie formy kształcenia prowadzące do uzyskania kwalifikacji zawodowych zaliczane są do szkolnictwa średniego II stopnia, z wyjątkiem kształcenia prowadzącego do nabycia specjalistycznych kwalifikacji zawodowych, klasyfikowanego jako poziom szkolnictwa pomaturalnego.

Inną charakterystyczną cechą szkół średnich jest realizowanie procesu dydaktycznego w formie kursów oferujących indywidualny tryb nauczania. Ogółem kursów jest 75, z czego około 50 to kursy obowiązkowe, a pozostałe - fakultatywne, uzupełniające lub profilowane. W ich ramach realizowane jest również doradztwo zawodowe, które koncentruje się głównie na projektowaniu kariery ucznia, monitorowaniu postępów w nauce oraz działalności informacyjnej co do dalszej edukacji i sposobach zdobywania konkretnych kwalifikacji. Przedmiot (kurs) prowadzony jest przez nauczycieli szkolnych lub przez zewnętrznych doradców zawodowych zatrudnianych przez szkołę. Ponadto każda klasa ma swojego nauczyciela-wychowawcę, który przygotowany jest do udzielania uczniom pomocy w ogólnych kwestiach związanych z kształceniem (wybór przedmiotów opcjonalnych, organizowanie praktyk zawodowych itp.).

Cały program nauczania zaplanowany jest do wykonania w ciągu 3 lat, jednakże można go zaliczyć w ciągu 2 lub 4 lat.

Rok szkolny dzieli się na 5-6 cykli, podczas których uczniowie przyswajają program z kilku przedmiotów. Uczniowie muszą sami zadbać o zaliczenie wystarczającej liczby kursów. Nie ma rejonizacji, a przyjęcia do szkół odbywają się 
w procesie elektronicznego konkursu ocen uzyskanych na świadectwie ukończenia szkoły podstawowej. Egzaminy maturalne organizowane są wiosną i jesienią każdego roku. Uczniowie mogą zdawać maturę za jednym razem lub rozłożyć egzaminy na trzy następujące kolejno po sobie sesje egzaminacyjne. Ogólnokrajowy egzamin maturalny, oprócz testu z języka ojczystego, składa się z trzech obowiązkowych elementów. Uczniowie wybierają trzy przedmioty egzaminacyjne spośród następujących: drugiego języka ojczystego, języka obcego lub matematyki albo testu ogólnego łączącego elementy przedmiotów humanistycznych przyrodniczych i ścisłych. W ramach egzaminu uczniowie mogą również przystąpić do nieobowiązkowych sprawdzianów. Po zdaniu egzaminu maturalnego i zaliczeniu całego programu nauczania dla szkoły średniej II stopnia, uczniowie otrzymują odrębne świadectwo (Ylioppilastutkintotodistus), zawierające informacje o zaliczonych egzaminach oraz uzyskanym poziomie i ocenach. Po spełnieniu odpowiednich warunków, do egzaminu maturalnego mogą również przystępować uczniowie zawodowych szkół średnich II stopnia.

Nauka w średniej szkole zawodowej trwa 3 lata i kończy się egzaminem w zakresie podstawowych umiejętności zawodowych uprawniających do ubiegania się o miejsce w wyższych szkołach zawodowych i uniwersytetach. Praktyka zawodowa trwa około pięciu miesięcy. Niektóre szkoły zawodowe przygotowują równocześnie do egzaminu maturalnego w zakresie liceum ogólnokształcącego wówczas nauka w nich trwa do 4 lat. 0 wyborze ścieżki i postępach uczniów decydują indywidualne plany kształcenia opracowywane dla poszczególnych uczniów. Umiejętności i wiedzę uczniów ocenia się po ukończeniu każdego specjalnościowego modułu. Dokumentacja potwierdzająca kwalifikacje zawodowe została wzbogacona o nową formę oceniania - prezentację umiejętności sprawdzanych testem organizowanym i ocenianym przez nauczycieli we współpracy z lokalnymi środowiskami zawodowymi. Po zaliczeniu wszystkich przedmiotów wymienionych w indywidualnym planie kształcenia, uczniowie otrzymują świadectwo potwierdzające posiadanie określonych kwalifikacji. Świadectwo wydawane jest przez instytucję prowadzącą kształcenie.

\section{Szkoła wyższa}

W ramach szkolnictwa wyższego działają uniwersytety i wyższe szkoły zawodowe. Studia wyższe są prowadzone w dwóch typach uczelni: w uniwersytetach (Yliopisto/Universitet) oraz zawodowo ukierunkowanych politechnikach (Ammattikorkeakoulu/Yrkeshogskola), które często nazywane są uniwersytetami 
nauk stosowanych. Każdy z sektorów ma swój profil: uniwersytety kładą nacisk na badania naukowe i dydaktykę, natomiast w politechnikach przyjęto podejście $\mathrm{w}$ większym stopniu uwzględniające nauczanie praktyczne. Prawo do ubiegania się o przyjęcie na wszystkie kierunki studiów zapewnia fińskie świadectwo maturalne. 0 przyjęcie na wszystkie kierunki studiów w uniwersytetach mogą również ubiegać się osoby posiadające tytuł zawodowy uzyskany na fińskiej politechnice, kwalifikacje zawodowe na poziomie policealnym lub kwalifikacje zawodowe uzyskane po ukończeniu co najmniej trzyletniego cyklu kształcenia. Uniwersytety mogą także przyjmować kandydatów, którzy ukończyli wymagane przez daną uczelnię studia na uniwersytecie otwartym, lub kandydatów, którzy według danej uczelni posiadają umiejętności i wiedzę niezbędną do podjęcia studiów. Wstęp na studia na wszystkich kierunkach jest ograniczony, zgodnie z zasadą numerus clausus.

Uniwersytety od 2010 roku działają jako niezależne instytucje prawa publicznego lub fundacje podlegające prawu cywilnemu. Przykładowo jako fundacje działają: Uniwersytet Technologiczny w Tampere oraz Uniwersytet im. Alvara Aalto (Helsinki, Espoo), który powstał w wyniku fuzji Politechniki, Wyższej Szkoły Wzornictwa Przemysłowego i Wyższej Szkoły Handlowej. Obydwie uczelnie samodzielnie poszukują środków finansowych na działalność w sektorze prywatnym. Dotacja państwowa to 2,5-krotność kwoty uzyskanej ze źródeł niepublicznych.

\section{Nauczyciele}

Pedagodzy w placówkach przedszkolnych i opiekuńczych posiadają uniwersytecki lub politechniczny tytuł licencjata lub kwalifikacje, które określano wcześniej jako policealne kwalifikacje zawodowe. Nauczyciele na poziomie przedszkolnym są albo posiadającymi tytuł licencjata $\mathrm{w}$ dziedzinie pedagogiki nauczycielami wychowania przedszkolnego, albo nauczycielami kształcenia zintegrowanego. Nauczyciele uczący w klasach I-VI szkoły podstawowej są na ogół nauczycielami kształcenia zintegrowanego, natomiast nauczyciele klas VII-IX szkoły podstawowej i szkół średnich II stopnia są nauczycielami przedmiotu. Nauczyciele kształcenia zintegrowanego mają tytuł magistra pedagogiki, a nauczyciele przedmiotu są absolwentami studiów magisterskich w dziedzinie odpowiadającej przedmiotowi, którego uczą, oraz studiów pedagogicznych. 0 przyjęcie na studia przygotowujące wychowawców klas mogą ubiegać się kandydaci, którzy zdali egzamin maturalny.

Wydziały pedagogiczne co roku przeżywają stan prawdziwego oblężenia o jedno miejsce walczy od 7 do 10 kandydatów. Sam proces rekrutacji jest bardzo 
rygorystyczny i tylko najlepsi mają szansę na zdobycie indeksu. Przyszli nauczyciele muszą osiągnąć najwyższe wyniki na maturze (konkurs świadectw) oraz zdać egzamin pisemny zorganizowany przez uczelnię. Kandydaci biorą również udział $\mathrm{w}$ inscenizowanych zajęciach, $\mathrm{w}$ trakcie których sprawdza się ich umiejętności interpersonalne, oraz są zapraszani na rozmowy kwalifikacyjne i pytani, dlaczego chcą zostać nauczycielami. Ten wielostopniowy proces selekcji pozwala wyłowić osoby, które mają psychologiczne predyspozycje do wykonywania zawodu i autentycznie chcą pracować z dziećmi. Studenci pedagogiki mogą wybrać nauczanie wczesnoszkolne (zintegrowane) typowe dla klas od I do VI lub nauczanie przedmiotowe. W tym ostatnim przypadku muszą najpierw zdobyć określoną specjalizację, a następnie w ciągu roku opanować dydaktykę nauczania danego przedmiotu. Podczas studiów szczególny nacisk kładziony jest na łączenie teorii z praktyką. Studenci przygotowują zajęcia i prowadzą lekcje w szkołach, dzięki czemu poznają tajniki procesu dydaktycznego i budują własny warsztat pedagogiczny. Są również zachęcani do pracy naukowej, np. praca magisterska musi zawierać wyniki badań własnych w zakresie edukacji. Wysokie kryteria stawiane kandydatom na studia (selekcja pozytywna) oraz doskonałe przygotowanie merytoryczne i metodyczne studentów do pracy w szkolnictwie - to dwa czynniki powodujące, że do zawodu faktycznie trafiają „najlepsi z najlepszych”. Nic więc dziwnego, że status pedagoga jest w Finlandii znacznie wyższy niż w wielu innych krajach, a nauczyciele cieszą się dużym prestiżem i zaufaniem społecznym.

\section{Niemcy}

\section{Organizacja administracji oświatowej}

W Republice Federalnej Niemiec zakres odpowiedzialności za system edukacji wynika z federalnej struktury państwa. Zgodnie z Ustawą zasadniczą (Grundgesetz) ${ }^{14}$ odpowiedzialność za oświatę została rozdzielona pomiędzy władze federalne i kraje związkowe (landy). Koordynacja spraw oświatowych między landami i władzami centralnymi odbywa się w ramach Stałej Konferencji Ministrów Edukacji i Kultury, Nauki i Oświaty Krajów Związkowych Republiki Federalnej Niemiec (Kultusministerkonferenz; dalej: Stała Konferencja) ${ }^{15}$.

14 https://www.bundestag.de/grundgesetz.

15 https://www.kmk.org/. 


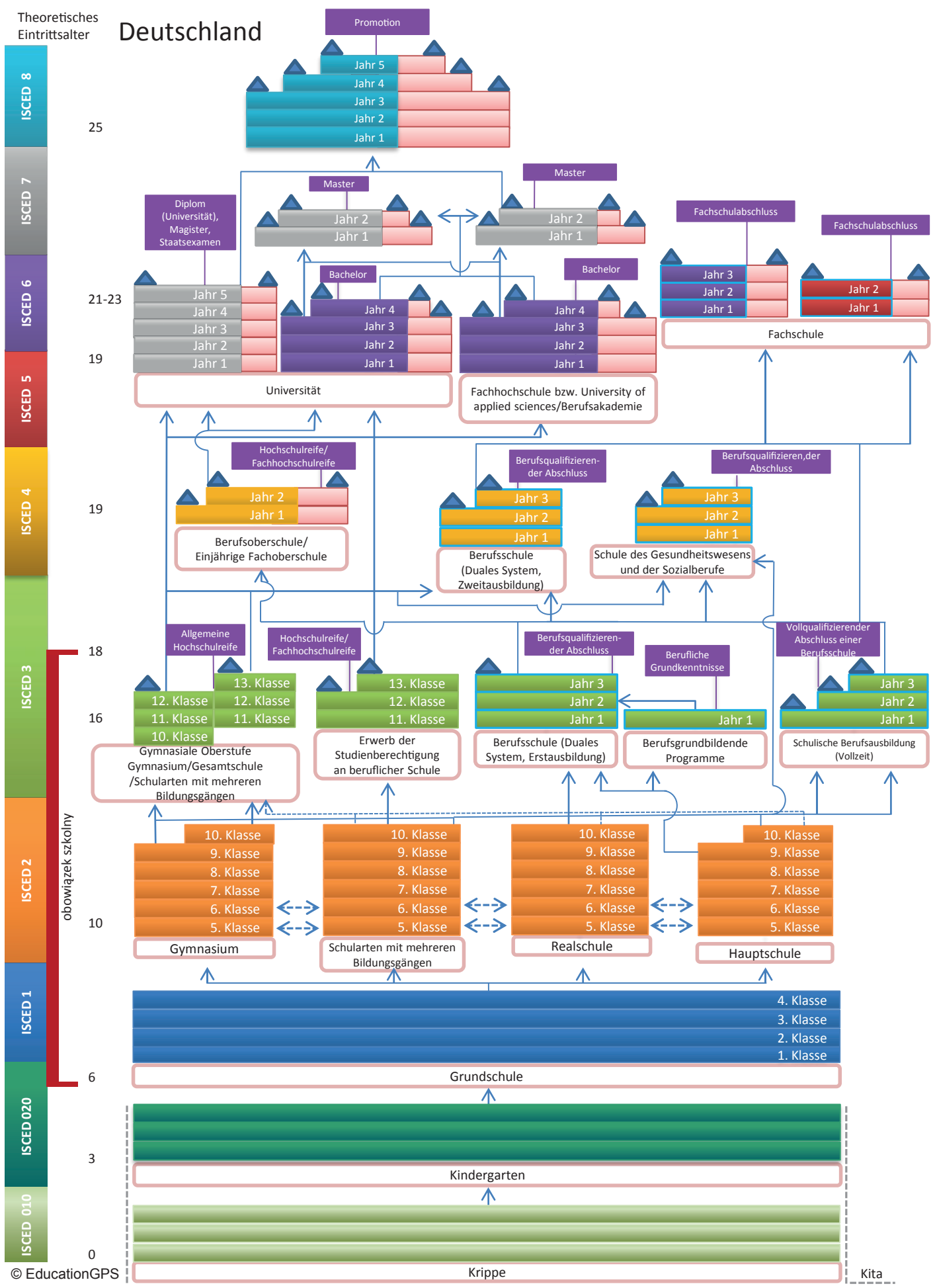




\section{Legenda (wyjaśnienie terminów użytych na rysunku)}

\section{POZIOMY EDUKACYJNE}

Krippe - żłobek

Kindergärten - przedszkole

Grundschule - szkoła podstawowa

Gymnasium - liceum

Schularten mit mehreren Bildungsgängen - szkoły z różnymi specjalistycznymi programami

Realschule - szkoła realna

Hauptschule - szkoła główna

Gymnasiale Oberstufe - szkoła średnia wyższa (drugiego stopnia)

Gymnasium - liceum

Gesamtschule - szkoła ogólnokształcąca

Schularten mit mehreren Bildungsgängen - szkoły z różnymi programami

Erwerb der Studienberechtigung an beruflicher Schule - szkoły średnie ogólnokształcące zapewniające warunki do uzyskania kwalifikacji zawodowych

Berufsschule (Duales System, Erstausbildung) - szkoła średnia zawodowa (system dualny - łączenie nauki i pracy, kształcenie wstępne)

Berufsgrundbildende Programme - podstawowe programy zawodowe

Schulische Berufsausbildung (Vollzeit) - kształcenie zawodowe realizowane w szkole (w pełnym wymiarze godzin)

Berufsoberschule - szkoła średnia zawodowa

Einjährige Fachoberschule - roczna szkoła średnia techniczna

Berufsschule (Duales System, Zweitausbildung) - szkoła średnia zawodowa (system dualny, kształcenie średnie)

Schule des Gesundheitswesens und der Sozialberufe - szkolnictwo kształcące do zawodów medycznych i opieki społecznej

Universität - uniwersytet

Fachhochschule - uczelnia prowadząca studia w dziedzinie nauk stosowanych

Berufsakademie - akademia zawodowa

Fachschule - szkoły o profilu handlowym i technicznym

\section{DYPLOMY}

Allgemeine Hochschulreife - matura ogólnokształcąca umożliwiająca dostęp do szkolnictwa wyższego

Hochschulreife - matura

Fachhochschulreife - matura szkoły o profilu handlowym i technicznym

Berufsqualifizierender Abschluss - dyplom kwalifikacji zawodowych

Berufliche Grundkenntnisse - certyfikaty podstawowych umiejętności zawodowych

Vollqualifizierender Abschluss einer Berufsschule - dyplom potwierdzający uzyskane kwalifikacje zawodowe Diplom (Universität) - dyplom (uniwersytecki)

Magister - dyplom magisterski

Staatsexamen - egzamin państwowy

Bachelor - licencjat

Master - magister

Fachschulabschluss - dyplom potwierdzający wykształcenie wyższe techniczne

Promotion - doktorat 
Zadania rządu federalnego w dziedzinie edukacji obejmują m.in. ustanawianie przepisów wyznaczających ogólne ramy współpracy oświatowej pomiędzy szczeblem federalnym i landami, np. w zakresie planowania edukacji i promowania badań. Za ustawodawstwo i administrację oświatową odpowiadają przede wszystkim landy oraz władze nadzorujące szkoły na niższym administracyjnym szczeblu (Schulamt). Ministerstwa edukacji w landach odpowiedzialne są za ustalanie programów nauczania, zalecanie metod nauczania i zatwierdzanie do użytku szkolnego pomocy i podręczników. Programy i treści nauczania opracowywane są w taki sposób, aby spełniały kryteria zawarte w przyjętych przez Stałą Konferencję krajowych standardach kształcenia.

Do zadań władz nadzorujących szkoły w każdym landzie należy przeprowadzanie inspekcji oraz sprawowanie nadzoru pedagogicznego, nadzoru w zakresie zgodności działań z regulacjami prawnymi i nadzoru w sprawach kadrowych w systemie szkolnym. W każdej szkole działa rada pedagogiczna odpowiedzialna za sprawy dydaktyczne oraz rada szkoły (złożona z nauczycieli, rodziców i uczniów), która ustanawia przepisy szkolne i zasady dyscypliny. Zakres uprawnień tych rad jest różny, zależnie od landu.

Kształcenie w ramach tzw. duale system (dualnego systemu kształcenia zawodowego - w zakładzie pracy i szkole), którym objęte jest blisko dwie trzecie młodzieży, kształcenie w zakładzie pracy jest finansowane przez firmy, a w szkole przez landy. Zajęcia w zakładzie pracy odbywają się zgodnie z koordynowanymi na szczeblu krajowym zasadami kształcenia, a programy nauczania dla szkół są według tych zasad opracowywane przez landy. Kształcenie zawodowe w zakładzie pracy nadzorują izby gospodarcze i handlowe (np. izby przemysłu i handlu, izby rzemieślnicze itp.).

\section{Organizacja i struktura edukacji publicznej}

Na strukturę systemu edukacji w Niemczech składają się następujące placówki oświatowe:

- przedszkole (Kindergärten),

- szkoła podstawowa (Grundschule),

- szkoły średnie I stopnia (Gymnasium, Realschule, Hauptschule, Gesamtschule),

- szkoły średnie II stopnia o profilu ogólnokształcącym i zawodowym (Gymnasium, Gesamtschule, Berufsfachschulen, Fachoberschule, Berufliches Gymnasium, Fachgymnasium, Berufsoberschule),

- szkolnictwo wyższe. 


\section{Przedszkole (Kindergärten)}

W większości landów za edukację przedszkolną odpowiadają ministerstwa ds. socjalnych. Dzieci w wieku od 3 do 6 lat mogą uczęszczać do przedszkoli (Kindergärten), które są prowadzone głównie przez instytucje niepubliczne (przede wszystkim kościoły i stowarzyszenia opieki społecznej), przy czym pomimo znacznych dotacji publicznych przyznawanych tym placówkom i finansowania z innych źródeł w kosztach obowiązkowo partycypują również rodzice.

Dzieci sześcioletnie, które osiągnęły wiek obowiązkowej nauki, ale których poziom rozwoju (dojrzałości szkolnej) nie pozwala jeszcze na rozpoczęcie nauki w szkole, kierowane są do placówek uzupełniających (przejściowych) Schulkindergärten lub Vorklassen. W większości landów władze nadzorujące szkoły są uprawnione do kierowania sześciolatków do tych placówek.

\section{Obowiq̨zek szkolny}

W Niemczech długość trwania obowiązku szkolnego zależna jest od landu i rodzaju kształcenia. Kształcenie w pełnym wymiarze jest obowiązkowe dla uczniów od 6 do 15 lub 16 roku życia, a kształcenie w niepełnym wymiarze obowiązuje od 6 do 18 roku życia ${ }^{16}$. Kształcenie obowiązkowe jest w całości bezpłatne.

Obowiązek szkolny obejmuje następujące szczeble kształcenia:

- Szkoła podstawowa (Grundschule) - wiek: 6-10 lat (6-12, Berlin i Brandenburgia),

- Szkoły średnie I stopnia ${ }^{17}$ - Gymnasium, Realschule, Hauptschule, Gesamtschule (różne rodzaje szkół prowadzące kilka cykli kształcenia) - wiek:

16 Kształcenie w pełnym wymiarze jest obowiązkowe w wieku od 6 do 15 lat w większości landów (Badenia-Wirtembergia, Bawaria, Hamburg, Hesja, Meklemburgia-Pomorze Przednie, Dolna Saksonia, Nadrenia Północna-Westfalia w Gymnasium, Nadrenia-Palatynat, Saara, Saksonia, Saksonia-Anhalt, Szlezwik-Holsztyn) lub 16 lat (Berlin, Brandenburgia, Brema, Nadrenia Północna-Westfalia w innych typach szkół poza Gymnasium, Turyngia), a kształcenie w niepełnym wymiarze jest obowiązkowe do wieku 18 lat dla osób, które nie uczęszczają do szkoły w pełnym wymiarze.

17 Szczebel średni I stopnia (Sekundarstufe I) prawie w każdym kraju związkowym ukształtowany jest inaczej. Jedynym typem szkoły występującym we wszystkich landach jest gimnazjum (od klasy V lub VII, z maturą po klasie XII lub XIII). Klasyczny podział systemu szkolnego, obejmujący trzy odrębne szkoły (Hauptschule, Realschule i Gymnasium) modelu trójdrożnego, istnieje jedynie w Badenii-Wirtembergii i Bawarii. W Berlinie, Hamburgu, Hesji, Dolnej Saksonii, Nadrenii-Westfalii i w Szlezwiku-Holsztynie zmodyfikowano ten model poprzez wprowadzenie szkoły rozszerzonej (Gesamtschule), a więc na rzecz czteroczłonowości. W większości nowych landów przyjęto zasadę dwuczłonowości systemu 
10/12-15/16 lat. Ważnym elementem szkolnictwa średniego I stopnia jest objęcie wszystkich uczniów dwóch pierwszych klas (klasa V i VI; wiek uczniów 10-12 lat) we wszystkich rodzajach szkół tzw. fazą orientacji (Orientierungsstufe), która służy wspieraniu rozwoju i polepszaniu orientacji uczniów co do ich dalszego toku kształcenia, a także ma wesprzeć ucznia w ewentualnej zmianie lub w potwierdzeniu decyzji o wyborze konkretnej szkoły,

- Szkoły średnie II stopnia - wiek: 15/16-18/19 lat.

\section{Szkoła podstawowa (Grundschule)}

Do Grundschule przyjmuje się uczniów w wieku od 6 lat. Dzieci objęte obowiązkiem nauki szkolnej wstępują do jednakowej dla wszystkich lokalnej szkoły podstawowej. Do przedmiotów nauczanych w szkole podstawowej należą: czytanie, pisanie, arytmetyka, wprowadzenie do przedmiotów przyrodniczych i społecznych (Sachunterricht), wychowanie plastyczne, wychowanie muzyczne, wychowanie fizyczne i edukacja religijna. Programy i treści nauczania opracowywane są w taki sposób, aby spełniały kryteria zawarte w przyjętych przez Stałą Konferencję krajowych standardach kształcenia dla szkoły podstawowej.

Uczniowie promowani są automatycznie z klasy I do II. Od II klasy szkoły podstawowej uczniowie, w zależności od osiągnięć (wyników w nauce) mogą być promowani bądź powtarzać klasę. Decyzja o promocji ucznia jest podejmowana na podstawie stopni, jakie uczeń otrzymuje na koniec roku szkolnego (odnotowywanych na świadectwie Zeugnis). Decyzje podejmowane są wspólnie przez nauczycieli uczących danego ucznia (Klassenkonferenz) lub przez Radę Pedagogiczną, czyli wszystkich nauczycieli danej szkoły (Lehrerkonferenz). Decyzja o promocji lub jej braku jest odnotowywana na świadectwie.

szkolnego (Zweigliedriges Schulsystem), która jest stopniowo przejmowana również przez stare landy. I tak w Saksonii są to szkoły średnie (Mittelschule), w Saksonii-Anhalt - Sekundarschule, a w Turyngii - Regelschule, wszystkie kontynuowane w szkole głównej lub realnej (Hauptschule i Realschule). Podobny układ widoczny jest w Zagłębiu Saary, gdzie przyjęto rozszerzoną szkołę realną (erweiterte Realschule), oferującą kształcenie w toku szkoły głównej i realnej, oraz w Bremie - szkoły typu Sekundarschule z klasami Haupt i Real od klasy IX. Najbardziej zróżnicowany krajobraz szkolny prezentuje Nadrenia-Palatynat, gdzie obok szkół: głównej, realnej, rozszerzonej oraz gimnazjów istnieją szkoły regionalne (Regionale Schule) ze zintegrowanym tokiem nauczania typu Haupt i Real oraz dualne szkoły średnie (Duale Oberschule), których zadaniem jest połączenie wykształcenia ogólnego $\mathrm{z}$ zawodowym. 
Przejście ze szkoły podstawowej do jednej z kilku rodzajów szkół średnich odbywa się zgodnie z różnymi przepisami, zależnie od ustawodawstwa danego kraju związkowego (landu). 0 wyborze szkoły średniej I stopnia decydują rodzice z dziećmi, na podstawie oceny dokonanej przez szkołę podstawową. Przyjęcie do różnych szkół średnich może być uzależnione od wyników w nauce i/lub decyzji władz edukacyjnych.

\section{Szkoły średnie}

Gimnazjum (Gymnasium) na poziomie szkoły średniej I stopnia trwa 6 lat (klasy V-X). Uczęszczają do niego uczniowie wykazujący się najlepszymi osiągnięciami. Po ukończeniu klasy X można kontynuować naukę w gimnazjum na poziomie szkoły średniej II stopnia (klasy XI-XII lub XIII; wiek ucznia 16-18 lub 19 lat). Warunkiem przyjęcia do klasy XI jest konkurs świadectw, w którym biorą udział wyłącznie najlepsze świadectwa szkoły średniej I stopnia. W gimnazjum na poziomie szkoły średniej II stopnia zamiast tradycyjnych lekcji przedmiotowych obowiązuje tzw. system kursowy. Przed przystąpieniem do egzaminu maturalnego (abitur) każdy uczeń musi ukończyć ustaloną liczbę kursów, na podstawie których układany jest jego profil egzaminów końcowych. Każdy uczeń musi zdawać egzamin z języka niemieckiego, języka obcego i wybranego przedmiotu. Świadectwo maturalne upoważnia do podjęcia studiów w szkole wyższej.

Szkoła główna (Hauptschule) trwa od 5 do 6 lat (klasy V-IX lub X). Celem kształcenia jest przekazanie uczniowi ogólnych wiadomości i umiejętności, które stanowić będą podstawę do dalszej nauki w szkole zawodowej. Po ukończeniu szkoły głównej i zdaniu końcowego egzaminu uczeń otrzymuje dyplom Hauptschulabschluss. Ukończenie szkoły głównej uprawnia do rozpoczęcia nauki w szkole zawodowej (Fachschule), wyższej szkole zawodowej (Fachoberschule) oraz daje prawo podpisania umowy umożliwiającej rozpoczęcie praktycznej nauki zawodu.

Szkoła realna (Realschule) trwa z reguły 5-6 lat (klasy V-IX lub X). Jest alternatywą dla Hauptschule. Celem kształcenia w Realschule jest przekazanie uczniowi poszerzonej wiedzy podstawowej ze szczególnym naciskiem na tematykę związaną z gospodarką, techniką i polityką socjalną. Nauka w szkole kończy się egzaminem Mittlere Reife, po którym uczeń może podjąć pracę w sektorze administracyjnym lub gospodarczym, bądź też kontynuować naukę w wyższej szkole zawodowej (Fachoberschule). 
Szkoła zbiorcza (Gesamtschule) ${ }^{18}$ jest połączeniem gimnazjum, szkoły głównej i szkoły realnej. W Gesamtschule występują więc trzy podstawowe rodzaje szkół jakby pod wspólnym szyldem. W zależności od zainteresowań, zdolności i postępów ucznia, może on uczestniczyć w kursach o mniejszych lub większych wymaganiach. 0 tym, jakie wykształcenie widnieje na świadectwie ukończenia szkoły, decyduje liczba i oceny ze zdanych egzaminów. Uczeń może uzyskać jedno z trzech rodzajów wykształcenia, oferowanych po ukończeniu Gymnasium, Hauptschule, Realschule lub szkoły średniej zawodowej.

\section{Kształcenie zawodowe}

Podstawą szkolnictwa zawodowego w Niemczech jest tzw. system dualny ( $d u$ ale system). System dualny zwany też przemiennym lub dwutorowym polega na praktycznej nauce zawodu organizowanej przez pracodawcę oraz ogólnokształcącym i teoretycznym kształceniu zawodowym realizowanym w placówce szkolnej lub poprzez formy pozaszkolne.

W Niemczech ponad 2/3 młodzieży kończącej szkołę obowiązkową wybiera jako dalszą ścieżkę edukacyjną kształcenie zawodowe w systemie dualnym. Trwa ono 2 lub 3 lata, w zależności od wyboru specjalizacji (zawodu). Celem systemu jest zapewnienie możliwie najlepszej edukacji zawodowej, tj. właściwie skonstruowanego profilu kształcenia umożliwiającego zdobycie umiejętności, wiedzy i kwalifikacji zawodowych niezbędnych do wykonywania danego zawodu w zmieniających się okolicznościach rynku pracy. System umożliwia ponadto zdobycie wymaganego doświadczenia zawodowego.

Młoda osoba podejmująca szkolenie zawodowe w systemie dualnym jest zatrudniona na podstawie umowy cywilnoprawnej między nią a firmą oferującą szkolenie. Na podstawie umowy uczeń ma obowiązek podjąć szkolenie praktyczne (w miejscu pracy) i teoretyczne (w szkole). Uczniowie spędzają na ogół od 3 do 4 dni w miejscu pracy i 1 lub 2 dni w tygodniu w szkole. Przedsiębiorca ponosi koszt szkolenia w miejscu pracy i wypłaca pensję ustalaną na zasadzie kontraktu negocjowanego na podstawie umowy zbiorowej. Wysokość pensji wzrasta z każdym rokiem szkolenia i równa się średnio $1 / 3$ wynagrodzenia wykwalifikowanego pracownika rozpoczynającego pracę.

Uczeń kończący kształcenie w systemie dualnym uzyskuje formalne kwalifikacje do podjęcia pracy w jednym z 350 zawodów regulowanych. Jedynym wa-

18 Nie występuje we wszystkich landach. 
runkiem koniecznym do rozpoczęcia nauki w systemie dualnym jest uzyskanie świadectwa ukończenia szkoły obowiązkowej. Nie ma innych dodatkowych wymagań - możliwość kształcenia w systemie dualnym jest otwarta dla wszystkich. Większość kandydatów decyduje się na podjęcie kształcenia w tym systemie od razu po zakończeniu edukacji na poziomie średnim I stopnia, chociaż około 20\% uczniów wybiera tę formę kształcenia dopiero po ukończeniu szkoły średniej II stopnia.

\section{Szkoły średnie II stopnia o profilu zawodowym}

Szkoła średnia zawodowa Berufsfachschulen trwa w zależności od specjalizacji od 1 roku do 3 lat (wiek uczniów: 16-19 lat). Przygotowuje do zawodu, oferując wstępne szkolenie zawodowe w jednym lub kilku zawodach regulowanych, lub prowadzi do uzyskania pełnych kwalifikacji zawodowych w określonym zawodzie. Proponuje również dalszą edukację ogólnokształcącą. Berufsfachschulen kształcą w kierunkach: biznesowym, języków obcych, sztuki, rzemiosła, pracy społecznej, pracy w sektorze zdrowia. Listę konkretnych zawodów reguluje prawo federalne. W przypadku, gdy uczeń nie uzyskuje pełnych kwalifikacji, kończąc ten typ szkoły, ukończenie jej może zostać zaliczone do formalnego szkolenia w zawodzie, który wymaga takiego stażu. Absolwenci Berufsfachschulen mogą również przystąpić do egzaminu walidacyjnego przed odpowiednim organem (jeśli dany land przyjął odpowiednie regulacje, które to umożliwiają) i potwierdzić swoje kwalifikacje oraz ich zgodność z kwalifikacjami nabywanymi w systemie dualnym. Warunkiem przyjęcia do Berufsfachschulen jest certyfikat ukończenia edukacji obowiązkowej.

Szkoła średnia techniczna Fachoberschule trwa 2 lub 3 lata (wiek uczniów: 1618/19 lat). Kształci w kierunku ogólnym oraz specjalistycznym (w zakresie wiedzy teoretycznej i praktycznej), prowadzi do zdobycia kwalifikacji umożliwiających kształcenie na poziomie wyższym. Dziedziny kształcenia to: biznes i administracja, kierunki techniczne, żywienie, rolnictwo, praca społeczna i zdrowie, projektowanie, bioinżynieria i ochrona środowiska. Przedmioty obowiązkowe bez względu na specjalizację obejmują: język niemiecki, wiedzę o społeczeństwie, matematykę, nauki przyrodnicze, język obcy i przedmiot zawodowy. Szkolenie praktyczne odbywa się w pierwszym roku nauki w miejscu pracy (fabryce, firmie, instytucji) związanej z wybraną specjalizacją.

Berufliches Gymnasium/Fachgymnasium - Szkoła ta stanowi wyższy poziom Gymnasium uzupełniony o specjalizację zawodową. Ten typ szkoły nie ma odpo- 
wiednika na niższym poziomie - w praktyce w niektórych landach są to ostatnie 3 lata Gymnasium ze specjalizacjami zorientowanymi na konkretne zawody. Przedmioty zawodowe są dodane do programów nauczania ogólnego obowiązującego w szkole ogólnokształcącej na tym poziomie i są zdawane podczas egzaminu końcowego. Przedmioty zawodowe, takie jak np.: przedsiębiorczość, biznes, technika, technologia informacyjna, żywienie, agronomia, nauki społeczne i o zdrowiu, jeśli są realizowane w trybie intensywnym, mogą być zdawane na egzaminie maturalnym zamiast przedmiotów ogólnych. Niektóre Berufliches Gymnasium/Fachgymnasium oferują uczniom możliwość uzyskania podwójnych kwalifikacji, tj. kwalifikacji umożliwiających podjęcie studiów wyższych, zgodnie z prawem obowiązującym na terenie danego landu. Ten typ kształcenia zawodowego oferują również inne instytucje, np. Oberstufenzentren (Centrum Wyższego Kształcenia Zawodowego), trwa ono zazwyczaj od 3 do 4 lat.

Zawodowa szkoła średnia Berufsoberschule, której celem jest umożliwienie uczniom, którzy kształcili się w systemie dualnym, dostępu do edukacji na poziomie wyższym. Kształcenie w Berufsoberschule trwa 2 lata w pełnym wymiarze godzin i kończy się egzaminem maturalnym. Niektóre szkoły oferują także odpowiednio dłuższy cykl kształcenia w niepełnym wymiarze godzin. Uczniowie przyjmowani są do Berufsoberschule na podstawie certyfikatu uzyskiwanego po ukończeniu szkoły średniej I stopnia oraz po odbyciu dwóch lat kształcenia zawodowego lub pięciu lat praktyki zawodowej.

\section{Szkolnictwo wyższe}

Do szkolnictwa wyższego zalicza się: Universitäten (uniwersytety) i równorzędne uczelnie (Technische Hochschulen/Universitäten, Pädagogische Hochschulen, Theologische Hochschulen), Kunsthochschulen (uczelnie artystyczne), Musikhochschulen (uczelnie muzyczne) i Fachhochschulen (uczelnie prowadzące studia w dziedzinie nauk stosowanych). Szczególną rolę pełni 29 uczelni prowadzących studia w dziedzinie administracji publicznej (Verwaltungsfachhochschulen), które szkolą przyszłych urzędników tzw. wyższego szczebla służby cywilnej. Utrzymywane są z budżetu władz centralnych lub danego landu. Do szkolnictwa wyższego należą również Berufsakademie, funkcjonujące w niektórych landach, które łączą kształcenie akademickie w Studienakademie z praktycznym kształceniem zawodowym w zakładzie pracy, zgodnie z zasadą systemu dualnego. Status uczelni wyższych posiadają także Fachschulen, które przyjmują kandydatów mających ukończony okres kształcenia formalnego w danym zawodzie i są aktual- 
nie zatrudnieni, oraz dwuletnie i trzyletnie szkoły zdrowia publicznego Schulen des Gesundheitswesens przygotowujące do pracy w sektorze służby zdrowia, np. pielęgniarki czy fizjoterapeutów. Wiele takich placówek jest logistycznie i organizacyjnie związanych ze szpitalami, w których odbywają się zajęcia zarówno praktyczne, jak i teoretyczne.

Głównymi kryteriami przyjęcia na studia na poziomie krajowym są: średnia ocen uzyskanych przez kandydata na egzaminie Abitur, okres między zdaniem egzaminu Abitur a złożeniem podania o przyjęcie na studia oraz wynik procedury selekcyjnej obowiązującej na konkretnej uczelni. Na poziomie regionalnym mogą obowiązywać inne zasady rekrutacji. I tak, panuje tendencja do zwiększania liczby lokalnych ograniczeń dotyczących przyjęć do niektórych szkół wyższych na kierunki, których nie obejmują ogólnokrajowe procedury selekcyjne. W takich przypadkach za wybór kandydatów odpowiadają jedynie poszczególne placówki.

\section{Nauczyciele}

Zawód nauczyciela w Niemczech regulowany jest przepisami poszczególnych krajów związkowych, które określają konkretne warunki i kwalifikacje, jakie należy spełnić, aby uczyć w szkole.

W Niemczech nauczyciele zazwyczaj kształcą się na dwóch kierunkach. Nauka zawodu obejmuje studia dające możliwość nauczania dwóch przedmiotów i następującą po nich praktykę przygotowawczą. W niektórych landach można uzyskać dopuszczenie do praktyki przygotowawczej, mając ukończony jeden kierunek i ewentualnie kierunek dodatkowy, który musi wynikać ze świadectwa ukończenia szkoły wyższej. Możliwość taką dopuszcza się w przypadku tzw. przedmiotów deficytowych, w których brakuje nauczycieli. Po zakończeniu praktyki przygotowawczej odbywa się egzamin państwowy, którego zdanie uprawnia do wykonywania zawodu nauczyciela.

Nauczyciele szkół podstawowych są nauczycielami przedmiotów zintegrowanych, a nauczyciele szkół średnich specjalizują się w określonych przedmiotach. Nauczyciele są na ogół zatrudniani przez land i mają z reguły status urzędnika państwowego. W ostatnich latach w ramach kształcenia nauczycieli wprowadzono nowe etapowe programy studiów. Jeśli kwalifikacje otrzymywane po ich ukończeniu zachowują standardy kształcenia uzgodnione przez Stałą Konferencję, są wówczas wzajemnie uznawane przez kraje związkowe. W Niemczech duży nacisk kładzie się na permanentne dokształcanie i doskonalenie zawodowe 
nauczycieli, które na ogół odbywa się na uniwersytetach. W organizację doskonalenia nauczycieli włączają się też związki zawodowe oraz samorządy gmin.

\section{Norwegia}

\section{Organizacja administracji oświatowej}

W Norwegii nadzór nad edukacją sprawuje Ministerstwo Edukacji i Badań. Odpowiada całościowo za wszystkie poziomy edukacji, włącznie z edukacją przedszkolną i szkolnictwem wyższym. Władze okręgowe odpowiadają za szkolnictwo średnie II stopnia, a władze gminne zarządzają wszystkimi aspektami kształcenia obowiązkowego. Jednym z głównych zadań gubernatorów wszystkich okręgów jest nadzór nad władzami lokalnymi w zakresie kształcenia oferowanego przez szkoły podstawowe i średnie. Gubernatorzy okręgów nadzorują również prowadzenie przedszkoli przez poszczególne gminy oraz zajmują się koordynacją poradnictwa i działań prorozwojowych na szczeblu lokalnym. Dyrekcja ds. Edukacji i Szkoleń (agencja wykonawcza Ministerstwa Edukacji i Badań) odpowiada za przygotowanie programów nauczania, opracowanie systemu oceniania i systemu egzaminacyjnego, system nadzoru i kontroli, prowadzenie ogólnokrajowych statystyk i badań oraz rozwój szkolnictwa podstawowego i średniego.

\section{Organizacja i struktura edukacji publicznej}

Na strukturę systemu edukacji w Norwegii składają się następujące placówki oświatowe:

- przedszkole (Barnehage),

- szkoła podstawowa (Grunnskole),

- szkoła średnia II stopnia (Videregående skole),

- szkoła policealna (Fagskole),

- szkolnictwo wyższe.

W Norwegii edukacja przedszkolna (Barnehage) dla dzieci w wieku od 1 do 6 roku życia jest nieobowiązkowa. Przedszkola prywatne stanowią 50\% wszystkich placówek. Zarówno publiczne, jak i prywatne placówki są zobowiązane do przestrzegania zaleceń ustawy przedszkolnej i planu ramowego. Placówki prywatne otrzymują wsparcie finansowe od państwa i z gmin.

Programy przedszkolne opierają się na holistycznym podejściu pedagogicznym, w którym podstawę pracy z dzieckiem stanowią opieka, zabawa i nauka. 
Plan ramowy zawiera wytyczne co do wartości, treści i zadań edukacji przedszkolnej. Placówki zapewniają opiekę dzieciom w czasie godzin pracy rodziców. W związku z tym, że płatny urlop macierzyński trwa prawie rok jedynie nieliczni rodzice ubiegają się o miejsce w takiej placówce, zanim dziecko ukończy pierwszy rok życia. W ostatnich latach do przedszkoli uczęszczało około $90 \%$ wszystkich dzieci w wieku od 1 do 5 roku życia (w tym 79\% dzieci rocznych i dwuletnich, 96,5\% dzieci w wieku 3-5 lat). Władze lokalne są prawnie zobowiązane do zapewnienia odpowiedniej liczby miejsc. Przedszkola są płatne, a wysokość opłat regulowana jest prawnie przez rząd. W 2012 roku maksymalna kwota opłaty za przedszkole wynosiła 2330 koron norweskich. Gminy są zobowiązane do wprowadzenia zniżek dla rodzeństw oraz rodzin o bardzo niskich dochodach (rodziny te mogą być również całkowicie zwalniane z opłat). Dzieci ze specjalnymi potrzebami edukacyjnymi oraz dzieci objęte kuratelą opieki społecznej mają pierwszeństwo przyjęcia do placówek przedszkolnych, za co również odpowiadają władze gmin. Dzieci posługujące się językiem mniejszości narodowych objęte są specjalnym rządowym wsparciem finansowym umożliwiającym gminom realizację programów integracyjnych i wsparcia językowego.

\section{Obowiązek szkolny}

W Norwegii długość obowiązku szkolnego wynosi 10 lat. Kształcenie jest obowiązkowe od 6 do 16 roku życia. Obowiązkiem szkolnym objęta jest cała dziesięcioletnia szkoła podstawowa (Grunnskole) podzielona na dwa etapy:

- etap szkoły podstawowej (Barnetrinn) klasy I-VII - wiek: 6-13 lat,

- etap szkoły średniej I stopnia (Ungdomstrinnet) klasy VIII-X - wiek: 13-16 lat.

Uczniowie rozpoczynają obowiązkową naukę w roku kalendarzowym, w którym kończą 6 lat. Zgodnie z ogólną zasadą, uczniowie uczęszczają do szkoły publicznej, która jest położona najbliżej ich miejsca zamieszkania, lub szkoły wyznaczonej jako rejonowa dla ich miejsca zamieszkania. Po złożeniu odpowiedniego podania, uczeń może zostać przyjęty do innej szkoły, jeśli są w niej wolne miejsca. Kształcenie obowiązkowe jest bezpłatne w szkołach publicznych, natomiast w szkołach prywatnych od uczniów pobiera się czesne. Administracja szkolna może sama ustalać dzienny wymiar zajęć. W wielu gminach nauka obejmuje więcej godzin zajęć niż wymagane minimum. Uczniów dzieli się na grupy, zgodnie z odpowiednimi kryteriami pedagogicznymi. Grupy mogą składać się z uczniów w tym samym lub różnym wieku. Nie istnieją przepisy dotyczące klas i ich maksymalnej wielkości. Zajęcia prowadzi jeden nauczyciel przedmiotów zintegrowa- 


\section{Norge}

Teoretisk

begynneralder*

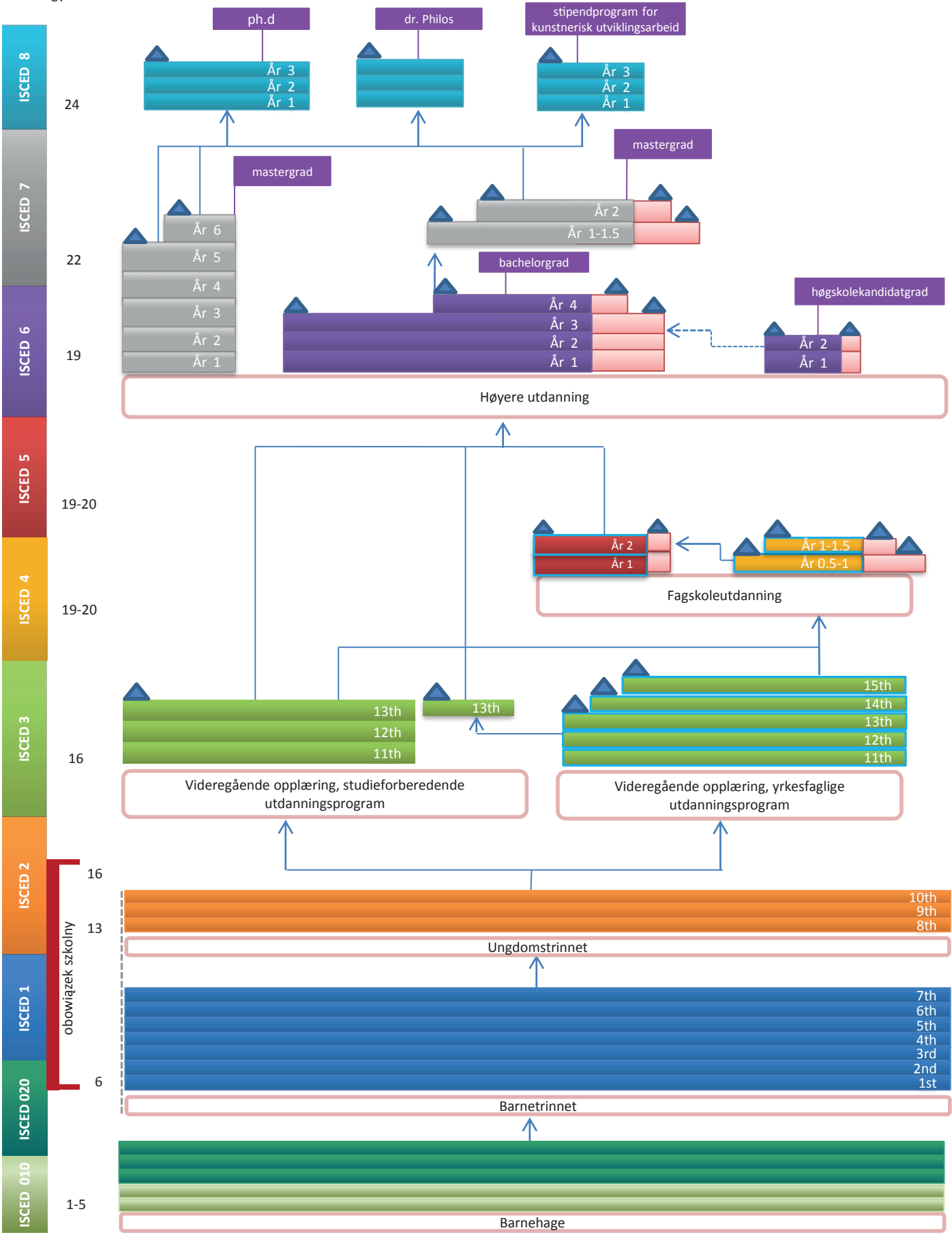




\section{Legenda (wyjaśnienie terminów użytych na rysunku)}

\section{POZIOMY EDUKACYJNE}

Barnehage - przedszkole

Barnetrinnet - nauczanie początkowe

Ungdomstrinnet - szkoła średnia I stopnia

Videregående oppleering, studieforberedende utdanningsprogram - etap szkolnictwa średniego II stopnia, przygotowujący do studiów wyższych

Videregående opplcering, yrkesfaglige utdanningsprogram - etap szkolnictwa średniego II stopnia o profilu kształcenia zawodowego

Fagskoleutdanning - szkolnictwo zawodowe powyżej szkoły średniej

Høyere utdanning - szkolnictwo wyższe

\section{DYPLOMY}

Bachelorgrad - licencjat

Høgskolekandidatgrad - dyplom ukończenia dwóch lat studiów

Mastergrad-magisterium

Ph.d., dr. Philos - doktorat

Stipendprogram for kunstnerisk utviklingsarbeid - program stypendialny w obszarze prac związanych z rozwojem artystycznym

OPIS TRANSFERÓW EDUKACYJNYCH (STRZAŁKI) I OZNACZEŃ LAT NAUKI

Ar - rok 
nych, nauczyciel kilku przedmiotów lub nauczyciele przedmiotu. Rolę podobną do roli wychowawcy pełni tzw. nauczyciel do kontaktu - każdy uczeń jest przypisany do nauczyciela, który odpowiada za jego zadania szkolne, w tym także kontakty z rodzicami.

Podstawy programowe dla poszczególnych przedmiotów zawierają opis kompetencji, jakie uczeń nabywa w ciągu roku nauki (po skończeniu danej klasy). Program podkreśla znaczenie rozwijania pięciu umiejętności podstawowych, które stanowią integralną część wszystkich przedmiotów i promocji wiedzy poprzez podejście oparte na efektach uczenia się. Przez cały okres kształcenia obowiązkowego program nauczania obejmuje następujące przedmioty: język norweski, matematyka, język angielski, przedmioty przyrodnicze, wiedza o społeczeństwie i historia, religia, filozofia i etyka, wychowanie plastyczne i prace ręczne, odżywianie i zdrowie, wychowanie muzyczne, wychowanie fizyczne, język obcy, praca na rzecz samorządu klasowego i uczniowskiego oraz przedmioty do wyboru. Nauczyciele mają prawo wyboru podręczników i programów nauczania.

Na poziomie Barnetrinn (klasy I-VII) nie prowadzi się formalnej oceny. Na poziomie Ungdomstrinnet (klasy VIII-X) stopnie są wystawiane z każdego przedmiotu dwa razy do roku na podstawie oceny dokonywanej przez nauczyciela. Promocja do następnej klasy jest automatyczna.

Zgodnie z wytycznymi Ministerstwa Edukacji i Badań uczniowie klas V, VIII i IX corocznie biorą udział w ogólnokrajowych sprawdzianach z podstawowych umiejętności. Sprawdziany obejmują czytanie, język angielski i matematykę. Obowiązkowo przeprowadza się również ogólnokrajowe testy w klasach I, II i III w zakresie umiejętności czytania oraz umiejętności matematycznych w klasie II.

Na zakończenie nauki w Grunnskole wszyscy uczniowie przystępują do ogólnokrajowych egzaminów i otrzymują świadectwo, w którym podaje się wszystkie uzyskane stopnie. Uczniowie, którzy otrzymali świadectwo, mają zagwarantowany wstęp do szkoły średniej II stopnia.

Za ogólnokrajowe egzaminy i ocenę ucznia odpowiada ministerialna Dyrekcja ds. Szkolnictwa Podstawowego i Średniego, która wydaje również wytyczne w tym zakresie.

\section{Szkoła średnia II stopnia (Videregående skole)}

Wszyscy uczniowie w wieku 16-19 lat, którzy ukończyli Grunnskole, mają ustawowo zagwarantowane prawo do nauki w szkole średniej II stopnia. Dla młodych ludzi w wieku 15-21 lat, którzy nie pracują i nie uczęszczają do szkoły, stworzono 
system informacji, poradnictwa i praktycznej pomocy. Uczniowie mogą ubiegać się o przyjęcie do szkół poza terenem swej gminy.

Kształcenie na poziomie średnim II stopnia obejmuje zarówno kształcenie ogólne, jak i kształcenie zawodowe i prowadzi do uzyskania kwalifikacji pozwalających na wstęp na wyższe uczelnie lub do kolegiów, uzyskania kwalifikacji zawodowych lub udokumentowania częściowych kwalifikacji. Kształcenie ogólne w szkole obejmuje:

- kształcenie na poziomie I (Videregående trinn Vg1),

- kształcenie na poziomie II (Videregående trinn Vg2),

- kształcenie na poziomie III (Videregående trinn Vg3).

Każdy z poziomów przewidziany jest na rok nauki. Kształcenie obejmuje 12 programów: 3 programy kształcenia ogólnego i 9 programów kształcenia zawodowego. Kształcenie zawodowe obejmuje 2 lata w szkole i roczne lub dwuletnie (jeśli dotyczy zawodów produkcyjnych) przyuczenie do zawodu.

Wspólna podstawa programowa obejmuje język norweski, religię i etykę, język angielski (oraz inne języki obce dla programów kształcenia ogólnego), wiedzę o społeczeństwie, geografię, historię, przedmioty ścisłe i przyrodnicze, matematykę i wychowanie fizyczne. Każdy program kształcenia składa się z roku przygotowawczego i 2 lat specjalizacji. W ramach większości programów kształcenia zawodowego ostatni rok specjalizacji zamienia się na dwuletnie przyuczenie do zawodu w zakładach pracy, z tego powodu standardowy model kształcenia zawodowego jest często nazywany modelem $2+2$.

Treści nauczania dla szkoły średniej II stopnia są opracowywane przez władze lokalne w taki sposób, aby dostosować je do indywidualnych potrzeb uczniów i lokalnego rynku pracy. Norwegowie stosują zasadę ukierunkowywania kształcenia na realizację celów, a nie szczegółowe ustalanie treści. Choć istnieje swoboda ustalania programów nauczania, to wszystkie programy muszą uzyskać akredytację Norweskiej Agencji ds. Zapewniania Jakości w Edukacji (Nasjonalt organ for kvalitet i utdanningen, NOKUT).

\section{Szkoła policealna (Fagskole)}

Fagskole to kolegia zawodowe, które oferują kształcenie policealne (ISCED 4). Przyjęcie do kolegiów zawodowych odbywa się po ukończeniu szkoły średniej II stopnia lub równorzędnych kwalifikacji zdobytych w miejscu pracy lub w efekcie pozaformalnej edukacji. Kolegia prowadzą praktyczne kursy i programy zawodowe, które trwają od pół roku do dwóch lat i stanowią alternatywę dla stu- 
diów wyższych. Ukończenie kursów skutkuje uzyskaniem zawodu i kwalifikacji pozwalających na bezpośrednie podjęcie pracy. Podobnie jak w przypadku Videregående skole, wszystkie programy nauczania Fagskole muszą uzyskać akredytację NOKUT.

\section{Szkolnictwo wyższe}

Studia wyższe są prowadzone w 8 uniwersytetach (państwowych), 9 specjalistycznych uczelniach (w tym 3 prywatnych), 23 kolegiach uniwersyteckich (państwowych), w tym 2 uniwersyteckich kolegiach sztuk pięknych i 31 uczelniach prywatnych prowadzących akredytowane programy (24 z nich otrzymują częściowe dofinansowanie z budżetu państwa). Dodatkowo istnieje 6 placówek szkolnictwa wyższego działających pod auspicjami innych ministerstw, np. Ministerstwa Obrony (5 placówek) oraz Ministerstwa Sprawiedliwości i Policji (1 placówka). Ogółem w Norwegii istnieje 77 instytucji szkolnictwa wyższego. Przyjęcia na studia w uczelniach państwowych podlegają regulacjom ilościowym i są uzależnione od liczby miejsc w poszczególnych uczelniach. Prawo do ubiegania się o przyjęcie na studia mają osoby, które ukończyły z pozytywnymi ocenami trzyletnią szkołę średnią II stopnia (Videregående skole) lub, co dotyczy osób powyżej 23 roku życia, mają pięcioletnie doświadczenie zawodowe, bądź odpowiednie wykształcenie w połączeniu z doświadczeniem zawodowym. W każdym przypadku obowiązują minimalne wymogi dotyczące języka norweskiego, języka angielskiego, historii, wiedzy o społeczeństwie, matematyki i przedmiotów przyrodniczych. Od 2001 roku na studia mogą również zostać przyjęte osoby, które mają kwalifikacje łączone, uzyskane w ramach kształcenia formalnego, pozaformalnego i nieformalnego (również osoby powyżej 25 roku życia). Od jesieni 2003 roku wprowadzono nową, zgodną z założeniami procesu bolońskiego, strukturę studiów, która obejmuje trzyletnie studia licencjackie/inżynierskie, a następnie dwuletnie studia magisterskie (oraz trzyletnie studia doktoranckie). Istnieje również kilka kierunków, na których nie wprowadzono modelu 3+2; są to: programy magisterskie trwające od roku do półtora roku, studia prowadzące do uzyskania dotychczasowego tytułu zawodowego høgskolekandidat, przyznawanego po ukończeniu dwuletnich studiów w kolegiach uniwersyteckich, pięcioletnie jednolite studia magisterskie, sześcioletnie studia na kilku kierunkach, czteroletnie studia licencjackie na kierunkach muzyka estradowa i sztuki widowiskowe oraz czteroletnie studia na kierunku pedagogika. 


\section{Nauczyciele}

Nauczycieli przedszkolnych kształci się w ramach trzyletniego programu pedagogiki przedszkolnej w kolegiach nauczycielskich lub uniwersytetach. Kształcenie kończy się świadectwem uprawniającym do nauczania na poziomie przedszkolnym i otrzymaniem tytułu licencjata. Nauczyciele szkoły podstawowej i średniej I stopnia mogą wybrać różne ścieżki uzyskania kwalifikacji pedagogicznych. Większość nauczycieli na tym poziomie kończy czteroletnie ogólne studia pedagogiczne. Niektórzy mają ukończone dawne studia uniwersyteckie (czteroletnie lub sześcioletnie) lub obowiązujące obecnie (trzyletnie lub pięcioletnie) oraz dodatkowy roczny kurs w zakresie teorii i praktyki pedagogicznej (istnieje też możliwość odbycia jednolitych studiów pięcioletnich). Nauczyciele na poziomie przedszkolnym i podstawowym (niższe klasy szkoły podstawowej) są przeważnie nauczycielami przedmiotów zintegrowanych. W klasach wyższych szkoły podstawowej specjalizują się w nauczaniu określonych przedmiotów. Dla nauczycieli szkoły obowiązkowej przewidziany jest specjalny czteroletni program kształcenia z dwoma ścieżkami specjalizacyjnymi dla nauczycieli klas I-VII lub klas V-X.

Ukończenie pełnego roku studiów w zakresie określonego przedmiotu uprawnia nauczyciela przedmiotów zintegrowanych do nauczania przedmiotów, takich jak matematyka, język angielski i język norweski. Pół roku nauki wystarcza do uzyskania uprawnień do nauczania innych przedmiotów na poziomie Ungdomstrinnet oraz nauczania matematyki i języka norweskiego na poziomie Barnetrinn. W szkołach średnich II stopnia uczą wyłącznie nauczyciele przedmiotu, którzy ukończyli trwające od 3 do 6 lat studia na uniwersytecie i roczny kurs w zakresie teorii i praktyki pedagogicznej, lub mają wykształcenie zawodowe i kwalifikacje nauczycielskie. Nauczycieli przedszkolnych oraz nauczycieli szkół podstawowych i średnich I stopnia zatrudniają gminy, natomiast zatrudnianie nauczycieli szkół średnich II stopnia leży w gestii okręgów.

\section{Wielka Brytania}

\section{Ogólna charakterystyka}

System edukacji w Wielkiej Brytanii funkcjonuje na podstawie ustawy oświatowej z 1944 r. (Education Act 1944) ${ }^{19}$. Władze centralne odpowiadają za określenie

19 http://www.legislation.gov.uk/ukpga/Geo6/7-8/31/contents/enacted. 
krajowych celów edukacji, włącznie z Krajowym Programem Nauczania (National Curriculum) i ewaluacją uczniów w wieku obowiązku szkolnego, finansują badania naukowe, ustalają minimalne standardy ofert edukacyjnych oraz dysponują środkami oddziaływania i kontroli. Minister Edukacji ustala także kryteria kształcenia nauczycieli (Qualified Teacher Status Standards) oraz warunki pracy i siatkę płac.

Struktura organizacyjna systemu szkolnego Wielkiej Brytanii nie jest jednolita. Administracja szkolna jest zdecentralizowania, a zarządzanie i odpowiedzialność za kształt i funkcjonowanie oświaty spoczywa w rękach władzy centralnej i lokalnej każdego spośród czterech części składowych (constituent part) kraju Anglii, Walii, Szkocji i Irlandii Północnej. Struktury oświatowe Anglii i Walii są relatywnie podobne, natomiast systemy szkolne Szkocji i Irlandii Północnej regulowane są odrębnymi ustawami. Występują w nich inne typy szkół, inne programy i odmienne organizacje pracy szkolnej. Ze względu na obszerność zagadnienia w poniższym opracowaniu przedstawiono przede wszystkim informacje na temat systemu edukacji w Anglii, a informacje o szkolnictwie w pozostałych constituent part Walii, Szkocji i Irlandii Północnej potraktowano skrótowo, skupiając się na szkolnictwie obowiązkowym.

\section{Anglia}

\section{Organizacja administracji oświatowej}

W Anglii za organizację oświaty odpowiadają Ministerstwo Edukacji (Department for Education, DfE) ${ }^{20}$ oraz Ministerstwo ds. Biznesu, Innowacji i Umiejętności (Department for Business, Innovation and Skills, BIS) ${ }^{21}$. Do obowiązków DfE należą: planowanie i monitorowanie organizacji edukacji w szkołach, zapewnianie zintegrowanych usług dla najmłodszych oraz koordynacja polityki dotyczącej dzieci i młodzieży. Natomiast BIS jest odpowiedzialne za kształcenie ustawiczne, innowacje, szkolnictwo wyższe i działalność gospodarczą. Ponadto kontrolę nad usługami realizowanymi na rzecz dzieci, szkół, kolegiów, systemu kształcenia nauczycieli, kształcenia w miejscu pracy i edukacji dorosłych sprawuje pozaresortowa rządowa instytucja - Urząd ds. Standardów Kształcenia, Usług na rzecz Dzieci i Umiejętności (Office for Standards in Education, Children’s Services and Skills, Ofsted) ${ }^{22}$.

20 https://www.gov.uk/government/organisations/department-for-education.

21 https://www.gov.uk/government/organisations/department-for-business-innovation-skills.

22 https://www.gov.uk/government/organisations/ofsted. 
Na szczeblu lokalnym organizacją kształcenia w szkołach finansowanych ze środków publicznych zajmuje się ponad 150 organów lokalnych władz różnego szczebla. Ramy prawne dla dotowanych szkół podstawowych i średnich dzielą je na szkoły lokalne (community schools), szkoły społeczne (voluntary schools) oraz szkoły fundacyjne (foundation schools). Większość stanowią szkoły lokalne. Wszystkie szkoły posiadają szeroką autonomię organizacyjną.

\section{Organizacja i struktura edukacji publicznej}

Na strukturę systemu edukacji w Anglii składają się następujące placówki oświatowe:

- edukacja przedszkolna - EYFS (Early Years Foundation Stage),

- szkoła początkowa (primary school),

- szkoła średnia (secondary school),

- szkolnictwo wyższe.

\section{Edukacja przedszkolna}

W Anglii opiekę nad dziećmi w wieku od 3 miesięcy do 3 lat zapewnia się głównie w sektorze placówek prywatnych i społecznych, a od rodziców pobiera się opłaty. Zgodnie z ustawą o opiece nad dzieckiem (Childcare Act 2006) ${ }^{23}$ oraz ustawowymi wytycznymi dla władz lokalnych dotyczącymi zapewniania wczesnej edukacji i opieki nad dziećmi (Statutory guidance. Early education and childcare) ${ }^{24}$, wychowanie przedszkolne realizowane jest jako Etap Przygotowawczy Wczesnej Edukacji (Early Years Foundation Stage, EYFS) ${ }^{25}$. Zawarte w EYFS przepisy dotyczą uczenia się, rozwoju i opieki nad dziećmi poniżej 5 roku życia. Na życzenie rodziców wszystkie trzylatki i czterolatki mogą uczęszczać bezpłatnie na zajęcia przedszkolne. Zajęcia są organizowane w dotowanych przedszkolach, w klasach przedszkolnych $\mathrm{w}$ dotowanych szkołach podstawowych, społecznych lub prywatnych placówkach. Dzieci mogą uczęszczać na zajęcia w wymiarze 15 godzin zajęć tygodniowo przez 38 tygodni w roku. Zdecydowana większość trzylatków i czterolatków uczęszcza na zajęcia tego typu.

W Anglii kształcenie jest obowiązkowe dla uczniów w wieku od 5 do 16 lat, ale wiele dzieci rozpoczyna naukę już w klasie zerowej (reception) szkoły podstawowej w wieku 4 lat.

23 http://www.legislation.gov.uk/ukpga/2006/21/contents.

24 https://www.gov.uk/government/publications/early-education-and-childcare--2.

25 https://www.gov.uk/early-years-foundation-stage. 
Theoretical starting age

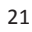

0

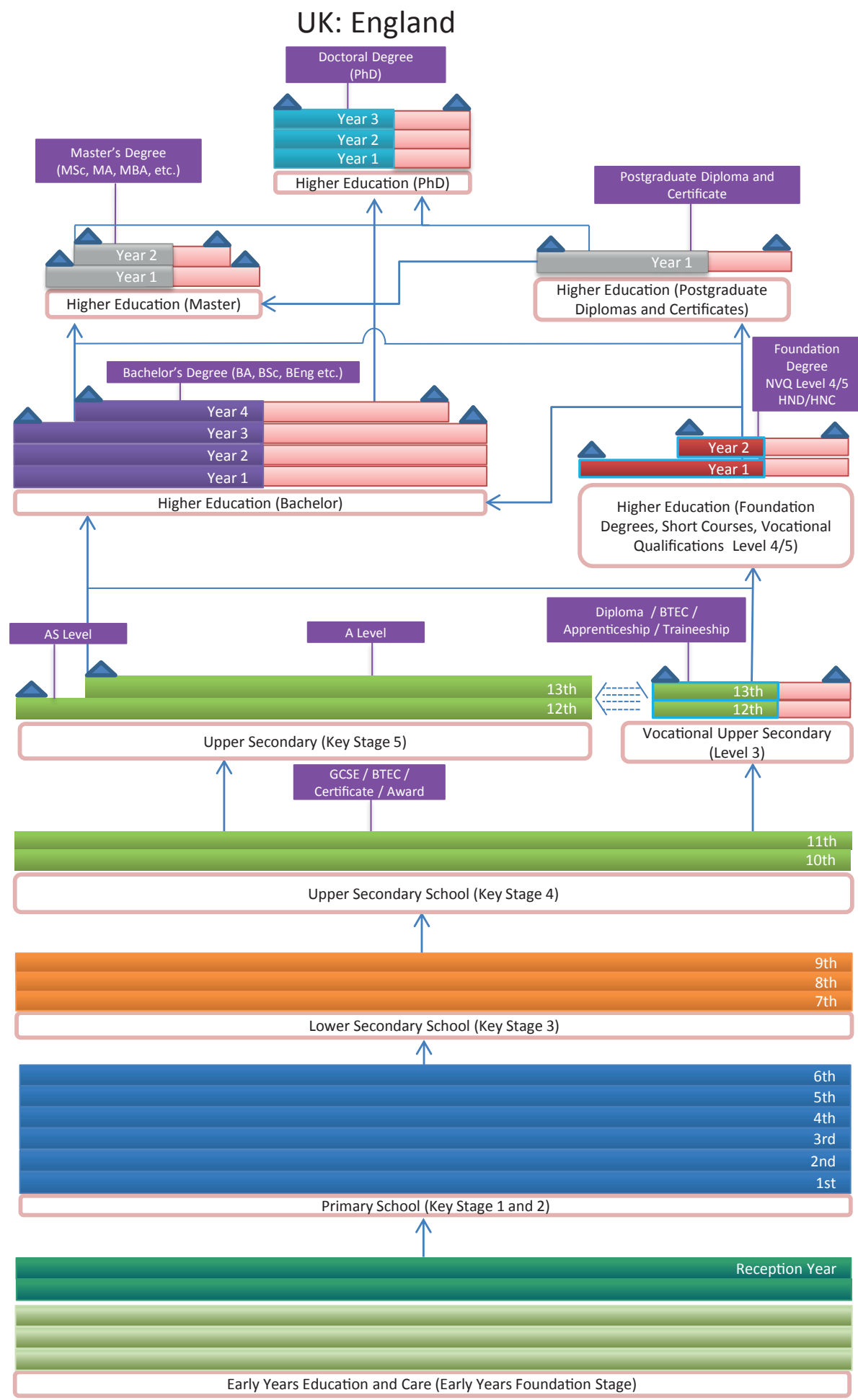

(C) EducationGPS 


\section{Legenda (wyjaśnienie terminów użytych na rysunku)}

\section{POZIOMY EDUKACYJNE}

Early Years Education and Care (Early Years Foundation Stage) - wczesna edukacja i opieka (etap przygotowawczy)

Primary School (Key Stage 1 and 2) - szkoła początkowa (etap kluczowy 1 i 2)

Lower Secondary School (Key Stage 3) - szkoła średnia I stopnia (etap kluczowy 3)

Upper Secondary School (Key Stage 4) - szkoła średnia II stopnia (etap kluczowy 4)

Upper Secondary (Key Stage 5) - szkoła średnia II stopnia (etap kluczowy 5)

Vocational Upper Secondary (Level 3) - średnia szkoła zawodowa (poziom 3)

Higher Education (Bachelor) - szkolnictwo wyższe (licencjackie)

Higher Education (Foundation Degrees, Short Courses, Vocational Qualifications Level 4/5) - szkolnictwo wyższe (podstawowe stopnie akademickie, krótkie studia, kwalifikacje zawodowe na poziomie 4/5) Higher Education (Master) - szkolnictwo wyższe (magisterskie)

Higher Education (Postgraduate Diplomas and Certificates) - szkolnictwo wyższe (dyplomy studiów podyplomowych i certyfikaty)

Higher Education (PhD) - szkolnictwo wyższe (studia doktoranckie)

\section{DYPLOMY}

GCSE (General Certificate of Secondary Education) - świadectwo ukończenia szkoły średniej

BTEC (Business and Technology Education Council) - dyplom kwalifikacji zawodowych z poziomu szkoły średniej II stopnia

Certificate, Award - świadectwo, nagroda

AS Level - egzamin po zakończeniu 12 roku nauki

A Level - egzamin końcowy po zakończeniu szkoły średniej II stopnia

Diploma, BTEC, Apprenticeship, Traineeship - dyplomy jakie można uzyskać po ukończeniu średniej szkoły zawodowej

Bachelor's Degree (BA, BSC, BEng etc.) - tytuły licencjata

Foundation Degree - dyplomy zawodowe szkolnictwa wyższego

NVQ Level 4/5 (National Vocational Qualification) - krajowe kwalifikacje zawodowe uzyskane na poziomie edukacyjnym 4/5

HND (Higher National Diploma) - krajowy dyplom kształcenia technicznego uzyskany na poziomie edukacyjnym 4/5

HNC (Higher National Certificate) - krajowy certyfikat technika uzyskany na poziomie edukacyjnym 4/5

Master's Degree (MSC, MA, MBA, etc.) - tytuły magistra

Postgraduate Diploma and Certificate - dyplom i świadectwo ukończenia studiów podyplomowych

Doctoral Degree (PhD) - stopień doktorski

OPIS TRANSFERÓW EDUKACYJNYCH (STRZAŁKI) I OZNACZEŃ LAT NAUKI

Reception Year - klasa zerowa

6th - szósty rok nauki

Year - rok studiów 


\section{Szkoła początkowa i średnia (do 16 roku życia)}

Obowiązek szkolny obejmuje następujące szczeble kształcenia:

- szkolnictwo początkowe (primary education) (ISCED 1) - wiek: 5-11 lat,

- szkolnictwo średnie I stopnia (secondary education) (ISCED 2) - wiek: 11-16 lat. Program kształcenia obowiązkowego jest podzielony na tzw. etapy kluczowe (key stages) - KS:

- KS1 - infant school (czas trwania 2 lata, wiek: 5-7 lat),

- KS2 - junior school (czas trwania 4 lata, wiek 7-11 lat),

- KS3 - secondary school (czas trwania 3 lata, wiek: 11-14 lat),

- KS4 - secondary school (czas trwania 2 lata, wiek: 14-16 lat).

Większość uczniów przechodzi ze szkoły początkowej (primary school) do szkoły średniej (secondary school) w wieku 11 lat, choć w niektórych regionach Anglii uczniowie uczęszczają do middle school w wieku, odpowiednio - od 8 lub 9 roku życia do 12 lub 13 roku życia. Wiele szkół średnich I stopnia prowadzi również kształcenie na poziomie średnim II stopnia dla uczniów będących w wieku powyżej 16 lat.

Obowiązkowymi przedmiotami programu nauczania na etapach KS1-KS3 są m.in.: język angielski, matematyka, przedmioty ścisłe i przyrodnicze, projektowanie i technika, technologie informacyjno-komunikacyjne, historia, geografia, wychowanie plastyczne i projektowanie, muzyka oraz wychowanie fizyczne. Na etapie KS3 obowiązkowymi przedmiotami jest również język obcy i wychowanie obywatelskie. Na etapie KS4 liczba przedmiotów obowiązkowych jest mniejsza, są to: język angielski, matematyka, nauki ścisłe i przyrodnicze, technologie informacyjno-komunikacyjne, wychowanie obywatelskie i wychowanie fizyczne.

W Anglii nie określa się w przepisach liczby godzin, jaką należy przeznaczyć na poszczególne przedmioty w programie nauczania, i nie wydaje się ogólnych zaleceń w sprawie metod nauczania czy materiałów dydaktycznych. Szkoły i nauczyciele ponoszą odpowiedzialność za wybór metod nauczania i materiałów. Podręczniki są wydawane przez wydawców komercyjnych i nie wymagają zatwierdzenia przez władze odpowiedzialne za edukację.

Uczniowie prawie zawsze są promowani do następnej klasy. Nie jest to wymóg prawny, a raczej zwyczaj i praktyka, wynikające z faktu, że podział uczniów na grupy leży w gestii szkoły. Niskim osiągnięciom pojedynczych uczniów przeciwdziała się przez zastosowanie zróżnicowanego podejścia do nauczania oraz zapewnienie wsparcia, powtarzanie roku jest rzadko praktykowane. 
Obowiązkowa edukacja kończy się w Anglii w 16 roku życia. Kończąc cykl szkoły obowiązkowej uczniowie przystępują do egzaminu, w wyniku którego uzyskują świadectwo ukończenia szkoły średniej I stopnia General Certificate of Secondary Educaton - GCSE ${ }^{26}$ (odpowiednik polskiego egzaminu gimnazjalnego). Uzyskanie GCSE jest warunkiem koniecznym do kontynuowania nauki na poziomie nieobowiązkowej szkoły średniej II stopnia, która jest bezpłatna do ukończenia 19 roku życia.

\section{Szkoła średnia (od 16 roku życia)}

Szkolnictwo średnie II stopnia (secondary education) (ISCED 3), wiek: 16-18+ lat jest szkolnictwem nieobowiązkowym na poziomie szkoły średniej II stopnia uczniowie mogą kontynuować naukę w następujących szkołach:

- Sixth form colleges - placówki o profilu kształcenia ogólnego (odpowiednik polskiego liceum ogólnokształcącego, lecz dla młodzieży z bardzo dobrymi świadectwami GCSE), które mogą oferować także przedmioty zawodowe,

- Further education colleges - placówki o profilu kształcenia zawodowego, które mogą oferować także kształcenie ogólne,

- Tertiary colleges - placówki prowadzące zarówno kształcenie ogólne, jak i zawodowe.

Warunki przyjęć są ustalane przez poszczególne szkoły. Najwyższe wymagania stawiają kandydatom Sixth Form Colleges, których uczniowie w wieku 18 lat przystępują do zaawansowanego egzaminu końcowego, tzw. A-level, złożonego z kilku przedmiotów.

Na poziomie szkolnictwa II stopnia nie ma treści obowiązkowych. Uczniowie wybierają cykl kształcenia z oferty szkoły lub placówki zależnie od kwalifikacji, jakie zamierzają uzyskać. Nauczyciele samodzielnie wybierają odpowiednie metody kształcenia i materiały dydaktyczne. Wszelkie egzaminy i wydawane dyplomy realizowane są przez instytucje zewnętrzne. Najczęściej, kończąc szkołę średnią II stopnia, uczniowie przystępują do egzaminu, w wyniku którego mogą uzyskać General Certificate of Education Advanced level - GCE A-Levels ${ }^{27}$ (odpowiednik polskiej matury). W zależności od profilu szkół dostępny jest również szeroki zakres kwalifikacji zawodowych. Kwalifikacje uzyskane na tym pozio-

26 http://www.schoolsearch.co.uk/general-certificate-of-secondary-education-gcse.

27 https://www.nidirect.gov.uk/articles/as-and-a-levels. 
mie mogą prowadzić do podjęcia pracy, dalszego specjalistycznego szkolenia lub kształcenia na poziomie szkolnictwa wyższego.

\section{Szkolnictwo wyższe}

System szkolnictwa wyższego obejmuje universities (uniwersytety), higher education colleges (kolegia prowadzące studia zawodowe) i niewielką liczbę university colleges (kolegiów uniwersyteckich). Uczelnie są zróżnicowane pod względem rodzajów, wielkości, misji i historii. Uczelnie wyższe są instytucjami autonomicznymi i każda z nich samodzielnie określa własną politykę i warunki przyjęć na studia. Mogą one być wyrażone w punktach UCAS (Universities and Colleges Admissions Service). Przelicznik UCAS umożliwia porównywanie różnych rodzajów kwalifikacji na terenie całego Zjednoczonego Królestwa. Mimo to uczelnie wyższe nie są zobowiązane korzystać z tego przelicznika, a wstęp na wiele kierunków wymaga podania wyników z A-Levels z konkretnych przedmiotów i na konkretnym poziomie. Większość uczelni wyższych przyjmuje podania od dorosłych kandydatów, którzy mimo braku formalnych kwalifikacji mają odpowiednie doświadczenie zawodowe. Uczelnie wyższe są uprawnione do pobierania rocznych opłat od dziennych studentów na studiach I stopnia. Prawo reguluje wysokość opłat. Wymiar czesnego dla studentów na studiach II i III stopnia nie jest regulowany prawem.

W Zjednoczonym Królestwie kwalifikacje akademickie nie stanowią kwalifikacji państwowych, lecz są przyznawane przez poszczególne uczelnie, spośród których wiele posiada uprawnienia do przyznawania własnych tytułów, stopni i innych kwalifikacji. Tytuły i inne kwalifikacje przyznawane przez większość higher education colleges zatwierdzają instytucje zewnętrzne - uniwersytet lub państwowy organ akredytacyjny.

Poszczególne uczelnie przyznają różne kwalifikacje i tytuły: świadectwa ukończenia studiów (higher education certificates) i dyplomy ukończenia studiów (higher education diplomas), tytuły ukończenia studiów w kolegiach przygotowujących do dłuższych lub bardziej zaawansowanych studiów (foundation degrees), tytuły licencjata (bachelor’s degree) i licencjata z wyróżnieniem (bachelor's degrees with honours), a po ukończeniu studiów wyższego stopnia - tytuły magisterskie (master's degrees) i doktoraty (doctorates). Największą grupę programów stanowią studia I stopnia prowadzące do bachelor's degrees with honours, określanych często jako honours degrees. Studia prowadzące do tych tytułów trwają na ogół 3 lata (w przypadku studentów studiów dziennych), choć 
niektóre są dłuższe. W Anglii, Walii i Irlandii Północnej opracowano pięciopoziomową strukturę ramową, która ma przedstawiać w sposób bardziej przejrzysty klasyfikację kwalifikacji uzyskiwanych w szkolnictwie wyższym i przyczynić się do spójnego używania nazw kwalifikacji.

\section{Nauczyciele}

Nauczycieli szkolnych zatrudniają władze lokalne lub poszczególne placówki, zależnie od rodzaju szkoły. Nauczyciele w innych typach kształcenia są pracownikami poszczególnych instytucji. Ścieżka nauczyciela do uzyskania statusu wykwalifikowanego nauczyciela QTS (Qualified Teacher Status) może przebiegać w różny sposób, według modelu równoległego lub etapowego. Model równoległy jest przeznaczony dla nauczycieli, którzy mają już stopień licencjata. Model ten oparty jest na zawodowym szkoleniu prowadzącym do uzyskania świadectwa PGCE (Professional Graduate/Postgraduate Certificate in Education) ${ }^{28}$ - stopnia akademickiego, z tzw. QTS - kwalifikacją zawodową. Zazwyczaj kursy, prowadzone zgodnie z modelem równoległym, były przeznaczone dla praktykantów przygotowujących się do nauczania w szkołach średnich, jednak model etapowy jest coraz bardziej popularny w szkolnictwie podstawowym i stanowi obecnie ścieżkę wybieraną przez większość przyszłych nauczycieli szkół podstawowych. Na model równoległy składają się trzyletnie lub czteroletnie studia prowadzące do uzyskania stopnia licencjata z QTS. Większość kursów w ramach modelu równoległego jest przeznaczona dla nauczycieli szkół podstawowych. Studia kończą się uzyskaniem dyplomu licencjata Bachelor of Education (BEd). Nauczyciele, którzy zamierzają uczyć konkretnych przedmiotów na poziomie szkoły średniej, muszą uzyskać dyplom licencjata w jakiejś specjalności, np. Bachelor of Science (BSc) z QTS. Model równoległy jest zazwyczaj organizowany na podstawie zintegrowanego wzoru, na który składa się kształcenie w instytucji szkolnictwa wyższego, w tym zajęcia teoretyczne i praktyczne. Wszyscy nauczyciele rozpoczynający pracę w sektorze further education (czyli kształcenie osób, które przekroczyły wiek obowiązku szkolnego z wyłączeniem szkół wyższych) są zobowiązani posiadać specjalistyczne kwalifikacje pedagogiczne, np. nauczyciel wykwalifikowany (Qualified Teacher Learning and Skills, QTLS) lub nauczyciel o niepełnych kwalifikacjach (Associate Teacher Learning and Skills, ATLS).

28 https://www.findamasters.com/advice/finding/postgraduate-certificate-in-education-pgce-guide.aspx. 


\section{Walia}

W Walii kształcenie jest obowiązkowe dla uczniów w wieku od 5 do 16 lat, ale wiele dzieci rozpoczyna naukę już w klasie zerowej szkoły podstawowej w wieku 4 lat. Obowiązek szkolny obejmuje następujące szczeble kształcenia:

- szkolnictwo podstawowe (primary education) (ISCED 1) - wiek: 5-11 lat,

- szkolnictwo średnie I stopnia (secondary education) (ISCED 2) - wiek: 11-16 lat. Program kształcenia obowiązkowego jest podzielony na tzw. kluczowe etapy - KS (key stages):

- KS1 (wiek: 5-7 lat),

- KS2 (wiek: 7-11 lat),

- KS3 (wiek: 11-14 lat),

- KS4 (wiek: 14-16 lat).

W Walii za organizację oświaty odpowiadają Ministerstwo Edukacji i Umiejętości (Department for Education and Skills, DfES) ${ }^{29}$ oraz Inspektorat Edukacji i Szkolenia w Walii (Inspectorate for Education and Training in Wales, Estyn) ${ }^{30}$. Za całokształt organizacji systemu szkolnictwa odpowiada DfES, a zadaniem Estynu jest zapewnienie niezależnej służby kontroli oraz doradztwa w sprawie jakości i standardów funkcjonowania walijskich placówek szkolnych.

Organizacją kształcenia na poziomie lokalnym zajmują się powołane do tego 22 oświatowe jednostki władz lokalnych. Ich podstawowymi zadaniami są: zapewnienie odpowiedniej liczby miejsc w szkołach, zapewnienie wysokich standardów wychowawczo-dydaktycznych oraz przeciwdziałanie zjawiskom niepożądanym wśród dzieci i młodzieży.

\section{Szkocja}

Obowiązek szkolny w Szkocji trwa 11 lat i obejmuje dzieci oraz młodzież w wieku od 5 do 16 roku życia, a realizowany jest w ramach następujących szczebli kształcenia:

- szkoła podstawowa (primary school) (ISCED 1) - wiek: 5-12 lat,

- szkoła średnia I stopnia (secondary school) (ISCED 2) - wiek: 12-16 lat.

Program kształcenia obowiązkowego w szkole podstawowej podzielony jest na siedem etapów oznaczanych literą P (primary), a w szkole średniej na cztery eta-

29 http://gov.wales/topics/educationandskills/?lang=en.

30 http://www.estyn.gov.wales/. 
py oznaczane literą S (secondary): P1 (wiek: 5-6 lat), P2 (wiek: 6-7 lat), P3 (wiek: 7-8 lat), P4 (wiek: 8-9 lat), P5 (wiek: 9-10 lat), P6 (wiek: 10-11 lat), P7 (wiek:11-12 lat), S1 (wiek: 12-13 lat), S2 (wiek: 13-14 lat), S3 (wiek: 14-15 lat), S4 (wiek: 15-16 lat).

W Szkocji za ogólny nadzór nad edukacją i rozwojem usług edukacyjnych odpowiada premier Szkocji. W jego imieniu obowiązki te wykonuje Sekretarz ds. Edukacji i Kształcenia Ustawicznego (Secretary for Education \& Lifelong Learning) ${ }^{31}$. Jest wspierany przez dwóch ministrów - Ministra ds. Dzieci i Młodzieży (Minister for Children \& Young People) ${ }^{32}$ oraz Ministra ds. Kształcenia, Nauki i Języków Szkocji (Minister for Learning, Science \& Scotland's Languages) ${ }^{33}$. Do ich zadań należy m.in. organizacja szkolnictwa obowiązkowego, średniego, wyższego oraz kształcenia ustawicznego, poprawa standardów szkolnych jakości poziomu kształcenia, ochrona praw dzieci, dbałość o jakość i kultywowanie tradycji języków Szkocji.

Około 96\% uczniów kształci się w szkołach finansowanych ze środków publicznych. Szkoły niepubliczne nie otrzymują środków publicznych na swoją działalność i nie podlegają lokalnym władzom. Organizacją kształcenia finansowanego ze środków publicznych zajmują się 32 rady terytorialne (unitary councils), szkockie władze lokalne (Local Authorities, SLAs). Odpowiadają za zatrudnianie pracowników szkół, obsługę finansową większości usług edukacyjnych oferowanych przez szkoły oraz za nadzór nad wdrażaniem polityki edukacyjnej rządu. Dyrektorzy szkół administrują budżetem szkół przyznanym przez władze lokalne, kierują i zarządzają szkołą, opracowują program dydaktyczny i wychowawczy szkoły.

System edukacyjny w Szkocji wykształcił wiele instytucji, firm, agencji zajmujących się doradztwem, szkoleniami i konsultacjami dla nauczycieli. Do najważniejszych należą: Education Scotland ${ }^{34}$, Scottish Qualifications Authority ${ }^{35}$, Scottish Council for Research in Education ${ }^{36}$, Scottish Funding Council ${ }^{37}$, General Teaching Council for Scotland ${ }^{38}$. Podmioty te oferują pomoc nauczycielom będą-

31 http://www.gov.scot/About/People/Ministers/Cabinet-Secretary-for-Education-andLifelong-Learn.

32 http://www.gov.scot/About/People/Ministers/Minister-for-Children-and-Young-People.

33 http://www.gov.scot/About/People/Ministers/Minister-for-Learning.

34 http://www.educationscotland.gov.uk/.

35 http://www.sqa.org.uk/sqa/70972.html.

36 http://www.eep.ac.uk/dnn2/Organizations/SCRE/tabid/86/Default.aspx.

37 http://www.sfc.ac.uk/aboutus/aboutus.aspx.

38 http://www.gtcs.org.uk/home/home.aspx. 
Theoretical

starting age

21

19

芯
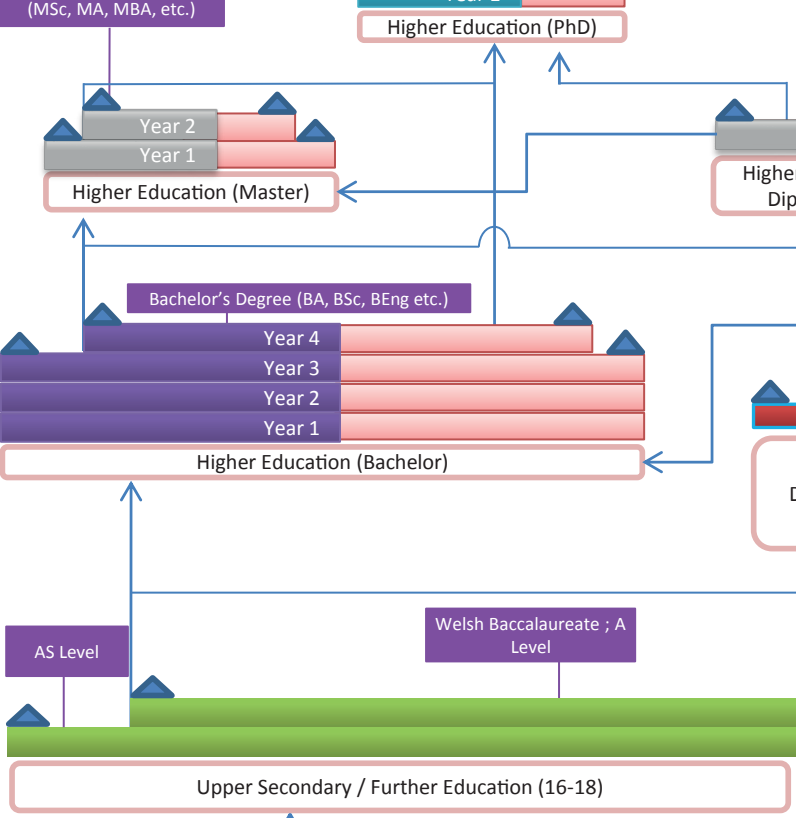

Higher Education (Foundation Degrees, Short Courses, Vocational Qualifications Level 4/5)
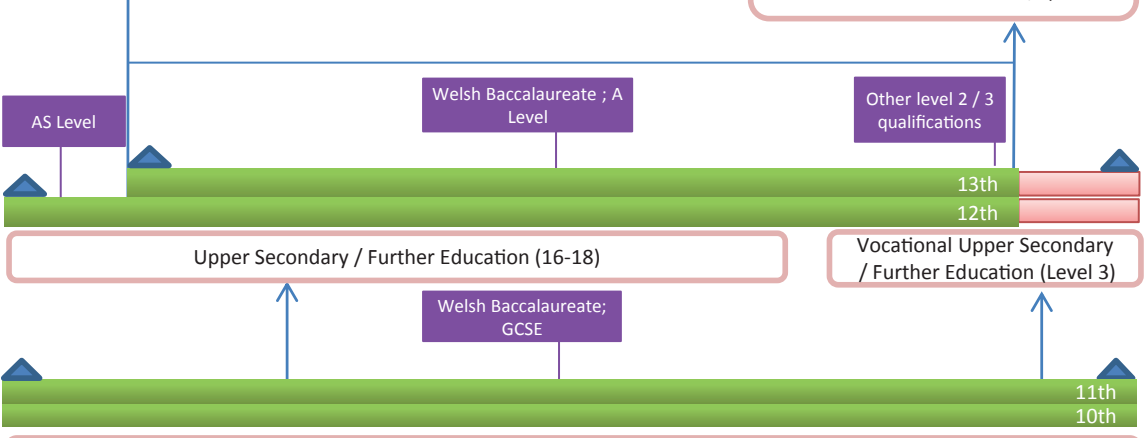

Upper Secondary School (Key Stage 4)

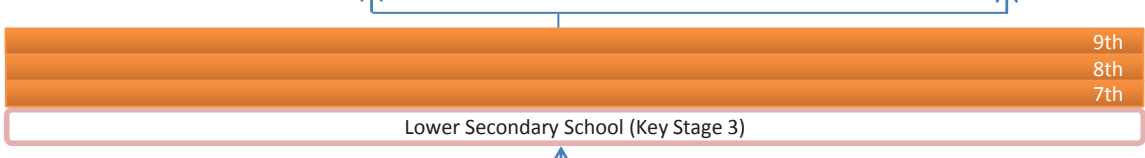

Lower Secondary School (Key Stage 3)
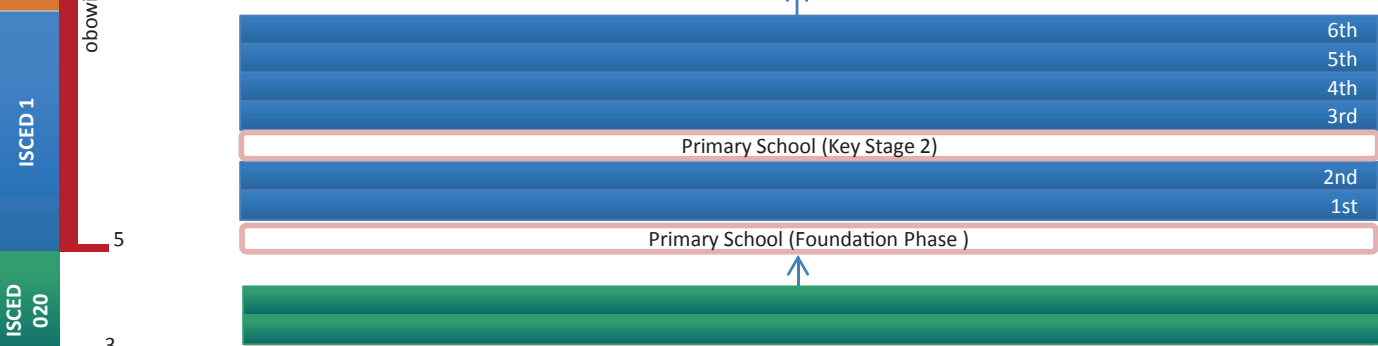

Early Years Education (Foundation Phase )

Early Years

() EducationGPS 


\section{Legenda (wyjaśnienie terminów użytych na rysunku)}

\section{POZIOMY EDUKACYJNE}

Early Years - opieka żłobkowa

Early Years Education (Foundation Phase) - wczesna edukacja (faza podstawowa)

Primary School (Foundation Phase) - szkoła początkowa (faza podstawowa)

Primary School (Key Stage 2) - szkoła początkowa (etap kluczowy 2)

Lower Secondary School (Key Stage 3) - szkoła średnia I stopnia (etap kluczowy 3)

Upper Secondary School (Key Stage 4) - szkoła średnia II stopnia (etap kluczowy 4)

Upper Secondary / Furter Education (16-18) - szkoła średnia II stopnia / dalsze kształcenie (wiek uczniów 16-18 lat)

Vocational Upper Secondary / Furter Education (Level 3) - średnia szkoła zawodowa / dalsze kształcenie zawodowe (poziom 3)

Higher Education (Bachelor) - szkolnictwo wyższe (licencjackie)

Higher Education (Foundation Degrees, Short Courses, Vocational Qualifications Level 4/5) - szkolnictwo wyższe (podstawowe stopnie akademickie, krótkie studia, kwalifikacje zawodowe na poziomie 4/5) Higher Education (Master) - szkolnictwo wyższe (magisterskie)

Higher Education (Postgraduate Diplomas and Certificates) - szkolnictwo wyższe (dyplomy studiów podyplomowych i certyfikaty)

Higher Education (PhD) - szkolnictwo wyższe (studia doktoranckie)

\section{DYPLOMY}

Welsh Baccalaureate; GCSE (General Certificate of Secondary Education) - walijskie świadectwo ukończenia szkoły średniej

AS Level - egzamin po zakończeniu 12 roku nauki

Welsh Baccalaureate; A Level - walijski egzamin końcowy po zakończeniu szkoły średniej II stopnia

Other level 2/3 qualifications - inne kwalifikacje zawodowe na poziomie 2/3

Bachelor's Degree (BA, BSC, BEng etc.) - tytuły licencjata

Level 4/5/6 qualifications - kwalifikacje zawodowe na poziomie 4/5/6

Master's Degree (MSC, MA, MBA, etc.) - tytuły magistra

Postgraduate Diploma and Certificate - dyplom i świadectwo ukończenia studiów podyplomowych

Doctoral Degree (PhD) - stopień doktorski

OPIS TRANSFERÓW EDUKACYJNYCH (STRZAŁKI) I OZNACZEŃ LAT NAUKI

6th - szósty rok nauki

Year - rok studiów 
Theoretical starting age
UK: Scotland
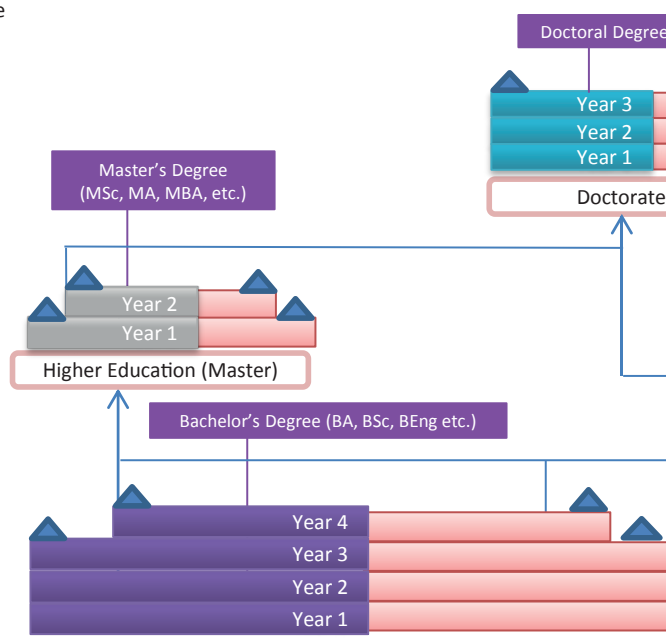

Higher Education (Bachelor)
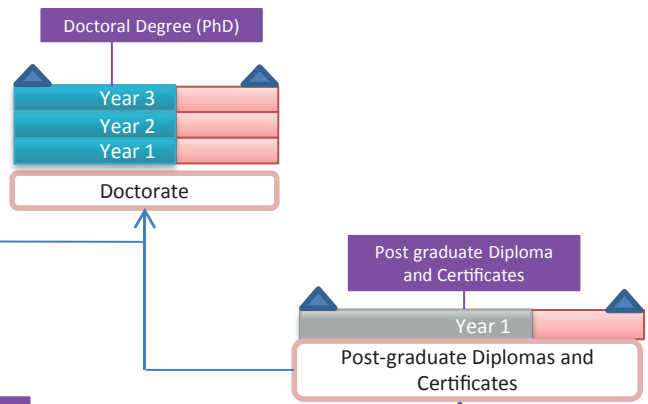
Certificates

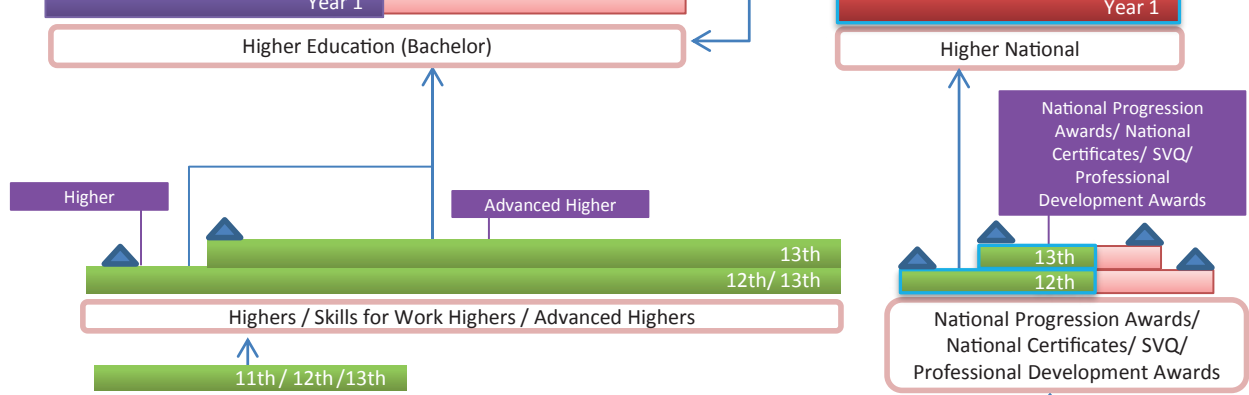

National 5

$\uparrow \Uparrow$
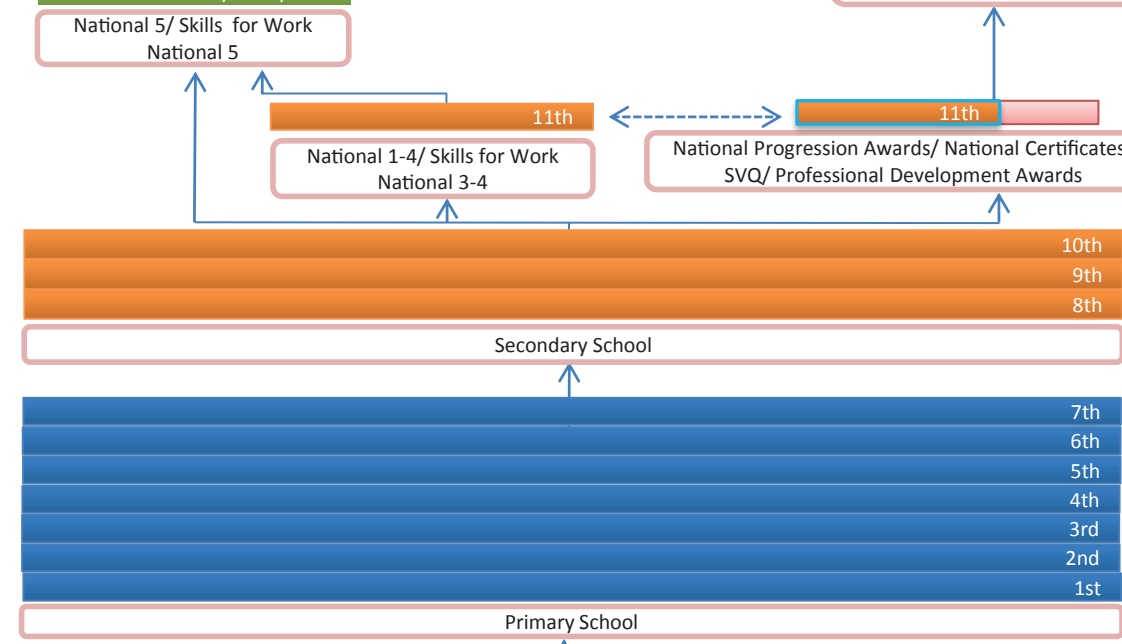

$\uparrow$ 


\section{Legenda (wyjaśnienie terminów użytych na rysunku)}

\section{POZIOMY EDUKACYJNE}

Early Learning and Childcare - wczesne nauczanie i opieka nad dziećmi

Primary School - szkoła początkowa

Secondary School - szkoła średnia

National 1-4/Skills for Work National 3-4 - ogólnokształcący poziom edukacyjny, na którym można osiągnąć określone umiejętności i zdolności oznaczone krajowymi standardami 1-4 oraz 3-4

National Progression Awards / National Certificates/ SVQ/ Professional Development Awards - poziom edukacyjny kształcenia zawodowego, na którym można uzyskać różne dyplomy, certyfikaty określone krajowymi wymaganiami

National 5 / Skills for Work National 5 - ogólnokształcący poziom edukacyjny, na którym można osiągnąć określone umiejętności i zdolności oznaczone krajowymi standardami 5

Highers / Skills for Work Highers / Advanced Highers - ogólnokształcący poziom edukacyjny, na którym można osiągnąć określone umiejętności i zdolności oznaczone jako wyższe i/lub zaawansowane Higher Education (Bachelor) - szkolnictwo wyższe (licencjackie)

Higher National - szkolnictwo wyższe (podstawowe stopnie akademickie, krótkie studia, kwalifikacje zawodowe)

Higher Education (Master) - szkolnictwo wyższe (magisterskie)

Post-graduate Diplomas and Certificates) - szkolnictwo wyższe (dyplomy studiów podyplomowych i certyfikaty)

Doctorate - szkolnictwo wyższe (studia doktoranckie)

DYPLOMY

Higher - dyplom szkoły średniej II stopnia

Advanced Higher - wyższy dyplom szkoły średniej II stopnia

Bachelor's Degree (BA, BSC, BEng etc.) - tytuły licencjata

Master's Degree (MSC, MA, MBA, etc.) - tytuły magistra

Postgraduate Diploma and Certificates - dyplom i świadectwa ukończenia studiów podyplomowych

Doctoral Degree (PhD) - stopień doktorski

OPIS TRANSFERÓW EDUKACYJNYCH (STRZAŁKI) I OZNACZEŃ LAT NAUKI

6th - szósty rok nauki

Year - rok studiów 
Theoretical starting age

21

19

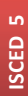

16

\section{UK: Northern Ireland}

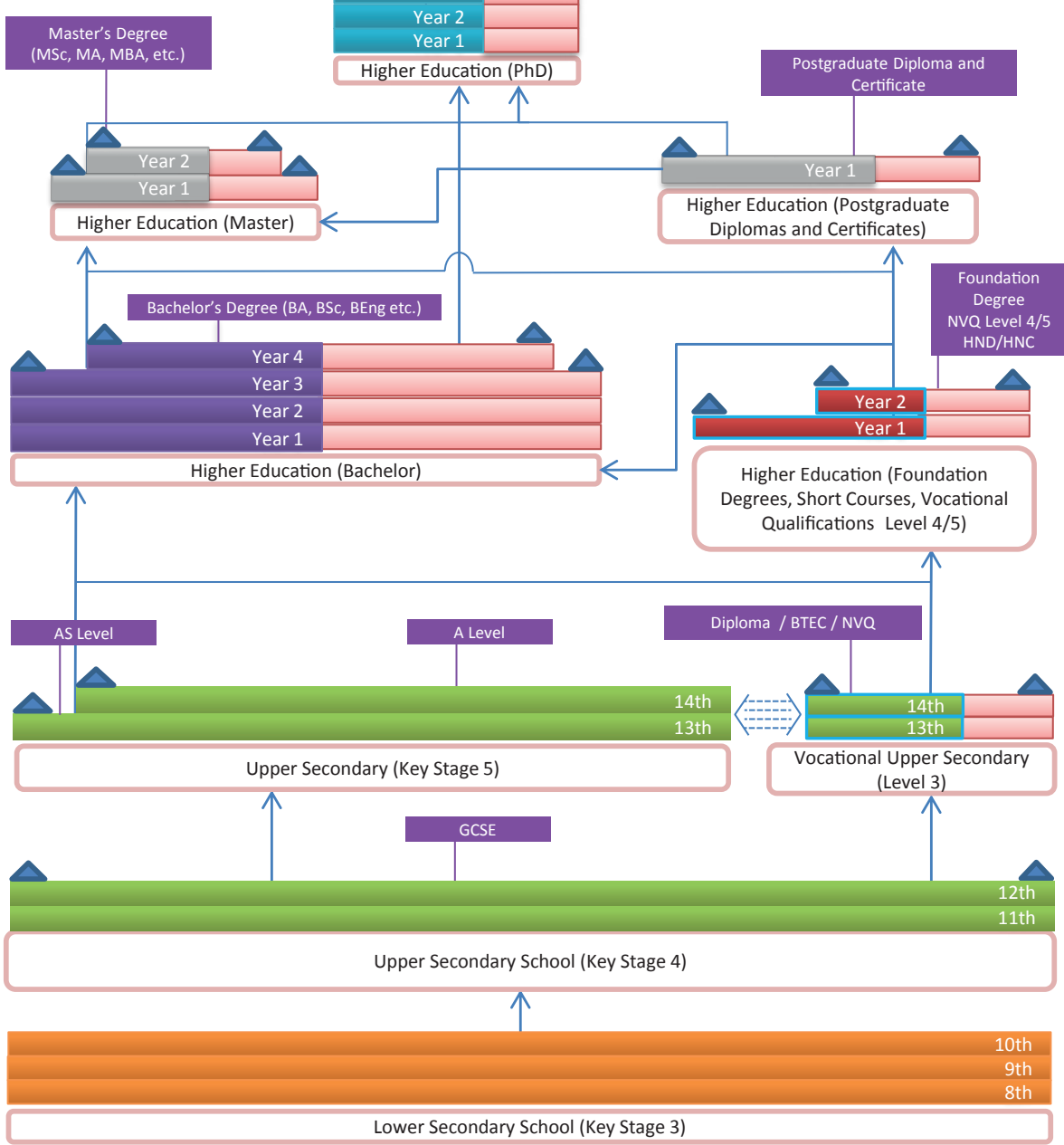

Lower Secondary School (Key Stage 3)

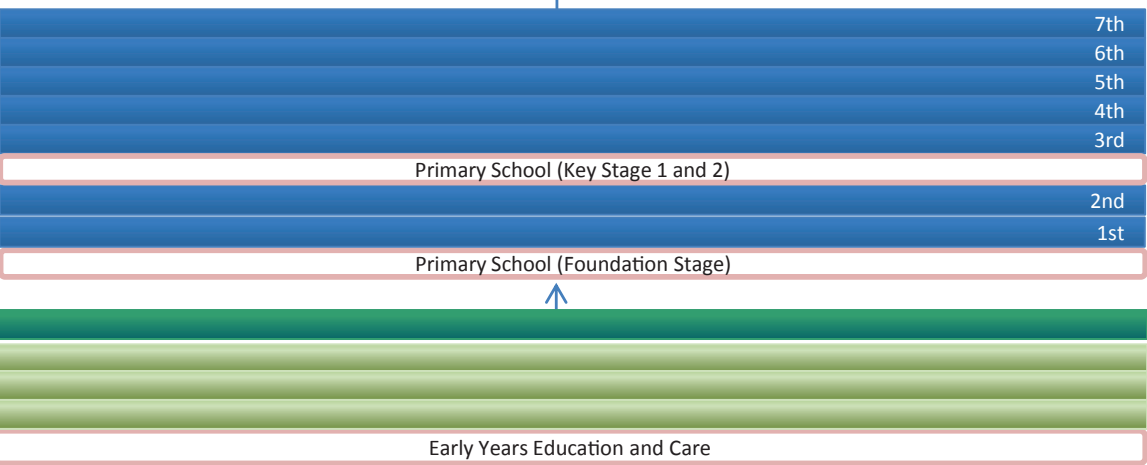




\section{Legenda (wyjaśnienie terminów użytych na rysunku)}

\section{POZIOMY EDUKACYJNE}

Early Years Education and Care - wczesna edukacja i opieka

Primary School (Fondation Stage) - szkoła początkowa (etap podstawowy)

Primary School (Key Stage 1 and 2) - szkoła początkowa (etap kluczowy 1 i 2)

Lower Secondary School (Key Stage 3) - szkoła średnia I stopnia (etap kluczowy 3)

Upper Secondary School (Key Stage 4) - szkoła średnia II stopnia (etap kluczowy 4)

Upper Secondary (Key Stage 5) - szkoła średnia II stopnia (etap kluczowy 5)

Vocational Upper Secondary (Level 3) - średnia szkoła zawodowa (poziom 3)

Higher Education (Bachelor) - szkolnictwo wyższe (licencjackie)

Higher Education (Foundation Degrees, Short Courses, Vocational Qualifications Level 4/5) - szkolnictwo wyższe (podstawowe stopnie akademickie, krótkie studia, kwalifikacje zawodowe na poziomie 4/5) Higher Education (Master) - szkolnictwo wyższe (magisterskie)

Higher Education (Postgraduate Diplomas and Certificates) - szkolnictwo wyższe (dyplomy studiów podyplomowych i certyfikaty)

Higher Education (PhD) - szkolnictwo wyższe (studia doktoranckie)

\section{DYPLOMY}

GCSE (General Certificate of Secondary Education) - świadectwo ukończenia szkoły średniej

BTEC (Business and Technology Education Council) - dyplom kwalifikacji zawodowych z poziomu szkoły średniej II stopnia.

AS Level - egzamin po zakończeniu 13 roku nauki

A Level - egzamin końcowy po zakończeniu szkoły średniej II stopnia

Diploma, BTEC, NVQ - dyplomy, jakie można uzyskać po ukończeniu średniej szkoły zawodowej zgodnie z krajowymi wymaganiami zawodowymi

Bachelor's Degree (BA, BSC, BEng etc.) - tytuły licencjata

Foundation Degree - dyplomy zawodowe szkolnictwa wyższego

NVQ Level 4/5 (National Vocational Qualification) - krajowe kwalifikacje zawodowe uzyskane na poziomie edukacyjnym 4/5

HND (Higher National Diploma) - krajowy dyplom kształcenia technicznego uzyskany na poziomie edukacyjnym 4/5

HNC (Higher National Certificate) - krajowy certyfikat technika uzyskany na poziomie edukacyjnym 4/5

Master's Degree (MSC, MA, MBA, etc.) - tytuły magistra

Postgraduate Diploma and Certificate - dyplom i świadectwo ukończenia studiów podyplomowych

Doctoral Degree (PhD) - stopień doktorski

OPIS TRANSFERÓW EDUKACYJNYCH (STRZAŁKI) I OZNACZEŃ LAT NAUKI

6th - szósty rok nauki

Year - rok studiów 
cym w zawodzie i przygotowującym się do podjęcia pracy. Zapewniają porady w sprawach związanych z organizacją nauczania, doborem narzędzi i metod dydaktycznych, dostępnych kursów i szkoleń dla nauczycieli.

\section{Irlandia Północna}

W Irlandii Północnej kształcenie obowiązkowe rozpoczyna się w wieku 4 lat i trwa do 16 roku życia ${ }^{39}$. Obowiązek szkolny realizowany jest w ramach następujących szczebli kształcenia:

- szkoła podstawowa (primary school) (ISCED 1) - wiek: 4-11 lat,

- szkoła średnia I stopnia (secondary school) (ISCED 2) - wiek: 11-16 lat.

Program kształcenia obowiązkowego jest podzielony na cztery tzw. kluczowe etapy (key stages) - KS:

- KS1 (wiek: 4-7 lat),

- KS2 (wiek: 7-11 lat),

- KS3 (wiek: 11-14 lat),

- KS4 (wiek: 14-16 lat).

W Irlandii Północnej za organizację systemu oświaty odpowiada Ministerstwo Edukacji (Department of Education, DE) ${ }^{40}$. Za kształcenie ustawiczne i szkolnictwo wyższe odpowiedzialność ponosi Ministerstwo Zatrudnienia i Kształcenia (Department for Employment and Learning, DEL). Na poziomie lokalnym organizacją szkolnictwa zajmują się lokalne jednostki władzy oświatowej (Education and Library Boards, ELBs).

\section{Włochy}

\section{Organizacja administracji oświatowej}

We Włoszech za system edukacji odpowiada całościowo Ministerstwo Edukacji, Szkolnictwa Wyższego i Badań Naukowych (Ministero dell'Istruzione, dell'Università e della Ricerca $)^{41}$ działające na poziomie centralnym. Przedstawicielem ministerstwa na szczeblu lokalnym są urzędy ds. edukacji w regionach i prowincjach. Wszystkie szkoły mają autonomię w zakresie administracji, organizacji, dydak-

39 Structure of the education system in Northern Ireland 2014-15, https://www.nfer.ac.uk/nfer/ eurydice/publications/structure-diagram-ni.cfm.

40 https://www.deni.gov.uk/.

41 http://www.miur.gov.it/. 
tyki, badań oraz prowadzenia przedsięwzięć eksperymentalnych i rozwojowych. Konstytucja Włoch stanowi, że państwo ma obowiązek zapewnić i finansować naukę w szkołach publicznych, ale szkoły niepubliczne mają prawo istnieć. Mówi się o dwóch typach szkół niepublicznych: szkołach o równym statusie (paritarie) i szkołach o nierównym statusie (non paritarie). Te pierwsze mogą być prowadzone przez podmioty prywatne bądź państwowe. Szkoły o równym statusie uzyskały go na skutek spełnienia wymagań dotyczących m.in. posiadania programu zgodnego z przepisami prawa, przyjmowania wszystkich kandydatów, zatrudniania nauczycieli mających kwalifikacje pedagogiczne zgodne z ogólnokrajowymi regulacjami prawnymi. Szkoły o równym statusie mogą wydawać uznawane przez państwo świadectwa i stanowią część krajowego systemu edukacji i szkoleń. Szkoły o nierównym statusie to takie, które nie ubiegały się o otrzymanie równego statusu lub nie spełniają określonych wymagań. Szkoły te nie mają prawa wydawać oficjalnych świadectw, nie są nazywane szkołami i nie są instytucjami zapewniającymi kształcenie w ramach obowiązku i prawa do nauki. Od wielu lat uczęszczający do tego typu szkół stanowią około 5\% populacji szkolnej.

\section{Organizacja i struktura edukacji publicznej}

Na strukturę włoskiego ustroju szkolnego składają się następujące poziomy kształcenia:

- przedszkole (scuola dell'infanzia),

- szkoła początkowa (scuola primaria),

- szkoła średnia I stopnia (scuola secondaria di i grado),

- szkoła średnia II stopnia (secondo ciclo di istruzione),

- szkoła policealna techniczna (istruzione e formazione tecnica superiore),

- szkolnictwo wyższe (istruzione terzaria).

\section{Przedszkole (scuola dell'infanzia)}

Przedszkole stanowi pierwszy etap systemu szkolnego dla dzieci od 3 do 6 roku życia. Jest nieobowiązkowe i bezpłatne. Rodzice ponoszą jedynie koszty transportu i wyżywienia dzieci. Do scuola dell'infanzia mogą uczęszczać dzieci, które ukończyły 3 lata do 31 grudnia w danym roku szkolnym, ale na prośbę rodziców można przyjąć także dziecko, które osiągnęło ten wiek wcześniej - do 30 kwietnia danego roku szkolnego. System edukacji przedszkolnej we Włoszech jest bardzo zróżnicowany - dostępność przedszkoli, koszty, stosowane programy zależne 


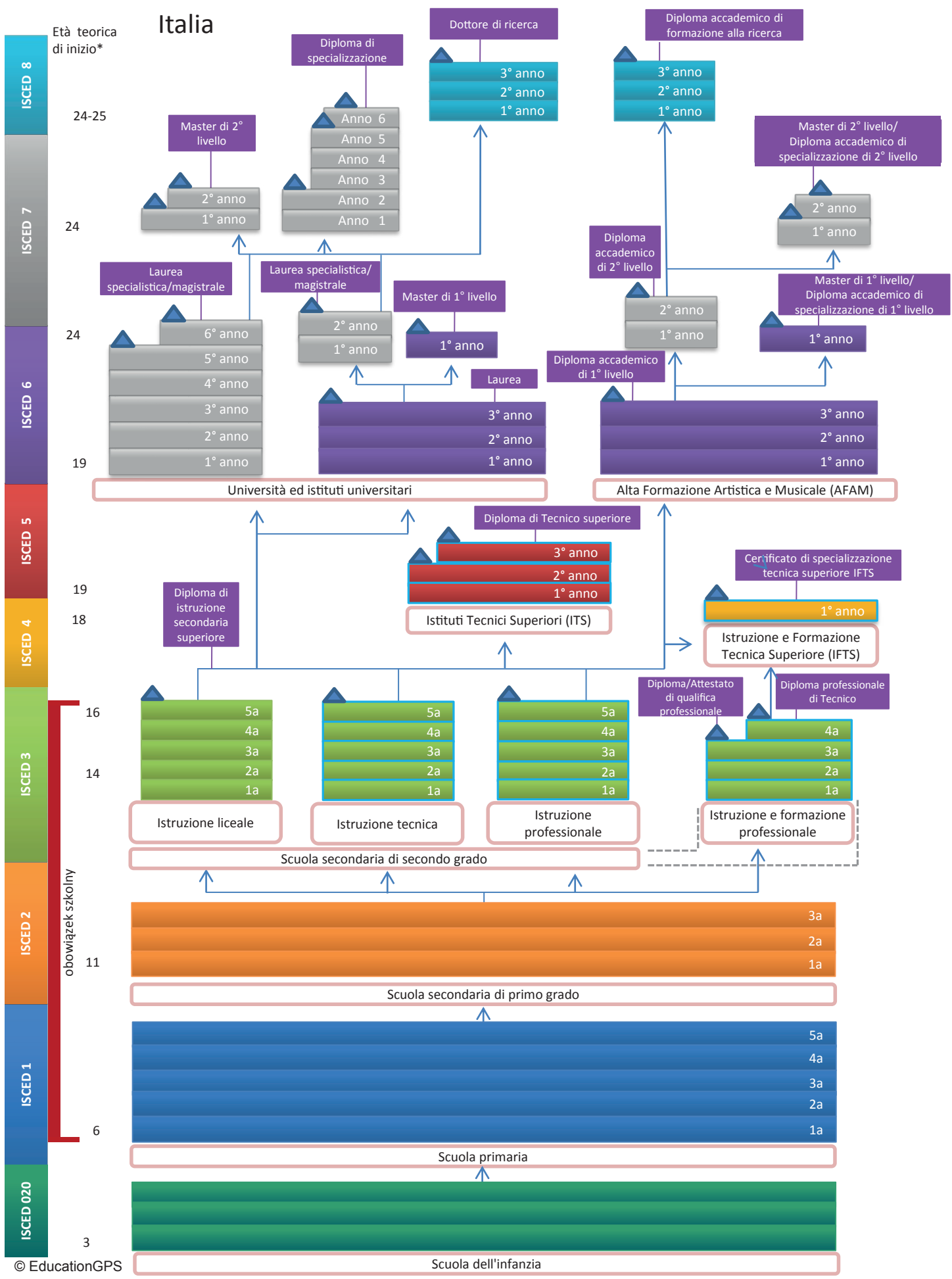




\title{
Legenda (wyjaśnienie terminów użytych na rysunku)
}

\section{POZIOMY EDUKACYJNE}

Scuola dell'infanzia - przedszkole

Scuola primaria - szkoła podstawowa

Scuola secondaria di primo grado - szkoła średnia I stopnia

Scuola secondaria di secondo grado - szkoła średnia II stopnia

Istruzione liceale - kształcenie licealne

Istruzione tecnica - kształcenie techniczne

Istruzione professionale - kształcenie zawodowe

Istruzione e formazione professionale - kształcenie i szkolenie zawodowe

Istituti Tecnici Superiori (ITS) - wyższe instytuty techniczne

Istruzione e Formazione Tecnica Superiore (IFTS) - wyższe kształcenie i szkolenie techniczne

Università ed istituti universitari - uniwersytety i instytuty uniwersyteckie

Alta Formazione Artistica e Musicale (AFAM) - wyższe kształcenie artystyczne i muzyczne

\section{DYPLOMY}

Diploma di istruzione secondaria superiore - dyplom ukończenia szkoły średniej II stopnia

Diploma/Attestato di qualifica professionale - dyplom/zaświadczenie uzyskania kwalifikacji zawodowych Diploma professionale di Tecnico - dyplom technika specjalisty

Diploma di Tecnico superiore - wyższy dyplom technika

Certificato di specializzazione tecnica superiore IFTS - świadectwo wyższej specjalizacji technicznej

Laurea - licencjat (po 3 latach studiów)

Diploma accademico di $1^{\circ}$ livello - dyplom akademicki 1 stopnia (po 3 latach studiów)

Laurea specialistica/magistrale - magisterium (po 6 lub po 3+2 latach studiów)

Master di $1^{\circ}$ livello - magisterium 1 stopnia (po co najmniej rocznych studiach specjalistycznych)

Diploma accademico di $2^{\circ}$ livello - dyplom akademicki 2 stopnia (po 2 latach studiów specjalistycznych)

Master di $1^{\circ}$ livello/Diploma accademico di specializzazione di $1^{\circ}$ livello - magisterium 1 stopnia / dyplom

akademicki specjalizacji akademickiej 1 poziomu

Master di $2^{\circ}$ livello - magisterium 2 stopnia (po co najmniej 2-letnich studiach specjalistycznych)

Diploma di specializzazione - dyplom akademicki studiów specjalistycznych

Dottore di ricerca - doktorat badawczy

Diploma accademico di formazione alla ricerca - dyplom studiów naukowych (badawczych)

Master di $2^{\circ}$ livello/ Diploma accademico di specializzazione di $2^{\circ}$ livello - dyplom magistra w specjalizacji akademickiej 2 poziomu

\author{
OPIS TRANSFERÓW EDUKACYJNYCH (STRZAŁKI) I OZNACZEŃ LAT NAUKI \\ $1 a$ - pierwszy rok nauki \\ $1^{\circ}$ anno - pierwszy rok studiów wyższych \\ Anno 1 - pierwszy rok zaawansowanych studiów akademickich
}


są od organów prowadzących. Ponad połowę przedszkoli prowadzi Ministerstwo Edukacji (zwłaszcza na południu kraju), 1/3 placówek prowadzona jest przez prywatne organizacje (w tym około $20 \%$ przez organizacje kościelne), a 13\% podlega jednostkom samorządu terytorialnego.

\section{Obowiązek szkolny}

We Włoszech długość obowiązku szkolnego wynosi 10 lat i obejmuje uczniów w wieku od 6 do 16 roku życia. Szczeble kształcenia objęte obowiązkiem szkolnym to: szkoła podstawowa (scuola primaria) i szkoła średnia I stopnia (scuola secondaria di i grado). Uczniowie uczęszczają na ogół do najbliższej szkoły w swoim rejonie. Kształcenie obowiązkowe jest bezpłatne.

\section{Szkoła podstawowa (scuola primaria) -} wiek: 6-11 lat; czas trwania 5 lat

Programy i treści nauczania dla szkoły podstawowej realizowane są na podstawie ogólnokrajowych wytycznych dotyczących zindywidualizowanych planów kształcenia (Indicazioni Nazionali per i piani personalizzati delle attività educative $)^{42}$ oraz wytyczne dotyczące programów nauczania (Indicazioni per il curricolo per la scuola dell'infanzia e per il primo ciclo di istruzione $)^{43}$. W wytycznych (Indicazioni) określono docelowy poziom, jaki powinni osiągnąć uczniowie w każdej szkole. Opracowuje się je na szczeblu krajowym, a każda szkoła dostosowuje je do potrzeb lokalnych w ramach swej autonomii. Dla każdego przedmiotu określono zasób wiedzy i umiejętności, a szkoła ma ułatwić uczniom przekształcenie ich w indywidualne kompetencje. Szczegółowe cele kształcenia w szkole podstawowej zdefiniowano dla następujących przedmiotów: religia katolicka, język włoski, język angielski, historia, geografia, matematyka, przedmioty przyrodnicze, wychowanie techniczne i informatyka, muzyka, plastyka, zajęcia sportowe i motoryczne. Nauczanie odbywa się w formie zintegrowanej. Nauczyciele mają prawo wybrać podręczniki i decydować o stosowanych metodach dydaktycznych. Od 2012 roku wszystkie podręczniki są udostępniane w formie elektronicznej. W roku szkolnym uczniowie podlegają dwukrotnej ocenie semestralnej - w styczniu i czerwcu. W tym czasie

42 http://www.edscuola.it/archivio/norme/decreti/dm100_02a.pdf.

43 https://archivio.pubblica.istruzione.it/normativa/2007/allegati/dir_310707.pdf. 
nauczyciele dokonują oceny wiedzy i wydają świadectwa zawierające oceny z poszczególnych przedmiotów (do ocen cyfrowych dołączona jest także ocena opisowa). Jeśli uczeń otrzymał od jednej do trzech ocen niedostatecznych (włoska skala obejmuje oceny od najniższej 0 do najwyższej 10, gdzie 6 jest pierwszą oceną z kategorii zaliczających), które zdaniem nauczycieli ma szansę poprawić, otrzymuje tzw. warunkową promocję do następnej klasy. W tym wypadku kolejnym krokiem ucznia jest nadrobienie zaległości, debito formativo - co w dosłownym tłumaczeniu nazywane jest spłatą „długu edukacyjnego”. By go spłacić uczeń musi uczęszczać na zajęcia wyrównawcze (corsi di recupero) zakończone egzaminem. We włoskiej nomenklaturze edukacyjnej istnieje również pojęcie kredytu edukacyjnego (credito formativo). Określa się nim zajęcia ponadprogramowe, w których uczniowie uczestniczą w charakterze ochotników. Za taką aktywność dostają punkty doliczane później do końcowej punktacji osiągniętej po zdaniu egzaminów maturalnych. Przejście ze szkoły podstawowej do szkoły średniej I stopnia odbywa się automatycznie, bez żadnych egzaminów państwowych, na podstawie pozytywnej oceny osiągnięć ucznia na zakończenie szkoły podstawowej.

\section{Szkoła średnia I stopnia (scuola secondaria di I grado) - wiek: 11-14 lat; czas trwania 3 lata}

Programy i treści nauczania dla szkoły średniej I stopnia realizowane są na podstawie ogólnokrajowych wytycznych dotyczących zindywidualizowanych planów kształcenia (Indicazioni Nazionali per i piani personalizzati delle attività educative) oraz wytycznych dotyczących programów nauczania (Indicazioni per il curricolo per la scuola dell'infanzia e per il primo ciclo di istruzione). W wytycznych (Indicazioni) określono docelowy poziom, jaki powinni osiągnąć uczniowie w każdej szkole. Opracowuje się je na szczeblu krajowym, a każda szkoła dostosowuje je do potrzeb lokalnych w ramach swej autonomii. Dla każdego przedmiotu określono zasób wiedzy i umiejętności, a szkoła ma ułatwić uczniom przekształcenie ich w indywidualne kompetencje. Szczegółowe cele kształcenia w szkole średniej I stopnia zdefiniowano dla następujących przedmiotów: religia katolicka, język włoski, język angielski, drugi język obcy, historia, geografia, matematyka, przedmioty przyrodnicze, technika, informatyka, muzyka, plastyka, zajęcia sportowe i motoryczne. Nauczyciele mają prawo wybrać podręczniki i decydować o stosowanych metodach dydaktycznych. Od 2012 roku wszystkie podręczniki są udostępniane w formie elektronicznej. 
Na poziomie szkoły średniej I stopnia, uczniowie przechodzą do następnej klasy pod warunkiem otrzymania minimum oceny 6 z każdego przedmiotu. Uczniowie są również oceniani z zachowania w skali od 0 do 10 . Uczeń otrzymujący ocenę poniżej 6, przyznaną przez wszystkich nauczycieli, nie może otrzymać promocji do następnej klasy ani być dopuszczony do końcowego egzaminu państwowego. Po ukończeniu scuola secondaria di I grado uczniowie przystępują do egzaminu państwowego, który warunkuje przyjęcie do szkoły średniej II stopnia. Minimalna ocena warunkująca otrzymanie świadectwa ukończenia szkoły średniej I stopnia to 6.

\section{Szkoła średnia II stopnia (secondo ciclo di istruzione) - wiek: 14-17/19 lat; czas trwania 3-5 lat}

Kształcenie na poziomie szkoły średniej II stopnia nazywane jest drugim cyklem systemu edukacji (secondo ciclo di istruzione). Uczniowie mogą podjąć naukę w następujących placówkach:

- liceum o profilu klasycznym (liceo classico) - czas trwania nauki 5 lat,

- liceum o profilu ścisłym (liceo scientifico) - czas trwania nauki 5 lat,

- liceum o profilu językowym (liceo linguistico) - czas trwania nauki 5 lat,

- liceum o profilu socjologiczno-psychologiczno-pedagogicznym (liceo socio-psico-pedagogico) - czas trwania nauki 5 lat,

- liceum o profilu artystycznym (liceo artistico) - czas trwania nauki 4-5 lat,

- szkole technicznej (istituto tecnico) - czas trwania nauki 5 lat,

- szkole zawodowej (istituto professionale) - czas trwania nauki 3-5 lat,

- szkole artystycznej (istituti d'arte) - czas trwania nauki 3-5 lat,

- kształcenia zawodowego (formazione professionale di base) - czas trwania nauki 3 lata.

Do placówek szkolnictwa średniego II stopnia przyjmuje się osoby, które mają świadectwo ukończenia scuola secondaria di I grado. Za naukę w szkołach średnich II stopnia pobiera się czesne, którego wysokość stanowi stałą ustalaną centralnie kwotę. Uczniowie szkół publicznych pierwszego, drugiego i trzeciego roku są zwolnieni z opłat w ramach wypełniania obowiązku szkolnego.

Programy nauczania oraz wytyczne dotyczące metod nauczania dla każdego typu kształcenia opracowywane są przez centralne władze oświatowe. Przedmiotami oferowanymi we wszystkich typach szkół są: język włoski, historia, nowożytny język obcy, matematyka i wychowanie fizyczne.

Oceny okresowe i roczne w skali od 0 do 10 obejmują wyniki w nauce i zachowanie. Aby otrzymać promocję do następnej klasy, uczeń musi otrzymać mi- 
nimum ocenę 6 z każdego przedmiotu oraz z zachowania. W przypadku otrzymania oceny niższej niż 6 promocja jest wstrzymana, a uczeń powinien nadrobić zaległości do rozpoczęcia kolejnego roku szkolnego. Uczeń przystępuje do egzaminu poprawkowego przed rozpoczęciem nowego roku szkolnego. Uczniowie, którzy uzyskają wtedy co najmniej ocenę 6, są przyjmowani do następnej klasy.

Na zakończenie nauki w liceum uczeń przystępuje do egzaminu maturalnego (esame di Stato). Jest to egzamin wieloetapowy składający się z części pisemnej (wypracowanie, test) i ustnej. Ci, którzy otrzymają pozytywny wynik, uzyskują dyplom ukończenia szkoły średniej II stopnia, który pozwala na kontynuowanie nauki na poziomie szkolnictwa policealnego i wyższego. Natomiast, kończąc szkoły techniczne uzyskuje się dyplom technika. Ścieżki kształcenia zawodowego kończą się oceną kwalifikacji zawodowych i uzyskaniem świadectw wydawanych przez władze regionalne.

\section{Szkoła policealna techniczna (istruzione e formazione tecnica} superiore): wiek 19-21; czas trwania 2 lata

Do szkół policealnych przyjmowane są osoby posiadające świadectwo ukończenia szkoły średniej II stopnia, dyplom ukończenia trzyletniego kursu zawodowego, kandydaci przyjęci do V klasy szkoły liceo.

Oferta policealnego kształcenia technicznego została całkowicie zreformowana w 2008 roku. Obecnie kształcenie policealne obejmuje: kursy oferowane przez wyższe instytuty techniczne (Istituti Tecnici Superiori) i ścieżki zawodowe w ramach policealnego kształcenia i szkolenia technicznego.

\section{Szkolnictwo wyższe}

We Włoszech istnieją dwa główne rodzaje studiów: studia akademickie i zawodowe. W sektorze uczelni zawodowych prowadzi się studia w dziedzinach sztuk pięknych i muzyki (Sistema dell'Alta formazione artistica e musicale, Afam). Do obszaru Afam należą: akademie sztuk pięknych, państwowa akademia teatralna, uczelnie artystyczne, państwowa akademia tańca, konserwatoria. Jedynie uniwersytety i instytucje Afam mają prawo przyznawać tytuły i stopnie naukowe. Kształcenie na uniwersytetach i w instytucjach Afam obejmuje trzy cykle: pierwszy trzyletni, drugi dwuletni i trzeci o różnej długości. Studia medyczne i weterynaria wciąż są zorganizowane jako jednolity pięcio-/sześcioletni cykl edukacyjny. 
Kandydaci na studia muszą posiadać świadectwo ukończenia szkoły średniej II stopnia lub równorzędne kwalifikacje uzyskane za granicą. Wstęp na studia i liczba miejsc na kierunkach medycyna, weterynaria i architektura są regulowane centralnie. W wypadku innych kierunków uczelnie same ustalają procedury selekcji kandydatów. Warunki wstępu na uczelnie zawodowe (system Afam) obejmują wymagania dotyczące podstawowych umiejętności. Żądane umiejętności i procedury oceny są różne, gdyż definiują je poszczególne uczelnie.

Uczelnie są autonomiczne w tworzeniu programów studiów, ustalaniu nazw kierunków, celów kształcenia, przyznawaniu liczby punktów zaliczeniowych, tworzeniu systemów oceniania. Na szczeblu krajowym definiowane są wspólne ogólne kryteria i cele dla różnych kierunków. Uczelnie przyznają następujące stopnie: tytuł I stopnia (Laurea) uzyskiwany po 3 latach studiów (180 punktów), tytuł II stopnia (Laurea Specialistica/Magistrale, LS/LM) po kolejnych 2 latach studiów (120 punktów) i tytuł III stopnia: doktorat akademicki (Dottorato di Ricerca), tu okres studiowania różni się w zależności od kierunku studiów.

\section{Nauczyciele}

Nauczyciele przedszkoli i szkół podstawowych muszą posiadać licencjat (diploma di laurea) w dziedzinie pedagogiki. Nauczyciele szkół średnich muszą legitymować się dyplomem ukończenia studiów magisterskich (laurea magistrale). Nauczyciele szkół podstawowych są nauczycielami przedmiotów zintegrowanych, natomiast nauczyciele szkół średnich są nauczycielami przedmiotu. Nauczyciele mają status urzędników państwowych.

\section{Bibliografia}

Opetus- ja kulttuuriministeriö, http://www.minedu.fi/OPM/Julkaisut/2013/liitteet/Brochure_2013.pdf?lang=fi.

Structure of the education system in Northern Ireland 2014-15, https://www.nfer.ac.uk/ nfer/eurydice/publications/structure-diagram-ni.cfm.

\section{Akty prawne}

Basic Education Act 628/1998 Amendments up to 1136/2010, http://www.finlex.fi/en/laki/kaannokset/1998/en19980628.pdf.

Childcare Act 2006 (UK), http://www.legislation.gov.uk/ukpga/2006/21/contents. 
Education Act 1944 (UK), http://www.legislation.gov.uk/ukpga/Geo6/7-8/31/contents/enacted. Grundgesetz, https://www.bundestag.de/grundgesetz.

Laki kunta- ja palvelurakenneuudistuksesta, https://www.finlex.fi/fi/laki/ajantasa/2007/ 20070169.

Statutory guidance for local authorities on the provision of early education and childcare, https://www.gov.uk/government/publications/early-education-and-childcare--2.

Zákon ze dne 24. září 2004 o předškolním, základním, středním, vyšším odborném a jiném vzdělávání (školský zákon), https://www.zakonyprolidi.cz/cs/2004-561.

\section{Strony internetowe}

http://www.msmt.cz/.

https://www.google.pl/search?q=Sch\%C3\%A9ma+vzd\%C4\%9Bl\%C3\%A1vac\%C3\%ADho+sy st $\%$ C3\%A9mu+v+\%C4\%8Cesk\%C3\%A9+republice\&espv=2\&biw=1263\&bih=897\&source =lnms\&tbm=isch\&sa=X\&ved=0ahUKEwj006qh66XRAhULvhQKHY9fCo4Q_AUIBigB\#tb $\mathrm{m}=\mathrm{isch} \& \mathrm{q}=\mathrm{Sch} \% \mathrm{C} 3 \% \mathrm{~A} 9 \mathrm{ma}+\mathrm{vzd} \% \mathrm{C} 4 \% 9 \mathrm{Bl} \% \mathrm{C} 3 \% \mathrm{~A} 1 \mathrm{vac} \% \mathrm{C} 3 \% \mathrm{ADho}+\mathrm{syst} \% \mathrm{C} 3 \% \mathrm{~A} 9 \mathrm{mu}+\mathrm{v}+$ \%C4\%8Cesk\%C3\%A9+republice+2015\&imgrc=zcv45z6wEmIY_M\%3A/.

http://www.localfinland.fi/en/authorities/local-self-government/Documents/Finnish\%20

Local\%20Government\%20Act.pdf.

https://www.google.pl/search?q=Kaavio+kouluj\%C3\%A4rjestelm\%C3\%A4n+Suomessa\&es

pv=2\&biw=1680\&bih=920\&tbm=isch\&tbo=u\&source=univ\&sa=X\&ved=0ahUKEwjbwO

KChanRAhVFFSwKHZlJC7cQsAQIGQ\#imgrc=F-r_pckYO8IblM\%3A.

https://www.kmk.org/.

https://www.google.pl/search?q=Educational+system+in+Germany\&espv=2\&biw=1680\&b

ih=920\&source=lnms\&tbm=isch\&sa=X\&ved=0ahUKEwiT2vW34KrRAhVFuhQKHeovC WoQ_AUIBigB\#imgrc=5dRq3PFZt0zIHM\%3A.

https://www.google.pl/search?q=OVERSIKT+skolesystemet+i+NORGE\&espv=2\&biw=1270\&

bih=958\&source=lnms\&tbm=isch\&sa=X\&ved=0ahUKEwi3t8Xf8a3RAhWECCwKHXSW

BzUQ_AUIBigB\#imgrc=gW4zoNgIGQ5yyM\%3A.

https://www.gov.uk/government/organisations/department-for-business-innovation-skills. https://www.gov.uk/government/organisations/ofsted.

https://www.nfer.ac.uk/eurydice/structure-diagram-england.html.

https://www.findamasters.com/advice/finding/postgraduate-certificate-in-education-pgce-

-guide.aspx.

https://www.gov.uk/early-years-foundation-stage.

http://www.schoolsearch.co.uk/general-certificate-of-secondary-education-gcse.

https://www.nidirect.gov.uk/articles/as-and-a-levels. 
https://www.findamasters.com/advice/finding/postgraduate-certificate-in-education-pgce-guide.aspx.

http://gov.wales/topics/educationandskills/?lang=en.

http://www.estyn.gov.wales/.

http://www.gov.scot/About/People/Ministers/Cabinet-Secretary-for-Education-and-Lifelong-Learn.

http://www.gov.scot/About/People/Ministers/Minister-for-Children-and-Young-People.

http://www.gov.scot/About/People/Ministers/Minister-for-Learning.

http://www.educationscotland.gov.uk/.

http://www.sqa.org.uk/sqa/70972.html.

http://www.eep.ac.uk/dnn2/Organizations/SCRE/tabid/86/Default.aspx.

http://www.sfc.ac.uk/aboutus/aboutus.aspx.

http://www.gtcs.org.uk/home/home.aspx.

https://www.deni.gov.uk/.

http://www.miur.gov.it/.

http://www.edscuola.it/archivio/norme/decreti/dm100_02a.pdf.

https://archivio.pubblica.istruzione.it/normativa/2007/allegati/dir_310707.pdf. 


\title{
1.3. Szkolnictwo średnie w wybranych państwach Unii Europejskiej
}

\author{
Secondary education in selected European Union \\ countries
}

\begin{abstract}
W opracowaniu przedstawiono problematykę szkolnictwa średniego z uwzględnieniem szkolnictwa średniego zawodowego w wybranych państwach Unii Europejskiej. W artykule zaprezentowano podstawowe definicje i pojęcia używane dla określenia szkolnictwa średniego. Przedstawiono syntetyczną informację na temat organizacji i funkcjonowania szkolnictwa średniego ogólnokształcącego, technicznego i zawodowego następujących państw: Czechy, Francja, Niemcy, Słowacja, Wielka Brytania.
\end{abstract}

Słowa kluczowe: szkoła średnia, szkoła ogólnokształcąca, szkoła zawodowa, szkoła techniczna, zawód, Unia Europejska

The paper presents the problem of secondary education, including secondary vocational education in selected European Union countries. The article presents the basic definitions and terms used to describe secondary education. Synthetic information about the organization and functioning of secondary general, technical and vocational education of the following countries was presented: Czech Republic, France, Germany, Slovakia, United Kingdom.

Keywords: secondary school, general secondary school, vocational school, technical school, profession, European Union

\section{Podstawowe pojęcia}

Dla potrzeb ujednolicenia i usystematyzowania nazewnictwa struktur poziomów edukacyjnych występujących w różnych krajach, UNESCO opracowało Międzynarodową Standardową Klasyfikację Edukacji, tzw. klasyfikację ISCED (International Standard Classification of Education) ${ }^{1}$. Podstawową jednostką klasyfikacji w ISCED pozostaje program kształcenia. Programy kształcenia są definiowane na podstawie ich treści: jako zestaw lub ciag działań edukacyjnych, które organizuje się, by osiagnać zdefiniowany na wstępie cel lub wyspecyfikowany zestaw zadań

1 http://europass.frse.org.pl/files/isced.pdf. 
edukacyjnych ${ }^{2}$. Treść kształcenia jest podstawą do zakwalifikowania określonego programu kształcenia do jednego z poziomów kształcenia w klasyfikacji ISCED. W najnowszej klasyfikacji ISCED wyróżniamy 7 poziomów edukacyjnych: 0, 1, 2, 3, 4, 5, 6 .

Poziomy w klasyfikacji ISCED:

- ISCED 0 - wychowanie przedszkolne,

- ISCED 1 - kształcenie podstawowe lub I etap edukacji podstawowej,

- ISCED 2 - szkoła średnia I stopnia,

- ISCED 3 - szkoła średnia II stopnia,

- ISCED 4 - kształcenie powyżej średniego (nie wyższe),

- ISCED 5 - I etap kształcenia wyższego (nieprowadzący bezpośrednio do zaawansowanych kwalifikacji badawczych),

- ISCED 6 - II etap kształcenia wyższego (prowadzący do zaawansowanych kwalifikacji badawczych).

Polski system edukacji w przełożeniu na klasyfikację poziomów ISCED²:

- ISCED 0 - przedszkole,

- ISCED 1 - szkoła podstawowa,

- ISCED 2 - gimnazjum,

- ISCED 3 - liceum ogólnokształcące, liceum profilowane, technikum, uzupełniające liceum ogólnokształcące, technikum uzupełniające, zasadnicza szkoła zawodowa,

- ISCED 4 - szkoły policealne,

- ISCED 5 - wyższe studia licencjackie, studia magisterskie, studia uzupełniające magisterskie, studia podyplomowe,

- ISCED 6 - studia doktoranckie.

Pojęcie kształcenia zawodowego ${ }^{4}$ definiuje się najczęściej w literaturze pedagogicznej jako proces, którego celem jest przekazanie uczniom określonego zasobu wiedzy i umiejętności z zakresu przemysłu, rolnictwa i hodowli oraz szeroko rozumianych usług. Proces ten obejmuje przekazanie określonego za-

2 Tamże.

3 D. Dziewulak, Wymiar czasu pracy nauczycieli w wybranych państwach Unii Europejskiej, „Analizy BAS” 2009, nr 13(21), http://orka.sejm.gov.pl/WydBAS.nsf/0/5B394EDCA941C294C12576480048C3F7/\$file/Analiza_\%20BAS_2009_21.pdf.

4 Opracowanie przygotowano na podstawie ekspertyzy Biura Analiz Sejmowych nr 835/14 z 27 czerwca 2014 r. D. Dziewulaka zatytułowanej Informacja na temat szkolnictwa średniego ze szczególnym uwzględnieniem zawodowego szkolnictwa średniego w wybranych państwach Unii Europejskiej (Czechy, Francja, Niemcy, Stowacja, Wielka Brytania). 
sobu wiedzy ogólnej oraz specjalistycznych umiejętności teoretycznych i praktycznych, których opanowanie uprawnia uczniów do wykonywania wybranego zawodu. Rezultatem kształcenia zawodowego jest wykształcenie zawodowe uzyskane w konkretnej specjalności ${ }^{5}$. W większości państw świata kształcenie zawodowe realizowane jest w ramach systemu oświatowego, którego częścią jest system szkolny definiowany jako układ powiązanych ze sobą placówek szkolnych różnego typu i szczebla o określonej strukturze organizacyjnej i programowej ${ }^{6}$. Kształcenie zawodowe realizowane jest w ramach szkoły typu zawodowego, czyli szkoły zawodowej. Należy zwrócić uwagę, że pojęcia szkoła zawodowa lub szkolnictwo zawodowe są terminami wieloznacznymi ${ }^{7}$ i mogą oznaczać:

- instytucję edukacyjną, której głównym celem jest przygotowanie kwalifikowanych kadr dla gospodarki narodowej,

- instytucję oświatowo-wychowawczą, zajmującą się celowo organizowanym kształceniem zawodowym, prowadzącym do zdobycia kwalifikacji pracowniczych, umożliwiających podjęcie pracy w określonym zawodzie lub na odpowiednim stanowisku pracy,

- wielopodmiotową instytucję zorganizowanych działań edukacyjnych, wśród których podstawowa rola przypada czynnościom nauczania nauczycieli szkół zawodowych oraz czynnościom uczenia się uczniów szkół zawodowych, których ogólna wymowa prowadzi do wychowania człowieka, obywatela i pracownika zarazem,

- miejsce realizacji procesu kształcenia zawodowego (np. szkoła przyzakładowa).

Wieloznaczność terminu wynika także stąd, że w polskim systemie szkolnym wyróżnia się trzy główne poziomy kształcenia zawodowego:

- zasadniczy (zwany niekiedy podstawowym),

- średni - średnie szkoły zawodowe (w tym technika i licea specjalistyczne lub policealne szkoły zawodowe),

- wyższy - wyższe szkoły zawodowe (np. politechniki).

5 C. Kupisiewicz, M. Kupisiewicz, Słownik pedagogiczny, Wydawnictwo Naukowe PWN, Warszawa 2009, s. 90.

6 Tamże, s. 170-171.

7 Encyklopedia pedagogiczna XXI wieku, t. VI, Wydawnictwo Akademickie „Żak”, Warszawa 2007, s. 310. 


\section{Szkolnictwo średnie w wybranych państwach ${ }^{8}$}

\section{Czechy}

\section{Administracja i finansowanie edukacji}

W roku szkolnym 2010/2011 do szkół sektora publicznego uczęszczało 98\% uczniów w szkolnictwie obowiązkowym i 84\% w ponadobowiązkowym (z wyłączeniem szkolnictwa wyższego). Administracja szkolna odzwierciedla strukturę administracji państwa, w której wyodrębnia się szczebel centralny, regionalny i gminny. Za zintegrowaną politykę edukacyjną państwa odpowiada Ministerstwo Edukacji, Młodzieży i Sportu (Ministerstvo školství, mládeže a tělovýchovy). Opracowuje czteroletnie strategie kształcenia i rozwoju systemu edukacji. Do zadań ministerstwa należy przede wszystkim:

- określanie treści nauczania: zatwierdzanie ramowych programów nauczania, które stanowią podstawę rozwoju szkolnych programów edukacyjnych,

- akredytacja programów edukacyjnych dla zawodowych szkół wyższych oraz instytucji szkolnictwa wyższego,

- odpowiedzialność za krajową politykę finansowania oświaty (przygotowanie budżetu i decydowanie o zasadach jego podziału),

- odpowiedzialność za prowadzenie wykazu szkół, co wynika z postanowień konstytucyjnych: jedynie zarejestrowane instytucje mają prawo prowadzić działalność oświatową oraz otrzymywać środki publiczne,

- powoływanie organu prowadzącego instytucje doskonalenia zawodowego nauczycieli.

Centralne zarządzanie oświatą przez Ministerstwo Edukacji, Młodzieży i Sportu odbywa się również przy współudziale Ministerstwa Spraw Wewnętrznych (szkoły policyjne), Ministerstwa Obrony (szkolnictwo wojskowe), Ministerstwa Sprawiedliwości (szkoły przy zakładach karnych), Ministerstwa Spraw Zagranicznych (szkoły przy przedstawicielstwach dyplomatycznych). Odpowiedzialność za szkolenia i przekwalifikowanie zawodowe znajduje się we właściwości Ministerstwa Pracy i Spraw Społecznych (Ministerstvo práce a sociálních

8 W opracowaniu wykorzystano materiały uzyskane za pośrednictwem Sieci Informacji o Edukacji w Europie (Eurydice), Ministerstwa Edukacji Narodowej RP oraz dostępne na stronach internetowych instytucji i organizacji zajmujących się zagadnieniem kształcenia zawodowego w państwach UE. Informacje statystyczne zaczerpnięto z publikacji Organizacji Współpracy Gospodarczej i Rozwoju (OECD) zatytułowanej Education at a Glance 2013: indicators OECD. 
věcî. Usługi edukacyjne i szkoleniowe prowadzone na zasadzie swobody działalności nie podlegają żadnemu organowi. Jednak, aby wydawać świadectwa, dana jednostka musi pozytywnie przejść proces akredytacji; dotyczy to wszystkich jednostek kształcących umiejętności posługiwania się językiem obcym oraz jednostek realizujących szkolenia na zlecenie urzędów pracy.

Władze regionalne opracowują co cztery lata - zgodnie z celami ogólnokrajowymi - długoterminowe strategie dla swego regionu oraz odpowiadają za zakładanie i prowadzenie szkół średnich II stopnia i wyższych szkół zawodowych. Gminy odpowiadają za zapewnienie warunków dla kształcenia obowiązkowego, w związku z czym ustanawiają one i prowadzą szkoły powszechne. Zazwyczaj są one również organami prowadzącymi nieobowiązkowe przedszkola. Dyrektorzy szkół ponoszą pełną odpowiedzialność za jakość procesu dydaktycznego, zarządzanie finansami, politykę kadrową oraz współpracę ze społecznością lokalną. Podmiot założycielski placówki oświatowej jest zobowiązany powołać jej radę, która powinna mieć możliwość uczestnictwa w zarządzaniu szkołą. Dyrektorzy szkół mianowani są na podstawie konkursu.

Finansowanie szkół odbywa się z dwóch źródeł. Wydatki bieżące i inwestycyjne pokrywają organy założycielskie (regiony i gminy) z własnych budżetów, a środki związane $\mathrm{z}$ wynagrodzeniami i pomocami dydaktycznymi pochodzą $\mathrm{z}$ budżetu centralnego. Finansowanie odbywa się zgodnie z zasadą przyznawania środków w przeliczeniu na jednego ucznia.

Centralnym organem nadzoru jest Czeski Inspektorat Szkolny (Česká školní inspekce), podległy bezpośrednio Ministerstwu Edukacji, Młodzieży i Sportu. Zadaniem inspektoratu jest kontrolowanie szkół i szkolnej infrastruktury: warunków i wyników nauczania, jakości zarządzania, efektywności wykorzystania funduszy oraz przestrzegania obowiązujących przepisów na wszystkich poziomach, z wyjątkiem szkół wyższych.

\section{Pomoc finansowa dla uczniów}

W Czechach obowiązkowe nauczanie jest bezpłatne. W trudnych sytuacjach życiowych uczniowie mogą otrzymać wsparcie finansowe z budżetu Ministerstwa Pracy i Spraw Socjalnych oraz z budżetu Ministerstwa Edukacji, Młodzieży i Sportu. Ucząca się młodzież do 26 roku życia znajdująca się w trudnej sytuacji życiowej lub materialnej może otrzymać zasiłek, lecz decyzja o jego przyznaniu zależy od poziomu dochodów rodziny. Zasiłek dla uczniów niepełnoletnich pobierany jest przez rodziców (lub ustawowych opiekunów), a po osiągnięciu 
pełnoletności zasiłek pobiera sam uczeń. Opieka zdrowotna jest bezpłatna w ramach ogólnego systemu ubezpieczeń zdrowotnych. Koszty ubezpieczenia zdrowotnego dla uczniów i studentów pokrywa budżet państwa. Uczniowie i studenci, którzy dojeżdżają do szkoły korzystają ze zniżek w opłatach za bilety środków transportu. Uczniowie od 6 do 15 roku życia płacą nie więcej niż 37,5\% normalnej taryfy, a uczniowie w wieku od 15 do 26 roku życia - nie więcej niż 75\%. Różnica w cenie jest wypłacana firmom transportowym z budżetu gmin, zgodnie z zasadami określonymi przez Ministerstwo Edukacji, Młodzieży i Sportu9

\section{Bezrobocie}

Stopa bezrobocia wśród absolwentów szkolnictwa średniego zawodowego i pomaturalnego wahała się w zależności od typu szkoły i wynosiła w 2013 roku od około 13\% w szkolnictwie średnim zawodowym (ISCED 3) do około 19\% w szkolnictwie pomaturalnym (ISCED 4) ${ }^{10}$.

\section{Kontynuacja studiów}

Odsetek absolwentów szkół średnich ogólnokształcących podejmujących w 2013 roku naukę na poziomie szkolnictwa wyższego wynosił 94\%, a absolwentów szkół średnich zawodowych - 64\%. Wśród absolwentów szkół policealnych $34 \%$ kontynuuje naukę w wyższych uczelniach ${ }^{11}$.

\section{System szkolnictwa w Republice Czeskiej}

W Republice Czeskiej obowiązek szkolny trwa 9 lat i obejmuje uczniów w wieku od 6 do 15 roku życia.

Szczeble kształcenia objęte obowiązkiem szkolnym to:

- szkoła podstawowa i średnia I stopnia (základni škola) (ISCED 1 i ISCED 2) wiek: 6-10 lat - I etap; 11-15 lat - II etap.

9 https://webgate.ec.europa.eu/fpfis/mwikis/eurydice/index.php/Czech-Republic:Early_ Childhood_and_School_Education_Funding\#Financial_Support_for_Learners.27_Families.

10 Nezaměstnanost absolventů škol se stř̌edním a vyšším odborným vzděláním - 2013, http:// www.infoabsolvent.cz/Temata/PublikaceAbsolventi?Stranka=9-0-82\&NazevSeo=Nezamestnanost-absolventu-skol-se-strCednim-a-.

11 Přechod absolventů SŠ do terciárního vzdělávání - 2014, http://www.infoabsolvent.cz/Temata/PublikaceAbsolventi?Stranka=9-0-88\&NazevSeo=Prechod-absolventu-SS-do-terciarniho-vzdelavani-. 
- szkoła średnia ogólnokształcąca II stopnia (gymnázium) (ISCED 3) - wiek: 1113/15 lat.

Szkoły są zrejonizowane, ale rodzice mają prawo wybrać dla ucznia dowolną placówkę. Uczniowie mogą przejść z základni škola po ukończeniu V klasy do ośmioletniego gymnázium lub po ukończeniu VII klasy do sześcioletniego gymnázium, pod warunkiem zdania egzaminu wstępnego, przeprowadzanego przez szkołę. W gymnázium kształci się 10\% populacji wiekowej uczniów.

\section{Szkolnictwo średnie II stopnia i policealne}

\begin{tabular}{|c|c|c|c|c|}
\hline Szkolnictwo średnie & Typy kształcenia & $\begin{array}{l}\text { Czas } \\
\text { trwania } \\
\text { (lata) }\end{array}$ & $\begin{array}{l}\text { Poziom } \\
\text { ISCED }\end{array}$ & $\begin{array}{c}\text { Wiek } \\
\text { uczniów }\end{array}$ \\
\hline \multirow{3}{*}{$\begin{array}{l}\text { Szkolnictwo średnie } \\
\text { zakończone egzami- } \\
\text { nem maturalnym (střed- } \\
\text { ní vzdělánís maturitní } \\
\text { zkouškou) }\end{array}$} & $\begin{array}{l}\text { Ogólne, na poziomie średnim } \\
\text { II stopnia w gymnázium }\end{array}$ & 4 & ISCED 3 & $15-19$ \\
\hline & $\begin{array}{l}\text { Techniczne, na poziomie średnim } \\
\text { II stopnia w szkole średniej }\end{array}$ & \multirow[t]{2}{*}{4} & \multirow[t]{2}{*}{ ISCED 3} & \multirow[t]{2}{*}{$15-19$} \\
\hline & $\begin{array}{l}\text { Edukacja artystyczna w konserwa- } \\
\text { torium } 1\end{array}$ & & & \\
\hline $\begin{array}{l}\text { Szkolnictwo średnie } \\
\text { prowadzące do zdobycia } \\
\text { certyfikatu praktyk zawo- } \\
\text { dowych (střední vzdělání } \\
\text { s výućním listem) }\end{array}$ & $\begin{array}{l}\text { Zawodowe, na poziomie średnim } \\
\text { II stopnia w szkole średniej }\end{array}$ & $2 / 3$ & ISCED 3 & $15-17 / 18$ \\
\hline $\begin{array}{l}\text { Szkolnictwo średnie } \\
\text { (střední vzdělání) }\end{array}$ & $\begin{array}{l}\text { Szkolnictwo średnie ogólne i zawo- } \\
\text { dowe II stopnia w szkole średniej² }\end{array}$ & $1-2$ & ISCED 3 & $15-16 / 17$ \\
\hline $\begin{array}{l}\text { Szkolnictwo policealne, } \\
\text { poza ramami } \\
\text { szkolnictwa wyższego } 3\end{array}$ & Typy kształcenia & $\begin{array}{l}\text { Czas } \\
\text { trwania } \\
\text { (lata) }\end{array}$ & $\begin{array}{l}\text { Poziom } \\
\text { ISCED } 4\end{array}$ & $\begin{array}{c}\text { Wiek } \\
\text { uczniów }\end{array}$ \\
\hline \multirow{2}{*}{$\begin{array}{l}\text { Szkolnictwo policealne } \\
\text { zakończone egzaminem } \\
\text { maturalnym maturitní } \\
\text { zkouška }\end{array}$} & $\begin{array}{l}\text { techniczny cykl uzupełniający } \\
\text { (nástavbové studium) w szkole śred- } \\
\text { niej }\end{array}$ & 2 & ISCED 4 & $18+$ \\
\hline & $\begin{array}{l}\text { techniczny skrócony cykl (zkrácené } \\
\text { studium) w szkole średniej }\end{array}$ & $1-2$ & ISCED 4 & $18+$ \\
\hline $\begin{array}{l}\text { Szkolnictwo policealne } \\
\text { prowadzące do uzyska- } \\
\text { nia certyfikatu praktyk } \\
\text { zawodowych }\end{array}$ & $\begin{array}{l}\text { zawodowy skrócony cykl (zkrácené } \\
\text { studium) w szkole średniej }\end{array}$ & $1-2$ & ISCED 4 & $18+$ \\
\hline
\end{tabular}


1 Uczniowie w konserwatoriach mogą również ukończyć naukę egzaminem maturitní zkouška (poziom ISCED 3), jednak nie przed ukończeniem klasy IV lub klasy VIII w przypadku ośmioletnich konserwatoriów tanecznych. Mimo to, większość uczniów w konserwatoriach (poziom ISCED 5) kończy naukę uzyskaniem dyplomu absolutorium.

2 Uczniowie zdobywają wykształcenie średnie poprzez ukończenie programu edukacyjnego trwającego rok lub dwa lata. Uczniowie mogą uczęszczać na cykle praktická škola (rok lub 2 lata; poziom ISCED 2) lub cykle odborné učilište (2 lata; poziom ISCED 3).

3 Absolwenci z wykształceniem średnim II stopnia mogą podwyższyć lub zmienić swoje kwalifikacje w trzech typach cyklów policealnych: w dwuletnim nástavbové studium (cykl uzupełniający) umożliwiającym absolwentom trzyletnich cyklów zawodowych (ISCED 3) z ogólnymi i teoretycznymi przedmiotami w danym obszarze osiągnięcie poziomu ISCED 4, oraz w dwóch rodzajach zkrácené studium (cyklów skróconych) umożliwiających absolwentom ogólnych i technicznych cyklów na poziomie ISCED 3 zdobyć wiedzę z innego obszaru albo umiejętności na poziomie ISCED 4 (dla absolwentów cyklów na poziomie ISCED 3).

\section{Kryteria przyjęć}

Warunkiem przyjęcia do szkoły średniej II stopnia (ISCED 3) jest ukończenie kształcenia obowiązkowego i spełnienie wymogów wstępnych określonych przez dyrektora szkoły, który również decyduje o przyjęciu kandydata. Jednym z wymogów jest organizowany przez szkołę egzamin wstępny (ewentualnie test zdolności). Egzamin wstępny przeprowadzany jest w większości szkół zawodowych i technicznych. Obejmuje on sprawdzenie umiejętności w zakresie języka ojczystego, matematyki i w niektórych przypadkach języka obcego. Jednak do zasadniczych szkół zawodowych zazwyczaj nie przeprowadza się egzaminów wstępnych. Niezbędne jest też przedstawienie zaświadczenia lekarskiego o braku przeciwwskazań do nauki w danym typie szkoły (według wzoru określonego przez ministra zdrowia). Kryteria przyjęć ustala dyrektor szkoły, może przy tym wziąć pod uwagę także wyniki egzaminów gimnazjalnych.

W przypadku szkół artystycznych mogą być przeprowadzane dodatkowe testy, sprawdzające określone umiejętności kandydata predestynujące do nauki w szkole artystycznej. Procedura przyjęć do konserwatoriów oparta jest na egzaminie sprawdzającym konkretne umiejętności kandydata. Uczniowie mogą zdawać do trzech wybranych przez siebie szkół. Uczniowie, którzy nie zostali przyjęci, mogą brać udział w kolejnym naborze w szkołach, które mają wolne miejsca.

Warunkiem przyjęcia do policealnego cyklu kształcenia jest ukończenie szkoły średniej w zależności od ścieżki edukacyjnej i spełnienia wymogów dla kandydatów. 
Ramowy program nauczania dla kształcenia średniego II stopnia (gymnázium) określa 8 obszarów edukacji, 5 ścieżek międzyprzedmiotowych, jak również podstawowe kompetencje absolwentów. Tygodniowa liczba godzin lekcyjnych wynosi od 27 do 35 w każdym roku szkolnym. Dyrektor szkoły określa przedmioty dodatkowe, a także sposób wykorzystania dodatkowych godzin lekcyjnych. Minimalna liczba godzin lekcyjnych przypadająca na dany przedmiot to 132, jednak dyrektor może ją zwiększyć do 140.

Ramowy program nauczania dla techników i szkół zawodowych zawiera zarówno ogólne, jak i techniczne/zawodowe obszary nauczania, ścieżki międzyprzedmiotowe, podstawowe i szczegółowe kompetencje.

Istnieją specjalne ramowe programy nauczania dla cyklów uzupełniających (poziom ISCED 4), podczas gdy kursy skrócone są opracowane na podstawie ramowych programów nauczania w poszczególnych programach kształcenia na poziomie średnim II stopnia.

Konserwatoria zajmują się edukacją artystyczną. Można ją realizować poprzez kursy tańca, muzyki oraz muzyczno-teatralne kursy artystyczne.

\section{Ocena, promocja i kwalifikacje}

Wszystkie szkoły średnie II stopnia samodzielnie przeprowadzają egzaminy końcowe:

- maturitní zkouška w czteroletnim ogólnym lub technicznym cyklu kształcenia (poziom ISCED 3) i dwuletnim cyklu uzupełniającym lub skróconym (poziom ISCED 4); absolwenci szkół otrzymują świadectwo vysvědćení o maturitní zkoušce, które umożliwia ubieganie się o przyjęcie na wyższy poziom edukacji,

- závěrečná zkouška - na zakończenie trzyletniego i dwuletniego cyklu kształcenia (poziom ISCED 3) lub cyklu skróconego (poziom ISCED 4), w których egzamin obejmuje część praktyczną; absolwenci szkół otrzymują świadectwo vysvědčení o závěrečne zkoušce oraz výuční list poświadczające ich umiejętności,

- závĕrečná zkouśka - w dwuletnim lub rocznym cyklu ogólnym lub zawodowym (poziom ISCED 2 i ISCED 3), absolwenci otrzymują świadectwo vysvědćení o závěrečne zkoušce. 


\section{Francja}

\section{Administracja i finansowanie edukacji}

We Francji system oświaty zarządzany jest centralnie. Kształtowanie i egzekwowanie realizacji polityki edukacyjnej należy do centralnych władz wykonawczych. Taki model organizacji i zarządzania oświatą został wprowadzony w XIX wieku dekretem Napoleona ustanawiającym monopol państwa w sprawach organizacji ustroju szkolnego (mianowanie na wszystkie stanowiska pracy, kontrola nauczycieli, prawo otwierania szkół, przydzielanie stypendiów itp.). Do zadań francuskiego Ministerstwa Edukacji Narodowej, Szkolnictwa Wyższego i Badań Naukowych (Ministère de l'Éducation nationale, de l'Enseignement supérieur et de la recherche ${ }^{12}$; dalej: Ministerstwo Edukacji) ${ }^{13}$ należy:

- opracowywanie szczegółowych programów nauczania wszystkich przedmiotów oraz wytycznych dotyczących organizacji i metodyki nauczania (wybór podręczników i metod nauczania należy do decyzji nauczycieli),

- prowadzenie naboru do zawodu nauczycielskiego i organizowanie kształcenia nauczycieli,

- podejmowanie decyzji w sprawie obsady etatów poprzez centralne określanie liczby nauczycieli i pracowników placówek,

- określanie statusu i zasad funkcjonowania szkół,

- problematyka kształcenia i doskonalenia zawodowego,

- przeprowadzanie egzaminów, przyznawanie państwowych kwalifikacji oraz wydawanie świadectw maturalnych (baccalauréat).

Za realizację centralnej polityki edukacyjnej odpowiedzialne są na terenie kraju wydziały administracyjne, tzw. akademie (académies). Terytorium Francji podzielone jest na 30 akademii i 97 dyrekcji departamentalnych (directions des services départementaux). Na czele akademii stoi rektor (recteur) powoływany przez premiera. Rektor jako przedstawiciel ministerstwa $\mathrm{w}$ terenie czuwa nad wykonywaniem rozporządzeń i wdrażaniem postanowień centralnych władz oświatowych. Podlegają mu szkoły podstawowe, średnie, kształcenie ustawiczne,

12 Od 2000 roku Ministerstwo Edukacji Narodowej czterokrotnie zmieniało swoją nazwę: Ministère de l'Éducation nationale (w latach 2000-2014); Ministère de l'Éducation nationale, de l'Enseignement supérieur et de la Recherche (w latach 2014-2017); Ministère de l'Éducation nationale (w latach 2017-2020); Ministère de l'Éducation nationale et de la Jeunesse (od $2020 \mathrm{roku})$.

13 http://www.education.gouv.fr/. 
szkoły prywatne, szkolnictwo wyższe (z uwzględnieniem jego autonomii). W zakresie szkolnictwa podstawowego i średniego rektor uczestniczy w planowaniu kształcenia, określaniu struktury zatrudnienia pedagogicznego, zatwierdzaniu programów pedagogicznych, ustalaniu środków bezpieczeństwa w szkołach i przydzielaniu sprzętu dydaktycznego. W zakresie szkolnictwa prywatnego podejmuje decyzje dotyczące podpisywania tzw. umów stowarzyszeniowych oraz sprawuje nadzór pedagogiczny.

Akademia, odpowiadająca terytorialnie jednemu regionowi administracyjnemu, obejmuje zazwyczaj kilka departamentów (départements). Każdym departamentem należącym do danej akademii kieruje inspektor akademii (inspecteur d'académie), mianowany dekretem prezydenta Republiki. Inspektor akademii nadzoruje $\mathrm{w}$ departamencie realizację zaplanowanych zadań edukacyjnych. Kompetencje inspektora akademii odnoszą się do wszystkich poziomów nauczania z wyjątkiem szkolnictwa wyższego. Inspektor akademii podlega zarówno prefektowi (naczelnikowi departamentu w ramach podziału administracyjnego kraju), jak i rektorowi.

W zakresie szkolnictwa podstawowego inspektor akademii sprawuje dwa typy funkcji: funkcje administracyjne i funkcje pedagogiczne. Jego kompetencje administracyjne zezwalają mu na podejmowanie decyzji odnośnie do otwierania i zamykania klas oraz przydziału etatów nauczycielskich w szkołach podstawowych. Do jego kompetencji należy również zarządzanie kadrą placówek oświatowych oraz prowadzenie nadzoru pedagogicznego. Wizytacje przeprowadzają inspektorzy - inspektorzy generalni i inspektorzy oświatowi. Inspektorom generalnym powierzono szeroki zakres wszelkich zadań kontrolnych i ewaluacyjnych na wszystkich szczeblach edukacyjnych, a do zadań inspektorów oświatowych należy kontrola szczebla przedszkolnego, szkolnictwa podstawowego i średniego. Oddzielną kategorią inspektorów są inspektorzy ds. dydaktyki, którzy odpowiadają za sprawy związane z ewaluacją pracy dydaktycznej nauczyciela.

Kształcenie w bezpłatnym szkolnictwie publicznym prowadzone jest równolegle z kształceniem oferowanym przez placówki niepubliczne. W sektorze niepublicznym większość placówek funkcjonuje na podstawie tzw. umów stowarzyszeniowych (contrats d'association), w wyniku których część finansowania szkół - w tym uposażenia nauczycieli - jest realizowane z budżetu Ministerstwa Edukacji. W 2011 roku do publicznych szkół podstawowych uczęszczało około 87\% uczniów, a do publicznych szkół średnich około 78\% uczniów. 


\section{Pomoc finansowa dla uczniów}

We Francji nauczanie obowiązkowe jest bezpłatne. Prawie 25\% uczniów ze szkół średnich I i II stopnia pobiera zasiłki i stypendia. W 2012 roku Ministerstwo Edukacji przeznaczyło na bezpośrednią pomoc finansową dla uczniów 568,2 mln euro. Z różnych form pomocy finansowej skorzystało 1,3 mln uczniów. Największy odsetek beneficjentów to uczniowie liceów zawodowych (lycée professionnel) - 32\% oraz liceów ogólnokształcących i technicznych (lycée d'enseignement général et technologique)-17,2\%. Wśród oferowanych stypendiów znajdują się:

- stypendia krajowe (bourses nationales) - płacone z budżetu Ministerstwa Edukacji lub władz lokalnych,

- stypendia dla szkolnictwa ponadpodstawowego (bourses du second degré) przeznaczone dla uczniów z rodzin o niskich dochodach. Kwota przyznanego stypendium szacowana jest według skali ogólnokrajowej i jest inna dla uczniów ze szkół średnich I stopnia i szkół średnich II stopnia. Kwota stypendium dla uczniów szkolnictwa średniego I stopnia zależy od dochodu rodziny. Wypłacana jest jednorazowo raz w roku w wysokości 80,90 euro lub 240,10 euro, lub 350,00 euro. Uczniowie szkół licealnych, jeżeli spełniają odpowiednie warunki, mogą otrzymać roczne stypendium w wysokości od 134,37 euro (wypłacane w 3 transzach) do 447,90 euro (wypłacane w 10 transzach),

- stypendia adaptacyjne (bourses d'enseignement d'adaptation) - przeznaczone dla uczniów z rodzin o niskich dochodach realizujących obowiązek szkolny w placówkach pedagogiki specjalnej lub dla uczniów realizujących uzupełniające zajęcia reedukacyjne podlegającym obowiązkowi szkolnemu,

- stypendia z funduszu stołówkowego (fonds social pour les cantines) - przeznaczone dla uczniów z rodzin o niskich dochodach i umożliwiające korzystanie z posiłków w szkolnej stołówce,

- stypendia z funduszu szkół średnich (fonds sociaux collégiens et lycéens) przeznaczone dla uczniów, którzy znaleźli się w trudnej sytuacji życiowej lub rodzinnej. Stypendium może zostać przyznane na wydatki związane z kosztami zakupu pomocy szkolnych lub innymi obowiązkowymi opłatami szkolnymi. Stypendium może zostać przyznane w formie rzeczowej lub finansowej.

Oprócz różnych grup stypendiów przyznawanych na poziomie szkolnictwa średniego uczniowie mogą uzyskać różnego rodzaju pomoc finansową. Między innymi należą do nich: 
- dodatek przyznawany uczniom przy zapisie do jednej z trzech klas szkoły średniej w kwocie 217,06 euro. Dodatek wypłacany jest jednorazowo pod warunkiem, że uczeń nie powtarza klasy,

- dodatek na pomoce naukowe przyznawany uczniom liceów technicznych i średnich szkół zawodowych na zakup materiałów edukacyjnych. Dodatek w wysokości 341,71 euro wypłacany jest jednorazowo na początku roku szkolnego,

- dodatek specjalnościowy przyznawany uczniom, którzy będąc w szkole średniej dodatkowo podejmują kształcenie w celu zdobycia dodatkowych uprawnień zawodowych. Dodatek w wysokości 435,84 euro płatny jest w trzech ratach.

\section{Bezrobocie}

W 2013 roku bezrobocie we Francji wynosiło ogółem 10,6\%14. Stopa bezrobocia wśród absolwentów szkolnictwa średniego zawodowego kształtowała się na poziomie 19,0\%, wśród absolwentów szkolnictwa średniego technicznego wynosiła 14,6\%, wśród absolwentów szkolnictwa pomaturalnego (matura + 2 lata nauki) 9,5\%, a wśród absolwentów szkolnictwa wyższego (studia wyższe I i II stopnia) wynosiła $9,3 \%{ }^{15}$.

\section{Kontynuacja studiów}

Odsetek absolwentów szkół średnich ogólnokształcących podejmujących w 2008 roku naukę na poziomie szkolnictwa wyższego wynosił 85\%, absolwentów liceów technicznych - 51\%, absolwentów szkół średnich zawodowych - 54\% ${ }^{16}$.

\section{System szkolnictwa we Francji}

\section{Edukacja przedszkolna}

We Francji przedszkole - école maternelle (poziom ISCED 0) - przeznaczone jest dla dzieci w wieku od 2 do 6 lat. Francja ma długoletnią tradycję bezpłatnej, powszechnej edukacji przedszkolnej. Edukacja na tym poziomie nie jest obowiązkowa, ale do école maternelle uczęszcza ponad 90\% rocznikowej populacji, po-

14 http://www.capital.fr/carriere-management/actualites/hausse-du-chomage-a-10-4-au-1er-trimestre-2013-848975.

15 http://www.inegalites.fr/spip.php?article1585.

16 http://orientation.blog.lemonde.fr/2011/05/26/apres-le-bac-qui-reussit-et-ou/. 


\section{Rysunek 11. Schemat organizacji systemu szkolnictwa we Francji}

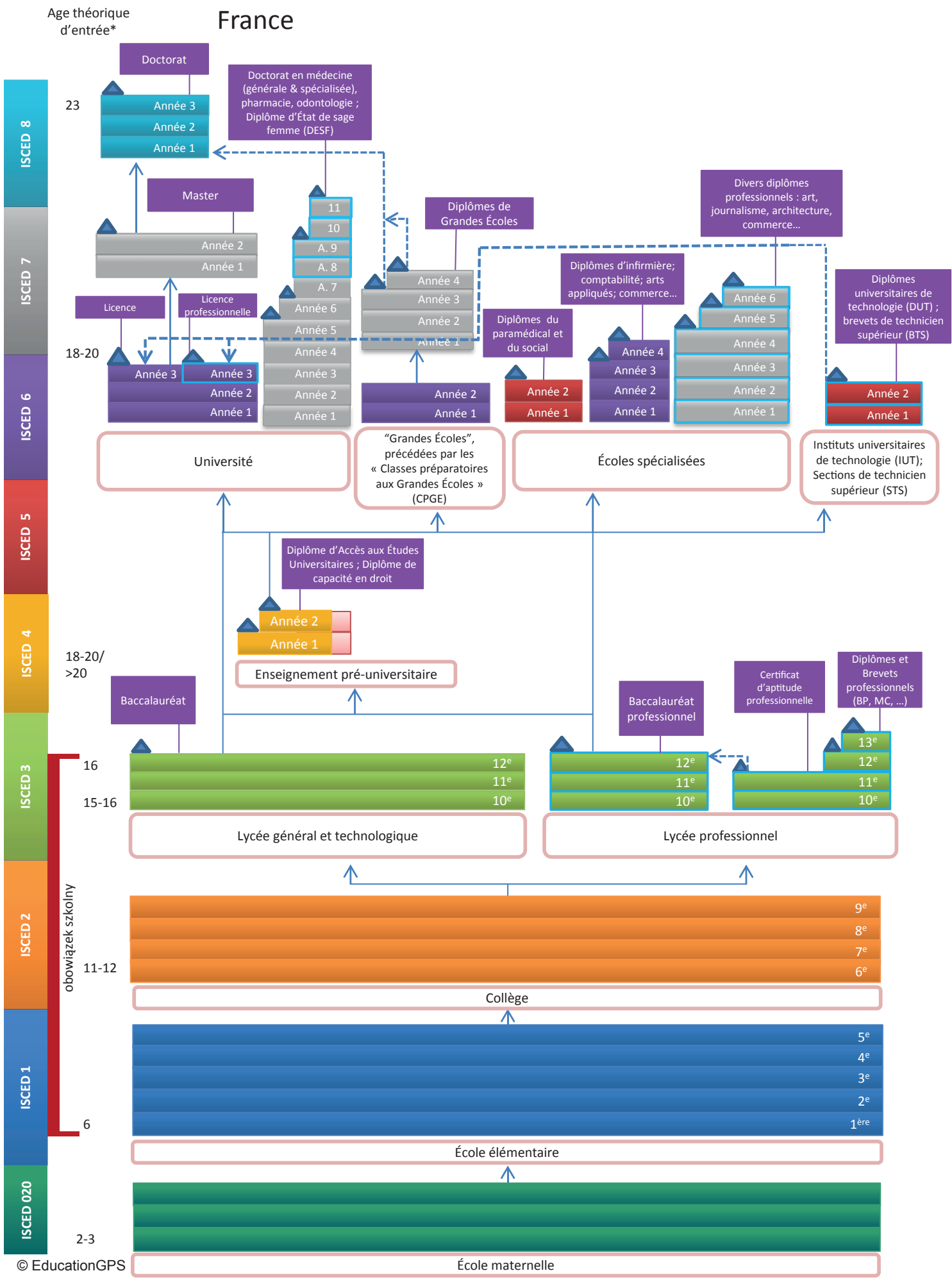




\section{Legenda (wyjaśnienie terminów użytych na rysunku)}

\section{POZIOMY EDUKACYJNE}

École maternelle - przedszkole

École élémentaire - szkoła elementarna

Collège - kolegium (szkoła średnia I stopnia)

Lycée général et technologique - liceum ogólnokształcące i techniczne

Lycée professionnel - liceum zawodowe

Enseignement pré-universitaire - kształcenie przeduniwersyteckie (poziom edukacji policealnej)

Université - uniwersytet

Grandes Écoles, précédées par les Classes préparatoires aux Grandes Écoles (CPGE) - Wielkie Szkoły poprze-

dzone kształceniem w klasach przygotowawczych do Wielkich Szkół

Écoles spécialisées - szkoły wyższe kształcące w dziedzinach specjalistycznych

Instituts universitaires de technologie (IUT) - uniwersyteckie instytuty techniczne

Sections de technicien supérieur (STS) - placówki kształcenia techników na poziomie wyższym

\section{DYPLOMY}

Licence - licencjat

Licence professionnelle - licencjat zawodowy

Master - magisterium

Doctorat - doktorat

Doctorat en médecine (générale \& spécialisée), pharmacie, odontologie - doktorat z medycyny (ogólny \& specjalizacyjny), farmacja, odontologia

Diplôme d'État de sage femme (DESF) - państwowy dyplom położnictwa

Diplômes de Grandes Écoles - dyplomy Wielkich Szkół

Diplômes du paramédical et du social - dyplomy z dziedzin paramedycznych i społecznych

Diplômes d'infirmière; comptabilité; arts appliqués; commerce... - dyplomy z dziedziny pielęgniarstwa, rachunkowości, sztuk stosowanych, handlu...

Divers diplômes professionnels: art, journalisme, architecture, commerce... - dyplomy z różnych dziedzin: sztuka, dziennikarstwo, architektura, handel...

Diplômes universitaires de technologie (DUT) - dyplom uniwersytecki w dziedzinach technicznych Brevets de technicien supérieur (BTS) - dyplom wyższych studiów technicznych

OPIS TRANSFERÓW EDUKACYJNYCH (STRZAŁKI) I OZNACZEŃ LAT NAUKI

6e - szósty rok nauki

Année 1 - pierwszy rok studiów 
cząwszy od 3 roku życia, a czasem nawet od 2 roku życia (w roku 2010/2011 do przedszkoli uczęszczało 4,4\% francuskich dwulatków). Przedszkole jest dostępne dla wszystkich dzieci w wieku od 2 do 6 lat, ale w przypadku dwulatków o przyjęciu do placówki decyduje liczba wolnych miejsc.

\section{Kształcenie obowiązkowe}

\begin{tabular}{|l|c|}
\hline \multicolumn{1}{|c|}{ Nazwa szkoły } & Wiek uczniów \\
\hline Szkoła podstawowa (école élémentaire); ISCED 1 & 6-11 lat \\
\hline Szkoła średnia I stopnia (collège); ISCED 2 & $11-15$ lat \\
\hline $\begin{array}{l}\text { Liceum ogólnokształcące i techniczne (lycée d'enseignement général } \\
\text { et technologique) - pierwszy rok nauki w szkole średniej II stopnia } \\
\text { Liceum zawodowe (lycée professionnel); ISCED 3 }\end{array}$ & $15-16$ lat \\
\hline
\end{tabular}

Obowiązek szkolny trwa 10 lat i podlegają mu uczniowie w wieku od 6 do 16 lat. Szczeble kształcenia objęte obowiązkiem szkolnym to:

- szkoła elementarna (école élémentaire) - wiek: 6-11 lat,

- szkoła średnia I stopnia (collège) - wiek: 11-15 lat,

- szkoła średnia II stopnia (lycée) - na ogół w wieku 15 lat uczniowie wstępują do liceum ogólnokształcącego i technicznego (lycée d'enseignement général et technologique) lub liceum zawodowego (lycée professionnel), w którym rozpoczynają piąty rok nauki w szkole średniej (classe de seconde). W momencie ukończenia tej klasy osiągają wiek odpowiadający zakończeniu obowiązku szkolnego. Dalsza edukacja nie jest obowiązkowa.

\section{Kryteria przyjęć}

Rekrutacja uczniów do szkół publicznych odbywa się zgodnie z zasadą rejonizacji. Uczniów zapisuje się na ogół do école élémentaire, collège i lycée w rejonie, w którym mieszkają ich rodzice. Istnieje także możliwość zapisania dziecka do szkoły znajdującej się poza rejonem, a liczba dostępnych miejsc w placówkach przeważnie umożliwia realizację życzenia rodziców. Jeśli szkoła wyczerpie limit dostępnych miejsc, inspektor akademii przyznaje miejsca w danej szkole, uwzględniając pierwszeństwo dla dzieci niepełnosprawnych, dzieci wymagających leczenia specjalistycznego w pobliżu szkoły, uczniów z wysokimi wynikami w nauce, uczniów pobierających stypendium socjalne, uczniów ze specjalnymi potrzebami edukacyjnymi, uczniów mających rodzeństwo w danej szkole oraz 
uczniów zamieszkujących w pobliżu danego rejonu, ale poza jego obwodem. Brak jest zaleceń w sprawie liczebności klas. Klasy mogą mieć różną liczbę uczniów, zależnie od polityki władz akademii, która powinna uwzględniać lokalne uwarunkowania (np. rozmieszczenie ludności na obszarach zurbanizowanych i wiejskich departamentu). Średnia krajowa wynosi około 25 uczniów w klasie szkoły podstawowej, $24 \mathrm{w}$ collèges, $28 \mathrm{w}$ lycées généraux et technologiques i $20 \mathrm{w}$ lycées professionnels.

\section{Ocena, promocja i kwalifikacje w szkolnictwie obowiq̨zowym}

Edukacja w szkołach podstawowych jest podzielona na dwa etapy: etap nauczania początkowego (cycle des apprentissages fondamentaux), który rozpoczyna się w grupie wstępnej w przedszkolu i jest kontynuowany w pierwszych dwóch latach szkoły podstawowej (klasy przygotowawcze - CP, a następnie I klasa elementarna - CE 1), oraz etapu rozwoju umiejętności, obejmującego ostatnie trzy lata (II klasa elementarna - CE 2, a następnie I i II klasa na poziomie średniozaawansowanym, odpowiednio - CM 1 i CM 2) przed wstąpieniem do collège. Uwzględniając tempo nauki indywidualnych uczniów, rada pedagogiczna (conseil des professeurs) może przedłużyć lub skrócić o rok okres kształcenia ucznia w ramach każdego z tych etapów. Po zakończeniu nauki w szkole podstawowej nie jest przewidziany żaden egzamin, a uczeń ma prawo kontynuować naukę w szkole średniej I stopnia (collège). Zgodnie z prawem po ukończeniu 12 roku życia wszyscy uczniowie, niezależnie od reprezentowanego poziomu, muszą opuścić szkołę podstawową i rozpocząć naukę w collège.

Kształcenie w collège trwa 4 lata i jest podzielone na trzy etapy:

- etap obserwacji i adaptacji (cycle d'observation et d'adaptation) odpowiadający klasie VI (6ème) - wiek: 11-12 lat,

- etap główny (cycle central), obejmujący klasy V i IV (5ème i 4ème) - wiek: 12-14 lat,

- etap orientacji (cycle d'orientation), odpowiadający klasie III (3ème) - wiek: 14-15 lat.

\section{Szkolnictwo średnie I stopnia (poziom ISCED 2)}

Uczniowie z collège, u których występują bardzo poważne trudności w nauce i/lub w zachowaniu uczęszczają na zajęcia w sekcjach realizujących specjalnie sprofilowany program kształcenia ogólnego i zawodowego (sections d'enseigne- 
Rysunek 12. Schemat organizacji systemu szkolnictwa średniego we Francji

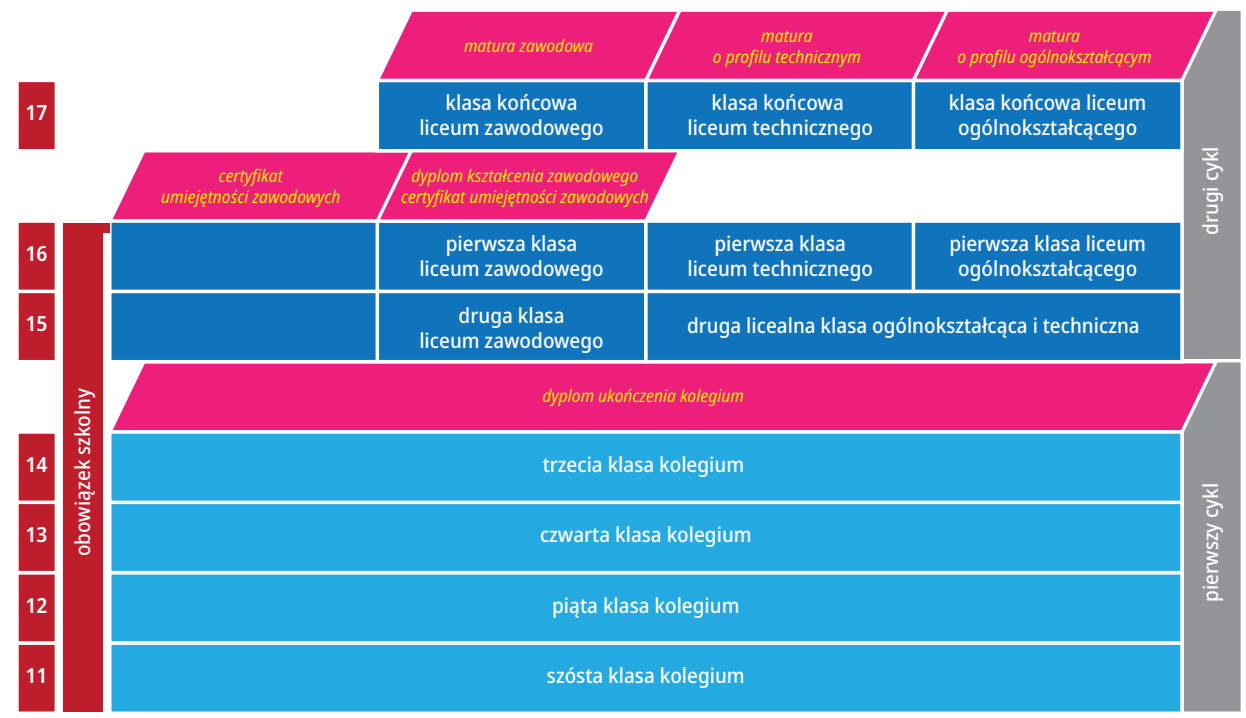

Źródło:http://fr.wikipedia.org/wiki/Terminale_(lyc\%C3\%Age)\#mediaviewer/Fichier:Enseign_France_-_ Secondaire_-_2009.png.

ment général et professionnel adapté, SEGPA). Ponadto, począwszy od IV klasy collège, prowadzi się kształcenie typu zawodowego dla młodzieży, która ukończyła 14 lat, umożliwiające uczniom bezpośredni kontakt ze światem pracy i lepsze poznanie różnych zawodów przy jednoczesnym kontynuowaniu kształcenia ogólnego. Po ukończeniu IV klasy uczniowie mogą kontynuować naukę, wybierając następujące ścieżki kształcenia:

- kształcenie ogólne w ostatniej klasie collège (III klasa),

- kształcenie typu orientacja zawodowa w ostatniej klasie collège (III klasa) w wymiarze 6 godzin tygodniowo,

- kształcenie typu przedzawodowego w ostatniej klasie collège (III klasa),

- kształcenie w ramach kursu przygotowującego do zawodu, tzw. DIMA (Dispositif d'Initiation aux Métiers en Alternance).

Po ukończeniu ostatnich dwóch lat nauki w collège (klasa IV i III) uczniowie otrzymują świadectwo państwowe, tzw. DNB (Diplôme national du brevet). Kontynuowanie nauki w liceum (lycée) nie jest uzależnione od posiadania brevet. $\mathrm{Na}$ zakończenie collège szkoła podejmuje dwie osobne decyzje dotyczące dalszej nauki ucznia: decyzję o przyznaniu brevet oraz decyzję o dydaktycznym ukierunkowaniu ucznia. W tej ostatniej bierze się pod uwagę konkretne umiejętności i za- 
interesowania ucznia w kontekście dalszej nauki. Decyzja ta jest pochodną opinii wynikającej z diagnozy orientacji i poradnictwa zawodowego, uzdolnień ucznia, opinii rodziny i grona pedagogicznego.

\section{Szkolnictwo średnie II stopnia (poziom ISCED 3)}

\begin{tabular}{|l|l|}
\hline Nazwa szkoły & Wiek uczniów \\
\hline $\begin{array}{l}\text { Liceum ogólnokształcące i techniczne - lycée d'enseignement général } \\
\text { et technologique: ISCED 3 }\end{array}$ & $15-18$ lat \\
\hline Liceum zawodowe - lycée professionnel: ISCED 3 & $15-17 / 19$ lat \\
\hline
\end{tabular}

Po ukończeniu collège i uzyskaniu świadectwa DNB uczniowie mają do wyboru trzy następujące ścieżki kształcenia na poziomie ISCED 3:

- kształcenie ogólnokształcące (enseignement général),

- kształcenie techniczne (enseignement technologique),

- kształcenie zawodowe (enseignement professionnel).

Kształcenie ogólnokształcące i techniczne realizowane jest w liceach ogólnokształcących i technicznych (lycée d'enseignement général et technologique). Nauka w tych szkołach trwa 3 lata. Pierwszy rok nauki odbywa się w klasie ogólnokształcącej i technicznej (classe seconde général et technologique), a program nauczania jest wspólny dla profilu ogólnego i technicznego. Drugi i trzeci rok nauki realizowany jest już zgodnie ze sprofilowanymi programami - ogólnokształcącym i technicznym - odpowiednio prowadzącymi do matury ogólnokształcącej (baccalauréat général) i matury technicznej (baccalauréat technologique). W ramach profilu ogólnego uczniowie mają do wyboru trzy typy sprofilowanej matury ogólnokształcącej (nauki humanistyczne, ekonomiczno-społeczne lub ścisłe) albo osiem typów sprofilowanej matury technicznej:

- nauki i techniki laboratoryjne - STL (sciences et technologies du laboratoire),

- nauki i techniki zarządzania - STG (sciences et technologies de la gestion),

- nauki i techniki zrównoważonego rozwoju - STI2D (sciences et technologies de l'industrie et du développement durable),

- nauki i techniki projektowania i sztuk stosowanych - STD2A (sciences et technologies du design et des arts appliqués),

- techniki zdrowia i nauk społecznych - ST2S (sciences et technologies de la santé et du social),

- techniki muzyki i tańca - TMD (techniques de la musique et de la danse);

- hotelarstwo i catering (baccalauréat hôtellerie), 
- agronomia i nauki i technologie dotyczące przyrody ożywionej - STAV (baccalauréat sciences et technologies de l'agronomie et du vivant).

Kształcenie zawodowe realizowane jest w dwuletnich liceach zawodowych (lycée professionnel), które przygotowują uczniów do uzyskania kwalifikacji zawodowych pozwalających na kontynuowanie nauki lub podjęcie pracy. Uczniowie liceów zawodowych mogą uzyskać następujące świadectwa i dyplomy:

- matura zawodowa - Bac Pro (baccalauréat professionnel),

- certyfikat umiejętności zawodowych - CAP (certificat d'aptitude professionnelle),

- dyplom kształcenia zawodowego - BEP (brevet d'etudes professionnelles).

Matura zawodowa (Bac Pro). Chcąc przystąpić do matury zawodowej, należy ukończyć collège, liceum zawodowe, zrealizować staż lub kształcenie zawodowe na odległość, uzupełniając je praktykami w miejscu pracy i uzyskać jeden z dwóch dyplomów CAP lub BEP. Bac Pro potwierdza umiejętności zawodowe na poziomie zaawansowanym w jednej z 75 specjalności.

Certyfikat umiejętności zawodowych (CAP) można uzyskać po dwóch latach kształcenia zawodowego. Daje uprawnienia do wykonywania zawodu w 200 specjalizacjach.

Dyplom kształcenia zawodowego (BEP) można uzyskać w ramach trzyletniego cyklu przygotowującego do matury zawodowej lub dwuletniego cyklu kształcenia w wybranych obszarach zawodowych: zdrowie i opieka społeczna, usługi transportowe, usługi hotelowe i cateringowe oraz optyka.

\section{Programy i treści nauczania}

W pierwszym roku nauki przedmiotami podstawowymi w lycée général et technologiques są: język francuski, matematyka, historia/geografia, dwa nowożytne języki obce, matematyka, fizyka/chemia, nauki o życiu i Ziemi, wychowanie fizyczne i sport, wychowanie obywatelskie oraz edukacja prawna i społeczna. Dodatkowo uczniowie wybierają dwa kolejne przedmioty, a mogą także dodać do tej listy trzeci przedmiot do wyboru lub np. uczestnictwo w warsztatach artystycznych.

W przedostatniej i ostatniej klasie (classes de première et terminale) lista przedmiotów obowiązkowych i przeznaczona na nie liczba godzin zależą od tego, jak przedmioty zostały pogrupowane w profilach. Poza przedmiotami obowiązkowymi dla wszystkich uczniów plany określają przedmioty obowiązkowe dla danego profilu: uczeń w danym profilu ma więcej godzin danego przedmiotu 
w ostatnim roku nauki, co daje lepsze przygotowanie do studiów wyższych na wybranym kierunku.

Licea zawodowe (lycées professionnel) prowadzą zarówno kształcenie ogólne, jak też teoretyczne i praktyczne kształcenie zawodowe, włącznie z praktykami w zakładach pracy. Przedmioty teoretyczne i zawodowe obejmują od $40 \%$ do $60 \%$ obowiązkowego wymiaru godzin. Są one realizowane w postaci tradycyjnych lekcji, ale także, w zależności od wybranej specjalizacji, w warsztatach, laboratoriach lub zakładach pracy. Przedmioty ogólne także odgrywają ważną rolę w tym typie kształcenia (język francuski, matematyka, historia, geografia, nauki ścisłe i przyrodnicze oraz język angielski).

Ramowy system kwalifikacji zawodowych przyznawanych przez Ministerstwo Edukacji opracowuje się zawsze we współpracy z danym sektorem gospodarki, w ramach zawodowych zespołów konsultacyjnych (commissions professionnelles consultatives, CPS).

\section{Ocena, promocja i kwalifikacje}

Uczniów przyjętych do lycée d'enseignement général et technologique ocenia się przez cały pierwszy rok nauki (klasa druga). W trakcie pierwszego roku uczniowie wybierają rodzaj egzaminu maturalnego (baccalauréat), który najlepiej odpowiada ich zdolnościom i zainteresowaniom. Na zakończenie roku, uwzględniając wyniki oceny, rada pedagogiczna podejmuje decyzję o zatwierdzeniu lub niezatwierdzeniu ich wyboru. W drugim i trzecim roku nauki (klasa I i końcowa) uczniowie realizują program sprofilowany pod wybrany rodzaj matury.

Lycées professionnels przygotowują uczniów do uzyskania kwalifikacji na dwóch poziomach - ogólnym i zawodowym. W obu wypadkach wspólnym elementem programów nauczania są obowiązkowe praktyki w zakładzie pracy. Zgodnie z przepisami dotyczącymi uznawania kwalifikacji zawodowych i doświadczenia zawodowego (validation des acquis professionnels), w uzasadnionych przypadkach uczniowie mogą zostać zwolnieni z niektórych praktyk oraz egzaminów zawodowych.

Świadectwo maturalne, zarówno ogólne, techniczne, jak i zawodowe, uprawnia do podjęcia studiów wyższych. Jednakże, o ile ogólne i techniczne świadectwa maturalne stanowią z założenia kwalifikacje ukierunkowane na kontynuowanie nauki, o tyle zawodowe świadectwo maturalne ma przede wszystkim umożliwić podjęcie pracy zawodowej bezpośrednio po ukończeniu szkoły średniej. 


\section{Doradztwo zawodowe}

Doradztwo zawodowe w systemie oświatowym Francji realizowane jest na podstawie ustawy z 10 lipca 1989 roku$^{17}$ o szkolnictwie oraz ustawy z 23 kwietnia $2005 \mathrm{roku}^{18} 0$ orientacji i programie dla przyszłości szkoły. Oba akty prawne stanowią, że oświata jest najważniejszym priorytetem narodowym i wskazują na konieczność przygotowania dla każdego ucznia indywidualnego planu rozwoju edukacyjno-zawodowego. Plan rozwoju powinien być tworzony przy współpracy szkoły, nauczycieli i doradców zawodowych. Za kluczowy moment w procesie orientacji edukacyjno-zawodowej uznaje się koniec kolegium - szkoły średniej I stopnia (collège), gdy uczeń decyduje o wyborze szkoły średniej II stopnia. Szkoła średnia II stopnia prowadzi do uzyskania matury lub dyplomu technika o wybranej specjalizacji, staje się więc początkiem specjalistycznej edukacji młodego człowieka, bezpośrednio wpływając na jego wybory życiowe ${ }^{19}$.

Uczeń może korzystać z doradztwa edukacyjno-zawodowego na terenie swojej szkoły, w ministerialnym Centrum Informacji i Orientacji (Centre d'information et d'orientation, CIO) ${ }^{20}$ lub w Krajowej Agencji Pracy (Pôle emploi) ${ }^{21}$. Istnieje także wiele innych organizacji publicznych oraz prywatnych (np. Młodzieżowe Centrum Informacji i Dokumentacji - Centre d'Information et de Documentation Jeunesse, CIDJ) ${ }^{22}$, w których można otrzymać poradę, wsparcie i ukierunkowanie w zakresie budowy własnej ścieżki zawodowej. Najpopularniejszą instytucją wspierającą szkolny proces doradztwa edukacyjno-zawodowego jest jednak Centrum Informacji i Orientacji. Zostało ono powołane w 1969 roku z inicjatywy ówczesnego Ministerstwa ds. Młodzieży i Sportu, dysponuje obecnie ponad 1500 placówkami we wszystkich departamentach na terenie całego kraju. Jest

17 Loi n89-486 du 10 juillet 1989, http://www.legifrance.gouv.fr/affichTexte.do?cidTexte=LEGITEXT000006069117\&dateTexte $=20050423$.

18 Loi n 2005-380 du 23 avril 2005 d'orientation et de programme pour l'avenir de l'école, http://www.legifrance.gouv.fr/affichTexte.do?cidTexte=JORFTEXT000000259787\&dateTexte=\&categorieLien=id.

19 L'éducation à l'orientation professionnelle dans l'enseignement obligatoire à temps plein en Europe. Commission européenne, http://www.education.gouv.fr/archives/2012/refondonslecole/wp-content/uploads/2012/07/rapport_eurydice_l_education_a_l_orientation_ professionnelle_dans_l_enseignement_obligatoire_a_temps_plein_en_europe_2008.pdf.

20 http://www.education.gouv.fr/cid160/les-lieux-d-information-de-l-orientation.html\#les-centres-d-information-et-d-orientation-c-i-o-.

21 http://www.pole-emploi.fr/accueil/.

22 http://www.cidj.com/le-cidj/historique/le-cidj-et-l-information-jeunesse. 
finansowane z budżetu państwa i ze środków władz lokalnych. Głównym celem CIO jest wspieranie i uzupełnianie działalności orientacyjno-poradniczej realizowanej przez nauczycieli z placówek szkolnych. Pracownicy Centrum - edukatorzy, doradcy zawodowi i psycholodzy - udzielają informacji i prowadzą indywidualne doradztwo edukacyjno-zawodowe skierowane do młodzieży szkolnej.

Instytucją zajmującą się działalnością informacyjną i szkoleniową w zakresie doradztwa zawodowego jest Krajowe Biuro Informacji o Kształceniu i Zawodach (Office National d'Information sur les Enseignements et les Professions, ONISEP). Jest to instytucja publiczna o statusie jednostki administracji publicznej powołana do życia w 1970 roku. Kieruje nią Generalny Inspektor Edukacji Narodowej, który podlega Ministrowi Edukacji Narodowej ${ }^{23}$. Na obszarze całej Francji znajduje się 28 regionalnych biur oraz sieć biur lokalnych i centrów informacyjnych tej instytucji. Celem działalności ONISEP jest udzielanie uczniom, nauczycielom i rodzicom wszechstronnych i profesjonalnych porad oraz przekazywanie informacji na temat kierunków kształcenia, a w wypadku zainteresowania konkretnymi zawodami, wskazywanie ewentualnych ścieżek zawodowych w systemie szkolnictwa zawodowego.

Kolejną instytucją jest Centrum Studiów i Badań Kwalifikacji Zawodowych (Centre d'études et de recherches sur les qualifications, CEREQ) ${ }^{24}$. Jest to instytucja publiczna powołana w ramach ONISEP. Pełną niezależność organizacyjną uzyskała w 1985 roku. Podlega Ministerstwu Edukacji Narodowej oraz Ministerstwu Pracy, Zatrudnienia, Kształcenia Zawodowego i Dialogu Społecznego. Celem CEREQ jest prowadzenie badań i analiza sytuacji na rynku pracy, zatrudnienia i realizowanych szkoleń w celu zapewnienia większej między nimi spójności. Centrum przygotowuje i opracowuje materiały na temat bieżącej i przewidywanej sytuacji rynkowej w obszarze zapotrzebowania na konkretne zawody. Informacje te są przekazywane do ONISEP, który rozpowszechnia je wśród zainteresowanych uczniów i nauczycieli kształcenia zawodowego.

\section{Niemcy}

\section{Administracja i finansowanie edukacji}

W Niemczech zarządzanie systemem oświatowym uwarunkowane jest federalną strukturą państwa. Zadania rządu federalnego w dziedzinie edukacji zostały okre-

23 Zob. przyp. 12 na s. 114.

24 http://www.cereq.fr/. 
ślone w Ustawie Zasadniczej (Grundgesetz) i obejmują m.in. ustanawianie przepisów dotyczących przyjęć do szkół wyższych, przyznawania stopni naukowych oraz udzielania pomocy finansowej i wspierania młodych pracowników nauki.

Zgodnie z Grundgesetz za ustawodawstwo i administrację oświatową odpowiadają przede wszystkim kraje związkowe (landy), które koordynują swoje działania w ramach Stałej Konferencji Ministrów Edukacji i Kultury (Kultusministerkonferenz, $\mathrm{KMK}^{25}$ ). Do zadań landów w obszarze oświaty należy przeprowadzanie inspekcji oraz sprawowanie nadzoru pedagogicznego, nadzoru w zakresie zgodności działań z regulacjami prawnymi i nadzoru w sprawach kadrowych w systemie szkolnym. W każdej szkole działa rada pedagogiczna odpowiedzialna za sprawy dydaktyczne oraz rada szkoły (złożona z nauczycieli, rodziców i uczniów), która ustanawia przepisy szkolne i zasady dyscypliny. Zakres uprawnień tych rad jest różny, zależnie od landu.

Władze krajów związkowych odpowiedzialne są także za kształcenie zawodowe. Najczęściej spotykaną formą jest dualny system kształcenia zawodowego (duale system) polegający na proporcjonalnym rozdzieleniu czasu przeznaczonego na edukację realizowaną w szkole i w zakładzie pracy. W skali całego kraju z systemu dualnego korzysta blisko dwie trzecie uczącej się młodzieży. Landy pokrywają koszty nauki w szkole, a praktyki i staże finansują firmy. Zajęcia w zakładzie pracy realizowane są zgodnie z wytycznymi federalnymi, a szkolne programy nauczania opracowywane są przez landy. Poziom kształcenia zawodowego w zakładzie pracy nadzorują izby gospodarcze i handlowe (np. izby przemysłu i handlu, izby rzemieślnicze itp.).

Wszystkie landy gwarantują uprawnionym szkołom standardowe wsparcie finansowe, wliczając w to udział w kosztach związanych z płacami pracowników i zakupem wyposażenia. Udział finansów publicznych w całkowitych kosztach prowadzenia placówek prywatnych różni się w poszczególnych landach i zależy od typu szkoły.

\section{Pomoc finansowa dla uczniów}

W Niemczech zagadnienie pomocy finansowej dla uczniów realizowane jest zgodnie $\mathrm{z}$ federalną ustawą o wspieraniu kształcenia (Bundesausbildungsförderungsgesetz, BAfö $\mathrm{G}^{26}$ ). Uczniowie ze średnich szkół ogólnokształcących i zawodowych,

25 http://www.kmk.org/.

26 Bundesgesetz über individuelle Förderung der Ausbildung, http://www.das-neue-bafoeg. de/de/204.php. 
spełniający określone wymogi, mają prawo do uzyskania wsparcia finansowego realizowanego w formie stypendiów, zapomóg lub pokrycia kosztów szkoleń. W przypadku niektórych typów szkół zawodowych wsparcie finansowe dla uczniów uzależnione jest od sytuacji finansowej ucznia i jego rodziców, odległości miejsca zamieszkania od szkoły oraz od wysokości kosztów szkoleń, kursów lub praktyk.

Od 2010 roku, zgodnie z ustawą o wspieraniu kształcenia (BAföG), uczniowie mogą - w zależności od tego, w jakiej są placówce i czy mieszkają z rodzicami otrzymywać pomoc finansową w wysokości od 216 do 465 euro miesięcznie. W indywidualnych przypadkach uczniowie przewlekle chorzy lub podlegający długoterminowej opiece medycznej (szpital, sanatorium, rekonwalescencja) mogą uzyskać dodatek zdrowotny w wysokości 73 euro miesięcznie.

W 2012 roku beneficjentami BAföG było 308 tys. uczniów. Rząd federalny i władze landowe w ramach ustawowej pomocy szkolnej i szkoleniowej przeznaczyły ogółem na wsparcie finansowe dla uczącej się młodzieży kwotę $913 \mathrm{mln}$ euro. Oprócz federalnej pomocy szkoleniowej, uczniowie mogą także skorzystać z pomocy finansowej gwarantowanej przepisami Drugiej Księgi Kodeksu Społecznego - bezpieczeństwo podstawowe dla osób poszukujących pracy (Sozialgesetzbuch Zweites Buch, SGB II - Grundsicherung für Arbeitsuchende ${ }^{27}$. Świadczenia, jakie mogą uzyskać uczniowie, to zasiłki dla bezrobotnych, finansowanie kształcenia ustawicznego, doskonalenia zawodowego oraz niektórych świadczeń z obszaru pomocy społecznej.

\section{Bezrobocie}

W lutym 2014 roku stopa bezrobocia w Niemczech wyniosła 5,1\% ${ }^{28}$. Stopa bezrobocia wśród absolwentów szkolnictwa średniego i pomaturalnego (w wieku 25-64 lat) wynosiła 5,8\%, a wśród absolwentów szkolnictwa wyższego (w wieku 25-64 lat) wynosiła 2,4\%29.

\section{System szkolnictwa w Niemczech}

W większości landów za edukację przedszkolną odpowiadają ministerstwa ds. socjalnych. Przedszkola (Kindergärten) przeznaczone są dla dzieci w wieku od 3 do 6 lat. Placówki prowadzone są głównie przez instytucje niepubliczne (przede

27 http://www.sozialgesetzbuch-sgb.de/sgbii/1.html.

28 http://www.oecd.org/edu/Germany_EAG2013\%20Country\%20Note.pdf.

29 Tamże. 
wszystkim kościoły i stowarzyszenia opieki społecznej). Finansowane są z budżetu landów, dotacji rodziców i innych źródeł.

W Niemczech długość trwania obowiązku szkolnego zależna jest od decyzji władz szkolnych landu i rodzaju kształcenia. Kształcenie w pełnym wymiarze jest obowiązkowe dla uczniów od 6 do 15 lub 16 roku życia, a kształcenie w niepełnym wymiarze obowiązuje od 6 do 18 roku życia.

Kształcenie w pełnym wymiarze jest obowiązkowe:

- w wieku 6-15 lat w landach: Badenia-Wirtembergia, Bawaria, Hamburg, Hesja, Meklemburgia-Pomorze Przednie, Dolna Saksonia, Nadrenia Północna-Westfalia (w Gymnasium), Nadrenia-Palatynat, Saara, Saksonia, Saksonia-Anhalt, Szlezwik-Holsztyn,

- w wieku 6-16 lat w landach: Berlin, Brandenburgia, Brema, Nadrenia Północna-Westfalia (w szkołach innych niż Gymnasium), Turyngia.

We wszystkich landach kształcenie w niepełnym wymiarze jest obowiązkowe do 18 roku życia dla osób, które nie uczęszczają do szkoły w pełnym wymiarze.

Obowiązek szkolny obejmuje następujące szczeble kształcenia:

- szkoła podstawowa (Grundschule) (poziom ISCED 1) - wiek: 6-10 lat (6-12, Berlin i Brandenburgia),

- szkoły średnie I stopnia (Orientierungsstufe, tzw. faza orientacji w różnych rodzajach szkół lub jako odrębna jednostka organizacyjna) (poziom ISCED 2) wiek: 10-12 lat,

- szkoły średnie I stopnia (poziom ISCED 2) Gymnasium, Realschule, Hauptschule, Gesamtschule (rodzaje szkół prowadzące różne typy kształcenia) - wiek: 10/12-15/16 lat,

- szkoły średnie II stopnia (poziom ISCED 3) - wiek: 15/16-18/19 lat.

Na ogół dzieci przyjmuje się do Grundschule od 6 roku życia. Przejście ze szkoły podstawowej do jednej z kilku rodzajów szkół średnich odbywa się zgodnie z różnymi przepisami, zależnie od ustawodawstwa danego landu. 0 wyborze szkoły średniej I stopnia decydują rodzice, na podstawie oceny dokonanej przez szkołę podstawową. Przyjęcie do różnych typów szkół średnich może być uzależnione od wyników w nauce i/lub decyzji władz edukacyjnych. Kształcenie obowiązkowe w całości jest bezpłatne.

Kryteria przyjęć

Do Grundschule przyjmuje się na ogół dzieci sześcioletnie. Dzieci objęte obowiązkiem nauki szkolnej wstępują do jednakowej dla wszystkich lokalnej szkoły 
podstawowej. Przejście ze szkoły podstawowej do jednej z kilku rodzajów szkół średnich odbywa się zgodnie z różnymi przepisami, zależnie od ustawodawstwa danego landu. 0 wyborze szkoły średniej I stopnia (ISCED 2) decydują rodzice, szkoła lub władze nadzorujące szkoły na podstawie oceny dokonanej przez szkołę podstawową. Przyjęcie do różnych szkół średnich może być uzależnione od wyników w nauce i/lub decyzji władz edukacyjnych. Kształcenie obowiązkowe jest bezpłatne na wszystkich jego etapach.

Programy i treści nauczania opracowywane są w taki sposób, aby spełniały kryteria zawarte w przyjętych przez Stałą Konferencję Ministrów Edukacji i Kultury standardach kształcenia dla szkoły podstawowej i szkół średnich. Standardy kształcenia precyzują cele edukacyjne, programy nauczania natomiast opisują i określają sposoby ich osiągnięcia.

\section{Szkolnictwo średnie II stopnia i policealne}

W ramach szkolnictwa średniego II stopnia wyróżniamy następujące rodzaje kształcenia:

- kształcenie w szkole ogólnokształcącej (Gymnasiale Oberstufe),

- kształcenie w szkole średniej II stopnia o profilu zawodowym:

- Berufsfachschule - szkoła zawodowa,

- Fachoberschule - średnia szkoła techniczna,

- Berufliches Gymnasium/Fachgymnasium - liceum ze specjalizacją zawodową,

- Berufsoberschule - średnia szkoła zawodowa,

- kształcenie w systemie dualnym.

Berufsfachschule przygotowuje do zawodu (jednego bądź kilku), oferując wstępne szkolenie zawodowe w jednym lub kilku zawodach regulowanych lub prowadzi do uzyskania pełnych kwalifikacji zawodowych w określonym zawodzie. Oferuje również dalszą edukację ogólną. Berufsfachschule kształci w kierunkach: biznesowym, języków obcych, sztuki, rzemiosła, pracy socjalnej, pracy w sektorze zdrowia. Listę konkretnych zawodów reguluje prawo federalne. W przypadku, gdy uczeń nie uzyskuje pełnych kwalifikacji, kończąc ten typ szkoły, ukończenie szkoły może zostać zaliczone do formalnego szkolenia w zawodzie, który wymaga takiego stażu. Absolwenci Berufsfachschule mogą również przystąpić do egzaminu walidacyjnego przed odpowiednim organem (jeśli dany land przyjął odpowiednie regulacje, które to umożliwiają) i potwierdzić swoje kwalifikacje oraz ich zgodność z kwalifikacjami nabywanymi w systemie dualnym. Warunkiem przyjęcia do Berufsfachschule jest certyfikat ukończenia edu- 
kacji obowiązkowej. Czas trwania nauki, w zależności od specjalizacji, wynosi od 1 roku do 3 lat (16-19 lat).

Nauka w Fachoberschule trwa dwa lata (obejmuje 11 i 12 rok edukacji, dla uczniów w wieku 16-18 lat). Szkoła kształci w kierunku ogólnym oraz specjalistycznym (w zakresie wiedzy teoretycznej i praktycznej), nauka prowadzi do zdobycia kwalifikacji umożliwiających kształcenie na poziomie wyższym w Fachhochschule. W niektórych landach ten typ szkoły umożliwia kształcenie o 1 rok dłużej (13 rok edukacji) i przygotowuje do egzaminów uprawniających do kontynuowania edukacji na poziomie wyższym.

Dziedziny kształcenia to: biznes i administracja, kierunki techniczne, żywienie, rolnictwo, praca socjalna i zdrowie, projektowanie, bioinżynieria i ochrona środowiska. Kształcenie obejmuje naukę w szkole i szkolenie praktyczne. Przedmioty obowiązkowe bez względu na specjalizację obejmują: język niemiecki, wiedzę o społeczeństwie, matematykę, nauki przyrodnicze, język obcy i przedmiot zawodowy. Szkolenie praktyczne odbywa się w pierwszym roku nauki (11 roku edukacji) w miejscu pracy (fabryce, firmie, instytucji) związanej z wybraną specjalizacją. Zaliczona wcześniej praktyka zawodowa może powodować przejście bezpośrednio na drugi rok (12 rok edukacji).

Berufliches Gymnasium/Fachgymnasium to wyższy poziom Gymnasium ze specjalizacją zawodową. Gymnasium z zasady oferuje ciągły tok nauki od 5 do 12 lub 13 roku edukacji. Ten typ szkoły nie ma odpowiednika na niższym poziomie w praktyce w niektórych landach są to ostatnie trzy lata Gymnasium ze specjalizacjami zorientowanymi na konkretne zawody. Przedmioty zawodowe są dodane do programów nauczania ogólnego obowiązującego w szkole ogólnokształcącej na tym poziomie i są zdawane podczas egzaminu końcowego. Przedmioty zawodowe, takie jak np.: przedsiębiorczość, biznes, technika, technologia informacyjna, żywienie, agronomia, nauki społeczne i o zdrowiu, jeśli są realizowane $\mathrm{w}$ trybie intensywnym, mogą być zdawane na egzaminie maturalnym zamiast przedmiotów ogólnych. Niektóre Berufliches Gymnasium/Fachgymnasium oferują uczniom możliwość uzyskania kwalifikacji umożliwiających podjęcie studiów wyższych, zgodnie z prawem obowiązującym na terenie danego landu. Ten typ kształcenia zawodowego oferują również inne instytucje, np. Oberstufenzentren (centrum wyższego kształcenia zawodowego), trwa ono zazwyczaj od 3 do 4 lat.

Szkolnictwo typu Berufsoberschule powstało w niektórych landach w celu umożliwienia uczniom, którzy kształcili się w systemie dualnym dostępu do edukacji na poziomie wyższym. Kształcenie w Berufsoberschule trwa 2 lata w pełnym wymiarze godzin i kończy się egzaminem maturalnym. 
Niektóre szkoły oferują także odpowiednio dłuższy cykl kształcenia w niepełnym wymiarze godzin. Uczniowie przyjmowani są do Berufsoberschule na podstawie Mittlerer Schulabschluss - certyfikatu uzyskiwanego po ukończeniu szkoły średniej I stopnia - oraz po odbyciu dwóch lat kształcenia zawodowego lub pięciu lat praktyki zawodowej.

Ponad 2/3 młodzieży kończącej szkołę obowiązkową wybiera jako dalszą ścieżkę edukacyjną kształcenie zawodowe w systemie dualnym. Trwa ono 2 lub 3 lata, w zależności od wyboru specjalizacji (zawodu). System nazywany jest dualnym, ponieważ zakłada, że nauka odbywa się w dwóch miejscach: zakładzie pracy oraz szkole (Berufsschule). Celem systemu jest zapewnienie możliwie najlepszej edukacji zawodowej, tj. właściwie skonstruowanego profilu kształcenia umożliwiającego zdobycie umiejętności, wiedzy i kwalifikacji zawodowych niezbędnych do wykonywania danego zawodu w zmieniających się okolicznościach rynku pracy. System umożliwia ponadto zdobycie wymaganego doświadczenia zawodowego. Uczeń kończący kształcenie w systemie dualnym uzyskuje formalne kwalifikacje do podjęcia pracy w jednym z 350 zawodów regulowanych. Jedynym warunkiem koniecznym do rozpoczęcia nauki w systemie dualnym jest uzyskanie świadectwa ukończenia szkoły obowiązkowej. Nie ma innych dodatkowych wymagań - możliwość kształcenia w systemie dualnym jest otwarta dla wszystkich.

Większość kandydatów decyduje się na podjęcie kształcenia w tym systemie od razu po zakończeniu edukacji na poziomie średnim I stopnia, choć około 20\% uczniów wybiera tę formę kształcenia dopiero po ukończeniu szkoły średniej II stopnia.

Młoda osoba podejmująca szkolenie zawodowe w systemie dualnym jest zatrudniona na podstawie umowy cywilnoprawnej między nią a firmą oferującą szkolenie. Na podstawie umowy uczeń ma obowiązek podjąć szkolenie praktyczne (w miejscu pracy) i teoretyczne (w szkole). Uczniowie spędzają na ogół od 3 do 4 dni w miejscu pracy i 1 lub 2 dni w tygodniu w szkole. Przedsiębiorca ponosi koszt szkolenia w miejscu pracy i wypłaca pensję ustalaną na zasadzie umowy negocjowanej na podstawie umowy zbiorowej. Wysokość pensji równa się średnio 1/3 wynagrodzenia wykwalifikowanego pracownika rozpoczynającego pracę i wzrasta z każdym rokiem szkolenia. Umiejętności, wiedza i kwalifikacje zawodowe, jakie uczeń zdobywa w trakcie kształcenia w systemie dualnym, zostały określone w specjalnych regulacjach - szczegółowe cele szkolenia w miejscu pracy określa dla każdego ucznia przedsiębiorca prowadzący szkolenie w dokumencie będącym indywidualnym planem szkoleniowym. 
Szczegółowe dane dotyczące kształcenia zawodowego, w szczególności kształcenia w systemie dualnym, są dostępne w corocznym raporcie na temat edukacji i szkolenia zawodowego Berufsbildungsbericht publikowanym przez Federalne Ministerstwo Edukacji i Badań (Bundesministerium für Bildung und Forschung, $\mathrm{BMBF})^{30}$.

\section{Szkolenie zawodowe w miejscu pracy}

W Niemczech szkolenie zawodowe w miejscu pracy zorganizowane jest na podstawie regulacji federalnych wypracowanych wspólnie przez landowe ministerstwa oświaty, podmioty odpowiedzialne w poszczególnych landach za edukację zawodową, pracodawców i związki zawodowe.

Szkolenie zawodowe w miejscu pracy odbywa się głównie w przedsiębiorstwach związanych z przemysłem, handlem oraz sektorem usług, ale także, choć w znacznie mniejszym stopniu, w prywatnych gospodarstwach domowych. Wymogi dotyczące poszczególnych zawodów, które uczeń powinien spełnić podczas szkolenia, określone są federalnymi przepisami (Ausbildungsordnungen). Monitoring i kontrolę spełniania przez firmy szkolące standardów kształcenia każdego zawodu prowadzą lokalne izby przedsiębiorców.

Szkolenie praktyczne w miejscu pracy zapewnia kwalifikacje potrzebne w danej praktyce zawodowej. Umiejętności i wiedza dla poszczególnych zawodów zostały ujęte w planie ramowym określającym czas trwania i konkretne treści nauczania. Plan ramowy jest podstawą do stworzenia indywidualnego programu nauczania w poszczególnych firmach. Częstą praktyką jest, że firmy szkolące, które nie mogą same zapewnić realizacji wszystkich treści nauczania określonych prawem, łączą się z innymi firmami/przedsiębiorstwami, tworząc stowarzyszenia, sieci firm czy międzyfirmowe centra szkoleniowe mogące oferować dodatkowe elementy szkolenia (np. te wymagające specjalistycznego sprzętu), których nie są w stanie zapewnić mniejsze firmy.

\section{Kształcenie zawodowe w szkole}

Kształcenie w szkole zawodowej (Berufsschule) ma na celu przekazanie wiedzy ogólnej i teoretycznej wiedzy zawodowej. Tygodniowy plan nauczania przewiduje 4 godziny lekcyjne przedmiotów ogólnych (język niemiecki, nauki społeczne

30 http://www.bmbf.de/. 
i ekonomia, religia i sport) niezależnie od wybranej specjalizacji oraz 8 godzin lekcyjnych przeznaczonych na przedmioty zawodowe. Języki obce są uwzględniane w puli przedmiotów zawodowych w takim wymiarze godzinowym, w jakim są istotne w danym zawodzie (np. w pracy biurowej, w specjalności hotelarskiej).

Organizacja nauki w szkole odbywa się w porozumieniu z przedsiębiorstwami i instytucjami nadzorującymi szkołę oraz właściwymi przedstawicielami przemysłu w celu zapewnienia uczniom najdogodniejszych warunków kształcenia.

\section{Kryteria przyjęć}

Warunkiem rozpoczęcia kształcenia zawodowego w szkole średniej II stopnia są zdobyte kwalifikacje oraz świadectwo ukończenia szkoły średniej I stopnia. Zależnie od celów kształcenia, w procesie rekrutacji do Berufsfachschulen od uczniów wymaga się, aby przedstawili świadectwa Hauptschulabschluss albo Mittlerer Schulabschluss, podczas gdy w przypadku Fachoberschule wymagane jest posiadanie Mittlerer Schulabschluss. Szkoły Berufliches Gymnasium lub Fachgymnasium wymagają świadectwa Mittlerer Schulabschluss lub jego ekwiwalentu z ocenami spełniającymi warunki przyjęć do Gymnasiale Oberstufe. Przed rozpoczęciem kształcenia zawodowego należy zakończyć kształcenie obowiązkowe. W przypadku systemu dualnego nie istnieją żadne dodatkowe wymogi formalne - jest on otwarty dla wszystkich absolwentów szkół średnich I stopnia, niezależnie od wyników w nauce.

\section{Programy i treści nauczania}

Programy nauczania dla szkolnictwa średniego II stopnia określane są przez ministerstwa poszczególnych landów. Zróżnicowanie treści nauczania zależy od typu kształcenia. Uczniowie Gymnasiale Oberstufe obowiązkowo uczą się przedmiotów z następujących trzech grup: przedmioty humanistyczne, przedmioty społeczne, przedmioty matematyczno-przyrodnicze i techniczne.

Programy kształcenia zawodowego w Berufsfachschulen obejmują język niemiecki, przedmioty w zakresie nauk społecznych, matematykę, przedmioty przyrodnicze, język obcy i wychowanie fizyczne oraz przedmioty zawodowe. Nauka w Fachoberschule jest podzielona na kilka obszarów tematycznych: biznes i administracja, technika, zdrowie i praca socjalna, projektowanie, żywienie i gospodarstwo domowe oraz rolnictwo. Kształcenie obejmuje zajęcia praktyczne i teoretyczne, na które się składają: język niemiecki, język obcy, matematyka, przedmioty przyrodnicze, ekonomia i społeczeństwo oraz przedmiot zawodowy. 
Kształcenie zawodowe w systemie dualnym przygotowuje do pracy w 350 zawodach, a nauka podzielona jest na zajęcia realizowane w szkole według landowych programów nauczania oraz na zajęcia odbywane w zakładzie pracy zgodnie praktyką stosowaną przez pracodawcę.

\section{Słowacja}

\section{Administracja i finansowanie edukacji}

Na Słowacji nadzór nad systemem oświaty sprawuje Ministerstwo Edukacji, Nauki, Badań i Sportu ${ }^{31}$. Zgodnie z ustawą nr 596/2003 o administracji państwowej w oświacie i samorządzie szkolnym oraz o zmianie niektórych ustaw ${ }^{32}$ ministerstwo odpowiada za całokształt organizacji sieci placówek edukacyjnych, ustala zasady kierowania działalnością dydaktyczno-wychowawczą szkół oraz opracowuje projekty aktów prawnych i koncepcje rozwoju systemu edukacji. Finansowanie kształcenia zawodowego na poziomach ISCED 2, ISCED 3 i ISCED 4 regulowane jest ustawą nr 597/2003 w sprawie finansowania szkół.

Na szczeblu lokalnym działa 8 regionalnych urzędów oświatowych. Sprawy związane z administracją na szczeblu lokalnym leżą w kompetencjach gmin. Budżetowe środki finansowe rozdzielane są przez Ministerstwo Edukacji, Nauki, Badań i Sportu z uwzględnieniem potrzeb oświatowych samorządów, szczególnych osiągnięć placówek, realizowanych projektów rozwojowych, potrzeb uczniów pochodzących z defaworyzowanych środowisk społecznych oraz potrzeb związanych z uczniami szczególnie uzdolnionymi (olimpiady przedmiotowe). Środki finansowe przyznaje się na podstawie algorytmu związanego z liczbą uczniów i sumą wydatków przeznaczaną na jednego mieszkańca gminy. Na Słowacji nie ma zbiorczego państwowego funduszu wyłącznie na kształcenie zawodowe. Długotrwałe wysiłki mające na celu przekonanie ministra finansów, aby wprowadzić ulgi podatkowe lub inne zachęty dla osób pragnących współfinansować kształcenie zawodowe zaowocowały ustanowieniem w 2010 roku niepaństwowego Funduszu na rzecz Kształcenia Zawodowego.

31 Ministerstvo školstva, vedy, výskumu a športu Slovenskej republiky, https://www.minedu. sk/statut-ministerstva-skolstva-vedy-vyskumu-a-sportu-sr/.

32 Zákon č. 596/2003 Z.z. o štátnej správe v školstve a školskej samospráve a o zmene a doplnení niektorých zákonov v znení neskorších predpisov, https://www.minedu.sk/zakon-c-5962003-zz-0-statnej-sprave-v-skolstve-a-skolskej-samosprave-a-o-zmene-a-doplneni-niektorych-zakonov-v-zneni-neskorsich-predpisov/. 


\section{Pomoc finansowa dla uczniów}

Edukacja w szkołach średnich jest bezpłatna. Rodzice i opiekunowie uczniów ponoszą część kosztów związanych z wyżywieniem w stołówkach i zakwaterowaniem w internatach lub akademikach. Rodzice i opiekunowie ucznia/studenta, który nie przekroczył 25 roku życia, mogą uzyskać zasiłek rodzinny w wysokości 23,35 euro miesięcznie na każde dziecko, jeżeli spełniają jeden z poniższych warunków:

- dziecko musi być uczniem zarejestrowanym w szkole od początku roku szkolnego,

- dziecko ukończyło realizację obowiązku szkolnego i uczęszcza do szkoły średniej lub na kurs w pełnym wymiarze czasu umożliwiający zdobycie wykształcenia ponadgimnazjalnego,

- dziecko nie może uczęszczać do placówek szkolnych z powodu choroby lub wypadku.

Zasiłki szkolne oraz stypendia przyznawane są uczniom i studentom uczącym się w trybie stacjonarnym (dziennym). Wysokość miesięcznego stypendium uzależniona jest od dochodów rodziny i średniej uzyskanych ocen. Uczniowie, których średnia ocen wynosi między bardzo dobry i dobry, otrzymują miesięcznie kwotę równą 50\% minimum socjalnego (45,21 euro). Uczniowie, których średnia ocen wynosi między dobry i dostateczny plus, otrzymują miesięcznie 35\% minimum socjalnego (31,65 euro), a uczniowie, których średnia ocen wynosi między dostateczny plus i zadowalający plus - otrzymują miesięcznie 25\% minimalnego socjalnego (22,61 euro).

Inną formą pomocy finansowej dla uczniów decydujących się na podjęcie nauki w szkolnictwie zawodowym jest stosowanie systemu motywacyjnego. Ma on zachęcić młodych ludzi do wybierania kierunku kształcenia zawodowego, w ramach którego pracodawcy przeznaczają finansowe środki stypendialne. Pracodawca fundujący stypendium podpisuje umowę ze szkołą i uczniem, co daje mu w konsekwencji stabilność zespołu pracowniczego oraz możliwość odliczenia kwoty stypendium od podatku.

\section{Bezrobocie}

Mediana stopy bezrobocia wśród absolwentów szkolnictwa średniego (ISCED 3) w okresie czerwiec 2012 roku - maj 2013 roku wynosiła 16,51\%. Przy uwzględnieniu absolwentów szkolnictwa średniego, którzy podjęli studia, stopa bezrobocia kształtowała się na poziomie 29,12\%. 


\section{Slovenská republika}

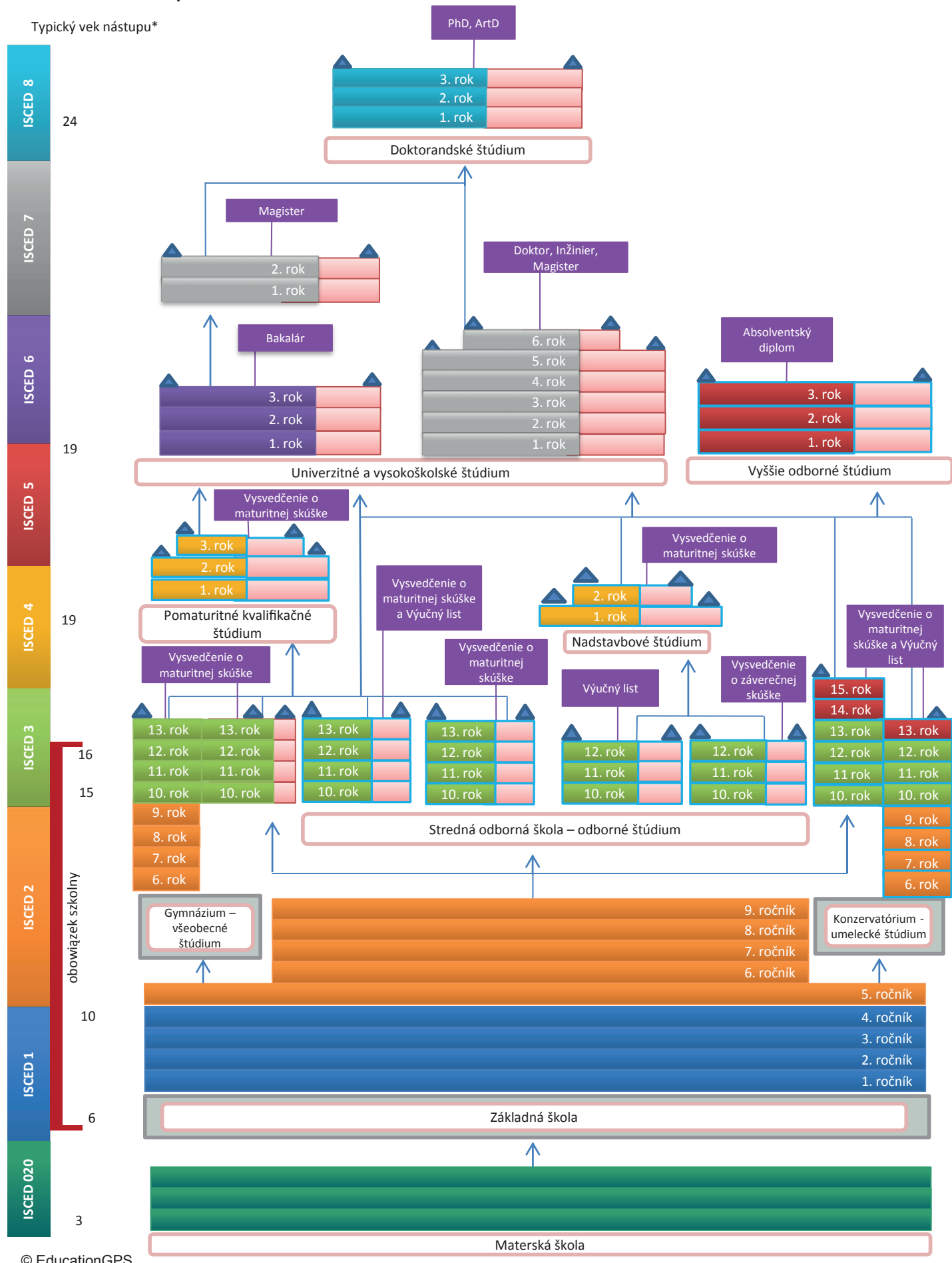




\section{Legenda (wyjaśnienie terminów użytych na rysunku)}

\section{POZIOMY EDUKACYJNE}

Mateřská škola - przedszkole

Základni škola - szkoła podstawowa

Gymnázium - všeobecné štúdium - szkoła średnia ogólnokształcąca

Stredná odborná škola - odborné štúdium - średnia szkoła techniczna (kształcenie zawodowe)

Konzervatórium - umelecké štúdium - konserwatorium (kształcenie artystyczne)

Pomaturitné kvalifikačné štúdium - studium podyplomowe

Nadstavbové štúdium - studia podyplomowe (przeznaczone dla absolwentów trzyletnich kursów zawodowych w średnich szkołach zawodowych)

Univerzitné a vysokoškolské štúdium - uniwersytet i placówki szkolnictwa wyższego

Vyššie odborné štúdium - wyższe studia zawodowe

Doktorandské štúdium - studia doktoranckie

\section{DYPLOMY}

Vysvedčenie o maturitnej skúške - świadectwo maturalne

Výučný list - świadectwo przygotowania zawodowego

Vysvedčenie o maturitnej skúške a Výučný list - świadectwo maturalne i świadectwo przygotowania zawodowego

Bakalár - licencjat

Magister - magisterium

Doktor, Inžinier, Magister - lekarz, inżynier, mistrz

PhD, ArtD - doktorat (filozofia, sztuka)

OPIS TRANSFERÓW EDUKACYJNYCH (STRZAŁKI) I OZNACZEŃ LAT NAUKI

ročník - rok nauki

rok-rok studiów 


\section{Kontynuacja studiów}

W 2013 roku odsetek absolwentów szkolnictwa średniego zawodowego podejmujących naukę na poziomie szkolnictwa wyższego wynosił 36,05\%.

\section{System szkolnictwa na Słowacji}

Nieobowiązkowe przedszkole - mateřská škola (poziom ISCED 0), obejmuje dzieci w wieku od 3 lat do 6 lat. Publiczna edukacja przedszkolna jest bezpłatna. Obowiązek szkolny na Słowacji wynosi 10 lat. Rozpoczyna się w wieku 6 lat i trwa do końca roku szkolnego, w którym uczeń kończy 16 rok życia. Kształcenie obowiązkowe jest bezpłatne. Pierwszym szczeblem obowiązkowego kształcenia jest dziewięcioletnia szkoła podstawowa - základná škola (poziom ISCED 1), podzielona na dwa etapy:

- etap pierwszy na poziomie podstawowym (klasy I-IV),

- etap drugi na poziomie szkoły średniej I stopnia (klasy V-VIII lub V-IX).

Po ukończeniu V klasy szkoły podstawowej uczniowie mogą zostać przyjęci do I klasy ośmioletniego programu kształcenia w gimnazjum - gymnázium lub do konserwatorium - konzervatórium (poziom ISCED 2). Aby zostać przyjętym do ośmioletniego gymnázium (w wieku 11 lat), uczniowie muszą ukończyć V klasę szkoły podstawowej i zdać egzamin wstępny. Chętni do gimnazjum dwujęzycznego muszą ukończyć VIII klasę szkoły podstawowej i zdać egzamin wstępny (w wieku 14 lat, nauka trwa 5 lat). Aby zostać przyjętym do ośmioletniego konzervatórium o profilu tanecznym (w wieku lat 11), uczniowie muszą ukończyć V klasę szkoły podstawowej i zdać egzamin wstępny.

W ramach szkolnictwa średniego II stopnia wyróżniamy następujące szkoły:

- gymnázium - szkoła średnia ogólnokształcąca przygotowująca do studiów wyższych. Na poziomie szkolnictwa średniego II stopnia posiada cztery klasy dla uczniów w wieku 15-19 lat,

- stredná odborná škola - średnia szkoła techniczna (drugi i wyższy rok kształcenia zawodowego na poziomie średnim II stopnia i dwa lata nauki uzupełniającej) - wiek: 15-19, 16-20 lat,

- odborné učilištia - szkoła zawodowa zapewnia program nauczania dla uczniów, którzy ukończyli szkołę podstawową w klasach niższych niż dziewiąta lub nie ukończyli dziewiątej klasy. Nauka trwa od 1 roku do 4 lat i przeznaczona jest dla uczniów w wieku 16-18 lat. Szkoła wydaje świadectwa przydatności zawodowej, 
- konzervatórium - konserwatorium (drugi i wyższy rok kształcenia artystycznego na poziomie średnim II stopnia) - wiek: 15-19 lat.

W ramach szkolnictwa policealnego znajduje się policealna średnia szkoła zawodowa (stredná odborná škola) - szkoła zawodowa po maturze, lecz nie o charakterze szkolnictwa wyższego dla uczniów w wieku: 19-21 lat.

Rekrutacja do większości szkół zawodowych prowadzona jest przez placówki zgodnie z ich wewnętrznymi zasadami. Nabór do szkół zawodowych realizowany jest także w ramach kilku projektów pilotażowych, polegających na ścisłej współpracy z Austriacką Izbą Gospodarczą i niemieckimi partnerami. Kontakt z tymi podmiotami ma na celu bezpośrednie angażowanie firm w proces rekrutacji absolwentów szkół podstawowych. Bezpośredni udział pracodawców wykorzystywany jest przede wszystkim przy naborze do tzw. kształcenia dualnego realizowanego w szkole zawodowej i u pracodawców na wskazanym stanowisku pracy.

\section{Treść i kontrola programów nauczania}

Zgodnie z ustawą o edukacji z 1 września 2008 roku programy nauczania dla I klasy szkoły podstawowej (základná škola) i dla I klasy kształcenia ogólnego na poziomie szkoły średniej I stopnia (V klasa základná škola i I klasa ośmioletniego gymnázium i konzervatórium), jak również dla I klasy kształcenia na poziomie szkoły średniej II stopnia (I klasa gymnázium, stredná odborná škola i konzervatórium) są ustalane na podstawie państwowego programu kształcenia. Cechą charakterystyczną jest wprowadzanie tzw. ścieżek międzyprzedmiotowych, dzięki którym nauczyciele mają możliwość dowolnego rozszerzania podstawowych zagadnień przedmiotowych. Ścieżki te mogą być realizowane w zakresie konkretnego przedmiotu, w formie kursu lub przedmiotu dodatkowego. Zgodność realizacji przez nauczycieli programu nauczania z wytycznymi państwowego programu kształcenia jest kontrolowana przez Państwową Inspekcję Szkolną.

\section{Ocena, promocja i kwalifikacje}

Na Słowacji stosuje się pięciopunktową skalę ocen. Uczeń, który na koniec roku szkolnego nie zaliczył więcej niż dwóch przedmiotów obowiązkowych, nie otrzymuje promocji i powtarza klasę. Uczniowie IX klasy szkoły podstawowej zdają ogólnokrajowy test (Testovanie 9) z języka ojczystego i matematyki, a uczniowie uczęszczający do szkół z wykładowym językiem mniejszości także z języka słowackiego. Wyniki testu stanowią kryterium przyjęcia do szkoły średniej. 
Uczniowie otrzymują świadectwo na koniec pierwszego semestru i na koniec każdego roku szkolnego. Na zakończenie IX klasy szkoły podstawowej (základná škola) uczeń otrzymuje świadectwo z dodatkowym dokumentem potwierdzającym ukończenie edukacji w szkole średniej I stopnia.

\section{Doradztwo zawodowe}

Zakres doradztwa zawodowego w słowackim szkolnictwie reguluje rozporządzenie Ministra Edukacji nr 43/1996. Dokument zobowiązuje szkoły m.in. do:

- prowadzenia diagnostyki edukacyjnej,

- określania przyczyn problemów uczniów w zakresie rozwoju społecznego, edukacyjnego i zawodowego,

- rozwiązywania kwestii dotyczących dalszej edukacji uczniów we współpracy z rodzicami i nauczycielami.

Rozporządzenie określa także zakres działań doradcy edukacyjnego, który w szkołach - oprócz pedagoga i psychologa - odpowiada za doradztwo zawodowe. Do zadań doradcy edukacyjnego należy:

- udzielanie porad uczniom w celu zapobiegania problemom rozwojowym,

- zapewnianie konsultacji dla uczniów i rodziców w celu rozwiązywania problemów edukacyjnych i szkoleniowych,

- udzielanie informacji w zakresie wyboru i planowania kariery zawodowej,

- systematyczne monitorowanie rozwoju uczniów,

- ścisła współpraca z poradniami pedagogiczno-psychologicznymi w zakresie planowania kariery edukacyjno-zawodowej,

- wsparcie metodyczne dla nauczycieli danej szkoły w zakresie doradztwa zawodowego,

- prowadzenie doradztwa dla uczniów i rodziców,

- zapewnienie pomocy w rozwiązywaniu problemów osobistych, społecznych i edukacyjnych,

- monitorowanie edukacyjnych problemów uczniów,

- realizacja ukierunkowanych działań profilaktycznych adresowanych do uczniów i rodziców (dyskusje grupowe i konferencje na aktualne tematy dotyczące nauczania i uczenia się, zachowań i relacji międzyludzkich, porady w zakresie profilaktyki uzależnień i innych patologii społecznych),

- monitorowanie i rejestrowanie zainteresowań uczniów co do dalszych studiów i ścieżki zawodowej, 
- aktywne uczestnictwo w warsztatach, seminariach i szkoleniach organizowanych dla doradców edukacyjnych,

- zamieszczanie informacji z zakresu doradztwa edukacyjnego na tablicy ogłoszeń i stronie internetowej szkoły.

Doradcami edukacyjnymi są często nauczyciele, którzy odbyli specjalistyczny kurs doradztwa zawodowego. Obowiązki z zakresu doradztwa zawodowego wykonują w ramach swojego pensum nauczycielskiego. Nauczyciel doradca może odliczyć liczbę godzin pracy przeznaczoną na doradztwo edukacyjne od swojego pensum dydaktycznego, co w efekcie powoduje zmniejszenie liczby godzin pracy „pod tablicą”. Każdy doradca edukacyjny przygotowuje plan pracy na dany rok szkolny, w którym określa szczegółowo miesięczne plany i cele. Muszą one być zgodne z głównymi zadaniami szkoły.

Kolejnym elementem doradztwa zawodowego realizowanego w słowackim systemie szkolnym jest wprowadzenie do programów nauczania opcjonalnego przedmiotu wprowadzenie do świata pracy (Úvod do sveta práce), na który można uczęszczać w ostatnich dwóch latach nauki w szkołach średnich II stopnia. Główne cele nauczania tego przedmiotu to:

- uzyskanie podstawowych informacji na temat kariery w różnych dziedzinach: zarządzania, rolnictwa, produkcji, leśnictwa, zdrowia, handlu, gastronomii, budownictwa,

- poznanie charakteru i warunków pracy,

- zapoznanie uczniów z potrzebnymi kwalifikacjami i niezbędnymi szkoleniami dla każdego zawodu.

W ramach realizacji wyżej wymienionego przedmiotu uczniowie mają również możliwość rozmowy i dyskusji na temat ich zdolności do pracy, realistycznej oceny własnych umiejętności. Uczą się opracowania planu własnej kariery zawodowej oraz nabywają podstawowe umiejętności zachowania się podczas rozmowy kwalifikacyjnej.

Innym ogniwem doradztwa zawodowego realizowanego na Słowacji są poradnie psychologiczno-pedagogiczne (školská pedagogicko-psychologická poradna). Głównym zadaniem tych placówek jest diagnozowanie uczniów pod kątem planowania ich ścieżki edukacyjno-zawodowej. Poradnie współpracują w obszarze doradztwa zawodowego zarówno z uczniami, jak i rodzicami oraz doradcami edukacyjnymi. Poradnie pedagogiczno-psychologiczne służą również jako baza informacji na temat lokalnego i krajowego rynku pracy, wykazu zawodów, szkół i uczelni. 


\section{Wielka Brytania}

Struktura organizacyjna systemu szkolnego Wielkiej Brytanii nie jest jednolita. Struktury oświatowe Anglii i Walii są relatywnie podobne, natomiast systemy szkolne Szkocji i Irlandii Północnej wymagają oddzielnego omówienia, gdyż są regulowane odrębnymi ustawami i decyzjami władz lokalnych. Występują w nich inne typy szkół, inne programy i odmienne organizacje pracy szkolnej.

Anglia

Administracja i finansowanie edukacji

\section{Szczebel krajowy}

W Anglii za organizację oświaty odpowiadają Ministerstwo Edukacji (Department for Education, DfE) oraz Ministerstwo ds. Biznesu, Innowacji i Umiejętności (Department for Business, Innovation and Skills, BIS). Do zadań DfE należą: planowanie i monitorowanie organizacji edukacji w szkołach, zapewnianie zintegrowanych usług dla najmłodszych oraz koordynacja polityki dotyczącej dzieci i młodzieży. Natomiast BIS jest odpowiedzialne za kształcenie i innowacje, umiejętności, further education, szkolnictwo wyższe i działalność gospodarczą. Urząd ds. Standardów Kształcenia, Usług na rzecz Dzieci i Umiejętności (Office for Standards in Education, Children's Services and Skills, Ofsted) jest pozaresortową instytucją odpowiedzialną za kontrolowanie, w jaki sposób jest realizowana opieka dzienna i społeczna nad dziećmi. Ponadto Ofsted prowadzi także kontrolę usług na rzecz dzieci, szkół, kolegiów oraz monitoruje kształcenie nauczycieli, realizację inicjatyw młodzieżowych, kształcenie w miejscu pracy i edukację dorosłych. W ramach szkolnictwa wyższego instytucją zajmującą się kontrolą jakości kształcenia jest Agencja ds. Zapewnienia Jakości w Szkolnictwie Wyższym (Quality Assurance Agency for Higher Education, QAA). Agencja jest instytucją niezależną od władz oświatowych Zjednoczonego Królestwa powołaną przez dyrektorów placówek szkolnictwa wyższego.

Finansowanie placówek szkolnych odbywa się głównie ze środków publicznych. Są one przeznaczane na tzw. szkoły dotowane (maintained schools) oraz akademie (academies). Wśród placówek niedotowanych znajdują się szkoły prywatne lub niezależne. Według danych opublikowanych w styczniu 2011 roku $^{33}$

33 Schools, Pupils and their Characteristics, Department for Education, January 2011. 
w Anglii do maintained schools uczęszczało 91\% populacji uczniów, 4\% do academies, a 5\% do niedotowanych szkół niezależnych.

\section{Szczebel lokalny}

Na szczeblu lokalnym szkoły finansowane ze środków publicznych podlegają kontroli ponad 150 różnych organów władz lokalnych. Ich zadaniem jest utrzymanie wysokiego poziomu edukacji i zapewnienie oferty szkoleń zawodowych zgodnych z aktualnym zapotrzebowaniem rynku pracy.

Władze lokalne rozdzielają dotacje rządowe, stosując własny algorytm podziału funduszy. Finansowaniu podlegają maintained schools, placówki wczesnoszkolne (kształcenie trzylatków oraz czterolatków) - włącznie z placówkami prywatnymi i społecznymi. Z puli dotacji rządowych nie są finansowane academies ani kształcenie i szkolenia dla szesnasto-, dziewiętnastolatków.

Od 2005 roku, zgodnie z narodowym programem „Liczy się każde dziecko” (Every Child Matters $)^{34}$, władze lokalne mają obowiązek mianować Dyrektora ds. Usług na rzecz Dzieci (Director of Children's Service, DCS), który bezpośrednio odpowiedzialny jest za edukację i pomoc socjalną przeznaczoną dla dzieci. Ponadto obowiązkiem DCS jest podnoszenie jakości kształcenia w placówkach przez zabieganie o zapewnianie odpowiedniego poziomu usług edukacyjnych świadczonych przez władze lokalne.

\section{Szczebel placówki szkolnej}

Wszystkie szkoły mają szeroką autonomię w ramach własnej organizacji pracy, lecz w dużej mierze zależy ona od podmiotu założycielskiego. Podmiot założycielski i prowadzący szkołę ma obowiązek powołać do współpracy ciało, w którego skład wchodzą przedstawiciele różnych grup społecznych korzystających z placówki. W zależności od podmiotu założycielskiego lokalne szkoły podstawowe i średnie dzielą się na szkoły gminne (community schools) - zakładane przez gminę, szkoły społeczne (voluntary schools) - zakładane przez towarzystwa społeczne, oraz szkoły fundacyjne (foundation schools) - zakładane przez fundacje. Zdecydowaną większość placówek stanowią szkoły gminne, które są zakładane i w całości finansowane przez władze lokalne. Szkoły społeczne były pierwotnie zakładane przez organizacje i instytucje społeczne, głównie kościoły,

34 http://webarchive.nationalarchives.gov.uk/20130401151715/https://www.education.gov.uk/ publications/eOrderingDownload/ECM-Summary.pdf. 
które zachowały pewną kontrolę nad ich zarządzaniem, jednakże obecnie finansowane są przez władze lokalne, a zarządzanie nimi pozostało w rękach organu prowadzącego, np. fundacji charytatywnej. Szkoły fundacyjne powstają w wyniku utworzenia funduszu charytatywnego wraz z partnerem zewnętrznym, np. z firmą lub organizacją dobroczynną.

\section{Pomoc finansowa dla uczniów}

W szkołach średnich edukacja uczniów powyżej 16 roku życia jest płatna. Ucząca się młodzież w wieku 16-19 lat pochodząca z rodzin oscylujących na poziomie minimum socjalnego może stać się beneficjentem rządowego wsparcia dla uczącej się młodzieży tzw. 16-19 Bursary Fund. Fundusz stypendialny składa się z dwóch obszarów:

Vulnerable bursaries - skierowany do uczniów, którzy potrzebują wsparcia finansowego, wychowawczego, wychowywali się poza środowiskiem rodzinnym, posiadają dysfunkcje utrudniające uczestnictwo w procesie edukacyjnym. Kwota stypendium wynosi do 1200 funtów rocznie,

Discretionary bursaries - stypendia o charakterze uznaniowym skierowane są do tych wszystkich uczniów, którzy nie mogą kontynuować edukacji z powodu braku możliwości finansowych, np. na opłacenie biletów na transport z domu do szkoły, zakup posiłków, książek i pomocy szkolnych. Źródła i wysokość finansowania zależą od typu szkoły, jej budżetu i instytucji wspierającej finansowo placówkę.

\section{Bezrobocie}

W Wielkiej Brytanii na przełomie 2013/2014 roku stopa bezrobocia wśród osób w wieku produkcyjnym od 16 do 64 roku życia wynosiła 6,8\%35. Dla grupy wiekowej 18-24 rok życia stopa bezrobocia wyniosła $16,9 \%{ }^{36}$.

\section{Kontynuacja studiów}

W 2011 roku w różnych typach nieobowiązkowego szkolnictwa średniego i wyższego (poziom ISCED 3, ISCED 4 i ISCED 5 i 6) zarejestrowanych było 62\% uczącej

35 http://www.ons.gov.uk/ons/rel/lms/labour-market-statistics/april-2014/statistical-bulletin. html.

36 http://www.parliament.uk/business/publications/research/briefing-papers/SN05871/youth-unemployment-statistics. 
się młodzieży. Z tej grupy uczniów i studentów do szkół zawodowych (further education college) przeznaczonych dla uczniów powyżej 16 roku życia uczęszczało 8\% uczniów. 3\% uczniów uczęszczało do szkół średnich prowadzących do uzyskania odpowiednika matury (A-level). 3\% młodzieży uczyło się w placówkach przysposobienia zawodowego lub realizowało praktykę zawodową $\mathrm{w}$ zakładzie pracy, a naukę na poziomie szkolnictwa wyższego realizowało $48 \%{ }^{37}$.

\section{System szkolnictwa w Anglii i Walii}

Ustawa o strukturze i standardach w szkolnictwie z 1998 r. (School Standards and Framework Act 1998) ${ }^{38}$ definiuje edukację przedszkolną jako kształcenie w pełnym lub niepełnym wymiarze godzin przeznaczone dla dzieci, które nie osiągnęły jeszcze wieku obowiązku szkolnego (co następuje podczas pierwszego semestru po piątych urodzinach dziecka), prowadzone zwykle w przedszkolach, klasach przedszkolnych, szkołach podstawowych lub innych placówkach edukacyjnych.

Opiekę nad dziećmi w wieku od 3 miesięcy do 3 lat zapewnia się głównie w sektorze placówek prywatnych i społecznych. Koszty opieki ponoszą rodzice. Jednakże dzieciom z rodzin o najniższych zarobkach i będącym w trudnej sytuacji ekonomicznej zapewnia się dostęp do 10-15 godzin bezpłatnej opieki tygodniowo. Dzieci powyżej trzeciego i czwartego roku życia mają zapewnione bezpłatnie zajęcia przedszkolne. Zajęcia organizowane są $\mathrm{w}$ dotowanych przedszkolach, w klasach przedszkolnych organizowanych w gminnych oraz w społecznych lub prywatnych szkołach podstawowych. Dzieci mogą uczęszczać na zajęcia w wymiarze 15 godzin zajęć tygodniowo przez 38 tygodni w roku.

\section{Szkoła obowiązkowa}

Obowiązek szkolny w Anglii (Szkocji i Walii) wynosi 11 lat. Rozpoczyna się w wieku 5 lat i trwa do końca roku szkolnego, w którym uczeń kończy 16 rok życia. Należy zwrócić uwagę, że w Anglii istnieje możliwość posłania dziecka do szkoły już w wieku 4 lat - na co decyduje się wielu rodziców. Kształcenie obowiązkowe jest bezpłatne.

37 https://www.gov.uk/government/uploads/system/uploads/attachment_data/file/207749/ Main_text_-_SFR19_2013.pdf.

38 http://www.legislation.gov.uk/ukpga/1998/31/contents. 
Szkoła obowiązkowa obejmuje następujące szczeble kształcenia:

\begin{tabular}{|l|c|}
\hline \multicolumn{1}{|c|}{ Nazwa szkoły } & Wiek uczniów \\
\hline Primary school (szkoła podstawowa) - ISCED 1 & 5-11 lat \\
\hline Secondary school (szkoła średnia I stopnia) - ISCED 2 & 11-16 lat \\
\hline
\end{tabular}

Większość uczniów przechodzi ze szkoły podstawowej (primary school) do szkoły średniej I stopnia (secondary school) w wieku 11 lat, choć w niektórych regionach Anglii uczniowie uczęszczają do szkoły średniej I stopnia w wieku, odpowiednio, od 8 lub 9 roku życia do 12 lub 13 roku życia. Wiele szkół średnich prowadzi również kształcenie na poziomie ponadobowiązkowym dla uczniów w wieku od 16 lat do 18 lat i powyżej.

Programy nauczania opracowywane są indywidualnie przez poszczególne placówki w sposób odzwierciedlający specyfikę ich potrzeb i warunków działania. Jednakże szkoły zobowiązane są zadbać o to, by program był odpowiednio zrównoważony i opierał się na szerokiej podstawie tematycznej. Jednolite wymagania dotyczące nauczania określonych przedmiotów obowiązują wszystkie szkoły finansowane ze środków publicznych, włącznie ze szkołami stosującymi system selekcji uczniów.

Program kształcenia obowiązkowego jest podzielony na cztery tzw. kluczowe etapy, czyli KS (key stages): KS1 (wiek: 5-7 lat), KS2 (7-11 lat), KS3 (11-14 lat), KS4 (14-16 lat). Obowiązkowymi przedmiotami krajowego programu nauczania na etapach KS1-KS3 są m.in.: język angielski, język obcy, matematyka, przedmioty ścisłe i przyrodnicze, projektowanie i technika, technologie informacyjno-komunikacyjne, historia, geografia, wychowanie plastyczne i projektowanie, muzyka oraz wychowanie fizyczne. Na etapie KS4 liczba przedmiotów obowiązkowych jest mniejsza, są to: język angielski, matematyka, nauki ścisłe i przyrodnicze, technologie informacyjno-komunikacyjne, wychowanie obywatelskie i wychowanie fizyczne. Dodatkowo przepisy wyznaczają tzw. obszary tematyczne - curriculum entitlement areas (CEA), czyli cztery dziedziny wiedzy, w ramach których szkoły zobowiązane są organizować zajęcia. Wśród dziedzin znalazły się: sztuka, projektowanie i technologie, przedmioty humanistyczne, nowożytne języki obce. Szkoły zobowiązane są organizować zajęcia w zakresie co najmniej jednego cyklu w każdym z czterech curriculum entitlement areas.

Istnieją również inne przedmioty obowiązkowe, które nie wchodzą jednak w zakres krajowego ramowego programu nauczania: religioznawstwo - na etapach KS1-KS4, oraz wychowanie seksualne i orientacja zawodowa - na etapach 
KS3-KS4. Prowadzenie kształcenia na potrzeby rynku pracy jest wymagane na poziomie KS4. Przedmiot zatytułowany „Rozwój indywidualny, przygotowanie do życia w społeczeństwie, ekonomia i edukacja zdrowotna” (Personal, social, health and economic, PSHE) nie jest wprawdzie obowiązkowy w Anglii, ale od szkół oczekuje się prowadzenia zajęć w ramach wyżej wymienionych zagadnień na wszystkich etapach nauczania.

W Anglii w programach nauczania nie określa się liczby godzin, jaką należy przeznaczyć na poszczególne przedmioty oraz nie wydaje się ogólnych zaleceń ani w sprawie metodyki nauczania, ani w sprawie materiałów dydaktycznych.

Szkoły i nauczyciele ponoszą całkowitą odpowiedzialność za wybór metod nauczania i materiałów dydaktycznych. Podręczniki wydawane są przez wydawców komercyjnych i nie wymagają zatwierdzenia przez władze odpowiedzialne za edukację ${ }^{39}$.

\section{Ocena, promocja i kwalifikacje}

W Anglii zgodnie z przepisami uczeń podlega pierwszej obowiązkowej ocenie w I klasie primary school i przed zakończeniem kluczowych etapów KS1, KS2 i KS3. Obejmuje ona ocenę dokonywaną przez nauczycieli oraz - w niektórych przypadkach - sprawdziany przeprowadzane i oceniane przez instytucje zewnętrzne lub weryfikowane przez te instytucje pod kątem jednolitego stosowania zasad oceniania.

\section{Szkolnictwo średnie II stopnia (ISCED 3) i policealne (ISCED 4)}

W wieku 16 lat, po ukończeniu etapu KS4 uczniowie mogą przystąpić do nieobowiązkowego egzaminu kończącego obowiązkową szkołę średnią I stopnia (General Certificate of Secondary Education, GCSE). Po skończeniu szkoły średniej I stopnia mogą kontynuować edukację w pełnym wymiarze w szkole lub college’u oferującym naukę do 19 roku życia. Istnieje też możliwość kontynuowania nauki w połączeniu z podjęciem pracy i szkoleniem zawodowym. Uzyskane w wyniku nauki kwalifikacje będą zależały od wyboru typu szkoły oraz rodzaju dalszej edukacji.

39 D. Dziewulak, Finansowanie zakupu podręczników szkolnych $w$ wybranych państwach, „Analizy BAS” 2014, nr 4(108), http://orka.sejm.gov.pl/WydBAS.nsf/0/3E00B159E453662DC1257CA0002BC1A7/\$file/Analiza_BAS_2014_108.pdf. 
Kształcenie ponadobowiązkowe jest bezpłatne do ukończenia 19 roku życia. Uczeń może wybierać spośród następujących placówek:

- school's sixth form,

- sixth form college,

- further education college,

- specialist colleges.

School's sixth form - placówka edukacyjna, która oferuje naukę po ukończeniu 16 roku życia w dotychczasowej szkole średniej I stopnia, lecz w kierunku A-level ${ }^{40}$. Pozostanie w tym samym, dobrze znanym środowisku szkolnym może stanowić znaczne ułatwienie dla uczniów, może jednak wiązać się z ograniczeniem w zakresie oferowanych przedmiotów, zwykle mniejszym niż w sixth form colleges. Inna jest także atmosfera i sposób pracy z uczniami, będące kontynuacją programu i metod realizowanych we wcześniejszych latach nauki.

Sixth form college - placówka edukacyjna, która oferuje naukę po ukończeniu 16 roku życia w kierunku A-level, w kierunkach zawodowych oraz prowadzących do kwalifikacji zawodowych. Uczniowie studenci uczą się w zdecydowanie bardziej samodzielny sposób, co stanowi doskonałe przygotowanie do edukacji na poziomie wyższym. Zakres i liczba oferowanych przedmiotów jest znacznie bogatsza niż w placówkach school's sixth form, co w połączeniu z szerszymi możliwościami uzyskiwanych kwalifikacji daje studentom znacznie większą swobodę w kształtowaniu profilu wykształcenia.

Further education college - placówka edukacyjna, która głównie oferuje kształcenie zawodowe dla uczniów po ukończeniu 16 roku życia, w pełnym i nie-

40 A-level, tak w skrócie określa się dyplom General Certificate of Education Advanced Level, który można uzyskać, obierając ścieżkę edukacyjną niezbędną do rozpoczęcia nauki na szczeblu szkoły wyższej. Egzaminy A-level są odpowiednikiem polskiej matury. Przygotowanie do nich trwa dwa lata, zwykle w wieku 16-19 lat. Nauka odbywa się często w specjalistycznych placówkach. Pierwszy rok w takich szkołach nazywa się lower sixth i odpowiada II klasie szkoły średniej, a drugi - upper sixth, który z kolei odpowiada klasie maturalnej. Uczniowie przystępują do egzaminów pod koniec pierwszego roku i ponownie pod koniec drugiego. Mogą wybrać od 2 do 4 przedmiotów egzaminacyjnych, pod warunkiem że uzyskali już GCSE z tych przedmiotów (z wyjątkiem niektórych przedmiotów nieoferowanych na poziomie GCSE, jak np. prawo). W wyniku egzaminu uzyskują stopnie w skali od A (najwyższy) do U (najniższy), które określają poziom zdanych egzaminów. Uzyskanie dobrych wyników z egzaminów A-level jest szczególnie ważne, gdyż to one decydują o zakwalifikowaniu się na studia. Inną ścieżką edukacyjną jest uzyskanie dyplomu AS-level (Advanced Subsidiary). W tym wypadku na egzaminach wymagana jest wiedza z połowy zakresu wybranego przedmiotu, przy czym dwa AS-level stanowią odpowiednik jednego stopnia A-level. Wybór opcji AS-level pozwala na opóźnienie decyzji w wyborze ścisłej specjalizacji. 
pełnym wymiarze czasowym oraz dla osób dorosłych. W zakresie oferowanego kształcenia znajdują się takie dziedziny, jak: handel, przemysł, rolnictwo itp. Placówki wyróżniające się wysokimi standardami i wynikami nauczania mogą uzyskać tzw. status beacon. Beacon colleges uznawane są jako centra doskonalenia zawodowego (Centres of Vocational Excellence, CoVEs). W niektórych regionach Wielkiej Brytanii further education college stanowią główną lub nawet jedyną propozycję kontynuowania edukacji po 16 roku życia. Część placówek z powodzeniem oferuje wykształcenie odpowiadające poziomowi sixth form.

Specialist college - placówka edukacyjna typu further education college, lecz wyspecjalizowana w wybranej dziedzinie lub przystosowana do potrzeb uczniów niepełnosprawnych lub z problemami w przyswajaniu wiedzy.

Szkoły średnie school's sixth form, sixth form colleges prowadzą kształcenie ogólne, oferując również przedmioty zawodowe. Placówki further education colleges prowadzą głównie kształcenie zawodowe, choć wiele z nich prowadzi także kształcenie ogólne, a w tertiary colleges prowadzi się zarówno kształcenie ogólne, jak i zawodowe. Istnieje też możliwość kontynuowania nauki w połączeniu z podjęciem pracy i szkoleniem zawodowym. Uzyskane w wyniku nauki kwalifikacje będą zależały od wyboru typu szkoły oraz rodzaju dalszej edukacji.

Kryteria przyjęć

Warunki przyjęć są ustalane przez poszczególne szkoły i colleges. Uczniowie mogą ubiegać się o przyjęcie do każdej instytucji. Na tym poziomie kształcenia nie ma treści obowiązkowych. Uczniowie/słuchacze wybierają cykl kształcenia z oferty szkoły lub placówki further education zależnie od kwalifikacji, jakie zamierzają uzyskać. Nauczyciele samodzielnie wybierają odpowiednie metody kształcenia i materiały dydaktyczne.

\section{Dyplomy, uprawnienia i kwalifikacje}

Oprócz wcześniej omawianego nieobowiązkowego egzaminu i dyplomu GCSE znacznie zwiększającego możliwości dalszej edukacji w kierunku egzaminów A-level lub AS-level, można wyróżnić inne dyplomy potwierdzające kwalifikacje zawodowe uczniów, np.:

- AS/A Level - Vocational A-level,

- VCEs - Advanced extension awards,

- NVQ - krajowe kwalifikacje zawodowe, 
- HNC - krajowy certyfikat kształcenia wyższego,

- HND - krajowy dyplom kształcenia wyższego.

Dyplomy AS/A-Level - Vocational A-Level i VCEs - Advanced extension awards otwierają drogę do edukacji na poziomie szkolnictwa wyższego. Nauka w kierunku A-level daje ogromne możliwości wyboru zakresu i rodzaju przedmiotów przez połączenie programów o wyższym poziomie zaawansowania. Możliwy jest także dobór przedmiotów zawodowych w ramach kształcenia zawodowego Vocational A-level, VCEs. Uczeń ma do wyboru 14 przedmiotów z zakresu nauki, informatyki, inżynierii, opieki zdrowotnej i socjalnej, turystyki i wypoczynku, sztuk pięknych, wzornictwa i projektowania. W profilu Advanced Extension Awards oferuje się 17 przedmiotów, ale chcąc wybrać tę ścieżkę kształcenia kandydat musi wykazać się bardzo dobrymi wynikami na wcześniejszych szczeblach nauczania.

Krajowe kwalifikacje zawodowe (National Vocational Qualification, NVQ) uzyskuje się podczas szkolenia zawodowego w miejscu pracy. Kwalifikacje określane według krajowych standardów zawodowych można uzyskać w każdym wieku i na dowolnym etapie edukacji. NVQ dzieli się na pięć szczebli zaawansowania, od szczebla podstawowego (foundation) do najwyższego profesjonalnego poziomu zarządzania (chartered, professional and senior management).

Krajowy wyższy certyfikat (Higher National Certificate, HNC) oraz krajowy wyższy dyplom (Higher National Diploma, HND), które to dokumenty potwierdzają kwalifikacje zdobyte w wyniku rocznej lub dwuletniej nauki na poziomie szkolnictwa wyższego oraz umożliwiają kontynuowanie nauki w uczelni wyższej przez następne dwa lata w przypadku HNC, i przez rok w przypadku HND.

\section{Kształcenie zawodowe w Anglii realizowane w szkole}

W Anglii kształcenie zawodowe może być prowadzone przez różne podmioty, takie jak: Krajowy System Oświatowy, instytucje edukacyjne (np. Centrum Doskonalenia Zawodowego, tzw. CoVE - Centres of Vocational Excellence), autonomiczne instytuty zawodowe, firmy szkoleniowe, indywidualnych pracodawców itp. Kształcenie i szkolenie zawodowe organizowane jest w dwóch formach, jako: - kursy zawodowe prowadzące do uzyskania kwalifikacji zawodowych realizowane w kolegiach typu further education college,

- kursy czeladnicze (apprenticeships).

Kursy zawodowe oferowane są głównie na poziomie szkoły średniej II stopnia, choć elementy przygotowania do pracy (work-related subjects) muszą być obowiązkowo zawarte w programie szkoły przeznaczonej dla uczniów w wie- 
ku 14-16 lat na 4 etapie edukacji, czyli KS4. Po ukończeniu KS4 (poziom szkoły średniej I stopnia) większość uczniów ubiega się o General Certificate of Secondary Education (GCSE) z kilku wybranych przedmiotów. Wśród nich mogą znaleźć się także przedmioty zawodowe/praktyczne. Egzamin jest oceniany zewnętrznie. Zdany egzamin uprawnia do ubiegania się o miejsce w placówkach edukacyjnych na poziomie ponadobowiązkowym lub do podjęcia zatrudnienia.

Na poziomie szkoły średniej II stopnia przedmioty zawodowe są oferowane przez różne typy instytucji edukacyjnych: w szkołach ogólnokształcących tzw. sixth form colleges, oprócz przedmiotów ogólnokształcących uczy się również przedmiotów praktycznych/zawodowych. W Anglii placówki szkolne, w których większy nacisk kładzie się na kształcenie zawodowe to further education college i tertiary college, chociaż w tych typach szkół są także oferowane przedmioty ogólne. W szkołach tych można uzyskać następujące świadectwa i dyplomy:

- General Certificate of Education Advanced level examination (GCE A-levels),

- Advanced Subsidiary level examination (GSE AS-level),

- GSE A-levels z przedmiotów zawodowych.

Uzyskane świadectwa i dyplomy z przedmiotów zawodowych oraz liczba punktów zdobyta w trakcie egzaminów mają taką samą wartość jak punkty z innych przedmiotów ogólnokształcących, co stanowi podstawę na przykład przy rekrutacji na studia wyższe.

Najpopularniejsze dziedziny kształcenia zawodowego to:

- sztuka i wzornictwo,

- biznes,

- technologia informacyjna,

- nauka,

- inżynieria (engineering),

- zdrowie i pomoc społeczna,

- rekreacja i czas wolny

- media: komunikacja i produkcja,

- sztuki sceniczne,

- podróże i turystyka.

W Anglii szkolnictwo zawodowe na poziomie szkoły średniej II stopnia (poziom ponadobowiązkowy) realizowane jest najczęściej w kolegiach typu further education colleges. W placówkach tych można uzyskać jeden z najbardziej popularnych dyplomów, tzw. kwalifikację zawodową BTEC (Business \& Technology Education Council). Kwalifikacje tego typu można zdobyć równolegle lub zamiast świadectw GCSEs oraz A-levels. Uzyskanie BTEC pozwala na podjęcie pracy lub kontynuację 
nauki w trybie edukacji dorosłych (typu further) lub w instytucjach szkolnictwa wyższego. Kwalifikacje zawodowe BTEC związane są najczęściej z następującymi dziedzinami zawodowymi: praca z dziećmi i młodzieżą, budownictwo, kosmetyka, usługi hotelarskie i gastronomiczne, podróże i turystyka, usługi dla ludności.

W ramach kwalifikacji zawodowych BTEC można uzyskać różne stopnie specjalnościowe. Należą do nich:

- BTEC Introductory (BTEC kwalifikacja wstępna) - stanowią część kształcenia typu Foundation Learning przeznaczonego dla słuchaczy, którzy nie przystępują do egzaminów dających świadectwo ukończenia szkoły średniej General Certificate of Secondary Education (GCSE) lub innych uprawnień z tego poziomu edukacji,

- BTEC First Diploma (BTEC kwalifikacja pierwsza) - odpowiednik General Certificate of Secondary Education. Kwalifikacje te mogą być uzyskiwane przez uczniów równolegle ze świadectwem GCSE w ramach szkolnictwa obowiązkowego lub ponadobowiązkowego,

- BTEC National Qualification (BTEC kwalifikacja krajowa) - odpowiednik dyplomu General Certificate of Education Advanced level examination GCE A-levels (poziom szkoły średniej II stopnia) przeznaczony dla uczniów w wieku 16+ i polecana w szczególności uczniom z dobrymi wynikami z egzaminu GCSE oraz tym, którzy już uzyskali BTEC kwalifikację pierwszą.

- BTEC Higher National Certificates and Diplomas (BTEC świadectwa i dyplomy krajowe szkolnictwa wyższego) - kwalifikacje uzyskiwane w ramach szkolnictwa wyższego.

Kształcenie zawodowe w Anglii - szkolenie w ramach praktyk zawodowych, szkolenie w miejscu pracy

Szkolenie w ramach praktyk zawodowych obejmuje programy szkoleniowe w miejscu pracy zaprojektowane specjalnie pod kątem potrzeb rynku pracy i pracodawców. Szkolenia tego typu są otwarte dla kandydatów w wieku 16+ i odbywają się w niepełnym wymiarze. Wszystkie programy tych szkoleń muszą zawierać następujące elementy:

- prezentacja kompetencji/umiejętności w danej dziedzinie, zawodzie czy rodzaju działalności gospodarczej,

- opis umiejętności technicznych, rozumienia koncepcji teoretycznych oraz wiedzy dotyczącej danej gałęzi przemysłu i związanego z nią rynku oraz rodzaju działalności gospodarczej, 
- przedstawienie kluczowych umiejętności (np. praca zespołowa, rozwiązywanie problemów, komunikacja czy korzystanie z nowych technologii) lub umiejętności funkcjonalnych, takich jak matematyka czy język ojczysty.

Praktyki zawodowe oferowane są na trzech poziomach w zależności od poziomu kwalifikacji: średniozaawansowanym, zaawansowanym i wyższym. Za organizację praktyk zawodowych odpowiedzialne jest Krajowe Biuro Praktyk Zawodowych (The National Apprenticeship Service). Od kwietnia 2011 roku wszystkie programy muszą być zgodne $\mathrm{z}$ angielskim standardami (Specification of Apprenticeship Standards for England, SASE) ${ }^{41}$. Wśród najistotniejszych elementów znalazły się następujące zagadnienia:

- programy praktyk muszą zapewnić wysoką jakość szkoleń, prowadzić do uzyskania kwalifikacji uznawanych w Anglii i odpowiadających danej umiejętności czy zawodowi, zarówno z punktu widzenia pracownika jak i szkolącego go pracodawcy,

- każdy praktykant powinien zrealizować rocznie przynajmniej 280 godzin nauki pod nadzorem opiekuna (guided learning). Nauka pod nadzorem jest definiowana jako czas, podczas którego pracownicy danej firmy są obecni w celu zapewnienia specjalnego wsparcia dla uczącego się czeladnika. Wsparcie obejmuje wykłady, zajęcia praktyczne z opiekunem oraz naukę pod opieką doświadczonego pracownika,

- praktykanci w wieku od 16 do 18 lat, którzy nie uzyskali jeszcze świadectwa GCSE z oceną C (i wyżej) z języka ojczystego i matematyki, powinni uzyskać taką możliwość podczas trwania szkolenia.

\section{Szkocja}

\section{Administracja i finansowanie edukacji}

W Szkocji za organizację oświaty i rozwój usług edukacyjnych odpowiada Ministerstwo Edukacji Rządu Szkockiego (Scottish Government's Directorate General of Education $)^{42}$. W ramach ministerstwa nadzór nad oświatą sprawują: Minister ds. Edukacji i Kształcenia Ustawicznego (Secretary for Education and Lifelong Learning), Sekretarz Stanu ds. Kształcenia, Nauki i Języków Szkocji (Minister for

\footnotetext{
41 http://www.apprenticeships.org.uk/About-Us/ /media/Documents/SASE/11-521-Specification-of-apprenticeship-standards-for-england.ashx.

42 http://scotland.gov.uk/About/People/Directorates.
} 
Rysunek 14. Porównanie systemów szkolnictwa Anglii, Walii, Irlandii Płn. i Szkocji

\begin{tabular}{|c|c|c|c|c|c|c|}
\hline Wiek & \multicolumn{2}{|c|}{ Anglia i Walia } & \multicolumn{2}{|c|}{ Irlandia Północna } & \multicolumn{2}{|c|}{ Szkocja } \\
\hline 17-18 & \multicolumn{2}{|c|}{ rok 13} & \multicolumn{2}{|c|}{ rok 14} & \multicolumn{2}{|c|}{ S6 } \\
\hline $16-17$ & \multicolumn{2}{|c|}{ rok 12} & \multicolumn{2}{|c|}{ rok 13} & \multicolumn{2}{|c|}{ S5 } \\
\hline \multicolumn{7}{|c|}{ koniec obowiązku szkolnego } \\
\hline $15-16$ & \multicolumn{2}{|c|}{ rok 11} & \multicolumn{2}{|c|}{ rok 12} & \multicolumn{2}{|c|}{ S4 } \\
\hline $14-15$ & rok 10 & $\begin{array}{c}\text { czwarty } \\
\text { etap kluczowy }\end{array}$ & rok 11 & $\begin{array}{c}\text { czwarty } \\
\text { etap kluczowy }\end{array}$ & \multicolumn{2}{|c|}{ S3 } \\
\hline $13-14$ & \multicolumn{2}{|c|}{ rok 9} & \multicolumn{2}{|c|}{ rok 10} & \multicolumn{2}{|c|}{$\mathrm{S} 2$} \\
\hline $12-13$ & \multicolumn{2}{|c|}{ rok 8} & \multicolumn{2}{|c|}{ rok 9} & $\mathrm{~S} 1$ & drugi \\
\hline $11-12$ & rok 7 & $\begin{array}{c}\text { trzeci } \\
\text { etap kluczowy }\end{array}$ & rok 8 & $\begin{array}{c}\text { trzeci } \\
\text { etap kluczowy }\end{array}$ & & \\
\hline $10-11$ & \multicolumn{2}{|c|}{ rok 6} & \multicolumn{2}{|c|}{ rok 7} & \multicolumn{2}{|c|}{ P6 } \\
\hline $9-10$ & \multicolumn{2}{|c|}{ rok 5} & \multicolumn{2}{|c|}{ rok 6} & \multicolumn{2}{|c|}{ P5 } \\
\hline $8-9$ & \multicolumn{2}{|c|}{ rok 4} & \multicolumn{2}{|c|}{ rok 5} & \multicolumn{2}{|c|}{ P4 } \\
\hline $7-8$ & rok 3 & $\begin{array}{c}\text { drugi } \\
\text { etap kluczowy }\end{array}$ & rok 4 & $\begin{array}{c}\text { drugi } \\
\text { etap kluczowy }\end{array}$ & \multicolumn{2}{|c|}{ P3 } \\
\hline $6-7$ & \multicolumn{2}{|c|}{ rok 2} & \multicolumn{2}{|c|}{ rok 3} & \multicolumn{2}{|c|}{$\mathrm{P} 2$} \\
\hline $5-6$ & \multicolumn{2}{|c|}{ rok 1} & \multicolumn{2}{|c|}{ rok 2} & P1 & pierwszy \\
\hline 4-5 & klasa „zerowa” & $\begin{array}{c}\text { pierwszy } \\
\text { etap kluczowy }\end{array}$ & rok 1 & $\begin{array}{c}\text { pierwszy } \\
\text { etap kluczowy }\end{array}$ & \multicolumn{2}{|c|}{ żłobek } \\
\hline 3 & \multicolumn{2}{|c|}{ żłobek } & \multicolumn{2}{|c|}{ Żłobek } & & \\
\hline
\end{tabular}

Źródło: http://www.primarylearningsupport.co.uk/uk-education-systems/.

Learning, Science \& Scotland’s Languages) oraz Sekretarz Stanu ds. Dzieci i Młodzieży (Minister for Children and Young People).

Ministrom doradza Inspektorat Jej Wysokości ds. Edukacji (Her Majesty’s Inspectorate of Education, HMIE) oraz instytucje państwowe zajmujące się opracowywaniem programu nauczania - Szkockie Biuro ds. Kształcenia i Nauczania (Learning \& Teaching Scotland) oraz instytucja odpowiedzialna za system egzaminowania - Szkocki Urząd ds. Kwalifikacji (Scottish Qualifications Authority). Ponadto za finansowanie 42 szkockich colleges i 20 uczelni odpowiada Szkocka Rada ds. Finansowania (Scottish Funding Council, SFC).

Blisko 96\% uczniów kształci się w szkołach finansowanych ze środków publicznych, szkoły prywatne są niezależne, nie podlegają lokalnym władzom i nie 
otrzymują środków publicznych na swoją działalność. Bezpośrednią organizacją kształcenia finansowanego ze środków publicznych zajmują się szkockie władze lokalne (Local Authorities, SLAs). Rady terytorialne (unitary councils) odpowiadają za nadzór nad wdrażaniem polityki edukacyjnej rządu, zatrudnianie nauczycieli, finansowanie większości usług edukacyjnych. Placówki prowadzące tzw. further education (kształcenie średnie na poziomie poniżej szkolnictwa wyższego dla osób, które przekroczyły wiek obowiązku szkolnego) i uczelnie wyższe są instytucjami autonomicznymi.

\section{System szkolnictwa w Szkocji}

Edukacja przedszkolna nie jest obowiązkowa. Zgodnie ze szkocką ustawą z 2000 r. o standardach kształcenia i wychowania, władze lokalne zobowiązane są zapewnić edukację przedszkolną wszystkim trzylatkom i czterolatkom, których rodzice chcieliby posłać je do przedszkoli.

\section{Szkoła obowiqzkowa}

Obowiązek szkolny w Szkocji wynosi 11 lat. Rozpoczyna się w wieku 5 lat i trwa do końca roku szkolnego, w którym uczeń ukończy 16 rok życia.

Szkoła obowiązkowa obejmuje następujące szczeble kształcenia:

\begin{tabular}{|l|c|}
\hline \multicolumn{1}{|c|}{ Nazwa szkoły } & Wiek uczniów \\
\hline $\begin{array}{l}\text { Primary school (P1-P7) } \\
\text { (szkoła podstawowa) - ISCED 1 }\end{array}$ & 5-12 lat \\
\hline $\begin{array}{l}\text { Secondary school (S1-S4) } \\
\text { (szkoła średnia I stopnia) - ISCED 2 }\end{array}$ & $12-16$ lat \\
\hline
\end{tabular}

Uczniowie przechodzą ze szkoły podstawowej do średniej I stopnia po ukończeniu siedmiu klas szkoły podstawowej (w wieku 12 lat). Nie ma ograniczeń dotyczących przyjęć, np. egzaminów wstępnych, i uczniowie nie powtarzają klas. W programie nauczania szkoły podstawowej wyodrębnia się następujące dziedziny: język, matematyka, nauka o środowisku, sztuka oraz religia i etyka wraz z rozwojem indywidualnym, społecznym i edukacją zdrowotną. W szkole średniej I stopnia program nauczania jest podzielony na dwa etapy. W pierwszych dwóch klasach (S1 i S2) prowadzi się kształcenie ogólne, zgodnie z wytycznymi narodowego programu nauczania dla uczniów w wieku 5-14 lat (National 
5-14 Programme), natomiast w III i IV klasie (S3 i S4) wprowadza się elementy kształcenia zawodowego dla wszystkich uczniów. Nauczyciele mają swobodę wyboru podręczników i pomocy naukowych, choć w niektórych szkołach istnieją listy podręczników ustalone dla poszczególnych przedmiotów bądź etapów nauczania.

\section{Ocena, promocja i kwalifikacje}

W szkole średniej uczniowie są oceniani w sposób ciągły, zgodnie z procedurami obowiązującymi w poszczególnych placówkach, i przechodzą automatycznie do następnej klasy. W pierwszych dwóch klasach szkoły średniej I stopnia (S1, S2) ocenę prowadzi się zgodnie z ogólnokrajowymi wytycznymi National 5-14 Programme. Zwykle w klasie S3 uczniowie zaczynają przygotowywać się do egzaminów prowadzących do uzyskania państwowych kwalifikacji (National Qualifications, NQ), które wydaje Szkocki Urząd ds. Kwalifikacji (Scottish Qualifications Authority, SQA). Kwalifikacje dotyczą poszczególnych przedmiotów (matematyki, angielskiego, geografii itp.) oraz podstawowych umiejętności (komunikacji, rozwiązywania problemów, pracy w grupie).

Szkolnictwo średnie II stopnia (poziom ISCED 3) i policealne (ISCED 4)

Szkolnictwo średnie II stopnia i policealne jest nieobowiązkowe. Po ukończeniu poziomu S4 uczniowie mogą kontynuować naukę w ogólnokształcących szkołach średnich II stopnia (S5-S6) przeznaczonych dla uczniów w wieku 16-18 lat lub further education college - kształcenie ogólnokształcące i zawodowe (ISCED 3) oraz szkołach policealnych (ISCED 4) przeznaczonych dla uczniów powyżej 16 roku życia.

Kryteria przyjęć

Kształcenie zawodowe prowadzą placówki oświatowe realizujące further education, niezależne ośrodki szkoleniowe oraz pracodawcy w zakładach pracy. Uczniowie, którzy kontynuują edukację po ukończeniu kształcenia obowiązkowego (po klasie S4, koniec ISCED 2), mogą kontynuować naukę w szkole średniej II stopnia, zazwyczaj w ramach tej samej placówki. Mogą też przenieść się do jednego z further education colleges, gdzie mogą podjąć kształcenie prowadzące do uzyskania kwalifikacji państwowych (National Qualifications, NQ) na pozio- 
mie ISCED 3 i ISCED 4 lub podjąć naukę prowadzącą do uzyskania szkockich kwalifikacji zawodowych (Scottish Vocational Qualifications). Władze lokalne we współpracy z further education colleges organizują dla uczniów zarówno w szkołach, jak i colleges kursy o profilu zawodowym (często w niepełnym wymiarze godzin lub odbywające się częściowo w szkole, a częściowo w miejscu pracy). Jednym z priorytetów polityki edukacyjnej Szkocji jest promowanie tego rodzaju partnerskiej współpracy między przedsiębiorstwami a placówkami edukacyjnymi.

\section{Programy i treści nauczania}

Z oferty dydaktycznej szkoły lub placówki further education uczniowie/słuchacze wybierają cykl kształcenia kończący się uzyskaniem oficjalnie uznawanych kwalifikacji państwowych (NQ). Szkoły i władze lokalne decydują o treściach i metodach nauczania, tak jak dzieje się to na poziomie szkół średnich I stopnia. Further education colleges mają całkowitą swobodę wyboru treści nauczania.

\section{Ocena, promocja i kwalifikacje}

Further education colleges i inne placówki realizują program kwalifikacji państwowych przewidzianych dla wszystkich uczniów/słuchaczy, których kształcenie wykracza poza poziom standardowy (Standard Grade). Są one administrowane przez Scottish Qualifications Authority, a świadectwo kwalifikacji zawiera oceny z wybranych przedmiotów i podstawowych umiejętności. Oceny zależą od kwalifikacji, ale mogą obejmować jeden lub kilka egzaminów pisemnych, ustnych i praktycznych lub ocenę ciągłą. Szkockich kwalifikacji zawodowych (Scottish Vocational Qualifications) nie przyznaje się na podstawie egzaminów, natomiast kandydaci muszą wykazać się kompetencją w wykonywaniu określonych zadań. W szkockim systemie edukacyjnym można uzyskać następujące rodzaje kwalifikacji:

- $\quad$ szkockie świadectwo wyższych kwalifikacji - Scottish Qualification Certificate at Higher Grade,

- szkockie świadectwo kwalifikacji na wyższym zaawansowanym poziomie Scottish Qualifications Certificate at Advanced Higher Grade - oraz

- $\quad$ szkockie kwalifikacje zawodowe - Scottish Vocational Qualifications (SVQs). 


\section{Wskaźniki zatrudnienia absolwentów liceów, techników, szkół zawodowych i szkół policealnych}

Międzynarodowe badania porównawcze w zakresie polityki oświatowej nie odnoszą się wprost do typów i rodzajów szkół. Szkoły w systemach oświaty w poszczególnych krajach zbyt się od siebie różnią, aby mogły być wprost porównywalne. Bezpośrednim powodem różnic (jak i podobieństw) w strukturach szkolnych poszczególnych państw są ich uwarunkowania historyczne, polityczne, ekonomiczne, społeczne, demograficzne, geograficzne itp. Nie zawsze więc konkretny typ lub rodzaj szkoły charakterystyczny dla jednego kraju będzie występował w systemie szkolnym innego państwa. Dla ułatwienia porównań międzynarodowych stworzona została Międzynarodowa Standardowa Klasyfikacja Edukacji - ISCED, za pomocą której porównuje się poziomy kształcenia. Zgodnie z tą klasyfikacją nasze zasadnicze szkoły zawodowe, technika i licea zostały zaliczone do poziomu ISCED 3, a szkoły policealne do ISCED 4.

Stopę zatrudnienia absolwentów mierzy się w Europie według wskaźnika dostępnego w bazie Eurostat ${ }^{43}$. Wskaźnik ten, w odniesieniu do absolwentów szkół na poziomie ISCED 3 - ISCED 6 , jest jednocześnie jednym z tzw. benchmarków (poziomów odniesienia) współpracy europejskiej w dziedzinie kształcenia i szkolenia (ET 2020). W tabeli 2 na s. 161 przedstawione zostały wartości tego wskaźnika dla absolwentów szkół na poziomie ISCED 3 i ISCED 4. Jak wynika z powyższego zestawienia, odsetek zatrudnienia absolwentów szkolnictwa ISCED 3 i 4 w 2013 roku wynosił: w Niemczech - 86,5\%, w Wielkiej Brytanii - 78,1\%, w Czechach - 75,4\%, we Francji - 67,3\%, a na Słowacji-63,1\%.

W większości państw Unii Europejskiej odsetek zatrudnienia absolwentów szkół z poziomu ISCED 3 i ISCED 4 (odpowiadającym w Polsce zasadniczym szkołom zawodowym, technikom, liceom oraz szkołom policealnym) był wyższy niż w Polsce. Przy czym średnia w UE w tym zakresie wynosiła 69,5\%, a w Polsce 62,8\%. W Polsce, podobnie jak w UE, wskaźnik ten obniża się od 2008 roku, choć w ostatnich dwóch latach widać zahamowanie tego spadku.

43 http://appsso.eurostat.ec.europa.eu/nui/show.do?dataset=edat_lfse_24\&lang=en. 
Tabela 2. Odsetek zatrudnionych absolwentów w wieku od 20 do 34 lat, którzy zakończyli kształcenie lub szkolenie na poziomie ISCED 3 i ISCED 4 nie wcześniej niż trzy lata przed rokiem referencyjnym

\begin{tabular}{|c|c|c|c|c|c|c|c|c|c|c|c|c|}
\hline & 요 & ஜ̊ & 요 & 요 & $\begin{array}{l}\text { ஜ } \\
\text { ஓ }\end{array}$ & 요 & $\begin{array}{l}\infty \\
\stackrel{\wp}{\circ} \\
\text { ○ }\end{array}$ & $\begin{array}{l}\text { ᄋ } \\
\text { ஜ }\end{array}$ & $\frac{o}{\grave{\sigma}}$ & $\bar{\sigma}$ & $\frac{\sim}{\sigma}$ & $\stackrel{m}{\grave{\sigma}}$ \\
\hline UE-28 & . &. & $\cdot$ &. & 73,8 & 75,6 & 77,1 & 72,5 & 72,1 & 71,3 & 69,8 & 69,5 \\
\hline Austria & 1,1 & 38,9 & 84,7 & 86,9 & 89,9 & 89,9 & 89,0 & 87,7 & 38,2 & 91,0 & 90,1 & 88,7 \\
\hline Belgia & 8,4 & 1,9 & 79,8 & 68,1 & 72,0 & 73,2 & 73,6 & 71,9 & 71,5 & 73,5 & 71,4 & 71,1 \\
\hline Bułgaria & 9,4 & 49,2 & 54,1 & 55,4 & 58,8 & 62,5 & 74,1 & 63,7 & 58,4 & 49,7 & 56,6 & 54,3 \\
\hline Cho & : & : & 57,7 & 56,8 & 65,0 & 68,1 & 72,7 & 73,0 & 66,5 & 57,8 & 52,0 & 49,0 \\
\hline Cypr & 8,2 & 80,0 & 72,1 & 57,0 & 74,0 & 71,5 & 80,9 & 73,8 & 70,0 & 57,2 & 65,4 & 48,3 \\
\hline Czechy & 1,1 & 4,2 & : & & 80,9 & 86,1 & 87,6 & 81,7 & 77,4 & 76,7 & 77,8 & 75,4 \\
\hline Dania & 8,7 & 85,3 & 83,6 & 84,5 & 89,3 & 89,0 & 90,2 & 84,2 & 82,0 & 82,9 & 82,4 & 79,0 \\
\hline Estonia & 75,9 & 68,0 & 78,2 & 68,2 & 78,6 & 81,7 & 81,9 & 64,5 & 48,4 & 68,4 & 65,6 & 66,8 \\
\hline Finlandia & 75,4 & 78,2 & 72,3 & 75,9 & 75,3 & 81,4 & 78,9 & 72,9 & 76,3 & 73,6 & 77,4 & 75,9 \\
\hline Francja & : & 77,9 & 73,2 & 74,1 & 71,3 & 72,9 & 75,1 & 68,6 & 69,3 & 68,6 & 67,0 & 67,3 \\
\hline Grecja & 59,6 & 58,0 & 59,7 & 53,7 & 62,6 & 64,2 & 62,9 & 60,1 & 55,8 & 46,2 & 34,4 & 29,7 \\
\hline Hiszpania & 75,4 & 67,6 & 73,9 & 71,9 & 77,7 & 81,7 & 74,5 & 63,8 & 60,5 & 51,4 & 48,1 & 41,0 \\
\hline Holandia & $:$ & 8,3 & 88,6 & 89,3 & 90,7 & 91,9 & 91,4 & 91,3 & 89,7 & 89,1 & 87,0 & 81,9 \\
\hline Irlandi & 6,3 & 4 & 74,2 & 77,9 & 82,0 & 81,2 & 79,2 & 62,0 & 57,0 & 52,7 & 50,6 & 55,9 \\
\hline Litwa & 8 & 67,8 & 3,3 & 68,6 & 74,7 & 72,7 & 68,4 & 57,8 & 54,2 & 48,7 & 61,3 & 63,2 \\
\hline Lukse & 2 & 90,9 & 87,1 & 87,6 & 86,5 & 87,7 & 80,0 & 79,3 & 86,6 & 78,5 & 83,8 & 71,4 \\
\hline Łotwa & 65,4 & 68,5 & 67,8 & 76,5 & 73,1 & 77,9 & 77,6 & 59,2 & 54,0 & 55,4 & 57,2 & 70,9 \\
\hline Malta & 85,3 & r. & 91,2 & 91,9 & 85,1 & 90,4 & 96,6 & 90,6 & 87,9 & 86,0 & 88,5 & 91,2 \\
\hline Niemcy & 83,9 & 79,4 & 76,0 & 75,4 & 77,9 & 79,6 & 83,2 & 81,0 & 83,7 & 84,5 & 85,6 & 86,5 \\
\hline Polska & 51,5 & 48,4 & 50,3 & 54,4 & 60,7 & 64,9 & 70,1 & 68,7 & 67,4 & 65,8 & 62,7 & 62,8 \\
\hline Portugalia & 83,0 & 82,1 & 78,6 & 80,4 & 80,7 & 79,7 & 81,9 & 79,9 & 77,4 & 73,5 & 66,1 & 64,9 \\
\hline Słowacja & 53,8 & 60,3 & 59,9 & 66,4 & 71,7 & 77,8 & 79,5 & 67,9 & 60,5 & 61,6 & 61,6 & 63,1 \\
\hline Słowenia & 75,0 & 70,4 & 69,9 & 72,3 & 77,4 & 78,0 & 79,8 & 73,3 & 75,1 & 68,7 & 63,0 & 61,8 \\
\hline Szwecja & 85,1 & 79,8 & 75,6 & 74,2 & 78,5 & 81,1 & 81,6 & 74,6 & 77,6 & 79,4 & 78,1 & 80,2 \\
\hline Rumunia & 56,0 & 54,2 & 65,5 & 62,7 & 64,8 & 70,7 & 77,1 & 69,1 & 61,3 & 58,8 & 59,3 & 55,5 \\
\hline Węgry & 75,3 & 79,7 & 76,0 & 62,1 & 71,8 & 72,9 & 71,7 & 66,4 & 65,9 & 63,5 & 61,5 & 64,9 \\
\hline Wielka B & 82,6 & 83,1 & 83,8 & 83,7 & 84,7 & 82,0 & 79,5 & 75,0 & 76,5 & 75,9 & 73,3 & 78,1 \\
\hline Włochy & 58,9 & 59,6 & 62,9 & 61,7 & 63,6 & 62,6 & 60,5 & 56,0 & 52,3 & 50,6 & 46,2 & 40,8 \\
\hline Islandia & 93,7 & 93,2 & 88,4 & 91,7 & 89,0 & 94,3 & 89,9 & 81,7 & 81,4 & 84,2 & 88,9 & 84,1 \\
\hline Szwajcaria & 89,0 & 84,7 & 85,3 & 84,5 & 85,3 & 86,2 & 84,5 & 84,0 & 86,4 & 83,8 & 83,7 & 81,7 \\
\hline Macedo & : & . & : & : & 24,8 & 30,5 & 36,3 & 38,0 & 40,4 & 40,1 & 39,1 & 39,0 \\
\hline Turcja & : & 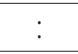 & $:$ & $\dot{0}$ & 40,4 & 40,6 & 44,1 & 42,9 & 46,7 & 47,8 & 45,1 & 48,0 \\
\hline
\end{tabular}

Źródło: Eurostat edat_Ifse_24. 
Odsetek absolwentów szkół średnich (ISCED 3) i policealnych (ISCED 4) podejmujących studia wyższe

Podobnie jak w wypadku poprzedniego pytania, odpowiedzi można udzielić jedynie na podstawie klasyfikacji ISCED’97. Problematykę tę mierzy wskaźnik OECD dotyczący odsetka osób do 25 roku życia podejmujących studia (w typowym wieku rozpoczęcia studiów).

Tabela 3. Odsetek osób do 25 roku życia rozpoczynających studia wyższe (2011 r.)

\begin{tabular}{|c|c|c|c|c|c|}
\hline & $\begin{array}{c}\text { Udział } \\
\text { poniżej } \\
25 \text { roku życia }\end{array}$ & $\begin{array}{c}\text { Kobiety } \\
\text { i mężczyźni } \\
\text { razem }\end{array}$ & Mężczyźni & Kobiety & $\begin{array}{c}\text { Udział } \\
\text { poniżej } \\
25 \text { roku życia }\end{array}$ \\
\hline & (5) & (6) & (7) & (8) & (10) \\
\hline Australia & $\mathrm{m}$ & 72 & 62 & 83 & 74 \\
\hline Polska & $\mathrm{m}$ & 71 & 62 & 80 & 86 \\
\hline Słowenia & 59 & 69 & 53 & 86 & 90 \\
\hline Portugalia & $\mathrm{m}$ & 69 & 58 & 80 & 64 \\
\hline Holandia & 28 & 58 & 53 & 63 & 90 \\
\hline Norwegia & $\mathrm{m}$ & 58 & 48 & 69 & 77 \\
\hline Korea & 87 & 58 & 56 & 59 & 82 \\
\hline USA & $\mathrm{m}$ & 54 & 51 & 58 & 77 \\
\hline Dania & 43 & 53 & 44 & 63 & 76 \\
\hline Islandia & 18 & 52 & 45 & 60 & 66 \\
\hline Nowa Zelandia & 53 & 52 & 45 & 61 & 71 \\
\hline Wielka Brytania & 33 & 52 & 48 & 57 & 81 \\
\hline Czechy & 80 & 51 & 45 & 57 & 81 \\
\hline Finlandia & a & 51 & 46 & 55 & 74 \\
\hline Słowacja & m & 49 & 43 & 56 & 79 \\
\hline Szwecja & 54 & 49 & 42 & 56 & 70 \\
\hline Hiszpania & 73 & 46 & 39 & 54 & 81 \\
\hline Irlandia & 72 & 45 & 40 & 50 & 86 \\
\hline Włochy & $\mathrm{m}$ & 45 & 37 & 52 & 92 \\
\hline Węgry & 84 & 43 & 40 & 47 & 81 \\
\hline Niemcy & 73 & 40 & 39 & 41 & 86 \\
\hline Austria & 44 & 40 & 34 & 46 & 75 \\
\hline Izrael & 69 & 39 & 29 & 49 & 65 \\
\hline Francja & m & 37 & 33 & 42 & 95 \\
\hline
\end{tabular}




\begin{tabular}{|l|c|c|c|c|c|}
\hline & $\begin{array}{c}\text { Udział } \\
\text { poniżej } \\
25 \text { roku życia }\end{array}$ & $\begin{array}{c}\text { Kobiety } \\
\text { i mężczyźni } \\
\text { razem }\end{array}$ & Mężczyźni & Kobiety & $\begin{array}{c}\text { Udział } \\
\text { poniżej } \\
\text { 25 roku życia }\end{array}$ \\
\cline { 2 - 6 } & $(5)$ & $(6)$ & $(7)$ & $(8)$ & $(10)$ \\
\hline Estonia & 72 & 37 & 33 & 42 & 86 \\
\hline Grecja & 92 & 36 & 28 & 44 & 87 \\
\hline Szwajcaria & 44 & 34 & 32 & 37 & 76 \\
\hline Turcja & 81 & 34 & 32 & 35 & 85 \\
\hline Chile & 70 & 33 & 29 & 37 & 76 \\
\hline Belgia & 95 & 32 & 31 & 34 & 97 \\
\hline Meksyk & 94 & 31 & 31 & 31 & 93 \\
\hline Kanada & $\mathrm{m}$ & $\mathrm{m}$ & $\mathrm{m}$ & $\mathrm{m}$ & $\mathrm{m}$ \\
\hline Japonia & $\mathrm{m}$ & $\mathrm{m}$ & $\mathrm{m}$ & $\mathrm{m}$ & $\mathrm{m}$ \\
\hline Luksemburg & $\mathrm{m}$ & $\mathrm{m}$ & $\mathrm{m}$ & $\mathrm{m}$ & $\mathrm{m}$ \\
\hline OECD średnia & 62 & 48 & 42 & 54 & 81 \\
\hline EU-21 średnia & 60 & 49 & 43 & 55 & 83 \\
\hline
\end{tabular}

$m$ - brak danych

a - brak danych z powodu niewystępowania kategorii

Źródło: OECD, Education at a Glance 2013, Tabela C3.1b.

Powyższe dane dotyczą odsetka osób podejmujących studia i są obliczone w stosunku do całej populacji osób w typowym wieku rozpoczynania studiów. W zestawieniu tych danych istotne dla Polski jest porównanie w kolumnie 6 . Wynika z niego, że Polska należy do czołówki krajów OECD i UE pod względem odsetka młodych osób dorosłych rozpoczynających kształcenie na poziomie szkolnictwa wyższego. Odsetek ten wynosi 71\% i znacznie przekracza średnią w OECD (48\%) i UE-21 (49\%). W Wielkiej Brytanii odsetek rozpoczynających kształcenie na poziomie szkolnictwa wyższego wynosi 52\%, w Czechach - 51\%, w Niemczech - 40\%, na Słowacji - 49\%, a we Francji -31\%.

\section{Bibliografia}

Dziewulak D., Wymiar czasu pracy nauczycieli w wybranych państwach Unii Europejskiej, „Analizy BAS” 2009, nr 13(21), http://orka.sejm.gov.pl/WydBAS.nsf/0/5B394EDCA941C294C12576480048C3F7/\$file/Analiza_\%20BAS_2009_21.pdf.

Encyklopedia pedagogiczna XXI wieku, t. VI, Wydawnictwo Akademickie „Żak”, Warszawa 2007. 
Kupisiewicz C., Kupisiewicz M., Stownik pedagogiczny, Wydawnictwo Naukowe PWN, Warszawa 2009.

Minimalne wynagrodzenie za prace, seria BAS „Przed pierwszym czytaniem” 2012, nr 1, http://orka.sejm.gov.pl/WydBAS.nsf/0/F255034B81806511C1257A070039A7C3/\$file/ ppc_1-2012.pdf.

\section{Akty prawne}

Francuska ustawa z 1989 r. o szkolnictwie, Loi n89-486 du 10 juillet 1989, http://www.legifrance.gouv.fr/affichTexte.do?cidTexte=LEGITEXT000006069117\&dateTexte=20050423.

Francuska ustawa z 2005 r. o orientacji i programie dla przyszłości szkoły, Loi n 2005-380 du 23 avril 2005 d'orientation et de programme pour l'avenir de l'école, http://www.legifrance.gouv.fr/affichTexte.do?cidTexte=JORFTEXT000000259787\&dateTexte=\&categorieLien=id.

Federalna ustawa o wspieraniu kształcenia, Bundesausbildungsförderungsgesetz.

Bundesgesetz über individuelle Förderung der Ausbildung, http://www.das-neue-bafoeg. de/de/204.php.

Ustawa szkolna o administracji państwowej w oświacie i samorządzie szkolnym oraz o zmianie niektórych ustaw, Zákon č. 596/2003 Z.z. o štátnej správe v školstve a školskej samospráve a o zmene a doplnení niektorých zákonov v znení neskorších predpisov, https://www.minedu.sk/zakon-c-5962003-zz-o-statnej-sprave-v-skolstve-a-skolskej-samosprave-a-o-zmene-a-doplneni-niektorych-zakonov-v-zneni-neskorsich-predpisov/.

Ustawa o finansowaniu szkolnictwa Słowacji, Zákon o financovaní základných škôl, stredných škôl a školských zariadení; http://www.zakonypreludi.sk/zz/2003-597.

Ustawa Szkocji i Walii o strukturze i standardach w szkolnictwie z 1998 r., School Standards and Framework Act 1998, http://www.legislation.gov.uk/ukpga/1998/31/contents.

\section{Strony internetowe}

http://europass.frse.org.pl/files/isced.pdf.

https://webgate.ec.europa.eu/fpfis/mwikis/eurydice/index.php/Czech-Republic:Early_ Childhood_and_School_Education_Funding\#Financial_Support_for_Learners.27_Families.

http://www.nuov.cz/uploads/PaK/schema.jpg.

http://www.education.gouv.fr/.

http://www.capital.fr/carriere-management/actualites/hausse-du-chomage-a-10-4-au-1er-

-trimestre-2013-848975. 
http://www.inegalites.fr/spip.php?article1585.

http://orientation.blog.lemonde.fr/2011/05/26/apres-le-bac-qui-reussit-et-ou/.

http://www.cinemafrancais-fle.com/Images/films/scolaire.png.

http://www.education.gouv.fr/archives/2012/refondonslecole/wp-content/uploads/2012/07/

rapport_eurydice_l_education_a_l_orientation_professionnelle_dans_l_enseigne-

ment_obligatoire_a_temps_plein_en_europe_2008.pdf.

http://www.education.gouv.fr/cid160/les-lieux-d-information-de-l-orientation.html\#les-

-centres-d-information-et-d-orientation-c-i-o-.

http://www.pole-emploi.fr/accueil/.

http://www.cidj.com/le-cidj/historique/le-cidj-et-l-information-jeunesse.

http://www.cereq.fr/.

http://www.kmk.org/.

http://www.sozialgesetzbuch-sgb.de/sgbii/1.html.

http://www.oecd.org/edu/Germany_EAG2013\%20Country\%20Note.pdf.

http://www.bachelorundmaster.de/fileadmin/user_upload/images/neueZahlenbilder/

neue_Oktober/bildungssystem.png.

http://www.bmbf.de/.

https://www.minedu.sk/statut-ministerstva-skolstva-vedy-vyskumu-a-sportu-sr/.

http://voieproeurope.onisep.fr/en/files/2012/11/slovaquie_en.jpg.

http://www.ons.gov.uk/ons/rel/lms/labour-market-statistics/april-2014/statistical-bulletin.

html.

http://www.parliament.uk/business/publications/research/briefing-papers/SN05871/

youth-unemployment-statistics.

https://www.gov.uk/government/uploads/system/uploads/attachment_data/file/207749/

Main_text_-_SFR19_2013.pdf.

http://www.childresearch.net/PROJECT/ECEC/europe/uk/images/edu_img.gif.

http://www.apprenticeships.org.uk/About-Us/ /media/Documents/SASE/11-521-Specifica-

tion-of-apprenticeship-standards-for-england.ashx.

http://scotland.gov.uk/About/People/Directorates.

http://www.primarylearningsupport.co.uk/uk-education-systems/.

http://appsso.eurostat.ec.europa.eu/nui/show.do?dataset=edat_lfse_24\&lang=en.

Nezaměstnanost absolventů škol se středním a vyšším odborným vzděláním - 2013, http:// www.infoabsolvent.cz/Temata/PublikaceAbsolventi?Stranka=9-0-82\&NazevSeo=Nezamestnanost-absolventu-skol-se-strCednim-a-.

Přechod absolventů SŠ do terciárního vzdělávání - 2014, http://www.infoabsolvent.cz/Temata/PublikaceAbsolventi?Stranka=9-0-88\&NazevSeo=Prechod-absolventu-SS-do-terciarniho-vzdelavani-. 


\title{
1.4. Szkolnictwo wyższe w świetle raportów edukacyjnych
}

\author{
Higher education in the light of educational reports
}

\begin{abstract}
W opracowaniu przedstawiono problematykę funkcjonowania szkolnictwa wyższego w aspekcie przemian cywilizacyjnych zachodzących na świecie i w Polsce. W artykule zaprezentowano raporty oświatowe międzynarodowych organizacji, w których wskazano priorytety rozwoju oświaty i szkolnictwa wyższego na najbliższe dekady. Na tym tle w drugiej części artykułu autor przedstawił syntetyczne informacje na temat dotychczasowych reform i kierunków rozwoju szkolnictwa wyższego w Polsce w okresie od 1918 roku do 2013 roku.
\end{abstract}

Słowa kluczowe: oświata, szkolnictwo wyższe, raport oświatowy, reforma oświatowa, organizacje międzynarodowe, Polska

The paper deals with the functioning of higher education in the circumstances of civilization changes taking place in Poland and worldwide. The author examines educational reports published by international organizations outlining priorities for the development of education and higher education over the next decades. In the second part of the article, he presents a brief description of the reforms of Polish higher education system which were carried out between 1918 and 2013.

Keywords: education, higher education, educational report, educational reform, international organizations, Poland

\section{Wstęp}

Genezy szkolnictwa wyższego najczęściej poszukuje się w tradycjach uczelni antycznych, uczelni arabskich oraz uniwersytetów europejskich działających w wiekach średnich. Nazwa uniwersytet - placówka oświatowa powszechnie kojarzona ze szkolnictwem wyższym - pochodzi od łacińskiego słowa universitas, które pierwotnie oznaczało wspólnotę zawodową osób nauczających i uczących się (universitas studiorum et studentium), swego rodzaju zrzeszenie, korporację, cech. Celem tej edukacyjnej wspólnoty było bezinteresowne, lecz naukowo odpowiedzialne (uzasadnione) poznawanie i głoszenie prawdy o świecie i człowieku. Dopiero później zaczęto używać pojęcia universitas w szerszym zakresie, odno- 
sząc go do powszechności nauk, czyli wszechnicy obejmującej szeroki zakres wiedzy.

Europejskie zręby szkolnictwa wyższego pojawiły się na przełomie XI i XII wieku. Wtedy to powstały uczelnie wyższe w Bolonii i Paryżu określane terminem studium generale. Z upływem lat zaczęto je określać zaszczytnym mianem europejskich uniwersytetów matek ${ }^{1}$. Podwaliną polskiego szkolnictwa wyższego był Uniwersytet Jagielloński założony jako studium generale w Krakowie w 1364 roku przez Kazimierza III Wielkiego i odnowiony w 1400 roku przez Władysława II Jagiełłę.

Celem opracowania jest prezentacja problematyki funkcjonowania szkolnictwa wyższego w świetle raportów edukacyjnych diagnozujących stan i uwarunkowania cywilizacyjne oraz wskazujących kierunki rozwoju na najbliższe lata²

Opracowanie składa się z trzech części. W pierwszej przedstawiono krótkie omówienie najważniejszych zjawisk przemian cywilizacyjnych przełomu XX i XXI wieku oraz ich wpływu na zmieniające się oczekiwania i potrzeby społeczne wobec szkolnictwa wyższego i szeroko rozumianej oświaty. Część drugą poświęcono idei deskolaryzacji, roli międzynarodowych organizacji oświatowych - omówiono najważniejsze idee kluczowych raportów oświatowych oraz dokonano krótkiej prezentacji istoty procesu bolońskiego dla współczesnego szkolnictwa wyższego. W trzeciej części skupiono się na omówieniu reform i kierunków rozwoju szkolnictwa wyższego w Polsce od okresu odzyskania niepodległości w 1918 roku do współczesności. Przedstawiono charakterystyczne cechy polskiego szkolnictwa wyższego w okresie 1918-1945. Zaprezentowano projekty reform zawarte w najważniejszych raportach oświatowych z lat 1945-1989. Poddano analizie tendencje i kierunki zmian proponowane w obszarze polskiego szkolnictwa wyższego od 1989 roku do 2013 roku ze szczególnym uwzględnieniem ustawy z 18 marca 2011 r. o zmianie ustawy - Prawo o szkolnictwie wyższym oraz raportów na temat misji, wizji i celów strategicznych szkolnictwa wyższego w Polsce do 2020 roku.

1 Uniwersytety średniowieczne tworzyły cztery fakultety, do których zaliczały się: sztuki wyzwolone (atrium), prawo kanoniczne, teologia, medycyna. Sztuki wyzwolone był to pierwszy stopień nauczania, przygotowujący do dalszego studiowania. Kończył się uzyskaniem tytułu bakałarza lub magistra atrium. Pierwszy tytuł uprawniał do nauczania na poziomie sztuk wyzwolonych, natomiast tytuł magistra atrium dawał uprawnienia do kontynuowania studiów na wyższym poziomie, tzn. na prawie, medycynie lub teologii.

2 Opracowanie przygotowano na podstawie eksperckiego artykułu D. Dziewulaka zatytułowanego Szkolnictwo wyższe w świetle raportów edukacyjnych, „Studia BAS” 2013, nr 3(35), s. 149-174. 


\section{Edukacja a globalizacja}

Przemiany cywilizacyjne, odkrycia naukowe, wynalazki, rozwój przemysłowy i technologiczny oraz postępująca globalizacja spowodowały, że ogólnoświatowe tendencje gospodarcze, społeczne i kulturalne stały się dla poszczególnych państw wyznacznikiem kierunków ich rozwoju. Współczesny świat skurczył się tak znacznie, że najtrafniej odzwierciedla to zjawisko powszechnie używane określenie „globalna wioska”3. Pojęcie globalizacji szczególnie powiązane jest z powszechnym dostępem do informacji, a więc i wiedzy. Ta powszechność i łatwość dostępu do wiedzy generuje zainteresowanie podniesieniem poziomu wykształcenia, co z jednej strony powoduje formalny wzrost liczby osób legitymujących się dyplomami ukończenia wyższych studiów, a z drugiej komercjalizację wykształcenia wyższego i towarzyszący mu spadek poziomu nauczania. Jedną z konsekwencji powszechności, czyli umasowienia szkolnictwa wyższego, jest wieloletnie dążenie władz oświatowych do wydłużania obowiązku szkolnego i obowiązku nauczania. Nie powinno zatem dziwić, że upowszechnienie szkolnictwa wyższego stało się jedną z najbardziej charakterystycznych cech wskazywanych jako tendencje edukacyjne współczesnego świata.

Zjawisko globalizacji stało się dominującą cechą końca XX wieku i dwóch pierwszych dekad początku XXI wieku. W latach osiemdziesiątych XX wieku globalizacja była postrzegana i rozumiana przede wszystkim jako upowszechnianie się konsumpcyjnego modelu życia. Dzisiaj zjawiska globalizacji możemy odnaleźć w światowej ekonomii, polityce, demografii, życiu społecznym i kulturze. Polegają one na rozprzestrzenianiu się analogicznych zjawisk, niezależnie od kontekstu geopolitycznego i stopnia gospodarczego zaawansowania danego regionu4. Wśród często przywoływanych określeń opisujących zjawisko globalizacji znajduje się definicja Anthony’ego McGrewa ${ }^{5}$, według której globalizacja to mnogość powiązań i współzależnych oddziaływań państw i społeczeństw tworzących obecny system światowy. Choć zagadnienie globalizacji rozpatrywane jest najczęściej w aspekcie gospodarki, polityki i życia społecznego, to coraz wy-

3 Po raz pierwszy termin globalna wioska (ang. global village) został użyty przez kanadyjskiego teoretyka mediów i komunikacji H.M. McLuhana w 1962 r. w książce Galaktyka Gutenberga (The Gutenberg Galaxy). Autor przedstawia w niej trend, w którym powszechne media elektroniczne obalają bariery czasowe i przestrzenne, umożliwiając ludziom swobodny dostęp do wiedzy i nieskrępowaną wymianę myśli na masową skalę.

4 Encyklopedia Popularna PWN, Warszawa 2010, s. 331.

5 A. McGrew, Conceptualizing Global Politics, [w:] Global Politics: Globalization and the Nation-State, red. A. McGrew, P. Lewis, Polity Press, Cambridge 1992, s. 28. 
raźniej zjawisko to ma swoje odniesienie także i w oświacie. Wszechobecna globalizacja sprawia, że tendencje występujące w jednym państwie mogą stać się na tyle istotne, iż stają się tendencjami ogólnoświatowymi, i na odwrót - te uznawane za światowe kierunki rozwoju stają się krajowym wzorem stymulującym przemiany w jednym państwie lub na obszarze o wiele szerszym, pankontynentalnym.

Skomplikowany system powiązań społecznych, gospodarczych, politycznych i kulturowych wynikający z modelu współczesnego świata wymusza na dzisiejszej oświacie realizację nowych celów edukacyjnych, zupełnie innych niż te, jakie znały starsze pokolenia. Od systemu kształcenia oczekujemy już nie tylko przekazywania wiadomości, ale także jej zrozumienia wraz z umiejętnością jej wykorzystania. Od współczesnego procesu edukacyjnego oczekuje się, aby przygotował człowieka do zarządzania własnym życiem, dokonywania przemyślanych i świadomych wyborów na rynku pracy z wykorzystaniem strategicznego i innowacyjnego myślenia. Organizacja systemu edukacyjnego powinna stać się zatem sprzymierzeńcem ucznia, studenta, wykładowcy w znalezieniu miejsca w otaczającym go świecie.

\section{Raporty edukacyjne}

Polityka oświatowa drugiej połowy XX wieku charakteryzowała się rosnącymi oczekiwaniami społecznymi wobec edukacji obowiązkowej, a zwłaszcza szkolnictwa wyższego. Powszechne zainteresowanie nowymi celami i metodami kształcenia odzwierciedlało z jednej strony niezadowolenie społeczne z coraz większej przepaści między ofertą ówczesnych systemów edukacyjnych i przemianami cywilizacyjnymi, a z drugiej - wskazywało na zainteresowanie świata polityki i nauki poszukującego bardziej efektywnych przyszłościowych rozwiązań edukacyjnych.

\section{Deskolaryzacja}

Druga połowa XX wieku przyniosła głębokie przeobrażenia w gospodarce światowej będące wynikiem liberalizacji stosunków gospodarczych. Okres ten charakteryzował się początkiem rewolucji informatycznej i wzrostem znaczenia międzynarodowych korporacji. W konsekwencji dotychczasowy model kształcenia przestał spełniać społeczne oczekiwania, gdyż nie nadążał za cywilizacyjnymi przemianami. Próbę zdiagnozowania problemu i jego rozwią- 
zania zaczęli podejmować przedstawiciele środowisk społecznych, naukowych i politycznych.

$\mathrm{Na}$ fali społecznego niezadowolenia $\mathrm{z}$ funkcjonowania systemu oświaty w 1971 roku Ivan Illich, austriacki myśliciel i przedstawiciel grupy radykalnych krytyków systemu szkolnego (zwanych deskolaryzatorami) opublikował książkę Deschooling society (polskie wydanie ukazało się w 1976 r. ${ }^{6}$ ). Poddał w niej ostrej krytyce instytucję szkoły. Zarzucił systemowi edukacyjnemu:

- reprodukowanie struktur społecznych i ekonomicznych, a tym samym utrwalanie ich ze szkodą dla postępu społeczno-gospodarczego,

- traktowanie nauczania jako towaru, a nie środka służącego rozwojowi człowieka,

- tłumienie naturalnej aktywności i inicjatywy uczniów, narzucając treści i metody kształcenia obce ich zainteresowaniom i potrzebom poznawczym,

- przypisywanie świadectwom szkolnym i dyplomom nadmiernego znaczenia, co powoduje, że uczniowie uczą się dla dyplomów, a nie dla własnych potrzeb,

- szerzenie przekonania jakoby tylko w tak zorganizowanym systemie edukacyjnym można było zdobyć wartościowe wykształcenie, choć w rzeczywistości człowiek uczy się najwięcej i zarazem najskuteczniej właśnie poza zinstytucjonalizowanym systemem oświatowym, rozwiązując problemy, które stawia przed nim życie.

Według I. Illicha rozwiązaniem problemów współczesnego systemu edukacji byłaby deskolaryzacja, czyli całkowite odbiurokratyzownie i zdeinstytucjonalizowanie systemu edukacyjnego. Tak zorganizowany proces nauczania-uczenia się miałby stać się aktywnością człowieka, która nie wymagałaby kierowania z zewnątrz przez innych, lecz przede wszystkim opierałaby się na zapewnieniu swobodnego dostępu do źródeł informacji i dobrowolności. Nauka miałaby odbywać się za pośrednictwem specjalnej sieci edukacyjnej, która objęłaby wszystkie lokalne instytucje i placówki oświatowe - kina, muzea, szpitale, biblioteki, warsztaty rzemieślnicze, zakłady pracy itp. Sieć taka wsparta placówkami edukacyjnymi pośredniczącymi w doborze partnerów do wspólnych przedsięwzięć badawczych i dydaktycznych ułatwiałaby wzajemny kontakt nauczających z uczącymi się. Uzupełnieniem tak skonstruowanego systemu edukacji byłyby bony oświatowe, którymi każdy obywatel mógłby płacić zgodnie z własnymi potrzebami edukacyjnymi.

$6 \quad$ I. Illich, Społeczeństwo bez szkoły, Państwowy Instytut Wydawniczy, Warszawa 1976. 


\section{Rola międzynarodowych organizacji oświatowych}

Ivan Illich mimo swojego radykalizmu w sprawach systemu edukacyjnego nie był odosobniony w krytykowaniu współczesnego szkolnictwa i poszukiwaniu rozwiązań na najbliższe dekady. W grupie badających oświatę i proponujących przeprowadzenie zmian w funkcjonowaniu systemów edukacyjnych ważną rolę odegrały i odgrywają także międzynarodowe organizacje oświatowe, takie jak:

- Organizacja Narodów Zjednoczonych ds. Oświaty, Nauki i Kultury (United Nations Educational, Scientific and Cultural Organization, UNESCO) ${ }^{7}$ z Międzynarodowym Biurem Wychowania (International Bureau of Education, IBE) ${ }^{8}$,

- Organizacja Współpracy Gospodarczej i Rozwoju (Organization for Economic Co-operation and Development, OECD $)^{9}$ prowadząca Program Międzynarodowej Oceny Uczniów (Programme for International Student Assessment, PISA $)^{10}$, tj. międzynarodowe badanie mierzące osiągnięcia uczniów w wieku 15 lat ze szkół średnich I lub II stopnia w zakresie umiejętności czytania i pisania oraz umiejętności matematycznych i w zakresie nauk ścisłych,

- Centrum Badań i Innowacji w Oświacie (Centre for Educational Research and Innovation, CERI) ${ }^{11}$,

- Rada Europy (Council of Europe, CE) ${ }^{12}$.

Główny obszar działalności oświatowej wyżej wymienionych organizacji to:

- międzynarodowa współpraca z państwami w zakresie oświaty,

- prowadzenie porównawczych badań systemów oświatowych,

- planowanie rozwoju oświaty zgodnie z istniejącymi tendencjami ekonomicznymi oraz nowymi technologiami związanymi z kształceniem ustawicznym,

- opiniowanie projektów administracyjnych w zakresie polityki oświatowej,

- prezentowanie oceny systemów edukacyjnych poszczególnych krajów,

- organizowanie konferencji i spotkań ministrów edukacji,

- opiniowanie i rekomendowanie projektów administracyjnych, pedagogicznych i badawczych,

- opracowywanie raportów związanych z proponowanymi strategiami edukacyjnymi.

7 http://www.unesco.org/new/en.

8 http://www.ibe.unesco.org/en.html.

9 http://www.oecd.org.

10 http://www.oecd.org/pisa.

11 http://www.oecd.org/edu/ceri.

12 http://hub.coe.int. 
Właśnie ta ostatnia działalność - międzynarodowe raporty edukacyjne - stanowi ważny wkład w wytyczanie kierunków rozwoju oświaty na najbliższe lata. Raporty oświatowe są współczesną platformą wymiany poglądów w zakresie stanu edukacji oraz źródłem propozycji wprowadzenia bardziej efektywnych rozwiązań w oświacie od wychowania przedszkolnego poczynając, a kończąc na szkolnictwie wyższym i kształceniu ustawicznym. Pierwsze raporty zaczęto publikować na przełomie lat sześćdziesiątych i siedemdziesiątych XX wieku.

\section{Raport Faure'a (1972 rok)}

Raport został przygotowany przez Międzynarodową Komisję ds. Rozwoju Edukacji UNESCO, pod przewodnictwem francuskiego polityka Edgara Faure'a ${ }^{13}$ i opublikowany w 1972 roku pod angielskim tytułem Learning to be. The World of education today on tommorrow. Polskie tłumaczenie tekstu raportu zostało wydane w 1975 roku, a tytuł brzmiał Uczyć się, aby być.

Raport zawiera informacje o stanie oświaty lat sześćdziesiątych XX wieku i potrzebach rozwoju edukacji na najbliższe kilka dekad. Dokument silnie akcentuje ideę upowszechnienia kształcenia wyższego i ustawicznego, która w XXI wieku nic nie straciła ze swej aktualności. Autorzy wskazali w raporcie trzy zasady, od których miały zależeć dalsze zmiany w edukacji. Zaliczono do nich powszechność oświaty, ustawiczność kształcenia oraz elastyczność organizacyjną, programową i metodyczną systemu edukacyjnego - w tym także szkolnictwa wyższego.

Wśród wytycznych obejmujących obszar szkolnictwa wyższego i ustawicznego raport wskazywał następujące obszary działalności edukacyjnej:

- możliwość uczenia się przez całe życie będąca bazą całościowej strategii oświatowej,

- usunięcie barier między różnymi typami, cyklami i szczeblami nauczania oraz między kształceniem formalnym i nieformalnym,

- zróżnicowanie kształcenia na poziomie szkolnictwa wyższego tak, aby można było spełnić coraz liczniejsze oczekiwania edukacyjne i rynku pracy,

- włączenie do programów nauczania środków masowego przekazu.

Źródłem raportu stały się dokumenty zebrane w ponad 20 krajach oraz materiały uzyskane w wyniku konsultacji przeprowadzonych z 13 międzynarodowymi organizacjami. Opublikowanie raportu przyczyniło się do ożywienia prac

13 Edgar Faure (1908-1988) - francuski polityk, premier, minister sprawiedliwości, przewodniczący Zgromadzenia Narodowego, członek Akademii Francuskiej. 
nad narodowymi systemami edukacyjnymi oraz zapoczątkowało okres reform i przemian w edukacji na świecie.

\section{Raporty Klubu Rzymskiego (1979 rok, 1991 rok)}

\section{Uczyć się bez granic. Jak zewrzeć lukę ludzką?}

Próba opisania i znalezienia rozwiązania problemów globalnych, z którymi przyszło się zmierzyć społeczeństwu drugiej połowy XX wieku, stała się inspiracją do powstania raportu edukacyjnego No Limits to Learning: Bridging the human gap ${ }^{14}$ (polskie tłumaczenie zatytułowane Uczyć się bez granic. Jak zewrzeć lukę ludzką? wydano w 1982 r.). Raport opracowało trzech autorów: James Botkin, Mircea Malitza i Mahdi Elmandjra, a powstał pod auspicjami Klubu Rzymskiego - międzynarodowej organizacji społeczno-ekonomicznej typu think tank zrzeszającej intelektualistów, naukowców, pisarzy, dziennikarzy, biznesmenów, polityków dostrzegających znaczenie globalnych problemów i zaniepokojonych brakiem mogących im zapobiec przedsięwzięć.

Ideą raportu było zwrócenie uwagi na dystans między rosnącą złożonością świata a zdolnością do jego postrzegania, który skutkuje naszym brakiem umiejętności rozumienia pojawiających się problemów. Raport wskazuje, że głównym źródłem ludzkich problemów jesteśmy my sami, czyli nasze słabości i możliwości. Zwraca uwagę, że postęp cywilizacyjny stanowi dla znacznej części społeczeństwa źródło frustracji wynikającej z uświadomienia braku własnych zdolności adaptacyjnych do skomputeryzowanej i stechnologizowanej rzeczywistości. Ten galopujący postęp i nasze braki związane z możliwością rozumienia zmian zostały określone w raporcie mianem „luki ludzkiej”. Zjawisko „luki ludzkiej” generowane jest przez nas samych, gdyż nie potrafimy w pełni zrozumieć powodowanych przez samych siebie zmian w środowisku naturalnym i społecznym, przez co coraz bardziej oddalamy się od aktualnego świata. Tak właśnie powstaje „luka ludzka”. Autorzy raportu zastanawiają się, czy taką lukę uda się zewrzeć, czyli zmniejszyć? Według nich w człowieku tkwią niewykorzystane pokłady zdolności twórczych oraz zasoby energii, które można zmobilizować, aby przeciwdziałać rozłamowi między postępującymi zmianami i brakiem rozumienia tych przemian. Sposobem na zmniejszenie „luki ludzkiej” ma być między innymi zmiana systemu edukacji z kształcenia podającego - na uczenie się innowacyjne,

14 http://www.elmandjra.org/limits.pdf. 
którego najważniejszymi elementami składowymi są: antycypacja (czyli przewidywanie) i partycypowanie (czyli uczestnictwo) ${ }^{15}$. Jak sugerują autorzy raportu, najlepszym sposobem na zmniejszanie „luki ludzkiej” jest więc uczenie się. Ta konkluzja została ujęta nawet w slogan i umieszczona jako hasło przewodnie raportu: Ucz się albo giń!!!

\section{Pierwsza rewolucja globalna. Jak przetrwać?}

W 1991 roku powstał kolejny raport Klubu Rzymskiego zatytułowany The First Global Revolution ${ }^{16}$ (polskie wydanie ukazało się w 1992 r.) ${ }^{17}$. Raport zwraca uwagę na konieczność przeprowadzenia zmian w podejściu do edukacji, gdyż problemy, przed którymi staje współczesny człowiek wymagają nowego podejścia do przekazywania wiedzy i zdobywania umiejętności. Zmiany edukacyjne stanowią nie tylko problem poszczególnych państw lub poszczególnych dziedzin oświaty, lecz mają charakter globalny.

Autorzy dokumentu Alexander King i Bertrand Schneider poszukują skutecznej systemowej strategii rozwiązywania cywilizacyjnych problemów. Metoda równoczesnego i wszechstronnego analizowania problemów została określona mianem „rezolutyki”. Rezolutyka to strategia rozwiązywania współczesnych problemów obejmująca wiele wątków problematyki światowej oraz uwzględniająca wzajemne sprzężenia zwrotne aspektów społecznych, demograficznych, politycznych, historycznych, ekonomicznych, ekologicznych itd.

Raport wskazuje, że za przygotowanie społeczeństwa do korzystania z tej strategii odpowiada cały system kształcenia, a szczególne znaczenie ma w tym procesie szkolnictwo wyższe. Głównym celem procesu kształcenia nie powinno być przekazywanie wiedzy, a zwrócenie uwagi na:

- kształtowanie inteligencji i umiejętności krytycznego myślenia,

- dobre poznanie samego siebie, swoich talentów i ograniczeń,

- opanowanie umiejętności komunikowania się i współżycia z innymi,

15 Uczenie antycypacyjne polega na nastawieniu się na przygotowanie do możliwych wydarzeń wymagających mobilizacji sił oraz nabycia umiejętności rozpatrywania długotrwałych wariantów działania. Uczenie partycypacyjne to nabyta w procesie edukacyjnym umiejętność współdziałania, wykorzystania dialogu, zdolność wczuwania się oraz nieustanne świadome weryfikowanie zasad działania i przyjętych wartości. W konsekwencji świadoma weryfikacja skutkuje selekcją i wyborem najbardziej optymalnych rozwiązań. http://www.geoengineeringwatch.org/documents/TheFirstGlobalRevolution_text.pdf.

17 A. King, B. Schnider, Pierwsza rewolucja globalna. Jak przetrwać?, Polskie Towarzystwo Współpracy z Klubem Rzymskim, Warszawa 2000. 
- stwarzanie warunków do ukształtowania własnego całościowego poglądu na świat i rozumienie zachodzących w nim zmian,

- rozwijanie umiejętności i zdolności do samodzielnego rozwiązywania nowych problemów.

\section{Biała księga Komisji Europejskiej (1995 rok)}

Biała księga ${ }^{18}$, publikacja Komisji Europejskiej dotycząca kształcenia i doskonalenia zatytułowana Teaching and Learning - Towards the learning society ${ }^{19}$ (Nauczanie i uczenie się. Na drodze do uczącego się spoleczeństwa $)^{20}$, powstała w 1995 roku z inicjatywy komisarza do spraw badań naukowych, wychowania i kształcenia Edit Cresson oraz komisarza do spraw zatrudnienia i spraw społecznych Padraiga Flynna. Źródłem dokumentu stały się nowe potrzeby i oczekiwania edukacyjne współczesnych społeczeństw wynikające z dynamicznych przemian cywilizacyjnych, rozwoju społeczeństwa informacyjnego oraz powszechnej dostępności do wiedzy naukowo-technicznej. Główną ideą proponowanych zmian w polityce oświatowej państw europejskich była koncepcja uczenia się przez całe życie prowadząca do budowy społeczeństwa ustawicznie uczącego się, w którym kluczową rolę miało pełnić szkolnictwo średnie i wyższe.

Autorzy białej księgi zwracali także uwagę, że postępujące zmiany w otaczającym nas świecie sprawiają, że rosną edukacyjne aspiracje społeczeństwa wynikające z pogoni za lepszą, bardziej interesującą i lepiej płatną pracą. Wysokie aspiracje bezpośrednio wpływają na nowe oczekiwania co do kształcenia realizowanego w ramach systemu oświaty. Najważniejszym oczekiwaniem wobec edukacji staje się więc odejście w szkolnictwie od realizowanego od wielu lat „przygotowania zawodowego” na rzecz skoncentrowania się na „rozwoju przydatności do zatrudnienia”. Rozwój przydatności do zatrudnienia wymusza kształtowanie:

- umiejętności podstawowych (akumulacja wiedzy, posiadane umiejętności oraz motywacja do dalszego uczenia się),

18 Biała księga (ang. White Papers) - nazwa dokumentu opracowywanego przez Komisję Europejską dotyczącego różnych szczególnie istotnych aspektów funkcjonowania Wspólnot. Zawiera oficjalne propozycje na temat kierunków zmian danej polityki wspólnotowej. Ma formę politycznej deklaracji - nie jest wiążąca dla Komisji ani adresatów tego dokumentu, lecz jej nieformalna waga skłania wszystkie strony do respektowania jej zapisów. http://europa.eu/documents/comm/white_papers/pdf/com95_590_en.pdf.

20 Biała księga Komisji Europejskiej: Nauczanie i uczenie się na drodze do uczącego się społeczeństwa, Wyższa Szkoła Pedagogiczna, Warszawa 1995. 
- umiejętności technicznych (wykorzystanie nowoczesnych technologii informatycznych, NTI),

- umiejętności społecznych (kreatywność, odpowiedzialność, współpraca, umiejętność komunikowania).

Biała księga zawierała także propozycje kierunków reform oświatowych, które miałyby zbliżyć systemy edukacyjne państw członkowskich Unii Europejskiej do aktualnych oczekiwań społecznych. Wśród priorytetów wskazano m.in. zwiększanie oferty szkolnictwa wyższego i edukacji ustawicznej, intensyfikowanie współpracy placówek edukacyjnych i przedsiębiorstw, zwiększanie staży edukacyjnych, zwiększanie wykorzystania programów edukacyjnych.

\section{Raport Jacquesa Delorsa (1996 rok)}

Raport został przygotowany dla UNESCO przez Międzynarodową Komisję ds. Edukacji dla XXI wieku. W składzie komisji, na czele której stanął Jacques Delors $^{21}$, znalazło się 14 osobistości, przedstawicieli kontynentów, kultur i religii. Raport zatytułowano Learning: the Treasure Within ${ }^{22}$ (Edukacja. Jest w niej ukryty skarb) ${ }^{23}$.

W raporcie analizowano zmiany, jakie zaszły na świecie od chwili opublikowania raportu E. Faure’a oraz wskazywano potencjalne nowe zjawiska, które miałyby wpływać na obraz przyszłości. Do nich zaliczono m.in. globalizację, dynamiczny rozwój krajów spoza cywilizacji zachodniej (zwłaszcza państw południowo-wschodniej Azji) oraz rewolucję informatyczną z dominującym znaczeniem środków przekazu, komunikowania się i informacji. Autorzy dokumentu podkreślali znaczenie edukacji, która powinna wspierać współtworzenie świata z poszanowaniem praw człowieka, przyczyniać się do eliminacji ubóstwa, wykluczenia społecznego i przeciwdziałania wszelkim przejawom przemocy. Ponadto wskazywali, że współczesna edukacja - w tym szkolnictwo wyższe - powinna być zbudowana i osadzona na czterech filarach:

- filar 1: uczyć się, aby żyć wspólnie (zaangażowanie w budowanie solidaryzmu społecznego, tolerancja i akceptacja dla inności, akceptacja pluralizmu),

- filar 2: uczyć się, aby wiedzieć (wiedza sama w sobie jako wartość naczelna, centralna o charakterze ogólnym, szerokoprofilowym),

21 Jacques Delors (1925-) - francuski ekonomista i polityk, minister finansów. Przez trzy kadencje (10 lat) pełnił funkcję przewodniczącego Komisji Europejskiej.

22 http://unesdoc.unesco.org/images/0010/001095/109590eo.pdf.

$23 \quad$ Edukacja. Jest w niej ukryty skarb, red. J. Delors, Wydawnictwo UNESCO, Warszawa 1998. 
- filar 3: uczyć się, aby działać (oznacza umiejętność wykorzystania naszej wiedzy w działaniu charakteryzującym się innowacyjnością, racjonalnością, komunikatywnością, zdolnością do pracy w zespole i odpornością na stres),

- filar 4: uczyć się, aby być (edukacja jako proces rozwoju jednostki prowadzący do uzyskania i potwierdzenia w codziennym życiu swojej tożsamości intelektualnej, zawodowej, społecznej i duchowej. Edukacja powinna troszczyć się o rozwój niezależnego myślenia, zdolności krytycznego osądu, uczuć i fantazji - bez tego światu grozi odhumanizowanie).

W raporcie, podejmującym próbę przedstawienia całościowej koncepcji edukacji, za największy problem oświaty europejskiego kręgu cywilizacyjnego uznano przygotowanie absolwentów szkół średnich do świadomej edukacji na poziomie szkolnictwa wyższego lub do podjęcia kształcenia umożliwiającego zdobycie kwalifikacji i uprawnień zawodowych.

\section{Proces boloński}

Proces boloński (ang. Bologna process) ${ }^{24}$ to całokształt działań podejmowanych przez państwa europejskie skierowanych na współpracę, koordynację i harmonizację systemów szkolnictwa wyższego. U podstaw prób wypracowania zharmonizowanego systemu szkolnictwa wyższego legły przede wszystkim przemiany społeczne, polityczne i gospodarcze ostatniej dekady XX wieku i pierwszego dziesięciolecia XXI wieku. Przełom wieków był dla Starego Kontynentu procesem największego w historii rozszerzenia Unii Europejskiej zakończonym przyjęciem 15 nowych państw, w tym Polski (2004 r.). Idea wspólnej Europy wiąże się nierozerwalnie z koncepcją jednolitego rynku UE, którego celem jest realizacja czterech zasad swobodnego przepływu: towarów, usług, kapitału i osób. Wśród powyższych zasad swobodny przepływ osób staje się kluczowym wyzwaniem w zapewnieniu jednakowego traktowania obywateli państw Unii, między innymi w dostępie do pracy, w zakresie wynagrodzenia oraz wszelkich innych warunków traktowania na wolnym rynku pracy. Chcąc zrealizować swobodę w zatrudnianiu pracowników z dowolnego państwa członkowskiego, konieczne jest zapewnienie ogólnoeuropejskiego systemu uznawania dyplomów i kwalifikacji zawodowych. Stąd proces boloński ujawnił konieczność ulepszenia systemu edukacji i dostosowania go do szybko zmieniających się warunków w Europie i na świecie.

24 http://ec.europa.eu/education/higher-education/bologna_en.htm. 
Właśnie w tym celu na początku lat dziewięćdziesiątych XX wieku podjęto kroki, by zreformować dotychczasowy system nauczania. Postawiono przede wszystkim na wzajemne zbliżenie i ujednolicenie systemu szkolnictwa wyższego, a także - zwiększenie mobilności zarówno uczących się, jak i wykładowców w państwach Unii.

\section{Deklaracja sorbońska i bolońska}

Początkiem wzajemnego zbliżania struktur i programów szkolnictwa wyższego państw członkowskich Unii Europejskiej było podpisanie w 1998 roku w gmachu paryskiej Sorbony przez ministrów edukacji Francji, Niemiec, Włoch i Wielkiej Brytanii wspólnej deklaracji sorbońskiej ${ }^{25}$. Dokument skupiał się na:

- poprawianiu międzynarodowej przejrzystości studiów i uznawaniu kwalifikacji dzięki stopniowemu zbliżaniu się do wspólnej ramowej struktury kwalifikacji i poziomów studiów,

- wspieraniu mobilności studentów i nauczycieli akademickich na obszarze europejskim oraz ich integracji z europejskim rynkiem pracy,

- stworzeniu wspólnego systemu tytułów dla studiów I stopnia (tytuł licencjata) i powyżej (tytuły magistra i doktora) ${ }^{26}$,

- wspieraniu mobilności studentów i nauczycieli akademickich na obszarze europejskim oraz ich integracji z europejskim rynkiem pracy,

- budowaniu jednolitego systemu tytułów dla studiów I stopnia (licencjat) i powyżej (magister, doktor).

Deklaracja sorbońska stała się podstawą przyjętej w 1999 roku deklaracji bolońskiej ${ }^{27}$, która zapoczątkowała wdrażanie tzw. systemu bolońskiego w krajach członkowskich. Deklaracja bolońska o Europejskim Obszarze Szkolnictwa Wyższego została podpisana przez ministrów odpowiedzialnych za szkolnictwo wyższe z 29 państw europejskich.

W deklaracji bolońskiej ministrowie potwierdzili swoje zamiary związane z:

- przyjęciem systemu łatwych do identyfikacji i porównywalnych tytułów. Obejmuje on wprowadzenie wspólnego suplementu do dyplomu mającego poprawić przejrzystość,

- wprowadzeniem systemu bazującego zasadniczo na dwóch głównych cyklach. Pierwszym (licencjackim), ukierunkowanym na rynek pracy i trwa-

25 http://www.accreditation.org/accords.php?page=SorbonneDeclaration.

26 http://www.eurydice.org.pl/sites/eurydice.org.pl/files/SWwE1.pdf.

27 http://ec.europa.eu/education/policies/educ/bologna/bologna.pdf. 
jącym co najmniej trzy lata, oraz drugim (magisterskim), wymagającym pomyślnego ukończenia cyklu pierwszego,

- ustanowieniem systemu punktów zaliczeniowych ECTS ${ }^{28}$, takich jak w programie Socrates-Erasmus gwarantującym zaliczanie studiów krajowych i zagranicznych do programu realizowanego przez studenta w macierzystej uczelni. Program ECTS ma na celu ujednolicenie sposobu studiowania w Europie, a tym samym prowadzi do pełnego uznawania okresu studiów odbywanych za granicą i w kraju,

- wspieraniem mobilności studentów, nauczycieli i pracowników naukowych. Pokonanie przeszkód na drodze do swobodnego przemieszczania się,

- promowaniem współpracy europejskiej w zakresie zapewniania jakości kształcenia,

- promowaniem wymiaru europejskiego w szkolnictwie wyższym przez zwiększenie liczby modułów oraz obszarów nauczania i badań, których tematyka, kierunek lub organizacja mają wymiar europejski.

Deklaracja stała się podstawowym dokumentem stosowanym przez państwa-sygnatariuszy przy tworzeniu ogólnej struktury modernizacji i reformowania europejskiego szkolnictwa wyższego. Od chwili podpisania dokumentu proces reform zaczął być nazywany procesem bolońskim.

Kolejnymi inicjatywami, które przyjęli ministrowie odpowiedzialni za szkolnictwo wyższe w celu rozwijania i uzupełniania idei procesu bolońskiego, były: komunikat praski (2001 r. $)^{29}$, komunikat berliński (2003 r.) ${ }^{30}$, komunikat z Bergen (2005 r.) $)^{31}$, komunikat londyński (2007 r. $)^{32}$, komunikat z Leuven (2009) ${ }^{33}$, komunikat z Bukaresztu (2012 r.) $)^{34}$. Wśród wskazywanych priorytetów i kierunków rozwoju procesu bolońskiego znalazły się m.in.: promowanie uczenia się przez całe życie, uznawanie tytułów i okresów studiów, opracowanie krajowych ram

28 Europejski System Transferu Punktów (European Credit Transfer System), jest systemem punktów zaliczeniowych stosowanym w szkołach wyższych Europejskiego Obszaru Szkolnictwa Wyższego, który obejmuje wszystkie kraje zaangażowane w proces boloński. W większości krajów biorących udział w procesie bolońskim ECTS wprowadzono do krajowych systemów szkolnictwa wyższego za pomocą odpowiednich aktów prawnych. http://ekspercibolonscy.org.pl/sites/ekspercibolonscy.org.pl/files/2001_PL_Prague.pdf. http://ekspercibolonscy.org.pl/sites/ekspercibolonscy.org.pl/files/2003_PL_Berlin.pdf. http://ekspercibolonscy.org.pl/sites/ekspercibolonscy.org.pl/files/2005_PL_Bergen.pdf . http://ekspercibolonscy.org.pl/sites/ekspercibolonscy.org.pl/files/2007_PL_London.pdf. http://ekspercibolonscy.org.pl/sites/ekspercibolonscy.org.pl/files/2009_PL_Leuven_Louvain-la-Neuve.pdf. 
kwalifikacji zgodnie z przyjętą ramową strukturą kwalifikacji Europejskiego Obszaru Szkolnictwa Wyższego, przyznawanie i uznawanie tytułów łączonych, ustanowienie Europejskiego Rejestru Agencji ds. Zapewnienia Jakości (European Quality Assurance Register for Higher Education, EQAR), upodmiotowienie studenta w procesie kształcenia, wzmacnianie powiązań pomiędzy edukacją, badaniami i innowacyjnością.

\section{Reformy i kierunki rozwoju szkolnictwa wyższego w Polsce}

\section{Okres II Rzeczypospolitej i drugiej wojny światowej (1918-1945)}

Polskie szkolnictwo wyższe, jego struktura organizacyjna, poziom nauczania, rola w rozwoju nauki, prestiż, zasięg oddziaływania zaczęły kształtować się na początku XX wieku. Po odzyskaniu niepodległości w 1918 roku polskie szkolnictwo wyższe zostało podporządkowane - podobnie jak cały system oświatowy II Rzeczypospolitej - Ministerstwu Wyznań Religijnych i Oświecenia Publicznego. Mimo takiego rozwiązania, szkolnictwo wyższe posiadało szeroką autonomię i uprawnienia samorządowe. Status szkół akademickich miało 10 państwowych uczelni - 5 uniwersytetów (Kraków, Lwów, Poznań, Warszawa, Wilno), 2 politechniki (Warszawa, Lwów), Akademia Medycyny we Lwowie, Szkoła Główna Gospodarstwa Wiejskiego w Warszawie i Akademia Górnicza w Krakowie, oraz 4 prywatne - Akademia Sztuk Pięknych w Krakowie, Katolicki Uniwersytet Lubelski, Wolna Wszechnica Polska oraz Wyższa Szkoła Handlowa w Warszawie. Z czasem liczba szkół wyższych powiększyła się, powstały np. Szkoła Inżynierska im. Hipolita Wawelberga i Stanisława Rotwanda w Warszawie, Państwowa Szkoła Techniczna w Wilnie, czy wyższe szkoły pedagogiczne m.in. w Katowicach, Krakowie, Kielcach. Odrębnie funkcjonowały wyspecjalizowane typy szkolnictwa wyższego, takie jak szkolnictwo artystyczne, wojskowe oraz szkolnictwo specjalne ${ }^{35}$.

W okresie drugiej wojny światowej polska oświata, w tym szkolnictwo wyższe, poniosły ogromne straty intelektualne i materialne. Duża część wykładowców zginęła w obozach koncentracyjnych, egzekucjach i mordach ulicznych oraz w wyniku działań wojennych. Największe straty poniosły ośrodki w Warszawie, Krakowie, Poznaniu, Lwowie i Wilnie. Wojna zniszczyła większość budynków szkół wyższych oraz instytutów badawczych, towarzystw i fundacji naukowych.

35 Ogromne zasługi na tym polu położyła Maria Grzegorzewska, autorka koncepcji programowej i organizatorka Państwowego Instytutu Pedagogiki Specjalnej kształcącego nauczycieli szkół specjalnych. 


\section{Okres PRL (1945-1989)}

Mimo zniszczeń wojennych, szkolnictwo wyższe i cały system oświaty od 1945 roku mozolnie odbudowywał swój stan posiadania. Wprowadzane zmiany wynikały z konieczności politycznej, gospodarczej, ale także i cywilizacyjnej. Od 1945 roku do czasu zmian ustrojowych w 1989 roku powstały w Polsce trzy raporty edukacyjne analizujące ówczesny stan szkolnictwa wszystkich szczebli, w tym także szkolnictwa wyższego. Były to: Raport o stanie oświaty w PRL z 1973 roku, Ekspertyza dotyczaca sytuacji i rozwoju oświaty w PRL z 1979 roku oraz Edukacja narodowym priorytetem z 1989 roku.

Pierwszym kompleksowym dokumentem dotyczącym stanu oświaty w Polsce - w tym szkolnictwa wyższego - był Raport o stanie oświaty $w$ PRL opublikowany w $1973 \mathrm{roku}^{36}$. Celem raportu było opracowanie diagnozy systemu edukacyjnego oraz zaproponowanie wariantowych sposobów jego udoskonalenia. Autorzy dokumentu za najważniejsze priorytety kształcenia wyższego uznali przygotowanie wysoko wykwalifikowanych kadr specjalistów, ich doskonalenie w toku działalności zawodowej oraz kształcenie kadr naukowych dla zadań szkoleniowych i badawczych. Proponowana struktura szkolnictwa wyższego miała zostać oparta na studiach wyższych zawodowych (2-3 lata) zakończonych pracą klauzurową i egzaminem dyplomowym, studiach wyższych magisterskich (4-6 lat) zakończonych pracą magisterską i egzaminem dyplomowym, studium naukowym (około 2 lat) przygotowującym do doktoratu i do pracy naukowo-badawczej oraz studiach podyplomowych (0,5-1,5 roku), których zadaniem byłoby aktualizowanie wiedzy, uzupełnianie, pogłębianie i rozszerzanie zakresu specjalizacji, realizując ideę kształcenia ustawicznego ${ }^{37}$.

Ostatni kompleksowy raport tuż przed przemianami ustrojowymi w Polsce w 1989 roku przygotował i opublikował 34-osobowy Komitet Ekspertów ds. Edukacji Narodowej (1987-1989). W obszernym dokumencie zatytułowanym Edukacja narodowym priorytetem ${ }^{38}$ przedstawiono trzy scenariusze reformy systemu edukacji, a mianowicie: stagnacji, ożywienia i rozwoju ${ }^{39}$. Między innymi w scenariuszu ożywienia, uzależnionym od nakładów z budżetu państwa na oświatę, które zakładano na poziomie powyżej 5\% PKB, postulowano wydłużenie obo-

36 Raport o stanie oświaty w PRL, Wydawnictwo Naukowe PWN, Warszawa 1973.

37 Tamże, s. 220-221.

38 Edukacja narodowym priorytetem, Wydawnictwo Naukowe PWN, Warszawa-Kraków 1989.

39 C. Kupisiewicz, O reformach szkolnych, Wydawnictwo Akademickie „Żak”, Warszawa 1999, s. 207-209. 
wiązku nauczania i upowszechnienie szkolnictwa średniego. Konsekwencją upowszechnienia szkoły średniej miała być także reforma szkolnictwa wyższego polegająca m.in. na zróżnicowaniu studiów na trzy cykle: zawodowy, magisterski i doktorski. Przy nakładach budżetowych na oświatę w wysokości około 10\% PKB planowano wdrożenie scenariusza rozwoju. Miałby on stać się źródłem powszechności, drożności, ustawiczności, elastyczności programowej i organizacyjnej systemu oświatowego, a szkolnictwo wyższe miałoby stać się bardziej dostępne dla absolwentów szkół średnich. Zakładano, że co najmniej 20\% maturzystów z każdego rocznika będzie miało możliwość podjęcia studiów zawodowych ${ }^{40}$. Na owe czasy zakładany 20-procentowy udział absolwentów szkół średnich w szkolnictwie wyższym uznawany był jako bardzo wysoki i świadczył o dużym zrozumieniu dla upowszechniania kształcenia wyższego.

\section{Okres III Rzeczypospolitej (od 1989 roku)}

W Polsce okres transformacji ustrojowej zbiegł się ze zjawiskami demokratyzacji, postępującej globalizacji i otwierania granic. Wzrost aspiracji edukacyjnych młodego pokolenia realizującego konstytucyjny obowiązek pobierania nauki do 18 roku życia, powszechny dostęp do informacji, powszechna szeroka oferta uczelni publicznych i niepublicznych sprawiły, że przełom wieków XX i XXI stał się momentem zwrotnym dla polskiego szkolnictwa wyższego. Parafrazując slogan raportu edukacyjnego Klubu Rzymskiego z 1979 roku „ucz się albo giń!!!”, hasło „zmień się albo giń” byłoby dobrym wyznacznikiem bezwzględnej konieczności zmian w polskim szkolnictwie wyższym. Potrzeba zmian była dobrze rozumiana i - co więcej - szczerze oczekiwana. Tak więc od okresu przemian ustrojowych polskie szkolnictwo wyższe wielokrotnie podejmowało próby dostosowania się do cywilizacyjnych wyzwań współczesności. Zmieniano rozwiązania organizacyjne i prawne. W strukturach ministerialnych pod względem organizacyjnym sektor szkolnictwa wyższego oraz nauki traktowany był czasami wspólnie, a czasami rozłącznie. Stąd przed 1989 rokiem różne resorty obejmowały te obszary swoją opieką. Były to Ministerstwo Oświaty (1944-1966), Ministerstwo Szkolnictwa Wyższego (1954-1966), Ministerstwo Oświaty i Szkolnictwa Wyższego (1967-1972), Ministerstwo Nauki, Szkolnictwa Wyższego i Techniki (19721984), Ministerstwo Nauki i Szkolnictwa Wyższego (1985-1987), a także Urząd Komitetu Badań Naukowych oraz Ministerstwo Nauki i Informatyzacji. Dzisiejsze

40 Tamże, s. 210. 
Ministerstwo Nauki i Szkolnictwa Wyższego (MNiSW) utworzono w 2006 roku. Wcześniej, w latach 2005-2006, problematyka nauki i szkolnictwa wyższego znajdowała się w Ministerstwie Edukacji i Nauki, a jeszcze wcześniej, w latach 2001-2005, w Ministerstwie Edukacji Narodowej i Sportu. Częste zmiany organizacyjne szczęśliwie nie wpływały na ugruntowaną pozycję nauki i szkolnictwa wyższego w polskim społeczeństwie. Wiele dziedzin nieźle radziło sobie także na międzynarodowym rynku nauki. Jednak wraz z wejściem w nowe tysiąclecie postępujące procesy globalizacji, powszechna dostępność wiedzy i łatwość wymiany doświadczeń oraz upowszechnienie kształcenia wyższego wymusiły dokonanie oceny i sformułowanie przyszłościowego programu dla sektora nauki i szkolnictwa wyższego. Masowość obowiązkowej edukacji trwającej do 18 roku życia oraz łatwość dostępu do placówek szkolnictwa wyższego (publiczne i niepubliczne) sprawiły, że upowszechnienie studiów wyższych stało się faktem. Te nowe okoliczności należało wnikliwie przeanalizować i na ich podstawie zaproponować przyszłościowy plan działania, uwzględniając nowe, cywilizacyjne oczekiwania społeczne.

W Polsce pod koniec pierwszej dekady XXI wieku pojawiło się kilka raportów, opracowań i pogłębionych analiz na temat aktualnej sytuacji oraz propozycji przeprowadzenia zmian w sektorze nauki i szkolnictwa wyższego.

Strategia rozwoju nauki w Polsce do 2015 roku

W czerwcu 2007 roku Ministerstwo Nauki i Szkolnictwa Wyższego (MNiSW) opublikowało dokument zatytułowany Strategia Rozwoju Kraju 2007-2015. Strategia rozwoju nauki $w$ Polsce do 2015 roku ${ }^{41}$. Została w nim zawarta ówczesna diagnoza stanu nauki i techniki w Polsce. Oceniono, że system nauki charakteryzuje się dużym rozdrobnieniem organizacyjnym i tematycznym, podziałami branżowymi (jednostki badawczo-rozwojowe, instytuty Polskiej Akademii Naukowej, uczelnie wyższe) oraz przewagą badań poznawczych nad badaniami przemysłowymi. Za cel nadrzędny strategii rozwoju nauki w Polsce do 2015 roku uznano wzrost międzynarodowej konkurencyjności polskiej nauki, który miał być realizowany przez: wzmocnienie współpracy nauki z gospodarką, poprawę ilościowego i jakościowego poziomu kadry naukowej, poprawę efektywności instytucji prowadzących i finansujących badania, rozwój infrastruktury naukowo-badawczej.

41 http://www.bip.nauka.gov.pl/_gAllery/20/48/2048/20070629_Strategia_Rozwoju_Nauki_w_ Polsce_do_2015.pdf. 
Misja, wizja i cele strategiczne szkolnictwa wyższego w Polsce w perspektywie 2020 roku

W listopadzie 2009 roku konsorcjum Instytut Badań nad Gospodarką Rynkową oraz Ernst\&Young Business Advisory przygotowało raport cząstkowy zatytułowany Misja, wizja i cele strategiczne szkolnictwa wyższego $w$ Polsce $w$ perspektywie $2020 \mathrm{roku}^{42}$. Autorzy raportu wskazali na szkolnictwo wyższe jako obszar polityki edukacyjnej mający ogromny wpływ na osiąganie narodowych celów społecznych i gospodarczych przez budowanie kapitału intelektualnego i społecznego kraju. Do najważniejszych funkcji szkolnictwa wyższego zaliczono kształcenie i prowadzenie badań naukowych.

W zakresie kształcenia wśród najważniejszych zadań wskazano m.in.:

- wyrabianie u studentów umiejętności samodzielnego zdobywania i uzupełniania wiedzy przez całe życie oraz krytycznego myślenia,

- pobudzanie kreatywności,

- wyrabianie umiejętności współpracy opartej na wzajemnym zaufaniu oraz umiejętności kierowania pracą zespołową,

- wyrabianie otwartości na świat i wrażliwości na kulturę.

W zakresie badań naukowych najważniejszą misją szkolnictwa wyższego miałoby być m.in.:

- prowadzenie badań naukowych motywowanych ciekawością poznawczą, jak i myślą o dobru wspólnym,

- przyswajanie wyników badań prowadzonych na świecie,

- popularyzowanie i upowszechnienie nauki.

Autorzy omawianego raportu wskazali sześć celów strategicznych, które powinny zostać osiągnięte w perspektywie 2020 roku. Wśród nich znalazły się: różnorodność, otwartość, mobilność, konkurencja, efektywność, rozliczalność i przejrzystość. Poniżej przedstawiono krótką charakterystykę powyższych celów strategicznych:

- różnorodność - zwiększona dywersyfikacja instytucji szkolnictwa wyższego. Wyodrębnienie grup uczelni (lub ich jednostek) z zastosowaniem odmiennych kryteriów akredytacji i ewaluacji oraz dostosowaniem programów kształcenia do ich zróżnicowanej misji,

42 http://www.nauka.gov.pl/fileadmin/user_upload/Finansowanie/fundusze_europejskie/PO_ KL/Projekty_systemowe/20100727_Etap_2_misja_wizja_cele_strategiczne_SW.pdf. 
- otwartość - upowszechnienie wyższego wykształcenia, otwarcie uczelni na potrzeby edukacyjne różnych środowisk społecznych i gospodarczych oraz grup wiekowych (np. pracodawcy, osoby tzw. trzeciego wieku),

- mobilność - przygotowanie studentów do funkcjonowania w globalnej społeczności. W ramach mobilności instytucjonalnej nauczyciele akademiccy zatrudniani są w innej uczelni niż w tej, którą ukończyli, w której zdobyli stopień naukowy lub doświadczenie badawcze i stopnie naukowe,

- konkurencja - wprowadzenie obiektywnych zasad finansowania kształcenia i badań sprzyjających podnoszeniu jakości i efektywności. Badania naukowe finansowane są ze środków publicznych na podstawie ewaluacji dokonywanej według międzynarodowych standardów, z udziałem zagranicznych ekspertów,

- efektywność - zarządzanie uczelniami musi odbywać się z wysoką dbałością o jakość badań i kształcenia. Organizacja uczelni powinna w sposób elastyczny zostać dostosowana do zmieniających się uwarunkowań ekonomicznych, technologicznych i postępu nauki,

- rozliczalność i przejrzystość - rozliczalność z wydatkowania środków pochodzących z budżetu państwa, sponsorów i studentów oraz przejrzystość zarządzania działalnością uczelni.

Strategia rozwoju szkolnictwa wyższego w Polsce do 2020 roku drugi wariant

Kolejnym raportem autorstwa konsorcjum Instytutu Badań nad Gospodarką Rynkową oraz Ernst\&Young Business Advisory był dokument zatytułowany Strategia rozwoju szkolnictwa wyższego $w$ Polsce do 2020 roku - drugi wariant ${ }^{43}$. W opracowanym raporcie wzięto pod uwagę opinie środowisk akademickich, młodzieży, studentów, przedsiębiorców i samorządowców w sprawie kierunku rozwoju polskiego szkolnictwa wyższego.

Dokument składa się z trzech części. Część pierwsza opisuje czynniki wpływające na możliwość wdrożenia niezbędnych zmian. Omówiono tu zarówno czynniki wewnętrzne (aktualny stan i problemy szkolnictwa wyższego), jak i czynniki zewnętrzne (uwarunkowania ekonomiczne, demograficzne, prawne i społeczno-polityczne). W części drugiej zaprezentowano proponowane strategie rozwo-

43 http://www.nauka.gov.pl/fileadmin/user_upload/Finansowanie/fundusze_europejskie/PO_ KL/Projekty_systemowe/20100727_Strategia_rozwoju_SW_w_Polsce_do_2020_roku_war_2. pdf. 
ju szkolnictwa wyższego do 2020 roku, a wśród nich wskazano następujące cele strategiczne:

- zwiększenie różnorodności uczelni i programów studiów,

- większe otwarcie uczelni na ich otoczenie społeczne i gospodarcze,

- zwiększenie mobilności kadry akademickiej i studentów,

- wzmocnienie efektywności wykorzystania zasobów uczelni44.

W części trzeciej dokumentu omówiono najważniejsze uwarunkowania dotyczące realizacji strategii - harmonogram, ramy prawne oraz zagadnienia finansowe.

Wśród innych dostępnych dokumentów i raportów cząstkowych, które miały służyć diagnozie i opracowaniu kierunków zmian w polskim systemie szkolnictwa wyższego można wskazać między innymi następujące opracowania ${ }^{45}$ :

- Uwarunkowania przyszłego rozwoju szkolnictwa wyższego w Polsce: globalizacja, demografia i zmiany społeczno-gospodarcze w Polsce,

- Analiza zadań i celów strategicznych szkolnictwa wyższego wynikających z krajowych dokumentów strategicznych ${ }^{46}$,

- Diagnoza stanu szkolnictwa wyższego w Polsce ${ }^{47}$,

- Raport z konsultacji instytucjonalnych Strategii rozwoju szkolnictwa wyższego $w$ Polsce do roku $2020^{48}$.

Analiza przygotowanych raportów miała ułatwić podjęcie próby opisania aktualnego stanu polskiego szkolnictwa wyższego. Do osiągnięć należy zaliczyć: gęstą sieć uczelni na terenie kraju, wysoki współczynnik skolaryzacji w grupie wiekowej 20-29 lat, postępy we wdrażaniu procesu bolońskiego, wysoki prestiż wykładowcy akademickiego, rozpoznawalne na świecie osiągnięcia badawcze w kilku dyscyplinach. Wśród słabych stron polskiego szkolnictwa wyższego znalazły się: brak strategicznego zarządzania uczelniami, brak motywacyjnego systemu

44 Tamże, s. 5.

45 Wszystkie dokumenty znajdują się na stronie internetowej MNiSW, http://www.nauka.gov. pl/finansowanie/fundusze-europejskie/program-operacyjny-kapital-ludzki/projekty-systemowe/strategia-rozwoju-sw-do-roku-2020.

46 http://www.nauka.gov.pl/fileadmin/user_upload/Finansowanie/fundusze_europejskie/ PO_KL/Projekty_systemowe/20100727_Etap_2_analiza_zadan_i_celow_SW_wynikajacych_z_ krajowych_dokumentow_strategicznych.pdf.

47 http://www.nauka.gov.pl/fileadmin/user_upload/Finansowanie/fundusze_europejskie/PO_ KL/Projekty_systemowe/20100727_Diagnoza_stanu_SW.pdf.

48 http://www.nauka.gov.pl/fileadmin/user_upload/Finansowanie/fundusze_europejskie/PO_ KL/Projekty_systemowe/20100727_Raport_z_konsultacji_instytucjonalnych_Strategii_rozwoju_SW_w_Polsce_do_2020.pdf. 
wynagradzania, który sprzyjałby podnoszeniu edukacyjnej jakości, niska jakość kształcenia na popularnych kierunkach studiów i na studiach niestacjonarnych, niska produktywność naukowa. Taki właśnie stan polskiego szkolnictwa wyższego ostatnich dwóch dekad przełomu wieków XX i XXI poddano próbie zmiany.

\section{Ustawa z 18 marca 2011 r. o szkolnictwie wyższym}

W dniu 18 marca 2011 r. przyjęto ustawę o zmianie ustawy - Prawo o szkolnictwie wyższym, ustawy o stopniach naukowych i tytule naukowym oraz o stopniach i tytule w zakresie sztuki oraz o zmianie niektórych innych ustaw. Prezydent RP nowelizację ustaw reformujących szkolnictwo wyższe podpisał 5 kwietnia $2011 \mathrm{roku}^{49}$.

Wcześniej ustawa z 27 lipca 2005 r. - Prawo o szkolnictwie wyższym (Dz.U. nr 164, poz. 1365, ze zm.) ${ }^{50}$ zastąpiła trzy ustawy: ustawę z 31 marca 1965 r. o wyższym szkolnictwie wojskowym, ustawę z 12 września 1990 r. o szkolnictwie wyższym (Dz.U. nr 65, poz. 385, ze zm.) ${ }^{51}$ oraz ustawę z 26 czerwca $1997 \mathrm{r}$. o wyższych szkołach zawodowych (Dz.U. nr 96, poz. 590, ze zm.) ${ }^{52}$.

Ustawa z 18 marca 2011 r. weszła w życie w dniu 1 października 2011 r. W tym dniu weszła też w życie znaczna część przepisów wykonawczych. W uzasadnieniu projektu rządowego podkreślono, że zaproponowane zmiany legislacyjne wynikają z potrzeby dostosowania polskiego systemu szkolnictwa wyższego do bezprecedensowego wzrostu skali zadań, jakie czekają na podjęcie w tym systemie. Priorytetem szkolnictwa wyższego staje się podniesienie jakości studiów. Zaproponowane zmiany mają służyć wdrożeniu głównych założeń deklaracji bolońskiej. Wdrożenie przedstawionych zmian systemowych ma na celu zapew-

49 Niniejszą ustawą zmieniono: ustawę z 26 lipca 1991 r. o podatku dochodowym od osób fizycznych, ustawę z 20 czerwca 1992 r. o uprawnieniach do ulgowych przejazdów środkami publicznego transportu zbiorowego, ustawę z 5 grudnia 1996 r. o zawodach lekarza i lekarza dentysty, ustawę z 17 lipca 1998 r. o pożyczkach i kredytach studenckich, ustawę z 7 października 1999 r. o języku polskim, ustawę z 24 maja 2002 r. o Agencji Bezpieczeństwa Wewnętrznego oraz Agencji Wywiadu, ustawę z 20 kwietnia 2004 r. o Narodowym Planie Rozwoju, ustawę z 9 czerwca 2006 r. o Centralnym Biurze Antykorupcyjnym, ustawę z 9 czerwca 2006 r. o Służbie Kontrwywiadu Wojskowego oraz Służbie Wywiadu Wojskowego, ustawę z 18 października 2006 r. o ujawnianiu informacji o dokumentach organów bezpieczeństwa państwa z lat 1944-1990 oraz treści tych dokumentów, ustawę z 10 kwietnia 2010 r. o zasadach finansowania nauki i ustawę z 10 kwietnia 2010 r. o Polskiej Akademii Nauk.

50 http://static1.money.pl/d/akty_prawne/pdf/DU/1965/14/DU19650140102.pdf.

51 http://isap.sejm.gov.pl/DetailsServlet?id=WDU19900650385.

52 http://isap.sejm.gov.pl/DetailsServlet?id=WDU19970960590. 
nienie polskim studentom wyższej jakości ksztatcenia, a zatem lepszego przygotowania do dynamicznie zmieniających się warunków gospodarczych, polskim uczonym stworzenie szans szerszego uczestnictwa $w$ największych międzynarodowych przedsięwzięciach badawczych, a polskim uczelniom stworzenie perspektywy systematycznego rozwoju i stałego powiększania potencjału badawczo-dydaktycznego $0^{53}$.

W obszarze zarządzania i organizacji pracy uczelni nowelizacja ustawy - Prawo o szkolnictwie wyższym wzmocniła kompetencje rektora, nakładając jednocześnie na niego nowe obowiązki, chociażby takie, jak opracowanie i realizację strategii rozwoju uczelni (art. 66. ust. 1a.). Wprowadzono także zakaz wielokadencyjności. Zgodnie z art. 77 ust 2. i 2a w uczelni publicznej rektor, prorektor, kierownik podstawowej jednostki organizacyjnej i jego zastępca nie mogą być wybierani do pełnienia tej samej funkcji na więcej niż dwie następujące po sobie kadencje. W uczelni publicznej ta sama osoba nie może być członkiem senatu lub członkiem konwentu dłużej niż dwie następujące po sobie kadencje. Nie dotyczy to osób wchodzących w skład senatu lub konwentu w związku z pełnieniem funkcji organu jednoosobowego uczelni.

Nowelizacja wprowadziła zmiany w obszarze kompetencji, trybu działania i relacji Polskiej Komisji Akredytacyjnej (PKA) z uczelniami. W zakresie warunków realizacji przebiegu studiów nowym rozwiązaniem jest możliwość samodzielnego tworzenia programów kształcenia przez jednostki mające uprawnienia habilitacyjne.

Zgodnie z ustawą z 18 marca 2011 r. uczelnie m.in. mają prawo używać w swoich nazwach następujących określeń w zależności od posiadanych uprawnień:

- uniwersytet - uprawnienia do nadawania stopnia naukowego doktora w co najmniej 10 dyscyplinach, w tym co najmniej po 2 uprawnienia w każdej z następujących grup dziedzin nauki:

- humanistycznych, prawnych, ekonomicznych lub teologicznych,

- matematycznych, fizycznych, nauk o Ziemi lub technicznych,

- biologicznych, medycznych, chemicznych, farmaceutycznych, rolniczych lub weterynaryjnych,

- uniwersytet techniczny - uprawnienia do nadawania stopnia naukowego doktora w co najmniej 10 dyscyplinach, w tym co najmniej 6 uprawnień w zakresie nauk technicznych,

53 H. Izdebski, J. Zieliński, Prawo o szkolnictwie wyższym. Ustawa o stopniach naukowych i tytule naukowym, Wolters Kluwer Polska, Warszawa 2011, s. 12. 
- uniwersytet uzupełniony przymiotnikiem w celu określenia profilu - co najmniej 6 uprawnień do nadawania stopnia naukowego, w tym co najmniej 4 uprawnienia w dziedzinach objętych profilem uczelni,

- politechnika - uprawnienia do nadawania stopnia naukowego doktora w co najmniej 6 dyscyplinach, w tym co najmniej 4 uprawnienia w zakresie nauk technicznych,

- akademia - co najmniej 2 uprawnienia do nadawania stopnia naukowego doktora.

\section{Dalsze zmiany prawa o szkolnictwie wyższym}

Reforma szkolnictwa wyższego, która weszła w życie 1 października 2011 roku. rozpoczęła proces zmian w obszarze podniesienia jakości studiów oraz zarządzania i organizacji pracy uczelni. Planowane są kolejne nowelizacje umożliwiające m.in. otwarcie uczelni na kształcenie ustawiczne, polepszenie jakości studiów oraz zwiększenie szans absolwentów na rynku pracy. W tej sprawie 21 maja 2013 roku rząd przyjął projekt założeń projektu ustawy o zmianie ustawy - Prawo o szkolnictwie wyższym oraz niektórych innych ustaw ${ }^{54}$. Wśród najważniejszych propozycji nowych rozwiązań znalazły się m.in.:

- ułatwienie dostępu do studiów wyższych osobom dojrzałym ${ }^{55} \mathrm{w}$ ramach uczenia się przez całe życie - proponowany przepis daje uczelniom możliwość potwierdzania efektów kształcenia uzyskanych poza systemem szkolnictwa wyższego, np. w pracy, na kursach, szkoleniach, w ramach wolontariatu. Po weryfikacji wiedzy i umiejętności uczelnie będą mogły zaliczyć je do dorobku studenta, który będzie mógł być zwolniony z części zajęć. W ten sposób skróci się okres odbywania studiów lub ograniczy liczbę zajęć,

- zróżnicowanie uczelni na dwa typy ${ }^{56}$ : zawodowe (bez prawa nadawania stopnia doktora) i akademickie (z prawem nadawania stopnia doktora). Uczelnie zawodowe mają skoncentrować się na kształceniu praktycznym przygotowującym absolwentów do rynku pracy. Uczelnie akademickie będą mogły prowadzić zarówno studia ogólnoakademickie, jak i praktyczne,

54 http://bip.kprm.gov.pl/portal/kpr/115/2126/Porzadek_obrad_Rady_Ministrow_rok_2013.html.

55 http://www.nauka.gov.pl/ministerstwo/aktualnosci/aktualnosci/artykul/rzad-przyjal-zalozenia-nowelizacji-prawa-o-szkolnictwie-wyzszym.

56 Tamże. 
- możliwość prowadzenia wspólnych studiów interdyscyplinarnych ${ }^{57} \mathrm{w}$ ramach tej samej uczelni oraz między uczelniami. Daje to możliwość łączenia odmiennych dyscyplin naukowych na jednym kierunku studiów,

- wprowadzenie skuteczniejszej walki z plagiatami prac dyplomowych i naukowych ${ }^{58}$.Za pracę dyplomową można będzie uznać nie tylko klasyczną pracę pisemną, ale również opublikowany artykuł, wykonane prace projektowe, konstrukcyjne, technologiczne lub artystyczne.

\section{Zakończenie}

Świat przełomu wieków XX i XXI to świat zdominowany przez procesy globalizacji oraz postępującej uniwersalizacji życia. Najbardziej charakterystyczną cechą współczesnej cywilizacji stała się powszechność i łatwość dostępu do informacji. Ułatwienie dostępu do wiedzy z jednej strony dało poczucie szybkiego, łatwego i powszechnego dostępu do wykształcenia, a z drugiej - chaosu informacyjnego wywołanego nadmiarem danych. Zatem przekazywanie wiedzy, które do tej pory było najważniejszym zadaniem szkolnictwa, należało zweryfikować w kontekście nowych wyzwań zmienionej rzeczywistości społeczno-gospodarczej. Trudno nie zauważyć, że w tak zmieniającym się świecie odpowiedzią systemu edukacyjnego na rosnące potrzeby i oczekiwania społeczne stało się upowszechnienie systemu oświaty nie tylko na poziomie podstawowym, ale przede wszystkim na szczeblu szkoły średniej i wyższej. o powszechności szkolnictwa wyższego, jego źródłach i konsekwencjach mówiono i pisano już na przełomie lat sześćdziesiątych i siedemdziesiątych XX wieku. Był to okres, który w literaturze przedmiotu nazwano okresem eksplozji szkolnej, a w przypadku szkolnictwa wyższego - eksplozji zapisów ${ }^{59}$. Analizy, ekspertyzy i raporty edukacyjne w Polsce i na świecie podobnie definiowały i wskazywały potrzeby edukacyjne zmieniającej się rzeczywistości. W tym kontekście szkolnictwo wyższe od najdawniejszych czasów do współczesności starało się spełniać społeczne oczekiwania. Miejmy nadzieję, że wysiłki międzynarodowych oraz krajowych instytucji naukowych i oświatowych dobrze zostaną wykorzystane w procesie reformowania szkolnictwa wyższego dla potrzeb rozwoju cywilizacyjnego współczesnych społeczeństw.

57 Tamże.

58 Tamże.

59 C. Kupisiewicz, O reformach szkolnych, Wydawnictwo Akademickie „Żak”, Warszawa 1999, s. 151. 


\section{Bibliografia}

Biała księga Komisji Europejskiej: Nauczanie i uczenie się na drodze do uczącego się społeczeństwa, Wyższa Szkoła Pedagogiczna, Warszawa 1995.

Chałupka M., Prawo o szkolnictwie wyższym z komentarzem, seria „Biblioteka Dziennika Gazety Prawnej”, Infor Biznes, Warszawa 2011.

Edukacja. Jest w niej ukryty skarb, red. Delors J., Wyd. UNESCO, Warszawa 1998.

Edukacja narodowym priorytetem, Państwowe Wydawnictwo Naukowe, Warszawa-Kraków 1989.

Efektywność funkcjonowania zachodnioeuropejskich instytucji akademickich, red. Morawski R.Z., Instytut Spraw Publicznych, Warszawa 1999.

Encyklopedia Pedagogiczna XXI wieku, t. VI, Wydawnictwo Akademickie „Żak”, Warszawa 2007.

Haliżak E., Kuźniar R., Symonides J., Globalizacja a stosunki międzynarodowe, Oficyna Wydawnicza Branta, Bydgoszcz-Warszawa 2004.

Illich I., Społeczeństwo bez szkoły, Państwowy Instytut Wydawniczy, Warszawa 1976.

Izdebski H., Zieliński J., Prawo o szkolnictwie wyższym. Ustawa o stopniach naukowych i tytule naukowym, Wolters Kluwer Polska, Warszawa 2011.

King A., Schnider B., Pierwsza rewolucja globalna. Jak przetrwać?, Polskie Towarzystwo Współpracy z Klubem Rzymskim, Warszawa 2000.

Kupisiewicz C., Koncepcje reform szkolnych $w$ latach osiemdziesiatych, Państwowe Wydawnictwo Naukowe, Warszawa 1991.

Kupisiewicz C., O reformach szkolnych, Wydawnictwo Akademickie „Żak”, Warszawa 1999. McGrew A., Conceptualizing Global Politics, [w:] Global Politics: Globalization and the Nation-State, red. McGrew A., Lewis P., Polity Press, Cambridge 1992, s. 28.

Stachowiak-Kudła M., Autonomia szkół wyższych a instytucjonalne mechanizmy zapewnienia jakości w Polsce i wybranych państwach Europejskich, Difin, Warszawa 2012.

Stiglitz J.E., Globalizacja, PWN, Warszawa 2004.

Szymański W., Interesy i sprzeczności globalizacji, Difin, Warszawa 2004.

Zacher L.W., Spór o globalizację, Komitet Prognoz Polska 200 Plus.

\section{Akty prawne}

Ustawa z 18 marca 2011 r. o zmianie ustawy - Prawo o szkolnictwie wyższym, ustawy o stopniach naukowych i tytule naukowym oraz o stopniach i tytule w zakresie sztuki oraz o zmianie niektórych innych ustaw, Dz.U. nr 84, poz. 455, ze zm., Dz.U. nr 112, poz. 654 . 


\title{
1.5. System szkolny Finlandii
}

\author{
School system of Finland
}

W opracowaniu przedstawiono informacje na temat systemu edukacyjnego Finlandii. Analizie poddano administrację szkolną, finansowanie oświaty oraz organizację systemu szkolnictwa.

Słowa kluczowe: edukacja, system szkolny, Finlandia

The paper presents information on the Finnish education system. The analysis covered the school administration, financing of education and organization of the education system.

Keywords: education, school system, Finland

\section{Podstawowe informacje. Administracja szkolna}

Finlandia (fiń. Suomi, Suomen Tasavalta; szw. Finland, Republiken Finland) jest republiką opartą na systemie demokracji parlamentarno-gabinetowej. Głową państwa jest prezydent wybierany w wyborach powszechnych na sześcioletnią kadencję. Władza ustawodawcza należy do jednoizbowego Parlamentu (Eduskunta) wybieranego na czteroletnią kadencję. Władzę wykonawczą sprawuje rząd (Valtioneuvosto) powoływany przez prezydenta. Językami urzędowymi są fiński i szwedzki. Administracyjnie Finlandia składa się z 20 regionów, które podzielone są na 72 podregiony, a te na 342 gminy.

Sprawy oświaty ${ }^{1}$ znajdują się w kompetencji jednego Ministerstwa Edukacji i Kultury kierowanego przez dwóch ministrów. Za problematykę oświatową odpowiada Minister Edukacji i Nauki, a za sprawy kultury Minister Kultury i Sportu. Prace obu pionów ministerstwa koordynuje Stały Sekretarz.

1 Opracowanie przygotowano na podstawie ekspertyzy Biura Analiz Sejmowych nr 2731/13 z 15 listopada 2013 r. D. Dziewulaka zatytułowanej Informacja na temat systemu edukacyjnego Finlandii. 
Podstawowym aktem prawnym dla fińskiej oświaty jest ustawa o kształceniu obowiązkowym ${ }^{2}$. System edukacji w Finlandii jest zdecentralizowany. Przepisy dotyczące administrowania i zarządzania szkołami zawarte zostały w ustawie o samorządzie lokalnym³ ${ }^{3}$. Osobą bezpośrednio odpowiedzialną za funkcjonowanie szkoły jest jej dyrektor. Sposób organizacji kształcenia w placówce określają przepisy przyjęte przez radę szkoły.

Za kształtowanie polityki oświatowej w Finlandii odpowiada rząd i parlament. Wdrażaniem tej polityki na poziomie centralnym zajmują się rząd, Ministerstwo Edukacji i Kultury ${ }^{4}$ oraz Fiński Krajowy Urząd ds. Edukacji (Finnish National Board of Education). Działania ministerstwa wspierają następujące instytucje: Rada ds. Edukacji Dorosłych, Fińska Rada Szkolnictwa Wyższego oraz utworzona w 2003 roku Fińska Rada ds. Ewaluacji Edukacji (Finnish Education Evaluation Council) $)^{5}$, której zadaniem jest opracowywanie planu zewnętrznej ewaluacji zgodnie z wytycznymi Ministerstwa Edukacji i Kultury.

\section{Wydatki na oświatę}

Budżet Ministerstwa Edukacji i Kultury na 2013 rok wynosił 6,6 mld euro, czyli około $12 \%$ budżetu państwa (54,1 mld euro) ${ }^{6}$. Ze środków resortu na oświatę przeznaczono 5 mld euro. Pozostałe 1,7 mld euro skierowane są na kulturę i sport.

Poniżej przedstawiono szacunkową strukturę wydatków na oświatę:

- szkolnictwo ogólnokształcące (podstawowe + licea) . . 1000000 mln euro

- szkolnictwo zawodowe . . . . . . . . . . . . . . . . . . 0,73 mln euro

- oświata dorosłych . . . . . . . . . . . . . . . . 0,53 mln euro

- szkolnictwo wyższe i badania naukowe . . . . . . . . . 2800000 mln euro

\section{Organizacja systemu szkolnictwa w Finlandii}

Obowiązek szkolny w Finlandii trwa 9 lat. Kształcenie jest obowiązkowe od 7 do 16 roku życia. Uczniowie muszą rozpocząć kształcenie obowiązkowe w roku,

2 http://www.finlex.fi/en/laki/kaannokset/1998/en19980628.pdf.

3 https://www.finlex.fi/fi/laki/kaannokset/2015/en20150410.pdf.

4 http://www.minedu.fi/OPM.

5 http://www.edev.fi/portal/english5.

6 Na podstawie notatki informacyjnej Ambasady RP w Helsinkach z 12 listopada $2013 \mathrm{r}$.

7 W Finlandii w 2012 r. wydatki na oświatę stanowiły 6,4\% PKB (średnia dla państw OECD 6,2\%), http://www.oecd.org/edu/EAG2012 - Key Facts - Finland.pdf. 
w którym przypadają ich siódme urodziny. Około 1\% dzieci rozpoczyna naukę w szkole wcześniej, lecz wymaga to uzyskania zaświadczenia potwierdzającego dojrzałość szkolną dziecka. W Finlandii rodzice mogą zażądać odroczenia przyjęcia swojego dziecka do szkoły podstawowej na podstawie wyników testów psychologicznych, a jeśli to niezbędne - lekarskich, które wykażą, że dziecko nie jest pod względem psychicznym lub fizycznym gotowe do podjęcia nauki w szkole. Testy może przeprowadzić wybrany przez rodziców lekarz, psycholog lub pracownik szkoły bądź samorządu. Wyniki testów są dla szkoły wiążące.

W Finlandii szkolnictwo obowiązkowe jest w całości bezpłatne. Władze lokalne przydzielają każdemu dziecku miejsce w szkole znajdującej się w pobliżu jego miejsca zamieszkania, ale rodzice mogą wybrać szkołę powszechną zgodnie ze swymi preferencjami ${ }^{8}$.

\section{Schemat systemu edukacji w Finlandii}

Na strukturę fińskiego ustroju szkolnego składają się:

- żłobki i przedszkola,

- klasa zerowa,

- szkoła podstawowa,

- szkoła średnia,

- szkolnictwo wyższe.

\section{Żłobki i przedszkola}

Nieobowiązkowa opieka i edukacja realizowana w ramach żłobków i przedszkoli przeznaczona jest dla dzieci od chwili narodzin do 5 roku życia.

\section{Klasa zerowa}

Przedpoczątkowa edukacja realizowana w przedszkolach. Bezpłatną, nieobowiązkową opieką klas zerowych objęte są dzieci w wieku 6-7 lat. Z tej formy edukacji korzysta 96\% sześciolatków.

8 D. Dziewulak, Obowiązek szkolny w Unii Europejskiej, „Analizy BAS” 2010, nr 9(34), http:// parl.sejm.gov.pl/WydBAS.nsf/0/A4F8763AAD6E8E70C12576EE0029DFE9/\$file/Analiza_\%20 BAS_2009_34.pdf. 


\section{Szkoła podstawowa}

Jednolita, obowiązkowa, bezpłatna ogólnokształcąca szkoła podstawowa (peruskoulu) przeznaczona dla uczniów od 7 do 16 roku życia. Nauka trwa 9 lat. Szkoła podstawowa może również obejmować fakultatywny dziesiąty rok nauki przeznaczony dla tych uczniów, którzy nie dostali się do szkół średnich i pomimo ukończenia obowiązkowej nauki pragną uzupełnić wiedzę oraz poprawić wyniki w nauce potrzebne do ubiegania się o przyjęcie do szkół średnich.

\section{Szkoła średnia}

Nieobowiązkowa szkoła średnia przeznaczona dla uczniów od 16 do 19 roku życia. Po uzyskaniu świadectwa ukończenia szkoły podstawowej ponad $90 \%$ absolwentów peruskoulu kontynuuje naukę na szczeblu szkolnictwa średniego, z czego ponad 60\% kontynuuje naukę w trzyletnich ogólnokształcących szkołach średnich (Lukio), a 40\% w trzyletnich lub czteroletnich szkołach zawodowych. Charakterystyczną cechą szkół średnich jest realizowanie procesu dydaktycznego w formie kursów oferujących indywidualny tryb nauczania. Ogółem kursów jest 75, z czego około 50 to kursy obowiązkowe, a pozostałe to zajęcia fakultatywne, uzupełniające lub profilowane. Program nauczania zaplanowany jest do wykonania w ciągu 3 lat, jednakże można go zaliczyć w ciągu 2 lub 4 lat. Rok szkolny dzieli się na 5-6 cykli, podczas których uczniowie przyswajają program z kilku przedmiotów. Uczniowie muszą sami zadbać o zaliczenie wystarczającej liczby kursów. Nie ma rejonizacji, a przyjęcia do szkół odbywają się w procesie elektronicznego konkursu ocen uzyskanych na świadectwie ukończenia szkoły podstawowej. Egzaminy maturalne organizowane są wiosną i jesienią każdego roku. Uczniowie mogą zdawać maturę za jednym razem lub rozłożyć egzaminy na trzy następujące kolejno po sobie sesje egzaminacyjne. Nauka w średniej szkole zawodowej trwa 3 lata i kończy się egzaminem w zakresie podstawowych umiejętności zawodowych uprawniających do ubiegania się o miejsce w wyższych szkołach zawodowych i uniwersytetach. Praktyka zawodowa trwa około 5 miesięcy. Niektóre szkoły zawodowe przygotowują równocześnie do egzaminu maturalnego w zakresie liceum ogólnokształcącego - wówczas nauka w nich trwa do 4 lat. 


\section{Szkolnictwo wyższe}

W ramach szkolnictwa wyższego działają uniwersytety i wyższe szkoły zawodowe.

Uniwersytety od 2010 roku działają jako niezależne instytucje prawa publicznego lub fundacje podlegające prawu cywilnemu. Przykładowo jako fundacje działają: Uniwersytet Technologiczny w Tampere oraz Uniwersytet im. Alvara Aalto (Helsinki, Espoo), który powstał w wyniku fuzji Politechniki, Wyższej Szkoły Wzornictwa Przemysłowego i Wyższej Szkoły Handlowej. Obydwie uczelnie samodzielnie poszukują środków finansowych na działalność w sektorze prywatnym. Dotacja państwowa to 2,5-krotność kwoty uzyskanej ze źródeł niepublicznych.

Wyższe Szkoły Zawodowe działają jako placówki wielobranżowe i regionalne. Pierwsza taka szkoła rozpoczęła eksperymentalną działalność w 1991 roku. Obecnie działa w Finlandii 27 wyższych szkół zawodowych. Nauka w nich trwa w zależności od kierunku - od 3,5 do 4,5 lat. Studia kończą się uzyskaniem dyplomu upoważniającego do ubiegania się o stanowiska, na których wymagany jest dyplom uczelni wyższej.

\section{Nadzór pedagogiczny}

Przepisy dotyczące nadzoru pedagogicznego i ewaluacji placówek szkolnych zawarte są w pięciu ustawach: o kształceniu obowiązkowym, o szkolnictwie średnim, o kształceniu zawodowym, o kształceniu dorosłych oraz o kształceniu artystycznym ${ }^{9}$. W Finlandii nie istnieje odrębny inspektorat szkolny, a władze publiczne zrezygnowały na początku lat dziewięćdziesiątych XX wieku z przeprowadzania wizytacji w szkołach. Główną rolę w przeprowadzaniu analizy kształcenia ogólnego, zawodowego oraz kształcenia dorosłych odgrywa w Finlandii Rada ds. Ewaluacji Edukacji. Do jej zadań należy ewaluacja funkcjonowania placówek oświatowych oraz systemu nauczania. Na poziomie krajowym ewaluacja ukierunkowana jest głównie na ocenę realizacji celów zawartych w krajowej polityce edukacyjnej oraz w krajowych podstawach programowych. Na poziomie lokalnym i regionalnym ewaluacja może koncentrować się na ocenie dostępności edukacji, finansowej odpowiedzialności instytucji edukacyjnych oraz realizacji lokalnej polityki w dziedzinie edukacji i kultury. Ocenie poddawany jest również stopień realizacji zasady równości i bezpieczeństwa w edukacji.

$9 \quad$ D. Dziewulak, Nadzór pedagogiczny $w$ systemach edukacyjnych $w$ Polsce $i w$ wybranych państwach Unii Europejskiej, „Analizy BAS” 2013, nr 7(96), http://orka.sejm.gov.pl/WydBAS. nsf/0/48E6767D7B4A3052C1257B5900484D97/\$file/Analiza_BAS_2013_96.pdf. 
Zgodnie z przepisami ustawy o kształceniu obowiązkowym instytucje edukacyjne są zobowiązane do regularnego przeprowadzania oceny własnej działalności i jej efektów. Ocena taka opiera się przede wszystkim na podsumowaniu realizacji celów zawartych w podstawie programowej, analizie wdrażania reform pedagogicznych i programowych oraz wykorzystaniu zasobów.

\section{Doradztwo edukacyjno-zawodowe}

Zgodnie z fińską ustawą o edukacji podstawowej poradnictwo edukacyjne i zawodowe realizowane jest w sposób ciągły od najmłodszych lat przez cały cykl edukacji szkolnej ${ }^{10}$. Poradnictwo ma umożliwić uczniom uzyskanie informacji dotyczących ścieżek edukacyjnych przed i w trakcie kształcenia, a także praktycznych wiadomości o rynku pracy i o potencjalnych możliwościach zatrudnienia. Ponadto w ramach specjalnych szkoleń naucza się sposobów poszukiwania informacji na temat dostępnych szkoleń i zawodów, zwracając szczególną uwagę na zagadnienia związane z podejmowaniem decyzji i tworzeniem planów edukacyjnych i zawodowych dostosowanych do zmieniającej się sytuacji na rynku pracy.

W szkolnictwie podstawowym, zwłaszcza w ostatnich trzech latach nauki, uczniowie objęci są intensywną opieką doradczo-edukacyjną. Uczeń może skorzystać z indywidualnych i grupowych spotkań z doradcą, podczas których uczy się poznawać i oceniać własne umiejętności i zainteresowania, oraz jak ukierunkować własne oczekiwania zawodowe na zmieniającym się rynku pracy.

Specyfiką fińskiego trzyletniego szkolnictwa średniego jest brak przedmiotów obowiązkowych. Program nauczania obejmuje jedynie sugerowany zestaw kursów tematycznych. Istotne jest, by w ciągu 3 lat uczeń ukończył określoną przez szkołę liczbę kursów. W ich ramach realizowane jest również doradztwo zawodowe, które koncentruje się głównie na projektowaniu kariery ucznia, monitorowaniu postępów w nauce oraz działalności informacyjnej co do dalszej edukacji i sposobach zdobywania konkretnych kwalifikacji. Przedmiot (kurs) prowadzony jest przez nauczycieli szkolnych lub przez zewnętrznych doradców zawodowych zatrudnianych przez szkołę. Ponadto każda klasa ma swojego nauczyciela-wychowawcę, który przygotowany jest do udzielenia uczniom pomocy w ogólnych kwestiach związanych z kształceniem (wybór przedmiotów opcjonalnych, organizowanie praktyk zawodowych itp.).

10 D. Dziewulak, Doradztwo edukacyjno-zawodowe $w$ szkolnictwie zawodowym $w$ Polsce i w wybranych państwach Unii Europejskiej, „Analizy BAS” 2013, nr 4(93), http://orka.sejm. gov.pl/WydBAS.nsf/0/ECBB4C2938216BB1C1257B4A0036C07D/\$file/Analiza_BAS_2012_93.pdf. 


\section{Zasady fińskiej edukacji11}

Wśród najczęściej wymienianych powodów sukcesu fińskiej edukacji wymienia się jej charakterystyczne zasady: równość, bezpłatny dostęp, indywidualizm, praktyka, zaufanie, dobra wola, niezależność.

- Równość:

- równość szkół - nie istnieją szkoły dla elit lub szkoły przeciętne. Największa szkoła liczy 960 uczniów, a ta najmniejsza 11. Wszystkie szkoły wspomagane są takimi samymi środkami - proporcjonalnie do swego rozmiaru. Zdecydowana większość szkół to placówki państwowe. Do niedawna Finowie nie mogli dokonywać wyboru szkoły dla swojego dziecka i zobligowani byli do zapisania dziecka do placówki zlokalizowanej najbliżej. Nakaz ten został zniesiony, ale mimo to większość rodziców nadal wozi swoje dzieci do szkół w rejonie zamieszkania,

- równość przedmiotów - nie ma przedmiotów ważnych i mniej ważnych. Wszystkie przedmioty pomagają uczniowi w zrozumieniu siebie i otaczającego go świata. Jedynym wyjątkiem jest tworzenie grup specjalnych dla uczniów z pasją do muzyki, sztuki i sportu,

- równość rodziców - informacja dotycząca wykonywanego zawodu lub statusu społecznego rodziców jest przekazywana kadrze pedagogicznej tylko w wyjątkowych przypadkach i nie ma żadnego znaczenia dla procesu edukacyjnego realizowanego przez szkołę,

- równość uczniów - uczniów nie porównuje się i klasyfikuje się według ich uzdolnień. Nie ma uczniów dobrych czy słabych. Finowie cenią sobie integrację społeczeństwa, a także wkładają duży wysiłek w utrzymywanie relacji z osobami, które wymagają szczególnej uwagi. Oczywiście szkoły są również bardzo przyjazne dla osób niepełnosprawnych,

- równość nauczycieli - nie ma nauczycieli ulubionych oraz tych znienawidzonych. Wszyscy traktowani są z szacunkiem zarówno przez uczniów, rodziców, jak i we własnym gronie pedagogicznym. Taką samą wagę przywiązuje się do wszystkich specjalizacji. Nauczyciel muzyki jest tak samo potrzebnym pedagogiem jak nauczyciel fizyki,

11 Zasady fińskiej edukacji zostały opracowane na podstawie materiału zamieszczonego w artykule 7 zasad fińskiego cudu edukacyjnego, http://www.mamyrade.pl/2017/09/30/7-zasad-finskiego-cudu-edukacyjnego/. 
- równość praw dorosłych i praw dzieci - od początku procesu edukacji mówi się wiele o prawach człowieka, a także się uświadamia, kiedy, gdzie i komu można zgłosić swoje skargi.

- Bezpłatny dostęp:

- do nauki samej w sobie,

- do posiłku w stołówce szkolnej,

- do wizyt w muzeach i zajęć dodatkowych,

- do transportu - jeżeli szkoła jest oddalona o więcej niż dwa kilometry - dzieci są do niej przywożone i odwożone busami,

- do książek, zeszytów, kredek, długopisów oraz laptopów i tabletów.

- Indywidualizm:

- dla każdego ucznia projektuje się indywidualny plan nauki oraz rozwoju,

- podejście indywidualne znajduje odzwierciedlenie w dostosowaniu książek, zadań i ćwiczeń (wykonywanych w czasie lekcji oraz w domu), a także czasu potrzebnego na ich wykonanie do możliwości każdego ucznia,

- w czasie lekcji uczniowie rozwiązują zadania dostosowane do swoich możliwości (jedne mają wyższy, a inne niższy poziom trudności, ale wszystkie obejmują podobny materiał). Dziecko oceniane jest na podstawie poziomu, który reprezentuje. Jeżeli jednego dnia uczeń potrafi rozwiązać zadanie z poziomu podstawowego, następnego dnia otrzyma kolejne, nieco trudniejsze. Gdy sobie z nim nie poradzi - nic w tym złego. Po prostu powróci do poziomu nieco niższego,

- płatne korepetycje są zabronione. W kłopotach i zaległościach w nauce obowiązkowo pomagają nauczyciele. Praca z uczniem odbywa się na terenie szkoły w czasie lekcji lub po zajęciach szkolnych.

- Praktyka:

- Finowie mawiają: Możemy przygotować dzieci do egzaminów lub do życia. Wybieramy to drugie - dlatego w szkołach fińskich nie ma klasówek i sprawdzianów. Jeżeli nauczycielowi na tym zależy, może wprowadzić pewną próbną formę kontroli. Jedynym egzaminem obowiązkowym jest ogólny sprawdzian pod koniec cyklu nauczania II stopnia, lecz jego wynik ma charakter orientujący ucznia, nauczyciela i rodziców co do ewentualnych dalszych losów edukacyjnych ucznia,

- nauka w szkole podstawowej skoncentrowana jest na tym, co może okazać się przydatne w życiu - dlatego unika się materiału teoretycznego. Przykładowo fińscy uczniowie świetnie wiedzą, czym jest kontrakt i jak posługiwać się kartą kredytową. Wiedzą również, ile wynosi podatek dochodowy lub podatek 
od nieruchomości. Umieją stworzyć prostą stronę internetową oraz policzyć cenę produktu uwzględniającą rabat.

- Zaufanie:

- nauczyciele i inni pracownicy oświaty obdarzeni są dużym zaufaniem społecznym. Wytyczne dla nauczycieli konstruowane są hasłowo i bardzo ogólnie, tak aby każdy pedagog mógł mieć swobodę w budowaniu programu i doborze metod do zainteresowań i potrzeb uczniów,

- ufa się również uczniom. Panuje przekonanie, że młody człowiek potrafi wybrać to, co jest dla niego ważne, dobre i wartościowe. Jeżeli w czasie lekcji uczeń uznaje, że jej tematyka go nie interesuje - ma pełną swobodę do robienia czegoś innego, na przykład czytania książki.

- Dobra wola:

- system edukacyjny Finlandii zakłada dobrą wolę uczniów przy pełnej realizacji spełniania obowiązku szkolnego. Gdy uczniowie znajdują się w klasie, to uczy się ten, kto rzeczywiście tego chce. Rolą nauczyciela jest zachęcenie uczniów do pogłębiania wiedzy, ale jeśli ktoś nie ma chęci lub zdolności do nauki - kierowany jest ku zdobyciu zawodu praktycznego.

- Niezależność:

- głównym celem fińskiego szkolnictwa jest przygotowanie uczniów do świadomej niezależności w podejmowaniu decyzji o swym przyszłym życiu prywatnym, społecznym, zawodowym. Wychowując niezależnego człowieka, szkoła uczy rozwiązywania problemów, wykorzystując samodzielne myślenie ucznia.

\section{Charakterystyczne cechy fińskiej edukacji ${ }^{12}$}

Obowiązek szkolny rozpoczyna się w 7 roku życia i kończy w 16. Uczniowie nie noszą mundurków, a do nauczycieli zwracają się po imieniu. Klasy liczą średnio 15-20 uczniów. W początkowych latach nauka przypomina zabawę nakierowaną na naukę pisania i czytania. Uczniowie otrzymują bezpłatne podręczniki, przybory szkolne i posiłki w stołówce.

Kształcenie nastawione jest na wspieranie twórczego działania, szuka się dobrych stron ucznia i zachęca do pogłębiania swoich zainteresowań. Jedna trzecia przedmiotów w szkołach średnich wybierana jest według uznania. Uczniowie

12 Charakterystyczne cechy fińskiej edukacji zostały opracowane na podstawie materiału zamieszczonego w artykule 10 różnic pomiędzy polskim a fińskim systemem edukacji, https:// dziecisawazne.pl/10-roznic-pomiedzy-polskim-a-finskim-systemem-edukacji/. 
sami decydują również o tym, które z tych przedmiotów będą zdawać na egzaminie dojrzałości. Wszystkie dzieci uczą się razem, nie ma podziału na dobrych i słabszych uczniów. Nie ma także programów odrębnej pracy ze szczególnie uzdolnionymi uczniami. Nauczyciel współpracuje z uczniem na zasadach zespołowych i partnerskich.

Wysoki poziom kształcenia nauczycieli związany jest z dużymi wymaganiami zawodowymi, samodzielnością i stabilnością pracy zawodowej. Proces rekrutacji na studia nauczycielskie jest wyjątkowo rygorystyczny. Składa się z egzaminu z wiedzy teoretycznej oraz z kilkuetapowego egzaminu predyspozycji pedagogicznych. Średnio na studia nauczycielskie zostaje przyjętych około 10\% zdających kandydatów. W Finlandii nauczyciel cieszy się bardzo wysokim statusem społecznym. Doskonalenie zawodowe nauczycieli jest obowiązkowe i całkowicie finansowane $\mathrm{z}$ budżetu państwa.

Fińska szkoła powszechnie uznawana jest za jedną z najlepszych na świecie. Poniżej zostały przedstawione opinie zebrane z różnych źródeł na temat funkcjonowania systemu szkolnego w tym kraju przez pryzmat zasad i charakterystycznych cech.

\section{Bibliografia}

Dziewulak D., Doradztwo edukacyjno-zawodowe w szkolnictwie zawodowym w Polsce $i$ w wybranych państwach Unii Europejskiej, „Analizy BAS” 2013, nr 4(93), http:// orka.sejm.gov.pl/WydBAS.nsf/0/ECBB4C2938216BB1C1257B4A0036C07D/\$file/Analiza_ BAS_2012_93.pdf.

Dziewulak D., Nadzór pedagogiczny $w$ systemach edukacyjnych $w$ Polsce $i w$ wybranych państwach Unii Europejskiej, „Analizy BAS” 2013, nr 7(96), http://orka.sejm.gov.pl/WydBAS.nsf/0/48E6767D7B4A3052C1257B5900484D97/\$file/Analiza_BAS_2013_96.pdf.

Dziewulak D., Obowiązek szkolny w Unii Europejskiej, „Analizy BAS” 2010, nr 9(34), http:// parl.sejm.gov.pl/WydBAS.nsf/0/A4F8763AAD6E8E70C12576EE0029DFE9/\$file/Analiza_\%20BAS_2009_34.pdf.

\section{Akty prawne}

Basic Education Act 628/1998 Amendments up to 1136/2010, http://www.finlex.fi/en/laki/kaannokset/1998/en19980628.pdf.

Local Government Act (410/2015), https://www.finlex.fi/fi/laki/kaannokset/2015/en20150410. pdf. 


\section{Strony internetowe}

http://www.finlex.fi/en/laki/kaannokset/1998/en19980628.pdf.

http://www.localfinland.fi/en/authorities/local-self-government/Documents/Finnish Local

Government Act.pdf.

http://www.minedu.fi/OPM.

http://www.edev.fi/portal/english5.

http://www.mamyrade.pl/2017/09/30/7-zasad-finskiego-cudu-edukacyjnego/.

https://dziecisawazne.pl/10-roznic-pomiedzy-polskim-a-finskim-systemem-edukacji/. 


\title{
1.6. System szkolny Irlandii
}

\author{
The school system of Ireland
}

\begin{abstract}
W opracowaniu podjęto próbę prezentacji systemu szkolnego Irlandii. Analizie poddano administrację szkolną, finansowanie oświaty, organizację systemu szkolnictwa, edukację specjalną oraz kształcenie nauczycieli.
\end{abstract}

Słowa kluczowe: szkoła, edukacja, system szkolny, Irlandia

This paper provides an attempt to describe the system of school education in Ireland. Topics addressed by the author include school administration, financing of education, organization of school system, special education and teacher education.

Keywords: school, education, school system, Ireland

\section{Podstawowe informacje}

Irlandia jest republiką opartą na systemie demokracji parlamentarnej. Głową państwa jest prezydent (irl. Uachtarán na hÉireann) wybierany w powszechnych wyborach na siedmioletnią kadencję. Władza ustawodawcza należy do dwuizbowego parlamentu Irlandii (irl. Oireachtas Éireann) - Izby Reprezentantów (irl. Dáil Éireann) i Senatu (irl. Seanad Éireann). Deputowani wybierani są na kadencję, której długość wynosi 5 lat. Zgodnie art. 28 Konstytucji Irlandii ${ }^{1}$ władza wykonawcza należy do rządu (irl. Rialtas na hÉireann). Irlandia jest członkiem Unii Europejskiej od 1 stycznia 1973 roku.

Obszar 70,3 tys. km² zamieszkuje 4,5 mln mieszkańców (dane z 2011 r.). Zgodnie z art. 8 Konstytucji Irlandii, język irlandzki jako język narodowy jest pierwszym językiem urzędowym² ${ }^{2}$. Drugim językiem urzędowym jest język angielski. Konstytucja dopuszcza ustawowe wprowadzenie przepisów o wyłącznym stosowaniu jednego z dwóch wymienionych języków dla jednego lub więcej celów urzędowych na terytorium całego państwa lub w jego określonej części.

1 Konstytucja Irlandii, Wydawnictwo Sejmowe, Warszawa 2006, s. 58.

2 Tamże, s. 35. 
Administracyjnie Irlandia podzielona jest na 4 prowincje i 29 hrabstw. Dla celów pocztowych oraz w kontekstach sportowych i kulturowych stosuje się historyczny podział na 26 hrabstw.

\section{Charakterystyka administracji szkolnej}

Podstawowe zasady prawne dotyczące funkcjonowania oświaty w Irlandii ${ }^{3}$ uchwalane są przez parlament, a odpowiedzialność za wdrożenie ich w życie spoczywają na rządzie ${ }^{4}$. Jednolitym systemem oświaty zarządza Ministerstwo Edukacji i Umiejętności (ang. Department of Education and Skills, irl. an Roinn Oideachais agus Scileanna) $)^{5}$. Głównym zadaniem ministerstwa jest organizacja systemu oświaty w taki sposób, aby umożliwić każdemu uczniowi rozwinięcie własnego potencjału intelektualnego, umiejętności, zdolności i talentów. Ponadto ministerstwo realizuje zadania związane $\mathrm{z}$ wdrażaniem rozwiązań poprawiających skuteczność procesu kształcenia, umożliwiających podnoszenie kwalifikacji i przekwalifikowanie zgodnie z potrzebami zmieniającego się rynku pracy. Do ustawowych zadań Ministerstwa Edukacji i Umiejętności należy także całościowe planowanie polityki oświatowej, pozyskiwanie środków oraz zapewnienie szerokiego zakresu usług wsparcia dla sektora edukacji ${ }^{6}$. Wsparciem tym zajmuje się sieć ponad 30 instytucji, agencji, komitetów i wydziałów działających w ramach ministerstwa lub współpracujących z resortem. Są to instytucje zajmujące się m.in. przemocą wobec dzieci - Commission to Inquire into Child Abuse Act $(\mathrm{CICA})^{7}$, finansowaniem oświaty - Education Finance Board (EFB) ${ }^{8}$, szkolnictwem wyższym oraz badaniami w różnych dziedzinach nauki - Higher Education Authority (HEA) ${ }^{9}$, wymianą i współpracą międzynarodową - The Exchange Bureau

3 Opracowanie przygotowano na podstawie ekspertyzy Biura Analiz Sejmowych nr 1632/14 z 6 października 2014 r. D. Dziewulaka zatytułowanej Informacja na temat systemu edukacyjnego Irlandii oraz artykułu tegoż autora System szkolny Irlandii, „Analizy BAS” 2014, nr 14(118), s. 1-10.

4 W opracowaniu przedstawiono informację na temat systemu edukacyjnego Irlandii. W informacji wykorzystano materiały uzyskane za pośrednictwem Sieci Informacji o Edukacji w Europie (Eurydice), materiały otrzymane z Ambasady Irlandii w Warszawie oraz dostępne na stronach internetowych irlandzkich instytucji oświatowych.

5 http://www.education.ie/en/.

6 Education Act 1998; http://www.irishstatutebook.ie/1998/en/act/pub/0051/.

7 http://www.childabusecommission.ie/.

8 http://www.educationfinanceboard.ie/.

9 http://hea.ie/. 
(Léargas) ${ }^{10}$, poradnictwem edukacyjnym - National Centre for Guidance in Education (NCGE) ${ }^{11}$, szkolnictwem zawodowym - Vocational Education Committees $\left(\right.$ VECs $^{12}$, stypendiami i grantami - Student Grants Appeals Board ${ }^{13}$, transportem szkolnym - School Transport Appeals Board ${ }^{14}$ itd.

Rolę doradczą i kontrolną nad całością działań Ministerstwa Edukacji i Umiejętności pełni ministerialny Inspektorat (Inspectorate) ${ }^{15}$. Inspektorat odpowiedzialny jest za ocenę szkół podstawowych, średnich oraz ośrodków kształcenia i doskonalenia zawodowego. Inspektorzy to doświadczeni nauczyciele, z których wielu pełniło wcześniej funkcje dyrektorów szkół, doradców metodycznych, ekspertów w dziedzinie projektowania programów nauczania, wdrażania innowacji dydaktycznych lub prowadzenia badań edukacyjnych. Do zadań Inspektoratu należy:

- przeprowadzanie wizytacji w szkołach i ośrodkach kształcenia,

- dokonywanie ewaluacji pracy krajowych placówek edukacyjno-wychowawczych,

- doradztwo metodyczno-wychowawcze,

- promowanie języka irlandzkiego oraz dobrych praktyk edukacyjnych,

- publikowanie sprawozdań z przeprowadzonych kontroli,

- przygotowywanie raportów na temat programów nauczania, metod dydaktycznych i rozwiązywania problemów wychowawczych,

- upowszechnianie informacji na temat polityki edukacyjnej ministerstwa ${ }^{16}$.

W Irlandii sieć szkół jest bardzo rozdrobniona. Cechą charakterystyczną jest funkcjonowanie wielu małych szkół podstawowych. W roku szkolnym 2012/2013 działało 3293 szkół podstawowych ${ }^{17}$. W ponad 400 placówkach zatrudnionych było od jednego do dwóch nauczycieli, w 300 - tylko trzech nauczycieli, a w ponad 1200 - pracowało od czterech do siedmiu nauczycieli. Na jednego nauczyciela statystycznie przypadało 16,4 uczniów ${ }^{18}$.

10 https://www.leargas.ie/.

11 https://www.ncge.ie/.

12 https://www.education.ie/en/The-Department/Bodies-and-Committees/Vocational-Education-Committees-VECs-html.

13 https://www.studentgrantappeals.ie/.

14 https://www.education.ie/en/The-Department/Bodies-and-Committees/Information.html.

15 http://www.education.ie/en/The-Department/Management-Organisation/Inspectorate.html.

16 http://www.education.ie/en/The-Department/Management-Organisation/Inspectorate.html\#sthash.foXmqRau.dpuf.

17 http://www.education.ie/en/Publications/Statistics/Key-Statistics/Key-Statistics-2012-2013. pdf.

18 Tamże, s. 2. 


\section{Finansowanie oświaty}

\section{Kontekst europejski}

W 2008 roku udział wydatków publicznych na edukację w wielu państwach europejskich przekraczał 5\% $\mathrm{PKB}^{19}$. W Danii, na Cyprze i w Islandii odsetek ten był najwyższy i przekraczał 7\%, a w innych państwach skandynawskich oraz w Belgii i na Malcie przekraczał 6\%. Z kolei na Słowacji i w Liechtensteinie publiczne wydatki na edukację stanowiły mniej niż 4\% PKB. W latach 2001-2008 ogólny odsetek PKB w 27 państwach Unii Europejskiej przeznaczany na edukację utrzymywał się na stabilnym poziomie około 5\%. Jednakże ta stabilna średnia europejska skrywa nierówności między poszczególnymi państwami - w niektórych w tym okresie doszło do zasadniczych zmian. W Bułgarii, na Cyprze i w Islandii odsetek PKB przeznaczany na edukację zwiększył się w latach 2001-2008 o ponad 20\%, a w Irlandii w tym samym okresie o ponad $30 \%{ }^{20}$. Znaczący wzrost (powyżej 10\%) odnotowano też w Zjednoczonym Królestwie.

Stabilność ogólnych danych za lata 2001-2008 kryje też różnice wysokości wydatków przeznaczanych na różne poziomy kształcenia. W latach 2001-2008 wydatki na kształcenie przedszkolne i szkolnictwo wyższe, wyrażone jako odsetek PKB, wzrosły o ponad 5\%. Z kolei wydatki na szkoły średnie nieco spadły.

Środki publiczne przeznaczane na poszczególne poziomy kształcenia są różne w poszczególnych państwach, co wynika po części ze strukturalnych odmienności systemów edukacji, długości obowiązku szkolnego oraz wskaźników uczestnictwa w kształceniu po zakończeniu edukacji obowiązkowej.

W niemal wszystkich krajach europejskich całkowite wydatki publiczne na edukację przeznaczone na kształcenie na poziomie średnim są większe niż nakłady na pozostałe poziomy, ale nigdzie nie przekraczają 3,2\% PKB. W Chorwacji, Hiszpanii, Liechtensteinie, Polsce i na Słowacji jest to mniej niż 2\% PKB. Całkowite wydatki publiczne na edukację na poziomie podstawowym generalnie nie przekraczają 2\% PKB, z wyjątkiem Cypru i Islandii, gdzie sięgają 2,5\%.

Na szczeblu europejskim (27 państw członkowskich UE) odsetek PKB wydawany na kształcenie podstawowe i wyższe jest prawie taki sam (odpowiednio 1,1\% i 1,2\%). Jednak kwoty przeznaczane na osobę są dużo większe na poziomie wyższym niż na poziomie podstawowym. Odsetek PKB przeznaczany na szkol-

19 Kluczowe dane o edukacji w Europie 2012, http://ekspercibolonscy.org.pl/sites/ekspercibolonscy.org.pl/files/2012_pl_kluczowe_dane_o_edukacji_w_europie_2012.pdf.

20 Tamże, s. 87. 
nictwo wyższe w większości państw Unii Europejskiej wynosi od 0,8\% do 2,2\% ich PKB. Tylko w Danii i Norwegii przekracza 2\% PKB.

\section{Finansowanie oświaty w Irlandii}

W Irlandii całkowite wydatki publiczne na instytucje edukacyjne na wszystkich poziomach ISCED 0-6 wyniosły w 2010 roku 6,4\% PKB (średnia w OECD 6,3\%) ${ }^{21}$. Od 2005 roku Irlandia zwiększyła swoje wydatki na edukację o 1,9 punktów procentowych (średni wzrost w OECD wyniósł 0,5 pkt proc.). W 2012 roku budżet irlandzkiego Ministerstwa Edukacji i Umiejętności wyniósł 8603,5 ml euro ${ }^{22}$.

Roczne wydatki na osobę uczącą się na poziomie od szkoły podstawowej do szkolnictwa wyższego wyniosły w 2010 roku 7943 euro (średnia w państwach OECD to 6923 euro). Ten wskaźnik nie uwzględnia dotacji publicznych, które obejmują finansową pomoc dla studentów szkół wyższych. W latach 2005-2010 wydatki na jedną osobę uczącą się na poziomie szkolnictwa podstawowego, średniego i pomaturalnego wzrosły o 33\%, podczas gdy liczba uczących się na tych poziomach edukacyjnych wzrosła o $8 \% 23$.

W Irlandii 95\% szkół jest finansowanych z budżetu państwa, ale tylko nieliczne z nich to szkoły państwowe. Większość prowadzona jest przez Kościół katolicki, fundacje wyznaniowe, osoby prywatne (Irlandia jest jedynym krajem Unii Europejskiej utrzymującym wyznaniowy charakter systemu szkolnego). Finansowanie ze środków publicznych obejmuje wszystkie poziomy kształcenia i większość usług edukacyjnych od szkoły podstawowej do poziomu kształcenia dorosłych. Szkoły mogą również podejmować działania w celu pozyskiwania funduszy ${ }^{24}$.

Rodzice o niskich dochodach mogą ubiegać się o pomoc finansową na zakup mundurków oraz podręczników. W przypadku mundurków mogą skorzystać z programu Back to School Clothing \& Footwear Scheme ${ }^{25}$, który jest uruchamia-

21 Eurostat, UOE i sprawozdania krajowe (dane uzyskane w czerwcu 2011 r.) [w:] Kluczowe dane o edukacji w Europie 2012, Eurydice, Warszawa 2012, s. 88. http://ekspercibolonscy.org. pl/sites/ekspercibolonscy.org.pl/files/2012_pl_kluczowe_dane_o_edukacji_w_europie_2012. pdf. Education policy outlook: Ireland, OECD 2013, http://www.oecd.org/edu/EDUCATION POLICY OUTLOOK IRELAND_EN.pdf.

22 http://www.education.ie/en/.

23 http://www.oecd.org/edu/EDUCATION POLICY OUTLOOK IRELAND_EN.pdf.

24 Ośrodek Rozwoju Edukacji, http://www.ore.edu.pl/wp-content/plugins/download-attachments/includes/download.php?id=3871.

25 http://www.citizensinformation.ie/en/social_welfare/social_welfare_payments/social_welfare_ payments_to_families_and_children/back_to_school_clothing_and_footwear_allowance.html. 
ny od 1 czerwca i trwa do 30 września każdego roku. Prowadzą go lokalne oddziały HSE (Health Service Executive). Pomoc w zakupie podręczników świadczą także szkoły ze swojego budżetu.

Tabela 4. Roczne wydatki instytucji sektora publicznego na ucznia/ studenta według poziomu kształcenia w Irlandii w 2008 roku

\begin{tabular}{|l|c|}
\hline \multicolumn{1}{|c|}{ Poziom kształcenia } & $\begin{array}{c}\text { Wydatki w tys. euro według } \\
\text { standardu siły nabywczej (PPS) }{ }^{26}\end{array}$ \\
\hline ISCED 1 & 6,1 \\
\hline ISCED 2-4 & 8,2 \\
\hline ISCED 5-6 & 12,8 \\
\hline Razem: ISCED 0-6 & 5,6 \\
\hline
\end{tabular}

Źródło: Eurostat, UOE i sprawozdania krajowe (dane uzyskane w czerwcu 2011 roku) [w:] Kluczowe dane o edukacji w Europie 2012, Warszawa 2012, s. 92, http://ekspercibolonscy.org.pl/sites/ekspercibolonscy.org. pl/files/2012_pl_kluczowe_dane_o_edukacji_w_europie_2012.pdf.

Wydatki na edukację pokrywane są z dwóch rodzajów źródeł: funduszy publicznych i funduszy prywatnych. Nakłady publiczne obejmują bezpośrednie opłacanie wszystkich zasobów edukacyjnych w sektorze publicznym (niezależnie od szczebla administracyjnego), natomiast wydatki prywatne odnoszą się do pokrywania czesnego (i innego rodzaju opłat) przede wszystkim przez gospodarstwa domowe (tzn. uczniów i ich rodziny), firmy i organizacje pozarządowe. Stosunek wielkości finansowania edukacji ze źródeł publicznych i prywatnych wiąże się ze stopniem autonomii instytucji w zakresie gromadzenia funduszy i określania sposobu ich wydatkowania. Na stosunek publicznych i prywatnych nakładów na edukację wpływa także sam sposób subsydiowania sektora szkół prywatnych.

26 Standard siły nabywczej (PPS, ang. Purchasing Power Standard) to sztuczna jednostka walutowa (waluta), dzięki której można porównywać różne wskaźniki ekonomiczne w krajach funkcjonujących w odmiennych systemach walutowych. W teorii za jeden PPS można kupić tę samą ilość dóbr i usług w każdym państwie świata, dzięki czemu wyklucza się ryzyko, że na wyniki porównań mogą wpłynąć np. wahania kursu walut. Standard siły nabywczej wyznaczany jest przez podzielenie łącznej wartości gospodarki kraju wyrażonej w walucie krajowej przez jej odpowiedni parytet siły nabywczej. Wirtualna jednostka monetarna PPS stosowana jest przez Eurostat do wyrażenia różnych wielkości rachunków narodowych skorygowanych parytetem siły nabywczej, tzw. Purchasing Power Parities (PPP). Standard siły nabywczej może być interpretowany jako kurs wymiany PPS na euro. 
W Irlandii w 2010 roku odsetek nakładów na edukację ze źródeł publicznych wyniósł 92,5\% (średnia w OECD - 83,6\%), a ze źródeł prywatnych - 7,5\% (średnia w OECD - 16,4\%) ${ }^{27}$.

Wykres 1. Nakłady na edukację (ISCED 0-6) w Irlandii w 2010 roku jako procent PKB

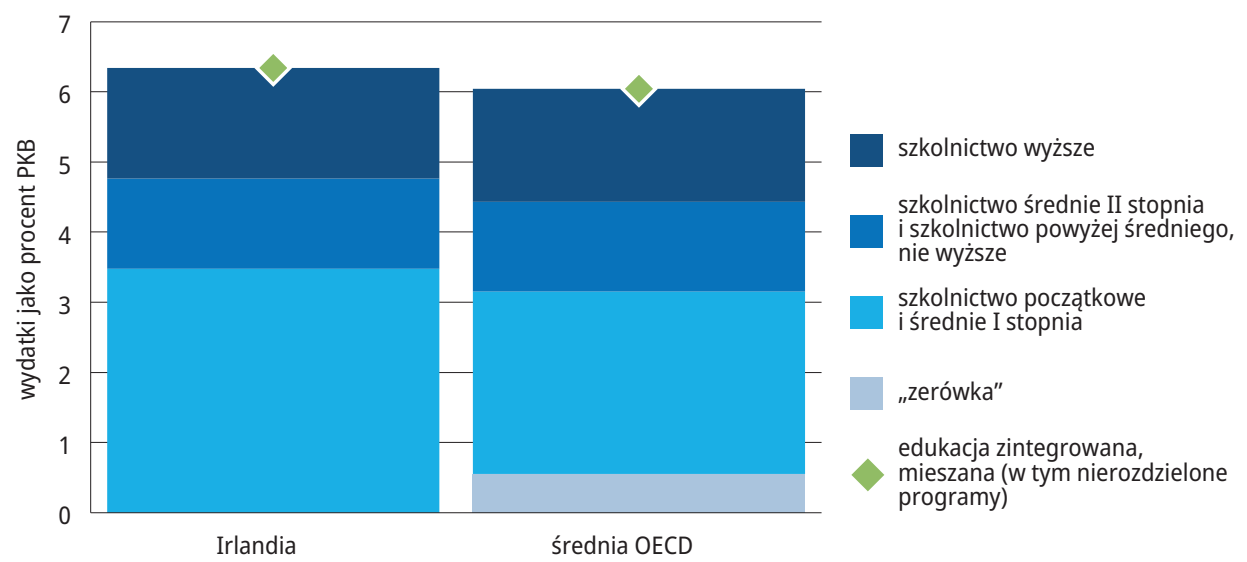

Źródło: Education policy outlook: Ireland, OECD 2013,

http://www.oecd.org/edu/EDUCATION\%20POLICY\%20OUTLOOK\%20IRELAND_EN.pdf.

Wydatki placówek edukacyjnych sektora publicznego dzielą się na dwie główne kategorie - wydatki bieżące i inwestycyjne. Do wydatków bieżących należą pensje i koszty związane z personelem, a także koszty utrzymania budynków, zakup materiałów edukacyjnych i wydatki operacyjne (opłaty codzienne). Wydatki inwestycyjne obejmują nakłady na majątek trwały (o przewidywalnym okresie użytkowania dłuższym niż 1 rok), np. na budynki, remonty, rekonstrukcje itp.

We wszystkich 27 państwach UE koszty kadrowe to średnio 70\% rocznych wydatków na edukację. W Irlandii wynoszą one prawie 73\% rocznych wydatków na edukację. W Belgii i Portugalii kwota ta sięga nawet 85\%, a w Republice Czeskiej, na Słowacji i w Finlandii nie przekracza 60\%.

27 Education policy outlook: Ireland, OECD 2013, http://www.oecd.org/edu/EDUCATION POLICY OUTLOOK IRELAND_EN.pdf. 
Tabela 5. Całkowite roczne wydatki irlandzkich placówek oświatowych (ISCED 0-6) sektora publicznego według najważniejszych kategorii w 2008 roku

\begin{tabular}{|l|c|}
\hline \multicolumn{1}{|c|}{ Kategorie wydatków } & Odsetek \\
\hline Inwestycyjne & 9,2 \\
\hline Bieżące - pensje & 72,9 \\
\hline Bieżące - inne & 18,0 \\
\hline
\end{tabular}

Źródło: Eurostat, UOE i sprawozdania krajowe (dane uzyskane w czerwcu 2011 roku) [w:] Kluczowe dane o edukacji w Europie 2012, Warszawa 2012, s. 95, http://ekspercibolonscy.org.pl/sites/ekspercibolonscy. org.pl/files/2012_pl_kluczowe_dane_o_edukacji_w_europie_2012.pdf.

\section{Organizacja systemu szkolnictwa}

Zgodnie z art. 42 ust. 1 i 2 Konstytucji Irlandii państwo uznaje, że pierwotnym i naturalnym wychowawcą dziecka jest rodzina, i gwarantuje respektowanie niezbywalnego prawa i obowiązku rodziców do zapewnienia swoim dzieciom, w miarę możliwości, edukacji religijnej i moralnej, intelektualnej, fizycznej oraz społecznej. Rodzicom przysługuje swoboda zapewnienia takiej edukacji w swych domach, szkołach prywatnych, w szkołach utworzonych przez państwo lub przez nie uznanych ${ }^{28}$. W ust. 3 podkreśla się jednocześnie, że państwo nie może zobowiązać rodziców, z naruszeniem ich sumienia i legalnego prawa wyboru, do posyłania ich dzieci do szkół ustanowionych przez państwo albo do innego szczególnego typu szkoły. Państwo, będąc strażnikiem dobra wspólnego, wymaga, aby ze względu na istniejące warunki dzieci otrzymały pewną minimalną edukację moralną, intelektualną i społeczną. W ust. 4 art. 42 wskazuje się, że państwo zapewnia bezpłatną edukację podstawową oraz stara się uzupełniać i rozsądnie wspomagać prywatną i publiczną inicjatywę edukacyjną, a ponadto, kiedy dobro publiczne tego wymaga, zapewniać inne usługi lub instytucje edukacyjne, respektując jednakże prawa rodziców, szczególnie w kwestii kształtowania religijnego i moralnego ${ }^{29}$.

W Irlandii zasadniczo nie istnieje zorganizowana centralnie publiczna sieć żłobków i placówek wychowania przedszkolnego. Żłobki i przedszkola oferujące usługi opiekuńczo-wychowawcze dla najmłodszych są to płatne placówki zakładane i prowadzone przez osoby prywatne lub przez inne podmioty (np. związ-

28 Konstytucja Irlandii, dz. cyt., s. 76.

29 Tamże, s. 76. 
ki wyznaniowe, kościoły). Wśród żłobków najbardziej rozpowszechnione są tzw. creche lub nursery school przeznaczone dla dzieci od trzeciego miesiąca do piątego roku życia.

Funkcjonowanie irlandzkiego szkolnictwa podstawowego i średniego reguluje ustawa o edukacji z 1998 roku (Education Act 1998) ${ }^{30}$.

Obowiązek szkolny trwa w Irlandii 10 lat i objęci są nim uczniowie w wieku od 6 do 16 lat.

W ramach struktury irlandzkiego ustroju szkolnego wyróżniamy następujące poziomy kształcenia:

- klasy przedpoczątkowe (Early Start Programme) - ISCED 0,

- szkolnictwo podstawowe (Primary school) - ISCED 1,

- szkolnictwo średnie I stopnia (Junior Cycle) - ISCED 2,

- szkolnictwo średnie II stopnia (Senior Cycle) - ISCED 3,

- szkolnictwo powyżej średniego, nie wyższe (Further and Adult Education) ${ }^{31}$ ISCED 4,

- szkolnictwo wyższe I i II stopnia - ISCED 5,

- szkolnictwo wyższe III stopnia - ISCED 6.

\section{Klasy przedpoczq̨tkowe (przedzerówkowe)}

Nieobowiązkowa, płatna opieka i edukacja realizowana dla dzieci w wieku od 3 lat i 2 miesięcy do 4 lat i 7 miesięcy. Jest to roczny program adaptacyjno-edukacyjny nazwany Early Start Programme realizowany przez ponad 40 szkół podstawowych i przeznaczony dla 1650 osób. Skierowany jest do dzieci pochodzących ze środowisk zagrożonych i defaworyzowanych. Celem jest dotarcie do rodziców z tych środowisk i zachęcenie do skorzystania przez ich dzieci do udziału w zajęciach prowadzonych przez wyspecjalizowanych nauczycieli opiekunów. Program obejmuje cztery przedmioty: język ojczysty, poznawanie świata, rozwój społeczny i rozwój jednostki. Zajęcia odbywają się w formie zabawy. Grupa może liczyć maksymalnie 30 osób, a w placówce może istnieć oddział 60-osobowy, czyli dwie grupy po 30 osób. Po ukończeniu rocznego Early Start Programme dziecko zostaje przeniesione do klasy Junior Infants.

30 http://www.irishstatutebook.ie/1998/en/act/pub/0051/.

31 Odpowiednik zbliżony do polskiego szkolnictwa pomaturalnego, policealnego i uzupełniającego. 


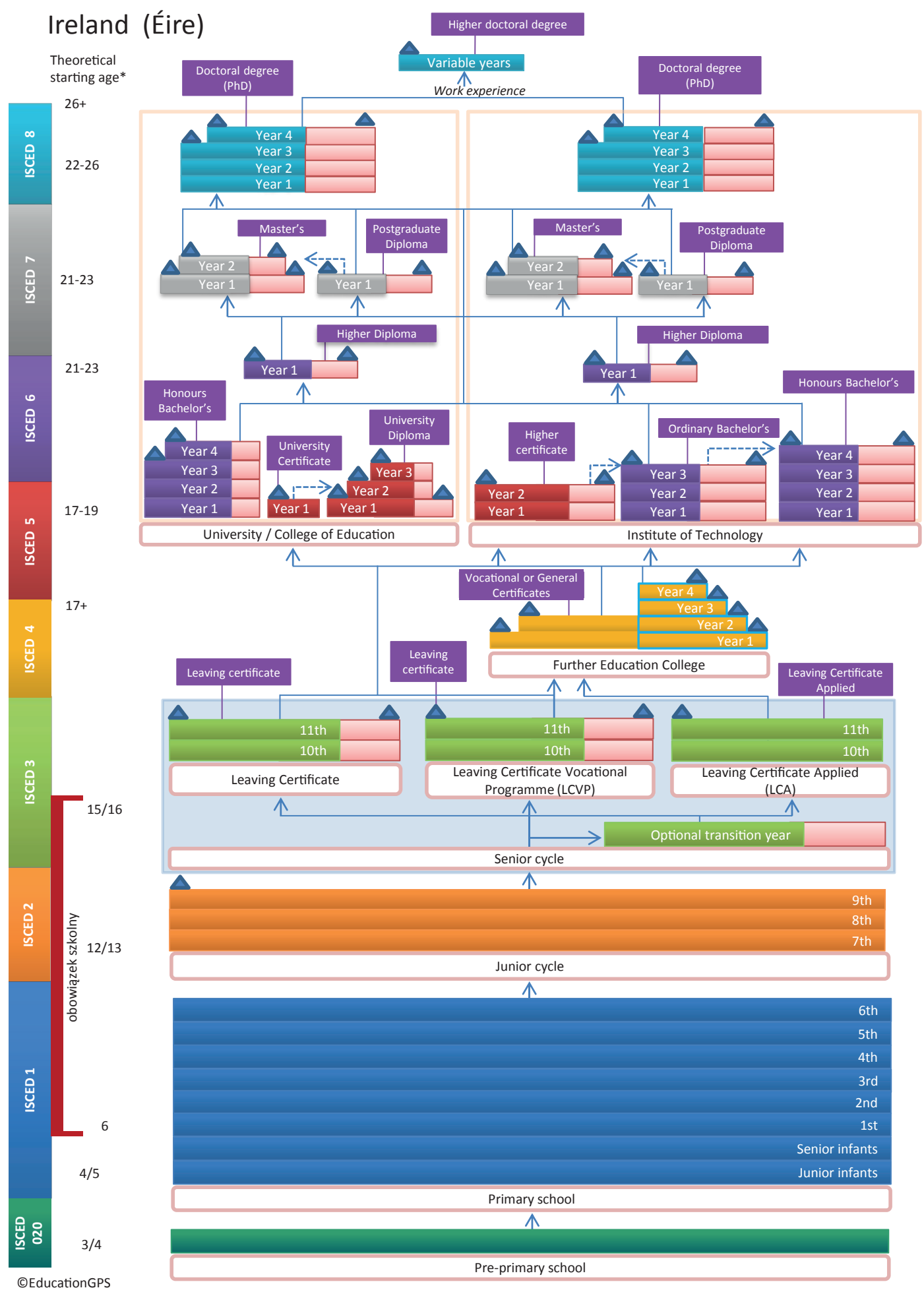




\section{Legenda (wyjaśnienie terminów użytych na rysunku)}

\section{POZIOMY EDUKACYJNE}

Pre-primary school - „zerówka”

Primary school - szkoła początkowa

Junior cycle - szkoła średnia I stopnia

Senior cycle - szkoła średnia II stopnia

Leaving Certificate - szkoły średnie II stopnia przygotowujące do państwowego egzaminu maturalnego o profilu ogólnokształcącym

Leaving Certificate Vocational Programme (LCVP) - szkoły średnie II stopnia przygotowujące do państwowego egzaminu maturalnego o profilu technicznym

Leaving Certificate Applied (LCA) - szkoły średnie zawodowe przygotowujące do uzyskania świadectwa przygotowania zawodowego

Further Education College - kształcenie w szkołach poziomu policealnego

University - uniwersytet

College of Education - kolegia

Institute of Technology - szkoła wyższa o profilu technicznym

\section{DYPLOMY}

Leaving Certificate - państwowy dyplom maturalny o profilu ogólnokształcącym

Leaving Certificate Applied - państwowe świadectwo przygotowania zawodowego

Vocational or General Certificates - zawodowe lub ogólne świadectwa

Honours Bachelor's - licencjat (uniwersytecki)

University Certificate - świadectwo uniwersyteckie

University Diploma - dyplom uniwersytecki

Higher Diploma - wyższy dyplom studiów uniwersyteckich

Master's - magisterium

Postgraduate Diploma - dyplom studiów podyplomowych

Doctoral degree (PhD) - stopień doktorski

Higher certificate - świadectwo studiów wyższych

Ordinary Bachelor's - licencjat

Honours Bachelor's - wyższy licencjat

Higher doctoral degree - wyższy stopień doktorski

OPIS TRANSFERÓW EDUKACYJNYCH (STRZAŁKI) I OZNACZEŃ LAT NAUKI

Junior infants - klasy przeznaczone dla czterolatków

Senior infants - klasy przeznaczone dla pięciolatków

Optional transition year - nieobowiązkowy rok przejściowy

Work experience - doświadczenie w pracy zawodowej

6th - szósty rok nauki

Year - rok studiów 


\section{Szkolnictwo podstawowe}

Etap edukacji podstawowej podzielony jest na dwa cykle: nieobowiązkowy dwuletni cykl edukacji początkowej pre-school i obowiązkową sześcioletnią szkołę podstawową primary school.

Pre-school - to odpowiednik polskiej zerówki przeznaczony dla dzieci w wieku 4 i 5 lat. Nauka w pre-school trwa dwa lata i podzielona jest na dwa poziomy:

- Junior Infants (dla czterolatków),

- Senior Infants (dla pięciolatków).

Dziecko, aby mogło rozpocząć naukę w pre-school na poziomie Junior Infants musi mieć ukończony 4 rok życia. Zajęcia w pre-school odbywają się przy szkołach podstawowych (primary school), zwykle w odrębnym budynku. Zgodnie z informacjami publikowanymi na stronie Ministerstwa Edukacji i Umiejętności (wrzesień 2014 r.) ten typ edukacji cieszy się dużą popularnością. Mimo że dzieci nie muszą uczęszczać do szkoły aż do szóstego roku życia, spora część populacji rozpoczyna naukę we wrześniu po swoich czwartych urodzinach. Do pre-school uczęszcza ponad 40\% czterolatków i prawie 98\% pięciolatków ${ }^{32}$.

Szkoła podstawowa (primary school) jest obowiązkowa, bezpłatna i powszechna dla uczniów od 6 do 12 roku życia. Nauka trwa 6 lat. Bez względu na charakter podmiotu założycielskiego i zarządzającego wszystkie szkoły podstawowe - publiczne, prywatne, wyznaniowe i laickie - wspierane są z budżetu państwa. Ministerstwo pokrywa większość kosztów budowy i bieżących wydatków placówki wraz z uposażeniem nauczycieli. W finansowaniu partycypują także władze lokalne.

Rok szkolny obejmuje 183 dni (od września do końca czerwca). Szkoły są czynne pięć dni w tygodniu. Minimalny roczny wymiar zajęć w szkole podstawowej wynosi 915 godzin. Nie określa się obowiązkowej liczby lekcji, lecz jednostka lekcyjna w szkole podstawowej trwa na ogół 30 minut.

Głównym celem primary school jest przygotowanie dziecka do kształcenia przez całe życie. Program nauczania jest tak skonstruowany, aby zapewniał dostęp ucznia do szerokiego doświadczenia edukacyjnego poprzez bogaty wybór metod nauczania i uczenia się zaspokajających indywidualne potrzeby poszczególnych uczniów. Skupia się na pielęgnowaniu u dziecka jego życia duchowego, moralnego, poznawczego, emocjonalnego, intelektualnego, estetycznego, społecznego i fizycznego. Program nauczania obejmuje siedem następujących obszarów

32 http://www.education.ie/en/The-Education-System/Early-Childhood/. 
edukacyjnych: 1) język irlandzki i angielski, 2) matematyka, 3) wiedza o społeczeństwie, przyrodzie i środowisku (historia, geografia, przedmioty przyrodnicze), 4) edukacja artystyczna (wychowanie plastyczne, sztuki wizualne, muzyka i teatr), 5) wychowanie fizyczne, 6) wychowanie i edukacja zdrowotna, 7) religia.

Na zakończenie nauki w szkole podstawowej nie przeprowadza się formalnej oceny uczniów. Nauczyciele stosują jednak w swej codziennej pracy dydaktycznej wiele różnych metod oceny, m.in. sprawdziany na zakończenie roku. Promocja do następnej klasy odbywa się na ogół automatycznie, a uczniowie powtarzają klasę jedynie w wyjątkowych przypadkach.

\section{Szkolnictwo średnie}

Szkolnictwo średnie obejmuje uczniów od 12 do 18 roku życia. Wyróżnia się dwa cykle kształcenia:

- szkolnictwo średnie I stopnia (Junior Cycle),

- szkolnictwo średnie II stopnia (Senior Cycle).

Pierwszy cykl kształcenia (Junior Cycle) w szkole średniej jest obowiązkowy. Trwa trzy lata, przeznaczony jest dla uczniów w wieku 12-15 lat i prowadzi do uzyskania świadectwa ukończenia szkoły średniej I stopnia - Junior Certifcate. W szkołach średnich rok szkolny trwa 179 dni (od września do końca maja). Lekcje trwają na ogół 35-45 minut, a tygodniowy wymiar zajęć wynosi od 35 do 42 lekcji. Podstawa programowa dla pierwszego cyklu nauki we wszystkich Junior Cycle obejmuje język irlandzki, język angielski, matematykę, wychowanie obywatelskie z wiedzą o społeczeństwie i polityce oraz wychowanie fizyczne i edukację zdrowotną. W programie nauczania znajduje się 26 zatwierdzonych przez ministerstwo przedmiotów, lecz decyzję o wyborze określonego zestawu dla uczniów podejmuje szkoła.

W ramach szkolnictwa średniego I stopnia funkcjonują szkoły ogólnokształcące i zawodowe różnego typu. Źródłem ich nazw, zakresu programów nauczania, podmiotów zarządzających i finansujących działalność placówek są wielowiekowe tradycje kształtowania struktur oświatowych wynikające z uwarunkowań historyczno-społecznych Irlandii. Wśród szkół średnich I stopnia wyróżniamy trzy typy szkół: Voluntary secondary school, Vocational school i Community colleges, Community school i Comprehensive school ${ }^{33}$.

33 http://www.citizensinformation.ie/en/education/primary_and_post_primary_education/going_to_post_primary_school/types_of_post_primary_school.html. 
- Voluntary secondary school - prywatne szkoły średnie o profilu ogólnokształcącym, technicznym i zawodowym. Nadzorowane są przez wspólnoty religijne, rady lub osoby prywatne. Szkoły mogą być płatne lub bezpłatne. Placówki płatne nie otrzymują ministerialnych dotacji na utrzymanie szkół. Placówki bezpłatne otrzymują finansowanie i subwencje ze strony państwa.

- Vocational school i Community colleges - średnie szkoły zawodowe i kolegia. Ich właścicielami są lokalne rady ds. edukacji i szkoleń (Education and Training Boards, ETB) ${ }^{34}$. Szkoły tego typu w 93\% finansowane są z budżetu państwa. Pierwotnie tworzone były dla zapewnienia uczniom kształcenia zawodowego. Obecnie są to szkoły łączące kształcenie ogólnokształcące i zawodowe, otwarte także na kształcenie ustawiczne i edukację dorosłych.

- Community school i Comprehensive school - szkoły średnie ogólnokształcące zakładane przez społeczności lokalne w celu zapewnienia młodzieży programów nauczania dających możliwość łączenia kształcenia ogólnego i zawodowego. Kładą silny nacisk na orientację i poradnictwo pedagogiczno-zawodowe. Zarządzane są przez ciała reprezentujące interesy władz lokalnych. Placówki finansowane są z budżetu Ministerstwa Edukacji i Umiejętności. Organem przedstawicielskim szkół jest stowarzyszenie Association of Community and Comprehensive Schools (ACCS) ${ }^{35}$.

Na zakończenie nauki w trzyletnim Junior Cycle uczniowie przystępują do ogólnokrajowego egzaminu przeprowadzanego i ocenianego przez instytucje zewnętrzne. W wyniku egzaminu uzyskują Junior Certificate uprawniający do podjęcia nauki w wybranej placówce szkolnictwa średniego II stopnia, choć przeważająca większość uczniów przechodzi z pierwszego do drugiego cyklu w tej samej placówce szkolnej.

Drugi cykl kształcenia (Senior Cycle) w szkole średniej przeznaczony jest dla uczniów w wieku 15-18 lat. Tylko pierwszy rok nauki w tym cyklu objęty jest obowiązkiem szkolnym ${ }^{36}$, a pozostałe nie są obowiązkowe. W ramach szkolnictwa średniego II stopnia funkcjonują szkoły ogólnokształcące i zawodowe różnego typu. Podobnie jak w Junior Cycle, wśród szkół średnich II stopnia wyróżniamy następujące typy placówek: Voluntary secondary school, Vocational school i community colleges, Community school i comprehensive school. Jest częstą praktyką,

34 Jest to ustawowy lokalny organ oświatowy, któremu podlega szkolnictwo średnie i edukacja dorosłych. Zgodnie z podziałem administracyjnym w Irlandii działa 16 rad ds. edukacji i szkoleń.

35 http://www.accs.ie/.

36 Obowiązek szkolny trwa w Irlandii 10 lat i objęci są nim uczniowie w wieku od 6 do 16 lat. 
że w poszczególnych typach placówek w jednej szkole prowadzi się dwa cykle nauczania - Junior Cycle i Senior Cycle. Senior Cycle trwa dwa lub trzy lata zależnie od tego, czy uczniowie rozpoczną naukę, zapisując się na nieobowiązkowy tzw. rok przejściowy Transition Year (TY) ${ }^{37}$. Rok przejściowy jest ofertą dla uczniów, którzy ukończyli szkołę średnią I stopnia, nie są pewni, jaki kierunek lub profil szkoły ich interesuje i chcą lepiej przygotować się do podjęcia nauki w szkole średniej II stopnia. W ramach roku przejściowego nacisk kładzie się na rozwój indywidualny i społeczny uczniów oraz rozwijanie ich umiejętności ogólnych, umiejętności technicznych i umiejętności uczenia się. Często z TY korzystają uczniowie, którzy chcą rozwinąć swoje zainteresowania i pasje przedmiotowe. Mimo że Transition Year nie jest obowiązkowy, to ten dodatkowy (przejściowy) rok nauki wybiera około 80\% uczniów. Najmniejszą popularnością rok przejściowy cieszy się wśród uczniów, którzy wybierają zawodową ścieżkę edukacyjną. Główną ideą Transition Year jest wsparcie rozwoju indywidualnego i społecznego ucznia, rozwinięcie zainteresowań oraz pomoc w znalezieniu i odkryciu jego talentów. Kryteria naboru i proponowany program nauczania ustalają same szkoły na podstawie lokalnych potrzeb i zgodnie z ogólnymi wytycznymi Ministerstwa Edukacji i Umiejętności. Program może zawierać następujące obszary tematyczne: wychowanie obywatelskie i społeczeństwo, rozwój indywidualny i społeczny, orientacja i poradnictwo, religia, filozofia, wychowanie estetyczne, wychowanie fizyczne, języki irlandzki i angielski, poznanie istoty badań naukowych, środowisko naturalne i społeczne, technologie informatyczne, matematyka, biznes i przedsiębiorczość, przygotowanie do wyboru zawodu, przygotowanie do dorosłego życia i pracy. Dodatkowym, ważnym elementem programu jest wolontariat zorganizowany tak, aby uczniowie mogli uczestniczyć w działalności na rzecz społeczności lokalnych i organizacji charytatywnych. Zajęcia prowadzone podczas Transition Year mają charakter poznawczy i praktyczny. Brak jest formalnych sprawdzianów, testów i egzaminów. Najważniejszym elementem oferowanych zajęć jest poszerzenie doświadczenia życiowego i samorozwój ucznia.

Uczniowie kończący rok przejściowy i ci, którzy przechodzą bezpośrednio po ukończeniu Junior Cycle do dwuletniej szkoły Senior Cycle, realizują program przygotowujący do zewnętrznego państwowego egzaminu maturalnego Leaving Certificate (LC). Egzamin składa się obowiązkowo z pięciu lub siedmiu

37 Transition Year wprowadzono do szkolnictwa irlandzkiego jako projekt pilotażowy w 1974 r. Na stałe umieszczono go w strukturze systemu oświatowego od września 1994 r. 
przedmiotów zatwierdzonych przez centralną komisję egzaminacyjną, z których jednym musi być język irlandzki.

Na poziomie Senior Cycle istnieją trzy odrębne typy szkół realizujące trzy ciągi edukacyjne: ogólnokształcący, techniczny i zawodowy. Wybór profilu szkoły daje możliwość uzyskania świadectwa maturalnego zgodnego z dalszym planem edukacyjnym ucznia:

- po szkole średniej ogólnokształcącej uczniowie uzyskują świadectwo Leaving Certificate (LC). Świadectwo umożliwia podjęcie nauki na poziomie kształcenia wyższego,

- $\quad$ po szkole średniej technicznej uczniowie uzyskują świadectwo Leaving Certificate Vocational Programme (LCVP), w którym oprócz obowiązkowych ocen z przedmiotów ogólnokształcących znajdują się oceny z przedmiotów technicznych i związanych z nimi modułów zawodowych. Świadectwo umożliwia także podjęcie nauki na poziomie kształcenia wyższego,

- po szkole średniej zawodowej uczniowie uzyskują świadectwo Leaving Certificate Applied Programme (LCA). Potwierdza ono przygotowanie uczniów do dorosłego życia oraz późniejszego zatrudnienia. Świadectwo LCA nie jest wystarczające do podjęcia studiów wyższych, natomiast umożliwia absolwentom szkoły średniej kontynuację nauki na poziomie szkolnictwa policealnego (Post-Leaving Certificate Courses).

\section{Szkolnictwo powyżej średniego, nie wyższe (Further and Adult Education)}

Zasady funkcjonowania Further and Adult Education regulowane są dwiema ustawami z 2013 r.: ustawą o radach ds. edukacji i szkoleń (Education and Training Boards Act 2013) ${ }^{38}$ oraz ustawą o edukacji i szkoleniach (Further Education And Training Act 2013) ${ }^{39}$. System irlandzkiego szkolnictwa pomaturalnego, policealnego i ustawicznego (ISCED 4) zbliżony jest do systemu polskich szkół policealnych z rozszerzeniem na ustawiczną edukację dorosłych.

Tworzenie i prowadzenie ośrodków szkoleniowych kształcenia ustawicznego należy do rad ds. edukacji i szkoleń (Education and Training Boards, ETBs). Są to ustawowe jednostki władz oświatowych odpowiedzialne za wdrażanie programów szkoleniowych skierowanych do młodzieży i dorosłych oraz za realiza-

38 http://www.irishstatutebook.ie/2013/en/act/pub/0011/index.html.

39 http://www.irishstatutebook.ie/2013/en/act/pub/0025/index.html. 
cję polityki kształcenia ustawicznego. W ramach Further and Adult Education irlandzki system oświaty proponuje m.in.:

- roczne lub dwuletnie dzienne kształcenie zawodowe w pełnym wymiarze czasowym (Full-Time Programmes in Futer Education). Absolwenci uzyskują świadectwo ukończenia kursu na poziomie szkolnictwa powyżej średniego, tzw. PLC (Post Leaving Certificate),

- szkolenia zawodowe - VTOS (Vocational Training Opportunities Scheme). Szkolenia skierowane do bezrobotnych absolwentów szkół średnich powyżej 21 roku życia,

- Youthreach - szkolenia dla uczniów i młodzieży w wieku 15-20 lat pozostających bez żadnych kwalifikacji zawodowych, którzy z różnych powodów nie ukończyli szkoły średniej, lecz uzyskali Junior Certificate. Jego celem jest rozwijanie podstawowych umiejętności niezbędnych do podjęcia dalszego kształcenia i uzyskania zatrudnienia. Absolwenci Youthreach mogą uzyskać świadectwa ukończenia kursów w zakresie gastronomii, fryzjerstwa, stolarstwa, opieki nad dziećmi, obsługi programów komputerowych itp.

\section{Szkolnictwo wyższe}

Zasady funkcjonowania szkolnictwa wyższego w Irlandii regulowane są ustawą z 1997 r. o uniwersytetach (Universities Act 1997) ${ }^{40}$. Ustawowym organem planowania i rozwoju szkolnictwa wyższego oraz badań naukowych jest Urząd ds. Szkolnictwa Wyższego (Higher Education Authority, HEA) ${ }^{41}$. Urząd jest regulatorem systemu szkolnictwa wyższego, a do jego zadań należy nadzór i koordynowanie systemu szkolnictwa wyższego, rozdzielanie środków finansowych Ministerstwa Edukacji i Umiejętności przeznaczonych dla podległych jednostek oraz zapewnienie wysokiego poziomu kształcenia. Odpowiedzialny jest także za wdrożenie i realizację Narodowej Strategii Szkolnictwa Wyższego do 2030 roku (National Strategy for Higher Education to 2030) ${ }^{42}$. Strategia została przyjęta przez rząd w 2011 roku, a jej celem jest transformacja sektora szkolnictwa wyższego przez:

- wprowadzenie bardziej elastycznego systemu studiów,

- poprawę jakości nauczania i uczenia się ze szczególnym uwzględnieniem znaczenia efektów uczenia się,

40 http://www.irishstatutebook.ie/1997/en/act/pub/0024/.

41 http://www.hea.ie/en/about-hea.

42 http://www.education.ie/en/Publications/Policy-Reports/National-Strategy-for-Higher-Education-2030.pdf. 
- skoordynowanie programów nauczania z oczekiwaniami absolwentów, pracodawców i dynamicznie zmieniającego się rynku pracy.

W Irlandii działa 7 uniwersytetów (Universities), 14 instytutów technicznych (Institutes of Technology), 7 kolegiów pedagogicznych (Colleges of Education), 8 specjalistycznych szkół wyższych o profilu medycznym, teologicznym, prawniczym, rolniczym, muzycznym i sztuk pięknych.

Organizacyjnie szkolnictwo wyższe podzielone jest na sektor uniwersytecki i nieuniwersytecki. Sektor uniwersytecki oferuje programy studiów w takich dziedzinach, jak nauki humanistyczne, techniczne, ścisłe, społeczne i medyczne. Sektor nieuniwersytecki proponuje programy dające wyższe kwalifikacje zawodowe o profilu technicznym i nauczycielskim.

Zgodnie z procesem bolońskim i konsolidacją Europejskiego Obszaru Szkolnictwa Wyższego w irlandzkim szkolnictwie wyższym studia dzielą się na:

- szkolnictwo wyższe I i I stopnia (ISCED 5),

- studia I stopnia - trwają 3-4 lata i kończą się uzyskaniem tytułu zawodowego licencjata lub inżyniera,

- studia II stopnia - trwają 2 lata i kończą się uzyskaniem tytułu zawodowego magistra, magistra inżyniera albo tytułu równorzędnego,

- szkolnictwo wyższe III stopnia (ISCED 6),

- studia III stopnia - trwają 3-4 lata, kończą się uzyskaniem stopnia naukowego doktora. Doktorat jest w Irlandii najwyższą kwalifikacją akademicką.

\section{Kształcenie specjalne}

Zasady funkcjonowania szkolnictwa specjalnego regulowane są ustawą z $2004 \mathrm{r}$. o edukacji osób ze specjalnymi potrzebami edukacyjnymi (Education for Persons with Special Educational Needs Act 2004, EPSEN Act 2004) ${ }^{43}$. Artykuł 2 ustawy Edukacja włączająca (Inclusive education) - stanowi, że dzieci ze specjalnymi potrzebami edukacyjnymi są kształcone razem z dziećmi, które takich potrzeb nie mają, o ile jest to zgodne z ich dobrem.

Działania władz oświatowych w obszarze kształcenia specjalnego ukierunkowane są na maksymalną integrację niepełnosprawnych uczniów w szkołach ogólnodostępnych. Do najczęściej stosowanych rozwiązań integracyjnych zalicza się trzy formuły uczestnictwa dziecka w kształceniu specjalnym:

43 http://www.irishstatutebook.ie/2004/en/act/pub/0030/. 
- uczeń niepełnosprawny może pobierać naukę w szkole i klasie ogólnodostępnej, w której pozostaje pod opieką nauczyciela i/lub asystenta specjalizującego się w kształceniu specjalnym,

- uczeń niepełnosprawny może pobierać naukę w klasie specjalnej w szkole ogólnodostępnej,

- uczeń niepełnosprawny może pobierać naukę w szkole specjalnej dla uczniów z określonym rodzajem dysfunkcji. Szkoły specjalne funkcjonują w strukturze systemu szkolnego Irlandii od poziomu edukacji przedpoczątkowej (Early Start Programme) do szczebla szkolnictwa średniego II stopnia włącznie (Senior (ycle).

Zgodnie z wytycznymi Ministerstwa Edukacji i Umiejętności w klasach specjalnych i szkołach specjalnych liczba uczniów przypadających na jednego nauczyciela nie powinna przekraczać 12 i jednocześnie odzwierciedlać charakter i stopień niepełnosprawności uczniów. Uczniowie niepełnosprawni i ze specjalnymi potrzebami edukacyjnymi podlegają opiece Krajowego Ośrodka Opieki Pedagogiczno-Psychologicznej (National Educational Psychological Service, NEPS) ${ }^{44}$. Charakter pracy psychologów NEPS zbliżony jest do zakresu działalności polskich poradni psychologiczno-pedagogicznych i związany jest z diagnozowaniem i oceną poziomu rozwoju intelektualnego dzieci i młodzieży, pomocą świadczoną dla uczniów ze specjalnymi trudnościami w nauce oraz określaniem predyspozycji do wykonywania zawodu. Do obowiązków pracowników NEPS należy współpraca z nauczycielami, rodzicami i dziećmi w identyfikacji potrzeb edukacyjnych. Uczniowie, którzy zostali ocenieni jako osoby mające specjalne potrzeby edukacyjne, mają ułatwiony dostęp do wielu specjalnych usług wsparcia.

W placówkach, do których uczęszczają uczniowie o specjalnych potrzebach edukacyjnych, opiekę nad nimi sprawują trzy kategorie nauczycieli-specjalistów: - Resource Teacher (terapeuta) - odpowiedzialny przede wszystkim za uczniów, którzy otrzymali z NEPS specjalne orzeczenie o deficytach i dysfunkcjach (statement of special educational needs). Do jego zadań należy opracowanie indywidualnego programu nauczania dla tych uczniów oraz codzienna pomoc pedagogiczno-psychologiczna. Liczba etatów Resource Teacher przypadająca na szkołę zmienia się każdego roku i zależna jest od liczby uczniów posiadających orzeczenie NEPS,

- Support teacher (nauczyciel wspomagający) - odpowiedzialny za dodatkowe nauczanie uczniów, którzy potrzebują pomocy. Pracuje z uczniami w trak-

44 http://www.education.ie/en/Parents/Information/Educational-Psychological-Services/. 
cie lekcji lub po ich zakończeniu. Forma pracy to zajęcia indywidualne lub w grupach. Wśród zadań stawianych Support teacher znajdują się: 1) pomoc uczniom $\mathrm{w}$ przezwyciężaniu problemów spowodowanych trudnościami w nauce, 2) rozwijanie i wspieranie odpowiednich zdolności i umiejętności społecznych w celu umożliwienia optymalnego rozwoju ucznia, 3) zachęcanie ucznia do rozwijania pewności siebie i niezależności, 4) dotarcie do potencjału intelektualnego ucznia i jego talentów. Liczba etatów przeznaczonych dla nauczycieli wspomagających zależy od liczby uczniów i klas w szkole, ale przede wszystkim od tego, czy szkoła została zakwalifikowana do programu działań na rzecz integracji edukacyjnej (Delivering Equality of Opportunity in Schools, DEIS) ${ }^{45}$,

- ESL Teachers (nauczyciel języka angielskiego jako drugiego języka) ${ }^{46}$ - odpowiedzialny za nauczanie języka angielskiego jako języka dodatkowego. Zatrudniani są w szkołach, w których uczniowie posługujący się w domach językiem innym niż angielski stanowią znaczny odsetek wszystkich uczniów. ESL Teachers uczą języka angielskiego, wykorzystując spontaniczność dziecka w środowisku dwujęzycznym, pomagając jednocześnie w realizacji różnych aspektów programu szkolnego, z którymi dzieci dwujęzyczne mogą mieć problemy (np. czytanie i pisanie).

\section{Kształcenie nauczycieli}

Zawód nauczyciela w Irlandii jest zawodem regulowanym. Od roku szkolnego 2012/2013 każda osoba wykonująca zawód nauczyciela musi być zarejestrowana w Radzie ds. Nauczania (Teaching Council) ${ }^{47}$. Rada pełni funkcję regulatora zawodu nauczycielskiego, określa standardy zawodowe w nauczaniu, weryfikuje przygotowanie merytoryczne nauczycieli i ich kwalifikacje zawodowe oraz dba o prestiż zawodu nauczyciela.

W Irlandii funkcjonują dwa modele kształcenia nauczycieli - czteroletni i sześcioletni. Pierwszy z nich zakłada jednoczesne zdobywanie kompetencji peda-

45 Program Działań na rzecz Integracji Edukacyjnej zainicjowany przez irlandzkie Ministerstwo Edukacji i Umiejętności w 2005 r. Program skupia się na rozwiązywaniu potrzeb edukacyjnych dzieci i młodzieży ze środowisk defaworyzowanych w wieku od 3 do 18 lat. Programem objętych jest 657 szkół podstawowych i 192 szkoły średnie z dzielnic i miejsc uznanych za obszary zagrożone patologiami społecznymi.

46 English as a second language (ESL), http://www.eslopportunities.com/.

47 http://www.teachingcouncil.ie/. 
gogicznych i przedmiotowych realizowane w trybie czteroletnich studiów pedagogiczno-przedmiotowych. Ten model przeznaczony jest dla osób planujących podjęcie pracy jako nauczyciel na poziomie szkolnictwa przedpoczątkowego (Early Start Programme) oraz podstawowego (Primary). Drugi model przewiduje etap czteroletnich studiów w ramach wybranego przedmiotu, a następnie dwuletni etap zdobywania kompetencji pedagogicznych na studiach magisterskich. Ten model przeznaczony jest dla przyszłych nauczycieli w szkole średniej I i II stopnia (Junior Cycle i Senior Cycle).

Kształcenie nauczycieli dla Primary schools prowadzone jest w kolegiach pedagogicznych (Colleges of Education), które znane są w Irlandii z bardzo wysokich wymagań rekrutacyjnych. Ważnym elementem studiów jest realizacja praktyk nauczycielskich w szkołach w wymiarze 8,5 godziny tygodniowo. Praktyki obserwowane i nadzorowane są przez wykładowców, którzy siedem razy w roku dokonują kompleksowej oceny przeprowadzonych lekcji. Absolwenci kolegiów otrzymują dyplom Bachelor of Education degree (B.Ed.) będący odpowiednikiem dyplomu licencjackiego.

Kształcenie nauczycieli dla szkolnictwa średniego odbywa się na uniwersytetach w trybie studiów dwustopniowych (licencjat i magisterium) zakończonych dyplomem magisterskim (Master). Aby zostać nauczycielem szkoły średniej niezbędne jest:

- uzyskanie dyplomu magisterskiego ukończenia uczelni wyższej,

- przepracowanie jako nauczyciel jednego roku próbnego oraz

- uznanie kwalifikacji przez Teaching Council.

Przeciętne tygodniowe pensum dydaktyczne nauczyciela w Irlandii wynosi 23 (22-25) godziny. Nauczycieli zatrudnia szkoła, ale ich wynagrodzenia finansuje państwo, gdyż mają oni status urzędników państwowych. Spośród wszystkich absolwentów studiów nauczycielskich tylko 4\% znajduje stałą pracę na pełny etat. Pozostali przez 6-7 lat pracują na umowę na czas określony i dopiero po tym okresie mogą liczyć na stałe zatrudnienie ${ }^{48}$.

\section{Podsumowanie. Problemy}

Cechą charakterystyczną oświaty Irlandii jest jej wyznaniowy charakter oraz duże rozdrobnienie małych szkół podstawowych. 95\% szkół finansowanych jest z budże-

48 Ośrodek Rozwoju Edukacji, http://www.ore.edu.pl/wp-content/plugins/download-attachments/includes/download.php?id=3871. 
tu państwa, choć większość z nich zakładana i prowadzona jest przez Kościół katolicki, fundacje wyznaniowe oraz osoby prywatne. Nad całością ustroju szkolnego czuwa Ministerstwo Edukacji i Umiejętności (Department of Education and Skills), do którego zadań należy całościowe planowanie polityki oświatowej, pozyskiwanie środków oraz zapewnienie szerokiego zakresu usług wsparcia dla sektora edukacji. Wsparciem tym zajmuje się sieć ponad 30 instytucji, agencji, komitetów i wydziałów działających w ramach ministerstwa lub współpracujących z resortem.

Wydatki publiczne na irlandzkie instytucje edukacyjne osiągają poziom 6,4\% PKB. Odsetek nakładów na edukację ze źródeł publicznych wynosi 92,5\%, a ze źródeł prywatnych 7,5\%. Finansowanie ze środków publicznych obejmuje wszystkie poziomy kształcenia oraz większość usług edukacyjnych od szkoły podstawowej do kształcenia dorosłych.

W Irlandii zasadniczo nie istnieje zorganizowana centralnie publiczna sieć żłobków i placówek wychowania przedszkolnego. Żłobki i przedszkola oferujące usługi opiekuńczo-wychowawcze dla najmłodszych są to płatne placówki zakładane i prowadzone przez osoby prywatne lub przez inne podmioty. Obowiązek szkolny trwa w Irlandii 10 lat i objęci są nim uczniowie w wieku od 6 do 16 lat. W ramach struktury irlandzkiego ustroju szkolnego, oprócz klasycznej struktury kształcenia od szkoły podstawowej do studiów doktoranckich, ciekawym rozwiązaniem jest wprowadzenie roku przejściowego (Transition Year) jako propozycji dla uczniów, którzy ukończyli szkołę średnią I stopnia, nie są pewni, jaki kierunek lub profil szkoły ich interesuje w dalszym etapie kształcenia i chcą lepiej przygotować się do podjęcia nauki w szkole średniej II stopnia. Mimo że Transition Year nie jest obowiązkową formułą, to ten dodatkowy (przejściowy) rok nauki wybiera około 80\% uczniów.

Zawód nauczyciela w Irlandii jest zawodem regulowanym, a każda osoba wykonująca zawód nauczyciela musi być zarejestrowana w Radzie ds. Nauczania (Teaching Council). Rada pełni funkcję regulatora zawodu nauczycielskiego, określa standardy zawodowe w nauczaniu, weryfikuje przygotowanie merytoryczne nauczycieli i ich kwalifikacje zawodowe oraz dba o prestiż nauczycielskiego zawodu.

Jednym z ciekawszych i specyficznych problemów szkolnictwa Irlandii jest zagadnienie nauki języka irlandzkiego. Zgodnie zapisami konstytucji język irlandzki (Gaeilge) jako język narodowy jest pierwszym językiem urzędowym, drugim jest język angielski. Mimo zapisu konstytucyjnego, obowiązkowej nauki w szkołach, umieszczania nazw ulic i informacji na drogowskazach, szacuje się, że językiem Gaeilge włada około 10\% mieszkańców. Aby zwiększyć zaintereso- 
wanie tym językiem, Ministerstwo Edukacji i Umiejętności wdraża od 2010 roku program - 20-letnia strategia dla języka irlandzkiego 2010-203049. Jego celem jest zwiększenie popularności języka irlandzkiego wśród mieszkańców kraju. Realizacji tego celu ma sprzyjać zwiększenie nacisku na kształcenie językowe na poszczególnych poziomach edukacji, realizacja specjalnych programów promujących język i kształcenie nauczycieli języka irlandzkiego.

\section{Bibliografia}

Konstytucja Irlandii, Wydawnictwo Sejmowe, Warszawa 2006.

Education policy outlook: Ireland, OECD 2013, http://www.oecd.org/edu/EDUCATION POLICY OUTLOOK IRELAND_EN.pdf.

\section{Akty prawne}

Education Act 1998, http://www.irishstatutebook.ie/1998/en/act/pub/0051/.

ESPEN Act 2004 (Education for Persons with Special Educational Needs), http://www.irishstatutebook.ie/2004/en/act/pub/0030/.

\section{Strony internetowe}

http://www.education.ie/en/.

http://www.irishstatutebook.ie/1998/en/act/pub/0051/.

http://www.irishstatutebook.ie/2013/en/act/pub/0011/index.html.

http://www.childabusecommission.ie/.

http://www.educationfinanceboard.ie/.

http://hea.ie/.

http://www.hea.ie/en/about-hea.

http://www.education.ie/en/Publications/Policy-Reports/National-Strategy-for-Higher-

Education-2030.pdf.

https://www.leargas.ie/.

https://www.ncge.ie/.

https://www.education.ie/en/The-Department/Bodies-and-Committees/Vocational-

Education-Committees-VECs-.html.

49 20-Year Strategy for the Irish Language 2010-2030, http://www.education.ie/en/Publications/Policy-Reports/20-Year-Strategy-for-the-Irish-Language-2010-2030.pdf. 
https://www.studentgrantappeals.ie/.

http://www.accs.ie/.

https://www.education.ie/en/The-Department/Bodies-and-Committees/Information.html.

http://www.education.ie/en/The-Department/Management-Organisation/Inspectorate.

html.

http://www.education.ie/en/The-Department/Management-Organisation/Inspectorate. html\#sthash.foXmqRau.dpuf.

http://www.education.ie/en/Publications/Statistics/Key-Statistics/Key-Statistics-2012-2013. pdf.

http://ekspercibolonscy.org.pl/sites/ekspercibolonscy.org.pl/files/2012_pl_kluczowe_ dane_o_edukacji_w_europie_2012.pdf.

http://ekspercibolonscy.org.pl/sites/ekspercibolonscy.org.pl/files/2012_pl_kluczowe_ dane_o_edukacji_w_europie_2012.pdf.

http://www.oecd.org/edu/EDUCATION POLICY OUTLOOK IRELAND_EN.pdf.

http://www.citizensinformation.ie/en/social_welfare/social_welfare_payments/social_ welfare_payments_to_families_and_children/back_to_school_clothing_and_footwear_ allowance.html.

http://www.ibe.unesco.org/fileadmin/user_upload/archive/Countries/WDE/2006/

WESTERN_EUROPE/Ireland/Ireland.htm.

http://www.education.ie/en/The-Education-System/Early-Childhood/.

http://www.citizensinformation.ie/en/education/primary_and_post_primary_education/

going_to_post_primary_school/types_of_post_primary_school.html.

http://www.education.ie/en/Parents/Information/Educational-Psychological-Services/.

http://www.eslopportunities.com/.

http://www.teachingcouncil.ie/.

http://www.education.ie/en/Publications/Policy-Reports/20-Year-Strategy-for-the-Irish-

Language-2010-2030.pdf. 
Część 2

\title{
Program nauczania
}

\author{
Part 2 \\ School curriculum
}


DOI: https://doi.org/10.31268/d.dziewulak.2020.01 


\title{
2.1. Kształcenie zawodowe w Polsce i wybranych państwach członkowskich Unii Europejskiej
}

\author{
Vocational education systems in Poland and in selected \\ EU member states
}

W opracowaniu przedstawiono problematykę systemu kształcenia zawodowego w Polsce i w wybranych państwach Unii Europejskiej. W artykule zaprezentowano podstawowe definicje i pojęcia z obszaru tytułowego zagadnienia. Przedstawiono syntetyczną informację na temat wybranych problemów i organizacji kształcenia zawodowego w systemach szkolnych następujących państw: Polski, Austrii, Danii, Holandii, Niemiec, Szwecji, Wielkiej Brytanii.

Słowa kluczowe: edukacja, szkoła, nauczanie, zawód, Unia Europejska

The paper provides an overview of the systems of vocational education in Poland and in selected EU member states. It presents basic definitions and concepts within the subject area. The author gives a brief overview of the organizational structure and examines selected issues concerning the system of vocational education in the school systems in the following countries: Poland, Austria, Denmark, Netherlands, Germany, Sweden and United Kingdom.

Keywords: education, school, teaching, profession, European Union

\section{Podstawowe definicje i pojęcia}

Pojęcie kształcenia zawodowego ${ }^{1}$ definiuje się najczęściej w literaturze pedagogicznej jako proces, którego celem jest przekazanie uczniom określonego zasobu wiedzy i umiejętności z zakresu przemysłu, rolnictwa i hodowli oraz szeroko rozumianych usług. Proces ten obejmuje przekazanie określonego zasobu wiedzy ogólnej oraz specjalistycznych umiejętności teoretycznych i praktycznych, których opanowanie uprawnia uczniów do wykonywania wybranego zawodu. Rezultatem kształcenia zawodowego jest wykształcenie zawodowe uzyskane

1 Opracowanie przygotowano na podstawie ekspertyzy Biura Analiz Sejmowych nr 3073/12 z 18 lutego 2013 r. D. Dziewulaka zatytułowanej Informacja nt. na temat systemu ksztatcenia zawodowego w Polsce i $w$ wybranych państwach Unii Europejskiej (Austria, Dania, Holandia, Niemcy, Szwecja, Wielka Brytania) oraz artykułu tegoż autora Ksztatcenie zawodowe w Polsce i w wybranych państwach Unii Europejskiej, „Analizy BAS” 2013, nr 6(95), s. 1-12. 
w określonej specjalności ${ }^{2}$. W większości państw świata kształcenie zawodowe realizowane jest w ramach powszechnego systemu oświatowego, którego częścią jest system szkolny definiowany jako układ powiązanych ze sobą placówek szkolnych różnego typu i szczebla o określonej strukturze organizacyjnej i programowej$^{3}$. Kształcenie zawodowe realizowane jest w ramach szkoły typu zawodowego, czyli szkoły zawodowej. Należy zwrócić uwagę, że pojęcia szkoła zawodowa lub szkolnictwo zawodowe są terminami wieloznacznymi4 i mogą oznaczać:

- instytucję edukacyjną, której głównym celem jest przygotowanie kwalifikowanych kadr dla gospodarki narodowej,

- instytucję oświatowo-wychowawczą, zajmującą się celowo organizowanym kształceniem zawodowym, prowadzącym do kwalifikacji pracowniczych, umożliwiających podjęcie pracy w określonym zawodzie lub na odpowiednim stanowisku pracy,

- wielopodmiotową instytucję zorganizowanych działań edukacyjnych, wśród których podstawowa rola przypada czynnościom nauczania nauczycieli szkół zawodowych oraz czynnościom uczenia się uczniów szkół zawodowych, których ogólna wymowa prowadzi do wychowania człowieka, obywatela i pracownika zarazem,

- miejsce realizacji procesu kształcenia zawodowego (np. szkoła przyzakładowa). Wieloznaczność terminu wynika także stąd, że w polskim systemie szkolnym wyróżnia się trzy główne poziomy kształcenia zawodowego:

- zasadniczy (zwany niekiedy podstawowym),

- średni - średnie szkoły zawodowe (w tym technika i licea specjalistyczne lub policealne szkoły zawodowe),

- wyższy - wyższe szkoły zawodowe (np. politechniki).

\section{System kształcenia zawodowego w Polsce}

\section{Wprowadzenie}

Zgodnie z art. 70 Konstytucji Rzeczypospolitej Polskiej, prawo do nauki przysługuje każdemu, a władze publiczne są zobowiązane do zapewnienia wszystkim

2 C. Kupisiewicz, M. Kupisiewicz, Słownik pedagogiczny, Państwowe Wydawnictwo Naukowe, Warszawa 2009, s. 90.

3 Tamże, s. 170-171.

4 Encyklopedia pedagogiczna XXI wieku, t. VI, Wydawnictwo Akademickie „Żak”, Warszawa 2007, s. 310. 
obywatelom równego dostępu do wykształcenia. Konstytucja stanowi również, że nauka w szkołach publicznych jest bezpłatna, a nauka jest obowiązkowa do ukończenia 18 roku życia. Realizowana jest ona w ramach obowiązku szkolnego i obowiązku nauki5 . Obowiązek szkolny dziecka rozpoczyna się z początkiem roku szkolnego w tym roku kalendarzowym, w którym dziecko kończy 7 lat, oraz trwa do ukończenia gimnazjum, nie dłużej jednak niż do ukończenia 18 roku życia. Po ukończeniu gimnazjum obowiązek nauki spełnia się: przez uczęszczanie do publicznej lub niepublicznej szkoły ponadgimnazjalnej albo przez realizowanie przygotowania zawodowego u pracodawcy. $\mathrm{W}$ polskim systemie oświaty wybór ścieżki zawodowej jest możliwy po ukończeniu gimnazjum (w państwach UE uczniowie na ogół rozpoczynają edukację zawodową w 16 roku życia).

Od 1 września 2012 roku kształcenie zawodowe w Polsce, zgodnie z przepisami wprowadzonymi ustawą z 19 sierpnia 2011 roku o zmianie ustawy o systemie oświaty oraz niektórych innych ustaw (Dz.U. nr 205, poz. 1206), odbywa się w następujących typach szkół:

- trzyletniej zasadniczej szkole zawodowej, której ukończenie umożliwia uzyskanie dyplomu potwierdzającego kwalifikacje zawodowe po zdaniu egzaminów potwierdzających kwalifikacje w danym zawodzie, a także dalsze kształcenie począwszy od klasy II liceum ogólnokształcącego dla dorosłych,

- czteroletnim technikum, którego ukończenie umożliwia uzyskanie dyplomu potwierdzającego kwalifikacje zawodowe po zdaniu egzaminów potwierdzających kwalifikacje w danym zawodzie, a także uzyskanie świadectwa dojrzałości po zdaniu egzaminu maturalnego,

- szkole policealnej dla osób posiadających wykształcenie średnie, o okresie nauczania nie dłuższym niż 2,5 roku, umożliwiającej uzyskanie dyplomu potwierdzającego kwalifikacje zawodowe po zdaniu egzaminów potwierdzających kwalifikacje w danym zawodzie,

- trzyletniej szkole specjalnej przysposabiającej do pracy dla uczniów z upośledzeniem umysłowym w stopniu umiarkowanym lub znacznym oraz dla uczniów z niepełnosprawnościami sprzężonymi, której ukończenie umożliwia uzyskanie świadectwa potwierdzającego przysposobienie do pracy.

5 Zob. D. Dziewulak, Obowiazek szkolny w Unii Europejskiej, „Analizy BAS” 2010, nr 9(34), http://parl.sejm.gov.pl/WydBAS.nsf/0/A4F8763AAD6E8E70C12576EEE029DFE9/\$file/Analiza_\%20BAS_2009_34.pdf. 


\section{Klasyfikacja zawodów szkolnictwa zawodowego}

W szkołach kształcenie zawodowe jest prowadzone w zawodach ujętych w klasyfikacji zawodów szkolnictwa zawodowego. Klasyfikację zawodów szkolnictwa zawodowego określa $w$ drodze rozporządzenia minister właściwy do spraw oświaty i wychowania na podstawie wniosków ministrów właściwych dla zawodów, wyznaczonych ze względu na odpowiedni dział administracji rządowej, wskazany w ustawie z 4 września 1997 r. o działach administracji rządowej (Dz.U. 2007, nr 65, poz. 437, ze zm.).

Z dniem 1 września 2012 roku - w związku z wdrażaną modernizacją systemu kształcenia zawodowego - weszła w życie nowa klasyfikacja zawodów szkolnictwa zawodowego ustalona rozporządzeniem Ministra Edukacji Narodowej z 23 grudnia 2011 r. w sprawie klasyfikacji zawodów szkolnictwa zawodowego (Dz.U. 2012, poz. 7). Nowe ujęcie zawodów w klasyfikacji polega przede wszystkim na tym, że nie tylko określa ona zawody i wskazuje typ szkoły, w którym może być prowadzone kształcenie w danym zawodzie, ale także wskazuje i nazywa wyodrębnione w nich kwalifikacje. A ponadto określa, czy kształcenie w zakresie danej kwalifikacji może być prowadzone w pozaszkolnych formach kształcenia realizowanych w trybie kwalifikacyjnych kursów zawodowych.

W Polsce nowa klasyfikacja zawodów szkolnictwa zawodowego przewiduje kształcenie w zakresie 200 zawodów i 252 kwalifikacji wyodrębnionych w ramach zawodów. Poszczególne zawody przypisane są do obszarów kształcenia.

Uwzględniając Polską Klasyfikację Działalności (PKD) ${ }^{6}$, wyodrębniono osiem obszarów kształcenia?:

- administracyjno-usługowy (A),

- budowlany (B),

- elektryczno-elektroniczny (E),

6 Polska Klasyfikacja Działalności jest umownie przyjętym, hierarchicznie usystematyzowanym podziałem zbioru rodzajów działalności społeczno-gospodarczej, jakie realizują jednostki (podmioty gospodarcze). Została opracowana na podstawie Europejskiej Klasyfikacji Działalności - NACE Rev. 1, opublikowanej w Official Journal of the European Communities (OJ) nr L 293 z 24 października 1990 r. z późniejszymi zmianami opublikowanymi w (OJ) nr 83 z 3 kwietnia 1993 r. Zgodnie z rozporządzeniem Rady Ministrów z 7 października 1997 r. w sprawie Polskiej Klasyfikacji Działalności (Dz.U. nr 128, poz. 829, ze zm.) w okresie od 1 stycznia 1998 r. do 31 grudnia 1999 r. Polską Klasyfikację Działalności stosowano równolegle z Europejską Klasyfikacją Działalności (EKD). Od 1 stycznia 2000 r. PKD zastąpiła całkowicie EKD.

7 Rozporządzenie Ministra Edukacji Narodowej z 23 grudnia 2011 r. w sprawie klasyfikacji zawodów szkolnictwa zawodowego, Dz.U. 2012, poz. 7. 
- mechaniczny i górniczo-hutniczy (M),

- rolniczo-leśny z ochroną środowiska (R),

- turystyczno-gastronomiczny (T),

- medyczno-społeczny (Z),

- $\operatorname{artystyczny}(\mathrm{S})$.

\section{Podstawy programowe}

Nauka w szkołach prowadzących kształcenie zawodowe oparta jest na dwóch podstawach programowych: kształcenia ogólnego i kształcenia w zawodach. Podstawy programowe określają efekty kształcenia, które powinien osiągnąć uczeń kończący szkołę i uzyskujący kwalifikacje w systemie oświaty. Poziom opanowania przez ucznia wiadomości i umiejętności wynikających z podstaw programowych podlega $w$ trakcie nauki w szkole ocenie dokonywanej przez nauczycieli. Podstawy programowe determinują także zakres wiadomości i umiejętności, które będą sprawdzane w zakresie kształcenia ogólnego na egzaminie maturalnym, a w zakresie kształcenia zawodowego na egzaminie potwierdzającym kwalifikacje w zawodzie, tym samym stanowią one standardy egzaminacyjne.

\section{Podstawa programowa kształcenia ogólnego}

Począwszy od 1 września 2012 roku, w klasach pierwszych szkół ponadgimnazjalnych (liceum ogólnokształcące, technikum i zasadnicza szkoła zawodowa) obowiązuje nowa podstawa programowa kształcenia ogólnego ${ }^{8}$. Program nauki w liceach ogólnokształcących, technikach i zasadniczych szkołach zawodowych został powiązany z programem realizowanym w gimnazjach, co oznacza, że treści ogólnokształcące rozpoczęte w gimnazjum mają być kontynuowane w zakresie podstawowym na poziomie ponadgimnazjalnym.

W liceum ogólnokształcącym, technikum i zasadniczej szkole zawodowej w zakresie podstawowym realizowane są te same przedmioty ogólnokształcące. Różny jest jednak okres ich realizacji: w liceum ogólnokształcącym - rok, w technikum 2 lata, w zasadniczej szkole zawodowej - 3 lata. Dzięki temu absolwenci zasadniczych szkół zawodowych, aby uzyskać wykształcenie średnie mogą kontynuować naukę w liceach ogólnokształcących dla dorosłych bezpośrednio od klasy drugiej.

8 Rozporządzenie Ministra Edukacji Narodowej z 27 sierpnia 2012 r. w sprawie podstawy programowej wychowania przedszkolnego oraz kształcenia ogólnego w poszczególnych typach szkół, Dz.U. poz. 977. 
Różnica między poszczególnymi typami szkół ponadgimnazjalnych dotyczy przedmiotów ogólnokształcących w zakresie rozszerzonym. Uczniowie liceum ogólnokształcącego wybierają od 2 do 4 przedmiotów ujętych w podstawie programowej kształcenia ogólnego w zakresie rozszerzonym. Co najmniej jednym z tych przedmiotów powinna być: historia, geografia, biologia, chemia lub fizyka. Uczniowie, którzy nie realizują w zakresie rozszerzonym przedmiotu historia, obowiązani są realizować przedmiot uzupełniający historia i społeczeństwo. Uczniowie, którzy nie realizują w zakresie rozszerzonym przedmiotu geografia, biologia, chemia lub fizyka, obowiązani są realizować przedmiot uzupełniający przyroda. Takie rozwiązanie ma gwarantować zachowanie równowagi między nauczaniem przedmiotów ścisłych i humanistycznych.

Uczniowie technikum mają możliwość wyboru dwóch przedmiotów ujętych w podstawie programowej kształcenia ogólnego w zakresie rozszerzonym. Jednym z tych przedmiotów powinna być geografia, biologia, chemia, fizyka lub matematyka. Uczniowie technikum będą mogli realizować również w zakresie rozszerzonym przedmiot historia. Uczeń, który realizuje w zakresie rozszerzonym przedmioty historia i matematyka, jest obowiązany realizować przedmiot uzupełniający przyroda. Przedmioty realizowane w zakresie rozszerzonym powinny być powiązane z zawodem, w którym kształci szkoła. Istotną zasadą jest bowiem korelacja kształcenia ogólnego i zawodowego.

\section{Podstawa programowa kształcenia w zawodach}

Istotna zmiana w kształceniu zawodowym wprowadzona od 1 września 2012 roku dotyczy podstawy programowej kształcenia w zawodach. Obejmuje ona obowiązkowe zestawy celów kształcenia i treści nauczania opisane w formie oczekiwanych efektów kształcenia: wiedzy, umiejętności zawodowych oraz kompetencji personalnych i społecznych, niezbędnych dla zawodów lub kwalifikacji wyodrębnionych w zawodach, które należy uwzględnić w programach nauczania. Podstawa programowa kształcenia w zawodach określa także warunki realizacji kształcenia w zawodach, w tym zalecane wyposażenie w pomoce dydaktyczne i sprzęt oraz minimalną liczbę godzin kształcenia zawodowego.

Treści nauczania, opisane w formie oczekiwanych efektów kształcenia obejmują:

- efekty kształcenia wspólne dla wszystkich zawodów: bezpieczeństwo i higiena pracy, podejmowanie i prowadzenie działalności gospodarczej, język obcy ukierunkowany zawodowo, kompetencje personalne i społeczne oraz organizacja pracy małych zespołów (w technikum i szkole policealnej), 
- efekty kształcenia wspólne dla zawodów w ramach obszaru kształcenia, stanowiące podbudowę do kształcenia w zawodzie lub grupie zawodów,

- efekty kształcenia właściwe dla kwalifikacji wyodrębnionych w zawodach.

\section{Kształcenie praktyczne i współpraca z pracodawcami}

Praktyczna nauka zawodu może odbywać się w placówkach kształcenia ustawicznego, placówkach kształcenia praktycznego, warsztatach szkolnych, pracowniach szkolnych, u pracodawców, a także w indywidualnych gospodarstwach rolnych. Może ona mieć formę zajęć praktycznych (dotyczy zasadniczej szkoły zawodowej) lub praktyk zawodowych (dotyczy technikum) ${ }^{9}$. Zajęcia praktyczne organizuje się dla uczniów i młodocianych w celu opanowania przez nich umiejętności zawodowych, niezbędnych do podjęcia pracy w danym zawodzie. Praktyki zawodowe organizuje się dla uczniów w celu zastosowania i pogłębienia zdobytej wiedzy i umiejętności zawodowych w rzeczywistych warunkach pracy.

W zasadniczej szkole zawodowej szczególny nacisk został położony na kształcenie praktyczne. Dlatego też w ciągu trzech lat nauki ma ono obejmować ponad $60 \%$ całego czasu przeznaczonego na kształcenie zawodowe.

Praktyczna nauka zawodu realizowana u pracodawców odbywa się na podstawie umowy zawartej między szkołą a pracodawcą. Umowa określa m.in. sposób ponoszenia kosztów realizowania praktycznej nauki zawodu. Oprócz zawarcia umowy ważnym elementem współpracy szkoły z zakładem pracy jest włączenie pracodawców w proces kształtowania programów kształcenia dla zawodu, w szczególności w części dotyczącej praktycznej nauki zawodu. Współpraca pracodawców ze szkołami ma obejmować takie formy, jak: udział w życiu szkoły, wycieczki przedmiotowe czy wsparcie bazy technodydaktycznej szkoły. W szkole może też być zatrudniona osoba niebędąca nauczycielem, a mająca przygotowanie zawodowe uznane przez dyrektora szkoły za odpowiednie do prowadzenia zajęć z zakresu kształcenia zawodowego, z tym że zatrudnienie tej osoby następuje za zgodą organu prowadzącego (np. gminy). Szkoła sama ustala zawody, w których zamierza kształcić uczniów, lecz następuje to w porozumieniu z organem prowadzącym (np. gminą) oraz po zasięgnięciu opinii powiatowej i wojewódzkiej rady zatrudnienia w sprawie zgodności z potrzebami rynku pracy.

9 Wymiar praktyk zawodowych określony został w podstawie programowej kształcenia w zawodach. 


\section{Centra kształcenia zawodowego i ustawicznego}

Zmiany w systemie kształcenia zawodowego wprowadzone od 1 września 2012 roku umożliwiają tworzenie nowych jednostek organizacyjnych, jakimi są centra kształcenia zawodowego i ustawicznego. Powstają one przez połączenie techników i zasadniczych szkół zawodowych, a także szkół policealnych z kształceniem osób dorosłych. Nowoczesne centrum kształcenia zawodowego i ustawicznego ma dać możliwość szybkiego i efektywnego przygotowania zarówno do egzaminu maturalnego, jak i zdobycia kwalifikacji zawodowych, np. przez prowadzenie kwalifikacyjnych kursów zawodowych. Do zadań centrum należy także nawiązywanie i utrzymywanie współpracy z pracodawcami i organizacjami pracodawców, a także prowadzenie poradnictwa i informacji zawodowej ${ }^{10}$.

\section{Kształcenie w rzemiośle}

W Polsce ważnym uzupełnieniem kształcenia zawodowego realizowanego w ramach systemu oświaty jest kształcenie zawodowe prowadzone w rzemiośle. Działalność rzemiosła jest regulowana przez odrębną ustawę ${ }^{11}$.

Rzemieślnicy przygotowują swoich uczniów zarówno w zawodach określonych w klasyfikacji zawodów szkolnictwa zawodowego, jak i tych należących wyłącznie do klasyfikacji zawodów i specjalności dla potrzeb rynku pracy.

W przypadku kształcenia w zawodach szkolnych realizowane są programy nauczania zgodne z podstawą programową kształcenia w zawodach. W wypadku pozostałych zawodów realizowany jest program zapewniający spełnienie wymagań egzaminacyjnych określonych w standardach egzaminacyjnych na tytuł czeladnika. Uprawnienia do prowadzenia zajęć praktycznych mają rzemieślnicy posiadający określone w prawie kwalifikacje, najczęściej tytuł mistrza, i przygotowanie pedagogiczne, należący do jednej z organizacji samorządu gospodarczego. Nadzór nad przebiegiem przygotowania zawodowego w rzemiośle pracowników młodocianych sprawuje właściwa izba rzemieślnicza lub z jej upoważnienia odpowiedni cech. Nauka zawodu przebiega w dwóch równolegle realizowanych częściach: praktycznej, zorganizowanej u pracodawcy (w zakładzie rzemieślni-

10 Podobne rozwiązania przyjęte są w państwach UE, np. w Anglii (ośrodki CeVoE) i Holandii (ośrodki ROCs).

11 Ustawa z 22 marca 1989 r. o rzemiośle, http://bip.mg.gov.pl/files/upload/13036/Ustawa_Rzemioslo_1989.pdf. 
czym) i teoretycznej, zorganizowanej w szkole zawodowej ${ }^{12}$. Dokształcanie teoretyczne może odbywać się na turnusach dokształcania teoretycznego młodocianych pracowników prowadzonych przez ośrodki dokształcania i doskonalenia zawodowego. Dokształcanie teoretyczne może prowadzić także sam pracodawca.

Po zakończeniu nauki zawodu uczeń może przystąpić do egzaminu czeladniczego przeprowadzanego przez komisje egzaminacyjne izb rzemieślniczych.

Oprócz świadectwa czeladniczego w rzemiośle nadawany jest dyplom mistrzowski, który nie ma swojego odpowiednika w systemie szkolnym.

\section{System kształcenia zawodowego w wybranych państwach UE}

\section{Austria}

W Austrii obowiązek szkolny trwa 9 lat ${ }^{13}$. Obejmuje dzieci i młodzież w wieku 6-15 lat. Szczeble kształcenia objęte obowiązkiem szkolnym to:

- Szkoła podstawowa (Volksschule lub Grundschule) - wiek: 6-10 lat,

- Szkoła średnia I stopnia - wiek: 10-14 lat:

- szkoła podstawowa - poziom wyższy (Volksschule),

- szkoła ogólnokształcąca średnia I stopnia - (Hauptschule),

- szkoła ogólnokształcąca średnia o profilu akademickim - I stopień (Allgemein bildende höhere Schule),

- Klasa IX - wiek: od 14 roku życia:

- szkoła politechniczna (Polytechnische Schule) prowadząca wstępne roczne kształcenie zawodowe, tzw. rok przedzawodowy.

Kształcenie obowiązkowe jest bezpłatne we wszystkich szkołach, z wyjątkiem szkół prywatnych.

W ostatnim roku edukacji obowiązkowej istnieje możliwość wybrania wstępnego rocznego kształcenia zawodowego, tzw. roku przedzawodowego w szkole politechnicznej (Polytechnische Schule) dla uczniów w wieku 14-15 lat chcących bezpośrednio po zakończeniu edukacji obowiązkowej podjąć pracę lub kontynuować kształcenie zawodowe w systemie dualnym ${ }^{14}$. W ramach roku przygoto-

12 Podobne rozwiązania stosowane są w państwach UE, np. w Austrii i Niemczech.

13 Zob: D. Dziewulak, Obowiązek szkolny w Unii Europejskiej, dz. cyt.

14 System dualny zakłada połączenie nauki teoretycznej z praktyczną nauką zawodu, która stanowi de facto wstępne szkolenie zawodowe. Terminujący uczniowie podejmują równoległe przyuczenie do zawodu w zakładzie pracy i kształcenie w niepełnym wymiarze w szkole. Zakład pracy pokrywa koszt części praktycznej szkolenia realizowanego na jego 
wawczego uczniowie objęci są doradztwem zawodowym oraz szkoleniem praktycznym w firmach, organizowanym w wybieranych przez uczniów zawodach odpowiadających głównym dziedzinom gospodarki. Program Politechnische Schule obejmuje przedmioty obowiązkowe ogólne, takie jak: język niemiecki, matematyka, język obcy, ekonomia i nauki polityczne, religia, orientacja zawodowa i praktyczne umiejętności życiowe oraz przedmioty do wyboru w ramach jednej z siedmiu specjalizacji (Fachbereiche). Pula przedmiotów obowiązkowych i dodatkowych w ramach wybranych specjalizacji określana jest na poziomie szkoły.

Polytechnische Schule funkcjonują jako samodzielne instytucje lub są połączone z innymi - najczęściej ogólnokształcącymi - szkołami średnimi.

Kształcenie zawodowe na poziomie szkoły średniej II stopnia obejmuje następujące podstawowe typy szkół:

- Bildungsanstalten für Kindergartenpädagogik - szkoły zawodowe dla nauczycieli przedszkolnych,

- Bildungsanstalten für Sozialpädagogik - szkoły zawodowe dla edukatorów,

- Berufsschule - zasadnicze szkoły zawodowe dla uczniów kształcących się w systemie dualnym, w których odbywa się kształcenie w niepełnym wymiarze godzin równolegle z kształceniem w miejscu pracy,

- szkoły zawodowe o profilu medycznym,

- Berufsbildende mittlere Schulen (BMS) - szkoły średnie techniczno-zawodowe,

- Berufsbildende höhere Schulen (BHS) - kolegia techniczno-zawodowe.

Bildungsanstalten für Kindergartenpädagogik (szkoły zawodowe dla nauczycieli przedszkolnych) - są to szkoły pięcioletnie, które przyjmują uczniów po zakończeniu ósmego roku edukacji (14/15 rok życia). Liczba godzin lekcyjnych nie przekracza tygodniowo 40 godzin. Szkoły przygotowują do egzaminu maturalnego i dyplomowego. Oprócz specjalizacji nauczycielskiej na poziomie przedszkolnym, szkoły te kształcą również wychowawców do szkół z internatem, a także od 1999 roku - oferują specjalizację z wczesnej edukacji i opieki (praca z dziećmi do lat 3).

W ramach Bildungsanstalten für Kindergartenpädagogik istnieje również możliwość realizowania czterosemestralnego kursu uprawniającego do pracy w przedszkolach specjalnych.

Bildungsanstalten für Sozialpädagogik (szkoły zawodowe dla pedagogów, wychowawców i edukatorów) - podobnie do szkół zawodowych dla nauczycie-

terenie (w tym pensje terminujących uczniów), a szkoła finansowana jest ze środków publicznych. 
li przedszkolnych oferują kształcenie pięcioletnie i przyjmują kandydatów, którzy ukończyli 14/15 rok życia (ósmy rok edukacji). Bildungsanstalten für Sozialpädagogik prowadzą także kursy dla dorosłych w trybie wieczorowym. Szkoły te przygotowują do egzaminu maturalnego i dyplomowego w ramach specjalizacji - praca z dziećmi i młodzieżą w ośrodkach dla dzieci i młodzieży lub ośrodkach dla młodzieży i dzieci o specjalnych potrzebach edukacyjnych.

Berufsbildende mittlere Schulen i Berufsbildende höhere Schulen (szkoły techniczno-zawodowe II stopnia) - uczniowie w wieku 14/15 lat mają prawo wybrać specjalizację zawodową i kształcić się w jednym z 300 techniczno-zawodowych wariantów kształcenia w różnych typach szkół. Kształcenie może się odbywać w niepełnym wymiarze godzin w ramach systemu dualnego Berufsschulen (szkołach zawodowych, do których uczęszczają uczniowie szkolący się równolegle w miejscu pracy) lub w pełnym wymiarze godzin w szkołach średnich II stopnia techniczno-zawodowych - BMS, lub kolegiach techniczno-zawodowych, także na poziomie szkoły średniej II stopnia - BHS.

Berufsbildende mittlere Schulen (BMS) oferują szkolenie w pełnym wymiarze pod kątem konkretnego zawodu obejmujące przedmioty ogólne i zawodowe. Kształcenie zawodowe składa się przede wszystkim z zajęć praktycznych w warsztatach szkolnych, laboratoriach czy szkolnych kuchniach. Nauka trwa od roku do czterech lat (średnio trzy lata) i prowadzi do uzyskania tytułu wykwalifikowanego pracownika/robotnika lub pracownika średniego szczebla. Warunkiem przyjęcia do BMS jest ukończenie ósmego roku nauki lub roku przedzawodowego. Kształcenie kończy się egzaminem zawodowym zdawanym przed komisją. Wśród BMS dominują szkoły trzyletnie lub czteroletnie kształcące m.in. w specjalizacjach takich, jak: specjalizacja techniczna i rzemieślnicza, handlowa, odzieżowa (projektowanie, moda), hotelarska i turystyczna, społeczna oraz rolniczo-leśna.

Berufsbildende höhere Schulen (BHS) są kolegiami techniczno-zawodowymi na poziomie szkoły średniej II stopnia. Przyjęcie do szkół tego typu odbywa się na podstawie świadectwa ukończenia ósmego roku nauki (14/15 rok życia), a średnia ocen na świadectwie powinna być co najmniej oceną dobrą. 0 przyjęcie do BHS można ubiegać się także na podstawie egzaminu wstępnego. Szkoły o profilu artystycznym wymagają zdania egzaminu wstępnego. Edukacja w kolegium prowadzi bezpośrednio do wykonywania zawodu bądź kontynuowania nauki na poziomie uniwersyteckim. Nauka trwa pięć lat w pełnym wymiarze godzin. Program nauczania składa się z trzech równych części: edukacja ogólna, teoria zawodowa, praktyka zawodowa. Kolegia oferują następujące ścieżki kształce- 
nia: mechaniczna, inżynieryjna, elektryczna, elektroniczna (przetwarzanie i organizacja danych), budowlana, chemiczno-przemysłowa, informatyczna, modowa, wzornicza, turystyczna, handlowa, przemysłowa, rolniczo-leśna. Absolwent Berufsbildende höhere Schulen uzyskuje podwójne kwalifikacje: ogólne (dyplom i świadectwo maturalne) i zawodowe.

Berufsschule to zasadnicze szkoły zawodowe dla uczniów kształcących się w systemie dualnym łączącym naukę teoretyczną z praktyczną nauką zawodu. Obejmują okres od 10 do 13 roku nauki, czyli 16-19 rok życia ucznia. W systemie dualnym bierze udział około 40 tys. przedsiębiorstw, szczególnie małych i średnich, zwłaszcza z branży handlowej, rzemieślniczej, turystycznej i organizacji wypoczynku. System proponuje kształcenie w 220 zawodach. Stosunek czasu przeznaczonego przez ucznia na praktyczną naukę zawodu w miejscu pracy do nauki w szkole wynosi około 4:1. Celem kształcenia w szkole jest uzupełnienie i poszerzenie ogólnej wiedzy ucznia, a przede wszystkim zdobycie podstawowej wiedzy teoretycznej w zakresie wybranej specjalizacji. Uczeń kształcący się w systemie dualnym jest zatrudniony na podstawie umowy czeladniczej i ma prawo do wynagrodzenia na poziomie $25-40 \%$ początkowej pensji wykwalifikowanego pracownika. Poziom wynagrodzenia wzrasta corocznie.

W systemie dualnym kształci się około 40\% uczniów kończących edukację obowiązkową, z czego jedna trzecia to dziewczęta. Najczęściej wybierane obszary kształcenia to: handel i rzemiosło, przemysł, turystyka i wypoczynek, transport, doradztwo i informacja oraz bankowość i ubezpieczenia. W wypadku większości specjalności uczniowie przystępują do egzaminu końcowego po trzech latach nauki. Kształcenie w systemie dualnym może zakończyć się po:

- 2,5 roku - głównie w wypadku zawodów rzemieślniczych (np. cukiernik, konserwator fasad budynków i pomników, masażysta),

- 3 latach - co dotyczy około 70\% zawodów, m.in. pracownik biurowy, sprzedawca, fryzjer, kucharz, stolarz,

- 3,5 roku - głównie w wypadku zawodów technicznych, takich jak: mechanik samochodowy, technik laboratoryjny, optyk, fotograf itp.,

- 4 latach - np. w zawodach technik dentystyczny, technik mechanik, technik elektryk.

Oprócz systemu dualnego w Berufsschule mogą pobierać naukę uczniowie terminujący (apprentices), czyli tacy, którzy odbywają kształcenie w niepełnym wymiarze w szkole i jednocześnie podejmują przyuczenie do zawodu w miejscu pracy. W takim przypadku kształcenie zawodowe w Berufsschule rozpoczyna się w momencie podjęcia pracy przez terminującego ucznia i trwa od 2 do 4 lat. Re- 
gulacje dotyczące szkolenia w miejscu pracy wprowadza ustawa o kształceniu zawodowym opracowana przez Ministerstwo Pracy i Gospodarki ${ }^{15}$.

\section{Dania}

W Danii obowiązek szkolny trwa 10 lat $^{16}$. Kształcenie jest obowiązkowe dla uczniów w wieku od 6/7 do 16/17 lat. Obowiązkiem szkolnym objęta jest dziesięcioletnia jednolita szkoła podstawowa i szkoła średnia I stopnia - Folkeskole (szkoła ludowa). Większość Folkeskole prowadzi nieobowiązkową klasę zerową oraz nieobowiązkową klasę X. Dzieci rozpoczynają kształcenie obowiązkowe w sierpniu tego roku kalendarzowego, w którym przypadają ich szóste urodziny. Rodzice mogą wybrać dowolną szkołę na terenie swojej gminy. Kształcenie w Folkeskole jest bezpłatne.

Kształcenie zawodowe rozpoczyna się na poziomie szkoły średniej II stopnia i obejmuje uczniów w wieku 16-19 lat. Realizowane w ramach szkół średnich ogólnokształcących i szkół o profilu zawodowym.

Szkoły średnie ogólnokształcące II stopnia oferują następujące 3 programy z elementami kształcenia zawodowego:

- program HF (program przygotowawczy do egzaminu na studia wyższe) obejmuje uczniów w wieku 17-19 lat i trwa 2 lata. Podstawowym kryterium przyjęcia jest ukończenie Folkeskole, zdanie egzaminu końcowego z języka duńskiego i z dwóch wybranych przedmiotów. Program HF kończy się egzaminem uprawniającym do wstępu na studia wyższe,

- program HHX (program o profilu handlowym). obejmuje uczniów w wieku 16-19 lat i trwa 3 lata. Prowadzi do uzyskania dyplomu o profilu ogólnym i handlowym, uprawniającego do przyjęcia na studia wyższe. Program obejmuje kształcenie w ramach przedmiotów obowiązkowych (język duński, języki obce, księgowość, finanse, prawo handlowe, przetwarzanie danych, matematyka, ekonomia) oraz bezpośrednio związanych z praktyką zawodową w dziedzinie biznesu, administracji i zarządzania,

- program HTX (program o profilu technicznym) skierowany jest dla uczniów w wieku 16-19 lat i trwa 3 lata. Program obejmuje kształcenie w ramach przedmiotów obowiązkowych (język duński, języki obce, technologia i nauki przyrodnicze), przedmiotów zawodowych (teoria) oraz cykl warsztatów za-

15 Berufsausbildungsgesetz, http://www2.wkstmk.at/wko.at/lst/rechtsinfo/BAG.html.

16 Zob. D. Dziewulak, Obowiazek szkolny w Unii Europejskiej, dz. cyt. 
wodowych i praktyk laboratoryjnych. Program HTX zapewnia kwalifikacje zawodowe i wstęp na studia wyższe.

Wszystkie trzy programy są realizowane w ramach stacjonarnej nauki w szkole, a ich cele i treści są nakierowane na przygotowanie kadry dla firm prywatnych. Programy kształcenia zawodowego przygotowywane są w porozumieniu z pracodawcami i partnerami społecznymi. Ciałem koordynującym powstawanie programów lub wprowadzenie do nich zmian jest Rada ds. Edukacji Zawodowej będąca organem doradczym Ministra Edukacji.

Szkoły o profilu zawodowym oferują kształcenie dla uczniów między 15 a 20 rokiem życia. Większość uczniów rozpoczyna naukę zawodu w szkolnych strukturach, lecz mogą oni najpierw rozpocząć pracę zawodową, a następnie zrealizować program kształcenia teoretycznego. W ramach szkolnictwa zawodowego najwięcej szkół kształci młodzież w kierunku biznesowym, technicznym, biznesowo-technicznym, rolniczym oraz w kierunkach usług publicznych (np. fryzjerstwo, hotelarstwo, transport itp.).

Duński system kształcenia zawodowego ma na celu przekazanie treści ogólnokształcących oraz rozwój umiejętności zawodowych i osobistych uczniów przygotowujący ich do kształcenia ustawicznego oraz aktywnego obywatelstwa.

System kształcenia zawodowego opiera się na trzech podstawowych zasadach:

- zasadzie podwójnego szkolenia - kształcenie w szkole na przemian ze szkoleniem w przedsiębiorstwie. Zasada ta gwarantuje, że uczestnicy nabywają teoretyczne, praktyczne, ogólne i osobiste umiejętności, które są zbieżne z zapotrzebowaniem rynku pracy,

- zasadzie udziału partnerów społecznych, zgodnie z którą partnerzy społeczni uczestniczą bezpośrednio w procesie funkcjonowania systemu kształcenia w szkole i systemu szkolenia zawodowego,

- zasadzie kształcenia ustawicznego, zgodnie z którą system oświatowy oferuje uczniom możliwość kształcenia w każdym wieku i na każdym etapie rozwoju zawodowego.

\section{Zasady realizacji programu kształcenia zawodowego}

Kształcenie zawodowe składa się z dwóch okresów: wstępnego i głównego. Każdy uczeń realizuje własny plan edukacyjny, zapewniający znalezienie optymalnego połączenia zainteresowań i umiejętności ucznia z faktycznym przebiegiem nauki. Plan zawiera więc treści nauczania o charakterze teoretycznym wraz $\mathrm{z}$ elementami praktyki zawodowej. W planie bierze się pod uwagę potrzeby 
i oczekiwania ucznia, szkoły oraz pracodawcy, u którego odbywa się praktyka zawodowa. Takie podejście systemu oświaty do kształcenia zawodowego wynika z założenia, że to uczeń przede wszystkim decyduje o tym, jak wygląda jego ścieżka edukacyjna.

Po ustaleniu planu edukacyjnego uczeń kierowany jest na kurs wstępny. Jego celem jest utwierdzenie kandydata w wyborze specjalności oraz zapewnienie możliwości przyjrzenia się różnym programom, głównie w praktyce, i skorzystania z rad dotyczących wyboru zawodu, możliwości edukacyjnych. Po okresie wstępnym uczeń dokonuje wyboru programu, w którym chce się dalej kształcić. Kurs trwa zazwyczaj od 20 do 25 tygodni, z czego 5 tygodni poświęcone jest obowiązkowemu kształceniu ogólnemu, 5 tygodni kształceniu zawodowemu, a pozostałe 10 tygodni - innym przedmiotom zawodowym, które mają rozszerzyć wiedzę ucznia o dziedzinie, w której pragnie się specjalizować. W wypadku szkolenia technicznego kurs może być przedłużony do około 60 tygodni. W wypadku szkolenia handlowego okres kursu wstępnego jest dłuższy i trwa od minimum 38 tygodni do maksimum 2 lat. Po zakończeniu kursu wstępnego uczniowie są przyjmowani na kurs główny, co oznacza, że muszą podpisać umowę o szkoleniu z pracodawcą. Kurs składa się z kształcenia teoretycznego i praktycznego szkolenia. Od roku szkolnego 2008/2009 obowiązuje 12 ścieżek edukacyjnych, z których każda prowadzi do specjalistycznych kursów głównych.

Około 50-70\% okresu szkolenia odbywa się w miejscu pracy, a 30-50\% na terenie placówki szkolnej. Zajęcia są zorganizowane w systemie blokowym (bloki 5-10-tygodniowe), czyli szkolenie teoretyczne przeplata się z praktyką zawodową w miejscu pracy. Całkowity czas trwania kursu nie przekracza 3,5 roku. Kurs rozpoczyna się od szkolenia praktycznego w zakładzie pracy, a po nim następuje kilka okresów kształcenia teoretycznego w szkole naprzemiennie z praktykami w miejscu pracy.

Celem kursu jest takie przygotowanie uczniów, aby ich kompetencje odpowiadały potrzebom rynku pracy. Szkolenie praktyczne odbywa się w jednej lub kilku firmach lub instytucjach.

Znalezienie miejsca praktyki należy do ucznia. Przed rozpoczęciem praktyki uczeń podpisuje umowę z pracodawcą. Umowa określa warunki całości szkolenia, w tym: okresy nauki w szkole i szkolenia w firmie oraz egzamin końcowy. Umowa jest zawsze sporządzana na piśmie; w przypadku uczniów niepełnoletnich konieczna jest zgoda rodziców.

W Danii w ramach kształcenia zawodowego istnieje także system zasadniczych szkół zawodowych Produktionsskole (szkoły produkcyjne). Grupą docelo- 
wą dla tych szkół są osoby poniżej 25 roku życia nieposiadające wykształcenia zawodowego oraz uczniowie, którzy nie ukończyli żadnego szczebla kształcenia. Nauka w Produktionsskole trwa maksymalnie 12 miesięcy. Uczniowie, którzy w trakcie nauki podejmą pracę lub rozpoczną praktykę zawodową w innym miejscu, mogą w każdym momencie zrezygnować z tego typu szkoły. Najczęściej uczniowie pozostają w szkole około 5 miesięcy. Charakterystyczną cechą Produktionsskole jest elastyczność programów i metod nauczania. Nauka jest dostosowana do potrzeb wynikających z praktycznych sytuacji, nie ma egzaminów ani obowiązkowych przedmiotów, choć w każdej z tych szkół uczniowie mogą uczęszczać na lekcje języka duńskiego, nauk społecznych, matematyki, nauk politycznych. Najbardziej typowe dziedziny kształcenia zawodowego w szkołach produkcyjnych to: rolnictwo, ogrodnictwo, leśnictwo, hodowla ryb, przemysł tekstylny, produkcja paneli słonecznych, stolarstwo, wyrób pamiątek. Dziedziny i typ kształcenia ustalany jest w porozumieniu z przedstawicielami lokalnego biznesu. Założeniem szkół produkcyjnych jest umożliwienie uczniom zdobycia kwalifikacji, które pozwolą im na kontynuację kształcenia zawodowego. W Danii funkcjonuje około 90 szkół produkcyjnych.

\section{Holandia}

W Holandii obowiązkiem szkolnym objęci są uczniowie w wieku od 5 do 18 roku życia. Obowiązek szkolny trwa ogółem 13 lat ${ }^{17}$. Uczniowie muszą kształcić się w szkole w pełnym wymiarze czasu przez 12 pełnych lat szkolnych i w każdym przypadku do końca roku szkolnego, w którym kończą 16 lat. Następnie powyższy obowiązek jest uzupełniony tzw. obowiązkiem w niepełnym wymiarze w placówce prowadzącej kształcenie w ramach obowiązku nauki co najmniej dwa razy w tygodniu przez kolejny rok. Młodzi ludzie, którzy odbywają kształcenie praktyczne na podstawie odpowiedniej umowy w określonym sektorze zatrudnienia, uczęszczają na zajęcia raz w tygodniu w ramach urlopu szkoleniowego i pracują w pozostałe dni tygodnia.

Szczeble kształcenia objęte obowiązkiem szkolnym to:

- Szkolnictwo podstawowe (Primair onderwijs) - wiek: 5-12 lat,

- Szkolnictwo średnie (Voortgezet onderwijs):

- szkoły średnie przygotowujące do podjęcia studiów wyższych (Voorbereidend wetenschappelijk onderwijs, VWO) - wiek: 12-18 lat,

17 Zob. D. Dziewulak, Obowiazek szkolny w Unii Europejskiej, dz. cyt. 
- szkoły średnie prowadzące kształcenie ogólne na wyższym etapie (Hoger algemeen voortgezet onderwijs, HAVO) - wiek: 12-17 lat,

- szkoły średnie prowadzące kształcenie przedzawodowe (Voorbereidend middelbaar beroepsonderwijs, VMBO) - wiek: 12-16 lat,

- szkoły średnie prowadzące kształcenie specjalne (Speciaal voortgezet onderwijs) - wiek: 12-18/20 lat.

Kształcenie w szkole podstawowej jest bezpłatne. Do szkoły średniej przyjmuje się uczniów po ukończeniu szkoły podstawowej lub specjalnej szkoły podstawowej, na ogół w wieku 12 lat. Decyzje w sprawie przyjęcia do szkoły VMBO, HAVO lub VWO podejmuje organ prowadzący (zarząd szkoły), który może powołać komisję rekrutacyjną, aby podejmowała takie decyzje w jego imieniu. Rekrutacja do szkół VMBO, HAVO i VWO odbywa się na podstawie oceny predyspozycji uczniów. W tym celu najczęściej w ostatniej klasie szkoły podstawowej przeprowadza się ogólnokrajowe sprawdziany, które pozwalają ocenić poziom wiedzy i umiejętności uczniów.

Szkolnictwo zawodowe (middelbaar beroepsonderwijs) obejmuje uczniów, którzy ukończyli 16 lat. Zapewnia szkolenie teoretyczne i praktyczne w wielu dziedzinach kształcenia zawodowego. Uczestnicy programów płacą czesne, a jeśli uczestniczą w kształceniu zawodowym (middelbaar beroepsonderwijs, MBO) $\mathrm{w}$ ramach systemu szkolnego w pełnym wymiarze czasowym, to przysługuje im pomoc finansowa ze strony państwa.

Kształcenie zawodowe MBO (na poziomie szkoły średniej II stopnia) odzwierciedla strukturę sektorów gospodarczych: biznes, inżynieria i technologia, usługi dla ludności (społeczne i indywidualne) oraz opieka zdrowotna. System kształcenia zawodowego oparty został w Holandii na kursach zawodowych, które realizowane są na czterech poziomach edukacyjnych prowadzących do uzyskania różnych kwalifikacji. Różny jest też czas trwania szkolenia.

Czas trwania kursów według systemu krajowych kwalifikacji zawodowych (obowiązujący od 1996 r.) wynosi odpowiednio:

- szkolenie pomocnika, asystenta: od 6 do 12 miesięcy,

- podstawowe szkolenie zawodowe: 2-3 lata,

- szkolenie zawodowe: od 2 do 4 lat,

- szkolenie kadry kierowniczej średniego szczebla: od 3 do 4 lat,

- szkolenie specjalistyczne: od roku do 2 lat,

- inne kursy: przynajmniej 15 tygodni.

We wszystkich dziedzinach obowiązują cztery poziomy kursów: 
- poziom pierwszy asystencki - wyposaża w umiejętności w zakresie wykonywania podstawowych zadań i jest adresowany do tych, którzy nie są w stanie zdobyć kwalifikacji na poziomie drugim. Uczestnicy otrzymują certyfikat,

- poziom drugi - podstawowe szkolenie zawodowe przygotowuje do wykonywania zadań na nieco wyższym poziomie. Dyplom ukończenia tego poziomu jest zarazem kwalifikacją minimum, którą każdy podejmujący pracę powinien posiadać,

- poziom trzeci - zawodowy. Posiadacz dyplomu na tym poziomie ma prawo wykonywać zadania samodzielnie, ma także obowiązek nadzorowania innych w zakresie stosowania podstawowych procedur,

- poziom czwarty - przygotowuje do samodzielnego wykonywania zawodu. Przeznaczony dla osób pragnących zdobyć umiejętności specjalistyczne lub dla kadry kierowniczej średniego szczebla. Szkolenie zakłada uzyskanie specjalistycznych umiejętności zawodowych i przygotowuje do przyjęcia obowiązków organizacyjnych na różnych poziomach hierarchii zawodowej.

Kształcenie zawodowe prowadzone jest w Holandii przez placówki podległe Ministerstwu Edukacji i Ministerstwu Rolnictwa. Odbywa się w ramach regionalnych centrów szkoleniowych (ROC) ${ }^{18}$. Instytucje te mają za zadanie oferować specjalnie zaprojektowane kursy dla osób szukających pracy, pracujących oraz młodych ludzi bez doświadczenia zawodowego. Placówki ROC łączą edukację formalną z możliwością pracy zawodowej. W Holandii działa ponad 40 ośrodków tego typu, oferując kursy szkoleniowe w wybranych zawodach. Istnieje także 13 ośrodków kształcenia w dziedzinie rolnictwa. Wszystkie kursy zawodowe są w bazie Centralnego Rejestru Kursów Zawodowych, tzw. CREBO. Jest to rejestr, który określa, jakie instytucje prowadzą poszczególne kursy i jakie kwalifikacje przysługują po ich zakończeniu. W 2012 roku zarejestrowano około 700 różnych kwalifikacji zawodowych. Przyjmuje się zasadę, że każdy kurs powinien być oferowany w dwóch wariantach (dwie alternatywne ścieżki kształcenia). Obecnie taka możliwość dotyczy nieco ponad połowy wszystkich kursów. W programie każdego kursu znajduje się część o charakterze praktycznym. Praktyczne szkolenie odbywa się na podstawie trójstronnej umowy zawieranej pomiędzy instytucją szkolącą, uczniem a firmą, w której odbywa się praktyka. Umowa obejmuje prawa i obowiązki każdej ze stron, ustala liczbę godzin szkolenia, sposoby monitorowania ucznia oraz to, jakie umiejętności będą oceniane i w jaki sposób.

18 Centraal toegangsloket voor het onderwijs in Nederland, http://www.roc.nl/default.php. 


\section{Niemcy}

W Niemczech długość trwania obowiązku szkolnego zależna jest od landu i rodzaju kształcenia. Kształcenie w pełnym wymiarze jest obowiązkowe dla uczniów od 6 do 15 lub 16 roku życia, a kształcenie w niepełnym wymiarze obowiązuje od 6 do 18 roku życia ${ }^{19}$.

Obowiązek szkolny obejmuje następujące szczeble kształcenia:

- Szkoła podstawowa (Grundschule) - wiek: 6-10 lat (6-12 lat w Berlinie i Brandenburgii),

- Szkoły średnie I stopnia (Orientierungsstufe - tzw. faza orientacji w różnych rodzajach szkół lub jako odrębna jednostka organizacyjna) - wiek: 10-12 lat,

- Szkoły średnie I stopnia Gymnasium, Realschule, Hauptschule, Gesamtschule (rodzaje szkół prowadzące kilka cykli kształcenia) - wiek: 10/12-15/16 lat,

- Szkoły średnie II stopnia - wiek: 15/16-18/19 lat.

Na ogół dzieci przyjmuje się do Grundschule od 6 roku życia. Dzieci objęte obowiązkiem nauki szkolnej wstępują do jednakowej dla wszystkich lokalnej szkoły podstawowej. Przejście ze szkoły podstawowej do jednej z kilku rodzajów szkół średnich odbywa się zgodnie z różnymi przepisami, zależnie od ustawodawstwa danego landu. 0 wyborze szkoły średniej I stopnia decydują rodzice, na podstawie oceny dokonanej przez szkołę podstawową. Przyjęcie do różnych szkół średnich może być uzależnione od wyników w nauce i/lub decyzji władz edukacyjnych. Kształcenie obowiązkowe jest w całości bezpłatne.

Edukacja zawodowa rozpoczyna się na poziomie szkoły średniej II stopnia. Istnieją dwie ścieżki umożliwiające zdobycie kwalifikacji zawodowych:

- kształcenie w szkole średniej II stopnia o profilu zawodowym;

- kształcenie w systemie dualnym.

\section{Szkoły średnie II stopnia o profilu zawodowym}

Berufsfachschulen (szkoła zawodowa) przygotowuje do zawodu (jednego bądź kilku), oferując wstępne szkolenie zawodowe w jednym lub kilku zawodach regulowanych albo prowadzi do uzyskania pełnych kwalifikacji zawodowych w określonym zawodzie. Proponują również dalszą edukację ogólną. Berufsfachschulen kształcą w kierunkach: biznesowym, języków obcych, sztuki, rzemiosła, pracy społecznej, pracy w sektorze zdrowia. Listę konkretnych zawo-

19 Zob. D. Dziewulak, Obowiązek szkolny w Unii Europejskiej, dz. cyt. 
dów reguluje prawo federalne. W przypadku gdy uczeń nie uzyskuje pełnych kwalifikacji, kończąc ten typ szkoły, ukończenie szkoły może zostać zaliczone do formalnego szkolenia w zawodzie, który wymaga takiego stażu. Absolwenci Berufsfachschulen mogą również przystąpić do egzaminu walidacyjnego przed odpowiednim organem (jeśli dany land przyjął odpowiednie regulacje, które to umożliwiają) i potwierdzić swoje kwalifikacje oraz ich zgodność z kwalifikacjami nabywanymi w systemie dualnym. Warunkiem przyjęcia do Berufsfachschule jest certyfikat ukończenia edukacji obowiązkowej. Czas trwania nauki w zależności od specjalizacji wynosi od 1 roku do 3 lat (16-19 lat).

Fachoberschule (szkoła średnia techniczna) trwa 2 lata (obejmuje 11 i 12 rok edukacji, dla uczniów w wieku 16-18 lat). Kształci w kierunku ogólnym oraz specjalistycznym (w zakresie wiedzy teoretycznej i praktycznej), co prowadzi do zdobycia kwalifikacji umożliwiających kształcenie na poziomie wyższym w Fachhochschule. W niektórych landach ten typ szkoły umożliwia kształcenie o 1 rok dłużej (13 rok edukacji) i przygotowuje do egzaminów uprawniających do kontynuowania edukacji na poziomie wyższym.

Dziedziny kształcenia to: biznes i administracja, kierunki techniczne, żywienie, rolnictwo, praca społeczna i zdrowie, projektowanie, bioinżynieria i ochrona środowiska. Kształcenie obejmuje naukę w szkole i szkolenie praktyczne. Przedmioty obowiązkowe bez względu na specjalizację obejmują: język niemiecki, wiedzę o społeczeństwie, matematykę, nauki przyrodnicze, język obcy i przedmiot zawodowy. Szkolenie praktyczne odbywa się w pierwszym roku nauki (11 roku edukacji) w miejscu pracy (fabryce, firmie, instytucji) związanej z wybraną specjalizacją. Zaliczona wcześniej praktyka zawodowa może powodować przejście bezpośrednio na kolejny, czyli drugi rok (pierwszy rok edukacji).

Berufliches Gymnasium/Fachgymnasium to wyższy poziom Gymnasium ze specjalizacją zawodową. Gymnasium z zasady oferuje ciągły tok nauki od 5 do 12 lub 13 roku edukacji. Ten typ szkoły nie ma odpowiednika na niższym poziomie - w praktyce w niektórych landach są to ostatnie 3 lata Gymnasium ze specjalizacjami zorientowanymi na konkretne zawody. Przedmioty zawodowe są dodane do programów nauczania ogólnego obowiązującego w szkole ogólnokształcącej na tym poziomie i są zdawane podczas egzaminu końcowego. Przedmioty zawodowe, takie jak np.: przedsiębiorczość, biznes, technika, technologia informacyjna, żywienie, agronomia, nauki społeczne i o zdrowiu, jeśli są realizowane w trybie intensywnym, mogą być zdawane na egzaminie maturalnym zamiast przedmiotów ogólnych. Niektóre Berufliches Gymnasium/Fachgymnasium oferują uczniom możliwość uzyskania podwójnych kwalifikacji, tj. kwalifikacji 
umożliwiających podjęcie studiów wyższych, zgodnie z prawem obowiązującym na terenie danego landu. Ten typ kształcenia zawodowego oferują również inne instytucje, np. Oberstufenzentren (Centrum Wyższego Kształcenia Zawodowego), trwa ono zazwyczaj od 3 do 4 lat.

Szkolnictwo typu Berufsoberschule (zawodowa szkoła średnia) powstało w niektórych landach w celu umożliwienia uczniom, którzy kształcili się w systemie dualnym, dostępu do edukacji na poziomie wyższym. Kształcenie w Berufsoberschule trwa 2 lata w pełnym wymiarze godzin i kończy się egzaminem maturalnym.

Niektóre szkoły oferują także odpowiednio dłuższy cykl kształcenia w niepełnym wymiarze godzin. Uczniowie przyjmowani są do Berufsoberschule na podstawie Mittlerer Schulabschluss - certyfikatu uzyskiwanego po ukończeniu szkoły średniej I stopnia - oraz po odbyciu dwóch lat kształcenia zawodowego lub pięciu lat praktyki zawodowej.

\section{Kształcenie w systemie dualnym}

Ponad 2/3 młodzieży kończącej szkołę obowiązkową wybiera jako dalszą ścieżkę edukacyjną kształcenie zawodowe w systemie dualnym. Trwa ono 2 lub 3 lata, w zależności od wyboru specjalizacji (zawodu). System nazywany jest dualnym, ponieważ zakłada, że nauka odbywa się w dwóch miejscach: zakładzie pracy oraz szkole (Berufsschule). Celem systemu jest zapewnienie możliwie najlepszej edukacji zawodowej, tj. właściwie skonstruowanego profilu kształcenia umożliwiającego zdobycie umiejętności, wiedzy i kwalifikacji zawodowych niezbędnych do wykonywania danego zawodu w zmieniających się okolicznościach rynku pracy. System umożliwia ponadto zdobycie wymaganego doświadczenia zawodowego. Uczeń kończący kształcenie w systemie dualnym uzyskuje formalne kwalifikacje do podjęcia pracy w jednym z 350 zawodów regulowanych.

Jedynym warunkiem koniecznym do rozpoczęcia nauki w systemie dualnym jest uzyskanie świadectwa ukończenia szkoły obowiązkowej. Nie ma innych dodatkowych wymagań - możliwość kształcenia w systemie dualnym jest otwarta dla wszystkich.

Większość kandydatów decyduje się na podjęcie kształcenia w tym systemie od razu po zakończeniu edukacji na poziomie średnim I stopnia, choć około $20 \%$ uczniów wybiera tę formę kształcenia dopiero po ukończeniu szkoły średniej II stopnia.

Młoda osoba podejmująca szkolenie zawodowe w systemie dualnym jest zatrudniona na podstawie umowy cywilno-prawnej między nią a firmą oferującą 
szkolenie. Na podstawie umowy uczeń ma obowiązek podjąć szkolenie praktyczne (w miejscu pracy) i teoretyczne (w szkole). Uczniowie spędzają na ogół od 3 do 4 dni w miejscu pracy i 1 lub 2 dni w tygodniu w szkole. Przedsiębiorca ponosi koszt szkolenia w miejscu pracy i wypłaca pensję ustalaną na zasadzie kontraktu negocjowanego na podstawie umowy zbiorowej. Wysokość pensji wzrasta z każdym rokiem szkolenia i równa się średnio $1 \frac{1}{3}$ wynagrodzenia wykwalifikowanego pracownika rozpoczynającego pracę. Umiejętności, wiedza i kwalifikacje zawodowe, jakie uczeń zdobywa w trakcie kształcenia w systemie dualnym, zostały sprecyzowane w specjalnych regulacjach. Szczegółowe zaś cele szkolenia w miejscu pracy określa dla każdego ucznia przedsiębiorca prowadzący szkolenie w dokumencie będącym indywidualnym planem szkoleniowym.

Szczegółowe dane dotyczące kształcenia zawodowego, w szczególności kształcenia w systemie dualnym, są dostępne w corocznym raporcie na temat edukacji i szkolenia zawodowego Berufsbildungsbericht publikowanym przez Federalne Ministerstwo Edukacji i Badań (Bundesministerium für Bildung und Forschung, $\mathrm{BMBF})^{20}$.

\section{Szkolenie zawodowe w miejscu pracy}

W Niemczech szkolenie zawodowe w miejscu pracy zorganizowane jest na podstawie regulacji federalnych wypracowanych wspólnie przez landowe ministerstwa oświaty, podmioty odpowiedzialne w poszczególnych landach za edukację zawodową, pracodawców i związki zawodowe.

Szkolenie zawodowe w miejscu pracy odbywa się głównie w przedsiębiorstwach związanych z przemysłem, handlem oraz sektorem usług, ale także, choć w znacznie mniejszym stopniu, w prywatnych gospodarstwach domowych. Wymogi dotyczące poszczególnych zawodów, które uczeń powinien spełnić podczas szkolenia, określone są federalnymi przepisami (Ausbildungsordnungen). Monitoring i kontrolę spełniania przez firmy szkolące standardów kształcenia każdego zawodu prowadzą lokalne izby przedsiębiorców.

Szkolenie praktyczne w miejscu pracy zapewnia kwalifikacje potrzebne w danej praktyce zawodowej. Umiejętności i wiedza dla poszczególnych zawodów zostały ujęte w planie ramowym określającym czas trwania i konkretne treści nauczania. Plan ramowy jest podstawą do stworzenia indywidualnego programu nauczania w poszczególnych firmach. Jednak firmy szkolące, które nie mogą

20 http://www.bmbf.de/. 
same zapewnić realizacji wszystkich treści nauczania określonych prawem, często łączą się z innymi firmami/przedsiębiorstwami, tworząc stowarzyszenia, sieci firm czy międzyfirmowe centra szkoleniowe, które mogą oferować dodatkowe elementy szkolenia (np. te wymagające specjalistycznego sprzętu), których nie są w stanie zapewnić mniejsze firmy.

\section{Kształcenie zawodowe w szkole}

Kształcenie w szkole zawodowej (Berufsschule) ma na celu przekazanie wiedzy ogólnej i teoretycznej wiedzy zawodowej. Tygodniowy plan nauczania przewiduje 4 godziny lekcyjne przedmiotów ogólnych (język niemiecki, nauki społeczne i ekonomia, religia i sport) niezależnie od wybranej specjalizacji oraz 8 godzin lekcyjnych przeznaczonych na przedmioty zawodowe. Języki obce są uwzględniane $\mathrm{w}$ puli przedmiotów zawodowych $\mathrm{w}$ takim zakresie, $\mathrm{w}$ jakim są istotne w danym zawodzie (np. w pracy biurowej, w specjalności hotelarskiej).

Organizacja nauki w szkole odbywa się w porozumieniu z przedsiębiorstwami i instytucjami nadzorującymi szkołę oraz właściwymi przedstawicielami przemysłu w celu zapewnienia uczniom najdogodniejszych warunków kształcenia.

\section{Szwecja}

W Szwecji obowiązek szkolny wynosi 9 lat ${ }^{21}$. Kształcenie jest obowiązkowe dla uczniów w wieku od 7 do 16 roku życia. Istnieje możliwość rozpoczęcia nauki w szkole w wieku 6 lub 7 lat. Obowiązkiem szkolnym objęta jest jednolita 9-letnia szkoła podstawowa - Grundskola. 0 wyborze szkoły decydują rodzice, ale w szkołach, w których liczba kandydatów przekracza liczbę miejsc, pierwszeństwo mają uczniowie mieszkający w pobliżu. Kształcenie we wszystkich szkołach jest bezpłatne. Edukacja zawodowa rozpoczyna się na poziomie szkoły średniej II stopnia - Gymnasieskola i obejmuje uczniów w wieku 16-19 lat.

Na poziomie szkoły średniej II stopnia realizowane jest nauczanie w ramach dwóch typów kształcenia: ogólnokształcącego i zawodowego. Wśród kryteriów przyjęcia uczniów do programów zawodowych znajduje się: pozytywna ocena z języka szwedzkiego, języka angielskiego i matematyki oraz co najmniej pięciu innych przedmiotów nauczanych w Grundskola. Dla uczniów, którzy nie spełniają tych kryteriów, ale chcieliby korzystać z programów o profilu zawodowym,

21 Zob. D. Dziewulak, Obowiazek szkolny w Unii Europejskiej, dz. cyt. 
przygotowano możliwość alternatywnego realizowania jednego z pięciu tzw. zawodowych programów wstępnych.

W Szwecji ze względu na brak na poziomie szkoły średniej II stopnia klasycznych szkół zawodowych we wszystkich Gymnasieskola realizuje się 18 krajowych programów edukacyjnych, z czego 12 to programy zawodowe. Podstawą wszystkich 18 krajowych programów jest ten sam zestaw 9 przedmiotów obowiązkowych, do których zalicza się: język szwedzki, matematykę, język angielski, historię, wiedzę o społeczeństwie, nauki ścisłe i przyrodnicze, religię, zajęcia artystyczne oraz wychowanie fizyczne i zdrowotne. Pozostałe przedmioty - w tym także zawodowe - które wprowadzają placówki szkolne uzależnione są od profilu i charakteru szkoły.

Szwedzki system szkolny zapewnia możliwość kształcenia praktycznego w miejscu pracy. Uczniowie po ukończeniu szkoły średniej II stopnia uzyskują osobne dyplomy dla programów ogólnych i zawodowych. Uzyskanie dyplomu ukończenia programu zawodowego wiąże się z koniecznością zarówno zrealizowania szkolnego programu kształcenia ogólnego, zawodowego, jak i obowiązkowych praktyk zawodowych. Praktyki zawodowe dla uczniów szkół średnich stwarzające możliwość kształcenia zawodowego w miejscu pracy realizowane są w ramach wprowadzonego w 2008 roku krajowego programu stażowego Gymnasial lärlingsutbildning ${ }^{22}$. Na każde miejsce takiej praktyki zawodowej rząd przeznaczył rocznie 25 tys. koron szwedzkich. Od jesieni 2011 roku program ten funkcjonuje jako pełnoprawna alternatywa szkolnych programów zawodowych. Działa on według tych samych przepisów i stosuje te same programy nauczania, zakłada jednak, że co najmniej połowa czasu kształcenia zawodowego przebiegać powinna w jednym lub kilku miejscach pracy. Realizacja programu praktyk może rozpocząć się w pierwszym, drugim lub trzecim roku nauki, a korzystający z niego uczeń zdobywa podstawowe kwalifikacje niezbędne do kontynuowania edukacji na poziomie wyższym.

Zgodnie z założeniami programu stażowego Gymnasial lärlingsutbildning, który przewiduje dostosowywanie się placówek szkolnych do potrzeb rynku pracy przez odpowiadanie na jego potrzeby oraz realne uczestnictwo w tworzeniu i wpływaniu na kształcenie i szkolenie zawodowe, szkoła jest głównym pośrednikiem w organizowaniu praktyk zawodowych. W procesie planowania i realizacji kształcenia współpracuje więc z przedstawicielami poszczególnych branż

22 http://www.skolverket.se/forskola-och-skola/gymnasieutbildning/2.2903/gymnasial-larlingsutbildning-1.127186. 
i pracodawców, którzy tworząc lokalne rady ds. praktyk zawodowych zgłaszają potrzeby i wskazują bieżące kierunki w kształceniu zawodowym.

\section{Wielka Brytania (Anglia)}

Struktura organizacyjna systemu szkolnego Wielkiej Brytanii nie jest jednolita. Struktury oświatowe Anglii i Walii są relatywnie podobne, natomiast systemy szkolne Szkocji i Irlandii Północnej regulowane są odrębnymi ustawami. Występują w nich inne typy szkół, inne programy i odmienne organizacje pracy szkolnej.

Obowiązek szkolny w Szkocji wynosi 11 lat i obejmuje dzieci oraz młodzież $\mathrm{w}$ wieku od 5 do 16 roku życia ${ }^{23}$. Obowiązek szkolny realizowany jest w ramach następujących szczebli kształcenia:

- Szkoła podstawowa (primary school) - wiek: 5-11 lat,

- Szkoła średnia I stopnia (secondary school) - wiek: 12-16 lat.

W Anglii i Walii kształcenie jest obowiązkowe dla uczniów w wieku od 5 do 16 lat, ale wiele dzieci rozpoczyna naukę już w klasie zerowej szkoły podstawowej w wieku 4 lat. W Irlandii Północnej obowiązek szkolny rozpoczyna się w wieku 4 lat i trwa do 16 roku życia. Obowiązek szkolny obejmuje następujące szczeble kształcenia:

- Szkolnictwo podstawowe (primary education) - wiek: 5-11 lat (Anglia/Walia), wiek: 4-11 lat (Irlandia Północna),

- Szkolnictwo średnie I stopnia (secondary education) - wiek: 11-16 lat.

Większość uczniów przechodzi ze szkoły podstawowej (Primary school) do szkoły średniej (Secondary school) w wieku 11 lat, choć w niektórych regionach Anglii uczniowie uczęszczają do middle school w wieku, odpowiednio - od 8 lub 9 roku życia do 12 lub 13 roku życia. Wiele szkół średnich I stopnia prowadzi również kształcenie na poziomie średnim II stopnia dla uczniów będących w wieku powyżej 16 lat.

\section{Kształcenie zawodowe w Anglii realizowane w szkole}

W Anglii obowiązek szkolny realizowany jest przez uczniów w wieku 5-16 lat. Szkolnictwo zawodowe obejmuje uczniów w wieku 16-18+ lat. Kształcenie zawodowe może być prowadzone przez różne podmioty, takie jak: angielski system

23 Zob. D. Dziewulak, Obowiąek szkolny w Unii Europejskiej, dz. cyt. 
oświatowy, instytucje edukacyjne (np. Centrum Doskonalenia Zawodowego, tzw. CoVE - Centres of Vocational Excellence), autonomiczne instytuty zawodowe, firmy szkoleniowe, indywidualnych pracodawców itp.

Kształcenie i szkolenie zawodowe organizowane jest w dwóch formach, jako:

- kursy zawodowe prowadzące do uzyskania kwalifikacji zawodowych realizowane w kolegiach typu further education college,

- kursy czeladnicze (apprenticeships).

Kursy zawodowe oferowane są głównie na poziomie szkoły średniej II stopnia, choć elementy przygotowania do pracy (work-related subjects) muszą być obowiązkowo zawarte w programie szkoły przeznaczonej dla uczniów w wieku 14-16 lat na czwartym etapie edukacji, tzw. key stage 4 (KS4).

Po ukończeniu key stage 4 (poziom szkoły średniej I stopnia) większość uczniów ubiega się o General Certificate of Secondary Education (GCSE) z kilku wybranych przedmiotów. Wśród nich mogą znaleźć się także przedmioty zawodowe/praktyczne. Egzamin jest oceniany zewnętrznie. Zdany egzamin uprawnia do ubiegania się o miejsce w placówkach edukacyjnych na poziomie ponadobowiązkowym lub do podjęcia zatrudnienia.

Na poziomie szkoły średniej II stopnia przedmioty zawodowe są oferowane przez różne typy instytucji edukacyjnych: w szkołach ogólnokształcących, tzw. sixth form colleges, oprócz przedmiotów ogólnokształcących uczy się również przedmiotów praktycznych/zawodowych.

W Anglii placówki szkolne, w których większy nacisk kładzie się na kształcenie zawodowe, to further education college i tertiary college, chociaż w tych typach szkół są także oferowane przedmioty ogólne. W szkołach tych można uzyskać następujące świadectwa i dyplomy:

- General Certificate of Education Advanced level examination (GCE A-levels),

- Advanced Subsidiary level examination (GSE AS-level),

- GSE A-levels z przedmiotów zawodowych.

Uzyskane świadectwa i dyplomy z przedmiotów zawodowych oraz liczba punktów zdobyta w trakcie egzaminów mają taką samą wartość jak punkty z innych przedmiotów ogólnokształcących, co stanowi podstawę na przykład przy rekrutacji na studia wyższe.

W Anglii szkolnictwo zawodowe na poziomie szkoły średniej II stopnia (poziom ponadobowiązkowy) realizowane jest najczęściej w kolegiach typu further education colleges. W placówkach tych można uzyskać jeden z najbardziej popularnych dyplomów - tzw. kwalifikację zawodową BTEC (Business \& Technology Education Council). Kwalifikacje tego typu można zdobyć równolegle lub zamiast 
świadectw GCSEs oraz A-levels. Uzyskanie BTEC pozwala na podjęcie pracy lub dalszą kontynuację nauki w trybie edukacji dorosłych (typu further) lub w instytucjach szkolnictwa wyższego. Kwalifikacje zawodowe BTEC związane są najczęściej z następującymi dziedzinami zawodowymi: praca z dziećmi i młodzieżą, budownictwo, kosmetyka, usługi hotelarskie i gastronomiczne, podróże i turystyka, usługi dla ludności.

W ramach kwalifikacji zawodowych BTEC można uzyskać różne stopnie specjalnościowe. Należą do nich:

- BTEC Introductory (BTEC kwalifikacja wstępna) - stanowią część kształcenia typu Foundation Learning przeznaczonego dla słuchaczy, którzy nie przystępują do egzaminów dających świadectwo ukończenia szkoły średniej General Certificate of Secondary Education (GCSE) lub innych uprawnień z tego poziomu edukacji,

- BTEC First Diploma (BTEC kwalifikacja pierwsza) - odpowiednik General Certificate of Secondary Education. Kwalifikacje te mogą być uzyskiwane przez uczniów równolegle ze świadectwem GCSE w ramach szkolnictwa obowiązkowego lub ponadobowiązkowego,

- BTEC National Qualification (BTEC kwalifikacja krajowa) - odpowiednik dyplomu General Certificate of Education Advanced level examination GCE A-levels (poziom szkoły średniej II stopnia) przeznaczony dla uczniów w wieku 16+ i polecany w szczególności uczniom z dobrymi wynikami z egzaminu GCSE oraz tym, którzy już uzyskali BTEC kwalifikację pierwszą,

- BTEC Higher National Certificates and Diplomas (BTEC świadectwa i dyplomy krajowe szkolnictwa wyższego) - kwalifikacje uzyskiwane w ramach szkolnictwa wyższego.

Kształcenie zawodowe w Anglii - szkolenie czeladnicze, szkolenie w miejscu pracy

Szkolenie czeladnicze obejmuje programy szkoleniowe w miejscu pracy zaprojektowane specjalnie pod kątem potrzeb rynku pracy i pracodawców. Szkolenia tego typu są otwarte dla kandydatów w wieku 16+ i odbywają się w niepełnym wymiarze.

Wszystkie programy szkoleń czeladniczych muszą zawierać następujące elementy:

- prezentację kompetencji/umiejętności w danej dziedzinie, zawodzie czy rodzaju działalności gospodarczej, 
- opis umiejętności technicznych, rozumienia koncepcji teoretycznych oraz wiedzy dotyczącej danej gałęzi przemysłu i związanego z nią rynku oraz rodzaju działalności gospodarczej,

- przedstawienie kluczowych umiejętności (np. praca zespołowa, rozwiązywanie problemów, komunikacja czy korzystanie z nowych technologii) lub umiejętności funkcjonalnych, takich jak matematyka czy język ojczysty.

Szkolenia czeladnicze oferowane są na trzech poziomach w zależności od poziomu kwalifikacji: średniozaawansowanym, zaawansowanym i wyższym.

Za organizację szkoleń typu czeladniczego odpowiedzialny jest Krajowy Urząd Czeladniczy (The National Apprenticeship Service). Od kwietnia 2011 roku wszystkie programy czeladnicze izb rzemieślniczych muszą być zgodne z angielskimi standardami czeladniczymi (Specification of Apprenticeship Standards for England, SASE) ${ }^{24}$. Wśród najistotniejszych elementów znalazły się następujące zagadnienia:

- programy czeladnicze muszą zapewnić wysoką jakość szkoleń, prowadzić do uzyskania kwalifikacji uznawanych w Anglii i odpowiadających danej umiejętności czy zawodowi zarówno z punktu widzenia pracownika, jak i szkolącego go pracodawcy,

- każdy czeladnik powinien zrealizować rocznie przynajmniej 280 godzin nauki pod nadzorem opiekuna (guided learning). Nauka pod nadzorem guided learning jest definiowana jako czas, podczas którego pracownicy danej firmy są obecni w celu zapewnienia specjalnego wsparcia dla uczącego się czeladnika. Wsparcie obejmuje wykłady, zajęcia praktyczne z opiekunem oraz naukę pod opieką doświadczonego pracownika,

- czeladnicy w wieku od 16 do 18 lat, którzy nie uzyskali jeszcze świadectwa GCSE z oceną C (i wyżej) z języka ojczystego i matematyki, powinni uzyskać taką możliwość podczas trwania szkolenia.

\section{Bibliografia}

Dziewulak D., Obowiązek szkolny w Unii Europejskiej, „Analizy BAS” 2010, nr 9(34), http:// parl.sejm.gov.pl/WydBAS.nsf/0/A4F8763AAD6E8E70C12576EE0029DFE9/\$file/Analiza_\%20BAS_2009_34.pdf.

Encyklopedia pedagogiczna XXI wieku, t. VI, Wydawnictwo Akademickie „Żak”, Warszawa 2007.

24 http://www.apprenticeships.org.uk/About-Us/ /media/Documents/SASE/11-521-Specification-of-apprenticeship-standards-for-england.ashx. 
Kupisiewicz C., Kupisiewicz M., Słownik pedagogiczny, Wydawnictwo Naukowe PWN, Warszawa 2009.

\section{Akty prawne}

Austriacka ustawa o kształceniu zawodowym, Gesamte Rechtsvorschrift für Berufsausbildungsgesetz, https://www.ris.bka.gv.at/GeltendeFassung.wxe?Abfrage=Bundesnormen\&Gesetzesnummer=10006276.

Ustawa z 7 września 1991 r. o systemie oświaty, Dz.U. nr 95, poz. 425.

Ustawa z 4 września 1997 r. o działach administracji rządowej, Dz.U. 2007, nr 65, poz. 437, ze. zm.

Ustawa z 22 marca 1989 r. o rzemiośle, Dz.U. nr 17, poz. 92.

Rozporządzenie Ministra Edukacji Narodowej z 23 grudnia 2011 r. w sprawie klasyfikacji zawodów szkolnictwa zawodowego, Dz.U. 2012, poz. 7.

Rozporządzenie Rady Ministrów z 7 października 1997 r. w sprawie Polskiej Klasyfikacji Działalności (PKD), Dz.U. nr 128, poz. 829, ze zm.

Europejska Klasyfikacja Działalności - NACE Rev. 1, Dz.Urz. WE L 293 z 24 października 1990 r., Dz.Urz. WE L 83 z 3 kwietnia 1993 r.

Rozporządzenie Ministra Edukacji Narodowej z 27 sierpnia 2012 r. w sprawie podstawy programowej wychowania przedszkolnego oraz kształcenia ogólnego w poszczególnych typach szkół, Dz.U. poz. 977.

\section{Strony internetowe}

http://www.roc.nl/default.php http://www.legislation.gov.uk//ukpga/2001/10/contents http://www.bmbf.de/.

http://www.skolverket.se/forskola-och-skola/gymnasieutbildning/2.2903/gymnasial-. 


\title{
2.2. Szkolna przedsiębiorczość w systemach oświatowych wybranych państw europejskich
}

\author{
School enterprise in education systems in selected \\ European countries
}

\begin{abstract}
W opracowaniu podjęto próbę omówienia problematyki przedsiębiorczości w systemach oświatowych. Analizie poddano nauczanie przedmiotu o przedsiębiorczości oraz projekty i inicjatywy związane z przedsiębiorczością realizowane na terenie szkół przez uczniów i nauczycieli w systemach oświatowych wybranych państw europejskich: Austrii, Hiszpanii, Niemiec, Wielkiej Brytanii i Włoch.
\end{abstract}

Słowa kluczowe: szkoła, system szkolny, przedmiot, przedsiębiorczość, przedsiębiorstwo

The paper attempts to discuss the subject of entrepreneurship in educational systems. The subject of entrepreneurship studies as well as projects and initiatives related to entrepreneurship implemented in schools by students and teachers in the educational systems of selected European countries were analyzed: Austria, Spain, Germany, United Kingdom and Italy.

Keywords: school, school system, entrepreneurship education, enterprise

\section{Wstęp}

\section{Definicje nauczania przedsiębiorczości}

Pojęcie nauczania przedsiębiorczości ${ }^{1}$ oraz nauczania przedsiębiorczości jako całokształtu obszaru pewnych umiejętności coraz częściej zaczęło pojawiać się w obiegu edukacyjnym w kontekście zalecenia Parlamentu Europejskiego i Rady w sprawie kompetencji kluczowych w procesie uczenia się z 2006 roku².

1 Opracowanie przygotowano na podstawie ekspertyzy Biura Analiz Sejmowych nr 1115/18z2lipca 2018 r. D. Dziewulaka zatytułowanej Informacja na temat szkolnej przedsiębiorczości w wybranych państwach europejskich (Austria, Hiszpania, Niemcy, Wielka Brytania, Włochy).

2 Zalecenie Parlamentu Europejskiego i Rady nr 2006/962/WE z 18 grudnia 2006 r. w sprawie kompetencji kluczowych w procesie uczenia się przez całe życie, Dz.Urz. UE L 394/10 z 30 grudnia $2006 \mathrm{r}$. 
Kompetencje kluczowe to zestaw pewnych cech (m.in. wiedza, doświadczenie, umiejętności, kreatywność, samodzielność, odpowiedzialność, skuteczność, profesjonalizm, kultura osobista i kultura pracy), których potrzebujemy, aby być zdolnym do działania, oraz aby sprostać osobistym i społecznym wyzwaniom. We wspomnianym zaleceniu Parlamentu Europejskiego i Rady inicjatywność i przedsiębiorczość określono jako jedną z ośmiu kompetencji kluczowych ${ }^{3}$. Sama definicja przedsiębiorczości jako kompetencji kluczowej została rozbudowana przez Tematyczną Grupę Roboczą ds. Nauczania Przedsiębiorczości (utworzoną przez Komisję Europejską). Definicja brzmi następująco: Nauczanie przedsiębiorczości polega na rozwijaniu przez uczniów umiejętności i gotowości do przeksztatcania kreatywnych pomysłów $w$ przedsiębiorcze działania. Jest to kompetencja istotna dla wszystkich osób uczących się, która wspiera rozwój osobisty i aktywność obywatelska, zapobiega wykluczeniu społecznemu oraz zwiększa możliwości zatrudnienia. Ma ona znaczenie dla procesu uczenia się przez całe życie, we wszystkich dyscyplinach $i$ we wszystkich formach ksztatcenia i szkolenia (formalnego, pozaformalnego i nieformalnego), które przyczyniają się do rozwoju ducha przedsiębiorczości lub zachowań przedsiębiorczych mających na celu działania komercyjne lub nie ${ }^{4}$.

Takie rozumienie przedsiębiorczości jako kompetencji kluczowej wskazuje na dwoisty obszar zainteresowania. Po pierwsze, wykształcenie postaw przedsiębiorczych, wiedzy i umiejętności powinno umożliwić jednostkom wcielanie pomysłów w czyn. Po drugie, wykształcone postawy i świadomość przedsiębiorczości wiążą się nie tylko z działalnością gospodarczą i tworzeniem przedsiębiorstw, lecz mogą mieć szersze zastosowanie w różnych dziedzinach życia, np. od aktywności zawodowej do świadomej aktywności społecznej. Innowacyjne i kreatywne działania mogą być podejmowane w ramach nowego przedsięwzięcia lub w ramach istniejących organizacji, tj. jako przedsiębiorczość pracownicza.

3 Osiem kompetencji kluczowych: 1) porozumiewanie się w języku ojczystym, 2) porozumiewanie się w językach obcych, 3) kompetencje matematyczne i podstawowe kompetencje naukowo-techniczne, 4) kompetencje informatyczne, 5) umiejętność uczenia się, 6) kompetencje społeczne i obywatelskie, 7) inicjatywność i przedsiębiorczość, 8) świadomość i ekspresja kulturalna.

4 Uzgodniona w Genewie 18 stycznia 2012 r. przez grupę roboczą, w której skład wchodzili przedstawiciele ETF, GIZ, MOP, UNESCO i UNEVOC. 


\section{Wytyczne w odniesieniu do metod nauczania przedsiębiorczości}

Analizując proces dydaktyczny nauczania-uczenia się przedsiębiorczości w szkolnictwie obowiązkowym, zwraca uwagę fakt, że nauczanie formalne nie jest jedynym działaniem, które może kształtować zdolności uczniów do stawania się dobrymi przedsiębiorcami. Równorzędne znaczenie dydaktyczne ma wymiar praktyczny, zaangażowanie uczniów oraz doświadczenie interdyscyplinarne i międzynarodowe. Zmiany cywilizacyjne, wzrost gospodarczy i oczekiwania konsumentów wskazują, że umiejętności szkolne wymagane w obszarze przedsiębiorczości ulegają zmianie i różnią się od rzeczywistych umiejętności potrzebnych w rozwijającej się firmie, co w sposób oczywisty wymusza poszukiwanie nowych, innowacyjnych metod nauczania przedsiębiorczości w szkołach.

Obecnie wśród najczęściej spotykanych metod nauczania-uczenia się wykorzystywanych w nauczaniu przedsiębiorczości wymienia się:

- aktywne uczenie się,

- kształcenie oparte na projektach,

- uczenie się przez doświadczenie,

- zajęcia pozaszkolne umożliwiające uczniom poznanie potrzeb i oczekiwań społeczności lokalnych oraz funkcjonujących w nich przedsiębiorstw,

- praktyczne doświadczenia w zakresie przedsiębiorczości, rozumiane jako konkretne jednorazowe doświadczenie.

Należy zwrócić uwagę, że powyższe metody nie zawsze dotyczą wyłącznie nauczania przedsiębiorczości, ale mogą być i są wykorzystywane w nauczaniu innych przedmiotów. Jednakże w kontekście nauczania przedsiębiorczości są to metody wiodące i zalecane przez większość poradników metodycznych.

\section{Praktyczne doświadczenia}

W komunikacie Komisji Europejskiej z 2012 roku w sprawie nowego podejścia do edukacji ${ }^{5}$ wzywa się państwa członkowskie do zapewnienia wszystkim uczniom co najmniej jednego praktycznego doświadczenia w zakresie przedsiębiorczości przed ukończeniem przez nich obowiązkowego kształcenia.

5 Komunikat Komisji do Parlamentu Europejskiego, Rady, Europejskiego Komitetu Ekonomiczno-Społecznego i Komitetu Regionów z 20 listopada 2012 r. w sprawie nowego podejścia do edukacji „Inwestowanie w umiejętności na rzecz lepszych efektów społeczno-gospodarczych”, KOM(2012)669 wersja ostateczna. 
Praktyczne doświadczenie w zakresie przedsiębiorczości rozumiane jest jako doświadczenie edukacyjne, w którym uczący się ma możliwość tworzenia pomysłów, wskazywania dobrych pomystów oraz wprowadzania ich w czyn. Powinno ono być inicjatywa prowadzona przez uczniów indywidualnie lub $w$ małym zespole, która obejmuje uczenie się przez działanie oraz prowadzi do wymiernego efektu. Celem takich możliwości jest rozwijanie przez uczących się umiejętności, pewności siebie oraz zdolności dostrzegania możliwości, wskazywania rozwiazań i realizacji własnych pomystów $w$ praktyce ${ }^{6}$.

Wśród przykładów zdobywania przez uczniów praktycznego doświadczenia w zakresie przedsiębiorczości można wskazać następujące obowiązkowe lub fakultatywne przykłady:

- praca oparta na projektach - przypadki, w których występuje wyraźny proces generowania pomysłów, a w wyniku otrzymujemy konkretny efekt końcowy,

- praktyczne wyzwania - projekty wybrane przez organizacje przedsiębiorców lub organizacje społeczne w celu rozwiązania problemu występującego w środowisku pracy,

- wyzwania społeczne - wykorzystanie innowacyjnych pomysłów w celu opracowania rozwiązań problemów lokalnych lub społecznych,

- tworzenie mikro-, mini-, młodzieżowych lub uczniowskich przedsiębiorstw pomysł na przedsiębiorstwo lub przedsiębiorstwo społeczne oraz założenie przedsiębiorstwa i prowadzenie go przez określony czas,

- uczniowskie inicjatywy mikrofinansowania -konkretne pomysły i projekty typu crowdfunding ${ }^{7}$, mające na celu osiągnięcie zysku lub oddziaływanie społeczne.

Praktyczne doświadczenie w zakresie przedsiębiorczości w postaci pracy opartej na projektach uwzględnione jest w programach nauczania w kilkunastu krajach. Bułgaria, Bośnia i Hercegowina oraz Czarnogóra realizują je na wszystkich poziomach kształcenia (od szkoły podstawowej do szkolnictwa wyższego). Austria, Estonia, Finlandia i Polska na trzech (szkoła podstawowa, szkoła średnia I stopnia, szkoła średnia II stopnia). Hiszpania, Łotwa, Rumunia i Szwecja na dwóch (szkoła średnia I stopnia, szkoła średnia II stopnia). Francja, Litwa i Norwegia zapewniają je na jednym poziomie (szkoła średnia I stopnia). Nauka przedsiębiorczości oparta na projektach jest zatem jednym z najczęstszych przy-

6 Tamże.

7 Crowdfunding - forma finansowania różnego rodzaju projektów przez społeczność, która jest lub zostanie wokół tych projektów zorganizowana. Przedsięwzięcie jest w takim przypadku finansowane przez dużą liczbę drobnych, jednorazowych wpłat dokonywanych przez osoby zainteresowane projektem. 
kładów szkolnego sposobu realizacji praktycznego doświadczenia w zakresie przedsiębiorczości, chociaż i tak występuje w mniej niż 1/3 krajów europejskich.

Drugim najbardziej rozpowszechnionym przykładem praktycznego doświadczenia w zakresie przedsiębiorczości jest tworzenie miniprzedsiębiorstw (lub mikro-, lub przedsiębiorstw młodzieżowych, lub przedsiębiorstw uczniowskich). Ponieważ jest ono bardziej odpowiednie dla starszych uczniów, jedynym przykładem, w którym bywa realizowane już na poziomie szkoły podstawowej, jest Hiszpania. Metoda tworzenia miniprzedsiębiorstw zawarta jest w programach nauczania począwszy od szkół średnich I stopnia w Estonii, Finlandii, Francji, Hiszpanii i na Litwie. W szkołach średnich ogólnokształcących II stopnia lub w szkołach zawodowych projekt ten występuje obowiązkowo lub fakultatywnie w Austrii, Bośni i Hercegowinie, Bułgarii, Czarnogórze, Danii, Estonii, Finlandii, Grecji, we Francji, na Litwie, w Luksemburgu, na Łotwie, w Niemczech, Rumunii, na Słowacji i w Szwecji.

Uczestnictwo uczniów w tworzeniu miniprzedsiębiorstw jest często wspierane przez specjalistyczne organizacje. W Danii rząd powołał w 2010 roku Duńską Fundację Przedsiębiorczości, której celem jest uczynienie z kreatywności i innowacji fundamentalnej części kształcenia uczniów na wszystkich poziomach edukacji.

W niektórych krajach praktyczne doświadczenia w zakresie przedsiębiorczości w postaci miniprzedsiębiorstw stanowią już szeroko rozpowszechnioną praktykę. Dla przykładu w Szwecji, w roku szkolnym 2014/2015, ponad 24000 uczniów (stanowiących ponad 20\% osób kończących szkoły średnie) wzięło udział w programie „Firma”. W Finlandii w roku szkolnym 2013/2014 założono około 1300 przedsiębiorstw uczniowskich, a w odpowiednich programach uczestniczyło około 4100 uczniów. W Austrii w obszarze kształcenia zawodowego działa ponad 1000 miniprzedsiębiorstw. W Estonii w roku szkolnym 2014/2015 działały 42 miniprzedsiębiorstwa na poziomie szkół średnich I stopnia, podczas gdy na poziomie szkół średnich II stopnia z tego rodzaju programu korzystały 62 placówki szkolne, co stanowi 32\% estońskich szkół.

Poniżej przedstawiono szczegółowe informacje na temat szkolnej przedsiębiorczości w Austrii, Hiszpanii, Niemczech, Wielkiej Brytanii i Włoszech.

\section{Austria}

W systemie oświatowym Austrii wszelkie przepisy dotyczące organizacji struktur szkolnych, procesu kształcenia, wynagrodzenia i uprawnień emerytalnych nauczycieli uchwalane są na szczeblu federalnym. Landy odpowiadają głównie za zapewnienie kadry nauczycielskiej oraz wspierają finansowo gminy w bu- 
dowaniu i prowadzeniu placówek szkolnictwa obowiązkowego. Kształcenie zawodowe w Austrii prowadzą zarówno szkoły, jak i organizacje pracodawców. Jednym ze sposobów zdobycia kwalifikacji zawodowych jest udział w szkoleniu prowadzonym przez firmę i jednoczesne uczęszczanie do szkoły zawodowej w niepełnym wymiarze godzin. Innym jest uczestniczenie wyłącznie w zajęciach oferowanych przez szkoły zawodowe.

\section{Finansowanie}

W Austrii federalne finansowanie oświaty obejmuje różne organizacyjne i edukacyjne inicjatywy. Między innymi należą do nich:

- austriackie centrum przedsiębiorczości na rzecz innowacji w szkołach (EESIImpulse (entre) wraz z regionalnymi jednostkami odpowiedzialnymi za koncepcję przedsiębiorczości nauczania w każdym z landów,

- programy wspierające działania będące częścią austriackiej strategii uczenia się przez całe życie, w tym również środki finansowe przeznaczone na koszty pracy i nauczanie przedsiębiorczości,

- konkurs Jugend Innovativ dla uczniów i studentów mających innowacyjne pomysły na biznes w zakresie projektowania, inżynierii i nauki oraz zagadnień tematycznych, takich jak TIK (technologie informacyjno-komunikacyjne) lub ochrona środowiska i klimatu.

\section{Podejście do nauczania przedsiębiorczości}

Nauka przedsiębiorczości realizowana jest od szkoły podstawowej do szkolnictwa średniego. W szkole podstawowej nauka przedsiębiorczości jest obowiązkowa dla wszystkich i realizowana jako przedmiot odrębny lub zintegrowany z innymi przedmiotami. W szkole średniej I stopnia nauka przedsiębiorczości jest obowiązkowa dla wszystkich i realizowana jako przedmiot odrębny lub zintegrowany z innymi przedmiotami. Na poziomie szkoły średniej ogólnokształcącej II stopnia i w szkołach średnich zawodowych w zależności od profilu szkoły nauka przedsiębiorczości może być obowiązkowa, fakultatywna i/lub międzyprzedmiotowa.

Praktyczne doświadczenia w zakresie przedsiębiorczości propagowane w ramach dodatkowych inicjatyw to przede wszystkim konkursy na najlepsze pomysły lub na przedsiębiorstwo. Realizowane są w ramach zajęć pozalekcyjnych. Wśród najbardziej znanych są konkursy „Następne pokolenie” i „Festiwal pomysłów” przeznaczone dla uczniów szkół zawodowych, podczas których we współ- 
pracy z trenerami biznesowymi poznają i analizują pomysły związane z przedsiębiorczością zaproponowane przez innych uczniów.

Obecnie w Austrii (oraz Danii, Luksemburgu, Portugalii i Słowenii) realizowany jest projekt europejski Erasmus+ o nazwie Youth Start - Entrepreneurial Challenges $^{8}$. Ma on na celu promowanie nauczania przedsiębiorczości przez program wyzwań oraz ocenę jego wpływu na uczniów. Chodzi tu o stworzenie nowej metody nauczania umiejętności związanych z przedsiębiorczością, tak aby móc je wykorzystać i rozpowszechniać w szkołach podstawowych oraz średnich I i II stopnia. Wśród głównych zadań projektu znalazły się: zaangażowanie uczestników, skuteczne kształcenie nauczycieli oraz prowadzenie badań poświęconych szkołom uczącym przedsiębiorczości. Ostatecznym celem jest uświadomienie, że umiejętności związane z przedsiębiorczością nauczane w ramach tego rodzaju programów skutecznie wzmacniają inne umiejętności przedmiotowe uczniów.

\section{Kształcenie i formy wsparcia dla nauczycieli}

Obecnie nauczanie przedsiębiorczości i doskonalenie zawodowe w tym przedmiocie jest obowiązkowe tylko w wypadku kształcenia przyszłych nauczycieli ekonomii i geografii pracujących w szkołach średnich ogólnokształcących i zawodowych ${ }^{9}$. Inną formą wsparcia nauczycieli są oferty innowacyjnych programów nauczania, materiałów dydaktycznych oraz szkoleń organizowanych przez EESI i wspieranych przez IFTE (Initiative for Teaching Entrepreneurship ${ }^{10}$, inicjatywa na rzecz nauczania przedsiębiorczości), a także przez Ministerstwo Edukacji, Nauki i Badań Naukowych.

\section{Praktyczna nauka przedsiębiorczości}

W Austrii obowiązujące przepisy umożliwiają uczniom i nauczycielom podejmowanie działalności gospodarczej na terenie szkoły oraz włączenie jej do programu nauczania. Najczęściej działalność taka ma charakter indywidualnych i zespołowych projektów dyplomowych (np. Junior Company) ${ }^{11}$ realizowanych przez uczniów w celu włączenia zebranych i udokumentowanych wyników do

8 http://www.youthstartproject.eu/.

9 Sytuacja ta może ulec zmianie, ponieważ obecnie w Austrii realizowana jest reforma kształcenia nauczycieli.

10 http://www.ifte.at/.

11 https://www.junior.cc/. 
końcowego egzaminu dyplomowego lub maturalnego. Działalność prowadzona jest w szkołach średnich ogólnokształcących niższego stopnia (Allgemeinbildende höhere Schule Unterstufe, AHS) i w szkołach średnich II stopnia techniczno-zawodowych (Berufsbildende mittlere Schulen, BMS) lub kolegiach techniczno-zawodowych (Berufsbildende höhere Schulen, BHS).

Oprócz doświadczeń zawodowych zdobywanych przez uczniów na terenie szkoły ważnym fragmentem kształcenia jest też praktyczna nauka zawodu, która może odbywać się w placówkach kształcenia ustawicznego, placówkach kształcenia praktycznego, warsztatach szkolnych, pracowniach szkolnych, u pracodawców, a także w indywidualnych gospodarstwach rolnych. Może ona mieć formę zajęć praktycznych lub praktyk zawodowych. Zajęcia praktyczne organizuje się dla uczniów w celu opanowania przez nich umiejętności zawodowych niezbędnych do podjęcia pracy w danym zawodzie. Tak więc nauka przedsiębiorczości nie odbywa się wyłącznie podczas przedmiotu o tej nazwie, lecz podczas nauki konkretnego zawodu. W zasadniczej szkole zawodowej (Berufsschule) szczególny nacisk został położony na kształcenie praktyczne realizowane w systemie dualnym łączącym naukę teoretyczną z praktyczną nauką zawodu. System nazywany jest dualnym (podwójnym), ponieważ zakłada, że nauka odbywa się w dwóch miejscach: zakładzie pracy oraz szkole. W systemie dualnym bierze udział około 40000 przedsiębiorstw, małych i średnich, zwłaszcza z branży handlowej, rzemieślniczej, turystycznej i organizacji wypoczynku. System proponuje kształcenie w 220 zawodach. Stosunek czasu przeznaczonego przez ucznia na praktyczną naukę zawodu w miejscu pracy do nauki w szkole wynosi około 4:1. Celem kształcenia w szkole jest uzupełnienie i poszerzenie ogólnej wiedzy ucznia, a przede wszystkim zdobycie podstawowej wiedzy teoretycznej w zakresie wybranej specjalizacji. Uczeń kształcący się w systemie dualnym jest zatrudniony na podstawie umowy czeladniczej i ma prawo do wynagrodzenia na poziomie 25-40\% początkowej pensji wykwalifikowanego pracownika. Poziom wynagrodzenia wzrasta corocznie. Oprócz systemu dualnego w Berufsschule mogą pobierać naukę uczniowie terminujący, czyli tacy, którzy odbywają w szkole kształcenie w niepełnym wymiarze i jednocześnie podejmują przyuczenie do zawodu w miejscu pracy. W takim przypadku kształcenie zawodowe w Berufsschule rozpoczyna się w momencie podjęcia pracy przez terminującego ucznia i trwa od 2 do 4 lat. Regulacje dotyczące szkolenia w miejscu pracy wprowadza ustawa o kształceniu zawodowym ${ }^{12}$ opracowana przez Ministerstwo Pracy i Gospodarki.

12 Berufsausbildungsgesetz, http://www2.wkstmk.at/wko.at/lst/rechtsinfo/BAG.html. 
Praktyczna nauka zawodu realizowana u pracodawców odbywa się na podstawie umowy zawartej pomiędzy szkołą a pracodawcą. Umowa określa między innymi sposób ponoszenia kosztów realizowania praktycznej nauki zawodu. Oprócz zawarcia umowy ważnym elementem współpracy szkoły z zakładem pracy jest włączenie pracodawców w proces kształtowania programów kształcenia dla zawodu, w szczególności w części dotyczącej praktycznej nauki zawodu. Współpraca pracodawców ze szkołami ma obejmować takie formy, jak: udział w życiu szkoły, wycieczki przedmiotowe czy wsparcie bazy technicznej i dydaktycznej szkoły. W szkole może też być zatrudniona osoba niebędąca nauczycielem, a posiadająca przygotowanie zawodowe uznane przez dyrektora szkoły za odpowiednie do prowadzenia zajęć z zakresu kształcenia zawodowego, z tym że zatrudnienie tej osoby następuje za zgodą organu prowadzącego (np. gminy). Szkoła sama ustala zawody, w których zamierza kształcić uczniów, lecz następuje to po zasięgnięciu opinii landowej i lokalnej rady zatrudnienia w sprawie zgodności z potrzebami rynku pracy.

\section{Hiszpania}

W Hiszpanii obowiązuje zdecentralizowany model administracji oświatowej, według którego odpowiedzialność za oświatę jest podzielona między państwo, wspólnoty autonomiczne, administrację lokalną i szkoły. Władze centralne zachowały odpowiedzialność tylko w zakresie ogólnych uregulowań oświatowych, a większość zadań została w 1978 roku przekazana 17 samorządom regionalnym (wspólnotom autonomicznym). Programy nauczania tworzy się na trzech poziomach: centralnym (krajowa podstawa programowa), wspólnot autonomicznych (przystosowanie do uwarunkowań historycznych, kulturowych, społecznych i ekonomicznych wspólnoty), szkolnym (zgodnie z potrzebami klasy).

\section{Finansowanie}

W Hiszpanii krajowa strategia nauczania przedsiębiorczości jest finansowana m.in. z budżetu krajowego. Wśród podmiotów biorących udział w finansowaniu znajdują się Ministerstwo Edukacji, Kultury i Sportu we współpracy z ministerstwami: Przemysłu, Energii i Turystyki, Zatrudnienia i Zabezpieczenia Społecznego, Gospodarki i Konkurencyjności.

Na poziomie regionalnym wspólnoty autonomiczne stosują różne mechanizmy finansowania strategii nauczania przedsiębiorczości - od odrębnego regio- 
nalnego budżetu, przez korzystanie z dotacji centralnych, aż do finansowania z programów unijnych.

\section{Podejście do nauczania przedsiębiorczości}

Nauka przedsiębiorczości realizowana jest od szkoły podstawowej do szkoły średniej. W szkole podstawowej nauka przedsiębiorczości jest obowiązkowa dla wszystkich i realizowana jako przedmiot odrębny lub zintegrowany z innymi przedmiotami, lub jako kształcenie międzyprzedmiotowe. W szkole średniej I stopnia nauka przedsiębiorczości w zależności od profilu szkoły może być obowiązkowa, fakultatywna i/lub międzyprzedmiotowa. W szkole średniej ogólnokształcącej II stopnia - może mieć charakter fakultatywny dla wszystkich, może być realizowana jako przedmiot odrębny lub zintegrowany z innymi przedmiotami lub realizować podejście międzyprzedmiotowe. W szkolnictwie średnim zawodowym nauka przedsiębiorczości jest obowiązkowa, realizowana dla wszystkich uczniów jako przedmiot odrębny lub zintegrowany z innymi przedmiotami, lub realizowana jako podejście międzyprzedmiotowe.

Praktyczne doświadczenia w zakresie przedsiębiorczości propagowane w ramach dodatkowych inicjatyw to przede wszystkim praca oparta na projektach. Jest ona realizowana w niektórych wspólnotach autonomicznych, tj. w Andaluzji i na Wyspach Kanaryjskich, a projekty o przedsiębiorczości o charakterze społecznym w Kastylii i Leónie, La Rioja, Katalonii i Estremadurze. Inną formą jest tworzenie mini- lub młodzieżowych przedsiębiorstw w szkołach średnich I stopnia realizujących różne przedmioty fakultatywne. W wielu przypadkach istotą takiego przedmiotu jest stworzenie i zarządzanie miniprzedsiębiorstwem lub spółdzielnią uczniowską w trakcie roku szkolnego (np. Empresa Joven Europea, EJE $^{13}$, w Asturii, Estremadurze i La Rioja).

W Hiszpanii wiele wspólnot autonomicznych realizuje własne, lokalne programy w zakresie przedsiębiorczości o charakterze fakultatywnym. Programy takie są często opracowywane i finansowane przez instytucje finansowe (banki, fundacje). Na przykład program Equilicuá współfinansowany przez fundację Caja Navarra czy program pożyczek udzielanych przez Cajastur na zakładanie mikroprzedsiębiorstw szkolnych w Asturii. W innych przypadkach wspólnoty autonomiczne tworzą partnerstwa z agencjami publicznymi lub prywatnymi firmami albo organizacjami pozarządowymi. Istnieją również inne inicjaty-

13 http://www.valnaloneduca.com/eje/. 
wy promowane przez sektor prywatny, ale tworzone bezpośrednio w środowiskach edukacyjnych na poziomie krajowym (np. projekt fundacji Telefónica zatytułowany ThinkBig) i regionalnym (np. projekt Startinova wspierany przez sześć regionalnych gazet z grupy medialnej Vocento w sześciu wspólnotach autonomicznych). Wspólnym celem tych inicjatyw jest promowanie aktywnego uczenia się w powiązaniu z doświadczeniami zdobywanymi w codziennym życiu. Jeżeli są to mikroprzedsiębiorstwa edukacyjne, to najczęściej funkcjonują we współpracy ze stowarzyszeniami młodzieżowymi, spółdzielniami, przedsiębiorstwami produkcyjnymi lub firmami. Udział szkół w tych inicjatywach jest fakultatywny.

\section{Kształcenie i formy wsparcia dla nauczycieli}

Hiszpańska ustawa 14/2013 z 27 września 2013 roku o wspieraniu przedsiębiorców i ich internacjonalizacji (dalej: ustawa 14/2013) ${ }^{14}$ priorytetowo traktuje rolę nauczycieli w nauczaniu przedsiębiorczości. Po pierwsze, podkreśla rolę kształcenia i doskonalenia zawodowego nauczycieli, w ramach którego muszą oni nabyć kompetencje i umiejętności związane z przedsiębiorczością, w tym dotyczące zakładania i rozwoju działalności gospodarczej. Po drugie, ustawowo zobowiązuje Ministerstwo Edukacji, Kultury i Sportu we współpracy ze wspólnotami autonomicznymi do włączania nauczania przedsiębiorczości w program doskonalenia zawodowego nauczycieli.

Ogólna strategia oświatowa formułowana jest przez centralne władze oświatowe, jednak szczegółowe plany związane z doskonaleniem zawodowym nauczycieli są definiowane na poziomie regionalnym i wiele z nich odnosi się bezpośrednio do nauczania przedsiębiorczości. Na przykład w Galicji Plan Edukacji Przedsiębiorczości (EduEmprende) ${ }^{15}$ zawiera konkretne zobowiązania do wdrażania w szkolnictwie idei przedsiębiorczości, m.in. przez umożliwienie nauczycielom uzyskania odpowiednich kwalifikacji do wspierania nabywania przez uczniów kompetencji w zakresie przedsiębiorczości.

Doskonalenie zawodowe nauczycieli z obszaru przedsiębiorczości jest dostępne w większości regionów. Niektóre kursy koncentrują się na nauczaniu przedsiębiorczości przez zakładanie startupów i miniprzedsiębiorstw. Inne obejmują szerszą perspektywę, np. podejścia międzyprzedmiotowego i interdyscy-

14 Ley 14/2013, de 27 de septiembre, de apoyo a los emprendedores y su internacionalización, https://www.boe.es/diario_boe/txt.php?id=BOE-A-2013-10074.

15 http://www.edu.xunta.es/fp/eduemprende. 
plinarnego, proponując wsparcie metodyczne, w wyniku którego wyposaża się nauczycieli w umiejętności potrzebne do opracowywania, tworzenia i realizacji własnych projektów w zakresie przedsiębiorczości.

\section{Praktyczna nauka przedsiębiorczości}

W Hiszpanii obowiązujące przepisy umożliwiają uczniom i nauczycielom podejmowanie działalności gospodarczej na terenie szkoły i włączenie jej do programu nauczania. Zakładanie na terenie szkół różnych form aktywności gospodarczej prowadzonych przez uczniów i nauczycieli reguluje ustawa 14/2013 ${ }^{16}$.

Przedsiębiorstwa określane są w ustawie jako miniprzedsiębiorstwa lub przedsiębiorstwa uczniowskie. Podstawą do ich założenia jest charakter edukacyjno-pedagogiczny, jaki mają do spełnienia w placówce szkolnej. Przedsiębiorstwo uczniowskie musi zostać zarejestrowane w odpowiednim rejestrze przez podmiot realizujący program miniprzedsiębiorczości. Rejestracja umożliwia prowadzenie działalności w określonym roku szkolnym, ale działalność może zostać przedłużona na kolejny rok szkolny. Po tym okresie miniprzedsiębiorstwo lub przedsiębiorstwo uczniowskie musi zostać zlikwidowane. Miniprzedsiębiorstwo lub przedsiębiorstwo uczniowskie musi być objęte ubezpieczeniem od odpowiedzialności cywilnej. Zgodnie z ustawą 14/2013 miniprzedsiębiorstwa lub przedsiębiorstwa uczniowskie mogą być zakładane w szkołach podstawowych oraz średnich ogólnokształcących i zawodowych.

\section{Niemcy}

W Niemczech zakres odpowiedzialności za system edukacji wynika z federalnej struktury państwa i został rozdzielony pomiędzy władze federalne oraz kraje związkowe (landy). Koordynacja spraw oświatowych między landami i władzami centralnymi odbywa się w ramach Stałej Konferencji Ministrów Edukacji i Kultury, Nauki i Oświaty Krajów Związkowych Republiki Federalnej Niemiec (Kultursministerkonferenz, KMK; dalej: Stała Konferencja) ${ }^{17}$. Zadania rządu federalnego w dziedzinie edukacji obejmują m.in. ustanawianie przepisów wyznaczających ogólne ramy współpracy oświatowej między szczeblem federalnym i landami. Za ustawodawstwo i administrację oświatową odpowiadają przede wszystkim

16 Ley 14/2013, de 27 de septiembre, de apoyo a los emprendedores y su internacionalización, https://www.boe.es/diario_boe/txt.php?id=BOE-A-2013-10074.

17 https://www.kmk.org/. 
landy oraz władze nadzorujące szkoły na niższym administracyjnym szczeblu (Schulamt). Każdy land ma własne ministerstwo edukacji, które odpowiedzialne jest za ustalanie programów nauczania, zalecanie metod nauczania i zatwierdzanie do użytku szkolnego pomocy i podręczników. Programy i treści nauczania opracowywane są $\mathrm{w}$ taki sposób, aby spełniały kryteria zawarte $\mathrm{w}$ przyjętych przez Stałą Konferencję krajowych standardach kształcenia. W każdej szkole działa rada pedagogiczna odpowiedzialna za sprawy dydaktyczne oraz rada szkoły (złożona z nauczycieli, rodziców i uczniów), która ustanawia przepisy szkolne i zasady dyscypliny. Zakres uprawnień tych rad jest różny, zależnie od landu.

\section{Finansowanie}

W Niemczech finansowanie oświaty, nauki i kultury odbywa się z trzech źródeł: budżetu federalnego, landowego i samorządowego (lokalnego). Podmioty zarządzające szkołami publicznymi i prywatnymi otrzymują od władz landów dofinansowanie w różnych formach. Wszystkie landy gwarantują uprawnionym szkołom standardowe wsparcie finansowe, wliczając $\mathrm{w}$ to udział $\mathrm{w}$ kosztach związanych z płacami pracowników i zakupem wyposażenia. Procent finansów publicznych w całkowitych kosztach prowadzenia placówek prywatnych różni się w poszczególnych landach i zależy od typu szkoły.

\section{Podejście do nauczania przedsiębiorczości}

Ze względu na specyfikę systemu oświatowego Niemiec wynikającą z decentralizacji systemu szkolnego, nauczanie przedsiębiorczości odbywa się zgodnie z wymogami poszczególnych landów i/lub oczekiwaniami konkretnych placówek szkolnych. Przedsiębiorczość może być nauczana jako oddzielny przedmiot, jako przedmiot o charakterze interdyscyplinarnym lub może stanowić konsekwencję wyboru ścieżki kształcenia zawodowego (ścieżka kształcenia w szkole średniej o profilu zawodowym, ścieżka kształcenia w systemie dualnym).

Poniżej przedstawiono syntetyczny przegląd organizacji szkolnictwa zawodowego w Niemczech, gdzie przedsiębiorczość może stanowić oddzielny przedmiot nauczania lub być nauczana w formie interdyscyplinarnej. 


\section{Szkoły średnie II stopnia o profilu zawodowym}

Berufsfachschulen - szkoła zawodowa

Berufsfachschulen przygotowuje do zawodu (jednego bądź kilku), oferując wstępne szkolenie zawodowe w jednym lub kilku zawodach regulowanych lub prowadzi do uzyskania pełnych kwalifikacji zawodowych w określonym zawodzie. Oferują również dalszą edukację ogólną. Berufsfachschulen kształcą w kierunkach: biznesowym, języków obcych, sztuki, rzemiosła, pracy społecznej, pracy w sektorze zdrowia. Listę konkretnych zawodów reguluje prawo federalne. Czas trwania nauki w zależności od specjalizacji wynosi od 1 roku do 3 lat (dla uczniów w wieku 16-18 lat lub 16-19 lat w zależności od landu).

\section{Fachoberschule - szkoła średnia techniczna}

Fachoberschule kształci w kierunku ogólnym oraz specjalistycznym (w zakresie wiedzy teoretycznej i praktycznej), prowadzi do zdobycia kwalifikacji umożliwiających kształcenie na poziomie wyższym w Fachhochschule. W niektórych landach ten typ szkoły umożliwia kształcenie o 1 rok dłużej (13 rok edukacji) i przygotowuje do egzaminów uprawniających do kontynuowania edukacji na poziomie wyższym. Dziedziny kształcenia to: biznes i administracja, kierunki techniczne, żywienie, rolnictwo, praca społeczna i zdrowie, projektowanie, bioinżynieria i ochrona środowiska. Kształcenie obejmuje naukę w szkole i szkolenie praktyczne. Szkolenie praktyczne odbywa się w pierwszym roku nauki (11 roku edukacji) w miejscu pracy (fabryce, firmie, instytucji) związanej z wybraną specjalizacją. Nauka trwa 2-3 lata (dla uczniów w wieku 16-18 lat).

\section{Berufliches Gymnasium/Fachgymnasium}

Berufliches Gymnasium/Fachgymnasium to wyższy poziom Gymnasium (szkoła średnia ogólnokształcaca) ze specjalizacją zawodową. Gymnasium z zasady oferuje ciągły tok nauki od 5 do 12 lub 13 roku edukacji. Przedmioty zawodowe są dodane do programów nauczania obowiązującego w szkole ogólnokształcącej na tym poziomie i są zdawane podczas egzaminu końcowego. Przedmioty zawodowe, takie jak np. przedsiębiorczość, biznes, technika, technologia informacyjna, żywienie, agronomia, nauki społeczne i o zdrowiu, jeśli są realizowane w trybie 
intensywnym, mogą być zdawane na egzaminie maturalnym zamiast przedmiotów ogólnych.

\section{Berufsoberschule - zawodowa szkoła średnia}

Szkolnictwo typu Berufsoberschule powstało w niektórych landach w celu umożliwienia uczniom, którzy kształcili się w systemie dualnym, dostępu do edukacji na poziomie wyższym. Kształcenie w Berufsoberschule trwa 2 lata w pełnym wymiarze godzin i kończy się egzaminem maturalnym. Niektóre szkoły oferują także odpowiednio dłuższy cykl kształcenia w niepełnym wymiarze godzin.

\section{Kształcenie w systemie dualnym}

Ponad 2/3 młodzieży kończącej szkołę obowiązkową wybiera jako dalszą ścieżkę edukacyjną kształcenie zawodowe w systemie dualnym, który zakłada, że nauka odbywa się w dwóch miejscach: zakładzie pracy oraz szkole. Taka nauka trwa 2 lub 3 lata w zależności od wyboru specjalizacji (zawodu). Celem systemu jest zapewnienie możliwie najlepszej edukacji zawodowej, tj. właściwie skonstruowanego profilu kształcenia umożliwiającego zdobycie umiejętności, wiedzy i kwalifikacji zawodowych niezbędnych do wykonywania danego zawodu w zmieniających się okolicznościach rynku pracy. System umożliwia ponadto zdobycie wymaganego doświadczenia zawodowego. Uczeń kończący kształcenie w systemie dualnym uzyskuje formalne kwalifikacje do podjęcia pracy w jednym z 350 zawodów regulowanych. Osoba podejmująca szkolenie zawodowe w systemie dualnym jest zatrudniona na podstawie umowy cywilno-prawnej między nią a firmą oferującą szkolenie. Na podstawie umowy uczeń ma obowiązek podjąć szkolenie praktyczne (w miejscu pracy) i teoretyczne (w szkole). Uczniowie spędzają na ogół od 3 do 4 dni w miejscu pracy i 1 lub 2 dni w tygodniu w szkole. Przedsiębiorca ponosi koszt szkolenia w miejscu pracy i wypłaca pensję ustalaną na zasadzie kontraktu negocjowanego na podstawie umowy zbiorowej. Wysokość pensji wzrasta z każdym rokiem szkolenia i równa się średnio 1/3 wynagrodzenia wykwalifikowanego pracownika rozpoczynającego pracę. Umiejętności, wiedza i kwalifikacje zawodowe, jakie uczeń zdobywa w trakcie kształcenia w systemie dualnym, zostały określone w specjalnych regulacjach. Szczegółowe cele szkolenia w miejscu pracy określa dla każdego ucznia przedsiębiorca prowadzący szkolenie (indywidualny plan szkoleniowy). 


\section{Szkolenie zawodowe w miejscu pracy}

W Niemczech szkolenie zawodowe w miejscu pracy zorganizowane jest na podstawie regulacji federalnych wypracowanych wspólnie przez landowe ministerstwa oświaty, podmioty odpowiedzialne w poszczególnych landach za edukację zawodową, pracodawców i związki zawodowe. Szkolenie zawodowe w miejscu pracy odbywa się głównie w przedsiębiorstwach związanych z przemysłem, handlem oraz sektorem usług, ale także, choć w znacznie mniejszym stopniu, w prywatnych gospodarstwach domowych. Wymogi dotyczące poszczególnych zawodów, które uczeń powinien spełnić podczas szkolenia, określone są federalnymi przepisami (Ausbildungsordnungen). Monitoring i kontrolę spełniania przez firmy szkolące standardów kształcenia każdego zawodu prowadzą lokalne izby przedsiębiorców. Szkolenie praktyczne w miejscu pracy zapewnia kwalifikacje potrzebne w danej praktyce zawodowej. Umiejętności i wiedza dla poszczególnych zawodów zostały ujęte w planie ramowym określającym czas trwania i konkretne treści nauczania. Jest on podstawą do stworzenia indywidualnego programu nauczania w poszczególnych firmach. Często spotykaną praktyką jest, że firmy szkolące, które nie mogą same zapewnić realizacji wszystkich treści nauczania określonych prawem, łączą się z innymi firmami/ przedsiębiorstwami, tworząc stowarzyszenia, sieci firm czy międzyfirmowe centra szkoleniowe, które mogą oferować dodatkowe elementy szkolenia (np. te wymagające specjalistycznego sprzętu), których nie są w stanie zapewnić mniejsze firmy.

\section{Kształcenie zawodowe w szkole}

Kształcenie w szkole zawodowej (Berufsschule) ma na celu przekazanie wiedzy ogólnej i teoretycznej wiedzy zawodowej. Tygodniowy plan nauczania przewiduje 4 godziny lekcyjne przedmiotów ogólnych (język niemiecki, nauki społeczne i ekonomia, religia i sport) niezależnie od wybranej specjalizacji oraz 8 godzin lekcyjnych przeznaczonych na przedmioty zawodowe. Języki obce są uwzględniane w puli przedmiotów zawodowych $\mathrm{w}$ takim zakresie, $\mathrm{w}$ jakim są istotne w danym zawodzie (np. w pracy biurowej, w specjalności hotelarskiej). Organizacja nauki w szkole odbywa się w porozumieniu z przedsiębiorstwami i instytucjami nadzorującymi szkołę oraz właściwymi przedstawicielami przemysłu w celu zapewnienia uczniom najdogodniejszych warunków kształcenia. 


\section{Zakładanie przedsiębiorstw}

W Niemczech obowiązujące prawo pozwala uczniom i nauczycielom na podjęcie działalności gospodarczej na terenie szkoły, jeżeli działalność taka odbywa się w ramach projektu szkolnego i została zatwierdzona przez dyrektora szkoły. Istotą i celem przedsiębiorstwa szkolnego jest zatem jego charakter pedagogiczno-dydaktyczny ${ }^{18}$.

Przedsiębiorstwa szkolne mogą być zakładane we wszystkich typach szkół jako projekty szkolne, które działają:

- pod patronatem prawnym szkoły lub organu utrzymującego,

- we współpracy ze stowarzyszeniem szkolnym (sponsorzy, kluby boosteringowe, np. wspierające szkolną drużynę sportową),

- we współpracy z instytucją lub przedsiębiorstwem spoza szkoły.

Sprzedaż i zysk muszą pozostać poniżej określonych kwot (roczny obrót nie może przekroczyć 17500 euro, a zysk 3835 euro), w przeciwnym razie działalność przedsiębiorstwa zaczyna podlegać przepisom podatkowym.

Sam projekt przedsiębiorstwa szkolnego i jego efekty mogą zostać włączone do programu nauczania danej szkoły, w zależności od charakteru i obszaru działalności lub mogą być realizowane jako oddzielne inicjatywy, projekty lub grupy robocze. Przedsiębiorstwa szkolne nie mają własnego statusu prawnego. Szkoła lub podmiot utrzymujący przedsiębiorstwo szkolne ponoszą pełną odpowiedzialność prawną w zakresie ubezpieczeń i podatków.

Ani uczniowie, ani nauczyciele nie mogą być zatrudniani przez przedsiębiorstwa szkolne, ale mogą otrzymywać niewielkie wynagrodzenie w zależności od sposobu organizacji przedsiębiorstwa i zawartych umów.

\section{Wielka Brytania}

Struktura organizacyjna systemu szkolnego Wielkiej Brytanii nie jest jednolita. Administracja szkolna jest zdecentralizowania, a zarządzanie i odpowiedzialność za kształt i funkcjonowanie oświaty spoczywa w rękach władzy centralnej i lokalnej każdego spośród czterech części składowych (constituent part) kraju - Anglii, Walii, Szkocji i Irlandii Północnej. Struktury oświatowe Anglii i Walii są relatywnie podobne, natomiast systemy szkolne Szkocji i Irlandii Północnej regulowane

18 http://schuelerfirmen.com/index.php/darf-man-das/steuern-und-gesetze/, http://www.al-hh-online.de/HuEAB-Schuelerfirma.pdf. 
są odrębnymi ustawami. Występują w nich inne typy szkół, inne programy, inne modele kształcenia nauczycieli i odmienne organizacje pracy szkolnej. Finansowanie nauczania przedsiębiorczości realizowane jest z różnych źródeł, m.in. z krajowego i lokalnego budżetu oraz funduszy organizacji, instytucji i fundacji.

W Wielkiej Brytanii nie ma ogólnokrajowej strategii nauczania przedsiębiorczości. Jednakże w poszczególnych regionach realizowane są inicjatywy związane z ideą przedsiębiorczości, takie jak tzw. drabina umiejętności lub matryca efektów w zakresie umiejętności przedsiębiorczych, realizowane na przykład przez organizację ReadyUnlimited ${ }^{19}$ na rzecz promowania przedsiębiorczych szkół.

Praktyczne doświadczenia w zakresie przedsiębiorczości można zdobyć w Wielkiej Brytanii, korzystając z programów i pomocy różnych instytucji i fundacji. Przykładowo ogólnokrajowa organizacja charytatywna MyBank ${ }^{20}$ uczy młodych ludzi, jak zarządzać swoimi pieniędzmi i jak zakładać własne firmy, natomiast Young Enterprise ${ }^{21}$ jest organizacją charytatywną zajmującą się działalnością gospodarczą i przedsiębiorstwami non profit, która pomaga młodzieży poznawać świat biznesu i pracy zawodowej za pomocą wielu programów. Young Enterprise działa w Anglii i Walii, podczas gdy w Szkocji22 i Irlandii Północnej ${ }^{23}$ istnieją niezależne organizacje, które z nią współpracują. W Irlandii Północnej jej programy są wpisane do krajowego programu nauczania. W szkolnictwie podstawowym jednym z tych programów jest Business Beginnings, umożliwiający uczniom w wieku 8-11 lat zdobywanie doświadczenia biznesowego przez tworzenie i prowadzenie własnego przedsiębiorstwa. Podobne projekty realizowane są w szkołach średnich. W Anglii jednym z podstawowych zadań Careers and Enterprise Company ${ }^{24}$, która powstała w lutym 2015 roku w celu zmiany organizacji poradnictwa zawodowego dla młodzieży, jest opracowanie dla uczniów „paszportu przedsiębiorcy”, czyli cyfrowego rejestru zajęć pozalekcyjnych związanych z przedsiębiorczością.

19 ReadyUnlimited to organizacja zajmująca się kształceniem dyrektorów szkól, nauczycieli i wspieraniem edukatorów w tworzeniu procesu przedsiębiorczego uczenia się w celu pomocy uczniom w rozwijaniu wiedzy o przedsiębiorczości. Rozwijanie przedsiębiorczego myślenia ma pomóc młodym ludziom w realizacji planów osobistych i zawodowych przez wyrobienie w nich: poczucia przynależności do swojej społeczności, rozwijanie przyjemności z uczenia się przez całe życie, ułatwienie nawiązania kontaktu ze środowiskiem rynku pracy i biznesu, rozwijanie zdolności rozumienia mechanizmów ekonomii i biznesu, http://www.readyunlimited.com/.

20 https://mybnk.org/.

21 https://www.young-enterprise.org.uk/.

22 http://www.yes.org.uk/.

23 http://www.yeni.co.uk/.

24 https://www.careersandenterprise.co.uk/. 
Oprócz programów i działalności instytucji pozaszkolnych istnieje wiele inicjatyw krajowych, które zapewniają uczniom zajęcia z przedsiębiorczości. Obejmują one między innymi Tycoons in Schools ${ }^{25}$ - ogólnokrajowy szkolny konkurs w dziedzinie przedsiębiorczości, który umożliwia uczniom założenie i prowadzenie działalności gospodarczej w trakcie nauki w szkole lub college’u, dzięki czemu zdobywają oni cenne praktyczne doświadczenie w prowadzeniu przedsiębiorstwa. Kolejny przykład to Enterprise Challenge Programme $e^{26}$, w którym szkoły mają możliwość założenia i zarządzania przedsiębiorstwem, natomiast Tenner Challenge ${ }^{27}$ to konkurs na działalność gospodarczą i inicjatywę mikrofinansowania dla uczniów w wieku od 11 do 19 lat. Konkurs ten daje im szansę na stworzenie nowego pomysłu na przedsiębiorstwo i zrealizowania go z wykorzystaniem prawdziwych pieniędzy (10 funtów), a więc do podejmowania ryzyka w dziedzinie biznesu, wypracowania zysku i wykorzystania go do wprowadzenia zmian w społeczności lokalnej. Z kolei konkurs Fiver Challenge ${ }^{28}$ stwarza podobne możliwości uczniom szkół podstawowych w wieku od 5 do 11 lat. Oba programy działają we wszystkich regionach Wielkiej Brytanii. Dodatkowo w Walii realizowany jest nieobowiązkowy program Welsh Baccalaureate zapewniający możliwości zdobycia praktycznego doświadczenia w zakresie przedsiębiorczości, odpowiadającego zarówno wyzwaniom praktycznym, jak i społecznym. Jest on dostępny dla uczniów w wieku od 14 do 19 roku życia realizujących kształcenie na poziomie szkoły średniej ogólnokształcącej i zawodowej.

Ze względu na dużą samodzielność placówek oświatowych w Anglii, Walii, Szkocji i Irlandii Północnej w sprawach programowych, metodycznych i organizacyjnych nie ma przepisów, które odgórnie regulowałyby problematykę prowadzenia działalności gospodarczej podejmowanej przez uczniów lub nauczycieli na terenie szkoły. Zatem decyzję o tym, czy taka działalność będzie miała miejsce czy nie, podejmuje organ bezpośrednio odpowiedzialny za zarządzanie placówką szkolną.

Jeżeli szkoły decydują się na zakładanie miniprzedsiębiorstw uczniowskich, to najczęściej realizują taki projekt z pomocą i współudziale organizacji Young Enterprise (YE) ${ }^{29}$ - członka Junior Achievement Worldwide ${ }^{30}$. Kontrolę nad mi-

25 http://www.tycooninschools.com/.

26 http://www.nationalenterprisechallenge.co.uk/.

27 http://www.tenner.org.uk/.

28 http://www.fiverchallenge.org.uk/.

29 https://www.young-enterprise.org.uk/.

30 https://www.jaworldwide.org/. 
niprzedsiębiorstwami uczniowskimi i organizacjami wspierającymi sprawuje brytyjski Urząd Nadzoru Finansowego (Financial Conduct Authority, FCA) ${ }^{31}$.

\section{Anglia}

Za organizację oświaty w Anglii odpowiadają Ministerstwo Edukacji (Department for Education, DfE) ${ }^{32}$ oraz Ministerstwo ds. Biznesu, Innowacji i Umiejętności (Department for Business, Innovation and Skills, BIS) ${ }^{33}$. Do obowiązków DfE należą: planowanie i monitorowanie organizacji edukacji w szkołach, zapewnianie zintegrowanych usług dla najmłodszych oraz koordynacja polityki dotyczącej dzieci i młodzieży. Natomiast BIS jest odpowiedzialne za kształcenie ustawiczne, innowacje, szkolnictwo wyższe i działalność gospodarczą. Ponadto kontrolę nad usługami realizowanymi na rzecz dzieci, szkół, kolegiów, systemu kształcenia nauczycieli, kształcenia w miejscu pracy i edukacji dorosłych sprawuje pozaresortowa rządowa instytucja - Urząd ds. Standardów Kształcenia, Usług na rzecz Dzieci i Umiejętności (Office for Standards in Education, Children's Services and Skills, Ofsted) ${ }^{34}$. Organizacją kształcenia w szkołach finansowanych ze środków publicznych zajmują się 152 organy lokalnych władz różnego szczebla. Ramy prawne dla dotowanych szkół podstawowych i średnich dzielą je na szkoły lokalne (community schools), szkoły społeczne (voluntary schools) oraz szkoły fundacyjne (foundation schools). Większość stanowią szkoły lokalne. Wspólną ich cechą jest to, że posiadają szeroką autonomię programową i organizacyjną.

\section{Podejście do nauczania przedsiębiorczości w Anglii}

W Anglii koncepcja nauczania przedsiębiorczości opiera się na idei pomocy uczniom: w przejawianiu postaw kreatywnych i innowacyjnych, w podejmowaniu ryzyka i zarządzaniu nim oraz $w$ realizacji tych działań z determinacją i zapaŁem $^{35}$. Nauczanie przedsiębiorczości dzieli się na trzy obszary:

- umiejętności przedsiębiorcze - przedsiębiorczość i zapał do działania,

31 https://www.fca.org.uk/.

32 https://www.gov.uk/government/organisations/department-for-education.

33 https://www.gov.uk/government/organisations/department-for-business-innovation-skills.

34 https://www.gov.uk/government/organisations/ofsted.

35 http://webarchive.nationalarchives.gov.uk/20130123124929/https://www.education.gov.uk/ publications/eOrderingDownload/00228-2010BKT-EN.pdf. 
- umiejętności finansowe - rozumienie zagadnień finansowych i podstawowe zarządzanie finansami,

- rozumienie zagadnień w dziedzinie biznesu i e-gospodarki - rozumienie kontekstu biznesowego.

\section{Kształcenie i formy wsparcia dla nauczycieli}

Nauczanie przedsiębiorczości nie jest wyraźnie wyszczególnione w standardach kształcenia nauczycieli i w konsekwencji nie ma formalnego obowiązku doskonalenia zawodowego w tej dziedzinie, jednak szkoły mogą skierować nauczyciela na taki kurs. Kursy doskonalenia zawodowego dla nauczycieli realizowane są przez wiele różnych podmiotów, np. Ministerstwo Edukacji, władze lokalne, instytucje edukacyjne, organizacje przedsiębiorców, fundacje charytatywne.

\section{Walia}

Za organizację oświaty odpowiadają Ministerstwo Edukacji i Umiejętności (Department for Education and Skills, DfES) ${ }^{36}$ oraz Inspektorat Edukacji i Szkolenia w Walii (Inspectorate for Education and Training in Wales, Estyn) ${ }^{37}$. Za całokształt organizacji systemu szkolnictwa odpowiada DfEs, a zadaniem Estynu jest zapewnienie niezależnej służby kontroli oraz doradztwa w sprawie jakości i standardów funkcjonowania walijskich placówek szkolnych. Organizacją kształcenia na poziomie lokalnym zajmują się powołane do tego 22 oświatowe jednostki władz lokalnych. Ich podstawowymi zadaniami są: zapewnienie odpowiedniej liczby miejsc w szkołach, zapewnienie wysokich standardów wychowawczo-dydaktycznych oraz przeciwdziałanie zjawiskom niepożądanym wśród dzieci i młodzieży.

\section{Podejście do nauczania przedsiębiorczości}

W Walii nauczanie przedsiębiorczości jest obowiązkowe dla wszystkich uczniów i realizowane jako przedmiot odrębny lub zintegrowany z innymi przedmiotami. Program i sposób jego realizacji oparty jest na strategii przedsiębiorczości młodzieży (Youth Enterprise Strategy, YES) z 2004 roku i zaktualizowanej w 2010 roku w formie planu działań. Jej główne cele to: rozwój i wychowanie samowystarczal-

36 http://gov.wales/topics/educationandskills/?lang=en.

37 http://www.estyn.gov.wales/. 
nych, przedsiębiorczych młodych ludzi ze wszystkich środowisk społecznych Walii, którzy będa mieć wkład w gospodarczy i społeczny sukces kraju ${ }^{38}$. Plan działań obejmuje dwa główne obszary:

- zaangażowanie - promowanie wartości związanych z przedsiębiorczością w celu tworzenia możliwości i zapewnienia szans rozwojowych młodym ludziom:

- uruchomienie kampanii Big Ideas Wales celem zachęcania młodych ludzi do idei przedsiębiorczości oraz zapewnienia pomocy osobom zainteresowanym rozpoczęciem działalności gospodarczej,

- realizacja ukierunkowanych działań i organizacja wydarzeń mających na celu stymulowanie zainteresowania i uczestnictwa w sektorze przedsiębiorczości, szczególnie skierowanych do osób bezrobotnych i/lub nieaktywnych zawodowo,

- zachęcanie przedsiębiorstw do zaangażowania się w działania skierowane do młodzieży i środowisk akademickich,

- przygotowanie - wspieranie młodych ludzi w tworzeniu i rozwijaniu przedsiębiorstw:

- przygotowanie młodzieży do podjęcia kolejnego kroku w kierunku rozpoczęcia działalności gospodarczej;

- wspieranie młodzieży w podejmowaniu decyzji o założeniu działalności gospodarczej,

- zapewnienie wsparcia startupom o wysokim potencjale rozwojowym, szczególnie tym zakładanym w priorytetowych sektorach i przez absolwentów,

- czerpanie z doświadczeń i wiedzy społeczności biznesowej do celów wspierania młodych przedsiębiorców.

Nauczanie przedsiębiorczości w szkolnictwie podstawowym, średnim I i II stopnia (uczniowie w wieku od 5 do 16 roku życia) jest realizowane w ramach obowiązkowego przedmiotu edukacja osobista i społeczna (Personal and Social Education, PSE) $)^{39}$. Oprócz tego przedmiotu zagadnienia z przedsiębiorczości znalazły się także (zgodnie z podstawą programową dla szkolnictwa I i II stopnia) w ścieżce międzyprzedmiotowej w obowiązkowej dziedzinie kariera zawodowa i świat pracy (Careers and the world of work, CWW) ${ }^{40}$. Dodatkowo nauczanie przedsiębiorczości uwzględniono w walijskim zestawie kwalifikacji (Welsh Baccalaureate Qualification, WBQ), który określa umiejętności, jakimi powinni się

38 http://www.young-entrepreneurs.eu.

39 http://learning.gov.wales/resources/improvementareas/curriculum/?lang=en.

40 http://learning.gov.wales/resources/browse-all/careers-world-of-work/?skip=1\&lang=en. 
wykazać uczniowie, aby uzyskać dostęp do kształcenia w kolegiach, uniwersytetach lub podjąć pracę w określonym zawodzie.

\section{Kształcenie i formy wsparcia dla nauczycieli}

W Walii nauczanie przedsiębiorczości nie jest wyraźnie wyszczególnione w standardach kształcenia i doskonalenia nauczycieli. Ani wymogi walijskiego Ministerstwa Edukacji i Umiejętości (DfES), ani standardy nadawania statusu wykwalifikowanego nauczyciela (Qualified Teacher Status, QTS) ${ }^{41}$ nie zawierają odniesienia do dziedziny przedsiębiorczości. Można znaleźć jedynie stwierdzenie, że oczekuje się od nauczycieli pełnej realizacji programu nauczania przedmiotów PSE i CWW.

\section{Szkocja}

W Szkocji za szkolnictwo obowiązkowe, średnie, wyższe oraz kształcenie ustawiczne, poprawę standardów szkolnych, ochronę praw dzieci oraz kultywowanie tradycji języków Szkocji odpowiedzialny jest Sekretarz ds. Edukacji i Kształcenia Ustawicznego (Secretary for Education \& Lifelong Learning) ${ }^{42}$. Podlegają mu dwaj ministrowie - Minister ds. Dzieci i Młodzieży (Minister for Children \& Young People $)^{43}$ oraz Minister ds. Kształcenia, Nauki i Języków Szkocji (Minister for Learning, Science \& Scotland’s Languages) ${ }^{44}$. Organizacją szkolnictwa publicznego zajmują się 32 rady terytorialne (unitary councils), szkockie władze lokalne (Local Authorities, SLAs).

\section{Podejście do nauczania przedsiębiorczości}

W Szkocji nie ma odrębnej strategii nauczania przedsiębiorczości. Przedmiot ten jako interdyscyplinarny został włączony do dwóch szkockich strategii oświatowych zatytułowanych „Szkocja potrafi - może stać się wiodącym na świecie, przedsiębiorczym i innowacyjnym narodem” (Scotland Can Do - Becoming

41 https://www.ewc.wales/site/index.php/en/registration/recognition-as-a-qualified-school-teacher-in-wales.html.

42 http://www.gov.scot/About/People/Ministers/Cabinet-Secretary-for-Education-andLifelong-Learn.

43 http://www.gov.scot/About/People/Ministers/Minister-for-Children-and-Young-People.

44 http://www.gov.scot/About/People/Ministers/Minister-for-Learning. 
a World-Leading, Entrepreneurial and Innovative Nation $)^{45}$ oraz „Rozwój młodej siły roboczej - strategia zatrudnienia młodzieży w Szkocji” (Developing the Young Workforce - Scotland's Youth Employment Strategy) ${ }^{46}$

Strategia „Szkocja potrafi - może stać się wiodącym na świecie, przedsiębiorczym i innowacyjnym narodem” obejmuje lata 2013-2020. Jednym z pięciu celów strategii jest reforma systemu edukacji, w którego centrum znalazły się przedsiębiorczość i innowacyjność jako źródła technologicznej i społecznej nowoczesności. Wśród konkretnych działań realizowanych w zakresie strategii znalazły się m.in. ułatwienia w opracowywaniu zasobów promujących nauczanie przedsiębiorczości w szkołach, wspieranie wdrażania inicjatywy Bridge 2 Business, interaktywnego programu, który ma inspirować do innowacyjnej przedsiębiorczości.

Natomiast strategia „Rozwój młodej siły roboczej - strategia zatrudnienia młodzieży w Szkocji” została opublikowana w grudniu 2014 roku. Jej celem jest zmniejszenie do 2021 roku bezrobocia młodzieży o 40\% przez lepsze przygotowanie młodych ludzi do wejścia na rynek pracy.

Strategia jest spójna z ramowym programem nauczania, który zapewnia elastyczność umożliwiającą stosowanie mieszanego podejścia do uczenia się, poszerzenie zakresu ścieżek kształcenia i zwiększenie możliwości wyboru specjalizacji dla wszystkich uczniów. Powiązana jest również z promowaniem interdyscyplinarnego uczenia się przedsiębiorczości.

\section{Kształcenie i formy wsparcia dla nauczycieli}

System edukacyjny w Szkocji wykształcił wiele instytucji, firm i agencji zajmujących się doradztwem, szkoleniami oraz konsultacjami dla nauczycieli. Do najważniejszych należą: Education Scotland ${ }^{47}$, Scottish Qualifications Authority ${ }^{48}$, Scottish Council for Research in Education ${ }^{49}$, Scottish Funding Council50, General Teaching Council for Scotland ${ }^{51}$. Podmioty te oferują pomoc nauczycielom już pracującym w zawodzie i tym przygotowującym się do podjęcia pracy. Zapewnia-

\footnotetext{
45 http://www.gov.scot/Publications/2013/11/7675.

46 http://www.gov.scot/Publications/2014/12/7750.

47 http://www.educationscotland.gov.uk/.

48 http://www.sqa.org.uk/sqa/70972.html.

49 http://www.eep.ac.uk/dnn2/Organizations/SCRE/tabid/86/Default.aspx.

50 http://www.sfc.ac.uk/aboutus/aboutus.aspx.

51 http://www.gtcs.org.uk/home/home.aspx.
} 
ją porady w sprawach związanych z organizacją nauczania, doborem narzędzi i metod dydaktycznych, dostępnych kursów i szkoleń dla nauczycieli.

W szkockich standardach kształcenia nauczycieli nie ma szczegółowych wytycznych dotyczących kształcenia nauczycieli w zakresie przedsiębiorczości. Jednocześnie standardy kształcenia określają, że wszyscy nauczyciele szkół podstawowych i średnich powinni być przeszkoleni w zakresie wszystkich zagadnień związanych z programem nauczania, co należy rozumieć jako uwzględnienie również nauczania przedsiębiorczości. Osoby zainteresowane dokształcaniem z dziedziny przedsiębiorczości mogą ukończyć odpowiednie kursy doskonalenia zawodowego realizowane przez podmioty pozarządowe uczestniczące w projektach: Enterprising Schools lub Social Enterprise Academy. Jednym z centralnie wspieranych i finansowanych programów kształcenia jest dwudniowy staż Excellence in Education through Business Links (EEBL ${ }^{52}$ - Doskonałość w edukacji przez związki z biznesem), w ramach którego organizowane są szkolenia skierowane do nauczycieli szkół podstawowych i średnich.

\section{Irlandia Północna}

W Irlandii Północnej za organizację systemu oświaty odpowiada Ministerstwo Edukacji (Department of Education, DE) ${ }^{53}$. Za kształcenie ustawiczne i szkolnictwo wyższe odpowiedzialność ponosi Ministerstwo Zatrudnienia i Kształcenia (Department for Employment and Learning, DEL) ${ }^{54}$. Na poziomie lokalnym organizacją szkolnictwa zajmują się lokalne jednostki władzy oświatowej, tzw. ELBs (Education and Library Boards) ${ }^{55}$.

\section{Podejście do nauczania przedsiębiorczości}

Nauczanie przedsiębiorczości uwzględnione zostało w strategii ogólnej zatytułowanej „Strategia innowacji dla Irlandii Północnej na lata 2014-2025” (Northern Ireland Innovation Strategy 2014-2025) ${ }^{56}$. Strategia dotyczy wszystkich szczebli

\footnotetext{
52 https://www.fsb.org.uk/docs/default-source/fsb-org-uk/fsb_j587_business-engagement-in-schools-web-final---use.pdf?sfvrsn=0.

53 https://www.deni.gov.uk/.

54 https://www.delni.gov.uk/.

55 http://www.eani.org.uk/.

56 https://www.economy-ni.gov.uk/publications/northern-ireland-innovation-strategy.
} 
edukacji od szkół podstawowych do szkół wyższych. Jednym z jej głównych celów jest promowanie wśród młodych ludzi przedsiębiorczej samodzielności.

W strategii podkreślono, że nauczanie przedsiębiorczości w szkołach podstawowych, średnich i policealnych jest jednym z podstawowych wymogów, które muszą zostać spełnione, aby ułatwić rozwój przedsiębiorczości we wszystkich dziedzinach życia. Na poziomie szkolnictwa podstawowego (uczniowie w wieku 4-11 lat) nauczanie przedsiębiorczości jest uwzględnione w obowiązkowym przedmiocie o nazwie „Rozwój osobisty i wzajemne zrozumienie” (Personal Development and Mutual Understandingmm, PD\&MU) ${ }^{57}$. Celem przedmiotu jest uświadomienie uczniom siebie, swoich emocji i relacji z rówieśnikami w taki sposób, aby stali się pewnymi siebie, niezależnymi i odpowiedzialnymi obywatelami oraz przez całe życie dokonywali świadomych i odpowiedzialnych wyborów. Przedmiot ten obejmuje wprowadzenie do świata pracy i edukację finansową.

Na poziomie szkolnictwa średniego I i II stopnia (uczniowie w wieku 11-16 lat) nauczanie przedsiębiorczości jest uwzględnione w przedmiocie wiedza potrzebna w życiu i pracy (Learning for Life and Work, LLW). Ten obszar nauczania ma kluczowe znaczenie dla rozwijania przez młodych ludzi podstawowych umiejętności zdobywania wiedzy, analizowania i oceniania informacji i poglądów o otaczającym ich świecie, które są i będą im niezbędne w życiu i pracy. Przedmiot LLW obejmuje zagadnienia związane z rozwojem osobistym, możliwościami zatrudnienia, umiejętnościami zarządzania budżetem domowym oraz obywatelskim uczestnictwem w życiu lokalnym i globalnym.

\section{Kształcenie i formy wsparcia dla nauczycieli}

W Irlandii Północnej nauka przedsiębiorczości jest obowiązkowa, choć realizowana jest nie jako odrębny przedmiot, a jako obszar tematyczny zintegrowany z innymi przedmiotami. Brak jest szczegółowych informacji o kształceniu nauczycieli w przedmiocie przedsiębiorczości, gdyż to instytucje oferujące kształcenie decydują o programie nauczania, metodach i podręcznikach, przestrzegając wymogów określonych przez Ministerstwo Edukacji. W Irlandii Północnej doskonalenie zawodowe dla nauczycieli realizowane jest przez wiele różnych organizacji, w tym przez pracodawców, fundacje oświatowe, biura pracy i karier zawodowych, placówki szkolne, władze lokalne.

57 http://www.nicurriculum.org.uk/docs/key_stages_1_and_2/areas_of_learning/pdmu/PD-Guidance.pdf. 


\section{Włochy}

We Włoszech kompetencje ustawodawcze w zakresie ogólnej organizacji systemu szkolnego należą do Ministerstwa Edukacji, Szkolnictwa Wyższego i Badań Naukowych (Ministero dell'Istruzione, dell'Università e della Ricerca; dalej: Ministerstwo Edukacji) ${ }^{58}$. Włochy podzielone są na 20 regionów (5 z nich na prawach szczególnych), 107 prowincji (z których 2 są autonomiczne) i 8092 gminy. Agendami ministerstwa na szczeblu lokalnym - w regionach i prowincjach - są urzędy ds. edukacji. Regiony mogą przekazać niektóre obowiązki oświatowe prowincjom i gminom. Zgodnie z ustawą nr 59 z 15 marca 1997 r. i późniejszym dekretem Prezydenta Republiki (DPR 275/1999) ${ }^{59}$ szkoły posiadają pełną autonomię w zakresie administracji, organizacji procesu dydaktycznego oraz prowadzenia oświatowej działalności eksperymentalnej i rozwojowej. Organizacja regionalnego systemu kształcenia i szkolenia zawodowego należy do wyłącznej kompetencji regionów.

\section{Finansowanie}

We Włoszech finansowanie nauczania przedsiębiorczości odbywa się z budżetu ogólnego. Brak jest oddzielnego źródła finansowania tego przedmiotu.

\section{Podejście do nauczania przedsiębiorczości}

Na poziomie szkolnictwa podstawowego i średniego I stopnia nauka przedsiębiorczości ma charakter międzyprzedmiotowy i choć nie zdefiniowano efektów kształcenia jako takich, to opracowano ogólne wytyczne dotyczące przedsiębiorczości w aspekcie społecznym. Wynika z nich, że na poziomie szkoły podstawowej uczniowie powinni wykazywać się oryginalnością i inicjatywą oraz realizować proste projekty, a na poziomie szkoły średniej dodatkowo przyjmować odpowiedzialność, umieć prosić o pomoc, kiedy mają trudności, oraz udzielać pomocy tym, którzy o nią proszą. Powinni też umieć przeprowadzić samoocenę oraz radzić sobie w nowych i zaskakujących sytuacjach.

Na poziomie szkolnictwa ogólnokształcącego II stopnia przedsiębiorczość jest przedmiotem fakultatywnym - nosi nazwę prawo i ekonomia. W szkolnic-

58 http://www.miur.gov.it/.

59 Decreto del Presidente della Repubblica n. 275, 8 marzo 1999, Regolamento recante norme in materia di autonomia delle istituzioni scolastiche ai sensi dell'art. 21, della legge 15 marzo 1997, n. 59, http://www.edscuola.it/archivio/norme/decreti/aut3.html. 
twie średnim zawodowym przygotowującym do pracy w sektorze gospodarki i technologii, celem tego przedmiotu jest nabywanie przez uczniów umiejętności przedsiębiorczych realizowane jako zarządzanie projektem, zarządzanie procesem produkcji ze szczególnym uwzględnieniem wdrażania przepisów krajowych i unijnych w zakresie bezpieczeństwa pracy i ochrony środowiska. Jedną z umiejętności, którą uczniowie powinni nabyć, jest rozpoznawanie aspektów prawnych i ekonomicznych, które charakteryzują działalność przedsiębiorczą.

Innym rozwiązaniem nauczania przedsiębiorczości jest alternanza scuola-lavoro (kształcenie dualne) ${ }^{60}$ - naprzemienna nauka w szkole połączona $\mathrm{z}$ doświadczeniem praktycznym, zdobywanym $\mathrm{w}$ ramach praktyk zawodowych (staży) lub poprzez aktywność przedsiębiorczą realizowaną przez uczniów na terenie szkoły przy wsparciu ekspertów zewnętrznych (np. Junior Achievement ${ }^{61}$ ).

Naprzemienna nauka w systemie szkoła-praca jest realizowana we wszystkich ścieżkach kształcenia w szkołach średnich II stopnia, szkołach policealnych technicznych, a także w szkolnictwie wyższym akademickim i zawodowym. Formy kształcenia mogą się znacząco różnić w poszczególnych szkołach, ze względu na autonomię szkół w zakresie opracowywania programów nauczania. Przykładowo mogą one przybierać formę symulacji działalności gospodarczej organizowanej w szkole i prowadzonej przez uczniów. Mogą to być również praktyki zawodowe realizowane w wybranych firmach.

\section{Bibliografia}

Nauczanie przedsiębiorczości $w$ szkołach $w$ Europie (Entrepreneurship Education at School in Europe), Urząd Publikacji Unii Europejskiej, Komisja Europejska/Eurydice 2016, http://eurydice.org.pl/wp-content/uploads/2017/01/PL_Entrepreneurship-Education.pdf.

60 Nauka naprzemienna została wprowadzona w 2003 r. na mocy dekretu 2005/77, w technikach i szkołach zawodowych, a także w ogólnokształcących szkołach średnich II stopnia. Także reforma oświaty z roku szkolnym 2010/2011 (dekret 87/2010) wyraźnie określiła kształcenia naprzemienne jako metodę nauczania dla ścieżek kształcenia we wszystkich technikach, szkołach zawodowych i ogólnokształcących szkołach średnich II stopnia, http:// www.istruzione.it/allegati/2015/Guida_Operativa.pdf.

61 Junior Achievement (JA) to największa na świecie organizacja non profit zajmująca się edukacją ekonomiczno-przedsiębiorczą w szkole. W 122 krajach sieć JA zrzesza ponad 450000 wolontariuszy ze wszystkich sektorów zawodowych, a wraz z nimi dociera do ponad 10 mln uczniów na całym świecie, http://www.jaitalia.org. 


\section{Akty prawne}

Zalecenie Parlamentu Europejskiego i Rady nr 2006/962/WE z 18 grudnia 2006 r. w sprawie kompetencji kluczowych w procesie uczenia się przez całe życie. Dz.Urz. UE L 394/10 z 30 grudnia 2006 r.

Komunikat Komisji do Parlamentu Europejskiego, Rady, Europejskiego Komitetu Ekonomiczno-Społecznego i Komitetu Regionów z 20 listopada 2012 r. w sprawie nowego podejścia do edukacji: Inwestowanie w umiejętności na rzecz lepszych efektów społeczno-gospodarczych, KOM(2012)669 wersja ostateczna.

Ley 14/2013, de 27 de septiembre, de apoyo a los emprendedores y su internacionalización, https://www.boe.es/diario_boe/txt.php?id=BOE-A-2013-10074.

Decreto del Presidente della Repubblica n. 275, 8 marzo 1999, Regolamento recante norme in materia di autonomia delle istituzioni scolastiche ai sensi dell'art. 21, della legge 15 marzo 1997, n. 59, http://www.edscuola.it/archivio/norme/decreti/aut3.html.

\section{Strony internetowe}

http://www.youthstartproject.eu/.

http://www.ifte.at/.

https://www.junior.cc/.

http://www2.wkstmk.at/wko.at/lst/rechtsinfo/BAG.html.

http://www.valnaloneduca.com/eje/.

http://www.edu.xunta.es/fp/eduemprende.

https://www.boe.es/boe_gallego/dias/2013/09/28/pdfs/BOE-A-2013-10074-G.pdf.

https://www.kmk.org/.

http://schuelerfirmen.com/index.php/darf-man-das/steuern-und-gesetze/.

http://www.al-hh-online.de/HuEAB-Schuelerfirma.pdf.

https://mybnk.org/.

https://www.young-enterprise.org.uk/.

http://www.yes.org.uk/.

http://www.yeni.co.uk/.

https://www.careersandenterprise.co.uk/.

http://www.tycooninschools.com/.

https://www.gov.uk/government/organisations/department-for-education.

https://www.gov.uk/government/organisations/department-for-business-innovation-skills.

https://www.gov.uk/government/organisations/ofsted. 
http://webarchive.nationalarchives.gov.uk/20130123124929/https://www.education.gov.uk/ publications/eOrderingDownload/00228-2010BKT-EN.pdf. http://gov.wales/topics/educationandskills/?lang=en.

http://www.estyn.gov.wales/.

http://learning.gov.wales/resources/improvementareas/curriculum/?lang=en.

http://learning.gov.wales/resources/browse-all/careers-world-of-work/?skip=1\&lang=en. https://www.ewc.wales/site/index.php/en/registration/recognition-as-a-qualified-school-teacher-in-wales.html.

http://www.gov.scot/About/People/Ministers/Cabinet-Secretary-for-Education-and-Lifelong-Learn.

http://www.gov.scot/About/People/Ministers/Minister-for-Children-and-Young-People.

http://www.gov.scot/About/People/Ministers/Minister-for-Learning.

http://www.gov.scot/Publications/2013/11/7675.

http://www.gov.scot/Publications/2014/12/7750.

http://www.educationscotland.gov.uk/.

http://www.sqa.org.uk/sqa/70972.html.

http://www.eep.ac.uk/dnn2/Organizations/SCRE/tabid/86/Default.aspx.

http://www.sfc.ac.uk/aboutus/aboutus.aspx.

http://www.gtcs.org.uk/home/home.aspx.

https://www.fsb.org.uk/docs/default-source/fsb-org-uk/fsb_j587_business-engagement-in-

-schools-web-final---use.pdf?sfvrsn=0.

https://www.deni.gov.uk/.

https://www.delni.gov.uk/.

http://www.eani.org.uk/.

https://www.economy-ni.gov.uk/publications/northern-ireland-innovation-strategy.

http://www.nicurriculum.org.uk/docs/key_stages_1_and_2/areas_of_learning/pdmu/PD-

-Guidance.pdf.

http://www.miur.gov.it/. 


\title{
2.3. Edukacja kulturalna w szkolnictwie wybranych państw europejskich
}

\author{
Cultural and artistic education at school in selected \\ European countries
}

W opracowaniu przedstawiono problematykę edukacji kulturalnej i artystycznej w szkolnictwie obowiązkowym w Polsce i w wybranych krajach europejskich. W artykule podjęto próbę zdefiniowania pojęcia edukacja kulturalna i przedstawienia jej miejsca we współczesnym świecie. Dokonano przeglądu problematyki związanej z przedmiotem szkolnym o nazwie edukacja kulturalna realizowanym na poziomie obowiązkowej szkoły podstawowej i średniej w wybranych państwach europejskich. Analizie poddano szkolne programy nauczania ze szczególnym uwzględnieniem przedmiotów o charakterze kulturalnym i artystycznym. Dla lepszego zilustrowania stosowanych rozwiązań omawiane zagadnienia osadzono w kontekście organizacji ustrojów szkolnych, programów nauczania i miejsca nauczycieli przedmiotów artystycznych w edukacji szkolnej i kształceniu ustawicznym.

Słowa kluczowe: kultura, oświata, szkoła, szkolnictwo obowiązkowe, edukacja kulturalna i artystyczna, Austria, Belgia, Estonia, Finlandia, Francja, Grecja, Hiszpania, Irlandia, Niemcy, Polska, Wielka Brytania

This paper presents an overview of cultural and artistic education in compulsory education in Poland and in selected European countries. An attempt is made to define the concept of cultural education and to examine the place it has in the modern world. The review includes the issues related to cultural education as a compulsory school subject in primary and secondary schools in selected European countries. An analysis is made of school curricula, with special emphasis on cultural and artistic subjects. The context of the school organization systems and curricula, as well as the status of teachers in art school education and lifelong learning, was used to better exemplify the issues under consideration.

Keywords: culture, education, school, compulsory education, cultural and arts education, Poland, Austria, Belgium, Estonia, Finland, France, Greece, Spain, Ireland, Germany, United Kingdom 


\section{Wstęp ${ }^{1}$}

Literatura związana z zagadnieniami edukacji kulturalnej jest wyjątkowo bogata, przy tym wieloaspektowa, a więc i system pojęciowy w tej dziedzinie pozostaje mocno zróżnicowany. W literaturze pedagogicznej i socjologicznej, a szczególnie w literaturze dotyczącej instytucji oświatowych i systemów szkolnych, można spotkać się z takimi terminami, jak: edukacja kulturalna, edukacja kulturowa, edukacja dla kultury, edukacja w dziedzinie kultury, edukacja kulturalna i artystyczna, edukacja kulturalna i estetyczna, wychowanie estetyczne. Jednakże większość źródeł zwartych - w tym Encyklopedia pedagogiczna XXI wiek $u^{2}$ - wskazuje na dominację terminu edukacja kulturalna, gdzie edukacja (łac. educatio - wychowanie; educo - wyprowadzić, wyciągnąć, poprowadzić, wychować) ${ }^{3}$ jest fundamentalnym pojęciem pedagogicznym obejmującym ogół wielowymiarowych działań oraz procesów służących wychowaniu i kształceniu osób czy grup społecznych, a kultura (łac. colere - uprawiać, pielęgnować, kształcić) ${ }^{4}$ najczęściej określa całokształt materialnego i duchowego dorobku ludzkości gromadzony, utrwalany, wzbogacany i przekazywany z pokolenia na pokolenie.

W potocznym znaczeniu termin edukacja kulturalna, a zwłaszcza przymiotnik kulturalna, może sugerować emocjonalny ładunek wartościująco-oceniający i stąd w języku polskim próba zamiany pojęcia edukacja kulturalna na terminy bardziej neutralne jak edukacja kulturowa, edukacja dla kultury, edukacja w dziedzinie kultury. W praktyce oświatowej innych państw w użyciu jest pojęcie cultural education (ang.), education culturelle (fr.), kulturelle Erziehung (niem.), co wprost odpowiada polskiemu terminowi edukacja kulturalna. Gdy jednak próbujemy zdefiniować edukację kulturalną, okazuje się, że dotykamy niezwykle szerokiego wachlarza pojęciowego od wychowania estetycznego (przygotowanie wychowanka do odbioru wartości piękna) do pedagogiki kultury (ujmowanie i przeżywanie dziedzictwa kulturowego). Od edukacji humanistycznej (wprowadzanie w kulturę zastaną, czyli w różne obszary wiedzy, norm, zachowań i postaw społecznych), przez edukację do kultury (kultura

1 Opracowanie przygotowano na podstawie eksperckiego artykułu D. Dziewulaka Edukacja kulturalna w szkolnictwie wybranych państw europejskich, „Studia BAS” 2016, nr 2(46), s. 77-146.

2 Encyklopedia pedagogiczna XXI wieku, t. I, Wydawnictwo Akademickie „Żak”, Warszawa 2003, s. 923-930.

3 Tamże, s. 905.

4 Wielka encyklopedia PWN, t. 15, Wydawnictwo Naukowe PWN, Warszawa 2003, s. 181-183. 
symboliczna wypełniająca obszar duchowy, świadomościowy, w którym człowiek zaczyna interpretować, rozumować, zastanawiać się i przeżywać nie tylko wytwory artystyczne, ale również religię i naukę) - aż do edukacji artystycznej (kultura artystyczna, np. sztuki piękne: malarstwo, rzeźba, architektura, muzyka, taniec, teatr).

Na podstawie analizy dokumentów międzynarodowych organizacji UNESCO i Rady Europy można przyjąć, że we współczesnym świecie przez edukację kulturalną najczęściej rozumie się edukację artystyczną, edukację twórczą, edukację wdrażającą do samorozwoju człowieka i przygotowującą do umiejętności korzystania z ofert instytucji kultury, a także edukację ekspresji i odbioru sztuki.

\section{Edukacja kulturalna w dobie globalizacji}

Przemiany cywilizacyjne, odkrycia naukowe, wynalazki, rozwój przemysłowy i technologiczny oraz postępująca globalizacja spowodowały, że ogólnoświatowe tendencje gospodarcze, społeczne i kulturalne stały się dla poszczególnych państw wyznacznikiem kierunków ich rozwoju. Współczesny świat skurczył się tak bardzo, że najtrafniej odzwierciedla to zjawisko powszechnie używane określenie globalna wioska5 ${ }^{5}$ Zjawisko globalizacji stało się dominującą cechą końca XX wieku i dwóch pierwszych dekad początku XXI wieku. W latach osiemdziesiątych XX wieku globalizacja była postrzegana i rozumiana przede wszystkim jako upowszechnianie się konsumpcyjnego modelu życia. Dzisiaj zjawiska globalizacji możemy odnaleźć w światowej ekonomii, polityce, demografii, życiu społecznym i oczywiście w kulturze. Polegają one na rozprzestrzenianiu się analogicznych zjawisk, niezależnie od kontekstu geopolitycznego i stopnia rozwoju gospodarczego danego regionu. Choć zagadnienie globalizacji rozpatrywane jest najczęściej w aspekcie gospodarki, życia społecznego i kultury, to coraz wyraźniej analizowane zjawisko ma swoje odniesienie także i w oświacie. Skomplikowany system powiązań społecznych, gospodarczych, politycznych i kulturowych, wynikający z modelu współczesnego świata, wymusza na dzisiejszej oświacie realizację nowych celów edukacyjnych, zupełnie innych niż te, jakie znały starsze pokolenia. Od systemu kształcenia oczekujemy już nie tylko przekazywania wia-

$5 \quad$ Po raz pierwszy termin globalna wioska (ang. global village) został użyty przez kanadyjskiego teoretyka mediów i komunikacji H.M. McLuhana w 1962 r. w książce Galaktyka Gutenberga (The Gutenberg Galaxy). Autor opisuje w niej kierunek, w którym powszechne media elektroniczne obalają bariery czasowe i przestrzenne, umożliwiając ludziom swobodny dostęp do wiedzy i nieskrępowaną wymianę myśli na masową skalę. 
domości, ale także jej zrozumienia wraz z umiejętnością jej wykorzystania. Te postulaty dotyczą także edukacji kulturalnej, a świadomość jej znaczenia dla kształtowania rozumienia kultury i wrażliwości przyszłych pokoleń we współczesnym zglobalizowanym świecie potwierdza wiele międzynarodowych dokumentów, m.in.: Konwencja ramowa Rady Europy w sprawie znaczenia dziedzictwa kulturowego dla społeczeństwa (Faro 2005 r.) ${ }^{6}$, Konwencja UNESCO w sprawie ochrony i promowania różnorodności form wyrazu kulturowego (Paryż, 20 października 2005 r. $)^{7}$, Rezolucja Parlamentu Europejskiego w sprawie studiów artystycznych w Unii Europejskiej (Parlament Europejski 2009 r.) ${ }^{8}$.

Gdyby jednak spojrzeć na problem edukacji kulturalnej z perspektywy europejskiej instytucji szkoły, przeanalizować programy nauczania i sposób ich realizacji, to dziedziną najczęściej nauczaną w szkołach obejmującą obszar szeroko rozumianej kultury jest edukacja artystyczna i kulturalna ${ }^{9}$. Jak wynika z analizy programów nauczania, w państwach europejskich celem dydaktyczno-wychowawczym tego przedmiotu szkolnego jest rozumienie znaczenia dziedzictwa kulturowego dla życia człowieka, rozwijanie wiedzy i umiejętności artystycznych, udział w różnych formach tworzenia sztuki, dzielenie się doświadczeniami artystycznymi oraz kształtowanie u uczniów umiejętności wyrażania opinii na temat wytworów sztuki i kultury.

6 Council of Europe Framework Convention on the Value of Cultural Heritage for Society, http://www.kpd.lt/uploads/Teises\%20aktai/Konvencijos/Konvencija\%20d\%C4\%971\%20kulturos\%20paveldo\%20vert\%C4\%97s\%20visuomenei.pdf.

7 http://www.abc.com.pl/du-akt/-/akt/dz-u-2007-215-1585.

8 http://www.europarl.europa.eu/sides/getDoc.do?pubRef=-//EP//TEXT+TA+P6-TA-20090153+0+DOC+XML+V0//PL.

9 Raporty i publikacje UE: Biała księga Komisji Europejskiej, A new impetus for European Youth, Bruksela 2001, KOM(2001)681 wersja ostateczna; Inwestowanie w młodzież i mobilizowanie jej do działania - strategia UE na rzecz młodzieży. Odnowiona otwarta metoda koordynacji na potrzeby wyzwań i możliwości stojących przed młodzieżą, 2009, KOM(2009)200 wersja ostateczna; Aktualizacja strategicznych ram współpracy europejskiej w dziedzinie kształcenia i szkolenia, KOM(2008) 865 wersja ostateczna; Absolwent na rynku pracy - poradnik dla Ucznia i Nauczyciela, ECORYS Polska Sp. z o.o., https://ckziunr3. pl/wp-content/uploads/KCDZ/doradz15.pdf; Zalecenie Parlamentu Europejskiego i Rady nr 2006/962/WE z 18 grudnia 2006 r. w sprawie kompetencji kluczowych w procesie uczenia się przez całe życie, Dz.Urz. UE L 394/10 z 30 grudnia 2006; Entrepreneurship 2020 Action Plan. Reigniting the entrepreneurial spirit in Europe; 2012 EU Youth Report, Joint Report of the Council and the Commission on the implementation of the renewed framework for European cooperation in the youth field, KOM(2012) 795 wersja ostateczna; Nowe podejście do edukacji: Inwestowanie w umiejętności na rzecz lepszych efektów społeczno-gospodarczych, KOM(2012) 669 wersja ostateczna. 


\section{Kompetencje kluczowe a edukacja kulturalna}

Dyskusja na temat, jak uczyć, aby dobrze nauczyć - odpowiadając jednocześnie i na potrzeby młodego pokolenia, i oczekiwania współczesności - trwa od wielu lat. Wyraźnym segmentem tej dyskusji w Europie są tzw. kompetencje kluczowe (łac. competentia - odpowiedniość, zgodność) rozumiane jako połączenie: wiedzy, umiejętności i postaw odpowiednich do sytuacji uważanych za niezbędne dla realizacji potrzeb samorealizacji, aktywnego obywatelstwa, integracji społecznej oraz zatrudnienia.

Kompetencje i ich katalog zdefiniowano prawie 10 lat temu w zaleceniu Parlamentu Europejskiego i Rady z 18 grudnia 2006 r. w sprawie kompetencji kluczowych w procesie uczenia się przez całe życie $(2006 / 962 / \mathrm{WE})^{10}$. Zalecenie to w załączniku - Europejskie ramy odniesienia - zawiera wykaz kompetencji kluczowych niezbędnych współczesnemu człowiekowi w uczeniu się przez całe życie (określenie ramy odniesienia odnosi się do priorytetów, orientuje na to, co niezbędne w edukacji pojmowanej jako niekończący się proces - zmienny i dynamiczny). Europejskie ramy odniesienia wymieniają osiem kompetencji kluczowych ${ }^{11}$, wśród których znalazła się także kompetencja z obszaru kultury określona jako świadomość i ekspresja kulturalna. W przywołanym dokumencie jest ona pojmowana jako twórcze wyrażanie idei, doświadczeń i uczuć za pośrednictwem artystycznych środków wyrazu, w tym muzyki, sztuk teatralnych, literatury i sztuk wizualnych. Samo pojęcie świadomości i ekspresji kulturalnej odnosi się do kategorii wiedzy, umiejętności i postaw kształtowanych u ucznia w procesie nauczania-uczenia się. W obszarze wiedzy mamy na myśli znajomość najważniejszych dzieł kultury, świadomość lokalnego, narodowego i europejskiego dziedzictwa kulturalnego oraz jego miejsca w świecie i wynikającego stąd kształtowania postaw poszanowania m.in. dla odrębności narodowych. Oprócz wiedzy ważną kategorią są oczekiwane umiejętności i postawy ucznia, jakimi powinien się charakteryzować w obszarze świadomości i ekspresji kulturalnej. Należą do nich m.in. wrażliwość i przyjemność wynikająca z odbioru dzieł sztuki i widowisk, jak i potrzeba oraz odwaga wyrażania siebie poprzez różnorodne środki

10 http://eur-lex.europa.eu/legal-content/pl/TXT/PDF/?uri=CELEX:32006H0962\&from=pl.

11 Osiem kompetencji kluczowych to: 1) porozumiewanie się w języku ojczystym, 2) porozumiewanie się w językach obcych, 3) kompetencje matematyczne i podstawowe kompetencje naukowo-techniczne, 4) kompetencje naukowo-techniczne, 5) kompetencje informatyczne, 6) umiejętność uczenia się, 7) kompetencje społeczne i obywatelskie - inicjatywność i przedsiębiorczość, 8) świadomość i ekspresja kulturalna. 
wyrazu z wykorzystaniem wrodzonych zdolności. Ważnymi umiejętnościami nabywanymi przez ucznia powinna być kreatywność oraz chęć pielęgnowania zdolności estetycznych przez udział w szerokim życiu kulturalnym, a także rozpoznawanie i wykorzystywanie społecznych i ekonomicznych szans w działalności kulturalnej.

\section{Edukacja kulturalna w wybranych państwach}

W powszechnym pojęciu kultury wyodrębniamy wiele obszarów, takich jak: humanizm, nauka, wolność, demokracja, sprawiedliwość, rodzina, moralność, sztuka, religia, filozofia, ekonomia, ekologia i oczywiście edukacja. Kilkunastoletni okres szkolnej edukacji jest dla młodego człowieka czasem kształtowania osobowości, postaw i określania priorytetów, a dla władz oświatowych niezwykłą okazją do ukształtowania pokoleń zainteresowanych, rozumiejących i świadomych swojego miejsca w kulturze. Świadome osadzenie w kulturze, rozumienie i umiejętność czerpania z niej, z wykorzystaniem narzędzi będących w dyspozycji państwa, jakimi jest szkolnictwo obowiązkowe, zdecydowanie ułatwiłoby proces asymilacji młodego pokolenia w środowisko społeczne, zawodowe i kulturowe państwa. Jak zatem w szkolnictwie obowiązkowym programy nauczania i podejmowane rozwiązania szkolne oraz pozaszkolne odnoszą się do edukacji kulturalnej? Czy i jak uczy się o kulturze? Czy możemy mówić o jakimś wspólnym modelu w edukacji kulturalnej?

Próbę odpowiedzi na powyższe pytania przedstawiono na podstawie przeglądu problematyki związanej z edukacją kulturalną realizowaną na poziomie obowiązkowej szkoły podstawowej i średniej - ISCED 1 i ISCED $2^{12} \mathrm{w}$ wybranych państwach europejskich. Wyboru państw dokonano na podstawie zróżnicowania językowo-kulturowego (np. Austria i Niemcy, Belgia i Francja, Irlandia i Wielka Brytania), geograficznego (np. Estonia i Finlandia, Grecja, Hiszpania) oraz na podstawie doboru różnych systemów organizacji szkolnictwa (np. Wielka Brytania, Francja, Finlandia). Porównawczy przegląd uzupełniono, przedstawiając system edukacyjny w Polsce. Analizie poddano szkolne programy nauczania ze szczególnym uwzględnieniem przedmiotów o charakterze kulturalnym i arty-

12 ISCED to Międzynarodowa Standardowa Klasyfikacja Edukacji (International Standard Classification of Education) opracowana przez UNESCO dla potrzeb ujednolicenia i usystematyzowania nazewnictwa poziomów edukacyjnych występujących w różnych krajach. Kodem ISCED 1 określa się poziom kształcenia podstawowego lub pierwszy etap edukacji podstawowej, ISCED 2 - szkołę średnią I stopnia, a ISCED 3 - szkołę średnią II stopnia. 
stycznym. Dla lepszego zilustrowania stosowanych rozwiązań omawiane zagadnienia osadzono w kontekście organizacji ustrojów szkolnych, programów nauczania i miejsca nauczyciela przedmiotów artystycznych w edukacji szkolnej i kształceniu ustawicznym

\section{Polska}

\section{Organizacja i struktura obowiq̨zkowej edukacji publicznej}

Obowiązek nauki i obowiązek szkolny reguluje w Polsce ustawa zasadnicza i ustawa o systemie oświaty.

Konstytucja Rzeczypospolitej Polskiej z 2 kwietnia 1997 roku w rozdziale II Wolności prawa i obowiązki człowieka i obywatela - w art. 70 stwierdza: 1. Każdy ma prawo do nauki. Nauka do 18 roku życia jest obowiąkowa. Sposób wykonywania obowiązku szkolnego określa ustawa ${ }^{13}$.

Formy spełniania obowiązku szkolnego reguluje ustawa z 7 września 1991 roku o systemie oświaty (Dz.U. 2004, nr 256, poz. 2572, ze zm.) oraz ustawa z 19 marca 2009 roku o zmianie ustawy o systemie oświaty oraz o zmianie niektórych innych ustaw (Dz.U. nr 56, poz. 458). Czytamy w niej w art. 15 ust. 2: Obowiqzek szkolny dziecka rozpoczyna się z początkiem roku szkolnego $w$ roku kalendarzowym, w którym dziecko kończy 6 lat, oraz trwa do ukończenia gimnazjum, nie dłużej jednak niż do ukończenia 18 roku życia.

Ustawa określiła też możliwość wcześniejszego rozpoczęcia nauki w szkole podstawowej, jeżeli rodzice dziecka wystąpią z takim wnioskiem. Naukę w szkole podstawowej może rozpocząć dziecko, które w danym roku kalendarzowym kończy 5 rok życia, jeśli wykazuje psychofizyczną dojrzałość do podjęcia nauki szkolnej. Decyzję o wcześniejszym przyjęciu dziecka do szkoły podstawowej podejmuje dyrektor szkoły po zasięgnięciu opinii poradni psychologiczno-pedagogicznej, natomiast decyzję w sprawie odroczenia obowiązku szkolnego podejmuje dyrektor publicznej szkoły podstawowej, w obwodzie której dziecko mieszka, po zasięgnięciu opinii poradni psychologiczno-pedagogicznej.

Szczeble kształcenia objęte obowiązkiem szkolnym to:

- szkoła podstawowa (podzielona na dwa etapy edukacyjne):

- I etap edukacyjny, obejmujący klasy I-III szkoły podstawowej - edukacja wczesnoszkolna (wiek: 6-9 lat),

13 http://www.sejm.gov.pl/prawo/konst/polski/kon1.htm. 
- II etap edukacyjny, obejmujący klasy IV-VI szkoły podstawowej (wiek: 9-12 lat),

- $\quad$ szkoła średnia I stopnia - gimnazjum (wiek: 12-15 lat).

W Polsce w roku szkolnym 2015/2016 mamy zatem do czynienia z ustawową realizacją dwóch obowiązków:

- ustawowym 10-letnim obowiązkiem szkolnym trwającym od 6 roku życia do ukończenia gimnazjum, obejmującym szkołę podstawową i gimnazjum (od roku szkolnego 2016/2017 obowiązek szkolny obejmie uczniów od 7 roku życia do ukończenia gimnazjum) ${ }^{14}$ oraz

- konstytucyjnym obowiązkiem nauki trwającym do 18 roku życia.

Obowiązek szkolny spełnia się więc przez uczęszczanie do szkoły podstawowej i gimnazjum, publicznych albo niepublicznych, a po ukończeniu gimnazjum podlega się obowiązkowi nauki, który spełnia się przez:

- uczęszczanie do publicznej lub niepublicznej szkoły ponadgimnazjalnej,

- uczęszczanie na zajęcia realizowane w formach pozaszkolnych w placówkach publicznych i niepublicznych posiadających odpowiednią akredytację (szkoły dla dorosłych, placówki kształcenia ustawicznego, placówki kształcenia praktycznego, ośrodki dokształcania i doskonalenia zawodowego),

- uczęszczanie na zajęcia realizowane w ramach działalności oświatowej prowadzonej przez osoby prawne lub fizyczne,

- realizowanie przygotowania zawodowego u pracodawcy.

Uczeń, który ukończył szkołę ponadgimnazjalną przed ukończeniem 18 roku życia, może również spełniać obowiązek nauki przez uczęszczanie do szkoły wyższej.

14 Ustawa z 29 grudnia 2015 r. o zmianie ustawy o systemie oświaty oraz niektórych innych ustaw, http://dziennikustaw.gov.pl/DU/2016/35. Ustawa zawiera, w szczególności:

a) obowiązek szkolny od 7 roku życia,

b) prawo rodziców do zdecydowania o podjęciu przez dziecko edukacji szkolnej od 6 roku życia,

c) obowiązek odbycia rocznego przygotowania przedszkolnego przez dziecko sześcioletnie,

d) zniesienie obowiązku odbycia rocznego przygotowania przedszkolnego przez dziecko pięcioletnie,

e) wydłużenie terminu możliwości funkcjonowania oddziałów przedszkolnych w szkołach podstawowych do 1 września 2019 r.,

f) wzmocnienie roli kuratora oświaty w kształtowaniu sieci przedszkoli i planu sieci szkół, w tym przywrócenie obowiązku uzyskiwania pozytywnej opinii organu nadzoru pedagogicznego w przypadku likwidacji szkoły lub placówki prowadzonej przez jednostkę samorządu terytorialnego. 
Odpowiedzialność za koordynowanie polityki oświatowej ponosi minister właściwy do spraw oświaty i wychowania. Polityka oświatowa całego państwa jest przygotowywana i wdrażana centralnie, natomiast zarządzanie oświatą oraz kierowanie szkołami, przedszkolami i innymi placówkami oświatowymi jest zdecentralizowane. Uprawnienia w zakresie zarządzania przedszkolami i szkołami podstawowymi (a od roku szkolnego 1999/2000 także gimnazjami) zostały przekazane gminom. Zarządzanie szkołami ponadgimnazjalnymi, artystycznymi oraz specjalnymi zostało przekazane powiatom jako ich statutowy obowiązek. Natomiast województwa samorządowe prowadzą jedynie szkoły o znaczeniu regionalnym i ponadregionalnym ${ }^{15}$. Do zadań własnych powiatu należy zakładanie i prowadzenie publicznych szkół podstawowych specjalnych i gimnazjów specjalnych, szkół ponadgimnazjalnych, w tym z oddziałami integracyjnymi, szkół sportowych i mistrzostwa sportowego oraz placówek, z wyjątkiem szkół i placówek o znaczeniu regionalnym i ponadregionalnym ${ }^{16}$. Do zadań własnych gminy należy zakładanie i prowadzenie publicznych przedszkoli, w tym z oddziałami integracyjnymi, i przedszkoli specjalnych, szkół podstawowych oraz gimnazjów, w tym z oddziałami integracyjnymi, z wyjątkiem szkół podstawowych specjalnych i gimnazjów specjalnych, szkół artystycznych oraz szkół przy zakładach karnych, zakładach poprawczych i schroniskach dla nieletnich ${ }^{17}$.

\section{Nauczanie i ocenianie przedmiotów artystycznych i kulturalnych}

Cele kształcenia i wychowania w zakresie poszczególnych edukacji realizowane są na bazie podstawy programowej dla szkoły podstawowej dla klas I-III i klas IV-VI. Podstawa programowa kształcenia ogólnego dla klas I-III realizowana jest w formie kształcenia zintegrowanego, w zakres którego wchodzą: edukacja polonistyczna, edukacja społeczna (z etyką), edukacja przyrodnicza, edukacja matematyczna, edukacja muzyczna, edukacja plastyczna, zajęcia komputerowe, zajęcia techniczne, wychowanie fizyczne i edukacja zdrowotna. Podstawa programowa kształcenia ogólnego dla klas IV-VI realizowana jest

15 https://webgate.ec.europa.eu/fpfis/mwikis/eurydice/index.php/Polska:Zarz\%C4\%85dzanie_i_kierowanie_edukacj\%C4\%85_na_szczeblu_lokalnym_(szczebel_gminy_i_powiatu)_i/ lub_instytucjonalnym_(szko\%C5\%82\%C4\%85/plac\%C3\%B3wk\%C4\%85_0\%C5\%9Bwiatow\%C4\%85/uczelni\%C4\%85).

16 Tamże.

17 Tamże. 
w formie kształcenia przedmiotowego: język polski, język obcy nowożytny, muzyka, plastyka, historia i społeczeństwo, przyroda, matematyka, zajęcia komputerowe, zajęcia techniczne, wychowanie fizyczne, etyka. Podobnie zbudowana jest podstawa programowa kształcenia ogólnego w gimnazjum, która też przewiduje kształcenie przedmiotowe, a w nim następujące przedmioty: język polski, języki obce nowożytne, muzyka, plastyka, historia, wiedza o społeczeństwie, geografia, biologia, chemia, fizyka, matematyka, informatyka, wychowanie fizyczne, edukacja dla bezpieczeństwa, etyka. Przedmioty uzupełniające nauczane w gimnazjum to zajęcia artystyczne, zajęcia techniczne ${ }^{18}$.

Tak więc edukacja artystyczna i kulturalna na poziomie ISCED 1 i 2 realizowana jest w polskim systemie oświaty jako edukacja muzyczna, edukacja plastyczna (w szkole podstawowej w klasach I-III) oraz muzyka i plastyka (w szkole podstawowej w klasach IV-VI i w gimnazjum). Zajęcia artystyczne jako przedmiot uzupełniający mogą stanowić bardzo dobrą propozycję rozwijania uzdolnień artystycznych uczniów. Najczęściej są to dodatkowe zajęcia muzyczne lub plastyczne, ale mogą to być zajęcia uwzględniające ich indywidualne sugestie. Propozycją może być nauka gry na gitarze czy na perkusji, zajęcia wokalne lub w wypadku zajęć plastycznych nauka grafiki komputerowej, malarstwo lub warsztaty tworzenia biżuterii artystycznej. Innym wariantem zajęć artystycznych mogą być $\mathrm{np}$. warsztaty teatralne lub filmowe.

Wśród celów i zadań przedmiotów artystycznych i kulturalnych dla szkolnictwa poziomu ISCED 1 i ISCED 2 polskie programy nauczania, podobnie jak w większości krajów europejskich, wskazują m.in.: na umiejętności artystyczne, przekazanie wiedzy i jej zrozumienie, umiejętność dokonania interpretacji krytycznej dzieła, świadomość dziedzictwa kulturowego, umożliwienie indywidualnej ekspresji artystycznej, rozumienie różnorodności kulturowej. Wśród celów nauczania bezpośrednio związanych ze sztuką polskie i europejskie programy akcentują stworzenie uczniowi możliwości zetknięcia się z różnymi doświadczeniami i różnymi sposobami artystycznego wyrazu oraz wyrobienie umiejętności wykonywania lub prezentowania dzieła.

Zakładana liczba godzin lekcyjnych przeznaczanych w klasach I-III i IV-VI szkoły podstawowej na przedmioty z dziedziny edukacji plastycznej i muzycznej wynosi co najmniej po 90 godzin z każdego przedmiotu. Uczeń gimnazjum podczas swojej trzyletniej nauki powinien mieć zorganizowane przynajmniej:

18 http://www.ceo.org.pl/sites/default/files/news-files/podstawa_programowa_do_ponadgimnazjalnych.pdf. 
30 godzin muzyki, 30 godzin plastyki i 60 godzin zajęć artystycznych w modułach 30-godzinnych do wyboru ${ }^{19}$.

Oprócz zajęć przedmiotowych i interdyscyplinarnych z obszaru edukacji artystycznej i kulturalnej nauczyciel może zrealizować program wizyt uczniów w miejscach związanych z kulturą (zabytki, muzea, galerie sztuki, teatry, sale koncertowe) oraz rozwijać ideę włączania artystów do projektów szkolnych (przedstawienia, tematyczne wystawy fotografii i malarstwa).

Z przedmiotów artystycznych uczniowie podlegają ocenianiu kształtujące$\mathrm{mu}^{20}$ i sumującemu ${ }^{21}$. Kryteria oceniania postępów w nauce $\mathrm{z}$ tych przedmiotów opracowują sami nauczyciele - indywidualnie lub jako grono pedagogiczne. W Polsce w nauczaniu zintegrowanym w klasach I-III szkoły podstawowej ustala się jedną roczną ocenę klasyfikacyjną z zajęć edukacyjnych i roczną ocenę klasyfikacyjną z zachowania - nauczyciele stosują przy ocenianiu postępów ucznia oceny opisowe. W klasach IV-VI i w gimnazjum stosuje się liczbową skalę ocen: 6 (stopień celujący), 5 (stopień bardzo dobry), 4 (stopień dobry), 3 (stopień dostateczny), 2 (stopień dopuszczający), 1 (stopień niedostateczny) ${ }^{22}$. Przy ustalaniu oceny z wychowania fizycznego, techniki, zajęć technicznych, plastyki, muzyki i zajęć artystycznych bierze się w szczególności pod uwagę wysiłek wkładany przez ucznia w wywiązywanie się z obowiązków wynikających ze specyfiki tych zajęć.

Począwszy od klasy IV szkoły podstawowej oceny z zachowania ustala się według następującej skali: wzorowe, bardzo dobre, dobre, poprawne, nieodpowiednie, naganne.

\section{Nauczyciele przedmiotów artystycznych i kulturalnych}

Kształcenie nauczycieli odbywa się na poziomie szkolnictwa wyższego (studia I i II stopnia, jednolite studia magisterskie, studia podyplomowe). Studia licencjackie przygotowują do pracy w przedszkolach i szkołach podstawowych,

19 Informacja o projekcie ramowego planu nauczania w szkole podstawowej i gimnazjum, http://www.nowaera.pl/artykuly/informacja-o-projekcie-ramowego-planu-nauczania-w-szkole-podstawowej-i-gimnazjum.html.

20 Ocenianie kształtujące ma na celu dostarczenie uczniowi informacji zwrotnych dotyczących procesu dydaktycznego w trakcie jego trwania.

21 Ocenianie sumujące potwierdza i określa stopień, w jakim uczniowie osiągnęli założone i oczekiwane cele dydaktyczne.

22 Rozporządzenie Ministra Edukacji Narodowej z 10 czerwca 2015 r. w sprawie szczegółowych warunków i sposobu oceniania, klasyfikowania i promowania uczniów i słuchaczy w szkołach publicznych, http://isap.sejm.gov.pl/DetailsServlet?id=WDU20150000843. 
natomiast studia magisterskie do pracy w gimnazjach i szkołach ponadgimnazjalnych. Oprócz kształcenia ogólnego i merytorycznego przyszłych nauczycieli obowiązuje przygotowanie pedagogiczne.

Edukacja artystyczna w klasach I-III szkoły podstawowej realizowana jest przez nauczycieli przedmiotów zintegrowanych. Program kształcenia przyszłych nauczycieli przewiduje obowiązkowe przygotowanie do nauczania dwóch przedmiotów: sztuki plastyczne i muzyka. Przedmioty teatr i taniec nie są obowiązkowe. Na poziomie szkoły średniej I stopnia (ISCED 2) lekcje powinny być prowadzone przez nauczycieli przedmiotowych, jednak często nauczycielami przedmiotów artystycznych są osoby, dla których jest do specjalność dodatkowa.

Ważnym fragmentem edukacji kulturalnej w Polsce jest szkolnictwo artystyczne, które umożliwia szczególnie uzdolnionym artystycznie dzieciom i młodzieży zindywidualizowane kształcenie w poszczególnych dziedzinach sztuki.

Szkolnictwo artystyczne tworzy niemal 1000 szkół i placówek artystycznych oraz 19 uczelni, w których kształci się odpowiednio prawie 100 tys. uczniów i ponad 16 tys. studentów (dane za rok szkolny 2015/2016) ${ }^{23}$. Szkolnictwo artystyczne nadzorowane jest przez Ministra Kultury i Dziedzictwa Narodowego i tworzy odrębny system kształcenia w stosunku do systemu kształcenia ogólnego. Wśród typów szkół artystycznych I i II stopnia znajdują się szkoły prowadzące wyłącznie kształcenie w zakresie przedmiotów artystycznych oraz szkoły, w których uczniowie mogą realizować także obowiązek szkolny oraz obowiązek nauki. Podstawy programowe kształcenia w zawodach szkolnictwa artystycznego określa Minister Kultury i Dziedzictwa Narodowego, natomiast kształcenie ogólne oparte jest na podstawach programowych dla szkoły podstawowej, gimnazjum oraz liceum wydawanych przez Ministra Edukacji Narodowej. Szkoły artystyczne kształcą w następujących zawodach: aktor cyrkowy, aktor scen muzycznych, animator kultury, bibliotekarz, muzyk, plastyk, tancerz ${ }^{24}$. Na zakończenie nauki w każdym typie szkoły artystycznej (oprócz szkoły muzycznej I stopnia i ogólnokształcącej szkoły muzycznej I stopnia) uczeń zdaje egzamin dyplomowy, potwierdzający jego umiejętności.

System szkolnictwa artystycznego tworzą oprócz szkół i uczelni artystycznych placówki takie, jak ogniska artystyczne oraz bursy, czyli placówki zapewniające opiekę i wychowanie uczniom w okresie pobierania nauki poza miejscem stałego zamieszkania.

23 http://www.mkidn.gov.pl/pages/strona-glowna/uczniowie-i-studenci/szkoly-artystyczne.php.

24 Tamże. 


\section{Austria}

\section{Organizacja i struktura obowiq̨zowej edukacji publicznej}

Obowiązek szkolny w Austrii wynosi 9 lat i rozpoczyna się w 6 roku życia.

Szczeble kształcenia objęte obowiązkiem szkolnym to:

- Szkoła podstawowa (Volksschule lub Grundschule) (ISCED 1) - wiek: 6-10 lat.

- Szkoła średnia I stopnia (ISCED 2) - wiek: 10-14 lat:

- szkoła podstawowa - poziom wyższy (Volksschule)

- szkoła ogólnokształcąca średnia I stopnia - (Hauptschule)

- szkoła ogólnokształcąca średnia o profilu akademickim - I stopień (Allgemein bildende höhere Schule).

- Klasa IX - wiek: od 14 lat:

- szkoła politechniczna prowadząca wstępne roczne kształcenie zawodowe; tzw. rok przedzawodowy (Polytechnische Schule) lub dowolna inna szkoła średnia II stopnia.

Dzieci rozpoczynające naukę w szkole podstawowej muszą ukończyć 6 rok życia do 1 września roku, w którym rozpoczynają I klasę. Dzieci urodzone między 1 września i 31 grudnia mogą rozpocząć naukę wcześniej, jeżeli są dostatecznie dojrzałe umysłowo i fizycznie. Przejście do szkoły średniej I stopnia wymaga ukończenia z pozytywnymi ocenami IV klasy szkoły podstawowej. Do Allgemein bildende höhere Schule przyjmuje się na podstawie wyników w nauce lub wyników sprawdzianu wstępnego. Kształcenie obowiązkowe jest bezpłatne we wszystkich szkołach, z wyjątkiem szkół prywatnych.

W Austrii odpowiedzialność za uchwalanie i wdrażanie przepisów prawnych jest podzielona między federację i kraje związkowe (landy). Szczebel federalny wyznacza ogólne ramy prawne, natomiast za wdrażanie szczegółowych przepisów odpowiedzialne są landowe parlamenty. Wszelkie aspekty dotyczące organizacji struktur szkolnych, procesu kształcenia, wynagrodzenia i uprawnień emerytalnych nauczycieli uchwalane są na szczeblu federalnym. Landy odpowiadają głównie za zapewnienie kadry nauczycielskiej oraz wspierają finansowo gminy w budowaniu i prowadzeniu placówek szkolnictwa obowiązkowego.

Odpowiedzialność za kształcenie i zdobywanie kwalifikacji rozdzielone jest pomiędzy różne podmioty. Nadzór administracyjny nad szkolnictwem podstawowym, średnim oraz kolegiami nauczycielskimi sprawowany jest przez Federalne Ministerstwo ds. Edukacji i Kobiet (Bundesministerium für Bildung und 
Frauen ${ }^{25}$. Za szkolnictwo wyższe odpowiada Federalne Ministerstwo Nauki, Badań i Gospodarki (Bundesministerium für Wissenschaft, Forschung und Wirtschaft ${ }^{26}$. Federalne instytucje związane z gospodarką oraz partnerzy społeczni (reprezentanci pracowników i pracodawców federalnych oraz regionalnych ciał doradczych, reprezentujących podmioty zapewniające naukę rzemiosła) odpowiedzialni są za kwalifikacje uzyskiwane w ramach szkoleń zawodowych prowadzonych przez firmy, a Federalne Ministerstwo Zdrowia (Bundesministerium für Gesundheit ${ }^{27}$ odpowiada za uzyskiwanie kwalifikacji w ramach szkoleń zawodowych dla zawodów medycznych (poza lekarskimi). Kształcenie zawodowe w Austrii prowadzą zarówno szkoły, jak i organizacje pracodawców. Jednym ze sposobów zdobycia kwalifikacji zawodowych jest udział w szkoleniu prowadzonym przez firmę i jednoczesne uczęszczanie do szkoły zawodowej w niepełnym wymiarze godzin. Innym jest uczestniczenie wyłącznie w zajęciach oferowanych przez szkoły zawodowe.

\section{Nauczanie i ocenianie przedmiotów artystycznych i kulturalnych}

Ramowy program nauczania powstaje na podstawie projektów opracowywanych przez grupy robocze ds. programów nauczania, konsultacji z organami edukacyjnymi na szczeblu landów i okręgów oraz organizacjami i związkami nauczycielskimi. Choć ramowy program oraz listę podręczników zatwierdza Federalne Ministerstwo ds. Edukacji i Kobiet, to szkoły mają pełną swobodę w dostosowywaniu programu nauczania do lokalnych potrzeb, a wybór podręczników zależy od decyzji nauczycieli. Podobnie jest z przedmiotami artystycznymi i kulturalnymi.

Przedmiotami obowiązkowymi w szkole podstawowej i średniej są: język niemiecki, nowożytny język obcy, religia, historia, geografia, biologia, matematyka, prace ręczne i techniczne, wychowanie fizyczne, bezpieczeństwo drogowe oraz przedmioty artystyczne i kulturalne.

Wśród celów i zadań przedmiotów artystycznych i kulturalnych dla szkolnictwa poziomu ISCED $1 \mathrm{i}$ ISCED 2 austriackie programy wskazują m.in.: na umiejętności artystyczne, przekazanie wiedzy i jej zrozumienie, umiejętność dokonania interpretacji krytycznej dzieła, świadomość dziedzictwa kulturowego, umożliwienie indywidualnej ekspresji artystycznej, rozumienie różnorodności kultu-

25 https://www.bmbf.gv.at.

26 http://www.bmwfw.gv.at/Seiten/default.aspx.

27 http://www.bmg.gv.at/home. 
rowej. Wśród celów nauczania bezpośrednio związanych ze sztuką austriackie programy akcentują stworzenie uczniowi możliwości zetknięcia się z różnymi doświadczeniami i różnymi sposobami artystycznego wyrazu oraz wyrobienie umiejętności wykonywania lub prezentowania dzieła.

W austriackim szkolnictwie wśród konkretnych przedmiotów w obszarze edukacji artystycznej i kulturalnej znalazły się:

- w ramach przedmiotów obowiązkowych: sztuki plastyczne, muzyka, rękodzieło,

- w ramach przedmiotów łączonych z innym nieartystycznym przedmiotem: taniec,

- w ramach fakultetów: teatr, sztuki medialne.

Z przedmiotów artystycznych uczniowie podlegają ocenianiu kształtującemu i sumującemu. Kryteria oceniania postępów w nauce z tych przedmiotów opracowują sami nauczyciele - indywidualnie lub jako grono pedagogiczne. W Austrii nauczyciele na poziomie ISCED $1 \mathrm{i}$ ISCED 2 stosują przy ocenianiu postępów ucznia (także przedmiotów artystycznych i kulturalnych) liczbową skalę ocen od 1 do 5.

Tabela 6. Skala ocen stosowana w szkolnictwie w Austrii w odniesieniu do polskiego systemu oceniania

\begin{tabular}{|c|l|l|}
\hline \multicolumn{2}{|c|}{ Austriacki system oceniania } & \multicolumn{1}{c|}{ Polski system oceniania } \\
\hline symbol & \multicolumn{1}{|c|}{ opena i opis } \\
\hline 1 & bardzo dobry & 5 (bardzo dobry) \\
\hline 2 & dobry & 4 (dobry) \\
\hline 3 & zadowalający & 3 (dostateczny) \\
\hline 4 & dostateczny & 2 (dopuszczający) \\
\hline 5 & niedostateczny & 1 (niedostateczny) \\
\hline
\end{tabular}

Źródło: Opracowanie własne.

Minimalna roczna liczba godzin przeznaczonych na przedmioty obowiązkowe $\mathrm{z}$ dziedziny edukacji artystycznej i kulturalnej w pierwszych 10 latach nauki na poziomach ISCED 1 i 2 oscyluje w wymiarze od 100 godzin (w pierwszym roku nauki) do 190 godzin (w piątym i szóstym roku nauki). Austria pod względem liczby obowiązkowych godzin przeznaczonych na edukację artystyczną i kulturalną, przy średniej europejskiej wynoszącej około 20-75 godzin rocznie, znajduje się w czołówce państw europejskich. Charakterystyczne jest także to, że edukacja artystyczna i kulturalna realizowana jest jako kształcenie interdyscyplinarne w formie ścieżek międzyprzedmiotowych, które tworzone są przez łączenie 
przedmiotów artystycznych z innymi przedmiotami. Zgodnie z zarząadzeniem federalnych władz oświatowych w sprawie nauczania metodą projektów ${ }^{28}$ władze oświatowe wskazują i zalecają tworzenie takiego środowiska pracy dydaktyczno-metodycznej dla wszystkich przedmiotów, aby ułatwić szersze wprowadzenie kształcenia interdyscyplinarnego ze szczególnym uwzględnieniem edukacji artystycznej i kulturalnej.

Dodatkowo szkoła otrzymuje wsparcie w ramach kształcenia równoległego, w którym duże znaczenie odgrywa eksperckie centrum edukacji artystycznej i kulturalnej - EDUCULT ${ }^{29}$. Centrum prowadzi badania w zakresie szkolnej i pozaszkolnej edukacji kulturalnej, realizuje kulturalne projekty i programy edukacyjne, organizuje sympozja, konferencje i warsztaty, ułatwia kontakty i dostęp do sieci lokalnych i międzynarodowych instytucji artystycznych.

Oprócz zajęć przedmiotowych i interdyscyplinarnych z obszaru edukacji artystycznej i kulturalnej austriackie szkoły realizują program wizyt uczniów $\mathrm{w}$ miejscach związanych z kulturą (zabytki, muzea, galerie sztuki, teatry, sale koncertowe) oraz rozwijają ideę włączania artystów do projektów szkolnych (przedstawienia, tematyczne wystawy fotografii i malarstwa). Instytucją wspierającą takie działania jest KulturKontakt Austria (KKP) ${ }^{30}$. Jest to organizacja non profit, współpracująca z Federalnym Ministerstwem ds. Edukacji i Kobiet. Podstawowym celem KKP jest:

- realizacja głównych zasad federalnej polityki oświatowej i kulturalnej ze szczególnym udziałem kształcenia ustawicznego,

- ułatwianie równego dostępu do edukacji, kultury i sztuki,

- promocja wymiany i współpracy między instytucjami edukacyjnymi Austrii i państw Europy Południowo-Wschodniej i Wschodniej,

- wspieranie współpracy między szkołami i instytucjami kulturalnymi w Austrii.

W Austrii edukacja artystyczna i kulturalna oprócz zajęć szkolnych prowadzona jest także w ramach zajęć pozalekcyjnych. Jedną z najpopularniejszych form jest edukacja muzyczna realizowana między innymi w szkołach muzycznych (Musikschulen) finansowanych przez władze lokalne. Program Musikschu-

28 Grundsatzerlass zum Projektunterricht Wiederverlautbarung der aktualisierten Fassung Geschäftszahl: 10.077/5-I/4a/2001, https://www.bmbf.gv.at/ministerium/rs/2001_44.html, https://www.vdloe.at/wien/recht/download/rs1992_400.pdf.

29 http://educult.at.

30 KulturKontakt Austria, http://www.kulturkontakt.or.at/html/D/wp.asp?pass=x\&p_title=80 $39 \& r n=157145$. 
len obejmuje edukację muzyczną, naukę gry na instrumentach muzycznych, a niektóre placówki rozszerzają program o zajęcia teatralne i taneczne.

\section{Nauczyciele przedmiotów artystycznych i kulturalnych}

Wszyscy nauczyciele przedmiotów zintegrowanych oraz przedmiotów artystycznych, aby uzyskać prawo do nauczania muszą uzyskać zawodowe uprawnienia pedagogiczne związane z nauczanymi przedmiotami artystycznymi. Zawodowi artyści, ludzie sztuki i kultury, którzy chcieliby nauczać specjalistycznych przedmiotów z dziedziny edukacji artystycznej i kulturalnej, muszą ukończyć kształcenie dające uprawnienia kwalifikacji pedagogicznych. W kształceniu nauczycieli przedmiotów zintegrowanych i/lub nauczycieli przedmiotów artystycznych (sztuki wizualne i muzyka) dla potrzeb szkół średnich obowiązkowymi obszarami tematycznymi są: rozwój dziecka przez sztukę, programy przedmiotów artystycznych, dydaktyka sztuki, historia sztuki, osobiste umiejętności artystyczne, ocenianie uczniów (dla ISCED 2).

Edukacja artystyczna i kulturalna w austriackim szkolnictwie podstawowym (ISCED 1) realizowana jest przez nauczycieli przedmiotów zintegrowanych. Program kształcenia przyszłych nauczycieli przewiduje obowiązkowe przygotowanie do nauczania dwóch przedmiotów: sztuki plastyczne i muzyka. Przedmioty teatr i taniec nie są obowiązkowe.

Na poziomie szkoły średniej I stopnia (ISCED 2) lekcje powinny być prowadzone przez nauczycieli przedmiotowych, jednak często nauczycielami przedmiotów artystycznych są osoby, dla których jest to specjalność dodatkowa lub są to nauczyciele bez specjalistycznego przedmiotowego przygotowania.

\section{Belgia}

\section{Organizacja i struktura obowiq̨zkowej edukacji publicznej}

Szkolnictwo w Belgii odzwierciedla strukturę narodowo-językową państwa, w której istnieje podział na francuskojęzycznych Walonów, flamandzkojęzycznych Flamandów i mniejszość niemieckojęzyczną. Każda z tych grup ma zapewniony autonomiczny system kształcenia. Wspólnoty: Flamandzka, Francuska i Niemieckojęzyczna mają niezależne władze oświatowe - w tym odrębnych ministrów oświaty. 


\section{Wspólnota Flamandzka Belgii (język holenderski)}

W obszarze Wspólnoty Flamandzkiej obowiązek szkolny trwa 9 lat i rozpoczyna się w 6 roku życia. Następnie uczniowie objęci są ustawowym obowiązkiem nauczania do czasu ukończenia 18 lat.

Szczeble kształcenia objęte obowiązkiem szkolnym to:

- Szkoła podstawowa (Basis onderwijs) (ISCED 1) - wiek: 6-12 lat,

- Szkoła średnia (Secundair onderwijs) (ISCED 2) - wiek: 12-16 lub do 18 lat.

Naukę w szkole podstawowej rozpoczyna się na ogółwe wrześniu tego roku, w którym przypadają szóste urodziny dziecka. Nie obowiązują specjalne kryteria przyjęć. Do szkoły średniej przyjmuje się przeważnie dzieci w wieku 12 lat, a warunkiem przyjęcia jest w większości przypadków posiadanie świadectwa ukończenia szkoły podstawowej (Getuigschrift basisonderwijs). Kształcenie obowiązkowe jest bezpłatne.

\section{Wspólnota Francuska Belgii (język francuski)}

W obszarze Wspólnoty Francuskiej nauka jest obowiązkowa w wieku od 6 do 18 lat. Każda osoba niepełnoletnia kształci się więc obowiązkowo przez 12 lat. Na ten obowiązek składa się obowiązek szkolny, który wynosi 9 lat oraz trzyletni obowiązek nauczania. Obowiązek szkolny, czyli kształcenie obowiązkowe w pełnym wymiarze, odbywa się do wieku 15 lat i obejmuje 6 lat kształcenia w szkole podstawowej (przy czym w wyjątkowych wypadkach może trwać 7, 8 lub 9 lat) oraz co najmniej dwa pierwsze lata kształcenia w pełnym wymiarze w szkole średniej. Obowiązkiem szkolnym nie są w żadnym wypadku objęte osoby w wieku powyżej 16 lat. Po ukończeniu kształcenia obowiązkowego w pełnym wymiarze rozpoczyna się kształcenie obowiązkowe w niepełnym wymiarze. Obowiązek nauki można wypełniać $\mathrm{w}$ formie kształcenia w pełnym wymiarze w szkole średniej lub zgodnie z planem zajęć o zmniejszonej liczbie godzin (w niepełnym wymiarze), bądź w ramach programu, który uznaje się za spełniający wymogi obowiązku nauki. Osoba niepełnoletnia może również wypełniać obowiązek nauki, kształcąc się w domu, jeżeli jest to zgodne $\mathrm{z}$ warunkami określonymi przez rząd.

Szczeble kształcenia objęte obowiązkiem szkolnym to:

- Szkoła podstawowa (ISCED 1) - wiek: 6-12 lat,

- Szkolnictwo średnie (ISCED 2 i 3) - wiek: 12-15/16 lub do 18 lat.

Sześcioletnie kształcenie w szkole podstawowej jest podzielone na trzy dwuletnie etapy. W ramach kształcenia w szkole średniej wyodrębniono również trzy dwuletnie etapy. 
Nauka w szkole podstawowej rozpoczyna się we wrześniu roku kalendarzowego, w którym dzieci osiągają wiek 6 lat. Nie obowiązują żadne specjalne warunki przyjęć. Do szkoły średniej dzieci wstępują na ogół w wieku 12 lat. Warunkiem przyjęcia do I klasy szkoły średniej jest posiadanie świadectwa ukończenia szkoły podstawowej (certificat d'études de base, CEB). Rodzice mogą sami wybrać dla swego dziecka zarówno szkołę podstawową, jak i średnią. Kształcenie obowiązkowe jest bezpłatne, a koszty niektórych pomocy szkolnych pokrywają organizatorzy kształcenia. Rodzice ponoszą jednak pewne wydatki, m.in. koszty wstępu na basen, koszty związane z imprezami kulturalnymi i sportowymi itp.

\section{Wspólnota Niemieckojęzyczna Belgii (język niemiecki)}

W obszarze Wspólnoty Niemieckojęzycznej kształcenie w pełnym wymiarze jest obowiązkowe w wieku od 6 do 15 lub 16 lat. Następnie nauka jest obowiązkowa do czasu ukończenia 18 lat. Uczniowie, którzy nie ukończyli pierwszych dwóch klas szkoły średniej do czasu ukończenia 15 lat, obowiązkowo kształcą się w pełnym wymiarze co najmniej do czasu ukończenia 16 lat.

Szczeble kształcenia objęte obowiązkiem szkolnym to:

- Szkoła podstawowa (Primarschule) (ISCED 1) - wiek: 6-12 lat,

- Szkoła średnia (Sekundarschule) (ISCED 2 i 3) - wiek: 12-16 lub 18 lat.

Sześcioletnia szkoła podstawowa jest podzielona na dwuletnie etapy, przy czym klasy mogą być pogrupowane w sposób odbiegający od tego podziału. Szkoła średnia jest również podzielona na trzy dwuletnie etapy.

Nauka w szkole podstawowej rozpoczyna się zwykle we wrześniu tego roku, w którym przypadają szóste urodziny dziecka. Nie obowiązują specjalne kryteria przyjęć. Do szkoły średniej przyjmuje się przeważnie dzieci w wieku 12 lat, a warunkiem przyjęcia jest zwykle posiadanie świadectwa ukończenia szkoły podstawowej (Abschlusszeugnis der Grundschule). Kształcenie jest bezpłatne.

\section{Nauczanie i ocenianie przedmiotów artystycznych i kulturalnych}

Wśród celów i zadań przedmiotów artystycznych i kulturalnych dla szkolnictwa poziomu ISCED 1 i ISCED 2 belgijskie programy nauczania - podobnie jak w zdecydowanej większości państw europejskich - wskazują m.in. na: umiejętności artystyczne, przekazanie wiedzy i jej zrozumienie, umiejętność dokonania interpretacji krytycznej dzieła, świadomość dziedzictwa kulturowego, umożliwienie indywidualnej ekspresji artystycznej, rozumienie różnorodności kulturowej. 
Wśród celów nauczania bezpośrednio związanych ze sztuką belgijskie programy akcentują stworzenie uczniowi możliwości zetknięcia się z różnymi doświadczeniami i różnymi sposobami artystycznego wyrazu oraz wyrobienie umiejętności wykonywania lub prezentowania dzieła.

W belgijskim szkolnictwie poziomu ISCDE 1 i 2 wśród konkretnych przedmiotów w obszarze edukacji artystycznej i kulturalnej znalazły się:

- w ramach przedmiotów obowiązkowych:

- Wspólnota Francuska - sztuki plastyczne, muzyka,

- Wspólnota Niemieckojęzyczna - sztuki plastyczne, muzyka,

- Wspólnota Flamandzka - sztuki plastyczne, muzyka, rękodzieło, teatr, taniec, sztuki medialne i architektura. W obszarze nauczania zintegrowanego do opisania przedmiotów o charakterze artystycznym używa się określenia sztuki ekspresywne ${ }^{31}$,

- w ramach przedmiotów łączonych z innym nieartystycznym przedmiotem:

- Wspólnota Niemieckojęzyczna - taniec,

- w ramach fakultetów:

- Wspólnota Francuska - rękodzieło, teatr.

W Belgii we wszystkich trzech wspólnotach szkoły mają szeroką autonomię w określaniu liczby godzin dydaktycznych przeznaczonych na edukację artystyczną i kulturalną. Ministerialne wytyczne wyznaczają jedynie minimalną liczbę godzin, którą szkoły mogą zgodnie z własnym uznaniem przeznaczyć na konkretne przedmioty. W pierwszych 6 latach nauki roczny wymiar godzinowy przedmiotów artystycznych ma charakter elastyczny. W siódmym i ósmym roku obowiązkowej nauki we Wspólnocie Francuskiej edukacja artystyczna zajmuje 30 godzin rocznie, we Wspólnocie Niemieckojęzycznej oddzielne zajęcia artystyczne nie są wykazywane jako realizowany przedmiot, a we Wspólnocie Flamandzkiej przedmioty artystyczne realizowane są w elastycznym wymiarze godzinowym $\mathrm{w}$ formie ścieżek międzyprzedmiotowych złożonych z połączenia przedmiotów artystycznych z innymi przedmiotami. Uzupełnieniem takiego interdyscyplinarnego realizowania programu edukacji artystycznej i kulturalnej jest włączenie technologii informacyjno-komunikacyjnych (TIK). We Wspólnocie Flamandzkiej od 2007 roku realizowany jest program edukacyjny wykorzystujący TIK w edukacji artystycznej, np. wirtualny dostęp do muzeów, galerii obrazów lub zabytków na różnych kontynentach. Innym elementem tego projektu jest założenie, że uczniowie powinni mieć możliwość wykorzystywania technologii informacyjno-ko-

31 Przedmiot architektura nauczany jest tylko na poziomie szkoły średniej jako część „edukacji ekspresywno-kreatywnej”. 
munikacyjnych do kreatywnego wyrażania własnych artystycznych pomysłów. Stosowanie TIK umożliwia uczniom, którzy na przykład nie mają zdolności do malarstwa czy muzyki, korzystanie z nowoczesnych technologii jako alternatywnego sposobu prezentowania i realizowania swoich pomysłów.

Uczniowie z przedmiotów artystycznych najczęściej podlegają ocenianiu kształtującemu i sumującemu. Jednakże brak jest odgórnych zaleceń dla nauczycieli co do sposobu oceniania i stosowanej skali ocen. Kryteria oceniania postępów w nauce z tych przedmiotów opracowywane są indywidualnie przez każdego nauczyciela lub przez szkolne grono pedagogiczne. W Belgii nauczyciele na poziomie ISCED 1 i ISCED 2 stosują przy ocenianiu postępów ucznia - w przedmiotach innych niż artystyczne - liczbową skalę ocen od 0 do 20. Poniżej przedstawiono tabelaryczne porównanie belgijskiej i polskiej skali ocen.

Tabela 7. Skala ocen stosowana w szkolnictwie w Belgii w odniesieniu do polskiego systemu oceniania

\begin{tabular}{|c|l|l|}
\hline \multicolumn{2}{|c|}{ Belgijski system oceniania } & \multicolumn{1}{c|}{ Polski system oceniania } \\
\hline skala & \multicolumn{1}{|c|}{ opis } & \multicolumn{1}{c|}{ ocena i opis } \\
\hline $20-18$ & celujący (la plus grande distinction) & 6 (celujący) \\
\hline $17-16$ & bardzo dobry (grande distinction) & 5 (bardzo dobry) \\
\hline $15-14$ & dobry (distinction) & 4 (dobry) \\
\hline 13 & satysfakcjonujący (satisfaction) & 3 (dostateczny) \\
\hline 12 & satysfakcjonujący (satisfaction) & 2 (dopuszczający) \\
\hline $11,5-0$ & niedostateczny (échec) & 1 (niedostateczny) \\
\hline
\end{tabular}

Źródło: Opracowanie własne.

Znaczącym elementem wspierającym działalność edukacyjno-wychowawczą w belgijskich szkołach jest obecność i udział w oświacie organizacji oraz sieci promujących i rozwijających idee edukacji artystycznej i kulturalnej.

We Wspólnocie Flamandzkiej jest to organizacja Canon Cultuurce ${ }^{32}$ powołana przez Ministerstwo Edukacji. Do jej zadań należy inspirowanie, wspieranie i pomaganie w nawiązywaniu kontaktów między placówkami szkolnymi a światem sztuki i kultury, informowanie o wydarzeniach kulturalnych oraz udzielanie wsparcia nauczycielom w przygotowywaniu projektów artystyczno-kulturalnych. Ciekawą inicjatywą podjętą przez Canon Cultuurcel jest uruchomienie

32 http://www.canoncultuurcel.be. 
elektronicznej platformy umiejętności korzystania z mediów o nazwie INgeBEELD - Platform rond mediawijsheid ${ }^{33}$. Celem projektu jest prowadzenie i animowanie platformy on-line poświęconej zagadnieniom współpracy nauczycieli z przedstawicielami kultury i sztuki. INgeBEELD wspiera ideę wykorzystania technologii informacyjno-komunikacyjnych w nauczaniu przedmiotów artystycznych oraz stanowi integralną część przedmiotu edukacja medialna. Platforma bezpłatnie oferuje uczniom i nauczycielom pakiety dydaktyczne uczące wykorzystania komunikacji audiowizualnej do samodzielnych prób badawczych. Multimedialne i interdyscyplinarne podejście do edukacji realizowane na przykład przez tworzenie eksperymentalnych filmów, nagrań i krótkich sekwencji audiowizualnych umożliwia rozbudzenie wyobraźni, zwiększenie zainteresowania i wykorzystanie samodzielności myślenia ucznia w rozwiązywaniu problemów.

We Wspólnocie Francuskiej działa specjalne Biuro ds. Kultury i Edukacji

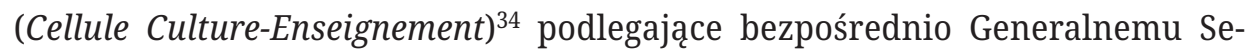
kretariatowi Ministerstwa Wspólnoty Francuskiej (Secrétariat général du Ministère de la Fédération Wallonie-Bruxelles) ${ }^{35}$. Biuro jest odpowiedzialne za inicjowanie oraz wspieranie inicjatyw ukierunkowanych na współpracę pomiędzy szkołami i światem kultury. Zgodnie z dekretem z 24 marca 2006 r. zwiększającym promocję i współpracę w obszarze kultura - szkolnictwo (nowelizowany 3 kwietnia 2014) ${ }^{36}$ współpraca kultura - szkolnictwo powinna być realizowana w czterech obszarach: współpraca między szkołą i operatorem kulturowym lub instytucją partnerską, współpraca ad hoc między szkołą a konkretnym podmiotem kultury, uczestnictwo w projektach prowadzonych i realizowanych przez Wspólnotę Francuską, udział w projektach realizowanych na podstawie specjalnych partnerstw (długoletnia umowa partnerska między operatorem kultury a Wspólnotą Francuską). W latach 2015-2016 Cellule Culture-Enseignement proponuje szeroką ofertę interdyscyplinarnych programów i projektów artystyczno-kulturalnych dla szkół i nauczycieli. Na przykład: W porządku, teraz zaśpiewajmy (Et bien, chantez maintenant), Narysuj mi przyszłość... (Dessine-moi un avenir...), Zrobimy nasze kino! (On se fait notre cinéma!), Kim jestem? (Qui suis-je?), Śmiałość - ciało i słowa (Audace - en corps et en mots”), Sztuka \&

33 http://www.ingebeeld.be.

34 http://www.culture-enseignement.cfwb.be/index.php?id=286.

35 http://www.enseignement.be/index.php?page=25707.

36 Décret relatif à la mise en oeuvre, la promotion et le renforcement des Collaborations entre la Culture et l`Enseignement, http://www.gallilex.cfwb.be/document/pdf/30655_002.pdf. 
Uczucia: wyrażanie i tworzenie (Art \& Emotions: expression et création), Mówiłeś, że „inny”? (Vous avez dit „différent”?) ${ }^{37}$. Każdy projekt ma swój cel i tytuł, realizowany jest przez konkretną organizację/instytucję oraz posiada pośrednika ds. kultury (opérateur culturel), który odpowiada za organizacyjną realizację projektu. Do zadań pośrednika należy także ułatwianie nawiązywania współpracy między szkołami i instytucjami kultury lub bezpośrednio z wybranymi artystami.

\section{Nauczyciele przedmiotów artystycznych i kulturalnych}

W Belgii nie ma ogólnokrajowych programów nauczania ani centralnych zaleceń ramowych. Instytucje kształcące nauczycieli we wspólnotach Francuskiej i Flamandzkiej są autonomiczne - same decydują o formie i programach nauczania. Przyszli nauczyciele ze Wspólnoty Niemieckojęzycznej kształceni są za granicą, najczęściej w Niemczech.

Edukacja artystyczna i kulturalna w belgijskim szkolnictwie podstawowym (ISCED 1) realizowana jest przez nauczycieli przedmiotów zintegrowanych. Program kształcenia przyszłych nauczycieli na terenie całej Belgii przewiduje obowiązkowe przygotowanie do nauczania dwóch przedmiotów artystycznych: sztuki plastyczne i muzyka. We Wspólnocie Niemieckojęzycznej dodatkowo obowiązkowymi przedmiotami są: teatr i taniec. W pozostałych dwóch wspólnotach przedmioty teatr i taniec znajdują się w programie kształcenia nauczycieli, jednakże jako przedmioty nieobowiązkowe.

Na poziomie szkoły średniej I stopnia (ISCED 2) lekcje powinny być prowadzone przez nauczycieli przedmiotowych, lecz często nauczycielami przedmiotów artystycznych są osoby, dla których jest to specjalność dodatkowa lub są to nauczyciele bez specjalistycznego przedmiotowego przygotowania.

Wszyscy nauczyciele przedmiotów zintegrowanych oraz przedmiotów artystycznych, aby uzyskać prawo do nauczania muszą uzyskać zawodowe uprawnienia pedagogiczne związane z nauczanymi przedmiotami artystycznymi. Uprawnienia wydawane są przez autonomiczne instytucje kształcenia nauczycieli.

37 Tableau des projets de collaboration durable 2015-2016 sélectionnés, http://www.culture-enseignement.cfwb.be/index.php?eID=tx_nawsecuredl\&u=0\&file=fileadmin/sites/cult_ens/ upload/cult_ens_super_editor/cult_ens_editor/documents/Decret/Tableau_projets_durables_2015-2016_selectionnes.pdf\&hash=37d4124339191cc9f9bebd1b285120f7a1c91d19. 


\section{Estonia}

\section{Organizacja i struktura obowiq̨zowej edukacji publicznej}

Obowiązek szkolny trwa 10 lat. Kształcenie jest obowiązkowe od 7 roku życia do czasu ukończenia szkoły podstawowej i średniej I stopnia lub do osiągnięcia wieku 17 lat.

Szczeble kształcenia objęte obowiązkiem szkolnym to jednolita szkoła podstawowa i średnia I stopnia (Põhihariduse baasil) (ISCED 1 i 2) - wiek: 7-15 lat.

Naukę w szkole rozpoczynają obowiązkowo dzieci, które osiągnęły wiek 7 lat przed 1 października danego roku. Samorządy lokalne są zobowiązane zagwarantować miejsce w szkole każdemu dziecku. Szkoły muszą zapewnić miejsca dla wszystkich dzieci w swoim rejonie. Rodzice mogą zapisać swoje dziecko do dowolnej szkoły, jeśli jest w niej miejsce. Kształcenie obowiązkowe jest bezpłatne.

W Estonii ogólnokrajowe standardy kształcenia ustalane są na szczeblu centralnym. Ministerstwo Edukacji i Badań (Haridus- ja Teadusministeerium) ${ }^{38}$ odpowiada na szczeblu krajowym za opracowywanie i wdrażanie polityki edukacyjnej oraz nadzoruje szkoły obowiązkowe i średnie. Samorządy nadzorują na szczeblu regionalnym placówki przedszkolne i szkoły oraz zapewniają w pewnym zakresie poradnictwo i opiekę psychologiczną, natomiast samorządy lokalne prowadzą placówki przedszkolne, szkoły obowiązkowe i średnie. Każda szkoła opracowuje własny program nauczania, opierając się na ogólnokrajowej podstawie programowej, która zawiera m.in. listę przedmiotów obowiązkowych (takich samych dla wszystkich uczniów). Nauczyciele mają swobodę w doborze metod nauczania i podręczników ${ }^{39}$.

\section{Nauczanie i ocenianie przedmiotów artystycznych i kulturalnych}

Wśród celów i zadań przedmiotów artystycznych i kulturalnych dla szkolnictwa poziomu ISCED 1 i ISCED 2 estońskie programy wskazują m.in. na: umiejętności artystyczne, przekazanie wiedzy i jej zrozumienie, umiejętność dokonania interpretacji krytycznej dzieła, świadomość dziedzictwa kulturowego, umożliwienie indywidualnej ekspresji artystycznej, rozumienie różnorodności kulturowej. Wśród celów nauczania bezpośrednio związanych ze sztuką estońskie programy akcentują stworzenie uczniowi możliwości zetknięcia się z różnymi doświadcze-

38 https://www.hm.ee/et.

39 http://orka.sejm.gov.pl/WydBAS.nsf/0/42BC75F0F3BA4265C12579350029570B/\$file/Analiza_\%20BAS_2011_64.pdf. 
niami i różnymi sposobami artystycznego wyrazu oraz wyrobienie umiejętności wykonywania lub prezentowania dzieła.

W Estonii w programie nauczania wśród przedmiotów związanych z edukacją artystyczną i kulturalną znalazły się:

- w ramach przedmiotów obowiązkowych: sztuki plastyczne, muzyka, sztuki medialne,

- $\quad$ w ramach przedmiotów łączonych z innym nieartystycznym przedmiotem: taniec,

- w ramach fakultetów: rękodzieło, teatr.

Minimalna roczna liczba godzin przeznaczonych na przedmioty obowiązkowe z dziedziny edukacji artystycznej i kulturalnej w pierwszych 10 latach nauki w Põhihariduse baasil na poziomach ISCED 1 i ISCED $2 \mathrm{w}$ klasach I-III wynosi 525 godzin, w klasach IV-VI wynosi 245 godzin i w klasach VII-IX wynosi 210 godzin. Liczba godzin ogółem przewidziana jest nie na poszczególne lata nauki, a na poszczególne trzyletnie cykle nauczania. Wynika to z możliwości indywidualnego kształtowania przez nauczycieli sposobu realizacji programu nauczania z jednoczesną możliwością dostosowania liczby godzin do koncepcji dydaktycznej dla poszczególnych przedmiotów w kolejnych latach nauki.

Z przedmiotów artystycznych uczniowie podlegają ocenianiu kształtującemu i sumującemu. Kryteria oceniania postępów w nauce z tych przedmiotów opracowują sami nauczyciele - indywidualnie lub jako grono pedagogiczne. W Estonii w klasach I-II szkoły podstawowej (ISCED 1 i ISCED 2) przy ocenianiu postępów ucznia (także z przedmiotów artystycznych i kulturalnych) stosują komentarze słowne, korzystając z następującej skali ocen: doskonały, bardzo dobry, dobry, dostateczny, niedostateczny. W klasach III-IX obowiązują skale liczbowe od 10 do 1.

Tabela 8. Skala ocen stosowana w szkolnictwie w Estonii w odniesieniu do polskiego systemu oceniania

\begin{tabular}{|c|l|l|}
\hline \multicolumn{2}{|c|}{ Estoński system oceniania } & \multicolumn{1}{c|}{ Polski system oceniania } \\
\hline skala & \multicolumn{1}{|c|}{ opis } & \multicolumn{1}{c|}{ ocena i opis } \\
\hline $10-9$ & doskonały & 6 (celujący) \\
\hline $8-7$ & bardzo dobry & 5 (bardzo dobry) \\
\hline 6 & dobry & 4 (dobry) \\
\hline 5 & dostateczny & 3 (dostateczny) \\
\hline $4-1$ & niedostateczny & 1 (niedostateczny) \\
\hline
\end{tabular}

Źródło: opracowanie własne. 
Ze względu na dużą swobodę realizacji przez nauczycieli treści programowych edukacja artystyczna i kulturalna realizowana jest najczęściej jako kształcenie interdyscyplinarne $\mathrm{w}$ formie ścieżek międzyprzedmiotowych, które tworzone są przez łączenie przedmiotów artystycznych z innymi przedmiotami. Dodatkowym wsparciem dla międzyprzedmiotowej dydaktyki jest wykorzystywanie technologii informacyjno-komunikacyjnych we wszystkich przedmiotach - w tym w przedmiotach o charakterze artystycznym. Już w 1996 roku do placówek szkolnych wprowadzono program Tygrysi Skok. Jest to projekt szkolenia zarówno uczniów, jak i nauczycieli, którego celem jest wprowadzenie do placówek edukacyjnych możliwości szerokiego wykorzystania technologii informacyjno-komunikacyjnych. Wszystkie szkoły w Estonii korzystają z tych programów i technologiii ${ }^{40}$.

Oprócz zajęć interdyscyplinarnych z obszaru edukacji artystycznej i kulturalnej estońskie szkoły w ramach kształcenia równoległego rozwijają system edukacji muzealnej. W Estonii we wszystkich muzeach zatrudnione są osoby specjalizujące się w przygotowaniu ofert edukacyjnych (lekcje, wizyty, debaty, inscenizacje), które kierowane są do nauczycieli, uczniów i całych środowisk szkolnych. Wizyty uczniów w miejscach związanych z kulturą są ważnym elementem pracy dydaktyczno-wychowawczej w kształtowaniu świadomości dziedzictwa kulturowego i budowaniu tożsamości narodowej.

W ramach pozalekcyjnych działań artystycznych i kulturalnych skierowanych do młodzieży szkolnej co 4 lata organizowane są dziecięce festiwale piosenki i tańca, a corocznie wystawy prac z rysunku, malarstwa, fotografii i rękodzieła wykonanego przez dzieci i młodzież. Najczęściej organizatorem tych wydarzeń są Ministerstwo Edukacji i Badań, Ministerstwo Kultury i zainteresowane organizacje oświatowe.

\section{Nauczyciele przedmiotów artystycznych i kulturalnych}

Kształcenie nauczycieli prowadzą uniwersytety i wyższe szkoły zawodowe. Nauczyciele przedmiotów zintegrowanych (klasy I-II szkoły podstawowej) kończą trzyletnie licencjackie studia uniwersyteckie. W wypadku nauczycieli przedmiotowych muszą ukończyć studia magisterskie.

Edukacja artystyczna i kulturalna w pierwszych trzech klasach szkoły podstawowej najczęściej realizowana jest przez nauczycieli przedmiotów zintegro-

40 http://www.eesti.pl/system-edukacyjny-estonii-11947.html. 
wanych, ale dyrektorzy szkół mogą zdecydować także o zatrudnieniu nauczycieli konkretnych przedmiotów, np. nauczania muzyki. W programie kształcenia przyszłych nauczycieli przedmiotów zintegrowanych sztuki plastyczne, muzyka, teatr, taniec i sztuki wizualne są przedmiotami do wyboru, z których muszą wybrać jeden. Ponadto częstą praktyką uniwersytecką stosowaną wobec przyszłych nauczycieli przedmiotów zintegrowanych jest umieszczenie w programie studiów obowiązkowych wprowadzających kursów ze sztuk wizualnych i muzyki.

W klasach IV-IX szkoły podstawowej lekcje prowadzone są przez nauczycieli przedmiotowych, jednak często nauczycielami przedmiotów artystycznych są osoby, dla których jest to specjalność dodatkowa lub są to nauczyciele bez specjalistycznego przedmiotowego przygotowania, choć mają niezbędne uprawnienia pedagogiczne.

Wszyscy nauczyciele przedmiotów zintegrowanych oraz przedmiotów artystycznych, aby uzyskać prawo do nauczania, muszą uzyskać zawodowe uprawnienia pedagogiczne związane $\mathrm{z}$ nauczanymi przedmiotami artystycznymi. Zawodowi artyści, ludzie sztuki i kultury, którzy chcieliby nauczać w szkole specjalistycznych przedmiotów z dziedziny edukacji artystycznej i kulturalnej mogą być zatrudnieni w placówce, ale czasowo (np. gdy nie ma innego wykwalifikowanego nauczyciela). Po określonym czasie muszą ukończyć studia lub odpowiednie szkolenie dające uprawnienia dydaktyczno-pedagogiczne. W Estonii większość kadry zajmująca się kształceniem przyszłych nauczycieli przedmiotów artystycznych i kulturalnych to zawodowi artyści - plastycy, muzycy, aktorzy, tancerze i twórcy kultury.

\section{Finlandia}

\section{Organizacja i struktura obowiqzkowej edukacji publicznej}

Obowiązek szkolny trwa w Finlandii 9 lat. Kształcenie jest obowiązkowe od 7 do 16 roku życia. Obowiązkiem szkolnym objęta jest cała dziewięcioletnia szkoła podstawowa, która składa się z następujących dwóch poziomów edukacyjnych:

- Szkoła podstawowa (ISCED 1 i ISCED 2):

- klasy I-VI (peruskoulu) - wiek: 7-12 lat,

- klasy VII-IX (grundskola) - wiek: 13-16 lat.

Ustawa o kształceniu obowiązkowym (628/1998) w Finlandii, która weszła w życie 1 stycznia 1999 r., nie wyodrębnia już w szkole powszechnej etapu niższego i wyższego. W ustawie stwierdza się jedynie, że kształcenie obowiązkowe 
trwa dziewięć lat, oraz że zajęcia dydaktyczne są na ogół prowadzone przez wychowawców klas w klasach I-VI i przez nauczycieli przedmiotu w klasach VII-IX.

Uczniowie muszą rozpocząć kształcenie obowiązkowe w roku, w którym przypadają ich siódme urodziny. Około 1\% rozpoczyna naukę w szkole wcześniej, wymaga to jednak zaświadczenia potwierdzającego dojrzałość szkolną dziecka. Kształcenie obowiązkowe jest w całości bezpłatne. Władze lokalne przydzielają każdemu dziecku miejsce w szkole znajdującej się w pobliżu jego miejsca zamieszkania, ale rodzice mogą wybrać szkołę powszechną zgodnie ze swymi preferencjami.

Zarządzanie fińskim systemem oświaty odbywa się na zasadzie decentralizacji zadań. Ministerstwo Edukacji i Kultury określa we współpracy z Fińskim Narodowym Urzędem ds. Edukacji (Finnish National Board of Education, FNBE) cele, treści i metody ogólnokrajowego programu kształcenia dla poziomu szkoły podstawowej (ISCED 1 i ISCED 2) i średniej (ISCED 3) oraz kształcenia dorosłych. Funkcjonowanie szkoły podstawowej regulowane jest na podstawie zapisów ustawy 628/1998 i dekretu 852/1998 o szkolnictwie podstawowym oraz rozporządzenia 1435/2001 o celach i podziale godzin lekcyjnych w edukacji podstawowej ${ }^{41}$.

W każdej z sześciu fińskich prowincji sprawami edukacji zajmuje się odpowiedni Departament Edukacji i Kultury. Zarządzanie oświatą na szczeblu lokalnym należy do zadań władz lokalnych (gmin), które odgrywają istotną rolę w tym procesie jako organizatorzy kształcenia. Znakomita większość szkół podstawowych i średnich II stopnia prowadzona jest przez władze lokalne lub federacje gmin. Do prywatnych szkół powszechnych uczęszcza mniej niż 3\% uczniów. Szkoły prywatne są nadzorowane przez władze publiczne: realizują ogólnokrajowe programy nauczania i stosują się do wytycznych w sprawie kwalifikacji zatwierdzanych przez Krajowy Urząd ds. Edukacji. Otrzymują również fundusze publiczne w takiej samej wysokości, jak szkoły publiczne. Odpowiedzialność za finansowanie edukacji jest podzielona między państwo i władze lokalne.

O zakresie autonomii szkół publicznych decydują władze lokalne. Cele kształcenia i kryteria oceny określa ogólnokrajowy program nauczania. Na jego podstawie szkoły i władze lokalne przygotowują własne regulacje dotyczące programów nauczania, które uwzględniają własną lokalną specyfikę. Nauczyciele mają swobodę wyboru metod kształcenia i materiałów dydaktycznych ${ }^{42}$.

41 https://webgate.ec.europa.eu/fpfis/mwikis/eurydice/index.php/Finland:Single_Structure_ Education_(Integrated_Primary_and_Lower_Secondary_Education).

42 http://orka.sejm.gov.pl/WydBAS.nsf/0/42BC75F0F3BA4265C12579350029570B/\$file/Analiza_\%20BAS_2011_64.pdf. 


\section{Nauczanie i ocenianie przedmiotów artystycznych i kulturalnych}

Wśród celów i zadań przedmiotów artystycznych i kulturalnych dla szkolnictwa poziomu ISCED 1 i ISCED 2 fińskie programy nauczania - podobnie jak w zdecydowanej większości państw europejskich - wskazują m.in. na: umiejętności artystyczne, przekazanie wiedzy i jej zrozumienie, umiejętność dokonania interpretacji krytycznej dzieła, świadomość dziedzictwa kulturowego, umożliwienie indywidualnej ekspresji artystycznej, rozumienie różnorodności kulturowej. Wśród celów nauczania bezpośrednio związanych ze sztuką fińskie programy akcentują stworzenie uczniowi możliwości zetknięcia się z różnymi doświadczeniami i różnymi sposobami artystycznego wyrazu oraz wyrobienie umiejętności komunikacyjnych i społecznych przy tworzeniu i prezentowaniu dzieła. Ważnym celem realizacji przedmiotów artystycznych i kulturalnych jest także osiągnięcie przez uczniów radości, przyjemności i satysfakcji z kontaktu z tymi przedmiotami.

W programie fińskiej szkoły podstawowej poziomu ISCDE 1 i ISCED 2 wśród przedmiotów w obszarze edukacji artystycznej i kulturalnej znalazły się:

- w ramach przedmiotów obowiązkowych: sztuki plastyczne, muzyka, rękodzieło, sztuki medialne (fotografia, film, wideo, animacja komputerowa), architektura (obserwacja, planowanie i konstruowanie przestrzeni, sztuka projektowania brył architektonicznych),

- w ramach przedmiotów łączonych z innym nieartystycznym przedmiotem: teatr (występ teatralny, dramatopisarstwo i zrozumienie teatru), taniec (występ taneczny, choreografia, interpretacja tańca).

Minimalna roczna liczba godzin przeznaczonych na przedmioty obowiązkowe z dziedziny edukacji artystycznej i kulturalnej w pierwszych 10 latach nauki w szkole podstawowej na poziomie ISCED 1 w klasach I-IV wynosi 470 godzin, w klasach V-IX wynosi 527 godzin. Liczba godzin ogółem przewidziana jest nie na poszczególne lata nauki, a na poszczególne cykle nauczania. Wynika to z możliwości indywidualnego kształtowania przez nauczycieli sposobu realizacji programu nauczania z jednoczesną możliwością dostosowania liczby godzin do koncepcji dydaktycznej dla poszczególnych przedmiotów w kolejnych latach nauki. W ogólnokrajowym programie nauczania określono ogólny czas przeznaczany na grupę przedmiotów muzyka, sztuki plastyczne, rękodzieło i wychowanie fizyczne oraz minima godzinowe dla każdego przedmiotu. Dla tzw. podstawowego nauczania w zakresie sztuki i wychowania fizycznego Ministerstwo Edukacji i Kultury określiło jako obowiązkowy wymiar 6 godzin dydaktycznych dla klas 
I-IV i taki sam dla klas V-IX. Dzięki temu szkoły i nauczyciele w zależności od potrzeb wychowawczych i dydaktycznych mogą z całej pozostałej puli godzinowej przeznaczyć odpowiednio więcej lub mniej godzin dydaktycznych na wybrane przedmioty artystyczne, kulturalne lub wychowanie fizyczne.

Uczniowie z przedmiotów artystycznych najczęściej podlegają ocenianiu kształtującemu i sumującemu. W Finlandii istnieją kryteria oceniania przedmiotów artystycznych i są nimi przykłady tego, co składa się na dobry poziom osiągnięć uczniów pod koniec procesu dydaktycznego. Jeżeli używana jest liczbowa skala ocen, to ten dobry poziom określa ocena 8 (skala ocen od 4 do 10). Przykłady zawarte w kryteriach oceniania traktowane są przez nauczycieli jako swoiste punkty odniesienia. Przykładowo dla przedmiotu muzyka takim kryterium odniesienia jest dla młodszych klas szkoły podstawowej wiedza o tym, jak używać głosu do śpiewania grupowego (unisono - zgodne wykonanie przebiegu melodycznego przez całą grupę), a dla ostatniej klasy szkoły podstawowej - udział w zespole wokalnym i wiedza, jak śpiewać zgodnie z melodią i rytmem. Jednakże brak jest odgórnych zaleceń dla nauczycieli co do sposobu oceniania i stosowanej skali ocen. Kryteria oceniania postępów w nauce z tych przedmiotów opracowywane są indywidualnie przez każdego nauczyciela lub przez szkolne grono pedagogiczne. W Finlandii nauczyciele w szkole podstawowej (ISCED 1 i 2) stosują przy ocenianiu postępów ucznia liczbową skalę ocen od 10 do 4.

Tabela 9. Skala ocen stosowana w szkolnictwie w Finlandii w odniesieniu do polskiego systemu oceniania

\begin{tabular}{|c|l|l|}
\hline \multicolumn{2}{|c|}{ Fiński system oceniania } & \multicolumn{1}{c|}{ Polski system oceniania } \\
\hline skala & \multicolumn{1}{c|}{ ocena i opis } \\
\hline 10 & doskonały & 6 (celujący) \\
\hline 9 & bardzo dobry & 5 (bardzo dobry) \\
\hline 8 & dobry & 4 (dobry) \\
\hline 7 & średni & 4 (dobry) \\
\hline 6 & dostateczny & 3 (dostateczny) \\
\hline 5 & zły & 2 (dopuszczający) \\
\hline 4 & niedostateczny & 1 (niedostateczny \\
\hline
\end{tabular}

Źródło: opracowanie własne.

Ze względu na dużą swobodę realizacji przez nauczycieli treści programowych edukacja artystyczna i kulturalna realizowana jest najczęściej jako 
kształcenie interdyscyplinarne w formie ścieżek międzyprzedmiotowych, które tworzone są przez łączenie przedmiotów artystycznych z innymi przedmiotami (jest to wymóg zapisany w fińskich programach nauczania przedmiotów artystycznych). Dodatkowym wsparciem dla międzyprzedmiotowej dydaktyki jest obowiązkowe wykorzystywanie technologii informacyjno-komunikacyjnych (TIK) we wszystkich przedmiotach - w tym w przedmiotach o charakterze artystycznym.

Znaczącym elementem wspierającym działalność edukacyjno-wychowawczą w fińskich szkołach są zewnętrzne programy i inicjatywy oświatowe różnych instytucji, organizacji, fundacji oraz sieci promujących i rozwijających idee edukacji artystycznej i kulturalnej. Jedną z takich inicjatyw jest wieloletni projekt nazwany Fiński Dąb (Suomen Tammi ${ }^{43}$ mający na celu poszerzenie wiedzy uczniów o historii i dziedzictwie kulturowym narodu i kraju oraz:

- wywołanie zainteresowania dziedzictwem kulturowym,

- rozwijanie w uczniach umiejętności do pielęgnowania i ożywiania dziedzictwa kulturowego i środowiska naturalnego,

- zwiększenie znaczenia instytucji kształcenia równoległego (muzeów, wystaw) w ich wykorzystaniu w procesie wychowawczo-dydaktycznym,

- zwiększenie świadomości własnego wkładu ucznia w możliwość wpływania na kultywowanie i budowanie obszaru dziedzictwa kulturowego kraju,

- wzmocnienie u uczniów ich świadomości tożsamości kulturowej ${ }^{44}$.

Dla potrzeb programu Suomen Tammi powstała sieć informatyczna (o tej samej nazwie), której zadaniem jest wspieranie współpracy między szkołami a ekspertami, informowanie nauczycieli i uczniów o ofertach muzeów i innych placówek kulturalnych oraz wspieranie interdyscyplinarnej edukacji związanej z tematyką dziedzictwa kulturowego ${ }^{45}$.

Inną propozycją wspierającą prace szkoły w zakresie edukacji kulturalnej jest projekt Kultura Szerokopasmowa (Kulttuurin laajakaista) ${ }^{46}$ realizowany przez wiodące krajowe instytucje kultury na czele z Fińskim Narodowym Urzędem ds. Edukacji. Polega on na tworzeniu, udostępnieniu i wykorzystaniu zasobów instytucji kultury jako materiałów dydaktycznych umożliwiających poznawanie dziedzictwa kulturowego i zdobywanie wiarygodnych informacji z dziedzin sztuki.

43 http://www.oph.fi/kehittamishankkeet/suomen_tammi.

44 http://www.edu.fi/projektit/tammi.

45 http://www.edu.fi/yleissivistava_koulutus/teemat/kulttuuriperintoopetus/suomen_tammi_ hanke.

46 http://www.kulttuurinvuosikello.fi. 
W Finlandii, podobnie jak w innych krajach, uczniowie mogą uczestniczyć w pozalekcyjnych zajęciach artystycznych i kulturalnych. Zazwyczaj odbywają się one po zakończeniu lekcji lub w czasie dłuższych przerw obiadowych.

\section{Nauczyciele przedmiotów artystycznych i kulturalnych}

W Finlandii kształcenie nauczycieli prowadzą uniwersytety i szkoły wyższe. Nauczyciele przedmiotów zintegrowanych (klasy I-VI szkoły podstawowej) muszą mieć ukończone wyższe studia magisterskie (II stopnia) i tytuł magistra pedagogiki. Nauczyciele przedmiotowi szkoły podstawowej (klasy VII-IX) powinni ukończyć wyższe studia magisterskie w dziedzinie odpowiadającej przedmiotowi, którego będą nauczać, ze specjalnością nauczycielską (pedagogiczną). Na studia nauczycielskie obowiązuje egzamin wstępny, który składa się z egzaminu pisemnego, testu zdolności i rozmów kwalifikacyjnych. W niektórych uniwersytetach egzamin wstępny obejmuje także sprawdzenie w przykładowej sytuacji umiejętności pracy z grupą i nieobowiązkową prezentację umiejętności pedagogicznych.

Edukacja artystyczna i kulturalna w fińskim szkolnictwie podstawowym (ISCED 1) realizowana jest przez nauczycieli przedmiotów zintegrowanych, choć w tym zakresie mogą występować różnice pomiędzy szkołami. Program kształcenia nauczycieli przedmiotów zintegrowanych przewiduje obowiązkowe przygotowanie do nauczania dwóch przedmiotów artystycznych: sztuki plastyczne i muzyka. Dodatkowymi przedmiotami, które znajdują się w programie nauczania innych przedmiotów są: teatr (część nauki języka ojczystego) i taniec (część wychowania fizycznego). W wyższych klasach szkoły podstawowej lekcje prowadzone są przez nauczycieli przedmiotowych, lecz często nauczycielami przedmiotów artystycznych są osoby, dla których jest to specjalność dodatkowa, lub są to nauczyciele bez specjalistycznego przedmiotowego przygotowania.

Wszyscy nauczyciele przedmiotów zintegrowanych oraz przedmiotów artystycznych, aby uzyskać prawo do nauczania muszą uzyskać zawodowe uprawnienia pedagogiczne związane z nauczanymi przedmiotami artystycznymi.

Zawodowi artyści, ludzie sztuki i kultury, którzy chcieliby nauczać w szkole specjalistycznych przedmiotów z dziedziny edukacji artystycznej i kulturalnej, muszą ukończyć studia lub odpowiednie szkolenie dające uprawnienia dydaktyczno-pedagogiczne. 


\section{Francja}

\section{Organizacja i struktura obowiq̨zkowej edukacji publicznej}

Obowiązek szkolny trwa 10 lat. Kształcenie jest obowiązkowe dla uczniów w wieku od 6 do 16 lat.

Szczeble kształcenia objęte obowiązkiem szkolnym to:

- Szkoła elementarna (école élementaire) (ISCED 1) - wiek: 6-11 lat,

- Szkoła średnia I stopnia (collège) (ISCED 2) - wiek: 11-15 lat,

- Szkoła średnia II stopnia (lycée) (ISCED 3) - na ogół w wieku 15 lat uczniowie wstępują do liceum ogólnokształcącego i technicznego (lycée d'enseignement général et technologique) lub liceum zawodowego (lycée professionnel), w którym rozpoczynają piąty rok nauki w szkole średniej (classe de seconde). W momencie ukończenia tej klasy osiągają wiek odpowiadający zakończeniu obowiązku szkolnego. Dalsza edukacja nie jest obowiązkowa.

Scentralizowany system edukacji we Francji podlega Ministerstwu Edukacji Narodowej, Szkolnictwa Wyższego i Badań Naukowych (Ministère de l'Éducation nationale, de l'Enseignement supérieur et de la Recherche; dalej: Ministerstwo Edukacji $^{47}$. Systemem edukacji objęte jest nieodpłatne kształcenie w sektorze publicznym prowadzone równolegle z kształceniem oferowanym przez sektor prywatny. Sektor prywatny składa się w większości z instytucji posiadających umowę z państwem obejmującą także odpowiedzialność za wynagrodzenia nauczycieli, a także - w przeważającej części przypadków - na mocy tzw. umów stowarzyszeniowych (contrats d'association), za funkcjonowanie danej placówki. 87,7\% uczniów szkół podstawowych i 78,7\% uczniów szkół średnich uczęszcza do placówek publicznych. Ministerstwo opracowuje szczegółowy program nauczania każdego przedmiotu na wszystkich poziomach edukacji, określa cele edukacyjne oraz wytyczne dotyczące organizacji i metodyki nauczania, nie zobowiązując jednak nauczycieli do stosowania określonych metod kształcenia. Definiuje także warunki ogólne i cele dla programów kształcenia przyszłych nauczycieli w szkołach wyższych, określa tematykę doskonalenia zawodowego nauczycieli, decyduje o obsadzie etatów nauczycielskich oraz określa status i zasady funkcjonowania szkół, przydzielając im odpowiednią liczbę pracowników. Ministerstwo ${ }^{48}$ organizuje również egzaminy i przyznaje państwowe kwalifikacje.

47 http://www.education.gouv.fr.

48 Zob. przyp. 12 na s. 114. 
W ramach systemu edukacji szkoły mają pewną autonomię w sprawach administracyjnych i dydaktycznych, a na poziomie szkolnictwa średniego (collèges i lycées) - również w sprawach finansowych.

\section{Nauczanie i ocenianie przedmiotów artystycznych i kulturalnych}

Wśród celów i zadań przedmiotów artystycznych i kulturalnych dla szkolnictwa elementarnego (ISCED 1) i średniego I stopnia - kolegium (ISCED 2) francuskie programy nauczania - podobnie jak w zdecydowanej większości państw europejskich - wskazują m.in. na: umiejętności artystyczne, przekazanie wiedzy i jej zrozumienie, umiejętność dokonania interpretacji krytycznej dzieła, świadomość dziedzictwa kulturowego, umożliwienie indywidualnej ekspresji artystycznej, rozumienie różnorodności kulturowej. Wśród celów nauczania bezpośrednio związanych ze sztuką francuskie programy akcentują stworzenie uczniowi możliwości zetknięcia się z różnymi doświadczeniami i różnymi sposobami artystycznego wyrazu oraz wyrobienie umiejętności komunikacyjnych i społecznych przy tworzeniu i prezentowaniu dzieła.

Zgodnie z ustawą oświatową o planowaniu i kierowaniu dla przeszłości szkoły ${ }^{49}$, kształcenie obowiązkowe musi zagwarantować każdemu uczniowi środki potrzebne do zdobycia wspólnej podstawy programowej obejmującej zestaw umiejętności i wiedzy. Podstawa składa się z 7 elementów, gdzie 2 ostatnie umiejętności społeczne i obywatelskie oraz niezależność i inicjatywa - związane są z dyscyplinami artystycznymi.

W programie francuskiej szkoły elementarnej (ISCDE 1) i kolegium (ISCDE 2) wśród przedmiotów w obszarze edukacji artystycznej i kulturalnej znalazły się:

- $\quad$ w ramach przedmiotów obowiązkowych: sztuki plastyczne, muzyka, rękodzieło, sztuki medialne (fotografia, film, wideo, animacja komputerowa),

- w ramach przedmiotów łączonych z innym nieartystycznym przedmiotem: teatr jako część nauki języka ojczystego (występ teatralny, dramatopisarstwo i zrozumienie teatru), taniec jako część wychowania fizycznego (występ taneczny, choreografia, interpretacja tańca),

- w ramach przedmiotów fakultatywnych: architektura, sztuki użytkowe, sztuka smaku, kino, sztuki cyrkowe, kultura naukowa i techniczna, wieś.

Minimalna roczna liczba godzin przeznaczonych na przedmioty obowiązkowe z dziedziny edukacji artystycznej i kulturalnej określona jest na poszczególne

49 Loi d'orientation et de programme pour l'avenir de l'école (L. $\mathrm{n}^{\circ}$ 2005-380 du 23-4-2005. JO du 24-4-2005), http://www.education.gouv.fr/bo/2005/18/MENX0400282L.htm\#loi. 
lata nauki. W klasach szkoły elementarnej (ISCED 1) wynosi 108 godzin rocznie (razem podczas nauki w szkole elementarnej 540 godzin). W kolegium (ISCED 2) wynosi 72 godzin rocznie (razem podczas nauki w kolegium 288 godzin).

Uczniowie z przedmiotów artystycznych najczęściej podlegają ocenianiu kształtującemu i sumującemu. We Francji dla szkół elementarnych i kolegiów centralne władze oświatowe nie określają kryteriów oceniania postępów ucznia w zakresie przedmiotów artystycznych. Ustalenie zasad i kryteriów oceniania pozostaje więc w gestii placówek szkolnych, a najczęściej samego nauczyciela. We Francji w szkole elementarnej i kolegium (ISCED 1 i 2) oficjalną skalą ocen stosowaną przy ocenianiu postępów ucznia - z wyłączeniem przedmiotów edukacji artystycznej i kulturalnej - jest liczbowa skala od 20 do 0.

Tabela 10. Skala ocen stosowana w szkolnictwie we Francji

w odniesieniu do polskiego systemu oceniania

\begin{tabular}{|c|l|l|}
\hline \multicolumn{2}{|c|}{ Francuski system oceniania } & \multicolumn{1}{c|}{ Polski system oceniania } \\
\hline skala & \multicolumn{1}{|c|}{ opis } & \multicolumn{1}{c|}{ ocena i opis } \\
\hline $20-18$ & wspaniały (excellent) & 6 (celujący) \\
\hline $17-16$ & bardzo dobry (très bien) & 5 (bardzo dobry) \\
\hline $15-14$ & bardzo dobry (bien) & 4 (dobry) \\
\hline $13-12$ & dość dobry (assez bien) & 3 (dostateczny) \\
\hline $11-10$ & zadowalający (passable) & 2 (dopuszczający) \\
\hline $9-0$ & niewystarczający (insuffisant) & 1 (niedostateczny) \\
\hline
\end{tabular}

Źródło: Opracowanie własne.

Ze względu na charakter pracy dydaktycznej w szkole elementarnej realizacja treści programowych edukacji artystycznej i kulturalnej odbywa się najczęściej jako kształcenie interdyscyplinarne w formie projektów międzyprzedmiotowych (projets interdisciplinaires), które tworzone są przez łączenie przedmiotów artystycznych z innymi przedmiotami. Programy powstają najczęściej na poziomie lokalnym, gdyż włączane treści interdyscyplinarne często dotyczą zagadnień bliskich uczniom i społecznościom, z których pochodzą. Ministerstwo Edukacji wraz z Ministerstwem Kultury i Komunikacji zalecają, zachęcają i promują tworzenie autorskich programów nauczania o charakterze międzyprzedmiotowych projektów artystycznych i kulturalnych we wszystkich szkołach i placówkach oświatowych. Wśród propozycji takich projektów znalazły się na przykład muzyka-tekst-język; sztuki wizualne-perspektywa-geome- 
tria; sport/wychowanie fizyczne-taniec-rytm-muzyka; język francuski-teatr. Władze oświatowe w ramach rozpowszechnienia inicjatywy tworzenia ścieżek międzyprzedmiotowych uruchomiły program zatytułowany „Inter, trans, wieloprzedmiotowy - aby poznać trochę lepiej” (Inter, trans, pluri... disciplinaire: pour y voir un peu plus clair) ${ }^{50}$, który skierowany jest do nauczycieli i rodziców. Oprócz interdyscylinarności we Francji zgodnie z ustawą n 2013-59551 oraz dekretem n²015-372 ${ }^{52}$ od roku szkolnego 2016/2017 planowane jest wejście w życie nowej podstawy programowej dotyczącej wiedzy, kompetencji i kultury (Socle commun de connaissances, de compétences et de culture) ${ }^{53}$. Jednym z ważniejszych zadań dydaktyczno-wychowawczych szkoły w obszarze edukacji artystycznej i kulturalnej umieszczonych w nowej podstawie programowej jest znajomość i rozumienie społeczeństw we współczesnym świecie oraz świadoma interpretacja wytworów kultury człowieka, a także korzystanie z technologii informacyjno-komunikacyjnych (TIK). We francuskich programach nauczania przedmiotów artystycznych wykorzystywanie TIK jest określone jako obowiązek dydaktyczny nauczyciela. W ramach Ministerstwa Edukacji oraz Ministerstwa Kultury i Komunikacji za rozwój technologii informacyjno-komunikacyjnych odpowiedzialne jest Krajowe Centrum Dokumentacji Pedagogicznej (Centre national de documentation pédagogique, CNDP) ${ }^{54}$. Opracowuje ono programy i pomoce szkolne, tworzy i rozpowszechnia elektroniczne zasoby edukacyjne i bazy danych. Prowadzi kształcenie i doskonalenie zawodowe nauczycieli z wykorzystaniem TIK w szkole, w tym również dla potrzeb edukacji artystycznej i kulturalnej.

Znaczącym elementem wspierającym realizację kształcenia artystycznego i kulturalnego we francuskich szkołach jest współpraca z zewnętrznymi instytucjami i organizacjami promującymi i rozwijającymi idee edukacji artystycznej i kulturalnej. Zgodnie z ustawą no 88-20 o edukacji artystycznej ${ }^{55}$ szkoły elemen-

50 http://www.sitecoles.org/index.php?WebZoneID=590\&ArticleID=2241.

51 Loi n 2013-595 du 8.07.2013 d'orientation et de programmation pour la refondation de l'école de la République, http://www.legifrance.gouv.fr/affichTexte.do?cidTexte=JORFTEXT0000 27677984\&dateTexte=\&categorieLien=id.

52 Décret n²015-372 du 31 mars 2015 Le nouveau socle commun de connaissances, de compétences et de culture à la rentrée 2016, http://www.education.gouv.fr/pid25535/bulletin_officiel.html\&cid_bo=87834.

53 http://www.education.gouv.fr/cid2770/le-socle-commun-de-connaissances-et-de-competences.html.

54 http://www.reseau-canope.fr.

55 Loi n88-20 du 6 janvier 1988 relative aux enseignements artistiques, http://www.legifrance. gouv.fr/affichTexte.do?cidTexte=JORFTEXT000027677984\&dateTexte=\&categorieLien=id. 
tarne i kolegia w swoich programach pracy edukacyjnej i planach nauczania muszą uwzględnić włączenie do kształcenia artystycznego i kulturalnego wszystkich swoich uczniów. Jednocześnie instytucje, organizacje, fundacje, stowarzyszenia dofinansowywane przez Ministerstwo Kultury i Komunikacji mają obowiązek uwzględnić elementy edukacyjne we wszystkich realizowanych projektach i kontraktach.

Długoletnią tradycję i renomę mają we Francji programy współpracy uczniów $\mathrm{z}$ artystami i przedstawicielami kultury. Inicjatorami tych programów od wielu lat są Ministerstwo Edukacji oraz Ministerstwo Kultury i Komunikacji, które zapewniają uczniom możliwość poznania artystów, realizacji i współfinansowania wspólnych projektów. Mogą być one realizowane w ramach zajęć szkolnych lub pozaszkolnych.

\section{Nauczyciele przedmiotów artystycznych i kulturalnych}

We Francji nauczyciele w placówkach publicznych mają status urzędników państwowych. Przy scentralizowanym systemie oświaty oznacza to, że pracodawcą nie jest dyrektor konkretnej szkoły, ale państwo za pośrednictwem Ministra Edukacji. Żeby zostać nauczycielem w szkole, oprócz ukończenia studiów wyższych, należy zdać bardzo selektywne centralne egzaminy państwowe.

We Francji kształcenie nauczycieli prowadzą uniwersytety i szkoły wyższe. Nauczyciele zatrudnieni w szkołach elementarnych i kolegiach muszą mieć ukończone studia magisterskie. Uzyskanie kwalifikacji niezbędnych do wykonywania zawodu nauczyciela na wszystkich poziomach nauczania następuje drogą egzaminu konkursowego przeprowadzanego podczas końcowego roku studiów. Przyszli nauczyciele w szkołach elementarnych muszą przystąpić do zewnętrznego konkursu dla kandydatów na nauczycieli CERPE (concours externe de recrutement de professeur des écoles) ${ }^{56}$. Uprawnienia, jakie otrzymują, pozwalają na podjęcie pracy z dziećmi w wieku od 2 do 11 roku życia, a więc w przedszkolach (école maternelle) i szkołach elementarnych (école élementaire). Mogą pracować w placówkach prywatnych i państwowych. Uczą przedmiotów ogólnokształcących, takich jak: język ojczysty, matematyka, historia, geografia, plastyka, muzyka. Najczęściej są to nauczyciele przedmiotów zintegrowanych. We Francji w szkołach elementarnych do nauczania przedmiotów artystycznych i kulturalnych zatrudnia się przede wszystkim nauczycieli przedmiotów zintegrowanych.

56 http://www.education.gouv.fr/cid71562/epreuves-des-concours-de-recrutement-de-professeurs-des-ecoles.html. 
W programie kształcenia nauczycieli przedmiotów zintegrowanych przedmiotami artystycznymi są sztuki plastyczne i muzyka.

Przyszli nauczyciele w szkołach średnich muszą przystąpić do zewnętrznego konkursu prowadzącego do uzyskania zaświadczenia o przygotowaniu nauczycielskim na poziomie szkoły średniej CAPES (certificat d'aptitude au professorat de l'enseignement $d u$ second degré ${ }^{57}$. Jest to konkurs bardzo selektywny i wymaga pogłębionej wiedzy z kierunkowego przedmiotu, którego chce się nauczać. Żeby przystąpić do egzaminu, trzeba mieć tytuł magistra (wymagana matura plus 5 lat studiów) lub być w trakcie jego zdobywania. Po zdaniu egzaminu odbywa się roczny staż. Dopiero po jego zaliczeniu, kandydat staje się pełnoprawnym nauczycielem.

Uprawnienia, jakie otrzymują, pozwalają na podjęcie pracy z uczniami w wieku od 11 do 18 roku życia, a więc w kolegiach (collège), czyli szkołach średnich I stopnia, i szkołach średnich II stopnia, np. liceum (lycée). Nauczyciele przedmiotów artystycznych, oprócz studiów w dziedzinie, która będzie ich przedmiotem, muszą ukończyć kształcenie pedagogiczno-dydaktyczne. W programie takiego szkolenia dla nauczycieli sztuk wizualnych i muzyki znajdują się następujące przedmioty: rozwój dziecka przez sztukę, program przedmiotów artystycznych, dydaktyka sztuki, historia sztuki, osobiste umiejętności artystyczne, ocenianie uczniów.

\section{Grecja}

\section{Organizacja i struktura obowiq̨zkowej edukacji publicznej}

Obowiązek szkolny trwa 10 lat. Kształcenie jest obowiązkowe dla uczniów w wieku od 5 do 15 lat.

Szczeble kształcenia objęte obowiązkiem szkolnym to:

- Przedszkole (nipiagogeio) - wiek: 3/4-5/6 lat,

- Szkoła podstawowa (dimotiko scholio) (ISCED 1) - wiek: 5-12 lat,

- Szkoła średnia I stopnia (gymnasio) (ISCED 2) - wiek: 12-15 lat.

Edukacja przedszkolna trwa dwa lata, od 3 lub 4 do 5 lub 6 lat, i jest prowadzona w przedszkolach, które stanowią samodzielne placówki lub część szkoły podstawowej. Do państwowych szkół podstawowych i średnich przyjmuje się wyłącznie uczniów mieszkających w rejonie szkoły. Do szkół średnich I stopnia

57 http://www.education.gouv.fr/cid1058/professeur-certifie.html. 
uczniów przyjmuje się automatycznie, po ukończeniu przez nich szkoły podstawowej. We wszystkich państwowych szkołach podstawowych i średnich kształcenie jest bezpłatne.

W Grecji zarządzanie oświatą jest scentralizowane, ale w ostatnich latach podjęto działania w celu przekazania pewnych zadań szczeblowi regionalne-

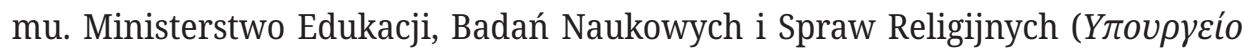

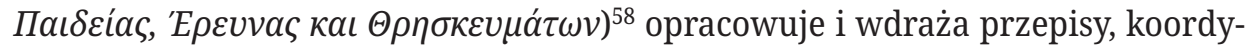
nuje i ocenia działalność urzędów regionalnych, zarządza funduszami, zatwierdza programy nauczania dla szkół podstawowych i średnich oraz mianuje nauczycieli. Prefektury (lub w dużych prefekturach urzędy ds. edukacji) nadzorują szkoły, koordynują działania szkół oraz odpowiadają za szkolne budynki i ich wyposażenie. Dyrektorzy szkół nadzorują działalność placówki i odpowiadają za przestrzeganie przez szkołę wymogów prawnych. Szkolne rady pedagogiczne zajmują się wdrażaniem regulacji dotyczących programów nauczania oraz monitorowaniem frekwencji i dyscypliny w szkole. Komitety szkolne odpowiadają za sprawy administracyjne oraz zarządzają funduszami.

\section{Nauczanie i ocenianie przedmiotów artystycznych i kulturalnych}

Programy nauczania opracowywane są przez Instytut Pedagogiki i zatwierdzane przez Ministerstwo Edukacji, Badań Naukowych i Spraw Religijnych (dalej: Ministerstwo Edukacji). Przedmiotami obowiązkowymi w szkole podstawowej są: religia, język grecki, matematyka, historia, ekologia, geografia, przyroda, wiedza o społeczeństwie, wychowanie artystyczne, język obcy i wychowanie fizyczne. Przedmioty te (z wyjątkiem ekologii i wychowania artystycznego) są również obowiązkowe we wszystkich klasach szkoły średniej I stopnia. Do przedmiotów obowiązkowych w szkole średniej I stopnia należą również: informatyka i/lub technika, literatura starożytnej Grecji, nauki polityczne i społeczne, orientacja zawodowa i zajęcia z gospodarstwa domowego. Nauczyciele mogą korzystać z pomocy metodycznej Instytutu Pedagogiki, ale sami wybierają metody kształcenia. Materiały dydaktyczne i podręczniki muszą opierać się na programach nauczania zatwierdzonych przez Ministerstwo Edukacji ${ }^{59}$.

Wśród celów i zadań przedmiotów artystycznych i kulturalnych dla szkolnictwa poziomu ISCED 1 i ISCED 2 greckie programy nauczania - podobnie jak

58 https://www.minedu.gov.gr.

59 http://orka.sejm.gov.pl/WydBAS.nsf/0/42BC75F0F3BA4265C12579350029570B/\$file/Analiza_\%20BAS_2011_64.pdf. 
w zdecydowanej większości państw europejskich - wskazują m.in. na: umiejętności artystyczne, przekazanie wiedzy i jej zrozumienie, umiejętność dokonania interpretacji krytycznej dzieła, świadomość dziedzictwa kulturowego, umożliwienie indywidualnej ekspresji artystycznej, rozumienie różnorodności kulturowej. Wśród celów nauczania bezpośrednio związanych ze sztuką greckie programy akcentują stworzenie uczniowi możliwości zetknięcia się z różnymi doświadczeniami i różnymi sposobami artystycznego wyrazu oraz wyrobienie umiejętności komunikacyjnych i społecznych przy tworzeniu i prezentowaniu dzieła. Ważnym celem realizacji przedmiotów artystycznych i kulturalnych jest także osiągnięcie przez uczniów radości, przyjemności i satysfakcji z kontaktu $\mathrm{z}$ tymi przedmiotami.

W programie greckiej szkoły podstawowej poziomu ISCDE 1 i 2 edukacja artystyczna i kulturalna realizowana jest jako przedmiot edukacja estetyczna ( $\alpha \iota \sigma \theta \eta \tau \iota \kappa \eta ́ ~ \alpha \gamma \omega \gamma \eta ́)$. Znalazły się w nim następujące zagadnienia:

- w ramach przedmiotów obowiązkowych: sztuki plastyczne, muzyka, rękodzieło, teatr (występ teatralny, dramatopisarstwo i zrozumienie teatru), architektura (obserwacja, planowanie i konstruowanie przestrzeni, sztuka projektowania brył architektonicznych),

- w ramach przedmiotów łączonych z innym nieartystycznym przedmiotem: taniec (występ taneczny, choreografia, interpretacja tańca).

Minimalna roczna liczba godzin przeznaczonych na przedmioty obowiązkowe z dziedziny edukacji artystycznej i kulturalnej w pierwszych 10 latach nauki w szkole podstawowej na poziomie ISCED $1 \mathrm{w}$ pierwszych czterech klasach wynosi 90 godzin rocznie i w dwóch następnych klasach wynosi 60 godzin rocznie. Na poziomie szkoły średniej ISCED 2 wynosi ona 50 godzin rocznie.

Uczniowie z przedmiotów artystycznych najczęściej podlegają ocenianiu kształtującemu i sumującemu. W Grecji istnieją kryteria oceniania przedmiotów artystycznych i są nimi przykłady tego, co składa się na dobry poziom osiągnięć uczniów pod koniec procesu dydaktycznego. W szkole podstawowej w klasie I i II stosowane są komentarze słowne, w klasie III i IV używana jest skala literowa, a w klasie V i VI obowiązuje skala ocen werbalnych i liczbowych.

W Grecji nauczyciele w szkole podstawowej (ISCED 1) i szkole średniej I stopnia (ISCED 2) stosują przy ocenianiu postępów ucznia następującą skalę ocen:

- w szkole podstawowej (Dimotiko scholio) dla klasy III i IV (skala literowa od A do D), 
Tabela 11. Skala ocen stosowana w Grecji w szkole podstawowej (Dimotiko scholio) dla klasy III i IV w odniesieniu do polskiego systemu oceniania

\begin{tabular}{|c|l|l|}
\hline \multicolumn{2}{|c|}{ Grecki system oceniania } & \multicolumn{1}{c|}{ Polski system oceniania } \\
\hline skala & \multicolumn{1}{|c|}{ opis } & \multicolumn{1}{c|}{ ocena i opis } \\
\hline A & doskonały & 6 (celujący) \\
\hline B & bardzo dobry & 5 (bardzo dobry) \\
\hline C & dobry & 4 (dobry) \\
\hline D & dostateczny & 3 (dostateczny) \\
\hline
\end{tabular}

Żródło: Opracowanie własne.

- w szkole podstawowej (Dimotiko scholio) dla klasy V i VI (skala liczbowa od 10 do 1),

Tabela 12. Skala ocen stosowana w Grecji w szkole podstawowej (Dimotiko scholio) dla klasy V i VI w odniesieniu do polskiego systemu oceniania

\begin{tabular}{|c|l|l|}
\hline \multicolumn{2}{|c|}{ Grecki system oceniania } & \multicolumn{1}{c|}{ Polski system oceniania } \\
\hline skala & \multicolumn{1}{|c|}{ opis } & \multicolumn{1}{c|}{ ocena i opis } \\
\hline $10-9$ & doskonały & 6 (celujący) \\
\hline $8-7$ & bardzo dobry & 5 (bardzo dobry) \\
\hline $6-5$ & dobry & 4 (dobry) \\
\hline $4-1$ & dostateczny & 3 (dostateczny) \\
\hline
\end{tabular}

Źródło: Opracowanie własne.

- w szkole średniej I stopnia (Gymnasio) (skala liczbowa od 20 do 1).

Tabela 13. Skala ocen stosowana w Grecji w szkole średniej I stopnia (Gymnasio) w odniesieniu do polskiego systemu oceniania

\begin{tabular}{|c|l|l|}
\hline \multicolumn{2}{|c|}{ Grecki system oceniania } & \multicolumn{1}{c|}{ Polski system oceniania } \\
\hline skala & \multicolumn{1}{|c|}{ opis } & \multicolumn{1}{c|}{ ocena i opis } \\
\hline $20-18,5$ & doskonały & 6 (celujący) \\
\hline $18,4-15,5$ & bardzo dobry & 5 (bardzo dobry) \\
\hline $15,4-12,5$ & dobry & 4 (dobry) \\
\hline $12,4-10,1$ & dostateczny & 3 (dostateczny) \\
\hline 10 & dopuszczający & 2 (dopuszczający) \\
\hline $9-1$ & niedostateczny & 1 (niedostateczny) \\
\hline
\end{tabular}

Źródło: opracowanie własne. 
Przedmiot edukacja estetyczna realizowany jest najczęściej jako kształcenie interdyscyplinarne $\mathrm{w}$ formie ścieżek międzyprzedmiotowych, które tworzone są przez łączenie przedmiotów artystycznych z innymi przedmiotami. Dodatkowym wsparciem dla międzyprzedmiotowej dydaktyki jest wykorzystywanie technologii informacyjno-komunikacyjnych (TIK) w przedmiotach o charakterze

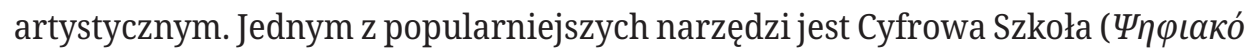
$\Sigma \chi 0 \lambda \varepsilon i o)^{60}$. Portal oferuje bogate zasoby elektronicznych podręczników, pakiety dydaktyczne dla uczniów, pomoce dydaktyczne dla nauczycieli, gry dydaktyczne.

Znaczącym elementem wspierającym edukację estetyczną w greckich szkołach są zewnętrzne programy i inicjatywy oświatowe różnych instytucji, organizacji, fundacji oraz sieci promujących i rozwijających idee edukacji kulturalnej.

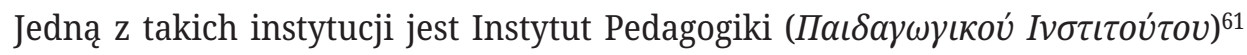
powołany w celu wspierania edukacji estetycznej i kulturalnej w szkolnictwie podstawowym i średnim. Prowadzi on badania naukowe, przygotowuje podręczniki, tworzy materiały dydaktyczne, pomaga w realizacji programów nauczania w zakresie edukacji estetycznej, historii sztuki, sztuk plastycznych, muzyki, sztuk wizualnych, teatru, tańca. Instytut ułatwia wirtualny dostęp do muzeów, wystaw i zabytków architektury. Udostępnia cyfrowe katalogi bibliotek, szkoli nauczycieli oraz organizuje i prowadzi zajęcia tematyczne (np. „Sztuka od czasów starożytnych aż do dzisiaj”, „Waluty starożytnej Grecji”, „Koło czasu”, „Kim jestem? Potrzeby, moich uczuć i marzeń!”, „Strach w sztuce”) ${ }^{62}$.

Duże znaczenie we wspieraniu szkolnych działań w kształtowaniu świadomości i wrażliwości kulturalnej uczniów ma udział szkół w różnego rodzaju wydarzeniach organizowanych przez ministerstwa i inne instytucje edukacyjne. Przykładowo od wielu lat Ministerstwo Edukacji co roku organizuje festiwal sztuki zatytułowany „Krajowe Kulturalne Igrzyska Uczniów”, którego celem jest uświadomienie uczniom wagi sztuki w edukacji i życiu. Innym przykładem jest program edukacyjny Narodowej Opery zatytułowany „Sekrety w Operze”63.

Grecki system oświatowy dysponuje także programową ofertą pozalekcyjnych zajęć artystycznych, jednak wykorzystanie ich w praktyce zależne jest nie tylko od zainteresowania uczniów, ale także od możliwości finansowych placówek.

\footnotetext{
60 http://ebooks.edu.gr/new/allmaterial.php.

61 http://www.pi-schools.gr/content/index.php?lesson_id=27.

62 http://www.e-yliko.gr/htmls/aisth_agogh/episk.aspx.

63 http://www.nationalopera.gr/en/education.
} 


\section{Nauczyciele przedmiotów artystycznych i kulturalnych}

W Grecji kształcenie nauczycieli przedmiotów zintegrowanych dla szkół podstawowych odbywa się na poziomie uniwersyteckim (głównie w wyższych szkołach pedagogicznych), które kończą się uniwersyteckim tytułem zawodowym. Nauczyciele szkół średnich po ukończeniu czteroletnich studiów uzyskują uniwersytecki tytuł zawodowy w dziedzinie odpowiadającej przedmiotowi, którego uczą. Podjęcie pracy w zawodzie w szkołach państwowych (podstawowych i średnich) jest poprzedzone przystąpieniem do egzaminów konkursowych organizowanych przez Wysoką Radę ds. Rekrutacji Urzędników Służby Cywilnej -

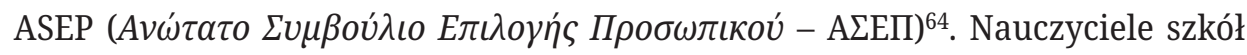
sektora publicznego zatrudnieni na wszystkich poziomach edukacyjny mają status urzędników służby cywilnej.

Edukacja artystyczna i kulturalna (edukacja estetyczna) w greckim szkolnictwie podstawowym (ISCED 1) realizowana jest przez nauczycieli przedmiotów zintegrowanych. Program kształcenia nauczycieli przedmiotów zintegrowanych przewiduje fakultatywny wybór przedmiotów artystycznych: sztuki plastyczne, muzyka, teatr lub taniec. W szkole podstawowej lekcje prowadzone są przez nauczycieli przedmiotów zintegrowanych, dla których często edukacja estetyczna jest specjalnością dodatkową. Nauczyciele w szkole średniej są to nauczyciele jednego lub kilku przedmiotów, więc w wypadku wyboru specjalności, np. w przedmiotach sztuk wizualnych i muzyki, obowiązkowymi obszarami pedagogicznego kształcenia będą: rozwój dziecka przez sztukę, program przedmiotów artystycznych, dydaktyka sztuki, historia sztuki, osobiste umiejętności artystyczne.

Wszyscy nauczyciele przedmiotów zintegrowanych oraz przedmiotów artystycznych, aby uzyskać prawo do nauczania, muszą uzyskać zawodowe uprawnienia pedagogiczne związane z nauczanymi przedmiotami artystycznymi.

Zawodowi artyści, ludzie sztuki i kultury, którzy chcieliby nauczać w szkole edukacji estetycznej lub innych specjalistycznych przedmiotów artystycznych muszą ukończyć odpowiednie szkolenie dające uprawnienia dydaktyczno-pedagogiczne. Wyjątkiem są muzycy z dyplomem ukończenia konserwatorium, którzy mogą uczyć w państwowych szkołach podstawowych bez posiadania formalnych uprawnień pedagogicznych.

64 https://www.asep.gr/asep/site/home.csp. 


\section{Hiszpania}

\section{Organizacja i struktura obowiq̨zkowej edukacji publicznej}

Obowiązek szkolny trwa 10 lat. Kształcenie jest obowiązkowe dla uczniów w wieku od 6 do 16 roku życia.

Szczeble kształcenia objęte obowiązkiem szkolnym to:

- Szkoła podstawowa (Educación Primaria) (ISCED 1) - wiek: 6-12 lat,

- Szkoła średnia I stopnia (Educación Secundaria Obligatoria, ESO) (ISCED 2) wiek: 12-16 lat.

Kształcenie obowiązkowe dzieli się na dwa poziomy: kształcenie na poziomie podstawowym, składające się z trzech dwuletnich etapów, oraz kształcenie na poziomie średnim I stopnia, trwające 4 lata.

Naukę w szkole podstawowej mogą rozpocząć dzieci, które ukończyły 6 lat. Jeśli liczba kandydatów jest większa niż liczba miejsc, stosuje się określone kryteria przyjęć (dochód w rodzinie, rejon szkoły i rodzeństwo w szkole). Przejście ze szkoły podstawowej do szkoły średniej I stopnia odbywa się automatycznie. Kształcenie obowiązkowe jest bezpłatne zarówno w placówkach publicznych, jak i placówkach prywatnych finansowanych ze środków publicznych.

W Hiszpanii obowiązuje zdecentralizowany model administracji oświatowej, według którego odpowiedzialność za oświatę jest podzielona między państwo, wspólnoty autonomiczne, administrację lokalną i szkoły. Władze centralne zachowały odpowiedzialność tylko w zakresie ogólnych uregulowań oświatowych, a większość zadań została w 1978 roku przekazana 17 samorządom regionalnym (wspólnotom autonomicznym).

Do zadań centralnych władz oświatowych należy: ogólna organizacja systemu oświaty, ustalenie podstawowych wymagań dla szkół, podstawa programowa, ogólne plany kształcenia i regulacje dla kwalifikacji zawodowych i akademickich, podstawy programowe gwarantujące prawo i obowiązek sprawnego posługiwania się językiem hiszpańskim, międzynarodowa współpraca w obszarze edukacji.

Do zadań wspólnot autonomicznych należy: oświatowa odpowiedzialność administracyjna w obrębie ich terytoriów, tworzenie, autoryzacja i zarządzanie szkołami, wdrażanie państwowych regulacji dotyczących programów nauczania i regulacja poziomów, gałęzi, ocen i specjalizacji, poradnictwo i wsparcie dla uczniów, zarządzanie kadrą, inspekcja kształcenia, nadzór nad podręcznikami i innymi materiałami dydaktycznymi, ocena diagnostyczna w szkołach. 
Do zadań administracji lokalnej należy: utrzymywanie i renowacja przedszkoli, szkół podstawowych, planowanie zajęć ponadprogramowych i uzupełniających, monitorowanie kształcenia obowiązkowego, tworzenie rad szkoły w obrębie gminy.

Do zadań placówki szkolnej należy: organizacja procesu wychowawczego i dydaktycznego szkoły, dystrybucja przypisanych środków finansowych, dostosowanie działań wychowawczych do potrzeb uczniów i do specyfiki środowiska szkolnego. Szkoły są autonomiczne w sprawach organizacyjnych, edukacyjnych i finansowych.

Programy nauczania tworzy się na trzech poziomach: centralnym (krajowa podstawa programowa), wspólnot autonomicznych (przystosowanie do uwarunkowań historycznych, kulturowych, społecznych i ekonomicznych wspólnoty), szkolnym (zgodnie z potrzebami klasy).

\section{Nauczanie i ocenianie przedmiotów artystycznych i kulturalnych}

Przedmiotami obowiązkowymi w szkole podstawowej są: środowisko naturalne, społeczne i kulturalne, edukacja artystyczna, wychowanie fizyczne, język hiszpański z literaturą, drugi język urzędowy wraz z literaturą wspólnoty autonomicznej, język obcy i matematyka, wychowanie obywatelskie i prawa człowieka. Czytanie ze zrozumieniem, wypowiadanie się ustne i pisemne, komunikacja audiowizualna, technologia informacyjna i nauka w zakresie wartości są wprowadzane w ramach wszystkich przedmiotów.

Na poziomie szkoły średniej I stopnia obowiązkowe przedmioty to:

- pierwsze trzy lata nauki: nauki przyrodnicze, wiedza o społeczeństwie, geografia i historia, język hiszpański z literaturą, drugi język urzędowy wraz z literaturą wspólnoty autonomicznej, język obcy, matematyka, wychowanie obywatelskie i prawa człowieka (tylko 1 rok nauki), wychowanie fizyczne, edukacja plastyczna i wizualna, muzyka i technika. Dodatkowo podczas tych trzech lat uczniowie muszą wybrać przedmiot z fakultatywnego zestawu, który musi zawierać drugi język obcy i kulturę klasyczną.

- czwarty rok nauki: geografia i historia, język hiszpański z literaturą, drugi język urzędowy wraz z literaturą wspólnoty autonomicznej, matematyka i pierwszy język obcy, wiedza o społeczeństwie, etyka i wychowanie obywatelskie, wychowanie fizyczne. Dodatkowo uczniowie muszą wybrać trzy z następujących przedmiotów: fizyka i chemia, informatyka, biologia i geologia, drugi język obcy, technika, edukacja plastyczna i wizualna, łacina, muzyka. 
Uczniowie mogą także wybrać jeden lub więcej przedmiotów opcjonalnych, zgodnie z ustaleniami danej wspólnoty autonomicznej.

Metody dydaktyczne są ustalane na poziomie szkoły przez zespoły nauczycieli. Nauczyciele mają dowolność w wyborze podręczników i innych materiałów dydaktycznych.

Wśród celów i zadań przedmiotów artystycznych i kulturalnych dla szkolnictwa poziomu ISCED 1 i 2 hiszpańskie programy wskazują m.in. na: umiejętności artystyczne, przekazanie wiedzy i jej zrozumienie, umiejętność dokonania interpretacji krytycznej dzieła, świadomość dziedzictwa kulturowego, umożliwienie indywidualnej ekspresji artystycznej, rozumienie różnorodności kulturowej. Wśród celów nauczania bezpośrednio związanych ze sztuką hiszpańskie programy akcentują stworzenie uczniowi możliwości zetknięcia się z różnymi doświadczeniami i różnymi sposobami artystycznego wyrazu oraz wyrobienie umiejętności wykonywania lub prezentowania dzieła.

W Hiszpanii edukacja artystyczna i kulturalna na poziomie szkoły podstawowej jest prowadzona w ramach zintegrowanego nauczania różnych dziedzin sztuki i kultury, a przedmiot nazywany jest sztuki plastyczne i wizualne. Na poziomie szkoły średniej nauczanie ma charakter przedmiotowy.

W programie hiszpańskiej szkoły w obszarze edukacji artystycznej i kulturalnej znalazły się następujące przedmioty:

- w ramach przedmiotów obowiązkowych: sztuki plastyczne, muzyka, teatr, sztuki medialne,

- w ramach przedmiotów łączonych z innym nieartystycznym przedmiotem: taniec,

- w ramach fakultetów: rękodzieło (ISCED 2) i teatr.

Minimalna liczba godzin przeznaczonych na przedmioty obowiązkowe z dziedziny edukacji artystycznej i kulturalnej w szkole podstawowej w ciągu roku wynosi 55 godzin. W szkole średniej I stopnia - 65 godzin. Wyznaczone wielkości odpowiadają krajowemu minimum programowemu, które obejmuje tylko 45-55\% godzin. 0 ewentualnym zwiększeniu liczby godzin decydują władze wspólnot autonomicznych. Podobnie jak w innych krajach, także w Hiszpanii edukacja artystyczna i kulturalna realizowana jest jako kształcenie interdyscyplinarne $\mathrm{w}$ formie ścieżek międzyprzedmiotowych, które tworzone są przez łączenie przedmiotów artystycznych z innymi przedmiotami. Jednym z celów takiego podejścia jest nabycie przez uczniów ogólnych kompetencji artystycznych i kulturalnych. Obowiązkowym elementem wspomagającym edukację artystyczną i kulturalną jest stosowanie technologii informacyjno-komunikacyjnych (TIK) tak w szkole podstawowej, jak i średniej, a jednym z celów wskazanych dla tych 
przedmiotów jest umiejętność wykorzystywania środków audiowizualnych i TIK do dokonywania obserwacji, szukania informacji, dopracowywania własnych wytworów plastycznych, wizualnych i muzycznych.

Z przedmiotów artystycznych uczniowie podlegają ocenianiu kształtującemu i sumującemu. Brak jest centralnie określonych kryteriów. Kryteria oceniania postępów w nauce z tych przedmiotów opartych na wyznaczonych celach lub umiejętnościach opracowują sami nauczyciele - indywidualnie lub jako grono pedagogiczne. Należy zwrócić uwagę, że uzyskanie oceny niedostatecznej z przedmiotów artystycznych nie ma wpływu na promocję ucznia z klasy do klasy.

W Hiszpanii na poziomie szkoły podstawowej (Educación Primaria) przy ocenianiu postępów ucznia nauczyciele stosują werbalną skalę ocen. Na poziomie szkoły podstawowej nauczyciele oceniają postęp uczniów we wszystkich obszarach w całościowy i ciągły sposób. Promocja jest automatyczna wewnątrz każdego z cykli szkoły podstawowej, jednak, by przejść do następnego cyklu, uczeń musi spełniać cele programowe dla danego cyklu. Uczniowie, którzy otrzymają promocję do następnego cyklu, mimo negatywnej oceny w jednym lub większej liczbie obszarów, muszą otrzymać odpowiednie wsparcie dydaktyczne w celu nadrobienia zaległości.

Tabela 14. Skala ocen stosowana w szkole podstawowej w Hiszpanii w odniesieniu do polskiego systemu oceniania

\begin{tabular}{|c|l|l|}
\hline \multicolumn{2}{|c|}{ Hiszpański system oceniania } & \multicolumn{1}{c|}{ Polski system oceniania } \\
\hline symbol & \multicolumn{1}{|c|}{ ocena i opis } \\
\hline SB & wybitny (sobresaliente) & 6 (celujący) \\
\hline NT & bardzo dobry (notable) & 5 (bardzo dobry) \\
\hline BI & dobry (bien) & 4 (dobry) \\
\hline SU & wystarczający (suficiente) & 3 (dostateczny) \\
\hline IN & niewystarczający (insuficiente) & 1 (niedostateczny) \\
\hline
\end{tabular}

Źródło: opracowanie własne.

Na poziomie szkoły średniej I stopnia (Educación Secundaria Obligatoria) stosowana jest liczbowa skala ocen od 10 do 1 . Na tym poziomie ocenianie jest ciągłe i osobne dla każdego przedmiotu. Uczniowie, którzy uzyskali ocenę niedostateczną z trzech lub większej liczby przedmiotów, muszą powtarzać cały rok, ponownie uczęszczając na wszystkie zajęcia. 
Tabela 15. Skala ocen stosowana w szkole średniej w Hiszpanii w odniesieniu do polskiego systemu oceniania

\begin{tabular}{|c|l|l|}
\hline \multicolumn{2}{|c|}{ Hiszpański system oceniania } & \multicolumn{1}{c|}{ Polski system oceniania } \\
\hline skala & \multicolumn{1}{|c|}{ opis } & \multicolumn{1}{c|}{ ocena i opis } \\
\hline $10-9$ & wybitny (sobresaliente) & 6 (celujący) \\
\hline $8-7$ & bardzo dobry (notable) & 5 (bardzo dobry) \\
\hline 6 & dobry (bien) & 4 (dobry) \\
\hline 5 & wystarczający (suficiente) & 3 (dostateczny) \\
\hline $4-1$ & niewystarczający (insuficiente) & 1 (niedostateczny) \\
\hline
\end{tabular}

Źródło: opracowanie własne.

Oprócz zajęć przedmiotowych i interdyscyplinarnych z obszaru edukacji artystycznej i kulturalnej hiszpańskie szkoły realizują programy pozalekcyjnych zajęć artystycznych i kulturalnych. Przykładowo poza kształceniem obowiązkowym istnieje oferta dobrze zorganizowanych specjalistycznych kursów z zakresu muzyki i tańca (Enseñanzas elementales y profesionales de Música y Danza) ${ }^{65}$ skierowana do dzieci objętych obowiązkiem szkolnym. Program składa się z czteroletniego kursu podstawowego dla dzieci w wieku 8 do 12 lat i sześcioletniego kursu na poziomie średniozaawansowanym dla uczniów w wieku od 12 do 18 lat.

Oprócz zajęć i kursów pozalekcyjnych realizowane są projekty współpracy między szkołami i instytucjami kształcenia równoległego (muzea, galerie sztuki, teatry, koncerty), a także rozwijające ideę włączania artystów do projektów szkolnych (przedstawienia, tematyczne wystawy fotografii i malarstwa). Inicjatywy takie ze względu na specyfikę systemu oświatowego Hiszpanii powstają na poziomie wspólnot autonomicznych przy ścisłej współpracy władz lokalnych.

\section{Nauczyciele przedmiotów artystycznych i kulturalnych}

W Hiszpanii kandydat na nauczyciela szkoły podstawowej musi ukończyć studia licencjackie lub magisterskie. Chcąc podjąć pracę w zawodzie, musi uzyskać tytuł nauczyciela ze specjalizacją $\mathrm{w}$ zakresie kształcenia na poziomie szkoły podsta-

65 Información sobre las enseñanzas artísticas de música y danza, http://www.hezkuntza.ejgv. euskadi.eus/contenidos/informacion/dic7/es_2047/adjuntos/informacion_general_musica_ danza_2013_c.pdf. Enseñanzas artísticas de Danza, http://www.mecd.gob.es/educacion-mecd/areas-educacion/sistema-educativo/ensenanzas/ensenanzas-artisticas/danza.html. 
wowej (Maestro en Educación Primaria) ${ }^{66}$. Nauczyciele szkoły podstawowej mają uprawnienia do prowadzenia nauczania zintegrowanego i sprawowania funkcji wychowawcy klasy. Nauczyciele szkoły średniej muszą ukończyć cztero-, pięciolub sześcioletnie studia wyższe. Program studiów przedmiotowych zawiera szkolenie pedagogiczne i dydaktyczne.

Edukacja artystyczna i kulturalna w hiszpańskim szkolnictwie podstawowym (ISCED 1) realizowana jest przez nauczycieli przedmiotów zintegrowanych. Ucząc przedmiotu sztuka, prowadzą zajęcia zintegrowane z teatru, sztuk wizualnych i tańca. Przedmioty muzyka, języki obce i wychowanie fizyczne nauczane są przez nauczycieli przedmiotowych. Nauczyciele muzyki przygotowywani są do wykonywania zawodu w specjalistycznych kolegiach nauczycielskich. Na poziomie szkoły średniej I stopnia (ISCED 2) lekcje prowadzone są przez nauczycieli przedmiotowych. Jednakże często nauczycielami przedmiotów artystycznych są osoby bez specjalistycznego przygotowania lub dla których jest to specjalność dodatkowa.

Wszyscy nauczyciele przedmiotów zintegrowanych oraz przedmiotów artystycznych, aby uzyskać prawo do nauczania, muszą uzyskać zawodowe uprawnienia pedagogiczne związane $\mathrm{z}$ nauczanymi przedmiotami artystycznymi. Zawodowi artyści, ludzie sztuki i kultury, którzy chcieliby nauczać specjalistycznych przedmiotów z dziedziny edukacji artystycznej i kulturalnej, muszą także ukończyć kształcenie dające uprawnienia kwalifikacji pedagogicznych.

\section{Irlandia}

\section{Organizacja i struktura obowiq̨zowej edukacji publicznej}

Obowiązek szkolny trwa 10 lat. Kształcenie jest obowiązkowe dla uczniów w wieku od 6 do 16 roku życia.

Szczeble kształcenia objęte obowiązkiem szkolnym to:

- Szkoła podstawowa (ISCED 1) - wiek: 6-12 lat,

- Szkoły ogólnokształcące lub zawodowe o różnym profilu kształcenia (Community school, Comprehensive school, Vocational school, Voluntary secondary school) (ISCED 2) - wiek: 12-16 lat.

W Irlandii do szkoły przyjmuje się dzieci w wieku od 4 lat (chociaż kształcenie obowiązkowe rozpoczyna się dopiero $\mathrm{w}$ wieku 6 lat). Po ukończeniu szkoły

66 Ley Orgánica 2/2006, de 3 de mayo, de Educación, https://www.boe.es/buscar/act.php?id=BOE-A-2006-7899. 
podstawowej (w wieku 12 lat) uczniowie rozpoczynają naukę w pierwszym cyklu (junior cycle) szkoły średniej. Rodzice mogą wybrać szkołę. Kształcenie jest bezpłatne we wszystkich szkołach z wyjątkiem szkół finansowanych ze środków prywatnych.

Podstawowe zasady prawne dotyczące funkcjonowania oświaty uchwalane są przez parlament, a odpowiedzialność za wdrożenie ich w życie spoczywają na rządzie ${ }^{67}$. Jednolitym systemem oświaty zarządza Ministerstwo Edukacji i Umiejętności (ang. Department of Education and Skills; irl. an Roinn Oideachais agus Scileanna; dalej: Ministerstwo Edukacji ${ }^{68}$. Głównym zadaniem Ministerstwa Edukacji jest organizacja systemu oświaty w taki sposób, aby umożliwić każdemu uczniowi rozwinięcie własnego potencjału intelektualnego, umiejętności, zdolności i talentów. Ponadto realizuje ono zadania związane z wdrażaniem rozwiązań poprawiających skuteczność procesu kształcenia, umożliwiających podnoszenie kwalifikacji i przekwalifikowanie zgodnie z potrzebami zmieniającego się rynku pracy. Do ustawowych zadań Ministerstwa Edukacji należy także całościowe planowanie polityki oświatowej, pozyskiwanie środków oraz zapewnienie szerokiego zakresu usług wsparcia dla sektora edukacji ${ }^{69}$. Wsparciem tym zajmuje się sieć ponad 30 instytucji, agencji, komitetów i wydziałów działających w ramach Ministerstwa Edukacji lub współpracujących z resortem. Są to instytucje zajmujące się m.in. przemocą wobec dzieci (Commission to Inquire into Child Abuse Act, CICA), finansowaniem oświaty (Education Finance Board, EFB), szkolnictwem wyższym oraz badaniami w różnych dziedzinach nauki (Higher Education Authority, HEA), wymianą i współpracą międzynarodową (Léargas - The Exchange Bureau), poradnictwem edukacyjnym (National Centre for Guidance in Education, NCGE), szkolnictwem zawodowym (Vocational Education Committees, VECs), stypendiami i grantami (Student Grants Appeals Board), transportem szkolnym (School Transport Appeals Board) itd.

Rolę doradczą i kontrolną nad całością działań Ministerstwa Edukacji pełni ministerialny Inspektorat (Inspectorate ${ }^{70}$. Inspektorat odpowiedzialny jest za ocenę szkół podstawowych, średnich oraz ośrodków kształcenia i doskonalenia zawodowego. Inspektorzy to doświadczeni nauczyciele, z których wielu peł-

67 W opracowaniu przedstawiono informację na temat systemu edukacyjnego Irlandii. W informacji wykorzystano materiały uzyskane za pośrednictwem Sieci Informacji o Edukacji w Europie (Eurydice), materiały otrzymane z Ambasady Irlandii w Warszawie oraz dostępne na stronach internetowych irlandzkich instytucji oświatowych. http://www.education.ie/en. Education Act, 1998, http://www.irishstatutebook.ie/eli/1998/act/51/enacted/en/html. 
niło wcześniej funkcje dyrektorów szkół, doradców metodycznych, ekspertów w dziedzinie projektowania programów nauczania, wdrażania innowacji dydaktycznych lub prowadzenia badań edukacyjnych. Do zadań Inspektoratu należy:

- przeprowadzanie wizytacji w szkołach i ośrodkach kształcenia,

- dokonywanie ewaluacji pracy krajowych placówek edukacyjno-wychowawczych,

- doradztwo metodyczno-wychowawcze,

- promowanie języka irlandzkiego oraz dobrych praktyk edukacyjnych,

- publikowanie sprawozdań z przeprowadzonych kontroli,

- przygotowywanie raportów na temat programów nauczania, metod dydaktycznych i rozwiązywania problemów wychowawczych,

- upowszechnianie informacji na temat polityki edukacyjnej ministerstwa ${ }^{71}$.

\section{Nauczanie i ocenianie przedmiotów artystycznych i kulturalnych}

Główne wytyczne programów nauczania przedmiotów artystycznych i kulturalnych tworzone są na poziomie centralnym oświaty, a kwestie zakresu realizacji oraz metod pozostają w gestii nauczycieli.

Wśród celów i zadań przedmiotów artystycznych i kulturalnych dla szkolnictwa poziomu ISCED 1 i 2 irlandzkie programy wskazują m.in. na: umiejętności artystyczne, przekazanie wiedzy i jej zrozumienie, umiejętność dokonania interpretacji krytycznej dzieła, świadomość dziedzictwa kulturowego, umożliwienie indywidualnej ekspresji artystycznej, rozumienie różnorodności kulturowej. Wśród celów nauczania bezpośrednio związanych ze sztuką irlandzkie programy akcentują stworzenie uczniowi możliwości zetknięcia się z różnymi doświadczeniami i różnymi sposobami artystycznego wyrazu oraz wyrobienie umiejętności wykonywania lub prezentowania dzieła.

W Irlandii w programach nauczania wśród przedmiotów związanych z edukacją artystyczną i kulturalną znalazły się:

- w ramach przedmiotów obowiązkowych: sztuki plastyczne i muzyka (ISCED 1),

- $\quad$ w ramach przedmiotów łączonych z innym nieartystycznym przedmiotem: taniec (z WF), sztuki medialne,

- w ramach fakultetów: sztuki plastyczne i muzyka (ISCED 2), rękodzieło (ISCED 1), taniec, teatr.

71 http://www.education.ie/en/The-Department/Management-Organisation/Inspectorate.html\#sthash.foXmqRau.dpuf. 
Minimalna roczna liczba godzin przeznaczonych na przedmioty obowiązkowe z dziedziny edukacji artystycznej i kulturalnej w pierwszych dwóch latach nauki w szkole podstawowej wynosi 92 godzin, a w kolejnych sześciu latach nauki (4 lata w szkole podstawowej i 2 lata w szkole średniej) wynosi 110 godzin. Liczba godzin przewidziana jest nie na poszczególne lata nauki, a na osiem lat nauki obowiązkowej ogółem. Wynika to z możliwości indywidualnego kształtowania przez nauczycieli sposobu realizacji programu nauczania z jednoczesną możliwością dostosowania liczby godzin do koncepcji dydaktycznej dla poszczególnych przedmiotów w kolejnych latach nauki.

Z przedmiotów artystycznych uczniowie podlegają ocenianiu kształtującemu i sumującemu. Kryteria oceniania postępów w nauce opracowują sami nauczyciele - indywidualnie lub jako grono pedagogiczne. Najczęściej stosują komentarze słowne. Dla przedmiotów artystycznych brak jest jednolitej skali ocen, gdyż w Irlandii uczniowie są oceniani według określonych kryteriów dopiero podczas końcowego egzaminu, który przypada na zakończenie szkoły średniej (ISCED 2). Wtedy to wyznaczana jest skala ocen odnosząca się do różnych poziomów kompetencji. Poszczególne przedmioty, jak i uzyskiwane dyplomy mogą mieć różną skalę ocen.

Poniżej przedstawiono przykładową skalę ocen stosowaną w irlandzkim szkolnictwie średnim ${ }^{72}$.

Tabela 16. Skala ocen stosowana w szkolnictwie w Irlandii w odniesieniu do polskiego systemu oceniania

\begin{tabular}{|c|c|c|c|}
\hline \multicolumn{3}{|c|}{ Irlandzki system oceniania } & Polski system oceniania \\
\hline stopień & skala & opis & ocena i opis \\
\hline$A$ & $100-85,00$ & wspaniały (excellent) & 6 (celujący) \\
\hline B & $84,99-70,00$ & bardzo dobry (very good) & 5 (bardzo dobry) \\
\hline C & $69,99-55,00$ & dobry (good) & 4 (dobry) \\
\hline D & $54,99-40,00$ & satysfakcjonujący (satisfactory) & 3 (dostateczny) \\
\hline E & $39,99-25,00$ & słaby (weak) & 2 (dopuszczający) \\
\hline $\mathrm{F}$ & $24,99-10,00$ & niedostateczny (fail) & 1 (niedostateczny) \\
\hline NG & $9,99-0,00$ & nieklasyfikowany (no grade) & NK (nieklasyfikowany) \\
\hline
\end{tabular}

Źródło: opracowanie własne.

72 Grading System in Ireland, http://www.classbase.com/countries/Ireland/Grading-System. 
Ze względu na dużą swobodę realizacji przez nauczycieli treści programowych edukacja artystyczna i kulturalna realizowana jest najczęściej jako kształcenie interdyscyplinarne $\mathrm{w}$ formie ścieżek międzyprzedmiotowych, które tworzone są przez łączenie różnych dziedzin sztuki z innymi przedmiotami. Dodatkowym wsparciem dla międzyprzedmiotowej dydaktyki jest wykorzystywanie technologii informacyjno-komunikacyjnych (TIK) we wszystkich przedmiotach - w tym w przedmiotach o charakterze artystycznym. Używanie TIK zostało nawet wpisane do programów nauczania przedmiotów artystycznych.

W Irlandii instytucją, która wspiera wykorzystanie TIK w oświacie jest Serwis Rozwoju Zawodowego dla Nauczycieli (Professional Development Service for Teachers, PDST) ${ }^{73}$. Serwis powstał w 2010 roku jako powszechna, zintegrowana i międzysektorowa e-platforma usług wsparcia dla szkół. Utworzenie PDST było synonimem fuzji i restrukturyzacji wielu autonomicznych projektów wykorzystywania w edukacji technologii informacyjno-komunikacyjnych, w tym włączenia do całej struktury Narodowego Centrum Technologii w Edukacji (National Centre for Technology in Education, NCTE) ${ }^{74}$. Serwis dysponuje obecnie w Irlandii największą profesjonalną ofertą TIK dla potrzeb kształcenia dyrektorów szkół i nauczycieli, np. przedmiotów artystycznych i kulturalnych. Szczególnym zainteresowaniem cieszą się wśród uczniów i nauczycieli opracowane w interaktywnej formie elektronicznej treści programowe. Współpracując $\mathrm{z}$ The Ireland Funds ${ }^{75}$, PDST wspiera irlandzką kulturę i dziedzictwo narodowe przez zwiększanie publicznego dostępu do różnych form sztuki i inicjatyw artystycznych.

W ramach pozalekcyjnych działań artystycznych i kulturalnych skierowanych do młodzieży szkolnej placówki organizują wiele zajęć fakultatywnych. Są to inicjatywy wypływające z potrzeb i zainteresowań społeczności lokalnych, więc programy i charakter tych zajęć mogą się różnić od siebie. Najbardziej popularne są zajęcia muzyczne prowadzone często jako gra na instrumentach, śpiew chóralny i taniec. Aktywność uczniów w obszarze edukacji artystycznej w placówkach zewnętrznych zapewniają w Irlandii tzw. urzędy sztuki (Arts Offices), które ułatwiają przygotowanie oferty edukacyjnej dla młodzieży składającej wizytę w muzeach, galeriach sztuki, miejscach zabytkowych itp.

73 http://pdst.ie.

74 http://www.asti.ie/operation-of-schools/outside-agencies/national-centre-for-technology-in-education.

75 https://www.theirelandfunds.org/irish-culture-heritage. 


\section{Nauczyciele przedmiotów artystycznych i kulturalnych}

Zawód nauczyciela w Irlandii jest zawodem regulowanym, a nauczyciele mają status urzędników państwowych. Od roku szkolnego 2012/2013 każda osoba wykonująca ten zawód musi być zarejestrowana w Radzie ds. Nauczania (Teaching


dardy zawodowe w nauczaniu, weryfikuje przygotowanie merytoryczne nauczycieli i ich kwalifikacje zawodowe oraz dba o prestiż zawodu nauczyciela. W Irlandii funkcjonują dwa modele kształcenia nauczycieli - czteroletni i sześcioletni ${ }^{77}$. Pierwszy z nich zakłada jednoczesne zdobywanie kompetencji pedagogicznych i przedmiotowych realizowane w trybie czteroletnich studiów pedagogiczno-przedmiotowych. Ten model przeznaczony jest dla osób planujących podjęcie pracy jako nauczyciel na poziomie szkolnictwa przedpoczątkowego (Early Start Programme) oraz podstawowego (Primary). Drugi model przewiduje etap czteroletnich studiów w ramach wybranego przedmiotu, a następnie dwuletni etap zdobywania kompetencji pedagogicznych na studiach magisterskich. Ten model przeznaczony jest dla przyszłych nauczycieli w szkole średniej I i II stopnia (Junior Cycle i Senior Cycle). Kształcenie nauczycieli dla Primary schools prowadzone jest w kolegiach pedagogicznych (Colleges of Education), które znane są w Irlandii z bardzo wysokich wymagań rekrutacyjnych. Absolwenci kolegiów otrzymują dyplom Bachelor of Education degree (B.Ed.) będący odpowiednikiem dyplomu licencjackiego. Kształcenie nauczycieli dla szkolnictwa średniego odbywa się w uniwersytetach w trybie studiów dwustopniowych (licencjat i magisterium) zakończonych dyplomem magisterskim (Master).

Edukacja artystyczna i kulturalna w szkole podstawowej najczęściej realizowana jest przez nauczycieli przedmiotów zintegrowanych, ale w niewielkiej liczbie szkół dyrektorzy zatrudniają także nauczycieli (przedmiotowych) do prowadzenia konkretnych przedmiotów, jak teatr i muzyka. W programie kształcenia przyszłych nauczycieli przedmiotów zintegrowanych obowiązkowymi przedmiotami są: sztuki plastyczne, muzyka, teatr, taniec i sztuki wizualne. Jednym z warunków koniecznych do pomyślnego zakończenia studiów jest zademonstrowanie umiejętności w tych dziedzinach.

W programie kształcenia nauczycieli przedmiotowych do nauczania przedmiotów artystycznych w szkole średniej, oprócz wybranych dziedzin studiów, obowiązkowym kursem są sztuki wizualne i muzyka.

7639 http://www.teachingcouncil.ie.

77 D. Dziewulak, System szkolny Irlandii, „Analizy BAS” 2014, nr 14(118). 
Zawodowi artyści, ludzie sztuki i kultury, którzy chcieliby nauczać w szkole specjalistycznych przedmiotów z dziedziny edukacji artystycznej i kulturalnej muszą ukończyć studia lub odpowiednie szkolenie dające uprawnienia dydaktyczno-pedagogiczne.

\section{Niemcy}

\section{Organizacja i struktura obowiqzkowej edukacji publicznej}

W Niemczech długość trwania obowiązku szkolnego zależna jest od landu i rodzaju kształcenia. Kształcenie w pełnym wymiarze jest obowiązkowe dla uczniów od 6 do 15 lub 16 roku życia, a kształcenie w niepełnym wymiarze obowiązuje od 6 do 18 roku życia ${ }^{78}$.

Obowiązek szkolny obejmuje następujące szczeble kształcenia:

- Szkoła podstawowa (Grundschule) (ISCED 1) - wiek: 6-10 lat (6-12, Berlin i Brandenburgia),

- Szkoły średnie I stopnia (Orientierungsstufe - tzw. faza orientacji w różnych rodzajach szkół lub jako odrębna jednostka organizacyjna) (ISCED 2) - wiek: 10-12 lat,

- Szkoły średnie I stopnia Gymnasium, Realschule, Hauptschule, Gesamtschule (rodzaje szkół prowadzące kilka cykli kształcenia) (ISCED 2) - wiek: 10/1215/16 lat,

- Szkoły średnie II stopnia (ISCED 3) - wiek: 15/16-18/19 lat.

Na ogół uczniów przyjmuje się do Grundschule od 6 lat. Dzieci objęte obowiązkiem nauki szkolnej wstępują do jednakowej dla wszystkich lokalnej szkoły podstawowej. Przejście ze szkoły podstawowej do jednej z kilku rodzajów szkół średnich odbywa się zgodnie z różnymi przepisami, zależnie od ustawodawstwa danego kraju związkowego (landu). 0 wyborze szkoły średniej I stopnia decydują rodzice z dziećmi, na podstawie oceny dokonanej przez szkołę podstawową. Przyjęcie do różnych szkół średnich może być uzależnione od wyników w nauce

78 Kształcenie w pełnym wymiarze jest obowiązkowe w wieku od 6 do 15 lat w większości landów (Badenia-Wirtembergia, Bawaria, Hamburg, Hesja, Meklemburgia-Pomorze Przednie, Dolna Saksonia, Nadrenia Północna-Westfalia w Gymnasium, Nadrenia-Palatynat, Saara, Saksonia, Saksonia-Anhalt, Szlezwik-Holsztyn) lub 16 lat (Berlin, Brandenburgia, Brema, Nadrenia Północna-Westfalia w innych typach szkół poza Gymnasium, Turyngia), a kształcenie w niepełnym wymiarze jest obowiązkowe do wieku 18 lat dla osób, które nie uczęszczają do szkoły w pełnym wymiarze. 
i/lub decyzji władz edukacyjnych. Kształcenie obowiązkowe jest w całości bezpłatne.

W Niemczech zgodnie z Ustawą Zasadniczą (Grundgesetz) ${ }^{79}$ i wynikająca z niej federalną strukturą państwa odpowiedzialność za oświatę została rozdzielona pomiędzy władze federalne i kraje związkowe (landy). Koordynacja spraw oświatowych między landami i władzami centralnymi odbywa się w ramach Stałej Konferencji Ministrów Edukacji i Kultury, Nauki i Oświaty Krajów Związkowych Republiki Federalnej Niemiec (Kultusministerkonferenz, KMK; dalej: Stała Konferencja ${ }^{80}$.

Zadania rządu federalnego w dziedzinie edukacji obejmują m.in. ustanawianie przepisów wyznaczających ogólne ramy współpracy oświatowej pomiędzy szczeblem federalnym i landami, np. w zakresie planowania edukacji i promowania badań. Za ustawodawstwo i administrację oświatową odpowiadają przede wszystkim landy oraz władze nadzorujące szkoły na niższym administracyjnym szczeblu (Schulamt). Ministerstwa edukacji w landach odpowiedzialne są za ustalanie programów nauczania, zalecanie metod nauczania i zatwierdzanie do użytku szkolnego pomocy i podręczników. Programy i treści nauczania opracowywane są w taki sposób, aby spełniały kryteria zawarte w przyjętych przez Stałą Konferencję krajowych standardach kształcenia.

\section{Nauczanie i ocenianie przedmiotów artystycznych i kulturalnych}

Do przedmiotów nauczanych w szkole podstawowej należą: czytanie, pisanie, arytmetyka, wprowadzenie do przedmiotów przyrodniczych i społecznych, wychowanie plastyczne, wychowanie muzyczne, wychowanie fizyczne i religia. Programy nauczania na poziomie szkolnictwa średniego I stopnia zależą od rodzaju i typu placówki, ale zazwyczaj stanowią kontynuację przedmiotów ze szkoły podstawowej i obejmują co najmniej jeden język obcy oraz przedmioty przyrodnicze i społeczne. W programach szkolnictwa średniego II stopnia obowiązkowo znajdują się przedmioty z następujących trzech grup: 1) języki, literatura, przedmioty humanistyczne, 2) przedmioty społeczne oraz 3) matematyka, przedmioty przyrodnicze, technika. Programy kształcenia zawodowego w szkołach o profilu zawodowym obejmują język niemiecki, przedmioty społeczne, matematykę, przedmioty przyrodnicze, język obcy i wychowanie fizyczne oraz przedmioty zawodowe.

79 https://www.bundestag.de/grundgesetz.

80 https://www.kmk.org. 
Wśród celów i zadań przedmiotów artystycznych i kulturalnych dla szkolnictwa poziomu ISCED 1 i ISCED 2 niemieckie programy wskazują m.in. na: umiejętności artystyczne, przekazanie wiedzy i jej zrozumienie, umiejętność dokonania interpretacji krytycznej dzieła, świadomość dziedzictwa kulturowego, umożliwienie indywidualnej ekspresji artystycznej, rozumienie różnorodności kulturowej. Wśród celów nauczania bezpośrednio związanych ze sztuką niemieckie programy akcentują stworzenie uczniowi możliwości zetknięcia się z różnymi doświadczeniami i różnymi sposobami artystycznego wyrazu, wyrobienie umiejętności wykonywania lub prezentowania dzieła oraz wpojenie zainteresowania sztuką na całe życie.

W niemieckich landowych programach nauczania wśród konkretnych przedmiotów w obszarze edukacji artystycznej i kulturalnej znalazły się:

- $\quad$ w ramach przedmiotów obowiązkowych: sztuki plastyczne, muzyka, rękodzieło,

- $\quad$ w ramach przedmiotów łączonych z innym nieartystycznym przedmiotem: sztuki medialne,

- w ramach fakultetów: teatr, taniec ${ }^{81}$.

Minimalna roczna liczba godzin przeznaczonych na przedmioty obowiązkowe z dziedziny edukacji artystycznej i kulturalnej w pierwszych dwóch latach nauki na poziomach ISCED 1 wynosi 100 godzin rocznie, w kolejnych czterech 110 godzin rocznie, a na poziomie szkoły średniej I stopnia (Gymnasium, Realschule, Hauptschule) -60 godzin rocznie.

W Niemczech nie ma odgórnych kryteriów oceniania postępów w nauce $\mathrm{w}$ przedmiotach artystycznych. Kryteria takie opracowują sami nauczyciele - indywidualnie lub jako grono pedagogiczne. Na wszystkich poziomach powszechną praktyką jest ocena ciągła, prowadzona na podstawie wypowiedzi pisemnych i ustnych. W większości przypadków oceny dokonuje nauczyciel. W szkole podstawowej uczniowie są automatycznie promowani z klasy I do II. Od II klasy szkoły podstawowej uczniowie, w zależności od osiągnięć (wyników w nauce) mogą być promowani bądź powtarzać klasę. Decyzja o promocji ucznia jest podejmowana na podstawie stopni, jakie uczeń otrzymuje na koniec roku szkolnego (odnotowywanych na świadectwie Zeugnis). Decyzję podejmują nauczyciele uczący danego ucznia (Klassenkonferenz) lub rada pedagogiczna, czyli wszyscy nauczyciele danej szkoły (Lehrerkonferenz). Decyzja o promocji lub jej braku jest odnotowywana na świadectwie. Uczniowie, którzy

81 Taniec prowadzony jest w 62 szkołach podstawowych w Nadrenii Północnej-Westfalii. 
osiągnęli zadowalający poziom na zakończenie nauki w szkole średniej I stopnia, otrzymują świadectwo ukończenia szkoły (Hauptschulabschluss i Mittlerer Schulabschluss).

W Niemczech nauczyciele na poziomie ISCED 1 i ISCED 2 stosują przy ocenianiu postępów ucznia z przedmiotów artystycznych i kulturalnych liczbową skalę ocen od 1 (bardzo dobry) do 5 (niedostateczny).

Tabela 17. Skala ocen stosowana w szkolnictwie podstawowym w Niemczech w odniesieniu do polskiego systemu oceniania

\begin{tabular}{|c|l|l|}
\hline \multicolumn{2}{|c|}{ Niemiecki system oceniania } & \multicolumn{1}{c|}{ Polski system oceniania } \\
\hline stopień & \multicolumn{1}{c|}{ ocena i opis } \\
\hline 1 & bardzo dobry (sehr gut) & 5 (bardzo dobry) \\
\hline 2 & dobry (gut) & 4 (dobry) \\
\hline 3 & dostateczny (befriedigend) & 3 (dostateczny) \\
\hline 4 & dopuszczający (ausreichend) & 2 (dopuszczający) \\
\hline 5 & niedostateczny (mangelhaft) & 1 (niedostateczny) \\
\hline
\end{tabular}

Źródło: opracowanie własne.

Ze względu na duże zróżnicowanie typów szkół i stosowanych w nich metodach nauczania charakterystyczną cechą szkolnictwa niemieckiego jest to, że edukacja artystyczna i kulturalna realizowana jest jako kształcenie interdyscyplinarne i jako kształcenie przedmiotowe. W szkole podstawowej nauczyciele najczęściej korzystają ze ścieżek międzyprzedmiotowych, które tworzone są przez łączenie przedmiotów artystycznych z innymi przedmiotami. W szkołach średnich kształcenie artystyczne i kulturalne odbywa się w formie zajęć przedmiotowych. W niektórych landach przedmioty z dziedziny edukacji artystycznej umieszcza się w planach nauczania, tak aby przeplatać konkretne przedmioty. Przykładowo w jednym roku nauki sztuki wizualne, w następnym muzyka, i w kolejnym znowu sztuki wizualne.

Oprócz zajęć przedmiotowych i interdyscyplinarnych z obszaru edukacji artystycznej i kulturalnej niemieckie szkoły realizują program wizyt uczniów w miejscach związanych z kulturą. W niektórych landach wybrane muzea jako zachętę oferują jeden dzień w tygodniu z bezpłatnym wejściem dla grup szkolnych. 


\section{Nauczyciele przedmiotów artystycznych i kulturalnych}

Edukacja artystyczna i kulturalna w niemieckim szkolnictwie podstawowym (ISCED 1) realizowana jest przez nauczycieli przedmiotów zintegrowanych. Na poziomie szkoły średniej I stopnia przedmioty artystyczne prowadzone są przez nauczycieli przedmiotowych jednakże często nauczycielami przedmiotów artystycznych są osoby, dla których jest to specjalność dodatkowa.

Nauczyciele w szkołach publicznych zatrudniani są przez władze oświatowe landu i z reguły mają status urzędnika państwowego. Kształcenie nauczycieli szkół podstawowych i średnich odbywa się na uniwersytetach oraz w kolegiach sztuk pięknych lub kolegiach muzycznych. Na zakończenie studiów zdają państwowy egzamin (Staatsprüfung) na ogół złożony z dwóch dziedzinowych przedmiotów kierunkowych i z pedagogiki. Zgodnie z uzgodnieniami Stałej Konferencji Ministrów Edukacji i Kultury dyplomy są uznawane wzajemnie przez kraje związkowe. Nauczyciele w szkołach podstawowych są nauczycielami przedmiotów zintegrowanych, a w szkołach średnich - nauczycielami przedmiotowymi.

\section{Wielka Brytania}

\section{Organizacja i struktura obowiq̨zkowej edukacji publicznej}

Struktura organizacyjna systemu szkolnego Wielkiej Brytanii nie jest jednolita. Administracja szkolna jest zdecentralizowania, a zarządzanie i odpowiedzialność za kształt i funkcjonowanie oświaty spoczywa w rękach władzy centralnej i lokalnej każdego spośród czterech części składowych (constituent part) kraju Anglii, Walii, Szkocji i Irlandii Północnej. Struktury oświatowe Anglii i Walii są relatywnie podobne, natomiast systemy szkolne Szkocji i Irlandii Północnej regulowane są odrębnymi ustawami. Występują w nich inne typy szkół, inne programy i odmienne organizacje pracy szkolnej.

\section{Anglia}

W Anglii kształcenie jest obowiązkowe dla uczniów w wieku od 5 do 16 lat, ale wiele dzieci rozpoczyna naukę już w klasie zerowej (reception) szkoły podstawowej w wieku 4 lat.

Obowiązek szkolny obejmuje następujące szczeble kształcenia: 
- Szkolnictwo podstawowe (primary education) (ISCED 1) - wiek: 5-11 lat,

- Szkolnictwo średnie I stopnia (secondary education) (ISCED 2) - wiek: 11-16 lat. Program kształcenia obowiązkowego jest podzielony na tzw. kluczowe etapy - KS (key stages):

- KS1 (wiek: 5-7 lat),

- KS2 (wiek: 7-11 lat),

- KS3 (wiek: 11-14 lat),

- KS4 (wiek: 14-16 lat).

Większość uczniów przechodzi ze szkoły podstawowej (primary school) do szkoły średniej (secondary school) w wieku 11 lat, choć w niektórych regionach Anglii uczniowie uczęszczają do middle school w wieku, odpowiednio - od 8 lub 9 roku życia do 12 lub 13 roku życia. Wiele szkół średnich I stopnia prowadzi również kształcenie na poziomie średnim II stopnia dla uczniów będących w wieku powyżej 16 lat.

W Anglii za organizację oświaty odpowiadają Ministerstwo Edukacji (Department for Education, DfE) $)^{82}$ oraz Ministerstwo ds. Biznesu, Innowacji i Umiejętności (Department for Business, Innovation and Skills, BIS) ${ }^{83}$. Do obowiązków DfE należą: planowanie i monitorowanie organizacji edukacji w szkołach, zapewnianie zintegrowanych usług dla najmłodszych oraz koordynacja polityki dotyczącej dzieci i młodzieży. Natomiast BIS jest odpowiedzialne za kształcenie ustawiczne, innowacje, szkolnictwo wyższe i działalność gospodarczą. Ponadto kontrolę nad usługami realizowanymi na rzecz dzieci, szkół, kolegiów, systemu kształcenia nauczycieli, kształcenia w miejscu pracy i edukacji dorosłych sprawuje pozaresortowa rządowa instytucja: Urząd ds. Standardów Kształcenia, Usług na rzecz Dzieci i Umiejętności (Office for Standards in Education, Children's Services and Skills, Ofsted $)^{84}$.

Na szczeblu lokalnym organizacją kształcenia w szkołach finansowanych ze środków publicznych zajmują się 152 organy lokalnych władz różnego szczebla. Ramy prawne dla dotowanych szkół podstawowych i średnich dzielą je na szkoły lokalne (community schools), szkoły społeczne (voluntary schools) oraz szkoły fundacyjne (foundation schools). Większość stanowią szkoły lokalne. Wszystkie szkoły posiadają szeroką autonomię organizacyjną.

82 https://www.gov.uk/government/organisations/department-for-education.

83 https://www.gov.uk/government/organisations/department-for-business-innovation-skills .

84 https://www.gov.uk/government/organisations/ofsted. 


\section{Walia}

W Walii kształcenie jest obowiązkowe dla uczniów w wieku od 5 do 16 lat, ale wiele dzieci rozpoczyna naukę już w klasie zerowej szkoły podstawowej w wieku 4 lat.

Obowiązek szkolny obejmuje następujące szczeble kształcenia:

- Szkolnictwo podstawowe (primary education) (ISCED 1) - wiek: 5-11 lat,

- Szkolnictwo średnie I stopnia (secondary education) (ISCED 2) - wiek: 11-16 lat.

Program kształcenia obowiązkowego jest podzielony na tzw. kluczowe etapy - KS (key stages):

- KS1 (wiek: 5-7 lat),

- KS2 (wiek: 7-11 lat),

- KS3 (wiek: 11-14 lat),

- KS4 (wiek: 14-16 lat).

W Walii za organizację oświaty odpowiadają Ministerstwo Edukacji i Umiejętości (Department for Education and Skills, DfES) ${ }^{85}$ oraz Inspektorat Edukacji i Szkolenia w Walii (Inspectorate for Education and Training in Wales, Estyn) ${ }^{86}$. Za całokształt organizacji systemu szkolnictwa odpowiada DfES, a zadaniem Estynu jest zapewnienie niezależnej służby kontroli oraz doradztwa w sprawie jakości i standardów funkcjonowania walijskich placówek szkolnych.

Organizacją kształcenia na poziomie lokalnym zajmują się powołane do tego 22 oświatowe jednostki władz lokalnych. Ich podstawowymi zadaniami są: zapewnienie odpowiedniej liczby miejsc w szkołach, zapewnienie wysokich standardów wychowawczo-dydaktycznych oraz przeciwdziałanie zjawiskom niepożądanym wśród dzieci i młodzieży.

\section{Szkocja}

Obowiązek szkolny w Szkocji wynosi 11 lat i obejmuje dzieci oraz młodzież w wieku od 5 do 16 roku życia.

Obowiązek szkolny realizowany jest w ramach następujących szczebli kształcenia:

- Szkoła podstawowa (primary school) (ISCED 1) - wiek: 5-12 lat,

- Szkoła średnia I stopnia (secondary school) (ISCED 2) - wiek: 12-16 lat.

85 http://gov.wales/topics/educationandskills/?lang=en.

86 http://www.estyn.gov.wales. 
Program kształcenia obowiązkowego w szkole podstawowej podzielony jest na siedem etapów oznaczanych literą P (primary), a w szkole średniej na cztery etapy - S (secondary): P1 (wiek: 5-6 lat), P2 (wiek: 6-7 lat), P3 (wiek: 7-8), P4 (wiek: 8-9), P5 (9-10), P6 (10-11), P7 (11-12), S1 (12-13),S2 (13-14), S3 (14-15), S4 (15-16).

W Szkocji za ogólny nadzór nad edukacją i rozwojem usług edukacyjnych odpowiada premier Szkocji. W jego imieniu obowiązki te wykonuje Sekretarz ds. Edukacji i Kształcenia Ustawicznego (Secretary for Education \& Lifelong Learning ${ }^{87}$. Jest wspierany przez dwóch ministrów - Ministra ds. Dzieci i Młodzieży (Minister for Children \& Young People) ${ }^{88}$ oraz Ministra ds. Kształcenia, Nauki i Języków Szkocji (Minister for Learning, Science \& Scotland's Languages) ${ }^{89}$. Do ich zadań należy m.in.: organizacja szkolnictwa obowiązkowego, średniego, wyższego oraz kształcenia ustawicznego, poprawa standardów szkolnych jakości poziomu kształcenia, ochrona praw dzieci, dbałość o jakość i kultywowanie tradycji języków Szkocji.

Około 96\% uczniów kształci się w szkołach finansowanych ze środków publicznych. Szkoły niepubliczne nie otrzymują środków publicznych na swoją działalność i nie podlegają lokalnym władzom. Organizacją kształcenia finansowanego ze środków publicznych zajmują się 32 rady terytorialne (unitary councils), szkockie władze lokalne (Local Authorities, SLAs). Odpowiadają za zatrudnianie pracowników szkół, obsługę finansową większości usług edukacyjnych oferowanych przez szkoły oraz za nadzór nad wdrażaniem polityki edukacyjnej rządu. Dyrektorzy szkół administrują budżetem szkół przyznanym przez władze lokalne, kierują i zarządzają szkołą, opracowują program dydaktyczny i wychowawczy szkoły.

System edukacyjny w Szkocji wykształcił wiele instytucji, firm, agencji zajmujących się doradztwem, szkoleniami i konsultacjami dla nauczycieli. Do najważniejszych należą: Education Scotland ${ }^{90}$, Scottish Qualifications Authority ${ }^{91}$, Scottish Council for Research in Education ${ }^{92}$, Scottish Funding Council ${ }^{93}$, General Teaching Council for Scotland ${ }^{94}$. Podmioty te oferują pomoc nauczycielom będą-

87 http://www.gov.scot/About/People/Ministers/Cabinet-Secretary-for-Education-and-Lifelong -Learn.

88 http://www.gov.scot/About/People/Ministers/Minister-for-Children-and-Young-People.

89 http://www.gov.scot/About/People/Ministers/Minister-for-Learning.

90 http://www.educationscotland.gov.uk.

91 http://www.sqa.org.uk/sqa/70972.html.

92 http://www.eep.ac.uk/dnn2/Organizations/SCRE/tabid/86/Default.aspx.

93 http://www.sfc.ac.uk/aboutus/aboutus.aspx.

94 http://www.gtcs.org.uk/home/home.aspx. 
cym w zawodzie i przygotowującym się do podjęcia pracy. Zapewniają porady w sprawach związanych z organizacją nauczania, doborem narzędzi i metod dydaktycznych, dostępnych kursów i szkoleń dla nauczycieli.

\section{Irlandia Północna}

W Irlandii Północnej kształcenie obowiązkowe rozpoczyna się w wieku 4 lat i trwa do 16 roku życia ${ }^{95}$.

Obowiązek szkolny realizowany jest w ramach następujących szczebli kształcenia:

- Szkoła podstawowa (primary school) (ISCED 1) - wiek: 4-11 lat,

- Szkoła średnia I stopnia (secondary school) (ISCED 2) - wiek: 11-16 lat.

Program kształcenia obowiązkowego jest podzielony na tzw. kluczowe etapy - KS (key stages):

- KS1 (wiek: 4-7 lat),

- KS2 (wiek: 7-11 lat),

- KS3 (wiek: 11-14 lat),

- KS4 (wiek: 14-16 lat).

W Irlandii Północnej za organizację systemu oświaty odpowiada Ministerstwo Edukacji (Department of Education, DE) ${ }^{96}$. Za kształcenie ustawiczne i szkolnictwo wyższe odpowiedzialność ponosi Ministerstwo Zatrudnienia i Kształcenia (Department for Employment and Learning, DEL). Na poziomie lokalnym organizacją szkolnictwa zajmują się lokalne jednostki władzy oświatowej, tzw. ELBs (Education and Library Boards).

\section{Nauczanie i ocenianie przedmiotów artystycznych i kulturalnych}

Główne wytyczne programów nauczania przedmiotów artystycznych i kulturalnych tworzone są dla Anglii, Walii i Irlandii Północnej na poziomie centralnym ich administracji oświatowej, a kwestie zakresu realizacji oraz doboru metod pozostawione są gestii nauczycieli. W Szkocji odpowiedzialność za wytyczne rozdzielona została jednakowo pomiędzy centralną i lokalną władzę oświatową.

Wśród celów i zadań przedmiotów artystycznych i kulturalnych dla szkolnictwa poziomu ISCED 1 i ISCED 2 programy Anglii, Walii, Szkocji i Irlandii Północnej

95 Structure of the education system in Northern Ireland 2014-15, https://www.nfer.ac.uk/ nfer/eurydice/publications/structure-diagram-ni.cfm.

96 https://www.deni.gov.uk. 
wskazują na zbieżność celów, m.in. na: umiejętności artystyczne, przekazanie wiedzy i jej zrozumienie, umiejętność dokonania interpretacji krytycznej dzieła, świadomość dziedzictwa kulturowego, umożliwienie indywidualnej ekspresji artystycznej, rozumienie różnorodności kulturowej. Wśród celów nauczania bezpośrednio związanych ze sztuką programy akcentują stworzenie uczniowi możliwości zetknięcia się z różnymi doświadczeniami i różnymi sposobami artystycznego wyrazu oraz wyrobienie umiejętności wykonywania lub prezentowania dzieła.

W Wielkiej Brytanii w programach nauczania wśród przedmiotów związanych z edukacją artystyczną i kulturalną znalazły się:

- w ramach przedmiotów obowiązkowych: sztuki plastyczne i muzyka (Anglia, Walia, Szkocja i Irlandia Płn.), rękodzieło (Anglia, Walia i Irlandia Płn.), teatr (Szkocja),

- w ramach przedmiotów łączonych z innym nieartystycznym przedmiotem: taniec (Anglia, Walia, Szkocja i Irlandia Płn.) i teatr (Anglia, Walia i Irlandia Płn.).

System oceniania osiągnięć szkolnych ucznia w Anglii, Walii, Szkocji i Irlandii Północnej jest zróżnicowany i zależy od wieku i zdolności ucznia, przedmiotu i metody nauczania, poziomu edukacyjnego i systemu oceniania przyjętego przez nauczyciela. W szkołach podstawowych ze względu na charakter pracy szkolnej uczniowie oceniani są w sposób opisowy. Pozwala to zarówno nauczycielom, jak i rodzicom na ocenę tego, co dziecko opanowało, a czego jeszcze nie. W świadectwach szkolnych ocena ma charakter opisowy. W szkole średniej uczniowie podlegają ocenie opisowej i/lub literowej, i/lub liczbowej. Niektórzy nauczyciele oprócz opisowej oceny stosują jeszcze skalę procentową. Inni stosują skalę alfabetyczną od A+ (polska ocena 6) do F (polska ocena 1). W niektórych regionach stosuje się także skalę od 10 do 1, gdzie 10 to ocena celująca, a 1 niedostateczna.

Z przedmiotów artystycznych uczniowie podlegają ocenianiu kształtującemu i sumującemu. W Anglii, Walii i Szkocji kryteria oceniania postępów w nauce przedmiotów artystycznych opracowane zostały przez centralne władze oświatowe tych krajów. W Irlandii Północnej nie ma takich kryteriów. We wszystkich krajach, w których ułożono kryteria oceniania (z wyjątkiem Szkocji), określono skale ocen. W Anglii i Walii program każdego nauczanego przedmiotu artystycznego zawiera ośmiostopniową skalę opisową wiedzy i umiejętności. Skala nie jest ograniczona do wymaganych norm poziomu zrozumienia zagadnień dla określonego wieku ucznia, gdyż celem jest odpowiednie zróżnicowanie dydaktyczne w zależności od możliwości ucznia (indywidualizacja nauczania). 
W Anglii, Walii, Szkocji i Irlandii Północnej szkoły na poziomie ISCED 1 i ISCED 2 mają szeroką autonomię w ustalaniu podziału liczby godzin przedmiotów artystycznych. Władze oświatowe poszczególnych krajów określają wyłącznie minimalną roczną liczbę godzin dydaktycznych, jaką szkoły mogą przeznaczyć dla konkretnego przedmiotu. Wszystkie przedmioty wchodzące w zakres edukacji artystycznej i kulturalnej są w Wielkiej Brytanii obowiązkowe, ale o liczbie godzin dydaktycznych decydują poszczególne szkoły i nauczyciele. Umożliwia to nauczycielom indywidualne kształtowanie sposobu realizacji programu nauczania z jednoczesną możliwością dostosowania optymalnej liczby godzin do koncepcji dydaktycznej poszczególnych przedmiotów w kolejnych latach nauki.

Ze względu na dużą swobodę realizacji przez nauczycieli treści programowych edukacja artystyczna i kulturalna realizowana jest w Szkocji i Irlandii Północnej najczęściej jako kształcenie interdyscyplinarne w formie ścieżek międzyprzedmiotowych, które tworzone są przez łączenie różnych dziedzin sztuki z innymi przedmiotami. W Anglii i Walii różne dziedziny sztuki traktowane są najczęściej jako osobne przedmioty. Dodatkowym wsparciem dla nauczania przedmiotów artystycznych jest wykorzystywanie technologii informacyjno-komunikacyjnych (TIK). Przykładowo w Szkocji wprowadzono projekt The Consolarium $^{97} \mathrm{z}$ przeznaczeniem dla używania gier edukacyjnych przez nauczycieli i uczniów. Innym programem, który bardzo mocno promują i dofinansowują szkockie władze oświatowe, jest kreatywność w edukacji (Creativity in Education) ${ }^{98}$. Celem programu jest pobudzenie młodych ludzi do uruchomienia i wykorzystania własnej kreatywności przez pracę w grupach nad projektami o tematyce artystyczno-kulturalnej. Portal Education Scotland ${ }^{99}$ proponuje nauczycielom, rodzicom i uczniom multimedialne materiały wyjaśniające, czym jest kreatywność w nauce i dlaczego ważne są takie umiejętności we współczesnym świecie. Kreatywność w edukacji przez sztukę i kulturę stała się w Szkocji ważnym kierunkiem rozwoju systemu oświatowego. Inny portal o nazwie Creativity Portal ${ }^{100}$ stanowi bazę twórczych internetowych narzędzi edukacyjnych, przykładów dobrych praktyk pozwalających na wykorzystanie twórczych pomysłów w dziedzinie artystycznej i kulturalnej.

97 http://www.educationscotland.gov.uk/learningandteaching/approaches/ictineducation/gamesbasedlearning/consolarium.asp.

98 http://www.educationscotland.gov.uk/learningandteaching/approaches/creativity.

99 Education Scotland, http://www.educationscotland.gov.uk/learningandteaching/approaches/creativity.

100 http://creativityportal.org.uk. 
W 2013 roku szkockie władze oświatowe przygotowały Plan Kreatywnej Edukacji 2013 (Scotland's Creative Learning Plan 2013) ${ }^{101}$, którego celem jest w najbliższych 10 latach rozwój wśród szkockich uczniów kreatywności myślenia, działania i funkcjonowania w życiu społecznym i zawodowym. Partnerami tego programu są szkockie najważniejsze podmioty rządowe, gospodarcze i oświatowe: Scottish Government, Creative Scotland, Education Scotland, College Development Network and Association of Directors of Education in Scotland, Skills Development Network, General Teaching Council for Scotland i The Scottish Qualification Authority.

Oprócz inicjatyw organizacji, stowarzyszeń oraz władz oświatowych Anglii, Walii, Szkocji i Irlandii Północnej także na poziomie ogólnokrajowym istnieją programy i organizacje wspierające edukację kulturalną dzieci i nauczycieli. Przykładem może być Krajowe Stowarzyszenie Edukacji na rzecz Sztuki i Projektowania (National Society for Education in Art and Design, NSEAD) ${ }^{102}$. Do jego zadań należy wspomaganie programowe, metodyczne i dydaktyczne nauczycieli plastyki, rzeźby, sztuki, rzemiosła lub projektu (designu) prowadzących zajęcia w szkołach podstawowych i średnich. Stowarzyszenie oferuje do wykorzystania w pracy edukacyjnej: narzędzia dydaktyczne, interaktywne technologie informacyjne i komunikacyjne w sztuce i projektowaniu, publikacje specjalistyczne (dostęp do książek, czasopism - w tym do International Journal of Art \& Design Education), wyniki prac badawczych, zaproszenia na konferencje i szkolenia oraz oferty doskonalenia zawodowego.

W ramach pozalekcyjnych działań artystycznych i kulturalnych skierowanych do młodzieży szkolnej placówki szkolne w Anglii, Walii, Szkocji i Irlandii Północnej organizują wiele zajęć fakultatywnych. Ze względu na charakter organizacji systemu szkolnego $\mathrm{w}$ poszczególnych constituent part Wielkiej Brytanii są to inicjatywy wypływające z potrzeb i zainteresowań społeczności lokalnych, więc programy i charakter tych zajęć mogą się różnić od siebie. Najbardziej popularne są zajęcia muzyczne prowadzone często jako gra na instrumentach, śpiew chóralny i taniec.

\section{Nauczyciele przedmiotów artystycznych i kulturalnych}

W Wielkiej Brytanii nauczyciele zatrudniani są przez władze lokalne lub poszczególne placówki szkolne. Nauczyciele nie są urzędnikami państwowymi. W Anglii

101 http://www.creativescotland.com/resources/our-publications/plans-and-strategy-documents/scotlands-creative-learning-plan-2013.

102 http://www.nsead.org/home/index.aspx. 
i Walii nauczyciele muszą mieć status wykwalifikowanego nauczyciela (Qualified Teacher Status), a w Irlandii Północnej formalne uprawnienia do nauczania (eligibility to teach). Kształcenie nauczycieli może przebiegać według modelu równoległego lub etapowego. Na model równoległy składają się trzy- lub czteroletnie studia licencjackie na kierunku pedagogicznym kończące się uzyskaniem tytułu Bachelor of Education. Kształcenie według modelu etapowego zakłada studia licencjackie na wybranym kierunku związanym z przedmiotem nauczania, a następnie roczne studia pedagogiczne, w wyniku których uzyskuje się świadectwo podyplomowych studiów w dziedzinie edukacji (Postgraduate Certificate in Education, PGCE). W Anglii i Walii istnieją również inne ścieżki kształcenia, m.in. kształcenie w niepełnym wymiarze, kształcenie elastyczne i kształcenie w miejscu pracy. Nauczyciele szkół podstawowych kształcą się zwykle jako nauczyciele przedmiotów zintegrowanych, a nauczyciele szkół średnich specjalizują się w poszczególnych przedmiotach.

W Szkocji nauczyciele szkół podstawowych (i przedszkoli) muszą ukończyć czteroletni cykl studiów prowadzący do uzyskania dyplomu licencjackiego z pedagogiki (Bachelor of Education, BEd) lub dla osób mających licencjat z innej dziedziny zawodowej - roczny program zawodowy dla szkół podstawowych, tzw. PGDE (Professional Graduate Diploma in Education). Nauczyciele, którzy zamierzają podjąć pracę w publicznych szkołach podstawowych i średnich, oprócz ukończonych studiów muszą posiadać uprawnienia pedagogiczne (Teaching Qualification, TQ) i być zarejestrowani jako nauczyciele w Naczelnej Radzie Nauczycielstwa dla Szkocji (General Teaching Council for Scotland, GTCS). Wszyscy nauczyciele, którzy dopiero uzyskali kwalifikacje zawodowe, mogą pracować przez jeden rok szkolny na stanowisku nauczyciela stażysty w ramach programu wprowadzania nauczycieli do zawodu (Teacher Induction Scheme). Większość nauczycieli szkół średnich po uzyskaniu tytułu zawodowego w konkretnej dziedzinie, w której zamierzają nauczać (np. język angielski, muzyka, wychowanie fizyczne) uzyskuje dyplom studiów w dziedzinie edukacji (Professional Graduate Diploma in Education) i dopiero wtedy rozpoczyna pracę w zawodzie nauczycielskim.

W Wielkiej Brytanii placówki szkolne mają całkowitą autonomię w podejmowaniu decyzji, w jakiej formule dydaktycznej będą nauczane przedmioty artystyczne i kulturalne. W szkole podstawowej najczęściej realizowane są przez nauczycieli przedmiotów zintegrowanych, ale mogą to być także nauczyciele przedmiotowi do prowadzenia konkretnych przedmiotów, jak sztuki plastyczne, muzyka, teatr lub taniec. W programie kształcenia przyszłych nauczycieli przedmiotów zintegrowanych przedmioty z dziedziny edukacji artystycznej (sztuki 
plastyczne, muzyka, teatr, taniec i sztuki wizualne) są najczęściej częścią innego obowiązkowego przedmiotu.

Zawodowi artyści, ludzie sztuki i kultury, którzy chcieliby nauczać w szkole specjalistycznych przedmiotów z dziedziny edukacji artystycznej i kulturalnej, muszą ukończyć studia lub odpowiednie szkolenie dające uprawnienia dydaktyczno-pedagogiczne.

\section{Podsumowanie}

Analiza programów nauczania oraz podejmowanych rozwiązań szkolnych i pozaszkolnych w szkolnictwie obowiązkowym dziesięciu wybranych państw europejskich wskazuje, że edukacja kulturalna jako przedmiot szkolny może być realizowana jako edukacja dla kultury lub jako wprowadzanie w otaczającą nas kulturę, na przykład przez zaznajomienie uczniów z jej elementami - sztuki plastyczne, muzyka, rękodzieło, teatr, taniec, architektura, sztuki medialne.

Wydaje się, że najbardziej widocznym wspólnym mianownikiem dla edukacji kulturalnej realizowanej w wybranych systemach oświatowych jest:

- traktowanie edukacji kulturalnej jako przedmiotu obowiązkowego łączącego obszar edukacji artystycznej i kulturalnej najczęściej realizowanego poprzez dwa przedmioty - sztuki plastyczne i muzyka,

- przybliżenie uczniowi najważniejszych dzieł kultury i uświadomienie wagi dziedzictwa kulturalnego,

- umożliwienie uczniowi stworzenia i zaprezentowania własnego dzieła z obszaru kultury, np. z wykorzystaniem obszaru sztuk medialnych,

- stworzenie możliwości zetknięcia się z różnymi formami artystycznego wyrazu i umożliwienie uczniowi dokonania interpretacji krytycznej dzieła.

Przegląd systemów oświatowych dziesięciu państw europejskich skłania także do refleksji, że współczesne przeobrażenia w obszarach edukacji stały się naturalną konsekwencją dynamicznych zmian w sferze życia politycznego, gospodarczego i społecznego globalnego świata. Coraz wyraźniej uwidocznił się pogląd, że celem współczesnej szkoły powinien stać się nieskrępowany rozwój osobowości uczniów, wykształcenie człowieka samodzielnego, myślącego, kreatywnego i jednocześnie wrażliwego oraz otwartego na kulturę i jej pośrednie i bezpośrednie przejawy. Zatem edukacja kulturalna staje się coraz bardziej znaczącym fragmentem kształcenia ogólnego w masowej, obowiązkowej szkole, pełniąc ważną rolę szeroko rozumianej edukacji humanistycznej w zglobalizowanym świecie. 


\section{Bibliografia}

Dziewulak D., Obowiązek szkolny w Unii Europejskiej, „Analizy BAS” 2010, nr 9(34), http:// parl.sejm.gov.pl/WydBAS.nsf/0/A4F8763AAD6E8E70C12576EE0029DFE9/\$file/Analiza_\%20BAS_2009_34.pdf.

Dziewulak D., System szkolny Irlandii, „Analizy BAS” 2014, nr 14(118), http://orka.sejm.gov. pl/WydBAS.nsf/0/DBBC3DD1A2279309C1257D860030A66A/\$file/Analiza_BAS_2014_118. pdf.

Dziewulak D., Systemy szkolne Unii Europejskiej, Wydawnictwo Akademickie „Żak”, Warszawa 1997.

Edukacja artystyczna i kulturalna w szkołach w Europie, Fundacja Rozwoju Systemu Edukacji, Warszawa 2010.

\section{Akty prawne}

Ustawa z 29 grudnia 2015 r. o zmianie ustawy o systemie oświaty oraz niektórych innych ustaw, Dz.U. 2016, poz. 35.

Rozporządzenie Ministra Edukacji Narodowej z 10 czerwca 2015 r. w sprawie szczegółowych warunków i sposobu oceniania, klasyfikowania i promowania uczniów i słuchaczy w szkołach publicznych, Dz.U. poz. 843.

Décret relatif à la mise en oeuvre, la promotion et le renforcement des Collaborations entre la Culture et l'Enseignement (D. 24-03-2006 M.B. 22-05-2006 Modifications D. 3004-2009 - M.B. 09-07-2009 D. 03-04-2014 - M.B. 14-08-2014), http://www.gallilex.cfwb.be/ document/pdf/30655_002.pdf.

Décret n²015-372 du 31 mars 2015 relatif au socle commun de connaissances, de compétences et de culture (JO du 2-4-2015 ; BOEN n¹7 du 23-4-2015), http://www.education. gouv.fr/pid25535/bulletin_officiel.html\&cid_bo=87834.

Grundgesetz, https://www.bundestag.de/grundgesetz.

Irish Education Act 1998 (Number 51of 1998), http://www.irishstatutebook.ie/eli/1998/ act/51/enacted/en/html.

Ley Orgánica 2/2006, de 3 de mayo, de Educación, https://www.boe.es/buscar/act.php?id=BOE-A-2006-7899.

Loi d'orientation et de programme pour l'avenir de l'école (L. n 2005-380 du 23-4-2005. JO du 24-4-2005), http://www.education.gouv.fr/bo/2005/18/MENX0400282L.htm\#loi.

Loi $n^{\circ}$ 2013-595 du 8.07.2013 d'orientation et de programmation pour la refondation de l'école de la République, http://www.legifrance.gouv.fr/affichTexte.do?cidTexte=JORFTEXT000027677984\&dateTexte=\&categorieLien=id. 
Loi n88-20 du 6 janvier 1988 relative aux enseignements artistiques, http://www.legifrance.gouv.fr/affichTexte.do?cidTexte=JORFTEXT000027677984\&dateTexte=\&categorieLien=id.

Structure of the education system in Northern Ireland 2014-15, https://www.nfer.ac.uk/ nfer/eurydice/publications/structure-diagram-ni.cfm.

Tableau des projets de collaboration durable 2015-2016 sélectionnés, http://www.culture-enseignement.cfwb.be/index.php?eID=tx_nawsecuredl\&u=0\&file=fileadmin/ sites/cult_ens/upload/cult_ens_super_editor/cult_ens_editor/documents/Decret/Tableau_projets_durables_2015-2016_selectionnes.pdf\&hash=37d4124339191cc9f9bebd1b285120f7a1c91d19. 


\title{
2.4. Kształcenie dzieci i młodzieży w zakresie bezpieczeństwa ruchu drogowego w wybranych państwach członkowskich Unii Europejskiej
}

\author{
Road safety education for young and older children \\ in the selected European Union members states
}

\begin{abstract}
W opracowaniu podjęto próbę przedstawienia zagadnienia kształcenia dzieci i młodzieży w zakresie bezpieczeństwa ruchu drogowego w wybranych krajach Unii Europejskiej. Analizie porównawczej poddano programy nauczania bezpieczeństwa ruchu drogowego w Polsce, Austrii, Estonii, Finlandii, Grecji, Hiszpanii, na Łotwie, w Niemczech, Szwecji, Włoszech i Wielkiej Brytanii. Materiał uzupełniono o krótką charakterystykę systemu zarządzania oświatą w poszczególnych krajach i o ogólną informację na temat przyjętych zasad odnoszących się do realizacji szkolnych programów nauczania.
\end{abstract}

Słowa kluczowe: szkoła, edukacja, bezpieczeństwo drogowe, ruch drogowy, Unia Europejska

This paper attempts to present the provision of education on road safety to young and older children in the selected European Union countries. It contains a comparative analysis of road safety education programs applied in Poland, Austria, Estonia, Greece, Spain, Latvia, Germany, Sweden, Italy and the United Kingdom. A brief description of education management systems existing in individual countries and an overview of the principles of implementing school programs are also found in this paper.

Keywords: school, education, road safety, traffic, European Union

\section{Ogólna charakterystyka edukacji komunikacyjnej w państwach Unii Europejskiej}

Edukacja komunikacyjna dzieci i młodzieży ${ }^{1}$ dotyczy szerokiego pojęcia związanego z wychowaniem w zakresie bezpieczeństwa ruchu drogowego (BRD, ang. Road Safety Education, RSE). Charakterystyczną cechą edukacji BRD realizowa-

1 Opracowanie przygotowano na podstawie ekspertyzy Biura Analiz Sejmowych nr 1741/11 z 19 września 2011 r. D. Dziewulaka zatytułowanej Informacja nt. edukacji komunikacyjnej dzieci i młodzieży w Polsce i w wybranych krajach Unii Europejskiej oraz opracowania tegoż autora Kształcenie dzieci i młodzieży w zakresie bezpieczeństwa ruchu drogowego w wybranych krajach Unii Europejskiej, „ Analizy BAS” 2011, nr 20(64), s. 1-17. 
nej w szkolnictwie obowiązkowym i nieobowiązkowym, w odróżnieniu od innych obszarów edukacyjnych, jest wielość różnych podmiotów mających wpływ na koncepcję, program, finansowanie i sposób realizacji tego przedmiotu.

W państwach członkowskich Unii Europejskiej trudno mówić o jednolitym, skoordynowanym modelu edukacji o ruchu drogowym. Odpowiedzialność za kształcenie BRD najczęściej podzielona jest między ministerstwa edukacji i ministerstwa transportu, jednak rola programowa i finansowa obu tych podmiotów bywa różna w zależności od systemu oświatowego oraz przyjętej w danym kraju ogólnej koncepcji związanej z promowaniem bezpieczeństwa w ruchu drogowym. Oprócz instytucji rządowych w działania na rzecz wychowania komunikacyjnego angażują się również organizacje i instytucje pozarządowe. Najczęściej są to koncerny motoryzacyjne, organizacje społeczne i towarzystwa ubezpieczeniowe. Ich znaczący udział odczuwalny jest przede wszystkim w obszarze finansowania działań promocyjnych z zakresu edukacji komunikacyjnej.

W połowie pierwszej dekady XXI wieku w Unii Europejskiej przeprowadzono interesujący projekt badawczy ROSE25². Jego celem było zebranie informacji o realizacji działań z zakresu wychowania komunikacyjnego podejmowanych w poszczególnych krajach, sporządzenie europejskiego poradnika zawierającego opis najlepszych praktyk edukacyjnych oraz przedstawienie wytycznych dla skutecznego systemu wychowania komunikacyjnego w Unii Europejskiej. Projekt ROSE25 pokazał, że działania edukacyjne BRD skierowane do dzieci i młodzieży prowadzą wszystkie państwa członkowskie UE, jedynie różny jest sposób ich realizacji ${ }^{3}$. Najczęściej występującym modelem wychowania komunikacyjnego jest system funkcjonujący w ramach współpracujących ze sobą instytucji rządowych, pozarządowych, samorządowych i prywatnych. Istotny jest też poziom regionalny i lokalny, na którym finansuje się, koordynuje i rozwija politykę z tego zakresu. Bezpośrednimi realizatorami programów BRD są przede wszystkim placówki szkolne, jednakże w znacznej większości krajów Unii do współpracy i pomocy włączana jest także policja, która odgrywa kluczową rolę w nauczaniu i doskonaleniu praktycznych umiejętności dzieci z zakresu BRD. Wyznaczeni funkcjo-

2 W realizację projektu włączyli się przedstawiciele instytutów naukowych z Austrii, Belgii, Cypru, Czech, Danii, Estonii, Finlandii, Francji, Grecji, Hiszpanii, Holandii, Irlandii, Litwy, Luksemburga, Łotwy, Malty, Niemiec, Polski, Portugalii, Słowacji, Słowenii, Szwecji, Węgier, Wielkiej Brytanii i Włoch.

3 Więcej o projekcie w Final Report - ROSE25, Inventory and compiling of European Guide Practice Guide on Road safety education targeted at young people, 2005, https://ec.europa. eu/transport/road_safety/sites/roadsafety/files/pdf/projects/rose-25.pdf. 
nariusze pomagają nauczycielom przede wszystkim w prowadzeniu zajęć w rzeczywistym ruchu drogowym z udziałem pieszych i rowerzystów (dzieci w wieku 3-12 lat). W większości krajów Unii policjanci mają uprawnienia instruktora wychowania komunikacyjnego, co umożliwia im prowadzenie specjalistycznych szkoleń przeznaczonych właśnie dla nauczycieli.

Ze względu na zaangażowanie i udział programowy, realizacyjny i finansowy wielu podmiotów w niektórych krajach Unii powołano ciała koordynujące kształcenie BRD na poziomie krajowym. Są to przeważnie odpowiedniki działającej w Polsce Krajowej Rady Bezpieczeństwa Ruchu Drogowego (KRBRD) ${ }^{4}$ oraz jednostki z nimi współpracujące (np. instytuty naukowo-badawcze). Pełnią one funkcje doradczo-nadzorujące, a także finansują i tworzą krajową politykę edukacji w zakresie BRD. Różnie rozwiązano też problem odpowiedzialności szkół za realizację programu BRD. Przykładowo w Danii w każdej szkole jest wyznaczona osoba koordynująca wychowanie komunikacyjne. Koordynatorzy szkolni są odpowiedzialni za dostarczanie najnowszych informacji z tego zakresu innym nauczycielom, proponują pomoce dydaktyczne, służą radą i doświadczeniem, pomagają w realizacji zajęć teoretycznych i praktycznych. Koordynatorzy dzielą się swoimi spostrzeżeniami i pomagają tworzyć nowe rozwiązania. W Niemczech w każdej szkole jest mianowany nauczyciel ds. wychowania komunikacyjnego.

4 Krajowa Rada Bezpieczeństwa Ruchu Drogowego została powołana z dniem 1 stycznia 2002 r. na mocy ustawy - Prawo o ruchu drogowym jako międzyresortowy organ doradczy i pomocniczy Rady Ministrów w sprawach bezpieczeństwa ruchu drogowego (BRD). Przewodniczącym KRBRD jest minister właściwy ds. transportu - obecnie Minister Infrastruktury, jego zastępcami zaś są sekretarze lub podsekretarze stanu w Ministerstwie Infrastruktury i w Ministerstwie Spraw Wewnętrznych i Administracji. Członkami KRBRD są wskazani przez Premiera RP przedstawiciele Ministra Obrony Narodowej, Ministra Sprawiedliwości oraz ministrów właściwych do spraw: administracji publicznej, budżetu, finansów publicznych, gospodarki, gospodarki przestrzennej i mieszkaniowej, oświaty i wychowania, środowiska, transportu, wewnętrznych, pracy oraz Komendanta Głównego Policji, Komendanta Głównego Straży Pożarnej, Generalnego Dyrektora Dróg Krajowych i Autostrad oraz wojewodowie. Jednostką wykonawczą KRBRD jest Sekretariat, który działa w strukturze organizacyjnej Ministerstwa Infrastruktury. Krajowa Rada określa kierunki i koordynuje działania administracji rządowej w sprawach bezpieczeństwa ruchu drogowego. Do zadań KRBRD w zakresie poprawy bezpieczeństwa ruchu drogowego należy m.in.:

- proponowanie kierunków polityki państwa, opracowywanie programów poprawy BRD,

- zlecanie badań naukowych,

- inicjowanie oraz opiniowanie aktów prawnych w dziedzinie BRD,

- inicjowanie współpracy zagranicznej, jak również działalności edukacyjno-informacyjnej,

- współpraca z organizacjami społecznymi i instytucjami pozarządowymi,

- analizowanie i ocena podejmowanych działań. 
Jest to osoba, która ukończyła specjalistyczne kursy z zakresu wychowania komunikacyjnego i pomaga innym nauczycielom w realizacji zajęć. W Wielkiej Brytanii programami edukacji BRD zajmują się odpowiednio przygotowani urzędnicy, do których zadań należy planowanie, organizacja szkoleń i współpraca $\mathrm{z}$ organizacjami rządowymi.

\section{Realizacja edukacji BRD w państwach UE}

Wychowanie komunikacyjne w UE koncentruje się przede wszystkim na najmłodszych dzieciach i uczniach. Głównym miejscem realizacji zajęć z zakresu BRD są więc przedszkola i szkoły podstawowe. Programy szkół średnich w mniejszym stopniu zawierają zagadnienia dotyczące bezpieczeństwa w ruchu drogowym. Nauczyciele korzystają zarówno z programów nauczania zatwierdzonych przez organy rządowe odpowiedzialne za edukację, jak i z zaleceń, które w porównaniu z programami nauczania są ogólniejsze i dają większą swobodę nauczycielowi w dokonaniu wyboru problematyki ${ }^{5}$.

Edukacja BRD jest obowiązkowa w 15 krajach Unii Europejskiej. Obowiązku takiego nie ma we Wspólnocie Francuskiej Belgii, w Czechach, Estonii, Grecji, Litwie, Luksemburgu, Malcie i Wielkiej Brytanii. Większość państw korzysta ze specjalnie przygotowanych programów nauczania BRD lub wytycznych dla nauczania. W kilku państwach (Wspólnota Francuska Belgii, Czechy, Estonia, Grecja, Litwa, Luksemburg) nie ma podstaw programowych edukacji BRD, a decyzję o zakresie i sposobie przekazania wiedzy całkowicie pozostawia się nauczycielowi.

\section{Finansowanie edukacji BRD w państwach UE}

Finansowanie edukacji BRD odbywa się w państwach członkowskich Unii Europejskiej zależnie od ogólnie przyjętego systemu finansowania oświaty w danym państwie i trudno mówić o stosowaniu jednego wspólnego modelu. Możemy wyróżnić trzy główne kategorie dofinansowania: brak wsparcia finansowego, udostępnianie materiałów dydaktycznych bezpłatnie lub w specjalnej cenie, finansowanie z innych źródeł niż dotacje Ministerstwa Edukacji Narodowej. Najczęściej

5 W opracowaniu wykorzystano materiały uzyskane z Sieci Informacji o Edukacji w Europie - Eurydice (Eurydice Network - Information on Education Systems and Policies in Europe), Instytutu Transportu Samochodowego w Warszawie oraz stron internetowych instytucji i organizacji oświatowych zajmujących się zagadnieniami BRD. 
Tabela 18. Programy edukacji w zakresie bezpieczeństwa ruchu drogowego realizowane dla różnych grup wiekowych w państwach UE

\begin{tabular}{|c|c|c|c|}
\hline \multirow[t]{2}{*}{ Państwo } & $\begin{array}{l}\text { Obowiązkowe } \\
\text { wychowanie } \\
\text { komunikacyjne }\end{array}$ & $\begin{array}{c}\text { Programy z zakresu } \\
\text { wychowania } \\
\text { komunikacyjnego }\end{array}$ & $\begin{array}{c}\text { Zalecenia } \\
\text { dla wychowania } \\
\text { komunikacyjnego }\end{array}$ \\
\hline & \multicolumn{3}{|c|}{ (wiek ucznia) } \\
\hline Austria & $6-10$ & $6-10$ & $11-18$ \\
\hline Belgia francuskojęzyczna & - & - & - \\
\hline Belgia flamandzkojęzyczna & 3-18 & $3-18$ & $3-12$ \\
\hline Cypr & $12-15$ & $6-15$ & $6-15$ \\
\hline Czechy & - & - & - \\
\hline Dania & $7-16$ & $7-16$ & $7-16$ \\
\hline Estonia & - & - & - \\
\hline Finlandia & $6-16$ & $6-16$ & $2-7$ \\
\hline Francja & $6-15$ & $6-15$ & - \\
\hline Grecja & - & - & - \\
\hline Hiszpania & 2-15 & $2-15$ & 2-15 \\
\hline Holandia & $0-18$ & - & $0-18$ \\
\hline Irlandia & $4-12$ & $4-12$ & - \\
\hline Litwa & - & - & - \\
\hline Luksemburg & - & - & - \\
\hline Łotwa & $4-7$ & - & - \\
\hline Malta & - & - & $6-11$ \\
\hline Niemcy & $6-18$ & $6-18$ & $6-18$ \\
\hline Polska & $3-16$ & - & $3-16$ \\
\hline Portugalia & $6-8$ & $6-8$ & $3-18$ \\
\hline Słowacja & $3-15$ & $3-15$ & $3-15$ \\
\hline Słowenia & $2-14$ & $2-14$ & $6-14$ \\
\hline Szwecja & $7-18$ & - & - \\
\hline Węgry & $3-16$ & $3-16$ & $3-16$ \\
\hline Włochy & $3-18$ & $3-18$ & $3-18$ \\
\hline Wielka Brytania & - & - & $5-16$ \\
\hline
\end{tabular}

Źródło: Edukacja dzieci w zakresie bezpieczeństwa ruchu drogowego, Instytut Transportu Samochodowego, Warszawa 2011. 
Tabela 19. Wsparcie finansowe dla placówek oświatowych realizujących edukację bezpieczeństwa ruchu drogowego w państwach UE

\begin{tabular}{|c|c|c|c|c|c|c|}
\hline \multirow[b]{2}{*}{ Państwa } & \multicolumn{3}{|c|}{ Edukacja przedszkolna } & \multicolumn{3}{|c|}{ Edukacja szkolna } \\
\hline & 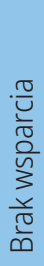 & 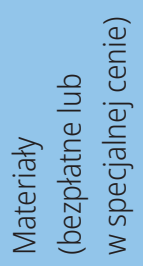 & 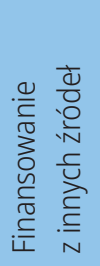 & $\begin{array}{l}\frac{0}{U} \\
\frac{0}{0} \\
\frac{0}{0} \\
\vdots \\
\frac{y}{0} \\
\frac{0}{\infty}\end{array}$ & 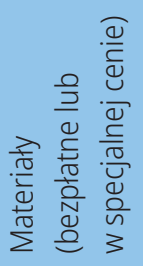 & 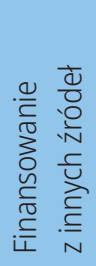 \\
\hline Austria & $x$ & & & & $\times$ & \\
\hline Belgia & & $x$ & & & $x$ & \\
\hline Cypr & $x$ & & & & $x$ & \\
\hline Czechy & & $x$ & & & $\times$ & \\
\hline Dania & $x$ & & & & $x$ & \\
\hline Estonia & & & $x$ & & & $x$ \\
\hline Finlandia & $\times$ & & & $\times$ & & \\
\hline Francja & & $\times$ & & & & \\
\hline Grecja & $\times$ & & & $\times$ & & \\
\hline Hiszpania & & $\times$ & & & $\times$ & \\
\hline Holandia & & $x$ & & & $x$ & $x$ \\
\hline Irlandia & $x$ & & & & $\times$ & \\
\hline Litwa (brak danych) & - & - & - & - & - & - \\
\hline Luksemburg & & & & & $\times$ & \\
\hline Łotwa (brak danych) & - & - & - & - & - & - \\
\hline Malta & $x$ & & & $\times$ & & \\
\hline Niemcy & & $x$ & & & & $\times$ \\
\hline Polska & $\times$ & & & $\times$ & & \\
\hline Portugalia & & $x$ & & & $\times$ & \\
\hline Słowacja & & & $\times$ & & & \\
\hline Słowenia & & $\times$ & & & $\times$ & \\
\hline Szwecja & $\times$ & & & $\times$ & & \\
\hline Węgry & & $\times$ & & & $\times$ & \\
\hline Włochy & $\times$ & & & & $x$ & $x$ \\
\hline Wielka Brytania & & $x$ & & & $x$ & \\
\hline
\end{tabular}

Źródło: Edukacja dzieci w zakresie bezpieczeństwa ruchu drogowego, Instytut Transportu Samochodowego, Warszawa 2011. 
stosowanym rozwiązaniem jest przekazywanie bezpłatnych materiałów dydaktycznych lub ich sprzedaż po obniżonych cenach. Na podkreślenie zasługuje fakt, że łatwy dostęp do atrakcyjnych materiałów jest dużym czynnikiem motywującym dla nauczycieli, aby umieścić treści z wychowania komunikacyjnego w programie przedmiotów, których nauczają.

\section{Tendencje w programach nauczania BRD w państwach UE}

W wyniku badań przeprowadzonych w ramach unijnego projektu ROSE25 ${ }^{6}$ dokonano przeglądu programów nauczania w zakresie BRD. Na jego podstawie unijni eksperci wskazali pojawiające się tendencje, zgodnie z którymi opracowano ogólne wskazówki dotyczące konstrukcji nowych programów BRD.

Zauważalną ogólną tendencją jest to, że programy nauczania w zakresie BRD stają się coraz powszechniej integralnym elementem treści nauczania na poziomie przedszkola i szkoły podstawowej. Na tych szczeblach nauczania przeciętny wymiar czasowy tematyki wychowania komunikacyjnego wynosi rocznie minimum 10 godzin zajęć. Najczęściej programy konstruowane są z uwzględnieniem treści przeznaczonych dla różnych grup użytkowników ruchu drogowego: pieszych, rowerzystów, motorowerzystów i kandydatów na kierowców. Ważne jest też uwzględnianie potrzeb i specyfiki występującej w środowiskach lokalnych na przykład przez włączanie lokalnych społeczności w działania uświadamiające wagę BRD dla zdrowia i życia mieszkańców. Widoczną tendencją w programach jest zwracanie uwagi, poza małymi dziećmi, na dwie grupy docelowe - nastolatków i rodziców - grupy rzadko do tej pory będące adresatami programów BRD. Nastolatki to grupa wiekowa wymagająca szczególnego podejścia, gdyż w krótkim czasie staną się potencjalnymi użytkownikami dróg jako grupa młodych kierowców. W programach nauczania chodzi więc o szczególne podkreślenie odpowiedzialności za zaistniałe zdarzenia, uwrażliwienie na problemy bezpieczeństwa i zagrożenia związane z uczestniczeniem w ruchu drogowym oraz podkreślenie wpływu własnych zachowań na możliwość wystąpienia wypadku. Ważne miejsce w programach BRD przypada także rodzicom, gdyż to oni odgrywają najważniejszą rolę $w$ wychowaniu komunikacyjnym swoich dzieci. Są wzorem do naśladowania i stąd konieczność położenia szczególnego nacisku na pedagogizację dorosłych. Programy BRD zwracają uwagę, że rodzice powinni w rozmowach z dziećmi poruszać zagadnienia związane z zachowaniem na drodze oraz zachę-

$6 \quad$ http://ec.europa.eu/transport/rose25/index_en.htm. 
cać do naśladowania prawidłowych zachowań w ruchu drogowym. Jednakże do wypełniania takiej roli muszą być właściwie przygotowani, a przede wszystkim świadomi, że dzieci naśladują ich zachowania i postawy. Przykładowo jako jeden z pierwszych tematów do dyskusji proponuje się zagadnienie bezpieczeństwa dzieci w samochodzie, a prawidłowe zapięcie pasów bezpieczeństwa na przednich i tylnych fotelach może być naturalną lekcją działań praktycznych.

Przy tworzeniu programów stosuje się ogólną zasadę, że zagadnienia z zakresu BRD powinny mieć jasno określone cele, treści i być metodycznie dostosowane do określonych grup wiekowych. Program powinno się realizować w sposób ciągły, gdyż taka formuła daje gwarancję utrwalania właściwych zachowań i kształtowania poprawnych nawyków. Doświadczenie uczy, że jednorazowe akcje, nawet najbardziej spektakularne, wywołują pozytywne skutki tylko na krótko. Realizowany program nauczania w dłuższym czasie przyniesie więc większe korzyści niż wydarzenie atrakcyjne, ale jednorazowe. Ponadto program powinien być stopniowany, nieprzeciążony, regularnie aktualizowany i atrakcyjny dla wszystkich - uczniów, rodziców i nauczycieli. Atrakcyjność i praktyczna formuła to ważny wyznacznik jakości programu.

\section{Główne problemy wychowania komunikacyjnego w UE}

Elementem strategii działań na rzecz bezpieczeństwa ruchu drogowego w większości krajów Unii Europejskiej jest ustawiczne upowszechnianie edukacji BRD wśród całego społeczeństwa, a nie skupianie się tylko na docelowej grupie dzieci i młodzieży. Różnice występujące w systemie zarządzania oświatą, odmienność struktur szkolnych, zróżnicowanie programów nauczania oraz uwarunkowania społeczne sprawiają, że wychowanie komunikacyjne realizowane jest w Europie bardzo różnorodnie i w związku z tym nie ma wspólnego jednolitego modelu kształcenia. Jednakże w większości krajów dopracowano się wielu dobrych praktyk i inicjatyw z zakresu edukacji BRD, które warto popularyzować i wdrażać w innych krajach. Oprócz inicjatyw, które przynoszą oczekiwane dobre rezultaty, pojawiają się też liczne problemy, z którymi na co dzień zderzają się podmioty realizujące edukację BRD w państwach Unii. Poniżej podjęto próbę syntetycznego przedstawienia katalogu najczęściej pojawiających się problemów związanych z realizacją wychowania komunikacyjnego w Unii Europejskiej:

- duża różnorodność systemów wychowania komunikacyjnego w szkołach,

- brak jednoznacznego stanowiska wobec obowiązku wychowania komunikacyjnego w szkołach, 
- ograniczone dofinansowanie lub całkowity brak finansowania wychowania komunikacyjnego,

- znaczne różnice między realnymi potrzebami a praktyczną realizacją wychowania komunikacyjnego,

- przestarzałe, nieefektywne metody nauczania (rozdźwięk między teorią a praktyką, uczenie samej teorii i przepisów),

- brak bezpośredniej odpowiedzialności nauczycieli za przekazywane treści z zakresu BRD, co spowodowane jest rozliczaniem pedagogów głównie za ich podstawowe obowiązki dydaktyczno-wychowawcze (za edukację z zakresu BRD odpowiedzialni są wszyscy, czyli nikt),

- brak miejsc do praktycznej nauki - wątpliwa użyteczność miasteczek ruchu drogowego,

- marginalizacja wychowania komunikacyjnego w placówkach oświatowych wynikająca ze zwyczajowej hierarchii innych przedmiotów,

- brak systemu motywacyjnego dla nauczycieli do prowadzenia zajęć z zakresu BRD,

- brak obowiązku zdobywania kwalifikacji do nauczania treści z zakresu BRD przez nauczycieli,

- różnice w poziomie realizacji wychowania komunikacyjnego przeznaczonego dla dzieci młodszych i starszych,

- brak przygotowania pedagogicznego policjantów do prowadzania zajęć z dziećmi z zakresu BRD,

- brak współpracy władz z placówkami oświatowymi i koordynacji na poziomie lokalnym i krajowym.

\section{Edukacja komunikacyjna w wybranych krajach UE}

\section{Polska}

\section{Zarządzanie oświatą i programy nauczania}

W Polsce odpowiedzialność za system oświaty ponosi Ministerstwo Edukacji Narodowej (MEN). Szkolnictwo wyższe podlega Ministerstwu Nauki i Szkolnictwa Wyższego (MNiSW). Nieliczne szkoły o specjalistycznym profilu mogą podlegać innym resortom. Ministerstwo Kultury i Dziedzictwa Narodowego (MKDN) może zakładać i prowadzić publiczne szkoły artystyczne oraz placówki dla uczniów szkół artystycznych, a także placówki doskonalenia nauczycieli szkół artystycz- 
nych. Ministerstwo Rolnictwa (MR) może zakładać i prowadzić publiczne szkoły rolnicze oraz placówki rolnicze o znaczeniu regionalnym i ponadregionalnym oraz publiczne placówki doskonalenia nauczycieli przedmiotów zawodowych, którzy nauczają w szkołach rolniczych. Ministerstwo Środowiska (MŚ) może zakładać i prowadzić publiczne szkoły leśne. Minister Obrony Narodowej (MON) może zakładać i prowadzić publiczne szkoły o profilu związanym z potrzebami resortu. Ministrowie Spraw Wewnętrznych i Administracji (MSWiA) oraz Sprawiedliwości (MS) mogą zakładać szkoły i placówki przy zakładach poprawczych, schroniskach dla nieletnich oraz zakładach karnych. Reforma administracji i systemu edukacji zakłada, że polityka edukacyjna jest tworzona i prowadzona centralnie, natomiast administracja i prowadzenie szkół, przedszkoli i innych instytucji edukacyjnych są zdecentralizowane. Odpowiedzialność za administrowanie przedszkolami, szkołami podstawowymi i gimnazjami należy do władz lokalnych. Sprawy administracyjne i organizacyjne oraz decyzje dotyczące wykorzystywania środków finansowych przez szkoły są przedmiotem konsultacji między szkołą i organem prowadzącym szkołę, tj. gminą (w wypadku przedszkoli, szkół podstawowych i gimnazjów) lub powiatem (w wypadku szkół ponadgimnazjalnych, artystycznych i specjalnych). Nadzór pedagogiczny nad szkołami sprawuje bezpośrednio Ministerstwo Edukacji Narodowej, a w jego imieniu zadania w tym zakresie w 16 województwach wykonują kuratoria oświaty.

Programy nauczania w szkole podstawowej i gimnazjum powstają na poziomie centralnym i są tworzone przez zespoły ekspertów powołane przez MEN. Szkoły (nauczyciele) mogą wybierać podręczniki z listy zatwierdzonej przez Ministerstwo Edukacji Narodowej, a także samodzielnie decydować o stosowanych metodach nauczania. Zestaw programów nauczania obowiązujący w szkole zatwierdza dyrektor szkoły. W klasach I-III szkoły podstawowej obowiązkowe zajęcia edukacyjne mają charakter kształcenia zintegrowanego, a w klasach IV-VI charakter przedmiotowy: język polski, historia i społeczeństwo, język obcy nowożytny, matematyka, przyroda, muzyka/plastyka (zajęcia te mogą być prowadzone w bloku przedmiotowym „sztuka”), technika, informatyka, wychowanie fizyczne, godzina wychowawcza oraz dodatkowo - zajęcia z religii lub etyki. W gimnazjum program obejmuje następujące przedmioty obowiązkowe: język polski, historia, wiedza o społeczeństwie, język obcy nowożytny, matematyka, fizyka i astronomia, chemia, biologia, geografia, plastyka/muzyka (mogą być prowadzone w bloku przedmiotowym sztuka), technika, informatyka, wychowanie fizyczne, godziny wychowawcze, dodatkowo - zajęcia z religii lub etyki. Na poziomie szkoły średniej II stopnia obowiązuje nauczanie przedmiotowe i w ramach ścieżek międzyprzedmiotowych. 
Ministerstwo Edukacji określa podstawę programową kształcenia ogólnego dla każdego rodzaju szkoły, dla każdego przedmiotu i ścieżki międzyprzedmiotowej. Nauczyciele mogą wybierać podręczniki z listy zatwierdzonej przez MEN, a także samodzielnie decydować o stosowanych metodach nauczania. Nauczyciele mogą również opracowywać własne programy nauczania oparte na podstawie programowej i przedkładać je dyrektorowi szkoły do zatwierdzenia.

\section{Kształcenie BRD}

Wychowanie komunikacyjne realizowane jest w polskiej oświacie od 1957 roku. Od końca lat pięćdziesiątych edukacja BRD znajdowała swoje miejsce między innymi w następujących aktach prawnych:

- 1972 r. - Uchwała Rady Ministrów w sprawie kierunków działań zmierzających do poprawy bezpieczeństwa i porządku na drogach,

- 1974 r. - Zarządzenie Ministra Oświaty i Wychowania w sprawie usprawnienia nauczania zasad i przepisów bezpieczeństwa ruchu drogowego,

- 1995 r. - Rozporządzenie Ministra Edukacji Narodowej w sprawie realizacji zajęć z zakresu bezpieczeństwa ruchu drogowego,

- 1999 r. i 2002 r. - Rozporządzenia Ministra Edukacji Narodowej w sprawie ramowych planów nauczania w szkołach publicznych,

- 2008 r. - Rozporządzenie Ministra Edukacji Narodowej w sprawie podstawy programowej wychowania przedszkolnego oraz kształcenia ogólnego w poszczególnych typach szkół („nowa podstawa programowa”)”.

Obecnie szkolna edukacja w zakresie bezpieczeństwa ruchu drogowego wpisana jest do podstaw programowych klas I-III szkoły podstawowej, a w starszych klasach szkoły podstawowej i gimnazjum w podstawy programowe przedmiotu technika oraz wychowanie dla bezpieczeństwa. W klasach młodszych dotyczy zagadnień związanych z poruszaniem się dziecka jako pieszego i pasażera samochodów osobowych oraz komunikacji publicznej. Tematy te realizuje nauczyciel kształcenia zintegrowanego. W starszych klasach (IV-VI) szkoły podstawowej i I-III gimnazjum problematyka BRD rozszerzona jest o zagadnienia związane z przygotowaniem do bezpiecznego, kulturalnego i partnerskiego zachowania ucznia jako rowerzysty (szkoła podstawowa) i motorowerzysty (gimnazjum). Edukację komunikacyjną prowadzi nauczyciel przedmiotu technika. Wymiar czasowy wynosi dwie godziny tygodniowo w trzyletnim cyklu nauczania.

http://lex.pl/serwis/du/2009/0017.htm. 
Zadania polskiej szkoły w zakresie wychowania komunikacyjnego zawarte w nowej podstawie programowej są następujące:

- zapewnienie bezpiecznej drogi do szkoły,

- przekazanie wiedzy oraz kształtowanie i utrzymanie umiejętności niezbędnych do odpowiedniego uczestnictwa w ruchu drogowym,

- stworzenie warunków do uzyskania karty rowerowej i motorowerowej,

- współpraca z rodzicami, władzami samorządowymi, społecznościami lokalnymi, instytucjami i organizacjami działającymi na rzecz BRD.

\section{Edukacja BRD w przedszkolu}

Celem edukacji przedszkolnej w zakresie bezpieczeństwa ruchu drogowego jest wdrażanie dzieci do dbałości o bezpieczeństwo własne oraz innych. Dziecko konczące przedszkole i rozpoczynające naukę w szkole podstawowej powinno:

- wiedzieć, jak trzeba zachować się w sytuacji zagrożenia i gdzie można otrzymać pomoc, umieć o nią poprosić,

- orientować się w bezpiecznym poruszaniu się po drogach i korzystaniu ze środków transportu,

- znać zagrożenia płynące ze świata ludzi, roślin oraz zwierząt i ich unikać,

- mieć rozeznanie, gdzie można się bezpiecznie bawić, a gdzie nie,

- próbować samodzielnie i bezpiecznie organizować swój czas wolny w przedszkolu i w domu.

\section{Edukacja BRD w szkole podstawowej}

Uczeń kończący etap edukacji wczesnoszkolnej (klasy I-III) powinien:

- wiedzieć, gdzie można bezpiecznie organizować zabawy, a gdzie nie można i dlaczego; wiedzieć, do kogo zwrócić się o pomoc w sytuacji zagrożenia zdrowia lub życia,

- znać zagrożenia, których źródłem jest człowiek oraz wiedzieć, jak powiadomić dorosłych o wypadku, zagrożeniu, niebezpieczeństwie,

- znać numery telefonów: pogotowia ratunkowego, straży pożarnej, policji oraz ogólnopolski numer alarmowy 112,

- $\quad$ wiedzieć, jak należy bezpiecznie poruszać się na drogach (w tym na rowerze) i korzystać ze środków komunikacji; wiedzieć, jak trzeba zachować się w sytuacji wypadku. 
Szeroko rozumiana tematyka bezpieczeństwa ruchu drogowego realizowana w programie drugiego etapu edukacji szkoły podstawowej (klasy IV-VI) znajduje się w programach kilku przedmiotów: przyrody, zajęć technicznych, wychowania fizycznego i etyki. Uczeń kończący szkołę podstawową powinien w ramach poszczególnych przedmiotów posiadać następujące umiejętności:

- przyroda: potrafi podać przykłady właściwego spędzania wolnego czasu, z uwzględnieniem zasad bezpieczeństwa w czasie gier i zabaw ruchowych oraz poruszania się po drodze; opisuje zasady udzielania pierwszej pomocy w niektórych urazach (stłuczenia, zwichnięcia, skaleczenia, złamania, ukąszenia, użądlenia), potrafi wezwać pomoc w różnych sytuacjach; wymienia zasady zdrowego stylu życia i uzasadnia konieczność ich stosowania,

- zajęcia techniczne: bezpiecznie uczestniczy w ruchu drogowym jako pieszy, pasażer i rowerzysta; zajęcia techniczne pozwalają przygotować ucznia do uzyskania karty rowerowej,

- wychowanie fizyczne: bezpiecznie uczestniczy w aktywności fizycznej o charakterze rekreacyjnym i sportowym ze zrozumieniem jej znaczenia dla zdrowia; stosuje zasady bezpieczeństwa podczas aktywności fizycznej,

- etyka: zna prawa i obowiązki, zasady i reguły postępowania, w tym także w ruchu drogowym.

\section{Edukacja BRD w gimnazjum i liceum}

W gimnazjum i liceum nie ma oddzielnego przedmiotu dotyczącego bezpieczeństwa ruchu drogowego. Zagadnienia te mogą być realizowane w ramach lekcji przyrody i zajęć technicznych jako przygotowanie do życia w cywilizacji technicznej. Szkoła średnia ma wyrobić umiejętności osobiste i społeczne sprzyjające zdrowiu i bezpieczeństwu, m.in. wyrabianie u uczniów prawidłowych nawyków oraz opanowanie zasad działania ratowniczego, szczególnie z zakresu udzielania pierwszej pomocy podczas wypadku i innych zagrożeń. W czasie ferii letnich mogą być organizowane specjalistyczne obozy szkoleniowo-wypoczynkowe z zakresu edukacji dla bezpieczeństwa.

W ramach realizacji edukacji dla bezpieczeństwa uczeń gimnazjum i liceum powinien poznać:

- zasady zachowania się podczas wypadków i katastrof komunikacyjnych, technicznych i innych,

- znaczenie udzielania pierwszej pomocy,

- zasady postępowania aseptycznego i bezpiecznego dla ratownika, 
- sposób wzywania odpowiedniej pomocy i rozpoznać stopień zagrożenia osoby poszkodowanej oraz wyjaśnić zasady bezpiecznego postępowania w rejonie wypadku,

- zasady zabezpieczenia miejsca wypadku,

- zasady udzielania pomocy w wypadku drogowym.

\section{Inne inicjatywy edukacyjno-społeczne w zakresie edukacji BRD}

Oprócz programów szkolnych w ramach edukacji BRD ważnym dodatkowym komponentem edukacyjnym są wszelkie inicjatywy podejmowane przez organizacje, instytucje, firmy i fundacje mające na celu szerzenie wiedzy o bezpieczeństwie ruchu drogowego. W Polsce w okresie ostatnich lat pojawiło się w tym obszarze kilka inicjatyw edukacyjno-społecznych. Do najbardziej znanych należą: „Klub Pancernika”, „Bezpieczeństwo dla wszystkich”, akcja „Niesłyszący bezpieczny uczestnik ruchu drogowego”, „Przedszkolak bezpieczny na drodze”, „Bezpieczni na drodze”, „Bielański konkurs chodzę i jeżdżę bezpiecznie”.

\section{"Klub Pancernika”}

Dostrzegając problem konieczności redukcji liczby zabitych na drogach, Komisja Europejska podjęła decyzję o organizowaniu wspólnych europejskich przedsięwzięć edukacyjnych w zakresie bezpieczeństwa ruchu drogowego. Pierwszą wspólną europejską kampanią społeczną skierowaną do dzieci, której tematem były urządzenia zabezpieczające w pojeździe, czyli pasy i foteliki, realizowano w latach 2005-2007. W 2005 roku uczestniczyło w niej 10 krajów Unii Europejskiej, w 2006 roku - 15 krajów, a w 2007 roku - 14 krajów.

Kampanię nazwano EUCHIRES (European public awareness campaign on the use of seat belts and child restraint systems). Wspólnym symbolem akcji we wszystkich państwach, które zdecydowały się wziąć w niej udział była zabawka przedstawiająca pancernika (ssak występujący w Ameryce Południowej). W Polsce kampanię znaną pod hasłem „Klub Pancernika Klika w Fotelikach” realizował Instytut Transportu Samochodowego ${ }^{8}$. Bezpośrednim adresatem kampanii zgodnie z założeniami międzynarodowymi były dzieci w wieku od 4 do 12 lat, a odbiorcą pośrednim - rodzice dzieci w tej grupie wiekowej. Kampania miała na celu

8 M. Dąbrowska-Loranc, J. Wacowska-Ślęzak, Klub Pancernika Klika w Fotelikach - kampania EUCHIRES w Polsce, „Kwartalnik BRD” 2006, nr 1, s. 19-22; J. Wacowska-Ślęzak, Klub Pancernika Klika w Fotelikach - po raz drugi, „Kwartalnik BRD” 2006, nr 4, s. 19-22, www. klubpancernika.pl. 
zachęcenie dzieci do stałego stosowania urządzeń zabezpieczających w pojeździe (foteliki, pasy) bez względu na rodzaj i długość podróży oraz wywieranie przez dzieci motywacyjnego wpływu na dorosłych do zapinania pasów bezpieczeństwa. Położono także nacisk na przekonanie rodziców do stosowania urządzeń zabezpieczających przeznaczonych dla dzieci w samochodzie i stosowania tych urządzeń w sposób prawidłowy, tzn. uwzględniając wzrost, wagę i wiek dziecka. Dodatkowym celem kampanii było wywołanie pozytywnych interakcji rodzice dzieci skupionych na konieczności dbania o bezpieczeństwo podczas podróży.

Koncepcja kampanii zakładała znalezienie formy przekazu angażującej zarówno dzieci, jak i dorosłych. Stąd też duża liczba produktów promocyjnych przygotowanych dla potrzeb kampanii: spot kinowy i telewizyjny, spot radiowy, materiały propagandowe, maskotka pancernika, gry dla dzieci, legitymacja klubu, plakaty, strona internetowa, materiały edukacyjne (w tym podręcznik metodyczny dla nauczycieli, scenariusze zajęć z dziećmi w przedszkolu, klasach I-III i IV-VI szkoły podstawowej). Dla potrzeb rysunkowego filmiku reklamującego kampanię zaadoptowano melodię z popularnego serialu „Czterej pancerni i pies”, do której napisano tekst zachęcający do zapinania pasów i podróżowania w foteliku. Melodia z serialu znanego rodzicom z okresu ich dzieciństwa miała być pretekstem do rozmów z dziećmi na tematy bezpieczeństwa drogowego. W filmie maskotka pancernika pokazuje prawidłowy sposób przewożenia dziecka na tylnym siedzeniu samochodu. Dziecko i pancernik wspólnie śpiewają piosenkę. Ta sama piosenka jest elementem spotu radiowego. Pierwszą edycję kampanii zrealizowano na przełomie października i listopada 2005 roku, ze szczególnym nasileniem działań medialnych w okresie intensywnych podróży związanych z Dniem Wszystkich Świętych. Kolejne edycje w 2006 i 2007 roku zorganizowano w okresie wakacji. Intensywne działania medialne miały miejsce w pierwszych tygodniach lipca i ostatnich sierpnia; a więc w okresach, kiedy dzieci jadą na wakacje, a następnie przed rozpoczęciem roku szkolnego, gdy z nich wracają. W tych dniach prowadzono nasilone kontrole policyjne pod kątem zapinania pasów i przewożenia dzieci w fotelikach, podczas których policjanci rozdawali pancerniki tym dzieciom, które były prawidłowo przewożone w pojazdach.

Zgodnie z założeniami ekspertów europejskich udział policji w kampanii powinien również mieć znaczenie dla wykreowania wśród dzieci pozytywnego wizerunku policjanta jako tego, który dba o bezpieczeństwo i nagradza dobre zachowanie, a nie tylko karze. Na ulicach większych miast umieszczono kilkaset billboardów promujących akcję. Spot kampanii emitowany był bardzo często w radiu i telewizji publicznej oraz na kanałach przeznaczonych dla dzieci, a tak- 
że w wybranych kinach przed seansami filmów dla młodych widzów. Kampania miała własną stronę internetową www.klubpancernika.pl, na której przeprowadzano konkursy dla dzieci i rodziców, a w części dla dorosłych dostępne było forum, informacje o fotelikach itd. Dużym zainteresowaniem cieszyły się scenariusze zajęć dla nauczycieli przedszkoli i szkół podstawowych związane z tematyką BRD. Każdy z nauczycieli zainteresowany realizacją akcji mógł bezpłatnie otrzymać materiały akcji (gry planszowe, plakaty, legitymacje klubu, maskotki pancernika na nagrody, smycze) i jako materiał uzupełniający - scenariusze do zajęć. Jak wykazały badania przeprowadzone wśród dzieci i rodziców, wysoka efektywność kampanii „Klubu Pancernika” sprawiła, że wzrosła liczba osób zapinających pasy bezpieczeństwa podczas jazdy samochodem ${ }^{9}$. W 2007 roku 83\% dzieci było prawidłowo przewożonych w samochodzie, co daje wzrost o $32 \% \mathrm{w}$ okresie 3 lat realizacji. Kolejna edycja kampanii rozpoczęła się w sierpniu 2011 roku.

\section{„Bezpieczeństwo dla wszystkich"10}

Międzynarodowy program edukacyjny przeznaczony dla uczniów szkół podstawowych. Głównym organizatorem i sponsorem akcji jest koncern Renault. Bezpieczeństwo dla wszystkich to największy tego rodzaju program w Europie, który swoim zasięgiem objął 20 na krajów na świecie. Dotychczas wzięło w nim udział 11 mln dzieci, z czego ponad 700 tys. z Polski. Uczestnictwo w programie jest całkowicie bezpłatne.

W Polsce program składa się z następujących czterech integralnych elementów:

- Pakiet edukacyjny „Droga i Ja” - jest zestawem dydaktycznym przeznaczonym dla uczniów i nauczyciela, składającym się z zeszytów ćwiczeń, podręcznika, filmu edukacyjnego i planszy ze znakami drogowymi. Pakiety edukacyjne „Droga i Ja”, które powstają we współpracy z ekspertami z zakresu prewencji, bezpieczeństwa na drodze i nauczania, mają na celu wykształcić $\mathrm{u}$ dzieci prawidłowe i bezpieczne zachowania na drodze, a nauczycielowi pomóc w prowadzeniu lekcji. Zestawy, opracowane przez metodyków i specjalistów od bezpieczeństwa ruchu drogowego, są podzielone na 24 lekcje tematyczne. Co roku zawartość merytoryczna jest aktualizowana we współpracy z ekspertami. Pakiet edukacyjny, na prośbę nauczyciela, wysyłany jest do każdej szkoły nieodpłatnie. Karty tematyczne dla nauczycieli z pakietów eduka-

9 Efektywność kampanii bezpieczeństwa ruchu drogowego - Klub Pancernika Klika w Fotelikach, materiały z Międzynarodowego Seminarium GAMBIT 2008, 22-26 kwietnia Gdańsk, 2008 (materiały niepubl.).

10 http://www.bezpieczenstwo.renault.pl. 
cyjnych „Droga i Ja” można pobrać na swój komputer i wydrukować także ze strony internetowej programu. Pakiety edukacyjne zostały wpisane przez Ministerstwo Edukacji Narodowej na listę środków dydaktycznych zalecanych do użytku szkolnego.

- E-learning - innowacyjny program multimedialny dostępny w Internecie dla dzieci, rodziców i nauczycieli. E-learning „Bezpieczeństwo dla wszystkich” jest jednym z najnowszych w Polsce bezpłatnych narzędzi internetowych, które w niezwykle praktyczny i nowoczesny sposób przedstawiają zasady ruchu drogowego, uczą jak bezpiecznie poruszać się po drogach, kształtują i utrwalają pozytywne nawyki, a także prezentują ciekawostki związane z BRD przydatne nawet najbardziej doświadczonym kierowcom. E-learning składa się z trzech sprofilowanych modułów - dla dzieci, nauczycieli i rodziców. Program został w 2006 roku oficjalnie wpisany do wykazu środków dydaktycznych zalecanych do użytku szkolnego przez Ministra Edukacji Narodowej. Przeznaczony jest do kształcenia ogólnego, kształcenia zintegrowanego i wychowania komunikacyjnego na poziomie szkoły podstawowej.

- Konkurs plastyczny - polega na przygotowaniu przez klasę dowolną techniką plastyczną plakatu ilustrującego hasło przewodnie danej edycji. Konkurs ma charakter grupowy i jest przeznaczony dla całych klas bądź zespołów (np. kół przedmiotowych, świetlicowych itp.). Zwycięski zespół reprezentuje Polskę na międzynarodowym finale we Francji - w Parku Disneyland pod Paryżem, a zwycięski plakat jest eksponowany na billboardach w całej Polsce.

- Szkolne kluby bezpieczeństwa - projekt przeznaczony jest dla uczniów i nauczycieli szkół podstawowych w całej Polsce. Celem klubów jest aktywne działanie na rzecz poprawy bezpieczeństwa ruchu drogowego wśród lokalnej społeczności - w szkole, jak i poza nią. Członkowie klubu mogą np.: organizować lokalne happeningi i akcje ulotkowe, prezentować na forum szkoły najważniejsze zagadnienia bezpieczeństwa ruchu drogowego z pomocą policji lub straży miejskiej czy też samodzielnie przeprowadzić szkolną akcję pt. „Detektyw bezpieczeństwa - czy nasza szkoła jest bezpieczna?”. Najbardziej aktywne i efektywne kluby zdobywają atrakcyjne nagrody - zarówno dla szkół, nauczyciela-opiekuna, jak i członków klubu.

Akcja "Niesłyszący - bezpieczny uczestnik ruchu drogowego"

Propaguje wśród dzieci niesłyszących i niepełnosprawnych intelektualnie w stopniu lekkim prawidłowe zachowania na drodze i w środkach komunikacji oraz naukę udzielania pierwszej pomocy. 
„Przedszkolak bezpieczny na drodze"

Działania podjęte w Grudziądzu w zakresie realizacji programu autorskiego i przeznaczone dla dzieci w wieku od 3 do 6 lat. Celem jest nauczenie i opanowanie zasad ruchu drogowego.

„Bezpieczni na drodze”

Projekt adresowany do uczniów szkół podstawowych w Darłowie. Miał na celu naukę zasad prawidłowego poruszania się w ruchu drogowym. Realizowany był od listopada 2007 roku do kwietnia 2008 roku.

\section{Bielański konkurs "Chodzę i jeżdżę bezpiecznie”}

Bielański konkurs „Chodzę i jeżdżę bezpiecznie” jest realizowany od 2001 roku, a od 2010 roku przeprowadzany pod zmienionym tytułem „Chodzę i jeżdżę bezpiecznie po Europie”. Organizatorami konkursu są Szkoła Podstawowa nr $80 \mathrm{im}$. Marii Kownackiej w Warszawie oraz Wydział Oświaty i Wychowania Dzielnicy Bielany m.st. Warszawy. Konkurs organizowany jest we współpracy z Instytutem Transportu Samochodowego, Wojewódzkim Ośrodkiem Ruchu Drogowego w Warszawie, Komendą Stołeczną Policji, Automobilklubem Polski i Strażą Miejską m.st. Warszawy.

Adresowany jest do uczniów warszawskich szkół podstawowych. Konkurs m.in. ujawnia zachowania dzieci i młodzieży w rzeczywistym ruchu drogowym poruszających się pieszo i rowerem. Jego wyniki są analizowane przez jury konkursu i przez nauczycieli. Wykazywane są mocne i słabe strony uczestników celem nakreślenia dalszych kierunków działań w zakresie edukacji komunikacyjnej dzieci i młodzieży. Zamierzeniem konkursu jest:

- poznanie podobnych i odmiennych rozwiązań w ruchu drogowym dotyczących pieszego, pasażera i rowerzysty w Polsce i poszczególnych krajach UE,

- kształtowanie bezpiecznych i kulturalnych zachowań dzieci i młodzieży w ruchu drogowym jako pieszych, pasażerów i rowerzystów,

- kształtowanie szacunku i odpowiedzialności za życie własne i innych uczestników ruchu drogowego oraz gotowości udzielania pomocy przedmedycznej,

- kształtowanie ciekawości poznawczej, kreatywności, innowacyjności i otwartości wobec Europy i świata,

- kształtowanie umiejętności korzystania z mapy i różnych źródeł wiedzy z zastosowaniem technologii informacyjno-komunikacyjnej,

- kształtowanie umiejętności prezentowania opracowanych materiałów,

- kształtowanie postaw prospołecznych i proekologicznych, 
- promowanie roweru jako ekologicznego i rekreacyjnego środka transportu drogowego.

\section{Wielka Brytania}

\section{Zarządzanie oświatą i programy nauczania}

System oświatowy Wielkiej Brytanii nie jest jednolity. Systemy szkolne Anglii i Walii są relatywnie podobne do siebie, lecz odmienne od systemów oświatowych Szkocji i Irlandii Północnej, które regulowane są odrębnymi ustawami i zarządzeniami władz lokalnych. W Anglii i Walii instytucjami odpowiedzialnymi za organizację oświaty jest Ministerstwo ds. Dzieci, Edukacji, Kształcenia Ustawicznego i Umiejętności (Department for Children, Education, Lifelong Learning and Skills, DCELLS). W Anglii dodatkowo za oświatę odpowiada Ministerstwo ds. Biznesu, Innowacji i Umiejętności (Department for Business, Innovation and Skills, BIS). W Irlandii Północnej za centralne administrowanie systemem kształcenia podstawowego i średniego odpowiada Ministerstwo Edukacji (Department of Education, DE), a za szkolnictwo wyższe - Ministerstwo Zatrudnienia i Kształcenia (Department for Employment and Learning, DEL). W Szkocji za ogólny nadzór nad edukacją i rozwojem usług edukacyjnych odpowiada Pierwszy Minister ds. Szkocji (First Minister of Scotland). W jego imieniu obowiązki te wykonuje Sekretarz Stanu ds. Edukacji i Kształcenia Ustawicznego (Secretary for Education and Lifelong Learning). Wspieraniem tworzenia i realizacji polityki oświatowej Szkocji zajmują się Inspektorat ds. Edukacji (Her Majesty's Inspectorate of Education, HMIE) oraz instytucje odpowiedzialne za opracowywanie programów nauczania, przeprowadzanie egzaminów i finansowanie szkockich placówek edukacyjnych - Szkockie Biuro ds. Uczenia się i Nauczania (Learning \&Teaching Scotland), Szkocki Urząd ds. Kwalifikacji (Scottish Qualifications Authority), Szkocka Rada ds. Wsparcia Finansowego Oświaty (Scottish Funding Council, SFC).

W Anglii, Walii i Irlandii Północnej programy nauczania opracowywane są samodzielnie przez szkoły w sposób odzwierciedlający specyfikę ich potrzeb i warunków działania. Placówki zobowiązane są zadbać o to, by program był odpowiednio zrównoważony i zgodny z ogólnymi wytycznymi. W ministerialnych przepisach ustalono specjalne wymogi dotyczące nauczania określonych przedmiotów. W Szkocji programy nauczania bazują na wskazówkach i wytycznych szkockich władz oświatowych. Wytyczne publikowane są w dokumentach programowych, które koncentrują się jedynie na dwóch przedmiotach: eduka- 
cja religijna wraz z praktykami religijnymi oraz język celtycki w rejonach, gdzie jest używany. Nauczanie pozostałych przedmiotów pozostaje w gestii szkoły. Należą do nich: język angielski, matematyka, nauka o środowisku, sztuka, etyka wraz z rozwojem indywidualnym, społecznym i edukacją zdrowotną. W szkole średniej program nauczania jest podzielony na dwa etapy. W pierwszych dwóch klasach prowadzi się kształcenie ogólne, zgodnie z narodowym programem 5-14 (National 5-14 Programme), natomiast w trzeciej i czwartej klasie wprowadza się elementy specjalizacji i kształcenia zawodowego dla wszystkich uczniów. Nauczyciele mają pełną swobodę wyboru podręczników i pomocy naukowych.

\section{Kształcenie BRD}

Model edukacji obowiązujący w Zjednoczonym Królestwie daje możliwość szerokiej promocji bezpieczeństwa drogowego na wszystkich poziomach edukacji. Już w latach trzydziestych XX wieku w ramach wychowania komunikacyjnego uczono dzieci przepisów ruchu drogowego i bezpiecznego poruszania się po drogach. Nie podchodzono do problemu jednak od strony psychologicznej i często winiono dzieci za powodowanie wypadków drogowych, gdyż te nie zachowywały się zgodnie ze wskazówkami, jakie otrzymywały od dorosłych.

Od wielu lat kształcenie w zakresie bezpieczeństwa ruchu drogowego wspierane jest przez Królewskie Stowarzyszenie Zapobiegania Wypadkom Drogowym. Pierwsze materiały edukacyjne dla dzieci zostały opublikowane już w 1935 roku. W 1936 roku upowszechniono dla potrzeb szkół kilka przykładów dobrych praktyk z zakresu wychowania komunikacyjnego, takich jak: model sygnalizacji świetlnej, trasy BRD na placach zabaw, pokazy bezpieczeństwa dla rodziców podczas dni otwartych. W latach pięćdziesiątych i sześćdziesiątych XX wieku z myślą o podniesieniu ogólnej wiedzy z dziedziny bezpieczeństwa ruchu drogowego wśród dzieci i uczniów szkół wszystkich szczebli zaczęto realizować programy BRD w ramach klubów: Klub Misia - dla dzieci poniżej 6 roku życia, Klub Uważaj i Klub Tufty - dla dzieci od 8 do 12 lat. Celem klubów było przybliżenie młodemu pokoleniu zagadnień związanych z tematyką bezpieczeństwa na drodze przez prelekcje i dystrybucję książek, plakatów informacyjnych o tematyce BRD. W latach siedemdziesiątych XX wieku wraz z gwałtownym rozwojem motoryzacji w Zjednoczonym Królestwie zmieniło się podejście do wychowania komunikacyjnego. Po pierwsze, to władze lokalne stały się odpowiedzialne za wychowanie komunikacyjne w podległych placówkach oświatowych. Po drugie, twórcy programów BRD zaczęli rozumieć, że dzieci to nie mali dorośli i ich postrzega- 
nie ruchu drogowego jest inne. Świadomość tego sprawiła, że nauczyciele zaczęli przywiązywać większą uwagę do możliwości fizycznych i psychicznych dzieci w różnym wieku i dostosowywać treści z zakresu BRD do ich potrzeb. Kolejna zmiana w podejściu do edukacji BRD zaszła w Wielkiej Brytanii w latach osiemdziesiątych XX wieku. Od tego czasu największy nacisk w wychowaniu komunikacyjnym zaczęto kłaść na podejście praktyczne. Wyniki szkoleń udowodniły, że ćwiczenia w małych grupach w rzeczywistym ruchu drogowym dają najlepsze rezultaty w kształtowaniu odpowiednich umiejętności i postaw dzieci podczas kształcenia komunikacyjnego.

Współcześnie realizowane zajęcia mają zarówno charakter teoretyczny, jak i praktyczny. Prowadzone są pod opieką nauczycieli, przedstawiciela Biura BRD (Road Safety Officers, RSOs) ${ }^{11}$, policji i rodziców wolontariuszy w rzeczywistym ruchu drogowym, nawet z małymi dziećmi po ich odpowiednim przygotowaniu teoretycznym. Obecnie wychowanie komunikacyjne realizowane jest w brytyjskich szkołach na podstawie ogólnych zaleceń, a treści tej tematyki wpisane są w programy kilku przedmiotów (np. edukacja zdrowotna). Uwagę zwraca rozbudowana sieć kampanii społecznych i programów edukacyjnych BRD realizowanych przez władze lokalne i policję, głównie poza szkołą. W realizację wychowania komunikacyjnego zaangażowane są ponadto koncerny samochodowe, stowarzyszenia, fundacje, towarzystwa ubezpieczeniowe oraz wiele organizacji i instytucji rządowych i pozarządowych (np. The Royal Society for the Prevention of Accidents, RoSPA).

Duże znaczenie w promowaniu wychowania BRD odgrywa Ministerstwo Transportu (Department for Transport), które oprócz edukacji dzieci i nastolatków wspomaga swoimi materiałami szkoleniowymi i publikacjami edukacyjnymi także rodziców i nauczycieli realizujących zajęcia z zakresu BRD.

\section{Inne inicjatywy edukacyjno-społeczne w zakresie edukacji BRD}

\section{Dziecięcy Klub Ruchu Drogowego ${ }^{12}$}

Działa w Wielkiej Brytanii od 1990 roku. Jest projektem regionalnym adresowanym do dzieci w wieku 3-5 lat, ich starszego rodzeństwa, rodziców i opiekunów. Można go również realizować w żłobkach i przedszkolach. Celem programu jest zmniejszenie liczby wypadków drogowych z udziałem dzieci, zwiększenie świadomości na temat bezpieczeństwa ruchu drogowego, uczenie dzieci bezpiecznych za-

11 http://www2.dft.gov.uk/pgr/roadsafety.

12 www.trafficclub.co.uk. 
chowań podczas wykonywania codziennych czynności. Poruszane są w nim następujące zagadnienia: bezpieczne zachowanie pieszych w ruchu drogowym, pojęcia związane z ruchem drogowym, poruszanie się w ruchu drogowym wspólnie z jego innymi uczestnikami, bezpieczeństwo w samochodzie i poza nim, bezpieczeństwo $\mathrm{w}$ transporcie miejskim, bycie widocznym na drodze, wspieranie i motywowanie rodziców do aktywności. Dziecko może zostać członkiem klubu po ukończeniu trzeciego roku życia. Członkom klubu raz na 3 miesiące przysyłana jest książeczka wraz z naklejkami i innymi atrakcyjnymi materiałami. Treścią książeczek są krótkie historyjki związane z bezpieczeństwem ruchu drogowego o przesłaniu łatwym do zrozumienia i zapamiętania przez dziecko. Zadaniem rodziców jest przeczytanie dziecku opowiadania na głos i porozmawianie z nim na ten temat. Historyjki w książeczkach podpowiadają rodzicom, jakie zagadnienia i w jakiej formie można omówić z dziećmi. Krótkie opowiadania są pretekstem do rozmów rodzica z dzieckiem o bezpiecznych miejscach zabawy, o prawidłowym przechodzeniu przez ulicę, o tym jak bezpiecznie podróżować i co zrobić, aby być widocznym na drodze.

\section{"Kerbcraft"13}

Program edukacyjny dotyczący BRD realizowany od 2002 roku w skali ogólnokrajowej jako część systemu szkolnego. Grupą docelową są dzieci w wieku 5-7 lat, rodzice, społeczność lokalna, dorośli ochotnicy pełniący rolę trenerów i piesi. Celem programu jest:

- nauczenie rozpoznawania niebezpiecznych miejsc w ruchu drogowym, pokonywanie ich i unikanie,

- kształtowanie umiejętności odpowiedniego zachowania w różnych sytuacjach w ruchu drogowym jako pieszych uczestników ruchu; stosowanie się do obowiązujących reguł,

- uświadomienie, że nawet przejście przez dobrze oznakowane skrzyżowanie wiąże się z ryzykiem wystąpienia wypadku, np. z powodu parkujących na poboczach pojazdów,

- nauczanie rodziców przekazywania dzieciom zasad poruszania się w ruchu drogowym; uczenie dzieci ze zrozumieniem.

Realizacja projektu wymaga:

- otrzymania pozwolenia rodziców na przeprowadzenie akcji z dziećmi,

- powołania trenerów ochotników wśród rodziców; szkolenia rodziców przez autorów projektu,

13 http://www.dft.gov.uk/topics/road-safety/kerb-craft. 
- wyznaczenia odpowiednich miejsc do testowania i przeprowadzenia treningu,

- trzydziestominutowych prób w ruchu drogowym, podczas których mówi się o bezpieczeństwie na drodze,

- rozpoznawania przez trzyosobowe grupy dzieci (z trenerem) miejsc niebezpiecznych na drodze; przechodzenia w grupach przez jezdnię w miejscach niebezpiecznych; obserwowania zachowania trenera i naśladowania jego zachowań w ruchu,

- sprawdzenia każdej nowo nabytej umiejętności.

Trenerami dzieci są ich rodzice ochotnicy. Nad nimi czuwają lokalni inspektorzy bezpieczeństwa ruchu drogowego i oni są odpowiedzialni za realizację akcji. Oni także są trenerami rodziców. W szkole nauczyciel koordynujący współpracuje z organizatorami i rodzicami.

W ramach programu „Kerbcraft” uczestnicy zdobywają trzy kluczowe umiejętności, których brak sprawia, że dzieci są bardziej narażone na udział w wypadku drogowym:

- rozpoznawanie niebezpiecznych miejsc w ruchu drogowym,

- przejście na drugą stronę ulicy między parkującymi samochodami,

- przejście na drugą stronę ulicy na skrzyżowaniu.

Zajęcia są dostosowane do etapu rozwoju i grupy wiekowej dzieci. Zaprojektowane tak, aby dziecko uczyło się w sposób naturalny, a przyswojone wiadomości były trwałe i stanowiły bazę do dalszych zajęć. Podczas zajęć praktycznych dzieci i rodzice noszą kamizelki odblaskowe.

Program rozpoczyna się w pierwszym roku szkoły, kiedy dziecko ma 5 lat. Składa się z 3 modułów, a każdy moduł z 4-6 sesji. Jedna sesja trwa 30 minut i odbywa się raz w tygodniu. Każde zajęcia wzmacniane są wieloma powtórzeniami. Dzieci muszą zaliczyć wszystkie moduły, gdyż brak zaliczenia jednego sprawia problemy w realizacji następnego. Rodzice są aktywnie włączeni w to działanie, które wymaga wysokiego poziomu organizacji i planowania. Jest prowadzone niezależnie od policji i innych organizacji. Akcji towarzyszy strona internetowa i forum dla koordynatorów i trenerów. Program ma własne logo, koszulki, plakaty itd.

\section{„Bikeability”14}

Rządowy program edukacyjny BRD przeznaczony dla rowerzystów (dzieci, młodzieży i dorosłych) realizowany od 2007 roku. Szkolenie jest prowadzone na

14 http://www.dft.gov.uk/bikeability. 
trzech poziomach. Poziom pierwszy poświęcony jest „panowaniu” nad rowerem. Zajęcia odbywają się na obszarze odizolowanym od ruchu drogowego. Wszystkie dzieci noszą kaski, kamizelki, ochraniacze na łokcie i kolana, aby uniknąć poważniejszych urazów. Obejmuje 1-2-godzinne zajęcia grupowe (15 osób) z instruktorem. Szkolenie to jest zalecane dla dzieci nie młodszych niż 8 lat. Poziom drugi realizowany jest na drogach o małym natężeniu ruchu, zazwyczaj na uczęszczanej przez dzieci trasie szkoła-dom. Składa się z 5 sesji z dwoma instruktorami z grupą liczącą nie więcej niż 12 osób. Sesja pierwsza obejmuje powtórzenie wiadomości i umiejętności z poziomu pierwszego. Poziom ten jest przeznaczony dla dzieci w wieku 10 lat. Poziom trzeci realizowany jest na drogach o normalnym natężeniu ruchu, z bardziej skomplikowanymi skrzyżowaniami. Poziom adresowany jest do dzieci powyżej 14 roku życia.

\section{"Camera Phone"15}

To ciekawa kampania społeczna uwrażliwiająca nastolatków na bezpieczne zachowanie na ulicy. „Camera Phone” to tytuł krótkiego filmu pokazywanego od czerwca 2008 do marca 2009 roku w brytyjskich kinach przed głównymi seansami. Film skierowany był do nastolatków w wieku 12-16 lat. W akcję włączyła się też muzyczna stacja telewizyjna MTV. Spot był nakręcony przy udziale nastolatków w technice imitującej zapis obrazu telefonem komórkowym. Przedstawia nieuważnego nastolatka, który przechodzi przez ulicę zajęty sprawami swoich rówieśników i wpada pod samochód. Film jest tak realistyczny, że organizatorzy kampanii zostali zasypani pytaniami, czy jest to zapis prawdziwego zdarzenia. Przekaz kampanii opierał się na takich kwestiach jak: myśl o tym, co robisz przechodząc przez jezdnię; słuchając muzyki, rozpraszasz się i nie będziesz mógł właściwie się skoncentrować na ruchu drogowym; nie ryzykuj przechodząc przez ulicę, używaj przejść dla pieszych - to bezpieczniejsze. Kampania uwzględniała oczekiwania młodych osób, które pragną niezależności, poruszają się samodzielnie i są przekonane, że wiedzą, jak należy zachowywać się w ruchu drogowym, choć zwykle przeceniają swoje umiejętności. Kampania pośrednio kierowana była do rodziców, którzy powinni wpajać dzieciom wiedzę o zasadach bezpieczeństwa, nie tylko o przepisach.

15 www.welovead.com/en/works/details/667zhuuv. 


\section{Szwecja}

\section{Zarządzanie oświatą i programy nauczania}

W Szwecji system zarządzania oświatą jest scentralizowany. Nad realizacją ustaw i rozporządzeń czuwa Ministerstwo Edukacji. Za organizację i funkcjonowanie szkół prowadzących kształcenie na poziomie podstawowym i średnim oraz kształcenie dorosłych odpowiadają gminy. Ramowy program nauczania, przedstawiający cele kształcenia, ustala się na szczeblu krajowym. Na podstawie tego programu każda gmina ma obowiązek określić cele i zadania dla swoich szkół. Następnie, na podstawie ramowego programu i lokalnych priorytetów edukacyjnych, każda szkoła obowiązkowo opracowuje plan pracy. Natomiast nauczyciele i szkoły samodzielnie wybierają metody nauczania i materiały dydaktyczne.

Ramowy program nauczania wyznacza przedmioty obowiązkowe, program nauczania danego przedmiotu oraz cele edukacyjne. W programie szkoły obowiązkowej istotne miejsce zajmuje język szwedzki, język angielski, matematyka, przedmioty przyrodnicze, praktyczne przedmioty artystyczne, przedmioty społeczne i drugi język obcy. W obowiązujących na szczeblu krajowym planach nauczania określono liczbę godzin przypadających na poszczególne przedmioty w dziewięcioletnim okresie nauki obowiązkowej, ale każda szkoła sama decyduje o tym, jak te godziny zostaną rozłożone na poszczególne lata i w której klasie należy wprowadzić dany przedmiot.

\section{Kształcenie BRD}

Wychowanie komunikacyjne zostało wprowadzone do szwedzkiego programu szkolnego w 1936 roku. Ważnym wydarzeniem dla rozwoju systemu kształcenia w zakresie BRD był 1967 rok, w którym w Szwecji zmieniono organizację ruchu drogowego z lewostronnego na prawostronny (słynny Dagen H, czyli „Dzień H”). Rząd przeznaczył wtedy specjalną dotację dla szkół na kształcenie BRD i wziął jednocześnie bezpośrednią odpowiedzialność za obszar wychowania komunikacyjnego społeczeństwa. W konsekwencji w 1976 roku zdefiniowano ogólnokrajowe cele edukacji z zakresu BRD. Zaliczono do nich:

- zwiększenie świadomości rozwoju transportu drogowego i związanych z nim zagrożeniami w ruchu drogowym,

- zwiększenie świadomości dzieci o ich wpływie na bezpieczeństwo ruchu drogowego oraz na zachowanie innych uczestników ruchu, 
- zachęcanie dzieci do odpowiedzialności i aktywności w działaniach na rzecz poprawy bezpieczeństwa ruchu drogowego.

W latach osiemdziesiątych XX wieku tradycyjne wychowanie komunikacyjne zaczęło przybierać bardziej praktyczny charakter. Nauczanie BRD oparto na zasadzie konieczności współdziałania wszystkich uczestników ruchu drogowego oraz na pozytywnych wzorcach zachowań. Kolejnym krokiem było w latach dziewięćdziesiątych włączenie do współpracy w kształceniu BRD rodziców i władz lokalnych.

Współcześnie w Szwecji wychowanie komunikacyjne jest obowiązkowe, lecz nie jest oparte na obowiązkowych programach szkolnych ${ }^{16}$. Zagadnieniem wychowania i kształcenia w zakresie bezpieczeństwa ruchu drogowego zajmują się instytucje rządowe i pozarządowe oraz organizacje i fundacje. Ich działanie polega na prowadzeniu akcji społecznych i organizowaniu szkoleń skierowanych do dzieci, młodzieży, rodziców i nauczycieli. Nauczyciele są odpowiedzialni za dokonanie wyboru treści z zakresu BRD i ich włączenie w proces edukacyjny. Tradycyjne pojęcie wychowania komunikacyjnego zostaje zastępowane przez nowe pojęcie „badają i uczą się”. Jego idea polega na aktywnym udziale dzieci w procesie tworzenia bezpiecznego lokalnego środowiska, którego jednym z ważnych elementów jest bezpieczeństwo ruchu drogowego.

\section{Inne inicjatywy edukacyjno-społeczne w zakresie edukacji BRD} „Baw się, badaj i ucz się"

Akcja ogólnokrajowa realizowana w Szwecji od 1993 roku. Przeznaczona jest dla dzieci w wieku 5-13 lat. Włączeni są w nią nauczyciele, dyrektorzy szkół, rodzice, przedstawiciele władzy lokalnej, drogowcy - projektanci i wykonawcy. Główne cele przedsięwzięcia, to:

- zapoznanie uczniów ze społecznymi i technicznymi aspektami ruchu drogowego,

- przygotowanie uczniów do uczestniczenia w ruchu drogowym,

- zachęcenie uczniów do większej aktywności w środowisku lokalnym.

- Zajęcia w ramach akcji „Baw się, badaj i ucz się” obejmują następujące zagadnienia:

- $\quad$ sporządzenie mapy miejsc niebezpiecznych w okolicy i zaproponowanie bezpieczniejszych rozwiązań,

16 http://www.seriforum.org/skrivutprojektaktuellt.asp?ID=2. 
- wpływanie na decydentów, by wspierali bezpieczeństwo drogowe,

- refleksja nad własnym zachowaniem w ruchu drogowym.

Akcja ma charakter multidyscyplinarny i służy wprowadzeniu do szerokiego partnerstwa przedstawicieli władzy lokalnej, rodziców, nauczycieli i uczniów. Uczniowie analizują mapy, dokumenty, zachowania uczestników ruchu drogowego. Uczą się, jak prowadzić konstruktywny dialog, jak formułować propozycje poprawy niebezpiecznych miejsc komunikacyjnych i współpracować ze sobą, aby osiągnąć wyznaczony cel. Ich działania przedstawiane są w lokalnych mediach, a proponowane rozwiązanie realizowane w praktyce.

Projekt wpływa na lokalne rozwiązania inżynierskie. Praca nad takim projektem trwa zazwyczaj kilka lat. Nauczyciel sam decyduje, ile czasu i jak często dzieci poświęcą każdemu zadaniu.

"Jesteś bezpieczny?"

Akcja przeznaczona dla dzieci w wieku 12-15 lat, realizowana w Malmö. Polega na włączeniu wybranych tematów z zakresu BRD do zajęć realizowanych w ramach różnych przedmiotów szkolnych. Atrakcyjność akcji polega na włączeniu się w jej realizację kilku nauczycieli danej szkoły. Wszyscy realizatorzy-nauczyciele umawiają się, jak przeprowadzą zajęcia. W ten sposób konkretne zagadnienie jest omówione z wielu perspektyw i tworzy całość, np. w ujęciu zdrowotnym (wpływ nieprawidłowego zachowania pieszego na bezpieczeństwo i jego zdrowie), matematycznym (obliczenie drogi hamowania pojazdu jadącego z różnymi prędkościami), plastycznym (wykonanie plakatów ostrzegających pieszych), teatralnym (przygotowanie krótkiej scenki/sztuki o postawach pieszych i kierowców) itd. Podstawową ideą akcji jest włączenie uczniów do aktywnego udziału w zajęciach oraz zaproszenie do udziału gości, np. przedstawicieli policji, ubezpieczycieli, uczestników i sprawców wypadków, ratowników medycznych i drogowych itd. Akcja wpływa na umocnienie prawidłowych postaw u dzieci, integruje wszystkich uczestników oraz wyrabia nawyki odpowiedzialności i wzajemnej współpracy w ruchu drogowym.

\section{„Don't Drink and Drive"}

Akcja jest realizowana w szkołach od 2003 roku. Grupą docelową jest młodzież w wieku od 15 do 24 lat. Celem jest redukcja liczby wypadków drogowych spowodowanych alkoholem przez uświadomienie młodym ludziom konsekwencji prowadzenia samochodu pod wpływem alkoholu oraz naukę skutecznego powstrzymania innych osób od prowadzenia samochodu w stanie nietrzeźwości. 
Zajęcia prowadzone są na przełomie sierpnia i września z udziałem specjalistów BRD, policji i zaproszonych gości. Czas trwania zajęć wynosi łącznie 8 godzin. Program zajęć obejmuje spotkanie z kimś, kto stracił bliską osobę w wypadku drogowym spowodowanym przez nietrzeźwego kierowcę oraz udział $\mathrm{w}$ nabożeństwie z zapalonymi świecami symbolizującymi ofiary wypadków drogowych. Następnie młodzież podzielona na cztery grupy przechodzi kolejno przez cztery stanowiska:

- test na symulatorze zderzeń - zaobserwowanie i poznanie mechanizmu znaczenia zapięcia pasów bezpieczeństwa podczas wypadku,

- test na symulatorze dachowania - zaobserwowanie i zrozumienie znaczenia zapięcia pasów bezpieczeństwa podczas wypadku,

- specjalny wyciąg, który podnosi uczestników do góry na wysokość odpowiadającą drodze hamowania, jaką pokonuje samochód przy różnych prędkościach. Przy tym stanowisku obecny jest policjant i przedstawiciel służb medycznych. Opowiadają oni o prędkości jazdy i jej konsekwencjach.

- prezentacja krótkiego filmu pokazującego ostatnie 7 sekund życia młodej osoby jadącej samochodem z prędkością $90 \mathrm{~km} / \mathrm{h}$ bez zapiętych pasów tuż przed wypadkiem.

Po przejściu czterech stanowisk przez uczestników zajęć, grupa zawodowych aktorów odgrywa przedstawienie na temat prowadzenia samochodu i picia alkoholu. Zgromadzona młodzież bierze aktywny udział w tym spektaklu i może wskazać własne zakończenie przedstawianej historii.

Przed rozpoczęciem szkolenia uczniowie wypełniają ankietę o niebezpiecznych sytuacjach na drodze powodowanych alkoholem i własnym postępowaniu. Ten sam kwestionariusz uczniowie wypełniają po zakończeniu kursu. Badanie powtarzane jest także po zakończeniu semestru i roku szkolnego.

\section{Austria}

\section{Zarządzanie oświatą i programy nauczania}

W Austrii odpowiedzialność za uchwalanie i wdrażanie przepisów prawnych jest podzielona między federację i kraje związkowe (landy). Szczebel federalny wyznacza ogólne ramy prawne, natomiast wdrażaniem szczegółowych przepisów zajmują się landowe parlamenty. Wszelkie aspekty dotyczące organizacji struktur szkolnych, procesu kształcenia, wynagrodzenia i uprawnień emerytalnych nauczycieli uchwalane są na szczeblu federalnym. Landy odpowiadają głównie 
za zapewnienie kadry nauczycielskiej oraz wspierają finansowo gminy w budowaniu i prowadzeniu placówek szkolnictwa obowiązkowego. Nadzór administracyjny nad szkolnictwem podstawowym, średnim oraz kolegiami nauczycielskimi sprawuje Federalne Ministerstwo Edukacji, Sztuki i Kultury. Za szkolnictwo wyższe odpowiada Federalne Ministerstwo Nauki i Badań, natomiast za przyuczenie do zawodu w zakładach pracy Federalne Ministerstwo Gospodarki i Pracy.

Ramowy program nauczania powstaje na podstawie projektów opracowywanych przez grupy robocze ds. programów nauczania, konsultacji z organami edukacyjnymi na szczeblu landów i okręgów, oraz organizacjami i związkami nauczycielskimi. Choć ramowy program oraz listę podręczników zatwierdza Federalne Ministerstwo Edukacji, Sztuki i Kultury, to szkoły mają pełną swobodę w dostosowywaniu programu nauczania do lokalnych potrzeb, a wybór podręczników zależy od decyzji nauczycieli. Przedmiotami obowiązkowymi w szkole podstawowej i średniej są: religia, geografia regionu/historia/biologia, język niemiecki, matematyka, wychowanie muzyczne, wychowanie plastyczne, prace ręczne i techniczne, wychowanie fizyczne, nowożytny język obcy i bezpieczeństwo drogowe (bez ocen).

\section{Kształcenie BRD}

Kształcenie z zakresu bezpieczeństwa ruchu drogowego jest w Austrii obowiązkowe dla uczniów klas I-IV szkół podstawowych i realizowane w wymiarze 10 godzin rocznie. W szkołach specjalnych BRD jest obowiązkowe dla uczniów klas $\mathrm{I}-\mathrm{V}$, a zajęcia odbywają się w wymiarze 8 godzin rocznie. Zgodnie z zaleceniami programowo-metodycznymi, kształcenie w klasach I-III powinno mieć charakter ćwiczeń praktycznych przeprowadzanych w rzeczywistym ruchu drogowym. W programie BRD przeznaczonym dla klasy IV i V, główny nacisk położony jest na zdobycie wiedzy i umiejętności umożliwiających uzyskanie karty rowerowej.

W ramach praktycznych ćwiczeń wychowania BRD w rzeczywistym ruchu drogowym uczniowie pod kierownictwem nauczyciela uczą się rozpoznawać i prawidłowo reagować na sygnały świetlne, odgłosy silnika jadącego i hamującego pojazdu, pisk opon itp. Dostrzegać, świadomie odróżniać i dostosowywać swoje zachowanie do sytuacji drogowej. Znać znaki drogowe, przepisy i zasady BRD (np. korzystanie z chodnika, zachowanie procedur przed przekroczeniem jezdni, przejścia dla pieszych). Poznanie i zrozumienie rzeczywistych warunków drogowych w rejonie szkoły, a zwłaszcza zidentyfikowanie miejsc niebezpiecznych ma bezpośredni wpływ na bezpieczeństwo uczniów. 
W szkołach zawodowych (Hauptschulen) i niższych klasach szkół średnich ogólnokształcących (allgemeinbildende höhere Schulen) istnieje możliwość prowadzenia zajęć z ruchu drogowego w ramach zajęć fakultatywnych i nieobowiązkowych ćwiczeń. W różnych rodzajach szkół średnich ogólnokształcących i zawodowych kształcenie BRD może być realizowane jako zajęcia nieobowiązkowe w wymiarze 1 godziny tygodniowo. Zadaniem tych zajęć jest praktyczne i teoretyczne przygotowanie uczniów do egzaminu na kartę motorowerową.

\section{Estonia}

\section{Zarządzanie oświatą i programy nauczania}

W Estonii ogólnokrajowe standardy kształcenia ustalane są na szczeblu centralnym. Ministerstwo Edukacji odpowiada na szczeblu krajowym za opracowywanie i wdrażanie polityki edukacyjnej oraz nadzoruje szkoły obowiązkowe i średnie. Samorządy nadzorują na szczeblu regionalnym placówki przedszkolne i szkoły oraz zapewniają w pewnym zakresie poradnictwo i opiekę psychologiczną, natomiast samorządy lokalne prowadzą placówki przedszkolne, szkoły obowiązkowe i średnie. Każda szkoła opracowuje własny program nauczania, opierając się na ogólnokrajowej podstawie programowej, która zawiera m.in. listę przedmiotów obowiązkowych (takich samych dla wszystkich uczniów). Nauczyciele mają swobodę w doborze metod nauczania i podręczników.

\section{Kształcenie BRD}

Programy szkolne w Estonii zbudowane są na bazie przedmiotów obowiązkowych, bloku przedmiotów do wyboru oraz bloku tematów międzyprzedmiotowych, interdyscyplinarnych. Program nauczania nie przewiduje oddzielnego przedmiotu wychowania komunikacyjnego. Kształcenie w zakresie BRD realizowane jest w ramach tematów międzyprzedmiotowych w bloku tematów interdyscyplinarnych. Wśród nich znajdują się np.: tematy dotyczące planowania kariery zawodowej, przedsiębiorczości, aktywnego stylu życia, tożsamości kulturowej, inicjatywy obywatelskiej czy problematyka zatytułowana zdrowie i bezpieczeństwo. Tematy zagadnień międzyprzedmiotowych budowane są w zależności od potrzeb, oczekiwań i zainteresowań środowiska lokalnego, szkolnego i indywidualnych preferencji uczniów i nauczycieli. Często wybrane zagadnienie do realizacji w obszarze międzyprzedmiotowym może być omawiane we współpracy 
z policją, strażą pożarną, innymi instytucjami ratowniczymi, oświatowymi, samorządowymi, kulturalnymi, stowarzyszeniami promującymi bezpieczeństwo na drodze. Zagadnienia związane z edukacją bezpieczeństwa ruchu drogowego omawiane są zatem przy okazji wielu tematów, które podejmują nauczyciel i uczniowie.

\section{Finlandia}

\section{Zarządzanie oświatą i programy nauczania}

Zarządzanie fińskim systemem oświaty odbywa się na zasadzie decentralizacji zadań. Ministerstwo Edukacji określa we współpracy z Krajowym Urzędem ds. Edukacji cele, treści i metody ogólnokrajowego programu kształcenia dla poziomu szkoły podstawowej i średniej oraz kształcenia dorosłych. W każdej z sześciu fińskich prowincji tymi sprawami zajmuje się odpowiedni Departament Edukacji i Kultury. Zarządzanie oświatą na szczeblu lokalnym należy do zadań władz lokalnych (gmin), które odgrywają istotną rolę w tym procesie jako organizatorzy kształcenia. Znakomita większość szkół powszechnych i średnich II stopnia prowadzona jest przez władze lokalne lub wspólne urzędy gminne (federacje gmin). 0 zakresie autonomii szkół decydują władze lokalne. Cele kształcenia i kryteria oceny określa ogólnokrajowy program nauczania. Na jego podstawie szkoły i władze lokalne przygotowują własne regulacje dotyczące programów nauczania, które uwzględniają lokalną specyfikę. Nauczyciele mają swobodę wyboru metod kształcenia i materiałów dydaktycznych.

Obowiązkowymi przedmiotami na poziomie kształcenia w szkole powszechnej są: język ojczysty (tj. fiński lub szwedzki) i literatura kraju ojczystego, drugi język ojczysty, języki obce, ekologia, edukacja zdrowotna, religia lub etyka, historia, wiedza o społeczeństwie, matematyka, fizyka, chemia, biologia, geografia, wychowanie fizyczne, wychowanie muzyczne, wychowanie plastyczne, prace ręczne, zajęcia z gospodarstwa domowego oraz lekcje wychowawcze i doradztwa pedagogicznego.

\section{Kształcenie BRD}

W Finlandii nie ma oddzielnego przedmiotu, w zakresie którego realizowane są zagadnienia bezpieczeństwa ruchu drogowego. Zagadnienie BRD zostało umieszczone w podstawie programowej wychowania przedszkolnego, szkolnictwa pod- 
stawowego oraz średniego i realizowane jest w ramach kilku różnych przedmiotów. Głównym zadaniem edukacyjnym jest zapobieganie wypadkom drogowym z udziałem młodych ludzi. Program nauczania przedszkolnego zakłada, że dzieci poznają podstawowe zasady bezpieczeństwa, jakie powinni stosować na przykład w drodze z domu do szkoły. Na poziomie szkoły podstawowej i średniej uczniowie powinni poznać zasady ruchu drogowego, uzupełnione o problematykę ratownictwa drogowego. Tematy te włączone są do przedmiotów związanych $\mathrm{z}$ ochroną środowiska naturalnego, edukacją zdrowotną i naukami społecznymi. Ze względu na wysoki poziom autonomii edukacyjnej uzależniony od potrzeb lokalnych trudno jest określić ogólny wymiar czasowy realizacji BRD. Niektóre szkoły oferują uczniom zajęcia fakultatywne z tematyki BRD, a inne włączają te zagadnienia do różnych przedmiotów. Fińska oświata kieruje się zasadą, że to nie liczba godzin konkretnego przedmiotu, a rzeczywista realizacja celów BRD zawartych w podstawie programowej powinna być wyznacznikiem wyedukowania młodzieży.

\section{Grecja}

\section{Zarządzanie oświatą i programy nauczania}

Ministerstwo Edukacji Narodowej i Spraw Religijnych opracowuje i wdraża przepisy, koordynuje i ocenia działalność urzędów regionalnych, zarządza funduszami, zatwierdza programy nauczania dla szkół podstawowych i średnich oraz mianuje nauczycieli. Prefektury (lub, w dużych prefekturach, urzędy ds. edukacji) nadzorują szkoły, koordynują działania szkół oraz odpowiadają za szkolne budynki i ich wyposażenie. Dyrektorzy szkół nadzorują działalność placówki i odpowiadają za przestrzeganie przez szkołę wymogów prawnych. Szkolne rady pedagogiczne zajmują się wdrażaniem regulacji dotyczących programów nauczania oraz monitorowaniem frekwencji i dyscypliny w szkole. Komitety szkolne odpowiadają za sprawy administracyjne oraz zarządzają funduszami na ogrzewanie, oświetlenie, remont i wyposażenie szkoły. Programy nauczania opracowywane są przez Instytut Pedagogiki i zatwierdzane przez Ministerstwo. Przedmiotami obowiązkowymi w szkole podstawowej są: religia, język grecki, matematyka, historia, ekologia, geografia, przyroda, wiedza o społeczeństwie, wychowanie artystyczne, język obcy i wychowanie fizyczne. Przedmioty te (z wyjątkiem ekologii i wychowania artystycznego) są również obowiązkowe we wszystkich klasach szkoły średniej I stopnia. Do przedmiotów obowiązkowych 
w szkole średniej I stopnia należą również: informatyka i/lub technika, literatura starożytnej Grecji, nauki polityczne i społeczne, orientacja zawodowa i zajęcia z gospodarstwa domowego. Nauczyciele mogą korzystać z pomocy metodycznej Instytutu Pedagogiki, ale sami wybierają metody kształcenia. Materiały dydaktyczne i podręczniki muszą opierać się na programach nauczania zatwierdzonych przez Ministerstwo Edukacji i Spraw Religijnych.

\section{Kształcenie BRD}

Kształcenie z zakresu bezpieczeństwa ruchu drogowego zostało wprowadzone do greckich programów nauczania w 2010 roku. Przedmiot realizowany jest w trzeciej klasie szkoły podstawowej. Na edukację BRD przeznaczono 1 godzinę w tygodniu. Zaleca się interdyscyplinarne podejście do realizacji programu w ramach tzw. elastycznej strefy interdyscyplinarnych działań twórczych skierowanych przede wszystkim na praktyczną stronę BRD, np. przez realizację ciekawych projektów edukacyjnych, omawianie zagadnień w szerszym aspekcie odpowiedzialności i kultury obywatelskiej. Zakres tematyczny i dydaktyczny wybierany jest przez samych nauczycieli we współpracy z osobą odpowiedzialną w placówce szkolnej lub w rejonie szkolnym za edukację zdrowotną.

\section{Hiszpania}

\section{Zarządzanie oświatą i programy nauczania}

W Hiszpanii w sprawach edukacji władze centralne zachowały odpowiedzialność tylko w zakresie ogólnych uregulowań oświatowych, a większość zadań została w 1978 roku przekazana 17 samorządom regionalnym (wspólnotom autonomicznym). Zasadniczym aspektem hiszpańskiego systemu edukacji jest społeczne uczestnictwo w edukacji. Zarówno na szczeblu krajowym, regionalnym, jak i lokalnym oraz w poszczególnych szkołach tworzy się rady szkolne, które mają zachęcać do uczestnictwa w konsultacjach społecznych wszystkie grupy zainteresowane edukacją. Na szczeblu ogólnokrajowym istnieje Państwowa Rada Szkolna, która umożliwia przedstawicielom społeczeństwa udział w ogólnym planowaniu oświaty oraz doradza w sprawie projektów ustaw i innych aktów prawnych proponowanych lub wydawanych przez rząd. W każdej szkole finansowanej ze środków publicznych działa Rada Szkolna, która jest organem przedstawicielskim różnych grup tworzących środowisko edukacyjne, zajmującym się 
zarządzaniem i nadzorem nad daną placówką. W jej skład wchodzi kierownictwo placówki oraz przedstawiciele nauczycieli, uczniów, rodziców, personelu administracyjnego i technicznego, jak również - w przypadku placówek prywatnych finansowanych ze środków publicznych - przedstawiciele właścicieli placówki. Do zadań Rady Szkolnej należy m.in. podejmowanie decyzji w sprawie naboru uczniów, zatwierdzanie budżetu placówki i analizowanie jej funkcjonowania. Radę informuje się także o przedstawianych władzom edukacyjnym wnioskach o mianowanie i zwalnianie członków kierownictwa.

W zakresie programów nauczania istnieje autonomia, która wyraża się w tym, że programy tworzy się na trzech poziomach. Przyjmując za punkt wyjścia podstawy programowe, które władze centralne ustalają dla całego kraju, każda wspólnota autonomiczna opracowuje własny, oficjalnie obowiązujący program nauczania (pierwszy poziom tworzenia programu). Następnie, na drugim poziomie tworzenia programu nauczania, placówka edukacyjna dostosowuje do swoich potrzeb i dopracowuje ten „wspólnotowy” program nauczania. Trzeci poziom tworzenia programu stanowi „programowanie w klasie”, na które składa się wiele jednostek dydaktycznych opracowywanych przez nauczyciela dla każdej konkretnej grupy uczniów. Przedmiotami obowiązkowymi w szkole podstawowej są: środowisko naturalne, społeczne i kulturowe, wychowanie artystyczne, wychowanie fizyczne, język i literatura hiszpańska, drugi język urzędowy i literatura danej wspólnoty autonomicznej, języki obce i matematyka. Placówki szkolne są również zobowiązane prowadzić zajęcia z religii katolickiej, ale uczęszczanie na te zajęcia nie jest obowiązkowe dla uczniów. Podstawa programowa w szkole średniej I stopnia obejmuje język i literaturę hiszpańską, drugi język urzędowy i literaturę danej wspólnoty autonomicznej, języki obce, matematykę, wychowanie fizyczne, przedmioty przyrodnicze, edukację plastyczną, wiedzę o społeczeństwie, geografię i historię, technikę oraz wychowanie muzyczne. Zajęcia z religii katolickiej są obowiązkowo prowadzone przez placówki, ale nieobowiązkowe dla uczniów.

\section{Kształcenie BRD}

W Hiszpanii kształcenie z zakresu bezpieczeństwa ruchu drogowego jest obowiązkowe dla uczniów od 2 do 15 roku życia (przedszkole, szkoła podstawowa i szkoła średnia I stopnia). Ogólna strategia dotycząca bezpieczeństwa drogowego wypracowywana i określana jest przez Wyższą Radę Bezpieczeństwa Drogowego (Consejo Superior de Seguridad Vial) działającą przy Ministerstwie Spraw 
Wewnętrznych, w której składzie znajduje się także przedstawiciel Ministerstwa Edukacji. Kształcenie z zakresu BRD odbywa się w Hiszpanii zgodnie z wytycznymi zawartymi w ustawie o edukacji z $2006 \mathrm{roku}^{17}$. Ustawa ma charakter dość ogólny i choć wskazuje cele nauczania, to nie zawiera szczegółowego wykazu przedmiotów. Wśród celów nauczania w szkole podstawowej wymienia promowanie wykształcenia w zakresie ruchu drogowego i kształtowanie postawy ostrożnego zachowania, które przyczyniają się do zapobiegania wypadkom drogowym (art. 18 lit. n.). Wśród celów szkolnictwa średniego wskazuje się na ugruntowanie postaw zachowania ostrożności w obszarze bezpieczeństwa drogowego (art. 33 lit. n.).

Problematyka bezpieczeństwa ruchu drogowego realizowana jest w szkołach podstawowych i średnich w charakterze interdyscyplinarnym (temat BRD rozproszony jest w ramach kilku przedmiotów, np. wychowanie obywatelskie, przyroda) i zintegrowanym (temat BRD jest elementem kluczowych kompetencji w ramach wybranych przedmiotów: edukacja na rzecz obywatelstwa i praw człowieka, wiedza o środowisku naturalnym, społecznym i kulturalnym człowieka). Podstawowym założeniem kształcenia BRD jest wyrobienie u uczniów świadomości odpowiedzialności za postępowanie człowieka jako uczestnika ruchu drogowego. W tym zakresie program nauczania szczegółowo opisany jest tzw. kluczowymi kompetencjami, jakie powinien nabyć uczeń. Obok odpowiedzialności za własne postępowanie, świadomości konsekwencji łamania przepisów uczniowie poznają zasady ruchu drogowego i prawidłowe ich stosowanie.

\section{Łotwa}

\section{Zarządzanie oświatą i programy nauczania}

Łotewska administracja oświatowa podzielona jest na trzy szczeble - krajowy, lokalny i szczebel szkolny. Najważniejszymi organami decyzyjnymi na szczeblu krajowym są: Sejm, Rada Ministrów oraz Ministerstwo Edukacji i Nauki. Najważniejszą instytucją odpowiedzialną za tworzenie polityki edukacyjnej jest Ministerstwo Edukacji i Nauki. Ministerstwo wydaje również zezwolenia niezbędne do założenia ogólnokształcących placówek edukacyjnych oraz określa standardy kształcenia wraz z treściami i zasadami kształcenia nauczycieli. Uprawnienia

17 Ley Orgánica, de 3 de mayo, de Educación, http://noticias.juridicas.com/base_datos/Admin/ lo2-2006.html. 
do tworzenia placówek edukacyjnych oraz prowadzenia nad nimi nadzoru administracyjnego i finansowego posiadają także ministerstwa: Rolnictwa, Opieki Socjalnej i Kultury. Władze lokalne (w porozumieniu z odpowiednim ministerstwem) mogą zakładać, reorganizować i zamykać szkoły, zgodnie z przepisami centralnymi. Miasta i okręgi odpowiadają za placówki przedszkolne, szkoły podstawowe oraz szkoły średnie I i II stopnia, z wyjątkiem placówek edukacyjnych prowadzonych bezpośrednio przez władze centralne i placówek utrzymywanych ze środków prywatnych. Szkoły mają stosunkowo szeroką autonomię w zakresie organizacji pracy, opracowywania przepisów wewnętrznych, zatrudniania i określania zakresu obowiązków kadry nauczycielskiej i personelu technicznego oraz dysponowania posiadanymi środkami. Za inspekcje szkolne odpowiada bezpośrednio Ministerstwo Edukacji i Nauki. Programy nauczania opracowuje się na szczeblu krajowym. Wszystkie przedmioty są obowiązkowe i prowadzone na tym samym poziomie dla uczniów we wszystkich szkołach, z wyjątkiem szkół z rozszerzonym programem nauki języków obcych lub wychowania muzycznego. Uczniowie mają również możliwość specjalizowania się w określonych przedmiotach. Nauczyciele samodzielnie dobierają metody nauczania i podręczniki z listy zatwierdzonej przez Ministerstwo Edukacji i Nauki. Podręczniki zalecane przez Ministerstwo Edukacji i Nauki można kupować z funduszy publicznych.

\section{Kształcenie BRD}

Na Łotwie nie ma w programach nauczania oddzielnego przedmiotu zatytułowanego wychowanie komunikacyjne. Placówki edukacyjne mają stosunkowo szeroką autonomię w zakresie organizacji pracy, realizacji zaleceń programowych, opracowywania przepisów wewnętrznych, zatrudniania i określania zakresu obowiązków kadry nauczycielskiej. Edukacja w zakresie bezpieczeństwa ruchu drogowego realizowana jest w ramach programu kształcenia ogólnego dziewięciu klas zintegrowanej szkoły obowiązkowej (szkoła podstawowa i średnia). Tematyka BRD została umieszczona w programie obowiązkowego przedmiotu nauki społeczne i godzin wychowawczych. Zagadnienia BRD obowiązkowo nauczane są we wszystkich klasach I-IX. Zgodnie z założeniami programu uczeń kończący klasę trzecią powinien znać podstawowe przepisy i umieć przestrzegać zasad ruchu drogowego. Po ukończeniu klasy szóstej powinien umieć przestrzegać zasad prawidłowego i bezpiecznego poruszania się na rowerze. W klasie dziewiątej nabywa zdolność prawidłowego analizowania różnych sytuacji związanych z BRD. 


\section{Niemcy}

\section{Zarządzanie oświatą i programy nauczania}

W Republice Federalnej Niemiec zakres odpowiedzialności za system edukacji wynika z federalnej struktury państwa. Zgodnie z Ustawą Zasadniczą (Grundgesetz), za ustawodawstwo i administrację oświatową odpowiadają przede wszystkim kraje związkowe - landy, w których działają landowe ministerstwa edukacji, kultury i nauki oraz struktury nadzorujące szkoły na niższym szczeblu (Schulamt). Taki podział odpowiedzialności dotyczy w szczególności struktury systemu szkolnego oraz programów i metod nauczania. Zadania rządu federalnego w dziedzinie edukacji obejmują m.in. ustanawianie przepisów wyznaczających ogólne ramy współpracy oświatowej pomiędzy szczeblem federalnym i landami, np. w zakresie planowania edukacji i promowania badań.

Ministerstwa edukacji w landach ustalają program nauczania, zalecają metody nauczania i zatwierdzają podręczniki. Do przedmiotów nauczanych w szkole podstawowej należą: czytanie, pisanie, arytmetyka, wprowadzenie do przedmiotów przyrodniczych i społecznych, wychowanie plastyczne, wychowanie muzyczne, wychowanie fizyczne i religia. Programy nauczania na poziomie średnim zależą od rodzaju placówki, ale zwykle stanowią kontynuację przedmiotów ze szkoły podstawowej i obejmują co najmniej jeden język obcy oraz przedmioty przyrodnicze i społeczne. Uczniowie szkół średnich II stopnia obowiązkowo uczą się przedmiotów z następujących trzech grup: języki/literatura/ przedmioty humanistyczne, przedmioty społeczne oraz matematyka/przedmioty przyrodnicze/technika. Programy kształcenia zawodowego w szkołach o profilu zawodowym obejmują język niemiecki, przedmioty społeczne, matematykę, przedmioty przyrodnicze, język obcy i wychowanie fizyczne oraz przedmioty zawodowe.

\section{Kształcenie BRD}

Kształcenie w zakresie BRD realizowane jest zgodnie zaleceniami wydanymi w 1972 roku przez Stałą Konferencję Ministrów Edukacji i Kultury, Nauki i Oświaty Krajów Związkowych Republiki Federalnej Niemiec. Zalecenia dotyczą szkoły podstawowej i średniej, ale w każdym landzie decyzję o realizacji programu podejmują władze regionalne oraz władze placówek oświatowych. Jeżeli kształcenie BRD jest realizowane w danej szkole, to nie w ramach oddzielnego 
przedmiotu. Program wychowania komunikacyjnego włączony jest do innych przedmiotów, takich jak geografia, historia i środowisko naturalne. Liczba godzin przeznaczanych na wychowanie BRD jest zmienna i waha się od 20 godzin rocznie w szkole podstawowej (wiek: 6-10 lat) do 10 godzin rocznie w szkole średniej (wiek: 11-18 lat). W szkole średniej podjęcie decyzji o realizacji problematyki wychowania komunikacyjnego całkowicie zależy od nauczyciela.

Władze niektórych landów dla potrzeb placówek oświatowych utworzyły specjalne, niezależne stanowisko eksperta ds. bezpieczeństwa ruchu drogowego (Beauftragten für Verkehrserziehung). Jest to nauczyciel specjalizujący się w szkoleniach z dziedziny bezpieczeństwa drogowego i komunikacyjnego. Odpowiada za prawidłowe wydatkowanie środków na BRD, realizację ciekawych programów edukacyjnych, a także za włączenie do współpracy szkolnej rodziców, sponsorów i innych instytucji zajmujących się promocją bezpieczeństwa w ruchu drogowym.

\section{Włochy}

\section{Zarządzanie oświatą i programy nauczania}

We Włoszech za system oświaty odpowiada całościowo Ministerstwo Edukacji, Szkolnictwa Wyższego i Badań Naukowych (Ministero dell'Istruzione, dell'Università e della Ricerca) działające na poziomie centralnym. Przedstawicielem ministerstwa na szczeblu lokalnym są urzędy ds. edukacji w regionach i prowincjach. Regiony mogą przekazać niektóre obowiązki prowincjom i gminom. Zgodnie z ustawą nr 59 z 15 marca 1997 roku i późniejszym rozporządzeniem (DPR 275/1999) wszystkie szkoły mają autonomię w zakresie administracji, organizacji, dydaktyki, badań oraz prowadzenia wszelkich przedsięwzięć eksperymentalnych i rozwojowych.

Programy nauczania w szkołach podstawowych i średnich I stopnia powinny być realizowane na podstawie ogólnokrajowych wytycznych dotyczących zindywidualizowanych planów kształcenia (Indicazioni Nazionali per i piani personalizzati delle attività educative) z 2004 r. oraz wytycznych dotyczących programów nauczania (Indicazioni per il curricolo per la scuola dell'infanzia e per primo ciclo di istruzione) wydanych w 2007 r. W wytycznych określa się docelowy poziom, jaki powinni osiągnąć uczniowie w każdej szkole. Każda szkoła dostosowuje wytyczne do potrzeb lokalnych w ramach swej autonomii. Dla każdego przedmiotu określa się zasób wiedzy i umiejętności, a szkoła ma ułatwić uczniom przekształ- 
cenie ich w indywidualne kompetencje. Szczegółowe cele kształcenia w szkole podstawowej zdefiniowano dla następujących przedmiotów: religia katolicka, język włoski, język angielski, historia, geografia, matematyka, przedmioty przyrodnicze, wychowanie techniczne i informatyka, muzyka, plastyka, zajęcia sportowe. Szczegółowe cele kształcenia w szkole średniej I stopnia zdefiniowano dla następujących przedmiotów: religia katolicka, język włoski, język angielski, drugi język obcy, historia, geografia, matematyka, przedmioty przyrodnicze, technika, informatyka, muzyka, plastyka, zajęcia sportowe. Nauczyciele mają pełną swobodę w dokonaniu wyboru podręczników i metod dydaktycznych. Od 2012 roku wszystkie podręczniki mają być udostępniane w Internecie.

\section{Kształcenie BRD}

We Włoszech zagadnienie bezpieczeństwa ruchu drogowego nie ma swojego oddzielnego przedmiotu i jeżeli jest nauczane, to decyzja w tej sprawie pozostawiona jest dyrekcji i nauczycielom danej placówki. Zgodnie z prawem oświatowym ${ }^{18}$, do programów nauczania szkół podstawowych i średnich wprowadzono przedmiot obywatelstwo i konstytucja. Obejmuje on wychowanie obywatelskie, edukację dla środowiska naturalnego, edukację świadomości prawnej, wychowanie zdrowotne, edukację dla pracy i wolontariatu oraz edukację bezpieczeństwa ruchu drogowego. Obywatelstwo i konstytucja to przedmiot, który został wprowadzony do szkół w roku szkolnym 2010/2011. Opiera się na na formule przygotowywania projektów, które opracowywane są przez tematyczne zespoły uczniowskie.

\section{Zakończenie}

Zasady kształtowania europejskiej polityki edukacyjnej zarysowane zostały w art. 165 Traktatu o funkcjonowaniu Unii Europejskiej, zgodnie z którym podkreśla się dążenie Unii do rozwoju edukacji wysokiej jakości, wskazując jednocześnie na pełne poszanowanie odpowiedzialności państw członkowskich za treści nauczania i organizację systemów edukacyjnych. Tak więc wpływ na kształt struktury szkolnictwa czy zakres treści nauczania pozostaje wyłącznie w indywidualnej gestii poszczególnych państw. Chcąc jednak pomóc krajom

18 http://www.istruzione.it/alfresco/d/d/workspace/SpacesStore/19b60061-d624-4dbd-be97784876cb6393/cm86_10.pdf. 
członkowskim w przygotowaniu uczniów do funkcjonowania w niezwykle szybko zmieniającej się rzeczywistości społeczno-gospodarczej, podjęto próbę sformułowania europejskich ram określających nowe umiejętności podstawowe uzyskiwane w procesie uczenia się przez całe życie, czyli podjęto próbę określenia tzw. kompetencji kluczowych. W zaleceniu Parlamentu Europejskiego i Rady z 18 grudnia 2006 r. w sprawie kompetencji kluczowych w procesie uczenia się przez całe życie (Dz.Urz. UE L 394/10 z 30 grudnia 2006 r.) wskazano osiem takich kompetencji: porozumiewanie się w języku ojczystym, porozumiewanie się w językach obcych, kompetencje matematyczne, kompetencje informatyczne, umiejętność uczenia się, inicjatywność i przedsiębiorczość, świadomość i ekspresja kulturalna, kompetencje społeczne i obywatelskie. Kształcenie z zakresu bezpieczeństwa ruchu drogowego wyśmienicie wpisuje się właśnie w tę ostatnią kompetencję kluczową, gdyż powinno w praktyce kształtować konkretne umiejętności niezbędne do odpowiedzialnego obywatelskiego życia.

Mimo że w analizowanych państwach członkowskich Unii Europejskiej nie ma jednolitego modelu kształcenia BRD, to bez wątpienia charakterystyczną cechą tej edukacji jest różnorodność rozwiązań programowych, organizacyjnych i skupianie się na wyposażeniu młodych ludzi w konkretne umiejętności mające uczyć ich odpowiedzialności za siebie i innych.

\section{Bibliografia}

Dąbrowska-Loranc M., Wacowska-Ślęzak J., Klub Pancernika Klika w Fotelikach - kampania EUCHIRES w Polsce, „Kwartalnik BRD” 2006, nr 1.

Dziewulak D., Kształcenie dzieci i młodzieży w zakresie bezpieczeństwa ruchu drogowego w wybranych krajach Unii Europejskiej, „Analizy BAS” 2011, nr 20(64).

Wacowska-Ślęzak J., Klub Pancernika Klika w Fotelikach - po raz drugi, „Kwartalnik BRD” 2006, $\mathrm{nr} 4$.

\section{Akty prawne}

Ley Orgánica, de 3 de mayo, de Educación, https://www.boe.es/buscar/act.php?id=BOE-A-2006-7899.

Zalecenie Parlamentu Europejskiego i Rady nr 2006/962/WE z 18 grudnia 2006 r. w sprawie kompetencji kluczowych w procesie uczenia się przez całe życie, Dz.Urz. UE L 394/10 z 30 grudnia 2006 r., https://ec.europa.eu/epale/pl/resource-centre/content/ zalecenie-parlamentu-europejskiego-i-rady-z-dnia-18-grudnia-2006-r-w-sprawie. 


\section{Strony internetowe}

https://ec.europa.eu/transport/road_safety/sites/roadsafety/files/pdf/projects/rose-25.pdf. http://ec.europa.eu/transport/rose25/index_en.htm.

http://lex.pl/serwis/du/2009/0017.htm.

www.klubpancernika.pl.

http://www.bezpieczenstwo.renault.pl.

http://www2.dft.gov.uk/pgr/roadsafety/.

www.trafficclub.co.uk.

http://www.dft.gov.uk/topics/road-safety/kerb-craft/.

http://www.dft.gov.uk/bikeability/.

www.welovead.com/en/works/details/667zhuuv.

http://www.seriforum.org/skrivutprojektaktuellt.asp?ID=2.

http://noticias.juridicas.com/base_datos/Admin/lo2-2006.html. 


\title{
2.5. Wychowanie fizyczne w szkołach w wybranych państwach europejskich
}

\author{
Physical education in schools in selected European \\ countries
}

\begin{abstract}
W opracowaniu przedstawiono problematykę zajęć wychowania fizycznego i liczebności grup na lekcjach wychowania fizycznego w szkołach w wybranych państwach europejskich. Ponadto w artykule syntetycznie omówiono obowiązkowe treści wychowania fizycznego oraz liczbę godzin wychowania fizycznego w programach szkół.

Słowa kluczowe: szkoła, klasa, wychowanie fizyczne, liczebność grupy

The paper presents the issues of physical education classes and the number of students in PE lessons at schools in selected European countries. In addition, the article synthetically discusses the mandatory content of physical education and the number of hours of physical education in school curricula.
\end{abstract}

Keywords: school, class, physical education, group size

\section{Wstęp}

We wszystkich europejskich państwach w programach nauczania na poziomie szkoły podstawowej i szkoły średniej I stopnia (w Polsce - gimnazjum) wychowanie fizyczne jest przedmiotem obowiązkowym ${ }^{1}$. Za główny cel wychowania fizycznego uznaje się fizyczny, indywidualny i społeczny rozwój dziecka. W niektórych krajach (Cypr, Finlandia, Irlandia) uzupełnieniem wychowania fizycznego jest promocja zdrowego stylu życia realizowana poprzez odrębny obowiązkowy przedmiot zatytułowany edukacja zdrowotna. Ponadto w niektórych państwach do przedmiotu wychowania fizycznego stosuje się podejście interdyscyplinarne. W Czechach, Niemczech i Norwegii w ramach zajęć wychowania fizycznego uczniowie poznają zasady ruchu drogowego. W krajach skandynawskich uczą się korzystać z mapy i poznają podstawowe zasady orientacji w terenie. W Czechach i Grecji zwraca się szczególną uwagę na przekazywanie w trakcie zajęć

1 Opracowanie przygotowano na podstawie ekspertyzy Biura Analiz Sejmowych nr 1434/14 z 15 września 2014 r. D. Dziewulaka zatytułowanej Informacja na temat zajęć wychowania fizycznego i liczebności grup na lekcjach WF w szkołach w wybranych krajach Unii Europejskiej. 
sportowych wiedzy o wartościach i symbolach olimpijskich. W Słowenii nauczyciele innych przedmiotów mają możliwość przerywania lekcji na tzw. minutę dla zdrowia, w trakcie której uczniowie wykonują proste ćwiczenia gimnastyczne i się relaksują.

\section{Obowiązkowe treści wychowania fizycznego}

Programy nauczania dla pierwszych klas szkoły podstawowej w większości krajów europejskich zawierają podstawowe ćwiczenia motoryczne, takie jak marsz, bieg, skoki i rzuty. Poziom trudności ćwiczeń wzrasta wraz z wiekiem uczniów stopniowo w miejsce podstawowych umiejętności wprowadza się inne bardziej skomplikowane realizowane najczęściej w ramach gier zespołowych. Równie po-

Wykres 2. Wykaz dyscyplin sportowych najczęściej występujących w programach nauczania wychowania fizycznego w szkolnictwie państw członkowskich Unii Europejskiej

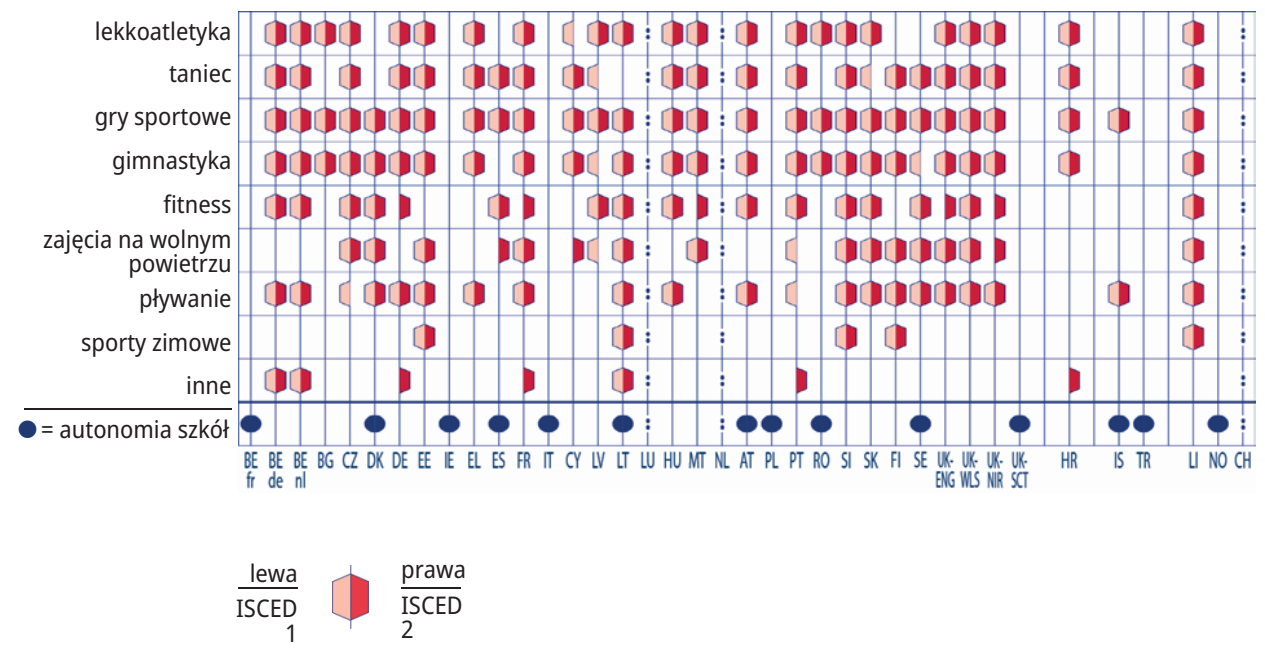

Symbole (domeny) krajów wykorzystane w diagramie: AT - Austria, BE fr - Belgia Wspólnota Francuska, BE de - Belgia Wspólnota Niemieckojęzyczna, BE nl - Belgia Wspólnota Flamandzka, BG - Bułgaria, HR Chorwacja, CZ - Czechy, CY - Cypr, DE - Niemcy, DK - Dania, EE - Estonia, EL - Grecja, ES - Hiszpania, FI - Finlandia, FR - Francja, HU - Węgry, IE - Irlandia, IS - Islandia, IT - Włochy, LI - Liechtenstein, LT Litwa, LU - Luksemburg, LV - Łotwa, MT - Malta, NL - Holandia, NO - Norwegia, PL - Polska, PT - Portugalia, RO - Rumunia, SE - Szwecja, SK - Słowacja, SI - Słowenia, TR - Turcja, UK-ENG/WLS/NIR - Anglia, Walia, Irlandia Płn., UK-SCT - Szkocja.

Źródło: https://eurydice.org.pl/wp-content/uploads/2014/12/PE_PL.pdf. 
pularne są: lekkoatletyka, taniec, gimnastyka i pływanie. Dyscypliny sportowe, które najczęściej występują w programach nauczania wychowania fizycznego, zostały wymienione na wykresie 3 . W niektórych krajach decyzję o tym, czy dana dyscyplina jest obowiązkowa dla uczniów czy nie, pozostawiono szkołom.

\section{Liczba godzin wychowania fizycznego w programach szkolnych}

W europejskich systemach szkolnych liczba godzin wychowania fizycznego jest zależna od wieku uczniów, szczebla edukacji, typu szkoły i sposobu organizacji pracy placówek oświatowych. Niektóre kraje wyznaczają minimalną liczbę godzin zajęć wychowania fizycznego na poziomie centralnym, inne natomiast pozostawiają decyzję o liczbie godzin kierownictwu placówek. Przykładowo w roku szkolnym 2011/2012 minimalna liczba godzin wychowania fizycznego na poziomie szkoły podstawowej (ISCED 1) wynosiła w Irlandii 37 godzin, a we Francji 108 godzin. Na poziomie szkoły średniej I stopnia (ISCED 2) 2 w Hiszpanii, na Malcie i w Turcji liczba ta oscylowała w przedziale od 24 do 35 godzin, a we Francji i Austrii od 102 do 108 godzin.

Analizy porównawcze dotyczące liczby godzin przeznaczonych na poszczególne przedmioty nauczania w szkolnictwie europejskim wskazują, że liczba godzin wychowania fizycznego jest prawie o połowę niższa niż na przykład liczba godzin matematyki czy języka ojczystego. Niewielka liczba godzin przeznaczonych na lekcje wychowania fizycznego uzupełniana jest przez szkoły przez zachęcanie uczniów do uczestnictwa w dodatkowych zajęciach sportowych oferowanych poza oficjalnym planem lekcji. Są to na przykład zawody w różnych dyscyplinach sportowych lub zajęcia prozdrowotne organizowane w celu zapewnienia uczniom dodatkowej możliwości korzystania ze sportu w atrakcyjniejszej formie. Zajęcia pozalekcyjne organizowane są w Europie na różnym poziomie: krajowym, regionalnym, lokalnym lub bezpośrednio przez szkoły. Sportowe zajęcia pozalekcyjne przeznaczone są dla wszystkich uczniów, choć w niektórych krajach organizuje się również specjalne zajęcia ruchowe dla uczniów niepełnosprawnych i potrzebujących szczególnego wsparcia zdrowotnego. Sportowe zajęcia pozalekcyjne (konkursy, zawody, spartakiady, turnieje itp.) mogą być organizowane w czasie przeznaczonym na inne przedmioty lub po zakończeniu

2 Więcej informacji na ten temat można znaleźć w: D. Dziewulak, Wymiar czasu pracy nauczycieli w wybranych państwach Unii Europejskiej, „Analizy BAS” 2009, nr 13(21), http:// orka.sejm.gov.pl/WydBAS.nsf/0/5B394EDCA941C294C12576480048C3F7/\$file/Analiza_\%20 BAS_2009_21.pdf. 
Wykres 3. Wykaz minimalnej obowiązkowej liczby godzin wychowania fizycznego jako procent ogólnej liczby obowiązkowych godzin na poziomie szkoły podstawowej i szkoły średniej I stopnia w szkolnictwie państw członkowskich Unii Europejskiej

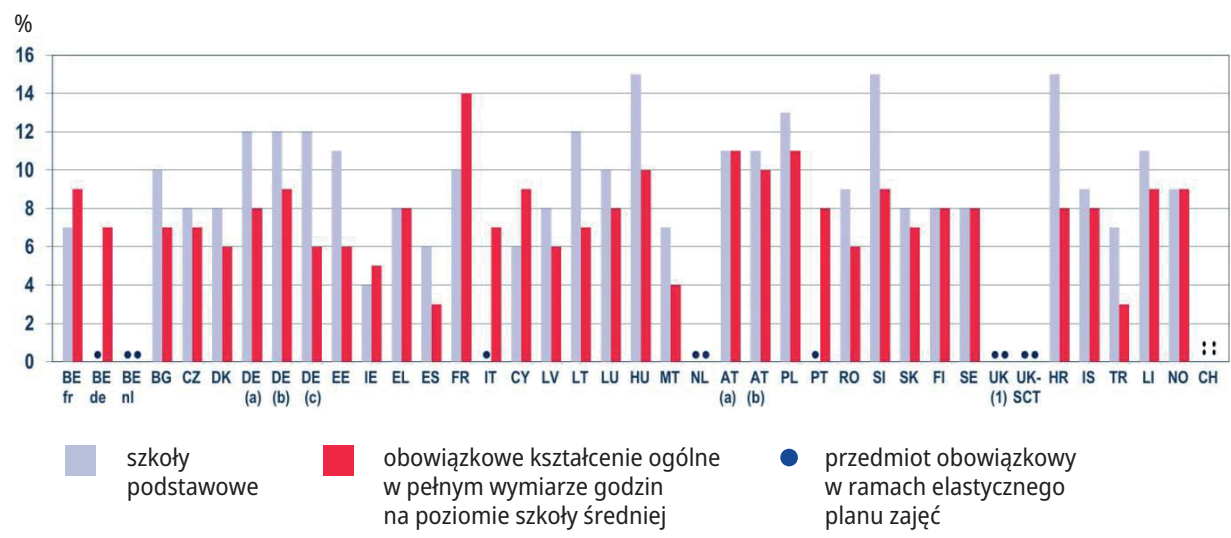

Symbole (domeny) krajów wykorzystane w diagramie: AT(a) - Austria [Volksschule+AHS], AT(b) - Austria [Volksschule+Hauptschule+PTS], BE fr - Belgia Wspólnota Francuska, BE de - Belgia Wspólnota Niemieckojęzyczna, BE nl - Belgia Wspólnota Flamandzka, BG - Bułgaria, HR - Chorwacja, CZ - Czechy, CY - Cypr, DE - Niemcy, DE(a) - Niemcy [Grundschule+Gymnasium], DE(b) - Niemcy [Grundschule+Hauptschule], DE(c) - Niemcy [Grundschule+Realschule], DK - Dania, EE - Estonia, EL - Grecja, ES - Hiszpania, FI - Finlandia, FR - Francja, HU - Węgry, IE - Irlandia, IS - Islandia, IT - Włochy, LI - Liechtenstein, LT - Litwa, LU - Luksemburg, LV - Łotwa, MT - Malta, NL - Holandia, NO - Norwegia, PL - Polska, PT - Portugalia, RO - Rumunia, SE - Szwecja, SK - Słowacja, SI - Słowenia, TR - Turcja, UK(1) - Wielka Brytania, UK-SCT - Szkocja.

Źródło: https://eurydice.org.pl/wp-content/uploads/2014/12/PE_PL.pdf.

innych lekcji. W części krajów stanowią one integralną część szkolnego dnia. Przykładowo w Danii w wielu szkołach na początku dnia, przed rozpoczęciem lekcji, wszyscy uczniowie uczestniczą w tzw. porannym biegu. W części krajów uczniowie mogą korzystać z zajęć sportowych organizowanych w czasie długich przerw, np. na sali gimnastycznej czy na boisku szkolnym.

W większości krajów postępy uczniów w ramach wychowania fizycznego ocenia się tak samo jak w innych przedmiotach. Ocen z WF nie wystawia się jedynie na Malcie i w Norwegii na poziomie ISCED 1 oraz w Irlandii na poziomach ISCED 1 i ISCED 2. W większości krajów europejskich istnieją ministerialne wytyczne dotyczące oceniania uczniów w zakresie wychowania fizycznego. Jedynie w Belgii i Islandii decyzja o sposobie oceniania postępów uczniów na lekcjach WF pozostawiona jest szkołom. 


\section{Liczba uczniów w klasie w szkolnictwie obowiązkowym}

W większości krajów europejskich istnieją regulacje dotyczące maksymalnej liczby uczniów w klasie na poziomie szkoły podstawowej i średniej I stopnia ${ }^{3}$. W niektórych przypadkach regulacje określają jednocześnie maksymalną i minimalną liczebność klasy (Austria, Bułgaria, Chorwacja, Cypr, Czechy, Liechtenstein, Luksemburg, Niemcy, Portugalia, Rumunia, Turcja, Włochy).

W kontekście ogólnoeuropejskim limity liczebności klas na poziomie ISCED 1 i ISCED 2 pozostają na poziomie 25-35 uczniów. Najwyższy górny limit uczniów w klasie obowiązuje w Wielkiej Brytanii w szkołach podstawowych i średnich I stopnia, gdzie wynosi 33 uczniów (Szkocja), a także w Hiszpanii i na Węgrzech, gdzie w szkołach średnich II stopnia wynosi 35 uczniów. Najmniejszą liczbę uczniów potrzebną do utworzenia klasy zanotowano w Republice Czeskiej i Rumunii, gdzie do założenia klasy w szkole podstawowej lub średniej potrzeba tylko 10 osób.

W szkołach średnich I stopnia na klasę przypada od 25 do 28 uczniów. Rzeczywista liczebność klas w większości państw jest mniejsza niż maksimum przewidziane w regulacjach. Zgodnie z przepisami, mimo ustalonego limitu uczniów, klasy mogą przekraczać wskazane wartości w Austrii, Estonii, na Słowacji, w Słowenii, Turcji i na Węgrzech. W szkolnictwie poziomu ISCED 2 najmniejsze liczebnie klasy występują najczęściej w państwach, w których nie wydano oficjalnych zaleceń dotyczących maksymalnej liczebności klas (np. Belgia, Dania, Łotwa, Finlandia, Islandia). Natomiast najliczniejsze klasy (ponad 30 uczniów) częściej zdarzają się w państwach, gdzie zdefiniowano oficjalną maksymalną liczebność klasy.

Zauważalną tendencją w szkolnictwie jest zwiększanie przez poszczególne państwa górnego limitu liczebności klas wraz z wiekiem uczniów. W większości systemów edukacji maksymalna liczba uczniów w klasie w szkolnictwie średnim jest wyższa niż w szkolnictwie podstawowym. Przepisy dotyczące wielkości klas

3 W Polsce zgodnie z przepisami zawartymi w nowelizacji ustawy o systemie oświaty z 30 sierpnia 2013 r., od 1 września 2014 r. do szkoły idą dzieci urodzone w 2007 r. (siedmiolatki) oraz urodzone do końca czerwca 2008 r. (sześciolatki). Aby zapobiec sytuacji, w której w jednej klasie uczyłaby się zbyt duża grupa dzieci, wprowadzony został przepis, zgodnie z którym liczba uczniów w klasach pierwszych nie powinna przekroczyć 25. Dochodzenie do tego standardu będzie stopniowe. Na początek liczba uczniów rozpoczynających naukę w 2014 r. w klasach pierwszych nie będzie mogła być większa niż 25. Od września 2015 r. zasada ta ma dotyczyć nie tylko klasy I, ale także klasy II. Od roku szkolnego 2016/2017 również w klasie III nie będzie mogło być więcej niż 25 uczniów. Określenie limitu uczniów w klasach I-III ma zbliżyć warunki wychowania i opieki w szkole nad najmłodszymi dziećmi do standardów przedszkolnych. W obecnym stanie prawnym taki limit jest jedynie zaleceniem. 
najczęściej dotyczą wszystkich poziomów i przedmiotów nauczania, jednakże z takich regulacji mogą być wyłączone niektóre przedmioty. Na przykład w Belgii (Wspólnota Francuska) w szkołach średnich I stopnia nauka religii i etyki odbywa się bez względu na liczbę zapisanych uczniów.

\section{Liczba uczniów na lekcjach wychowania fizycznego}

Ze względu na niewielką dostępność danych na temat liczebności grup ćwiczebnych na lekcjach wychowania fizycznego w europejskich szkołach podstawowych, Biuro Analiz Sejmowych zwróciło się za pośrednictwem Ministerstwa Edukacji Narodowej do europejskiej edukacyjnej bazy informacyjnej Eurydice z prośbą o udzielenie odpowiednich informacji. Do 15 września 2014 roku otrzymaliśmy odpowiedzi z 9 państw, które zostały przywołane w tym opracowaniu.

\section{Polska}

Zgodnie z rozporządzeniem Ministra Edukacji Narodowej z 7 lutego 2012 roku w sprawie ramowych planów nauczania w szkołach publicznych, w klasach IVVI szkoły podstawowej obowiązkowe lekcje wychowania fizycznego mogą być prowadzone w grupie oddziałowej, międzyoddziałowej lub międzyklasowej, a w przypadku zespołu szkół także w grupie międzyszkolnej, liczącej nie więcej niż 26 uczniów. W klasach IV-VI szkoły podstawowej, w gimnazjum i szkole ponadgimnazjalnej zajęcia wychowania fizycznego, w zależności od realizowanej formy tych zajęć, mogą być prowadzone łącznie albo oddzielnie dla dziewcząt i chłopców.

\section{Francja}

We Francji nie ma regulacji prawnych określających liczebność grup w szkołach podstawowych podczas zajęć wychowania fizycznego. Lekcje wychowania fizycznego prowadzone są w grupach koedukacyjnych.

\section{Holandia}

W Holandii nie ma uregulowań określających liczbę uczniów, która może wziąć udział w szkolnych zajęciach wychowania fizycznego. W publicznym i niepublicznym szkolnictwie podstawowym lekcje wychowania fizycznego - tak jak i zajęcia z innych przedmiotów - odbywają się w grupach koedukacyjnych. 


\section{Islandia}

Na Islandii nie ma uregulowań dotyczących liczebności uczniów na lekcjach wychowania fizycznego. Jedynym wyjątkiem są lekcje pływania, gdzie ze względów bezpieczeństwa grupa może liczyć maksymalnie 15 uczniów. Lekcje wychowania fizycznego w szkołach podstawowych odbywają się w grupach koedukacyjnych. Szkoły same decydują o programie i charakterze zajęć.

\section{Łotwa}

Na Łotwie w 2009 roku zniesiono przepisy określające liczebność klas. Tym samym brak jest regulacji określających liczbę uczniów w grupach podczas zajęć wychowania fizycznego. Lekcje wychowania fizycznego w szkołach podstawowych odbywają się w grupach koedukacyjnych. Podział na grupy dziewcząt i chłopców odbywa się w przypadkach, gdy wymaga tego specyfika zajęć.

\section{Malta}

Na Malcie nie ma oddzielnych przepisów określających w szkołach podstawowych dopuszczalną liczbę uczniów na lekcjach wychowania fizycznego. W wyniku porozumienia między Związkiem Nauczycieli a rządem Malty przyjmuje się, że szkoły nie powinny przekraczać liczebności powyżej 30 uczniów. W szkole podstawowej wszystkie przedmioty - w tym także wychowanie fizyczne - realizowane są w grupach koedukacyjnych.

\section{Niemcy}

W Niemczech nie ma regulacji prawnych określających liczebność grup podczas zajęć wychowania fizycznego. Wszystkie przedmioty w szkołach podstawowych prowadzone są klasach koedukacyjnych bez podziału na grupy. W niemieckich szkołach podstawowych klasa liczy średnio 24 uczniów.

\section{Szwecja}

W Szwecji nie ma regulacji prawnych określających liczebność grup w szkołach podstawowych podczas zajęć wychowania fizycznego. Lekcje odbywają się w grupach koedukacyjnych. Decyzja o tym, jak zorganizować zajęcia wychowa- 
nia fizycznego, należy do kierownictwa szkoły i nauczycieli. W szwedzkich szkołach podstawowych klasa liczy średnio 18-19 uczniów.

\section{Wielka Brytania}

W Wielkiej Brytanii (Anglia, Szkocja, Walia) nie ma regulacji prawnych określających liczebność grup w szkołach podstawowych podczas zajęć wychowania fizycznego. Nie ma także ustawowych limitów dotyczących liczebności klas w szkołach podstawowych, choć przyjęto praktykę, że klasa w szkole podstawowej nie powinna liczyć więcej niż 30 uczniów. Brak jest także aktów prawnych regulujących sposób prowadzenia lekcji wychowania fizycznego.

Całkowita odpowiedzialność za prawidłowe i bezpieczne przeprowadzenie zajęć wychowania fizycznego spoczywa na placówce szkolnej i nauczycielach. To poszczególne szkoły decydują o programie wychowania fizycznego i jego organizacji, a także o tym, czy chłopcy i dziewczęta biorą udział w zajęciach WF razem czy osobno.

Krajowy Związek Nauczycieli (National Union of Teachers, NUT) ${ }^{4}$ opublikował wytyczne dla nauczycieli dotyczące zachowania środków bezpieczeństwa na lekcjach. W zakresie wychowania fizycznego w dokumencie stwierdza się, że nauczyciel przygotowujący się do prowadzenia lekcji wychowania fizycznego powinien zwrócić uwagę na ryzyko wystąpienia zagrożeń, a w szczególności ocenić:

- charakter zajęć,

- miejsce zajęć (pomieszczenie zamknięte, teren),

- wiek, doświadczenie, dojrzałość, kompetencje oraz cechy motoryczne i emocjonalne uczniów 5 .

\section{Włochy}

We Włoszech przepisy oświatowe określają, że na wszystkich poziomach edukacji obowiązkowej liczba uczniów w klasie może wynosić maksymalnie 32. W szkole podstawowej liczba uczniów biorących udział w zajęciach wychowania fizycznego oraz podział na grupy dziewczęta-chłopcy nie są regulowane przepisami, a zależą od decyzji nauczyciela.

$4 \quad$ http://www.nut.org.uk/.

5 http://www.teachers.org.uk/files/safety-w-praktyce-lessons.doc. 


\section{Podsumowanie}

W szkołach podstawowych we Francji, Holandii, Islandii, na Łotwie, Malcie, w Niemczech, Szwecji, Wielkiej Brytanii i we Włoszech lekcje wychowania fizycznego odbywają się w grupach koedukacyjnych, natomiast brak jest uregulowań prawnych określających liczbę uczniów podczas lekcji wychowania fizycznego. Liczba ta jest konsekwencją regulacji określających dopuszczalną minimalną i maksymalna liczbę uczniów w klasie szkolnej przypadającej na jednego nauczyciela.

\section{Bibliografia}

Dziewulak D., Wymiar czasu pracy nauczycieli $w$ wybranych państwach Unii Europejskiej, „Analizy BAS” 2009, nr 13(21), http://orka.sejm.gov.pl/WydBAS.nsf/0/5B394EDCA941C294C12576480048C3F7/\$file/Analiza_\%20BAS_2009_21.pdf.

\section{Akty prawne}

Rozporządzenie Ministra Edukacji Narodowej z 7 lutego 2012 r. w sprawie ramowych planów nauczania w szkołach publicznych, Dz.U. poz. 204.

\section{Strony internetowe}

https://eurydice.org.pl/wp-content/uploads/2014/12/PE_PL.pdf.

http://www.nut.org.uk/.

http://www.teachers.org.uk/files/safety-w-praktyce-lessons.doc. 



\title{
Część 3
}

\section{Uczniowie}

\author{
Part 3
}

Students 
DOI: https://doi.org/10.31268/d.dziewulak.2020.01 


\title{
3.1. Wspieranie uczniów uzdolnionych w szkolnictwie europejskim i USA
}

\author{
Supporting the gifted students in the European \\ education and in the United States
}

W opracowaniu podjęto próbę omówienia systemów wspierania uzdolnionych uczniów w szkolnictwie wybranych państw europejskich i w Stanach Zjednoczonych. Analizie poddano pojęcia i definicje stosowane dla określenia uczniów zdolnych i utalentowanych. Omówiono kryteria identyfikowania uczniów utalentowanych i zdolnych oraz zastosowane rozwiązania edukacyjne pracy z takimi uczniami.

Słowa kluczowe: system szkolny, szkoła, uczniowie uzdolnieni, uczniowie utalentowani

The paper attempts to discuss systems supporting gifted students in the education of selected European countries and in the United States. The concepts and definitions used to describe gifted and talented students were analyzed. The criteria for identifying gifted and talented students as well as applied educational solutions for working with such students are discussed.

Keywords: school system, school, gifted students, talented students

\section{Wstęp}

W literaturze naukowej oraz podręcznikach psychologii i pedagogiki używa się wielu różnych terminów na określenie dzieci i młodzieży zdolnej¹. Terminy te mogą różnić się znacząco, zależnie od etymologii i kontekstu historycznego, miejsca analizy (Europa, Ameryka) oraz od przyjętej definicji uzdolnienia/talentu, do którego się odnoszą. Wydaje się również, że terminologia jest powiązana z polityką edukacyjną tworzoną z myślą o tej grupie dzieci i młodzieży.

1 Opracowanie przygotowano na podstawie ekspertyzy Biura Analiz Sejmowych nr 2085/14 z 9 października 2014 r. D. Dziewulaka, A. Pola zatytułowanej Informacja na temat systemu wspierania uczniów uzdolnionych w szkolnictwie państw europejskich i USA. 


\section{Część I: Państwa europejskie}

\section{Terminologia i definicje}

Spośród różnych definicji używanych w Europie w odniesieniu do dzieci i młodzieży uzdolnionej, w większości krajów najpowszechniej występują terminy „zdolny” i „utalentowany” (bądź „uzdolniony”, zależnie od kontekstu) (ang. gifted i talented). Należy jednak zauważyć, że w Zjednoczonym Królestwie (Anglii, Walii i Irlandii Północnej) różnicuje się ich znaczenie: „zdolny” jest terminem używanym w kontekście zdolności umysłowych lub akademickich/naukowych, natomiast „utalentowany” dotyczy raczej sztuk pięknych i sportu. Używa się również terminów „zdolny/posiadający zdolności” (able), „bardzo zdolny/posiadający duże zdolności” (very able, highly able), „zdolniejszy/posiadający większe zdolności” (more able) oraz „duże umiejętności” (high ability). W Irlandii oprócz terminu „zdolny/posiadający zdolności” (able) używa się drugiego określenia „uczeń wyjątkowo zdolny” (exceptionally able student). We Francuskiej Wspólnocie Belgii preferuje się określenie „młody człowiek o dużych potencjalnych zdolnościach” (jeunes à haut potentiel), we Flamandzkiej Wspólnocie Belgii używa się pojęcia „dzieci i młodzież o dużych zdolnościach” (Hoogbegaafde jongeren). We Francji - „dzieci nad wiek rozwinięte umysłowo” (intellectuellement précoces), w Hiszpanii - „uczniowie o dużych zdolnościach umysłowych” (alumnos con altas capacidades intelectuales). W Portugalii powszechnie używa się terminu „zdolny” (sobredotados), ale w oficjalnych dokumentach występuje termin „uczniowie o wyjątkowych zdolnościach do nauki” (alunos com capacidades excepcionais de aprendizagem). W oficjalnych dokumentach w Rumunii używa się terminów „uczniowie z predyspozycjami do osiągania dobrych wyników” (elevi cu abilităţi deosebite) i „uczniowie o wybitnych zdolnościach” (elevi capabili de performanţe). W Danii używane są dwa określenia: „dzieci/uczniowie o wyjątkowych zdolnościach” (Scerligt begavede børn/elever) oraz „dzieci/uczniowie o szczególnych predyspozycjach” (Børn/elever med særlige forudsœtninger). W Estonii przyjętym terminem jest „dziecko posiadające szczególny (wyjątkowy) talent lub uzdolnienie" (Eeriliste võimete ja annetega lapsed). W Holandii używa się terminu „(bardzo) zdolny” (Hoogbegaafd) lub „młodzież o specjalnych uzdolnieniach/ talentach” (Bijzonder getalenteerden). W Islandii przyjęty termin to „dziecko nad wiek rozwinięte” (Bráðger börn) i wykazujące szczególne potencjalne zdolności w pewnych dziedzinach. W Polsce stosuje się dwa terminy: „uczniowie zdolni” i „uczniowie szczególnie uzdolnieni”. W Finlandii, Szwecji i Norwegii nie używa 
się specjalnego terminu w odniesieniu do omawianej grupy dzieci i młodzieży. Jego brak wynika z faktu, że zgodnie z przyjętą w oświacie polityką integracji edukacyjnej unika się wszelkich form klasyfikowania dzieci i młodzieży, zwłaszcza pod kątem ich zdolności. Nacisk kładzie się na potencjał rozwojowy wszystkich młodych ludzi, nie dzieląc ich na tego rodzaju kategorie.

\section{Kryteria klasyfikacji}

Zdefiniowanie terminu, jakim określa się w danym państwie uczniów utalentowanych i zdolnych ${ }^{2}$, wymusza pytania o sposób zidentyfikowania takich jednostek w społeczności szkolnej - czyli pytania o kryteria klasyfikacji. Są one opracowane w celu identyfikowania dzieci i młodzieży o dużych potencjalnych zdolnościach. Najczęstszymi kryteriami klasyfikacji są wyniki sprawdzianów uzdolnień lub sprawdzianów potencjalnych zdolności, z których korzysta się w Austrii, Belgii, Bułgarii, Czechach, Francji, Irlandii, Liechtensteinie, Litwie, Niemczech, Portugalii, Rumunii, Słowenii, Węgrzech, Zjednoczonym Królestwie (Anglia, Walia, Irlandia Płn.) ${ }^{3}$. Również popularne jest stosowanie mierzenia osiągnięć i wyników w nauce, wyników sprawdzianów przedmiotowych (bądź sprawdzianów dotyczących określonego aspektu rozwoju), wyników egzaminów konkursowych lub innych egzaminów przeprowadzanych w celu selekcji. Mierzenie osiągnięć i/lub wyników stosuje się m.in. w Austrii, Bułgarii, we Francji, w Irlandii, Litwie, Portugalii, Rumunii, Słowenii, na Węgrzech, w Zjednoczonym Królestwie (Anglia, Walia, Szkocja, Irlandia Płn.).

Kryteria klasyfikacji przyjęte w wielu krajach koncentrują się przede wszystkim na wynikach w nauce, a zatem, jeśli uczniowie mają zostać zakwalifikowani do populacji dzieci i młodzieży zdolnej - i co za tym idzie mieć prawo do korzystania ze specjalnych rozwiązań edukacyjnych - muszą od początku pobytu w szkole wykazać się wyjątkowymi wynikami w nauce.

Oprócz wyników w nauce w wielu systemach szkolnych stosuje się ocenę różnych aspektów rozwoju ucznia, do których zalicza się:

2 W związku z tym, że dla określenia uczniów uzdolnionych najpowszechniej spotykanymi terminami są „utalentowany” i „zdolny”, tych właśnie terminów użyto w pozostałych częściach niniejszego opracowania w odniesieniu do dzieci i młodzieży zdolnej.

3 W artykule wykorzystano materiały Dyrekcji Generalnej ds. Edukacji i Kultury Komisji Europejskiej na temat uczniów uzdolnionych w szkolnictwie państw europejskich i USA oraz informacje zebrane podczas wizyt studyjnych i prowadzonych badań w analizowanych państwach. 
- interpersonalne i emocjonalne - umiejętności społeczne (umiejętność sprawowania przywództwa, zdolność przekonywania, zrozumienie, empatia itp.) i/lub umiejętności radzenia sobie z uczuciami i emocjami,

- psychomotoryczne - obejmują różne uwarunkowania psychologicznie, realizowane w sposób dowolny umiejętności fizyczne, które są wykorzystywane w działalności artystycznej, w sporcie lub w celu wykonywania określonych „fachowych” gestów/czynności,

- umysłowe - odnoszą się do różnych umiejętności poznawczych, które mogą być wykorzystywane w szkole (umiejętności językowe i umiejętność logicznego myślenia lub zdolności matematyczne), ale także do różnych innych czynności niezbędnych w procesie uczenia się, takich jak: rozumowanie indukcyjne/dedukcyjne, zapamiętywanie, rozwiązywanie problemów, percepcja obiektów trójwymiarowych i związane z tym umiejętności itp.,

- artystyczne - dotyczą zdolności twórczych we wszystkich dziedzinach ekspresji artystycznej, np. tańca, muzyki czy sztuk plastycznych.

\section{Rozwiqzania edukacyjne}

Rozwiązania edukacyjne przeznaczone dla uczniów uzdolnionych znalazły swoje odzwierciedlenie w prawodawstwie oświatowym. W 1994 roku w zaleceniu Rady Europy 1248(1994) w sprawie edukacji dzieci i młodzieży zdolnej ${ }^{4}$ zwrócono uwagę na specjalne potrzeby edukacyjne dzieci i młodzieży o wyjątkowym potencjale. $\mathrm{W}$ zaleceniu podkreślono, jak istotne jest zapewnienie im niezbędnej pomocy i wsparcia. Wprawdzie ze względów praktycznych systemy edukacji musza być tworzone $w$ taki sposób, aby zapewnić kształcenie dostosowane do większości dzieci i młodzieży, zawsze będa istnieć grupy, które maja specjalne potrzeby $i$ dla których trzeba wprowadzać specjalne rozwiazania. Jedna z takich grup sa dzieci i młodzież o dużych zdolnościach (...) Dzieci i młodzież zdolna powinny mieć możliwość korzystania z odpowiednich warunków ksztatcenia, które pozwola im w petni rozwinać swe zdolności - z pożytkiem dla siebie i calego spoteczeństwa. Żaden kraj nie może sobie przecież pozwolić na trwonienie talentów, a nierozpoznanie $w$ odpowiednim czasie możliwości intelektualnych lub innych byłoby marnotrawstwem zasobów ludzkich. Do tego celu potrzebne sa odpowiednie narzędzia. W zaleceniu nie wyróżnia się dzieci i młodzieży zdolnej jako grupy priorytetowej, stwierdza się jednak wyraźnie, że należy im zapewnić takie

4 http://assembly.coe.int/main.asp?Link=/documents/adoptedtext/ta94/erec1248.htm. 
kształcenie, które umożliwi im rozwinięcie w pełni swego potencjału. Badania przeprowadzone w tej dziedzinie wskazują na to, że chodzi tu o niemały odsetek dzieci i młodzieży. Według danych szacunkowych i kryteriów stosowanych w różnych krajach dzieci i młodzież zdolna stanowią od 3\% do 10\% populacji szkolnej ${ }^{5}$ Z $\mathrm{Z}$ badań wynika również, że część uczniów zdolnych korzysta z usług instytucji pomocy społecznej, na przykład z powodu niepowodzeń szkolnych lub przedwczesnego przerwania nauki.

Większość aktualnie istniejących w państwach europejskich specjalnych rozwiązań edukacyjnych przeznaczonych dla dzieci i młodzieży zdolnej oparta jest na ustawach, rozporządzeniach i innych aktach prawnych władz oświatowych (np. Austria, Czechy, Portugalia, Serbia, Słowacja, Zjednoczone Królestwo), stanowiąc integralną część systemu szkolnego. Jeżeli wprowadzone zostały jakiekolwiek rozwiązania „pozaszkolne”, współistnieją one na ogół z rozwiązaniami „szkolnymi”. Najczęściej większość państw europejskich stosuje rozwiązania zarówno w obrębie szkoły, jak i poza nią. Należy zauważyć, że gdy zdolnych i utalentowanych dzieci nie zalicza się do kategorii uczniów ze specjalnymi potrzebami edukacyjnymi, to nie wyklucza tworzenia dla nich innych specjalnych rozwiązań. W rzeczywistości niemal wszystkie kraje, które nie klasyfikują dzieci i młodzieży wyjątkowo zdolnej w tej grupie, starają się zaspokajać ich potrzeby przez stosowanie specjalnych rozwiązań w obrębie lub za pośrednictwem szkoły, bądź w ramach działań pozaszkolnych. Przykładowo na Malcie i w Norwegii dzieci i młodzieży zdolnej nie zalicza się do grupy uczniów ze specjalnymi potrzebami edukacyjnymi, a mimo to potrzeby edukacyjne tej grupy zaspokajane są przez stosowanie podejścia dydaktycznego, które odpowiada na indywidualne potrzeby wszystkich uczniów. Pod tym względem Maltę i Norwegię można uznać za kraje, które opracowują integracyjną politykę edukacyjną, a równocześnie wybierają model kształcenia zindywidualizowanego.

Bardzo często spotykanym rozwiązaniem jest kształcenie zindywidualizowane, prowadzone w ramach klas ogólnodostępnych o zróżnicowanym poziomie zdolności lub w odrębnych grupach (np. Austria, Belgia, Czechy, Dania, Hiszpania, Holandia, Szwecja). Tego rodzaju podejście jest na ogół umocowane w przepisach prawnych. Jeśli chodzi o kształcenie w grupach o zróżnicowanym poziomie zdolności lub odrębnych grupach, to należy zwrócić uwagę na różnice między szkolnictwem podstawowym i średnim. Na poziomie szkoły podstawowej obydwa rodzaje kształcenia prowadzi się niemal w takim samym zakresie,

5 http://www.eurydice.org.pl/sites/eurydice.org.pl/files/zdolny.pdf. 
natomiast na poziomie szkoły średniej I i II stopnia rzadziej spotyka się grupy o zróżnicowanym poziomie zdolności. Należy zauważyć, że odrębne rozwiązania w szkolnictwie podstawowym polegają przede wszystkim na dzieleniu uczniów na grupy według ich zdolności, a rzadziej na tworzeniu specjalistycznych szkół czy klas dla dzieci zdolnych.

Zajęcia pozaszkolne prowadzone są równie często jak kształcenie zindywidualizowane. Jednak zajęcia pozaszkolne w grupach o zróżnicowanym poziomie zdolności są znacznie mniej rozpowszechnionym rozwiązaniem niż zajęcia w grupach jednorodnych. Są one też rzadziej przedmiotem uregulowań prawnych, ponieważ na ogół prowadzą je placówki niezależne od państwa. Należy zauważyć, że za egzaminy konkursowe odpowiedzialne są centralne władze oświatowe, jak np. w wypadku konkursów dotyczących przedmiotów ogólnokształcących bądź konkursów sportowych czy artystycznych. Jednym z najbardziej rozpowszechnionych rozwiązań zarówno w szkolnictwie podstawowym, jak i średnim jest „szybka ścieżka”. Wszędzie tam, gdzie jest to możliwe, rozwiązanie to zostało przewidziane w przepisach prawnych. Tego rodzaju rozwiązanie przyjęto w zdecydowanej większości europejskich krajów. Dużą popularnością cieszą się także inne specjalne rozwiązania edukacyjne, jak np. ośrodki dla dzieci i młodzieży zdolnej, ich rodziców oraz nauczycieli oraz specjalne sieci edukacyjne umożliwiające współpracę uczniów lub wymianę doświadczeń.

W większości państw europejskich, które zaliczają dzieci i młodzież zdolną do grupy uczniów ze specjalnymi potrzebami edukacyjnymi (Czechy, Estonia, Francja, Hiszpania, Irlandia, Portugalia, Słowacja, Słowenia i Zjednoczone Królestwo), stosuje się kilka lub wszystkie specjalne rozwiązania edukacyjne. Jeśli uczniów zdolnych zalicza się do grupy ze specjalnymi potrzebami edukacyjnymi, to określone rozwiązania są przewidziane w przepisach prawnych, a w związku z tym szkoły są zobowiązane do stosowania ich w praktyce. Z analizy wynika również, że większość państw europejskich wprowadziła kryteria klasyfikacyjne służące identyfikowaniu dzieci i młodzieży zdolnej (m.in. Austria, Belgia, Bułgaria, Czechy, Francja, Hiszpania, Liechtenstein, Litwa, Niemcy, Portugalia, Rumunia, Węgry, Zjednoczone Królestwo). Takie podejście zdaje się potwierdzać założenie, że jeśli dla tej grupy mają być przewidziane pewne rozwiązania edukacyjne, należy najpierw określić, kogo można do niej zakwalifikować. W krajach tych istnienie kryteriów jest zatem niezbędnym warunkiem kształcenia dzieci i młodzieży zdolnej. Jednak w dwóch krajach, Estonii i Słowacji, nie istnieją oficjalne kryteria klasyfikacyjne umożliwiające identyfikowanie uczniów zdolnych. W Estonii może to wynikać z tego, że określanie wymagań młodych ludzi 
ze specjalnymi potrzebami edukacyjnymi i tworzenie dla nich indywidualnych programów nauczania należy do zadań nauczycieli.

\section{Rodzaje rozwiqzań edukacyjnych}

W literaturze dotyczącej kształcenia dzieci i młodzieży zdolnej zwraca się uwagę na kilka możliwych, wzajemnie uzupełniających się rozwiązań, które można sklasyfikować według następujących pięciu kategorii:

- Zajęcia na bardziej zaawansowanym poziomie lub bardziej zróżnicowane zajęcia w klasie,

- Kształcenie zindywidualizowane (lub zindywidualizowany program nauczania),

- Zajęcia pozaszkolne,

- Szybka ścieżka, tj. możliwość skrócenia czasu nauki lub przyspieszonej promocji ucznia z klasy niższej do klasy wyższej,

- Inne rozwiązania.

Spośród różnych wymienionych rodzajów rozwiązań edukacyjnych zajęcia na bardziej zaawansowanym poziomie i bardziej zróżnicowane prowadzi się częściej w szkolnictwie średnim niż podstawowym i najczęściej uzupełnia innymi rozwiązaniami.

Poniżej, na przykładzie wspomnianych wcześniej pięciu kategorii, przedstawiono charakterystykę rozwiązań edukacyjnych przeznaczonych dla uczniów zdolnych w szkolnictwie podstawowym (ISCED 1) ${ }^{6}$ i średnim (ISCED 2 i 3) w wybranych 22 państwach europejskich: Austrii, Belgii, Bułgarii, Czechach, Danii, Estonii, Finlandii, Francji, Hiszpanii, Holandii, Irlandii, Islandii, Litwie, Łotwie, Niemczech, Portugalii, Rumunii, Słowacji, Słowenii, Szwecji, Węgrzech, Zjednoczonym Królestwie.

\section{Austria}

- Zajęcia na bardziej zaawansowanym poziomie i bardziej zróżnicowane w grupach o zróżnicowanym poziomie zdolności lub w grupach jednorodnych:

- zależnie od wyniku oceny uczniów, wprowadzanie rozwiązań umożliwiających bardziej zróżnicowane podejście do programu nauczania w klasach,

6 Więcej informacji na ten temat można znaleźć w: D. Dziewulak, Wymiar czasu pracy nauczycieli w wybranych państwach Unii Europejskiej, „Analizy BAS” 2009, nr 13(21), http:// orka.sejm.gov.pl/WydBAS.nsf/0/5B394EDCA941C294C12576480048C3F7/\$file/Analiza_\%20 BAS_2009_21.pdf. 
- rozwiązania umożliwiające rozszerzenie realizowanego materiału w ramach pracy indywidualnej i grupowej w trakcie lekcji szkolnych i po lekcjach.

- Kształcenie zindywidualizowane lub zindywidualizowany program nauczania w grupach o zróżnicowanym poziomie zdolności lub w grupach jednorodnych:

- zróżnicowanie na zasadzie indywidualnej, zależnie od zainteresowań, z wykorzystaniem szerszego zestawu bardziej szczegółowych materiałów i kształcenia $\mathrm{w}$ grupach,

- szkoły pilotażowe i specjalne zajęcia po lekcjach (zwłaszcza w czasie przerw wakacyjnych) dla grup złożonych z uczniów zdolnych.

- Rozwiązania pozaszkolne dla grup o zróżnicowanym poziomie zdolności lub dla grup jednorodnych:

- obozy letnie,

- konkursy i olimpiady.

- Szybka ścieżka:

- zapis w ustawie oświatowej Schulunterrichtsgesetz $(S c h U G)^{7}$ umożliwiający „przeskakiwanie” poziomów edukacyjnych:

- wcześniejsze niż zwykle rozpoczynanie nauki w szkole podstawowej,

- zapisanie/przeniesienie do klasy programowo wyższej,

- wcześniejsze rozpoczynanie studiów wyższych lub uczęszczanie na zajęcia uniwersyteckie (tylko dla uczniów ISCED 3),

- możliwość uczęszczania na zajęcia w wyższej klasie, zgodnie z wymaganiami określonymi na podstawie oceny.

- Inne rozwiązania:

- regionalne instytucje koordynujące, które oferują pomoc dzieciom i młodzieży zdolnej (Bundesländer-Koordinationsstellen für Begabtenförderung) ${ }^{8}$ i Austriackie Centrum Rozwijania Zdolności i Badań nad Problematyką Zdolności (Österreichisches Zentrum für Begabtenförderung und Begabungsforschung, ÖZBF) ${ }^{9}$ oraz Krajowa Rada Szkolna (Landesschulräte) ${ }^{10}$ ze swymi stowarzyszeniami i stowarzyszenia prywatne (np. ECHA - Austria),

- bezpłatny mentoring,

- tok studiów uniwersyteckich przeznaczony dla uzdolnionych uczniów ze szkół średnich (Universitätslehrgang). Program umożliwia uzdolnionym

7 http://www.jusline.at/Schulunterrichtsgesetz_(SchUG).html.

8 https://bildung.bmbwf.gv.at/ministerium/rs/2017_25.html.

9 https://www.oezbf.at/.

10 http://www.landesschulrat.at/. 
uczniom bezpłatne uczęszczanie na wykłady prowadzone na austriackich uniwersytetach. Program został zainicjowany przez Federalne Ministerstwo Edukacji, Sztuki i Kultury, Austriackie Centrum Wsparcia i Rozwoju Osób Utalentowanych (ÖZBF), uniwersytety i krajowych koordynatorów do spraw wsparcia talentów.

\section{Belgia}

- Zajęcia na bardziej zaawansowanym poziomie i bardziej zróżnicowane w grupach o zróżnicowanym poziomie zdolności lub w grupach jednorodnych:

- szkoły i/lub nauczyciele mogą wprowadzać rozwiązania umożliwiające szersze i bardziej zróżnicowane kształcenie w trakcie lekcji lub po lekcjach bądź w trakcie południowej przerwy lekcyjnej. Takie rozwiązania mogą dotyczyć np.: języków obcych, matematyki, zajęć sportowych lub artystycznych. Mają one umożliwić uczniom poznanie określonego przedmiotu w szerszym zakresie, niż przewidziano w programie nauczania lub poznanie zagadnień, które nie są na ogół uwzględnione w programie nauczania. Organizacja tego rodzaju zajęć leży w gestii poszczególnych szkół, a uczniowie sami decydują o tym, czy chcą w nich uczestniczyć.

- Kształcenie zindywidualizowane lub zindywidualizowany program nauczania w grupach o zróżnicowanym poziomie zdolności lub w grupach jednorodnych:

- szkoły i/lub nauczyciele mogą wprowadzać rozwiązania służące zróżnicowaniu kształcenia, np. uelastycznienie kształcenia przez wprowadzenie fakultatywnych modułów w planie lekcji, rozszerzenie treści przedmiotów szkolnych w przypadku niektórych uczniów lub wyznaczanie im do wykonania dodatkowych prac podczas lekcji, czy zadawanie im dodatkowej pracy domowej.

- Rozwiązania pozaszkolne dla grup o zróżnicowanym poziomie zdolności lub dla grup jednorodnych:

- szkoły i/lub nauczyciele i/lub inne instytucje mogą organizować zajęcia pozalekcyjne, zachęcając uczniów do udziału w zajęciach otwartych i zajęciach rozwijających kreatywność, czy organizując specjalne formy kształcenia.

- Szybka ścieżka:

- możliwość rozpoczęcia nauki w szkole podstawowej wcześniej niż zwykle lub zapisania/przeniesienia do wyższej klasy, 
- możliwość przystąpienia wcześniej niż zwykle do egzaminów na zakończenie głównego etapu nauki w szkole średniej. Egzaminy przeprowadza centralna komisja egzaminacyjna.

- Inne rozwiązania:

- międzyuniwersytecka sieć zapewniająca opiekę i pomoc dzieciom i młodzieży o dużych zdolnościach,

- pogłębianie wiedzy o uczniach zdolnych przez działania zarówno w szkołach, jak i poza nimi.

\section{Bułgaria}

- Zajęcia na bardziej zaawansowanym poziomie i bardziej zróżnicowane w grupach o zróżnicowanym poziomie zdolności lub w grupach jednorodnych:

- dla uczniów zdolnych, w ramach zajęć lekcyjnych, przewidziana jest możliwość bardziej gruntownego lub zróżnicowanego kształcenia w danej dziedzinie,

- w przypadku przedmiotów fakultatywnych lub wynikających z profilu klasy organizuje się grupy uczniów dobranych zgodnie ze wspólnymi zainteresowaniami.

- Kształcenie zindywidualizowane lub zindywidualizowany program nauczania w grupach o zróżnicowanym poziomie zdolności lub w grupach jednorodnych:

- zajęcia ukierunkowane na rozwiązywanie problemów i zajęcia symulacyjne,

- tworzenie z uczniów zdolnych grup rozwijających ich zainteresowania i umiejętności.

- Rozwiązania pozaszkolne dla grup o zróżnicowanym poziomie zdolności lub dla grup jednorodnych:

- zajęcia pozalekcyjne i udział w pozalekcyjnych konkursach w różnych dziedzinach;

- udział w zajęciach kół zainteresowań.

- Szybka ścieżka:

- zgodnie z ustawą o oświacie publicznej dzieci i młodzież o wyraźnie widocznych zdolnościach/uzdolnieniach mogą uczyć się na zasadzie indywidualnego kształcenia lub samokształcenia.

- Inne rozwiązania:

- dobrowolny udział w kursach i zajęciach z różnych dziedzin prowadzonych przez ośrodki dla dzieci i młodzieży, organizacje pozarządowe i fundacje na rzecz dzieci i młodzieży o wyraźnie widocznych zdolnościach/uzdolnieniach. 


\section{Czechy}

- Zajęcia na bardziej zaawansowanym poziomie i bardziej zróżnicowane w grupach o zróżnicowanym poziomie zdolności lub w grupach jednorodnych:

- dodatkowe lekcje niektórych przedmiotów,

- rozszerzone nauczanie przedmiotów z programu nauczania (ISCED 1 i 2),

- różnicowanie tempa nauczania na lekcjach z niektórych przedmiotów.

- Kształcenie zindywidualizowane lub zindywidualizowany program nauczania w grupach o zróżnicowanym poziomie zdolności lub w grupach jednorodnych:

- specjalne zadania lub projekty dla uczniów zdolnych,

- indywidualne plany kształcenia,

- umieszczanie uczniów o szczególnych uzdolnieniach w jednej grupie,

- specjalne klasy/zajęcia dla uczniów zdolnych (ISCED 1 i 2),

- szkoły prowadzące kształcenie w dziedzinach sztuk pięknych - konserwatoria (Konzervatore) (ISCED 2-3).

- Rozwiązania pozaszkolne dla grup o zróżnicowanym poziomie zdolności lub dla grup jednorodnych:

- szkoły i/lub nauczyciele i/lub inne instytucje mogą organizować zajęcia pozalekcyjne, zachęcając uczniów do udziału w zajęciach otwartych i zajęciach rozwijających kreatywność lub organizując specjalne formy kształcenia,

- konkursy z różnych przedmiotów dla dzieci i młodzieży zdolnej organizowane przez Ministerstwo Edukacji,

- specjalna szkoła (w czasie wolnym) dla dzieci uzdolnionych artystycznie (ISCED 1-2).

- Szybka ścieżka:

- szczególnie uzdolnieni uczniowie mogą zostać przyjęci do wyższej klasy bez uczęszczania na lekcje niższej klasy na podstawie decyzji dyrektora szkoły i oceny przeprowadzonej przez komisję egzaminacyjną powołaną przez dyrektora,

- udział w lekcjach z wybranych przedmiotów odbywających się z uczniami ze starszego rocznika (ISCED 1 i 2 ).

- Inne rozwiązania:

- indywidualne plany nauczania przygotowywane przez szkołę dla uczniów zdolnych,

- tworzenie klas profilowanych złożonych z uczniów zdolnych,

- stypendia za bardzo dobre wyniki w nauce, 
- instytucje specjalizujące się w pracy z osobami wybitnie uzdolnionymi, np. Towarzystwo na rzecz Talentów i Uzdolnień, Centrum Wspierania Specjalnych Uzdolnień lub Centrum Rozwoju Dzieci Zdolnych,

- Instytut Poradnictwa Pedagogicznego i Psychologicznego organizuje specjalistyczne kursy doskonalenia zawodowego dla nauczycieli,

- Towarzystwo Dobroczynne prywatnego ośmioletniego Gymnázium Budánka wspiera dzieci o ponadprzeciętnych zdolnościach (ISCED 2 i 3).

\section{Dania}

- Zajęcia na bardziej zaawansowanym poziomie i bardziej zróżnicowane w grupach o zróżnicowanym poziomie zdolności lub w grupach jednorodnych:

- specjalne zajęcia z matematyki dla dzieci zdolnych (ISCED 2).

- Kształcenie zindywidualizowane lub zindywidualizowany program nauczania w grupach o zróżnicowanym poziomie zdolności lub w grupach jednorodnych:

- nauczanie zróżnicowane zależnie od potrzeb ucznia (ISCED 1 i 2),

- specjalistyczna szkoła prywatna dla dzieci zdolnych (ISCED 1 i 2),

- kształcenie na zaawansowanym poziomie dla dzieci uzdolnionych muzycznie, połączone z normalnym programem kształcenia,

- możliwość czteroletniej nauki w szkole dla wyjątkowo zdolnych młodych sportowców (ISCED 3).

- Rozwiązania pozaszkolne dla grup o zróżnicowanym poziomie zdolności lub dla grup jednorodnych:

- konkursy, głównie z przedmiotów przyrodniczych,

- program Forskerspire dla przyszłych naukowców (ISCED 3).

- Szybka ścieżka:

- możliwość zapisania/przeniesienia do klasy programowo wyższej na poziomie szkoły podstawowej i średniej I stopnia (ISCED 1 i 2).

- Inne rozwiązania:

- instytucje edukacyjne mają możliwość uhonorowania utalentowanych uczniów wyróżnieniami i dyplomami zawierającymi punkty ułatwiające przyjęcie do wybranych szkół i uczelni wyższych,

- uznanie wybitnych osiągnięć pozalekcyjnych zrealizowanych poza placówką szkolną jako wkład ucznia uzdolnionego w swój indywidualny program rozwoju talentu. Umieszczenie informacji na ten temat na dyplomie lub świadectwie szkolnym, 
- przydzielenie uczniom uzdolnionym dodatkowych punktów ECTS umożliwiających korzystanie z edukacyjnych ofert zajęć uniwersyteckich,

- możliwość wcześniejszego rozpoczęcia studiów przez utalentowanych uczniów ogólnokształcących i technicznych szkół średnich,

- „Obóz dla zdolnych 05” - inicjatywa duńskiego Ministerstwa Edukacji wspierająca rozwój zdolnych/utalentowanych uczniów.

\section{Estonia}

- Zajęcia na bardziej zaawansowanym poziomie i bardziej zróżnicowane w grupach o zróżnicowanym poziomie zdolności lub w grupach jednorodnych:

- brak.

- Kształcenie zindywidualizowane lub zindywidualizowany program nauczania w grupach o zróżnicowanym poziomie zdolności lub w grupach jednorodnych:

- uczniowie ze specjalnymi potrzebami edukacyjnymi mogą realizować indywidualny program kształcenia,

- specjalistyczne klasy/szkoły dla utalentowanych,

- szkoły sportowe, muzyczne, baletowe i językowe (ISCED 3).

- Rozwiązania pozaszkolne dla grup o zróżnicowanym poziomie zdolności lub dla grup jednorodnych:

- dodatkowe zajęcia pozalekcyjne organizowane w Centrum Rozwoju Zdolnych i Utalentowanych.

- Szybka ścieżka:

- możliwość zapisania/przeniesienia do klasy programowo wyższej,

- naukę w szkole średniej II stopnia (ISCED 3) można ukończyć wcześniej, przystępując do egzaminu państwowego.

- Inne rozwiązania:

- brak informacji.

\section{Finlandia}

- Zajęcia na bardziej zaawansowanym poziomie i bardziej zróżnicowane w grupach o zróżnicowanym poziomie zdolności lub w grupach jednorodnych:

- możliwość wybrania programów nauczania niektórych przedmiotów, np. języków obcych i matematyki,

- przedmioty/zajęcia fakultatywne (ISCED 3). 
- Kształcenie zindywidualizowane lub zindywidualizowany program nauczania w grupach o zróżnicowanym poziomie zdolności lub w grupach jednorodnych:

- wszyscy uczniowie w ogólnokształcących szkołach średnich II stopnia, (ISCED 3) realizują indywidualny program nauczania,

- tworzenie szkół średnich mających specjalne zadania edukacyjne skierowane do uczniów uzdolnionych.

- Rozwiązania pozaszkolne dla grup o zróżnicowanym poziomie zdolności lub dla grup jednorodnych:

- ogólnokrajowe konkursy (matematyka, chemia, fizyka, informatyka, język ojczysty, ekonomia),

- koła zainteresowań z różnych dziedzin, np. matematyki, szachów, sportu,

- letnie szkoły dla uzdolnionej młodzieży szkół średnich.

- Szybka ścieżka:

- uczniowie uznani za osoby utalentowane mogą rozpocząć kształcenie elementarne o rok wcześniej. Zdolność do podjęcia nauki ocenia się na podstawie testów psychologicznych i, w razie potrzeby, badań medycznych,

- na poziomie szkolnictwa średniego kształcenie uczniów uzdolnionych realizowane jest $\mathrm{w}$ trybie indywidualnym,

- uczniowie szkół średnich mają możliwość uczęszczania i zaliczania niektórych przedmiotów w wybranej uczelni wyższej.

- Inne rozwiązania:

- brak informacji.

\section{Francja}

- Zajęcia na bardziej zaawansowanym poziomie i bardziej zróżnicowane w grupach o zróżnicowanym poziomie zdolności lub w grupach jednorodnych:

- brak.

- Kształcenie zindywidualizowane lub zindywidualizowany program nauczania w grupach o zróżnicowanym poziomie zdolności lub w grupach jednorodnych:

- eksperymentalne programy ukierunkowane na wysoki poziom osiągnięć w nauce w niektórych gimnazjach (collèges),

- sekcje sportowe dla zdolnych i zmotywowanych uczniów w szkołach średnich I i II stopnia (collèges i lycées), w których organizuje się w sposób ciągły zajęcia sportowe w ulubionej dyscyplinie sportu. Istnieją również klasy ze 
specjalnym planem lekcji wychowania muzycznego i tańca dla uczniów, którzy wykazują się szczególnymi uzdolnieniami w tych dziedzinach.

- Rozwiązania pozaszkolne dla grup o zróżnicowanym poziomie zdolności lub dla grup jednorodnych:

- brak.

- Szybka ścieżka:

- uczniowie uzdolnieni mają możliwość skrócenia o rok nauki w szkole podstawowej.

- Inne rozwiązania:

- Académie w Lyonie przygotowała program umożliwiający specjalne kształcenie uczniów utalentowanych koncentrujący się na zaspokajaniu zróżnicowanych potrzeb ucznia,

- doraźne przedsięwzięcia eksperymentalne realizowane w niektórych szkołach w celu określenia specjalnych metod wspierających uczniów utalentowanych.

\section{Hiszpania}

- Zajęcia na bardziej zaawansowanym poziomie i bardziej zróżnicowane w grupach o zróżnicowanym poziomie zdolności lub w grupach jednorodnych:

- wprowadzanie rozwiązań umożliwiających bardziej zróżnicowane podejście do programu nauczania.

- Kształcenie zindywidualizowane lub zindywidualizowany program nauczania w grupach o zróżnicowanym poziomie zdolności lub w grupach jednorodnych:

- możliwość zindywidualizowanego kształcenia w obrębie klas zgodnie z potrzebami uczniów utalentowanych.

- Rozwiązania pozaszkolne dla grup o zróżnicowanym poziomie zdolności lub dla grup jednorodnych:

- udział w programach, wydarzeniach i zajęciach przeznaczonych dla dzieci i młodzieży zdolnej, organizowanych przez krajowe i lokalne stowarzyszenia (np. intensywne kursy tematyczne, letnie szkoły, staże i konferencje).

- Szybka ścieżka:

- możliwość „pominięcia” trzech klas na poziomach ISCED 1 i 2 oraz jednej klasy na poziomie ISCED 3.

- Inne rozwiązania: 
- specjalistyczny zespół psychologów wychowawczych, który przeprowadza ocenę i określa potrzeby dzieci i młodzieży utalentowanej oraz wskazuje odpowiednie rozwiązania służące zaspokojeniu ich potrzeb.

\section{Holandia}

- Zajęcia na bardziej zaawansowanym poziomie i bardziej zróżnicowane w grupach o zróżnicowanym poziomie zdolności lub w grupach jednorodnych:

- realizowane z inicjatywy szkoły/rodziców,

- różne organizacje/instytucje doradzają szkołom w sprawach dotyczących indywidualnej pracy z dziećmi i młodzieżą zdolną i dostosowywania kształcenia do ich potrzeb w ramach normalnych zajęć,

- niektóre szkoły tworzą specjalne klasy dla uczniów zdolnych.

- Kształcenie zindywidualizowane lub zindywidualizowany program nauczania w grupach o zróżnicowanym poziomie zdolności lub w grupach jednorodnych:

- realizowane z inicjatywy szkoły/rodziców.

- Rozwiązania pozaszkolne dla grup o zróżnicowanym poziomie zdolności lub dla grup jednorodnych:

- stowarzyszenia i organizacje prowadzą indywidualne i grupowe zajęcia pozalekcyjne dla dzieci i młodzieży zdolnej,

- Szybka ścieżka:

- możliwość pomijania poziomów kształcenia w przypadku uzdolnionych uczniów.

- Inne rozwiązania:

- ośrodki informacji dla wybitnie uzdolnionych dzieci i młodzieży prowadzone przez Holenderską Fundację ds. Programów Nauczania (Stichting Leerplanontwikkeling $)^{11}$ i Chrześcijańskie Centrum Poradnictwa Pedagogicznego,

- CPS (Christelijk Pedagogisch Studiecentrum) ${ }^{12}$. Ośrodki prowadzą doradztwo dla specjalistów zajmujących się edukacją uczniów utalentowanych.

\section{Irlandia}

- Zajęcia na bardziej zaawansowanym poziomie i bardziej zróżnicowane w grupach o zróżnicowanym poziomie zdolności lub w grupach jednorodnych:

11 https://www.slo.nl/.

12 https://www.cps.nl/over-cps/geschiedenis. 
- brak.

- Kształcenie zindywidualizowane lub zindywidualizowany program nauczania w grupach o zróżnicowanym poziomie zdolności lub w grupach jednorodnych:

- kształcenie zindywidualizowane dla uczniów o różnym poziomie zdolności.

- Rozwiązania pozaszkolne dla grup o zróżnicowanym poziomie zdolności lub dla grup jednorodnych:

- letnie, korespondencyjne i sobotnie kursy dla uzdolnionych dzieci i młodzieży organizowane przez Irlandzkie Centrum dla Młodzieży Uzdolnionej (Irish Centre for Talented Youth $)^{13}$,

- grupy rozwoju indywidualnego i wielkanocne obozy z przygodami organizowane przez Irlandzkie Stowarzyszenie na rzecz Dzieci Uzdolnionych (An Óige Tréitheach - Irish Association for Gifted Children) ${ }^{14}$,

- konkursy, np. „Młody naukowiec” (Young Scientist).

- Szybka ścieżka:

- brak.

- Inne rozwiązania:

- doradztwo i pomoc dla szkół, w których zdiagnozowano uczniów jako uzdolnionych, prowadzone przez Irlandzkie Centrum dla Młodzieży Uzdolnionej.

\section{Islandia}

- Zajęcia na bardziej zaawansowanym poziomie i bardziej zróżnicowane w grupach o zróżnicowanym poziomie zdolności lub w grupach jednorodnych:

- uczniowie szkół średnich mogą wybrać z programu nauczania jeden lub większą liczbę przedmiotów, które realizują w trybie rozszerzonym z wykorzystaniem różnych metod nauczania. Taka możliwość może być przeznaczona dla grup o zróżnicowanym poziomie lub wyłącznie dla uczniów o dużych zdolnościach.

- Kształcenie zindywidualizowane lub zindywidualizowany program nauczania w grupach o zróżnicowanym poziomie zdolności lub w grupach jednorodnych:

- kształcenie zindywidualizowane lub realizacja specjalnego programu nauczania, w wyniku którego uczeń utalentowany ma możliwość rozwijania własnych kompetencji w określonej dziedzinie,

13 https://www.dcu.ie/ctyi/index.shtml.

14 http://homepage.tinet.ie/ iagc/iagc.htm. 
- kształcenie zindywidualizowane prowadzone jest najczęściej w ramach szkolnictwa powszechnego, choć tam, gdzie jest to konieczne, dostosowuje się je do potrzeb ucznia lub grupy.

- Rozwiązania pozaszkolne dla grup o zróżnicowanym poziomie zdolności lub dla grup jednorodnych:

- istnieje możliwość organizowania zajęć dydaktycznych po lekcjach, zwłaszcza zajęć artystycznych i sportowych,

- uniwersytet letni, olimpiady z matematyki i fizyki.

- Szybka ścieżka:

- decyzję o przeniesieniu utalentowanego ucznia do klasy programowo wyższej może podjąć dyrektor szkoły w porozumieniu z rodzicami,

- istnieje możliwość wcześniejszego ukończenia szkoły średniej. Warunkiem jest zdanie egzaminów przygotowanych przez krajową komisję egzaminacyjną.

- Inne rozwiązania:

- brak informacji.

\section{Litwa}

- Zajęcia na bardziej zaawansowanym poziomie i bardziej zróżnicowane w grupach o zróżnicowanym poziomie zdolności lub w grupach jednorodnych:

- indywidualna praca z uczniami zdolnymi, przygotowująca do konkursu „Najlepsza piosenka” oraz innych konkursów muzycznych, sportowych i artystycznych na poziomie regionalnym lub ogólnokrajowym,

- olimpiady z biologii, chemii, historii, informatyki, języków obcych, matematyki, fizyki i filozofii oraz konkursy kreatywnego czytania i pisania dla szkół średnich.

- Kształcenie zindywidualizowane lub zindywidualizowany program nauczania w grupach o zróżnicowanym poziomie zdolności lub w grupach jednorodnych:

- w niektórych szkołach średnich instruktorzy i nauczyciele prowadzą specjalne zajęcia dla uzdolnionych dzieci i młodzieży, opracowując dla każdego $\mathrm{z}$ nich indywidualny program,

- rozszerzone lekcje z przedmiotów artystycznych w średnich szkołach ogólnokształcących,

- szkoły średnie specjalizujące się w dziedzinie sztuk pięknych, muzyki, choreografii i sztuk plastycznych. 
- Rozwiązania pozaszkolne dla grup o zróżnicowanym poziomie zdolności lub dla grup jednorodnych:

- co 5-8 lat organizuje się festiwale piosenki dla uczniów,

- coroczne konkursy muzyczne dla młodych wykonawców,

- coroczne krajowe ekspedycje dla młodych naukowców ze szkół średnich,

- akademia wiosenna dla młodych artystów ze szkół średnich,

- olimpiady dla młodych fizyków,

- profilowany program - szkoła młodych architektów, przyrodników i fotografów (ISCED 2 i 3).

- Szybka ścieżka:

- zapisanie/przeniesienie do klasy programowo wyższej.

- Inne rozwiązania:

- brak informacji.

\section{Łotwa}

- Zajęcia na bardziej zaawansowanym poziomie i bardziej zróżnicowane w grupach o zróżnicowanym poziomie zdolności lub w grupach jednorodnych:

- praca indywidualna lub w grupach dla dzieci i młodzieży zdolnej,

- kształcenie dostosowane do szczególnych uzdolnień plastycznych lub muzycznych.

- Kształcenie zindywidualizowane lub zindywidualizowany program nauczania w grupach o zróżnicowanym poziomie zdolności lub w grupach jednorodnych:

- gimnazja prowadzące kształcenie na wysokim poziomie, które przeprowadzają selekcję na podstawie wyników ze szkoły podstawowej lub rankingu uczniów w konkursach (ISCED 3),

- szkoły specjalizujące się w dziedzinie sztuk plastycznych i muzyki, które prowadzą zindywidualizowane kształcenie.

- Rozwiązania pozaszkolne dla grup o zróżnicowanym poziomie zdolności lub dla grup jednorodnych:

- konkursy przedmiotowe,

- obóz dla „młodych naukowców” i grupy robocze dla zdolnych uczniów szkół średnich,

- konkursy sportowe i artystyczne organizowane przez szkoły.

- Szybka ścieżka:

- zapisanie/przeniesienie do klasy programowo wyższej, 
- nauka zorganizowana w domu.

- Inne rozwiązania:

- brak informacji.

\section{Niemcy}

- Zajęcia na bardziej zaawansowanym poziomie i bardziej zróżnicowane w grupach o zróżnicowanym poziomie zdolności lub w grupach jednorodnych:

- brak.

- Kształcenie zindywidualizowane lub zindywidualizowany program nauczania w grupach o zróżnicowanym poziomie zdolności lub w grupach jednorodnych:

- indywidualny program nauczania przewidujący uczestnictwo zdolnych uczniów w akademickich zajęciach lub projektach badawczych,

- program specjalnych szkół z internatem dla uczniów wybitnie zdolnych.

- Rozwiązania pozaszkolne dla grup o zróżnicowanym poziomie zdolności lub dla grup jednorodnych:

- udział w konkursach uczniów uzdolnionych sportowo i muzycznie.

- Szybka ścieżka:

- możliwość wcześniejszego rozpoczęcia nauki w szkole podstawowej,

- możliwość „przeskoczenia” klasy lub uczęszczania na wybrane lekcje na wyższym poziomie nauczania,

- możliwość uczęszczania na zajęcia lub wzięcia udziału w projektach prowadzonych na wyższych uczelniach.

- Inne rozwiązania:

- fundacje zapewniające pomoc finansową wybitnie uzdolnionym dzieciom i młodzieży.

\section{Portugalia}

- Zajęcia na bardziej zaawansowanym poziomie i bardziej zróżnicowane w grupach o zróżnicowanym poziomie zdolności lub w grupach jednorodnych:

- wiele odrębnych rozwiązań dla uczniów bardzo zdolnych, przewidujących indywidualny nadzór nad uczniem w trakcie lekcji lub kształcenie zgodnie ze wskazówkami szkoły,

- specjalny status dla uczniów wykazujących wyjątkowe uzdolnienia sportowe (atletas de alta competição). 
- Kształcenie zindywidualizowane lub zindywidualizowany program nauczania w grupach o zróżnicowanym poziomie zdolności lub w grupach jednorodnych:

- wiele specjalnych zajęć dla uczniów bardzo zdolnych,

- indywidualny nadzór nad uczniem zdolnym w dziedzinach sztuk pięknych lub kształcenie zgodnie ze wskazówkami szkoły.

- Rozwiązania pozaszkolne dla grup o zróżnicowanym poziomie zdolności lub dla grup jednorodnych:

- zajęcia sportowe i muzyczne,

- zajęcia w soboty i kursy letnie poza szkołą,

- ogólnokrajowe konkursy z przedmiotów ścisłych i humanistycznych organizowane przez szkoły we współpracy ze stowarzyszeniami naukowymi.

- Szybka ścieżka:

- pierwszy etap edukacji można ukończyć wcześniej, przystępując do egzaminu przed normalnym terminem,

- zapisanie/przeniesienie do klasy programowo wyższej,

- rozpoczynanie nauki na pierwszym etapie szkolnym wcześniej niż zwykle, tj. w wieku 5 lat.

- Inne rozwiązania:

- zarządzenie nr 50/2005 z 9 listopada 2005 r. Ministerstwa Edukacji ${ }^{15}$ wskazuje, że uczniowie utalentowani mogą korzystać ze zindywidualizowanego programu nauczania, którego opracowanie należy do zadań szkoły. Szkoła jest także zobowiązana do opracowania i realizacji strategii pedagogiczno-dydaktycznej dla uzdolnionych uczniów,

- niektóre prywatne stowarzyszenia z udziałem rodzin i fachowej kadry odgrywają istotną rolę w diagnozowaniu uzdolnień i realizacji programów rozwojowych,

- w autonomicznym regionie Madery istnieje Biuro Koordynujące Wspieranie Rozwoju Uczniów Zdolnych (Gabinete Coordenador de Apoio à Sobredo(ação $)^{16}$.

\section{Rumunia}

- Zajęcia na bardziej zaawansowanym poziomie i bardziej zróżnicowane w grupach o zróżnicowanym poziomie zdolności lub w grupach jednorodnych:

15 Ministério da Educação, Despacho Normativo no 50/2005, https://dre.pt/pesquisa/-/se$\operatorname{arch} / 582996 /$ details/maximized.

16 http://www02.madeira-edu.pt/dre/educacao_especial/nucleo_apoio_sobredotacao.aspx. 
- podnoszenie poziomu wiedzy i umiejętności przez bardziej gruntowne podejście w nauczaniu przedmiotów i wykorzystanie odpowiednio wybranych i dostosowanych do potrzeb uczniów metod nauczania,

- Kształcenie zindywidualizowane lub zindywidualizowany program nauczania w grupach o zróżnicowanym poziomie zdolności lub w grupach jednorodnych:

- specjalne programy edukacyjne (zwłaszcza w systemie kształcenia na odległość) w obszarze przedmiotów ścisłych i artystycznych.

- Rozwiązania pozaszkolne dla grup o zróżnicowanym poziomie zdolności lub dla grup jednorodnych:

- dodatkowe zajęcia (po lekcjach), które umożliwiają uczniom pogłębienie wiedzy i przygotowanie się do ogólnokrajowych i międzynarodowych konkursów.

- Szybka ścieżka:

- możliwość indywidualnego realizowania programu nauczania wybranego przedmiotu lub przedmiotów i skrócenie nauki z dwóch lat do jednego roku.

- Inne rozwiązania:

- działalność centrów doskonalenia przeznaczonych dla uczniów uzdolnionych z predyspozycjami do osiągnięcia dobrych wyników. Centra oferują różne usługi edukacyjne, m.in. diagnozowania dzieci i młodzieży utalentowanej, przygotowywanie zindywidualizowanych programów nauczania oraz pomoc pedagogiczna i dydaktyczna dla nauczycieli pracujących z uzdolnionymi uczniami.

\section{Słowacja}

- Zajęcia na bardziej zaawansowanym poziomie i bardziej zróżnicowane w grupach o zróżnicowanym poziomie zdolności lub w grupach jednorodnych:

- możliwość uczenia się zgodnie z indywidualnym programem nauczania,

- tworzenie specjalistycznych klas z uczniami zdolnymi. W tych klasach kształcenie prowadzi się na bardziej wymagającym poziomie i w sposób bardziej zróżnicowany, a uczniowie mogą uczyć się w odrębnych grupach, zależnie od ich poziomu.

- Kształcenie zindywidualizowane lub zindywidualizowany program nauczania w grupach o zróżnicowanym poziomie zdolności lub w grupach jednorodnych:

- dwóch nauczycieli w każdej specjalistycznej klasie, 
- mniejsze grupy w każdej klasie,

- uczniowie wykonują indywidualne projekty w małych grupach lub samodzielnie i uczestniczą w zajęciach rozwijających kreatywność,

- stosowanie samooceny lub nowych form oceniania.

- Rozwiązania pozaszkolne dla grup o zróżnicowanym poziomie zdolności lub dla grup jednorodnych:

- dla uczniów uczęszczających do specjalistycznych szkół lub klas dla zdolnych organizuje się dodatkowe zajęcia pozalekcyjne w różnych dziedzinach, m.in. języki, informatyka, gotowanie, sport i szachy.

- Szybka ścieżka:

- możliwość zapisania/przeniesienia do klasy programowo wyższej.

- Inne rozwiązania:

- zagadnienia uczniów uzdolnionych reguluje rozporządzenie Ministerstwa Edukacji Republiki Słowackiej nr 307/2008 - Prawo o kształceniu i szkoleniu uczniów utalentowanych ${ }^{17}$.

\section{Słowenia}

- Zajęcia na bardziej zaawansowanym poziomie i bardziej zróżnicowane w grupach o zróżnicowanym poziomie zdolności lub w grupach jednorodnych:

- dodatkowe lekcje różnych przedmiotów (ISCED 1 i 2),

- specjalne projekty (ISCED 3),

- indywidualny program kształcenia (INDEP) dla uczniów zdolnych,

- uczniowie wykazujący duże uzdolnienia sportowe, artystyczne lub naukowe otrzymują specjalny status (ISCED 2 i 3),

- programy indywidualnego rozwoju (ISCED 1-3).

- Kształcenie zindywidualizowane lub zindywidualizowany program nauczania w grupach o zróżnicowanym poziomie zdolności lub w grupach jednorodnych:

- indywidualny tok nauki (ISCED 1-3),

- nauczanie o charakterze badawczym (ISCED 2 i 3),

- różnicowanie programu zgodnie z zainteresowaniami (ISCED 2 i 3),

- szkolne wsparcie psychologiczne i pedagogiczne.

- Rozwiązania pozaszkolne dla grup o zróżnicowanym poziomie zdolności lub dla grup jednorodnych:

17 https://www.minedu.sk/data/att/670.pdf. 
- festiwale muzyczne (ISCED 1-3),

- klasy sportowe oraz prywatne lekcje muzyki i dramatu (ISCED 1-3),

- konkursy zdolności i wiedzy w dziedzinach nauk ścisłych, sportu i sztuk pięknych (ISCED 2 i 3),

- obozy i kursy letnie (ISCED 1-3),

- konsultacje psychologiczne i pedagogiczne (ISCED 1-3),

- stypendia państwowe im. Zoisa i specjalne dotowane zajęcia na poziomie ISCED 3 dla bardzo uzdolnionych uczniów,

- specjalne stypendia stowarzyszeń prywatnych i zawodowych.

- Szybka ścieżka:

- wcześniejsze rozpoczynanie nauki na poziomie ISCED 1 lub ISCED 3,

- zapisywanie/przenoszenie do klasy programowo wyższej.

- Inne rozwiązania:

- w Narodowym Instytucie Edukacji (NEI) funkcjonuje grupa doradcza ds. diagnozowania i pracy z dziećmi i młodzieżą utalentowaną. Jej zadaniem jest wspieranie i monitorowanie działań związanych z diagnozowaniem zdolności i pracy z uczniami zdolnymi oraz monitorowanie i ocena funkcjonowania szkół,

- organizowanie kursów doskonalenia zawodowego dla nauczycieli,

- prowadzenie konsultacji i doradztwa dla szkół wraz z publikacją specjalistycznych książek z zakresu poradnictwa.

\section{Szwecja}

- Zajęcia na bardziej zaawansowanym poziomie i bardziej zróżnicowane w grupach o zróżnicowanym poziomie zdolności lub w grupach jednorodnych:

- brak.

- Kształcenie zindywidualizowane lub zindywidualizowany program nauczania w grupach o zróżnicowanym poziomie zdolności lub w grupach jednorodnych:

- szkoły specjalizujące się w dziedzinach tańca, muzyki i sportu (ISCED 2 i 3).

- Rozwiązania pozaszkolne dla grup o zróżnicowanym poziomie zdolności lub dla grup jednorodnych:

- olimpiady z matematyki i fizyki (ISCED 3).

- Szybka ścieżka:

- możliwość zapisania/przeniesienia do klasy programowo wyższej,

- uczniowie o wyjątkowych zdolnościach na poziomach ISCED 2 lub 3 mogą uczęszczać na poszczególne zajęcia na poziomie ISCED 3 lub na zajęcia oferowane przez uczelnie wyższe. 
- Inne rozwiązania:

- zgodnie z postanowieniami Szwedzkiej Narodowej Agencji ds. Edukacji (Statens skolverk) ${ }^{18} \mathrm{w}$ ośmiu wybranych szwedzkich szkołach średnich (poziom ISCED 2) wprowadzono realizację pilotażowego programu nauczania przedmiotów humanistyczno-społecznych i matematyczno-przyrodniczych. Dziesięcioletni pilotaż przewidziany jest na lata 2012-2022. Program jest tak skonstruowany, aby uczniom szczególnie uzdolnionym i zainteresowanym rozwijaniem swoich pasji naukowych umożliwić uczęszczanie na wybrane zajęcia na poziomie szkoły średniej II stopnia lub na poziomie studiów wyższych.

\section{Węgry}

- Zajęcia na bardziej zaawansowanym poziomie i bardziej zróżnicowane w grupach o zróżnicowanym poziomie zdolności lub w grupach jednorodnych:

- program nauczania przedmiotu przewiduje stosowanie alternatywnej rozszerzonej formuły z zastosowaniem zróżnicowanych metod nauczania,

- specjalistyczne programy rozwijania określonych umiejętności lub wiedzy w różnych dziedzinach.

- Kształcenie zindywidualizowane lub zindywidualizowany program nauczania w grupach o zróżnicowanym poziomie zdolności lub w grupach jednorodnych:

- klasy z kilkoma poziomami nauczania,

- szkoły specjalizujące się w rozwijaniu uzdolnień artystycznych i sportowych.

- Rozwiązania pozaszkolne dla grup o zróżnicowanym poziomie zdolności lub dla grup jednorodnych:

- zajęcia pozalekcyjne organizowane przez szkoły rozwijające uzdolnienia i umożliwiające pogłębienie wiedzy w określonym zakresie,

- konkursy, specjalistyczne obozy letnie, współpraca młodych naukowców.

- Szybka ścieżka:

- możliwość przejścia na wyższy szczebel nauczania z pominięciem nauki określonego przedmiotu lub wszystkich przedmiotów na danym szczeblu edukacji.

- Inne rozwiązania:

18 Powszechnie znany jako Skolverket - rządowa agencja nadzorująca funkcjonowanie szwedzkiego systemu edukacyjnego, https://www.skolverket.se/. 
- sieć instytutów kształcenia/doskonalenia zawodowego nauczycieli. Placówki udzielają informacji, świadczą pomoc oraz prowadzą doradztwo w zakresie rozwijania uzdolnień uczniów wybitnie zdolnych.

\section{Zjednoczone Królestwo (Anglia, Walia, Szkocja, Irlandia Północna)}

- Zajęcia na bardziej zaawansowanym poziomie i bardziej zróżnicowane w grupach o zróżnicowanym poziomie zdolności lub w grupach jednorodnych:

- możliwość prowadzenia bardziej zróżnicowanych lekcji,

- możliwość włączenia do programu nauczania przedmiotów spoza programu.

- Kształcenie zindywidualizowane lub zindywidualizowany program nauczania w grupach o zróżnicowanym poziomie zdolności lub w grupach jednorodnych.

- indywidualny program nauczania (ISCED 3),

- tworzenie w klasach grup na tym samym poziomie (ISCED 1 i 2),

- wykorzystywanie międzynarodowych sprawdzianów przedmiotowych, które mają motywować uczniów zdolnych oraz umożliwiać ich identyfikowanie w środowisku rówieśniczym klasy,

- uczniowie o zbliżonym poziomie zdolności umieszczani są w jednej grupie,

- prowadzenie szkół ogólnokształcących, w których przeprowadza się selekcję uczniów na podstawie ich zdolności,

- najlepsi uczniowie szkół średnich mogą przystępować do elitarnych egzaminów kończących się dyplomem Advanced Extension Awards.

- Rozwiązania pozaszkolne dla grup o zróżnicowanym poziomie zdolności lub dla grup jednorodnych:

- pozalekcyjne zajęcia rozwijające zdolności,

- tworzenie klas mistrzowskich przeznaczonych dla najlepszych uczniów,

- szkoły letnie organizowane na przykład przez Narodową Akademię Zdolnych i Utalentowanych Dzieci i Młodzieży (National Academy for Gifted and Talented Youth, NAGTY) ${ }^{19}$.

- Szybka ścieżka:

- możliwość wcześniejszego przystąpienia do egzaminów kończących poszczególne poziomy kształcenia,

19 https://warwick.ac.uk/newsandevents/pressreleases/ne10000002145/. 
- uczniowie zdolni mogą uczyć się wszystkich lub niektórych przedmiotów w klasie wyższej,

- elastyczność w realizacji programów nauczania, np. przyjęcie do szkoły średniej w trakcie ostatniego etapu nauki w szkole podstawowej.

- Inne rozwiązania:

- Narodowa Akademia Zdolnych i Utalentowanych Dzieci i Młodzieży koordynuje inicjatywy skierowane do uczniów zdolnych oraz udostępnia pomoce dydaktyczne,

- w Anglii średnie szkoły profilowane (specialist schools) z rozszerzonym zakresem nauczania wybranych dziedzin dokonują naboru na podstawie zdolności ucznia do nauki wybranego przedmiotu. Szkoły profilowane specjalizują się w określonej dziedzinie programu nauczania, ale równocześnie realizują w pełnym zakresie Narodowy Program Nauczania. Specialist schools stanowią kluczowy element w działaniach rządu, które mają na celu zindywidualizowanie kształcenia zgodnie z indywidualnymi potrzebami, zdolnościami i aspiracjami uczniów. Docelowo wszystkie szkoły średnie mają mieć swoją specjalność,

- Szkocka Sieć Uczniów Zdolnych (Scottish Network for Able Pupils) ${ }^{20}$ prowadzi doradztwo i oferuje pomoc uczniom zdolnym i ich rodzicom, a także świadczy doradztwo w zakresie dydaktyki,

- Athlete Support - program wsparcia dla dzieci i młodzieży uzdolnionej sportowo,

- Dewar Arts Awards - stypendia przyznawane wyjątkowo uzdolnionym młodym artystom w różnych dziedzinach kultury i sztuki.

\section{Część II: Stany Zjednoczone}

\section{Wstęp}

Na wstępie należy stwierdzić, że system oświatowy w Stanach Zjednoczonych różni się znacznie od systemów spotykanych w państwach europejskich. Chociaż jego omówienie nie jest możliwe w krótkim tekście, to warto jednak odnotować jego najistotniejsze cechy. Podstawowe znaczenie dla edukacji w USA ma szkolnictwo publiczne. Do szkół prywatnych uczęszcza 13\% młodzieży. Stosowane są też formy nauczania alternatywnego, np. charter schools, finansowane z fundu-

20 https://www.gla.ac.uk/research/az/ablepupils/. 
szy publicznych, niezależne od lokalnego kuratorium i realizujące własne programy. Coraz więcej dzieci (ponad półtora miliona) uczonych jest w domu (Homeschooling).

Podstawową cechą wyróżniającą amerykański system edukacyjny jest jego decentralizacja. Zakres kontroli nad szkołami sprawowanej przez rząd federalny i jego organy oświatowe jest bardzo ograniczony. Nie mogą one np. decydować o programach nauczania. Nie mogą ustalać standardów, licencjonować instytucji nauczania, ani regulować struktury i funkcjonowania szkół. Sprawy te zgodnie z Konstytucją Stanów Zjednoczonych Ameryki leżą w gestii poszczególnych stanów. W wielu przypadkach zakres regulacji oświaty publicznej jest określony w stanowej konstytucji. Niektóre stany wprowadziły własne prawa dotyczące zarządzania oświatą, a inne scedowały takie uprawnienia na niższy szczebel, tj. okręgów szkolnych (educational districts). W 2009 roku było ponad 18 tysięcy takich okręgów, a ich wielkość była znacznie zróżnicowana (Nowy Jork ma ponad milion uczniów, w niektórych okręgach jest ich zaledwie kilkuset, a nawet poniżej stu). Lokalne samorządy edukacyjne posiadają znaczne uprawnienia decyzyjne, obejmujące także sprawy edukacji uczniów uzdolnionych ${ }^{21}$.

\section{Definicje pojęcia uczniów uzdolnionych w USA}

W USA uczniów uzdolnionych określa się jako gifted lub gifted and talented students. Sposób zdefiniowania tych pojęć wyznacza ramy programów oraz usług przeznaczonych dla uzdolnionych uczniów i jest podstawą decyzji o zakwalifikowaniu ucznia do kategorii uzdolnionych oraz o zakresie usług świadczonych na jego rzecz. Nie ma jednak w Stanach Zjednoczonych jednej powszechnie obowiązującej definicji tych pojęćc ${ }^{22}$.

Według najbardziej znanej definicji, przedstawionej Kongresowi USA w tzw. Raporcie Marlanda z 1972 roku (Education of the gifted and talented) ${ }^{23}$, uzdolnionymi i utalentowanymi nazywamy dzieci, o których wykwalifikowani profesjonaliści orzekli, że dzięki wybitnym zdolnościom są w stanie wykazać się zaawansowanymi dokonaniami. W celu urzeczywistnienia wkładu, jaki dzieci te mogłyby wnieść w siebie i społeczeństwo, należy dostarczyć im zróżnicowanych

21 Krajobraz oświaty amerykańskiej, http://edurada.pl/artykuly/krajobraz-oswiaty-amerykanskiej/.

22 Więcej na ten temat: http://www.nagc.org/resources-publications/resources/definitions-giftedness\#sthash.vAszhUba.dpuf.

23 https://www.valdosta.edu/colleges/education/pcft/document\%20/marland-report.pdf. 
programów i/lub usług edukacyjnych, wykraczających poza standardowe programy szkolne. Wśród dzieci, które są w stanie wiele dokonać, znajdują się dzieci wykazujące się osiągnięciami i/lub potencjalnymi zdolnościami w jednej lub kilku dziedzinach, takich jak: ogólne zdolności umysłowe, specyficzne umiejętności w głównych przedmiotach szkolnych, twórcze, produktywne myślenie, zdolności przywódcze, sztuki plastyczne i wykonawcze, zdolności psychomotoryczne. Według tej definicji można przyjąć, że zastosowanie wyżej wymienionych kryteriów do rozpoznawania dzieci uzdolnionych wyodrębni przynajmniej 3-5\% populacji szkolnej24.

Według definicji Krajowego Stowarzyszenia na rzecz Dzieci Uzdolnionych (National Association for Gifted Children) ${ }^{25}$, największej organizacji typu non profit zajmującej się problematyką dzieci uzdolnionych: osoby utalentowane to te, które wykazuja wybitny poziom umiejętności (zdefiniowanej jako wyjątkowa zdolność do rozumowania i uczenia się) lub kompetencji (udokumentowanej wydajnościa i osiagnięciami zaliczanymi do 10\% lub mniejszego odsetka populacji) w jednej lub większej liczbie dziedzin. Dziedzinami sa wszelkie uporządkowane obszary działalności mające własne systemy symboli (np. matematyka, muzyka, język) i/lub zespót umiejętności sensomotorycznych (np. malarstwo, taniec, sport).

Niemal każdy stan ma własną definicję uczniów uzdolnionych ${ }^{26}$. Niektóre stany opierają tę definicję na porównaniu tej grupy z pozostałymi uczniami w tym samym wieku. Inne odwołują się do potrzeb wykraczających poza te, które są zaspokajane w zwykłej klasie. Nie we wszystkich stanach wymaga się stosowania definicji stanowej przez okręgi szkolne.

Ponadto istnieje definicja federalna zawarta w ustawie, zgodnie z którą określenie „uzdolnione” (gifted and talented) użyte w odniesienie do uczniów, dzieci i młodzieży oznacza tych spośród nich, którzy przejawiają możliwości zaawansowanych dokonań w dziedzinie umysłowej, twórczej, artystycznej, w zakresie zdolności przywódczych, czy w poszczególnych przedmiotach nauczania i które,

24 http://www.valdosta.edu/colleges/education/psychology-and-counseling/documents/marland-report.pdf.

25 http://www.nagc.org/.

26 Definicje te różnią się w znacznym stopniu. W większości stanów stosowana jest wspólna definicja terminu ,gifted and talented”, w niektórych występuje jedynie termin „gifted”, natomiast tylko w Luizjanie stosowane są odrębne definicje pojęć „gifted” i „talented”. (Pełen wykaz definicji stosowanych w poszczególnych stanach jest przedstawiony (w jęz. angielskim) na stronie Krajowego Stowarzyszenia na rzecz Uczniów Uzdolnionych, http://www. nagc.org.442elmp01.blackmesh.com/sites/default/files/Advocacy/State\%20definitions\%20 \%288-1-13\%29.pdf. 
w celu pełnego rozwinięcia tych możliwości, wymagają usług lub zajęć pozastandardowych niedostępnych w tradycyjnej szkole ${ }^{27}$.

\section{Edukacja uczniów uzdolnionych (gifted education) w USA}

Edukacja uczniów uzdolnionych, w odróżnieniu od szkolnictwa specjalnego, nie jest regulowana na szczeblu federalnym. Należy tu jednak wspomnieć o tzw. ustawie Jacoba K. Javitsa o edukacji uczniów uzdolnionych ${ }^{28}$. Jej celem było wspieranie badań, projektów wdrożeniowych i strategii innowacyjnych oraz innych działań służących zaspokajaniu potrzeb uczniów uzdolnionych przez szkoły podstawowe i średnie, w tym utworzenie krajowego ośrodka badawczego zajmującego się tą problematyką (National Research Center for the Education of Gifted and Talented Children and Youth ${ }^{29}$. Ponadto Departament Edukacji wydaje zalecenia w omawianym zakresie, takie jak ramowa ustawa stanowa dotycząca zaspokajania potrzeb uczniów uzdolnionych ${ }^{30}$.

\section{Regulacje obowiq̨ujq̨ce w stanie Ohio}

Poniżej przedstawiono regulacje stanowe w zakresie edukacji uczniów uzdolnionych na przykładzie stanu Ohio.

W stanie Ohio lokalne samorządy szkolne (school districts) nie są ustawowo zobowiązane do świadczenia usług na rzecz uzdolnionych dzieci, mają jednak obowiązek rozpoznania (identyfikacji) uczniów uzdolnionych w szkołach podstawowych i średnich (grades K-12). W 1999 roku Zgromadzenie Ogólne Ohio przyjęło nowelizację ustawy określającej proces identyfikacji uczniów uzdolnionych. Ustawa ${ }^{31}$ określa w ogólnych kategoriach tryb identyfikacji uzdolnionych uczniów oraz sposób zaspokajania ich potrzeb edukacyjnych. Rozwiązania szcze-

27 The term 'gifted and talented', when used with respect to students, children, or youth, means students, children, or youth who give evidence of high achievement capability in areas such as intellectual, creative, artistic, or leadership capacity, or in specific academic fields, and who need services or activities not ordinarily provided by the school in order to fully develop those capabilities. No Child Left Behind Act, P.L. 107-110 (Title IX, Part A, Definition 22) (2002); 20 USC 7801(22) (2004).

28 Jacob K. Javits, Gifted and Talented Students Education Act of 2001, Subpart 6 - Gifted and Talented Students, http://www2.ed.gov/policy/elsec/leg/esea02/pg72.html.

29 https://ies.ed.gov/funding/ncer_rfas/gifted.asp.

30 Model legislation: Gifted and talented, http://files.eric.ed.gov/fulltext/ED372590.pdf.

31 Ohio Revised Code, Title [33] XXXIII Education - Libraries. http://codes.ohio.gov/orc/3324. 
gółowe w tym zakresie zawarte są w Kodeksie administracyjnym (k.a.; Ohio Administrative Code) znanym także pod nazwą The Rule. Oprócz wyżej wspomnianych kwestii, dokument ten reguluje sposób korzystania z usług finansowanych przez stan, takich jak działalność specjalistów i pracowników interwencyjnych (coordinators and gifted intervention specialists). Lokalne samorządy Ohio muszą przestrzegać zarówno przepisów ustawy, jak i kodeksu.

Ustawa stanowi, że termin „uzdolnieni” (gifted) oznacza przede wszystkim uczniów, którzy uzyskują lub wykazują potencjał uzyskania wysokiego poziomu osiągnięć edukacyjnych w porównaniu z rówieśnikami.

Rada ds. nadzoru nad edukacją w każdym okręgu szkolnym opracowuje plan usług na rzecz uzdolnionych uczniów w danym okręgu, którzy zostali rozpoznani zgodnie z przepisem 3324.03 k.a. Usługi zawarte w planie mogą obejmować:

- zróżnicowany program nauczania,

- grupowanie uzdolnionych uczniów (cluster gouping) ${ }^{32}$,

- mentoring (mentorships),

- przyspieszony tok nauczania,

- możliwość uczestniczenia w programie nauczania w szkole na poziomie powyżej średniego, zgodnie z rozdziałem 3365 k.a. (przepis został uchylony z dniem 17 września 2014 r.),

- możliwość realizacji określonego przedmiotu na poziomie akademickim (advanced placement),

- klasy dla uzdolnionych uczniów (honors classes) - na wyższym poziomie nauczania (public high schools),

- szkoły-magnesy (magnet schools) ${ }^{33}$,

- klasy dla uzdolnionych uczniów (self-contained classrooms) - na niższym poziomie nauczania (elementary and middle schools),

- indywidualny tok nauczania,

- inne możliwości wyszczególnione w zasadach (rules) przyjętych przez stanowy Departament Edukacji (Department of Education).

Plany takie są przedkładane stanowemu Departamentowi Edukacji, który ocenia ich prawidłowość i uwzględnia w preliminarzu wydatków. Rady mogą realizować takie plany, jednak nie mają takiego obowiązku, o ile nie zobowiązu-

32 Jeżeli w szkole są trzy klasy na jednym poziomie nauczania i w klasach tych jest pięcioro uzdolnionych uczniów, to wszyscy powinni znaleźć się w jednej klasie.

33 Są to szkoły publiczne o specjalnych programach nauczania. Określenie „magnesy” wynika z faktu, że przyciągają one uzdolnione dzieci i młodzież z pominięciem zasady rejonizacji. 
je ich do tego inny akt prawny lub decyzja parlamentu stanowego albo kuratora stanowego.

Wspomniane powyżej szczegółowe standardy rozpoznawania i nauczania dzieci i młodzieży uzdolnionej (rules) stanowią, że okręg szkolny ustala kryteria korzystania uzdolnionych uczniów z określonych usług edukacyjnych. Wszyscy uczniowie spełniający te kryteria powinni mieć zapewniony równy dostęp do takich usług. Usługi te powinny być dostosowane do ich uzdolnień oraz zróżnicowane w celu zaspokojenia ich potrzeb edukacyjnych. Kryteria subiektywne, takie jak opinia nauczyciela, nie mogą eliminować ucznia z korzystania z usług.

Nauczanie dzieci i młodzieży uzdolnionej powinno być prowadzone $\mathrm{w}$ dniach nauki (regular school day). Może odbywać się ono zarówno w grupach o dużej lub małej liczbie uczestników, jak i indywidualnie.

Wśród dostępnych usług edukacyjnych dla uzdolnionych uczniów wymienia się:

- Rozwiązania stosowane w zwykłych klasach (ogólnodostępnych):

- promocję o więcej niż jedną klasę (grade acceleration),

- możliwość wcześniejszego podjęcia nauki w college’u (early entrance),

- grupowanie w jednostki, w których realizowany jest program na wyższym poziomie lub jest prowadzony przez specjalistę ds. nauczania osób uzdolnionych,

- możliwość wcześniejszej promocji (early graduation),

- przyspieszona edukacja w zakresie wybranych przedmiotów (subject acceleration).

- Klasy dla osób o specjalnych potrzebach edukacyjnych (resource rooms),

- Klasy dla uczniów uzdolnionych (self-contained classrooms),

- Szkoły-magnesy,

- Nauczanie w formie Advanced Placement prowadzone z upoważnienia rady college'u (College Board),

- Możliwość jednoczesnej nauki w szkole średniej i wyższej (dual enrollment opportunities),

- Klasy dla uzdolnionych uczniów (honors courses), program prowadzący do uzyskania międzynarodowej matury i inne programy,

- Wybór opcji edukacyjnych (educational options),

- Zaawansowane kursy i programy internetowe (w trybie online),

- Praktyki zawodowe w biznesie, organizacjach niedochodowych i artystycznych. Zakres i tempo nauczania powinny być dostosowane do możliwości i potrzeb uzdolnionych uczniów i uwzględniać szybszą realizację programu nauczania oraz dostęp do programu poszerzonego oraz indywidualnego trybu nauczania. 
Każdy stan może samodzielnie regulować kwestie edukacji uczniów uzdolnionych. Rozwiązania stosowane w poszczególnych stanach się różnią. Należy jednak zauważyć, że zakres usług faktycznie oferowanych uzdolnionym uczniom zależy w istotnym stopniu od budżetu stanu lub okręgu szkolnego ${ }^{34}$.

\section{Bibliografia}

Gifted Young Children: A Guide for Teachers and Parents, Allen \& Unwin, 2005 (2nd edition).

\section{Akty prawne}

Austriacka ustawa oświatowa, Schulunterrichtsgesetz (SchUG), https://www.jusline.at/gesetz/schug.

Podstawowe federalne zarządzenie o wspieraniu uczniów uzdolnionych, Bundesländer-Koordinationsstellen für Begabtenförderung, https://bildung.bmbwf.gv.at/ministerium/rs/2017_25.html.

Zarządzenie nr 50/2005 z 9 listopada 2005 r. Ministerstwa Edukacji Portugalii, Ministério da Educação, Despacho Normativo no 50/2005, https://dre.pt/pesquisa/-/search/582996/ details/maximized.

Rozporządzenie Ministerstwa Edukacji Republiki Słowackiej nr 307/2008 - Prawo o kształceniu i szkoleniu uczniów utalentowanych, https://www.minedu.sk/data/att/670.pdf.

Ustawa USA o uczniach zdolnych, Jacob K. Javits Gifted and Talented Students Education Act of 2001: Subpart 6 - Gifted and Talented Students Javits, http://www2.ed.gov/policy/ elsec/leg/esea02/pg72.html.

US. Model legislation: Gifted and talented, http://files.eric.ed.gov/fulltext/ED372590.pdf. Ohio Revised Code, Title [33] XXXIII Education - Libraries, http://codes.ohio.gov/orc/3324.

\section{Strony internetowe}

http://assembly.coe.int/main.asp?Link=/documents/adoptedtext/ta94/erec1248.htm. http://www.eurydice.org.pl/sites/eurydice.org.pl/files/zdolny.pdf. http://www.jusline.at/Schulunterrichtsgesetz_(SchUG).html. https://www.lsr-ooe.gv.at/fileadmin/erlasssammlung/2009/B5-5-1-2009.pdf. https://www.oezbf.at/. http://www.landesschulrat.at/.

34 Gifted Young Children: A Guide for Teachers and Parents, Allen \& Unwin, 2005 (2nd edition). 
https://www.slo.nl/.

https://www.cps.nl/over-cps/geschiedenis.

https://www.dcu.ie/ctyi/index.shtml.

http://homepage.tinet.ie/ iagc/iagc.htm.

https://dre.pt/pesquisa/-/search/582996/details/maximized.

http://www02.madeira-edu.pt/dre/educacao_especial/nucleo_apoio_sobredotacao.aspx. https://www.minedu.sk/data/att/670.pdf.

https://www.skolverket.se/.

https://warwick.ac.uk/newsandevents/pressreleases/ne10000002145/.

https://www.gla.ac.uk/research/az/ablepupils/.

https://www.valdosta.edu/colleges/education/pcft/document\%20/marland-report.pdf.

http://www.nagc.org/.

https://ies.ed.gov/funding/ncer_rfas/gifted.asp.

http://files.eric.ed.gov/fulltext/ED372590.pdf. 


\title{
3.2. Doradztwo edukacyjno-zawodowe w szkolnictwie zawodowym w Polsce i wybranych państwach Unii Europejskiej
}

\author{
Educational and professional counselling services \\ in vocational education in Poland and in selected \\ countries of the European Union
}

W opracowaniu przedstawiono problematykę doradztwa edukacyjno-zawodowego w szkolnictwie zawodowym w Polsce i w wybranych państwach Unii Europejskiej. W artykule zaprezentowano podstawowe definicje i pojęcia używane dla określenia tematyki doradztwa. Przedstawiono syntetyczną informację na temat funkcjonowania doradztwa edukacyjno-zawodowego w strukturach szkolnictwa zawodowego następujących państw: Polski, Austrii, Francji, Finlandii, Słowacji, Węgier, Wielkiej Brytanii.

Słowa kluczowe: edukacja, szkoła, szkolenie, nauczyciel, doradztwo, zawód, Polska, Unia Europejska

The paper deals with educational and vocational counselling services available within the vocational education system in Poland and selected countries of the European Union. It presents basic definitions and concepts which are used to specify the topics of counselling. The author gives a brief overview of the functioning of educational and vocational counselling in vocational education institutions in the following countries: Poland, Austria, France, Finland, Slovakia, Hungary and the United Kingdom.

Keywords: education, school, training, teacher, counseling, profession, European Union

\section{Wstęp}

Literatura dotycząca zagadnień i problemów orientacji, poradnictwa i doradztwa zawodowego jest wyjątkowo bogata, przy tym wieloaspektowa, a więc i system pojęciowy tej dziedziny wiedzy pozostaje mocno zróżnicowany. W literaturze pedagogicznej, psychologicznej i socjologicznej, a szczególnie w literaturze zawodoznawczej, spotkać się można z takimi terminami, jak: orientacja szkolna i zawodowa, orientacja i poradnictwo zawodowe, poradnictwo zawodowe, poradnictwo i doradztwo zawodowe, doradztwo zawodowe, preorientacja zawodowa, reorientacja zawodowa, selekcja zawodowa. Różni autorzy odmiennie je określają i interpretują, kierując się m.in. okresem lub zakresem oddziaływań zawodoznawczych, formami i metodami działań zawodoznawczych oraz wynika- 
mi oddziaływań zawodoznawczych. W środowisku specjalistów trwa dyskusja, które z tych pojęć można uznać jako dominujące i podstawowe. Jednakże większość źródeł zwartych - w tym Encyklopedia pedagogiczna XXI wieku ${ }^{1}$ - wskazuje na dominację trzech równoważnych i dopełniających się terminów, którymi są: orientacja zawodowa, poradnictwo zawodowe oraz doradztwo zawodowe. Poniżej przedstawiono skrótowy przegląd najczęściej występujących definicji i pojęć2.

\section{Podstawowe definicje i pojęcia}

Orientacja zawodowa (a właściwie orientacja szkolna i zawodowa lub szerzej orientacja edukacyjna i zawodowa) - to wszelkie oddziaływania wychowawcze i informacyjne, mające na celu umożliwienie podjęcia właściwej decyzji o wyborze zawodu, decyzji uwzględniającej zarówno zainteresowania i predyspozycje danej osoby, jak i potrzeby rynku pracy. Na orientację zawodową składa się więc: wiedza o zawodach i o psychofizycznych wymaganiach związanych z ich wykonywaniem, indywidualna ocena zainteresowań i własnych predyspozycji, wiedza o sposobie zdobywania kwalifikacji w wybranym zawodzie, rozeznanie w potrzebach rynku pracy w danym kraju. Od lat sześćdziesiątych i siedemdziesiątych XX wieku w naukach pedagogicznych używa się w zasadzie pojęcia orientacja szkolna i zawodowa. Orientacja zawodowa, oznaczająca przygotowanie wykwalifikowanych kadr na potrzeby gospodarki, nie obejmuje aspektu edukacyjnego, ważnego z punktu widzenia rozwoju zawodowego. Tak więc dopiero połączenie orientacji szkolnej i zawodowej tworzy spójny system działań wychowawczych, edukacyjnych i informacyjnych, umożliwiających młodemu człowiekowi podjęcie optymalnej decyzji w sprawie wyboru zawodu. Podstawowym ogniwem realizującym zadania orientacji zawodowej jest szkoła, która - oprócz pełnienia funkcji edukacyjnej - powinna stwarzać uczniom warunki optymalnego rozwoju psychofizycznego i intelektualnego (np. zajęcia fakultatywne i pozalekcyjne), jak również przygotowywać do wyboru zawodu, m.in. przez informacje o zawodach oraz kształtowanie nawyków i umiejętności dobrej pracy. Ze szkołą powinni ści-

1 Encyklopedia pedagogiczna XXI wieku, t. III, Wydawnictwo Akademickie „Żak”, Warszawa 2004, s. 920-923.

2 Opracowanie przygotowano na podstawie ekspertyzy Biura Analiz Sejmowych nr 212/13 z 18 lutego 2013 r. D. Dziewulaka zatytułowanej Informacja na temat doradztwa edukacyjno-zawodowego $w$ szkolnictwie zawodowym $w$ Polsce $i w$ wybranych państwach Unii Europejskiej (Austria, Francja, Finlandia, Słowacja, Węgry, Wielka Brytania) oraz artykułu tegoż autora Doradztwo edukacyjno-zawodowe w szkolnictwie zawodowym $i$ w wybranych państwach Unii Europejskiej, „Analizy BAS” 2013, nr 4(93), s. 1-8. 
śle współpracować w tym zakresie rodzice, poradnie zawodowe i inne organizacje oraz instytucje, np. służba zdrowia. Problem orientacji zawodowej dotyczy nie tylko młodzieży, ale także ludzi dorosłych, już pracujących i wykonujących określony zawód, ale z różnych przyczyn zmieniających pracę - jest to wówczas orientacja zawodowa ustawiczna, polegająca na konieczności dostosowania kwalifikacji do nowych wymagań wynikających z postępu technicznego czy też z „zanikania” starych zawodów ${ }^{3}$.

Poradnictwo zawodowe przez polskich autorów definiowane jest m.in. jako:

- pogłębienie wiedzy o wybranej grupie zawodów i przygotowanie do pracy w tych grupach,

- kształtowanie pożądanej społecznie motywacji i postawy zawodowej,

- zapoznanie z zapotrzebowaniem rynku pracy na kadry dla konkretnych zawodów w warunkach bezrobocia,

- pomaganie w realnej ocenie przydatności zawodowej i w samookreśleniu4.

W literaturze zagranicznej problematyka poradnictwa zawodowego jest analizowana najczęściej w powiązaniu z orientacją zawodową lub z doradztwem zawodowym. Takie podejście wiąże się z rozpatrywaniem poradnictwa zawodowego w trzech aspektach:

- jako system instytucji, zbiorowości społecznych, organizacji, a także idei i systemów wartości,

- jako zestaw różnych działań mających w ramach instytucji i organizacji przekazywać członkom społeczności określoną wiedzę i wartości,

- jako stan poinformowania społeczeństwa, przygotowania do wyboru zawodu, a także jako zasób wiedzy i poziom zainteresowania tą problematyką.

Doradztwo (ang. guidance, fr. guider, niem. Antraten, ros. консультирование) - jest procesem społecznym, który przebiega w interakcji dwupodmiotowej. Jego wyróżnikami są dobrowolność, dialog, spotkanie podmiotów prowadzące do zmiany w każdym z nich i w ich położeniu. Celem tak pojmowanego doradztwa jest wspomaganie człowieka w samodzielnym osiąganiu przez niego dojrzałości przez rozwijanie racjonalności, krytycyzmu i odwagi w ocenie i wyborach ${ }^{5}$. Nazwa doradztwo zawodowe została upowszechniona w Polsce w latach dzie-

3 http://biznes.pwn.pl/haslo/3951761/orientacja-zawodowa.html.

4 Encyklopedia, dz.cyt., s. 920-923.

5 M. Czerepaniak-Walczak, Doradztwo w reformowanej szkole - gimnazjum jako ośrodek doradztwa, [w:] Podejmowanie decyzji zawodowych przez młodzież i osoby dorosłe $w$ nowej rzeczywistości społeczno-politycznej, red. B. Wojtasik, Instytut Pedagogiki Uniwersytetu Wrocławskiego, Wrocław 2001. 
więćdziesiątych XX wieku w związku z podejmowanymi próbami wprowadzania rozwiązań stosowanych w państwach Unii Europejskiej w zakresie świadomego wyboru zawodu. Najczęściej używana jest amerykańska definicja Raya Lamba, który stwierdza, że doradztwo zawodowe jest to proces, w którym doradca zawodowy pomaga człowiekowi (uczniowi, klientowi) w osiągnięciu lepszego zrozumienia siebie samego w odniesieniu do środowiska pracy, aby umożliwić mu realistyczny wybór lub zmianę zatrudnienia albo też osiągnięcie właściwego dostosowania zawodowego ${ }^{6}$. Według innego spojrzenia na zagadnienie jest to proces w dużej mierze werbalny, w którym doradca i osoba zainteresowana (uczeń, klient) współpracują w dynamiczny sposób w celu osiągnięcia lepszego samozrozumienia oraz doprowadzenia do podejmowania przez ucznia „dobrych” decyzji zawodowych, przy czym to podejmujący decyzje odpowiedzialny jest za swoje działania ${ }^{7}$. Wybór własnej ścieżki kariery nie jest wyłącznie problemem ucznia, młodego człowieka, czy nawet jego rodziny. Jest to także akt, którego konsekwencje mają wyraźnie społeczny charakter. Jednym z takich społecznych kontekstów decyzji o dalszej drodze edukacji, a w dalszej perspektywie, funkcjonowania w określonej roli zawodowej, jest wpływ, jaki ma - lub może mieć - na nią szkoła. Dlatego okres pobytu w szkole powinien być przez uczniów wykorzystany na zdobycie informacji o różnych zawodach i ich wymaganiach, na odkrycie własnych możliwości, ustalenie celów na przyszłość oraz uświadomienie sobie swoich słabych stron, ewentualnych ograniczeń czy braków.

Współczesna działalność doradztwa zawodowego skupiona jest na aspekcie edukacyjnym (stąd pojęcie doradztwo edukacyjno-zawodowe lub inaczej doradztwo szkolno-zawodowe), czyli pomaga dzieciom, młodzieży i dorosłym w planowaniu i podejmowaniu decyzji dotyczących wyboru kierunku kształcenia i wyboru przyszłego zawodu. Dostarcza informacji o rynku pracy i możliwościach edukacyjnych, czyni je bardziej dostępnymi przez systematyzację, organizację i udostępnianie w możliwie każdym miejscu i czasie. Termin „doradztwo zawodowe” niejednokrotnie jest utożsamiany z pojęciem „poradnictwo zawodowe” i używany z nim zamiennie. W polskich publikacjach można spotkać różne sposoby definiowania doradztwa i określania jego różnic i podobieństw z poradnictwem. Najczęściej jednak pojęcie poradnictwa zawodowego (ang. vocational guidance, vocational counselling, fr. orientation professionelle, niem. Berufbera-

6 R. Lamb, Poradnictwo zawodowe $w$ zarysie, „Zeszyty informacyjno-metodyczne doradcy zawodowego", Warszawa 1998.

7 S.H. Cramer, E.L. Herr, Planowanie kariery zawodowej, Warszawa 2001, http://eurodoradztwo.praca.gov.pl/publikacje/15.pdf. 
tung, ros. профессиональная консультащия) definiowane jest jako działalność osoby potrzebującej pomocy, która wchodzi w relację z osobą udzielającą porady w celu określenia optymalnych dróg rozwoju zawodowego jednostki.

Celem doradztwa zawodowego jest:

- świadczenie pomocy uczniowi w dotarciu do informacji o nim samym w taki sposób, aby mógł poznać siebie, zorientować się we własnych upodobaniach i zainteresowaniach, cechach charakteru i usposobienia. Uświadomienie uczniowi jego mocnych i słabych stron,

- zapoznanie ucznia z informacjami o interesujących go zawodach, zarobkach, warunkach pracy i wymaganiach psychofizycznych,

- przybliżenie wiedzy o rynku pracy, możliwościach zatrudnienia w miejscu zamieszkania i najbliższym regionie,

- poinformowanie ucznia o sposobach kontaktowania się z pracodawcą.

Osobą zajmującą się doradztwem zawodowym jest doradca zawodowy lub nauczyciel, który przeszedł odpowiednie przeszkolenie w tym zakresie. Doradca zawodowy (ang. occupational counsellor, franc. conseiller d'orientation, niem. Berufsberater) pomaga w podejmowaniu decyzji dotyczącej przyszłej pracy i przygotowania do niej. Do jego głównych zadań należy9:

- gromadzenie, opracowywanie i aktualizowanie informacji o zawodach (stanowiskach pracy), instytucjach kształcenia zawodowego oraz możliwościach uzyskiwania kwalifikacji zawodowych, jak również o potrzebach rynku pracy,

- wykonywanie diagnostycznych badań przydatności do określonego zawodu oraz opracowywanie wyników tych badań,

- systematyczne diagnozowanie zapotrzebowania uczniów na informacje edukacyjne i zawodowe oraz na pomoc w planowaniu kształcenia i kariery zawodowej,

- prowadzenie odpowiedniej dokumentacji osób zgłaszających się po poradę, w tym archiwizowanie wykonywanych testów i ćwiczeń,

- gromadzenie, aktualizacja i udostępnianie informacji edukacyjnych i zawodowych właściwych dla danego poziomu kształcenia,

- wskazywanie uczniom, rodzicom i nauczycielom dodatkowych źródeł informacji na poziomie regionalnym, ogólnokrajowym, europejskim i światowym dotyczących:

8 G. Tadeusiewicz, Edukacja w Europie, Wydawnictwo Naukowe PWN, Warszawa-Łódź 1997, s. 110.

9 http://www.gazeta.edu.pl/Orientacja_zawodowa_czyli_planowanie_kariery-95_372-0.html. 
- rynku pracy,

- trendów rozwojowych w świecie zawodów i zatrudnienia,

- wykorzystania posiadanych uzdolnień i talentów przy wykonywaniu przyszłych zadań zawodowych,

- instytucji i organizacji wspierających funkcjonowanie osób niepełnosprawnych w życiu codziennym i zawodowym,

- alternatywnych możliwości kształcenia dla uczniów z problemami emocjonalnymi i dla uczniów niedostosowanych społecznie,

- programów edukacyjnych Unii Europejskiej;

- udzielanie indywidualnych porad uczniom i rodzicom,

- prowadzenie grupowych zajęć aktywizujących, przygotowujących uczniów do świadomego planowania kariery i podjęcia roli zawodowej,

- koordynowanie działalności informacyjno-doradczej prowadzonej przez szkołę,

- wspieranie w działaniach doradczych rodziców i nauczycieli przez organizowanie spotkań szkoleniowo-informacyjnych, udostępnianie informacji i materiałów do pracy z uczniami,

- współpraca z radą pedagogiczną w zakresie tworzenia i zapewnienia ciągłości działań wewnątrzszkolnego systemu doradztwa zawodowego, realizacji działań z zakresu przygotowania uczniów do wyboru drogi zawodowej, zawartych w programie wychowawczym szkoły i programie profilaktyki,

- współpraca z instytucjami wspierającymi wewnątrzszkolny system doradztwa zawodowego, w szczególności z poradniami psychologiczno-pedagogicznymi, w tym poradniami specjalistycznymi, oraz innymi instytucjami świadczącymi poradnictwo i specjalistyczną pomoc uczniom i rodzicom.

\section{Doradztwo edukacyjno-zawodowe w szkolnictwie zawodowym w Polsce}

W Polsce regulacje prawne dotyczące doradztwa edukacyjno-zawodowego obowiązują wszystkie szkoły i placówki systemu oświaty, a zatem w samym szkolnictwie zawodowym nie ma odrębnych rozwiązań i uregulowań dotyczących doradztwa ${ }^{10}$. Sposób realizacji poszczególnych zadań z obszaru doradztwa edukacyjno-zawodowego dostosowany jest do konkretnego etapu kształcenia.

10 W opracowaniu wykorzystano materiały uzyskane za pośrednictwem Sieci Informacji o Edukacji w Europie (Eurydice), Ministerstwa Edukacji Narodowej RP oraz dostępne na stronach internetowych instytucji i organizacji zajmujących się zagadnieniem kształcenia zawodowego w państwach UE. 
Szkoły zawodowe koncentrują się zatem na poszerzonej orientacji zawodowej oraz procesie reorientacji zawodowej. Działania te polegają przede wszystkim na pobudzaniu uczniów do refleksji związanej z oceną samego siebie i swoich możliwości, a także na przygotowaniu ich do odnalezienia się na rynku pracy, a w konsekwencji do podjęcia pracy. W szkołach zawodowych w zakresie doradztwa edukacyjno-zawodowego podejmowane są następujące działania:

- uświadomienie uczniom zmian, które zaszły na rynku pracy, i ich konsekwencji,

- kształcenie umiejętności samodzielnego poszukiwania pracy -zachowania się podczas rozmowy kwalifikacyjnej, sporządzania dokumentów aplikacyjnych,

- uświadomienie uczniom roli uczenia się przez całe życie i potrzeby ciągłego doskonalenia,

- udzielanie informacji zawodowej o dostępnych możliwościach rozwijania zainteresowań zawodowych uczniów.

\section{Przepisy prawne regulujqce funkcjonowanie doradztwa edukacyjno-zawodowego w polskim systemie oświaty}

Doradztwo edukacyjno-zawodowe w polskim systemie oświaty regulowane jest przez następujące akty prawne:

- ustawa z 7 września 1991 r. o systemie oświaty (Dz.U. 2004, nr 256, poz. 2572, ze zm.) i przepisy wykonawcze do ustawy regulują sposób świadczenia usług doradczych w szkołach i placówkach oświatowych. Ustawa stanowi, że system oświaty zapewnia m.in. przygotowanie uczniów do wyboru zawodu i kierunku kształcenia, zapewnia warunki do rozwoju zainteresowań i uzdolnień uczniów przez organizowanie zajęć pozalekcyjnych i pozaszkolnych oraz kształtowanie aktywności społecznej i umiejętności spędzania czasu wolnego (art. 1 pkt 14 i 15 ustawy),

- ustawa z 26 stycznia 1982 r. - Karta Nauczyciela (Dz.U. 2006, nr 97, poz. 674, ze zm.) w art. 42 ust. 7 pkt 3 stanowi, że tygodniowy obowiązkowy wymiar godzin zajęć doradców zawodowych prowadzących zajęcia związane z wyborem kierunku kształcenia i zawodu w celu wspomagania uczniów w podejmowaniu decyzji edukacyjnych i zawodowych określa organ prowadzący szkołę (jednostka samorządu terytorialnego),

- rozporządzenie Ministra Edukacji Narodowej z 17 listopada 2010 r. w sprawie zasad udzielania i organizacji pomocy psychologiczno-pedagogicznej w publicznych przedszkolach, szkołach i placówkach (Dz.U. nr 228, poz. 1487, ze 
zm.) ${ }^{11}$ określa, że pomoc psychologiczno-pedagogiczna realizowana w szkole powinna polegać m.in. na rozpoznaniu potrzeb rozwojowych i edukacyjnych poszczególnych uczniów oraz ich możliwości psychofizycznych, ponadto na rozpoznaniu zainteresowań i uzdolnień uczniów (§ 18). Zajęcia, które organizowane są w szkole bądź za jej pośrednictwem, powinny wspomagać uczniów w wyborze dalszej ścieżki kariery edukacyjno-zawodowej. W tym celu rozporządzenie ustala szczegółowe zadania, jakie powinno realizować się w zakresie doradztwa edukacyjno-zawodowego. Są to:

- systematyczne diagnozowanie zapotrzebowania poszczególnych uczniów na informacje edukacyjne i zawodowe oraz pomoc w planowaniu kształcenia i kariery zawodowej,

- gromadzenie, aktualizacja i udostępnianie informacji edukacyjnych i zawodowych właściwych dla danego poziomu kształcenia,

- prowadzenie zajęć przygotowujących uczniów do świadomego planowania kariery i podjęcia roli zawodowej,

- koordynowanie działalności informacyjno-doradczej prowadzonej przez szkołę i placówkę,

- współpraca z innymi nauczycielami w tworzeniu i zapewnieniu ciągłości działań w zakresie doradztwa edukacyjno-zawodowego. Rozporządzenie stanowi, że w przypadku braku doradcy zawodowego dyrektor wyznacza nauczyciela, który planuje i realizuje zadania z zakresu doradztwa edukacyjno-zawodowego w szkole lub placówce;

- rozporządzenie Ministra Edukacji Narodowej z 12 marca 2009 r. w sprawie szczegółowych kwalifikacji wymaganych od nauczycieli oraz określenia szkół i wypadków, w których można zatrudnić nauczycieli niemających wyższego wykształcenia lub ukończonego zakładu kształcenia nauczycieli (Dz.U. nr 50, poz. 400, ze zm. $)^{12}$, określa wymagania wobec osoby, która będzie wykonywać zadania doradcy zawodowego. Na stanowisku nauczyciela doradcy zawodowego może zostać zatrudniona osoba, która: ukończyła studia magisterskie na dowolnym kierunku i studia podyplomowe w zakresie doradztwa zawodowego oraz ma przygotowanie pedagogiczne, bądź też ukończyła studia I stopnia na dowolnym kierunku (specjalności) i studia podyplomowe w zakresie doradztwa zawodowego oraz ma przygotowanie pedagogiczne. Możliwość

11 http://prawo.legeo.pl/prawo/rozporzadzenie-ministra-edukacji-narodowej-z-dnia-17-listopada-2010-r-w-sprawie-zasad-udzielania-i-organizacji-pomocy-psychologiczno-pedagogicznej-w-publicznych-przedszkolach-szkolach-i-placowkach/.

12 http://isap.sejm.gov.pl/DetailsServlet?id=WDU20090500400. 
zajmowania stanowiska nauczyciela doradcy zawodowego w szkołach i placówkach ma także osoba, która uzyskała którąś z wymienionych kwalifikacji, a ponadto ukończyła studia podyplomowe lub kurs kwalifikacyjny w zakresie pedagogiki specjalnej, odpowiedniej do niepełnosprawności uczniów lub rodzaju placówki.

\section{Wspomaganie szkół w realizacji zadań z zakresu doradztwa edukacyjno-zawodowego w polskim systemie oświaty}

Istotnym wsparciem dla osób realizujących zadania z zakresu poradnictwa zawodowego oraz samych doradców zawodowych pracujących w systemie oświaty jest działalność Krajowego Ośrodka Wspierania Edukacji Zawodowej i Ustawicznej (KOWEZiU) ${ }^{13}$, który w ramach projektu Eurodoradztwo Polska opracował i wydał następujące publikacje:

- Podstawy poradnictwa kariery. Poradnik dla nauczycieli, adresowany do nauczycieli, którzy chcą uczestniczyć w kreowaniu kariery życiowej swoich uczniów. Poradnik nakreśla teoretyczne podstawy poradnictwa kariery, omawia zagadnienia związane z poradnictwem kariery dla młodzieży w resorcie edukacji oraz przedstawia metody działania nauczyciela jako doradcy kariery zarówno w indywidualnym, jak i grupowym poradnictwie. Poradnik został napisany przystępnym językiem i stanowi podstawę do zdobycia najważniejszych informacji dla osób, które dotychczas nie zajmowały się poradnictwem zawodowym;

- Przewodnik po zawodach, zawierający krótkie opisy zawodów oraz ścieżek edukacyjnych, które pozwalają je zdobyć. Przewodnik został opracowany na podstawie znowelizowanej klasyfikacji zawodów szkolnictwa zawodowego. Opisano w nim 193 zawody wraz z informacją o typach szkół ponadgimnazjalnych, w których odbywa się kształcenie. W części II Przewodnika każdy zawód opisano na dwóch stronach. Na pierwszej stronie znajdują się: krótka informacja o tym, co robi osoba zatrudniona w tym zawodzie; nazwa kwalifikacji; typ szkoły, w której można się kształcić w tym zawodzie; informacja, czy zawód ma kontynuację na poziomie technikum; informacja, czy zawodu można nauczyć się w rzemiośle lub na kwalifikacyjnych kursach zawodowych; informacja, czy w danym zawodzie uczy się wiele osób. Na drugiej stronie znajdują się informacje o warunkach pracy, potrzebnych kompetencjach, karierze edukacyjnej i zawodowej;

13 http://www.koweziu.edu.pl/. 
- Metody, techniki i narzędzia diagnostyczne w poradnictwie zawodowym. $\mathrm{Pu}$ blikacja zawiera informacje o narzędziach i materiałach metodycznych do badania predyspozycji i zainteresowań zawodowych uczniów;

- Od aktora do autora własnej kariery. Wspieranie młodzieży w konstruowaniu karier. Publikacja jest skierowana do uczniów gimnazjów i szkół ponadgimnazjalnych i zawiera konkretne wskazówki oraz porady ułatwiające wybór szkoły i kariery zawodowej.

Dodatkowo KOWEZiU organizuje regularne szkolenia podnoszące wiedzę i umiejętności doradców zawodowych oraz nauczycieli pracujących w systemie oświaty, którzy wspomagają uczniów i rodziców w podejmowaniu decyzji co do wyboru zawodu lub kierunku dalszego kształcenia.

\section{Doradztwo edukacyjno-zawodowe w wybranych krajach Unii Europejskiej}

Analizując sytuację i sposób realizacji poradnictwa zawodowego w poszczególnych krajach Unii, można zauważyć wiele rozwiązań zbliżonych do wprowadzonych i realizowanych w Polsce. Niemniej jednak, systemy te nie są jednorodne i często przyjęte rozwiązania mają charakter indywidualny.

\section{Austria}

W Austrii zadania doradztwa edukacyjno-zawodowego oraz orientacji szkolnej realizowane są przez Federalne Ministerstwo Edukacji, Sztuki i Kultury (Bundesministerium für Unterricht, Kunst und Kultur, BMUKK ${ }^{14}$. Problematyka orientacji zawodowej umieszczona jest także w kompetencjach Federalnego Ministerstwa Pracy, Spraw Społecznych i Ochrony Konsumenta (Bundesministerium für Arbeit, Soziales und Konsumentenschutz, BMASK) ${ }^{15}$.

W placówkach szkolnych doradztwo zawodowe realizowane jest przez:

- dostarczanie uczniom i rodzicom ogólnej informacji na temat kształcenia zawodowego, rynku pracy oraz potrzeb rozwoju zawodowego uczniów,

- realizowanie orientacji indywidualnej, przez cały czas trwania nauki szkolnej,

- współdziałanie z innymi instytucjami zajmującymi się wspieraniem doradztwa zawodowego.

14 http://www.bmukk.gv.at/.

15 http://www.bmask.gv.at/cms/siteEN/. 


\section{Finlandia}

Zgodnie z fińską ustawą o edukacji podstawowej, poradnictwo edukacyjne i zawodowe realizowane jest w sposób ciągły od najmłodszych lat przez cały cykl edukacji szkolnej. Poradnictwo ma umożliwić uczniom uzyskanie informacji dotyczących ścieżek edukacyjnych przed i w trakcie kształcenia, a także praktycznych wiadomości o rynku pracy i o potencjalnych możliwościach zatrudnienia. Ponadto w ramach specjalnych szkoleń naucza się sposobów poszukiwania informacji na temat dostępnych szkoleń i zawodów, zwracając szczególną uwagę na zagadnienia związane z podejmowaniem decyzji i tworzeniem planów edukacyjnych i zawodowych dostosowanych do zmieniającej się sytuacji na rynku pracy.

W szkolnictwie podstawowym ${ }^{16}$, zwłaszcza w ostatnich trzech latach nauki, uczniowie objęci są intensywną opieką doradczo-edukacyjną. Uczeń może skorzystać z indywidualnych i grupowych spotkań z doradcą, podczas których uczy się poznawać i oceniać własne umiejętności i zainteresowania, oraz jak ukierunkować własne oczekiwania zawodowe na zmieniającym się rynku pracy.

Specyfiką fińskiego trzyletniego szkolnictwa średniego jest brak przedmiotów obowiązkowych. Program nauczania obejmuje jedynie sugerowany zestaw kursów tematycznych. Istotne jest, by w ciągu 3 lat uczeń ukończył określoną przez szkołę liczbę kursów. W ich ramach realizowane jest również doradztwo zawodowe, które koncentruje się głównie na projektowaniu kariery ucznia, monitorowaniu postępów w nauce oraz działalności informacyjnej co do dalszej edukacji i sposobach zdobywania konkretnych kwalifikacji. Przedmiot (kurs) prowadzony jest przez nauczycieli szkolnych lub przez zewnętrznych doradców zawodowych zatrudnianych przez szkołę. Ponadto każda klasa ma swojego nauczyciela-wychowawcę, który przygotowany jest do udzielenia uczniom pomocy w ogólnych kwestiach związanych z kształceniem (wybór przedmiotów opcjonalnych, organizowanie okresów zdobywania doświadczeń zawodowych itp.).

\section{Francja}

Doradztwo zawodowe w systemie oświatowym Francji realizowane jest na podstawie ustawy z 1989 r. o szkolnictwie ${ }^{17}$ oraz ustawy z 2005 r. o orientacji i programie

16 W Finlandii nauka w szkole podstawowej trwa 9 lat i podzielona jest na klasy niższe (klasy I-VI) oraz wyższe (klasy VII-IX).

17 Loi n89-486 du 10 juillet 1989, http://www.legifrance.gouv.fr/affichTexte.do?cidTexte =LEGITEXT000006069117\&dateTexte=20050423. 
dla przyszłości szkoły ${ }^{18}$. Oba akty prawne stanowią, że oświata jest najważniejszym priorytetem narodowym i wskazują na konieczność przygotowania dla każdego ucznia indywidualnego planu rozwoju edukacyjno-zawodowego. Plan rozwoju powinien być tworzony przy współpracy szkoły, nauczycieli i doradców zawodowych. Za kluczowy moment w procesie orientacji edukacyjno-zawodowej uznaje się koniec kolegium - szkoły średniej I stopnia (collège), gdy uczeń decyduje o wyborze szkoły średniej II stopnia. Szkoła średnia II stopnia prowadzi do uzyskania matury lub dyplomu technika o wybranej specjalizacji, więc staje się początkiem specjalistycznej edukacji młodego człowieka, bezpośrednio wpływając na jego wybory życiowe ${ }^{19}$.

Uczeń może korzystać z doradztwa edukacyjno-zawodowego na terenie swojej szkoły, w ministerialnym Centrum Informacji i Orientacji (Centre d'information et d'orientation, $\mathrm{CIO})^{20}$ lub w Krajowej Agencji Pracy (Pôle emploi) ${ }^{21}$. Istnieje także wiele innych organizacji publicznych oraz prywatnych (np. Centrum Informacji i Dokumentacji Młodzieżowej, fr. Centre d'Information et de Documentation Jeunesse, CIDJ) ${ }^{22}$, w których można otrzymać poradę, wsparcie i ukierunkowanie w zakresie budowy własnej ścieżki zawodowej. Najpopularniejszą instytucją wspierającą szkolny proces doradztwa edukacyjno-zawodowego jest jednak Centrum Informacji i Orientacji. Zostało ono powołane w 1969 roku z inicjatywy ówczesnego Ministerstwa ds. Młodzieży i Sportu, posiada obecnie ponad 1500 placówek we wszystkich departamentach na terenie całego kraju. Jest finansowane z budżetu państwa i środków władz lokalnych. Głównym celem CIO jest wspieranie i uzupełnianie działalności orientacyjno-poradniczej realizowanej przez nauczycieli z placówek szkolnych. Pracownicy Centrum - edukatorzy, doradcy zawodowi i psycholodzy - udzielają informacji i prowadzą indywidualne doradztwo zawodowo-edukacyjne skierowane do młodzieży szkolnej i ich rodzin.

Instytucją zajmującą się działalnością informacyjną i szkoleniową w zakresie doradztwa zawodowego jest Krajowe Biuro Informacji o Kształceniu i Zawodach

18 Loi n² 2005-380 du 23 avril 2005 d'orientation et de programme pour l'avenir de l'école, http://www.legifrance.gouv.fr/affichTexte.do?cidTexte=JORFTEXT000000259787\&dateTexte=\&categorieLien=id.

19 L'éducation à l'orientation professionnelle dans l'enseignement obligatoire à temps plein en Europe. Commission européenne, http://www.education.gouv.fr/archives/2012/refondonslecole/wp-content/uploads/2012/07/rapport_eurydice_l_education_a_l_orientation_ professionnelle_dans_l_enseignement_obligatoire_a_temps_plein_en_europe_2008.pdf.

20 http://www.education.gouv.fr/cid160/les-lieux-d-information-de-l-orientation.html\#les-centres-d-information-et-d-orientation-c-i-o-.

21 http://www.pole-emploi.fr/accueil/.

22 http://www.cidj.com/le-cidj/historique/le-cidj-et-l-information-jeunesse. 
(Office National d'Information sur les Enseignements et les Professions, ONISEP). Jest to instytucja publiczna o statusie jednostki administracji publicznej powołana do życia w 1970 roku. Kieruje nią Generalny Inspektor Edukacji Narodowej, który podlega Ministrowi Edukacji Narodowej oraz Ministrowi Szkolnictwa Wyższego i Nauki ${ }^{23}$. Na obszarze całej Francji ma 28 regionalnych biur oraz sieć biur lokalnych i centrów informacyjnych. Celem działalności ONISEP jest udzielanie uczniom, nauczycielom i rodzicom wszechstronnych i profesjonalnych porad oraz przekazywanie informacji na temat kierunków kształcenia, a w wypadku zainteresowania konkretnymi zawodami, wskazywanie ewentualnych ścieżek zawodowych w systemie szkolnictwa zawodowego.

Kolejną instytucją jest Centrum Studiów i Badań Kwalifikacji Zawodowych (Centre d'études et de recherches sur les qualifications, CEREQ) ${ }^{24}$. Centrum jest instytucją publiczną powołaną w ramach ONISEP. Pełną niezależność organizacyjną uzyskało w 1985 roku. Podlega Ministerstwu Edukacji Narodowej oraz Ministerstwu Pracy, Zatrudnienia, Kształcenia Zawodowego i Dialogu Społecznego. Celem CEREQ jest prowadzenie badań i analiza sytuacji rynku pracy, zatrudnienia i realizowanych szkoleń w celu zapewnienia większej spójności między nimi. Centrum przygotowuje i opracowuje materiały na temat bieżącej i przewidywanej rynkowej sytuacji w obszarze zapotrzebowania na konkretne zawody. Informacje te są przekazywane do ONISEP, który rozpowszechnia je wśród zainteresowanych uczniów i nauczycieli kształcenia zawodowego.

\section{Słowacja}

Doradztwo zawodowe w systemie oświaty jest oparte głównie na rozporządzeniu Ministra Edukacji nr 43/1996, które zobowiązuje szkoły m.in. do:

- prowadzenia diagnostyki edukacyjnej,

- określania przyczyn problemów uczniów w zakresie rozwoju społecznego, edukacyjnego i zawodowego,

- rozwiązywania kwestii dotyczących dalszej edukacji uczniów we współpracy z rodzicami i nauczycielami.

Rozporządzenie określa także zakres działań doradcy edukacyjnego, który w szkołach odpowiada (obok pedagoga i psychologa) za doradztwo zawodowe. Do jego zadań należy:

23 Zob. przyp. 12 na s. 114.

24 http://www.cereq.fr/. 
- udzielanie porad uczniom w celu zapobiegania problemom rozwojowym,

- zapewnianie konsultacji dla uczniów i rodziców w celu rozwiązywania problemów edukacyjnych i szkoleniowych, udzielanie informacji w zakresie wyboru i planowania kariery zawodowej,

- systematyczne monitorowanie rozwoju uczniów,

- ścisła współpraca z poradniami pedagogiczno-psychologicznymi w zakresie planowania kariery edukacyjno-zawodowej,

- wsparcie metodyczne dla nauczycieli danej szkoły w zakresie doradztwa zawodowego,

- prowadzenie doradztwa dla uczniów i rodziców,

- zapewnienie pomocy w rozwiązywaniu problemów osobistych, społecznych i edukacyjnych,

- monitorowanie edukacyjnych problemów uczniów,

- realizacja ukierunkowanych działań profilaktycznych adresowanych do uczniów i rodziców (dyskusje grupowe i konferencje na aktualne tematy dotyczące nauczania i uczenia się, zachowań i relacji międzyludzkich, porady w zakresie profilaktyki uzależnień i innych patologii społecznych),

- monitorowanie i rejestrowanie zainteresowań uczniów co do dalszych studiów i zawodu,

- aktywne uczestnictwo w warsztatach, seminariach i szkoleniach organizowanych dla doradców edukacyjnych,

- zamieszczanie informacji z zakresu doradztwa edukacyjnego na tablicy ogłoszeń i stronie internetowej szkoły.

Doradcy edukacyjni (często taką rolę odgrywają nauczyciele, którzy odbyli specjalistyczny kurs doradztwa zawodowego) wykonują zadania z zakresu doradztwa zawodowego, jako część swoich obowiązków i są tym samym zwolnieni z części pracy dydaktycznej. Każdy doradca edukacyjny przygotowuje plan pracy na dany rok szkolny, w którym określa szczegółowo miesięczne plany i cele. Muszą one być zgodne z głównymi zadaniami szkoły.

Innym elementem doradztwa zawodowego realizowanego w systemie szkolnym jest wprowadzenie do programów nauczania opcjonalnego przedmiotu wprowadzenie do świata pracy (Uvod do sveta prace), na który można uczęszczać w ostatnich dwóch latach nauki w szkołach średnich II stopnia. Główne cele nauczania tego przedmiotu to:

- uzyskanie podstawowych informacji na temat kariery w różnych dziedzinach: zarządzania, rolnictwa, produkcji, leśnictwa, zdrowia, handlu i gastronomii, budownictwa, 
- poznanie charakteru pracy, warunków pracy,

- zapoznanie uczniów z potrzebnymi kwalifikacjami i niezbędnymi szkoleniami dla każdego zawodu.

W ramach realizacji wyżej wymienionego przedmiotu uczniowie mają również możliwość rozmowy i dyskusji dotyczących ich zdolności do pracy, realistycznej oceny swoich umiejętności przez samoocenę. Pracują nad planem własnej kariery zawodowej oraz zachowaniem podczas rozmowy kwalifikacyjnej.

Kolejnym ogniwem doradztwa zawodowego realizowanego na Słowacji są poradnie psychologiczno-pedagogiczne (školská pedagogicko-psychologická poradna).

Głównym zadaniem tych placówek jest diagnozowanie uczniów pod kątem planowania ich ścieżki edukacyjno-zawodowej. Poradnie współpracują w obszarze doradztwa zawodowego zarówno z uczniami, jak i rodzicami oraz doradcami edukacyjnymi. Poradnie pedagogiczno-psychologiczne służą również jako baza informacji na temat lokalnego i krajowego rynku pracy, wykazu zawodów, szkół i uczelni.

\section{Węgry}

Na Węgrzech poradnictwo zawodowe stanowi obowiązkowy element systemu oświaty. Zapewnienie obywatelom dostępu do poradnictwa zawodowego regulują ustawy o edukacji, o kształceniu zawodowym oraz o edukacji dorosłych:

- ustawa nr 79/1993 o edukacji publicznej (Törvény a közoktatásról szóló 79/1993) ${ }^{25}$ zawiera przepisy o pomocy w zakresie doradztwa pedagogiczno-zawodowego przygotowującego ucznia do przyszłego wyboru zawodu lub kierunku studiów (§ 34),

- ustawa nr 76/1993 o kształceniu zawodowym (A szakképzésről szóló 76/1993) określa prawo każdego ucznia do korzystania z poradnictwa zawodowego (§ 29),

- ustawa nr 110/2001 o edukacji dorosłych (Törvény a felnőttoktatásról szóló 110/2001), w której poradnictwo zawodowe jest określone jako jedno z narzędzi służących do pomocy we wkraczaniu w świat pracy przez osiągnięcie satysfakcji i spełnienia zawodowego.

Poradnictwo zawodowe znalazło swoje miejsce także w podstawie programowej na wszystkich etapach kształcenia. Przyjmuje ono następujące formy:

25 http://www.okm.gov.hu/letolt/kozokt/kozokt_tv_070823.pdf. 
- ścieżka międzyprzedmiotowa: nauka o życiu codziennym i umiejętnościach praktycznych - program wprowadzony na poziomie szkoły podstawowej, którego najważniejszym zadaniem jest zapoznanie uczniów z głównymi obszarami zawodowymi. Nauczyciele realizujący program (wszyscy w ramach swoich przedmiotów) skupiają się przede wszystkim na poznaniu zdolności uczniów na podstawie przekazywania informacji o różnych zawodach,

- przedmiot: poradnictwo zawodowe - przeznaczony dla uczniów w wieku 13-14 lat. Jego najważniejszym celem jest pomoc uczniom w zaplanowaniu ścieżki edukacyjnej, głównie przez wyznaczenie celów zawodowych,

- kursy z zakresu zawodoznawstwa - uczestniczą w nich uczniowie szkół średnich II stopnia. W ramach kursów uczniowie zapoznają się z opisami zadań i działań, jakie wykonuje się, realizując określone prace. Dowiadują się o możliwościach zatrudnienia, możliwych ścieżkach zdobycia kwalifikacji uprawniających do wykonywania określonego zawodu,

- programy z zakresu orientacji zawodowej - obejmują młodzież z zawodowych szkół średnich. Są wprowadzane przed podjęciem przez młodzież praktyk zawodowych w celu zapewnienia im optymalnej wiedzy z zakresu planowania ścieżki kariery. Tematyka programów oraz ich zakres mogą mieć charakter sformalizowany lub też nie, co w dużej mierze jest uzależnione od decyzji szkoły,

- przedmiot: wiedza o przedsiębiorczości - obejmuje każdy poziom kształcenia. Program zawiera podstawową wiedzę o mechanizmach rynkowych oraz opiera się na kształtowaniu u uczniów postawy przedsiębiorczej.

Inną formą poradnictwa zawodowego stosowaną w węgierskiej oświacie jest podejmowanie inicjatyw nawiązywania kontaktów z pracodawcami w celu realizacji bezpośrednich wizyt w przedsiębiorstwach. Są to na ogół kontakty o charakterze poglądowo-informacyjnym umożliwiające uczniom bezpośrednią obserwację potencjalnych miejsc ich pracy.

Węgierska oświata, poza ofertą skierowaną do wszystkich uczniów, zapewnia również doradztwo indywidualne. Funkcje tę pełnią wykwalifikowani doradcy zawodowi, a w tych placówkach, gdzie ich nie ma - funkcję tę pełnią wychowawcy klas lub inni nauczyciele. Do ich obowiązków należy przeprowadzenie jednej godziny tygodniowo doradztwa indywidualnego dla osoby, która ma problemy związane z planowaniem swojej ścieżki edukacyjno-zawodowej. Osoby odpowiedzialne za doradztwo zawodowe skupiają się przede wszystkim na takich zagadnieniach, jak:

- indywidualne talenty i umiejętności ucznia,

- możliwości ucznia, 
- przegląd zawodów i wymagania oczekiwane od kandydatów,

- kariera zawodowa w świadomości uczniów,

- uczenie się przez całe życie.

Doradztwo indywidualne realizowane jest przez szkoły na bardzo różne sposoby - od udziału uczniów w dodatkowych zajęciach po indywidualne spotkania o charakterze wychowawczo-poradniczym.

Oświata na Węgrzech realizuje zadania z zakresu poradnictwa zawodowego w ramach obowiązku narzuconego przez ustawę. W związku z tym duża część nauczycieli dokształca się $\mathrm{w}$ tej dziedzinie, aby prawidłowo stosować pomoce i narzędzia wykorzystywane w obszarze doradztwa zawodowego.

Oprócz wsparcia ze strony samej placówki szkolnej uczniowie mogą korzystać z usług doradcy zawodowego w okręgowych poradniach pedagogiczno-psychologicznych (Megyei pedagógiai intezet).

\section{Wielka Brytania (Anglia)}

System oświatowy Wielkiej Brytanii nie jest jednolity. Systemy szkolne Anglii i Walii są relatywnie podobne do siebie, lecz odmienne od ustrojów szkolnych Szkocji i Irlandii Północnej, które regulowane są odrębnymi ustawami i zarządzeniami władz lokalnych. W Anglii za rozwój i organizację poradnictwa zawodowego odpowiedzialne są dwa wydziały Ministerstwa Edukacji: Wydział Informacji i Poradnictwa Zawodowego oraz Wydział Wyboru Kariery zajmujące się doradztwem edukacyjnym dla młodzieży ${ }^{26}$. W Anglii szkoły zobowiązane są do umieszczania w programach nauczania zagadnień związanych z poradnictwem zawodowym i tworzeniem planu rozwoju zawodowego (Careers education and guidance, CEG). Szkoły mają jednak w tym zakresie znaczną autonomię i każda placówka realizuje program zgodnie z własnymi potrzebami. Nauczycielem przedmiotu CEG może być tzw. doradca kariery lub wyznaczony przez dyrektora placówki nauczyciel, który powinien ukończyć specjalistyczny kurs lub studia podyplomowe w tej dziedzinie.

Angielskie szkoły mają obowiązek współpracować z zewnętrznymi partnerami i ekspertami w zakresie poradnictwa kariery, aby zapewnić uczniom dostęp do niezależnego i bezstronnego doradztwa zawodowego dla uczniów. Obowiązujące przepisy wprowadzają również obowiązek wspierania doradztwa zawodo-

26 http://www.education.gov.uk/childrenandyoungpeople/youngpeople/participation/ g00205755/statutory-careers-guidance-for-young-people. 
wego przez władze lokalne przez dofinansowanie i pomoc w organizacji szkoleń oraz wizyt młodzieży w przedsiębiorstwach i zakładach pracy o różnym profilu zawodowym.

\section{Bibliografia}

Czerepaniak-Walczak M., Doradztwo w reformowanej szkole - gimnazjum jako ośrodek doradztwa, [w:] Podejmowanie decyzji zawodowych przez młodzież i osoby dorosłe w nowej rzeczywistości społeczno-politycznej, red. B. Wojtasik, Instytut Pedagogiki Uniwersytetu Wrocławskiego, Wrocław 2001.

Cramer S.H., Herr E.L., Planowanie kariery zawodowej, Warszawa 2001, http://eurodoradztwo.praca.gov.pl/publikacje/15.pdf.

Dziewulak D., Doradztwo edukacyjno-zawodowe $w$ szkolnictwie zawodowym i $w$ wybranych państwach Unii Europejskiej, „Analizy BAS” 2013, nr 4(93).

Ferre D., Pour une approche orientante de l'école française, Editions Qui plus est, Paris 2005.

Lamb R., Poradnictwo zawodowe w zarysie, „Zeszyty informacyjno-metodyczne doradcy zawodowego", Warszawa 1998.

Tadeusiewicz G., Edukacja w Europie, Wydawnictwo Naukowe PWN, Warszawa-Łódź 1997.

Encyklopedia pedagogiczna XXI wieku, t. III, Wydawnictwo Akademickie „Żak”, Warszawa 2004.

\section{Akty prawne}

Ustawa z 7 września 1991 r. o systemie oświaty, Dz.U. 2004, nr 256, poz. 2572, ze zm.

Ustawa z 26 stycznia 1982 r. - Karta Nauczyciela, Dz.U. 2006, nr 97, poz. 674, ze zm.

Rozporządzenie Ministra Edukacji Narodowej z 17 listopada 2010 r. w sprawie zasad udzielania i organizacji pomocy psychologiczno-pedagogicznej w publicznych przedszkolach, szkołach i placówkach, Dz.U. nr 228, poz. 1487, ze zm.

Rozporządzenie Ministra Edukacji Narodowej z 12 marca 2009 r. w sprawie szczegółowych kwalifikacji wymaganych od nauczycieli oraz określenia szkół i wypadków, w których można zatrudnić nauczycieli niemających wyższego wykształcenia lub ukończonego zakładu kształcenia nauczycieli, Dz.U. nr 50, poz. 400, ze zm.

Francuska ustawa z 1989 r. o szkolnictwie, Loi n89-486 du 10 juillet 1989, http://www.legifrance.gouv.fr/affichTexte.do?cidTexte=LEGITEXT000006069117\&dateTexte=20050423. 
Francuska ustawa z 2005 r. o orientacji i programie dla przyszłości szkoły, Loi nº 2005-380 du 23 avril 2005 d'orientation et de programme pour l'avenir de l'école, http://www.legifrance. gouv.fr/affichTexte.do?cidTexte=JORFTEXT000000259787\&dateTexte=\&categorieLien=id.

Węgierska ustawa nr 79/1993 o edukacji publicznej, Törvény a közoktatásról szóló 79/1993, http://www.okm.gov.hu/letolt/kozokt/kozokt_tv_070823.pdf.

\section{Strony internetowe}

http://biznes.pwn.pl/haslo/3951761/orientacja-zawodowa.html.

http://www.gazeta.edu.pl/Orientacja_zawodowa_czyli_planowanie_kariery-95_372-0.html. http://www.bmukk.gv.at/.

http://www.bmask.gv.at/cms/siteEN/.

http://www.education.gouv.fr/cid160/les-lieux-d-information-de-l-orientation.html\#les-centres-d-information-et-d-orientation-c-i-o-.

http://www.pole-emploi.fr/accueil/.

http://www.cidj.com/le-cidj/historique/le-cidj-et-l-information-jeunesse. 


\title{
3.3. Zwalnianie uczniów z lekcji wychowania fizycznego w szkołach w Polsce i wybranych państwach europejskich
}

\author{
Exempting students from physical education classes \\ in schools in Poland and selected European countries
}

\begin{abstract}
W opracowaniu przedstawiono zasady zwalniania uczniów z lekcji wychowania fizycznego w szkolnictwie w Polsce i w wybranych państwach europejskich. Zaprezentowano w nim także syntetyczną informację na temat obowiązkowych treści wychowania fizycznego, liczby realizowanych godzin, liczby uczniów w grupie oraz sposobu oceniania uczniów z wychowania fizycznego w Polsce, we Francji, w Grecji, Hiszpanii, Irlandii, Islandii, na Łotwie, Malcie, w Niemczech, na Słowacji, w Słowenii, Szwecji i Wielkiej Brytanii.
\end{abstract}

Słowa kluczowe: szkolnictwo, wychowanie fizyczne, zwolnienie z lekcji

The paper presents the principles for exempting students from physical education classes in schools in Poland and selected European countries. It provides a concise information on the mandatory content of physical education, the number of hours of physical education in curricula, the number of students in a group and the procedures for assessment of students in physical education in Poland, France, Greece, Spain, Ireland, Iceland, Latvia, Malta, Germany, Slovakia, Slovenia, Sweden and the UK.

Keywords: education, physical education, exemption from the lesson

\section{Wstęp}

W literaturze przedmiotu wychowaniu fizycznemu przypisuje się różne znaczenia: od pojęcia aktywnego wspólistnienia z przyrodą, przez szeroko rozumianą kulturę fizyczną, aż do zamierzonych i świadomych działań ukierunkowanych na kształtowanie trwałych postaw związanych z aktywnością fizyczną i troską o zdrowie własnego organizmu1. Współcześnie cele wychowania fizycznego łączą w sobie wszystkie te znaczenia ujęte jako wspieranie rozwoju społecznego,

1 Encyklopedia pedagogiczna XXI wieku, t. VII, Wydawnictwo Akademickie „Żak”, Warszawa 2008, s. 363-364. 
fizycznego oraz poznawczego w połączeniu z dbałością o świadomy i zdrowy tryb życia².

W państwach europejskich w szkolnictwie obowiązkowym wychowanie fizyczne jest przedmiotem obowiązkowym ${ }^{3}$. W programach nauczania na poziomie szkoły podstawowej (ISCED 1) i szkoły średniej I stopnia (ISCED 2) najczęściej wskazywanym głównym celem wychowania fizycznego jest fizyczny, indywidualny i społeczny rozwój dziecka.

\section{Obowiązkowe treści wychowania fizycznego}

W Polsce zgodnie z podstawą programową ${ }^{4}$ na każdym etapie edukacji celem wychowania fizycznego (WF) jest kształtowanie nawyku aktywności fizycznej. Zakłada się, że na lekcjach wychowania fizycznego należy rozwijać zainteresowania i postawy uczniów oraz wspomagać budowanie pozytywnego obrazu własnej osoby jako uczestnika aktywności fizycznej o charakterze rekreacyjnym, sportowym bądź turystycznym. Konkretne rozwiązania w różnych szkołach mogą przybierać odmienną postać, w zależności od dotychczasowych doświadczeń szkół i nauczycieli oraz w zależności od lokalnych warunków kształcenia. Zaleca się, aby zajęcia były prowadzone w sali sportowej, w specjalnie przygotowanym pomieszczeniu zastępczym lub na boisku szkolnym bądź w środowisku naturalnym. Podstawa programowa zaleca również, aby uczniowie w czasie zajęć wychowania fizycznego pełnili różnorakie role, w tym inicjatora i organizatora ćwiczeń, zabaw i gier ruchowych, zawodnika, sędziego i kibica. Decyzję o zakresie wyboru charakteru zajęć podejmuje dyrektor szkoły w porozumieniu z nauczycielami, uczniami i rodzicami.

W większości krajów europejskich programy wychowania fizycznego dla pierwszych klas szkoły podstawowej zawierają wykazy podstawowych ćwiczeń

2 R.R. Pate, R.C. Hohn, Summary. Health-related physical education - A direction for the $21^{\text {st }}$ Century, [in:] R.R. Pate, R.C. Hohn, (eds) Health and Fitness through Physical Education, Champaign, Illinois, Human Kinetics 1994, s. 215-217.

3 Opracowanie przygotowano na podstawie ekspertyzy Biura Analiz Sejmowych nr 1343/15 z 9 wrzesnia 2015 r. D. Dziewulaka zatytułowanej Informacja na temat zwalniania uczniów z lekcji wychowania fizycznego $w$ szkołach $w$ wybranych krajach Europy oraz opracowania tegoż autora Zwalnianie uczniów z lekcji wychowania fizycznego $w$ szkołach w Polsce i wybranych krajach Europy, „Analizy BAS” 2015, nr 12(132), s. 1-8.

4 Rozporządzenie Ministra Edukacji Narodowej z 27 sierpnia 2012 r. w sprawie podstawy programowej wychowania przedszkolnego oraz kształcenia ogólnego w poszczególnych typach szkół, Dz.U. poz. 977, http://isap.sejm.gov.pl/DetailsServlet?i d=WDU20120000977. 
motorycznych, takich jak marsz, bieg, skoki i rzuty. Poziom trudności ćwiczeń wzrasta wraz z wiekiem uczniów - stopniowo w miejsce podstawowych umiejętności wprowadza się inne bardziej skomplikowane realizowane najczęściej w ramach gier zespołowych. Równie popularne są: lekkoatletyka, taniec, gimnastyka, fitness (lub inne prozdrowotne), pływanie oraz sporty zimowe. W niektórych państwach uzupełnieniem WF jest promocja zdrowego stylu życia realizowana poprzez odrębny obowiązkowy przedmiot edukacja zdrowotna (Cypr, Finlandia, Irlandia). Widoczne jest też podejście interdyscyplinarne. Przykładowo w Czechach, Niemczech i w Norwegii w ramach zajęć wychowania fizycznego uczniowie poznają zasady ruchu drogowego. W krajach skandynawskich uczą się korzystać z mapy i poznają podstawowe zasady orientacji w terenie. W Czechach i Grecji zwraca się szczególną uwagę na przekazywanie w trakcie zajęć sportowych wiedzy o wartościach i symbolach olimpijskich. W Słowenii nauczyciele innych przedmiotów mają możliwość przerywania lekcji na tzw. minutę dla zdrowia, w trakcie której uczniowie wykonują proste ćwiczenia gimnastyczne i się relaksująa

\section{Liczba godzin wychowania fizycznego w programach szkolnych}

W Polsce zgodnie z rozporządzeniem w sprawie ramowych planów nauczania w szkołach publicznych liczba godzin wychowania fizycznego w klasach I-III wynosi razem 290 godzin, czyli dla klas I-III szkół podstawowych wynosi 96 godzin w roku szkolnym ${ }^{6}$, dla klas IV-VI szkół podstawowych i klas gimnazjalnych wynosi 128 godzin w roku szkolnym, a w szkołach ponadgimnazjalnych 96 godzin w roku szkolnym? ${ }^{7}$.

W europejskich systemach szkolnych liczba godzin wychowania fizycznego jest zależna od wieku uczniów, szczebla edukacji, typu szkoły i sposobu organizacji pracy placówek oświatowych. Niektóre kraje wyznaczają minimalną liczbę godzin zajęć wychowania fizycznego na poziomie centralnym, inne natomiast pozostawiają decyzję o liczbie godzin kierownictwu placówek. Przykładowo w roku szkolnym 2011/2012 minimalna liczba godzin wychowania fizycznego na

5 http://eacea.ec.europa.eu/Education/eurydice/documents/thematic_reports/150PL_HI.pdf.

6 Rozporządzenie Ministra Edukacji Narodowej z 7 lutego 2012 r. w sprawie ramowych planów nauczania w szkołach publicznych, Dz.U. poz. 204, http://isap.sejm.gov.pl/DetailsServlet?id=WDU20120000204.

7 Artykuł13a ust. 2 ustawy z 7 września 1991 r. o systemie oświaty, Dz.U. 2004, nr 256, poz. 2572, ze zm., http://isap.sejm.gov.pl/DetailsServlet?id=WDU20042562572\&min=1. 
poziomie ISCED 1 (szkoła podstawowa) w ciągu roku wynosiła w Irlandii 37 godzin, a we Francji 108 godzin (w Polsce 128 godzin). Na poziomie ISCED 2 (szkoła średnia I stopnia) w Hiszpanii, na Malcie i w Turcji liczba ta oscylowała w przedziale od 24 do 35 godzin w roku szkolnym, a we Francji i Austrii od 102 do 108 godzin w roku szkolnym ${ }^{8}$ (w Polsce 96 godzin).

\section{Liczba uczniów w grupie na lekcjach wychowania fizycznego}

W Polsce zgodnie z rozporządzeniem w sprawie ramowych planów nauczania w szkołach publicznych w klasach IV-VI szkoły podstawowej obowiązkowe lekcje WF mogą być prowadzone w grupie oddziałowej, międzyoddziałowej lub międzyklasowej, a w wypadku zespołu szkół - także w grupie międzyszkolnej, liczącej nie więcej niż 26 uczniów. Jeżeli w skład grupy wchodzą uczniowie niepełnosprawni uczęszczający do oddziałów integracyjnych lub uczniowie oddziałów specjalnych, liczba uczniów w grupie nie może być większa niż liczba uczniów odpowiednio w oddziale integracyjnym lub specjalnym określona w przepisach w sprawie ramowych statutów szkół publicznych. Zajęcia wychowania fizycznego, w zależności od realizowanej formy tych zajęć, mogą być prowadzone łącznie albo oddzielnie dla dziewcząt i chłopców9 .

W krajach europejskich zagadnienie liczebności uczniów w grupie na lekcji WF - podobnie jak w przypadku liczby godzin wychowania fizycznego - jest zależna od wieku uczniów, szczebla edukacji, typu szkoły i sposobu organizacji pracy placówek oświatowych. W niektórych krajach, np. w Austrii, Bułgarii, Chorwacji, na Cyprze, w Czechach, Liechtensteinie, Luksemburgu, Niemczech, Portugalii, Rumunii, Turcji, we Włoszech ${ }^{10}$, przepisy określają minimalną lub maksymalną albo wskazują jednocześnie minimalną i maksymalną liczebność

8 Źródło: raport Wychowanie fizyczne i sport w szkołach w Europie, Eurydice 2014, http:// eurydice.org.pl/wp-content/uploads/2014/12/PE_PL.pdf.

9 Rozporządzenia Ministra Edukacji Narodowej z 7 lutego 2012 r. w sprawie ramowych planów nauczania w szkołach publicznych, Dz.U. poz. 204, http://isap.sejm.gov. pl/DetailsServlet?id=WDU20120000204, oraz Rozporządzenie Ministra Edukacji Narodowej z 21 maja 2001 r. w sprawie ramowych statutów publicznych placówek oraz publicznych szkół , Dz.U. nr 61, poz. 624, ze zm., http://isap.sejm.gov.pl/DetailsServlet?id=WDU20010610624.

10 We Włoszech na wszystkich poziomach edukacji obowiązkowej liczba uczniów w klasie może wynosić maksymalnie 32. W szkole podstawowej decyzję o liczbie uczniów biorących udział w zajęciach wychowania fizycznego oraz o podziale na grupy dziewczęta - chłopcy podejmuje nauczyciel. 
klasy. W innych krajach decyzja o liczbie godzin pozostawiona została kierownictwu placówek. Przykładowo we Francji, w Holandii, Islandii ${ }^{11}$, na Łotwie, Mal$\mathrm{cie}^{12}$, w Szwecji ${ }^{13}$, Wielkiej Brytanii ${ }^{14}$ na poziomie szkolnictwa podstawowego nie ma regulacji prawnych określających liczebność grup podczas zajęć wychowania fizycznego. Szkoły mogą same decydować o programie i charakterze zajęć. Lekcje WF prowadzone są w grupach koedukacyjnych.

\section{Ocenianie uczniów na lekcjach wychowania fizycznego}

W Polsce, zgodnie z rozporządzeniem w sprawie szczegółowych warunków i sposobu oceniania, klasyfikowania i promowania uczniów i słuchaczy w szkołach publicznych ${ }^{15}$, ocenianie osiągnięć edukacyjnych i zachowania ucznia odbywa się w ramach oceniania wewnątrzszkolnego. Szczegółowe warunki i sposób oceniania wewnątrzszkolnego określa statut szkoły, z uwzględnieniem przepisów rozporządzenia. Nauczyciele na początku każdego roku szkolnego informują uczniów oraz ich rodziców o wymaganiach edukacyjnych niezbędnych do uzyskania poszczególnych śródrocznych i rocznych ocen klasyfikacyjnych, sposobach sprawdzania osiągnięć edukacyjnych uczniów, warunkach i trybie uzyskania wyższej niż przewidywana rocznej (semestralnej) oceny klasyfika-

11 W Islandii jedynym wyjątkiem są lekcje pływania, gdzie ze względów bezpieczeństwa grupa może liczyć maksymalnie 15 uczniów.

12 W wyniku porozumienia między Związkiem Nauczycieli a rządem Malty przyjmuje się, że szkoły nie powinny przekraczać liczebności powyżej 30 uczniów w klasie.

13 W szwedzkich szkołach podstawowych klasa liczy średnio 18-19 uczniów.

14 W Wielkiej Brytanii nie ma ustawowych limitów dotyczących liczebności klas w szkołach podstawowych, choć przyjęto praktykę, że klasa nie powinna liczyć więcej niż 30 uczniów. Całkowita odpowiedzialność za prawidłowe i bezpieczne przeprowadzenie zajęć wychowania fizycznego spoczywa na placówce szkolnej i nauczycielach. Szkoły decydują o programie wychowania fizycznego i jego organizacji, a także o tym, czy chłopcy i dziewczęta powinni uczyć się razem czy osobno. Krajowy Związek Nauczycieli (National Union of Teachers, NUT) opublikował wytyczne dla nauczycieli dotyczące zachowania środków bezpieczeństwa na lekcjach. W zakresie wychowania fizycznego dokument przypomina, że nauczyciel przygotowujący się do prowadzenia lekcji wychowania fizycznego powinien zwrócić uwagę na ryzyko wystąpienia zagrożeń, a w szczególności ocenić: charakter zajęć, miejsce zajęć (pomieszczenie zamknięte, teren), wiek, doświadczenie, dojrzałość, kompetencje oraz cechy motoryczne i emocjonalne uczniów.

15 Rozporządzenie Ministra Edukacji Narodowej z 10 czerwca 2015 r. w sprawie szczegółowych warunków i sposobu oceniania, klasyfikowania i promowania uczniów i słuchaczy w szkołach publicznych, Dz.U. poz. 843, http://isap.sejm.gov.pl/DetailsServlet?id=WDU2015 0000843. 
cyjnej. Ustalając ocenę z wychowania fizycznego, w szczególności bierze się pod uwagę wysiłek wkładany przez ucznia w wywiązywanie się z obowiązków wynikających ze specyfiki tych zajęć. Wychowanie fizyczne, podobnie jak inne przedmioty, oceniane jest zgodnie z przyjętymi zasadami na poszczególnych poziomach edukacyjnych. Stopnie z WF w skali 1-6 wystawiane są od IV klasy szkoły podstawowej.

Wśród krajów europejskich tylko w Irlandii, Norwegii i na Malcie uczniowie nie są oceniani z przedmiotu wychowania fizycznego. W szkolnictwie większości krajów europejskich stosuje się formalną ocenę z WF. Ocena może mieć charakter formatywny, czyli jakościowy i opisowy (np. Cypr, Hiszpania, Słowenia) lub sumatywny, czyli wyrażaną liczbowo lub literowo i przyznawaną po wykonaniu określonych zadań w danym okresie (np. Austria, Grecja, Niemcy). Ponadto w kilku państwach stopnie z wychowania fizycznego wystawiane są tylko od określonego poziomu edukacyjnego i wieku ucznia. Na Węgrzech stopnie z WF mogą być wystawiane od trzeciej klasy, w Grecji - są wystawiane od trzeciej klasy, na Łotwie i w Słowenii - od czwartej, w Portugalii - od piątej, w Szwecji - od szóstej. W niektórych krajach stosuje się skalę ocen z przeznaczeniem dla określonych dyscyplin sportowych nauczanych w ramach szkolnego programu WF (np. pchnięcie kulą, szermierka, narciarstwo). Przykładowo w Islandii taką dyscypliną jest pływanie. W okresie szkoły obowiązkowej pływanie oceniane jest pod koniec każdego roku w formie testu, w trakcie którego uczniowie muszą wykazać się oczekiwanymi umiejętnościami.

\section{Zwalnianie z lekcji wychowania fizycznego}

Poniżej przedstawiono syntetyczne informacje na temat zwalniania uczniów z lekcji wychowania fizycznego w szkołach w Polsce, we Francji, w Grecji, Hiszpanii, Irlandii, Islandii, na Łotwie, Malcie, w Niemczech, na Słowacji, w Słowenii, Szwecji i Wielkiej Brytanii ${ }^{16}$.

16 W opracowaniu wykorzystano materiały uzyskane za pośrednictwem Fundacji Rozwoju Systemu Edukacji (FRSE), Sieci Informacji o Edukacji w Europie (Eurydice), publikacji Agencji Wykonawczej Edukacji, Kultury i Sektora Audiowizualnego Komisji Europejskiej (EACEA), Międzynarodowego Biura Oświaty UNESCO oraz informacji dostępnych na stronach internetowych ministerstw oświaty oraz instytucji i organizacji zajmujących się zagadnieniem wychowania fizycznego w państwach europejskich. Dane statystyczne zaczerpnięto z raportu Wychowanie fizyczne i sport $w$ szkołach $w$ Europie, Eurydice 2014. 


\section{Polska}

W Polsce, zgodnie zobowiązującymi przepisami oraz zgodnie z informacją zawartą na stronie Ministerstwa Edukacji Narodowej ${ }^{17}$, z zajęć wychowania fizycznego może zwolnić ucznia jedynie dyrektor szkoły. Nie ma podstaw prawnych do zwalniania z zajęć wychowania fizycznego na podstawie dokumentu wystawionego przez rodziców (opiekunów prawnych) lub samego ucznia ${ }^{18}$. Nie ma również podstaw do zwolnienia z zajęć wychowania fizycznego z powodu braku stroju gimnastycznego.

Zasady zwalniania uczniów z zajęć WF zostały uregulowane w rozporządzeniu w sprawie szczegółowych warunków i sposobu oceniania, klasyfikowania i promowania uczniów i słuchaczy w szkołach publicznych ${ }^{19}$. Jest to rozporządzenie obowiązujące od 1 września roku szkolnego 2015/2016.

Od 1 września roku szkolnego 2015/2016 przepisy przewidują dwa rozwiązania. Pierwsze rozwiązanie - zgodnie z $§ 5$ ust. 1 rozporządzenia - polegające na tym, że dyrektor szkoły może zwolnić ucznia z wykonywania określonych ćwiczeń fizycznych na zajęciach wychowania fizycznego (takie rozwiązanie nie było stosowane do 1 września 2015 r.) na podstawie opinii lekarza o ograniczonych możliwościach wykonywania przez ucznia ćwiczeń ze wskazaniem, jakich ćwiczeń fizycznych - czy też - jakiego rodzaju ćwiczeń - uczeń nie może wykonywać, oraz przez jaki okres. W tym przypadku uczeń uczestniczy w zajęciach wychowania fizycznego z ograniczeniem wykonywania niektórych, wskazanych przez lekarza ćwiczeń fizycznych. Uczeń ten jest oceniany i klasyfikowany. Natomiast nauczyciel wychowania fizycznego ma obowiązek dostosować wymagania edukacyjne do indywidualnych potrzeb i możliwości ucznia. Drugie rozwiązanie - zgodnie z $\S 5$ ust. 2 rozporządzenia - polegające na tym, że dyrektor szkoły może całkowicie zwolnić ucznia z realizacji zajęć wychowania fizycznego (takie rozwiązanie było stosowane do 1 września 2015 r.) na podstawie opinii lekarza o braku możliwości uczestniczenia ucznia w zajęciach wychowania fizycznego,

17 MEN, Zwalnianie uczniów z zajęć wychowania fizycznego, https://men.gov.pl/zycie-szkoly/ abc-wychowania-fizycznego/8-zwalnianie-uczniow-z-zajec-wychowania-fizycznego.html.

W polskim systemie edukacyjnym obowiązują ogólne normy związane z zasadą zindywidualizowanego podejścia do uczniów oraz zasadą współpracy szkoły i nauczyciela z rodzicami. Stąd w niektórych przypadkach nauczyciele respektują zwolnienia od rodziców. czy w szkołach publicznych, Dz.U. poz. 843, http://isap.sejm.gov.pl/DetailsServlet?id=WDU20150000843. 
przez okres wskazany w tej opinii. W tym przypadku uczeń nie uczęszcza na zajęcia WF i przez okres zwolnienia nie jest z nich oceniany. Jeżeli okres zwolnienia z realizacji zajęć wychowania fizycznego uniemożliwia ustalenie śródrocznej, rocznej lub semestralnej oceny klasyfikacyjnej, uczeń nie podlega klasyfikacji, natomiast w dokumentacji przebiegu nauczania wpisuje się „Zwolniony” albo „Zwolniona”.

\section{Francja}

We Francji wychowanie fizyczne i sportowe (éducation physique et sportive) jest przedmiotem obowiązkowym w programach wszystkich szkół na poziomach ISCED 1-3. Liczba godzin wychowania fizycznego jako przedmiotu obowiązkowego w programie pierwszych dziesięciu lat szkoły obowiązkowej wynosi 1080 godzin $^{20}$. W szkołach podstawowych i średnich jednorazowe zwolnienie z zajęć WF mogą wystawić rodzice, a w sytuacji zwolnienia długoterminowego - konieczne jest zwolnienie od lekarza. Sposób zwalniania uczniów z aktywności fizycznej i/lub zajęć wychowania fizycznego i sportowego regulowany jest dekretem o nadzorze medycznym dotyczącym niezdolności do uczestnictwa w zajęciach wychowania fizycznego i sportowego w placówkach edukacyjnych ${ }^{21}$. Zgodnie $\mathrm{z}$ art. 1 dekretu uczniowie zgłaszający niezdolność do uczestnictwa w zajęciach WF muszą przedstawić odpowiednie zaświadczenie lekarskie (certificat médical) z określonym przez lekarza rodzajem tej niezdolności (np. całkowita, częściowa). W przypadku niezdolności częściowej zaświadczenie powinno zawierać niezbędne wskazówki dla nauczyciela dotyczące indywidualnego podejścia do ucznia w ramach realizacji zajęć wychowania fizycznego i sportowego. Zaświadczenie powinno być wydane przez lekarza szkolnego lub rodzinnego na formularzu zawartym w rozporządzeniu Ministerstwa Edukacji, Młodzieży i Sportu

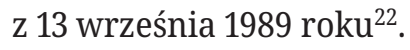

20 Dane dotyczące liczby godzin wychowania fizycznego w szkolnictwie państw prezentowanych w tym artykule zaczerpnięto z raportu Wychowanie fizyczne $i$ sport $w$ szkołach $w$ Europie, Eurydice 2014, s. 67, http://eurydice.org.pl/wp-content/uploads/2014/12/PE_PL.pdf.

21 Décret n88-977 du 11 octobre 1988 relatif au contrôle médical des inaptitudes à la pratique de l'éducation physique et sportive dans les établissements d'enseignement, http://www. legifrance.gouv.fr/affichTexte.do?cidTexte=LEGITEXT000006066952.

22 Arrêté du 13 septembre 1989, Contrôle médical des inaptitudes à la pratique de l'éducation physique et sportive dans les établissements d'enseignement, https://www.legifrance.gouv. fr/affichTexte.do?cidTexte=JORFTEXT000000840437\&dateTexte=20160715. 
Lekarz szkolny lub rodzinny, wystawiając zaświadczenie o niezdolności do uczestnictwa w lekcjach WF (Certificat médical d'inaptitude partielle à la pratique de l'éducation physique et sportive) ${ }^{23}$, potwierdza taką niezdolność. Na tej podstawie, zgodnie z dekretem o nadzorze medycznym (nr 88-977), decyzję o zwolnieniu ucznia z zajęć WF podejmuje nauczyciel i/lub dyrektor szkoły.

\section{Grecja}

W Grecji wychowanie fizyczne jest przedmiotem obowiązkowym w programach szkół na poziomach ISCED 1-3. Liczba godzin wychowania fizycznego jako przedmiotu obowiązkowego w programie szkoły obowiązkowej wynosi 502 godziny. Zwalnianie uczniów z lekcji WF opiera się na systemie zwolnień lekarskich udo-

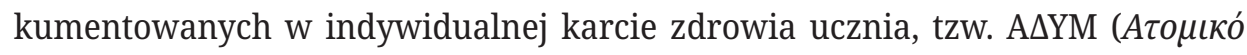

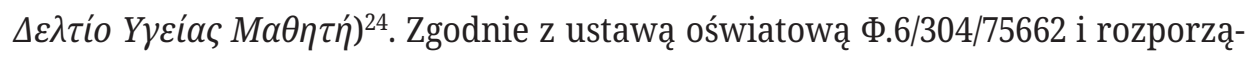
dzeniem ministra edukacji nr 1296 B z 21 maja 2014 r. ${ }^{25}$, indywidualna karta zdrowia ucznia jest obowiązkowym dokumentem warunkującym zapisanie dziecka do przedszkola, szkoły podstawowej i średniej. Kartę A $\Delta \mathrm{YM}$ wystawia instytucja oświatowa, która jako pierwsza przyjmuje dziecko do placówki przedszkolnej lub szkolnej. Przy zmianie szkoły indywidualna karta zdrowia ucznia przekazywana jest do nowej placówki. Karta A $\Delta \mathrm{YM}$ stanowi potwierdzenie przyjęcia dziecka do placówki oświatowej oraz potwierdzenie odbycia okresowego badania kardiologicznego, stomatologicznego i okulistycznego. Ma także charakter zaświadczenia lekarskiego o braku przeciwwskazań do uczestnictwa w zajęciach lekcyjnych, w tym także w lekcjach wychowania fizycznego ${ }^{26}$.

W wypadku krótkotrwałej lub dłuższej choroby ucznia konieczne jest zwolnienie lekarskie, które dokumentowane jest w karcie A $\Delta \mathrm{YM}$. Zapis taki stanowi podstawę do częściowego lub całkowitego zwolnienia ucznia z zajęć. Decyzję $\mathrm{w}$ tej sprawie podejmuje nauczyciel WF. W przypadku poważniejszych przeciw-

23 Certificat médical d'inaptitude partielle à la pratique de l'éducation physique et sportive, http://www.sante.gouv.fr/img/pdf/certific_inaptitude_physique.pdf.

24 http://www.moh.gov.gr/articles/health/dieythynsh-prwtobathmias-frontidas-ygeias/programmata-p-f-y-draseis-tmhma-g/2463-atomiko-deltio-ygeias-mathhth.

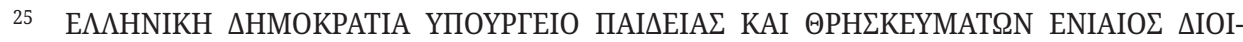

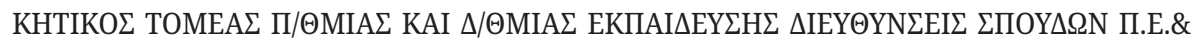

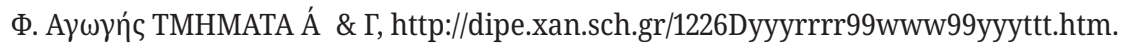

26 Zgodnie z postanowieniami art. 122 „równoważności świadectw zdrowia” ustawy 2071/1992 o modernizacji i organizacji systemu ochrony zdrowia (ФЕК 123 น.Á /15.7.1992), http://www.elinyae.gr/el/item_details.jsp?item_id=2736\&cat_id=686. 
wskazań zdrowotnych wpisanych przez lekarza do indywidualnej karty zdrowia ucznia decyzję o częściowym lub całkowitym zwolnieniu z lekcji WF podejmuje trzyosobowa komisja złożona z dyrektora szkoły, nauczyciela wychowania fizycznego i nauczyciela-wychowawcy.

\section{Hiszpania}

W Hiszpanii wychowanie fizyczne i sportowe (educación física) jest przedmiotem obowiązkowym w programach wszystkich szkół na poziomach ISCED 1-3. Liczba godzin wychowania fizycznego jako przedmiotu obowiązkowego w programie pierwszych dziesięciu lat szkoły obowiązkowej wynosi 458 godzin. Ważnym elementem hiszpańskiego systemu edukacji jest integracja realizowana w taki sposób, aby każdy uczeń mógł uczestniczyć w dowolnie wybranym przez siebie przedmiocie. Zwolnienie z przedmiotu (i to bez względu na nauczaną dziedzinę) traktowane jest jako ostateczność. Stąd wszyscy uczniowie, którzy są obecni w szkole, uczestniczą w lekcjach wychowania fizycznego na ogólnie przyjętych warunkach. W sytuacjach związanych z chorobą lub wywołanych inną tymczasową niezdolnością do wykonywania ćwiczeń nauczyciel indywidualizuje program, tak aby działalność ucznia była dostosowana do jego możliwości i realizowana bez uszczerbku na zdrowiu. Takie podejście umożliwia uczniowi bezpiecznie podejmowanie wyznaczonej aktywności - począwszy od zmniejszenia obciążeń treningowych aż do realizacji zadań organizacyjno-porządkowych (np. mierzenie czasu, sędziowanie, analiza taktyki gry, zgłaszanie składu drużyny na zawody itp.).

Większość przepisów określających procedury zwalniania z ćwiczeń fizycznych dotyczy przede wszystkim uczniów uprawiających wyczynowo sport lub uczniów ze szkół mistrzostwa sportowego. Sposób zwalniania uczniów z aktywności fizycznej i/lub zajęć wychowania fizycznego i sportowego regulowany jest dekretem ustanawiającym uznawanie przedmiotów między szkolnictwem zawodowym muzycznym i sportowym a szkolnictwem ogólnokształcącym gimnazjalnym i licealnym, jak również skutki, jakie w zakresie wychowania fizycznego ma mieć status sportowca wyczynowego ${ }^{27}$. Zgodnie z przepisami zwolnienie z lekcji wychowania fizycznego (całkowite lub częściowe) odbywa się na podstawie za-

27 Real Decreto 242/2009, de 27 de febrero, por el que se establecen convalidaciones entre las enseñanzas profesionales de Música y de Danza y la Educación secundaria obligatoria y el Bachillerato, así como los efectos que sobre la materia de Educación física deben tener la condición de deportista de alto nivel o alto rendimiento y las enseñanzas profesionales de Danza, http://www.boe.es/boe/dias/2009/02/28/pdfs/BOE-A-2009-3424.pdf. 
świadczenia lekarskiego. Zaświadczenie powinno być wydane przez lekarza na formularzu określonym przez władze wspólnot autonomicznych (Comunidades Autónomas ${ }^{28}$. Decyzję o zwolnieniu podejmuje dyrektor szkoły.

\section{Irlandia}

W Irlandii wychowanie fizyczne (physical education) jest przedmiotem obowiązkowym w programach wszystkich szkół objętych obowiązkiem szkolnym na poziomach ISCED 1-329. Zalecana liczba godzin wychowania fizycznego jako przedmiotu obowiązkowego w programie pierwszych dziesięciu lat szkoły obowiązkowej wynosi 402 godziny. Specyfiką systemu oświatowego Irlandii jest pozostawienie placówkom szkolnym dużej autonomii w sprawach sposobu realizacji programów nauczania. Przepisy oświatowe nie regulują spraw związanych ze zwolnieniami uczniów z lekcji WF, gdyż decyzja o takim zwolnieniu pozostawiona jest w gestii szkoły. Najczęściej w przypadku drobnej niedyspozycji lub krótkiej choroby ucznia, jego rodzice lub opiekunowie powinni przedstawić prośbę o tymczasowe zwolnienie z całych zajęć lub z ich części. W sytuacji dłuższej nieobecności spowodowanej poważniejszą chorobą lub niepełnosprawnością rodzice powinni dostarczyć zaświadczenie lekarskie określające przewidywany czas trwania choroby oraz katalog aktywności fizycznych, których chory uczeń nie powinien wykonywać. Lekarzy nie obowiązuje żaden specjalny formularz przeznaczony dla zwolnień z WF.

Decyzję o częściowym lub całkowitym zwolnieniu ucznia z uczestnictwa $\mathrm{w}$ lekcji wychowania fizycznego podejmuje nauczyciel przedmiotu. W przypadku częściowego zwolnienia, nauczyciel w porozumieniu z rodzicami, zachowując zasady dyskrecji, ustala optymalny alternatywny program angażujący ucznia w lekcje WF (np. sędziowanie, wyszukanie informacji o zasadach gier).

\section{Islandia}

W Islandii obowiązek szkolny trwa 10 lat i objęci są nim uczniowie w wieku od 6 do 16 roku życia. Przedmiot sport i wychowanie fizyczne (Ípróttir - líkams- og heilsurcekt) jest obowiązkowy dla wszystkich uczniów podlegających obowiązkowi szkolnemu. Zalecana liczba godzin wychowania fizycznego jako przedmio-

28 http://www.larioja.org/bor0/IMG/Bor/2009/2009ib15201.gif.

29 http://www.curriculumonline.ie/Primary/Curriculum-Areas/Physical-Education. 
tu obowiązkowego w programie pierwszych dziesięciu lat szkoły obowiązkowej wynosi 650 godzin.

Zgodnie z ustawą o obowiązku szkolnym ${ }^{30}$, przepisami dotyczącymi realizacji programu nauczania w szkolnictwie obowiązkowym ${ }^{31}$ i średnim ${ }^{32}$ oraz wytycznymi zawartymi w przewodniku dla szkolnictwa obowiązkowego zatytułowanym Islandzki Narodowy Program Nauczania ${ }^{33}$, zwolnienie ucznia z każdego obowiązkowego przedmiotu (w tym także z lekcji WF) powinno odbywać się według określonej procedury. Rodzice lub prawni opiekunowie dziecka, chcąc zwolnić ucznia z zajęć lekcyjnych, muszą w tej sprawie przedstawić odpowiedni pisemny wniosek. Dokument powinien zawierać wyjaśnienie przyczyn wniosku wraz z odpowiednią argumentacją. W zależności od okoliczności wszelkie wyjaśnienia i argumenty mogą pochodzić od rodziców, nauczycieli, lekarzy lub innych specjalistów. Lekarzy nie obowiązuje żaden specjalny formularz przeznaczony dla zwolnień z WF. Wniosek powinien zostać podpisany przez rodziców i ucznia. Dokument składa się u dyrektora szkoły, który po konsultacjach z nauczycielem-wychowawcą ma obowiązek pisemnie odpowiedzieć wnioskodawcom. Generalnie stosuje się zasadę, aby nie zwalniać uczniów z całego przedmiotu tylko indywidualizować program, biorąc pod uwagę wszystkie potrzeby i uwarunkowania. Przykładowo uczeń, który jako sportowiec wyczynowy uzyskał wyjątkowe osiągnięcia w pływaniu i w składanym wniosku klub sportowy potwierdzi ten fakt, może zostać zwolniony ze szkolnych zajęć pływackich, ale nie z wychowania fizycznego w ogóle.

W przypadku drobnej niedyspozycji ucznia rodzice lub opiekunowie zobowiązani są do przedstawienia pisemnej prośby o zwolnienie z zajęć WF. Decyzję o częściowym lub całkowitym zwolnieniu ucznia z uczestnictwa w lekcji wychowania fizycznego podejmuje dyrektor szkoły.

\section{Łotwa}

Zgodnie z łotewskim prawem oświatowym, szkoły posiadają pełną autonomię $\mathrm{w}$ realizacji programu edukacyjnego. Zalecana liczba godzin wychowania fizycz-

30 The Compulsory School Act No. 91, 12 June 2008, http://eng.menntamalaraduneyti.is/media/ MRN-pdf_Annad/Compulsory_school_Act.pdf.

31 http://www.menntamalaraduneyti.is/utgefid-efni/namskrar/adalnamskra-grunnskola/.

32 http://www.menntamalaraduneyti.is/utgefid-efni/namskrar/adalnamskra-framhaldsskola/.

33 The Icelandic National Curriculum. Guide for Compulsory Schools, http://eng.menntamalaraduneyti.is/publications/curriculum/. 
nego jako przedmiotu obowiązkowego w programie kształcenia obowiązkowego wynosi 413 godzin. Każda szkoła ustala własny sposób postępowania w sprawie zwolnień z lekcji wychowania fizycznego. Jednakże powszechnie przyjętą praktyką jest zwalnianie ucznia z zajęć WF na podstawie zaświadczenia lekarskiego. Lekarzy nie obowiązuje żaden specjalny formularz przeznaczony dla zwolnień z WF. Korzystają oni ze standardowych formularzy dokumentacji lekarskiej. Przy krótkotrwałej niedyspozycji ucznia akceptowane są także zwolnienia od rodziców.

Najczęściej decyzję o zwolnieniu ucznia z lekcji wychowania fizycznego podejmuje nauczyciel WF lub dyrektor szkoły.

\section{Malta}

Na Malcie wychowanie fizyczne jest przedmiotem obowiązkowym w programach wszystkich szkół realizujących jedenastoletni obowiązek szkolny (5-16 rok życia). Zalecana liczba godzin wychowania fizycznego jako przedmiotu obowiązkowego w programie szkoły obowiązkowej wynosi 512 godzin. W szkołach podstawowych i średnich jednorazowe zwolnienie z zajęć WF wystawiają rodzice, a w sytuacji zwolnienia długoterminowego - szkoły oczekują przedstawienia zwolnienia lekarskiego. Rodziców i lekarzy nie obowiązuje żaden specjalny formularz przeznaczony dla wypisania wniosku o zwolnienie ucznia z zajęć wychowania fizycznego.

Sposób zwalniania uczniów z lekcji wychowania fizycznego nie jest regulowany przepisami. Decyzję o zwolnieniu uczniów z aktywności fizycznej i/lub zajęć WF podejmuje nauczyciel wychowania fizycznego (zwolnienie krótkoterminowe) lub dyrektor szkoły (zwolnienie długoterminowe).

\section{Niemcy}

W Niemczech zakres odpowiedzialności za system edukacji wynika z federalnej struktury państwa. Zgodnie z konstytucją zadania rządu federalnego w dziedzinie edukacji obejmują m.in. ustanawianie przepisów wyznaczających ogólne ramy współpracy oświatowej między szczeblem federalnym i landami, np. w zakresie planowania edukacji i promowania badań. Za ustawodawstwo i administrację oświatową odpowiadają przede wszystkim kraje związkowe - landy, w których działają ministerstwa edukacji, kultury i nauki oraz struktury nadzorujące szkoły na niższym szczeblu (Schulamt). Taki podział odpowiedzialności dotyczy w szczególności struktury systemu szkolnego oraz programów i metod nauczania. 
W Niemczech wychowanie fizyczne (Bewegungsunterricht) jest przedmiotem obowiązkowym w programach wszystkich szkół na poziomach ISCED 1-3. Zalecana liczba godzin wychowania fizycznego jako przedmiotu obowiązkowego w programie pierwszych dziesięciu lat szkoły obowiązkowej wynosi 647 godzin.

Sposób zwolnienia ucznia z zajęć lekcyjnych i/lub zajęć WF regulują rozporządzenia ministerstw edukacji poszczególnych landów. Najczęściej stosowaną praktyką jest możliwość złożenia przez rodziców wniosku o zwolnienie ucznia jednorazowo na krótki okres oraz wniosek rodziców o zwolnienie długoterminowe z załączonym zaświadczeniem od lekarza. Decyzję o zwolnieniu krótkoterminowym podejmuje nauczyciel wychowania fizycznego w porozumieniu z wychowawcą klasy, decyzję o zwolnieniu długoterminowym podejmuje dyrektor szkoły.

Przykładowo zgodnie z rozporządzeniem Ministra Kultury i Edukacji Nadrenii Północnej-Westfalii ${ }^{34}$ zwolnienia zdrowotne z zajęć wychowania fizycznego powinny być rozpatrywane przez dyrektorów szkół i nauczycieli indywidualnie ze wskazaniem alternatywnych zajęć WF. Zwolnienie z lekcji wychowania fizycznego (całkowite lub częściowe) odbywa się na podstawie określonego przepisami zaświadczenia lekarskiego w sprawie uczestnictwa w sporcie szkolnym (Ärztliche Bescheinigung für die Teilnahme am Schulsport $)^{35}$. Zaświadczenie powinno być wydane przez lekarza na formularzu, którego wzór znajduje się w załączniku do rozporządzenia 12-52 nr 32 z 1988 r., określonym w porozumieniu między Ministerstwem Edukacji i Ministerstwem Pracy, Zdrowia i Spraw Socjalnych.

\section{Słowacja}

Na Słowacji wychowanie fizyczne (telesná výchova) jest przedmiotem obowiązkowym w programach wszystkich szkół na poziomach ISCED 1-3. Zalecana liczba godzin wychowania fizycznego jako przedmiotu obowiązkowego w programie pierwszych dziesięciu lat szkoły obowiązkowej wynosi 560 godzin.

Zgodnie z ustawą oświatową nr 245/200836 uczeń może być zwolniony z zajęć wychowania fizycznego na wniosek rodziców lub lekarza. W przypadku krótkiej niedyspozycji lub choroby to rodzice mogą wnioskować o zwolnienie ucznia

34 12-52 Nr. 32 Freistellung im Schulsport RdErl (GABl. NW. 1989 S. 38), http://www.schulsport-nrw.de/fileadmin/user_upload/schulsportentwicklung/pdf/12_-_52_Nr_32.pdf.

35 http://www.schulsport-nrw.de/fileadmin/user_upload/schulsportentwicklung/ pdf/12_52nr32_freistellung_anlage.pdf.

36 Zákon z 22. mája 2008 o výchove a vzdelávaní(školský zákon) a o zmene a doplneníniektorých zákonov (245/2008), https://www.slov-lex.sk/pravne-predpisy/SK/ZZ/2008/245/20150401. 
z każdego przedmiotu. Wniosek o dłuższe zwolnienie z zajęć, w tym także z zajęć WF, musi być wydane przez lekarza. W obu przypadkach konieczne jest skorzystanie ze specjalnego formularza, na którym rodzice lub lekarz pisemnie wnioskują o zwolnienie ucznia z zajęć.

Decyzję o częściowym lub całkowitym zwolnieniu ucznia z uczestnictwa w lekcji wychowania fizycznego podejmuje dyrektor szkoły. Uczeń może być zwolniony z zajęć wychowania fizycznego na pewien okres lub na cały rok szkolny.

\section{Słowenia}

W Słowenii wychowanie fizyczne (športna vzgoja) jest przedmiotem obowiązkowym ${ }^{37} \mathrm{w}$ programach wszystkich szkół na poziomach ISCED 1-3. Zalecana liczba godzin wychowania fizycznego jako przedmiotu obowiązkowego $\mathrm{w}$ programie szkoły obowiązkowej wynosi 797 godzin.

Zgodnie z ustawą szkolną nr 12/96 ${ }^{38}$, uczeń z powodu problemów zdrowotnych i na podstawie zaświadczenia lekarskiego może być zwolniony w całości lub częściowo z udziału w określonych formach zajęć szkolnych. Lekarzy nie obowiązuje żaden specjalny formularz przeznaczony dla zwolnień z WF.

Decyzję o zwolnieniu podejmuje dyrektor szkoły w trybie określonym przepisami postępowania administracyjnego. Uczniowie, którzy są zwolnieni częściowo z WF, mają obowiązek uczestniczenia w lekcji, zgodnie z programem zaleconym przez lekarza i dostosowanym przez nauczyciela wychowania fizycznego do warunków szkolnych.

\section{Szwecja}

W Szwecji wychowanie fizyczne (idrott) jest przedmiotem obowiązkowym dla wszystkich szkół na poziomach ISCED 1-3. Zalecana liczba godzin wychowania fizycznego jako przedmiotu obowiązkowego w programie szkoły obowiązkowej wynosi 500 godzin. Szwedzki system edukacji jest zdecentralizowany, a odpowiedzialność za jego funkcjonowanie spoczywa na jednostkach administracji lokalnej. Wiele szczegółowych spraw z obszaru organizacji pracy szkoły - w tym także zwolnienia z lekcji WF pozostają więc w gestii dyrekcji szkoły.

37 http://www.mizs.gov.si/fileadmin/mizs.gov.si/pageuploads/podrocje/os/prenovljeni_UN/ UN_sportna_vzgoja.pdf.

38 Zakon o osnovni šoli - ZOsn (Uradni list RS, št. 12/96 z dne 29. 2. 1996), https://www.uradni-list.si/1/content?id=74775. 
Tabela 20. Warunki zwolnienia uczniów z wychowania fizycznego w szkołach podstawowych (ISCED 1) i średnich I stopnia (ISCED 2) w wybranych państwach członkowskich Unii Europejskiej

\begin{tabular}{|c|c|c|c|}
\hline Państwo & Zwolnienie lekarskie & $\begin{array}{l}\text { Zwolnienie lekarskie } \\
\text { lub od rodziców }\end{array}$ & $\begin{array}{l}\text { Zwolnienie jednorazowe } \\
\text { od rodziców oraz } \\
\text { długoterminowe } \\
\text { zwolnienie od lekarza }\end{array}$ \\
\hline Austria & & & $x$ \\
\hline Belgia & & & $\times$ \\
\hline Bułgaria & & & $x$ \\
\hline Chorwacja & & & $x$ \\
\hline Cypr & & & $x$ \\
\hline Czechy & & & $x$ \\
\hline Dania & & $x$ & \\
\hline Estonia & & & $x$ \\
\hline Finlandia & & $x$ & \\
\hline Francja & & & $x$ \\
\hline Grecja & $x$ & & \\
\hline Hiszpania & $x$ & & \\
\hline Holandia & & & $x$ \\
\hline Irlandia & & & $x$ \\
\hline Islandia & & & $x$ \\
\hline Litwa & & & $x$ \\
\hline Łotwa & & & $x$ \\
\hline Malta & & & $x$ \\
\hline Niemcy & & & $\times$ \\
\hline Norwegia & $x$ & & \\
\hline Polska & $x$ & & \\
\hline Portugalia & & & $x$ \\
\hline Rumunia & & & $x$ \\
\hline Słowacja & & & $x$ \\
\hline Słowenia & & & $x$ \\
\hline Szwecja & & $x$ & \\
\hline Turcja & $x$ & & \\
\hline Węgry & & $x$ & \\
\hline Włochy & & & $\times$ \\
\hline Wielka Brytania & & & $x$ \\
\hline
\end{tabular}

Źródło: Opracowanie własne na podstawie raportu Wychowanie fizyczne i sport w szkołach w Europie, Eurydice 2014, http://eurydice.org.pl/wp-content/uploads/2014/12/PE_PL.pdf. 
Zgodnie ze szwedzką ustawą oświatową ${ }^{39}$, zwolnienie ucznia z części lub całego obowiązkowego przedmiotu szkolnego powinno odbywać się na podstawie wniosku rodziców lub opiekunów. Przy dłuższej nieobecności zaświadczenie o chorobie może wydać lekarz. Lekarzy nie obowiązuje żaden specjalny formularz przeznaczony dla zwolnień z WF.

W przypadku niedyspozycji ucznia lub choroby, która pozwala na uczęszczanie do szkoły, powszechnie stosowaną zasadą jest uczestnictwo chorego ucznia w alternatywnym programie WF. Decyzję o zwolnieniu ucznia z przedmiotu lub jego części podejmuje dyrektor szkoły.

\section{Wielka Brytania (Anglia)}

Struktura organizacyjna oświaty Wielkiej Brytanii nie jest jednolita. W Anglii, Walii, Szkocji i Irlandii Północnej występują różne typy szkół, różne programy nauczania i odmienny system pracy szkolnej. W Anglii wychowanie fizyczne (physical education) jest przedmiotem obowiązkowym dla uczniów w wieku od 5 do 16 roku życia, a określenie liczby godzin WF pozostaje w gestii szkoły. Szkoły mają ustawowy obowiązek wspierania rozwoju umysłowego, duchowego, moralnego, kulturowego oraz fizycznego uczniów. Przepisy oświatowe nie regulują spraw związanych ze zwolnieniami uczniów z lekcji WF, gdyż decyzja o takim zwolnieniu pozostawiona jest w gestii szkoły.

W angielskich szkołach z powodu krótkiej choroby lub urazu najczęściej stosowaną praktyką jest możliwość zwolnienia ucznia z lekcji wychowania fizycznego przez rodziców, którzy mają obowiązek przygotować w tej sprawie odpowiednią pisemną informację (a signed note). W razie dłuższej nieobecności wymagane jest zaświadczenie lekarskie o częściowej lub całkowitej niezdolności do uczestniczenia w lekcjach wychowania fizycznego. Lekarzy nie obowiązuje żaden specjalny formularz przeznaczony dla zwolnień z WF. Decyzję o zwolnieniu ucznia z uczestnictwa w lekcji wychowania fizycznego podejmuje nauczyciel przedmiotu.

\section{Podsumowanie}

Egzekwowanie uczestnictwa w lekcjach wychowania fizycznego w systemach oświatowych w dużej mierze zależy od specyfiki, tradycji, zwyczaju i organizacji

39 Skollag (2010:800), http://www.riksdagen.se/sv/Dokument-Lagar/Lagar/Svenskforfattningssamling/Skollag-2010800_sfs-2010-800/. 
szkolnictwa w poszczególnych krajach. Jednak najczęściej stosowanym rozwiązaniem jest możliwość jednorazowego zwalniania ucznia z lekcji WF przez rodziców, a w wypadku zwolnienia długoterminowego konieczność dostarczenia zwolnienia od lekarza. Takie rozwiązanie stosuje się m.in. w szkolnictwie Francji, Irlandii, Islandii, Litwy, Łotwy, Malty, Niemiec, Słowacji, Słowenii, Wielkiej Brytanii. Uzasadnienie nieobecności ucznia wyłącznie na podstawie zwolnienia lekarskiego stosuje się m.in. w Grecji, Hiszpanii, Norwegii i Polsce. W Danii, Finlandii, Szwecji i na Węgrzech szkoły same mogą decydować, czy będą akceptować pisemne zwolnienia od rodziców, czy też wymagać zwolnień lekarskich. Lekarskie zaświadczenia o zwolnieniu z zajęć WF wydawane są na specjalnym formularzu we Francji, w Grecji, Hiszpanii, Niemczech i na Słowacji. Lekarzy nie obowiązuje żaden specjalny formularz przeznaczony dla zwolnień z wychowania fizycznego w Irlandii, Islandii, na Łotwie, Malcie, w Słowenii, Szwecji i Wielkiej Brytanii (Anglii).

Charakter zwolnień także jest zróżnicowany. Zwolnienie może być czasowe lub długoterminowe, częściowe lub pełne, w zależności od tego, czy uczniowie mogą podejmować przynajmniej część aktywności. Jeżeli uczniowie są zwolnieni z uczestnictwa w zajęciach wychowania fizycznego ze względu na kontuzję lub chorobę, zwykle oczekuje się, że będą podejmować inną działalność w ramach przedmiotu. W przypadku częściowego zwolnienia uczeń może być zaangażowany w aktywność fizyczną, która jest dla niego bezpieczna mimo kontuzji lub choroby. W innych sytuacjach uczeń może wykonywać zadania teoretyczne lub niezwiązane z wysiłkiem fizycznym, takie jak napisanie raportu na dany temat, sędziowanie, kibicowanie lub liczenie punktacji. Takie rozwiązanie daje uczniom z jednej strony możliwość uczestnictwa w lekcji, a z drugiej - zniechęca do całkowitego unikania zajęć WF.

\section{Bibliografia}

Encyklopedia pedagogiczna XXI wieku, t. VII, Wydawnictwo Akademickie „Żak”, Warszawa 2008.

Pate R.R., Hohn R.C., Summary. Health-related physical education - A direction for the $21{ }^{\text {st }}$ Century, [in:] Pate R.R., Hohn R.C. (eds) Health and Fitness through Physical Education, Champaign, Illinois, Human Kinetics 1994.

Raport: Wychowanie fizyczne i sport w szkołach w Europie, Eurydice 2014, http://eurydice. org.pl/wp-content/uploads/2014/12/PE_PL.pdf.

The Icelandic National Curriculum. Guide for Compulsory Schools, http://eng.menntamalaraduneyti.is/publications/curriculum/ 


\section{Akty prawne}

Ustawa z 7 września 1991 r. o systemie oświaty, Dz.U. 2004, nr 256, poz. 2572, ze zm., http:// isap.sejm.gov.pl/DetailsServlet?id=WDU20042562572\&min=1.

Rozporządzenie Ministra Edukacji Narodowej z 7 lutego 2012 r. w sprawie ramowych planów nauczania w szkołach publicznych, Dz.U. poz. 204, http://isap.sejm.gov.pl/DetailsServlet?id=WDU20120000204.

Rozporządzenie Ministra Edukacji Narodowej z 21 maja 2001 r. w sprawie ramowych statutów publicznych placówek oraz publicznych szkół, Dz.U. nr 61, poz. 624, ze zm., http://isap.sejm.gov.pl/DetailsServlet?id=WDU20010610624.

Rozporządzenie Ministra Edukacji Narodowej z 10 czerwca 2015 r. w sprawie szczegółowych warunków i sposobu oceniania, klasyfikowania i promowania uczniów i słuchaczy w szkołach publicznych, Dz.U. poz. 843, http://isap.sejm.gov.pl/DetailsServlet?id=WDU20150000843.

Décret n88-977 du 11 octobre 1988 relatif au contrôle médical des inaptitudes à la pratique de l'éducation physique et sportive dans les établissements d'enseignement, http:// www.legifrance.gouv.fr/affichTexte.do?cidTexte=LEGITEXT000006066952.

Arrêté du 13 septembre 1989, Contrôle médical des inaptitudes à la pratique de l'éducation physique et sportive dans les établissements d'enseignement, https://www.legifrance. gouv.fr/affichTexte.do?cidTexte=JORFTEXT000000840437\&dateTexte=20160715.

Real Decreto 242/2009, de 27 de febrero, por el que se establecen convalidaciones entre las enseñanzas profesionales de Música y de Danza y la Educación secundaria obligatoria y el Bachillerato, así como los efectos que sobre la materia de Educación física deben tener la condición de deportista de alto nivel o alto rendimiento y las enseñanzas profesionales de Danza, http://www.boe.es/boe/dias/2009/02/28/pdfs/BOE-A-2009-3424.pdf.

The Compulsory School Act No. 91, 12 June 2008, http://eng.menntamalaraduneyti.is/media/MRN-pdf_Annad/Compulsory_school_Act.pdf.

12-52 Nr. 32 Freistellung im Schulsport RdErl (GABl. NW. 1989 S. 38), http://www.schulsport-nrw.de/fileadmin/user_upload/schulsportentwicklung/pdf/12_-_52_Nr_32.pdf.

Zákon z 22. mája 2008 o výchove a vzdelávaní (školský zákon) a 0 zmene a doplnení niektorých zákonov (245/2008); https://www.slov-lex.sk/pravne-predpisy/SK/ ZZ/2008/245/20150401, http://www.mizs.gov.si/fileadmin/mizs.gov.si/pageuploads/podrocje/os/prenovljeni_UN/UN_sportna_vzgoja.pdf.

Zakon o osnovni šoli - ZOsn (Uradni list RS, št. 12/96 z dne 29. 2. 1996), https://www.uradni-list.si/1/content?id=74775.

Skollag (2010:800), http://www.riksdagen.se/sv/Dokument-Lagar/Lagar/Svenskforfattningssamling/Skollag-2010800_sfs-2010-800/. 


\section{Strony internetowe}

http://eacea.ec.europa.eu/Education/eurydice/documents/thematic_reports/150PL_HI.pdf. http://eurydice.org.pl/wp-content/uploads/2014/12/PE_PL.pdf.

http://www.moh.gov.gr/articles/health/dieythynsh-prwtobathmias-frontidas-ygeias/programmata-p-f-y-draseis-tmhma-g/2463-atomiko-deltio-ygeias-mathhth. http://dipe.xan.sch.gr/1226Dyyyrrrr99www99yyyttt.htm.

http://www.curriculumonline.ie/Primary/Curriculum-Areas/Physical-Education.

http://www.menntamalaraduneyti.is/utgefid-efni/namskrar/adalnamskra-grunnskola/. http://www.menntamalaraduneyti.is/utgefid-efni/namskrar/adalnamskra-framhaldsskola/. http://www.schulsport-nrw.de/fileadmin/user_upload/schulsportentwicklung/ pdf/12_52nr32_freistellung_anlage.pdf. 


\title{
3.4. Dni wolne od zajęć szkolnych dla uczniów działających w sferze publicznej w wybranych państwach Unii Europejskiej
}

\author{
Additional days free from school activities for students \\ working in the public sphere in selected European Union \\ countries
}

\begin{abstract}
W opracowaniu podjęto próbę porównawczej prezentacji przepisów gwarantujących określoną liczbę dodatkowych dni wolnych od zajęć szkolnych dla uczniów działających w sferze publicznej w wybranych państwach Unii Europejskiej (Austria, Czechy, Finlandia, Łotwa, Niemcy, Portugalia, Szwecja, Wielka Brytania). Analizie poddano przepisy i regulaminy placówek szkolnych oraz zawarte w nich katalogi przypadków umożliwiających zwolnienie ucznia z lekcji.
\end{abstract}

Słowa kluczowe: szkoła, szkolnictwo, uczeń, zwolnienie z lekcji szkolnej, dni wolne, uczeń, Austria, Czechy, Finlandia, Łotwa, Niemcy, Portugalia, Szwecja, Wielka Brytania

The paper attempts a comparative presentation of provisions guaranteeing a certain number of additional days off from school activities for students operating in the public sphere in selected European Union countries (Austria, the Czech Republic, Finland, Latvia, Germany, Portugal, Sweden, the United Kingdom). The analysis covered the regulations and regulations of school facilities as well as the catalogs of cases contained in them enabling the student to be discharged from the lesson.

Keywords: school, education, student, exemption from school lesson, days off, Austria, Czech Republic, Finland, Latvia, Germany, Portugal, Sweden, United Kingdom

\section{Wstęp}

W prezentowanych w niniejszym opracowaniu ${ }^{1}$ ośmiu państwach Unii Europejskiej nie istnieją oddzielne przepisy, które gwarantowałyby określoną liczbę dodatkowych dni wolnych od zajęć szkolnych dla uczniów działających w sferze publicznej. W większości przypadków zagadnienie zwalniania ucznia z zajęć

1 Opracowanie przygotowano na podstawie ekspertyzy Biura Analiz Sejmowych nr 576/10 z 1 czerwca 2010 r. D. Dziewulaka zatytułowanej Informacja nt. przepisów gwarantujących określoną liczbę dodatkowych dni wolnych od zajęć szkolnych dla uczniów działających $w$ sferze publicznej w wybranych państwach Unii Europejskiej (Austria, Czechy, Finlandia, Łotwa, Niemcy, Portugalia, Szwecja, Wielka Brytania). 
szkolnych normuje regulamin placówki szkolnej, a ostateczną decyzję w tej sprawie podejmuje wychowawca lub dyrektor szkoły. Jednakże, jak wskazuje przegląd przepisów w poszczególnych krajach, prawie zawsze kierownik placówki ma możliwość zwolnienia ucznia z lekcji z ważnych powodów. Tak więc katalog przypadków umożliwiających zwolnienie, nawet jeśli jest ograniczony, jest dość elastyczny.

\section{Austria}

W Austrii nie ma ustawowych regulacji gwarantujących określoną liczbę dodatkowych dni wolnych od zajęć szkolnych dla uczniów działających w sferze publicznej². Przyjmuje się, że nieobecność w szkole powinna być usprawiedliwiona i może wynikać z choroby, uczestnictwa w świętach religijnych, wydarzeniach sportowych, edukacyjnych i kulturalnych (gdy uczeń reprezentuje szkołę). Inne pozaszkolne obowiązki i obciążenia czasowe ucznia, jeżeli kolidują z zajęciami szkolnymi, powinny być realizowane poza godzinami lekcyjnymi lub w czasie ferii lub wakacji.

\section{Czechy}

W Republice Czeskiej nie ma ustawowych regulacji gwarantujących określoną liczbę dodatkowych dni wolnych od zajęć dla uczniów działających w sferze publicznej, gdyż sprawy te pozostają w gestii szkół i regulowane są ich wewnętrznymi regulaminami ${ }^{3}$. W wypadku nieobecności ucznia w szkole jego absencja usprawiedliwiana jest przez rodziców lub prawnych opiekunów. Uczniowie pełnoletni sami zobowiązani są do uzasadniania swojej nieobecności na zajęciach szkolnych.

\section{Finlandia}

W Finlandii nie ma regulacji gwarantujących określoną liczbę dodatkowych dni wolnych od zajęć szkolnych uczniom działającym w sferze publicznej lub w obszarze wolontariatu. W przypadku zbiorowego uczestnictwa uczniów w konkretnej akcji na rzecz środowiska naturalnego, pomocy humanitarnej itp. decyzję

2 http://www.bmukk.gv.at/schulen/recht/gvo/schug.xml.

3 http://www.msmt.cz/dokumenty/skolsky-zakon. 
w sprawie zwolnienia lub odwołania zajęć szkolnych każdorazowo podejmuje dyrektor szkoły.

\section{Łotwa}

$\mathrm{Na}$ Łotwie nie ma regulacji prawnych, które gwarantowałyby uczniom dni wolne od nauki z przeznaczeniem na działalność społeczną lub publiczną. Ministerstwo Edukacji i Nauki jedynie zaleca szkołom możliwość wykorzystania w ciągu roku szkolnego do pięciu dni zajęć szkolnych z przeznaczeniem na potrzeby realizacji wycieczek edukacyjnych, uczestnictwa w olimpiadach, szkolnych wydarzeniach sportowych i innych wydarzeniach związanych z procesem kształcenia i wychowania. Decyzja w sprawie przyznania uczniowi dodatkowych dni wolnych od zajęć, np. na działalność w sferze publicznej, należy wyłącznie do szkoły.

\section{Niemcy}

W Niemczech nie ma jednolitych federalnych regulacji gwarantujących uczniom określoną liczbę dodatkowych dni wolnych od zajęć szkolnych. Wszelkie kwestie dotyczące funkcjonowania szkolnictwa pozostają w gestii ministerstw oświaty krajów związkowych. Zazwyczaj przyjmowana jest zasada, że w zależności od potrzeb i zaistniałej sytuacji wychowawca klasy może rocznie przyznać uczniowi dodatkowo trzy dni wolne od zajęć szkolnych, a dyrektor może wyrazić zgodę na zwolnienie ucznia z zajęć na okres maksymalnie czterech tygodni w roku (np. w związku z uczestnictwem ucznia w międzynarodowej wymianie szkolnej).

Najbardziej szczegółowe uregulowania dotyczące dni wolnych od zajęć znajdują się w przepisach szkolnych Nadrenii Północnej-Westfalii. W wytycznych właściwego ministerstwa zawartych w Dzienniku Urzędowym 12-52, nr 21, 31 i 32 z 26 marca 1980 r. znalazły się szczegółowe kategorie i wykazy okoliczności uprawniających do urlopowania lub zwolnienia uczniów z zajęć szkolnych. Są wśród nich m.in. wydarzenia religijne, śmierć w rodzinie, praktyki zawodowe, udział w konkursach przedmiotowych, zawodach sportowych oraz w kursach edukacyjnych organizowanych przez partie polityczne. Uczniowie ze szkół niepodlegających obowiązkowi szkolnemu mogą uzyskać zgodę na roczne urlopowanie od zajęć szkolnych po przedstawieniu odpowiedniej dokumentacji zaświadczającej m.in. ich:

- uczestnictwo w ochotniczym wolontariacie ekologicznym,

- dłuższy pobyt za granicą,

- dłuższe leczenie (np. sanatoryjne). 
Innymi przyczynami udzielenia dni wolnych od szkoły (z reguły nie więcej niż 7 dni w roku szkolnym) są:

- przyczyny osobiste (zmiana miejsca zamieszkania, jubileusze w rodzinie itp.),

- przyczyny religijne (kalendarz praktyk religijnych określonego wyznania itp.),

- wydarzenia sportowe (zgrupowania, uczestnictwo w zawodach itp.),

- uczestnictwo w programie wymiany młodzieży (zebrania, spotkania itp.),

- udział w posiedzeniach Rady Szkoły.

\section{Portugalia}

W Portugalii nie ma regulacji prawnych, które gwarantowałyby uczniom dni wolne od nauki w zamian za działalność w sektorze publicznym. Działalność w sferze publicznej może być prowadzona przez młodzież wyłącznie poza obowiązkowymi godzinami lekcyjnymi.

Dodatkowe dni wolne od zajęć szkolnych przysługują uczniom ze szkół sportowych i artystycznych, lecz są to dni przeznaczone na przykład na zgrupowania sportowe, zawody lub koncerty, plenery, wernisaże itp.

\section{Szwecja}

W szwedzkim szkolnictwie uczniom działającym w sferze publicznej nie przysługują z tego tytułu żadne dodatkowe dni wolne od nauki. Wyjątkiem jest piastowanie w Radzie Uczniowskiej funkcji przedstawiciela ds. bezpieczeństwa (uczeń realizujący zadania z szeroko pojętego obszaru BHP). Uczeń pełniący tę funkcję ma prawo do czasowej nieobecności na zajęciach szkolnych w momencie wykonywania swoich zadań ${ }^{4}$.

Uczniowie objęci obowiązkiem szkolnym są ustawowo zobligowani do przebywania w placówce edukacyjnej. Absencja ucznia w szkole może być usprawiedliwiona zwolnieniem lekarskim, a w innych ważnych przypadkach nieobecność ucznia w szkole wymaga zgody dyrektora placówki. Dyrektor ma prawo wydać zgodę na 10 dni nieobecności ucznia w roku szkolnym, a w sytuacjach wyjątkowych, gdy zachodzą ku temu niezwykle ważne powody, na dłuższy okres.

Uczniowie pobierający naukę na szczeblu nauczania, na którym nie obowiązuje obowiązek szkolny, gdy ich absencja na zajęciach przekroczy jeden miesiąc mogą być skreśleni z listy uczniów.

$4 \quad$ http://www.skolverket.se. 


\section{Wielka Brytania (Anglia) ${ }^{5}$}

W angielskim szkolnictwie nie ma szczegółowych regulacji prawnych dotyczących udzielania uczniom wolnych dni od nauki z powodu aktywności i działalności dla potrzeb sfery publicznej.

Zagadnienie wdrożenia młodzieży do aktywności publicznej realizowane jest w szkołach w ramach aktywnego obywatelstwa, zgodnie z tzw. programem promowania spójności społecznej (Guidance on the duty to promote community cohesion $^{6}$ ). Program ten może być realizowany przez zaangażowanie się uczniów na przykład w wolontariat lub w inną dowolną działalność odpowiadającą i zgodną z potrzebami społeczności lokalnej, tak aby nie była to działalność antyspołeczna i nie pociągała za sobą utrwalania nagannego zachowania ${ }^{7}$. Program realizowany jest z pomocą szkoły, w ramach obowiązkowych godzin lekcyjnych lub poza lekcjami, czyli w czasie wolnym ucznia. Program nie ogranicza edukacji aktywnego obywatelstwa tylko do osoby ucznia i obszaru szkoły, lecz włącza w prospołeczną aktywność także rodziców. Szczegółowe informacje na temat programów obywatelskich znalazły się w następujących dokumentach:

- Współpraca: Wsłuchiwanie się w głos dzieci i młodzieży [Working together: Listening to the voices of children and young people (DCSF 2008)] ${ }^{8}$,

- Dlaczego ważne jest promowanie aktywnych postaw obywatelskich i wolontariatu? [Extended schools: Why promoting active citizenship and volunteering by pupils is important? (Teachernet 2010) $]^{9}$.

W systemie szkolnym Anglii zgodę na nieobecność ucznia podczas lekcji może wyrazić wychowawca lub dyrektor szkoły, m.in. z ważnych powodów osobistych, rodzinnych, zdrowotnych, udziału w zawodach sportowych, międzyszkolnych konkursach wiedzy. Katalog okoliczności uprawniających do nieobecności umieszczony jest najczęściej w regulaminach poszczególnych szkół, uzgadnianych w drodze porozumień między radą nauczycielską, radą rodziców i uczniowskim ciałem przedstawicielskim.

5 Struktura organizacyjna systemu szkolnego Wielkiej Brytanii nie jest jednolita. Ustroje szkolne Anglii i Walii są relatywnie podobne, natomiast systemy szkolne Szkocji i Irlandii Północnej regulowane są odrębnymi ustawami. Zob. też D. Dziewulak, Systemy szkolne państw Unii Europejskiej, Wydawnictwio Akademickie „Żak”, Warszawa 1997.

6 http://www.teachernet.gov.uk/docbank/index.cfm?id=11635.

7 http://www.dcsf.gov.uk/everychildmatters/about/.

8 http://publications.teachernet.gov.uk/eOrderingDownload/DCSF-00410-2008.pdf.

9 http://www.teachernet.gov.uk/docbank/index.cfm?id=9728. 


\section{Bibliografia}

Dziewulak D., Systemy szkolne państw Unii Europejskiej, Wydawnictwo Akademickie „Żak”, Warszawa 1997.

\section{Strony internetowe}

http://www.bmukk.gv.at/schulen/recht/gvo/schug.xml.

http://www.msmt.cz/dokumenty/skolsky-zakon.

http://www.skolverket.se.

http://www.teachernet.gov.uk/docbank/index.cfm?id=11635.

http://www.dcsf.gov.uk/everychildmatters/about/.

http://publications.teachernet.gov.uk/eOrderingDownload/DCSF-00410-2008.pdf.

http://www.teachernet.gov.uk/docbank/index.cfm?id=9728. 


\title{
3.5. Ulgowe przejazdy dla uczniów i studentów w wybranych państwach członkowskich Unii Europejskiej
}

\author{
Reduced travel fares for students in selected \\ European Union members states
}

W opracowaniu przedstawiono problematykę ulgowych przejazdów środkami publicznego transportu zbiorowego dla dzieci, studentów i innych osób uprawnionych w wybranych państwach Unii Europejskiej. Analizie poddano zasady, jakie ustalają wybrane państwa Unii Europejskiej, aby uzyskać przywileje do ulgowych przejazdów.

Słowa kluczowe: uczniowie, studenci, transport publiczny, komunikacja, ulgi komunikacyjne, Czechy, Finlandia, Francja, Portugalia, Szwecja, Węgry, Włochy

The paper attempts the problem of reduced travels by means of public transport for children, students and other persons entitled in selected European Union countries. The analysis of the principles set by selected European Union countries to obtain privileges for concessionary journeys.

Keywords: pupils, students, public transport, transport, transport concessions, Czech Republic, Finland, France, Portugal, Sweden, Hungary, Italy

\section{Wstęp}

W państwach Unii Europejskiej nie ma jednolitego systemu ulg ani w komunikacji miejskiej, ani międzymiastowej ${ }^{1}$. Państwa członkowskie ustalają własne zasady w tym zakresie, przyznając przywileje według własnych potrzeb i kryteriów m.in. dla studentów, uczniów, kombatantów. Zasady dotyczące szczególnych uprawnień do przejazdów środkami publicznego transportu zbiorowego nie są też regulowane przez prawo europejskie. Prawo europejskie reguluje jedynie kwestię rekompensat dla przewoźników realizujących usługi służby publicznej

1 Opracowanie przygotowano na podstawie ekspertyzy Biura Analiz Sejmowych nr 252/10 z 26 lutego 2010 r. autorstwa D. Dziewulaka, D. Łukasz, M. Mroza, Ł. Żołądka na temat rozwiązań w krajach Unii Europejskiej dotyczących szczególnych uprawnień do przejazdów środkami publicznego transportu zbiorowego (Czechy, Finlandia, Francja, Portugalia, Szwecja, Węgry, Włochy). 
m.in. zniżki dla określonych grup² ${ }^{2}$ Uprawnienia do ulgowych przejazdów środkami transportu zbiorowego dla poszczególnych grup społecznych w krajach europejskich regulowane są przez prawo każdego z krajów członkowskich. Często decyzje o wysokości zniżki należnej na przykład studentom i uczniom podejmowane są w formie aktów prawa lokalnego stanowionego przez uprawnione do tego władze lokalne. Wysokość zniżek przyznawanych określonym grupom społecznym jest zróżnicowana, choć większość ulg w państwach UE przeznaczonych jest dla dzieci, młodzieży, osób w podeszłym wieku i wynosi około 50\%. Różne są też kategorie osób, którym przysługują na przykład przejazdy bezpłatne.

\section{Czechy}

Taryfy obowiązujące w środkach publicznego transportu zbiorowego odzwierciedlają zasady polityki realizowanej przez państwo (określone w ustawach i aktach wykonawczych) oraz przewoźników. Opłaty za przejazdy środkami tego transportu są objęte systemem cen regulowanych.

Występują tu dwie podstawowe kategorie:

- Ceny maksymalne ustalane przez Ministerstwo Finansów - obowiązują $\mathrm{w}$ środkach krajowego publicznego transportu kolejowego, realizowanego wyłącznie z wykorzystaniem ogólnokrajowych i regionalnych sieci publicznego transportu kolejowego,

- Ceny maksymalne ustalane przez województwa i gminy zgodnie z ustawą 265/1991 o uprawnieniach organów Republiki Czeskiej w zakresie cen (ze zm.) $)^{3}$ obowiązują w:

- środkach publicznego zbiorowego pasażerskiego regularnego transportu samochodowego i krajowego kolejowego pasażerskiego realizowanego w ramach usług transportu zintegrowanego,

- środkach publicznego zbiorowego transportu miejskiego oraz transportu podmiejskiego realizowanego w ramach zbiorowego transportu miejskiego.

2 Sprawę tę reguluje rozporządzenie 1370/2007 Parlamentu Europejskiego i Rady z 23 października 2007 r. dotyczące usług publicznych w zakresie kolejowego i drogowego transportu pasażerskiego. Przepisy określają warunki, na podstawie których właściwe organy, nakładając zobowiązania do świadczenia usług publicznych lub zawierając umowy dotyczące wykonywania tych zobowiązań, rekompensują poniesione koszty podmiotom świadczącym usługi publiczne.

3 Województwa i gminy stosują ceny maksymalne oraz ustalają ich wysokość w drodze zarządzenia (nařízení) przy spełnieniu warunków określonych w § 1 ust. 6 ustawy nr 526/1990 Sb. o cenach, w brzmieniu ustawy nr 141/2001 Sb. 
Zgodnie z $\$ 10$ ustawy nr 526/1990 o cenach (ze zm.) Ministerstwo Finansów publikuje wykaz towarów i usług objętych cenami regulowanymi, obowiązującymi wszystkich sprzedających i nabywców w Republice Czeskiej. W wykazie tym określone są m.in. zasady ustalania wysokości opłaty za przejazd środkami publicznego transportu zbiorowego oraz stosowania ulg wprowadzonych przez państwo.

Rozporządzenie Ministerstwa Finansów nr 01/2010 z 8 grudnia 2009 r. w sprawie wykazu towarów objętych cenami regulowanymi określa następujące uprawnienia do przejazdów środkami publicznego transportu zbiorowego":

- Środki publicznego zbiorowego transportu miejskiego oraz transportu podmiejskiego realizowanego $\mathrm{w}$ ramach zbiorowego transportu miejskiego

- prawo do bezpłatnych przejazdów przysługuje:

- dzieciom do lat 6,

- przedstawicielom organów władzy państwowej i innych organów państwowych oraz sędziom na podstawie przepisów ustawy o wynagrodzeniu i innych świadczeniach przysługujących przedstawicielom władzy państwowej i innym osobom ${ }^{5}$,

- inwalidom grup II i I (posiadaczom legitymacji inwalidzkiej ZTP i ZTP/P) wraz z przewodnikiem oraz psem przewodnikiem ${ }^{6}$ ),

- prawo do przejazdów ulgowych za opłatą w wysokości nie większej niż połowa normalnej opłaty za bilet okresowy imienny o ważności co najmniej 1 miesiąca na terenie miasta przysługuje:

- dzieciom od 6 do 15 lat,

- uczniom szkół podstawowych i średnich według ustawy szkolnej ${ }^{7}$ oraz studentom według ustawy o szkołach wyższych ${ }^{8}$ spełniających wymogi określone w § 11, 12, 13 a 14 ustawy o pomocy społecznej, z wyjątkiem studentów stale pracujących zarobkowo zgodnie z $§ 10$ tej ustawy 9 .

4 Tekst rozporządzenia jest dostępny na stronie internetowej czeskiego Ministerstwa Finansów, http://www.mfcr.cz/cps/rde/xbcr/mfcr/CenovyVestnik_13_2009_pdf.pdf.

5 Zákon č. 236/1995 Sb., o platu a dalších náležitostech spojených s výkonem funkce představitelů státní moci a některých státních orgánů a soudců, ve znění pozdějších předpisů.

6 Przepis wprowadzający ustawę o zabezpieczeniu społecznym i inne ustawy (Vyhláška č. 182/1991 Sb., kterou se provádí zákon o sociálním zabezpečení a zákon České národní rady o působnosti orgánů České republiky v sociálním zabezpečení, ve znění pozdějších předpisů).

7 Zákon č. 561/2004 Sb., o předškolním, základním, středním, vyšším odborném a jiném vzdělávání (školský zákon), ve znění pozdějších předpisů.

8 Zákon č.111/1998 Sb., o vysokých školách a o změně a doplnění dalších zákonů (zákon o vysokých školách), ve znění pozdějších předpisů.

9 Zákon č. 117/1995 Sb., o státní sociální podpoře, ve znění pozdějších předpisů. 
- Środki transportu zintegrowanego

- prawo do bezpłatnych przejazdów przysługuje:

- dzieciom do lat 6 (pasażer w wieku ponad 10 lat z ważnym biletem ma prawo do bezpłatnego przewozu dwojga dzieci w wieku do 6 lat),

- przedstawicielom organów władzy państwowej i innych organów państwowych oraz sędziom na podstawie przepisów ustawy o wynagrodzeniu i innych świadczeniach przysługujących przedstawicielom władzy państwowej i innym osobom ${ }^{10}$,

- przewodnikom inwalidów grupy I (posiadaczom legitymacji inwalidzkiej ZTP/P) oraz psom przewodnikom ${ }^{11}$,

- prawo do przejazdów ulgowych za opłatą w wysokości 50\% normalnej opłaty za przejazd pobieranej przez przewoźnika przysługuje:

- dzieciom od lat 6 do ukończenia 15 roku,

- rodzicom lub opiekunom dzieci upośledzonych umieszczonych w zakładzie lub uczęszczających do szkół specjalnych,

- prawo do przejazdów ulgowych za opłatą w wysokości nie wyższej niż 37,5\% normalnej opłaty za przejazd przysługuje uczniom w wieku do lat 15. Uprawnienie to nie obowiązuje w środkach miejskiego transportu publicznego. $\mathrm{Na}$ trasach objętych systemem transportu zintegrowanego rozpoczynających się (lub kończących się) na terenie miasta i wychodzących poza jego granice, uprawnienie to obowiązuje na obszarze miasta do momentu przesiadki do środka miejskiego transportu publicznego,

- prawo do przejazdów ulgowych za opłatą w wysokości nie wyższej niż 75\% normalnej opłaty za przejazd przysługuje uczniom i studentom w ramach studiów dziennych i zaocznych w wieku od lat 15 do 26. Uprawnienie to nie obowiązuje w środkach miejskiego transportu publicznego. Na trasach objętych systemem transportu zintegrowanego rozpoczynających lub kończących się na terenie miast i wychodzących poza jego granice, uprawnienie to obowiązuje również na obszarze miasta do miejsca przesiadki do środka miejskiego transportu publicznego,

10 Zákon č. 236/1995 Sb., o platu a dalších náležitostech spojených s výkonem funkce představitelů státní moci a některých státních orgánů a soudců, ve znění pozdějších předpisů.

11 Przepis wprowadzający ustawę o zabezpieczeniu społecznym i inne ustawy (Vyhláška č. 182/1991 Sb., kterou se provádí zákon o sociálním zabezpečení a zákon České národní rady o působnosti orgánů České republiky v sociálním zabezpečení, ve znění pozdějších předpisů). 
- prawo do przejazdów ulgowych za opłatą w wysokości nie wyższej niż 25\% normalnej opłaty za przejazd przysługuje inwalidom grupy I i II (posiadaczom legitymacji inwalidzkiej ZTP i ZTP/P),

- prawo do przejazdów ulgowych za opłatą w wysokości nie wyższej niż 75\% normalnej opłaty za bilet imienny okresowy przysługuje osobom w wieku powyżej 65 lat pobierającym pełną emeryturę lub rentę inwalidzką.

- Środki publicznego transportu kolejowego (regularne połączenia krajowe) oraz środki publicznego zbiorowego transportu samochodowego

- prawo do bezpłatnych przejazdów przysługuje:

- dzieciom do lat $6^{12}$,

- przedstawicielom organów władzy państwowej i innych organów państwowych oraz sędziom, na podstawie przepisów ustawy o wynagrodzeniu i innych świadczeniach przysługujących przedstawicielom władzy państwowej i innym osobom ${ }^{13}$,

- przewodnikom inwalidów grupy I (posiadaczom legitymacji inwalidzkiej $\mathrm{ZTP} / \mathrm{P})^{14}$,

- prawo do przejazdów ulgowych za opłatą w wysokości nie większej niż 50\% opłaty normalnej przysługuje:

- dzieciom od lat 6 do l5, w tym: podróżującym pociągami w 1 i 2 klasie,

- rodzicom lub opiekunom prawnym odwiedzającym dzieci umieszczone w zakładach opieki społecznej itp. ${ }^{15}$,

- emerytom i rencistom ${ }^{16}$,

- prawo do przejazdów ulgowych za opłatą w wysokości nie większej niż 25\% opłaty normalnej przysługuje:

- inwalidom grupy II i I (posiadaczom legitymacji ZTP i ZTP/P) ${ }^{17}$,

- rodzicom odwiedzającym dzieci umieszczone w zakładach opieki społecznej itp. - tylko, w szczególnych przypadkach, w pociągach w 2 klasie,

12 Po spełnieniu określonych warunków, np. w środkach transportu kolejowego pasażer w wieku ponad 10 lat z ważnym biletem ma prawo do bezpłatnego przewozu dwojga dzieci w wieku do 6 lat, jeżeli nie zajmują one więcej niż jednego miejsca siedzącego.

13 W środkach transportu kolejowego - tylko w pociągach osobowych w 1 i 2 klasie.

14 W środkach transportu kolejowego - tylko w klasie 2.

15 Dotyczy rodziców dzieci umieszczonych w zakładzie opieki społecznej na stale lub na okres ponad 3 miesięcy, w środkach transportu kolejowego - tylko w klasie 2.

16 Tylko w środkach transportu kolejowego - w klasie 2.

17 W środkach transportu kolejowego - tylko w klasie 2. 
- prawo do przejazdów ulgowych za opłatą w wysokości nie większej niż 37,5\% opłaty normalnej przysługuje uczniom w wieku do lat 15 (zgodnie z zasadami omówionymi poniżej),

- prawo do przejazdów ulgowych za opłatą w wysokości nie większej niż 75\% opłaty normalnej przysługuje uczniom i studentom w wieku od lat 15 do 26 (zgodnie z zasadami omówionymi poniżej).

\section{Zasady regulujqce uprawnienia do przejazdów ulgowych uczniów i studentów}

Obecny system opłat uczniowskich za przejazdy środkami publicznego transportu zbiorowego powstał w wyniku uchwały rządu nr 624 z 23 czerwca 2003 r., która poleciła Ministrowi Transportu opracowanie podstaw regulacji cenowej Ministerstwa Finansów wprowadzającej ulgi na przejazdy uczniów i studentów, w ramach rekompensaty za zlikwidowany dodatek socjalny na przejazdy (sociální príspěvek na dopravu). Regulacje te nie obejmują przejazdów środkami publicznego zbiorowego transportu miejskiego ${ }^{18}$.

Uprawnienia do ulgowych przejazdów mają uczniowie i studenci, którzy wypełniając obowiązek szkolny lub przygotowując się do przyszłego zawodu w szkołach średnich, wyższych zawodowych i wyższych, zarówno w trybie dziennym jak i zaocznym (prezenční formy studia), korzystają ze środków krajowego publicznego transportu kolejowego lub samochodowego w celu dojazdu z miejsca stałego pobytu (w tym internatu, domu akademickiego) do miejsca siedziby szkoły w celu pobierania nauki lub udziału w zajęciach praktycznych. W środkach transportu kolejowego ulga obejmuje przejazdy wyłącznie w 2 klasie.

Prawo to przysługuje na przejazd od stacji (przystanku) najbliższej miejscowo lub czasowo od miejsca stałego pobytu ucznia lub studenta do stacji (przystanku) najbliżej usytuowanej szkoły lub miejsca odbywania zajęć praktycznych, które powinno znajdować się na terytorium Republiki Czeskiej. Uprawnienie jest ważne wyłącznie w okresie roku szkolnego/akademickiego. Do korzystania z ulg uprawnia specjalna legitymacja wystawiana przez przewoźnika, która jest uznawana przez pozostałych przewoźników kolejowych i samochodowych.

Uchwałą nr 398 z 28 kwietnia 2004 r. rząd postanowił o wydzieleniu środków finansowych na rekompensatę strat poniesionych przez przewoźników w związ-

18 Informacje dostępne na stronach czeskiego Ministerstwa Transportu, http://www.mdcr.cz/ cs/Legislativa/Ekonomika+a+finance/Zakovske_jizdne. 
ku z wprowadzeniem uczniowskich opłat za przejazdy w publicznej krajowej pasażerskiej komunikacji autobusowej oraz w krajowej publicznej regularnej kolejowej komunikacji pasażerskiej. Definicję udowodnionych strat w publicznym transporcie samochodowym zawiera zarządzenie rządu nr 493/2004, a w publicznym transporcie kolejowym - obwieszczenie nr 241/2005. Za wypłatę rekompensaty odpowiada województwo (kraj).

\section{Finlandia}

W odniesieniu do publicznego transportu miejskiego należy rozróżnić bilety miejskie oraz regionalne. Bilety regionalne przysługują stałym mieszkańcom obszaru metropolitarnego (stołeczne Helsinki wraz z podmiejskimi gminami Espoo, Kauniainen, Kerava, Kirkkonummi i Vantaa), miejskie zaś uprawniają do przejazdu w obrębie danego miasta (w niniejszym opracowaniu bilety miejskie zostały omówione na przykładzie Helsinek). W obu wariantach wskazane są pewne kategorie osób, uprawnionych do ulgowych przejazdów. Osoby mogące nabywać ulgowe bilety jednorazowe i abonamentowe podzielone są na dwie grupy:

- grupa 1, której przysługuje 25\% zniżki,

- grupa 2, której przysługuje 50\% zniżki.

Do przejazdów zniżkowych uprawnieni są emeryci pobierający świadczenia emerytalne wypłacane przez Kela (fiński urząd opieki społecznej) - zarówno posiadający pełny wymiar uprawnień, jak i częściowy. Emeryci, którym przysługuje pełna stawka należą do grupy 2 (50\% zniżki), pozostali zaś do grupy 1 (25\% zniżki). Aby kupić bilet zniżkowy, należy legitymować się dokumentem tożsamości ze zdjęciem oraz zaświadczeniem o pobieraniu świadczenia emerytalnego. W skład tej kategorii wchodzą: emeryci powyżej 65 roku życia, osoby na przedwczesnej emeryturze powyżej 62 roku życia, renciści legitymujący się uprawnieniami inwalidzkimi, osoby długotrwale bezrobotne urodzone przed 1950 rokiem niemające uprawnień emerytalnych ani renty inwalidzkiej.

Studenci należą do grupy 2 (50\% zniżki). Aby móc korzystać ze zniżki, studenci muszą uczyć się w uczelni znajdującej się na obszarze Helsinek (w wypadku biletu miejskiego) lub obszaru metropolitalnego (w wypadku biletu regionalnego). Muszą być studentami „pełnowymiarowymi” (co najmniej 25 godzin zajęć w tygodniu), a okres trwania ich programu nauczania musi wynosić co najmniej 9 miesięcy. Zniżki przysługują studentom, którzy nie przekroczyli 30 roku życia. Nabywając bilet, należy okazać dokument poświadczający fakt studiowania. Również studenci zagraniczni (w tym również przebywający na czasowej wymianie) jedy- 
nie tymczasowo mieszkający w Helsinkach lub obszarze metropolitalnym spełniający wyżej wskazane warunki mogą korzystać z przejazdów ulgowych.

Osoby niewidome uprawnione są do bezpłatnych przejazdów środkami transportu miejskiego. Również opiekun osoby niewidomej podróżujący z nią ma prawo do bezpłatnego przejazdu. Należy mieć przy sobie dokument bądź zaświadczenie lekarskie poświadczające ten fakt ${ }^{19}$.

Osobom niepełnosprawnym przysługuje zniżka w wysokości 25\%. Następujące schorzenia uprawniają do zniżkowych przejazdów:

- niewydolność dolnych kończyn, kręgosłupa, układu ruchowego,

- choroby krążenia i układu oddechowego skutkujące problemami z poruszaniem,

- choroby mózgu i wady rozwojowe skutkujące problemami z poruszaniem,

- inne choroby skutkujące problemami z poruszaniem.

Zniżki uprawniające do tańszych przejazdów odnoszą się do wszystkich środków transportu publicznego (autobusy, tramwaje, kolejka miejska, metro, prom). Za brak ważnego biletu lub posiadanie biletu ulgowego, do którego nie przysługują uprawnienia, nakładana jest grzywna w wysokości 80 euro plus koszt pojedynczego biletu.

W Helsinkach jednorazowy zwykły bilet kosztuje 2,5 euro (przy zakupie u kierowcy) i 2 euro (przy zakupie w automacie), bilety zniżkowe zaś kosztują odpowiednio 1,2 euro i 1 euro dla dzieci w wieku 7-16 lat. Dzieci poniżej 7 roku życia mogą jeździć za darmo ${ }^{20}$.

Bilety dla posiadaczy helsińskiej karty miejskiej - uprawniającej do zakupu ulgowych biletów - mają następujące zniżki: 25\% dla grupy 1 i 50\% dla grupy 2.

Zniżki nie przysługują na trasach nocnych - zarówno dorośli, jak i dzieci w wieku 7-16 lat płacą jednakową kwotę, tj. 4 euro przy zakupie u kierowcy, 3,5 euro przy zakupie w automacie oraz 4 euro przy zakupie przy użyciu telefonu komórkowego (sms).

Zniżki przysługują na prom Suomenlinna - ważny przez 12 godzin zwykły bilet jednorazowy kosztuje 3,8 euro, a dla dzieci w wieku 7-16 kosztuje 50\% tej kwoty, tj. 1,9 euro.

W Helsinkach funkcjonują bilety turystyczne - jedno-, trzy- oraz pięciodniowe zarówno w wersji zwykłej, jak i ulgowej. Zniżka wynosi 50\%. Koszt tych biletów to:

19 http://www.hsl.fi/EN/ticketsandfares/discountgroups/Pages/blindpersons.aspx.

20 http://www.hsl.fi/EN/ticketsandfares/discountgroups/Pages/children.aspx. 
- 1 dzień: 6,8 euro za bilet zwykły oraz 3,4 euro zniżkowy,

- 3 dni: 13,6 euro za bilet zwykły oraz 6,8 euro zniżkowy,

- 5 dni: 20,4 euro za bilet zwykły oraz 10,2 euro zniżkowy.

W przypadku biletów abonamentowych, 14-dniowa karta dla osób dorosłych kosztuje 21,6 euro, cena ulgowa (zniżka o 50\%) wynosi dla dzieci w przedziale wiekowym 7-16 lat 9 euro. Karta 14-dniowa jest to karta „bazowa” - do podstawowego czasu jej ważności można dokupić dowolną liczbę dni (tak aby maksymalny czas obowiązywania karty nie przekroczył 366 dni). Za każdy dodatkowy dzień opłata wynosi 1,23 euro dla dorosłych oraz 0,52 euro (zniżka 50\%) dla dzieci w wieku 7-16 lat. W przypadku osób z grupy 1 opłata ulgowa wynosi: 16,20 euro dla kwoty bazowej i 0,92 euro za każdy kolejny dzień oraz 10,70 euro dla kwoty bazowej i 0,62 euro za każdy kolejny dzień.

Bilety dla obszaru metropolitalnego (bilety regionalne) są nieznacznie droższe, natomiast schemat zniżek jest taki sam jak w przypadku biletów miejskich.

Przy zakupie karty należy okazać dokument ze zdjęciem oraz dokument poświadczający zamieszkiwanie na terenie Helsinek bądź obszaru metropolitalnego.

Fińskie Koleje - VR (Yhtymä Oy ${ }^{21}$ ) oferują swym pasażerom ulgowe bilety. Emeryci mają prawo do nabywania biletów kolejowych ze zniżką w wysokości 50\%. Bilety, które można kupować z tą ulgą, to bilety jednorazowe oraz abonamenty na 10 przejazdów. Osoba posiadająca bilet zniżkowy powinna legitymować się stosownym dokumentem zaświadczającym jej prawo do zniżki.

Osoby niepełnosprawne są uprawnione do przejazdów bezpłatnych. Również opiekun osoby niewidomej bądź cierpiącej na poważne zaburzenia poruszania jest zwolniony z opłaty. To samo dotyczy psa opiekuna osoby niewidomej.

Zniżki możliwe są także dla wszystkich pasażerów w wypadku przejazdów grupowych (przy zastrzeżeniu, że zniżek grupowych nie można łączyć z innymi ulgami):

- 15\% zniżki w wypadku grupy 3-10 osób,

- $20 \%$ zniżki w wypadku grupy 11 osób lub więcej.

Zniżka wynosi 50\%, gdy grupa złożona jest z emerytów. Dzieci w wieku szkolnym i studenci również są uprawnieni do 50-procentowych zniżek.

Dzieciom do 6 roku życia przysługuje bezpłatny przejazd pociągiem, a dzieciom i młodzieży w wieku 6-16 lat przysługuje zniżka w wysokości 50\%.

Zniżka rodzinna umożliwia dzieciom w wieku do lat 16 przejazd darmowy (a nie ze zniżką 50\%, jak to jest we wspomnianym standardowym wariancie).

21 http://www.vr.fi/fin. 
Aby zakupić bilety w tym trybie, liczba podróżujących członków rodziny musi wynosić co najmniej trzy osoby, z czego co najmiej jedna osoba musi być dorosła. Zniżki dotyczą biletów jednorazowych.

\section{Francja}

We Francji nie ma jednolitego systemu dostępnych ulg na przejazdy środkami transportu zbiorowego. Zagadnienie wprowadzania zniżek regulowane jest przeważnie na poziomie lokalnym różnymi rozporządzeniami, a te warunkowane są choćby zwyczajami i lokalnymi potrzebami. Ponadto dodatkowym elementem mającym wpływ na całościowy obraz korzystania ze zniżek w transporcie publicznym jest powszechnie stosowany system zakupu okresowej (np. $30 \mathrm{dni}$, 3 miesiące, 1 rok, 3 lata) karty zniżkowej, która z kolei uprawnia do zakupu biletów w konkretnej taryfie zniżkowej.

\section{Kolej}

Do najpopularniejszych należą zniżki na przejazdy kolejowe. Francuska sieć kolei żelaznych - SNCF (Service National de Chemins de Fer) - to pociągi różniące się komfortem, zasięgiem i szybkością podróżowania. Wyróżniamy wśród nich np. Eurostar, TGV 22, TER, Thalys. W każdym z nich zniżki są zróżnicowane i uzależnione od wielu czynników (wiek pasażera, pora dnia i miesiąc podróży, liczba rezerwowanych miejsc, zakup biletu w jedną lub obydwie strony itp.). Najpopularniejsza proponowana ulga wynosi 50\%. Do zakupu biletów z tą zniżką uprawnieni są:

- dzieci od 4 do 10 lat,

- duże rodziny (co najmniej 3 dzieci poniżej 18 roku życia),

- grupy młodzieżowe powyżej 10 osób (do 16 lat) z osobą towarzyszącą,

- przewodnicy niewidomych i kombatantów (ta grupa jest również duża i zróżnicowana),

- osoby powyżej 60 lat posiadający kartę seniora.

22 Szybka kolej TGV - duma francuskiej technologii, jedzie z prędkością 300 km/h. Bezpieczna, punktualna i wygodna, pozwala na podróż w rekordowym czasie. Trasę na odcinku ParyżLille pokonuje w 1 godzinę, Paryż-Marsylia lub Paryż-Bordeaux - w 3 godziny, Paryż-Rennes - w 2 godziny. Rezerwacja jest obowiązkowa, nawet tuż przed odjazdem pociągu. Ceny biletów zależą od komfortu, klasy (istnieją dwie klasy: 1 i 2) i godziny odjazdu (godzina szczytu lub poza szczytem). Zniżki można uzyskać na podstawie specjalnych kart rabatowych. 
Dodatkowo istnieją specjalne ulgi dla uczącej się młodzieży poniżej 26 lat (ulgi od 20\% do 50\% w zależności od zakupionych kart uprawniających do zniżek) i zniżki do wysokości 50\% przeznaczone dla grup zorganizowanych. Do najwyższych ulg w wysokości 75\% uprawnieni są mundurowi pracownicy wojska.

\section{Transport miejski23}

Zasada określania zniżek dla transportu miejskiego pozostaje w gestii władz lokalnych. We Francji największa sieć miejskiego transportu publicznego znajduje się w Paryżu i jego okolicach. W regionie paryskim miejska sieć transportu publicznego (tzw. RATP) oferuje podobne zniżki jak kolej (SNCF), a dodatkowo zgodnie z decyzją władz Paryża osobom w wieku powyżej 65 lat i zamieszkałym w stolicy przysługują przejazdy bezpłatne.

Podstawowy bilet jednorazowy w miejskim transporcie publicznym, tzw. bilet t, kosztuje 1,50 euro. Bilet obowiązuje na całą sieć metra i kolejkę Montmartre, kolejkę RER (RATP i SNCF) w obrębie Paryża, autobusy należące do RATP w Paryżu i na przedmieściach ( $\mathrm{z}$ wyjątkiem linii ze specjalnymi taryfami), na połączenia z przesiadkami w obrębie całej sieci metra i kolejki RER w obrębie Paryża, pod warunkiem że odstęp między pierwszym a ostatnim wejściem do pojazdu jest nie większy niż 1,5 godziny, oraz na autobusy nocne Noctilien, lecz bez możliwości przesiadki.

W metrze, miejskiej sieci kolejowej (RER) połączonej z siecią metra, tramwajach i autobusach najczęściej stosowanymi zniżkami są:

- zakup karnetu 10 biletów (cena 11,10 euro) i karnetu ze zniżką 50\% dla dzieci w wieku 4-9 lat (cena 5,55 euro),

- zakup Carte Orange (karta na tydzień lub miesiąc ważna na wszystkie środki transportu miejskiego obowiązująca w 8 strefach Paryża):

- karta tygodniowa (carte hebdomadaire) ważna jest od poniedziałku do niedzieli (cena najtańszej karty, obowiązującej w 2 strefach wynosi 16,30 euro),

- karta miesięczna (carte mensuelle) ważna jest przez 1 miesiąc kalendarzowy (cena najtańszej karty obowiązującej w 2 strefach wynosi 53,50 euro),

- zakup biletu Paris Visite Pass. Jest to oferta z myślą o turystach przebywających w Paryżu 1, 2, 3 lub 5 dni. Bilet jest ważny w: metrze, kolejce RER, autobusach, tramwaju, naziemnej kolejce linowej na Montmartrze, Montmartrobusie, autobusach nocnych (Noctilien), pociągach podmiejskich (SNCF), autobusach ADATRIF i APTR, dzięki którym można dojechać aż do Disneylan-

23 www.ratp.info. 
du, Wersalu albo na lotniska paryskie. Bilet pozwala na podróżowanie przez 1, 2, 3 lub 5 dni do wyboru niezależnie od tygodnia kalendarzowego. Paris Visite Pass można wykupić na strefy 1-3 (obszar miasta i sieć metra), lub 1-6 (region Île-de-France, gdzie kursują autobusy RATP i pociągi RER). Bilet można nabyć na głównych stacjach metra, wszystkich stacjach RER, w biurach handlowych, w 150 paryskich hotelach, w punktach sprzedaży biletów autobusowych, na dworcach kolejowych SNCF, na lotniskach paryskich. Za granicą karta ta jest sprzedawana w biurach podróży. Podstawowa i jedyna zniżka wynosi 50\% i przeznaczona jest dla dzieci w wieku 4-11 lat.

Ceny biletów Paris Visite Pass w strefie 1-3:

- bilet na 1 dzień: dorośli - 8,50 euro, dzieci (4-11 lat) - 4,25 euro,

- bilet na 2 dni: dorośli - 13,95 euro, dzieci (4-11 lat) - 6,95 euro,

- bilet na 3 dni: dorośli - 18,60 euro, dzieci (4-11 lat) - 9,30 euro,

- bilet na 5 dni: dorośli - 27,20 euro, dzieci (4-11 lat) - 13,60 euro. Ceny biletów Paris Visite Pass w strefie 1-6:

- bilet na 1 dzień: dorośli - 17,50 euro, dzieci (4-11 lat) - 8,50 euro,

- bilet na 2 dni: dorośli - 27,15 euro, dzieci (4-11 lat) - 13,55 euro,

- bilet na 3 dni: dorośli - 38,05 euro, dzieci (4-11 lat) - 19,05 euro,

- bilet na 5 dni: dorośli - 46,60 euro, dzieci (4-11 lat) - 23,30 euro.

- Inne zorganizowane środki transportu publicznego wraz z cenami biletów to:

- Roissybus - linia autobusowa dowożąca pasażerów na lotnisko im. Charles de Gaull'a. Cena biletu jednorazowego wynosi 8,60 euro, a z ulgi można jedynie skorzystać, wykupując Paris Visite Pass na strefy 1-6.

- Orlybus - linia autobusowa dowożąca pasażerów z centrum Paryża na lotnisko Orly. Cena biletu jednorazowego wynosi 6,00 euro. W przypadku chęci skorzystania z ulgi należy posłużyć się biletem Paris Visite Pass na strefy 1-6.

- Orlyval - linia metra dowożąca pasażerów na lotnisko Orly. Cena biletu normalnego wynosi 7,20 euro. Dzieciom w wieku 4-11 lat przysługuje zniżka 50\%, więc cena biletu ulgowego wynosi 3,60 euro.

- Open Tour - regularna linia autobusowa przeznaczona dla turystów, autobusy piętrowe typu open-deck, czyli bez zadaszenia. Trasa tej linii przebiega przez najbardziej charakterystyczne miejsca Paryża. Bilety są ważne 1 lub 2 kolejne dni, licząc od pierwszego użycia. Cena biletu normalnego wynosi 25 euro, a ulgowego dla dzieci (4-11 lat) - 12 euro. Przejazd dzieci poniżej 4 lat jest bezpłatny.

- Batobus - autobus wodny - regularna linia po Sekwanie. Batobus przemierza rzekę w obie strony, zatrzymuje się na ośmiu przystankach, gdzie można 
wsiąść i wysiąść. Bilet (tzw. Batobus Pass) pozwala na nielimitowaną liczbę kursów. Bilety są ważne na 1, 2 lub 5 kolejnych dni, licząc od pierwszego użycia. Taryfa obejmuje bilety dla dorosłych, bilety ulgowe (przysługują posiadaczom legitymacji studenckiej, kart: Imagine R, Orange, Intégrale, Améthyste lub Emeraude), bilety dla dzieci w wieku 4-16 lat. Przejazd dzieci poniżej 4 lat jest bezpłatny.

- Ceny Batobus Pass:

- bilet na 1 dzień: dorośli - 12 euro, ulgowy - 8 euro, dzieci (4-16 lat) - 6 euro,

- bilet na 2 dni: dorośli - 14 euro, ulgowy - 9 euro, dzieci (4-16 lat) - 7 euro,

- bilet na 5 dni: dorośli - 17 euro, ulgowy - 11 euro, dzieci (4-16 lat) - 8 euro.

\section{Portugalia}

W portugalskim systemie prawnym nie ma odrębnej ustawy o zakresie przedmiotowym analogicznym do polskiej ustawy z 20 czerwca 1992 r. o uprawnieniach do ulgowych przejazdów środkami publicznego transportu zbiorowego. Uprawnienia do przejazdów ulgowych wynikają z odrębnych ustaw dotyczących bądź poszczególnych środków transportu, bądź określonych kategorii osób.

Ogólne warunki funkcjonowania transportu lądowego określa ustawa $\mathrm{nr} 10 \mathrm{z} 17$ marca $1990 \mathrm{r}$. o systemie transportu lądowego ${ }^{24}$. Zgodnie z tą ustawą do środków publicznego transportu zbiorowego zalicza się:

- $\quad$ sieć kolei dalekobieżnej (połączenia krajowe i międzynarodowe) stanowiącej własność skarbu państwa,

- linie kolejowe należące do samorządów lub związków samorządowych,

- sieci komunikacji miejskiej i podmiejskiej w ramach regionów metropolitalnych (Lizbona i Porto) oraz ewentualnie w innych regionach.

Międzymiastowe przewozy samochodowe nie są klasyfikowane jako transport publiczny.

Przedsiębiorstwa przewozowe realizujące zadania publiczne działają na zasadach rynkowych, jednakże w interesie publicznym rząd może określać zasady ich funkcjonowania, tworzenia taryf i kształtowania cen. Taryfy i ceny biletów w sieciach komunikacji miejskiej, obsługiwanych przez przedsiębiorstwa komunalne, ustalają władze samorządowe, uwzględniając przepisy ustawowe ${ }^{25}$. Prze-

24 Lei n. ${ }^{\circ}$ 10/90 de 17 de Março. Lei de Bases do Sistema de Transportes Terrestres.

25 Rozporządzenie z mocą ustawy nr 8 z 11 stycznia 1993 r. (Decreto-Lei, n. 8/93, de 11 Janeiro), art. 10. 
woźnicy wykonujący zadania publiczne mają prawo do refundacji kosztów związanych z nakładanymi na nie obowiązkami.

\section{Ulgi w przewozach kolejowych}

Rodzaje przejazdów ulgowych w transporcie kolejowym (pociągi dalekobieżne, pociągi podmiejskie i tramwaje) określa rozporządzenie z mocą ustawy nr 58 z 28 marca 2008 r. ${ }^{26}$. Ulgi obejmują:

- dzieci do 4 lat - przejazdy bezpłatne bez prawa do osobnego miejsca,

- dzieci powyżej 4 roku do ukończenia 12 lat - zniżka maksymalnie 50\%,

- osoby od 65 roku życia - zniżka 50\%.

\section{Ulgi w sieciach komunikacyjnych metropolitalnych i municypalnych}

\section{Bilet szkolny (Passe 4_18@escola.tp)}

Na mocy rozporządzenia z mocą ustawy nr 186 z 19 września 2008 r. oraz rozporządzenia nr 138 z 3 lutego 2009 r. wprowadzono bilety ulgowe dla uczniów - Bilet 4_18 do szkoły (Passe 4_18@escola.tp) ${ }^{27}$. Bilet ten uprawnia wszystkich uczniów w wieku od 4 lat do ukończenia 18 roku, którzy nie korzystają z transportu szkolnego (gimbusy) do 50\% zniżki na bilety miesięczne w ramach danej metropolitalnej sieci transportowej (pociąg, autobus podmiejski, autobus, tramwaj, metro ${ }^{28}$. Bilet obejmuje określoną trasę z domu do szkoły. Poszczególne municypia (powiaty) niewchodzące w skład regionów metropolitalnych mogą wprowadzić podobną kartę w swojej sieci przewozowej po odpowiednich modyfikacjach oraz po powiadomieniu Instytutu Mobilności i Transportu Lądowego (Instituto de Mobilidade e Transporte Terrestre) ${ }^{29}$ o przystąpieniu do systemu Biletu 4_18 do szkoły.

Koszty związane z taryfami ulgowymi określonymi ustawowo są refundowane przewoźnikom z budżetu państwa. Refundacja przekazywana jest każdemu przewoźnikowi osobno w cyklach miesięcznych przez Generalną Dyrekcję Skarbu i Finansów.

26 Decreto-Lei n. 58/2008, de 28 de Março.

27 Decreto-Lei n. 186/2008, de de 19 Setembro; Portaria n.138/2009, de 3 de Fevreiro.

28 W sieciach metropolitalnych i municypalnych stosuje się bilety wspólne.

29 Instytut powołany w $2007 \mathrm{r}$. jest urzędem regulacyjnym i kontrolnym, odpowiedzialnym za organizację transportu na terenie całego kraju, por. www.imtt.pt. 


\section{Bilet studencki (Passe sub23@superior.tp)}

Bilet studencki przeznaczony jest dla studentów szkół wyższych do ukończenia 23 lat. Bilet ten funkcjonuje na takich samych zasadach jak bilet szkolny, z tym, że dodatkowo uprawnia do korzystania z 50\% zniżki w międzymiastowych przewozach autobusowych oraz w połączeniach kolejowych na trasie między miejscem zamieszkania a siedzibą uczelni. Wzór biletu studenckiego jest jednolity na terenie całego kraju ${ }^{30}$.

Przejazdy ulgowe na trasach innych niż te objęte biletem szkolnym lub studenckim

Uprawnienia do przejazdów ulgowych w ramach sieci transportu publicznego określają samorządy. W regionie Lizbony i Porto dzieci i młodzież korzystają z 25\% zniżki.

\section{Osoby od 65 roku oraz emeryci i renciści}

Osoby od 65 roku życia oraz emeryci i renciści, których dochód nie przekracza minimum krajowego, mają prawo do 50\% zniżki w przejazdach w ramach miejskich i metropolitalnych sieci komunikacyjnych.

\section{Inne ulgi}

Municypia w ramach polityki społecznej mogą wprowadzać ulgi dla określonych kategorii osób: bilety dla seniorów, bilety socjalne (np. dla rodzin wielodzietnych, dla bezrobotnych itp.).

\section{Przejazdy bezpłatne}

Ustawowe uprawnienia do korzystania z bezpłatnych przejazdów w trakcie wykonywania zadań służbowych i na trasie między miejscem zamieszkania a miejscem pracy posiadają sędziowie i prokuratorzy, funkcjonariusze policji sądowej oraz pracownicy służby więziennej. Koszty tych przejazdów pokrywają ze swoich budżetów właściwe instytucje ${ }^{31}$.

30 Decreto-Lei n. ${ }^{\circ}$ 203/2009, de 31 de Agosto; Portaria n. ${ }^{\circ}$ 982-B/2009 de 2 de Setembro.

31 Decreto-Lei 274/78, de 6 Setembro; Decreto-Lei 229//79, de 21 Julho; Decreto-Lei 149-A/83, de 5 de Abril, Decreto-Lei n. 106/87, de 6 de Março (Rectificações). 


\section{Szwecja}

W Sztokholmie ${ }^{32}$ dostępne są bilety strefowe uprawniające do przejazdu w granicach danych stref (strefa 1, 2 i 3 - w zależności od odległości od centrum) oraz bilet abonamentowy, uprawniający do przejazdów na terenie całego miasta. Dostępne są bilety na różne przedziały czasowe. Cena jest też zależna od formy płatności, np. od tego, czy zakup jest dokonywany w automacie, u kierowcy, czy dokonywany przez płatność sms.

Grupy, którym przysługują bilety w cenie ulgowej to:

- osoby po 65 roku życia,

- osoby, które przeszły na wcześniejszą emeryturę,

- osoby do 20 roku życia.

Cena biletów ulgowych wynosi $60 \%$ ceny biletu zwykłego, np:

- jednorazowy bilet opłacony przez sms w 1 strefie: 30 SEK (koron szwedzkich) bilet zwykły i 18 SEK ulgowy ( 1 PLN = 2,45 SEK, zatem koszt biletu za 30 koron szwedzkich równy jest 12,2 zł),

- jednorazowy bilet opłacony przez sms w 2 strefie: 45 SEK bilet zwykły i 27 SEK ulgowy,

- jednorazowy bilet opłacony przez sms w 3 strefie: 60 SEK bilet zwykły i 36 SEK ulgowy,

- bilet dzienny: 100 SEK bilet zwykły i 60 SEK ulgowy,

- bilet tygodniowy: 260 SEK bilet zwykły i 160 SEK ulgowy,

- bilet abonamentowy 30-dniowy: 690 SEK bilet zwykły i 420 SEK ulgowy;

- bilet sezonowy na okres sierpień-grudzień 2009 r.: 2670 SEK bilet zwykły i 1600 SEK ulgowy.

Funkcjonuje też mechanizm stworzony z myślą o młodzieży szkolnej i studenckiej - specjalny bilet na okres wakacyjny (1 czerwca - 31 sierpnia) kosztuje 550 SEK. Brak jest informacji o zniżkach przysługującym osobom niepełnosprawnym.

\section{Węgry}

Transport Publiczny Budapesztu (Budapesti Közlekedési Zrt, BKV) ${ }^{33}$ również prowadzi politykę zakładającą ulgowe przejazdy dla pewnych grup pasażerów. Jednorazowy zwykły bilet kosztuje 320 HUF (320 forintów, czyli 4,70 PLN; 1 PLN = 67 HUF).

32 http://www.sl.se/templates/PriceList.aspx?id=5302.

33 http://www.bkv.hu/english/jegyinfo/fares.html. 
Dzieci poniżej 3 roku życia zwolnione są z opłat za przejazd. Dzieciom w wieku 3-14 lat przysługuje bilet ulgowy, tj. w wysokości 50\% ceny biletu zwykłego. W budapeszteńskim transporcie publicznym funkcjonuje kilka rodzajów zniżek, w zależności od czasu ważności biletu:

- abonament na 10 przejazdów: 2800 HUF,

- bilet 24-godzinny: $1550 \mathrm{HUF}$,

- bilet 72-godzinny: $3850 \mathrm{HUF}$,

- bilet tygodniowy: 4600 HUF.

Do przejazdów ulgowych uprawnieni są studenci, emeryci i osoby niepełnosprawne. Uprawnienia dotyczą wszystkich środków transportu miejskiego kursujących w granicach Budapesztu oraz niektórych wskazanych linii podmiejskich. Do korzystania z uprawnień niezbędne jest wyrobienie stosownego dokumentu ze zdjęciem. W takim wypadku miesięczny zwykły bilet abonamentowy kosztuje 9800 HUF, a ceny miesięcznych abonamentów ulgowych są następujące:

- 8500 HUF dla niepełnosprawnych (zniżka o 14\%),

- 3850 HUF dla studentów (zniżka o 61\%),

- 3700 dla emerytów (zniżka o 63\%).

Można nabyć również abonamentowy bilet kwartalny (100-dniowy). W wypadku biletu normalnego koszt wynosi 29400 HUF, zniżki zaś przysługujące wymienionym kategoriom są proporcjonalnie takie same. Zgodnie z przepisami BKV osoby niepełnosprawne uprawione do przejazdów ulgowych muszą legitymować się zaświadczeniem lekarskim wskazującym co najmniej $7 \mathrm{w}$ skali niepełnosprawności (Disability Status Scale: 0 oznacza normę, 1-8 różne poziomy niepełnosprawności, 9 całkowitą niewydolność, a 10 zgon).

Węgierskie Koleje Państwowe (Magyar Államvasutak, MÁV) ${ }^{34}$ oferują kilka rodzajów przejazdów ulgowych:

- zniżka w wysokości 20\% przysługuje osobom powyżej 55 roku życia,

- zniżka w wysokości 33\% przysługuje:

- posiadaczom specjalnej karty (Hungary Card),

- w wypadku przejazdów rodzinnych (2 opiekunów oraz dzieci poniżej 18 roku życia),

- osobom poniżej 26 lat w wypadku przejazdów między piątkiem a niedzielą,

- zniżka w wysokości 50\% przysługuje:

- dzieciom i młodzieży poniżej 14 roku życia,

- pracownikom służby cywilnej,

34 http://elvira.mav-start.hu/elvira.dll/xslms. 
- emerytom,

- studentom (w tym również studentom zagranicznym).

- zniżka w wysokości 90\% przysługuje:

- bezrobotnym,

- niewidomym,

- opiekunowi osoby niewidomej,

- głuchoniemym,

- upośledzonym umysłowo,

- opiekunowi bądź członkowi rodziny osoby niepełnosprawnej (podczas podróży z osobą niepełnosprawną).

Do darmowego przejazdu upoważnione są natomiast następujące kategorie pasażerów:

- dzieci poniżej 6 roku życia,

- pies przewodnik osoby niewidomej,

- osoby powyżej 65 roku życia,

- uchodźcy.

\section{Włochy}

We włoskim systemie prawnym nie ma odrębnej ustawy o zakresie przedmiotowym analogicznym do polskiej ustawy z 20 czerwca 1992 r. o uprawnieniach do ulgowych przejazdów środkami publicznego transportu zbiorowego. Nie ma jednolitego systemu ulg ani w komunikacji miejskiej, ani międzymiastowej. Odrębne ustawy państwowe określają ogólnie prawo niektórych kategorii osób (inwalidzi, niewidomi, głuchoniemi, emeryci i renciści pobierający renty i emerytury socjalne, osoby od 65 roku życia, bezrobotni itp.) do ułatwień w transporcie. Zadania w zakresie publicznego transportu zbiorowego wykonują regiony na podstawie ustaw regionalnych. Systemowe rozwiązania zawarte w ustawach regionalnych są bardzo zróżnicowane zarówno ze względu na poziom zamożności poszczególnych regionów, jak i na gęstość oraz charakterystykę sieci komunikacji publicznej, jakimi dysponują. Poza siecią regionalną, funkcjonują także sieci prowincjonalne i komunalne (włoskie miasta mają status gminy). Straty przedsiębiorstw wynikające z ulg pokrywane są z budżetu regionu. Prowincje i gminy $\mathrm{w}$ zakresie swojego działania mogą $\mathrm{w}$ porozumieniu z władzami regionalnymi poszerzać katalog ulg obowiązujących w środkach transportu publicznego, z tym że muszą finansować takie ulgi z własnych budżetów. Ulgi w transporcie regionalnym dotyczące wszystkich środków transportu (pociągi regionalne i podmiej- 
skie, autobusy międzymiastowe, autobusy miejskie, tramwaje, trolejbusy, metro), jakie dana jednostka samorządowa ustali. Regiony, prowincje i gminy mogą również zawierać umowy z przewoźnikami ogólnokrajowymi (Włoskie Koleje Państwowe i inni prywatni przewoźnicy) w sprawie objęcia ulgami przejazdów realizowanych poza siecią publiczną. W niektórych wypadkach określone trasy lub połączenia są wyłączone z ulg (np. ulgi nie obowiązują w pociągach i autobusach na trasie Rzym Dworzec Termini - Lotnisko Fiumicino, w autobusach obsługujących specjalne trasy turystyczne).

Na podstawie przeglądu wybranych ustaw regionalnych o organizacji transportu regionalnego ${ }^{35}$ oraz stron internetowych agencji i przedsiębiorstw transportu publicznego w regionach, prowincjach i gminach można wyróżnić następujące elementy rozwiązań systemowych.

\section{Przejazdy bezpłatne}

W większości regionów i u większości przewoźników publicznych bezpłatne przejazdy przysługują:

- inwalidom wojennym i cywilnym oraz osobom niepełnosprawnym (niewidomi, głuchoniemi, osoby z niepełnosprawnością ruchową itp.) - z zastosowaniem kryterium dochodowego lub nie,

- emerytom, rencistom, osobom powyżej 65 roku o dochodach nieprzekraczających określonego pułapu (kryterium dochodowe zróżnicowane w zależności od regionu),

- dzieciom do 4 lat,

35 Lazio, Legge regionale 16 luglio 1998 n. 30, recante disposizioni in materia di trasporto pubblico locale. Friuli-Venezia Giulia, L.R. n. 23/2007, Attuazione del decreto legislativo 111/2004 in materia di trasporto pubblico regionale e locale, trasporto merci, motorizzazione, circolazione su strada e viabilità. Abruzzo, L.R. n. 18/2009, Interventi in materia di trasporto pubblico locale in favore degli studenti e dei lavoratori dei Comuni colpiti dal sisma del 6 aprile 2009. Liguria, L.R. n. 30/2009, Promozione della realizzazione delle autostrade di interesse regionale, delle infrastrutture ferroviarie regionali e della fattibilità di tratte viarie strategiche sul territorio regionale. B.U.R. Liguria - n. 15 del 12/08/2009. Lombardia, L.R. n. 11/2009, Testo unico delle leggi regionali in materia di trasporti Liguria, L.R. n. 13/2009, Modifica alla l.r. n. 31 del 1998 (norme in materia di trasporto pubblico locale) e successive modificazioni e intefgrazioni. Veneto, L.R. n. 11/2009, Disposizioni in materia di attività di trasporto di viaggiatori effettuato mediante noleggio di autobus con conducente e modifica dell'articolo 4 della legge regionale 30 ottobre 1998 n. 25B. Molise, L.R. n. 12/2009, Modifiche ed integrazioni alla legge regionale 24 marzo 2000, n. 19, ad oggetto: Norme integrative della disciplina in materia di trasporto pubblico locale. 
- dzieciom do 10 lat podróżującym w towarzystwie osoby dorosłej (komunikacja miejska).

W Lombardii prawo do bezpłatnych przejazdów mają funkcjonariusze policji, karabinierzy oraz inne osoby wykonujące zadania z zakresu bezpieczeństwa oraz dzieci do $1 \mathrm{~m}$ wzrostu. Część regionów przyznaje prawo do bezpłatnych przejazdów bezrobotnym (na wskazanej trasie i przy pewnych ograniczeniach). Region Lacjum przyznał prawo do bezpłatnych przejazdów wszystkim osobom powyżej 70 roku życia (o dochodach nieprzekraczających 15000 euro w skali roku).

\section{Przejazdy ulgowe na przykładzie regionu Lacjum i gminy Rzym ${ }^{36}$}

- Przejazdy ulgowe na obszarze gminy Rzym przysługują:

- młodzieży do ukończenia 20 lat oraz studentom do lat 26, emerytom (świadczenia z INPS ${ }^{37}$ ) - 40\% zniżki,

- inwalidom cywilnym oraz osobom niepełnosprawnym (z orzeczoną 67\% utratą zdolności do pracy), emerytom, rencistom, osobom powyżej 65 roku pobierającym renty i emerytury socjalne określonych kategorii - 87\% zniżki,

- bezrobotnym (pod określonymi warunkami) - 47\% zniżki.

- Przejazdy ulgowe na obszarze regionu Lacjum

Ulgowe przejazdy na obszarze całego regionu w systemie biletu wspólnego (jeden bilet na wszystkie środki transportu) przysługuje wyłącznie młodzieży do lat 20 podlegającej obowiązkowi szkolnemu oraz studentom do ukończenia 26 lat. Uczniowie i studenci mogą zakupić bilet roczny niedostępny dla innych klientów. Zakup biletu rocznego za gotówkę oznacza 49-procentową zniżkę w stosunku do ceny 12 biletów miesięcznych ${ }^{38}$.

\section{Ulgi w przejazdach Włoskimi Kolejami Państwowymi (Trenitalia)}

- Dzieci do 4 roku życia podróżują bezpłatnie (bez prawa do osobnego miejsca).

- Dzieci do 12 roku życia na osobnym miejscu - 50\% zniżki (30\% w wagonach sypialnych i z miejscami do leżenia).

- Zielona Karta - dla osób w wieku 12-26 lat.

36 www.atac.roma.it.

37 Istituto Nazionale della Previdenza Sociale - instytucja odpowiadająca polskiemu Zakładowi Ubezpieczeń Społecznych.

38 Bilet miesięczny obejmujący cały region (7 stref) kosztuje 93 euro (1116 euro rocznie), natomiast roczny bilet studencko-uczniowski kupiony za gotówkę kosztuje 576,40 euro. 
Koszt karty wynosi 40 euro i daje prawo do 10\% zniżki na wszystkich trasach kolejowych oraz 25\% zniżki w połączeniach międzynarodowych (program RAILPLUS).

Srebrna Karta - dla osób powyżej 60 roku.

Koszt karty - 30 euro. Dla osób, które ukończyły 75 lat - bezpłatnie.

Srebrna Karta jest ważna przez rok, daje prawo do 15\% zniżki na bilety 2 i 1 klasy oraz do 10\% zniżki w pociągach sypialnych i z miejscami do leżenia oraz do 25\% zniżki w połączeniach międzynarodowych (program RAILPLUS) z wyłączeniem połączeń obsługiwanych przez określonych przewoźników.

\section{Niebieska Karta}

Przeznaczona dla osób, które z tytułu orzeczonego stopnia inwalidztwa mają prawo do pomocy osoby towarzyszącej. Karta jest bezpłatna i ważna pięć lat. Posiadacz karty uprawniony jest do bezpłatnego biletu, a osoba towarzysząca do zniżki 50\%39.

\section{Bibliografia}

\section{Akty prawne}

Rozporządzenie 1370/2007 Parlamentu Europejskiego i Rady z 23 października 2007 r. dotyczące usług publicznych w zakresie kolejowego i drogowego transportu pasażerskiego, Dz.Urz. UE L 315 z 3 grudnia 2017 r., s. 1, https://eur-lex.europa.eu/legal-content/PL/ TXT/?Uri=CELEX\%3A32007R1370.

Zákon č. 236/1995 Sb., o platu a dalších náležitostech spojených s výkonem funkce představitelů státní moci a některých státních orgánů a soudců, ve znění pozdějších předpisů, https://www.zakonyprolidi.cz/cs/1995-236.

Vyhláška č. 182/1991 Sb., kterou se provádí zákon o sociálním zabezpečení a zákon České národní rady o působnosti orgánů České republiky v sociálním zabezpečení, ve znění pozdějších předpisů (Przepis wprowadzający ustawę o zabezpieczeniu społecznym $\mathrm{i}$ inne ustawy), https://www.zakonyprolidi.cz/cs/1991-182.

Zákon č. 561/2004 Sb., o předškolním, základním, stř̌edním, vyšším odborném a jiném vzdělávání (školský zákon), ve znění pozdějších předpisů. https://www.zakonyprolidi. cz/cs/2004-561.

39 Ferrovie dello Stato. Trenitalia, https://www.trenitalia.it. 
Zákon č.111/1998 Sb., o vysokých školách a o změně a doplnění dalších zákonů (zákon o vysokých školách), ve znění pozdějších předpisů, https://www.zakonyprolidi.cz/cs/1998-111.

Zákon č. 117/1995 Sb., o státní sociální podpoře, ve znění pozdějších předpisů, https://www. zakonyprolidi.cz/cs/1995-117.

Zákon č. 236/1995 Sb., o platu a dalších náležitostech spojených s výkonem funkce představitelů státní moci a některých státních orgánů a soudců, ve znění pozdějších předpisů, https://www.zakonyprolidi.cz/cs/1995-236.

Lei n. ${ }^{\circ}$ 10/90 de 17 de Março. Lei de Bases do Sistema de Transportes Terrestres, https:// antram.pt/attachments/legislacao/Lei_10_90_LEI_BASES.pdf.

Decreto-Lei, n. 8/93, de 11 Janeiro), art. 10, https://dre.pt/pesquisa/-/search/469604/details/ maximized.

Decreto-Lei n. 58/2008, de 28 de Março, https://dre.pt/pesquisa/-/search/246493/details/ maximized.

Decreto-Lei n. 186/2008, de de 19 Setembro; Portaria n.138/2009, de 3 de Fevreiro, https:// juventude.gov.pt/MigratedResources/461000/461015_DL1862008.pdf.

Decreto-Lei 274/78, de 6 Setembro, https://dre.tretas.org/dre/6022/decreto-lei-274-78-de-6de-setembro.

Decreto-Lei 229//79, de 21 Julho, https://dre.tretas.org/dre/6282/decreto-lei-229-79-de-21-dejulho.

Decreto-Lei 149-A/83, de 5 de Abril, https://dre.tretas.org/dre/14220/decreto-lei-149-A-83-de5-de-abril.

Decreto-Lei n. 106/87, de 6 de Março (Rectificações), https://dre.tretas.org/dre/5007/decreto-lei-106-87-de-6-de-marco.

Regione Lazio. Legge regionale 16 luglio 1998 n. 30, recante disposizioni in materia di trasporto pubblico locale, http://www.consiglioregionale.calabria.it/upload/istruttoria/ Regione\%20Lazio\%20-\%20L.R.\%2016\%20luglio\%201998,\%20n.\%2030.pdf.

Regione Friuli-Venezia Giulia, L.R. n. 23/2007, Attuazione del decreto legislativo 111/2004 in materia di trasporto pubblico regionale e locale, trasporto merci, motorizzazione, circolazione su strada e viabilità, http://federalismi.it/nv14/articolo-documento.cfm?Artid=8372\&content $=$ Attuazione + del + decreto+legislativo $+111 / 2004+$ in + materia + di + tra sporto+pubblico+regionale+e+locale,+trasporto+merci,+motorizzazione,+circolazione+su+strada+e+viabilit\%C3\%A0\&content_author=.

Abruzzo, L.R. n. 18/2009, Interventi in materia di trasporto pubblico locale in favore degli studenti e dei lavoratori dei Comuni colpiti dal sisma del 6 aprile 2009, http://federalismi.it/nv14/articolo-documento.cfm?artid=14720.

Liguria, L.R. n. 30/2009, Promozione della realizzazione delle autostrade di interesse regionale, delle infrastrutture ferroviarie regionali e della fattibilità di tratte viarie 
strategiche sul territorio regionale, http://federalismi.it/nv14/articolo-documento. cfm?Artid=14001\&content=Promozione+della+realizzazione+delle+autostrade+di+interesse+regionale,+delle+infrastrutture+ferroviarie+regionali + e+della+fattibilit $\% \mathrm{C} 3 \% \mathrm{~A} 0+$ di +tratte+viarie+strategiche+sul+territorio+regionale\&content_author=.

B.U.R. Liguria - n. 15 del 12/08/2009, http://federalismi.it/nv14/articolo-documento.cfm?Artid=14001\&content=Promozione+della+realizzazione+delle+autostrade $+d i+i n t e r e s-$ se+regionale,+delle+infrastrutture+ferroviarie+regionali+e+della+fattibilit\%C3\%A0+di+tratte+viarie+strategiche+sul+territorio+regionale\&content_author=.

Lombardia, L.R. n. 11/2009, Testo unico delle leggi regionali in materia di trasporti, http:// www.federalismi.it/nv14/articolo-documento.cfm?artid=13666.

Liguria, L.R. n. 13/2009, Modifica alla l.r. n. 31 del 1998 (norme in materia di trasporto pubblico locale) e successive modificazioni e intefgrazioni, http://federalismi.it/nv14/articolo-documento.cfm?Artid=13320\&content=\&content_author=.

Veneto, L.R. n. 11/2009, Disposizioni in materia di attività di trasporto di viaggiatori effettuato mediante noleggio di autobus con conducente e modifica dell'articolo 4 della legge regionale 30 ottobre 1998 n. 25B, http://federalismi.it/nv14/ articolo-documento.cfm?Artid=12937\&content=Disposizioni + in + materia + di + attivit\%C3\%A0+di+trasporto+di+viaggiatori+effettuato+mediante+noleggio+di+autobu$\mathrm{s}+$ con+conducente $+\mathrm{e}+$ modifica+dell\%27articolo+4+della+legge+regionale+30+ottobre+1998+n.+25\&content_author $=$.

\section{Strony internetowe}

http://www.vr.fi/fin.

www.ratp.info.

www.imtt.pt.

www.trenitalia.it.

http://www.sl.se/templates/PriceList.aspx?id=5302.

http://www.bkv.hu/english/jegyinfo/fares.html.

http://elvira.mav-start.hu/elvira.dll/xslms.

www.atac.roma.it.

https://www.inps.it/nuovoportaleinps/default.aspx. 


\title{
Część 4
}

\section{Organizacja pracy szkoły}

\author{
Part 4
}

Work organisation in school 
DOI: https://doi.org/10.31268/d.dziewulak.2020.01 


\title{
4.1. Kształcenie na odległość w wybranych państwach europejskich
}

\author{
E-learning in selected European countries
}

\begin{abstract}
W opracowaniu przedstawiono zagadnienie dotyczące kształcenia na odległość w wybranych państwach europejskich. W artykule zaprezentowano podstawowe definicje i synonimy tytułowego pojęcia. Przedstawiono syntetyczną informację o obecnym stanie i problemach kształcenia na odległość w następujących państwach: Polska, Czechy, Finlandia, Francja, Grecja, Hiszpania, Litwa, Niemcy, Norwegia, Portugalia, Szwecja, Węgry, Wielka Brytania.
\end{abstract}

Słowa kluczowe: szkoła, kształcenie na odległość, Unia Europejska

The paper attempts the development of e-learning in Czech Republic, Finland, France, Germany, Great Britain, Greece, Hungary, Lithuania, Norway, Poland, Portugal, Spain and Sweden. It begins with a brief overview of the definitions, history, advantages, as well and various approaches to e-learning services. Next, the author looks at the legal frameworks and challenges facing e-learning in the countries under review.

Keywords: school, distance learning, European Union

\section{Kształcenie na odległość - zarys problematyki}

Istotą kształcenia na odległość jest prowadzenie procesu nauczania w warunkach, gdy uczniowie oraz nauczyciele są oddaleni od siebie ${ }^{1}$. Zamiast klasycznej, bezpośredniej interakcji nauczyciel - uczeń wprowadza się kontakt pośredni, który realizowany jest z wykorzystaniem mediów elektronicznych (np. Internet, Intranet, Extranet, przekazy satelitarne, telewizja interaktywna) oraz dostępnych nośników zapisu (np. płyty CD i DVD).

1 Opracowanie przygotowano na podstawie ekspertyzy Biura Analiz Sejmowych nr 1817/12 z 3 października 2011 r. D. Dziewulaka zatytułowanej Informacja na temat kształcenia na odległość w wybranych państwach europejskich (Polska, Czechy, Finlandia, Francja, Grecja, Hiszpania, Litwa, Niemcy, Norwegia, Portugalia, Szwecja, Węry, Wielka Brytania) oraz opracowania tegoż autora Kształcenie na odległość w wybranych państwach Unii Europejskiej, „Analizy BAS” 2012, nr 18(85), s. 1-11. 
Kształcenie na odległość nie jest zjawiskiem nowym, gdyż już ponad sto lat wcześniej wykorzystywano tę metodę w procesie nauczania-uczenia się, przesyłając zwykłą pocztą materiały, podręczniki, książki i specjalistyczną prasę. Pierwsza szkoła korespondencyjna powstała w Anglii w 1840 roku, następne w 1856 roku w Berlinie, 1860 roku - w USA, 1916 roku - w Polsce. Pierwsze ustawy o edukacji na odległość przyjęto w Norwegii w 1914 roku.

W XX wieku wraz z upowszechnieniem radia, i w niedługim czasie telewizji, wprowadzono radiowe i telewizyjne programy edukacyjne. Pierwsze radio edukacyjne rozpoczęło działalność w latach dwudziestych XX wieku w USA, a wykorzystane zostało na powszechną skalę w latach trzydziestych ubiegłego stulecia w Australii. Podobnie w Polsce, już na początku lat dwudziestych XX wieku Polskie Towarzystwo Radiofoniczne i Wszechnica Radiowa nadawały cykliczne audycje w formie lekcji z historii Polski, literatury, sportu, wiedzy o świecie. Jako pierwszy telewizję dla potrzeb kształcenia na odległość wykorzystał w latach 1932-1937 stanowy Uniwersytet Iowa (USA), emitując kursy telewizyjne z zakresu higieny jamy ustnej oraz rozpoznawania konstelacji gwiazd. W Polsce telewizyjne kształcenie na odległość zainaugurowała w 1960 roku Wszechnica Telewizyjna. Pojawienie się komputerów w drugiej połowie XX wieku spowodowało powstanie zapotrzebowania na multimedialne programy edukacyjne, a współczesne elektroniczne nośniki przekazu, jak chociażby powszechny Internet, sprawiły, że kształcenie na odległość zaczęło przeżywać swój renesans. Masowość Internetu zagwarantowała dotarcie do dużej grupy uczniów bez konieczności konstruowania dedykowanych infrastruktur technicznych przeznaczonych jedynie do realizowania celów dydaktycznych. Kształcenie przez Internet może więc zostać uznane za obowiązujący aktualnie paradygmat kształcenia na odległość. Niestety, umieszczenie w Internecie wyłącznie treści dydaktycznych nie gwarantuje sukcesu w edukacji. Idea kształcenia nie polega wyłącznie na dostarczaniu wiedzy, ale również na kontroli i wspomaganiu ucznia w procesie uczenia się. W wypadku kształcenia na odległość możliwe jest to jedynie przez wykorzystanie dedykowanych systemów informatycznych takich jak: system do zarządzania szkoleniami (Learning Management Systems, LMS), system do zarządzania treścią szkoleniową (Learning Content Management System, LCMS), system do zarządzania komunikacją synchroniczną (Life Communication System, LCS), które umożliwiają przechowywanie treści dydaktycznych, zarządzanie nimi i ich publikowanie, a także pozwalają na kompleksową obsługę całego procesu edukacyjnego od chwili zapisu na kurs, aż do jego ukończenia.

Przemiany technologiczne zachodzące w kształceniu na odległość wpłynęły także na ewolucję oferowanych sposobów nauczania. Wcześniejsze sposoby na- 
uki na odległość miały charakter asynchroniczny, czyli taki, w którym nauczyciel i uczeń nie kontaktują się ze sobą w tym samym czasie i miejscu. Obecnie stosowana technologia pozwala już na nauczanie synchroniczne, czyli na komunikację w czasie rzeczywistym, tak jakby uczeń i nauczyciel siedzieli obok siebie, mimo przebywania w różnych miejscach. Najpopularniejszym, stale udoskonalanym rozwiązaniem nauczania synchronicznego jest korzystanie z wirtualnych platform edukacyjnych, a zwłaszcza ze spersonalizowanej internetowej przestrzeni dydaktycznej, która w swym założeniu powinna dawać nauczycielom dostęp do zasobów e-nauczania, umożliwiać bezpośrednią komunikację i współpracę z uczniami i innymi nauczycielami oraz umożliwić śledzenie postępów ucznia.

W chwili obecnej kształcenie na odległość jest najbardziej zaawansowaną technologicznie formą edukacji. W dzisiejszym szybko zmieniającym się świecie taka forma zdobywania wiedzy pozwala na ogromną redukcję kosztów, znacznie szybszy proces edukacji, łatwiejszy dostęp do szkoleń oraz szybką kontrolę i ocenę uczestników procesu szkoleniowego.

Wśród zalet nauczania na odległość wymienia się2:

- dostępność bez względu na ograniczenia czasowe i lokalowe,

- indywidualizację tempa nauczania,

- mniejsze koszty nauki (brak zakwaterowania, dojazdów itp.),

- efektywność procesu edukacyjnego.

Wśród wad wskazuje się na:

- brak „żywego” kontaktu nauczyciel-uczeń,

- brak wystarczającego zaplecza technologicznego, które nie nadąża za potrzebami i oczekiwaniami uczestników kształcenia,

- niedobór odpowiednio przygotowanej kadry nauczycielskiej,

- brak przepisów w wielu krajach umożliwiających uznanie dyplomów uzyskanych w procesie kształcenia na odległość, jako formalnego potwierdzenia zdobytych uprawnień.

\section{Kształcenie na odległość - pojęcia, synonimy}

Samo pojęcie kształcenia na odległość doczekało się w literaturze przedmiotu wielu synonimów, a także wielu prób zdefiniowania i opisania tego zjawiska. W Polsce kształcenie na odległość określane bywa jako nauczanie na odległość,

2 http://www.profesor.pl/mat/na9/pokaz_material_tmp.php?plik=na9/na9_m_piwonska_040113_1.php\&id_m=8850. 
nauka na odległość, uczenie się na odległość, nauczanie lub uczenie się zdalne, edukacja zdalna, kształcenie zdalne, wirtualna edukacja, e-edukacja, e-nauczanie, e-kształcenie, edukacja telematyczna, kształcenie przez Internet, kształcenie z wykorzystaniem Internetu. Zjawisko kształcenia na odległość próbuje się także opisywać, wykorzystując pojęcia zapożyczone z języka angielskiego. Wśród nich najczęściej używanym w polskiej literaturze jest e-learning. Ponadto spotyka się: distance education, distance learning, distance teaching, correspondence study, independent study, open education, teleteaching, teaching by network, telematic education, asynchronous learning, synchronous learning, distributed education, on-line learning, m-learning, CAL (Computer Aided Learning), CBT (Computer-Based Training), WBT (Web-Based Training).

\section{Kształcenie na odległość - definicje}

W literaturze przedmiotu zagadnienie kształcenia na odległość najczęściej definiowane jest jako metoda nauczania, która zamiast bezpośredniego kontaktu ucznia i nauczyciela (studenta i profesora) wykorzystuje kontakt pośredni. Uczyć się na odległość, oznacza opanować wiedzę samodzielnie bez udziału tradycyjnej formy lekcyjnej. Każdy uczestnik tego procesu wyznacza sobie (programuje) cel kształcenia dostosowany do swoich potrzeb oraz warunków i trybu swojego życia ${ }^{3}$.

Inne definicje także podkreślają znaczenie prowadzenia procesu dydaktycznego w warunkach, gdy nauczyciele i uczniowie (studenci) są od siebie oddaleni (często znacznie). Odległość między nauczycielem i uczniem nie stanowi jednak przeszkody, gdyż sam proces dydaktyczny wykorzystuje - oprócz tradycyjnych sposobów komunikowania się - nowoczesne technologie informacyjno-komunikacyjne, tzw. TIK (Information and Communication Technologies, ICT), umożliwiające przesłanie w czasie rzeczywistym drogą elektroniczną głosu, obrazu, danych oraz dowolnych materiałów wizualnych ${ }^{4}$.

\section{Kompetencje kluczowe w uczeniu się przez całe życie}

We współczesnych systemach oświatowych cele edukacyjne wyznaczane są z wykorzystaniem tzw. idei kompetencji i umiejętności. Zalecenia wydane przez Parlament Europejski i Radę w 2006 r. dotyczące kompetencji kluczowych w procesie uczenia

3 S. Juszczyk, Edukacja na odległość. Kodyfikacja pojęć, reguł i procesów, Wydawnictwo Adam Marszałek, Warszawa 2002, s. 124.

4 M.J. Kubiak, Wirtualna edukacja, Wydawnictwo MIKOM, Warszawa 2000, s. 11. 
się przez całe życie ${ }^{5}$ wyznaczają europejskie ramy edukacyjne $\mathrm{w}$ tej dziedzinie. Kompetencje kluczowe we współczesnym kształceniu ustawicznym - w tym także realizowanym w kształceniu na odległość - to połączenie wiedzy, umiejętności i odpowiednich postaw odniesione do konkretnych sytuacji. Są one szczególnie pomocne w kształtowaniu rozwoju osobistego, potrzeb samorealizacji, bycia aktywnym obywatelem i budowaniu umiejętności umożliwiających zdobycie zatrudnienia.

Do kompetencji kluczowych edukacyjnych zalicza sięe:

- porozumiewanie się w języku ojczystym,

- porozumiewanie się w językach obcych,

- kompetencje matematyczne i podstawowe kompetencje naukowo-techniczne,

- kompetencje informatyczne,

- umiejętność i zdolność konsekwentnego uczenia się,

- kompetencje społeczne i obywatelskie,

- kompetencje związane z przedsiębiorczością,

- kompetencje z obszaru świadomość i ekspresja kulturowa.

Uważa się, że osoby, które w szczególności powinny nabyć kompetencje kluczowe to młodzi ludzie kończący obowiązkową edukację oraz osoby dorosłe podlegające kształceniu ustawicznemu. Nie dziwi więc, że we współczesnym świecie, w którym komputer stał się częścią składową naszego codziennego życia, edukacja młodzieży oraz kształcenie ustawiczne dorosłych coraz powszechniej realizuje model kształcenia na odległość z wykorzystaniem wszelkich dostępnych technologii informacyjnych i komunikacyjnych.

Poniżej przedstawiono syntetyczne informacje na temat kształcenia na odległość w wybranych krajach europejskich.

\section{Kształcenie na odległość w wybranych krajach}

\section{Polska}

W Polsce regulacje prawne dotyczące kształcenia na odległość można znaleźć w ustawie o systemie oświaty, ustawie - Prawo o szkolnictwie wyższym i rozporządzeniu Ministra Nauki i Szkolnictwa Wyższego w sprawie warunków, jakie

5 Zalecenie Parlamentu Europejskiego i Rady nr 2006/962/WE z 18 grudnia 2006 r. w sprawie kompetencji kluczowych w procesie uczenia się przez całe życie, Dz.Urz. UE L 394 z 30 grudnia 2006 r., http://eur-lex.europa.eu/LexUriServ/LexUriServ.do?uri=CELEX:32006H0962:PL:NOT.

6 http://europa.eu/legislation_summaries/education_training_youth/lifelong_learning/ c11090_pl.htm. 
muszą być spełnione, aby zajęcia dydaktyczne na studiach mogły być prowadzone z wykorzystaniem metod i technik kształcenia na odległość.

Ustawa z 7 września 1991 r. o systemie oświaty ${ }^{7}$ (Dz.U. 2000, nr 256, poz. 2572, ze zm.) w art. 68a pkt. 3 określa, że kształcenie ustawiczne może być prowadzone jako stacjonarne lub zaoczne, a także z wykorzystaniem metod i technik kształcenia na odległość. Ustawa z 27 lipca 2005 r. - Prawo o szkolnictwie wyższym ${ }^{8}$ (Dz.U. nr 164, poz. 1365, ze zm.) w art. 164 pkt 3 stanowi, że zajęcia dydaktyczne na studiach mogą być prowadzone także z wykorzystaniem metod i technik kształcenia na odległość.

Rozporządzenie Ministra Nauki i Szkolnictwa Wyższego z 25 września 2007 r. ${ }^{9}$ w sprawie warunków, jakie muszą być spełnione, aby zajęcia dydaktyczne na studiach mogły być prowadzone z wykorzystaniem metod i technik kształcenia na odległość w § 1 określa, że zajęcia dydaktyczne mogą być prowadzone z wykorzystaniem metod i technik kształcenia na odległość na wszystkich kierunkach studiów, przy uwzględnieniu ich specyfiki, na wszystkich poziomach kształcenia na studiach stacjonarnych i niestacjonarnych. W rozporządzeniu z 2 listopada 2011 r. zmieniającym wcześniejsze rozporządzenie w sprawie warunków, jakie muszą być spełnione, aby zajęcia dydaktyczne na studiach mogły być prowadzone z wykorzystaniem metod i technik kształcenia na odległość, § 5 pkt 1 stanowi, że liczba godzin zajęć dydaktycznych na studiach stacjonarnych i niestacjonarnych, prowadzonych z wykorzystaniem metod i technik kształcenia na odległość, nie może być większa niż 60\% ogólnej liczby godzin zajęć dydaktycznych określonych w programach kształcenia dla poszczególnych kierunków studiów oraz poziomów kształcenia. Zgodnie z § 5 pkt 2 rozporządzenia metody i techniki kształcenia na odległość, w tym wirtualne laboratoria, mogą mieć jedynie charakter wspomagający wobec kształcenia praktycznego (np. zajęcia laboratoryjne, terenowe, warsztatowe) wymagającego bezpośredniego udziału nauczycieli akademickich i studentów.

W Polsce kształcenie na odległość rozwija się dwutorowo - w środowisku biznesu i w szkolnictwie, zwłaszcza wyższym.

Zainteresowanie biznesu kształceniem na odległość wynika najczęściej z potrzeb przeszkolenia dużej liczby pracowników firm i jednoczesnego ograniczenia kosztów takiej edukacji. Należy więc przypuszczać, że e-learning coraz bardziej

7 http://www.prawo.vulcan.edu.pl/przegdok.asp?qdatprz=akt\&qplikid=1.

8 http://www.nauka.gov.pl/fileadmin/user_upload/szkolnictwo/Reforma/20110523_USTAWA_z_dnia_27_lipca_2005.pdf.

9 http://www.bip.nauka.gov.pl/_gAllery/28/08/2808/20070925_rozporzadzenie.pdf. 
będzie wpływał na strategiczny rozwój przedsiębiorstw, wymuszając wprowadzanie nowych technologii edukacyjnych, wykorzystywanie platform edukacyjnych oraz tworzenie wirtualnych i mobilnych miejsc pracy.

W obszarze szkolnictwa podstawowego, średniego i pomaturalnego najczęściej oferowanymi szkoleniami e-learningowymi są kursy informatyczne, językowe, przygotowujące do matury lub podnoszące kwalifikacje zawodowe. Na poziomie akademickim kształcenie na odległość pozostaje w gestii poszczególnych uczelni i coraz częściej przybiera formy bardziej otwarte skierowane do środowisk pozaakademickich. Wśród najbardziej znanych w Polsce ośrodków kształcenia na odległość jest COME - Centrum Otwartej i Multimedialnej Edukacji Uniwersytetu Warszawskiego, OKNO - Ośrodek Kształcenia na Odległość Politechniki Warszawskiej, PUW - Polski Uniwersytet Wirtualny, Centrum Zdalnego Nauczania Uniwersytetu Jagiellońskiego, Centrum e-learningu AGH w Krakowie, CREN - Centrum Rozwoju Edukacji Niestacjonarnej Szkoły Głównej Handlowej w Warszawie.

Centrum Otwartej i Multimedialnej Edukacji (COME) jest ogólnouniwersytecką jednostką Uniwersytetu Warszawskiego. Powstało z przekształcenia Studium Kształcenia Otwartego na podstawie uchwały Senatu Uniwersytetu Warszawskiego z 23 czerwca 1999 roku. Misją COME jest rozszerzanie dostępu do edukacji uniwersyteckiej. Do głównych zadań Centrum należy:

- promowanie i koordynowanie działań Uniwersytetu w zakresie edukacji z wykorzystaniem Internetu,

- przygotowywanie i prowadzenie kursów przez Internet,

- organizacja i rozwijanie systemu obsługi edukacji przez Internet,

- dostarczanie usług edukacyjnych przeznaczonych dla osób dorosłych, niezależnie od ich wykształcenia i miejsca zamieszkania,

- prowadzenie prac badawczych nad edukacją zdalną z wykorzystaniem technologii TIK,

- przygotowywanie kadry dydaktycznej Uniwersytetu, zgodnie z wymaganiami stawianymi przez nowe formy edukacyjne,

- $\quad$ współpraca z Uniwersytetem Otwartym ${ }^{10}$ w części dotyczącej kursów przez Internet,

- współpraca z ośrodkami realizującymi podobne zadania w kraju i za granicą. Ośrodek Kształcenia na Odległość Politechniki Warszawskiej (OKNO) prowadzi kształcenie na odległość z wykorzystaniem tzw. modelu SPRINT opartego na

10 http://www.uo.uw.edu.pl/. 
metodzie stosowanej przez Open University w Wielkiej Brytanii i FernUniversität w Niemczech. Zastosowany model oparty jest na założeniu, że studiując na odległość student ma możliwość samodzielnego określania czasu, miejsca i tempa studiowania. Model SPRINT wykorzystuje najnowsze osiągnięcia telekomunikacji, informatyki i technik multimedialnych, oferując zajęcia dydaktyczne w trzech najważniejszych postaciach: kształcenie multimedialne, zajęcia laboratoryjne na uczelni, pisanie pracy dyplomowej (postępy prac nad projektami dyplomowymi prezentowane są na specjalnym wirtualnym seminarium dyplomowym, a praca dyplomowa prezentowana jest przez studenta w trakcie egzaminu, przed „żywą komisją”).

Polski Uniwersytet Wirtualny (PUW) uruchomił pierwsze kierunki studiów on-line w październiku 2002 roku. Obecnie PUW ma w swojej ofercie studia licencjackie, studia magisterskie i studia podyplomowe oraz kursy przez Internet. Uczelnia zajmuje się promowaniem w Polsce nowoczesnych metod kształcenia e-learningu.

Centrum Zdalnego Nauczania Uniwersytetu Jagiellońskiego to uczelniana jednostka pozawydziałowa, której celem jest promocja e-learningu akademickiego, wspieranie rozwoju nowych form i metod dydaktycznych na uniwersytecie oraz udzielanie pomocy wykładowcom w projektowaniu i prowadzeniu zajęć przez Internet. Do głównych zadań Centrum należy: prowadzenie szkoleń (w tym w zakresie obsługi uczelnianej platformy zdalnego nauczania), realizacja zajęć za pośrednictwem Internetu, tworzenie multimedialnego serwisu poświęconego e-learningowi (informacji na temat bezpłatnych e-materiałów, funduszy unijnych oraz konferencji). Centrum prowadzi konsultacje dla nauczycieli wykorzystujących Internet w nauczaniu i doradza, jak opracować programy nauczania do kształcenia prowadzonego przez Internet. Jest członkiem Stowarzyszenia e-Learningu Akademickiego i Seminarium Praktyków e-Edukacji. Interesującą inicjatywą Centrum jest Jagiellońskie Kompendium e-Edukacji - internetowy leksykon na temat różnych aspektów dydaktycznych, technologicznych i organizacyjnych e-nauczania.

Centrum Rozwoju Edukacji Niestacjonarnej Szkoły Głównej Handlowej w Warszawie (CREN) jest jednostką pozawydziałową SGH. Głównym celem Centrum jest organizowanie działalności uczelni w zakresie rozwoju nauczania przez Internet, prowadzenie szkoleń i kursów dla pracowników SGH oraz instytucji zewnętrznych. Do najważniejszych zadań CREN SGH należy:

- inicjowanie, inspirowanie i organizowanie projektów w dziedzinie edukacji niestacjonarnej i kształcenia ustawicznego, 
- prowadzenie punktu informacyjnego o realizowanych w SGH projektach w zakresie edukacji niestacjonarnej oraz ich promocja,

- organizowanie prac badawczych w zakresie edukacji niestacjonarnej i kształcenia ustawicznego,

- prowadzenie uczelnianej platformy nauczania przez Internet (tworzenie i promocja programów nauczania, opracowywanie odpowiednich narzędzi i metod dydaktycznych, wspomaganie indywidualnych inicjatyw oraz koordynacja ofert dydaktycznych pracowników, tworzenie i administrowanie multimedialną bazą podręczników i innych materiałów dydaktycznych),

- organizowanie seminariów i konferencji w zakresie nauczania przez Internet i kształcenia ustawicznego,

- prowadzenie redakcji uczelnianego pisma „e-mentor”. Pismo koncentruje się na zagadnieniach związanych z e-learningiem, zarządzaniem wiedzą, e-biznesem, kształceniem ustawicznym - w tym na metodach, formach i programach kształcenia,

- wydawanie i udostępnianie innych publikacji w zakresie nauczania przez Internet i kształcenia ustawicznego,

- współpraca z krajowymi i zagranicznymi ośrodkami zajmującymi się nauczaniem przez Internet i kształceniem ustawicznym,

- administrowanie uruchomionymi projektami edukacyjnymi, w tym prowadzenie rozliczeń z ich uczestnikami oraz wydawanie stosownych świadectw.

\section{Czechy}

W Republice Czeskiej podstawowe regulacje prawne dotyczące kształcenia na odległość znajdują się w trzech ustawach - o edukacji, o szkolnictwie wyższym oraz o weryfikacji i uznawaniu wyników kształcenia.

Ustawa o edukacji11 (ustawa nr 561/2004) w art. 25 określa, że kształcenie na poziomie szkoły średniej i wyższej zawodowej może być organizowane w trybie dziennym lub wieczorowym, jak również w formie e-learningu, kształcenia na odległość lub w formach łączonych. Ustawa wskazuje na równorzędność wszystkich tych form kształcenia i podaje ich definicje:

- e-learning - jako samodzielna edukacja pobierana przy zastosowaniu technologii informacyjnych, również uzupełniona o indywidualne konsultacje,

11 http://www.msmt.cz/areas-of-work/act-no-561-the-education-act?lang=2. 
- kształcenie na odległość rozumiane jest jako samodzielna edukacja (uzupełniona o indywidualne konsultacje naukowe) w wymiarze 200-220 godzin w ciągu całego roku szkolnego,

- łączone formy kształcenia - jako edukacja odbywająca się we wszystkich możliwych trybach i formach.

Czas trwania kształcenia w trzech powyższych formach może być dłuższy maksymalnie o jeden rok w stosunku do czasu trwania kształcenia prowadzonego w trybie stacjonarnym. Ustawa o szkolnictwie wyższym ${ }^{12}$ (ustawa nr 111/1998) w art. 44 określa trzy możliwe formy kształcenia: kształcenie w formie stacjonarnej, na odległość oraz kształcenie łączące obie te formy. Dyplomy kwalifikacji zawodowych uzyskane w Czechach w ramach kształcenia na odległość mogą być uznane za równorzędne z uzyskanymi w procesie kształcenia klasycznego, co zapewniają przepisy ustawy o weryfikacji i uznawaniu wyników kształcenia ${ }^{13}$ (ustawa nr 179/2006).

\section{Finlandia}

Kształcenie na odległość realizowane jest w Finlandii na podstawie ustawy nr 629/1998 o szkolnictwie średnim II stopnia oraz rozporządzeń nr 810/1998 i 955/2002 w sprawie celów kształcenia na poziomie szkoły średniej II stopnia i rozkładu godzin lekcyjnych ${ }^{14}$.

W Finlandii kształcenie na odległość na poziomie szkoły średniej II stopnia (ponadgimnazjalnej) skierowane było pierwotnie do uczniów dorosłych, a w ostatnich latach stało się także alternatywą edukacyjną dla uczniów realizujących obowiązek szkolny. Prognozy demograficzne Finlandii wskazują na znaczne zmniejszanie się liczby uczniów na poziomie szkoły podstawowej i szkoły średniej. Malejąca liczba uczniów powoduje likwidowanie placówek szkolnych, a w konsekwencji trudniejszy dostęp do edukacji. Zmiany te stanowią prawdziwe wyzwanie dla sieci instytucji oświatowych, które próbują dostosować się do nowej sytuacji, tak aby zapewnić gwarantowany prawem dostęp do edukacji wszystkim młodym ludziom, bez względu na ich miejsce zamieszkania, język czy sytuację finansową. Jednym z kluczowych środków do osiągnięcia tego

12 http://www.msmt.cz/vzdelavani/zakon-c-111-1998-sb-o-vysokych-skolach.

13 http://www.msmt.cz/dokumenty/zakon-c-179-2006-sb-o-overovani-a-uznavani-vysledku-dalsiho-vzdelavani-a-o-zmene-nekterych-zakonu-1.

14 http://www.finlex.fi/fi/laki/ajantasa/1998/19980629. 
celu jest wykorzystanie nowoczesnych technologii informacyjno-komunikacyjnych, e-learningu i kształcenia na odległość.

W ramach kształcenia na odległość uczeń lub słuchacz dorosły realizuje ustawową podstawę programową, która określa przedmioty i liczbę godzin. W celu odbycia takiego kształcenia, powinien zgłosić się do placówki prowadzącej kształcenie na odległość na poziomie szkoły średniej II stopnia, a następnie, przy pomocy indywidualnego opiekuna oraz nauczycieli poszczególnych przedmiotów, ułożyć indywidualny harmonogram swojej nauki. Tak zaplanowany harmonogram realizowany jest pod nadzorem nauczycieli w formie kształcenia na odległość. Uczeń lub słuchacz ma do swojej dyspozycji drukowane podręczniki i inne materiały w formie papierowej, specjalne programy do uczenia się na odległość z wykorzystaniem radia, telewizji, płyt $\mathrm{CD}$, poczty elektronicznej, materiałów internetowych i pomocy on-line.

Wśród głównych celów kształcenia na odległość na poziomie szkoły średniej II stopnia wskazuje się:

- stworzenie, głównie osobom dorosłym, możliwości zdobycia wykształcenia na poziomie szkoły średniej II stopnia i przystąpienia do egzaminu maturalnego,

- rozszerzenie możliwości kształcenia i podwyższania kwalifikacji (wiedzy i umiejętności) społeczeństwa w celu ułatwienia dostępu do globalnego międzynarodowego rynku pracy,

- rozwinięcie współpracy między szkołami średnimi, szkołami zawodowymi, organami administracji oświatowej a przemysłem i handlem (także branżą technologii komunikacyjnych) i stworzenie materiałów do kształcenia na odległość przy użyciu technologii komunikacyjnych,

- stworzenie/rozwinięcie i rozpowszechnianie metod kształcenia na odległość i użycia technologii informacyjno-komunikacyjnych w edukacji dla szkół średnich.

Obok kształcenia na odległość realizowanego na szczeblu szkoły średniej bardzo popularną formą edukacji w Finlandii jest wykorzystanie e-learningu w kształceniu ustawicznym dorosłych organizowanym głównie przez Centra Kształcenia Ustawicznego przy uniwersytetach otwartych. Głównym celem takiego kształcenia jest zapewnienie osobom dorosłym, posiadającym już wykształcenie w danej dziedzinie, możliwości aktualizowania swojej wiedzy oraz zdobycia nowych kwalifikacji zawodowych. Ponad 1/3 wszystkich kursów oferowanych przez Centra Kształcenia Ustawicznego realizowana jest przy zastosowaniu kształcenia na odległość. 


\section{Francja}

Francuska ustawa oświatowa ${ }^{15} \mathrm{w}$ artykule L.131-2 stanowi, że kształcenie na odległość we Francji ma zapewnić przede wszystkim dostęp do edukacji dzieciom, które nie mogą uczęszczać do szkół i żadnych innych placówek. Instytucją odpowiedzialną za realizację tego przepisu jest Krajowe Centrum Kształcenia na Odległość (Centre national d'enseignement à distance, $\mathrm{CNED}^{16}$ ) podległe Ministerstwu Edukacji Narodowej, Szkolnictwa Wyższego i Badań Naukowych ${ }^{17}$. Oferuje ono korespondencyjne kursy i szkolenia oparte na nowoczesnych technologiach komunikacyjnych. Wśród propozycji edukacyjnych znajduje się kształcenie adresowane do uczniów szkół podstawowych i średnich, którzy nie mogą z różnych przyczyn uczęszczać do szkoły, a także kształcenie skierowane do osób dorosłych (studia magisterskie, licencjackie, biznesowe, księgowe itd.). Centrum wykorzystuje nowe technologie informacyjno-komunikacyjne, ale również tradycyjne metody kształcenia na odległość, organizując wykłady, seminaria i spotkania studentów z wykładowcami - zwłaszcza gdy kształcenie prowadzi do uzyskania wyższych kwalifikacji zawodowych. Jednym z innowacyjnych programów stworzonych przez CNED jest „elektroniczny kampus” umożliwiający użytkownikom korzystanie ze wszystkich usług dostępnych w prawdziwym kampusie, takich jak: biblioteka, poradnictwo zawodowe, dokumentacja programów nauczania, przebiegu studiów, ewaluacji studentów i wykładowców itd. Centrum oferuje również kursy przygotowawcze do egzaminów na wszystkie kategorie określone w ścieżce zawodowej nauczyciela i personelu administracyjnego w krajowym systemie edukacji, a także - w porozumieniu z innymi podmiotami - organizuje kursy przygotowujące do egzaminów konkursowych związanych z ubieganiem się o stanowiska w administracji rządowej.

Centrum dysponuje także szeroką ofertą kursów i szkoleń skierowanych między innymi do osób bezrobotnych, odbywających staże, przygotowujących się do egzaminów podwyższających specjalistyczne kwalifikacje itp. Prowadzi specjalne kursy dla potrzeb dużych przedsiębiorstw i instytucji, w tym m.in. dla wojska, kolei francuskich (SNCF) czy prywatnych korporacji. Dodatkowo CNED uczestniczy w procesie reformowania francuskiego systemu szkolnictwa wyższego, które

15 Code de l'education, http://www.legifrance.gouv.fr/affichCode.do?idArticle=LEGIARTI0000 06525778\&idSectionTA=LEGISCTA000006182465\&cidTexte=LEGITEXT000006071191\&dateTe xte $=20100430$.

16 http://www.cned.fr/.

17 Zob. przyp. 12 na s. 114. 
od kilku lat podlega zmianom strukturalnym. Krajowe Centrum Kształcenia na Odległość jest de facto jedyną placówką publiczną we Francji realizującą z takim rozmachem i w tylu wymiarach ideę kształcenia ustawicznego $\mathrm{w}$ formie kształcenia na odległość przez całe życie - od dzieciństwa przez wiek dojrzały, aż do okresu starości.

\section{Grecja}

Kształcenie na odległość stanowi w Grecji istotne uzupełnienie krajowego systemu szkolnictwa wyższego. Szczególne znaczenie odgrywa także w kształceniu dorosłych, które realizowane jest w ramach edukacji ustawicznej.

Szkoły wyższe w Grecji podzielone są na dwie grupy. Do pierwszej grupy należą 24 państwowe uniwersytety, politechniki, wyższe szkoły artystyczne oraz

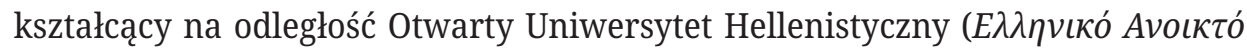

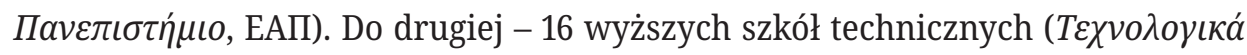

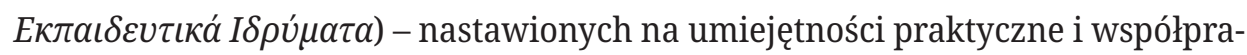
cę z biznesem. Młodzi ludzie mogą również studiować w kilkudziesięciu wyższych szkołach zawodowych, oferujących m.in. kierunki związane z turystyką i administracją. Na wszystkich poziomach szkolnictwa wyższego istnieje możliwość kształcenia na odległość.

Podstawowe akty prawne dotyczące kształcenia na odległość to:

- ustawa nr 3369/2005 o systematyzacji uczenia się przez całe życie i innych typach kształcenia ${ }^{18}$. Akt powołuje, między innymi, Ośrodek Kształcenia Ustawicznego na Odległość działający pod nadzorem Ministerstwa Edukacji, Kształcenia Ustawicznego i Spraw Religijnych,

- ustawa nr 2083/1992 o modernizacji szkolnictwa wyższego ${ }^{19}$. Akt ten stanowi podstawę utworzenia Otwartego Uniwersytetu Hellenistycznego - oficjalnej instytucji realizującej w Grecji ideę kształcenia przez całe życie. Przepisy dotyczące uniwersytetu zostały kilkakrotnie znowelizowane ustawą nr 2817/2000 o edukacji osób ze specjalnymi potrzebami edukacyjnymi oraz innych formach kształcenia oraz ustawą nr 3027/2002 o organizacji budynków szkolnych w szkolnictwie obowiązkowym, szkolnictwie wyższym i innych formach kształcenia.

18 http://www.dsanet.gr/Epikairothta/Nomothesia/n3369_05.htm.

19 http://www.poseedip.tuc.gr/fileadmin/users_data/poseedip/N_2083_1992.pdf. 


\section{Hiszpania}

Polityka oświatowa Hiszpanii od początku XXI wieku skupia się przede wszystkim na poprawie jakości i efektywności kształcenia realizowanego przez wzrost jakości kształcenia nauczycieli oraz zapewnienie wszystkim uczącym się swobodnego dostępu do technologii informacyjno-komunikacyjnych. Powszechne wykorzystanie nowoczesnych technologii TIK ułatwiło uczniom i osobom dorosłym dostęp do wyższych szczebli kształcenia oraz umożliwiło upowszechnienie idei kształcenia ustawicznego. Hiszpańska ustawa o edukacji ${ }^{20}$ wskazuje kształcenie na odległość jako ważne narzędzie tworzenia środowiska otwartej nauki umożliwiające obywatelom szeroki dostęp do oświaty z wykorzystaniem atrakcyjnych i zrozumiałych przez współczesne społeczeństwo form uczenia się. W efekcie kształcenie na odległość stało się ważnym narzędziem wspierania idei aktywnego i świadomego obywatelstwa, równości szans i spójności społecznej. Ma także pomóc w zmianie mentalności społecznej, zachęcając innowacyjnymi metodami dydaktycznymi do ustawicznego kształcenia jako procesu trwającego przez całe życie człowieka.

Ustawa o edukacji zapewnia:

- uczniom, studentom i słuchaczom, którzy z różnych względów nie mogą uczęszczać regularnie do szkoły, na uczelnię lub kurs, prawo do edukacji w formie kształcenia na odległość lub gwarantuje inne wsparcie uwzględniające specjalne potrzeby edukacyjne uczącego się,

- możliwość nauki wybranego przedmiotu w innej szkole lub w formie kształcenia na odległość, jeśli wybór i zakres przedmiotów wykładanych w danej szkole są niewystarczające w stosunku do potrzeb uczących się,

- włączenie kształcenia na odległość do szkół prowadzących naukę hiszpańskiego języka urzędowego (Konstytucja Hiszpanii stanowi, że: kastylijski jest hiszpańskim urzędowym językiem państwa),

- organizację i prowadzenie edukacji dorosłych w trybie stacjonarnym lub na odległość opartych na zasadach samodzielnego uczenia się, doświadczenia, potrzeby i zainteresowania słuchaczy,

- edukację na poziomie szkolnictwa policealnego na bazie kształcenia na odległość i opartej na najnowszych technologiach informacyjno-komunikacyjnych.

20 Ley Orgánica 2/2006, de 3 de mayo, de Educación, http://www.boe.es/aeboe/consultas/bases_datos/doc.php?id=BOE-A-2006-7899. 
Jedną z najważniejszych instytucji zajmujących się w Hiszpanii problematyką kształcenia na odległość jest Centrum Innowacji i Rozwoju Kształcenia na Odległość (Centro para la Innovación y Desarrollo de la Educación a Distancia, CIDEAD) utworzone na mocy dekretu $\mathrm{nr} 1180 \mathrm{z} 1992 \mathrm{r} .{ }^{21}$

Centrum Innowacji i Rozwoju Kształcenia na Odległość22 organizacyjnie podlega Ministerstwu Edukacji, a jego misją jest organizacja i koordynacja kształcenia na odległość na szczeblu krajowym. Do zadań CIDEAD należy: ułatwianie dostępu do edukacji zarówno osobom dorosłym, jak dzieciom i młodzieży w wieku szkolnym, które ze względów osobistych, społecznych, geograficznych lub innych nie mogą regularnie uczęszczać do szkoły. Centrum prowadzi kształcenie na poziomie szkoły podstawowej, średniej I i II stopnia, kształcenie zawodowe, naukę języka urzędowego oraz edukację ustawiczną dorosłych. Nauczanie odbywa się z wykorzystaniem odpowiednio zaadaptowanych programów edukacyjnych i multimedialnych materiałów dydaktycznych, doradczych i pomocniczych. Popularność kształcenia na odległość sprawia, że przewiduje się, iż w najbliższej przyszłości doskonalenie zawodowe nauczycieli specjalizujących się w zakresie aplikacji narzędzi TIK w procesie dydaktycznym będzie odbywać się wyłącznie w systemie kształcenia on-line.

Ze względu na specyfikę hiszpańskiego systemu edukacji, który jest systemem silnie zdecentralizowanym, co oznacza zróżnicowanie obowiązujących regulacji i stopnia zaawansowania realizacji kształcenia na odległość w poszczególnych wspólnotach autonomicznych, CIDEAD na mocy odpowiednich uzgodnień współpracuje z poszczególnymi wspólnotami. Współpraca dotyczy przede wszystkim upowszechnienia oferty edukacji na odległość dla dorosłych. Dzięki tym staraniom udało się stworzyć we wspólnotach autonomicznych sieć szkolnictwa podstawowego i średniego dla dorosłych działającą w trybie kształcenia na odległość.

Kształcenie na odległość funkcjonuje w Hiszpanii także w obszarze szkolnictwa wyższego. Instytucją specjalizującą się tym segmencie oświaty jest Narodowy Uniwersytet Kształcenia na Odległość (Universidad Nacional de Educación a Distancia, UNED) powołany na mocy dekretu nr 2310/1972 z $1972 \mathrm{r}^{23}$. Uniwersytet

21 Real Decreto 1180/1992, de 2 de octubre, por el que se crea el Centro para la Innovación y Desarrollo de la Educación a Distancia, http://www.boe.es/aeboe/consultas/bases_datos/ doc.php?id=BOE-A-1992-23316.

22 http://cidead.cnice.mec.es/.

23 Decreto 2310/1972, de 18 de agosto, por el que se crea la Universidad Nacional de Educación a Distancia, http://www.boe.es/buscar/doc.php?id=BOE-A-1972-1309 oraz: http://www.boe. es/boe/dias/2005/04/16/pdfs/A13117-13128.pdf, http://www.boe.es/boe/dias/2007/04/13/pdfs/ A16241-16260.pdf. 
jest krajową uczelnią publiczną podległą Ministerstwu Edukacji i Nauki ${ }^{24}$. Mając zarejestrowanych 250 tys. studentów i słuchaczy, jest największym uniwersytetem tego typu w Hiszpanii i drugim co do wielkości w Europie po Open University w Wielkiej Brytanii. Specjalizuje się w kształceniu na odległość. Jego oferta edukacyjna obejmuje 27 kierunków kształcenia w ramach Europejskiego Obszaru Szkolnictwa Wyższego, 49 kierunków kształcenia magisterskiego, 44 programy studiów doktoranckich oraz ponad 600 kursów umożliwiających rozwój zawodowy. Realizując zadania edukacyjne, łączy klasyczną dydaktykę z wykorzystaniem nowych technologii informacyjno-komunikacyjnych, oferując wirtualne kursy realizowane za pośrednictwem Internetu, telewizji edukacyjnej i programów radiowych.

W ramach UNED ważną działalność w obszarze kształcenia na odległość prowadzi Uniwersytecki Instytut Kształcenia na Odległość (Instituto Universitario de Educación a Distancia, IUED) ${ }^{25}$. Do najważniejszych zadań Instytutu należy szkolenie nauczycieli, ocena materiałów i metod dydaktycznych, promowanie badań edukacyjnych i innowacyjności w obszarze kształcenia na odległość.

\section{Litwa}

Kształcenie na odległość stanowi na Litwie ważny segment krajowego systemu edukacji, a jego znaczenie dla polityki oświatowej państwa znalazło swój wyraz w wielu aktach prawnych.

Litewska ustawa o edukacji (Švietimo İstatymo) ${ }^{26}$ z 1991 r. (nowelizowana w 2010 r.) wskazuje kształcenie na odległość jako jedną z form nauki wykorzystywanych na różnych poziomach edukacji, a zwłaszcza w realizacji kształcenia ustawicznego. Uregulowania art. 32 ustawy zobowiązują placówki szkolnictwa zawodowego, policealnego i wyższego do zapewnienia osobom uczącym się i jednocześnie pracującym dostępu do edukacji z wykorzystaniem kształcenia na odległość. W wypadku zapotrzebowania społecznego na inne formy kształcenia litewskie Ministerstwo Oświaty może tworzyć szkoły zawodowe dla dorosłych w trybie na przykład kształcenia na odległość. Ustawa o pozaformalnym kształceniu dorosłych ${ }^{27}$ (Neformaliojo Suaugusiujų Švietimo İstatymas) z 1998 r. (nowelizowana w 2010 r.) wymienia w art. 5 główne formy kształcenia dorosłych, do

24 http://portal.uned.es/portal/page?_pageid=93,1\&_dad=portal\&_schema=PORTAL.

25 http://portal.uned.es/portal/page?_pageid=93,23312205,93_23312206\&_dad=portal\&_schema=PORTAL.

26 http://www3.lrs.lt/pls/inter3/dokpaieska.showdoc_l?p_id=365736.

27 http://www3.lrs.lt/pls/inter3/dokpaieska.showdoc_l?p_id=370996. 
których zalicza różne kursy krótkie, długie, dzienne, wieczorowe oraz kształcenie na odległość.

W ustawie o szkolnictwie wyższym i badaniach naukowych ${ }^{28}$ (Mokslo Ir Studijų İstatymas) z 2009 r. uregulowania m.in. art. 47, 50, 55 i 70 uwzględniają implicite naukę na odległość jako jedną z form kształcenia wyższego. Zgodnie z realizowaną na Litwie strategią uczenia się przez całe życie, w większości szkół wyższych funkcjonują Ośrodki Kształcenia na Odległość, których celem jest rozwijanie szkolnictwa wyższego i ustawicznego opartego na technologiach TIK. Uważa się, że nowe technologie służą rozwojowi kształcenia pozaformalnego, ustawicznego oraz na odległość, a tym samym upowszechniają na niespotykaną dotąd skalę dostęp do edukacji i nowoczesnych form uczenia się i nauczania. Coraz szersze zastosowanie nowoczesnych technologii i zwiększające się wymagania edukacyjne studentów zmuszają kadrę dydaktyczną do nieustannego podwyższania kwalifikacji naukowo-dydaktycznych.

Misję klasycznego szkolnictwa wyższego uzupełnia na Litwie działalność Krajowego Uniwersytetu Wirtualnego (Virtualus Universitetas). Jego program na lata 2007-2012 obejmuje stworzenie na bazie dotychczasowych doświadczeń oraz z wykorzystaniem infrastruktury TIK powszechnej sieci kształcenia na odległość na poziomie szkolnictwa wyższego. W konsekwencji na Litwie następuje szybki rozwój infrastruktury e-learningowej i, co się z tym wiąże, rozwój zintegrowanej informacyjnej wirtualnej przestrzeni edukacyjnej w sektorze szkolnictwa wyższego i badań naukowych.

Zasady organizacji kształcenia na odległość reguluje zarządzenie Ministerstwa Edukacji o kształceniu eksternistycznym i zaocznym z 2007 r. ${ }^{29}$ Kształcenie na odległość dla dorosłych na poziomie podstawowym i średnim powinno być prowadzone w formie kursów i konsultacji indywidualnych lub grupowych. Konsultacje na odległość definiuje się jako działania edukacyjne prowadzone przy użyciu technologii informacyjno-komunikacyjnych, m.in. poczty elektronicznej czy programów internetowych stosowanych na przykład w telefonach komórkowych. Zgodnie z zarządzeniem, konsultacje $\mathrm{w}$ tej formie mogą stanowić 1/3 wszystkich zajęć ucznia/słuchacza pobierającego naukę w trybie eksternistycznym lub zaocznym. Wszystkie konsultacje mogą odbywać się na odległość tylko w wypadku, gdy proces dydaktyczny dotyczy uczniów niepełnosprawnych.

28 http://www3.lrs.lt/pls/inter3/dokpaieska.showdoc_l?p_id=366717.

29 http://www3.lrs.lt/pls/inter3/dokpaieska.showdoc_l?p_id=303759. 
W 2002 roku parlament Litwy przyjął uchwałę o długoterminowej strategii rozwoju państwa ${ }^{30}$. W sektorze edukacji i nauki za główny priorytet uznano zwiększenie konkurencyjności edukacji litewskiej na rynku światowym, która ma być osiągnięta przez rozwój kształcenia na odległość oraz zwiększanie praktycznego zastosowania technologii informacyjno-komunikacyjnych w procesie uczenia się i nauczania. Dokumentem szczegółowo prezentującym plany rozwoju litewskiej oświaty oraz sposoby jego realizacji jest Program Wdrażania Narodowej Strategii Edukacyjnej na lata 2003-2012. Część II dokumentu określa cele, do których należą: opracowanie, zaakceptowanie oraz wdrażanie projektów kształcenia na odległość, rozwój programów kształcenia na odległość oraz rozbudowa sieci usług w tym zakresie (ze szczególnym uwzględnieniem potrzeb osób o ograniczonej sprawności ruchowej i osób o specjalnych potrzebach edukacyjnych). Część IV prezentuje przykłady realizacji powyższych celów, do których zalicza się uruchomienie na Litwie elektronicznego systemu informacji dotyczącej szkolnictwa wyższego i badań naukowych LieMSIS ${ }^{31}$ oraz komputerowej sieci naukowo-badawczej LITNET $^{32}$. LieMSIS i LITNET mają zostać połączone z europejskimi sieciami i bazami informatycznymi.

Obydwie sieci wykorzystano w pierwszej dekadzie 2000 roku w realizacji Strategii Rozwoju Społeczeństwa Informacyjnego na Litwie. W 2003 roku, aby ułatwić mieszkańcom kraju zdobycie i doskonalenie umiejętności w zakresie TIK, stworzono możliwość indywidualnego uczestnictwa w kursach podstaw komputerowych prowadzonych na odległość. Ponadto w ramach szkolnictwa wyższego opracowano programy nauczania kształcenia na odległość oraz przygotowano osoby do ich prowadzenia.

Wśród innych programów realizowanych na Litwie w ramach kształcenia na odległość należy zwrócić uwagę na:

- „Program na rzecz zdobywania umiejętności obsługi komputera” (realizowany od 2004 r.),

- „Język litewski w społeczeństwie informacyjnym. Program na lata 20072010”33 (skierowany do osób litewskiego pochodzenia będących obywatelami innych krajów, a pragnących nauczyć się języka ojczystego),

30 http://www3.lrs.lt/pls/inter3/dokpaieska.showdoc_l?p_id=219184.

31 http://liemsis.liedm.lt/cms/liedm/app?service=external/index\&sp=3883\&sp=4060.

32 http://www.litnet.lt/.

33 Dèl Lietuvių Kalbos Informacinèje Visuomenèje 2007-2010 Metų Programos Patvirtinimo, http://www3.lrs.lt/pls/inter3/dokpaieska.showdoc_l?p_id=355421. 
- „Zastosowanie technologii informacyjno-komunikacyjnych w kształceniu ogólnym i zawodowym. Program oraz strategia na lata 2008-2012” (celem strategii jest uznanie kształcenia na odległość za równorzędną formę zdobywania wiedzy w ramach kształcenia ogólnego i zawodowego).

\section{Niemcy}

W Niemczech kształcenie na odległość prowadzące do uzyskania kwalifikacji zawodowych lub wykształcenia na poziomie wyższym cieszy się wśród uczniów i słuchaczy ogromną popularnością. Ten typ kształcenia realizowany jest głównie przez podmioty publiczne. Organizacja kształcenia na odległość na poziomie akademickim regulowana jest statutami poszczególnych uczelni wyższych.

Sposób realizacji kształcenia na odległość oraz zasady uczestnictwa w tym typie edukacji zostały uregulowane przez Federalne Ministerstwo Edukacji i Badań Naukowych w ustawie o ochronie uczestników kształcenia na odległość (Gesetz zum Schutz der Teilnehmer am Fernunterricht) ${ }^{34}$. Ustawa reguluje m.in. zagadnienia związane z prawami i obowiązkami podmiotów biorących udział w procesie kształcenia na odległość, sposobem organizacji kształcenia i zatwierdzaniem programów kursów. Jako instytucję nadzorującą funkcjonowanie kształcenia na odległość w Niemczech ustawa wskazuje Federalną Agencję ds. Kształcenia na Odległość (Staatliche Zentralstelle für Fernunterricht, ZFU). Do uprawnień ZFU należy:

- zatwierdzanie kursów i szkoleń, które odbywają się w ramach kształcenia na odległość,

- kontrola (raz na trzy lata) poziomu realizacji szkoleń, które uzyskały wcześniejszą zgodę Agencji,

- publikacja Przewodnika ksztatcenia na odległość wraz z wykazem dopuszczonych do realizacji kursów i szkoleń oraz spisu instytucji, które uzyskały zgodę Agencji na prowadzenie szkoleń,

- wspieranie rozwoju kształcenia na odległość w Niemczech,

- doradztwo dla landów w kwestiach kształcenia na odległość,

- kontrola i karanie podmiotów prowadzących kształcenie na odległość niezgodnie z obowiązującymi przepisami ustawy o ochronie uczestników kształcenia na odległość.

34 http://www.gesetze-im-internet.de/fernusg/. 


\section{Norwegia}

Norwegia, tak jak inne państwa skandynawskie, ma długą i bogatą tradycję kształcenia na odległość. Jedną z pierwszych ustaw oświatowych przyjętych w okresie powojennym w Norwegii była ustawa o szkołach korespondencyjnych z $1948 \mathrm{r}$. Pierwsza krajowa sieć szkolnictwa wyższego w ramach kształcenia na odległość (SOFF) powstała w 1990 roku w Tromso. Zajmowała się ona kształceniem z zastosowaniem technologii informacyjno-komunikacyjnych. Od 2004 roku SOFF stała się częścią sieci Norweskich Uniwersytetów Otwartych (NUO), która została założona w 1999 roku jako krajowa agencja wspierana przez Ministerstwo Edukacji i Nauki. Na swojej stronie internetowej NUO prowadzi obszerną bazę kursów kształcenia ustawicznego, zarówno tych w formie kształcenia na odległość jak i stacjonarnych, oferowanych przez wszystkie placówki.

Programy kształcenia na odległość realizowane z wykorzystaniem TIK stanowią alternatywę dla tradycyjnych kursów stacjonarnych oferowanych przez uczelnie. Programy tego rodzaju znaleźć można w ofercie większości uczelni w Norwegii. W przypadku niektórych programów zawodowych stosuje się wideokonferencje, które umożliwiają studentom z ośrodków wiejskich aktywny udział w wykładach i bezpośredni kontakt z wykładowcami. W latach dziewięćdziesiątych XX wieku przy większości norweskich uczelni powstały centra kształcenia ustawicznego i kształcenia na odległość mające uzupełniać klasyczną ofertę edukacyjną. Większość kursów kształcenia na odległość (ze wsparciem państwowym) prowadzi do uzyskania kwalifikacji zawodowych. Ponad 2/3 kursów obejmuje przedmioty z zakresu ekonomii i zarządzania, technologii, komunikacji, pracy socjalnej i zdrowia. Zgodnie z obowiązującymi rozporządzeniami norweskich władz oświatowych, kształcenie na odległość skierowane do dorosłych pobierających naukę na poziomie szkoły średniej II stopnia musi realizować wymóg elastyczności i dostosowania do indywidualnych potrzeb słuchacza/ studenta.

W Norwegii obok sieci publicznych placówek, realizujących zadania oświaty ustawicznej, działają także prywatne placówki kształcenia na odległość. Były one pionierami w stosowaniu transmisji telewizyjnych, wideokonferencji i narzędzi komputerowych. Obecnie 13 autoryzowanych prywatnych placówek kształcenia na odległość zrzeszonych jest w Norweskim Stowarzyszeniu ds. Elastycznego Kształcenia i Kształcenia na Odległość. Kursy proponowane przez podmioty prywatne są płatne. Stowarzyszenia i prywatne placówki kształcenia na odległość mogą tworzyć własne programy (oprócz prowadzących do uzyskania państwo- 
wych kwalifikacji na poziomie szkoły średniej i wyższej). Spośród 50000 kursów prowadzonych każdego roku przez stowarzyszenia pozarządowe większość stanowią szkolenia zawodowe. Tylko 15\% z nich związanych jest z obszarem nauki języków obcych, nauk społecznych lub religii.

Długa i bogata tradycja kształcenia na odległość oraz powszechność tej formy edukacji w Norwegii sprawiły, że w Oslo pod patronatem krajowych władz oświatowych umiejscowiono siedzibę sekretariatu Międzynarodowej Rady Kształcenia Otwartego i na Odległość (International Council for Open and Distance Education, ICDE) ${ }^{35}$. Głównym celem ICDE jest podejmowanie na forum międzynarodowym działań na rzecz promocji kształcenia na odległość.

\section{Portugalia}

W Portugalii podstawą prawną do funkcjonowania kształcenia na odległość jest ustawa o edukacji nr 46/86 z 1986 r. ${ }^{36}$, nr 115/97 z 1997 r. ${ }^{37}$ i nr 49/2005 z 2005 r. ${ }^{38}$ oraz rozporządzenie nr 812/2010 dotyczące kształcenia na odległość dla pracowników wędrownych ${ }^{39}$. Kształcenie na odległość realizowane jest przede wszystkim w obszarze kształcenia ustawicznego. Ministerstwo Edukacji i Nauki (Ministro da Educação e Ciência) we współpracy z Uniwersytetem Otwartym (Universidade Aberta) opracowuje i publikuje w ramach kształcenia na odległość materiały dydaktyczne i przygotowuje programy kursów specjalistycznych dla dorosłych oraz dla potrzeb kształcenia nauczycieli. Do ciekawszych portugalskich projektów realizowanych w ramach kształcenia na odległość można zaliczyć kształcenie ustawiczne dorosłych prowadzone od 2003 roku na Wyspach Azorskich oraz kursy kształcenia na odległość dla marynarzy/kadetów organizowane przez Morskie Centrum Kształcenia na Odległość pod patronatem Ministerstwa Edukacji i Nauki oraz Ministerstwa Obrony.

35 http://www.icde.org.

36 Lei n.ş 46/86 de 14 de Outubro, Lei De Bases Do Sistema Educativo, http://intranet.uminho. pt/Arquivo/Legislacao/AutonomiaUniversidades/L46-86.pdf.

37 Lei n. ${ }^{0}$ 49/2005 de 30 de Agosto, Segunda alteração à Lei de Bases do Sistema Educativo e primeira alteração à Lei de Bases do Financiamento do Ensino Superior, http://www.dges. mctes.pt/NR/rdonlyres/AE6762DF-1DBF-40C0-B194-E3FAA9516D79/1767/Lei115_97.pdf.

38 Lei n. ${ }^{0}$ 49/2005 de 30 de Agosto, Segunda alteração à Lei de Bases do Sistema Educativo e primeira alteração à Lei de Bases do Financiamento do Ensino Superior, http://www.dges. mctes.pt/NR/rdonlyres/720F589D-0360-48D2-AE1D-80142EA2BB8A/497/11Lei_49_2006.pdf.

39 Rozporządzenie Ministerstwa (lub Ministra) Edukacji z 28 sierpnia 2010 r., Ministério da Educação, Portaria n. ${ }^{0}$ 812/2010 de 26 de Agosto, http://edi.blog.dge.mec.pt/files/2010/10/2010.pdf. 
Należy też wspomnieć o utworzonym na przełomie 2005/2006 roku i wdrożonym w 2009 roku przez Departament Rozwoju Innowacyjności portugalskiego Ministerstwa Edukacji i Nauki, programie kształcenia na odległość Escola Móvel $^{40}$. Projekt ten miał na celu sprostanie potrzebom rodzin, których członkowie wraz z dziećmi ze względu na wykonywany zawód większość czasu spędzają w podróży. Program Escola Móvel skierowany był do uczniów szkoły podstawowej (dzieci pracowników wędrownych), a bazą edukacyjną była możliwość korzystania z komputerów posiadających dostęp do specjalnie przygotowanej platformy informatycznej. Projekt miał pełnić funkcję szkoły publicznej, która działa, opierając się na metodzie e-learningu. Dzięki temu Escola Móvel zaczął umożliwiać podróżującym uczniom wypełnianie obowiązku szkolnego realizowanego poprzez wirtualną regularną obecność na platformie internetowej, która zapewniła zarówno naukę, jak i społeczno-uczuciową stabilizację ucznia (stałe interakcje z tymi samymi nauczycielami i rówieśnikami). Innowacyjny program Escola Móvel w swej pierwotnej formie nie jest obecnie realizowany, ale jego założenia dotyczące oferty kształcenia na odległość zostały podtrzymane i wykorzystane w nowym rządowym projekcie skierowanym do migrantów zatytułowanym „Kształcenie na odległość dla ludności wędrownej” (Ensino à Distância para a Itinerância) ${ }^{41}$.

\section{Szwecja}

Kształcenie na odległość ma w Szwecji bardzo długą tradycję. Jej prekursorem były państwowe kursy korespondencyjne, istniejące od 1898 roku. Od począt$\mathrm{ku}$ istnienia traktowano je w Szwecji na równi z nauczaniem stacjonarnym, zwłaszcza że każdy kurs kończył się egzaminem „na żywo” przed egzaminatorem. Na ogromną popularność tego typu nauczania wpłynęły duże terytorium, rozproszenie ludności, mała liczba dużych miast i zbyt mała liczba ośrodków uniwersyteckich. Dodatkowo wieloletnie ogromne doświadczenie w tworzeniu sieci edukacyjnej sprawiły, że Szwecja stała się niepodważalnym prekursorem e-learningu, który zastąpił kursy korespondencyjne.

Priorytetem szwedzkiego systemu edukacji jest zapewnienie każdemu obywatelowi możliwości kształcenia, nawet jeśli zostało ono przerwane. Niezależnie od wieku i miejsca zamieszkania, każdy obywatel może podjąć naukę, którą

40 http://area.dgidc.min-edu.pt/escola_movel_en/escola.html.

41 http://www.dgidc.min-edu.pt/ensinodistancia/. 
zapewnia mu państwo. W Szwecji przyjęto wytyczne, według których w każdym okręgu powinien istnieć co najmniej jeden uniwersytet lub kolegium uniwersyteckie, a pozostałe uczelnie powinny dysponować ofertą różnych kursów i szkoleń, w tym również kursów w trybie kształcenia na odległość (e-learning) ${ }^{42}$.

W Szwecji duży nacisk kładzie się na zastosowanie edukacji na odległość i e-learningu w szkolnictwie obowiązkowym (np. uczeń nieobecny w szkole z powodu choroby jest zobowiązany odrobić zaległości na zajęciach on-line z nauczycielem) oraz w szkołach wyższych, w których stosuje się dwa modele studiowania:

- studia w formie klasycznej - student odbywa tylko część studiów bezpośrednio na uniwersytecie obejmującą przedmioty, które wymagają praktycznego zastosowania wiedzy,

- studia w formie kształcenia na odległość - druga część studiów wymagająca wybrania i łączenia przedmiotów dostępnych na różnych uniwersytetach.

W ramach systemowego wsparcia idei kształcenia na odległość w szwedzkim systemie oświaty funkcjonuje szeroka sieć stowarzyszeń, fundacji i organizacji utrzymujących się m.in. z grantów rządowych. W tym celu powołano rządowe programy, których celem było na przykład opracowanie nowych metod edukacji dorosłych z zastosowaniem nowych technologii informacyjno-komunikacyjnych. W konsekwencji tych działań utworzono między innymi Szwedzki Instytut Kształcenia na Odległość (DISTUM) oraz Szwedzką Agencję ds. Elastycznych Metod Uczenia się (CFL). Od 2008 roku ich zadania przejęła Krajowa Agencja ds. Edukacji, której celem jest kompleksowe wspieranie edukacji w Szwecji.

\section{Węgry}

Na Węgrzech kształcenie na odległość realizowane jest przede wszystkim w obszarze szkolnictwa wyższego i kształcenia ustawicznego. Odpowiednie przepisy możemy znaleźć w dwóch ustawach o szkolnictwie wyższym oraz o kształceniu dorosłych.

Ustawa o szkolnictwie wyższym ${ }^{43}$ definiuje kształcenie na odległość jako szczególną formę edukacji przy zastosowaniu narzędzi TIK oraz metod dydaktycznych opartych na interaktywnym kontakcie ucznia z nauczycielem oraz sa-

42 E-learning nowe aspekty: materiały z II ogólnopolskiej konferencji, Warszawa 14-15 września 2010, Wydawnictwo Stowarzyszenia Bibliotekarzy Polskich, Warszawa 2011, s. 85-96.

43 http://www.eurydice.org.pl/sites/eurydice.org.pl/files/rpkno.pdf. 
modzielnej pracy ucznia, gdzie konsultacje stanowią mniej niż 30\% zajęć na studiach prowadzonych w pełnym wymiarze.

Ustawa o kształceniu dorosłych ${ }^{44}$ stanowi, że edukacja dorosłych może być prowadzona wyłącznie na podstawie zatwierdzonych przez Ministerstwo Oświaty programów nauczania i wskazanych metod kształcenia, do których zaliczono m.in. kształcenie na odległość. Ustawa stanowi, że kształcenie dorosłych może również przyjąć formę otwartej edukacji i kształcenia na odległość polegających na stosowaniu narzędzi TIK, a także metod dydaktycznych opartych na interaktywnym kontakcie słuchacza i nauczyciela oraz na samodzielnej pracy słuchacza. Okres trwania tego typu kształcenia, jak również metody ewaluacji postępów oraz warunki ukończenia kształcenia pozostają całkowicie w gestii placówki prowadzącej kształcenie dorosłych.

\section{Wielka Brytania}

W Wielkiej Brytanii kształcenie na odległość najczęściej oferowane jest w formule kształcenia ustawicznego realizowanego przede wszystkim przez uniwersytety otwarte, specjalizujące się od wielu lat w tej formie edukacji. Oprócz nich kształcenie na odległość oferują także inne instytucje, np. takie jak National Open College Network, Open College of the Arts, czy prywatne korespondencyjne colleges. Wiele jest także ośrodków specjalizujących się w zbieraniu informacji o instytucjach oferujących kształcenie na odległość. Jednym z nich jest Centrum Kształcenia na Odległość (Distance Learning Centre, DLC ${ }^{45}$ ) dysponujące bazą kursów i placówek świadczących usługi edukacyjne na odległość.

Oprócz uniwersytetów otwartych i instytucji o zbliżonym charakterze, także większość placówek szkolnictwa wyższego od wielu lat wprowadza coraz powszechniejszą ofertę e-learningu dla słuchaczy i studentów, którzy z różnych powodów nie mogą bezpośrednio uczestniczyć w zajęciach.

Ze względu na zdecentralizowany charakter zarządzania brytyjską oświatą kształcenie na odległość nie jest regulowane centralnie, a sama oferta kształcenia na odległość zależy w dużej mierze od typu placówki edukacyjnej, rodzaju zdobywanego dyplomu oraz zapotrzebowania wśród potencjalnych studentów na ten model kształcenia.

44 Tamże, s. 6-7.

45 http://www.distance-learning-centre.co.uk/. 


\section{Podsumowanie}

W państwach europejskich sposób organizacji kształcenia na odległość w dużej mierze zależy od przyjętego w danym państwie modelu organizacji zarządzania oświatą. W Finlandii, Szwecji i Wielkiej Brytanii strona organizacyjna kształcenia na odległość pozostaje w gestii administracji lokalnej lub pozostawiona jest do decyzji placówki szkolnej, podobnie jak kwestie metod dydaktycznych, doboru podręczników i pomocy naukowych oraz sposobów organizacji nauczania. W pozostałych analizowanych państwach kształcenie na odległość znalazło swoje miejsce w następujących aktach prawnych: ustawy oświatowe (Czechy, Francja, Hiszpania, Litwa, Polska, Portugalia), ustawy o kształceniu ustawicznym (Grecja, Litwa, Węgry), ustawa o szkołach korespondencyjnych (Norwegia), ustawa o ochronie uczestników kształcenia na odległość (Niemcy), ustawa o szkolnictwie wyższym (Czechy, Grecja, Litwa, Polska, Portugalia, Węgry), ustawa o szkolnictwie średnim II stopnia (Finlandia). Niektóre kraje z myślą o kompleksowym podejściu do kształcenia na odległość powołały specjalne instytucje zajmujące się tą właśnie problematyką. We Francji taką placówką jest Krajowe Centrum Kształcenia na Odległość (CNED), w Hiszpanii - Centrum Innowacji i Rozwoju Kształcenia na Odległość (CIDEAD) i Narodowy Uniwersytet Kształcenia na Odległość (UNED), w Niemczech - Federalna Agencja do spraw Kształcenia na Odległość (ZFU), w Portugalii - Morskie Centrum Kształcenia na Odległość, w Szwecji - Szwedzki Instytut Kształcenia na Odległość (DISTUM).

\section{Zakończenie}

Odkąd w 1728 roku w The Boston Gazette Phillip Caleb, nauczyciel nowej metody stenografii, zamieścił ogłoszenie zachęcające mieszkańców USA do nowoczesnej nauki szybkiego pisania realizowanej za pomocą zestawu lekcji przesyłanych pocztą bezpośrednio do zainteresowanych - co uznaje się za symboliczny początek kształcenia na odległość - aż do współczesnej edukacji korzystającej z najnowszych platform edukacyjnych budowanych na bazie najnowocześniejszych technologii informacyjno-komunikacyjnych, kształcenie na odległość nadal pozostaje synonimem nowoczesności w edukacji i dążenia człowieka do własnego ustawicznego rozwoju. Zwiększające się tempo życia, konkurencja na rynku pracy, szybka dezaktualizacja wiedzy związana z gwałtownym rozwojem technologicznym i globalizacją badań naukowych wymuszają na nas ustawiczne zdobywanie lub uzupełnianie wiedzy bez konieczności zmiany miejsca zamieszkania, 
pracy lub aktualnego pobytu, tak aby jak najlepiej dostosować te potrzeby do naszych oczekiwań i cywilizacyjnych wyzwań. Właśnie dynamicznie rozwijające się kształcenie na odległość w Europie i na świecie wyśmienicie wpisuje się w te oczekiwania współczesnej cywilizacji.

\section{Bibliografia}

Dziewulak D., Kształcenie na odległość w wybranych państwach Unii Europejskiej, „Analizy BAS” 2012, $\mathrm{nr}$ 18(85).

Juszczyk S., Edukacja na odległość. Kodyfikacja pojęć, regut i procesów, Wydawnictwo Adam Marszałek, Warszawa 2002.

Kubiak M.J., Wirtualna edukacja, Wydawnictwo MIKOM, Warszawa 2000.

\section{Akty prawne}

Ustawa z 7 września 1991 r. o systemie oświaty, Dz.U. 2004, nr 256, poz. 2572, ze zm.

Ustawa z 27 lipca 2005 r. - Prawo o szkolnictwie wyższym, Dz.U. nr 164, poz. 1365, ze zm.

Rozporządzenie Ministra Nauki i Szkolnictwa wyższego z 25 września 2007 r. w sprawie warunków, jakie muszą być spełnione, aby zajęcia dydaktyczne na studiach mogły być prowadzone z wykorzystaniem metod i technik kształcenia na odległość, Dz.U. nr 188, poz. 1347.

Zalecenie Parlamentu Europejskiego i Rady nr 2006/962/WE z 18 grudnia 2006 r. w sprawie kompetencji kluczowych w procesie uczenia się przez całe życie, Dz.Urz. UE L 394 z 30 grudnia 2006 r., http://eur-lex.europa.eu/LexUriServ/LexUriServ.do?uri=CELEX:32006H0962:PL:NOT.

Ustawa oświatowa Republiki Czeskiej nr 561/2004, Zákon o předškolním, základním, středním, vy̌ším odborném a jiném vzdělávání (školský zákon, Zákon č. 561/2004 Sb), https://www.zakonyprolidi.cz/cs/2004-561.

Ustawa o szkolnictwie wyższym Republiki Czeskiej nr 111/1998, Zákon o vysokých školách a o změně a doplnění dalších zákonů (zákon o vysokých školách, Zákon č. 111/1998 Sb), https://www.zakonyprolidi.cz/cs/1998-111.

Ustawa o weryfikacji i uznawaniu wyników kształcenia w Republice Czeskiej nr 179/2006, Zákon o ověřování a uznávání výsledků dalšího vzdělávání a o změně některých zákonů (zákon o uznávání výsledků dalšího vzdělávání, Zákon č. 179/2006 Sb), https://www. zakonyprolidi.cz/cs/2006-179.

Ustawa nr 629/1998 o szkolnictwie średnim w Finlandii, Lukiolaki 21.8.1998/629, http:// www.finlex.fi/fi/laki/ajantasa/1998/19980629jw.?? 
Ustawa oświatowa Republiki Francuskiej, Code de l'education, http://www.legifrance.gouv.fr/affichCode.do?idArticle=LEGIARTI000006525778\&idSectionTA=LEGISCTA000006182465\&cidTexte=LEGITEXT000006071191\&dateTexte=20100430.

Ustawa nr 3369/2005 o systematyzacji uczenia się przez całe życie i innych typach kształ-

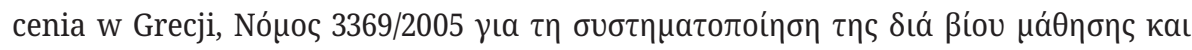

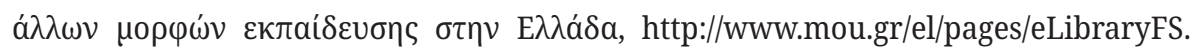
aspx?item=1764.

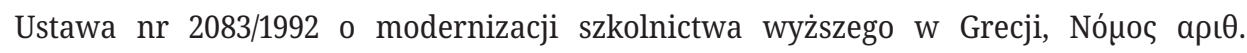

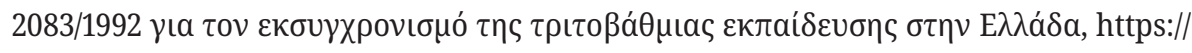
www.kodiko.gr/nomologia/document_navigation/227162/nomos-2083-1992.

Ustawa o edukacji Hiszpanii, Ley Orgánica 2/2006, de 3 de mayo, de Educación, http:// www.boe.es/aeboe/consultas/bases_datos/doc.php?id=BOE-A-2006-7899.

Dekret nr 1180 z 1992 r. o utworzeniu w Hiszpanii Centrum Innowacji i Rozwoju Kształcenia na Odległość (Centro para la Innovación y Desarrollo de la Educación a Distancia, CIDEAD), Real Decreto 1180/1992, de 2 de octubre, por el que se crea el Centro para la Innovación y Desarrollo de la Educación a Distancia, http://www.boe.es/aeboe/consultas/bases_datos/doc.php?id=BOE-A-1992-23316.

Dekret nr 2310/1972 z 1972 r. o utworzeniu Narodowego Uniwersytetu Kształcenia na Odległość w Hiszpanii (Universidad Nacional de Educación a Distancia, UNED), Decreto 2310/1972, de 18 de agosto, por el que se crea la Universidad Nacional de Educación a Distancia, http://www.boe.es/buscar/doc.php?id=BOE-A-1972-1309 oraz: http://www.boe.es/boe/dias/2005/04/16/pdfs/A13117-13128.pdf, http://www.boe.es/boe/ dias/2007/04/13/pdfs/A16241-16260.pdf.

Litewska ustawa o edukacji z 1991 r., Švietimo İstatymo 1991 (nowelizowana w 2010 r.), http://www3.lrs.lt/pls/inter3/dokpaieska.showdoc_l?p_id=365736.

Litewska ustawa o pozaformalnym kształceniu dorosłych z 1998 r., Neformaliojo Suaugusiųjų Švietimo İstatymas 1998 (nowelizowana w 2010 r.), http://www3.lrs.lt/pls/inter3/ dokpaieska.showdoc_l?p_id=370996.

Niemiecka ustawa o ochronie uczestników kształcenia na odległość, Gesetz zum Schutz der Teilnehmer am Fernunterricht, http://www.gesetze-im-internet.de/fernusg/.

Portugalska ustawa o edukacji nr 46/86 z 1986 r. (nr 115/97 z 1997 r. i nr 49/2005 z 2005 r.), Lei n.ş 46/86 de 14 de Outubro, Lei De Bases Do Sistema Educativo, http://intranet.uminho.pt/Arquivo/Legislacao/AutonomiaUniversidades/L46-86.pdf.

Lei n. ${ }^{\circ}$ 49/2005 de 30 de Agosto, Segunda alteração à Lei de Bases do Sistema Educativo e primeira alteração à Lei de Bases do Financiamento do Ensino Superior, http://www. dges.mctes.pt/NR/rdonlyres/AE6762DF-1DBF-40C0-B194-E3FAA9516D79/1767/Lei115_97. pdf. 
Lei n. ${ }^{0}$ 49/2005 de 30 de Agosto, Segunda alteração à Lei de Bases do Sistema Educativo e primeira alteração à Lei de Bases do Financiamento do Ensino Superior, http:// www.dges.mctes.pt/NR/rdonlyres/720F589D-0360-48D2-AE1D-80142EA2BB8A/497/ 11Lei_49_2006.pdf.

Rozporządzenie Ministra Edukacji Portugalii nr 812/2010 dotyczące kształcenia na odległość dla pracowników wędrownych, Ministério da Educação, Portaria n. ${ }^{\circ}$ 812/2010 de 26 de Agosto, Ensino à Distância para a Itinerância, http://edi.blog.dge.mec.pt/ files/2010/10/2010.pdf.

\section{Strony internetowe}

http://www.profesor.pl/mat/na9/pokaz_material_tmp.php?plik=na9/na9_m_piwonska_040113_1.php\&id_m=8850.

http://www.uo.uw.edu.pl/.

http://www.msmt.cz/areas-of-work/act-no-561-the-education-act?lang=2.

http://www.msmt.cz/vzdelavani/zakon-c-111-1998-sb-o-vysokych-skolach.

http://www.cned.fr/.

http://www3.lrs.lt/pls/inter3/dokpaieska.showdoc_l?p_id=303759.

http://www3.lrs.lt/pls/inter3/dokpaieska.showdoc_l?p_id=219184.

http://area.dgidc.min-edu.pt/escola_movel_en/escola.html.

http://www.dgidc.min-edu.pt/ensinodistancia/.

http://www.eurydice.org.pl/sites/eurydice.org.pl/files/rpkno.pdf.

http://www.distance-learning-centre.co.uk/. 


\title{
4.2. Wymiar czasu pracy nauczycieli w wybranych państwach Unii Europejskiej
}

\author{
Working time of teachers in selected European Union \\ members states
}

\begin{abstract}
W opracowaniu podjęto próbę porównawczej prezentacji wymiaru czasu pracy nauczycieli w Polsce i wybranych państwach Unii Europejskiej na szczeblu szkolnictwa podstawowego oraz szkolnictwa średniego I i II stopnia. Analizie poddano czas pracy nauczyciela na tle innych danych porównawczych, jak np. czas jednostki lekcyjnej, długość trwania roku szkolnego, tygodniowy wymiar godzin lekcyjnych dla poszczególnych szczebli kształcenia. Przedstawiono także klasyfikację szczebli edukacyjnych stosowaną przez Międzynarodową Standardową Klasyfikację Kształcenia.

Słowa kluczowe: nauczyciel, zajęcia dydaktyczne, pensum, Polska, Francja, Irlandia, Niemcy, Wielka Brytania

The paper attempts to give a comparative overview of working time of teachers in primary and secondary (lower and higher levels) education in Poland and selected EU member states. It provides an analysis of the working time of a teacher in the context of other comparative data, including the duration of a lesson unit, the duration of a school year and the number classroom learning hours per week for each level of education. the classification of educational levels applied by The International Standard Classification of Education is also described.
\end{abstract}

Keywords: teacher, classes, working hours, Poland, France, Ireland, Germany, United Kingdom

\section{Wstęp}

Zagadnienie wymiaru czasu pracy nauczycieli określa się różnie $\mathrm{w}$ różnych ustrojach edukacyjnych ${ }^{1}$. Czasem stosuje się tylko jedno kryterium, ale najczęściej jest to kombinacja kilku elementów: pensum dydaktyczne, wymiar godzin

1 Opracowanie przygotowano na podstawie ekspertyzy Biura Analiz Sejmowych nr 3446/08 z 22 stycznia 2009 r. D. Dziewulaka zatytułowanej Informacja dotycząca wymiaru czasu pracy nauczycieli szkół podstawowych, gimnazjalnych oraz ponadgimnazjalnych we Francji, Irlandii, Niemczech $i$ Wielkiej Brytanii oraz opracowania tegoż autora, Wymiar czasu pracy nauczycieli w wybranych państwach Unii Europejskiej, „Analizy BAS” 2009, nr 13(21). 
obowiązkowej obecności na terenie szkoły i łączny wymiar czasu pracy nauczycieli. W niektórych państwach czas pracy nauczycieli określony jest tylko przez pensum dydaktyczne (np. Belgia, Włochy), w niektórych przez wymiar godzin obowiązkowej obecności na terenie szkoły (np. Wielka Brytania), a także przez łączną sumę powyższych elementów (np. Holandia). W związku z powyższym trudno mówić o jednolitym lub dominującym modelu określającym czas pracy nauczycieli. Najczęstsze rozwiązania przyjęte w poszczególnych państwach są zazwyczaj wypadkową oczekiwań środowiska nauczycielskiego oraz uwarunkowań ekonomicznych, społecznych, historycznych i politycznych w danym kraju².

\section{Podstawowe pojęcia}

Dla potrzeb ujednolicenia i usystematyzowania nazewnictwa struktur poziomów edukacyjnych występujących w różnych krajach, UNESCO opracowało Międzynarodową Standardową Klasyfikację Edukacji, tzw. klasyfikację ISCED (International Standard Classification of Education) ${ }^{3}$.

Analizując wymiar czasu pracy nauczycieli na poszczególnych szczeblach kształcenia - szkoły podstawowe, gimnazjalne i ponadgimnazjalne - podstawową jednostką klasyfikacji w ISCED pozostaje „program kształcenia”. Programy kształcenia są definiowane na podstawie ich treści jako zestaw lub ciąg działań edukacyjnych, które organizuje się, by osiągnąć zdefiniowany na wstępie cel lub wyspecyfikowany zestaw zadań edukacyjnych. Treść kształcenia jest podstawą do zakwalifikowania określonego programu kształcenia do jednego z poziomów kształcenia w klasyfikacji ISCED. W najnowszej klasyfikacji ISCED wyróżniamy siedem poziomów edukacyjnych: 0, 1, 2, 3, 4, 5, 6 .

Poziomy w klasyfikacji ISCED:

- ISCED 0 - wychowanie przedszkolne,

- ISCED 1 - kształcenie podstawowe lub pierwszy etap edukacji podstawowej,

- ISCED 2 - szkoła średnia I stopnia,

- ISCED 3 - szkoła średnia II stopnia,

- ISCED 4 - kształcenie powyżej średniego (nie wyższe),

- ISCED 5 - pierwszy etap kształcenia wyższego (nieprowadzący bezpośrednio do zaawansowanych kwalifikacji badawczych),

2 D. Dziewulak, Systemy szkolne państw Unii Europejskiej, Wydawnictwo Akademickie „Żak”, Warszawa 1997.

3 http://europass.frse.org.pl/files/isced.pdf. 
- ISCED 6 - drugi etap kształcenia wyższego (prowadzący do zaawansowanych kwalifikacji badawczych).

Polski system edukacji w przełożeniu na klasyfikację poziomów ISCED:

- ISCED 0 - przedszkole,

- ISCED 1 - szkoła podstawowa,

- ISCED 2 - gimnazjum,

- ISCED 3 - liceum ogólnokształcące, liceum profilowane, technikum, uzupełniające liceum ogólnokształcące, technikum uzupełniające, zasadnicza szkoła zawodowa,

- ISCED 4 - szkoły policealne,

- ISCED 5 - wyższe studia zawodowe, studia magisterskie, studia uzupełniające magisterskie, studia podyplomowe,

- ISCED 6 - studia doktoranckie.

\section{Wymiar czasu pracy nauczycieli szkół podstawowych, gimnazjalnych i ponadgimnazjalnych}

\section{Polska}

W Polsce rok szkolny trwa 10 miesięcy, od września do czerwca, z czego wymiar zajęć dydaktycznych wynosi minimum 178 dni. Zajęcia dydaktyczno-wychowawcze rozpoczynają się w pierwszym powszednim dniu września, z wyjątkiem soboty, a kończą w najbliższy piątek po dniu 18 czerwca ${ }^{4}$. Każdy tydzień nauki trwa pięć dni. Jednostka lekcyjna wynosi 45 minut. Tygodniowy wymiar godzin lekcyjnych wynosi odpowiednio: 23 godziny (ISCED 1 - szkoła podstawowa klasy I-III), 28 godzin (ISCED 1 - szkoła podstawowa klasy IV-VI), 31 godzin (ISCED 2 - gimnazjum) i 35 godzin (ISCED 3 - szkoły ponadgimnazjalne).

Wszelkie kwestie związane z czasem pracy nauczyciela regulowane są w usta-

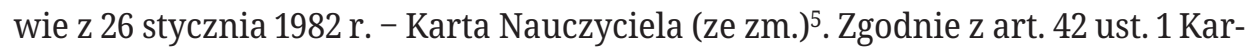
ty Nauczyciela czas pracy nauczyciela zatrudnionego w pełnym wymiarze nie może przekraczać 40 godzin tygodniowo. Na tygodniową normę składa się pensum (zajęcia dydaktyczne, wychowawcze, opiekuńcze, prowadzone bezpośrednio z uczniami albo na ich rzecz) oraz inne zajęcia i czynności wynikające z zadań statutowych szkoły. W tak ustalonym czasie pracy nauczyciel ma też obowiązek

4 Rozporządzenie Ministra Edukacji Narodowej i Sportu z 18 kwietnia 2002 r. w sprawie organizacji roku szkolnego, http://www.menis.pl/org_roku.html.

5 http://prawo.vulcan.pl/przegdok.asp?qdatprz=akt\&qplikid=2. 
przygotowywać się do zajęć, samodzielnie się kształcić i doskonalić zawodowo. Zgodnie z art. 42 ust. 7a Karty Nauczyciela, rejestrowane i rozliczane w dziennikach są zajęcia realizowane w ramach pensum, czyli prowadzone bezpośrednio z uczniami. W zależności od typu szkoły lub placówki wynosi ono od 15 do 30 godzin tygodniowo. Nie rozlicza się natomiast pozostałych zajęć i czynności, choć niektóre z nich też są odnotowywane w dziennikach, np. wywiadówki, zebrania $z$ rodzicami, wycieczki klasowe, rady pedagogiczne. Wyjątkiem są tu dodatkowo płatne zajęcia finansowane niekiedy przez organ prowadzący szkołę, np. kółka zainteresowań. Rozlicza się je w dziennikach zajęć.

Tygodniowy obowiązkowy wymiar godzin zajęć dydaktycznych, wychowawczych i opiekuńczych, prowadzonych bezpośrednio z uczniami lub wychowankami albo na ich rzecz, nauczycieli zatrudnionych w pełnym wymiarze zajęć ustala się, z zastrzeżeniem ust. 2a i 4a (art. 42), według następujących norm:

Tabela 21. Tygodniowy wymiar godzin zajęć dydaktycznych, wychowawczych i opiekuńczych dla nauczycieli zatrudnionych w pełnym wymiarze zajęć w Polsce

\begin{tabular}{|c|c|c|}
\hline Lp. & Stanowisko - typ (rodzaj) szkoły & $\begin{array}{l}\text { Tygodniowa liczba godzin } \\
\text { obowiązkowego wymiaru } \\
\text { zajęć dydaktycznych, } \\
\text { wychowawczych, } \\
\text { opiekuńczych }\end{array}$ \\
\hline 1 & $\begin{array}{l}\text { Nauczyciele przedszkoli, z wyjątkiem nauczycieli pracujących } \\
\text { z grupami dzieci 6-letnich }\end{array}$ & 25 \\
\hline 2 & $\begin{array}{l}\text { Nauczyciele przedszkoli i innych placówek przedszkolnych } \\
\text { pracujących z grupami dzieci 6-letnich }\end{array}$ & 22 \\
\hline 3 & $\begin{array}{l}\text { Nauczyciele: przedszkoli specjalnych, szkół podstawowych, } \\
\text { gimnazjów, szkół specjalnych, liceów ogólnokształcących, } \\
\text { liceów profilowanych i liceów uzupełniających, przedmiotów } \\
\text { teoretycznych w szkołach prowadzących kształcenie } \\
\text { zawodowe, w tym w szkołach specjalnych i szkolenia } \\
\text { rzemieślniczego w schroniskach dla nieletnich oraz } \\
\text { zakładach poprawczych, przedmiotów artystycznych } \\
\text { i ogólnokształcących w szkołach artystycznych i innych } \\
\text { placówkach kształcenia artystycznego }\end{array}$ & 18 \\
\hline 4 & $\begin{array}{l}\text { Nauczyciele kolegium nauczycielskiego, } \\
\text { z wyjątkiem nauczycieli kolegium języków obcych, } \\
\text { kulturalno-oświatowego i bibliotekarskiego }\end{array}$ & 15 \\
\hline 5 & $\begin{array}{l}\text { Nauczyciele praktycznej nauki zawodu we wszystkich typach } \\
\text { szkół }\end{array}$ & 22 \\
\hline
\end{tabular}




\begin{tabular}{|c|c|c|}
\hline 6 & $\begin{array}{l}\text { Wychowawcy świetlic szkolnych i półinternatów (z wyjątkiem } \\
\text { wychowawców świetlic szkół specjalnych), świetlic i klubów } \\
\text { środowiskowych, w tym: profilaktyczno-wychowawczych } \\
\text { i terapeutycznych, wychowawcy młodzieżowych ośrodków } \\
\text { socjoterapii }\end{array}$ & 26 \\
\hline 7 & $\begin{array}{l}\text { Wychowawcy internatów, burs, ogrodów jordanowskich, } \\
\text { świetlic dworcowych, stałych szkolnych schronisk } \\
\text { młodzieżowych }\end{array}$ & 30 \\
\hline 8 & Wychowawcy ośrodków szkolno-wychowawczych & 28 \\
\hline 9 & $\begin{array}{l}\text { Wychowawcy: } \\
\text { a) w placówkach socjalizacyjnych, zakładach } \\
\text { opiekuńczo-leczniczych dla dzieci, } \\
\text { b) w domach wczasów dziecięcych } \\
\text { - w tym na zajęcia dydaktyczne, } \\
\text { c) w specjalnych ośrodkach szkolno-wychowawczych, } \\
\text { zakładach poprawczych, schroniskach dla nieletnich, } \\
\text { świetlicach szkół specjalnych, placówkach interwencyjnych, } \\
\text { rodzinnych ośrodkach diagnostyczno-konsultacyjnych, } \\
\text { młodzieżowych ośrodkach wychowawczych, zespołach } \\
\text { pozalekcyjnych zajęć wychowawczych zorganizowanych } \\
\text { w zakładach opieki zdrowotnej, wychowawcy realizujący } \\
\text { zajęcia w domach pomocy społecznej }\end{array}$ & $\begin{array}{l}26 \\
26 \\
10\end{array}$ \\
\hline 10 & $\begin{array}{l}\text { Nauczyciele pałaców młodzieży, młodzieżowych domów } \\
\text { kultury, ognisk pracy pozaszkolnej, pozaszkolnych placówek } \\
\text { specjalistycznych, międzyszkolnych ośrodków sportowych } \\
\text { prowadzących bezpośrednią pracę z dziećmi i młodzieżą } \\
\text { systemem pracownianym }\end{array}$ & 18 \\
\hline 11 & Nauczyciele-bibliotekarze bibliotek szkolnych & 30 \\
\hline 12 & Nauczyciele poradni psychologiczno-pedagogicznej & 20 \\
\hline
\end{tabular}

Źródło: Ustawa z 26 stycznia 1982 r. - Karta Nauczyciela (ze zm.).

\section{Francja}

Rok szkolny trwa 180 dni, od września do czerwca. Szkoły są czynne sześć dni w tygodniu, ale lekcji nie prowadzi się w środowe i sobotnie popołudnia. Każdy tydzień nauki składa się z 26 lekcji 60-minutowych w szkole podstawowej i 25,5-30 lekcji 55-minutowych w szkole średniej (przy czym na zajęcia dla uczniów, którzy mają zaległości, oraz na przedmioty fakultatywne przewidziano 3 dodatkowe godziny). Minimalny roczny wymiar zajęć wynosi 846 godzin zega- 
rowych w szkołach podstawowych i 842 godziny zegarowe w szkołach średnich I stopnia.

Tygodniowy łączny wymiar czasu pracy nauczycieli na poziomie ISCED 1 , 2 i 3 wynosi 35 godzin zegarowych, z czego obowiązkowe pensum dydaktyczne dla nauczycieli wynosi:

- na poziomie ISCED 1 -23,8 godziny,

- na poziomie ISCED $2-16,5$ godziny,

- na poziomie ISCED 3 -13,8 godziny.

\section{Irlandia}

Rok szkolny obejmuje 183 dni (od września do końca czerwca) w szkołach podstawowych i 179 dni (od września do końca maja) w szkołach średnich. Szkoły są czynne pięć dni w tygodniu. Minimalny roczny wymiar zajęć w szkole podstawowej wynosi 915 godzin. Nie określa się obowiązkowej liczby lekcji. W szkole podstawowej lekcje trwają na ogół 30 minut; szkoły stosują się do ogólnych wytycznych dotyczących czasu przeznaczanego tygodniowo na poszczególne elementy programu nauczania. W szkole średniej lekcje trwają na ogół 35-45 minut, a tygodniowy wymiar zajęć wynosi od 35 do 42 lekcji.

W Irlandii kryterium określającym wymiar czasu pracy nauczycieli jest obowiązkowe pensum dydaktyczne, które wynosi:

- na poziomie ISCED 1 - 25,9 godziny,

- na poziomie ISCED 2 - 22,0 godziny,

- na poziomie ISCED 3 - 22,0 godziny.

\section{Niemcy}

Rok szkolny obejmuje od 188 dni (pięciodniowy tydzień nauki szkolnej) do 208 dni (sześciodniowy tydzień nauki szkolnej) w okresie od sierpnia do lipca. Dzienny i tygodniowy wymiar zajęć szkolnych ustalają poszczególne kraje związkowe. Szkoły są czynne przez pięć lub sześć dni w tygodniu (w większości przed południem). Każdy tydzień składa się z 19-28 lekcji w szkole podstawowej i 28-30 lekcji w szkole średniej. Lekcja trwa 45 minut. Średni minimalny roczny wymiar zajęć dydaktycznych w roku szkolnym 2002/2003 wynosił 698 godzin w szkolnictwie podstawowym i od 875 do 987 godzin, zależnie od rodzaju szkoły, w szkolnictwie średnim I stopnia. 
Tygodniowy łączny wymiar czasu pracy nauczycieli na poziomie ISCED 1, 2 i 3 wynosi 40 godzin zegarowych, z czego obowiązkowe pensum dydaktyczne dla nauczycieli wynosi:

- na poziomie ISCED 1 - od 20,3 do 21,0 godzin,

- na poziomie ISCED 2 - od 17,3 do 21,4 godziny,

- na poziomie ISCED 3 - od 17,3 do 20,3 godziny.

\section{Wielka Brytania}

Struktura organizacyjna ustroju szkolnego Zjednoczonego Królestwa Wielkiej Brytanii i Irlandii Północnej nie jest jednolita. Struktury oświatowe Anglii i Walii są relatywnie podobne, natomiast systemy szkolne Szkocji i Irlandii Północnej regulowane są odrębnymi ustawami i decyzjami władz lokalnych.

\section{Anglia, Walia, Irlandia Północna}

Szkoły muszą być czynne przez 190 dni w roku, natomiast dokładne terminy ustalają lokalne władze edukacyjne lub organ zarządzający szkołą, zależnie od statusu prawnego szkoły. Rok szkolny trwa na ogół od września do lipca. Szkoły prowadzą zwykle zajęcia przez pięć dni w tygodniu (od poniedziałku do piątku). Obecnie zmierza się do ustanowienia ujednoliconego roku szkolnego, podzielonego na sześć okresów. Wiele lokalnych władz edukacyjnych wprowadziło ten nowy model w roku szkolnym 2004/2005, a inne są w trakcie jego wprowadzania lub je planują. Decyzje w tej sprawie pozostają w gestii lokalnych władz edukacyjnych lub organu zarządzającego szkołą.

Minimalny zalecany tygodniowy wymiar zajęć dydaktycznych w Anglii i Walii wynosi 21 godzin (dla dzieci w wieku od 5 do 7 lat), 23,5 godziny (od 7 do 11 lat) i 24 godziny (25 godzin w Walii) (od 11 do 16 lat) oraz 25 godzin (dla młodzieży w wieku od 14 do 16 lat). W Irlandii Północnej minimalny dzienny wymiar zajęć wynosi 3 godziny dla uczniów w wieku poniżej 8 lat i 4,5 godziny dla dzieci w wieku powyżej 8 lat. Większość szkół prowadzi zajęcia przez większą liczbę godzin niż proponowane minimum. Dzień nauki w szkole rozpoczyna się na ogół około godz. 9.00, a kończy o 15.00 lub 16.00. 0 organizacji czasu w ciągu szkolnego dnia decyduje szkoła.

W Anglii, Walii i Irlandii Północnej kryterium określającym tygodniowy czas pracy nauczycieli jest wymiar godzin obowiązkowej obecności nauczyciela na terenie szkoły. Wynosi on: 
- na poziomie ISCED 1 - 32,4 godziny,

- na poziomie ISCED 2 - 32,4 godziny,

- na poziomie ISCED 3 - 32,4 godziny.

\section{Szkocja}

Szkoły są czynne 190 dni w roku, natomiast dokładne terminy semestrów ustalają władze lokalne. Rok szkolny rozpoczyna się na ogół w połowie sierpnia, a kończy w ostatnich dniach czerwca. Władze lokalne dość ściśle przestrzegają standardowych norm dotyczących tygodniowego wymiaru zajęć dydaktycznych: 25 godzin dla szkół podstawowych (z mniejszą liczbą godzin dla najmłodszych dzieci) i 27,5 godziny dla szkół średnich I stopnia. Lekcje trwają 40 lub 45 minut decyduje o tym dyrektor szkoły

W Szkocji tygodniowy łączny wymiar czasu pracy nauczycieli na poziomie ISCED 1, 2 i 3 wynosi 35 godzin zegarowych, z czego obowiązkowe pensum dydaktyczne wraz z wymiarem godzin obowiązkowej obecności na terenie szkoły wynosi:

- na poziomie ISCED 1 - 23,5 godziny,

- na poziomie ISCED 2 - 23,5 godziny,

- na poziomie ISCED 3 - 23,5 godziny.

\section{Bibliografia}

Dziewulak D., Polityka oświatowa Wspólnoty Europejskiej, Wydawnictwa Uniwersytetu Warszawskiego, Warszawa 1994.

Dziewulak D., Systemy szkolne państw Unii Europejskiej, Wydawnictwo Akademickie „Żak”, Warszawa 1997.

Dziewulak D., Tendencje oświatowe Wspólnot Europejskich, Biuletyn nr 4, Centrum Europejskie Uniwersytetu Warszawskiego, Wydawnictwo Ośrodka Informacji i Dokumentacji Rady Europy, Warszawa 1993.

Dziewulak D., Wymiar czasu pracy nauczycieli w wybranych państwach Unii Europejskiej, „Analizy BAS” 2009, nr 13(21).

\section{Akty prawne}

Rozporządzenie Ministra Edukacji Narodowej i Sportu z 18 kwietnia 2002 r. w sprawie organizacji roku szkolnego, http://www.menis.pl/org_roku.html. 
Ustawa z 26 stycznia 1982 r. - Karta Nauczyciela, Dz.U. nr 3 poz. 19, http://prawo.vulcan.pl/ przegdok.asp?qdatprz=akt\&qplikid=2.

\section{Strony internetowe}

http://www.eurydice.org.pl/files/nauczyciele_w_ue.pdf.

http://europass.frse.org.pl/files/isced.pdf. 


\title{
4.3. Nadzór pedagogiczny w systemach edukacyjnych w Polsce i wybranych państwach członkowskich Unii Europejskiej
}

\author{
Pedagogical supervision in the education system \\ of Poland and selected European Union members states
}

W opracowaniu przedstawiono problematykę nadzoru pedagogicznego w szkolnictwie w Polsce i w wybranych państwach Unii Europejskiej. Zaprezentowano podstawowe definicje i pojęcia używane dla określenia tematyki nadzoru pedagogicznego. Przedstawiono syntetyczną informację na temat organizacji nadzoru pedagogicznego w systemach oświatowych następujących państw: Polska, Czechy, Finlandia, Francja, Hiszpania, Holandia, Irlandia, Niemcy, Rumunia, Szwecja, Wielka Brytania.

Słowa kluczowe: edukacja, szkoła, nauczyciel, nadzór pedagogiczny, kontrola, Polska, Unia Europejska

The paper deals with pedagogical supervision in schools in Poland and selected EU member states. It presents basic definitions and concepts which are used to specify the topics of pedagogical supervision. The author gives a brief overview of the organization of pedagogical supervision in the system of education in the following countries: Poland, Czech Republic, Finland, France, Spain, the Netherlands, Ireland, Germany, Romania, Sweden and the United Kingdom.

Keywords: education, school, teacher, pedagogical supervision, control, Poland, European Union

\section{Wstęp}

Nadzór pedagogiczny ${ }^{1}$ definiuje się w pedagogice jako czynności sprawowane przez administrację oświatową różnych szczebli administracyjnych w celu kontrolowania oraz oceny jakości pracy instytucji placówek edukacyjnych, głównie szkół, oraz zatrudnionych w nich nauczycieli, a także wspomagania ich w pracy

1 Opracowanie przygotowano na podstawie ekspertyzy Biura Analiz Sejmowych nr 211/13 z 18 lutego 2013 r. D. Dziewulaka zatytułowanej Informacja na temat nadzoru pedagogicznego w systemie edukacyjnym w Polsce i w wybranych państwach Unii Europejskiej (Czechy, Finlandia, Francja, Hiszpania, Holandia, Irlandia, Niemcy, Rumunia, Szwecja, Wielka Brytania) oraz opracowania tegoż autora Nadzór pedagogiczny $w$ systemach edukacyjnych $w$ Polsce i w wybranych państwach Unii Europejskiej, „Analizy BAS” 2013, nr 7(96), 2013, s. 1-11. 
i zawodowym doskonaleniu ${ }^{2}$. Nadzór pedagogiczny jest jednym z podstawowych instrumentów realizacji polityki oświatowej państwa, której głównym celem jest zapewnienie wysokiej jakości kształcenia, wychowania i opieki w szkołach i placówkach systemu oświaty.

\section{Nadzór pedagogiczny w polskim systemie edukacyjnym}

Pojęcie nadzoru pedagogicznego nie jest definiowane w polskich przepisach prawa. Treść normatywna tego pojęcia wynika z konkretnych rozwiązań prawnych kształtujących ten nadzór. Obecnie jest ona zawarta w ustawie z 7 września 1991 r. o systemie oświaty (Dz.U. 2004, nr 256, poz. 2572, ze zm.; dalej: u.s.o.), a także w rozporządzeniu Ministra Edukacji Narodowej z 7 października 2009 r. w sprawie nadzoru pedagogicznego (Dz.U. nr 168, poz. 1324).

Nadzór pedagogiczny jako jeden z nielicznych nadzorów administracyjnych, znajduje bezpośrednie źródło w przepisach Konstytucji Rzeczypospolitej Polskiej. Przepis art. 70 ust. 3 Konstytucji RP wprost przewiduje nadzór pedagogiczny nad szkołami i zakładami wychowawczymi oraz nakazuje uregulowanie zasad jego sprawowania w ustawie zwykłej. Wytyczną zawartą w art. 70 ust. 3 Konstytucji $\mathrm{RP}$ realizuje ustawa o systemie oświaty, która określa przedmiot nadzoru pedagogicznego, organy uprawnione do jego sprawowania oraz środki służące organowi sprawującemu ten nadzór. Określenie szczegółowych zasad sprawowania nadzoru pedagogicznego oraz kwalifikacji osób uprawnionych do jego sprawowania ustawa deleguje $\mathrm{w}$ art. 35 ust. 6 na ministra właściwego do spraw oświaty i wychowania.

W rozporządzeniu Ministra Edukacji Narodowej z 7 października 2009 r. w sprawie nadzoru pedagogicznego został ustalony wykaz stanowisk w kuratoriach oświaty oraz urzędach innych organów sprawujących nadzór pedagogiczny i podporządkowanych im jednostkach organizacyjnych, których zajmowanie wymaga kwalifikacji pedagogicznych. Zgodnie z art. 33 ust. 1 u.s.o. nadzór pedagogiczny polega na:

- ocenianiu stanu i warunków działalności dydaktycznej, wychowawczej i opiekuńczej szkół, placówek i nauczycieli,

- analizowaniu i ocenianiu efektów działalności dydaktycznej, wychowawczej i opiekuńczej oraz innej działalności statutowej szkół i placówek,

2 C. Kupisiewicz, M. Kupisiewicz, Stownik pedagogiczny, Wydawnictwo Naukowe PWN, Warszawa 2009, s. 170. 
- udzielaniu pomocy szkołom, placówkom i nauczycielom w wykonywaniu ich zadań dydaktycznych, wychowawczych i opiekuńczych,

- inspirowaniu nauczycieli do innowacji pedagogicznych, metodycznych i organizacyjnych.

W ust. 2 określono, że w zakresie wymienionym w ust. 1 pkt 1 i 2 nadzorowi podlega w szczególności:

- zgodność zatrudniania nauczycieli z wymaganymi kwalifikacjami,

- realizacja podstaw programowych i ramowych planów nauczania,

- przestrzeganie zasad oceniania, klasyfikowania i promowania uczniów oraz przeprowadzania egzaminów, a także przestrzeganie przepisów dotyczących obowiązku szkolnego oraz obowiązku nauki,

- przestrzeganie statutu szkoły lub placówki,

- przestrzeganie praw dziecka i praw ucznia oraz upowszechnianie wiedzy o tych prawach,

- zapewnienie uczniom bezpiecznych i higienicznych warunków nauki, wychowania i opieki.

Zgodnie z rozporządzeniem w sprawie nadzoru pedagogicznego, nadzór pedagogiczny jest realizowany przez wykonywanie wskazanych powyżej zadań i czynności w trybie działań planowych lub doraźnych i ma służyć doskonaleniu systemu oświaty, w szczególności podnoszeniu efektów pracy szkół. Dodatkowym celem nadzoru jest ocena jakości działalności szkół i placówek oświatowych oraz wspomaganie ich pracy w dążeniu do uzyskiwania pożądanej jakości działalności dydaktycznej, wychowawczej i opiekuńczej oraz innej działalności statutowej. W rozporządzeniu $\mathrm{w}$ sprawie nadzoru pedagogicznego określono także formy nadzoru pedagogicznego, do których należą:

- ewaluacja działalności edukacyjnej szkół i placówek²,

- kontrola przestrzegania przepisów prawa dotyczących działalności dydaktycznej, wychowawczej i opiekuńczej szkół, placówek i nauczycieli,

- wspomaganie pracy szkół i placówek oraz nauczycieli w zakresie ich działalności dydaktycznej, wychowawczej i opiekuńczej oraz innej działalności statutowej.

W drodze ewaluacji określa się stopień spełniania przez szkołę lub placówkę ustalonych wymagań na podstawie oceny przebiegu procesów edukacyjnych, a także efektów podejmowanych działań dydaktycznych, wychowawczych i opie-

3 Rozróżniamy ewaluację zewnętrzną i wewnętrzną. Ewaluacja prowadzona przez organ sprawujący nadzór pedagogiczny jest ewaluacją zewnętrzną. Ewaluacja prowadzona przez dyrektora szkoły lub placówki we współpracy z nauczycielami jest ewaluacją wewnętrzną. 
kuńczych oraz warunków działania szkoły lub placówki, jakości zarządzania i jej funkcjonowania w środowisku lokalnym. Ocena ta, z jednej strony ma służyć każdej szkole i placówce, przynosząc informacje o tym, co należy poprawić, doskonalić, aby szkoła lub placówka jak najlepiej realizowała wyznaczone zadania. Z drugiej strony uogólnione przez organ sprawujący nadzór pedagogiczny wyniki ewaluacji stanowią podstawę do doskonalenia całego systemu oświaty. Ewaluacja obejmuje:

- zbieranie i analizowanie informacji o działalności edukacyjnej szkoły lub placówki,

- określenie poziomu spełniania przez szkołę lub placówkę wymagań ustalonych przez ministra właściwego do spraw oświaty i wychowania w rozporządzeniu.

Wymagania te są ujęte w czterech obszarach działalności szkół i placówek:

- efekty działalności dydaktycznej, wychowawczej i opiekuńczej oraz innej działalności statutowej szkoły lub placówki,

- procesy zachodzące w szkole lub placówce,

- funkcjonowanie szkoły lub placówki w środowisku lokalnym, w szczególności w zakresie współpracy z rodzicami uczniów,

- zarządzanie szkołą lub placówką.

Przez prowadzoną w szkole lub w placówce ewaluację ustala się ocenę spełnienia wymagań według pięciostopniowej skali następujących poziomów:

- poziom A - bardzo wysoki,

- poziom B-wysoki,

- poziom C - średni,

- poziom D-podstawowy,

- poziom E-niski.

Ewaluacja dokonywana we wszystkich obszarach funkcjonowania szkoły lub placówki, to ewaluacja całościowa. Ewaluacja dokonywana w zakresie niektórych problemów wybranych z obszarów działalności szkoły lub placówki, to ewaluacja problemowa.

Organ sprawujący nadzór pedagogiczny kontroluje również przestrzeganie przez szkoły i placówki przepisów prawa w zakresie działalności dydaktycznej, wychowawczej i opiekuńczej oraz innej działalności statutowej. Tematyka kontroli, wynikających z planu nadzoru pedagogicznego kuratora oświaty, musi być zgodna z ustalonymi przez ministra właściwego do spraw oświaty i wychowania podstawowymi kierunkami realizacji polityki oświatowej państwa oraz wytycznymi i poleceniami, o których mowa w art. 35 ust. 2 pkt 1 i 2 u.s.o. Po prze- 
prowadzonej w szkole lub placówce kontroli sporządza się protokół kontroli zawierający m.in. opis ustalonego stanu faktycznego, w tym ujawnionych nieprawidłowości oraz zalecenia, wnioski i uwagi. Zakres zadań organu sprawującego nadzór pedagogiczny uwzględnia także wspomaganie pracy szkół i placówek, m.in. przez:

- przygotowywanie i publikowanie (z wykorzystaniem strony internetowej):

- analiz wyników sprawowanego nadzoru pedagogicznego, w tym wniosków z ewaluacji zewnętrznych i kontroli przestrzegania przepisów prawa,

- przykładów dobrych praktyk,

- organizowanie konferencji i narad dla dyrektorów szkół i placówek.

Zadaniem organów sprawujących nadzór pedagogiczny w zakresie wspomagania pracy szkół i placówek jest także promowanie wykorzystania ewaluacji w procesie doskonalenia pracy szkół i placówek.

\section{Zadania nadzoru pedagogicznego o charakterze zewnętrznym}

Nadzór pedagogiczny o charakterze zewnętrznym sprawują:

- kuratorzy oświaty - nad publicznymi i niepublicznymi przedszkolami, innymi formami wychowania przedszkolnego, szkołami i placówkami oraz placówkami doskonalenia nauczycieli (w tym nad niepublicznymi placówkami doskonalenia nauczycieli o zasięgu ogólnokrajowym, mającymi siedzibę na obszarze województwa),

- minister właściwy do spraw oświaty i wychowania - nad publicznymi i niepublicznymi kolegiami nauczycielskimi i nauczycielskimi kolegiami języków obcych, publicznymi placówkami doskonalenia nauczycieli o zasięgu ogólnokrajowym, a także nad prowadzonymi przez siebie szkołami publicznymi przy polskich placówkach dyplomatycznych, urzędach konsularnych i przedstawicielstwach wojskowych. Minister właściwy do spraw oświaty i wychowania posiada ponadto kompetencje do nadzorowania i koordynowania wykonywania nadzoru pedagogicznego na obszarze kraju oraz stanowienia przepisów określających szczegółowe zasady sprawowania nadzoru pedagogicznego. Kuratorzy oświaty funkcjonują w ramach zespolonej administracji rządowej w województwie, wymieniony minister zachował wobec nich tak wiele istotnych kompetencji, że praktycznie pozycja kuratora oświaty niewiele się różni od pozycji organu administracji niezespolonej,

- minister właściwy do spraw kultury i ochrony dziedzictwa narodowego - nad publicznymi i niepublicznymi szkołami i placówkami artystycznymi (z wyjąt- 
kiem nadzoru nad kształceniem ogólnym), placówkami zapewniającymi zakwaterowanie i opiekę uczniom szkół artystycznych oraz nad publicznymi i niepublicznymi placówkami doskonalenia nauczycieli szkół artystycznych,

- minister właściwy do spraw rolnictwa - nad publicznymi szkołami rolniczymi (z wyjątkiem nadzoru nad nauczaniem przedmiotów ogólnokształcących), placówkami rolniczymi oraz placówkami doskonalenia nauczycieli przedmiotów zawodowych, którzy nauczają w szkołach rolniczych prowadzonych przez tego ministra,

- minister właściwy do spraw środowiska - nad publicznymi szkołami leśnymi przez siebie prowadzonymi (z wyjątkiem nadzoru nad nauczaniem przedmiotów ogólnokształcących),

- minister właściwy do spraw sprawiedliwości i podporządkowane mu organy - nad zakładami poprawczymi, schroniskami dla nieletnich i ośrodkami diagnostyczno-konsultacyjnymi (wymienione jednostki nie są jednostkami systemu oświaty, a mimo to są objęte nadzorem pedagogicznym) oraz nad szkołami w tych zakładach i schroniskach, a także nad szkołami przy zakładach karnych (z wyjątkiem nadzoru nad nauczaniem przedmiotów ogólnokształcących),

- minister właściwy do spraw transportu, budownictwa, gospodarki morskiej, który współdziała z kuratorami oświaty w sprawowaniu nadzoru pedagogicznego nad publicznymi i niepublicznymi szkołami prowadzącymi kształcenie w zawodach dla żeglugi morskiej i śródlądowej.

Przepisy art. 32a ust. 1 i 1a u.s.o. uprawniają ministra właściwego do spraw kultury i ochrony dziedzictwa narodowego, ministra właściwego do spraw rolnictwa oraz ministra właściwego do spraw środowiska do utworzenia specjalistycznych jednostek nadzoru, którym ministrowie ci mogą powierzyć wykonywanie należących do nich zadań w zakresie nadzoru pedagogicznego, a także wykonywanie zadań organu prowadzącego, określonych w art. 5 ust. 7, w stosunku do szkół prowadzonych przez tych ministrów. Regulacja taka w rzeczywistości pozwala wymienionym ministrom na tworzenie, pod nazwą „specjalistyczna jednostka nadzoru”, podporządkowanej sobie niezespolonej administracji oświatowej wykonującej za ministra wszystkie zadania związane z nadzorem pedagogicznym nad określonymi rodzajami szkół i placówek oraz ich prowadzeniem. W wyniku przyjęcia takich rozwiązań funkcjonują jednostki sprawujące nadzór pedagogiczny, pozostające poza ustawowymi kompetencjami nadzorczymi i koordynacyjnymi ministra właściwego do spraw oświaty i wychowania wynikającymi z art. 35 ust. 1 pkt 2 u.s.o. 
Ustawa o systemie oświaty wykonywanie czynności zewnętrznego nadzoru pedagogicznego rezerwuje wyłącznie dla osób zatrudnionych na stanowiskach wymagających kwalifikacji pedagogicznych w kuratoriach oświaty oraz w urzędach innych organów sprawujących nadzór pedagogiczny (przede wszystkim w ministerstwach) i podporządkowanych im jednostkach.

\section{Zadania ministra właściwego do spraw oświaty i wychowania} w zakresie nadzoru pedagogicznego

Minister Edukacji Narodowej sprawuje nadzór pedagogiczny ${ }^{4}$ nad:

- szkołami, zespołami szkół oraz szkolnymi punktami konsultacyjnymi przy przedstawicielstwach dyplomatycznych, urzędach konsularnych i przedstawicielstwach wojskowych Rzeczypospolitej Polskiej dla dzieci obywateli polskich czasowo przebywających za granicą,

- publicznymi placówkami doskonalenia nauczycieli o zasięgu ogólnokrajowym.

Minister właściwy do spraw oświaty i wychowania koordynuje i realizuje politykę oświatową państwa, współdziałając w tym zakresie z wojewodami oraz z innymi organami i jednostkami organizacyjnymi właściwymi w sprawach funkcjonowania systemu oświaty (art. 21 u.s.o.). Ustawa o systemie oświaty precyzuje w art. 35 ust. 2 sposób nadzorowania i koordynowania wykonywania nadzoru pedagogicznego na terenie kraju przez ministra właściwego do spraw oświaty i wychowania, który w szczególności:

- ustala podstawowe kierunki realizacji przez kuratorów oświaty polityki oświatowej państwa, w szczególności zadań z zakresu nadzoru pedagogicznego,

- kontroluje sprawność i efektywność nadzoru pedagogicznego sprawowanego przez kuratorów oświaty oraz przestrzeganie przepisów obowiązujących w tym zakresie, a także może wydawać na piśmie kuratorom oświaty wiążące ich wytyczne i polecenia, z wyjątkiem indywidualnych spraw rozstrzyganych w drodze decyzji administracyjnej,

- może żądać od kuratorów oświaty informacji, dokumentów i sprawozdań okresowych lub dotyczących określonej sprawy albo rodzaju spraw,

- może organizować szkolenia, narady i konferencje kuratorów oświaty,

$4 \quad$ Na podstawie art. 35 ust. 1 pkt 1 u.s.o. 
- może ogłaszać w wydawanym przez siebie dzienniku urzędowym zalecane standardy wyposażenia szkół niezbędne do nauczania przedmiotów ogólnokształcących.

Minister właściwy do spraw oświaty i wychowania jest organem wyższego stopnia, w rozumieniu Kodeksu postępowania administracyjnego, w stosunku do kuratorów oświaty w sprawach, w których kurator wydaje decyzje administracyjne. W zakresie nadzoru pedagogicznego $\mathrm{z}$ decyzją administracyjną mamy do czynienia na przykład w wypadku wydania polecenia usunięcia uchybień w wyznaczonym terminie (art. 34 ust. 1 u.s.o.).

\section{Zadania kuratora oświaty w zakresie nadzoru pedagogicznego}

Na podstawie art. 30 ust. 1 u.s.o. zgodę na powołanie i odwołanie kuratora oświaty wyraża minister właściwy do spraw oświaty i wychowania ${ }^{5}$. Zgodnie $\mathrm{z}$ art. 31 ust. 1 u.s.o. kurator oświaty wykonuje, w imieniu wojewody, zadania i kompetencje w zakresie oświaty, w szczególności:

- sprawuje nadzór pedagogiczny nad publicznymi i niepublicznymi szkołami i placówkami oraz placówkami doskonalenia nauczycieli, w tym nad niepublicznymi placówkami doskonalenia nauczycieli o zasięgu ogólnokrajowym, które znajdują się na obszarze danego województwa,

- wydaje decyzje administracyjne w sprawach określonych w ustawie,

- współdziała z radami oświatowymí,

- wykonuje zadania organu wyższego stopnia w rozumieniu przepisów Kodeksu postępowania administracyjnego:

- w stosunku do organów jednostek samorządu terytorialnego - w sprawach szkół publicznych, zakładanych i prowadzonych przez osoby prawne i fizyczne, oraz szkół i placówek niepublicznych,

5 Zadania i kompetencje kuratora oświaty wynikają bezpośrednio z ustawy z 7 września 1991 r. o systemie oświaty, Dz.U. 2004, nr 256, poz. 2572, ze zm.

6 Rada oświatowa jest społecznym organem w systemie oświaty. Do jej zadań należy:

a) badanie potrzeb oświatowych na obszarze działania jednostki samorządu terytorialnego oraz przygotowywanie projektów ich zaspokajania,

b) opiniowanie budżetu jednostki samorządu terytorialnego w części dotyczącej wydatków na oświatę,

c) opiniowanie projektów sieci publicznych szkół i placówek,

d) opiniowanie projektów aktów prawa miejscowego wydawanych w sprawach oświaty,

e) wyrażanie opinii i wniosków w innych sprawach dotyczących oświaty. 
- w stosunku do dyrektorów szkół - w sprawach z zakresu obowiązku szkolnego i obowiązku nauki oraz w sprawach skreślenia uczniów z listy uczniów,

- realizuje politykę oświatową państwa, a także współdziała z organami jednostek samorządu terytorialnego w tworzeniu i realizowaniu odpowiednio regionalnej i lokalnej polityki oświatowej, zgodnych z polityką oświatową państwa,

- opracowuje programy wykorzystania środków na dofinansowanie doskonalenia nauczycieli, wyodrębnionych w budżecie wojewody, po zasięgnięciu opinii związków zawodowych reprezentatywnych w rozumieniu ustawy z 6 lipca 2001 r. o Trójstronnej Komisji ds. Społeczno-Gospodarczych i wojewódzkich komisjach dialogu społecznego,

- organizuje olimpiady, konkursy, turnieje, przeglądy oraz inne formy współzawodnictwa i prezentacji osiągnięć uczniów szkół na obszarze województwa,

- współdziała z okręgowymi komisjami egzaminacyjnymi,

- bada potrzeby nauczycieli w zakresie doskonalenia oraz inicjuje i koordynuje działania związane z doskonaleniem nauczycieli, współdziałając z organami prowadzącymi szkoły i placówki, a także może podejmować działania wspomagające materialnie i organizacyjnie doskonalenie nauczycieli,

- wspomaga działania w zakresie organizowania egzaminów i sprawdzianów w szkołach,

- współdziała z organami jednostek samorządu terytorialnego w zakresie kształtowania i rozwoju bazy materialnej szkół i placówek,

- współdziała z właściwymi organami, organizacjami i innymi podmiotami w sprawach dotyczących warunków rozwoju dzieci i młodzieży, w tym w przeciwdziałaniu zjawiskom patologii społecznej, a także może wspomagać działania tych podmiotów,

- koordynuje, wspomaga i nadzoruje organizację wypoczynku dzieci i młodzieży na obszarze województwa w okresie ferii letnich i zimowych,

- wykonuje inne zadania określone w przepisach odrębnych, w szczególności w zakresie obronności.

Powyżej wymienione kompetencje kuratora oświaty nie wyczerpują jednak listy zadań kuratora realizowanych wobec szkół i placówek oraz organów prowadzących szkoły/placówki; przewidują je bowiem również liczne akty wykonawcze do ustawy o systemie oświaty, a także przepisy ustawy z 26 stycznia 1982 r. - Karta Nauczyciela (Dz.U. 2019, poz. 2215)ㄱ.

7 http://www.prawo.vulcan.edu.pl/przegdok.asp?qdatprz=akt\&qplikid=2. 


\section{Zadania nadzoru pedagogicznego o charakterze wewnętrznym}

Zgodnie z art. 39 ust. 1 pkt 2 u.s.o., dyrektor szkoły lub placówki sprawuje nadzór pedagogiczny o charakterze wewnętrznym, to znaczy w stosunku do nauczycieli i innych pracowników pedagogicznych zatrudnionych w szkole (placówce). Dyrektor szkoły (placówki) jest jedynym podmiotem w systemie, który jednocześnie kieruje i zarządza działalnością szkoły (placówki) oraz sprawuje nadzór pedagogiczny nad zatrudnionymi w niej nauczycielami. Istnieje jeden wyjątek od zasady, że do sprawowania wewnętrznego nadzoru pedagogicznego jest uprawniony wyłącznie dyrektor szkoły: w sytuacji, gdy na stanowisko dyrektora szkoły powołana zostaje osoba niebędąca nauczycielem (art. 36 ust. 2 u.s.o.), nadzór pedagogiczny sprawuje nauczyciel zajmujący inne stanowisko kierownicze w szkole, np. wicedyrektor (art. 36 ust. 2a u.s.o.).

W szkolnictwie zawodowym obowiązują te same podstawy prawne dotyczące nadzoru pedagogicznego jak dla całego systemu oświaty, w tym wymagania wobec szkół ponadgimnazjalnych, placówek kształcenia ustawicznego, placówek kształcenia praktycznego oraz ośrodków dokształcania i doskonalenia zawodowego. Nadzór pedagogiczny w kształceniu zawodowym prowadzony jest zgodnie z rozporządzeniem Ministra Edukacji Narodowej z 7 października 2009 r. w sprawie nadzoru pedagogicznego (Dz.U. nr 168, poz. 1324).

\section{Nadzór pedagogiczny w wybranych państwach Unii Europejskiej}

\section{Czechy}

W Czechach instytucją realizującą zadania nadzoru pedagogicznego jest Czeska Inspekcja Szkolna (Česká školní inspekce, CSI) ${ }^{8}$, będąca odpowiednikiem polskiego Kuratorium Oświaty. Kompetencje i zakres działań CSI zostały określone w ustawie szkolnej (školský zakon) z 2004 r. ${ }^{9}$ Najważniejsze zadania Czeskiej Inspekcji Szkolnej to:

- kontrola placówek oświatowych i placówek kształcenia zawodowego,

- zbieranie i analiza informacji na temat poziomu kształcenia,

- monitorowanie i ocena efektywności systemu edukacyjnego,

8 http://www.csicr.cz/.

9 Zákon č. 561/2004 Sb., o předškolním, základním, středním, vyšším odborném a jiném vzdělávání (školský zákon), http://aplikace.msmt.cz/Predpisy1/sb190-04.pdf. 
- ocena poziomu realizacji programu nauczania i jego zgodności z ramowym programem kształcenia,

- prawnoadministracyjna kontrola wykorzystania budżetowych środków finansowych.

Wszystkie czynności z zakresu nadzoru pedagogicznego zarówno inspekcje, jak i kontrole wykonują wyznaczeni inspektorzy. Kontrola placówek oświatowych przeprowadzana jest przez zespoły trzy-, czteroosobowe i trwa trzy dni. Głównym źródłem informacji podczas kontroli jest dokumentacja szkoły oraz rozmowa z dyrektorem. Czescy inspektorzy - w odróżnieniu od polskich wizytatorów - nie przeprowadzają w szkołach ankiet ani wywiadów z nauczycielami, rodzicami i uczniami, choć mogą stosować testy sprawdzające wiedzę uczniów. W czasie inspekcji dokonują obserwacji lekcji, zwracając uwagę na to, czy nauczyciele motywują uczniów, czy wymagania wobec nich są zróżnicowane, oraz czy nauczyciele doskonalą swoje umiejętności w zakresie pracy z dziećmi o szczególnych potrzebach edukacyjnych. Wynikiem przeprowadzonej kontroli jest raport, który zamieszczany jest na stronie internetowej Inspekcji oraz badanej szkoły. Ponadto zebrane dane umieszczane są w elektronicznej bazie CSI. Wyniki z raportu stanowią podstawę m.in. do tworzenia szkolnych planów nauczania, organizowania zajęć dodatkowych z przedmiotów, w zakresie których uczniowie uzyskują niskie wyniki nauczania.

Jeżeli szkoła nie spełnia kryteriów ustalonych przez Ministerstwo Szkolnictwa, Młodzieży i Sportu, inspektorzy mogą zobowiązać dyrektora do opracowania programu naprawczego ze wskazaniem terminu kontroli jego realizacji, a w przypadkach skrajnych - zastosować inne sankcje, włącznie z wystąpieniem z wnioskiem o wykreślenie szkoły z wykazu sieci placówek oświatowych.

\section{Finlandia}

Podstawowym aktem prawnym dla fińskiej oświaty jest ustawa o kształceniu obowiązkowym ${ }^{10}$. System edukacji w Finlandii jest zdecentralizowany. Przepisy dotyczące administrowania i zarządzania szkołami zawarte zostały w ustawie o samorządzie lokalnym ${ }^{11}$. Osobą bezpośrednio odpowiedzialną za funkcjonowanie szkoły jest jej dyrektor. Sposób organizacji kształcenia w placówce określają przepisy przyjęte przez radę szkoły.

10 http://www.finlex.fi/en/laki/kaannokset/1998/en19980628.pdf.

11 http://www.localfinland.fi/en/authorities/local-self-government/Documents/Finnish\%20 Local\%20Government\%20Act.pdf. 
Za kształtowanie polityki oświatowej w Finlandii odpowiada rząd i parlament. Wdrażaniem tej polityki na poziomie centralnym zajmuje się rząd, Ministerstwo Edukacji i Kultury ${ }^{12}$ oraz Fiński Krajowy Urząd ds. Edukacji (Finnish National Board of Education). Działania ministerstwa wspierają następujące instytucje: Rada ds. Edukacji Dorosłych, Fińska Rada Szkolnictwa Wyższego oraz utworzona w 2003 roku Fińska Rada ds. Ewaluacji Edukacji (Finnish Education Evaluation (ouncil) ${ }^{13}$, której zadaniem jest opracowywanie planu zewnętrznej ewaluacji, zgodnie z wytycznymi Ministerstwa Edukacji i Kultury.

Przepisy dotyczące nadzoru pedagogicznego i ewaluacji placówek szkolnych zawarte są w pięciu ustawach: ustawie o kształceniu obowiązkowym, ustawie o szkolnictwie średnim, ustawie o kształceniu zawodowym, ustawie o kształceniu dorosłych oraz ustawie o kształceniu artystycznym. W Finlandii nie istnieje odrębny inspektorat szkolny, a władze publiczne zrezygnowały na początku lat dziewięćdziesiątych XX wieku z przeprowadzania wizytacji w szkołach. Główną rolę w przeprowadzaniu analizy kształcenia ogólnego, zawodowego oraz kształcenia dorosłych odgrywa w Finlandii Rada ds. Ewaluacji Edukacji. Do jej zadań należy ewaluacja funkcjonowania placówek oświatowych oraz systemu nauczania. Na poziomie krajowym ewaluacja ukierunkowana jest głównie na ocenę realizacji celów zawartych w krajowej polityce edukacyjnej oraz w krajowych podstawach programowych. Na poziomie lokalnym i regionalnym ewaluacja może koncentrować się na ocenie dostępności edukacji, finansowej odpowiedzialności instytucji edukacyjnych oraz realizacji lokalnej polityki w dziedzinie edukacji i kultury. Ocenie poddawany jest również stopień realizacji zasady równości i bezpieczeństwa w edukacji.

Zgodnie z przepisami ustawy o kształceniu obowiązkowym, instytucje edukacyjne są zobowiązane do regularnego przeprowadzania oceny własnej działalności i jej efektów. Ocena taka opiera się przede wszystkim na podsumowaniu realizacji celów zawartych w podstawie programowej, analizie wdrażania reform pedagogicznych i programowych oraz wykorzystania zasobów.

\section{Francja}

We Francji system oświaty zarządzany jest centralnie. Kształtowanie i egzekwowanie realizacji polityki edukacyjnej należy do centralnych władz wykonaw-

12 http://www.minedu.fi/OPM/.

13 http://www.edev.fi/portal/english5. 
czych. Taki model organizacji i zarządzania oświatą został wprowadzony w XIX wieku dekretem Napoleona, ustanawiając monopol państwa w sprawach organizacji ustroju szkolnego (mianowanie na wszystkie stanowiska pracy, kontrola nauczycieli, prawo otwierania szkół, przydzielanie stypendiów itp.).

Do zadań francuskiego Ministerstwa Edukacji Narodowej należy:

- opracowywanie szczegółowych programów nauczania wszystkich przedmiotów oraz wytycznych dotyczących organizacji i metodyki nauczania (wybór podręczników i metod nauczania należy do decyzji nauczycieli),

- prowadzenie naboru do zawodu nauczycielskiego i organizowanie kształcenia nauczycieli,

- podejmowanie decyzji w sprawie obsady etatów przez centralne określanie liczby nauczycieli i pracowników placówek,

- określanie statusu i zasad funkcjonowania szkół,

- organizowanie egzaminów, przyznawanie państwowych kwalifikacji oraz wydawanie świadectw maturalnych.

Problematyka kształcenia i doskonalenia zawodowego leży w kompetencjach dwóch ministerstw: Ministerstwa Edukacji Narodowej oraz Ministerstwa Szkolnictwa Wyższego i Badań Naukowych ${ }^{14}$.

Za realizację centralnej polityki edukacyjnej odpowiedzialne są na terenie kraju wydziały administracyjne, tzw. akademie (académies). Francja jest podzielona na 30 akademii, którymi w imieniu ministra kierują rektorzy (recteurs), mianowani przez Prezydenta Republiki. Rektor jako przedstawiciel Ministerstwa Edukacji Narodowej w terenie czuwa nad wykonywaniem rozporządzeń i wdrażaniem postanowień centralnych władz oświatowych. Rektorowi podlegają szkoły podstawowe, średnie, kształcenie ustawiczne, szkoły prywatne, szkolnictwo wyższe (z uwzględnieniem jego autonomii). W zakresie szkolnictwa podstawowego i średniego rektor uczestniczy w planowaniu kształcenia, określaniu struktury zatrudnienia pedagogicznego, zatwierdzaniu programów pedagogicznych, ustalaniu środków bezpieczeństwa w szkołach i przydzielaniu sprzętu dydaktycznego. W zakresie szkolnictwa prywatnego podejmuje decyzje dotyczące podpisywania tzw. umów stowarzyszeniowych oraz sprawuje nadzór pedagogiczny.

Akademia, odpowiadająca terytorialnie jednemu regionowi administracyjnemu, obejmuje zazwyczaj kilka departamentów (départements). Każdym departamentem należącym do danej akademii kieruje inspektor akademii (inspecteur d'académie), mianowany dekretem Prezydenta Republiki. Inspektor akademii

14 Zob. przyp. 12 na s. 114. 
nadzoruje w departamencie realizację zaplanowanych zadań edukacyjnych. Kompetencje inspektora akademii odnoszą się do wszystkich poziomów nauczania z wyjątkiem szkolnictwa wyższego. Inspektor akademii podlega zarówno prefektowi (naczelnikowi departamentu w ramach podziału administracyjnego kraju), jak i rektorowi.

W zakresie szkolnictwa podstawowego inspektor akademii sprawuje dwa typy funkcji: funkcje administracyjne i funkcje pedagogiczne. Jego kompetencje administracyjne zezwalają mu na podejmowanie decyzji odnośnie do otwierania i zamykania klas oraz przydziału etatów nauczycielskich w szkołach podstawowych. Do jego kompetencji należy również zarządzanie kadrą placówek oświatowych oraz prowadzenie nadzoru pedagogicznego. Wizytacje przeprowadzają inspektorzy - inspektorzy generalni i inspektorzy oświatowi. Inspektorom generalnym powierzono szeroki zakres wszelkich zadań kontrolnych i ewaluacyjnych na wszystkich szczeblach edukacyjnych, a do zadań inspektorów oświatowych należy kontrola szczebla przedszkolnego, szkolnictwa podstawowego i średniego. Oddzielną kategorią inspektorów są inspektorzy ds. dydaktyki, którzy odpowiadają za sprawy związane z ewaluacją pracy dydaktycznej nauczyciela.

\section{Hiszpania}

Hiszpania podzielona jest administracyjnie na 17 autonomicznych wspólnot. Wspólnoty autonomiczne mają znaczną władzę ustawodawczą i wykonawczą, a tym samym dużą autonomię - głównie w kwestiach oświaty, szkolnictwa i podatków. W sprawach edukacji władze centralne zachowały odpowiedzialność tylko w zakresie ogólnych uregulowań oświatowych, a większość zadań została w 1978 roku przekazana władzom regionalnym, więc oprócz federalnego Ministerstwa Edukacji, Kultury i Sportu w strukturze zarządzania hiszpańską oświatą znajduje się 17 regionalnych ośrodków pełniących de facto funkcje regionalnych ministerstw.

Istotną cechą hiszpańskiego systemu oświaty jest społeczne uczestnictwo w edukacji. Zarówno na szczeblu krajowym, regionalnym, jak i lokalnym oraz w poszczególnych szkołach tworzy się rady szkolne, które mają zachęcać do uczestnictwa w konsultacjach społecznych wszystkie grupy zainteresowane edukacją. Na szczeblu ogólnokrajowym istnieje Państwowa Rada Szkolna, która umożliwia przedstawicielom społeczeństwa udział w ogólnym planowaniu oświaty oraz doradza w sprawie projektów ustaw i innych aktów prawnych proponowanych lub wydawanych przez rząd. W każdej szkole finansowanej ze 
środków publicznych działa Rada Szkolna, która jest organem przedstawicielskim różnych grup tworzących środowisko edukacyjne, zajmującym się zarządzaniem i nadzorem nad daną placówką. W jej skład wchodzi kierownictwo placówki oraz przedstawiciele nauczycieli, uczniów, rodziców, personelu administracyjnego i technicznego, jak również - w przypadku placówek prywatnych finansowanych ze środków publicznych - przedstawiciele właścicieli placówki. Do zadań Rady Szkolnej należy m.in. podejmowanie decyzji w sprawie naboru uczniów, zatwierdzanie budżetu placówki i analizowanie jej funkcjonowania; radę informuje się także o przedstawianych władzom edukacyjnym wnioskach o mianowanie lub odwołanie członków kierownictwa.

W zakresie programów nauczania istnieje autonomia, która wyraża się w tym, że programy tworzy się na trzech poziomach. Przyjmując za punkt wyjścia podstawy programowe, które władze centralne ustalają dla całego kraju, każda wspólnota autonomiczna opracowuje własny, oficjalnie obowiązujący program nauczania (pierwszy poziom tworzenia programu). Następnie, na drugim poziomie tworzenia programu nauczania, placówka edukacyjna dostosowuje do swoich potrzeb i dopracowuje ten „wspólnotowy” program nauczania. Trzeci poziom tworzenia programu stanowi „programowanie w klasie”, na które składa się wiele jednostek dydaktycznych opracowywanych przez nauczyciela dla każdej konkretnej grupy uczniów.

Powyższa specyfika funkcjonowania systemu oświaty powoduje, że regionalne jednostki odpowiedzialne za edukację mają w swoich kompetencjach o wiele szerszy zakres działania niż polskie kuratoria oświaty i to właśnie one kształtują system oświaty w poszczególnych autonomiach. Nauczyciele zatrudniani są przez regionalne wydziały edukacji. Oceny ich pracy dokonują inspektorzy. Każde regionalne Ministerstwo Oświaty ustala własne zasady i sposoby ewaluacji pracy placówek.

\section{Holandia}

W Holandii nadzór pedagogiczny prowadzi Inspektorat Edukacji i choć formalnie podlega Ministerstwu Edukacji , Kultury i Nauki, to posiada status instytucji niezależnej, co przejawia się przede wszystkim swobodą w decydowaniu o zakresie prowadzonych badań. Inspekcje szkolne przeprowadzane są raz na cztery lata, jednak w przypadku uchybień bądź osiągania przez uczniów niezadowalających wyników wizytacje odbywają się znacznie częściej. Placówki szkolne zobowiązane są do dostarczania Inspektoratowi Edukacji comiesięcznych sprawozdań, 
na podstawie których analitycy podejmują decyzje o terminie przeprowadzenia wizytacji. Przeprowadzenie inspekcji poprzedzone jest pismem zawiadamiającym o planowanym rozpoczęciu wizytacji szkoły, które dostarczane jest dyrektorowi na dwa dni przed kontrolą. Inspekcja trwa jeden dzień, rozpoczyna się krótką rozmową z dyrektorem, a następnie prowadzone są wycinkowe obserwacje lekcji oraz wywiady z nauczycielami, uczniami i rodzicami. Pod koniec dnia inspektorzy analizują dokumentację i ustalają wynik końcowy inspekcji, który jest omawiany z dyrektorem szkoły. Wyniki oraz wnioski są dostarczane w terminie siedmiu dni od zakończenia ewaluacji i następnie prezentowane całej radzie pedagogicznej. Holenderscy inspektorzy po każdej wizytacji sporządzają krótki, dwustronicowy raport jakościowy, który zawiera opis dobrych i słabych elementów pracy szkoły oraz podaje ocenę w kontekście średnich wyników krajowych. Placówki osiągające niezadowalające wyniki są zobowiązane do ich poprawy w ciągu dwóch lat. Brak takiej poprawy skutkuje odebraniem części budżetu lub nawet zamknięciem szkoły.

Holenderski Inspektorat Edukacji w ramach sprawowanego nadzoru gromadzi informacje na temat pracy szkół oraz dokonuje analizy danych pozyskanych z innych źródeł. Po otrzymaniu raportu zadaniem szkoły jest wdrożenie działań mających na celu poprawę w obszarach wskazanych jako słabe. Inspektorat prowadzi także stronę internetową dostępną dla rodziców i uczniów, na której zamieszczane są zewnętrzne oceny. Szkoła uznana za dobrą placówkę oznaczana jest zielonym kolorem, pomarańczowym - szkoła zagrożona ryzykiem, a kolorem czerwonym - szkoła źle funkcjonująca.

Bez względu na wynik oceny placówka może zwrócić się o pomoc do instytucji wspomagających funkcjonowanie szkoły, np. do Centrum Badań i Rozwoju Edukacji - PLATO ${ }^{15}$, Narodowego Instytutu Badania Jakości Kształcenia - CITO ${ }^{16}$ lub wielu innych agencji szkoleniowych. Do głównych zadań PLATO, działającego przy Uniwersytecie w Leiden, należy prowadzenie szkoleń i badań dotyczących ewaluacji. Centrum realizuje programy krajowe związane z edukacją, np: monitorowanie edukacji dzieci i młodzieży, monitorowanie wdrażania programów związanych z bezpieczeństwem życia i zdrowia uczniów, ewaluacja szkolnych programów zapobiegania wagarom. Szkoli również nauczycieli, wizytatorów oraz bada współczesne kierunki w kształceniu nauczycieli w Europie.

15 http://www.fsw.leidenuniv.nl/plato/expertise/oefenen.html.

16 http://www.cito.nl/. 


\section{Irlandia}

System oświaty w Irlandii zarządzany jest centralnie przez Ministerstwo Edukacji i Umiejętności (Ministry of Education and Skills) ${ }^{17}$. Jednostką odpowiedzialną za ewaluację podstawowych i ponadpodstawowych szkół i placówek oświatowych jest Inspektorat Departamentu Ministerstwa Edukacji i Umiejętności (Inspectorate of Department of Education and Skills). Inspektorat podejmuje decyzje dotyczące zakładania szkół, opracowuje programy nauczania, reguluje sprawy kadrowe, w tym płace nauczycieli.

Specyfiką irlandzkiej oświaty jest utrzymywanie przez państwo wielu małych szkół podstawowych, w których zatrudniony jest tylko jeden lub dwóch nauczycieli. Nauczyciele w szkołach podstawowych uczą wszystkich przedmiotów, a ich specjalizacja zawodowa dotyczy nauczania na danym szczeblu edukacyjnym, a nie tak jak w Polsce - w nauczaniu przedmiotów. W szkołach średnich (secondary schools) cykl edukacyjny podzielony jest na dwa etapy, po których uczniowie zdają egzaminy. Między pierwszym a drugim etapem kształcenia uczniowie mogą skorzystać z tzw. roku przejściowego. Jest to okres przeznaczony do przygotowywania ucznia do podjęcia nauki w drugim etapie kształcenia.

Do głównych zadań Inspectorate of Department of Education and Skills należy:

- przeprowadzanie kontroli w szkołach i ośrodkach kształcenia,

- propagowanie dobrych praktyk edukacyjnych i doskonalenia zawodowego nauczycieli oraz dyrektorów szkół,

- publikowanie jednostkowych i zbiorczych raportów kontrolnych,

- promowanie języka irlandzkiego,

- prowadzenie wszelkich wyjaśnień, porad i promocji z zakresu funkcjonowania irlandzkiego systemu edukacyjnego.

Osoby pełniące funkcje inspektorów są wieloletnimi doświadczonymi nauczycielami. Wielu z nich pełni funkcje dyrektorów szkół lub doradców edukacyjnych. Część specjalizuje się w projektowaniu programów nauczania, prowadzeniu badań edukacyjnych i zarządzaniu placówkami oświatowymi.

Przeprowadzenie całościowej ewaluacji placówki szkolnej obejmuje pięć obszarów jej działalności, do których zalicza się:

- jakość zarządzania szkołą,

- jakość planowania,

- jakość realizacji programu nauczania,

17 http://www.education.ie/en/. 
- jakość nauczania i uczenia się oraz

- jakość wsparcia udzielanego uczniom.

W Irlandii przeprowadzana kontrola koncentruje się głównie na ocenie jakości procesu kształcenia, mniejszą uwagę przywiązuje się do oceny działalności szkoły skierowanej na otoczenie zewnętrzne - w tym środowisko lokalne. Głównym zadaniem ewaluacji jest dostarczenie szkole informacji na temat jej dobrych i słabych stron, dlatego w końcowym raporcie inspektorzy nie wystawiają ocen, lecz formułują wnioski i rekomendacje z ewaluacji bez odwoływania się do danych ilościowych lub źródeł pozyskania informacji. (W polskiej praktyce wizytacji szkolnych raport ewaluacyjny nie zawiera rekomendacji, lecz wnioski z ewaluacji. W odróżnieniu od raportu irlandzkiego odwołuje się do danych ilościowych oraz ich źródeł).

Podczas ewaluacji przedmiotowej inspekcji poddaje się wszystkie elementy mające wpływ na jakość nauczania danego przedmiotu: przygotowanie nauczycieli, dobór podręczników, informację na temat bazy dydaktycznej oraz możliwości wyboru przedmiotu przez uczniów. Kontrola polega na obserwacji czterech-sześciu lekcji w ciągu jednego dnia, podczas których analizie poddaje się proces nauczania i uczenia się, formy oceniania, zasady udzielania informacji zwrotnej uczniowi i jego rodzicom oraz dokumenty świadczące o sposobach planowania pracy przez nauczyciela.

Liczba inspektorów zespołu przeprowadzającego kontrolę uzależniona jest od zakresu tematycznego ewaluacji lub od wielkości szkoły. Planowana inspekcja w szkole podstawowej powinna być zapowiedziana na pięć tygodni przed jej terminem, a w szkole ponadpodstawowej - na trzy tygodnie przed wizytacją. 0 inspekcji tematycznej szkoły informuje się z dwutygodniowym wyprzedzeniem.

\section{Niemcy}

W Republice Federalnej Niemiec zakres odpowiedzialności za system edukacji wynika z federalnej struktury państwa. Zgodnie z Ustawą Zasadniczą (Grundgesetz) za ustawodawstwo i administrację oświatową odpowiadają przede wszystkim kraje związkowe - landy, w których działają ministerstwa edukacji, kultury i nauki oraz struktury nadzorujące szkoły na niższym szczeblu (Schulamt). Taki podział odpowiedzialności dotyczy w szczególności struktury systemu szkolnego oraz programów i metod nauczania. Zadania rządu federalnego w dziedzinie edukacji obejmują m.in. ustanawianie przepisów wyznaczających ogólne ramy współpracy oświatowej między szczeblem federalnym i landami, np. w zakresie planowania edukacji i promowania badań. Ministerstwa edukacji w landach 
ustalają program nauczania, zalecają metody nauczania, zatwierdzają podręczniki i prowadzą kontrolę placówek.

Współpraca landowych ministerstw edukacji koordynowana jest przez Stałą Konferencję Ministrów Edukacji i Kultury Krajów Związkowych Republiki Federalnej Niemiec (Kultursministerkonferenz; dalej: Stała Konferencja). Określa ona obszary, w jakich landy powinny podjąć działania w celu podniesienia jakości kształcenia. Należą do nich: zapewnienie odpowiedniej jakości kształcenia w szkołach, opracowanie, wdrożenie i ocena standardów kształcenia (Bildungsstandards) oraz regularne składanie przez rząd federalny i landy sprawozdań dotyczących stanu oświaty w Niemczech. W latach 2003-2004 ministrowie krajów związkowych uzgodnili wspólne standardy kształcenia (wymagania) ${ }^{18}$, jakie powinni spełniać uczniowie po ukończeniu następujących trzech etapów edukacyjnych:

- w Grundschule w odniesieniu do języka niemieckiego i matematyki (po IV klasie),

- w Hauptschule w odniesieniu do języka niemieckiego, matematyki i pierwszego języka obcego: angielskiego lub francuskiego (po IX klasie),

- w Realschulen w odniesieniu do języka niemieckiego matematyki, pierwszego języka obcego, biologii, chemii i fizyki (po X klasie).

W październiku 2007 roku Stała Konferencja postanowiła zastosować również podczas egzaminu maturalnego jednakowe wymagania egzaminacyjne z języka niemieckiego, matematyki i pierwszego języka obcego (angielski lub francuski) oraz biologii, chemii i fizyki. Obecnie matura centralna przeprowadzana jest w 15 z 16 landów, przy czym w niektórych landach przeprowadzana jest nie ze wszystkich przedmiotów, a tylko z języka niemieckiego, matematyki i pierwszego języka obcego (angielski lub francuski). Wyniki testów po każdym etapie kształcenia są analizowane podczas ewaluacji zewnętrznej szkół przez instytucje do tego powołane w poszczególnych landach. Nie są one natomiast upubliczniane.

\section{Ewaluacja zewnętrzna w Nadrenii-Palatynacie ${ }^{19}$}

W 2005 roku na wniosek Ministra Oświaty Nadrenii Północnej-Palatynatu powołano Agencję Jakości, Ewaluacji i Samodzielności Szkół (Agentur für Qualitätssicherung, Evaluation und Selbstständigkeit von Schulen, AQS) ${ }^{20}$, której celem

18 Ze względu na autonomię oświatową landów należy zwrócić uwagę, że wspólne standardy kształcenia nie oznaczają jednakowych dla wszystkich landów testów egzaminacyjnych.

19 http://www.ptde.org/file.php/1/Archiwum/XVII_KDE/pedeefy/Krol.pdf.

20 http://www.aqs.rlp.de/. 
jest ewaluacja zewnętrzna szkół oraz przeprowadzanie analiz i zestawień statystycznych na temat oświaty na terenie landu. Ewaluacja zewnętrzna jest częścią składową całościowej strategii poprawy jakości szkół, a jej celem jest dawanie impulsów szkołom do trwałej poprawy procesu kształcenia. Zespoły wizytatorów AQS odwiedzające placówki składają się z wykwalifikowanych pedagogów, naukowców, specjalistów od zarządzania i informatyki. Ewaluacja zewnętrzna przeprowadzana jest według poniższych pięciu etapów:

- nawiązanie kontaktu z placówką szkolną,

- wizyta przygotowująca,

- ankietowanie uczniów, nauczycieli, rodziców,

- wizytacja w szkole,

- ocena danych przez AQS i sporządzenie raportu.

Podczas wizytacji inspektorzy AQS przeprowadzają wśród uczniów, nauczycieli i rodziców ankiety w formie pisemnej. Następnie prowadzą poufne rozmowy z dyrekcją szkoły, nauczycielami, rodzicami i przedstawicielami samorządów szkolnych. W proces ewaluacji włączone są również placówki finansujące szkołę i jej ewentualni partnerzy. Dodatkowymi źródłami informacji dla inspektorów są: dokumenty prezentujące program dydaktyczno-wychowawczy placówki, dane statystyczne szkoły oraz informacje zebrane w wyniku przeprowadzonych rozmów i wywiadów. Zebrane informacje są oceniane i przekazywane szkole w formie raportu, w którym szczególną uwagę zwraca się na wskazanie dobrych i słabych stron pracy szkoły. Pełny raport przekazywany jest dyrektorowi szkoły podczas specjalnej konferencji, w której udział biorą nauczyciele oraz przedstawiciele rodziców i nadzoru pedagogicznego. Najważniejsze wyniki i wnioski raportu prezentowane są przez kierownika zespołu wizytującego. Informacje zawarte w raporcie stają się punktem wyjścia do realizacji wytycznych pokontrolnych. W dokumencie znajduje się także ocena szkoły wyrażona w skali czterostopniowej:

- stopień $1-\mathrm{w}$ trakcie rozwoju,

- stopień 2 - poziom bazowy,

- stopień 3 - poziom docelowy (odpowiada dobrej praktyce),

- stopień 4 - poziom doskonałości.

\section{Rumunia}

W Rumunii nadzór pedagogiczny w systemie oświatowym realizowany jest przez kilka podmiotów. Zgodnie z wymogami rumuńskiego Ministerstwa Edu- 
kacji ${ }^{21}$ każda szkoła, przed rozpoczęciem działalności edukacyjnej musi uzyskać akredytację od Agencji Zarządzania Jakością Kształcenia (akredytacja jest odnawiana raz na pięć lat). Ministerstwo Edukacji nie przekazuje pieniędzy na ten cel. Szkoły muszą same zdobyć środki finansowe. Pozyskane fundusze Agencja przeznacza na opłacenie wizytatorów i poniesione koszty związane ich pracą.

Instytucje sprawujące w Rumunii nadzór pedagogiczny nad funkcjonowaniem placówek szkolnych to Agencja Zarządzania Jakością Kształcenia, Centrum Rozwoju Kształcenia Zawodowego i Technicznego, Instytut Badań i Edukacji oraz Inspektorat Oświatowy.

- Agencja Zarządzania Jakością Kształcenia (Agentia Româna de Asigurare a Calitatii în Învatamântul Preuniversitar, ARACIP) ${ }^{22}$. Agencja jest instytucją publiczną podlegającą Ministerstwu Edukacji. Sprawuje całościowy nadzór nad akredytacją i ewaluacją zewnętrzną jakości kształcenia w placówkach szkolnych i innych instytucjach oświatowych działających w Rumunii do poziomu szkolnictwa średniego włącznie. Wydaje akredytacje o spełnianiu standardów jakości kształcenia dostawców usług edukacyjnych. Opracowuje standardy, normy jakości oraz wskaźniki wydajności kształcenia. Prowadzi krajowy rejestr niezależnych wizytatorów/ewaluatorów. Publikuje opracowane raporty. Raport sporządzony przez ewaluatora opisuje jeden obszar w postaci tabelarycznej i zawiera ocenę słowną (zbieranie danych i wizyta w szkole trwają 1-2 dni).

- Centrum Rozwoju Kształcenia Zawodowego i Technicznego (Centrul Național de Dezvoltare a Învățământului Profesional și Tehnic, CNDIPT) ${ }^{23}$. Centrum to organ Ministerstwa Edukacji, którego głównym celem jest doskonalenie szkolnictwa zawodowego i technicznego. Zadania realizowane są przez: koordynację innowacyjnych projektów naukowych na rzecz rozwoju szkolnictwa technicznego i zawodowego, koordynację badań naukowych i wdrażanie programów nauczania, koordynację metodologii naukowej do projektowania systemu oceny i certyfikacji kształcenia zawodowego i technicznego.

- Instytut Badań i Edukacji (Institutul de Ştiinţe ale Educaţiei, IES)24. Instytut jest organem podległym bezpośrednio Ministerstwu Edukacji Narodowej. Zajmuje się opracowywaniem i realizacją projektów edukacyjnych, przygotowywaniem narzędzi do badań, testowaniem ich, wydawaniem publikacji

21 http://www.edu.ro/index.php/base/frontpage.

22 http://administraresite.edu.ro/index.php/articles/c809/.

23 http://cndiptoi.tvet.ro/.

24 http://www.ise.ro/. 
z zakresu pomiaru, ewaluacji itp. Instytut zatrudnia ekspertów z dziedziny socjologii, psychologii, pedagogiki. Raz do roku IES przedstawia rumuńskiemu parlamentowi raport ze swojej działalności badawczej.

- Inspektorat Oświatowy jest odpowiednikiem polskiego kuratorium oświaty. Jego zadaniem jest prowadzenie monitoringu i kontroli podległych szkół i placówek. Inspektorzy kontrolują i monitorują jakość pracy nauczycieli, poziom zdobytej wiedzy przez uczniów, wykorzystanie bazy dydaktycznej, respektowanie prawa oświatowego, współpracę z rodzicami, pracę dydaktyczną i wychowawczą szkoły. Inspektorzy przygotowują raport, w którym każdemu z wymienionych obszarów przypisują poziom spełnienia wymagań według pięciostopniowej skali (niesatysfakcjonujący, satysfakcjonujący, dobry, bardzo dobry, wyśmienity). Po stwierdzeniu uchybień szkoła opracowuje i wdraża plan naprawczy, uwzględniający rekomendacje inspektorów. Badanie placówki trwa miesiąc i jest dokonywane przez około 30 inspektorów (w zależności od liczby przedmiotów). Monitoring (inspekcja) odbywa się jednocześnie we wszystkich typach szkół danej miejscowości. Jeden inspektorat wykonuje 50 inspekcji rocznie.

\section{Szwecja}

W Szwecji system edukacji jest zdecentralizowany, a odpowiedzialność za jego funkcjonowanie spoczywa na jednostkach administracji lokalnej. Parlament przyjmuje ustawy w sprawie oświaty, a rząd odpowiedzialny jest za ich wdrożenie do realizacji. W strukturze systemu oświatowego ważną funkcję pełnią dwie instytucje centralne. Są to: Szwedzka Narodowa Agencja ds. Edukacji (Statens skolverk, powszechnie znana jako Skolverket ${ }^{25}$ oraz Szwedzka Inspekcja Szkolna (Skolinspektionen $)^{26}$.

Skolverket jest centralnym organem administracji publicznego systemu szkolnego. Podstawową misją Agencji jest aktywne działanie na rzecz realizacji celów oświatowych wyznaczonych przez parlament i rząd, wspieranie rozwoju szkolnictwa, dokonywanie oceny potrzeb oświaty, prowadzenie badań oraz zbieranie danych statystycznych na temat szwedzkiej oświaty. Skolverket prowadzi także edukacyjną działalność doradczą oraz opracowuje testy do krajowych przedmiotowych egzaminów szkolnych.

25 http://www.skolverket.se/.

26 http://skolinspektionen.se/. 
Skolinspektionen jest odpowiednikiem polskich kuratoriów. Do zadań Szwedzkiej Inspekcji Szkolnej należy między innymi przeprowadzanie raz na pięć lat wizytacji w szkołach i placówkach oświatowych oraz wydawanie zezwoleń na działalność edukacyjną dla niezależnych placówek oświatowych. Jeżeli w wyniku wizytacji okaże się, że szkoła osiąga niezadowalające wyniki dydaktyczno-wychowawcze, to ocena ta przekazywana jest kuratorom, czyli urzędnikom, którzy w ramach gminy sprawują nadzór nad placówką. Do ich obowiązków należy we współpracy z dyrektorem placówki - wypracowanie środków zaradczych. Natomiast w razie stwierdzenia przypadków łamania prawa Szwedzka Inspekcja Szkolna ma obowiązek zarządzić kontrolę szczegółową, w wyniku której może nałożyć kary finansowe lub podjąć decyzję o zamknięciu szkoły.

W Szwecji ewaluacji wewnętrznej i zewnętrznej podlegają wszystkie placówki szkolne. Ewaluację wewnętrzną szkoły przeprowadzają we własnym zakresie, natomiast za ewaluację zewnętrzną odpowiedzialne są organy prowadzące (władze lokalne), które zatrudniają w tym celu wyspecjalizowanych pracowników lub zlecają to zadanie odpowiednim firmom zewnętrznym.

\section{Wielka Brytania}

System oświatowy Wielkiej Brytanii nie jest jednolity. Systemy szkolne Anglii i Walii są relatywnie podobne do siebie, lecz odmienne od ustrojów szkolnych Szkocji i Irlandii Północnej, które regulowane są odrębnymi ustawami i zarządzeniami władz lokalnych. W Anglii i Walii instytucjami odpowiedzialnymi za organizację oświaty jest Ministerstwo ds. Dzieci, Edukacji, Kształcenia Ustawicznego i Umiejętności (Department for Children, Education, Lifelong Learning and Skills, DCELLS). W Anglii dodatkowo za oświatę odpowiada Ministerstwo ds. Biznesu, Innowacji i Umiejętności (Department for Business, Innovation and Skills, BIS). W Irlandii Północnej za centralne administrowanie systemem kształcenia podstawowego i średniego odpowiada Ministerstwo Edukacji (Department of Education, DE), a za szkolnictwo wyższe - Ministerstwo Zatrudnienia i Kształcenia (Department for Employment and Learning, DEL). W Szkocji za ogólny nadzór nad edukacją i rozwojem usług edukacyjnych odpowiada Pierwszy Minister ds. Szkocji (First Minister of Scotland). W jego imieniu obowiązki te wykonuje Sekretarz Stanu ds. Edukacji i Kształcenia Ustawicznego (Secretary for Education and Lifelong Learning). Wspieraniem tworzenia i realizacji polityki oświatowej Szkocji zajmują się Inspektorat ds. Edukacji (Her Majesty’s Inspectorate of Education, HMIE) oraz instytucje odpowiedzialne za opracowywanie programów naucza- 
nia, przeprowadzanie egzaminów i finansowanie szkockich placówek edukacyjnych - Szkockie Biuro ds. Uczenia się i Nauczania (Learning \&Teaching Scotland), Szkocki Urząd ds. Kwalifikacji (Scottish Qualifications Authority), Szkocka Rada ds. Wsparcia Finansowego Oświaty (Scottish Funding Council, SFC).

W Anglii, Walii i Irlandii Północnej programy nauczania opracowywane są samodzielnie przez szkoły w sposób odzwierciedlający specyfikę ich potrzeb i warunków działania. Placówki obowiązane są zadbać o to, by program był odpowiednio zrównoważony i zgodny z ogólnymi wytycznymi. W ministerialnych przepisach ustalono specjalne wymogi dotyczące nauczania określonych przedmiotów. W Szkocji programy nauczania bazują na wskazówkach i wytycznych szkockich władz oświatowych. Wytyczne publikowane są w dokumentach programowych, które koncentrują się jedynie na dwóch przedmiotach: edukacja religijna wraz z praktykami religijnymi oraz język celtycki w rejonach, w których jest używany. Nauczanie pozostałych przedmiotów pozostaje w gestii szkoły. Należą do nich: język angielski, matematyka, nauka o środowisku, sztuka, etyka wraz z rozwojem indywidualnym, społecznym i edukacją zdrowotną. W szkole średniej program nauczania jest podzielony na dwa etapy. W pierwszych dwóch klasach prowadzi się kształcenie ogólne zgodnie z narodowym programem 5-14 (National 5-14 Programme), natomiast w trzeciej i czwartej klasie wprowadza się elementy specjalizacji i kształcenia zawodowego dla wszystkich uczniów. Nauczyciele mają pełną swobodę wyboru podręczników i pomocy naukowych.

\section{System nadzoru pedagogicznego w Anglii}

Kontrole, nadzór pedagogiczny i wizytacje szkolne realizowane są przez Urząd ds. Standardów w Edukacji, Opieki nad Dziećmi i Umiejętności (Office for Standards in Education, Children's Services and Skills, Ofsted). Urząd realizuje zadania zgodne z polityką rządu. Podlega parlamentowi, któremu regularnie przedstawia sprawozdania ze swojej działalności. Głównym zadaniem Ofsted jest nadzór nad realizacją narodowego programu nauczania. Urząd obejmuje swoim zakresem działań wszystkie instytucje edukacyjne w Anglii (z wyjątkiem szkolnictwa wyższego). Nadzoruje także działalność placówek kształcenia dorosłych.

Angielski system nadzoru pedagogicznego koncentruje się przede wszystkim na wynikach egzaminów zewnętrznych i to one rzutują na ostateczną ocenę szkoły. Zadaniem inspektorów podczas wizytacji jest sprawdzenie, jak kształtują się wyniki egzaminów w dwóch aspektach. Po pierwsze, jak osiągane wyniki kształtują się w określonym obszarze czasowym, i po drugie - jak te wyniki odno- 
szą się do obowiązujących norm krajowych. Czynniki, które także brane są pod uwagę podczas kontroli, to efektywność kształcenia, wielokulturowość, pochodzenie etniczne, równość płci i integracja uczniów o zróżnicowanych i specyficznych możliwościach edukacyjno-wychowawczych.

Końcowy raport $\mathrm{z}$ przeprowadzonej wizytacji przedstawia informacje w odniesieniu do trzech obszarów pracy szkoły: prezentuje wyniki i osiągnięcia uczniów, ukazuje, w jakim stopniu szkoła wyrównuje szanse edukacyjne oraz przedstawia jakość szkolnych działań na rzecz bezpieczeństwa ${ }^{27}$.

Placówki szkolne w Anglii mają duży zakres autonomii w zakresie samooceny i doskonalenia. Zadania z zakresu oceny pracy placówki należą głównie do rad szkolnych i dyrektora. W Anglii dyrektor szkoły jest odpowiedzialny za wewnętrzną organizację, zarządzanie i kierowanie pracą szkoły. Dyrektorzy są zobowiązani do konsultacji z władzami lokalnymi, radą prowadzącą szkołę, pracownikami szkoły oraz rodzicami uczniów. Dyrektor szkoły jest odpowiedzialny za zarządzanie w następujących dziedzinach:

- organizacja pracy szkoły,

- zarządzanie kadrami,

- organizacja procesu nauczania i programu nauczania,

- promocja szkoły, dobre relacje z partnerami społecznymi,

- zasoby i budynek/grunty szkolne,

- dyscyplinowanie uczniów,

- autoewaluacja.

Dyrektor szkoły zobowiązany jest do prowadzenia w placówce regularnej autoewaluacji we wszystkich obszarach będących przedmiotem kontroli Ofsted. Co roku w szkole opracowany jest raport, którego źródłem jest szczegółowy arkusz samooceny, zawierający opis realizowanych działań, osiągnięte efekty i dowody je potwierdzające. Oprócz powyższego raportu szkoła przygotowuje dodatkową dokumentację samooceny. Karta samooceny zawiera dane z kilku lat, przez co umożliwia pokazanie pewnych tendencji w pracy szkoły w tym ewentualnych osiągnięć uczniów. Coroczne wyniki autoewaluacji przesyłane są do inspektorów z Ofstedu. Uzyskane dane weryfikowane są przez wizytatorów przy okazji realizowanej kontroli. Szkoły kontrolowane są zwykle w cyklu trzyletnim, przy czym te o słabszych wynikach, kontrolowane są częściej. Standardowa kontrola realizowana przez inspektorów Ofsted w szkole trwa dwa dni. Liczebność zespołu

27 Raport nadzoru pedagogicznego w Polsce przedstawia informacje przypisane do czterech obszarów pracy szkoły: efektów, procesów zachodzących w szkole, funkcjonowania szkoły w środowisku lokalnym oraz zarządzania. 
kontrolującego zależy od wielkości oraz specyfiki szkoły i waha się od dwóch do siedmiu osób. Kontrola skupia się przede wszystkim na ocenie wyników nauczania, jakości kształcenia, zarządzania placówką oraz na poziomie bezpieczeństwa uczniów i pojawiających się problemach wychowawczych.

\section{Bibliografia}

Dziewulak D., Obowiązek szkolny w Unii Europejskiej, „Analizy BAS” 2010, nr 9(34), http:// parl.sejm.gov.pl/WydBAS.nsf/0/A4F8763AAD6E8E70C12576EE0029DFE9/\$file/Analiza_\%20BAS_2009_34.pdf.

Encyklopedia pedagogiczna XXI wieku, t. VI, Wydawnictwo Akademickie „Żak”, Warszawa 2007.

Kupisiewicz C., Kupisiewicz M., Stownik pedagogiczny, Wydawnictwo Naukowe PWN, Warszawa 2009.

\section{Akty prawne}

Ustawa z 7 września 1991 r. o systemie oświaty, Dz.U. 2004, nr 256, poz. 2572, ze zm.

Ustawa z 26 stycznia 1982 r. - Karta Nauczyciela, Dz.U. nr 3, poz. 19.

Rozporządzenie Ministra Edukacji Narodowej z 7 października 2009 r. w sprawie nadzoru pedagogicznego, Dz.U. nr 168, poz. 1324.

Zákon č. 561/2004 Sb., o předškolním, základním, stř̌edním, vyšším odborném a jiném vzdělávání (školský zákon), http://aplikace.msmt.cz/Predpisy1/sb190-04.pdf.

Basic Education Act 628/1998 Amendments up to 1136/2010, http://www.finlex.fi/en/laki/kaannokset/1998/en19980628.pdf.

\section{Strony internetowe}

http://www.csicr.cz/.

http://www.finlex.fi/en/laki/kaannokset/1998/en19980628.pdf.

http://www.localfinland.fi/en/authorities/local-self-government/Documents/Finnish\%20

Local\%20Government\%20Act.pdf.

http://www.minedu.fi/OPM/.

http://www.edev.fi/portal/english5.

http://www.fsw.leidenuniv.nl/plato/expertise/oefenen.html.

http://www.cito.nl/.

http://www.education.ie/en/. 
http://www.ptde.org/file.php/1/Archiwum/XVII_KDE/pedeefy/Krol.pdf.

http://www.aqs.rlp.de/.

http://www.edu.ro/index.php/base/frontpage.

http://administraresite.edu.ro/index.php/articles/c809/.

http://cndiptoi.tvet.ro/.

http://www.ise.ro/.

http://www.skolverket.se/.

http://skolinspektionen.se/. 


\title{
4.4. Edukacja dwujęzyczna z językiem migowym dla uczniów głuchych w Polsce i wybranych państwach Unii Europejskiej
}

\author{
Bilingual education with sign language in schools \\ for deaf students in Poland and in selected European \\ Union countries
}

W opracowaniu podjęto próbę przedstawienia zagadnienia wprowadzania kształcenia dwujęzycznego z językiem migowym w szkołach dla uczniów głuchych i w szkołach integracyjnych w Polsce oraz w wybranych państwach Unii Europejskiej.

Słowa kluczowe: język migowy, uczniowie głusi, niepełnosprawni, szkolnictwo, Polska, Unia Europejska

The paper attempts to present the issue introducing bilingual education with sign language in schools for deaf students and in integration schools in Poland and in selected European Union countries.

Keywords: sign language, deaf students, disabled people, education, Poland, European Union

\section{Wstęp}

Język migowy jest naturalnym językiem służącym do porozumiewania się bez używania narządu słuchuํ. Opiera się na swoim własnym słownictwie oraz systemie gramatycznym. Na zasób pojęć migowych składają się znaki ideograficzne (zwane migami), które czasem są odpowiednikiem krótkich zwrotów w języku mówionym. Liczba znaków migowych w różnych rozwiniętych językach waha się od około 5000 do 15000 znaków. Na całym świecie używa się około 200-300 odmiennych języków migowych.

1 Opracowanie przygotowano na podstawie ekspertyzy Biura Analiz Sejmowych nr 2661/18 z 2 stycznia 2019 r. autorstwa D. Dziewulaka na temat wprowadzania edukacji dwujęzycznej w szkołach dla głuchych i w szkołach integracyjnych w Polsce oraz w wybranych państwach Unii Europejskiej (Belgia, Bułgaria, Czechy, Finlandia, Francja, Grecja, Hiszpania, Holandia, Irlandia, Islandia, Łotwa, Niemcy, Słowacja, Słowenia, Węgry, Wielka Brytania, Włochy). 
Pojęcie edukacji dwujęzycznej dla osób głuchych ${ }^{2}$ oznacza nauczanie posługiwania się dwoma lub więcej językami, z których przynajmniej jeden to język migowy. Przykładowo w Polsce dwujęzyczna edukacja z językiem migowym jest takim podejściem do edukacji osób głuchych, w którym wykorzystuje się polski język migowy i powszechnie używany język polski.

Problematyka dwujęzyczności z językiem migowym ma swoje źródła w lingwistycznym oraz kulturowym sposobie postrzegania głuchoty i w społecznym modelu niepełnosprawności. Dwujęzyczność z językiem migowym opiera się na zasadzie równości szans bez względu na język, pochodzenie etniczne, rasę, płeć oraz niepełnosprawność.

Kwestia wprowadzenia tzw. modelu edukacji dwujęzycznej głuchych była podnoszona w państwach europejskich i w Polsce w latach osiemdziesiątych XX wieku, po rewolcie studentów Uniwersytetu Gallaudeta w Waszyngtonie. Studenci - niezadowoleni z poziomu edukacji - domagali się poprawy w tej dziedzinie. Trzydzieści lat temu był to postulat uzasadniony, ponieważ wówczas tylko niewielka część osób z uszkodzeniami słuchu mogła korzystać z dobrodziejstwa nowoczesnego protezowania narządu słuchu. Dotyczyło to obecnego pokolenia trzydziesto- i czterdziestolatków. Wówczas w niektórych państwach europejskich, takich jak Holandia czy Szwecja, wprowadzono język migowy do nauczania w istniejących tam nielicznych szkołach, w których wcześniej obowiązywał zakaz jego używania. Wkrótce okazało się - wbrew przewidywaniom że skutkiem tego działania dramatycznie obniżył się poziom umiejętności czytania u uczniów z głębokimi uszkodzeniami słuchu. Trzeba było szybko podjąć dodatkowe starania w zakresie nauczania języków narodowych (dźwiękowych), bo tylko znajomość języka dźwiękowego w mowie umożliwia czytanie ze zrozumieniem. Jednakże w następnych latach - dzięki upowszechnieniu technik protetycznych (aparatów słuchowych oraz implantów ślimakowych) - nastąpiła rewolucyjna przemiana w rehabilitacji i edukacji dzieci z uszkodzeniami słuchu.

Wprowadzanie edukacji dwujęzycznej dla osób głuchych w europejskich systemach oświatowych uzależnione jest od wielu czynników, takich jak: system zarządzania oświatą, sposób organizacji kształcenia osób niepełnosprawnych (szkoły specjalne czy integracyjne), uwarunkowania historyczne, społeczne, budżetowe itp. Dlatego trudno wskazać jednolity model kształcenia osób z wadami słuchu i należałoby raczej mówić o podobieństwach i różnicach zastosowanych rozwiązań.

2 Definicje i problematyka dwujęzyczności na podstawie materiałów Polskiego Związku Głuchych, http://www.pzg.lodz.pl/edukacja/\#o_projekcie. 
W Polsce przepisy prawa oświatowego umożliwiają naukę języka migowego w trakcie wychowania przedszkolnego i kształcenia w szkole, jednakże w opinii Ministerstwa Edukacji Narodowej wprowadzanie ujednoliconego programu edukacji dwujęzycznej dla wszystkich dzieci z uszkodzeniami słuchu jest nieuzasadnione ze względów pedagogicznych i logopedycznych. W Belgii nie ma jednego modelu kształcenia realizowanego dla uczniów niesłyszących i niedosłyszących - choć edukacja dwujęzyczna też jest realizowana. W Bułgarii i Czechach brak jest precyzyjnych ustawowych zapisów dotyczących nauczania języka migowego i dwujęzyczności dla głuchych. W Finlandii uczniowie z niepełnosprawnością słuchu mają prawo do otrzymania wsparcia procesu kształcenia przez użycie języka migowego. Kształcenie w języku migowym może odbywać się w grupie uczniów używających języków migowych lub w grupie, która składa się z uczniów używających języka migowego i języka mówionego. We Francji uczniowie mogą kształcenie dwujęzyczne realizować w szkołach specjalnych lub w szkołach ogólnodostępnych. W Grecji dwujęzyczność w nauczaniu osób z dysfunkcją słuchu odbywa się przez nauczanie greckiego języka migowego i współczesnego języka greckiego w szkołach specjalnych lub w klasach włączających w szkołach ogólnodostępnych. W Hiszpanii nauczanie osób z zaburzeniami słuchu w formie dwujęzycznej jest realizowane w szkołach specjalnych i szkołach ogólnodostępnych w zależności od potrzeb, możliwości pedagogiczno-dydaktycznych i decyzji władz szkolnych. W Holandii edukacja dwujęzyczna dla uczniów niesłyszących prowadzona jest wyłącznie w szkołach specjalnych. W Irlandii w szkołach dla osób niesłyszących najczęściej przyjmuje się metodologię „całkowitej komunikacji” (total communication), polegającą na mieszaniu języków mówionego i migowego oraz zgodnie z potrzebami na „przełączaniu” języka angielskiego i irlandzkiego. W Islandii dwujęzyczność uczniów z upośledzeniem słuchu jest integralnym elementem wszystkich obowiązkowych przedmiotów szkolnych, $w$ tym także przedmiotów językowych związanych z językiem obcym. Na Łotwie nie ma precyzyjnych ustawowych zapisów dotyczących nauczania języka migowego i dwujęzyczności. W Niemczech w szkołach specjalnych, do których uczęszczają uczniowie z różnymi typami dysfunkcji, lekcje odbywają się w języku niemieckim fonetycznym lub niemieckim języku migowym. W ogólnodostępnych szkołach powszechnych podczas lekcji, w których biorą udział uczniowie z dysfunkcją słuchu, nauczyciel przedmiotowy wspierany jest przez osobę posługującą się językiem migowym. Na Słowacji dwujęzyczne kształcenie uczniów z dysfunkcją słuchu jest wdrażane tylko w szkołach specjalnych. W szkołach ogólnodostępnych uczniowie z wadami słuchu otrzymują wsparcie 
tłumacza języka migowego. W Słowenii nie wykorzystuje się modelu dwujęzycznej edukacji dla osób niesłyszących. Na Węgrzech w kształceniu osób niesłyszących nie korzysta się z dwujęzyczności z powodu braku jednolitego zestawu znaków ideograficznych oraz opisu gramatycznego i symbolicznego węgierskiego języka migowego. W Wielkiej Brytanii nie ma ogólnodostępnych szczegółowych wytycznych dla szkół dotyczących edukacji dwujęzycznej dla uczniów z zaburzeniami słuchu. We Włoszech uczniowie z wadami słuchu w większości uczęszczają do ogólnodostępnych placówek edukacyjnych. Podczas lekcji nauczyciele przedmiotowi wspierani są przez tłumaczy języka migowego.

Poniżej przedstawiono szczegółowe informacje na temat wprowadzania edukacji dwujęzycznej w szkołach specjalnych, integracyjnych i ogólnodostępnych w Polsce i wybranych państwach Unii Europejskiej33.

\section{Polska ${ }^{4}$}

W Polsce język migowy był używany przez uczniów w szkołach specjalnych od początku ich istnienia (1817 r.), co doprowadziło do powstania różnych odmian tego języka. W latach dziewięćdziesiątych XX wieku podjęto próby upowszechniania w większości szkół jednej z jego odmian (tzw. systemu językowo-migowego). Zanim jednak udało się przeprowadzić pełną ewaluację tego postępowania, sytuacja w rehabilitacji i edukacji dzieci z uszkodzeniami słuchu zmieniła się (podobnie jak w innych państwach). Wczesne wykrywanie uszkodzeń (badania przesiewowe noworodków), protezowanie, wspomaganie wczesnego rozwoju i wychowanie językowe oraz terapia logopedyczna w okresie niemowlęcym, poniemowlęcym i przedszkolnym, sprawiły, że do szkół zaczęły trafiać w większości dzieci, które mimo uszkodzenia słuchu są funkcjonalnie słyszące lub niedosłyszące i mogą - przy odpowiednim wsparciu - uczyć się razem ze słyszącymi (w integracji lub indywidualnej inkluzji). Ta grupa uczniów potrzebuje odpowiednich metod wsparcia: dobrego dostępu do dźwięków, trafnie dobranych metod wychowania językowego, ustawicznej opieki logopedycznej, wsparcia nauczycieli rozumiejących ich specjalne potrzeby, specjalistycznych podręczników,

3 Na podstawie informacji i materiałów zebranych od przedstawicieli krajów członkowskich w Radzie Europejskiej Agencji ds. Specjalnych Potrzeb i Edukacji Włączającej, które odpowiedziały na zapytanie w sprawie edukacji dwujęzycznej dla uczniów głuchych w poszczególnych państwach.

4 Materiał przekazany przez Departament Wychowania i Kształcenia Integracyjnego MEN (syg. DWKI-WSPE.4035.800.2018.JKP z 20 grudnia 2018 r.). 
urządzeń informatyczno-komunikacyjnych i powszechności napisów, a zwłaszcza konwersji mowy na tekst (speech to text) ${ }^{5}$. Uczniowie z tej grupy nie odczuwają potrzeby poznawania języka migowego, ale raczej dążą do opanowania na wysokim poziomie kolejnych języków dźwiękowych i z powodzeniem uczą się języka angielskiego (polscy pedagodzy mają w tej dziedzinie wybitne osiągnięcia). Trzeba też brać pod uwagę fakt, że 95\% dzieci z uszkodzeniami słuchu ma rodziców słyszących, którzy nie znają języka migowego i rozmawiają z dziećmi po polsku.

Istnieją jednak grupy uczniów z uszkodzeniami słuchu, które potrzebują korzystania z języka migowego. Są to:

- niesłyszące dzieci niesłyszących rodziców, których pierwszym językiem jest język migowy,

- dzieci z najgłębszymi i specyficznymi uszkodzeniami słuchu, u których zastosowanie aparatów słuchowych i/lub implantów nie przynosi pożądanych efektów.

Należy podkreślić, że liczba uczniów, którzy potrzebują stosowania języka migowego w nauczaniu, zmniejsza się z roku na rok. Niesłyszące dzieci rodziców niesłyszących stanowią około 5\% populacji dzieci z uszkodzeniami słuchu, ale większość z nich ma umiarkowane uszkodzenie i z zastosowaniem aparatów słuchowych może z powodzeniem uczyć się języka dźwiękowego w mowie i w piśmie. Natomiast zjawisko nieskuteczności aparatów i implantów słuchowych dotyczy około 30\% dzieci z najgłębszymi uszkodzeniami słuchu, co oznacza, że są to nieliczne przypadki w skali kraju (kilkoro dzieci rocznie).

Osobny, trudny problem stanowią specjalne potrzeby edukacyjne uczniów z uszkodzeniami słuchu i niepełnosprawnościami sprzężonymi. Takich uczniów jest znacznie więcej. Ich potrzeby są zróżnicowane i wielorakie. W niektórych takich przypadkach konieczne jest stosowanie języka migowego. W innych jest to niemożliwe z uwagi na ograniczenia sprawności rąk i wzroku.

Podstawą doboru metod komunikowania się z uczniem musi być wczesna, a następnie ustawicznie pogłębiana diagnoza funkcjonalna jego specjalnych potrzeb rozwojowych i edukacyjnych. Ministerstwo Edukacji Narodowej podjęło

5 Proces przekształcania wypowiedzianych słów w pisane teksty. Wszystkie systemy konwersji głosu na tekst opierają się na co najmniej dwóch modelach: modelu akustycznym i modelu językowym. Ponadto duże systemy słownictwa wykorzystują model wymowy. Ważne jest zrozumienie, że nie ma czegoś takiego, jak uniwersalny aparat rozpoznawania mowy. Aby uzyskać najlepszą jakość transkrypcji, wszystkie te modele mogą być wyspecjalizowane dla danego języka, dialektu, domeny aplikacji, rodzaju mowy i kanału komunikacji. 
działania zmierzające do doskonalenia postępowania specjalistycznego $\mathrm{w}$ tym zakresie. Przygotowywane są także specjalne materiały dydaktyczne w języku migowym. Szkoły specjalne zatrudniają nauczycieli niesłyszących, a także słyszących biegle posługujących się językiem migowym.

W związku z powyższym, w opinii Ministerstwa Edukacji Narodowej wprowadzanie ujednoliconego programu edukacji dwujęzycznej dla wszystkich dzieci z uszkodzeniami słuchu jest nieuzasadnione ze względów pedagogicznych i logopedycznych. Z informacji przekazanej przez Departament Wychowania i Kształcenia Integracyjnego MEN wynika, że stwarza ono warunki organizacyjno-prawne ${ }^{6}$ do kształcenia, wychowania i opieki pedagogicznej wszystkim dzieciom i młodzieży, w tym ze specjalnymi potrzebami edukacyjnymi, więc również dzieciom i młodzieży niesłyszącej i słabosłyszącej we wszystkich typach i rodzajach przedszkoli, szkół ogólnodostępnych, integracyjnych lub specjalnych, a także w placówkach systemu oświaty. Na bieżąco prowadzone są prace nad zmianami i opracowywaniem rozwiązań legislacyjno-organizacyjnych mających na celu zapewnienie uczniom niepełnosprawnym odpowiednich do ich potrzeb warunków kształcenia. Zarówno dotychczasowe, jak i nowe przepisy prawa oświatowego umożliwiają naukę języka migowego od momentu objęcia dziecka zajęciami wczesnego wspomagania rozwoju, które organizowane są od chwili wykrycia niepełnosprawności ${ }^{7}$, jak również w trakcie wychowania przedszkolnego i kształcenia w szkole.

Dla dzieci i młodzieży niesłyszącej posiadającej orzeczenia o potrzebie kształcenia specjalnego, nauka języka migowego lub innych alternatywnych metod komunikacji powinna być uwzględniona w ramach zajęć rewalidacyjnych ${ }^{8}$, których minimalny tygodniowy wymiar w poszczególnych typach i rodzajach szkół został określony w przepisach prawa oświatowego ${ }^{9}$. Nauka języka migowego

6 Artykuł 1 ustawy z 14 grudnia 2016 r. - Prawo oświatowe, Dz.U. 2018, poz. 996, ze zm.

7 Rozporządzenie Ministra Edukacji Narodowej z 24 sierpnia 2017 r. w sprawie organizowania wczesnego wspomagania rozwoju dzieci, Dz.U. poz. 1635.

8 O których mowa w przepisach $\S 6$ ust. 1 pkt 5 i ust. 2 rozporządzenia Ministra Edukacji Narodowej 9 sierpnia 2017 r. w sprawie warunków organizowania kształcenia, wychowania i opieki dla dzieci i młodzieży niepełnosprawnych, niedostosowanych społecznie i zagrożonych niedostosowaniem społecznym, Dz.U. poz. 1578, ze. zm.

9 Rozporządzenia Ministra Edukacji Narodowej:

- z 7 lutego 2012 r. w sprawie ramowych planów nauczania w szkołach publicznych, Dz.U. poz. 204, ze zm.,

- z 28 marca 2017 r. w sprawie ramowych planów nauczania dla publicznych szkół, Dz.U. poz. 703. 
może być również zorganizowana w szkole poza obowiązkowymi zajęciami edukacyjnymi, zgodnie z potrzebami uczniów, w szczególności dzieci i młodzieży niesłyszącej.

Zakres wsparcia, jaki jest niezbędny dziecku posiadającemu orzeczenie o potrzebie kształcenia specjalnego wydane ze względu na przykład na niesłyszenie lub słabe słyszenie, wynika z zaleceń wskazanych w wyżej wymienionym orzeczeniu oraz z wielospecjalistycznej oceny poziomu funkcjonowania dziecka dokonanej przez zespół nauczycieli i specjalistów prowadzących z nim zajęcia.

Dostosowanie treści i indywidualizacja procesu nauczania to zadanie nauczycieli i specjalistów pracujących z uczniem niesłyszącym lub słabosłyszącym. Wskazania, zalecenia i formy pracy określone zostają w indywidualnym programie edukacyjno-terapeutycznym (IPET).

Nauczyciele i specjaliści zatrudnieni w szkołach zobligowani są do udzielania uczniom i rodzicom pomocy psychologiczno-pedagogicznej po stwierdzeniu takiej potrzeby ${ }^{10}$. W systemie oświaty wsparcia uczniom, nauczycielom i rodzicom uczniów udzielają również poradnie psychologiczno-pedagogiczne ${ }^{11}$.

$\mathrm{Z}$ inicjatywy MEN powstały również podręczniki i materiały edukacyjne dla uczniów z różnymi rodzajami niepełnosprawności, w tym m.in. dla uczniów niesłyszących i słabosłyszących. W Systemie Informacji Oświatowej, w strefie dla zalogowanych, udostępniono dyrektorom szkół materiały edukacyjne dla wyżej wymienionej grupy uczniów. Zostały one opracowane przez Pracownię Lingwistyki Migowej Uniwersytetu Warszawskiego. Przygotowano je na podstawie aktualnie dopuszczonych do użytku szkolnego podręczników do klasy IV i VII szkoły podstawowej. Materiały mogą być przeglądane zarówno on-line, jak i pobierane z możliwością wydruku. Zawierają one odpowiednie dostosowania tekstowe i graficzne (zaadaptowane ilustracje, wykresy, schematy itp.), a także symbole PCS, czyli znaki graficzne obrazujące pojęcia (wspierające osoby z trudnościami w komunikowaniu się w rozumieniu treści i uczestnictwie w procesie dydaktycznym) oraz nagrania wideo w polskim języku migowym (PJM). Ponadto z inicjatywy Ministerstwa Edukacji Narodowej specjaliści z Uniwersytetu Warszawskiego przygotowali kurs polskiego języka migowego (PJM) dla uczniów klas I-III szkoły

10 Zgodnie z przepisami rozporządzenia Ministra Edukacji Narodowej z 9 sierpnia $2017 \mathrm{r}$. w sprawie zasad organizacji i udzielania pomocy psychologiczno-pedagogicznej w publicznych przedszkolach, szkołach i placówkach, Dz.U. poz. 1591.

11 W myśl przepisów rozporządzenia Ministra Edukacji Narodowej z 1 lutego 2013 r. w sprawie szczegółowych zasad działania publicznych poradni psychologiczno-pedagogicznych, w tym publicznych poradni specjalistycznych, Dz.U. poz. 199, ze zm. 
podstawowej po nazwą „Migaj razem z nami”. To pierwsza taka pomoc dla dzieci rozpoczynających naukę migania.

Obecnie Ministerstwo Edukacji Narodowej prowadzi również działania koncepcyjno-legislacyjne na rzecz podniesienia jakości kształcenia uczniów ze specjalnymi potrzebami edukacyjnymi, w tym niesłyszących i słabosłyszących. Prace te zmierzają do usprawnienia diagnozy wyżej wymienionej grupy dzieci i młodzieży, przez zbudowanie integralnego, efektywnego i kompleksowego systemu wsparcia, z zastosowaniem diagnozy funkcjonalnej opartej na Międzynarodowej Klasyfikacji Funkcjonowania, Niepełnosprawności i Zdrowia (ICF) - w tym w wersji dla dzieci i młodzieży (ICF-CY) - opracowanej przez Światową Organizację Zdrowia.

W październiku 2017 roku na mocy zarządzenia Ministra Edukacji Narodowej nr 39/2017 z 13 października 2017 r. został powołany Zespół ds. opracowania modelu kształcenia uczniów ze specjalnymi potrzebami edukacyjnymi, który na podstawie zebranych dotychczas wniosków, postulatów i rekomendacji, a także analizy doświadczeń i rekomendacji międzynarodowych, przygotuje propozycje założeń zmian w obszarze kształcenia dzieci i młodzieży ze specjalnymi potrzebami edukacyjnymi, począwszy od momentu wejścia dziecka do systemu edukacji do wejścia na rynek pracy lub kontynuacji nauki na poziomie wyższym. Nowe rozwiązania mają na celu podniesienie efektywności kształcenia uczniów ze specjalnymi potrzebami edukacyjnymi w szczególności w edukacji włączającej. Efektywne kształcenie ma zapewniać nie tylko wzrost wiedzy i umiejętności uczniów, ale również ich przygotowanie do samodzielności w życiu dorosłym i integrację społeczną.

Planuje się, że nowe rozwiązania umożliwią:

- bardziej efektywne planowanie wsparcia,

- dookreślenie standardów organizacji pomocy psychologiczno-pedagogicznej,

- usprawnienie systemu monitorowania i oceny jakości kształcenia uczniów ze specjalnymi potrzebami edukacyjnym,

- zapewnienie systemu szkoleń i wspierania nauczycieli z wykorzystaniem potencjału szkół i ośrodków specjalnych,

- bardziej trafne adresowanie środków finansowych na wspieranie uczniów ze specjalnymi potrzebami edukacyjnymi, uwarunkowane rzeczywistymi potrzebami uczniów,

- usprawnienie współpracy międzyresortowej na rzecz dzieci i młodzieży ze specjalnymi potrzebami edukacyjnymi.

Podstawą do dostosowania organizacji kształcenia oraz udzielenia wsparcia $\mathrm{w}$ jednostkach systemu oświaty jest trafna, rzetelna diagnoza potrzeb uczniów. 
Tabela 22. Liczba uczniów niesłyszących i słabosłyszących w Polsce w szkołach: ogólnodostępnych, integracyjnych i specjalnych w latach 2016-2018. Tabela zawiera dane o uczniach ze wszystkich typów szkół i placówek systemu oświaty

\begin{tabular}{|c|c|c|c|c|c|}
\hline \multirow{2}{*}{\multicolumn{2}{|c|}{ Rodzaj niepełnosprawności }} & \multirow{3}{*}{$\begin{array}{c}\text { Rodzaj szkoły } \\
\text { Ogólnodostępna }\end{array}$} & \multicolumn{3}{|c|}{ Rok szkolny } \\
\hline & & & \multirow{2}{*}{$\frac{2016 / 2017}{8786}$} & \multirow{2}{*}{$\begin{array}{c}2017 / 2018 \\
9399\end{array}$} & \multirow{2}{*}{$\frac{2018 / 2019}{9531}$} \\
\hline \multirow{6}{*}{ Niepełnosprawność } & \multirow{3}{*}{ Słabosłyszący } & & & & \\
\hline & & Integracyjna & 394 & 380 & 338 \\
\hline & & Specjalna & 850 & 857 & 797 \\
\hline & \multirow{3}{*}{ Niesłyszący } & Ogólnodostępna & 868 & 897 & 949 \\
\hline & & Integracyjna & 75 & 86 & 67 \\
\hline & & Specjalna & 1273 & 1138 & 1096 \\
\hline \multirow{6}{*}{$\begin{array}{l}\text { Niepełnosprawność } \\
\text { sprzężona }\end{array}$} & \multirow{3}{*}{ Słabosłyszący } & Ogólnodostępna & 1558 & 1724 & 2010 \\
\hline & & Integracyjna & 147 & 174 & 169 \\
\hline & & Specjalna & 1871 & 1914 & 2021 \\
\hline & \multirow{3}{*}{ Niesłyszący } & Ogólnodostępna & 105 & 110 & 128 \\
\hline & & Integracyjna & 12 & 14 & 16 \\
\hline & & Specjalna & 488 & 475 & 459 \\
\hline
\end{tabular}

Źródło: Materiał przekazany przez Departament Wychowania i Kształcenia Integracyjnego MEN (syg. DWKI-WSPE.4035.800.2018.JKP z 20 grudnia 2018 r.).

W nowym modelu planuje się, że diagnoza ta będzie miała charakter funkcjonalny, co oznacza, że będzie ukierunkowana na ocenę funkcjonowania dziecka, w której zostanie uwzględniony także wpływ środowiska nauczania i wychowania - zarówno bariery utrudniające funkcjonowanie dziecka, jak i czynniki wspierające jego rozwój. Takie podejście do diagnozy oparte jest ma modelu biopsychospołecznym, którego zastosowanie umożliwi bardziej skuteczną organizację kształcenia uczniów ze specjalnymi potrzebami edukacyjnymi. Uwzględniane będą bowiem nie tylko potrzeby w zakresie zapewnienia indywidualnego wsparcia, ale również niezbędne dostosowania środowiska szkolnego (np. potrzeby w zakresie technologii wspomagających, dostosowania miejsca nauki, zapewnienia odpowiednich pomocy dydaktycznych i metod pracy itp.). Przyjęcie uniwersalnego języka opisu funkcjonowania umożliwi usprawnienie współpracy międzyresortowej na rzecz dzieci i młodzieży ze specjalnymi potrzebami edukacyjnymi.

Ośrodek Rozwoju Edukacji (instytucja podległa MEN) realizuje projekty unijne, w ramach których powstają narzędzia dla poradni psychologiczno-pedago- 
gicznych i szkół, realizowane są szkolenia z zakresu pomocy psychologiczno-pedagogicznej dla pracowników poradni i nauczycieli oraz trwa pilotaż nowych rozwiązań.

Powyżej zamieszczone zostały dane statystyczne dotyczące liczby uczniów niesłyszących i słabosłyszących w szkołach ogólnodostępnych, integracyjnych i specjalnych w latach 2016-2018.

\section{Belgia (Francuska Wspólnota)}

Szkolnictwo w Belgii odzwierciedla strukturę narodowo-językową państwa, w której istnieje podział na francuskojęzycznych Walonów, flamandzkojęzycznych Flamandów i mniejszość niemieckojęzyczną. Każda z wyżej wymienionych grup ma zapewniony autonomiczny system kształcenia. Struktury oświatowe tych trzech wspólnot są regulowane odrębnymi ustawami. Mają niezależne władze oświatowe, w tym odrębnych ministrów oświaty. Każda wspólnota językowa ma inne typy szkół, inne programy, inne modele kształcenia nauczycieli i odmienne organizacje pracy szkolnej.

We Francuskiej Wspólnocie nie ma jednego modelu kształcenia realizowanego dla uczniów niesłyszących i niedosłyszących. Uczniowie z takim typem dysfunkcji uczęszczają do szkół specjalnych lub integracyjnych reprezentujących wszystkie poziomy edukacyjne - od szkoły podstawowej do wyższej. Szkoły specjalne realizujące program kształcenia wyższego dla studentów z poważnym upośledzeniem mowy stale współpracują z belgijskimi uniwersytetami oraz biorą udział w pracach międzynarodowej francuskojęzycznej sieci fonologii (Réseau Français de Phonologie, RFP).

Wprowadzaniem edukacji dwujęzycznej w szkołach dla głuchych i szkołach integracyjnych od wielu lat zajmuje się Instytut Sainte-Marie w Namur. Jest to szkoła dwujęzyczna prowadząca nauczanie w języku francuskim i języku migowym. Zajęcia prowadzone są przez dwóch nauczycieli. Jeden przekazuje wiedzę w sposób klasyczny, a drugi - migowy.

Dwujęzyczny projekt „Francuski język migowy” został wprowadzony w 2000 roku. Umożliwił stworzenie dwujęzycznych kursów języka francuskiego, w których grupy dzieci głuchych i słyszących uczą się wspólnie, z wykorzystaniem podwójnego przekazu: języka francuskiego i języka migowego.

Ukończenie edukacji dwujęzycznej (jęz. francuski - jęz. migowy) umożliwia kontynuowanie nauki na wyższych poziomach edukacji. 


\section{Bułgaria}

W Bułgarii nie ma precyzyjnych ustawowych zapisów dotyczących nauczania języka migowego i dwujęzyczności.

Bułgarskie Ministerstwo Edukacji i Nauki w ramach projektu „Wspieranie równego dostępu i rozwoju osobistego”, będącego częścią programu operacyjnego „Nauka i edukacja na rzecz inteligentnego wzrostu”, zainicjowało w 2015 roku długofalowe badania naukowe nad bułgarskim językiem migowym. Stanowią one podstawę do opracowania naukowych podstaw bułgarskiego języka migowego, zwiększenia umowności gestów, rozszerzenia struktury gramatycznej, opracowania metodycznych narzędzi uczenia się i ich wykorzystania we wszystkich sferach życia publicznego, w tym w szkolnym procesie dydaktycznym.

W konsekwencji podjętych prac wydano Stownik bułgarskiego języka migowego oraz Teoretyczny opis gramatyki bułgarskiego języka migowego.

Najbliższe plany działań w zakresie tworzenia bułgarskiego języka migowego zainicjowane przez Ministerstwo Edukacji i Nauki to:

- przeprowadzenie drugiego etapu badań dotyczących opisu bułgarskiego języka migowego,

- przeprowadzenie badań nad słownictwem dzieci w wieku przedszkolnym i szkolnym,

- przygotowanie przewodnika metodycznego dla potrzeb kształcenia w zakresie języka migowego dzieci w wieku przedszkolnym i szkolnym,

- przygotowanie przewodnika metodycznego dla potrzeb przygotowania tłumaczy bułgarskiego języka migowego.

\section{Czechy}

W Czechach nie ma konkretnych wytycznych dotyczących edukacji dwujęzycznej dla uczniów z zaburzeniami słuchu.

Uczniowie o specjalnych potrzebach edukacyjnych, w tym osoby z dysfunkcjami słuchu, mają prawo do takiej edukacji, która najlepiej odpowiada ich potrzebom i umiejętnościom. Przed rozpoczęciem roku szkolnego dla uczniów z niepełnosprawnościami ustalany jest indywidualny plan edukacyjny. Oczywiście we współpracy z rodzicami, szkołą i poradnią pedagogiczno-psychologiczną (ośrodkiem diagnostycznym) w celu zapewnienia i podjęcia optymalnych działań edukacyjnych zgodnych z indywidualnymi potrzebami ucznia. 
Uczniowie z zaburzeniami słuchu mogą być kształceni w szkołach specjalnych lub włączani do głównego nurtu edukacji na poziomie przedszkolnym, podstawowym lub średnim. Uczestnicząc w procesie edukacyjnym, mogą stosować i uczyć się z wykorzystaniem języka migowego. Ponadto zgodnie z możliwościami placówki szkolnej mają prawo do wyboru własnej metody kształcenia, np. programu dwujęzycznego, werbalnego lub zintegrowanej metody komunikacji.

Należy podkreślić, że w czeskich szkołach niemożliwa jest jedna metoda nauczania (na przykład dwujęzyczna), ponieważ w klasach znajdują się uczniowie z różnymi typami i kategoriami niepełnosprawności. W nauczaniu osób z dysfunkcjami dominuje indywidulane podejście do ucznia, w którym przede wszystkim brane są pod uwagę określone umiejętności komunikacyjne i wstępne warunki edukacyjne każdego dziecka.

\section{Finlandia}

W Finlandii zgodnie ustawą o szkolnictwie podstawowym ${ }^{12}$, ustawą o szkolnictwie średnim ${ }^{13}$ oraz ustawą o szkolnictwie zawodowym ${ }^{14} \mathrm{~W}$ szkołach podstawowych, średnich i zawodowych uczniowie z niepełnosprawnością słuchu mają prawo do otrzymania wsparcia procesu kształcenia z wykorzystaniem języka migowego. Kształcenie przy użyciu języka migowego powinno być prowadzone przynajmniej dla uczniów, którzy nauczyli się języka migowego jako pierwszego języka. Część nauczania może być prowadzona w języku innym niż język ojczysty uczniów, pod warunkiem że nie zagraża to zdolności uczniów do uczenia się.

Podstawowa edukacja w języku migowym może odbywać się w grupie uczniów używających języków migowych lub w grupie, która składa się z uczniów używających języka migowego i języka mówionego. Jeżeli istnieje taka potrzeba szkoła może zorganizować alternatywne usługi tłumaczeniowe dla uczniów z niepełnosprawnością słuchową, np. metodą porozumiewania się z wykorzystaniem systemu symboli.

W Finlandii językami urzędowymi są fiński i szwedzki. W związku z tym w wypadku użytkowników języka migowego program nauczania przedmiotów językowych obejmuje język fiński i/lub szwedzki.

12 Basic Educational Act, http://ncee.org/2017/01/finland-basic-education-act-1998/.

13 General upper secondary Education, https://minedu.fi/en/general-upper-secondary-education.

14 Vocational education and training in Finland, https://minedu.fi/en/vocational-education-and-training. 
W przypadku użytkowników języka migowego w szkole średniej językiem nauczania może być fiński język migowy lub fiński/szwedzki język migowy uzupełniony fińskim lub szwedzkim jako językiem używanym do czytania i pisania. Języki migowe lub metody komunikacji oparte na tych językach mogą być również używane razem.

\section{Francja}

We Francji, zgodnie z artykułem L.112-3 Kodeksu oświaty (2008 r.) ${ }^{15}$, rodzice uczniów, u których stwierdzono upośledzenie słuchu, mogą wybrać jeden z dwóch typów kształcenia językowego. Jest to:

- kształcenie dwujęzyczne realizowane w klasycznym języku francuskim z użyciem języka francuskiego migowego - LSF (langue des signes française) ${ }^{16}$,

- kształcenie dwujęzyczne realizowane w klasycznym języku francuskim z użyciem (lub bez) systemu kodowania francuskiego języka mówionego - LPC lub LfPC (langue française parlée complétée) ${ }^{17}$.

Ponadto we francuskim systemie szkolnym dla każdego ucznia z niepełnosprawnością, $\mathrm{w}$ tym także dla uczniów z dysfunkcjami słuchu, tworzony jest spersonalizowany projekt edukacyjny (projet personnalisé de scolarisation, PPS $)^{18}$. Jest to dokument opracowywany przez międzydyscyplinarny zespół Departamentalnego Ośrodka ds. Osób Niepełnosprawnych (Maison Départementale des Personnes Handicapées, MDPH ${ }^{19}$, który zawiera m.in. opis niepełnosprawności, diagnozę medyczną, życzenia i potrzeby ucznia. Dokument zaleca i wskazuje postępowanie pedagogiczne, psychologiczne i edukacyjne. Jest w nim także umieszczony typ kształcenia językowego wybrany przez rodziców dziecka z dysfunkcją słuchu. Dokument PPS stanowi dla szkoły podstawę do pracy i postępowania z uczniem niepełnosprawnym.

Kształcenie uczniów z niepełnosprawnością słuchu organizowane jest od przedszkola do szkolnictwa średniego. Edukacja może być realizowana w specjalnych ośrodkach dla młodzieży głuchej (le pôle d'enseignement des jeunes

15 Code de l'éducation - Article L112-3, https://www.legifrance.gouv.fr/affichCodeArticle. do?cidTexte=LEGITEXT000006071191\&idArticle=LEGIARTI000019911145.

16 LSF, http://www.languedessignes.fr/formations/cours-de-lsf/.

17 LPC, http://www.surdi.info/langue-francaise-parlee-completee/presentation-lpc/.

18 http://www.tousalecole.fr/content/projet-personnalis\%C3\%A9-de-scolarisation-pps.

19 https://handicap.gouv.fr/les-aides-et-les-prestations/maison-departementale-du-handicap/ article/maison-departementale-des-personnes-handicapees-mdph. 
sourds, PEJS) ${ }^{20}$ lub we wszystkich innych szkołach, które nie mają statusu szkół specjalnych.

Zgodnie z wyborem rodziców lub prawnych opiekunów i wytycznymi zawartymi w PPS uczeń może realizować kształcenie dwujęzyczne prowadzone w szkołach należących do PEJS oraz kształcenie w języku francuskim realizowane w szkołach ogólnodostępnych.

- Edukacja dwujęzyczna w szkołach należących do PEJS. Uczniowie z dysfunkcją słuchu nauczani są wszystkich przedmiotów w języku francuskim bez użycia języka migowego lub w połączeniu z językiem francuskim migowym. Ten dwujęzyczny model kształcenia może być zorganizowany w formie zajęć z uczniami niesłyszącymi, prowadzonych przez wyspecjalizowanego nauczyciela oraz zajęć mieszanych z uczniami słyszącymi i głuchymi, gdzie lekcje prowadzone są przez dwóch nauczycieli - nauczyciela przekazującego wiedzę w języku francuskim i nauczyciela odpowiedzialnego za przekaz w języku migowym.

- Edukacja w języku francuskim w szkołach ogólnodostępnych. Gdy rodzice lub prawni opiekunowie podejmą decyzję o kształceniu dziecka z niepełnosprawnością słuchu w szkołach ogólnodostępnych, uczeń niepełnosprawny będzie podlegał kształceniu w języku francuskim. W takim wypadku może rozpocząć kształcenie dwujęzyczne wspierane wykorzystaniem LPC (syste$\mathrm{mu}$ kodowania francuskiego języka mówionego). Uczniowi z dysfunkcją słuchu podczas lekcji towarzyszy osoba uprawniona do tłumaczenia w LPC.

\section{Grecja}

W Grecji problematykę kształcenia specjalnego dla uczniów z dysfunkcją słuchu, wzroku oraz z autyzmem reguluje ustawa nr 3699/200821. Zgodnie art. 7 ustawy grecki język migowy uważany jest za pierwszy język uczniów niesłyszących, natomiast współczesny język grecki wyrażany w formie mówionej i pisanej określany jest jako drugi język. Zarówno grecki język migowy, jak i współczesny język grecki, są uznawane za równoważne, więc pojęcie dwujęzyczności w nauczaniu oznacza nauczanie obu tych języków. Zatem w Grecji dwujęzyczność w nauczaniu osób z dysfunkcją słuchu odbywa się przez nauczanie greckiego języka migowego i współczesnego języka greckiego.

20 http://www.onisep.fr/Formation-et-handicap/Mieux-vivre-sa-scolarite/Par-type-de-handicap/Scolarite-et-troubles-auditifs/Le-pole-d-enseignement-des-jeunes-sourds-PEJS.

21 Law 3699/2008 (Greek Official Governmental Gazette. Law 3699 2/10/2008; 199), http://citeseerx.ist.psu.edu/viewdoc/download?doi=10.1.1.675.2602\&rep=rep1\&type=pdf 
Zgodnie z art. 6 ustawy nr 3699/2008 uczniowie z orzeczoną niepełnosprawnością i/lub specjalnymi potrzebami edukacyjnymi mogą podjąć naukę w ogólnodostępnych szkołach publicznych w następujących typach klas:

- w klasach ogólnodostępnych, w których wychowawca klasy pełni funkcję nauczyciela wspierającego uczniów z niepełnosprawnością. Ten typ klas przeznaczony jest dla uczniów z łagodnymi trudnościami w uczeniu się,

- w klasach ogólnodostępnych ze zindywidualizowanym wsparciem równoległym, zapewnionym przez drugiego nauczyciela edukacji specjalnej wspierającego nauczyciela przedmiotowego. Ten typ klas przeznaczony jest dla uczniów, którzy posługują się językiem migowym i wraz z pozostałymi uczniami mogą, przy odpowiednim indywidualnym wsparciu, realizować program nauczania,

- w klasach z nauczycielem włączającym, który może wspierać jednego lub więcej uczniów, współpracując z nauczycielem przedmiotowym. Nauczyciel włączający może prowadzić swoje zajęcia z uczniami w oddzielnym pomieszczeniu, przygotowując ich do włączenia do klasy ogólnodostępnej.

Uczniowie z orzeczoną niepełnosprawnością, której stopień uniemożliwia realizację programu nauczania w szkołach ogólnodostępnych lub klasach włączających, mogą podjąć naukę w szkołach specjalnych lub realizować nauczanie domowe.

\section{Hiszpania}

W Hiszpanii odpowiedzialność za oświatę rozdzielona jest pomiędzy państwo, wspólnoty autonomiczne, administrację lokalną i szkoły. Władze centralne zachowały odpowiedzialność tylko w zakresie ogólnych uregulowań oświatowych, a większość zadań została przekazana 17 samorządom regionalnym (wspólnotom autonomicznym). Programy nauczania tworzy się na trzech poziomach: centralnym (krajowa podstawa programowa), wspólnot autonomicznych (przystosowanie do uwarunkowań historycznych, kulturowych, społecznych i ekonomicznych wspólnoty) oraz na poziomie placówki szkolnej (zgodnie z potrzebami klasy).

Podstawą prawną dla edukacji dwujęzycznej osób z zaburzeniami słuchu jest ustawa 27/2007 z 23 października 2007 r. o uznaniu hiszpańskich języków migowych i określeniu środków wspierających komunikację werbalną osób głuchych, niedosłyszących i głuchoniewidomych ${ }^{22}$, która uznała języki migowe hiszpański

22 Ley 27/2007, de 23 de octubre, por la que se reconocen las lenguas de signos españolas y se regulan los medios de apoyo a la comunicación oral de las personas sordas, con discapacidad auditiva y sordociegas, https://www.boe.es/buscar/pdf/2007/BOE-A-2007-18476-consolidado.pdf. 
i kataloński za oficjalne języki osób głuchych, niedosłyszących i głuchoniewidomych, które decydują się na ich wykorzystanie.

W hiszpańskim systemie szkolnym język migowy i jego nauczanie w formie dwujęzycznej dla osób z zaburzeniami słuchu są realizowane w szkołach specjalnych i szkołach ogólnodostępnych w zależności od potrzeb, możliwości pedagogiczno-dydaktycznych i decyzji władz szkolnych. Zgodnie z przepisami oświatowymi, w celu ułatwienia integracji społecznej uczniów niesłyszących i głuchoniewidomych, modele edukacji dwujęzycznej powinny znaleźć się w szkolnym programie, a nauka języka migowego powinna stać się przedmiotem fakultatywnym w ogólnodostępnych szkołach powszechnych.

Ze względu na duży stopień decentralizacji systemu hiszpańskiej oświaty każda wspólnota autonomiczna ma szerokie kompetencje do wdrożenia i opracowania własnych zasad dotyczących nauczania języka migowego w szkołach w zależności od potrzeb i możliwości wspólnoty. Najczęstszym sposobem wsparcia uczniów z dysfunkcjami słuchu w szkołach ogólnodostępnych jest zapewnienie bezpłatnych tłumaczy języka migowego. W niektórych placówkach, np. w Madrycie i Katalonii, realizowana jest edukacja dwujęzyczna.

\section{Holandia}

W Holandii edukacja dwujęzyczna dla uczniów niesłyszących prowadzona jest wyłącznie w szkołach specjalnych dla osób z dysfunkcją słuchu. Liczba uczniów w klasie z edukacją dwujęzyczną zależy od poziomu szkoły. W szkole podstawowej liczba uczniów w klasie dwujęzycznej wynosi 10, w szkole średniej - 7.

W ogólnodostępnych szkołach powszechnych edukacja dwujęzyczna dla uczniów niesłyszących nie jest obowiązkowa. Jednakże, jeżeli uczniowie z taką dysfunkcją uczęszczają do szkoły ogólnodostępnej, to mogą ubiegać się o tłumacza języka migowego. Tłumacz pomaga niesłyszącemu uczniowi podczas pobytu w szkole - tłumaczy lekcje oraz rozmowy.

\section{Irlandia}

W Irlandii pojęcie dwujęzyczności osób niesłyszących związane jest z aspektem językowym i kulturowym. Irlandzki język migowy jest językiem osób niesłyszących, a językiem społeczności słyszącej - jest angielski i/lub irlandzki.

Przez większość XX wieku kształcenie głuchych w Irlandii związane było z segregacją oświatową wynikającą z niemożności podjęcia nauki przez osoby głu- 
che w ogólnodostępnych szkołach powszechnych. W ostatnich dziesięcioleciach nastąpiła radykalna zmiana w integracji niesłyszących uczniów w klasach ogólnodostępnych. Miało na to wpływ m.in. zastosowanie elektroniki w technologii aparatów słuchowych (1970 r.), wynalezienie implantów ślimakowych (1990 r.), uznanie języków migowych za pełnoprawne języki (1990 r.), a także przyjęcie ustawy o kształceniu osób ze specjalnymi potrzebami edukacyjnymi (2004 r.) oraz ustawy o irlandzkim języku migowym (2017 r.).

Obecnie w Irlandii w szkołach dla osób niesłyszących duży nacisk kładzie się na poprawę umiejętności komunikacyjnych uczniów. Głównym kierunkiem kształcenia jest promocja języka mówionego i pisanego, a także wspieranie obszaru kulturowego społeczności osób niesłyszących i tożsamości uczniów. Szkoły najczęściej przyjmują metodologię „całkowitej komunikacji” (total communication), polegającą na mieszaniu języków mówionego i migowego, oraz zgodnie z potrzebami na „przełączaniu” języka angielskiego i irlandzkiego. Stosowana metoda opiera się na indywidualnych możliwościach, preferencjach i potrzebach uczniów. Jednakże największym problemem dwujęzyczności osób niesłyszących - w porównaniu z dwujęzycznością osób słyszących, gdzie każdy z dwóch języków mówionych ma formę pisemną - jest brak formy pisemnej dla irlandzkiego języka migowego.

W Irlandii w szkołach dla niesłyszących większość nauczycieli nie ma wady słuchu, ale wielu nauczycieli wspierających (suport assistants) to osoby z taką dysfunkcją. Rolą nauczyciela wspierającego jest pomaganie uczniom w rozumieniu lekcji i w wyjaśnianiu pojawiających się pytań.

\section{Islandia}

W Islandii dwujęzyczność uczniów z upośledzeniem słuchu jest integralnym elementem wszystkich obowiązkowych przedmiotów szkolnych, w tym także przedmiotów językowych związanych z językiem obcym. Islandzki język migowy stanowi integralną część procesu realizacji programu nauczania, a uczniowie z dysfunkcją słuchu podczas wszystkich przedmiotów mają obowiązek uzyskania interpretacji przekazu dydaktycznego w formie języka migowego.

Integracja uczniów niesłyszących ze słyszącymi na poziomie szkoły podstawowej, szkoły średniej I i II stopnia (ISCED 1, 2, 3) jest powszechną praktyką. Jednakże młodsi uczniowie niesłyszący i ich rodzice w pierwszych latach edukacji chętniej wybierają specjalne szkoły podstawowe specjalizujące się w nauczaniu uczniów z dysfunkcją słuchu. 


\section{Łotwa}

W szkolnictwie na Łotwie nie ma precyzyjnych ustawowych zapisów dotyczących nauczania języka migowego i dwujęzyczności.

W listopadzie 2018 roku przyjęto nowy Krajowy Standard Edukacji Podstawowej, który ma wejść w życie w dniu 1 września 2020 roku. Określa on, że uczniom z wadami słuchu, którzy są włączeni do głównego nurtu edukacji, powinno zapewnić się możliwości rozwijania umiejętności komunikacyjnych, w tym z wykorzystaniem łotewskiego języka migowego. Edukacja dwujęzyczna przewidziana jest w programach szkół specjalnych, ale sposób jej realizacji nie jest uregulowany w przepisach.

\section{Niemcy}

W Niemczech, zgodnie z federalną strukturą państwa, odpowiedzialność za oświatę została rozdzielona pomiędzy władze federalne i kraje związkowe (landy). Zadania rządu federalnego w dziedzinie edukacji obejmują m.in. ustanawianie przepisów wyznaczających ogólne ramy współpracy oświatowej między szczeblem federalnym i landami, np. w zakresie planowania edukacji i promowania badań. Za ustawodawstwo i administrację oświatową odpowiadają przede wszystkim landy oraz władze nadzorujące szkoły na niższym administracyjnym szczeblu (Schulamt). Ministerstwa edukacji w landach odpowiedzialne są za ustalanie programów nauczania, zalecanie metod nauczania oraz zatwierdzanie do użytku szkolnego pomocy naukowych i podręczników.

W ogólnodostępnych szkołach powszechnych nauczanie w niemieckim języku migowym oferowane jest, w miarę możliwości szkoły, wszystkim uczniom jako przedmiot fakultatywny niepodlegający ocenie. Podczas lekcji, w których biorą udział uczniowie z dysfunkcją słuchu wymagającą wsparcia, nauczyciel przedmiotowy wspierany jest przez osobę posługującą się językiem migowym. Uczniowie z łagodnymi lub umiarkowanymi zaburzeniami słuchu także mogą otrzymać pomoc i asystę pedagogiczno-dydaktyczną osób specjalnie do tego przygotowanych. Asystent pedagogiczno-dydaktyczny zajmuje się także obsługą niezbędnego sprzętu technicznego i audiowizualnego oraz wykonuje inne pedagogiczne zadania, np. wspieranie uczestnictwa ucznia z dysfunkcją słuchu w życiu klasy, czy uświadamianie kadrze nauczycielskiej i rodzicom innych uczniów potrzeb niepełnosprawnego ucznia.

Rodzice uczniów i szkoła nie ponoszą żadnych kosztów takiego wsparcia. Udział tłumacza języka migowego i/lub asystenta jest opłacany przez landowe biuro pomocy społecznej. Wsparcie takie mogą uzyskać także rodzice z wadami 
słuchu. Gdy szkoła organizuje wywiadówki, spotkania organizacyjne lub wydarzenia świąteczne, rodzice z dysfunkcją słuchu mogą zamówić dla swoich potrzeb w landowym biurze pomocy społecznej tłumacza języka migowego - koszt jego uczestnictwa pokrywany jest z budżetu landu.

W szkołach specjalnych, do których uczęszczają uczniowie z różnymi typami dysfunkcji, lekcje odbywają się w języku niemieckim fonetycznym lub niemieckim języku migowym.

\section{Słowacja}

Na Słowacji zagadnienie nauczania osób niesłyszących i niedosłyszących reguluje ustawa nr 149/1995 o języku migowym, osobach niesłyszących i głuchych ${ }^{23}$, która zapewnia osobom z dysfunkcjami słuchu prawo do nauki i nauczania w słowackim języku migowym.

Od września 2016 roku obowiązuje nowy państwowy program kształcenia uczniów z upośledzeniem słuchu, który przewiduje m.in. nauczanie słowackiego języka migowego we wszystkich szkołach podstawowych i gimnazjalnych, zgodnie z potrzebami i możliwościami uczniów. Uczniowie ze specjalnych szkół podstawowych dla uczniów z uszkodzeniem słuchu uczą się słowackiego języka migowego na poziomach od A1 do B1, w zależności od czasu trwania nauki. Ten sam przedmiot nauczany jest także w szkołach ogólnodostępnych w klasach integracyjnych.

Mimo obowiązujących przepisów, dwujęzyczne kształcenie uczniów słyszących i uczniów z dysfunkcją słuchu jest wdrażane tylko w szkołach specjalnych dla uczniów z uszkodzonym słuchem. W szkołach ogólnodostępnych kształcenie uczniów z wadami słuchu odbywa się sporadycznie za pośrednictwem tłumacza języka migowego. Najczęściej jest to wsparcie wykorzystywane w nauce przedmiotów językowych.

\section{Słowenia}

W szkolnictwie Słowenii nie wykorzystuje się modelu dwujęzycznej edukacji dla osób niesłyszących. Osoby z dysfunkcjami słuchu i/lub zaburzeniami mowy korzystają z ogólnodostępnych przedszkoli i placówek szkolnych, w których uzyskują indywidualne specjalistyczne wsparcie odpowiednie do zdiagnozowanych

23 Zákon č. 149/1995 Z. z. Zákon Národnej rady Slovenskej republiky o posunkovej reči nepočujúcich osób, http://www.zakonypreludi.sk/zz/1995-149. 
potrzeb. Osoby z dysfunkcjami mogą też zostać skierowane do przedszkoli, szkół podstawowych oraz szkół zawodowych i technicznych, w których realizowane są zindywidualizowane programy edukacyjne dostosowane do zdiagnozowanego stopnia niepełnosprawności.

W kształceniu osób z niepełnosprawnością słuchu komunikacja zapewniona jest m.in. przez użycie języka migowego. Korzystanie z języka migowego zostało uregulowane w 2002 roku w ustawie o stosowaniu słoweńskiego języka migowego ${ }^{24}$.

Ustawa między innymi:

- ustanowiła słoweński język migowy oficjalnym językiem osób z dysfunkcją słuchu, a na obszarach zamieszkanych przez włoską lub węgierską wspólnotę narodową zapewniła tłumaczenie migowe języka włoskiego lub węgierskiego,

- określiła warunki dostępu do bezpłatnego tłumaczenia w języku migowym, zgodnie z którymi osoby niesłyszące i niedosłyszące mają prawo do używania słoweńskiego języka migowego i do zwrócenia się o pomoc tłumacza. Dlatego wszystkie dzieci z wadami słuchu, które komunikują się w słoweńskim języku migowym, są uprawnione do posiadania tłumacza języka migowego. Liczba godzin pracy tłumacza dla dziecka na tydzień jest podawana w indywidualnym programie dla danego dziecka,

- sformułowała zasady powołania, skład i zadania rządowej Rady Słoweńskiego Języka Migowego.

\section{Węgry}

Węgierski język migowy, chociaż jest wykorzystywany w mediach i innych obszarach życia społecznego, nie ma jednolitych podstaw nauczania. Na Węgrzech istnieją przepisy określające warunki realizacji dwujęzyczności w szkolnictwie specjalnym, lecz nie weszły one w życie. Powodem jest brak jednolitego zestawu znaków ideograficznych oraz opisu gramatycznego i symbolicznego węgierskiego języka migowego, co jest konsekwencją występowania wielu dialektów.

Na Węgrzech nie ma obowiązującej krajowej normy językowej oraz jednolitego słownika węgierskiego języka migowego. Od kilku lat w Instytucie Językoznawstwa Węgierskiej Akademii Nauk trwają prace nad standaryzacją i przygotowaniem lingwistycznego opisu węgierskiego języka migowego. Po zakończeniu prac i przyjęciu słownikowych podstaw węgierskiego języka migowe-

24 Zakon o uporabi slovenskega znakovnega jezika (ZUSZJ) Št. 001-22-130/02, 5. novembra 2002, http://www.mddsz.gov.si/fileadmin/mddsz.gov.si/pageuploads/dokumenti_pdf/zuszj.pdf. 
go powinien rozpocząć się proces wdrażania edukacji dwujęzycznej dla uczniów $\mathrm{z}$ dysfunkcjami słuchu.

\section{Wielka Brytania}

Struktura organizacyjna systemu szkolnego Wielkiej Brytanii nie jest jednolita. Administracja szkolna jest zdecentralizowania, a zarządzanie i odpowiedzialność za kształt i funkcjonowanie oświaty spoczywa w rękach władzy centralnej i lokalnej każdego spośród czterech części składowych (constituent parts) kraju - Anglii, Walii, Szkocji i Irlandii Północnej. Struktury oświatowe Anglii i Walii są relatywnie podobne, natomiast systemy szkolne Szkocji i Irlandii Północnej regulowane są odrębnymi ustawami. Występują w nich inne typy szkół, inne programy i odmienne organizacje pracy szkolnej.

\section{Anglia}

W Anglii nie ma szczegółowych wytycznych dotyczących edukacji dwujęzycznej dla uczniów z zaburzeniami słuchu.

Dokumentem definiującym, systematyzującym i opisującym specjalne potrzeby edukacyjne uczniów jest Kodeks dotyczący postępowania w zakresie specjalnych potrzeb edukacyjnych dla osób w wieku od 0 do 25 roku życia (Special Educational Needs and Disability, SEND) ${ }^{25}$. W dokumencie znajduje się zapis odnoszący się do edukacji osób niedosłyszących i niedowidzących, którym powinno się zapewnić porady i konsultacje realizowane przez osoby mające kwalifikacje do nauczania uczniów lub studentów z tymi upośledzeniami.

\section{Walia}

W Walii nie ma konkretnych wytycznych dotyczących edukacji dwujęzycznej dla uczniów z zaburzeniami słuchu.

Specjalny Kodeks postępowania w zakresie potrzeb edukacyjnych (Special Educational Needs Code of Practice for Wales, SEN) ${ }^{26}$ zawiera ogólne wskazówki dotyczące świadczenia specjalnej edukacji dla osób z dysfunkcjami.

25 SEND code of practice: 0 to 25 years, https://www.gov.uk/topic/schools-colleges-childrens-services/special-educational-needs-disabilities.

26 http://learning.gov.wales/resources/browse-all/special-education-needs-code-of-practice/ ?lang=en. 


\section{Szkocja}

W Szkocji nie ma szczegółowych wytycznych dotyczących edukacji dwujęzycznej dla uczniów z zaburzeniami słuchu, jednakże plan lokalnego rządu zakłada upowszechnienie na terenie Szkocji do 2020 roku brytyjskiego języka migowego (British Sign Language, BSL) ${ }^{27}$. Od 2011 roku BSL uznawany jest w Szkocji za język urzędowy, a jego dalsze upowszechnienie ma sprawić - jak w swoim wystąpieniu w 2017 roku powiedział szkocki minister ds. opieki nad dziećmi Mark McDonald - że w przyszłości Szkocja ma stać się najlepszym miejscem na świecie do życia, pracy i turystyki dla osób, których pierwszym lub preferowanym językiem jest British Sign Language ${ }^{28}$.

Główną organizacją zajmującą się problemami głuchych jest Szkocka Rada ds. Głuchoty (Scottish Council on Deafness, SCoD) ${ }^{29}$. Jej celem jest zapewnienie osobom z dysfunkcjami słuchu wsparcia prawnego i organizacyjnego w korzystaniu $z$ dostępu do informacji i usług oferowanych przez władze lokalne i centralne na rzecz osób głuchych, niedosłyszących i głuchoniemych. Rada opiera swoją działalność w zakresie spraw osób z wadami słuchu na utrzymywaniu skutecznego partnerstwa pomiędzy rządem Szkocji, sektorem instytucji publicznych, sektorem prywatnym oraz organizacjami pozarządowymi.

\section{Irlandia Północna}

W Irlandii Północnej nie ma konkretnych wytycznych dotyczących edukacji dwujęzycznej dla uczniów z upośledzeniem słuchu. Takie potrzeby edukacyjne realizowane są przez organizacje pozarządowe i/lub instytucje charytatywne.

Postępowanie w zakresie identyfikacji i oceny specjalnych potrzeb edukacyjnych uczniów zostało prawnie zapewnione poprzez umieszczenie odpowiednich zapisów w Kodeksie dotyczącym identyfikacji i postępowania dysfunkcji (Code of practice on the identification and assessment of special educational needs) $)^{30}$.

27 BSL jest pierwszym lub preferowanym językiem migowym osób z dysfunkcją słuchu używanym w Wielkiej Brytanii. BSL używa 125000 głuchych dorosłych i około 20000 dzieci.

Our long term aim is ambitious: we want to make Scotland the best place in the world for people whose first or preferred language is BSL to live, work and visit, The Scotsman. Scotland's National Newspaper, 24 October 2017, https://www.scotsman.com/news/scotland-aims-to-become-best-place-in-the-world-for-deaf-people-1-4595462. http://www.scod.org.uk/.

30 https://www.education-ni.gov.uk/publications/code-practice-identification-and-assessment-special-educational-needs. 


\section{Instytucje i organizacje wspierajq̨e}

W Wielkiej Brytanii edukację uczniów z wadami słuchu wspierają między innymi następujące instytucje i organizacje:

- Krajowe Partnerstwo na rzecz Upośledzenia Sensorycznego (National Sensory Impairment Partnership, NatSIP) ${ }^{31}$ - celem jego działalności jest poprawa wyników edukacyjnych u dzieci i młodzieży z upośledzeniem sensorycznym oraz niwelowanie wykluczenia społecznego,

- Krajowe Stowarzyszenie Dzieci Niesłyszących (National Deaf Children's So-

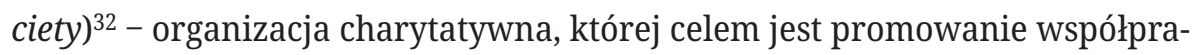
cy między pracownikami oświaty, opieki zdrowotnej i społecznej dla potrzeb dzieci i młodzieży z upośledzeniem słuchu,

- Brytyjskie Stowarzyszenie Nauczycieli osób Głuchych (British Association of Teachers of the Deaf, BATOD) ${ }^{33}$ - jest jedynym stowarzyszeniem w Wielkiej Brytanii reprezentującym interesy nauczycieli z Anglii, Irlandii Północnej, Szkocji i Walii. Celem stowarzyszenia jest promowanie edukacji dzieci, młodzieży i dorosłych z wadami słuchu, zapewnienie nauczycielom wysokiej jakości obowiązkowych szkoleń oraz ustawiczność kształcenia zawodowego.

\section{Włochy}

We Włoszech zdecydowana większość uczniów niepełnosprawnych uczęszcza do ogólnodostępnych placówek przedszkolnej, podstawowej i średniej I i II stopnia. Istnieje także możliwość realizacji kształcenia w kilku specjalistycznych instytutach dla osób niewidomych i niesłyszących.

W ogólnodostępnych placówkach szkolnych podczas zajęć edukacyjnych, które obejmują uczniów niesłyszących, zapewniony jest nauczyciel wspierający posługujący się środkami umożliwiającymi wsparcie procesu nauczania.

Wsparcie dydaktyczne uzupełnione jest przez osoby udzielające pomocy pedagogicznej. Są to tzw. asystenci ds. autonomii i komunikacji. Asystenci są rekrutowani przez lokalne władze i przydzielani konkretnemu uczniowi w zależności od zaistniałych potrzeb. Dodatkowym zadaniem asystentów jest podjęcie współpracy z nauczycielami w celu poprawienia relacji mikrospołecznych i umiejętności komunikacyjnych między uczniem niepełnosprawnym a grupą klasową.

31 https://www.natsip.org.uk/.

32 http://www.ndcs.org.uk/.

33 https://www.batod.org.uk/. 
Uczniowie z dysfunkcją słuchu (zwłaszcza posiadający implant ślimakowy) mogą uczestniczyć w nauce języka obcego. Studenci niesłyszący, którzy nie mają implantu ślimakowego, mogą zostać zwolnieni z części ustnej programu obcojęzycznego i uczestniczą tylko w pisemnej części nauki języka obcego.

\section{Bibliografia}

\section{Akty prawne}

Ustawa z 14 grudnia 2016 r. - Prawo oświatowe, Dz.U. 2018, poz. 996, ze zm.

Rozporządzenie Ministra Edukacji Narodowej z 24 sierpnia 2017 r. w sprawie organizowania wczesnego wspomagania rozwoju dzieci, Dz.U. poz. 1635.

Rozporządzenie Ministra Edukacji Narodowej z 9 sierpnia 2017 r. w sprawie warunków organizowania kształcenia, wychowania i opieki dla dzieci i młodzieży niepełnosprawnych, niedostosowanych społecznie i zagrożonych niedostosowaniem społecznym, Dz.U. poz. 1578, ze zm.

Rozporządzenie Ministra Edukacji Narodowej z 7 lutego 2012 r. w sprawie ramowych planów nauczania w szkołach publicznych, Dz.U. poz. 204, ze zm.

Rozporządzenie Ministra Edukacji Narodowej z 28 marca 2017 r. w sprawie ramowych planów nauczania dla publicznych szkół, Dz.U. poz. 703.

Rozporządzenie Ministra Edukacji Narodowej z 9 sierpnia 2017 r. w sprawie zasad organizacji i udzielania pomocy psychologiczno-pedagogicznej w publicznych przedszkolach, szkołach i placówkach, Dz.U. poz. 1591.

Rozporządzenie Ministra Edukacji Narodowej z 1 lutego 2013 r. w sprawie szczegółowych zasad działania publicznych poradni psychologiczno-pedagogicznych, w tym publicznych poradni specjalistycznych, Dz.U. poz. 199, ze zm.

Fińska ustawa oświatowa Finlandii, Finland Basic Educational Act, http://ncee.org/2017/01/ finland-basic-education-act-1998/.

Fińska ustawa oświatowa, Finland General upper secondary Education, https://minedu.fi/ en/general-upper-secondary-education.

Francuska ustawa oświatowa, Code de l'éducation - Article L112-3, https://www.legifrance.gouv.fr/affichCodeArticle.do?cidTexte=LEGITEXT000006071191\&idArticle=LEGIARTI000019911145.

Grecka ustawa, Law 3699/2008 (Greek Official Governmental Gazette. Law 3699 2/10/2008; 199), http://citeseerx.ist.psu.edu/viewdoc/download?doi=10.1.1.675.2602\&rep=rep1\&type=pdf.

Hiszpańska ustawa o uznaniu hiszpańskich języków migowych i określeniu środków wspierających komunikację werbalną osób głuchych, niedosłyszących i głuchoniewi- 
domych, Ley 27/2007, de 23 de octubre, por la que se reconocen las lenguas de signos españolas y se regulan los medios de apoyo a la comunicación oral de las personas sordas, con discapacidad auditiva y sordociegas, https://www.boe.es/buscar/pdf/2007/ BOE-A-2007-18476-consolidado.pdf.

Słowacka ustawa nr 149/1995 o języku migowym, osobach niesłyszących i głuchych, Zákon č. 149/1995 Z. z. Zákon Národnej rady Slovenskej republiky o posunkovej reči nepočujúcich osób, http://www.zakonypreludi.sk/zz/1995-149.

Słoweńska ustawa o stosowaniu słoweńskiego języka migowego, Zakon o uporabi slovenskega znakovnega jezika (ZUSZJ) Št. 001-22-130/02, 5. novembra 2002, http://www. mddsz.gov.si/fileadmin/mddsz.gov.si/pageuploads/dokumenti_pdf/zuszj.pdf.

UK Code of practice on the identification and assessment of special educational needs, https://www.education-ni.gov.uk/publications/code-practice-identification-and-assessment-special-educational-needs.

\section{Strony internetowe}

https://minedu.fi/en/vocational-education-and-training.

http://www.languedessignes.fr/formations/cours-de-lsf/.

http://www.surdi.info/langue-francaise-parlee-completee/presentation-lpc/.

http://www.tousalecole.fr/content/projet-personnalis\%C3\%A9-de-scolarisation-pps.

https://handicap.gouv.fr/le-secretariat-d-etat/acteurs/cncph/.

handicap/article/maison-departementale-des-personnes-handicapees-mdph.

http://www.onisep.fr/Formation-et-handicap/Mieux-vivre-sa-scolarite/Par-type-de-handi-

cap/Scolarite-et-troubles-auditifs/Le-pole-d-enseignement-des-jeunes-sourds-PEJS.

https://www.gov.uk/topic/schools-colleges-childrens-services/special-educational-needs-

-disabilities.

http://learning.gov.wales/resources/browse-all/special-education-needs-code-of-

practice/?lang=en.

https://www.scotsman.com/news/scotland-aims-to-become-best-place-in-the-world-for-

-deaf-people-1-4595462.

http://www.scod.org.uk/.

https://www.natsip.org.uk/.

http://www.ndcs.org.uk/.

https://www.batod.org.uk/. 


\title{
4.5. Dostęp do podręczników dla dzieci niewidomych i słabowidzących w Polsce, Szwecji i Wielkiej Brytanii
}

\author{
Access to textbooks for blind and partially sighted \\ children in Poland, Sweden and the United Kingdom
}

W opracowaniu podjęto próbę przedstawienia zagadnienia dostępu do podręczników dla dzieci niewidomych i słabowidzących w Polsce, Szwecji i Wielkiej Brytanii. Prezentację tego tematu uzupełniono o analizę związaną z problematyką zarządzania oświatą. Krótko scharakteryzowano programy nauczania i tendencje w kształceniu uczniów z dysfunkcjami.

Słowa kluczowe: edukacja, szkoła, podręczniki, uczniowie niepełnosprawni, Polska, Szwecja, Wielka Brytania

The paper is an attempt to present the problem of access to textbooks for blind and partially sighted children in Poland, Sweden and the UK. The presentation of this topic is supplemented by an analysis of issues related to educational management. The article also contains a brief overview of curricula and trends in the education of students with impairments.

Keywords: education, school, textbooks, disabled students, Poland, Sweden, United Kingdom.

\section{Wstęp}

Posługując się aparatem pojęciowym wypracowanym przez współczesną okulistykę i przyjętym przez Światową Organizację Zdrowia (World Health Organization, WHO), opisanie dysfunkcji wzroku (visual impairment) wymaga uwzględnienia trzech podstawowych parametrów wzrokowych: ostrości widzenia (visual acuity), pola widzenia (field of vision) i stanu funkcjonalnego narządu wzroku (visual functioning). Ostrość widzenia oznacza zdolność do postrzegania szczegółów z określonej odległości. Ściślej mówiąc, chodzi tu o maksymalną odległość, z jakiej oko widzi daną rzecz. Drugi parametr to pole widzenia zdefiniowane jako obszar, który można zobaczyć przed sobą za pomocą obu oczu, czyli, poruszając gałkami ocznymi, ale nie poruszając głową. Normalne pole widzenia wynosi 180 stopni. Określa się je za pomocą tak zwanego testu konfrontacyjnego z użyciem tablicy 
z koncentrycznymi kołami o różnej wielkości. W rozmaitych dysfunkcjach wzroku lub przy korekcji szkłami plusowymi o dużej mocy pole widzenia bywa bardzo ograniczone, co w skrajnych przypadkach oznacza widzenie „tunelowe”, które można porównać do widzenia przez dziurkę od klucza czy szczelinę w płocie. Trzeci istotny parametr, czyli funkcjonowanie narządu wzroku, jest najtrudniejsze do opisania, gdyż dotyczy kompleksu spraw związanych z doświadczeniem każdego człowieka (motywacjami, potrzebami i oczekiwaniami) w odniesieniu do jego możliwości wzrokowych oraz sposobu, w jaki dysfunkcja wzroku może ograniczać aktywność życiową (możliwości uczenia się, wybór zawodu). Te właśnie elementy - chociaż z medycznego punktu widzenia trudno je jednoznacznie opisać - odgrywają główną rolę w aspekcie szeroko rozumianej edukacji.

Dla potrzeb niniejszego opracowania omawiającego zagadnienie dostępu do podręczników dla dzieci niewidomych i słabowidzacych ${ }^{1}$ przyjęto, że niewidomy to osoba, która posługuje się technikami bezwzrokowymi, wykorzystując pozostałe zmysły i specjalne pomoce o charakterze kompensacyjnym. Natomiast słabowidzący (niedowidzący) to ten, który pomimo znacznej dysfunkcji widzenia posługuje się wzrokiem, wspomagając się różnymi pomocami optycznymi i technicznymi.

W opracowaniu wykorzystano m.in.: materiały Ministerstwa Edukacji Narodowej, Polskiego Związku Niewidomych, Europejskiej Agencji ds. Rozwoju Edukacji Uczniów ze Specjalnymi Potrzebami Edukacyjnymi (European Agency for Development in Special Needs Education, EADSNE) ${ }^{2}$ oraz Sieci Informacji o Edu-

1 Opracowanie przygotowano na podstawie ekspertyzy Biura Analiz Sejmowych nr 75/11 z1lutego 2012 r. D. Dziewulaka zatytułowanej Informacja nt. zapewnienia dostępu do podręczników i pomocy dydaktycznych dla dzieci niewidzacych i niedowidzących w Szwecji i Wielkiej Brytanii oraz opracowania tegoż autora Dostęp do podręczników dla dzieci niewidomych i słabowidzących w Polsce, Szwecji i Wielkiej Brytanii, „Analizy BAS” 2012, nr 8(75), s. 1-10.

2 Europejska Agencja ds. Rozwoju Edukacji Uczniów ze Specjalnymi Potrzebami Edukacyjnymi jest samorządną organizacją, powstałą w 1996 roku na drodze porozumienia ministrów edukacji państw członkowskich. Aktualnie zrzesza 27 państw członkowskich: Austrię, Belgię, Cypr, Czechy, Danię, Estonię, Finlandię, Francję, Niemcy, Grecję, Węgry, Islandię, Irlandię, Włochy, Łotwę, Litwę, Luksemburg, Maltę, Holandię, Norwegię, Polskę (od 2006 r.), Portugalię, Słowenię, Hiszpanię, Szwecję, Szwajcarię oraz Wielką Brytanię. Agencja stanowi platformę międzynarodowej współpracy w zakresie promowania jakości edukacji uczniów ze specjalnymi potrzebami edukacyjnymi. Swoje cele realizuje przez wymianę doświadczeń i informacji, na poziomie krajowym i europejskim. Jest utrzymywana przez państwa członkowskie Unii Europejskiej oraz Islandię, Norwegię i Szwajcarię. Agencja oferuje różne źródła informacji, które są dostępne za pośrednictwem strony internetowej www.european-agency.org. Są to raporty tematyczne, bazy danych, biuletyny, w tym również w formie elektronicznej. Publikacje tłumaczone są na 21 języków. 
kacji w Europie (Eurydice Network - Information on Education Systems and Policies in Europe, Eurydice) $)^{3}$.

\section{Polska}

\section{Zarzq̨dzanie oświatq i programy nauczania}

W Polsce odpowiedzialność za system oświaty ponosi Ministerstwo Edukacji Narodowej. Szkolnictwo wyższe podlega Ministerstwu Nauki i Szkolnictwa Wyższego. Nieliczne szkoły o specjalistycznym profilu mogą podlegać innym resortom. Ministerstwo Kultury i Dziedzictwa Narodowego może zakładać i prowadzić publiczne szkoły artystyczne oraz placówki dla uczniów szkół artystycznych, a także placówki doskonalenia nauczycieli szkół artystycznych. Ministerstwo Rolnictwa może zakładać i prowadzić publiczne szkoły rolnicze oraz placówki rolnicze o znaczeniu regionalnym i ponadregionalnym oraz publiczne placówki doskonalenia nauczycieli przedmiotów zawodowych, którzy nauczają w szkołach rolniczych. Ministerstwo Środowiska może zakładać i prowadzić publiczne szkoły leśne. Minister Obrony Narodowej może zakładać i prowadzić publiczne szkoły o profilu związanym z potrzebami resortu. Ministrowie Spraw Wewnętrznych i Administracji oraz Sprawiedliwości mogą zakładać szkoły i placówki przy zakładach poprawczych, schroniskach dla nieletnich oraz zakładach karnych. Reforma administracji i systemu edukacji zakłada, że polityka edukacyjna jest tworzona i prowadzona centralnie, natomiast administracja i prowadzenie szkół, przedszkoli i innych instytucji edukacyjnych są zdecentralizowane. Odpowiedzialność za administrowanie przedszkolami, szkołami podstawowymi i gimnazjami należy do władz lokalnych. Sprawy administracyjne i organizacyjne oraz decyzje dotyczące wykorzystywania środków finansowych przez szkoły są przedmiotem konsultacji między szkołą i organem prowadzącym szkołę, tj. gminą (w wypadku przedszkoli, szkół podstawowych i gimnazjów) lub powiatem (w wypadku szkół ponadgimnazjalnych, artystycznych i specjalnych). Nadzór pedagogiczny nad szkołami sprawuje bezpośrednio Ministerstwo Edukacji Naro-

3 Sieć istnieje od 1980 roku. Składa się z biur krajowych, utworzonych przez ministerstwa edukacji poszczególnych krajów, i z biura europejskiego (EACEA P9), utworzonego przez Komisję Europejską (Dyrekcja Generalna ds. Edukacji i Kultury). Pracując dla twórców polityki edukacyjnej i świata edukacji, Eurydice przygotowuje i publikuje opisowe analizy systemów edukacji, studia porównawcze na tematy będące przedmiotem zainteresowania Unii Europejskiej i wskaźniki dotyczące różnych poziomów edukacji. 
dowej, a w jego imieniu zadania w tym zakresie w 16 województwach wykonują kuratoria oświaty.

Programy nauczania w szkole podstawowej i gimnazjum powstają na poziomie centralnym i są tworzone przez zespoły ekspertów powołane przez MEN. Szkoły (nauczyciele) mogą wybierać podręczniki z listy zatwierdzonej przez Ministerstwo Edukacji Narodowej, a także samodzielnie decydować o stosowanych metodach nauczania. Zestaw programów nauczania obowiązujący w szkole zatwierdza dyrektor szkoły. W klasach I-III szkoły podstawowej obowiązkowe zajęcia edukacyjne mają charakter kształcenia zintegrowanego, a w klasach IV-VI charakter przedmiotowy. Na poziomie szkoły gimnazjalnej obowiązuje nauczanie przedmiotowe, a średniej II stopnia - dodatkowo w ramach ścieżek międzyprzedmiotowych. Ministerstwo Edukacji określa podstawę programową kształcenia ogólnego dla każdego rodzaju szkoły, dla każdego przedmiotu i ścieżki międzyprzedmiotowej. Nauczyciele mogą wybierać podręczniki z listy zatwierdzonej przez Ministerstwo Edukacji, a także samodzielnie decydować o stosowanych metodach nauczania. Nauczyciele mogą również opracowywać własne programy nauczania oparte na podstawie programowej i przedkładać je dyrektorowi szkoły do zatwierdzenia.

\section{Organizacja systemu oświaty}

W Polsce obowiązkowa nauka oraz obowiązek szkolny definiowane są w ustawie o systemie oświaty następująco:

- nauka jest obowiązkowa do ukończenia 18 roku życia,

- obowiązek szkolny dziecka rozpoczyna się z początkiem roku szkolnego w tym roku kalendarzowym, w którym dziecko kończy 6 lat, oraz trwa do ukończenia gimnazjum, nie dłużej jednak niż do ukończenia 18 roku życia (jednocześnie przepisy przejściowe stanowią, że obowiązek ten wchodzi w życie w określonym terminie, do tego czasu obowiązek szkolny dotyczy dzieci kończących 7 lat).

Po ukończeniu gimnazjum obowiązek nauki spełnia się przez:

- uczęszczanie do publicznej lub niepublicznej szkoły ponadgimnazjalnej,

- uczęszczanie na zajęcia realizowane w formach pozaszkolnych w placówkach publicznych i niepublicznych posiadających akredytację,

- uczęszczanie na zajęcia realizowane w ramach działalności oświatowej prowadzonej przez osoby prawne lub fizyczne, dla której osoby te uzyskały akredytację, 
- realizowanie, zgodnie z odrębnymi przepisami, przygotowania zawodowego u pracodawcy.

W Polsce nieobowiązkowe przedszkole przeznaczone jest dla dzieci w wieku od 3 do 5 lat. Dzieci, które ukończyły 6 rok życia, obowiązkowo uczęszczają (od roku 2004/2005) do oddziałów organizowanych w szkołach podstawowych. Od roku szkolnego 1999/2000 dzieci w wieku od 7 do 13 lat uczęszczają do nowej szkoły podstawowej, w której nauka trwa 6 lat (ośmioklasowa szkoła podstawowa przestała istnieć w 2000 roku). Szkoła podstawowa podzielona jest na dwa etapy: pierwszy etap odpowiada klasom od I do III i oferuje zintegrowaną edukację wczesnoszkolną, natomiast drugi etap to klasy od IV do VI. Po ukończeniu sześcioletniej szkoły podstawowej uczniowie przystępują do obowiązkowych sprawdzianów przeprowadzanych przez Okręgowe Komisje Egzaminacyjne (OKE) i ocenianych przez egzaminatorów zakwalifikowanych przez te komisje. Sprawdziany, które pełnią rolę informacyjną (nie są egzaminem), zostały po raz pierwszy przeprowadzone w kwietniu 2002 roku.

Od roku szkolnego 1999/2000 wszyscy absolwenci sześcioletniej szkoły podstawowej kontynuują naukę $\mathrm{w}$ trzyletnim gimnazjum. Pod koniec gimnazjum uczniowie przystępują do obowiązkowego egzaminu zewnętrznego przeprowadzanego przez OKE. Po ukończeniu gimnazjum absolwenci mogą kontynuować naukę w następujących szkołach:

- zasadnicza szkoła zawodowa o okresie nauczania nie krótszym niż 2 lata i nie dłuższym niż 3 lata, której ukończenie umożliwia uzyskanie dyplomu potwierdzającego kwalifikacje zawodowe po zdaniu egzaminu, a także dalsze kształcenie w szkołach uzupełniających,

- trzyletnie liceum ogólnokształcące, którego ukończenie umożliwia uzyskanie świadectwa dojrzałości po zdaniu egzaminu maturalnego,

- trzyletnie liceum profilowane kształcące w profilach kształcenia ogólnozawodowego, którego ukończenie umożliwia uzyskanie świadectwa maturalnego po zdaniu egzaminu maturalnego,

- czteroletnie technikum, którego ukończenie umożliwia uzyskanie dyplomu potwierdzającego kwalifikacje zawodowe po zdaniu egzaminu zawodowego, a także umożliwiające uzyskanie świadectwa maturalnego po zdaniu egzaminu maturalnego,

- trzyletnie szkoły specjalne przysposabiające do pracy dla uczniów z upośledzeniem umysłowym w stopniu umiarkowanym lub znacznym oraz dla uczniów z niepełnosprawnościami sprzężonymi, których ukończenie umożliwia uzyskanie świadectwa potwierdzającego przysposobienie do pracy. 
Absolwenci dwu-, trzyletniej zasadniczej szkoły zawodowej mają możliwość przystąpienia do matury, po ukończeniu dwuletniego uzupełniającego liceum ogólnokształcącego lub trzyletniego technikum uzupełniającego.

Absolwenci liceum ogólnokształcącego mogą, po rozmowie kwalifikacyjnej, kontynuować naukę w szkole policealnej o okresie nauczania nie dłuższym niż 2,5 roku, której ukończenie umożliwia uzyskanie dyplomu potwierdzającego kwalifikacje zawodowe po zdaniu egzaminu.

Egzamin maturalny zastąpił egzaminy wstępne na wyższe uczelnie i ma charakter zewnętrzny. Ustawa o systemie oświaty wprowadziła zewnętrzny egzamin maturalny począwszy od wiosny 2005 roku.

\section{Kształcenie uczniów z dysfunkcjami}

W Polsce kształceniem uczniów z dysfunkcjami obejmuje się dzieci i młodzież z zaburzeniami i odchyleniami rozwojowymi, wymagającymi stosowania specjalnej organizacji nauki i metod pracy. Kształcenie to może być prowadzone w formie nauki w szkołach ogólnodostępnych, szkołach lub oddziałach integracyjnych, szkołach lub oddziałach specjalnych i indywidualnego nauczania.

Kształceniem specjalnym obejmuje się następujące grupy dzieci i młodzieży niepełnosprawnej:

- z upośledzeniem umysłowym w stopniu lekkim,

- z upośledzeniem umysłowym w stopniu umiarkowanym lub znacznym,

- niesłyszących,

- słabosłyszących,

- niewidomych,

- słabowidzących,

- niepełnosprawnych ruchowo,

- z przewlekłą chorobą,

- z zaburzeniami psychicznymi,

- z niepełnosprawnościami sprzężonymi i z autyzmem,

- niedostosowanych społecznie, zagrożonych uzależnieniem, z zaburzeniami zachowania.

W publicznych poradniach psychologiczno-pedagogicznych i specjalistycznych działają zespoły orzekające o potrzebie kształcenia specjalnego oraz o potrzebie indywidualnego nauczania dzieci i młodzieży, których stan zdrowia uniemożliwia lub znacznie utrudnia uczęszczanie do szkoły. 
Zespoły określają w orzeczeniu zalecaną formę kształcenia specjalnego: w szkole ogólnodostępnej, szkole integracyjnej lub oddziale integracyjnym, szkole specjalnej lub oddziale specjalnym albo w specjalnym ośrodku szkolno-wychowawczym.

\section{Dostęp do podręczników dla uczniów niewidomych i słabowidzq̨cych ${ }^{4}$}

W Polsce kształcenie specjalne jest integralną częścią systemu edukacyjnego, o czym mówi ustawa z 7 września 1991 r. o systemie oświaty (dalej: u.s.o.). Zgodnie $\mathrm{z}$ art. 1 u.s.o. system ten zapewnia w szczególności:

- dostosowanie treści, metod i organizacji nauczania do możliwości psychofizycznych uczniów, a także możliwość korzystania z pomocy psychologiczno-pedagogicznej i specjalnych form pracy dydaktycznej,

- opiekę nad uczniami niepełnosprawnymi przez umożliwianie realizowania zindywidualizowanego procesu kształcenia, form i programów nauczania oraz zajęć rewalidacyjnych. Przepis art. 5 ust. 7 u.s.o. wskazuje natomiast, że organ prowadzący szkołę/placówkę odpowiada za jej działalność. Do jego zadań należy m.in. wyposażenie szkoły/placówki w pomoce dydaktyczne i sprzęt niezbędny do pełnej realizacji programów nauczania, programów wychowawczych, przeprowadzania sprawdzianów i egzaminów oraz wykonywania innych zadań statutowych.

Ministerstwo Edukacji Narodowej, działając na podstawie art. 71d u.s.o., dofinansowuje na szczeblu centralnym podręczniki szkolne i książki pomocnicze przeznaczone dla uczniów niewidomych i niedowidzących. Jednocześnie jednostki samorządu terytorialnego, które prowadzą szkołę/placówkę z uczęszczającymi do niej uczniami niewidomymi lub słabowidzącymi, otrzymują zwiększone środki finansowe w ramach podziału części oświatowej subwencji ogólnej. Zatem odpowiedzialność za zapewnienie uczniom pomocy naukowych dzielona jest między rząd i samorządy.

Od 2009 roku obowiązuje nowy system zapewniania uczniom niewidomym i słabowidzącym dostępu do podręczników szkolnych. Na zlecenie i ze środków MEN wykonywane są adaptacje wskazanych przez szkoły tytułów podręczników szkolnych i książek pomocniczych, dostosowane do potrzeb tych uczniów. Mini-

4 Na podstawie ekspertyzy Biura Analiz Sejmowych nr 74/11 z 27 grudnia 2011 r. J. Osieckiej-Chojnackiej zatytułowanej Informacja na temat liczby dzieci niedowidzacych i niewidomych $w$ systemie edukacyjnym w Polsce oraz zapewnienia im w praktyce dostępu do podręczników i pomocy dydaktycznych. 
sterstwo zawarło umowy z Uniwersytetem Warszawskim i Katolickim Uniwersytetem Lubelskim Jana Pawła II ${ }^{5}$, których przedmiotem jest wykonanie adaptacji podręczników szkolnych i książek pomocniczych dla uczniów niewidomych (w systemie Braille’a) i dla uczniów słabowidzących (w druku powiększonym) oraz, w miarę posiadanych środków, wydrukowanie adaptacji wskazanych przez szkoły. Za realizację zadań wynikających z obsługi umów odpowiada Ośrodek Rozwoju Edukacji (ORE) w Warszawie, który współpracuje z wydawnictwami podręczników szkolnych i książek pomocniczych. Wersje elektroniczne podręczników wykonanych w systemie Braille’a zamieszczane są na stronie internetowej ORE w specjalnie przygotowanym systemie informatycznym, umożliwiającym dyrektorom szkół i placówek bieżące ich pobieranie oraz drukowanie w całości lub części, zgodnie z indywidualnymi potrzebami edukacyjnymi uczniów ${ }^{6}$. Na stronie ORE jest zamieszczonych osiem list podręczników dla niewidomych i słabowidzących - w sumie 201 tytułów (232 podręczniki, gdyż 31 tytułów prezentowanych jest zarówno w Braille’u, jak i powiększonym druku) na około 1200 tytułów zatwierdzonych i dopuszczonych do użytku szkolnego.

Wybór podręczników - do kształcenia ogólnego lub kształcenia specjalnego - należy do nauczyciela. Uczniowie z dysfunkcjami realizują tę samą podstawę programową kształcenia ogólnego, co ich pełnosprawni rówieśnicy, więc nie zawsze zachodzi konieczność przygotowania nowego podręcznika. Można na przykład wykorzystać odpowiednie pomoce optyczne umożliwiające korzystanie z klasycznych podręczników dopuszczonych do powszechnego użytku szkolnego.

\section{Szwecja}

\section{Zarzq̨dzanie oświatq̨ i programy nauczania}

W Szwecji system zarządzania oświatą jest scentralizowany. Całościowo za oświatę odpowiada rząd, który określa ramy kształcenia na wszystkich poziomach edukacyjnych. Nad realizacją ustaw i rozporządzeń czuwa Ministerstwo Edukacji. Za organizację i funkcjonowanie szkół prowadzących kształcenie na poziomie podstawowym i średnim oraz kształcenie dorosłych odpowiadają gminy. Ramowy program nauczania przedstawiający cele kształcenia ustala się na szczeblu krajowym. Na jego podstawie każda gmina zobowiązana jest określić cele i zadania

5 Umowy obowiązują do końca 2012 roku.

6 Podręczniki w alfabecie Braille’a można również wypożyczać drogą elektroniczną w Bibliotece Centralnej Polskiego Związku Niewidomych: brajl@bcpzn.pl. 
dla szkół na swoim obszarze administracyjnym. O wyborze metod nauczania i doborze materiałów dydaktycznych (podręczniki i inne pomoce) samodzielnie decydują nauczyciele. Część zadań, w szczególności związanych z kontrolą i oceną systemu oświaty, realizowana jest przez wyspecjalizowane instytucje, takie jak:

- Szwedzka Narodowa Agencja ds. Edukacji (Skolverket) - zajmuje się monitorowaniem i oceną przedszkoli, szkół i placówek kształcenia dorosłych,

- Inspektorat ds. Szkół (Skolinspektionen) - sprawuje kontrolę i nadzór nad niepublicznymi przedszkolami, szkołami i placówkami kształcenia dorosłych. Odpowiada za przyznawanie licencji na ich prowadzenie,

- Rzecznik Dzieci i Młodzieży Szkolnej (Barn-och elevombudsmannen, BEO) przeciwdziała przestępstwom wobec dzieci i młodzieży.

W obszarze oświaty specjalnej jedną z instytucji wspierających proces organizacji szwedzkiego systemu oświatowego jest Agencja ds. Pedagogiki Specjalnej i Szkół Specjalnych (Specialpedagogiska skolmyndigheten). Agencja odpowiada za koordynację pomocy państwa dla sektora kształcenia specjalnego. Promuje dostęp do materiałów dydaktycznych dla uczniów dysfunkcyjnych, pomaga w tworzeniu i prowadzeniu szkół specjalnych oraz uczestniczy w rozdziale dotacji rządowych dla placówek edukacyjnych.

\section{Organizacja systemu oświaty}

W Szwecji edukacja na wszystkich poziomach kształcenia jest bezpłatna. W ramach szczebla opieki przedszkolnej funkcjonują przedszkola (förskola), rodzinne domy opieki dziennej (familjedaghem) oraz otwarte przedszkola (öppen förskola). Gminy są zobowiązane do zorganizowania zajęć przedszkolnych dla dzieci w wieku od 1 roku do 5 lat, których rodzice uczą się lub pracują. Wszystkie dzieci w wieku od 4 do 5 lat, a także te, których rodzice są bezrobotni lub przebywają na urlopie rodzicielskim, opiekując się drugim dzieckiem, mają prawo uczestniczyć w bezpłatnych zajęciach przedszkolnych przez co najmniej 3 godziny dziennie lub 15 godzin tygodniowo. Zajęcia finansuje się z budżetu gminy i opłat pobieranych od rodziców. Opłaty pobierane od rodziców są uzależnione od liczby dzieci w danej rodzinie.

Obowiązek szkolny trwa w Szwecji 9 lat i objęci są nim uczniowie w wieku od 7 do 16 roku życia, choć prawo szkolne dopuszcza możliwość wcześniejszego rozpoczęcia nauki przez sześciolatków 7 .

7 D. Dziewulak, Obowiązek szkolny w Unii Europejskiej, „Analizy BAS” 2010, nr 9(34), http:// orka.sejm.gov.pl/WydBAS.nsf/0/A4F8763AAD6E8E70C12576EE0029DFE9/\$file/Analiza_\%20 BAS_2009_34.pdf. 
Pierwszym szczeblem obowiązkowej edukacji jest Grundskola (szkoła podstawowa i średnia I stopnia) przeznaczona dla uczniów w wieku 7-16 lat. Drugi szczebel szkolnictwa przeznaczony dla uczniów w wieku 16-19 lat to Gymnasieskola (szkoła średnia II stopnia). Szwedzką specyfiką szkolnictwa średniego II stopnia jest kształcenie w ramach 17 ogólnych lub profilowanych programów. Spośród 17 programów kształcenia, 14 ma charakter zawodowy. Wszystkie ogólnokształcące programy kształcenia, jak również programy profilowane, zapewniają wykształcenie ogólne. Ukończenie Gymnasieskola uprawnia do ubiegania się o przyjęcie na studia.

\section{Kształcenie uczniów z dysfunkcjami}

Uczniowie z niepełnosprawnością fizyczną uczęszczają na ogół do ogólnodostępnych szkół publicznych. Na poziomie szkoły podstawowej i średniej ok. 2\% uczniów uczęszcza do szkół innych niż ogólnodostępne, tj. wyodrębnionych szkół dla dzieci z upośledzeniem umysłowym (särskolan) lub szkół specjalnych (specialskolan). Kształcenie na poziomie podstawowym i średnim możliwe jest również w specjalnych szkołach dla dzieci z upośledzeniem wzroku, słuchu i innymi wrodzonymi niepełnosprawnościami sprzężonymi lub poważnym upośledzeniem mowy. Należy podkreślić, że jednak większość dzieci z tego typu niepełnosprawnościami uczęszcza do ogólnodostępnych szkół publicznych.

Według obowiązującego prawa uczelnie wyższe zobowiązane są do aktywnego popierania równych praw studentów i kandydatów niezależnie od płci, pochodzenia etnicznego, orientacji seksualnej i stopnia niepełnosprawności.

\section{Dostęp do podręczników dla uczniów niewidomych i stabowidzqcych}

Jedną z podstawowych zasad polityki oświatowej Szwecji jest zasada bezpłatności, co oznacza, że rodzice nie ponoszą bezpośrednich obciążeń finansowych z tytułu pobierania nauki przez ich dzieci. Zatem pomoce dydaktyczne, a wśród nich także podręczniki, kupowane są bezpośrednio przez szkołę i rodzice nie ponoszą żadnych bezpośrednich kosztów z tym związanych. Dotyczy to zarówno podręczników w tzw. czarnodruku (a więc „zwykłych” podręczników), jak i podręczników w alfabecie Braille’a oraz e-booków dla dzieci niedowidzących. Szkoły najczęściej zamawiają podręczniki w formacie Braille’a, e-booków (format textview 
lub HTML) lub DAISY (standard książek elektronicznych) ${ }^{8}$ Należy przypomnieć, że od wielu lat w Szwecji nie stosuje się podręczników drukowanych czcionką powiększoną. Mimo że produkcja podręczników w alfabecie Braille’a i e-booków jest droższa, szkoły płacą taką samą cenę jak za „zwykły” podręcznik, niezależnie od tego, w jakim formacie są one wydrukowane.

Podmiotem odpowiedzialnym za wykonywanie adaptacji materiałów dydaktycznych dla uczniów niepełnosprawnych, w tym uczniów niewidomych i słabowidzących, realizujących obowiązkową edukację w szkołach podstawowych i średnich, jest Agencja ds. Pedagogiki Specjalnej i Szkół Specjalnych (Specialpedagogiska skolmyndigheten, SPSM). Agencja jest instytucją rządową nadzorowaną przez Ministerstwo Edukacji. Jednym z celów SPSM jest współpraca i koordynacja między podmiotami prywatnymi w Szwecji i za granicą w celu produkcji podręczników.

W szkolnictwie wyższym studenci niewidzący lub niedowidzący mogą bezpłatnie korzystać z podręczników zgromadzonych w szwedzkiej bibliotece książek mówionych oraz książek Braille’a (Talboks-och punktskriftsbiblioteket, TPB). Podobnie w bezpłatnej formie dystrybuowane są arkusze egzaminacyjne i formularze okresowych sprawdzianów dostosowane do dysfunkcji studentów.

\section{Wielka Brytania (Anglia, Walia, Szkocja, Irlandia Północna)}

\section{Zarzq̨dzanie oświatq i programy nauczania}

Struktura organizacyjna systemu edukacji w Wielkiej Brytanii nie jest jednolita, gdyż systemy szkolne Anglii, Walii, Szkocji i Irlandii Północnej regulowane są odrębnymi ustawami i decyzjami władz lokalnych. Występują w nich odmienne typy szkół i różne programy nauczania wynikające z uwarunkowań historycznych krajów Zjednoczonego Królestwa. W konsekwencji administracja szkolna jest zdecentralizowana, a zarządzanie i odpowiedzialność za kształt i funkcjonowanie oświaty rozłożone pomiędzy organy administracji centralnej i lokalnej.

8 Książki przygotowane w standardzie DAISY można czytać za pomocą aplikacji instalowanych na komputerze lub specjalnych urządzeń. Używając klawiszy nawigacyjnych, czytelnik może odnajdywać interesujące go fragmenty książki, słuchać ich treści lub czytać na ekranie monitora. Wyświetlany tekst można dostosować do potrzeb użytkownika przez zmianę wielkości i kroju czcionek, koloru tła i tekstu, natomiast w przypadku nagrania można regulować prędkość odtwarzania i wysokość głosu. 
W Anglii i Walii instytucją odpowiedzialną za organizację oświaty jest Ministerstwo ds. Dzieci, Edukacji, Kształcenia Ustawicznego i Umiejętności (Department for Children, Education, Lifelong Learning and Skills, DCELLS). W Anglii dodatkowo za oświatę odpowiada Ministerstwo ds. Biznesu, Innowacji i Umiejętności (Department for Business, Innovation and Skills, BIS). W Irlandii Północnej za centralne administrowanie systemem kształcenia podstawowego i średniego odpowiada Ministerstwo Edukacji (Department of Education, DE), a za szkolnictwo wyższe - Ministerstwo Zatrudnienia i Kształcenia (Department for Employment and Learning, DEL). W Szkocji za ogólny nadzór nad edukacją i rozwojem usług edukacyjnych odpowiada Pierwszy Minister ds. Szkocji (First Minister of Scotland). W jego imieniu obowiązki te wykonuje Sekretarz Stanu ds. Edukacji i Kształcenia Ustawicznego (Secretary for Education and Lifelong Learning). Wspieraniem tworzenia i realizacji polityki oświatowej Szkocji zajmują się Inspektorat ds. Edukacji (Her Majesty's Inspectorate of Education, HMIE) oraz instytucje odpowiedzialne za opracowywanie programów nauczania, przeprowadzanie egzaminów i finansowanie szkockich placówek edukacyjnych - Szkockie Biuro ds. Uczenia się i Nauczania (Learning \& Teaching Scotland), Szkocki Urząd ds. Kwalifikacji (Scottish Qualifications Authority), Szkocka Rada ds. Wsparcia Finansowego Oświaty (Scottish Funding Council, SFC).

W Anglii, Walii i Irlandii Północnej programy nauczania opracowywane są samodzielnie przez szkoły w sposób odzwierciedlający specyfikę ich potrzeb i warunków działania. Placówki zobowiązane są zadbać o to, by program był odpowiednio zrównoważony i zgodny z ogólnymi wytycznymi. W ministerialnych przepisach ustalono specjalne wymogi dotyczące nauczania określonych przedmiotów. W Szkocji programy nauczania bazują na wskazówkach i wytycznych szkockich władz oświatowych. Wytyczne publikowane są w dokumentach programowych, które koncentrują się jedynie na dwóch przedmiotach: edukacja religijna wraz z praktykami religijnymi oraz język celtycki. Zakres pozostałych przedmiotów pozostaje w gestii szkoły. Nauczyciele mają pełną swobodę wyboru podręczników i pomocy naukowych.

\section{Organizacja systemu oświaty}

W Anglii, Walii i Szkocji obowiązek szkolny trwa 11 lat - rozpoczyna się w wieku 5 lat i kończy w 16 roku życia. W Irlandii Północnej obowiązek szkolny trwa 12 lat od 4 do 16 roku życia. 
Edukacja przedszkolna realizowana jest w Wielkiej Brytanii przez władze lokalne oraz ich społecznych i prywatnych partnerów. W Anglii, Walii i Szkocji wszystkie trzylatki i czterolatki mogą uczęszczać bezpłatnie na zajęcia przedszkolne w niepełnym wymiarze, a w Irlandii Północnej możliwość ta dotyczy wszystkich dzieci na rok przed rozpoczęciem nauki w szkole (powyżej 3 roku życia).

Pierwszym szczeblem obowiązkowej edukacji jest primary school (szkoła podstawowa), przeznaczona dla uczniów w wieku 5-11 lat (Anglia, Walia, Szkocja) oraz 4-11 lat (Irlandia Północna). Drugi szczebel szkolnictwa obowiązkowego we wszystkich historycznych częściach Wielkiej Brytanii, przeznaczony dla uczniów w wieku 11-16 lat, to secondary school (szkoła średnia I stopnia). Na poziomie szkolnictwa średniego II stopnia i szkolnictwa policealnego przeznaczonego dla młodzieży w wieku od 16 do 18 lat (i więcej) system edukacyjny proponuje zróżnicowane rozwiązania. W Anglii, Walii i Irlandii Północnej szkoła średnia II stopnia dzieli się na secondary school i further education (kształcenie na poziomie poniżej szkolnictwa wyższego dla osób, które przekroczyły wiek obowiązkowej nauki). Na poziomie szkoły średniej II stopnia wyróżniamy następujące typy placówek:

- sixth form college (kształcenie ogólne uzupełnione zawodowym) - Anglia,

- further education college (kształcenie zawodowe uzupełnione ogólnokształcącym) - Anglia, Walia i Irlandia Północna,

- tertiary college (kształcenie ogólne i zawodowe) - Anglia i Walia.

W Szkocji szkoła średnia II stopnia dzieli się na secondary school (ogólnokształcąca szkoła średnia) i further education college (kształcenie średnie i policealne ogólnokształcące i zawodowe).

\section{Kształcenie uczniów z dysfunkcjami}

W Anglii, Walii i Irlandii Północnej generalną tendencją w edukacji uczniów z dysfunkcjami jest integracyjne kształcenie dzieci ze specjalnymi potrzebami edukacyjnymi (Special Educational Needs, SEN) z ich rówieśnikami w szkołach ogólnodostępnych. Zasada integracji stosowana w procesie edukacyjnym jest konsekwencją powszechnie wdrażanej koncepcji nauczania zorientowanego na ucznia z jednoczesną tendencją rezygnacji z tworzenia oddzielnych struktur SEN. Jeżeli uczeń wymaga pomocy w szerszym i bardziej specjalistycznym zakresie, niż szkoła jest mu w stanie zapewnić w ramach dostępnych środków, to władze lokalne są zobowiązane wydać orzeczenie o specjalnych potrzebach eduka- 
cyjnych, w którym przedstawia się szczegółowo potrzeby i zakres zastosowania niezbędnego dodatkowego kształcenia. Orzeczenie takie staje się podstawą do poszukiwania alternatywnych rozwiązań dotyczących form edukacji niepełnosprawnego ucznia.

Angielska i walijska ustawa o specjalnych potrzebach edukacyjnych i niepelnosprawności z 2001 r. (Special Educational Needs and Disabilities Act 2001) ${ }^{9}$ oraz rozporządzenie o specjalnych potrzebach edukacyjnych i niepełnosprawności (Special Educational Needs and Disabilities Order 2005) ${ }^{10} \mathrm{w}$ Irlandii Północnej zwiększyły prawa uczniów ze specjalnymi potrzebami edukacyjnymi w zakresie pobierania nauki w ogólnodostępnym szkolnictwie publicznym. Regulacje te nakładają na placówki edukacyjne obowiązek stworzenia odpowiednich warunków do kształcenia niepełnosprawnych uczniów i studentów.

W Szkocji dzieci mające specjalne potrzeby edukacyjne lub wymagające dodatkowej pomocy kształcą się, w miarę możliwości, w szkołach ogólnodostępnych. Uczniowie niepełnosprawni wymagający szczególnego wsparcia, mogą skorzystać z wielu form kształcenia, m.in. szkół dziennych lub szkół/oddziałów specjalnych z internatem lub klas specjalnych. Decyzje dotyczące rodzaju kształcenia specjalnego, jakie należy zapewnić uczniom w szkołach na danym terenie, podejmują władze lokalne, a koordynacja tego typu kształcenia jest prowadzona przez nauczycieli specjalistów z zakresu pedagogiki specjalnej. W Szkocji ok. 99\% uczniów o specjalnych potrzebach edukacyjnych kształci się w szkołach ogólnodostępnych.

\section{Dostęp do podręczników dla uczniów niewidomych i słabowidzq̨cych}

\section{Anglia}

W systemie edukacyjnym Anglii zapewnienie swobodnego dostępu do podręczników dla uczniów niewidomych i niedowidzących oraz całkowite pokrycie kosztów pomocy szkolnych przez placówki edukacyjne wynika z realizacji zasady bezpłatności szkolnictwa. Rodzice nie ponoszą zatem kosztów podręczników, także wówczas, gdy są one wykonane w druku powiększonym lub w alfabecie Braille’a. Organy prowadzące szkoły, jak i same szkoły, mają obowiązek zapewnienia realizacji wszystkich innych specjalnych potrzeb edukacyjnych uczniów, w tym podręczników w alfabecie Braille’a lub w druku powiększonym, jeśli tylko

9 http://www.legislation.gov.uk//ukpga/2001/10/contents.

10 http://www.legislation.gov.uk/nisi/2005/1117/contents/made. 
uczeń ich potrzebuje. Zagadnienie to regulowane jest zgodnie z przepisami The Equality Act $2010^{11}$ (ustawa o równości z 2010 r.). Na jej podstawie szkoły i organy prowadzące placówki edukacyjne zobowiązane są do wprowadzania tzw. racjonalnych dostosowań (reasonable adjustments), które mają zapobiegać dyskryminacji uczniów niepełnosprawnych. Najczęściej dotyczy to niwelowania barier, np. architektonicznych, lub wprowadzania dodatkowych elementów wyposażenia ułatwiającego pobyt ucznia z dysfunkcjami w placówce. Pobyt w placówce edukacyjnej mogą także ułatwić odpowiednio dostosowane pomoce dydaktyczne, do których zalicza się oczywiście specjalne podręczniki szkolne wykonane w druku powiększonym lub w alfabecie Braille’a. Zgodnie z ustawą o równości kosztami związanymi z wprowadzaniem reasonable adjustments nie mogą być obciążani rodzice.

Instytucją pełniącą ważną funkcję niesienia pomocy niewidomym i osobom z problemami widzenia jest Królewski Narodowy Instytut Osób Niewidomych (The Royal National Insitute for Blind People, RNIB) ${ }^{12}$. Wśród wielu inicjatyw na rzecz osób niewidomych, niedowidzących i dyslektycznych Instytut realizuje w latach 2010-2012 projekt stworzenia elektronicznego księgozbioru podręczników szkolnych oraz lektur i innych tekstów szkolnych. Wersje elektroniczne mają być dostępne w różnych formatach, w tym także jako pliki dźwiękowe. Założono również, że efektem tego dwuletniego projektu będzie przeszkolenie personelu szkół średnich I stopnia (secondary schools) w zakresie wykorzystania elektronicznych zasobów bibliotecznych oraz przygotowanie organizacji charytatywnych do świadczenia pomocy dydaktycznej szkołom w całej Anglii. Wysokość środków zaangażowanych w projekt to 1,3 mln funtów.

\section{Szkocja}

W Szkocji dzieci niewidome i niedowidzące zalicza się do szerszej grupy uczniów określonej jako print disability (co można tłumaczyć jako niepełnosprawność w zakresie czytania tekstu drukowanego). Do tej grupy zalicza się także dzieci z dysleksją oraz niepełnosprawnością ruchową uniemożliwiającą trzymanie książki lub odwracanie kartek w czasie czytania. Wysiłki szkockiego rządu ukierunkowane są na działania zapewniające dzieciom z wyżej wymienionymi dysfunkcjami dostęp do takiego samego materiału programowego i w tym samym

11 http://www.legislation.gov.uk/ukpga/2010/15/contents.

12 http://www.rnib.org.uk. 
czasie, w którym korzystają z nich ich pełnosprawni rówieśnicy. Idea ta realizowana jest przez projekt nazwany „Książki dla wszystkich” (Books for All) ${ }^{13}$. Baza projektu umożliwia wyszukiwanie i pobieranie książek oraz innych materiałów pomocniczych w formatach przystosowanych dla potrzeb uczniów niepełnosprawnych. Zasoby bazy danych są udostępniane na zasadach i warunkach drukowania określonych w Licencji Niepełnosprawności - CLA (Print Disability License $)^{14}$. System Books for All działa kompatybilnie z innymi dostępnymi programami (np. ePub3 w standardzie DAISY).

W Szkocji większość uczniów niewidomych uczy się w szkołach ogólnodostępnych, a ich edukacja jest wspierana przez nauczycieli wykwalifikowanych w zakresie tyflopedagogiki ${ }^{15}$. W każdym podmiocie administracyjnym prowadzącym szkołę jest jeden lub kilku wyspecjalizowanych w tej dziedzinie nauczycieli. Do ich obowiązków należy wspieranie placówek szkolnych w dostosowaniu programów nauczania do potrzeb uczniów niewidomych i niedowidzących. Najtrudniejszym sygnalizowanym przez nauczycieli problemem jest umożliwienie uczniowi niewidomemu dostępu do materiałów dydaktycznych w odpowiednim formacie podczas trwania lekcji. Przez ostatnie lata wszystkie podręczniki drukowane były w alfabecie Braille’a na indywidualne zapotrzebowanie konkretnego ucznia, stąd też ten sam podręcznik był często wielokrotnie tłumaczony dla wielu nauczycieli w różnych szkołach. Generowało to niepotrzebne koszty i wydłużało czas dostępu do podręcznika. Wśród powodów takiego stanu rzeczy wskazuje się:

- niezrozumienie przepisów prawa autorskiego - nikt nie był świadomy istniejącego w przepisach prawa autorskiego wyjątku dotyczącego możliwości otrzymania specjalnej licencji do wersji w formacie dostosowanym do potrzeb osoby niepełnosprawnej i w związku z tym nikt się o taką licencję nie ubiegał,

- brak systemu umożliwiającego sprawdzanie, czy istnieje już wersja danego materiału w dostosowanym formacie,

- brak bazy informacyjnej zapewniającej dostęp do dostosowanych wersji podręczników,

- wyraźny brak doświadczenia w tworzeniu dostosowanych wersji w sposób zapewniający ich wysoką jakość,

- brak zrozumienia tego, że na różnych etapach przygotowania dostosowanej wersji podręcznika, ale wciąż przed jej ostatecznym zakończeniem, istnie-

13 http://www.books4all.org.uk.

14 http://www.cla.co.uk/data/pdfs/print_disability/print_disability_licence.pdf.

15 Tyflopedagogika (z gr. typhlos - niewidomy) - dział pedagogiki specjalnej zajmujący się wychowaniem, edukacją, terapią i rehabilitacją osób niewidomych i niedowidzących. 
ją możliwości obniżenia kosztów produkcji różnych wersji, dostosowanych do potrzeb różnych odbiorców, co pozwala na znaczne całościowe obniżenie kosztów wykonania adaptacji, a tym samym podniesienie efektywności podejmowanych działań,

- potrzebę znowelizowania przepisów prawa autorskiego, tak by dotyczyło nie tylko uczniów niewidomych i niedowidzących, ale również uczniów z niepełnosprawnością ruchową, którzy nie mogą utrzymać książki lub odwracać stron w podręcznikach, jak również takich, u których występujące dysfunkcje (np. dysleksja) utrudniają korzystanie z materiałów drukowanych dostępnych na rynku.

Powyższe problemy zgłaszane przez Szkockie Centrum CALL (Communication, Access, Literacy and Learning Scotland Centre), działające przy Uniwersytecie $\mathrm{w}$ Edynburgu, jak również sygnalizowane przez instytucje prowadzące szkoły, skłoniły szkocki rząd w 2008 roku do zapewnienia uczniom materiałów edukacyjnych $\mathrm{w}$ formacie dostosowanym do rodzaju dysfunkcji, tak aby dostęp do pomocy dydaktycznych na lekcji był możliwy w tym samym czasie, w jakim korzystają z nich pozostali, pełnosprawni uczniowie. W konsekwencji stworzono system zawierający bazę danych o dostępnych tekstowych adaptacjach umożliwiającą wyszukiwanie potrzebnego materiału w odpowiednim formacie. Baza daje możliwość pobrania pliku bezpośrednio na pulpit ucznia lub skontaktowania się z autorem adaptacji. Takie rozwiązanie umożliwia błyskawiczne przesłanie uczniowi woluminów wydrukowanych w alfabecie Braille’a. Dostęp do bazy wymaga użycia hasła, które szkoccy nauczyciele mogą otrzymać przez działający w niemal każdej szkole intranet Glow. Dla zapewnienia wysokiej jakości adaptacji, materiały w bazie mogą być umieszczane tylko przez wybranych autorów. Jednocześnie zapewniono możliwość skorzystania z materiałów szkoleniowych (dostępnych również w plikach wideo). W bazie adaptacji umieszczono wiele pozycji w różnych formatach i pochodzących z różnych źródeł, np. Young Calibre ${ }^{16}$ (organizacja charytatywna zapewniająca bezpłatny dostęp do audiobooków dla dzieci i młodzieży poniżej 16 roku życia z różnymi rodzajami dysfunkcji, które uniemożliwiają korzystanie z materiałów drukowanych), Audible ${ }^{17}$, Seeing Ear ${ }^{18}$ (instytucje ułatwiające osobom niewidzącym dostęp do książek i różnych publikacji drukowanych).

16 http://www.calibre.org.uk.

17 http://www.audible.co.uk.

18 http://www.seeingear.org.uk. 


\section{Irlandia Północna}

W Irlandii Północnej działa pięć regionalnych Komisji Edukacji i Bibliotek (Education and Library Board, ELB) ${ }^{19}$, powołanych w 1973 roku. Są to:

- The Belfast Education and Library Board, BELB,

- The Southern Education and Library Board, SELB,

- The Western Education and Library Board, WELB,

- The Southeastern Education and Library Board, SEELB,

- The North Eastern Education and Library Board, NEELB.

Komisje zapewniają realizację usług bibliotecznych i edukacyjnych w zakresie powszechnej edukacji, kształcenia muzycznego, specjalnego oraz pomocy psychologicznej. Komisje ELB zapewniają żłobkom, przedszkolom, ogólnodostępnym szkołom podstawowym i średnim wsparcie metodyczne nauczycieli posiadających kwalifikacje z zakresu pracy z uczniami niewidomymi i niedowidzącymi. Nauczyciele specjaliści pomagają dostosować program oraz środowisko nauczania do potrzeb ucznia, z wykorzystaniem technologii wspomagających, specjalnych podręczników i specjalnych pomocy dydaktycznych. Zakres wsparcia udzielanego szkole zależy od potrzeb danego ucznia. Może być to porada i jednorazowa wizyta monitorująca lub systematyczna opieka w formie cotygodniowych konsultacji połączonych z rozwijaniem umiejętności pracy z uczniem dysfunkcyjnym.

Działania komisji ELB w zakresie zapewnienia uczniom niewidomym i słabowidzacym odpowiednich warunków kształcenia i wychowania, wspiera Królewski Narodowy Instytut Niewidomych oraz organizacja pozarządowa Angels Eyes, która zrzesza między innymi rodziców dzieci niewidomych. Od niedawna działa również, należąca do BELB, Regionalna Baza Zasobów Widzenia w Fortwilliam (Regional Vision Resource Base), z której korzystać mogą szkoły i osoby z dysfunkcją wzroku.

W celu realizacji potrzeb rozwojowych i edukacyjnych uczniów ze specjalnymi potrzebami edukacyjnymi, w tym niewidomych i niedowidzących, szkoły w Irlandii Północnej wprowadziły funkcje koordynatorów ds. specjalnych potrzeb edukacyjnych (special needs co-ordinators) oraz stanowiska asystentów nauczyciela (classroom assistant), którzy m.in. wspierają nauczycieli przedmiotów w przygotowaniu materiałów dydaktycznych dla potrzeb uczniów z dysfunkcją wzroku.

19 http://www.deni.gov.uk. 


\section{Zakończenie}

Edukacja dzieci niewidomych i słabowidzących w Europie i na świecie - w tym w Polsce, Szwecji i Wielkiej Brytanii - bazuje na podobnych wieloletnich doświadczeniach w pracy z uczniami dysfunkcyjnymi. Próby zmierzające do stworzenia narzędzi umożliwiających nauczanie bez udziału wzroku podejmowane były w Europie i na świecie już od dawna. Okresem cywilizacji szczególnie bogatym w poszukiwania sposobu korzystania z pisma przez osoby niewidome był XVI wiek, w którym uczeni proponowali grawerowanie liter na różnych materiałach, tak aby można je było rozpoznać dotykiem. W czasach późniejszych proponowano odlewanie liter z ołowiu, czy wykonywanie ich z drutu. Pierwsza w świecie szkoła dla niewidomych powstała w Paryżu w 1784 roku, a w 1786 roku ukazał się Podręcznik o wychowaniu dzieci niewidomych, który wydrukowano wypukłymi, powiększonymi literami alfabetu łacińskiego. W 1829 roku Francuz Ludwik Braille ogłosił zasady swojego systemu pisma punktowego (pismo Braille’a), które do dzisiaj na całym świecie jest powszechnie stosowane w edukacji osób z dysfunkcją wzroku. Także w Polsce oświata od XIX wieku aktywnie działała na polu edukacji osób z dysfunkcjami widzenia. W 1817 roku Komisja Oświecenia Publicznego Królestwa Polskiego wydała ustawę o urządzeniu Instytutu Głuchoniemych w Warszawie. Na jej mocy, wysiłkiem Jakuba Falkowskiego, został utworzony zakład kształcący dzieci niesłyszące, a od 1842 roku zaczęto do placówki przyjmować także dzieci z dysfunkcjami wzroku, określane w tym okresie ogólnym mianem „ociemniałe”. Od tego czasu w Polsce i Europie wiele zmieniło się w podejściu do kształcenia osób z dysfunkcjami widzenia. Oprócz zmian kulturowych i związanych z wrażliwością społeczną coraz częściej osoby niewidome i słabowidzące mają możliwość skorzystania z nowoczesnych, specjalnych pomocy ułatwiających uczestnictwo w procesie nauczania-uczenia się. Miejmy nadzieję, że komputer, screen reader (umożliwiający rozpoznawanie zawartości monitora), syntezator mowy (umożliwiający dźwiękowe odczytywanie zawartości wyświetlanej na ekranie komputera), monitor brajlowski zwany linijką brajlowską (przystawka umożliwiająca odczytywanie w alfabecie Braille’a zawartości ekranu komputera), skaner umożliwiający przekształcanie drukowanych tekstów z wersji graficznej na tekstową, czy mechaniczne brajlowskie maszyny do pisania będą w codziennej rzeczywistości szkolnej tylko jednymi z wielu powszechnie stosowanymi pomocami dydaktycznymi. 


\section{Bibliografia}

Dziewulak D., Dostęp do podręczników dla dzieci niewidomych i stabowidzących w Polsce, Szwecji i Wielkiej Brytanii, „Analizy Bas” 2012, nr 8(75).

Dziewulak D., Obowiązek szkolny w Unii Europejskiej, „Analizy BAS” 2010, nr 9(34), Warszawa 2010.

\section{Akty prawne}

Ustawa o równości, Equality Act 2010, http://www.legislation.gov.uk/ukpga/2010/15/contens.

Ustawa o specjalnych potrzebach edukacyjnych i niepełnosprawności z 2001 r., Special Educional Needs and Disabilities Act 2001, http://egislation.gov.uk/ukpga/2001/contens.

Ustawa z 7 września 1991 r. o systemie oświaty, Dz.U. nr 95, poz. 425.

\section{Strony internetowe}

www.european-agency.org.

http://www.legislation.gov.uk/nisi/2005/1117/contents/made.

http://www.rnib.org.uk.

http://www.cla.co.uk/data/pdfs/print_disability/print_disability_licence.pdf.

http://www.calibre.org.uk.

http://www.audible.co.uk.

http://www.seeingear.org.uk.

http://www.deni.gov.uk. 


\title{
4.6. Finansowanie zakupu podręczników szkolnych w wybranych państwach europejskich
}

\author{
Funding the purchase of school textbooks in selected \\ European countries
}

\begin{abstract}
W opracowaniu przedstawiono problematykę finansowania zakupu podręczników szkolnych w wybranych państwach europejskich. Zaprezentowano podstawowe definicje i pojęcia z obszaru tytułowego zagadnienia. Przedstawiono syntetyczną informację na temat źródeł finansowania oraz mechanizmów udostępniania podręczników uczniom w szkolnictwie obowiązkowym w systemach szkolnych następujących państw: Polski, Belgii, Chorwacji, Cypru, Czech, Finlandii, Grecji, Hiszpanii, Holandii, Islandii, Niemiec, Wielkiej Brytanii, Włoch.
\end{abstract}

Słowa kluczowe: bezpłatny podręcznik, uczeń, szkoła, oświata

This paper addresses the issue of funding the purchase of school textbooks in selected European countries. The author examines basic definitions and concepts relating to the above mentioned issue. He provides brief information about the sources of funding and how they are made available to students in obligatory education in the following countries: Poland, Belgium, Croatia, Cyprus, Czech Republic, Finland, Germany, Greece, Island, Italy, the Netherlands, Spain and the United Kingdom.

Keywords: free textbook, student, school, education

\section{Podstawowe pojęcia}

Pojęcie podręcznika występuje często w literaturze pedagogicznej, a zwłaszcza metodycznej, trudno jednak znaleźć jedną uniwersalną definicję tego określeniaํ. Wynika to z faktu, że w praktyce dydaktycznej mamy do czynienia z różnymi odmianami podręcznika dla ucznia, studenta, kursanta, słuchacza, prakty-

1 Opracowanie przygotowano na podstawie ekspertyzy Biura Analiz Sejmowych nr 277/14 z 21 lutego 2014 r. D. Dziewulaka, Informacja na temat finansowania zakupu podręczników szkolnych $w$ wybranych państwach $z$ uwzględnieniem wsparcia finansowego dla rodzin wielodzietnych (Belgia, Chorwacja, Cypr, Czechy, Finlandia, Grecja, Hiszpania, Holandia, Islandia, Niemcy, Słowacja, Wielka Brytania, Włochy) oraz tegoż autora Finansowanie zakupu podręczników szkolnych w wybranych państwach, „Analizy BAS” 2014, nr 4(108), s. 1-6. 
kanta itp., czyli książką dla odbiorcy o różnych potrzebach i oczekiwaniach, a nie z podręcznikiem w ogóle. Według Słownika języka polskiego podręcznik to książka zawierająca zbiór podstawowych wiadomości z zakresu jakiejś nauki². W Encyklopedii Popularnej PWN podręcznik zdefiniowano jako książkę przeznaczoną do celów dydaktycznych, mającą charakter wykładu systematyzującego wiadomości z danej dziedziny wiedzy w zakresie dostosowanym do programu i na poziomie przygotowania odbiorcy. Podręcznikiem może być także zbiór tekstów dobranych metodycznie ${ }^{3}$. Natomiast w Encyklopedii pedagogicznej XXI wieku wśród wielu definicji, przyjmuje się, że podręcznik jest to specyficzna kategoria książki przeznaczona do celów edukacyjnych, zawierająca dokładnie określony przez program nauczania zakres i poziom treści kształcenia, spełniająca zgodne $\mathrm{z}$ wyznaczonymi funkcjami wymagania pedagogiczne, językowe i graficzne ${ }^{4}$. W Wikipedii zaś podręcznik szkolny definiowany jest jako książka przeznaczona dla ucznia, w której zawarty jest materiał nauczania, przedstawiony za pomocą tekstów, ilustracji i schematów.

Dla potrzeb niniejszego opracowania podręcznik rozumiany będzie jako książka przeznaczona dla celów edukacyjnych, zgodna z obowiązującym szkolnym programem nauczania.

\section{Opłaty za podręczniki w wybranych krajach ${ }^{5}$}

\section{Polska}

W ustawie o systemie oświaty pojęcie podręcznika nie zostało zdefiniowane. Definicję podręcznika można wywieść z rozporządzenia Ministra Edukacji Narodowej z 21 czerwca 2012 r. w sprawie dopuszczania do użytku w szkole programów wychowania przedszkolnego i programów nauczania oraz dopuszczania do użytku szkolnego podręczników (Dz.U. poz. 752)6. Wynika z niej, że podręcznik to publikacja, która zawiera usystematyzowaną prezentację wszystkich treści naucza-

2 Słownik języka polskiego, Wydawnictwo Naukowe PWN, Warszawa 2006, s. 677.

3 Encyklopedia Popularna PWN, Wydawnictwo Naukowe PWN, Warszawa 2010, s. 791.

4 Encyklopedia pedagogiczna XXI wieku, t. IV, Wydawnictwo Akademickie „Żak”, Warszawa 2005, s. 462.

5 Wykorzystano materiał Eurydice - Podręczniki szkolne w Europie, publikacja, zatwierdzanie i finansowanie, opracowanie Ministerstwa Edukacji Narodowej RP oraz informacje dostępne na stronach internetowych instytucji i organizacji zajmujących się zagadnieniem kształcenia w państwach europejskich.

6 http://isap.sejm.gov.pl/DetailsServlet?id=WDU20120000752. 
nia z zakresu danych zajęć edukacyjnych na danym etapie edukacyjnym, ujętych w podstawie programowej kształcenia ogólnego ( 6 ust. 1 ww. rozporządzenia) ${ }^{7}$.

W Polsce całkowite koszty zakupu podręczników szkolnych na wszystkich poziomach nauczania ponoszą rodzice. Mając świadomość tych dużych obciążeń, wprowadzono ustawowy zapis zawarty w art. 22b ustawy o systemie oświaty (u.s.o), że dyrektor szkoły jest obowiązany podejmować działania organizacyjne umożliwiające obrót używanymi podręcznikami na terenie szkoły. Jednocześnie dla potrzeb najuboższych rodzin funkcjonuje od lat system dotowania podręczników. W 2002 roku wprowadzono program „Wyprawka szkolna” umożliwiający częściową refundację kosztów podręczników szkolnych, głównie na podstawie kryteriów dochodowych ${ }^{8}$. W pierwszych latach funkcjonowania programu stosowne rozporządzenia Rady Ministrów wydawano na podstawie ustawy o pomocy społecznej. Od 2005 roku stosowany jest art. 90u ust. 4 u.s.o. (rozdz. 8a: Pomoc materialna dla uczniów) ${ }^{9}$. Środki przeznaczane na program „Wyprawka szkolna” systematycznie rosły, ale gwałtowny wzrost nastąpił po wprowadzeniu reformy programowej i był związany z przewidywanym wzrostem cen podręczników (całkiem nowa oferta i brak rynku wtórnego). Z informacji zamieszczonej na stronie Ministerstwa Edukacji Narodowej w 2008 roku na program „Wyprawka szkolna” przeznaczono $50 \mathrm{mln}$ zł, ale w następnych latach było to: w 2009 roku 104 mln zł, w 2010 roku - 103 mln zł, w 2011 roku - 115 mln zł, w 2012 roku $128 \mathrm{mln}$ zł, w 2013 roku - blisko $180 \mathrm{mln}$ zł.

\section{Belgia (Wspólnota Francuska)}

W Belgii francuskojęzycznej publikowaniem podręczników zajmują się prywatne wydawnictwa i to na zasadach komercyjnych. Jedynie materiały udostępniane przez Ministerstwo Edukacji w formie elektronicznej (internetowej) finansowane są z budżetu państwa. Nie istnieje lista obowiązujących podręczników. Szkoła ma swobodę wyboru najlepszych jej zdaniem tytułów, lecz muszą one być zgodne z podstawą programową. Z uwagi na bogatą ofertę alternatywnych podręczników, decydując się na zakup podręcznika zgodnego z podstawą programową, szkoła uzyskuje zazwyczaj od państwa zwrot kosztów. W placówkach publicznych podręczniki przekazywane są uczniom za darmo, natomiast w szkołach

7 Opinia merytoryczna do rządowego projektu ustawy o zmianie ustawy o systemie oświaty (druk 2075), ekspertyza Biura Analiz Sejmowych nr 167/14 z 3 lutego 2014 r.

8 https://www.men.gov.pl/index.php/wyprawka-szkolna/155-wyprawka-szkolna-2013.

9 http://www.prawo.vulcan.edu.pl/przegdok.asp?qdatprz=akt\&qplikid=1. 
niepublicznych dofinansowanych ze środków publicznych rodzice zobowiązani są zaopatrzyć dzieci w materiały edukacyjne na własny koszt (istnieje również możliwość nabycia używanych podręczników).

\section{Chorwacja}

W Chorwacji obowiązek finansowania podręczników rozdzielony jest między rodziców i szkołę. Część podręczników kupują rodzice, ale część finansowana jest z budżetu państwa - przede wszystkim są to podręczniki do nauki języka chorwackiego, matematyki i języków obcych w niższych klasach szkoły podstawowej oraz podręczniki do języków obcych w wyższych klasach szkoły podstawowej.

W pierwszej połowie roku kalendarzowego poprzedzającego dany rok szkolny (np. w kwietniu na rok szkolny rozpoczynający się we wrześniu) Ministerstwo Nauki, Edukacji i Sportu publikuje listę podręczników dopuszczonych do użytku szkolnego dla każdego szczebla edukacji. Na podstawie tego wykazu szkoły, korzystając z elektronicznego systemu, zgłaszają zapotrzebowanie na wybrany podręcznik, podając liczbę osób, które zamierzają go zakupić. Po uzyskaniu tych informacji ministerstwo przystępuje do rozmów z wydawcami, negocjując cenę.

\section{Cypr}

Na Cyprze treść podręczników przygotowywana jest przez grupę ekspertów, nauczycieli i wykładowców akademickich z Ośrodka ds. Programów Szkolnych, działającego przy Instytucie Pedagogiki. Publikowaniem materiałów zajmują się niezależne wydawnictwa, w tym również kilka wydawnictw międzynarodowych. Wyboru książek zamieszczanych na liście publikacji zatwierdzonych do użytku szkolnego dokonują inspektorzy Instytutu Pedagogiki i komisja pod nadzorem Ministerstwa Edukacji i Kultury. Podczas oceny materiałów edukacyjnych uwzględniane są takie czynniki, jak: zawartość merytoryczna, szata graficzna, poziom trudności oraz cena. W wypadku większości przedmiotów w całym kraju obowiązuje wskazany przez Ministerstwo Edukacji jeden podstawowy podręcznik. Nauczyciele mogą jednak posługiwać się dodatkowymi pomocami naukowymi spełniającymi wymagania cypryjskiego programu nauczania. Wszelkie koszty związane z wydawaniem podręczników pokrywane są z budżetu państwa. Uczniowie wszystkich szkół publicznych na Cyprze mają zagwarantowane bezpłatne podręczniki, jednak niektóre z nich muszą zostać zwrócone placów- 
kom edukacyjnym przed końcem roku szkolnego. Dodatkowo uczniowie szkół podstawowych otrzymują darmowy zestaw artykułów papierniczych.

\section{Czechy}

W Czechach przygotowaniem materiału zawartego w podręcznikach zajmują się niezależni autorzy, którzy następnie zgłaszają się do wybranego przez siebie wydawnictwa. Przyjęte do druku tytuły muszą zawierać treści zgodne z założeniami obowiązującej ustawy o szkolnictwie, ramowym programem nauczania oraz innymi regulacjami prawnymi. Wszelkie koszty związane z publikacją pokrywa wydawnictwo. Ministerstwo Szkolnictwa, Młodzieży i Sportu publikuje listę podręczników, które uzyskały zgodę na wykorzystanie w procesie dydaktycznym w szkole. Wybierając tytuły wymienione w spisie, szkoła zazwyczaj uzyskuje zwrot kosztów zakupu podręczników. Decyzję o użyciu konkretnych materiałów dydaktycznych podejmuje dyrektor szkoły. Ponieważ w Czechach oferta podręczników jest zróżnicowana, w sprzedaży znajduje się wiele publikacji nieposiadających oficjalnego zatwierdzenia. Pomimo to władze szkoły mają prawo wybrać taką pozycję, pod warunkiem że spełnia ona wszystkie wymagania wyszczególnione w programie nauczania. Koszty nabycia podręczników pokrywane są zazwyczaj z budżetu państwa. Szkoła otrzymuje dotacje w limitowanej wysokości na zakup rekomendowanych podręczników. Uczniowie klas przygotowawczych i klas pierwszych dostają od państwa wyprawkę o wartości 200 CZK. Pozostałe koszty pokrywają rodzice. W przypadku uczniów ze szkół średnich, wszelkie wydatki związane z kupnem podręczników ponoszą rodzice. Rodziny w trudnej sytuacji materialnej, uczniowie niepełnosprawni oraz pochodzący z rodzin defaworyzowanych mogą otrzymać pomoc w postaci możliwości wypożyczenia podręczników ze szkoły.

\section{Finlandia}

W Finlandii znajduje się pięć głównych wydawnictw, które specjalizują się w sprzedaży podręczników. Wyjątek stanowią materiały dla uczniów ze specjalnymi potrzebami edukacyjnymi, dla dzieci imigrantów, uczniów posługujących się rzadkimi językami obcymi oraz dla dzieci z mniejszości religijnych. Zestaw podstawowych podręczników nie jest narzucany centralnie przez Ministerstwo Edukacji i Kultury, dlatego też za ich zawartość merytoryczną odpowiedzialni są eksperci z zakresu różnych dziedzin nauki współpracujący z poszczególnymi domami wydawniczymi, nie zaś ministerstwo. Decyzję o doborze odpowiedniej 
publikacji podejmuje nauczyciel. Każde z wydawnictw oferuje kilka różnych tytułów z danej dziedziny, jedynym wymogiem zatem względem nauczyciela jest wybranie podręcznika zgodnego z wytycznymi szkoły, a tym samym z krajową podstawą programową i odpowiednim ustawodawstwem. Rodzice na ogół nie biorą udziału w podejmowaniu decyzji o wyborze podręcznika. Nie ponoszą też żadnych kosztów związanych z kupnem podręczników dla uczniów szkoły podstawowej i gimnazjalnej. Ponadto dzieciom przysługuje darmowy zestaw artykułów papierniczych. Natomiast uczniowie szkoły średniej powinni nabyć niezbędne materiały we własnym zakresie lub wypożyczyć je ze szkoły.

\section{Grecja}

Zgodnie z ustawą z 2011 roku jednostką odpowiedzialną za publikację podręczników w Grecji jest Instytut Informatyki i Prasy - Diofantus (na rynku edukacyjnym nie funkcjonują żadne wydawnictwa międzynarodowe). Za treść materiałów dydaktycznych odpowiada Instytut Polityki Oświatowej podległy Ministerstwu Edukacji i Spraw Religijnych oraz Ministerstwu Kultury. Podręczniki są zatwierdzane i dopuszczane do użytku szkolnego na szczeblu centralnym. W całym kraju obowiązuje jeden zestaw podstawowych materiałów edukacyjnych. Do jednego przedmiotu obowiązuje jeden podręcznik. Wyjątek stanowią podręczniki do nauczania języków obcych, jednakże muszą to być tytuły, które wcześniej znalazły się na ministerialnej liście podręczników zatwierdzonych do użytku szkolnego. Wszelkie wydatki związane z publikacją i dystrybucją podręczników pokrywane są z budżetu państwa. W szkołach prywatnych koszty zakupu podręczników pokrywają rodzice.

\section{Hiszpania}

Na hiszpańskim rynku podręczników obecne są krajowe i międzynarodowe wydawnictwa edukacyjne, przy czym pozycje znajdujące się w ofercie tych pierwszych nie podlegają ocenie władz edukacyjnych. Wszelkie koszty związane z przygotowaniem nowego podręcznika pokrywane są zazwyczaj przez wydawnictwa, choć zdarza się, że niektóre wspólnoty autonomiczne, posługujące się obok hiszpańskiego innym językiem urzędowym, wspierają finansowo publikacje materiałów dydaktycznych w lokalnym języku. W Hiszpanii nie ma listy podręczników zatwierdzonych do użytku w szkole. Nie ma też obowiązku korzystania z podręczników w procesie dydaktycznym, w związku z tym w niektórych szkołach nie 
korzysta się z nich. Z uwagi na brak centralnej listy podręczników, wybór materiałów jest indywidualną sprawą każdej instytucji edukacyjnej. Ważne jest jednak, aby książki spełniały ogólne założenia podstaw programowych przeznaczonych dla ucznia w danym wieku. Wyboru podręczników dokonują nauczyciele na podstawie rekomendacji instytucji i podmiotów doradczych (np. rady szkoły).

Wszelkie wydatki z związane z zakupem podręczników ponoszą rodzice lub prawni opiekunowie dziecka. Uczniowie pochodzący z rodzin społecznie i ekonomicznie defaworyzowanych obejmowani są szkolnym programem wypożyczania materiałów edukacyjnych. Władze edukacyjne wspólnot autonomicznych wspierają takie rodziny przez system dofinansowania zakupu podręczników. W niektórych wspólnotach, np. w Estremadurze, wypożyczone podręczniki uznawane są za obowiązujące przez okres co najmniej 4 lat.

\section{Holandia}

Większość wydawnictw naukowych w Holandii oferuje podręczniki opracowane na podstawie różnych metod nauczania, dlatego też odpowiedzialność za wartość merytoryczną materiału dydaktycznego spoczywa na samym wydawnictwie, nie zaś na Ministerstwie Edukacji, Kultury i Nauki. Szkoły samodzielnie dobierają zestawy podręczników adekwatne dla wybranego programu kształcenia, często pozostawiając w tej kwestii autonomię samym nauczycielom. Z tego względu placówki edukacyjne podlegają stałej ocenie Inspektoratu Jakości Kształcenia. Uczniom szkół podstawowych i średnich darmowe podręczniki zapewnia szkoła i to do niej należy decyzja, czy dzieci dostaną książki na własność, czy też będą im wypożyczone.

\section{Islandia}

W Islandii publikacją podręczników zajmuje się Narodowe Centrum Materiałów Edukacyjnych (NCEM), państwowe wydawnictwo podlegające Ministerstwu Edukacji, Nauki i Kultury w Reykjaviku. Koszty publikacji podręczników są pokrywane z budżetu państwa. Centrum zapewnia materiały edukacyjne wszystkim uczniom w wieku od 6 do 16 lat. Treści zawarte w podręcznikach opracowywane są przez autorów wydawnictwa, jednak muszą one być zgodne z programem nauczania przygotowanym przez ministerstwo. Zdarza się, że niektórzy nauczyciele przygotowujący materiał do publikacji przez NCEM testują go na grupie swoich uczniów, choć nie jest to regułą. Mimo że islandzki rynek podręczników jest stosunkowo ograniczony, nauczyciele mogą korzystać z materiałów w róż- 
nym formacie (audio, wideo, programy multimedialne). Darmowy zestaw podręczników zgodnych z podstawą programową jest przekazywany uczniom przez NCEM, dlatego też rodzice nie ponoszą żadnych kosztów związanych z kupnem materiałów dydaktycznych. Zobowiązani są jedynie do zapewnienia dziecku wszelkich dodatkowych materiałów szkolnych, m.in. artykułów piśmienniczych.

\section{Łotwa}

Na Łotwie publikacją podręczników zajmują się prywatne (krajowe oraz międzynarodowe) wydawnictwa, które, w zależności od sytuacji na rynku, samodzielnie ustalają wysokość cen. Szkoły mają prawo wybrać dowolną książkę znajdującą się na liście podręczników zatwierdzonych do użytku w szkole, choć nie są przewidziane żadne prawne konsekwencje korzystania z tytułów niewyszczególnionych w zestawieniu. Wybór podręcznika figurującego na oficjalnej liście gwarantuje odpowiedni zakres materiału oraz jego wysoką jakość, jako że przed zamieszczeniem w spisie każda publikacja oceniana jest przez ekspertów z zakresu pedagogiki i metodyki. Szczególną uwagę zwraca się na jakość zawartych w podręczniku informacji, zgodność treści z programem nauczania oraz jego użyteczność w prowadzeniu zajęć. To nauczyciel wybiera odpowiedni podręcznik, choć decyzja ta wymaga akceptacji dyrektora danej placówki edukacyjnej. Państwo ponosi wszelkie koszty związane z zaopatrzeniem uczniów w podręczniki, jednak dotyczy to jedynie pozycji zawartych na liście podręczników zatwierdzonych do użytku w szkole. Książki te wykorzystywane są w szkole przez kolejne roczniki uczniów zazwyczaj przez okres od 3 do 5 lat. Rodzice zobowiązani są do zakupu zeszytów ćwiczeń do wszystkich przedmiotów (ostatnio trwa debata nad możliwością zakupu tych materiałów ze środków budżetowych).

\section{Niemcy}

W Niemczech funkcjonuje 45 wydawnictw, które specjalizują się w publikacji podręczników szkolnych. Wszystkie podręczniki przeznaczone do użytku w szkole muszą zostać zatwierdzone przez ministerstwa edukacji poszczególnych landów (nie wszystkie kraje związkowe stosują własną procedurę dopuszczającą podręczniki. Są takie, które korzystają z certyfikatów dopuszczeń innych landów, ale są również i takie, w których wystarczy oświadczenie wydawcy, że podręczniki są zgodne z podstawą programową i konstytucją Niemiec). Ocenie podlega zarówno ich jakość, jak i cena. Podręczniki o wygórowanej cenie mogą 
nie uzyskać dopuszczenia. W razie jakichkolwiek wątpliwości Federalne Ministerstwo Edukacji i Badań Naukowych prosi o opinię grupę ekspertów. Na liście podręczników zatwierdzonych do użytku w szkole znajduje się zazwyczaj od czterech do sześciu tytułów przeznaczonych do nauczania danego przedmiotu, spośród których szkoła zobowiązana jest wybrać jeden. W podjęciu decyzji dyrektorowi pomaga zazwyczaj grupa nauczycieli danego przedmiotu. Rodzice nie biorą udziału w procedurze wyboru podręczników. Podręczniki przeznaczone dla uczniów ze szkół podstawowych nabywane są odpłatnie, podczas gdy starsi uczniowie wypożyczają je ze szkoły (uznaje się, że przeciętnie podręcznik służy od 4 do 5 lat). Zgodnie z rozporządzeniami wydanymi przez ministerstwa edukacji każdego landu, rodzice pokrywają zazwyczaj od 1/5 do 1/3 kosztów zakupu podręcznika, pozostała kwota finansowana jest przez gminę. Ponadto rodzice zobligowani są do zakupu wszelkich pozostałych pomocy szkolnych.

\section{Bawaria}

W Bawarii podręczniki kupuje podmiot odpowiedzialny za wydatki szkoły (organ prowadzący). W szkołach publicznych są to najczęściej samorządy (gminy, miasta, powiaty), które zapewniają uczniom podręczniki. Inne książki pozostają własnością organu prowadzącego i są wypożyczane uczniom. Podręczniki są zamawiane i finansowane przez sektor publiczny. Rząd Bawarii przekazuje samorządom dotacje (regulacja ustawowa) na zakup podręczników, które stanowią 2/3 kosztów ich zakupu. Istnieje też możliwość samodzielnego zakupu podręczników przez rodziców. Zakup dodatkowych materiałów szkolnych, zeszytów ćwiczeń, lektur, atlasów, map, pomocy tabelarycznych, kalkulatorów itp. pozostaje w gestii rodziców.

Rodzina pobierająca świadczenia socjalne lub rodzina wielodzietna (powyżej trojga dzieci) może być zwolniona z obowiązku zapewnienia swoim dzieciom dodatkowych materiałów szkolnych. Materiały takie mogą zostać sfinansowane przez dotacje Rady Rodziców, która w porozumieniu ze szkołą ustala maksymalną wysokość kwot przeznaczanych na pomoce szkolne dla rodziny wielodzietnej.

\section{Dolna Saksonia}

W Dolnej Saksonii podręczniki mogą być zakupione przez rodziców, ale istnieje też możliwość skorzystania ze szkolnego systemu wypożyczania. Procedura polega na tym, że szkoła kupuje książki z własnego budżetu, po czym udostępnia je uczniom przez cztery lub pięć lat za odpłatnością, pobierając tylko 1/5 lub 1/4 pier- 
wotnej ceny (wyliczono, że po czterech-pięciu latach książki się spłacają). Koszty pozostałych pomocy i materiałów szkolnych ponoszą rodzice.

\section{Słowacja}

Na Słowacji podręczniki publikowane, sprzedawane i kolportowane są przez prywatne wydawnictwa. Tytuły dopuszczane są do użytku szkolnego przez Ministerstwo Edukacji poprzez umieszczenie ich na liście podręczników zatwierdzonych do użytku w szkole. Wartość materiału ocenia zespół ekspertów, zwracając szczególną uwagę na zgodność treści z wymaganiami podstawy programowej. Wyboru konkretnego podręcznika dokonuje nauczyciel w porozumieniu z gronem pedagogicznym, przy czym wskazana książka musi znajdować się w spisie pozycji zatwierdzonych przez ministerstwo. Zakup podręczników jest w pełni finansowany z budżetu państwa. Podręczniki stanowią własność szkoły, a uczniowie wypożyczają je od placówki na czas trwania roku szkolnego.

\section{Wielka Brytania (Anglia, Walia i Irlandia Północna)}

W Anglii, Walii i Irlandii Północnej podręczniki znajdują się jedynie w ofercie wydawnictw komercyjnych, a ich publikacja nie wymaga uprzedniego zatwierdzenia treści przez ministerstwa. Za wybór odpowiedniej książki odpowiedzialni są nauczyciele, jednak ich decyzja musi uzyskać akceptację nauczyciela koordynatora danego zespołu przedmiotowego oraz dyrektora szkoły. Nie istnieje lista obowiązkowych podręczników, a przy wyborze materiałów dydaktycznych najważniejsza jest zgodność treści z obowiązującą podstawą programową oraz ze standardami egzaminacyjnymi. Należy zwrócić uwagę, że w Wielkiej Brytanii szkoły powszechnie korzystają z elektronicznych zasobów edukacyjnych, więc klasyczne podręczniki stanowią dla ucznia tylko fragment wykorzystywanych pomocy dydaktycznych. Szkoły publiczne gwarantują swoim uczniom darmowe pomoce dydaktyczne (podręczniki i ćwiczenia). Podręczniki, które są finansowane z budżetu państwa, pozostają własnością szkoły i są oddawane uczniom do użytku jedynie na czas trwania roku szkolnego.

\section{Włochy}

We Włoszech funkcjonuje kilka wydawnictw specjalizujących się w dziedzinie podręczników. Domy wydawnicze koordynują i finansują proces publikacji, ko- 
Tabela 23. Opłaty rodziców za podręczniki szkolne w szkołach podstawowych i średnich I stopnia w wybranych państwach (listopad 2013 r.)

\begin{tabular}{|c|c|c|}
\hline Kraj & $\begin{array}{l}\text { Opłaty } \\
\text { rodziców }\end{array}$ & Uwagi \\
\hline Austria & Nie & \\
\hline Belgia & Nie & \\
\hline Cypr & Nie & Podręczniki - własność szkoły \\
\hline Chorwacja & Tak/nie & \\
\hline Czechy & Nie & $\begin{array}{l}\text { Podręczniki - własność szkoły (wyjątek: dzieci z I klasy } \\
\text { szkoły podstawowej dostają je na własność) }\end{array}$ \\
\hline Dania & Nie & \\
\hline Finlandia & Nie & \\
\hline Francja & Nie & \\
\hline Grecja & Nie & \\
\hline Hiszpania & Tak & Możliwe dofinansowanie \\
\hline Holandia & Nie & $\begin{array}{l}\text { Decyzja szkoły - czy oddają, czy wypożyczają podręczniki } \\
\text { dzieciom }\end{array}$ \\
\hline Irlandia & Tak & $\begin{array}{l}\text { W 76\% szkół podstawowych i 44\% ponadpodstawowych } \\
\text { istnieje możliwość darmowego wypożyczenia podręczników }\end{array}$ \\
\hline Islandia & Nie & \\
\hline Łotwa & Nie & Podręczniki - własność szkoły \\
\hline Malta & Nie & \\
\hline Niemcy & Tak & $\begin{array}{l}\text { W większości landów rodzice płacą około 1⁄3 ceny } \\
\text { podręczników }\end{array}$ \\
\hline Polska & Tak & Możliwa częściowa refundacja \\
\hline Portugalia & Tak & \\
\hline Słowacja & Nie & Podręczniki - własność szkoły \\
\hline Słowenia & Tak/nie & $\begin{array}{l}\text { Szkoła zapewnia możliwość wypożyczenia całego kompletu } \\
\text { podręczników - za co może pobierać opłaty wynoszące } \\
\text { maksimum 1⁄3 ceny kompletu }\end{array}$ \\
\hline Szwecja & Nie & \\
\hline Turcja & Nie & \\
\hline $\begin{array}{l}\text { Wlk.Brytania (Anglia, } \\
\text { Walia, Irlandia Płn.) }\end{array}$ & Nie & Podręczniki - własność szkoły \\
\hline Włochy & Tak/nie & $\begin{array}{l}\text { Szkoła podstawowa - finansowanie przez władze lokalne. } \\
\text { Szkoła średnia - za podręczniki płacą rodzice, ale ministerstwo } \\
\text { ustala maksymalną cenę całego zestawu podręczników }\end{array}$ \\
\hline
\end{tabular}

Źródło: http://www.eurydice.org.pl/sites/eurydice.org.pl/files/Podreczniki.pdf. 
rzystając z dofinansowania z budżetu państwa. Każdy podręcznik musi spełniać wymagania programowe uregulowane przez ministerstwo w rozporządzeniu nr 41 z 2009 roku. Natomiast nie ma centralnej listy podręczników zatwierdzonych do użytku w szkole. We Włoszech nauczyciele mogą samodzielnie dobierać odpowiednie pomoce naukowe, które następnie zostają zatwierdzone przez grono pedagogiczne danej szkoły. Co 5-6 lat pojawiają się nowe pozycje na rynku podręczników. Podręczniki dla uczniów szkół podstawowych są bezpłatne. Zgodnie z obowiązującymi regulacjami finansują je władze lokalne. Materiały dydaktyczne dla uczniów na dalszych etapach kształcenia finansują rodzice. Włoskie Ministerstwo Edukacji, Szkolnictwa Wyższego i Badań Naukowych co roku ustala zakres cen podręczników, narzucając jednocześnie nieprzekraczalny limit wydatków przewidziany na pełen zestaw książek. Aby dodatkowo ograniczyć wydatki związane z kupnem podręczników, umożliwia się uczniom wypożyczenie materiałów ze szkoły lub gwarantuje częściowy zwrot poniesionych kosztów.

\section{Podsumowanie}

W większości krajów europejskich podręczniki na poziomie szkolnictwa obowiązkowego są bezpłatne, a dostęp do nich zapewnia szkoła (Austria, Belgia, Cypr, Dania, Finlandia, Francja, Grecja, Holandia, Islandia, Łotwa, Malta, Słowacja, Szwecja, Turcja, Wielka Brytania - Anglia, Walia i Irlandia Płn.). W Chorwacji obowiązek finansowania podręczników rozdzielony jest między rodziców i szkołę. Część podręczników kupują rodzice, ale część finansowana jest z budżetu państwa. W Czechach i we Włoszech system jest mieszany - podręczniki do szkoły podstawowej są finansowane ze środków publicznych, natomiast koszty podręczników uczniów w szkołach średnich ponoszą rodzice. W Hiszpanii wydatki związane z zakupem podręczników ponoszą rodzice lub prawni opiekunowie dziecka. Uczniowie pochodzący z rodzin społecznie i ekonomicznie defaworyzowanych obejmowani są szkolnym programem wypożyczania materiałów edukacyjnych. W Irlandii podręczniki są płatne, jednakże w 76\% szkół podstawowych i 44\% ponadpodstawowych istnieje możliwość ich darmowego wypożyczenia. W Polsce wydatki związane z zakupem podręczników ponoszą rodzice lub prawni opiekunowie dziecka, choć dla najuboższych rodzin istnieje możliwość skorzystania z systemu dotowania niezbędnych wydatków podręcznikowych. W Niemczech podręczniki przeznaczone dla uczniów ze szkół podstawowych nabywane są odpłatnie. Zgodnie z rozporządzeniami wydanymi przez ministerstwa edukacji poszczególnych landów rodzice pokrywają zazwyczaj od 
1/5 do 1/3 kosztów zakupu podręcznika, pozostała kwota finansowana jest przez gminę. W Słowenii szkoła zapewnia możliwość wypożyczenia całego kompletu podręczników - za co może pobierać opłaty wynoszące maksimum $1 / 3$ ceny zestawu.

\section{Bibliografia}

Dziewulak D., Finansowanie zakupu podręczników szkolnych w wybranych państwach, „Analizy BAS” 2014, nr 4(108).

Encyklopedia Popularna PWN, Wydawnictwo Naukowe PWN, Warszawa 2010.

Encyklopedia pedagogiczna XXI wieku, t. IV, Wydawnictwo Akademickie „Żak”, Warszawa 2005.

Stownik języka polskiego, Wydawnictwo Naukowe PWN, Warszawa 2006.

\section{Akty prawne}

Rozporządzenia Ministra Edukacji Narodowej z 21 czerwca 2012 r. w sprawie dopuszczania do użytku w szkole programów wychowania przedszkolnego i programów nauczania oraz dopuszczania do użytku szkolnego podręczników, Dz.U. poz. 752.

\section{Strony internetowe}

https://www.men.gov.pl/index.php/wyprawka-szkolna/155-wyprawka-szkolna-2013.

http://www.prawo.vulcan.edu.pl/przegdok.asp?qdatprz=akt\&qplikid=1.

http://www.eurydice.org.pl/sites/eurydice.org.pl/files/Podreczniki.pdf. 


\section{Część 5}

\section{Uwarunkowania społeczno-ekonomiczne oświaty}

Part 5

Socio-economic

determinants

of education 
DOI: https://doi.org/10.31268/d.dziewulak.2020.01 


\title{
5.1. Wybrane zagadnienia prawa adopcyjnego na Białorusi, Litwie i Ukrainie
}

\author{
Selected issues of adoption law in Belarus, Lithuania \\ and Ukraine
}

W opracowaniu podjęto próbę przedstawienia zagadnienia prawa adopcyjnego na Białorusi, Litwie i Ukrainie. Analizie porównawczej poddano podstawowe akty prawne dotyczące prawa adopcyjnego oraz przedstawiono zasady procedur adopcyjnych w analizowanych państwach.

Słowa kluczowe: adopcja, Białoruś, Litwa, Ukraina

The paper attempts to present the issue of adoption law in Belarus, Lithuania and Ukraine. The basic legal acts regarding adoption law were submitted to the comparative analysis and the rules of adoption procedures in the analyzed countries were presented.

Keywords: adoption, Belarus, Lithuania and Ukraine

\section{Wstęp}

Adopcja, czyli przysposobienie oznacza nawiązanie między przysposabiającym a przysposobionym stosunku prawnorodzinnego podobnego do stosunku między rodzicami a dzieckiem. Podstawową funkcją społeczną, jaką spełnia obecnie przysposobienie dziecka, jest zastąpienie brakującego środowiska rodzinnego. Powstanie stosunku przysposobienia jest aktem formalnym i następuje na mocy aktu prawnego. Przysposabiający to osoba, która chce przysposobić dziecko oraz ma pełną zdolność do czynności prawnych. Przysposabiający musi należycie wywiązywać się z obowiązku wynikającego z przysposobienia dziecka - musi mieć odpowiednie kwalifikacje podmiotowe. Odpowiedni urząd (np. sąd) bada między innymi status i stan majątkowy przysposabiającego, jego poziom intelektualny, zdolności wychowawcze oraz tryb życia, ponieważ opiekę nad dzieckiem powinno powierzać się osobie, której cechy pozwalają na odpowiednie wychowanie dziecka. Mianem przysposabianego nazywamy adoptowane małoletnie dziecko ${ }^{1}$.

1 http://orszagh.com/adopcja. 
Dzieci z Litwy i Ukrainy mogą być przekazywane do adopcji zagranicznej, np. do Polski. Dzieci z Białorusi także mogą być adoptowane za granicę pod warunkiem, że przysposabiający udowodni więzy pokrewieństwa z dzieckiem lub jest obywatelem Włoch, państwa które podpisało z Białorusią ramowe porozumienie w sprawie zagranicznej adopcji.

Na Białorusi, Litwie i Ukrainie nie ma szczególnych regulacji odnoszących się do adopcji dzieci narodowości polskiej zamieszkałych w tych państwach².

Poniżej przedstawiono zagadnienie prawa adopcyjnego na Białorusi, Litwie i Ukrainie. W opracowaniu wykorzystano materiały uzyskane bezpośrednio z instytucji i organizacji zajmujących się adopcją dzieci. Są to: Narodowe Centrum Adopcji Republiki Białorusi przy białoruskim Ministerstwie Oświaty, litewski Państwowy Urząd Ochrony Praw Dziecka i Adopcji przy Ministerstwie Opieki Społecznej i Pracy, ukraińskie Ministerstwo Polityki Społecznej.

\section{Białoruś}

Najważniejsze przepisy prawne, regulujące zagraniczne adopcje w Republice Białorusi (RB) zawiera Kodeks małżeński i rodzinny (przede wszystkim art. 233) ${ }^{3}$ oraz rozporządzenie Rady Ministrów RB z 31 stycznia 2007 r. nr 122, ze zm. ${ }^{4}$

Wszelkie sprawy realizacji procedur adopcyjnych znajdują się w kompetencji Ministerstwa Oświaty RB i działającego w jego strukturach Narodowego Centrum Adopcji Republiki Białorusi (Национальный центр Усыновления Республики Беларусь) $)^{5}$.

Na Białorusi istnieje możliwość przekazywania dzieci do adopcji za granicę, lecz przysposabiający muszą udowodnić istnienie więzów pokrewieństwa z dzieckiem. W wypadku osób ze sobą niespokrewnionych, adopcja może się odbyć jedynie na podstawie ramowego dwustronnego porozumienia między Ministerstwem Oświaty RB i odpowiednim resortem państwa, którego obywatelstwo

2 Opracowanie przygotowano na podstawie ekspertyzy Biura Analiz Sejmowych nr 852/12 z 23 maja 2012 r. D. Dziewulaka, Informacja nt. prawa adopcyjnego na Białorusi, Litwie i Ukrainie oraz szczególnych regulacji odnoszacych się do polskich dzieci.

3 Кодекс о Браке и Семье Республики Беларусь, 9 июля 1999 г. № 278-3, http://www.tamby. info/kodeks/kobs.htm.

4 Постановление Совета Министров Республики Беларусь „Об утверждении Положения о порядке согласования процедуры международного усыновления и взаимодействия с компетентными организациями иностранных государств в рамках данной процедуры”, http://newsby.org/documents/index.htm.

5 http://www.child.of.by/. 
posiadają osoby zainteresowane adopcją dziecka. Obecnie Białoruś posiada takie porozumienie tylko z jednym państwem - Włochami. W związku z powyższym polscy obywatele zainteresowani adopcją dzieci mających obywatelstwo białoruskie mogą podjąć starania adopcyjne wyłącznie wobec dzieci, z którymi są spokrewnieni i takie pokrewieństwo udowodnią.

Czy istnieje możliwość, aby dzieci z Białorusi były przekazywane do adopcji za granice, np. do Polski?

Tak, dzieci z Białorusi mogą być przekazywane do adopcji za granicę, np. do Polski, pod warunkiem udowodnienia przez osoby przysposabiające istnienia pokrewieństwa.

Czy istniejq szczególne regulacje odnoszqce się do adopcji dzieci narodowości polskiej mieszkajacych na Białorusi?

Nie, na Białorusi nie istnieją szczególne regulacje - w tym ułatwienia - dotyczące adoptowania polskich dzieci mieszkających na Białorusi.

\section{Litwa}

Podstawowymi aktami prawnymi regulującymi procedurę adopcji międzynarodowej na Litwie jest:

- Konwencja haska o ochronie dzieci i współpracy w dziedzinie przysposobienia międzynarodowego z 1993 r.,

- Kodeks cywilny Republiki Litewskiej,

- „Tryb ewidencji adopcji dzieci w Republice Litewskiej”, zatwierdzony rozporządzeniem Rządu Republiki Litewskiej nr 457 z 20 maja 2009 r.,

- „Opis trybu udzielenia pełnomocnictw akredytowanym instytucjom zagranicznym do działania w zakresie przysposobienia międzynarodowego w Republice Litewskiej” zatwierdzony zarządzeniem Ministra Opieki Społecznej i Pracy Republiki Litewskiej nr Al-162 z 3 czerwca 2005 r.,

- „Opis procedury postępowania przygotowawczego w sprawie możliwych do adopcji dzieci specjalnej troski” zatwierdzony zarządzeniem Ministra Opieki Społecznej i Pracy Republiki Litewskiej nr Al-32 z 1 lutego 2007 r.

Zgodnie z zarządzeniem Ministra Opieki Społecznej i Pracy Republiki Litewskiej nr Al-8 z 10 stycznia 2012 r. o zmianie zarządzenia Ministra Opieki Społecznej i Pracy Republiki Litewskiej z dnia 3 czerwca 2005 r. o zatwierdzeniu „Opisu trybu udzielenia pełnomocnictw akredytowanym instytucjom zagranicz- 
nym do działania w zakresie przysposobienia międzynarodowego w Republice Litewskiej”, od 1 kwietnia 2012 roku obcokrajowcy (małżonkowie) stale mieszkający za granicą mogą zwracać się do urzędu adopcyjnego tylko o adopcję dzieci specjalnej troski. Tryb składania wniosków o adopcję dzieci na Litwie przez obywateli litewskich (małżonków) i stale mieszkających za granicą małżonków, z których jedno jest obywatelem litewskim, pozostaje ten sam, jaki obowiązywał dotychczas. Adopcję dzieci litewskich za granicę mogą realizować mieszkające za granicą osoby będące w związku małżeńskim, w którym jedna posiada obywatelstwo litewskie. Zgodnie z art. 3.7 ust. 2 Kodeksu cywilnego małżeństwem są mężczyzna i kobieta, którzy zawarli związek małżeński na zasadach ustalonych ustawowo.

\section{Czy istnieje możliwość, aby dzieci z Litwy były przekazywane do adopcji za granice, np. do Polski?}

Tak, dzieci z Litwy mogą być przekazywane do adopcji zagranicznej, np. do Polski. Poniżej przedstawiono statystykę adopcji dzieci litewskich za granicę:

- 2009 rok - 88 rodzin obcokrajowców adoptowało 146 dzieci (w tym 4 dzieci adoptowanych do Polski),

- 2010 rok - 78 rodzin obcokrajowców adoptowało 115 dzieci (w tym 2 dzieci adoptowanych do Polski),

- 2011 rok - 88 rodzin obywateli litewskich, stale mieszkających za granicą i obcokrajowców adoptowało 144 dzieci (w tym 5 dzieci adoptowanych do Polski) . $^{2}$

Większość dzieci adoptowanych za granicę były to dzieci wymagające specjalnej troski z poważnymi zaburzeniami zdrowotnymi albo rodzeństwa składające się z trzech i więcej osób. Należy zauważyć, że wszystkie adoptowane do Polski dzieci były w starszym wieku, a z rodzicami przybranymi łączyły je więzi emocjonalne, powstałe w czasie pobytu tych dzieci w Polsce.

\section{Czy istnieja szczególne regulacje odnoszace się do adopcji dzieci litewskich narodowości polskiej mieszkajacych na Litwie?}

Nie, nie ma specjalnych przepisów ułatwiających adopcję dzieci litewskich narodowości polskiej.

6 Więcej informacji statystycznej o międzynarodowym przysposobieniu można znaleźć na stronie internetowej urzędu www.vaikoteises.lt. 


\section{Ukraina}

Na Ukrainie procedura adopcji regulowana jest przez Kodeks rodzinny (Сімейн України ий кодекс z 10 stycznia 2002 r.; dalej: k.r.)7.

Zgodnie z art. 211 k.r. przysposabiającym może być:

- osoba pełnoletnia zdolna do czynności prawnych,

- osoba starsza od dziecka, które zamierza przysposobić, o nie mniej niż 15 lat. W przypadku przysposobienia osoby pełnoletniej różnica wieku nie może być mniejsza niż 18 lat,

- małżeństwo, lecz nie osoby tej samej płci.

Osoby, które nie pozostają w związku małżeńskim między sobą nie mogą przysposobić tego samego dziecka. Jeżeli takie osoby stanowią jedną rodzinę, sąd może wydać zgodę na przysposobienie przez nie dziecka. W przypadku, jeśli dziecko ma tylko matkę, to nie może być ono przysposobione przez mężczyznę, z którym matka nie pozostaje w związku małżeńskim. Jeżeli dziecko ma tylko ojca, to nie może być ono przysposobione przez kobietę, z którą ojciec nie jest w związku małżeńskim. Jednak, gdy takie osoby stanowią jedną rodzinę, sąd może wydać zgodę na przysposobienie przez nie dziecka.

Jeżeli dziecko ma tylko matkę lub tylko ojca, którzy na skutek przysposobienia utracą związek prawny z dzieckiem, przysposabiającym może być sam mężczyzna lub sama kobieta. Liczba dzieci, które mogą być przysposobione przez jednego przysposabiającego nie jest ograniczona.

Artykuł 212 k.r. wskazuje osoby, które nie mają prawa przysposobić dziecka. Zgodnie z nim przysposabiającymi nie mogą być osoby, które:

- mają ograniczoną zdolność do czynności prawnych,

- są uznane za niezdolne do czynności prawnych,

- są pozbawione praw rodzicielskich,

- przysposobiły inne dziecko, lecz przysposobienie zostało cofnięte lub unieważnione z ich winy,

- podlegają leczeniu w poradni neuropsychiatrycznej lub ośrodku dla narkomanów,

- nadużywają alkoholu lub środków narkotycznych,

- nie mają stałego miejsca zamieszkania i stałych zarobków (dochodów),

- chorują na choroby, wymienione w wykazie zatwierdzonym przez Ministerstwo Zdrowia Ukrainy.

7 http://zakon3.rada.gov.ua/laws/show/2947-14. 
Oprócz osób wyżej wymienionych przysposabiającymi nie mogą zostać osoby, których interesy są sprzeczne z dobrem dziecka.

Zgodnie z ukraińskim Kodeksem rodzinnym (art. 213) prawo pierwszeństwa przysposobienia dziecka ma przede wszystkim małżeństwo. W przypadku istnienia kilku osób, które chciałyby przysposobić to samo dziecko, prawo pierwszeństwa ma obywatel Ukrainy:

- w rodzinie, którego wychowuje się dziecko,

- który jest małżonkiem matki, małżonką ojca przysposobionego dziecka,

- który przysposabia kilkoro dzieci, będących rodzeństwem,

- który jest krewnym dziecka.

Obywatele ukraińscy zamieszkali poza granicami Ukrainy i cudzoziemcy, którzy chcą adoptować dziecko zamieszkałe na Ukrainie, składają w Ministerstwie Polityki Społecznej następujące dokumenty:

- poświadczony notarialnie wniosek o wpisanie do ewidencji kandydatów na przysposabiających,

- paszport lub inny dokument potwierdzający tożsamość i obywatelstwo,

- opinię kompetentnego organu państwa zamieszkania, potwierdzającą, że wnioskodawca może być przysposabiającym. W opinii podaje się adres, warunki mieszkaniowo-bytowe, życiorys, informacje o rodzinie (liczba osób zamieszkałych razem z wnioskodawcą, stopień pokrewieństwa, posiadanie własnych dzieci), stosunek wnioskodawców do przysposobienia. Opinia musi zawierać rekomendację odnośnie do liczby i stanu zdrowia dzieci, które mogą przysposobić wnioskodawcy. Rekomendację co do stanu zdrowia dziecka podaje się w przypadku, jeżeli wnioskodawcom zaproponowano przysposobienie dziecka chorego, które ma schorzenie figurujące w wykazie chorób zatwierdzonych przez ukraińskie Ministerstwo Zdrowia, dające prawo przysposobienia dziecka bez zachowania okresów umieszczania jego danych w ewidencji Ministerstwa Polityki Socjalnej, jak również dzieci w wieku do 5 lat. W przypadku, jeżeli opinia została wydana przez organ niepaństwowy, dodaje się do niej kopię licencji na prowadzenie przez ten organ działalności związanej z przysposobieniem. Cudzoziemcom zamieszkałym na stałe na terytorium Ukrainy, posiadającym kartę stałego pobytu wydaną przez ukraińskie Ministerstwo Spraw Wewnętrznych, opinię przygotowuje służba do spraw dzieci w miejscu ich zamieszkania,

- pozwolenie kompetentnego organu państwa zamieszkania wnioskodawcy na wjazd i pobyt stały adoptowanego dziecka (nie dotyczy obywateli Ukrainy oraz cudzoziemców zamieszkałych na terytorium państwa, z którym Ukraina utrzymuje ruch bezwizowy), 
- notarialnie poświadczone zobowiązanie wnioskodawcy do8:

- wpisania dziecka do ewidencji w odpowiednim urzędzie konsularnym lub przedstawicielstwie dyplomatycznym w ciągu miesiąca po wjeździe dziecka do państwa zamieszkania,

- zabezpieczenia prawa przysposabianego dziecka do zachowania przez dziecko obywatelstwa Ukrainy, aż do osiągnięcia 18 roku życia,

- regularnego informowania urzędu konsularnego lub przedstawicielstwa dyplomatycznego Ukrainy o warunkach bytowo-mieszkaniowych i stanie zdrowia przysposabianego dziecka. Informacja taka powinna być przekazywana nie rzadziej niż raz w roku na przestrzeni pierwszych trzech lat po przysposobieniu, a po tym terminie raz na trzy lata, aż do osiągnięcia przez przysposabiane dziecko 18 roku życia,

- umożliwiania kontaktu z dzieckiem przedstawicielowi urzędu konsularnego lub przedstawicielstwa dyplomatycznego Ukrainy,

- informowania urzędu konsularnego lub przedstawicielstwa dyplomatycznego Ukrainy o zmianie miejsca zamieszkania dziecka.

- notarialnie poświadczoną zgodę drugiego z małżonków na przysposobienie dziecka (w przypadku przysposabiania dziecka przez jedno z małżonków),

- zaświadczenie z miejsca pracy z podaniem wysokości zarobków za okres ostatnich 6 miesięcy lub kopię deklaracji o dochodach za poprzedni rok kalendarzowy, poświadczone notarialnie lub przez organ wydający,

- poświadczoną notarialnie kopię aktu ślubu, zarejestrowanego w kompetentnych organach państwowych,

- zaświadczenie o stanie zdrowia każdego wnioskodawcy, wydane według ustalonego wzoru,

- zaświadczenie o niekaralności dla każdego wnioskodawcy, wydane przez kompetentny organ państwa zamieszkania,

- poświadczoną notarialnie kopię dokumentu potwierdzającego prawo własności lub korzystania z lokalu mieszkalnego z podaniem ogólnej i mieszkalnej powierzchni oraz liczby sypialni,

- poświadczoną notarialnie zgodę wnioskodawcy-cudzoziemca, na uzyskanie informacji o nim w Interpolu i od organów ochrony porządku publicznego państwa, którego jest obywatelem oraz państwa, w którym zamieszkuje.

8 W zobowiązaniu powinien być zaznaczony adres lub adresy zamieszkania wnioskodawcy, dane paszportowe, numer telefonu i adres e-mail. 
Etapy procedury przysposobienia dziecka przez cudzoziemców i obywateli Ukrainy zamieszkałych za granicą:

- Kompletowanie dokumentów w państwie zamieszkania,

- Rejestracja w celu złożenia dokumentów,

- Złożenie kompletu dokumentów w Ministerstwie Polityki Społecznej,

- Otrzymanie zaproszenia na rozmowę w celu zapoznania się z informacją o dzieciach, które mogą być przysposobione,

- Rozmowa. Zapoznanie się z informacją o dzieciach, które mogą być adoptowane,

- Otrzymanie skierowania w celu nawiązania znajomości i ustanowienia kontaktu z dzieckiem,

- Nawiązanie znajomości z dzieckiem w miejscu jego zamieszkania,

- Złożenie dokumentów w Ministerstwie Polityki Społecznej w celu otrzymania zgody na przysposobienie dziecka,

- Otrzymanie zgody Ministerstwa Polityki Społecznej na przysposobienie dziecka,

- Złożenie wniosku i dokumentów do sądu. Rozprawa sądowa,

- Otrzymanie orzeczenia sądowego o przysposobieniu dziecka,

- Wystawienie nowego aktu urodzenia dziecka w USC,

- Przekazanie dziecka przysposabiającym,

- Załatwienie dokumentów wyjazdowych,

- Wpis dziecka do ewidencji w urzędzie konsularnym w miejscu zamieszkania.

Czy istnieje możliwość, aby dzieci z Ukrainy były przekazywane do adopcji za granice, np. do Polski?

Tak, dzieci z Ukrainy mogą być przekazywane do adopcji zagranicznej, np. do Polski. Procedura takiej adopcji jest jednakowa dla wszystkich obywateli nieposiadających obywatelstwa ukraińskiego. Zgodnie z informacjami uzyskanymi z Ministerstwa Polityki Społecznej w 2011 roku na Ukrainie zostało przysposobionych 5321 dzieci, z czego 1002 zostało przekazanych do adopcji zagranicznej.

Czy istniejq szczególne regulacje odnoszace się do adopcji ukraińskich dzieci narodowości polskiej mieszkajqcych na Ukrainie?

Nie, nie ma takich szczególnych regulacji odnoszących się do adopcji polskich dzieci mieszkających na Ukrainie. 


\section{Bibliografia}

\section{Akty prawne}

Kodeks małżeński i rodzinny Republiki Białoruś, 9 lipca 1999 r., nr 278-Z, Кодекс о Браке и Семье Республики Беларусь, 9 июля 1999 г. № 278-3, http://www.tamby.info/kodeks/ kobs.htm.

Rozporządzenia Rady Ministrów Republiki Białoruś z 31 stycznia 2007 r., nr 122, ze zm., w sprawie zatwierdzenia przepisów dotyczących koordynacji międzynarodowych procedur adopcyjnych i współdziałania z właściwymi organizacjami państw obcych w ramach procedury, Постановление Совета Министров Республики Беларусь „Об утверждении Положения о порядке согласования процедуры международного усыновления и взаимодействия с компетентными организациями иностранных государств в рамках данной процедуры”, http://newsby.org/documents/ index.htm.

Kodeks cywilny Republiki Litewskiej, Lietuvos Respublikos civilinis kodeksas, https:// www.e-tar.lt/portal/lt/legalAct/TAR.8A39C83848CB.

Opis trybu udzielenia pełnomocnictw akredytowanym instytucjom zagranicznym do działania w zakresie przysposobienia międzynarodowego w Republice Litewskiej zatwierdzony zarządzeniem ministra opieki społecznej i pracy Republiki Litewskiej nr Al-162 z 3 czerwca 2005 r., 2005 m. Birželio 3 d. Lietuvos Respublikos socialinès gerovès ir darbo ministro įsakymu Nr. Al-162 nustatyta tvarka patvirtinta ịgaliojimų suteikimas akredituotoms užsienio institucijoms už veiksmus tarptautinio įvaikinimo srityje Lietuvos Respublikoje, http://www3.lrs.lt/docs2/UDUEYYKQ.PDF.

Kodeks rodzinny Ukrainy z 10 stycznia 2002 r., Сімейний кодекс України Документ 2947-III, http://zakon.rada.gov.ua/laws/show/2947-14.

\section{Strony internetowe}

http://www.child.of.by/. www.vaikoteises.lt. 


\title{
5.2. Monitorowanie losów dziecka z użyciem baz danych w wybranych państwach członkowskich Unii Europejskiej
}

\author{
Monitoring the child's fate with the use of databases \\ in selected European Union members states
}

\begin{abstract}
W opracowaniu podjęto próbę przedstawienia zagadnienia monitorowania losów dzieci w Danii, we Francji, w Niemczech, Wielkiej Brytanii (Anglii) oraz Norwegii. Przeanalizowano system gromadzenia i przechowywania danych dotyczących dzieci, które znajdują się pod opieką instytucji świadczących pomoc oraz wsparcie dla dzieci i ich rodziców.
\end{abstract}

Słowa kluczowe: dzieci, baza danych, dane osobowe, Polska, Szwecja, Wielka Brytania

The paper attempts to present the issue of monitoring the fate of children in Denmark, France, Germany, UK (England) and Norway. The system of collecting and storing data concerning children, which are under the care of institutions providing help and support for children and their parents, was analyzed.

Keywords: children, database, personal data, Poland, Sweden, United Kingdom

\section{Wstęp}

Powszechnie dostępne publikacje (raporty organizacji międzynarodowych, naukowe opracowania porównawcze, informacje zamieszczane na stronach instytucji rządowych poszczególnych państw) dotyczące systemów opieki nad dzieckiem w państwach europejskich, nie zawierają szczegółowych informacji z zakresu organizacji pracy instytucji świadczących pomoc i wsparcie dzieciom i ich rodzinom. A taką informacją jest system gromadzenia i przechowywania danych dotyczących dzieci, które znajdują się lub mogą znaleźć pod opieką instytucji świadczących pomoc i wsparcie dzieciom i ich rodzinom.

Prezentowane opracowanie powstało w wyniku przeglądu baz danych Europejskiego Centrum Badań Parlamentarnych i Dokumentacji (The European Centre for Parliamentary Research and Documentation) oraz analizy odpowiedzi uzyskanych z poszczególnych państw na następujące pytania: 
- Czy w Pana/Pani kraju funkcjonuje centralny lub lokalny system gromadzenia informacji (baza danych) o wszystkich dzieciach w wieku do lat 18 lub o dzieciach z grup ryzyka?

- Jeśli tak, to jak jest zorganizowany?

- Kto ma dostęp do bazy danych i na jakich zasadach?

- Jakie dane są gromadzone?

- Jakie zabezpieczenia chronią bazę przed wyciekiem informacji do osób nieupoważnionych?

Uzyskane odpowiedzi posłużyły do sporządzenia poniższych informacji dotyczących Danii, Francji, Niemiec, Wielkiej Brytanii (Anglii) oraz Norwegii ${ }^{1}$.

\section{Dania}

W 2011 roku rozpoczęto tworzenie ogólnokrajowej bazy (oprzyrządowanie IBM), która nazywa się DUBU - digitalizacja, ochrona dzieci i młodzieży (Digitalisering - Udsatte Børn og Unge $)^{2}$.

Przewiduje się, że budowanie bazy zostanie zakończone pod koniec 2013 roku. W bazie gromadzone są informacje dotyczące dzieci z grup ryzyka, dane o sytuacji rodzinnej dziecka oraz o potrzebach i problemach, jakie ma dziecko. Aktualnie prawie połowa samorządów jest włączona do tej bazy. W Danii dziećmi z grup ryzyka zajmują się asystenci socjalni zatrudniani przez samorządy lokalne. Każdy samorząd ma dostęp tylko do przypadków z jego terenu. Jeżeli rodzina z problemami przenosi się na obszar innego samorządu, nowy samorząd uzyskuje dostęp do danych tej rodziny.

\section{Francja}

We Francji nie ma jednej centralnej lub regionalnej bazy danych zawierającej dane lub informacje umożliwiające identyfikowanie w jakikolwiek sposób osób poniżej 18 roku życia. Baza taka - o charakterze administracyjnym - istnieje tylko w ramach systemu oświaty (systemu szkolnego) i służy zbieraniu informacji związanych z procedurą zapisywania uczniów do szkoły podstawowej (baza uczniów:

1 Opracowanie przygotowano na podstawie ekspertyzy Biura Analiz Sejmowych nr 2039/12 z 15 października 2012 r. autorstwa D. Dziewulaka, J. Szymańczak i M. Mroza zatytułowanej Monitorowanie losów dziecka w państwach Unii Europejskiej.

2 https://www.kombit.dk/dubu. 
Base élèves, $\mathrm{BE})^{3}$, gimnazjum i liceum (krajowa baza uczniowska: Base Nationale des Identifiants Elèves, BNIE) ${ }^{4}$. Dla uczniów z niepowodzeniami szkolnymi, powtarzającymi klasę, u których stwierdzono deficyty dydaktyczno-wychowawcze, stworzono bazę SCONET (SDO) ${ }^{5}$, zawierającą dane dotyczące postępów w nauce.

Utworzenie powyższych baz jest konsekwencją wymogów uregulowań ustawy nr 78-17 z 6 stycznia 1978 r. o urządzeniach informatycznych, plikach danych i wolności (tzw. ustawa o ochronie danych osobowych) ${ }^{6}$. Ustawa reguluje zasady gromadzenia danych osobowych i ich przetwarzania. Instytucją, która czuwa nad przestrzeganiem tych zasad jest Krajowa Komisja ds. Informatyki i Wolności (Commission Nationale de l'Informatique et des Libertés, CNIL) ${ }^{7}$. Na stronie internetowej CNIL czytamy, że informacje znajdujące się w bazie danych o uczniach umieszczone są tam w ściśle określonym celu, a dostęp do tych informacji mają tylko osoby do tego upoważnione. Wśród osób upoważnionych znajdują się: pracownicy administracji szkolnej, nauczyciele, rodzice (tylko w odniesieniu do swoich dzieci), jak również określone osoby z kuratorium, instytucji nadzoru pedagogicznego, gminy (merostwa), sędziowie, policjanci oraz pracownicy administracji podatkowej.

W celu ujawnienia informacji o uczniu, która znajduje się w bazie danych, dyrektor placówki musi na nie uzyskać odpowiednią zgodę rodziców. Wyjątkiem od tej zasady jest udostępnianie danych z bazy dla potrzeb obowiązkowych publicznych badań statystycznych (np. spisu powszechnego).

Podobnie jak w wypadku braku centralnych lub lokalnych baz danych dla osób poniżej 18 roku życia, nie ma także baz uwzględniających osoby z tzw. grup ryzyka lub dzieci ze środowisk zagrożonych (l'enfance en danger).

Instytucją, która we Francji obejmuje opieką dzieci ze środowisk zagrożonych jest Krajowe Centrum Dzieci ze Środowisk Zagrożonych (Observatoire National de l'Enfance en Danger, ONED) ${ }^{8}$ powołane ustawą z 2 stycznia 2004 r. o opiece i ochronie dzieci. Głównym zadaniem ONED jest objęcie profilaktyką pedagogiczno-psychologiczną dzieci zagrożonych oraz zbieranie danych statystycznych

\footnotetext{
3 http://www.education.gouv.fr/cid24413/base-eleves-premier-degre.html.

4 http://retraitbaseeleves.wordpress.com/bnie.

5 http://retraitbaseeleves.wordpress.com/autres-fichiers-de-len/sdo.

6 Loi n ${ }^{\circ}$ 78-17 du 6 janvier 1978 relative à l'informatique, aux fichiers et aux libertés Version consolidée au 27 août 2011, http://www.legifrance.gouv.fr/affichTexte.do?cidTexte=JORFTEXT000000886460.

7 http://www.cnil.fr/.

8 http://oned.gouv.fr/.
} 
związanych z problematyką zagrożenia i przemocy wobec dzieci. Ma ono w każdym departamencie swoje lokalne Centrum (Observatoire Départemental de la Protection de l'enfance, ODPE) ${ }^{9}$, w skład którego wchodzą przedstawiciele samorządu, oświaty, wymiaru sprawiedliwości ds. nieletnich, opieki zdrowotnej (pediatra, psychiatra dziecięcy) oraz innych organizacji i stowarzyszeń społecznych.

\section{Niemcy}

W Niemczech w dniu 1 stycznia $2012 \mathrm{r}$. weszła w życie ustawa o wzmocnieniu aktywnej ochrony dzieci i młodzieży (Gesetz zur Stärkung eines aktiven Schutzes von Kindern und Jugendlichen). Celem ustawy jest stworzenie w Niemczech jednolitych regulacji dotyczących zlecania i przeprowadzania wizyt domowych przeprowadzanych przez Urząd ds. Młodzieży (Jugendamt) oraz kontynuacji opieki powizytacyjnej.

Corocznie przeprowadza się przegląd wszystkich urzędów ds. młodzieży. Przetwarzanie zebranych w związku z tym danych odbywa się zgodnie z § 16 (Utrzymanie tajemnicy) federalnej ustawy statystycznej (Gesetz über die Statistik für Bundeszwecke, nazwa skrócona: Bundesstatistikgesetz). Zgodnie z tym paragrafem zebrane dane jednostkowe tylko w jednoznacznie określonych wyjątkowych przypadkach mogą być przekazane urzędom statystycznym federalnym lub krajowym. Obowiązkowi zachowania tajemnicy podlegają również osoby, które zbierają dane jednostkowe. Zanonimizowany numer identyfikacyjny przypadku służy jedynie do sprawdzenia wiarygodności przeglądu. Po ukończeniu przeglądu numer jest likwidowany.

Federalny Urząd Statystyczny publikuje zebrane wyniki dla Niemiec i dla krajów związkowych w postaci informacji prasowych i zestawień tabelarycznych. Dane istotne regionalnie publikowane są przez statystyczne urzędy krajowe z zachowaniem tajemnicy.

Przekazuje się następujące dane:

- numer identyfikacyjny (bez imienia i nazwiska!),

- ogólne dane dotyczące małoletniego (płeć, wiek, moment dokonania oceny zagrożenia),

- wiek rodziców rodzonych, rodziców adopcyjnych,

- miejsce pobytu małoletniego w momencie dokonania oceny zagrożenia,

9 http://www.odpe.cg29.fr/Observatoire-departemental-de-la-protection-de-l-enfance/L-ODPE-en-Finistere/Organisation-de-l-ODPE. 
- instytucje lub osoby, które powiadomiły o możliwym zagrożeniu dziecka (np.: służby socjalne, urzędy ds. młodzieży, szkoły, lekarze, rodzice, krewni, powiadomienia anonimowe),

- możliwość skorzystania z ustawowych świadczeń pomocy dla dzieci i młodzieży w momencie dokonania oceny zagrożenia.

Nie ma specjalnych regulacji dotyczących bezpieczeństwa zebranych danych. Obowiązują wysokie standardy bezpieczeństwa Federalnego Urzędu Statystycznego i krajowych urzędów statystycznych.

\section{Wielka Brytania (Anglia)}

W Anglii na mocy przepisów ustawy Children Act 2004 zaczęto w 2005 roku tworzyć ogólnokrajową bazę danych - Contact Point, prace zakończono pod koniec 2008 roku. Baza zawierała dane wszystkich dzieci żyjących w Anglii w wieku poniżej 18 roku życia (blisko $11 \mathrm{mln}$ dzieci). Jej celem było umożliwienie komunikacji pomiędzy osobami, które w różnych instytucjach i służbach zajmują się pomocą dzieciom.

Baza została utworzona w odpowiedzi na głośne medialne wydarzenie, jakim była śmierć ośmioletniej dziewczynki Victorii Climbie, która zmarła na skutek długotrwałego maltretowania i głodzenia przez opiekunów (ciotki i partnera ciotki - oboje zostali skazani na karę dożywocia). Sytuacja dziewczynki była znana policji, służbom socjalnym, lokalnemu Kościołowi, organizacjom pozarząadowym zwalczającym przemoc wobec dzieci (m.in. NSPCC), a mimo tego nikt nie podjął skutecznej interwencji i nie pomógł dziecku.

Utworzenie bazy kosztowało około 270 mln funtów, a jej roczne utrzymanie, gdy już funkcjonowała w 2009 roku około 41 mln funtów. Baza funkcjonowała w 150 jednostkach władz lokalnych, dostęp do bazy miało blisko 330 tys. osób, które w pracy zawodowej mają kontakt z dziećmi (policjanci, lekarze, nauczyciele, pracownicy socjalni). Władze lokalne decydowały o upoważnieniu konkretnych osób do dostępu do bazy (każdy upoważniony miał indywidualny PIN i hasło). W bazie gromadzono informacje dotyczące dziecka: imię, nazwisko, płeć, data urodzenia, numer identyfikacyjny, imiona i nazwiska rodziców i opiekunów oraz ich dane kontaktowe, przebieg kariery edukacyjnej dziecka, informacje o sytuacji rodzinnej (np. nadużywanie alkoholu przez rodziców), dane osób, które zawodowo stykają się z dzieckiem.

Projekt utworzenia bazy Contact Point i samo jej utworzenie spotkało się z falą krytyki społecznej (m.in. rodziców, obrońców praw człowieka, Brytyjskiego Sto- 
warzyszenia Lekarzy, Rzecznika Praw Dziecka). Zdaniem krytyków gromadzenie dużej liczby danych wrażliwych o dzieciach jest niezgodne z Konwencją o prawach dziecka i Konwencją o ochronie praw człowieka i podstawowych wolności, łamie wolności obywatelskie, łamie prawo do prywatności, zagraża wartościom rodzinnym, zagraża władzy rodzicielskiej i naraża dzieci na niebezpieczeństwo (np. pedofile mogą włamywać się do bazy i poszukiwać potencjalnych ofiar).

Decyzją rządu w sierpniu 2010 roku baza została zlikwidowana.

\section{Norwegia}

W Norwegii obowiązuje restrykcyjna ustawa chroniąca dane osobowe (Act of 14. April 2000 No. 31). Zgodnie z jej przepisami nie można tworzyć ogólnokrajowych baz gromadzących dane osobowe. Instytucje świadczące pomoc socjalną oraz służby ochrony dziecka mają własne systemy gromadzenia informacji o swoich klientach. Korzystanie z tych baz i przekazywanie informacji określają restrykcyjne zasady.

\section{Bibliografia}

\section{Akty prawne}

Children Act 2004, http://www.legislation.gov.uk/ukpga/2004/31/notes/division/1/1, http:// webarchive.nationalarchives.gov.uk/20120107062850/https://www.education.gov.uk/ publications.

Ustawa nr 78-17 z 6 stycznia 1978 r. o urządzeniach informatycznych, plikach danych i wolności (tzw. ustawa o ochronie danych osobowych), Loi n 78-17 du 6 janvier 1978 relative à l'informatique, aux fichiers et aux libertés Version consolidée au 27 août 2011, http://www.legifrance.gouv.fr/affichTexte.do?cidTexte=JORFTEXT000000886460

Federalna ustawa o wzmocnieniu aktywnej ochrony dzieci i młodzieży, Gesetz zur Stärkung eines aktiven Schutzes von Kindern und Jugendlichen (Bundeskinderschutzgesetz, BKiSchG), https://www.bgbl.de/xaver/bgbl/start.xav?start=//*\%5B@attr_id=\%27 bgbl111s2975.pdf\%27\%5D\#_bgbl__\%2F\%2F*\%5B\%40attr_id\%3D\%27bgbl111s2975. pdf\%27\%5D_1535960048882.

Fedralna ustawa o statystykach, Gesetz über die Statistik für Bundeszwecke, https://www. gesetze-im-internet.de/bstatg_1987/.

Ustawa o ochronie danych osobowych, Act of 14 April 2000 No. 31 relating to the processing of personal data (Personal Data Act), http://app.uio.no/ub/ujur/oversatte-lover/ data/lov-20000414-031-eng.pdf. 


\section{Strony internetowe}

https://ecprd.secure.europarl.europa.eu/ecprd/public/page/about.

https://www.kombit.dk/dubu.

http://www.education.gouv.fr/cid24413/base-eleves-premier-degre.html.

http://retraitbaseeleves.wordpress.com/bnie/.

http://retraitbaseeleves.wordpress.com/autres-fichiers-de-len/sdo/.

http://www.cnil.fr/.

http://oned.gouv.fr/.

http://www.odpe.cg29.fr/Observatoire-departemental-de-la-protection-de-l-enfance/L-OD-

PE-en-Finistere/Organisation-de-l-ODPE. 


\title{
5.3. Monitorowanie przez polskie wyższe uczelnie karier zawodowych absolwentów
}

\author{
Graduate career monitoring by Polish institutions \\ of higher education
}

W opracowaniu zaprezentowano wyniki badania przeprowadzonego przez Biuro Analiz Sejmowych w okresie grudzień 2013 roku - styczeń 2014 roku dotyczącego wywiązywania się przez polskie uczelnie wyższe z nałożonego w 2011 roku obowiązku prowadzenia monitoringu karier zawodowych swoich absolwentów. W opracowaniu przedstawiono m.in. kwestie związane z: terminem, od kiedy uczelnie prowadzą lub zamierzają prowadzić taki monitoring, zakresem pozyskiwanych informacji, podmiotami, do których przekazywane są wyniki monitoringu, oraz wykorzystaniem tych wyników do wprowadzania zmian w programach kształcenia.

Słowa kluczowe: ustawa, kariera zawodowa, absolwenci, monitoring

The paper presents the results of a study conducted by the Bureau of Research of the Chancellery of the Sejm between December 2013 and January 2014 in institutions of higher education. In 2011 obligatory monitoring of professional careers of graduates was introduced in Poland. The paper investigates, inter alia, from which year Polish universities started (or plan to start) such monitoring, what information is gathered, who receives the results of the monitoring and whether they are used to introduce changes to the universities' curricula.

Keywords: law, professional career, graduates, monitoring

\section{Wstęp ${ }^{1}$}

W 2011 roku do ustawy z 27 lipca 2005 r. - Prawo o szkolnictwie wyższym (dalej: ustawa) wprowadzono nowy art. 13a, zgodnie z którym uczelnie wyższe zostały

1 Opracowanie przygotowano na podstawie ekspertyzy Biura Analiz Sejmowych nr 2821/13 z 31 stycznia 2014 r. D. Dziewulaka, A. Grycuka, P. Russela, Z. Wołodkiewicza-Donimirskiego zatytułowanej Informacja na temat, w jaki sposób uczelnie wyższe realizują obowiązek określony $w$ art. 13a ustawy z dnia 27 lipca 2005 r. Prawo o szkolnictwie wyższym (Dz.U. Nr 164 poz. 1365) w zakresie monitorowania losów swoich absolwentów? oraz opracowania tychże autorów Monitorowanie karier zawodowych absolwentów przez polskie uczelnie wyższe w świetle wyników badania Biura Analiz Sejmowych, „Analizy BAS” 2014, nr 5(109), s. 1-7. 
zobowiązane do monitorowania karier zawodowych swoich absolwentów w celu dostosowania kierunków studiów i programów kształcenia do potrzeb rynku pracy, w szczególności po trzech i pięciu latach od dnia ukończenia studiów ${ }^{2}$. Wykorzystanie przez uczelnie wyników monitorowania karier zawodowych absolwentów stanowi również od 2011 roku jedno z kryteriów oceny instytucjonalnej dokonywanej przez Polską Komisję Akredytacyjną w zakresie dostosowania oferty programowej uczelni do potrzeb rynku pracy3.

Biuro Analiz Sejmowych (BAS), działając na zlecenie Komisji Edukacji, Nauki i Młodzieży, przeprowadziło w okresie od 17 grudnia 2013 roku do 10 stycznia 2014 roku badanie ilościowe, którego celem było uzyskanie odpowiedzi na pytanie, w jaki sposób uczelnie wyższe realizują obowiązek określony w art. 13a ustawy, a w szczególności:

- czy uczelnia prowadziła monitoring losów absolwentów przed wejściem w życie art. 13a ustawy?

- czy uczelnia, zgodnie z art. 13a, monitoruje losy swoich absolwentów?

- od którego roku akademickiego jest lub będzie prowadzony monitoring losów absolwentów?

- jaki odsetek absolwentów wziął udział w ostatnim przeprowadzonym badaniu?

- jaki jest zakres informacji pozyskiwanych przez uczelnie w wyniku monitoringu?

- po jakim okresie, od dnia ukończenia studiów, uczelnia prowadzi lub zamierza prowadzić monitoring losów absolwentów?

- do kogo przekazywane są wyniki monitoringu?

- czy uczelnia ma wdrożony system implementacji wyników monitoringu w realizację zmian w dydaktycznej części statutowych zadań uczelni?

- kiedy uczelnia uzyskuje zgodę absolwentów na przetwarzanie ich danych osobowych dla potrzeb prowadzonego monitoringu?

Biuro Analiz Sejmowych w celu uzyskania odpowiedzi na te pytania opracowało projekt badania i przygotowało kwestionariusz ankiety internetowej. Prośbę o jej wypełnienie otrzymały władze rektorskie 394 uczelni (96 publicz-

2 Ustawa z 18 marca 2011 r. o zmianie ustawy - Prawo o szkolnictwie wyższym, ustawy o stopniach naukowych i tytule naukowym oraz o stopniach i tytule w zakresie sztuki oraz o zmianie niektórych innych ustaw, Dz.U. nr 84, poz. 455.

3 Zob. § 2 ust. 4 rozporządzenia Ministra Nauki i Szkolnictwa Wyższego z 29 września 2011 r. w sprawie warunków oceny programowej i oceny instytucjonalnej, Dz.U. nr 207, poz. 1232. 
nych i 298 niepublicznych) ${ }^{4}$. Badanie zostało poprzedzone pilotażem. W badaniu wzięło udział 198 uczelni - 76 publicznych (79,2\% szkół wyższych należących do tej kategorii) oraz 122 niepubliczne (40,9\%). Średnia zwrotność ankiet wyniosła 50,3\%. Jednocześnie w uczelniach, które wzięły udział w badaniu, w roku akademickim 2012/2013 studiowało 1,098 mln studentów, tj. 65\% ogółu osób studiujących w Polsce.

W niniejszym artykule zaprezentowano wyniki badania przeprowadzonego przez BAS. Struktura tekstu odzwierciedla układ ankiety i jest zgodna z treścią postawionych pytań badawczych.

Przedstawione zagadnienia mogą być szczególnie istotne w świetle nowych propozycji legislacyjnych przedstawionych przez rząd w styczniu 2014 roku, które zakładają likwidację obowiązku monitorowania przez uczelnie karier zawodowych ich absolwentów.

\section{Prowadzenie monitoringu losów absolwentów przed wejściem w życie art. 13a ustawy z 27 lipca 2005 r. - Prawo o szkolnictwie wyższym}

Wykres 4. Odsetek uczelni, które prowadziły monitoring losów absolwentów przed wejściem w życie art. 13a ustawy - Prawo o szkolnictwie wyższym

uczelnie, które nie prowadziły monitoringu przed wejściem w życie art. 13a ustawy $66,7 \%$

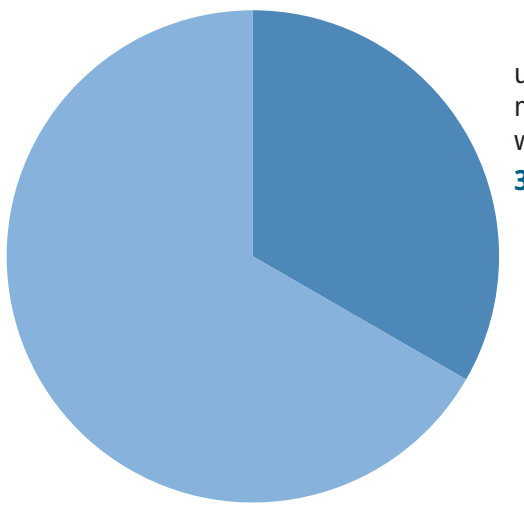

uczelnie, które prowadziły monitoring przed wejściem w życie art. 13a ustawy $33,3 \%$

4 Prośbę o wypełnienie ankiety wysłano do 400 uczelni wyższych na podstawie wykazów otrzymanych z Ministerstwa Nauki i Szkolnictwa Wyższego, jednak 6 listów adresowanych do uczelni niepublicznych zostało zwróconych do Biura Analiz Sejmowych. 
Ustawowy obowiązek monitorowania przez uczelnie karier zawodowych ich absolwentów wprowadzony przez dodanie art.13a w ustawie wszedł w życie w dniu 1 października 2011 roku. Spośród 198 uczelni, które udzieliły odpowiedzi na pytanie, czy uczelnia prowadziła monitoring losów absolwentów przed wprowadzeniem tego obowiązku, 66 uczelni (33,3\%) odpowiedziało twierdząco (wykres 4).

Uczelnie publiczne i niepubliczne wykazały prawie taką samą skłonność do wprowadzenia dobrowolnego monitoringu, tj. takiego, który mógł być realizowany przed wejściem w życie ustawowego obowiązku w tym zakresie. Na 122 uczelnie niepubliczne, które wypełniły ankietę BAS, 41 szkół (33,6\%) prowadziło monitoring losów swoich absolwentów przed 1 października 2011 roku. W wypadku uczelni publicznych odsetek ten był zbliżony i wyniósł 32,9\% (25 z 76).

\section{Wypełnianie przez polskie uczelnie ustawowego obowiązku w zakresie monitorowania losów zawodowych swoich absolwentów}

Spośród 198 uczelni, które udzieliły odpowiedzi na pytanie, czy zgodnie z art. 13a ustawy monitorują kariery zawodowe swoich absolwentów, 157 (79,3\%), odpowiedziało, że wdrożyło taki monitoring, a 41 uczelni (20,7\%) wskazało, iż jest w trakcie jego wdrażania (wykres 5). Nie uzyskano ani jednej odpowiedzi negatywnej na to pytanie, tj. wskazującej, że uczelnia ani nie monitoruje, ani nie jest w trakcie wdrażania monitoringu losów swoich absolwentów.

Wykres 5. Odsetek uczelni, które wdrożyły monitoring karier zawodowych swoich absolwentów

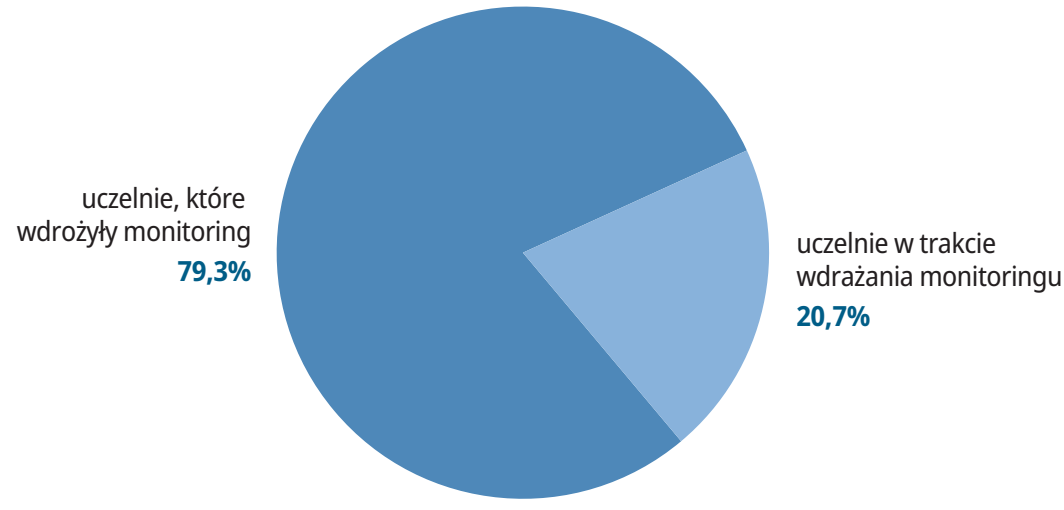

Źródło: badanie ankietowe Biura Analiz Sejmowych, grudzień 2013 r. - styczeń 2014 r. 
Uczelnie publiczne szybciej wdrożyły ustawowy obowiązek prowadzenia monitoringu losów absolwentów. Na 76 uczelni publicznych, które wzięły udział w badaniu BAS, aż 66 szkół (86,8\%) odpowiedziało, że wdrożyło monitoring, a tylko 10 (13,2\%) wskazało, iż jest w trakcie jego implementacji. Wśród 122 uczelni niepublicznych odsetek odpowiedzi wyniósł odpowiednio 74,6\% (91 uczelni) i 25,4\% (31).

W ankiecie BAS znalazło się również pytanie, od którego roku akademickiego jest lub będzie prowadzony monitoring losów absolwentów, zgodnie $\mathrm{z}$ art. 13a ustawy. Spośród 198 uczelni, które udzieliły odpowiedzi na to pytanie, 103 uczelnie (52\%) odpowiedziały, że wdrożyły monitoring w roku akademickim 2011/2012, 57 uczelni (28,8\%) zaś odpowiedziało, iż zrobiło to w roku akademickim 2012/2013. W przypadku 26 uczelni (13,1\%) monitoring zostanie wdrożony w bieżącym roku akademickim (2013/2014). Dwanaście uczelni wprowadzi w pełni monitoring w przyszłości: dla siedmiu będzie to rok akademicki 2014/2015, a dla pięciu okres po roku akademickim 2014/2015 (wykres 6).

Wykres 6. Odsetek uczelni według roku akademickiego, od którego jest lub będzie prowadzony monitoring losów zawodowych absolwentów zgodnie z art. 13a ustawy - Prawo o szkolnictwie wyższym

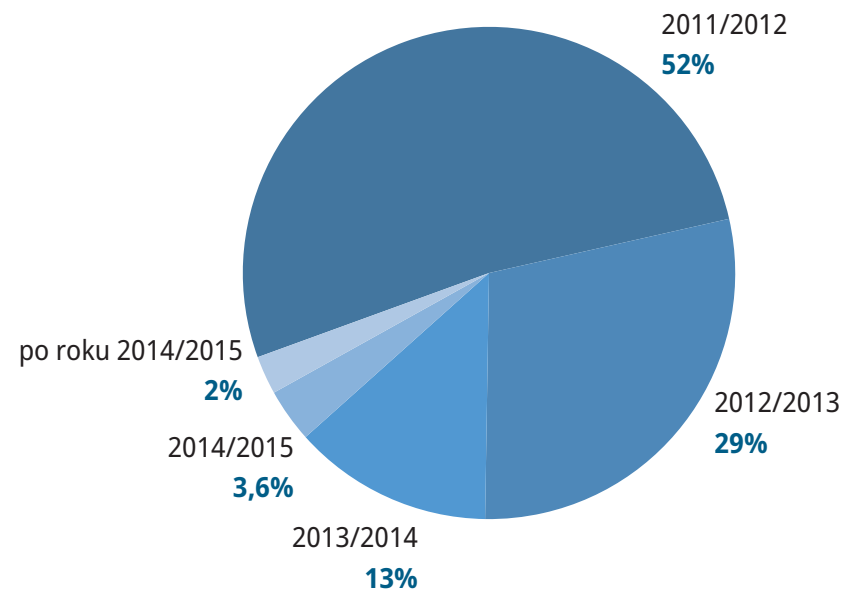

Źródło: badanie ankietowe Biura Analiz Sejmowych, grudzień 2013 r. - styczeń 2014 r.

Jak widać z przedstawionych danych, ponad połowa przebadanych uczelni wdrożyła monitoring w roku akademickim 2011/2012. Należy domniemywać, że było to spowodowane tym, iż od 1 października 2011 roku wszedł w życie wspomniany ustawowy obowiązek monitorowania przez uczelnie karier zawodo- 
wych ich absolwentów wprowadzony przez dodanie art. 13a w ustawie - Prawo o szkolnictwie wyższym. Należy jednak pamiętać, że w tej grupie znalazły się również uczelnie, które monitorowały kariery zawodowe swoich absolwentów przed wejściem w życie obowiązku ustawowego.

Wyniki badania BAS wskazują, że uczelnie publiczne w szybszym tempie wywiązują się z wypełniania ustawowego obowiązku dotyczącego prowadzenia monitoringu losów absolwentów. W ciągu trzech pierwszych lat akademickich od momentu wprowadzenia art. 13a (tj. 2011/2012, 2012/2013 i 2013/2014) na 76 uczelni publicznych, które wzięły udział w badaniu, monitoring będzie wdrożony w 74 jednostkach (97,4\%). Natomiast na 122 uczelnie niepubliczne monitoring zostanie wprowadzony w 112 uczelniach (91,8\%).

\section{Odsetek absolwentów biorących udział w monitoringu prowadzonym przez uczelnie}

Na pytanie, jaki odsetek wszystkich absolwentów danego rocznika wziął udział w ostatnim przeprowadzonym przez uczelnię badaniu, szczegółowej odpowiedzi udzieliło 120 (60,6\%) szkół wyższych, natomiast 78 uczelni (39,4\%) wybrało odpowiedź „trudno określić”. Największą grupą podmiotów, która udzieliła odpowiedzi „trudno określić”, stanowią uczelnie będące w trakcie wdrażania monitoringu oraz planujące to zrobić w kolejnych latach. W ostatnim badaniu przeprowadzonym przez uczelnie wyższe wzięło udział średnio 41\% absolwentów (w tym w uczelniach publicznych 37,1\% absolwentów, a w uczelniach niepublicznych - 43,8\%). Mediana wyniosła 35\%.

Wśród 120 uczelni, które określiły procent absolwentów, którzy wzięli udział w ostatnim przeprowadzonym badaniu, 79 osiągnęło zwrotność na poziomie nieprzekraczającym 50\% (wykres 7). Jednocześnie w badanej grupie znalazło się 15 uczelni, które osiągnęły zwrotność powyżej 80\%, przy czym część ankietowanych wskazywała, że odsetek absolwentów biorących udział w badaniach jest tym niższy, im dłuższy jest okres, który upłynął od momentu opuszczenia przez nich murów uczelni.

Jak wynika z danych przedstawionych na wykresie 4 oraz komentarzy zgłaszanych przez respondentów w ankiecie BAS, duża część polskich uczelni nie uzyskuje satysfakcjonującego ich poziomu zwrotności ankiet. Przyczynami niskiej zwrotności mogą być zarówno czynniki wewnętrzne, związane z organizacją przez uczelnie procesu monitoringu karier zawodowych swoich absolwentów, jak też rozwiązania prawne - wprowadzone w 2011 roku przepisy art. 13a nie dały bowiem uczelniom odpowiednich narzędzi władczych, które pozwoliłyby na 
Wykres 7. Liczba uczelni, dla których zwrotność ankiet kształtowała się w poszczególnych przedziałach

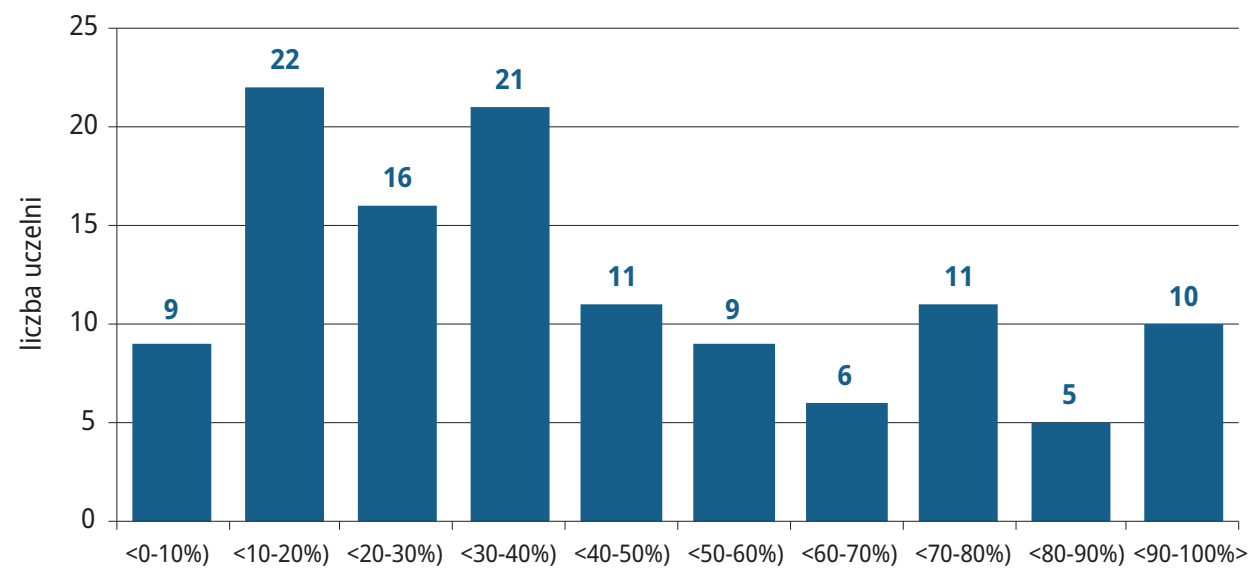

Źródło: badanie ankietowe Biura Analiz Sejmowych, grudzień 2013 r. - styczeń 2014 r.

zobligowanie absolwentów do uczestnictwa w monitoringu $u^{5}$. Jednocześnie część uczelni w dalszym ciągu doskonali - na podstawie pierwszych doświadczeń - nie tylko stosowane narzędzia badawcze, ale również poszukuje nowych rozwiązań, mogących zwiększyć odsetek absolwentów biorących udział w monitoringu.

\section{Zakres informacji pozyskiwanych przez uczelnie w wyniku prowadzonego monitoringu karier zawodowych swoich absolwentów}

Artykuł 13a ustawy nie precyzuje, jakie dane powinna pozyskać uczelnia, prowadząc monitoring karier zawodowych swoich absolwentów. Przeprowadzone przez BAS badanie pokazało, że wśród najczęściej zadawanych absolwentom pytań są kwestie dotyczące: dalszego kształcenia absolwenta po zakończeniu studiów, obecnego statusu na rynku pracy, związku wykonywanej pracy zawodowej z ukończonym kierunkiem studiów, oceny stopnia, w jakim uczelnia przygotowała go do wejścia na rynek pracy, oraz formy zatrudnienia. Pyta o to ponad 75\% uczelni (tabela 24).

5 H. Izdebski, J.M. Zieliński, Prawo o szkolnictwie wyższym. Komentarz, Wolters Kluwer Polska, Warszawa 2013, s. 72. 
Tabela 24. Zagadnienia najczęściej poruszane w pytaniach zadawanych przez uczelnie wyższe podczas prowadzonego monitoringu absolwentów

\begin{tabular}{|l|c|}
\hline & odsetek odpowiedzi \\
\hline Dalsze kształcenie po zakończeniu studiów & 91,41 \\
\hline Status absolwenta na rynku pracy & 90,91 \\
\hline Czy wykonywana praca ma związek z ukończonym kierunkiem studiów? & 90,91 \\
\hline $\begin{array}{l}\text { Ocena absolwenta, w jakim stopniu uczelnia przygotowała go do } \\
\text { wejścia na rynek pracy }\end{array}$ & 85,86 \\
\hline Forma zatrudnienia & 77,78 \\
\hline Czy absolwent podjął pracę zarobkową przed ukończeniem studiów? & 69,19 \\
\hline $\begin{array}{l}\text { Okres, jaki upłynął od momentu zakończenia studiów przez absolwenta } \\
\text { do podjęcia pracy }\end{array}$ & 68,18 \\
\hline Rodzaj umowy, na podstawie której świadczona jest praca & 65,15 \\
\hline Sposób znalezienia pracy & 62,12 \\
\hline Czy absolwent pracuje w kraju, czy za granicą? & 57,58 \\
\hline $\begin{array}{l}\text { Jaki rodzaj działalności prowadzi firma/instytucja, w której absolwent } \\
\text { pracuje? }\end{array}$ & 56,06 \\
\hline Czy wykonywana praca satysfakcjonuje absolwenta? & 45,96 \\
\hline $\begin{array}{l}\text { Miejsce pracy w kraju (np. w miejscu stałego zamieszkania, ukończenia } \\
\text { studiów) }\end{array}$ & 44,44 \\
\hline \begin{tabular}{l} 
Wysokość otrzymywanego wynagrodzenia \\
\hline $\begin{array}{l}\text { Jaka jest wielkość zatrudnienia w firmie/instytucji, w której absolwent } \\
\text { pracuje? }\end{array}$
\end{tabular} & 39,39 \\
\hline Czy absolwent był zarejestrowany w powiatowym urzędzie pracy? & 29,29 \\
\hline Liczba godzin pracy tygodniowo & 21,72 \\
\hline Jak długo absolwent był zarejestrowany w powiatowym urzędzie pracy? & 10,10 \\
\hline
\end{tabular}

Źródło: badanie ankietowe Biura Analiz Sejmowych, grudzień 2013 r. - styczeń 2014 r.

Wśród pozostałych pytań zadawanych przez uczelnie należy wymienić:

- motywy podjęcia przez absolwenta pracy niezgodnej z uzyskanym wykształceniem,

- czy absolwent wybrałby tę samą uczelnię i/lub kierunek studiów po raz kolejny,

- czy absolwent poleciłby swoją uczelnię osobom, które chcą podjąć studia wyższe,

- prośby o wskazanie wad systemu kształcenia własnej uczelni z perspektywy aktywnego uczestnika rynku pracy,

- propozycje i sugestie dotyczące zmian w programie studiów, które ukończył absolwent, 
- pytania dotyczące oceny poszczególnych elementów programu nauczania, m.in. przydatności praktyk zawodowych oraz jakości lektoratów języków obcych,

- deficyt, jakiej wiedzy odczuwa absolwent w obecnym miejscu pracy,

- czy absolwent zamierza poszukiwać pracy za granicą,

- powody założenia własnej firmy (rozpoczęcia własnej działalności gospodarczej) lub plany założenia własnej firmy w przyszłości,

- powody niepodjęcia przez absolwenta pracy zawodowej,

- angażowanie się podczas studiów w działalność społeczną i wolontariat,

- „dziedziczenie” przez absolwenta zawodu wykonywanego przez rodziców.

Badanie pokazało również, że zakres danych pozyskiwanych przez uczelnie publiczne jest szerszy niż uczelni niepublicznych. Przykładowo: uczelnie publiczne ponaddwukrotnie częściej pytają swoich absolwentów o wysokość wynagrodzenia oraz miejsce ich zatrudnienia na terenie Polski.

\section{Częstotliwość prowadzenia przez uczelnie monitoringu karier zawodowych swoich absolwentów}

Zgodnie z art.13a. ustawy, uczelnie powinny monitorować kariery zawodowe swoich absolwentów w szczególności po trzech i pięciu latach od dnia ukończenia studiów. Określenie „monitoring” wskazuje na permanentny charakter tego procesu, który w konsekwencji powinien przyczynić się do poprawy jakości kształcenia studentów i ich lepszego przygotowania do dynamicznie zmieniającego się rynku pracy.

Tabela 25. Okres od dnia ukończenia studiów przez absolwenta, po jakim uczelnia prowadzi lub zamierza prowadzić monitoring

\begin{tabular}{|c|l|c|c|c|}
\hline \multirow{2}{*}{ Lp. } & \multirow{2}{*}{$\begin{array}{c}\text { Po jakim okresie od dnia ukończenia studiów } \\
\text { prowadzony jest monitoring }\end{array}$} & $\begin{array}{c}\text { Szkoły } \\
\text { publiczne }\end{array}$ & $\begin{array}{c}\text { Szkoły } \\
\text { niepubliczne }\end{array}$ & Razem \\
\cline { 3 - 5 } & \multicolumn{1}{|c|}{ w ciągu miesiąca od dnia ukończenia studiów } & 12 & 29 & 41 \\
\hline 2. & po 6 miesiącach od dnia ukończenia studiów & 19 & 40 & 59 \\
\hline 3. & po 1 roku od dnia ukończenia studiów & 41 & 33 & 74 \\
\hline 4. & po 3 latach od dnia ukończenia studiów & 71 & 91 & 162 \\
\hline 5. & po 5 latach od dnia ukończenia studiów & 68 & 81 & 149 \\
\hline 6. & w innych terminach & 7 & 9 & 16 \\
\hline
\end{tabular}

* Można było zaznaczyć więcej niż jedną odpowiedź.

Źródło: badanie ankietowe Biura Analiz Sejmowych, grudzień 2013 r. - styczeń 2014 r. 
Jak wynika z przeprowadzonego przez Biuro Analiz Sejmowych badania, nie wszystkie uczelnie spośród 198 szkół wyższych, które wypełniły ankietę, prowadzą lub zamierzają prowadzić monitoring w okresach wymaganych przez ustawę (tabela 25). Jednocześnie istnieje duża grupa uczelni, która prowadzi lub zamierza prowadzić monitoring w innych (krótszych) terminach niż określone w art. 13a ustawy.

Jeśli chodzi o inne terminy prowadzenia monitoringu (pkt 6 tabeli 25), ankietowane uczelnie najczęściej wskazywały m.in.:

- w ciągu dwóch tygodni/miesiąca przed ukończeniem studiów,

- po zaliczeniu przez studenta ostatniego semestru studiów,

- przed obroną pracy dyplomowej lub egzaminem dyplomowym,

- w momencie odbioru dyplomu ukończenia uczelni,

- w momencie podpisania karty obiegowej przez absolwenta,

- w trakcie ostatniego roku studiów (I stopnia, II stopnia oraz jednolitych studiów magisterskich) ${ }^{6}$,

- po dwóch latach od dnia ukończenia studiów,

- w terminach wynikających z potrzeb uczelni.

Podsumowując, należy wskazać, że znaczna część uczelni rozpoczyna monitoring karier zawodowych swoich absolwentów w terminach znacznie krótszych niż trzy lata. Niektóre robią to nawet tuż przed obroną pracy dyplomowej (czyli de facto, kiedy nie są oni jeszcze formalnie absolwentami). Można domniemywać, że uczelnie uznały, iż trzyletni okres określony w ustawie jest zbyt długi i zmniejsza prawdopodobieństwo uzyskania wiarygodnych danych na temat losów zawodowych ich absolwentów, które pozwoliłyby wykorzystać wyniki monitoringu na przykład do dostosowania programów kształcenia do potrzeb rynku pracy.

\section{Sposób upowszechnienia wyników monitoringu}

Biuro Analiz Sejmowych zapytało również, do kogo przekazywane są wyniki prowadzonego przez uczelnie monitoringu karier zawodowych ich absolwentów. Odpowiedzi przedstawiono w tabeli 26.

W kategorii „innych podmiotów” (pkt 7 tabeli 26) ankietowane szkoły wyższe najczęściej wskazywały:

- senat uczelni,

- komisje senackie (ds. dydaktyki, jakości kształcenia lub nauki),

6 Badanie dotyczy aktywności podejmowanej podczas studiów, satysfakcji z uzyskanego wykształcenia oraz oceny programu studiów i efektów kształcenia. 
Tabela 26. Adresaci wyników monitoringu karier zawodowych prowadzonego przez polskie uczelnie

\begin{tabular}{|c|c|c|c|c|}
\hline \multirow[b]{2}{*}{ Lp. } & \multirow[b]{2}{*}{ Adresaci wyników monitoringu } & \multicolumn{3}{|c|}{ Liczba odpowiedzi (\%)* } \\
\hline & & $\begin{array}{l}\text { Uczelnie } \\
\text { publiczne }\end{array}$ & $\begin{array}{l}\text { Uczelnie } \\
\text { niepubliczne }\end{array}$ & Razem \\
\hline 1. & władze uczelni & $76(100 \%)$ & $117(95,9 \%)$ & $193(97,5 \%)$ \\
\hline 2 & $\begin{array}{l}\text { opinia publiczna (np. przez informację } \\
\text { na stronie internetowej uczelni) }\end{array}$ & $32(42,1 \%)$ & $24(19,7 \%)$ & $56(28,3 \%)$ \\
\hline 3. & pełnomocnik rektora ds. jakości kształcenia & $12(15,8 \%)$ & $37(30,3 \%)$ & $49(24,7 \%)$ \\
\hline 4. & samorząd studentów & $7(9,2 \%)$ & $26(21,3 \%)$ & $33(16,7 \%)$ \\
\hline 5. & Ministerstwo Nauki i Szkolnictwa Wyższego & $1(1,3 \%)$ & $5(4,1 \%)$ & $6(3 \%)$ \\
\hline 6. & Rzecznik Praw Absolwenta & $0(0 \%)$ & $0(0 \%)$ & $0(0 \%)$ \\
\hline 7. & inne podmioty & $20(26,3 \%)$ & $18(14,8 \%)$ & $38(19,2 \%)$ \\
\hline
\end{tabular}

* Można było zaznaczyć więcej niż jedną odpowiedź.

Źródło: badanie ankietowe Biura Analiz Sejmowych, grudzień 2013 r. - styczeń 2014 r.

- konwent uczelni,

- dziekanów, prodziekanów, dyrektorów instytutów,

- pełnomocników ds. systemu zapewniania jakości kształcenia,

- uczelniane i wydziałowe komisje (zespoły) ds. jakości i programów kształcenia,

- uczelniane biura karier,

- rzecznika prasowego uczelni,

- jednostki zajmujące się marketingiem i promocją uczelni,

- zainteresowanych pracowników uczelni,

- kandydatów na studia, studentów i absolwentów,

- Polską Komisję Akredytacyjną,

- wojewódzkie urzędy pracy (Kraków, Poznań, Bydgoszcz),

- pracodawców.

Jak widać z przedstawionych danych, wyniki monitoringu najczęściej przekazywane są władzom uczelni, opinii publicznej oraz pełnomocnikom rektora ds. jakości kształcenia. Jednocześnie należy zwrócić uwagę, że uczelnie publiczne ponaddwukrotnie częściej niż niepubliczne przekazują wyniki prowadzonego monitoringu karier zawodowych swoich absolwentów szeroko rozumianej opinii publicznej. Z kolei uczelnie niepubliczne znacznie częściej dzielą się wynikami monitoringu z samorządem studentów i pełnomocnikiem rektora ds. jakości kształcenia.

Należy także zwrócić uwagę, że zgodnie z art. 46d ustawy w system monitoringu karier absolwentów został także włączony - ustanowiony w 2011 roku - Rzecz- 
nik Praw Absolwenta (RPA). Jest on powoływany przez ministra właściwego do spraw szkolnictwa wyższego i działa przy Radzie Głównej Nauki i Szkolnictwa Wyższego ${ }^{7}$. Rzecznik współdziała z Radą w zakresie ograniczenia barier w dostępie do wykonywania zawodu zgodnego z kierunkiem studiów absolwenta. W tym celu powinien on analizować sytuację absolwentów na rynku pracy i stopień ich dostępu do określonych zawodów oraz przedstawiać odpowiednie wnioski Radzie i ministrowi właściwemu do spraw szkolnictwa wyższego ${ }^{8}$. Biorąc to pod uwagę, zastanawiać może fakt, że w świetle wyników badania żadna ze 198 ankietowanych uczelni nie przekazuje wyników monitoringu karier zawodowych swoich absolwentów do Rzecznika Praw Absolwenta.

\section{Wdrożenie systemu implementacji wyników monitoringu w realizację zmian w dydaktycznej części statutowych zadań uczelni}

Zgodnie z art. 13a ustawy rezultaty prowadzonego przez uczelnie monitoringu powinny być wykorzystywane do dostosowania kierunków studiów i programów kształcenia do potrzeb rynku pracy. Wśród 198 ankietowanych uczelni ponad połowa $(56,1 \%)$ odpowiedziała twierdząco na pytanie o posiadanie systemu implementacji wyników monitoringu absolwentów, a 43,9\% ankietowanych stwierdziło, że nie wdrożyło jeszcze takiego systemu (wykres 8).

Do kilkunastu uczelni, które wypełniły ankietę BAS i wskazały, że mają system implementacji wyników monitoringu, zwrócono się dodatkowo drogą elektroniczną z prośbą o podanie przykładów konkretnych rozwiązań w tym zakresie. Wśród otrzymanych odpowiedzi można wymienić m.in.:

- wdrożenie zasady częściowego prowadzenia zajęć przez praktyków z otoczenia biznesowego uczelni,

- wprowadzenie w ramach studiów I i II stopnia pilotażowego przedmiotu przygotowanego i realizowanego przez pracowników przedsiębiorstwa, które jest partnerem uczelni,

- wprowadzenie do oferty studiów przedmiotów umożliwiających studentom rozwój tzw. kompetencji miękkich,

- wprowadzenie sposobu zaliczania niektórych przedmiotów wymagających od studentów: współpracy w grupie, prezentacji/autoprezentacji, organizacji pracy własnej, komunikatywności,

$7 \quad$ H. Izdebski, J.M. Zieliński, Prawo, dz.cyt., s. 72 i 158.

8 Artykuł 46d ustawy z 7 lipca 2005 r. - Prawo o szkolnictwie wyższym, Dz.U. 2012, poz. 572. 
Wykres 8. Odsetek uczelni, które wdrożyły system implementacji wyników monitoringu w realizację zmian w dydaktycznej części swoich zadań statutowych

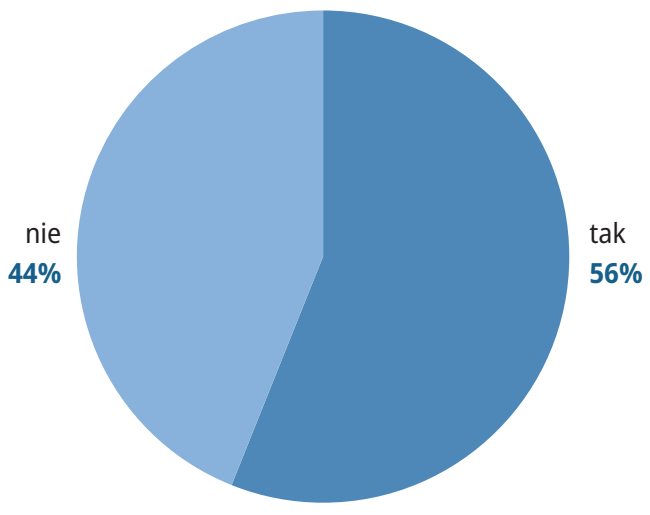

Źródło: badanie ankietowe Biura Analiz Sejmowych, grudzień 2013 r. - styczeń 2014 r.

- wprowadzanie do oferty studiów przedmiotów, podczas których studenci mogą pracować na specjalistycznym oprogramowaniu wykorzystywanym w danej branży,

- $\quad$ wprowadzenie szkoleń językowych z zakresu technicznego języka obcego realizowanych zarówno w ramach lektoratów, jak i dodatkowe kursy,

- dokonanie zmian w strukturach organizacyjnych wydziałów (np. zamykanie, łączenie i tworzenie zakładów/ katedr),

- wprowadzenie dodatkowego przedmiotu przygotowującego do egzaminów na aplikacje prawnicze.

Reasumując, należy wskazać, że blisko 44\% polskich uczelni nie ma jeszcze systemu, który pozwalałby przekładać wyniki monitoringu absolwentów na zmiany w procesie dydaktycznym, a odpowiedzi uzyskane od kilkunastu uczelni, które zadeklarowały jego posiadanie, wskazują na to, iż w większości jednostek wciąż trwają prace nad jego implementacją.

\section{Uzyskiwanie przez uczelnie zgody absolwentów na przetwarzanie danych osobowych dla potrzeb prowadzonego monitoringu}

W badaniach przeprowadzonych przez BAS znalazło się również pytanie, czy uczelnie pozyskują wymaganą zgodę na przetwarzanie danych osobowych od swoich absolwentów na potrzeby prowadzonego monitoringu przed czy po uzyskaniu dyplomu. Wyniki przedstawiono na wykresie 9. 
Wykres 9. Uzyskiwanie zgody na przetwarzanie danych osobowych dla potrzeb monitoringu karier zawodowych absolwentów przez uczelnie

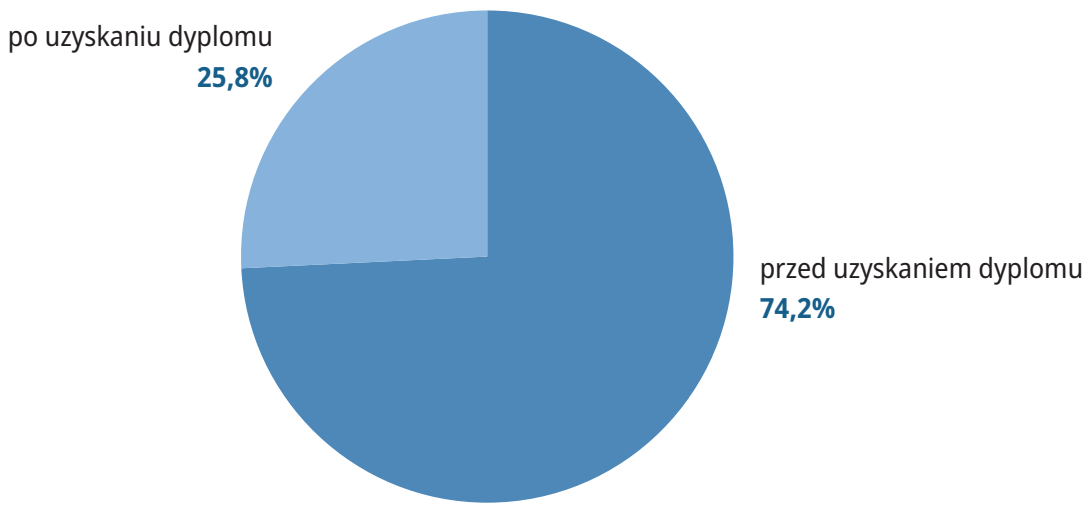

Źródło: badanie ankietowe Biura Analiz Sejmowych, grudzień 2013 r. - styczeń 2014 r.

Blisko trzy czwarte ankietowanych szkół wyższych $(74,2 \%)$ uzyskuje zgodę swoich absolwentów na przetwarzanie ich danych osobowych jeszcze przed uzyskaniem dyplomu, a co czwarta $(25,8 \%)$ robi to już po opuszczeniu przez absolwentów murów uczelni. Wyniki badania BAS pokazały, że ma to jednak niewielki wpływ na zwrotność ankiet. Uczelnie, które uzyskują zgodę na przetwarzanie danych osobowych przed wydaniem dyplomu, osiągnęły średnią zwrotność w ostatnim przeprowadzonym badaniu w wysokości 41,3\%, natomiast jednostki, które taką zgodę uzyskują po jego wydaniu - 40,1\%.

\section{Zakończenie}

Przeprowadzone przez Biuro Analiz Sejmowych badanie pozwoliło na sformułowanie następujących wniosków:

- jedna trzecia ankietowanych uczelni prowadziła monitoring karier zawodowych swoich absolwentów jeszcze przed wejściem w życie ustawowego obowiązku w tym zakresie,

- blisko 80\% ankietowanych szkół wyższych w styczniu 2014 roku wdrożyło już monitoring zgodnie z art. 13a ustawy, a około 20\% było w trakcie jego wdrażania,

- uczelnie publiczne szybciej niż niepubliczne wdrażają monitoring losów swoich absolwentów,

- najczęściej zadawane absolwentom pytania dotyczą: ich dalszego kształcenia po zakończeniu studiów, obecnego statusu na rynku pracy, związku wykony- 
wanej pracy zawodowej z ukończonym kierunkiem studiów, oceny stopnia, w jakim uczelnia przygotowała do wejścia na rynek pracy oraz formy zatrudnienia,

- w ostatnim badaniu przeprowadzonym przez uczelnie wzięło udział średnio 41\% absolwentów, przy czym występują duże różnice w poziomie zwrotności ankiet między poszczególnymi jednostkami,

- większość uczelni prowadzi lub zamierza prowadzić monitoring w okresach wymaganych przez ustawę, tj. trzech i pięciu lat od dnia ukończenia studiów, przy czym duża grupa uczelni realizuje monitoring w terminach krótszych niż trzy lata, co wydaje się być uzasadnione, biorąc pod uwagę możliwości wykorzystania wyników monitoringu do wprowadzania odpowiednich zmian na uczelniach,

- jedynie około $28 \%$ uczelni dzieli się wynikami monitoringu z opinią publiczną, przy czym uczelnie publiczne robią to ponaddwukrotnie częściej niż niepubliczne,

- zwraca uwagę fakt nieprzekazywania przez uczelnie wyników monitoringu Rzecznikowi Praw Absolwenta, który został włączony w system monitorowania karier zawodowych absolwentów w wyniku tej samej nowelizacji ustawy, która wprowadziła również art. 13a, zgodnie z którym uczelnie muszą obligatoryjnie prowadzić taki monitoring,

- mimo że ponad połowa uczelni wskazała, iż wdrożyła system implementacji wyników monitoringu, wydaje się, że system ten znajduje się dopiero w początkowej fazie tego procesu.

Przedstawione przez rząd w styczniu 2014 r. zmiany w ustawie - Prawo o szkolnictwie wyższym zakładają uchylenie art. 13a, a tym samym zniesienie obowiązku prowadzenia przez uczelnie monitoringu karier zawodowych swoich absolwentów ${ }^{9}$. Zgodnie z tym projektem Minister Nauki i Szkolnictwa Wyższego będzie prowadził ogólnopolski system monitorowania karier zawodowych na podstawie danych o absolwentach pochodzących z Systemu Informacji o Szkolnictwie Wyższym oraz danych Zakładu Ubezpieczeń Społecznych. Jednocześnie w celu dostosowania programu kształcenia do potrzeb rynku pracy uczelnia może prowadzić własny monitoring karier zawodowych swoich absolwentów.

Wyniki badania BAS pokazują, że zdecydowana większość ankietowanych szkół wyższych wdrożyła już monitoring zgodnie z art. 13a ustawy, chociaż nale-

9 Projekt ustawy o zmianie ustawy - Prawo o szkolnictwie wyższym oraz niektórych innych ustaw, druk sejmowy nr 2085/VII kad., s. 14-16, http://www.sejm.gov.pl/Sejm7.nsf/druk. xsp?documentId=32CE96E4BB128ADCC1257C6E00341EAB. 
ży ocenić, że dotychczasowe efekty prowadzonego monitoringu mają ograniczony wpływ na zmiany w ich programach kształcenia. Jednak, dostosowując się do wymogów art. 13a ustawy, szkoły wyższe wykonały duży wysiłek organizacyjny i finansowy, a w wielu z nich prowadzone są dalsze prace mające na celu jego doskonalenie. W świetle nowej propozycji rządu należy postawić pytanie, jaka część z nich będzie - jeśli propozycja rządu zostanie przyjęta - zainteresowana dalszym prowadzeniem dobrowolnego monitoringu. Można przypuszczać, że takie działania będą kontynuowały te uczelnie, którym zależy na podnoszeniu jakości kształcenia i uznają prowadzenie własnego monitoringu za dobre narzędzie służące dostosowywaniu ich programów kształcenia dla potrzeb polskiego i międzynarodowego rynku pracy.

\section{Bibliografia}

Izdebski H., Zieliński J.M., Prawo o szkolnictwie wyższym. Komentarz, Wolters Kluwer Polska, Warszawa 2013.

Dziewulak D., Grycuk A., Russel A., Wołodkiewicz-Donimirski Z., Monitorowanie karier zawodowych absolwentów przez polskie uczelnie wyższe w świetle wyników badania Biura Analiz Sejmowych, „Analizy BAS” 2014, nr 5(109), http://orka.sejm.gov.pl/WydBAS. nsf/0/5406692D978FB23DC1257CA8004BF496/\$file/Analiza_BAS_2014_109.pdf.

\section{Akty prawne}

Ustawa z 18 marca 2011 r. o zmianie ustawy - Prawo o szkolnictwie wyższym, ustawy o stopniach naukowych i tytule naukowym oraz o stopniach i tytule w zakresie sztuki oraz o zmianie niektórych innych ustaw, Dz.U. nr 84, poz. 455.

Projekt ustawy o zmianie ustawy - Prawo o szkolnictwie wyższym oraz niektórych innych ustaw, druk sejmowy nr 2085/VII kad., http://www.sejm.gov.pl/Sejm7.nsf/druk.xsp?documentId=32CE96E4BB128ADCC1257C6E00341EAB.

Rozporządzenie Ministra Nauki i Szkolnictwa Wyższego z 29 września 2011 r. w sprawie warunków oceny programowej i oceny instytucjonalnej, Dz.U. nr 207, poz. 1232. 


\title{
5.4. Instytucja rejestrowanego związku partnerskiego PACS we Francji
}

\author{
Civil solidarity pact (PACS) in France
}

W opracowaniu przedstawiono zagadnienie dotyczące instytucji rejestrowanego związku partnerskiego PACS we Francji. W artykule zaprezentowano syntetyczne informacje o formalnych warunkach zawarcia związku partnerskiego, konsekwencje cywilnoprawne i podatkowe dla osób decydujących się na zawarcie takiego związku oraz dane statystyczne porównujące tradycyjne związki małżeńskie i związki zawarte $\mathrm{w}$ ramach PACS.

Słowa kluczowe: prawo cywilne, umowa, związek partnerski, małżeństwo, Francja

The papers provides an overview of the civil solidarity pact (Pacte civil de solidarité, PACS) which is a form of civil union between two adults in France. The author briefly describes the legal conditions for PACS, as well as legal and tax consequences for those entering such a civil partnership. He also presents some statistical data on PACS and marriages in France over the last years.

Keywords: civil law, contract, partnership, marriage, France

\section{Wstęp}

Pacte civil de solidarité (PACS) ${ }^{1}$ „obywatelska umowa solidarności”, „cywilny pakt solidarności” to francuski rejestrowany związek partnerski legalizujący związki nieformalne między dwojgiem ludzi bez względu na płeć, wprowadzony

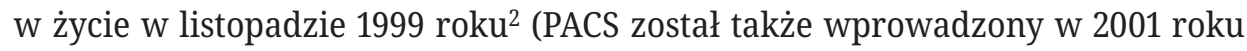
w Szwajcarii przez kanton genewski). Określa on, dla osób przystępujących do

1 W opracowaniu wykorzystano materiały francuskiego Narodowego Instytutu Statystyki i Badań Ekonomicznych (Institut national de la statistique et des études économiques INSEE), Wydziału Konsularnego Ambasady RP w Paryżu oraz informacje dostępne na stronach internetowych francuskich instytucji i organizacji.

2 Loi $\mathrm{n}^{\circ}$ 99-944 du 15 novembre 1999 relative au pacte civil de solidarité version consolidée au 30 mars 2011, http://www.legifrance.gouv.fr/affichTexte.do?cidTexte=JORFTE XT000000761717. 
PACS, wspólne deklaracje majątkowe od momentu zarejestrowania, zasady opieki zdrowotnej, społecznej i dziedziczenia oraz współodpowiedzialność za długi (zaciągnięte w czasie związku na potrzeby życia codziennego). Nie pozwala jednak na wspólną adopcję dzieci. Partnerzy zachowują również rozdzielność majątkową (o ile ich kontrakt nie przewiduje inaczej). Podobnie jak małżeństwo, PACS zwalnia od podatku spadkowego po zmarłym partnerze (konieczne jest jednak spisanie testamentu, gdyż sam kontrakt nie gwarantuje, że partner automatycznie stanie się spadkobiercą). Rozwiązanie PACS jest uproszczone w porównaniu do procedury rozwodu. Wystarczy, by jeden z partnerów wysłał do właściwego sądu w swojej miejscowości (tribunal d’instance) list polecony informujący o zerwaniu cywilnego paktu solidarności. Efekt takiej deklaracji jest natychmiastowy.

Od czasu wprowadzenia rejestrowanego związku partnerskiego akronim PACS wszedł już na stałe do współczesnego, codziennego języka francuskiego. Od akronimu PACS powstały więc: rzeczownik pacs, czyli nazwa związku partnerskiego, czasowniki pacser i se pacser oznaczające zawarcie PACS. W powszechnym użyciu występuje także określenie un couple pacsé, czyli pojęcie „pary spaksowanej” - pary będącej w związku partnerskim.

\section{Formalne warunki zawarcia związku partnerskiego PACS}

Obywatelska umowa solidarności (PACS) ${ }^{3}$ może zostać zawarta przez dwie osoby różnej lub tej samej płci. W celu podpisania takiej umowy należy spełnić podstawowy warunek, którym jest pełnoletność. Osoby małoletnie, nawet samodzielne, nie mogą zawrzeć PACS, a co więcej osoby pełnoletnie pozostające pod kuratelą powinny otrzymać zezwolenie opiekuna lub zezwolenie sędziego opiekuńczego, lub rady rodzinnej na zawarcie takiego związku. Posiadanie różnych obywatelstw nie ma wpływu na zawarcie PACS. Należy mieć jednak na uwadze, że jeśli PACS jest zawierany za granicą (w ambasadzie lub konsulacie Francji) przynajmniej jedna z osób powinna posiadać obywatelstwo francuskie.

PACS nie może być zawarty przez osoby znajdujące się w następujących relacjach pokrewieństwa:

3 Opracowanie przygotowano na podstawie ekspertyzy Biura Analiz Sejmowych nr 225/12 z 5 marca 2012 r. D. Dziewulaka zatytułowanej Informacja nt. instytucji obywatelskiej umowy solidarności (Pacte civil de solidarité - PACS) we Francji oraz opracowania tegoż autora Instytucja rejestrowanego związk partnerskiego PACS we Francji, „Analizy BAS” 2012, nr 22(89), s. 1-5. 
- wstępni i zstępni w linii bezpośredniej,

- krewni do trzeciego stopnia (brat z siostrą, wuj z siostrzenicą itd.),

- osoby spowinowacone w linii bezpośredniej (teściowa z zięciem itd.),

- osoby, które znajdują się w związku małżeńskim, czyli zawarły związek małżeński,

- osoby, które zawarły już PACS.

\section{Statystyka związków homoseksualnych i heteroseksualnych zawartych we Francji w ramach PACS}

Statystycznie od chwili wprowadzenia cywilnego paktu solidarności liczba zawieranych we Francji homoseksualnych związków PACS malała w stosunku do heteroseksualnych związków PACS. Obecnie liczba zawieranych homoseksualnych związków PACS utrzymuje się na poziomie około 5\% w stosunku do wszystkich zawieranych związków PACS.

Tabela 27. Związki partnerskie PACS zawarte we Francji

\begin{tabular}{|c|c|c|c|c|c|}
\hline \multirow{2}{*}{ Rok } & \multicolumn{5}{|c|}{ PACS } \\
\cline { 2 - 6 } & \multicolumn{2}{|c|}{ PACS homoseksualny } & \multicolumn{2}{c|}{ PACS heteroseksualny } & $\begin{array}{c}\text { Liczba } \\
\text { związków PACS } \\
\text { razem }\end{array}$ \\
\hline 2000 & 5412 & $24,30 \%$ & 16859 & $75,70 \%$ & 22271 \\
\hline 2001 & 3323 & $16,93 \%$ & 16306 & $83,07 \%$ & 19629 \\
\hline 2002 & 3622 & $14,31 \%$ & 21683 & $85,69 \%$ & 25305 \\
\hline 2003 & 4294 & $13,60 \%$ & 27276 & $86,40 \%$ & 31570 \\
\hline 2004 & 5023 & $12,53 \%$ & 35057 & $87,47 \%$ & 40080 \\
\hline 2005 & 4865 & $8,05 \%$ & 55597 & $91,95 \%$ & 60462 \\
\hline 2006 & 5071 & $6,56 \%$ & 72276 & $93,44 \%$ & 77347 \\
\hline 2007 & 6221 & $6,10 \%$ & 95778 & $93,90 \%$ & 101999 \\
\hline 2008 & 8201 & $5,62 \%$ & 137801 & $94,38 \%$ & 146002 \\
\hline 2009 & 8434 & $4,83 \%$ & 166089 & $95,17 \%$ & 174523 \\
\hline 2010 & 9143 & $4,45 \%$ & 196415 & $95,55 \%$ & 205558 \\
\hline
\end{tabular}

Źródło: http://www.insee.fr. 
Wykres 10. Związki partnerskie PACS zawarte we Francji w latach 2000-2010

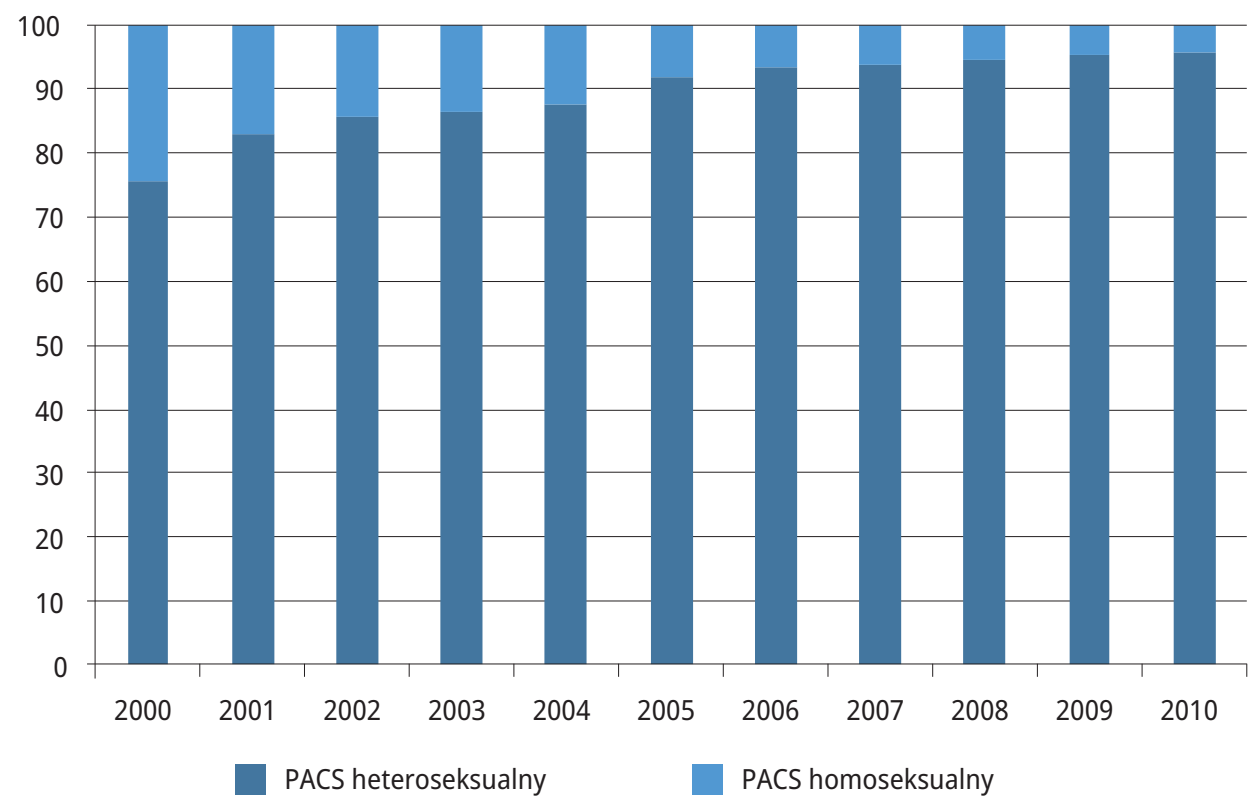

Źródło: http://www.insee.fr.

Statystyka zawieranych związków małżeńskich (heteroseksualnych) do liczby związków zawartych w ramach PACS

Proporcja liczby zawieranych małżeństw do związków zawieranych w ramach PACS maleje z roku na rok. Bezwzględna liczba zawieranych małżeństw również maleje z roku na rok od momentu wprowadzenia związków PACS. W 2010 roku związki małżeńskie stanowiły ponad 55\% wszystkich zawartych związków.

\section{Wpływ PACS na liczbę zawieranych tradycyjnych związków małżeńskich}

We Francji w latach 1990-2011 liczba zawieranych małżeństw heteroseksualnych oscylowała w granicach 250-300 tys. Od chwili wprowadzenia PACS, czyli od listopada 1999 roku, nastąpiło zmniejszenie liczby zawieranych tradycyjnych małżeństw. Tendencja spadkowa utrzymuje się nadal. Rośnie natomiast liczba zawieranych PACS o charakterze heteroseksualnym. 
Tabela 28. Związki małżeńskie i związki partnerskie PACS

zawarte we Francji w latach 2000-2010

\begin{tabular}{|c|c|c|c|c|c|}
\hline \multirow{2}{*}{ Rok } & \multicolumn{2}{|c|}{$\begin{array}{c}\text { Związki małżeńskie } \\
\text { (śluby) }\end{array}$} & \multicolumn{2}{c|}{ PACS } & $\begin{array}{c}\text { Wszystkie } \\
\text { związki razem } \\
\text { (śluby i PACS) }\end{array}$ \\
\hline 2000 & 305234 & $93,20 \%$ & 22271 & $6,80 \%$ & 327505 \\
\hline 2001 & 295720 & $93,78 \%$ & 19629 & $6,22 \%$ & 315349 \\
\hline 2002 & 286169 & $91,88 \%$ & 25305 & $8,12 \%$ & 311474 \\
\hline 2003 & 282756 & $89,96 \%$ & 31570 & $10,04 \%$ & 314326 \\
\hline 2004 & 278439 & $87,42 \%$ & 40080 & $12,58 \%$ & 318519 \\
\hline 2005 & 283036 & $82,40 \%$ & 60462 & $17,60 \%$ & 343498 \\
\hline 2006 & 273914 & $77,98 \%$ & 77347 & $22,02 \%$ & 351261 \\
\hline 2007 & 273669 & $72,85 \%$ & 101999 & $27,15 \%$ & 375668 \\
\hline 2008 & 265404 & $64,51 \%$ & 146002 & $35,49 \%$ & 411406 \\
\hline 2009 & 251478 & $59,03 \%$ & 174523 & $40,97 \%$ & 426001 \\
\hline 2010 & 251654 & $55,04 \%$ & 205558 & $44,96 \%$ & 457212 \\
\hline
\end{tabular}

Źródło: http://www.insee.fr.

Wykres 11. Śluby i wszystkie związki PACS zawarte we Francji w latach 2000-2010

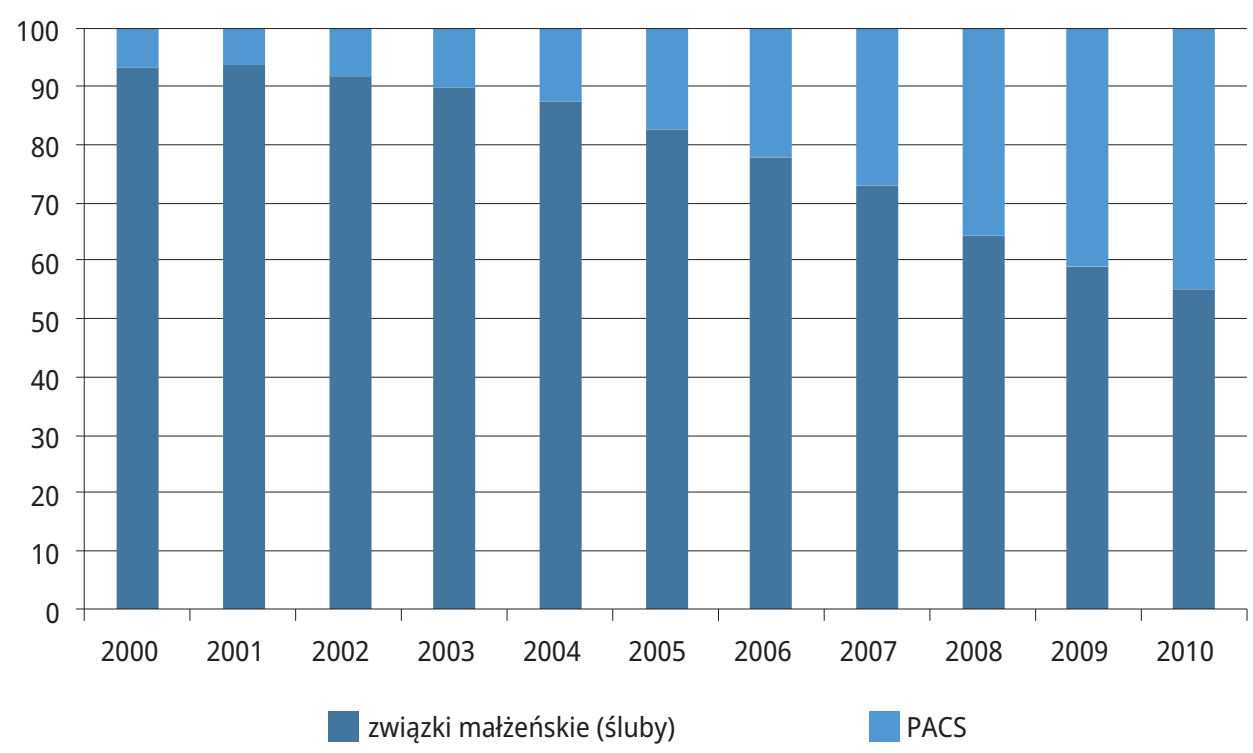

Źródło: http://www.insee.fr. 
Wykres 12. Liczba tradycyjnych związków małżeńskich zawieranych we Francji w latach 1990-2011. Strzałka wskazuje moment wprowadzenia PACS (listopad 1999 r.)

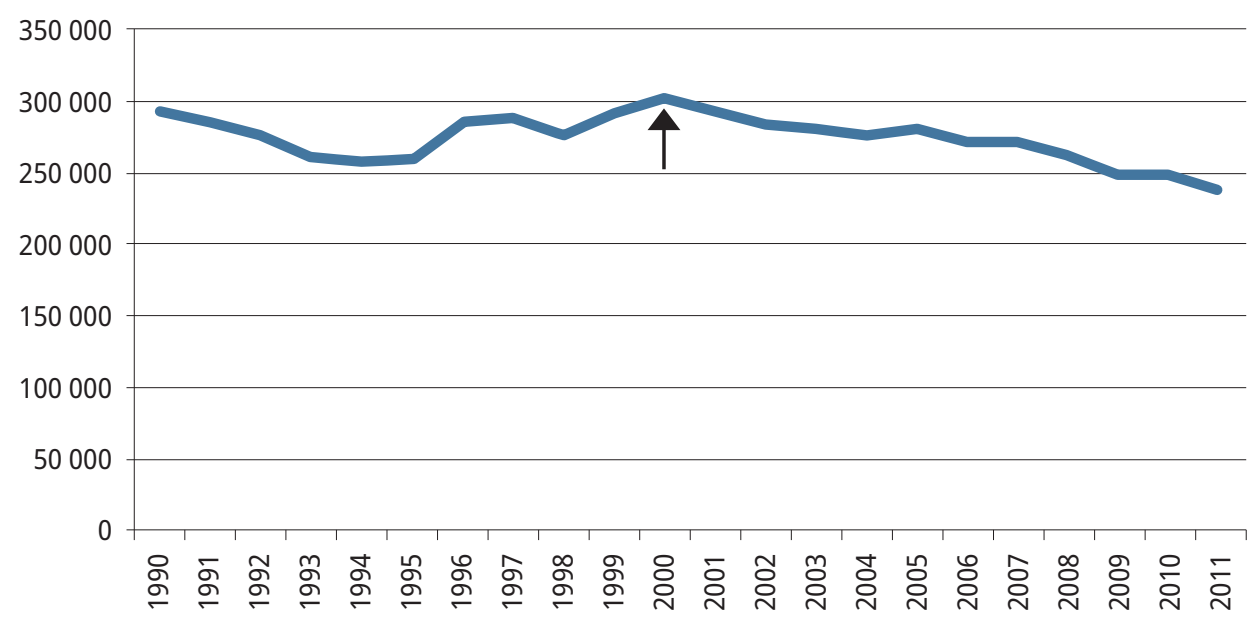

Źródło: http://www.insee.fr.

Wykres 13. Śluby oraz PACS heteroseksualny i homoseksualny zawarte we Francji w latach 1990-2011 (brak danych PACS za 2011 r.)

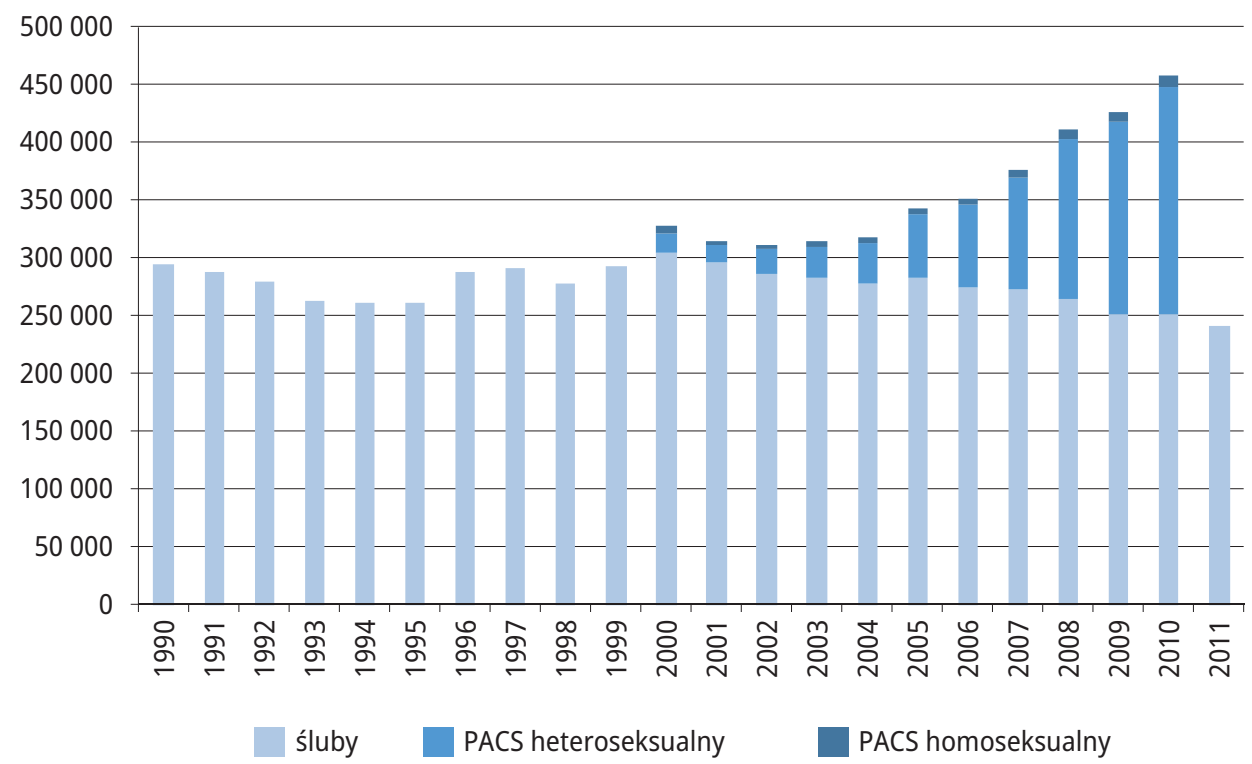

Źródło: http://www.insee.fr. 


\section{Konsekwencje cywilnoprawne i podatkowe dla osób decydujących się na zawarcie cywilnego paktu solidarności}

\section{Obowiqzek wzajemnej pomocy, w tym materialnej}

Cywilny pakt solidarności przewiduje, że partnerzy wspomagają się wzajemnie, w tym materialnie. Szczegóły dotyczące wzajemnej pomocy powinny zostać ustalone w umowie (na przykład: comiesięczny przelew w określonej kwocie na konto partnera, udostępnienie materialnych środków do życia, takich jak mieszkanie, uczestniczenie $\mathrm{w}$ kosztach wyżywienia itd.). W przypadku braku takich specjalnych zapisów w umowie, zakres pomocy powinien być proporcjonalny do środków, jakimi dysponuje dany partner.

\section{Wspólna odpowiedzialność za niektóre zobowiq̨zania}

W konsekwencji zawarcia PACS strony wspólnie odpowiadają za zobowiązania zaciągnięte przez jednego z partnerów u osób trzecich, w celu zaspokojenia potrzeb związanych z życiem codziennym (na przykład: koszty wyżywienia, koszty utrzymania samochodu, czynsz itd.). Każdy z partnerów jest zatem solidarnie odpowiedzialny za wszystkie tego typu zobowiązania, nawet jeśli zaciągnął je drugi partner. Z tego tytułu istnieje możliwość zajęcia zarobków, wynagrodzenia oraz dóbr osobistych zarówno tej osoby, która zaciągnęła zobowiązania, jak i jego partnera PACS.

Wspólna odpowiedzialność nie obowiązuje w przypadku zobowiązań innych niż tych dotyczących życia codziennego. Od 1 maja 2011 roku wspólna odpowiedzialność nie dotyczy zakupów na raty oraz pożyczek dużych kwot, niezwiązanych z potrzebami życia codziennego, jeżeli nie zostały one zaciągnięte za wspólną zgodą obydwu partnerów.

\section{Fiskalne konsekwencje PACS}

Z chwilą wprowadzenia PACS partnerzy zobowiązani byli do wypełniania trzech zeznań podatkowych: każdy partner po jednym zeznaniu dotyczącym osiągniętych dochodów w okresie od 1 stycznia do dnia zawarcia PACS oraz wspólne zeznanie dotyczące dochodów osiągniętych przez oboje partnerów od daty zawarcia PACS do końca roku kalendarzowego. Od 1 marca 2011 roku partnerzy PACS dokonują wspólnego rozliczenia podatkowego. Mogą jednak wybrać opcję 
osobnego zeznania dotyczącego dochodów własnych lub wspólnego zeznania dotyczącego udziału we wspólnych dochodach.

Rok po zawarciu umowy PACS partnerzy obowiązkowo rozliczają się wspólnie $\mathrm{z}$ dochodów, tracąc jednocześnie dotychczasowe ulgi wynikające $\mathrm{z}$ bycia poza związkiem. Przykładowo, podatnikowi będącemu kawalerem, panną lub rozwiedzionemu, przysługuje ulga z tytułu posiadania dziecka na utrzymaniu, pod warunkiem że żyje on sam i faktycznie ponosi koszty utrzymania dziecka. Zawarcie PACS powoduje automatyczną utratę takiej korzyści.

W wypadku rozwiązania umowy PACS, każdy z byłych partnerów rozlicza się osobno z dochodów osiągniętych od momentu rozwiązania umowy oraz ze swojego udziału we wspólnych dochodach osiągniętych do momentu rozwiązania umowy (w przypadku braku dowodów przyjmuje się, że jest to połowa wspólnych dochodów).

\section{Własność majq̨tkowa a PACS}

\section{Majątek nabyty przed zawarciem PACS}

Partnerzy pozostają właścicielami dóbr, które posiadali przed zawarciem PACS, jednakże $\mathrm{w}$ ich interesie leży sporządzenie listy przedmiotów do nich należących i dołączenie jej do umowy. W wypadku braku takiej listy oraz braku dokumentów poświadczających własność, podczas podziału majątku przedmioty takie będą uznawane za niepodzielną własność obojga partnerów. W zakresie majątku nabytego przed zawarciem obywatelskiej umowy solidarności każdy z partnerów sam odpowiada za wszelkie swoje zobowiązania zaciągnięte przed dniem zawarcia PACS.

\section{Majątek nabyty w trakcie trwania PACS}

Majątek nabyty w trakcie trwania PACS traktowany jest zgodnie z zasadą rozdzielności majątkowej. Przyjmuje się, że każdy z partnerów jest właścicielem majątku, który nabywa $\mathrm{w}$ trakcie trwania obywatelskiej umowy solidarności. Jest zatem jedyną osobą odpowiedzialną za zobowiązania zaciągnięte $\mathrm{w}$ czasie trwania PACS (z wyjątkiem wspólnej odpowiedzialności za zobowiązania wynikające z życia codziennego).

Zawierając PACS, partnerzy mogą także wybrać ustrój wspólnoty majątkowej. Wybór ten powinien zostać sprecyzowany w umowie początkowej lub mo- 
dyfikującej. W takim przypadku majątek nabyty wspólnie lub oddzielnie należy po połowie do każdego z partnerów. Jednakże niektóre dobra, uważane za osobiste ze względu na ich rodzaj, pozostają wyłączną własnością każdego z partnerów. Są to na przykład:

- oszczędności niewykorzystane do nabycia majątku,

- przedmioty stworzone przez jednego z partnerów i ich pochodne,

- dobra o charakterze osobistym, na przykład zdjęcia rodzinne,

- dobra, które należały do danego partnera przed zawarciem PACS,

- dobra nabyte w drodze darowizny lub spadku itd.

\section{Sytuacja rodzinna partnerów PACS}

Obywatelska umowa solidarności nie wpływa w żaden sposób na pokrewieństwo, jeśli chodzi o dzieci jednego z partnerów lub wspólne dzieci obojga partnerów. Umowa nie czyni automatycznie i całkowicie spadkobiercą partnera pozostającego przy życiu. Aby pozostający przy życiu partner mógł dziedziczyć, każda ze stron PACS powinna sporządzić swój własny testament, jako dokument odrębny niebędący częścią umowy.

Od 1 stycznia 2007 roku w sytuacji zgonu jednego z partnerów obywatelska umowa solidarności umożliwia pozostającemu przy życiu partnerowi złożenie wniosku o dysponowanie dotychczas zamieszkiwaną nieruchomością, zgodnie z następującymi dwoma zasadami:

- partner pozostający przy życiu przez okres jednego roku ma prawo do bezpłatnego korzystania z nieruchomości wraz z wyposażeniem (prawo to nie jest związane z testamentem),

- partner pozostający przy życiu może rościć sobie prawo do preferencyjnego przyznania mu nieruchomości wraz z wyposażeniem, o ile zmarły partner przewidział taką sytuację w testamencie.

\section{PACS i darowizny}

Partnerzy mogą dokonać między sobą darowizny za życia, jednakże w formie oddzielnego aktu, niebędącego częścią obywatelskiej umowy solidarności. Darowizny nie można unieważnić, nawet jeśli nastąpi rozwiązanie umowy PACS. 


\section{PACS a korzyści socjalne}

Wśród kilku korzyści socjalnych, jakie daje PACS, wymienić należy tę związaną z możliwością korzystania z ubezpieczenia zdrowotnego partnera. W wypadku zgonu jednego z partnerów, partner pozostający przy życiu może po spełnieniu pewnych warunków otrzymać kwotę przyznawaną przez zakład ubezpieczeń. W przypadku, gdy osoba związana umową PACS jest urzędnikiem państwowym otrzymującym skierowanie do pracy w innym regionie kraju, jego partner traktowany jest jako współmałżonek i otrzymuje wszelkie wsparcie związane z nowym miejscem pracy i zamieszkania. Zawarcie PACS powoduje jednakże ograniczenie niektórych świadczeń, a wśród nich utratę prawa do zasiłku dla samotnego rodzica, zasiłku rodzinnego oraz zasiłku dla wdowców. W razie zgonu jednego z partnerów PACS nie daje prawa do zasiłku dla wdowców ani do renty lub innego świadczenia z tytułu ogólnego ubezpieczenia społecznego. Umowa jako taka nie daje także prawa do uzyskania karty pobytu na terenie Republiki Francuskiej partnerowi niebędącemu francuskim obywatelem.

\section{Konsekwencje rozwiqzania umowy PACS}

Po rozwiązaniu PACS partnerzy sami powinni przystąpić do likwidacji swoich praw i obowiązków wynikających z ich umowy. W przypadku sporu dotyczącego konsekwencji majątkowych o rozwiązaniu umowy rozstrzyga sędzia rodzinny. W umowie PACS istnieje możliwość określenia i wprowadzenia zastrzeżeń rozwiązania takiej umowy, co może stanowić gwarancję zapobieżenia ewentualnym sporom.

\section{Zakończenie}

Poszukiwanie rozwiązań prawnych dotyczących możliwości rejestracji związków partnerskich lub małżeństw jednopłciowych jest zagadnieniem stosunkowo nowym. Pierwsze rozwiązania prawne dotyczące legalizacji związków innych niż klasyczny związek osób dwóch różnych płci pojawiły się na początku ostatniej dekady XX wieku. W 1989 roku pierwszym krajem na świecie, który wprowadził rejestrację związków partnerskich, także osób tej samej płci, była Dania. Następnie prawo rejestracji związków partnerskich wprowadzały kraje skandynawskie: Norwegia, Szwecja i Islandia, a następnie inne kraje Europy: Holandia, Węgry, Hiszpania, Francja, Belgia, Niemcy, Portugalia, Finlandia, 
Chorwacja, część Włoch, Luksemburg, Wielka Brytania, Słowenia, Andora, Czechy, Szwajcaria, Liechtenstein, Irlandia. W niektórych państwach pojawiła się w systemie prawnym także instytucja małżeństwa osób tej samej płci (małżeństwo jednopłciowe), czyli małżeństwa homoseksualnego, stanowiącego związek cywilny dwóch mężczyzn lub dwóch kobiet. Pierwszy raz instytucja małżeństwa jednopłciowego - pełnoprawnego małżeństwa cywilnego opartego na takich samych prawach jak małżeństwo kobiety i mężczyzny - wprowadzona została przez Holandię w 2001 roku. Od tego czasu legalizację małżeństw osób tej samej płci wprowadziły również: Belgia, Hiszpania, Kanada, RPA, Norwegia, Szwecja, Portugalia, Islandia i Argentyna. Do tego grona dołączyło także kilka stanów USA (Massachusetts, Connecticut, Iowa, Vermont, New Hampshire i Nowy Jork) oraz miasto Meksyk.

Francuski rejestrowany związek partnerski PACS wprowadzony 1999 roku wpisuje się więc $\mathrm{w}$ rozwiązania prawne stosowane w niektórych państwach na świecie.

\section{Bibliografia}

Dziewulak D., Instytucja rejestrowanego zwiazku partnerskiego PACS we Francji, „Analizy BAS” 2012, nr 22(89).

\section{Akty prawne}

Loi n 99-944 du 15 novembre 1999 relative au pacte civil de solidarité; NOR: JUSX9803236L, version consolidée au 02 septembre 2018, https://www.legifrance.gouv.fr/affichTexte. do?cidTexte=JORFTEXT000000761717.

\section{Strony internetowe}

https://insee.fr/fr/accueil. 


\title{
5.5. Zasady recenzowania wniosków o granty naukowe finansowane ze środków publicznych we Francji, w Niemczech i Wielkiej Brytanii
}

\author{
Rules for reviewing applications for research grants \\ financed from public funds in France, Germany \\ and the United Kingdom
}

W opracowaniu podjęto próbę przedstawienia zagadnienia dotyczącego zasad recenzowania wniosków o granty naukowe finansowane ze środków publicznych w wybranych państwach Unii Europejskiej. Analizie porównawczej poddano zasady recenzowania wniosków o granty naukowe we Francji, w Niemczech i Wielkiej Brytanii. Materiał uzupełniono o krótką charakterystykę modelu recenzowania wniosków o granty w analizowanych państwach.

Słowa kluczowe: nauka, granty, finansowanie, finanse publiczne, Francja, Niem-

cy, Wielka Brytania

The paper attempts to present an issue regarding the principles of reviewing applications for grants financed from public funds in selected European Union countries. A comparative analysis was carried out on the principles of reviewing applications for grants in France, Germany and the United Kingdom. The material was supplemented by a brief description of the model for reviewing grants applications in the analyzed countries.

Keywords: science, grants, financing, public finances, France, Germany, Great Britain

\section{Wstęp}

Zasady wybierania recenzentów oraz zasady recenzowania wniosków o granty naukowe we Francji, w Niemczech i Wielkiej Brytanii zależne są od przyjętego w powyższych krajach modelu postępowania ${ }^{1}$. Każde z tych państw wypracowało własny model i zasady recenzowania wniosków o granty. We Francji recenzowaniem zajmuje się Krajowa Agencja ds. Badań (Agence Nationale de la Recherche, ANR) podległa Ministerstwu Szkolnictwa Wyższego i Badań Naukowych², $\mathrm{w}$ Niemczech są to niezależne agencje zarządzania projektami (Projektträger),

1 Opracowanie przygotowano na podstawie ekspertyzy Biura Analiz Sejmowych nr 440/11 z 16 marca 2012 r. autorstwa D. Dziewulaka, D. Łukasz, M. Mroza, A. Pola zatytułowanej Informacja nt. zasad recenzowania wniosków o granty naukowe finansowane ze środków publicznych we Francji, Niemczech i Wielkiej Brytanii.

2 Zob. przyp. 12 na s. 114. 
a w Wielkiej Brytanii m.in. Rady ds. Badań Naukowych (Research Councils), Rada ds. Finansowania Szkolnictwa Wyższego w Anglii (Higher Education Funding Council for England, HEFCE), Brytyjska Agencja Kosmiczna (UK Space Agency) oraz krajowe akademie nauk (National Academies).

Recenzenci opiniujący wnioski o granty powoływani są spośród grupy wybitnych naukowców, zgodnie z ogólnie przyjętymi kryteriami kompetencji, rzetelności i obiektywności naukowej. Nie istnieje jednak jednolity schemat działania w tym zakresie, właściwy dla wszystkich państw. Sposób doboru osób opiniujących granty zależy od przyjętych procedur i struktur zarządzania środkami finansowymi. Jednakże tryb recenzowania we wszystkich omawianych krajach jest procesem wieloetapowym, w którym biorą udział komitety i zespoły eksperckie, sprawozdawcy i współsprawozdawcy, niezależni recenzenci oraz własna kadra naukowa instytucji odpowiedzialnych za wydatkowanie środków finansowych.

\section{Francja}

\section{Uwagi wstępne}

Programowanie oraz finansowanie badań naukowych ze środków Ministerstwa Szkolnictwa Wyższego i Badań Naukowych należy do zakresu działania podległej ministerstwu Krajowej Agencji ds. Badań (Agence Nationale de la Recherche, ANR). Agencja opracowuje i przyjmuje kilkuletnie programy badań naukowych. Pod względem naukowym i metodologicznym wnioski o granty oceniane są przez komisje ewaluacyjne. Ostateczną decyzję o przyznaniu grantu podejmują komisje pilotażowe, które oceniają wnioski zatwierdzone przez komisje ewaluacyjne pod kątem zgodności z celami programów badawczych przyjętych przez ANR. Organizację oraz zasady funkcjonowania komisji ewaluacyjnych i komisji pilotażowych określają ramowe regulaminy organizacyjne komisji ewaluacyjnych ${ }^{3}$.

\section{Procedura kwalifikowania wniosków o granty naukowe}

Kwalifikowanie wniosków o granty odbywa się dwuetapowo. Pierwszy etap stanowi ocena naukowo-metodologiczna poszczególnych projektów dokonywana przez komisję ewaluacyjną na dwóch posiedzeniach, z których każde może

3 Agence Nationale de la Recherche. Procédure d'organisation et fonctionnement des Comités d'Évaluation, 23 février 2010; Agence Nationale de la Recherche. Procédure d'organisation et fonctionnement des Comités de Pilotage, 8 avril 2010. 
trwać kilka dni. Po drugim posiedzeniu komisji ewaluacyjnej odbywa się jedno posiedzenie komisji pilotażowej.

\section{Etap komisji ewaluacyjnej}

\section{Pierwsze posiedzenie}

Na pierwszym posiedzeniu komisja ewaluacyjna przydziela do każdego przyjętego do oceny projektu, co najmniej dwóch recenzentów (ekspertów) zewnętrznych oraz sprawozdawcę (rapporteur) i współsprawozdawcę (lecteur) spośród członków komisji. Jeżeli wnioskodawca postulował wyłączenie wskazanych przez niego ekspertów, komisja powinna wziąć zastrzeżenie pod uwagę. Lista recenzentów ma charakter poufny i nie jest zamieszczana w sprawozdaniu z posiedzenia komisji ${ }^{4}$.

\section{Drugie posiedzenie}

Na drugim posiedzeniu komisji sprawozdawca przedstawia syntezę recenzji przygotowanych przez recenzentów zewnętrznych wraz ze swoją opinią. Współsprawozdawca może wówczas przedstawić swoje uwagi i stanowisko uzupełniające opinię sprawozdawcy. Komisja rozpatruje wnioski na podstawie informacji przedstawionych przez sprawozdawcę i współsprawozdawcę oraz formułuje opinię (avis) komisyjną. Lista recenzentów ma charakter poufny i nie jest zamieszczana w sprawozdaniu z drugiego posiedzenia komisji. Na zakończenie postępowania komisja przydziela wnioski do trzech kategorii:

- A - wnioski priorytetowe,

- B - wnioski niepriorytetowe,

- C - wnioski odrzucone.

\section{Etap komisji pilotażowej}

Ostateczną decyzję o przyznaniu grantu naukowego podejmuje komisja pilotażowa, kierując się zasadniczo opinią komisji ewaluacyjnej. Komisja pilotażowa rozpatruje wnioski z kategorii A i B pod kątem ich zgodności z ogólnymi celami programów badawczych przyjętych w ramach kilkuletniego planowania. Poza

4 Procédure d'organisation et fonctionnement des Comités d’Évaluation, dz.cyt., art. 3.5. 
procesem ewaluacji wniosków komisja pilotażowa bierze udział w ustalaniu planów i programów badawczych oraz w procedurze oceny wyników realizowanych projektów.

\section{W jaki sposób wybierani są recenzenci?}

W procedurze opiniowania wniosków o granty naukowe przyznawanych przez ANR występują dwa rodzaje recenzentów:

- recenzenci (eksperci) zewnętrzni,

- recenzenci (sprawozdawca i współsprawozdawca) wewnętrzni.

Recenzentów zewnętrznych powołuje ANR na wniosek koordynatorów poszczególnych programów badawczych ANR i po zasięgnięciu opinii komisji ewaluacyjnej, spośród wybitnych naukowców według kryterium kompetencji, osiągnięć naukowych, niezależności i rzetelności. Osoby odpowiedzialne za projekt objęty wnioskiem mogą wskazać recenzentów, którzy powinni zostać wyłączeni z postępowania w sprawie ich wniosku ${ }^{5}$.

Recenzenci wewnętrzni (sprawozdawca i współsprawozdawca) są powoływani spośród członków komisji ewaluacyjnej. Członków komisji ewaluacyjnej powołuje dyrektor ANR na wniosek koordynatorów poszczególnych programów badawczych ANR, spośród wybitnych naukowców według kryterium kompetencji, osiągnięć naukowych, niezależności i rzetelności. Przy wyborze członków komisji ewaluacyjnych preferuje się naukowców zagranicznych. Członkowie komisji ewaluacyjnych powoływani są na okres procesu ewaluacji danego projektu(ów) nie dłużej jednak niż na rok z możliwością przedłużenia mandatu na dwie kolejne kadencje ${ }^{6}$.

\section{Czy istnieje obowiązek upublicznienia recenzji?}

Nie. Całość postępowania zarówno w komisji ewaluacyjnej, jak i komisji pilotażowej ma charakter poufny. Dokumentacja (recenzje i sprawozdania z posiedzeń komisji) może być udostępniona jedynie członkom obydwu komisji oraz pracownikom ANR ${ }^{7}$. Wszystkie osoby biorące udział w postępowaniu z wnioskami zobo-

Tamże, art. 4.4.

6 Tamże, art. 4.3.

7 Tamże, art. 4.6 i art. 5.5; Procédure d’organisation et fonctionnement des Comités de Pilotage, dz.cyt., art. 4.4 i art. 5.5. 
wiązują się do przestrzegania zasad Kodeksu etyki ANR, w tym m.in. przestrzegania zasad poufności ${ }^{8}$.

\section{Czy osoba, która sporządza recenzję musi się pod nią podpisać?}

Ramowy regulamin komisji ewaluacyjnej nie odnosi się do kwestii podpisywania recenzji dokonywanych przez recenzentów (ekspertów) zewnętrznych i wewnętrznych.

\section{Niemcy}

W Niemczech istnieje system tzw. agencji zarządzania projektami (Projektträger - „podmioty odpowiedzialne za projekty” - co tłumaczone jest na angielski jako project management agencies). Ministerstwa dysponujące środkami publicznymi na finansowanie projektów badawczych - głównie Federalne Ministerstwo Edukacji i Badań (Bundesministerium für Bildung und Forschung) oraz Federalne Ministerstwo Gospodarki i Techniki (Bundesministerium für Wirtschaft und Technologie), ale także inne - zawierają z takimi agencjami umowy, zlecając im wdrożenie określonych narodowych programów finansowania projektów. Agencje są niezależnymi instytucjami lub stanowią specjalne wydziały takich instytucji. Ich zleceniodawcami są nie tylko ministerstwa, ale również prywatnoprawne lub publicznoprawne fundacje.

Taka agencja zarządzania projektami istnieje na przykład przy Niemieckim Centrum Lotniczym i Kosmicznym (Deutsches Zentrum für Luft- und Raumfahrt). Wykonuje ona zlecenia m.in. federalnych ministerstw: Edukacji i Badań, Gospodarki i Techniki, Zdrowia oraz Rodziny, Seniorów, Kobiet i Młodzieży9.

Każda agencja jest odpowiedzialna za proces oceny projektów jako zasadniczy element wdrażania odpowiednich programów finansowania. Nie istnieje jednak jeden schemat działania w tym zakresie, właściwy dla wszystkich agencji. Niektóre agencje mają własną kadrę naukową, która może oceniać projekty, zazwyczaj jednak ministerstwo powołuje niezależne komitety ekspertów, które nadzorują i ujednolicają proces oceny i przygotowują listę rankingową projektów. Praca takich komitetów wspierana jest organizacyjnie przez agencje. Człon-

8 ANR. Charte de déontologie, 09/03/09, DIR-REG-090309-L-01-01, art. 6.

9 Zob. Der Projektträger im DLR, http://www.dlr.de/pt//desktopdefault.aspx/tabid-4270/6848_ read-6936/. Uwaga: Wikipedia pod hasłem Projektträger wymienia dziesięć innych agencji tego typu, http://de.wikipedia.org/wiki/Projekttr\%C3\%A4ger. 
kami komitetów są zazwyczaj wybitni naukowcy z danej dziedziny, również naukowcy pracujący w sektorze prywatnym.

Niekiedy przeprowadza się dodatkowe postępowanie oceniające z wykorzystaniem większej liczby recenzentów będących specjalistami w danej dziedzinie (peer review). Wyniki takiego postępowania wykorzystywane są w końcowym postępowaniu oceniającym, prowadzonym przez agencję lub przez komisję ekspertów.

Ocena projektów nie jest podawana do publicznej wiadomości. Natomiast wnioskodawcom często przedstawia się syntetyczne sprawozdanie z jej przebiegu. Nie podaje się w nim jednak nazwisk recenzentów (peers). Publicznie ogłasza się zazwyczaj jedynie nazwiska członków komisji ekspertów, po tym jak zostaje ona powołana. W sprawach tych nie istnieje jednak powszechnie obowiązujący schemat.

\section{Wielka Brytania ${ }^{10}$}

Odpowiednikiem polskiego Ministerstwa Nauki i Szkolnictwa Wyższego jest w Wielkiej Brytanii Ministerstwo Biznesu, Innowacji i Umiejętności (Department for Business, Innovation and Skills). W systemie brytyjskim ministerstwo decyduje o ogólnej kwocie finansowania oraz o jej podziale na poszczególne jednostki odpowiedzialne za wydatkowanie tych środków. Ponadto określa priorytety strategii rozwoju i dba o zapewnienie bazy naukowej dla ich realizacji, proponując podejmowanie określonych programów badawczych. Pełni też istotną rolę w podejmowaniu decyzji dotyczących zobowiązań długookresowych i projektów o skali ogólnokrajowej, a także międzynarodowych umów w omawianym zakresie.

Ministerstwo jest odpowiedzialne m.in. za dystrybucję publicznych środków finansowych na badania naukowe instytucjom, które są odpowiedzialne za ich wydatkowanie. W latach 2010-2011 przekazało ono na ten cel około 4,6 mld GBP. Najwięcej środków otrzymały rady ds. badań naukowych (Research Councils) 56\%, Rada ds. Finansowania Szkolnictwa Wyższego w Anglii (Higher Education Funding Council for England, HEFCE) - 38\%, Brytyjska Agencja Kosmiczna (UK Space Agency) - 4\% oraz Akademie Nauk (National Academies) - 2\%.

Ministerstwo nie decyduje o tym, który z indywidualnych projektów uzyska finansowanie, ani który badacz otrzyma grant. Obowiązuje tzw. zasada Hal-

10 Z uwagi na decentralizację niektórych kompetencji w zakresie nauki i szkolnictwa wyższego poniższe informacje mogą ograniczać się do Anglii. 
dane’a, zgodnie z którą o przyznaniu grantu naukowego poszczególnym wnioskodawcom powinni decydować sami naukowcy za pośrednictwem recenzji naukowej (peer review). W recenzji takiej powinna znaleźć się ocena jakości, doniosłości i ewentualnych efektów proponowanych programów naukowo-badawczych. Należy odnotować, że w odróżnieniu od pozostałych wyżej wymienionych instytucji otrzymujących środki na badania naukowe, Rada ds. Finansowania Szkolnictwa Wyższego w Anglii (HEFCE) nie finansuje poszczególnych programów badawczych, lecz rozdziela pomiędzy poszczególne instytucje szkolnictwa wyższego środki na rzecz wsparcia infrastruktury badawczej oraz na rzecz umożliwienia podejmowania przez instytucje nowatorskich badań naukowych zgodnie z realizowaną misją. Rada nie korzysta z recenzji naukowych, a w sprawie podziału środków decydują wyspecjalizowane komisje (expert panels). Recenzje naukowe są stosowane przede wszystkim przez rady ds. badań naukowych.

Proces recenzowania wniosków o granty naukowe przypomina pod wieloma względami recenzowanie publikacji naukowych, zwłaszcza pod względem zasady, że ocena musi być dokonana przez osoby posiadające udokumentowane kompetencje. W praktyce istnieją jednak cztery istotne różnice:

- Decyzje w sprawie grantów są podejmowane na podstawie potencjalnej jakości badań realizowanych w wyniku ewentualnego przyznania grantu.

- W odróżnieniu od recenzji stosowanej w czasopismach („na ślepo”) tożsamość wnioskodawcy nie jest ukrywana przed recenzentami, gdyż analiza życiorysu zawodowego jest często w sposób uprawniony stosowana jako jeden ze wskaźników oceny potencjalnego sukcesu programu badawczego.

- W odróżnieniu od recenzji stosowanych w czasopismach naukowych przy opiniowaniu wniosku o grant istnieje mniej alternatyw dających możliwość odrzucenia takiego wniosku.

- W przypadku przyznawania grantów zaangażowane są pieniądze publiczne, bezpośrednio lub przez przychody podatkowe, z których korzystają charytatywne instytucje naukowe.

Różnice te nie mają jednak wpływu na podstawową cechę recenzji (peer review), jaką jest dokonywanie oceny na podstawie intelektualnej i naukowej wartości (quality) pracy.

Mimo wielu podobieństw, poszczególne instytucje wykazują istotne różnice w sposobie realizacji recenzji naukowych mających na celu przygotowanie decyzji o przyznaniu grantów naukowych. Z uwagi na znaczną ich liczbę omówiono rozwiązania obowiązujące w wybranych instytucjach. 


\section{Rada Badań Fizyczno-Inżynieryjnych (Engineering and Physical Sciences Research Councils, EPSRC) ${ }^{11}$}

Jedną z siedmiu rad ds. badań naukowych jest otrzymująca najwięcej środków na badania - 30\% - EPSRC. Instytucja ta korzysta z recenzji przy ocenie wniosków o granty naukowe i stypendia.

Większość recenzentów i członków komisji selekcyjnej jest wybierana spośród Kolegium Recenzentów liczącego około 4 tys. osób, wśród których rośnie znaczenie członków z zagranicy. Tworząc Kolegium, EPSRC dąży do zagwarantowania możliwości wykonywania recenzji z każdej dyscypliny, starając się o zapewnienie równowagi pod względem płci, wieku, pochodzenia etnicznego, miejsca zamieszkania, a także spełnienia kryterium odpowiedniego poziomu wykształcenia oraz zakresu wiedzy. Ponadto uwzględnia się dotychczasową praktykę w działalności w charakterze recenzenta.

Członkowie Kolegium powinni zrecenzować nie więcej niż 12 wniosków w ciągu roku. Mają termin 15 dni roboczych na przekazanie recenzji.

Postępowanie w sprawie recenzji jest następujące: po otrzymaniu wniosku EPSRC przesyła kopię co najmniej czterem recenzentom, w tym co najmniej jeden wskazany jest przez wnioskodawcę. Recenzenci swoje opinie przekazują zwykle drogą elektroniczną przez wspólny dla rad ds. badań elektroniczny system przyjmowania wniosków (system Je-S).

Otrzymane wnioski mają charakter poufny. Oznacza to, że nie mogą być udostępniane osobom trzecim, w celu innym niż podjęcie decyzji dotyczącej finansowania tego wniosku, również przez recenzentów. W niektórych przypadkach współpracownicy mogą mieć wgląd do części wniosku. Jednak udostępnienie im wniosku w celu konsultacji wymaga pisemnej zgody EPSRC.

Aby zachować anonimowość w wypadku przekazywania opinii recenzentów wnioskodawcom, na formularzu opinii nazwiska recenzentów są zastąpione numerem referencyjnym recenzenta. Wiąże on recenzenta $\mathrm{z}$ wnioskiem i jest unikatowy dla danego wniosku. Jeżeli recenzent otrzymuje do recenzowania więcej niż jeden wniosek, każdy z nich ma osobny numer referencyjny.

Obowiązuje termin trzech tygodni na przesłanie wniosków do recenzentów i uzyskanie ich opinii. Wszystkie opinie recenzentów otrzymane w terminie są przedstawiane na posiedzeniu zespołu oceniającego (peer review meeting) z podaniem nazwisk recenzentów.

11 https://epsrc.ukri.org/. 
Jeżeli wnioski nie uzyskały poparcia wystarczającego do przedstawienia ich na posiedzeniu wyżej wymienionego zespołu, badacze zostaną o tym powiadomieni, a opinie recenzentów są przesyłane wnioskodawcy.

Wnioski, które uzyskały pozytywną opinię od co najmniej dwóch recenzentów, są przedkładane na posiedzeniu zespołu w celu podjęcia decyzji o finansowaniu. Uwagi recenzentów są przekazywane badaczowi poprzez system Je-S w celu uzyskania komentarza na temat stwierdzonych nieścisłości lub innych poruszonych kwestii.

Badacz powinien w terminie pięciu dni odpowiedzieć na uwagi recenzentów. Odpowiedzi na posiedzenie zespołu są przekazywane w trybie poufnym. Na podstawie recenzji oraz ewentualnych odpowiedzi wnioskodawcy zespół podejmuje decyzje, ustalając priorytety finansowania wniosków ${ }^{12}$. Nie ma obowiązku upubliczniania recenzji, a autorzy wniosków przyjętych, jak i odrzuconych, otrzymują wszystkie recenzje dotyczące ich wniosków.

\section{Akademia Brytyjska (British Academy) ${ }^{13}$}

Akademia Brytyjska jest jedną z trzech akademii nauk otrzymujących środki na badania naukowe z Ministerstwa Biznesu, Innowacji i Umiejętności. W postępowaniu mającym na celu ocenę wniosku o grant naukowy uczestniczą niżej omówione podmioty ${ }^{14}$ :

- osoba udzielająca referencji (Referee): wyznaczony przez wnioskodawcę pracownik nauki, który może w sposób kompetentny wypowiedzieć się na temat wniosku. Zaleca się, aby wnioskodawca przedyskutował swój wniosek z osobą lub osobami udzielającymi referencji. Wnioskodawca powinien zapewnić dostarczenie w odpowiednim terminie do Akademii opinii (statement) osoby udzielającej referencji,

- opiniujący zewnętrzny (External evaluator): wyznaczony przez wnioskodawcę pracownik nauki, który może w sposób kompetentny wypowiedzieć się na temat wniosku. Zaleca się, aby wnioskodawca wskazał czterech kandydatów, spośród których Akademia wybiera dwie osoby do opiniowania wniosku. Wnioskodawca nie może w żaden sposób omawiać szczegółów swojego wniosku z osobami wskazanymi jako potencjalni opiniujący. Akademia odpowia-

12 EPSRC. Introduction to reviewing proposals, http://www.epsrc.ac.uk/funding/apprev/review/Pages/intro.aspx.

13 https://www.britac.ac.uk/.

14 http://www.britac.ac.uk/funding/peer-review.cfm. 
da za uzyskanie opinii od opiniujących zewnętrznych. Może także skorzystać z opinii osób innych niż wskazane przez wnioskodawcę,

- oceniający (Assessor): specjalista w danej dziedzinie, zwykle członek Akademii, który ocenia wniosek w kontekście referencji i opinii zewnętrznych (o ile są wykorzystywane),

- panel selekcyjny (Selection Panel): podkomisja, zwykle złożona z członków Akademii, która analizuje wnioski i zalecenia oceniających oraz szereguje pod względem ważności wnioski przed przekazaniem ich do komisji przyznającej granty,

- komisja przyznająca granty (Final Award Committee): komisja, w składzie której znajdują się przedstawiciele z różnych dziedzin nauki -zwykle członkowie Akademii. Zbiera się w celu ostatecznego podjęcia decyzji o przyznaniu grantów.

\section{Procedura dotycząca oceny wszystkich wniosków}

Przy ocenie projektów najważniejszym kryterium jest wartość naukowa. Zgodnie z ogólną procedurą wnioski oceniane są przez specjalistów z danej dziedziny w kontekście przedstawionych referencji i ewentualnych opinii zewnętrznych. Wnioski i zalecenia oceniających są kierowane do komisji decydującej o przyznaniu grantów, która, rozpatrując wnioski, podejmuje decyzję, biorąc pod uwagę zasady konkurencji oraz dostępność środków.

Wnioski oceniane są na podstawie ich wartości naukowej z uwzględnieniem następujących kryteriów:

- oryginalności,

- relacji do dotychczasowego stanu wiedzy w danej dziedzinie,

- poziomu naukowego proponowanych badań,

- właściwej metodologii badań,

- wykonalności projektu,

- specyfiki programu badawczego,

- prezentacji zastosowań,

- oczekiwanych wyników.

Przy ocenie możliwości podjęcia badań proponowanych przez kandydatów bierze się pod uwagę ich:

- dotychczasowe publikacje,

- staż naukowy,

- aktualny etap kariery.

Wstępna ocena jakości dotyczy celu badawczego ujętego we wniosku oraz sprawdzeniu, czy proponowana metodologia może zapewnić realizację tego celu. 
Sposób realizacji celu podlega indywidualnej ocenie w odniesieniu do każdego wniosku. Nie ma preferencji w stosunku do badań indywidualnych ani zbiorowych. W odniesieniu do badań z udziałem partnerów zagranicznych oceniający mogą uwzględniać możliwości współfinansowania projektu.

Jeżeli dla osiągnięcia celu badawczego istotne znaczenie ma interpretacja materiałów obcojęzycznych, oceniający mogą wziąć pod uwagę udokumentowaną znajomość odpowiednich języków obcych przez wnioskodawcę.

Efekty ekonomiczne projektu mogą być uwzględniane na końcowym etapie oceny wniosków.

\section{Reakcja wnioskodawcy na recenzję}

We wszystkich typach projektów reakcja wnioskodawcy na recenzję jest możliwa jedynie wówczas, gdy osoby oceniające lub komisja decydująca o przyznaniu grantów ma do przekazania wnioskodawcy szczególne uwagi dotyczące sposobu prowadzenia proponowanego badania lub konstruktywne wnioski dotyczące zmiany opracowania projektu w celu poprawy jakości.

Na stronie internetowej Akademii dotyczącej recenzji naukowych brak jest informacji na temat obowiązku upubliczniania recenzji.

\section{Bibliografia}

\section{Akty prawne}

Procédure d'organisation et fonctionnement des Comités d'Évaluation, http://www.agence-nationale-recherche.fr/fileadmin/user_upload/documents/uploaded/2010/Guide-Comite-Evaluation-ANR-2010.pdf.

\section{Strony internetowe}

http://www.agence-nationale-recherche.fr/.

http://www.dlr.de/pt//desktopdefault.aspx/tabid-4270/6848_read-6936/.

https://www.ukri.org/.

https://www.gov.uk/government/organisations/uk-space-agency.

https://epsrc.ukri.org/.

https://www.britac.ac.uk/. 


\section{Indeks rzeczowy}

absolwenci 47, 48, 65, 111, 129, 217, 221, 231, 246, 339, 606, 607

adopcja 637-639

Andora 679

Anglia 35, 76, 142, 251, 275, 344, 434, 459, 486, 547, 597, 612, 615, 631, 650

Austria 18, 21, 235, 259-261, 298, 300, 386, 415, 452, 483

baza danych 646,647

Belgia 22, 302, 417, 586, 624

bezpieczeństwo drogowe 299, 382, 384

bezpłatny podręcznik 622

Białoruś 637-639

Bułgaria 24, 259, 418, 587

Cypr 25, 38, 401, 464, 625

Czechy 25, 41, 106, 419, 483, 489, 521, 559, 587, 626

dane osobowe 646,651

Dania 25, 239, 420, 647

dni wolne 482, 484, 485

doradztwo 54, 124, 140, 195, 443, 445, 448, 452

edukacja komunikacyjna 356, 364 edukacja kulturalna i artystyczna 286, 288, 291

Estonia 26, 309, 385, 421

finansowanie 681, 684

Finlandia 26, 48, 190, 312, 386, 421, 453, 483, 494, 522, 560, 626

Francja 18, 26, 112, 115, 318, 402, 422, 453, 469, 497, 524, 545, 561, 589, 647, 681

granty $680,683,698$

Grecja 27, 323, 387, 470, 525, 590, 627

Hiszpania 27, 260, 264, 329, 388, 423, 471, 526, 563, 591, 627

Holandia 28, 242, 402, 424, 564, 592, 628

Irlandia 29, 201, 324, 424, 472, 546, 566, 592

Irlandia Północna 35, 92, 280, 348, 434, 547, 598, 698, 619

Islandia 403, 425, 472, 593, 628

język migowy 577, 580

kariera zawodowa 277, 459

kształcenie na odległość 513, 515-517

kultura 286 
Liechtenstein 204, 401, 411, 465, 679

Litwa 29, 426, 528, 639

Luksemburg 30, 260, 359, 401, 465, 679

Łotwa 30, 390, 403, 427, 473, 484, 594, 629

Malta 31, 403, 474

nadzór pedagogiczny 194, 550, 551, 554, 556, 559

nauczyciele $48,56,67,75,83,100,296,302$, 308, 311, 317, 322, 328, 333, 339, 344, 351, 541,543

Niemcy 31, 57, 125, 245, 267, 340, 392, 403, 428, 474, 484, 531, 546, 567, 594, 629, 649, 684

Norwegia 68, 535, 651

obowiązek szkolny 17, 20, 61, 69, 96

pensum 141, 221, 541-544, 546, 548

podręczniki $80,96,97,147,198,324,365$, $391,514,523,568,583,602,605,608-611$, $624,625,627-633$

Polska 292, 364, 402, 468, 517, 543, 580, 604, 623

Portugalia 32, 428, 485, 500, 533

przedsiębiorczość 256, 258, 261, 265, 267, $268,275,276,278,280,282$

raport edukacyjny 164, 167, 170, 171, 174
Rumunia 32, 429, 569

skala ocen $300,306,310,315,320,326,332$, 333, 337, 343

Słowacja 33, 134, 430, 455, 475, 595, 631

Słowenia 33, 431, 476, 595

Stany Zjednoczone 435

studenci 488, 493

system szkolny 190, 201

Szkocja 84, 153, 278, 346, 434, 548, 598, 612, 616

szkolnictwo wyższe $66,74,82,99,164,178$, 182, 194, 217

Szwajcaria 159, 161, 679

Szwecja 34, 249, 380, 403, 432, 476, 485, 503, 534, 571, 609

uczniowie głusi 577

uczniowie niepełnosprawni 219, 465, 615 uczniowie uzdolnieni 409, 410, 436, 438

Ukraina 641

Walia 35, 84, 276, 346, 547, 597

Węgry 34, 433, 457, 503, 535, 596

Wielka Brytania 35, 75, 142, 251, 272, 344, 374, 404, 459, 478, 486, 536, 547, 572, 597, 612, 631, 650, 685

Włochy 36, 92, 282, 393, 404, 505, 599, 631 wychowanie fizyczne 397, 462

zwolnienie z lekcji 462, 471, 475 


\section{Spis tabel}

Tabela 1. Długość obowiązku szkolnego w państwach członkowskich Unii

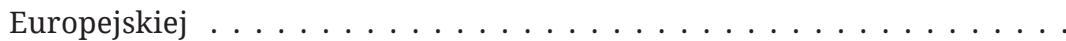

Tabela 2. Odsetek zatrudnionych absolwentów w wieku od 20 do 34 lat, którzy zakończyli kształcenie lub szkolenie na poziomie ISCED 3 i ISCED 4 nie wcześniej niż trzy lata przed rokiem referencyjnym . . . . . . . . . . . .

Tabela 3. Odsetek osób do 25 roku życia rozpoczynających studia wyższe (2011 r.) . . . . . . . . . . . . . . . . . . . . . . . . . .

Tabela 4. Roczne wydatki instytucji sektora publicznego na ucznia/studenta według poziomu kształcenia w Irlandii w 2008 roku . . . . . . . . . . . . .

Tabela 5. Całkowite roczne wydatki irlandzkich placówek oświatowych (ISCED 0-6) sektora publicznego według najważniejszych kategorii w 2008 roku

Tabela 6. Skala ocen stosowana w szkolnictwie w Austrii w odniesieniu do polskiego systemu oceniania . . . . . . . . . . . . . . . .

Tabela 7. Skala ocen stosowana w szkolnictwie w Belgii w odniesieniu do polskiego systemu oceniania . . . . . . . . . . . . . . . . . .

Tabela 8. Skala ocen stosowana w szkolnictwie w Estonii w odniesieniu do polskiego systemu oceniania . . . . . . . . . . . . . . . . .

Tabela 9. Skala ocen stosowana w szkolnictwie w Finlandii w odniesieniu do polskiego systemu oceniania . . . . . . . . . . . . . . . .

Tabela 10. Skala ocen stosowana w szkolnictwie we Francji w odniesieniu do polskiego systemu oceniania . . . . . . . . . . . . . . .

Tabela 11. Skala ocen stosowana w Grecji w szkole podstawowej (Dimotiko scholio) dla klasy III i IV w odniesieniu do polskiego systemu oceniania . .

Tabela 12. Skala ocen stosowana w Grecji w szkole podstawowej (Dimotiko scholio) dla klasy V i VI w odniesieniu do polskiego systemu oceniania . . .

Tabela 13. Skala ocen stosowana w Grecji w szkole średniej I stopnia (Gymnasio) w odniesieniu do polskiego systemu oceniania . . . . . . . . . .

Tabela 14. Skala ocen stosowana w szkole podstawowej w Hiszpanii w odniesieniu do polskiego systemu oceniania . . . . . . . . . . . . . . .

Tabela 15. Skala ocen stosowana w szkole średniej w Hiszpanii w odniesieniu do polskiego systemu oceniania . . . . . . . . . . . . . . . . 
Tabela 16. Skala ocen stosowana w szkolnictwie w Irlandii w odniesieniu do polskiego systemu oceniania . . . . . . . . . . . . .

Tabela 17. Skala ocen stosowana w szkolnictwie podstawowym w Niemczech w odniesieniu do polskiego systemu oceniania . . . . . . . . . . . . .

Tabela 18. Programy edukacji w zakresie bezpieczeństwa ruchu drogowego realizowane dla różnych grup wiekowych w państwach UE . . . . . . . .

Tabela 19. Wsparcie finansowe dla placówek oświatowych realizujących edukację bezpieczeństwa ruchu drogowego w państwach UE . . . . . . . .

Tabela 20. Warunki zwolnienia uczniów z wychowania fizycznego w szkołach podstawowych (ISCED 1) i średnich I stopnia (ISCED 2) w wybranych państwach członkowskich Unii Europejskiej . . . . . . . . . . . . . . . . .

Tabela 21. Tygodniowy wymiar godzin zajęć dydaktycznych, wychowawczych i opiekuńczych dla nauczycieli zatrudnionych w pełnym wymiarze zajęć w Polsce . . . . . . . . . . . . . . . . . . . . . . . .

Tabela 22. Liczba uczniów niesłyszących i słabosłyszących w Polsce w szkołach: ogólnodostępnych, integracyjnych i specjalnych w latach 2016-2018. Tabela zawiera dane o uczniach ze wszystkich typów szkół i placówek systemu oświaty . . . . . . . . . . . . .

Tabela 23. Opłaty rodziców za podręczniki szkolne w szkołach podstawowych i średnich I stopnia w wybranych państwach (listopad 2013 r.) . . . . . . .

Tabela 24. Zagadnienia najczęściej poruszane w pytaniach zadawanych przez uczelnie wyższe podczas prowadzonego monitoringu absolwentów

Tabela 25. Okres od dnia ukończenia studiów przez absolwenta, po jakim uczelnia prowadzi lub zamierza prowadzić monitoring . . . . . . . . . .

Tabela 26. Adresaci wyników monitoringu karier zawodowych prowadzonego przez polskie uczelnie . . . . . . . . . . . . . . . .

Tabela 27. Związki partnerskie PACS zawarte we Francji . . . . . . . . . . . . . . 671

Tabela 28. Związki małżeńskie i związki partnerskie PACS zawarte we Francji w latach $2000-2010 \ldots$. . . . . . . . . . . . . . . . . . . . . . . . . 


\section{Spis wykresów}

Wykres 1. Nakłady na edukację (ISCED 0-6) w Irlandii w 2010 roku jako

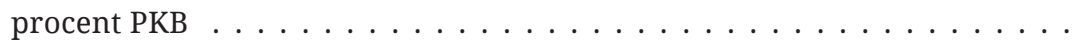

Wykres 2. Wykaz dyscyplin sportowych najczęściej występujących w programach nauczania wychowania fizycznego w szkolnictwie państw członkowskich Unii Europejskiej . . . . . . . . . . . . . . . . . .

Wykres 3. Wykaz minimalnej obowiązkowej liczby godzin wychowania fizycznego jako procent ogólnej liczby obowiązkowych godzin na poziomie szkoły podstawowej i szkoły średniej I stopnia w szkolnictwie państw członkowskich Unii Europejskiej . . . . . . . . . . . . . . . . . . .

Wykres 4. Odsetek uczelni, które prowadziły monitoring losów absolwentów przed wejściem w życie art. 13a ustawy - Prawo o szkolnictwie wyższym

Wykres 5. Odsetek uczelni, które wdrożyły monitoring karier zawodowych swoich absolwentów

Wykres 6. Odsetek uczelni według roku akademickiego, od którego jest lub będzie prowadzony monitoring losów zawodowych absolwentów zgodnie z art. 13a ustawy - Prawo o szkolnictwie wyższym . . . . . . . . . . . . .

Wykres 7. Liczba uczelni, dla których zwrotność ankiet kształtowała się w poszczególnych przedziałach . . . . . . . . . . . . . . . .

Wykres 8. Odsetek uczelni, które wdrożyły system implementacji wyników monitoringu w realizację zmian w dydaktycznej części swoich zadań

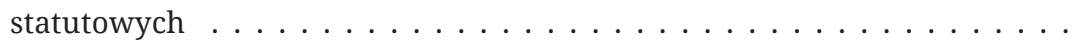

Wykres 9. Uzyskiwanie zgody na przetwarzanie danych osobowych dla potrzeb monitoringu karier zawodowych absolwentów przez uczelnie 666

Wykres 10. Związki partnerskie PACS zawarte we Francji w latach 2000-2010

Wykres 11. Śluby i wszystkie związki PACS zawarte we Francji w latach

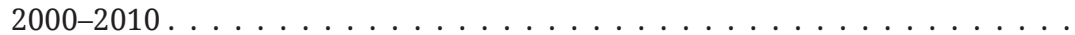

Wykres 12. Liczba tradycyjnych związków małżeńskich zawieranych we Francji w latach 1990-2011. Strzałka wskazuje moment wprowadzenia PACS (listopad 1999 r.) . . . . . . . . . . . . . . . . . . . . . . . . .

Wykres 13. Śluby oraz PACS heteroseksualny i homoseksualny zawarte we Francji w latach 1990-2011 (brak danych PACS za 2011 r.) . . . . . . . . 


\section{Spis rysunków}

Rysunek 1. Schemat organizacji systemu szkolnictwa w Czechach . . . . . . 42

Rysunek 2. Schemat organizacyjny fińskiego Ministerstwa Edukacji i Kultury $\quad 49$

Rysunek 3. Schemat organizacji systemu szkolnictwa w Finlandii . . . . . . . 52

Rysunek 4. Schemat organizacji systemu szkolnictwa w Niemczech . . . . . . 58

Rysunek 5. Schemat organizacji systemu szkolnictwa w Norwegii . . . . . . . 70

Rysunek 6. Schemat organizacji systemu szkolnictwa w Anglii . . . . . . . . 78

Rysunek 7. Schemat organizacji systemu szkolnictwa w Walii . . . . . . . . . . 86

Rysunek 8. Schemat organizacji systemu szkolnictwa w Szkocji . . . . . . . . . 88

Rysunek 9. Schemat organizacji systemu szkolnictwa w Irlandii Północnej . . $\quad 90$

Rysunek 10. Schemat organizacji systemu szkolnictwa we Włoszech . . . . . . 94

Rysunek 11. Schemat organizacji systemu szkolnictwa we Francji . . . . . . . . 116

Rysunek 12. Schemat organizacji systemu szkolnictwa średniego we Francji . 120

Rysunek 13. Schemat organizacji systemu szkolnictwa na Słowacji . . . . . . . 136

Rysunek 14. Porównanie systemów szkolnictwa Anglii, Walii, Irlandii Płn.

i Szkocji . . . . . . . . . . . . . . . . . . . . . . 154

Rysunek 15. Schemat systemu szkolnego w Irlandii . . . . . . . . . . . . . . . . 210 